\title{
Report on the Remedial Investigation of Bear Creek Valley at the Oak Ridge Y-12 Plant, Oak Ridge, Tennessee
}

\author{
Volume 2. \\ Appendix A-Waste Sites, Source Terms, \\ and Waste Inventory Report \\ Appendix B-Description of the Field Activities \\ and Report Database \\ Appendix C-Characterization of Hydrogeologic \\ Setting Report
}

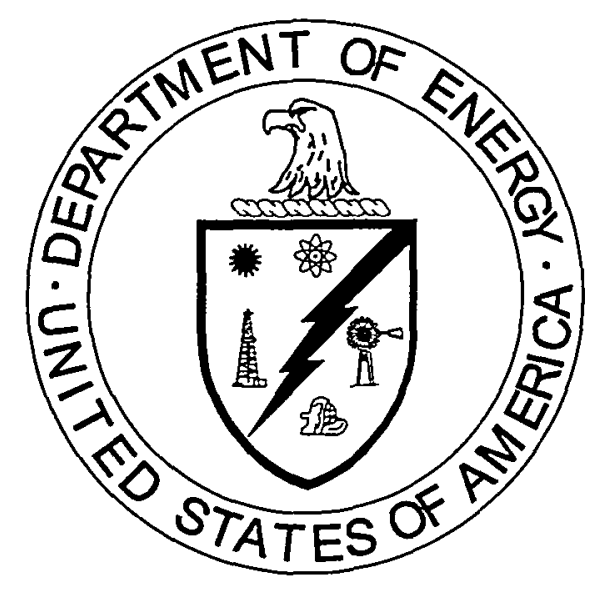

PECEIVED

DEC 191996

OSTI

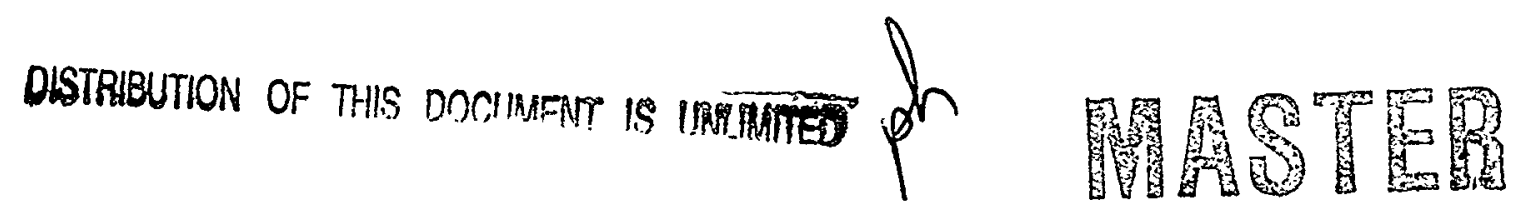

This document has been approved by the Y-12 Plant Technical Information Office for release to the public. Date: $8 / 23 / \%$ 


\section{DISCLAIMER}

This report was prepared as an account of work sponsored by an agency of the United States Government. Neither the United States Government nor any agency thereof, nor any of their employees, make any warranty, express or implied, or assumes any legal liability or responsibility for the accuracy, completeness, or usefulness of any information, apparatus, product, or process disclosed, or represents that its use would not infringe privately owned rights. Reference herein to any specific commercial product, process, or service by trade name, trademark, manufacturer, or otherwise does not necessarily constitute or imply its endorsement, recommendation, or favoring by the United States Government or any agency thereof. The views and opinions of authors expressed herein do not necessarily state or reflect those of the United States Government or any agency thereof. 


\section{DISCLAIMER}

Portions of this document may be illegible in electronic image products. Images are produced from the best available original document. 
Energy Systems Environmental Restoration Program

\title{
Report on the Remedial Investigation of Bear Creek Valley at the Oak Ridge Y-12 Plant, Oak Ridge, Tennessee
}

\author{
Volume 2. \\ Appendix A-Waste Sites, Source Terms, \\ and Waste Inventory Report \\ Appendix B-Description of the Field Activities \\ and Report Database \\ Appendix C-Characterization of Hydrogeologic \\ Setting Report
}

Date Issued-September 1996

\author{
Prepared by \\ Science Applications International Corporation \\ Oak Ridge, Tennessee \\ under subcontract 91B-99069C \\ Prepared for the \\ U.S. Department of Energy \\ Office of Environmental Management \\ under budget and reporting code EW 20 \\ Environmental Management Activities at the \\ OAK RIDGE Y-12 PLANT \\ Oak Ridge, Tennessee 37831-8169 \\ managed by \\ LOCKHEED MARTIN ENERGY SYSTEMS, INC. \\ for the \\ U.S. DEPARTMENT OF ENERGY \\ under contract DE-AC05-84OR21400
}




\section{Science Applications International Corporation}

contributed to the preparation of this document and should not be considered an eligible contractor for its review.

This report has been reproduced directly from the best available copy.

Available to DOE and DOE contractors from the Office of Scientific and Technical Information, P.O. Box 62, Oak Ridge, TN 37831; prices available from 423-576-8401 (fax 423-576-2865).

Available to the public from the National Technical Information Service, U.S. Department of Commerce, 5285 Port Royal Rd., Springfield, VA 22161. 


\section{PREFACE}

This Remedial Investigation Report on the Bear Creek Valley Characterization Area at the Oak Ridge Y-12 Plant (DOE/OR/01-1455/V1\&D1, -1455/V2\&D1, -1455/V3\&D1, -1455/V4\&D1, $-1455 / \mathrm{V} 5 \& \mathrm{D} 1$, and $-1455 / \mathrm{V} 6 \& \mathrm{D} 1$ ) was prepared in accordance with requirements under the Comprehensive Environmental Response, Compensation, and Liability Act (CERCLA) for reporting the results of a site characterization for public review. This work was performed under Work Breakdown Structure 1.4.12.1.1.02.41 (Activity Data Sheet 2302 "Bear Creek Valley"). Publication of this document on September 15, 1996, will meet a Federal Facilities Agreement milestone. This document provides the Environmental Restoration Program with information on the Bear Creek Valley remedial investigations that include results of the Bear Creek Valley OU 1 (1995) and OU 4 (1994) and Bear Creek Valley Floodplain Soils (1995) investigations, plus results of numerous other investigations and monitoring conducted in Bear Creek Valley. It includes information on risk assessments that have evaluated long-term impacts to human health and the environment. Information provided in this document forms the basis for the development of the Feasibility Study/Environmental Assessment Report. 



\section{CONTENTS}

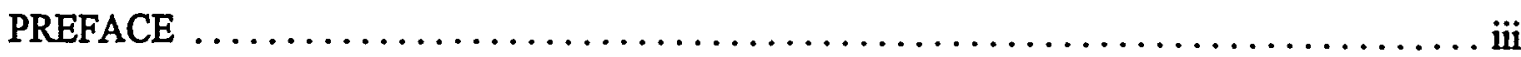

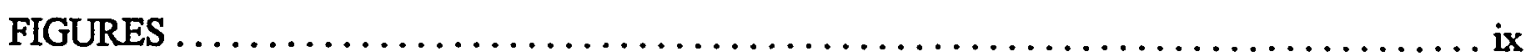

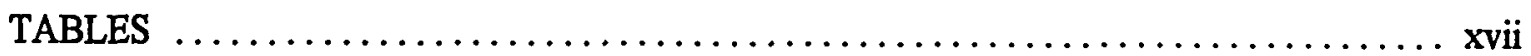

ACRONYMS AND ABBREVIATIONS $\ldots \ldots \ldots \ldots \ldots \ldots \ldots \ldots \ldots \ldots \ldots \ldots \ldots \ldots \ldots \ldots \ldots \ldots$

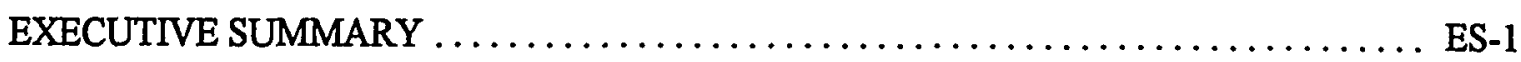

A.1 SITE DESCRIPTION ..................................... Al-3

A.1.1 GEOGRAPHICAL INFORMATION $\ldots \ldots \ldots \ldots \ldots \ldots \ldots \ldots \ldots \ldots \ldots \ldots \ldots \ldots \ldots$

A.1.2 BACKGROUND INFORMATION $\ldots \ldots \ldots \ldots \ldots \ldots \ldots \ldots \ldots \ldots \ldots \ldots \ldots \ldots \ldots$

A.1.3 OPERATIONAL INFORMATION AND DESCRIPTION

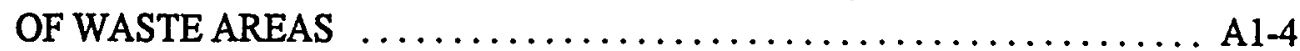

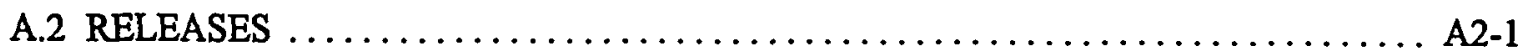

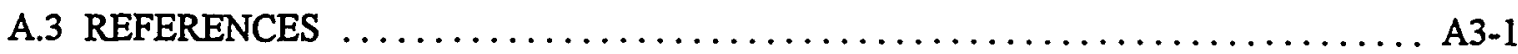

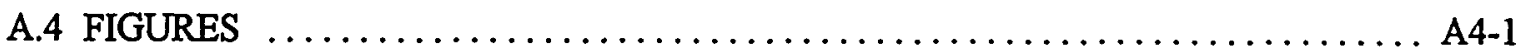

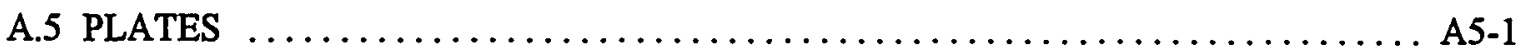

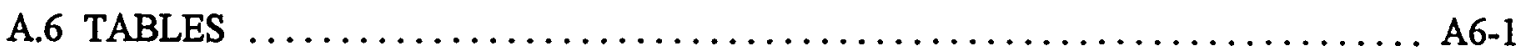

A.7 SUPPORTING INFORMATION FOR APPENDIX A:

BEAR CREEK BURIAL GROUNDS WASTE INVENTORY $\ldots \ldots \ldots \ldots \ldots \ldots$ A7-1

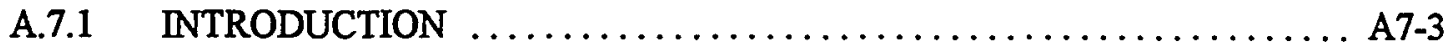

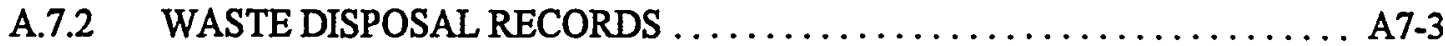

A.7.3 INVENTORY REVIEW ............................... A7-5

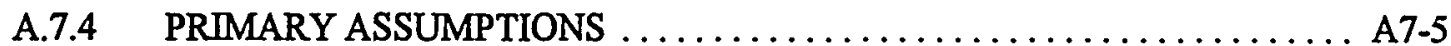

A.7.5 TOTAL URANIUM ESTIMATE COMPARISONS $\ldots \ldots \ldots \ldots \ldots \ldots \ldots$ A7-10

A.8 SUPPORTING INFORMATION FOR APPENDIX A-TABLES $\ldots \ldots \ldots \ldots \ldots$ A8-1

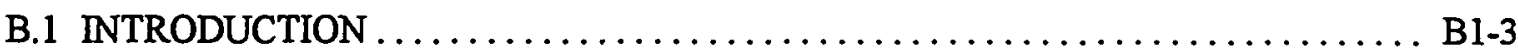

B.2 SUMMARY OF HISTORICAL DATA FOR BCV $\ldots \ldots \ldots \ldots \ldots \ldots \ldots \ldots \ldots$ B2-1

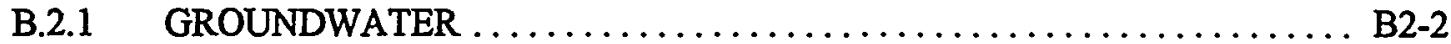

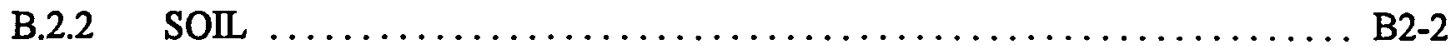

B.2.3 FLOODPLAIN SOIL/SEDIMENT $\ldots \ldots \ldots \ldots \ldots \ldots \ldots \ldots \ldots \ldots$, B2-2

B.2.4 SURFACE WATER $\ldots \ldots \ldots \ldots \ldots \ldots \ldots \ldots \ldots \ldots \ldots \ldots \ldots \ldots \ldots \ldots \ldots \ldots$, B2-3

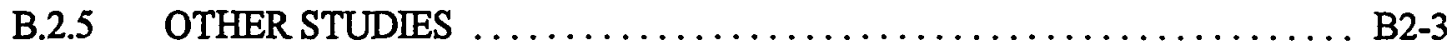

B.3 BCV OU 1 RI FIELD ACTIVITIES $\ldots \ldots \ldots \ldots \ldots \ldots \ldots \ldots \ldots \ldots \ldots \ldots \ldots$, B3-1

B.3.1 SUMMARY OF FIELD INVESTIGATIONS $\ldots \ldots \ldots \ldots \ldots \ldots \ldots \ldots$ B3-1 
B.3.2 DEVIATION FROM THE SAMPLING AND ANALYSIS PLAN ....... B3-1

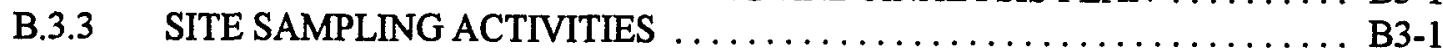

B.4 BCV OU 4 FIELD ACTIVITIES $\ldots \ldots \ldots \ldots \ldots \ldots \ldots \ldots \ldots \ldots \ldots \ldots \ldots \ldots \ldots \ldots \ldots$

B.4.1 SUMMARY OF FIELD INVESTIGATIONS $\ldots \ldots \ldots \ldots \ldots \ldots \ldots \ldots \ldots \ldots$ B4-1

B.4.2 DEVIATIONS FROM THE SAMPLING AND ANALYSIS PLAN . . . . . . . B4-1

B.4.3 SITE SAMPLING ACTIVITIES $\ldots \ldots \ldots \ldots \ldots \ldots \ldots \ldots \ldots$ B4-3

B.5 FIELD DATA COLLECTION-FLOODPLAIN SOILS AND SEDIMENTS $\ldots \ldots \ldots$ B5-1

B.5.1 SUMMARY OF FIELD INVESTIGATIONS $\ldots \ldots \ldots \ldots \ldots \ldots \ldots \ldots$ B5-1

B.5.2 BACKGROUND DETERMINATIONS (REFERENCE SAMPLES AND VALUES) $\ldots \ldots \ldots \ldots \ldots \ldots \ldots \ldots \ldots$ B5-1

B.5.3 SOIL SAMPLING $\ldots \ldots \ldots \ldots \ldots \ldots \ldots \ldots \ldots \ldots \ldots \ldots \ldots \ldots . \ldots \ldots$ B5-2

B.5.4 BEAR CREEK STREAM SEDIMENT CHARACTERIZATION . . . . . . . B B

B.5.5 SOURCE TERM ECOLOGICAL CHARACTERIZATION ............ B5-8

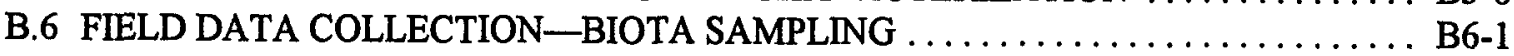

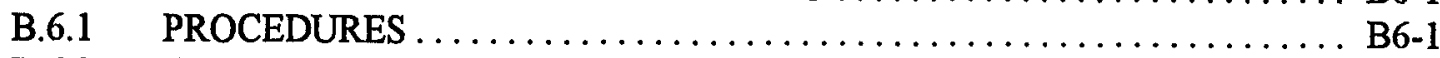

B.6.2 SOURCE TERM ECOLOGICAL CHARACTERIZATION ............ B6-2

B.6.3 BIOTA SAMPLING AT FLOODPLAIN AFIs $\ldots \ldots \ldots \ldots \ldots \ldots \ldots \ldots$ B6-3

B.6.4 ECOLOGICAL REFERENCE SAMPLES $\ldots \ldots \ldots \ldots \ldots \ldots \ldots \ldots \ldots . . \ldots \ldots$ B6-4

B.7 GWQR DATA QUALITY ASSESSMENT $\ldots \ldots \ldots \ldots \ldots \ldots \ldots \ldots \ldots \ldots \ldots \ldots$ B7-1

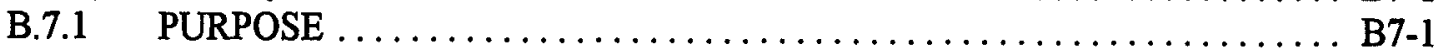

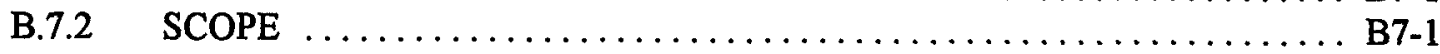

B.7.3 RI DATA QUALITY OBJECTIVES $\ldots \ldots \ldots \ldots \ldots \ldots \ldots \ldots \ldots \ldots \ldots$ B7-1

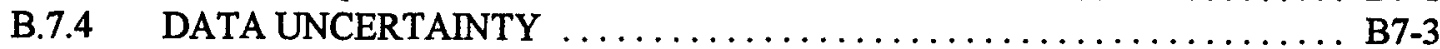

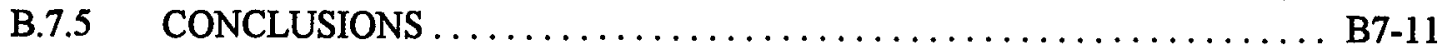

B.8 BCV INTEGRATING DATA QUALITY ASSESSMENT $\ldots \ldots \ldots \ldots \ldots \ldots \ldots$ B8-1

B.8.1 PURPOSE $\ldots \ldots \ldots \ldots \ldots \ldots \ldots \ldots \ldots \ldots \ldots \ldots \ldots \ldots$ B8-1

B.8.2 SCOPE $\ldots \ldots \ldots \ldots \ldots \ldots \ldots \ldots \ldots \ldots \ldots \ldots \ldots \ldots$ B8-1

B.8.3 DATA ACCEPTABILITY $\ldots \ldots \ldots \ldots \ldots \ldots \ldots \ldots \ldots \ldots$ B8-1

B.8.4 QUALITY ASSURANCE PROGRAM $\ldots \ldots \ldots \ldots \ldots \ldots \ldots \ldots$ B8-3

B.8.5 DATA EVALUATION $\ldots \ldots \ldots \ldots \ldots \ldots \ldots \ldots \ldots \ldots \ldots$ B8-5

B.8.6 CONCLUSIONS $\ldots \ldots \ldots \ldots \ldots \ldots \ldots \ldots \ldots \ldots \ldots$ B8-14

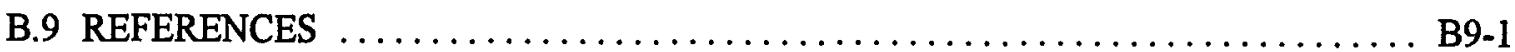

B.10 FIGURES $\ldots \ldots \ldots \ldots \ldots \ldots \ldots \ldots \ldots \ldots \ldots \ldots \ldots \ldots$ B10-1

B.11 PLATES $\ldots \ldots \ldots \ldots \ldots \ldots \ldots \ldots \ldots \ldots \ldots \ldots \ldots \ldots \ldots$

B.12 TABLES $\ldots \ldots \ldots \ldots \ldots \ldots \ldots \ldots \ldots \ldots \ldots \ldots \ldots \ldots \ldots$

B.13 SUPPORTING INFORMATION FOR APPENDIX B-

LITHOLOGIC LOGS . . . . . . . . . . . . . . . . . . B13-1 
C.1 CLIMATE

C.1.1 TEMPERATURE

C1-3

C.1.2 WINDS

C.1.3 PRECIPITATION

C. 2 TOPOGRAPHY .

C.3.1 BCV STRATIGRAPHY

C.3.2 STRUCTURAL GEOLOGY OF THE ORR

C.3.3 BCV BEDROCK STRUCTURES

C.3.4 FORMATION HYDRAULIC CHARACTERISTICS

C.4 BCV HYDROGEOLOGIC CONCEPTUAL MODEL - HYDROLOGY

C.4.1 WATER BALANCE MODEL FOR BCV

C.4.2 GROUNDWATER FLOW CHARACTERISTICS

C.4.3 TRANSIENT RESPONSES TO ANNUAL CHANGE

C.4.4 TRANSIENT RESPONSES TO STORMS

C.4.5 BEAR CREEK/MAYNARDVILLE LIMESTONE

C.5 REFERENCES

C.6 FIGURES

C. 7 TABLES

C.8 SUPPORTING INFORMATION FOR APPENDIX C-DETAILED

ANALYSIS OF HYDROGEOLOGIC MONITORING DATA

FOR BCV OU 4 RIFA

C.8.1 VERTICAL HYDRAULIC GRADIENTS

烈

C.8.2 PRESSURE PULSES IN RESPONSE TO RAINFALL $\ldots \ldots \ldots \ldots \ldots \ldots \ldots$ C8-5

C.8.3 SURFACE WATER FLOW MONITORING DATA $\ldots \ldots \ldots \ldots \ldots \ldots \ldots \ldots \ldots \ldots \ldots$

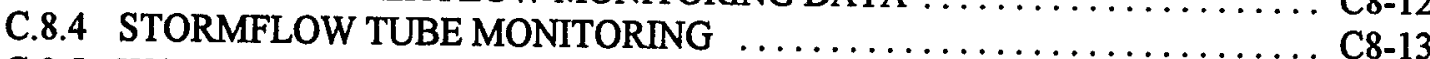

C.8.5 WATER BALANCE CALCULATION METHODOLOGY $\ldots \ldots \ldots \ldots \ldots \ldots \ldots . . \ldots \ldots$

C.9 SUPPORTING INFORMATION FOR APPENDIX C-FIGURES . . . . . . . . C9-1

C.10 SUPPORTING INFORMATION FOR APPENDIX C-TABLES $\ldots \ldots \ldots \ldots \ldots$ C10-1 


\section{FIGURES}

A.1 Location map for $\mathrm{BCV} \ldots \ldots \ldots \ldots \ldots \ldots \ldots \ldots \ldots \ldots \ldots \ldots \ldots \ldots \ldots$

A.2 Locations of waste storage areas and treatment and storage facilities in BCV ....... A4-5

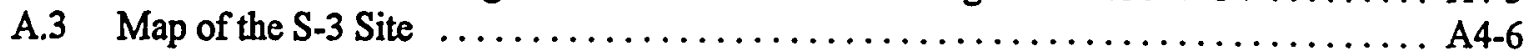

A.4 Locations of plots in the former Oil Landfarm $\ldots \ldots \ldots \ldots \ldots \ldots \ldots \ldots \ldots \ldots \ldots$ A4-7

A.5 Site map for the Oil Landfarm Area, including the Oil Landfarm,

the Boneyard/Burnyard, and the SL $1 \ldots \ldots \ldots \ldots \ldots \ldots \ldots \ldots \ldots \ldots \ldots \ldots \ldots$ A4-8

A.6 Locations of trenches, oil disposal pits, standpipes, and the

isolation area in BG-A North and BG-A South . . . . . . . . . . . . . . . A4-9

A.7 Locations of trenches, oil disposal pits, standpipes, and the

isolation area in BG-B, $-C,-D,-E$, and $-J$, and the Walk-In Pits ........... A4-10

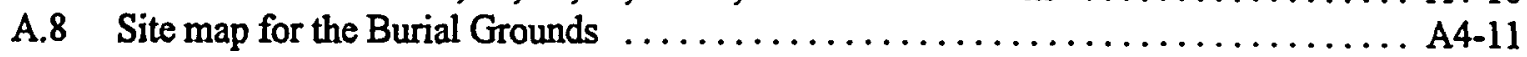

A.9 Estimated uranium concentrations in Burial Grounds $\ldots \ldots \ldots \ldots \ldots \ldots \ldots \ldots$ A4-12

B.1 Historical sampling sites in Bear Creek Valley . . . . . . . . . . . . . B10-3

B.2 Locations of OU 1 sampling activities at the $S-3$ Site $\ldots \ldots \ldots \ldots \ldots \ldots \ldots \ldots$. . . . . . . .

B.3 Locations of OU 1 sampling activities at BYBY, Oil Landfarm, and SL $1 \ldots \ldots \ldots$ B10-6

B.4 Locations of $\mathrm{OU} 1$ sampling activities at $\mathrm{BCBG} \ldots \ldots \ldots \ldots \ldots \ldots \ldots \ldots \ldots \ldots \ldots$

B.5 Locations of OU 4 sampling activities in $\mathrm{BCV} \ldots \ldots \ldots \ldots \ldots \ldots \ldots \ldots \ldots \ldots \ldots$

B.6 Surface water and groundwater sampling locations for August 1995

radiological sampling task in $\mathrm{BCV} \ldots \ldots \ldots \ldots \ldots \ldots \ldots \ldots \ldots \ldots \ldots \ldots \ldots$ B 0 -10

B.7 Surface water hydrographs showing flow during sampling periods for samples 2 through 7 at $\mathrm{BCK} 12.38 \mathrm{~N}$ Tunnel .......................... B10-11

B.8 Surface water hydrographs showing flow during sampling periods for samples 8 through 11,13 , and 17 at BCK $12.38 \mathrm{~N}$ Tunnel ............. B10-12

B.9 Surface water hydrographs showing flow during sampling periods for samples 18 through 21 at BCK $12.38 \mathrm{~N}$ Tunnel ....................... B10-13

B.10 Surface water hydrographs showing flow during sampling periods for samples 1 through 6 at BCK $12.38 \mathrm{~S}$ Tunnel ......................... B10-14

B.11 Surface water hydrographs showing flow during sampling periods for samples 7 through 12 at BCK 12.38 S Tunnel ......................... B10-15

B.12 Surface water hydrographs showing flow during sampling periods for samples $13,14,16$ through 19 at BCK 12.38 S Tunnel ................. B10-16

B.13 Surface water hydrographs showing flow during sampling periods for samples 20 and 21 at BCK $12.38 \mathrm{~S}$ Tunnel ........................... 10 10

B.14 Surface water hydrographs showing flow during sampling periods for samples 1 through 6 at NT-2 .............................. B10-18

B.15 Surface water hydrographs showing flow during sampling periods for samples 7 through 12 at NT-2 ............................ B10-19

B.16 Surface water hydrographs showing flow during sampling periods for

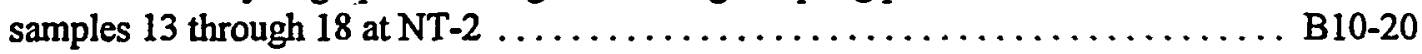

B.17 Surface water hydrographs showing flow during sampling periods for samples 19 through 21 at NT-2 .............................. B10-21

B.18 Surface water hydrographs showing flow during sampling periods for samples 1 through 6 at NT-3 
B.18 Surface water hydrographs showing flow during sampling periods for samples 1 through 6 at NT-3

B.19 Surface water hydrographs showing flow during sampling periods for samples 7 through 9 and 14 through 16 at NT-3 .................... $10-23$

B.20 Surface water hydrographs showing flow during sampling periods for samples $17,18,20$, and 21 at NT-3 ............................. $10-24$

B.21 Surface water hydrographs showing flow during sampling periods for

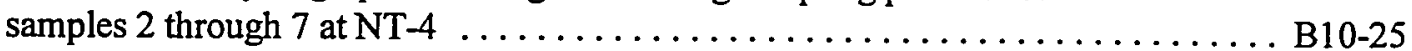

B.22 Surface water hydrographs showing flow during sampling periods for

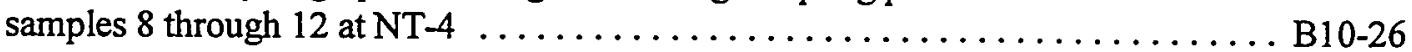

B.23 Surface water hydrographs showing flow during sampling periods for samples 1 through 6 at NT-5 ............................ B10-27

B.24 Surface water hydrographs showing flow during sampling periods for

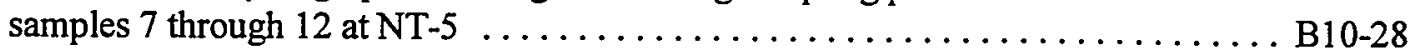

B.25 Surface water hydrographs showing flow during sampling periods for sample 13 at NT-5 ................................. B10-29

B.26 Surface water hydrographs showing flow during sampling periods for

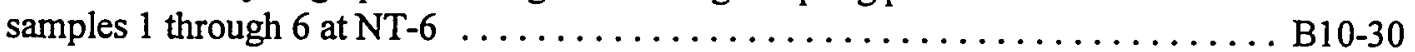

B.27 Surface water hydrographs showing flow during sampling periods for samples 7,8 , and 12 through 15 at NT $-6 \ldots \ldots \ldots \ldots \ldots \ldots \ldots \ldots \ldots \ldots \ldots \ldots$ B 0.31

B.28 Surface water hydrographs showing flow during sampling periods for samples 18 through 21 at NT-6 ............................ B10-32

B.29 Surface water hydrographs showing flow during sampling periods for

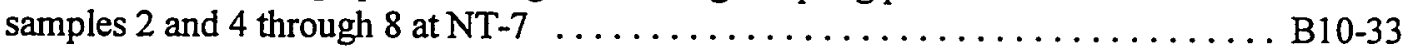

B.30 Surface water hydrographs showing flow during sampling periods for samples 9 through 14 at NT-7 . . . . . . . . . . . . . . . . . . B10-34

B.31 Surface water hydrographs showing flow during sampling periods for samples 15 through 17 , and 20 and 21 at NT $-7 \ldots \ldots \ldots \ldots \ldots \ldots \ldots \ldots \ldots$ B $0-35$

B.32 Surface water hydrographs showing flow during sampling periods for samples 2 through 5 , and 9 and 10 at NT-8 ......................

B.33 Surface water hydrographs showing flow during sampling periods for samples 11 and 12 at NT-8 ............................. $10-37$

B.34 Surface water hydrographs showing flow during sampling periods for samples 1 through 6 at BCK $9.47 \ldots \ldots \ldots \ldots \ldots \ldots \ldots \ldots \ldots \ldots \ldots \ldots \ldots . \ldots \ldots$ B 0.38

B.35 Surface water hydrographs showing flow during sampling periods for samples 7 through 12 at BCK $9.47 \ldots \ldots \ldots \ldots \ldots \ldots \ldots \ldots \ldots \ldots . \ldots \ldots$ B $0-39$

B.36 Surface water hydrographs showing flow during sampling periods for samples 14 through 18 , and 22 at BCK $9.47 \ldots \ldots \ldots \ldots \ldots \ldots \ldots \ldots \ldots$ B10-40

B.37 Surface water hydrographs showing flow during sampling periods for

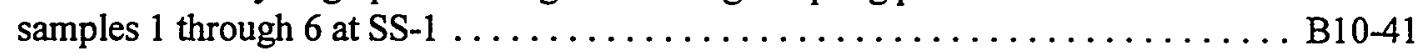

B.38 Surface water hydrographs showing flow during sampling periods for

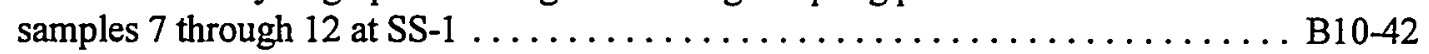

B.39 Surface water hydrographs showing flow during sampling periods for sample 13 at SS-1 ................................ $10-43$

B.40 Surface water hydrographs showing flow during sampling periods for samples 1 through 6 at SS-4 ............................ B10-44

B.41 Surface water hydrographs showing flow during sampling periods for samples 7 through 12 at SS-4 . 
B.42 Surface water hydrographs showing flow during sampling periods for sample 13 at SS-4

B.43 Surface water hydrographs showing flow during sampling periods for samples 1 through 3 and 5 through 7 at SS-5

B.44 Surface water hydrographs showing flow during sampling periods for samples 8 through 13 at SS-5

B.45 Surface water hydrographs showing flow during sampling periods for samples 1,3 , and 6 through 9 at SS- 6

B.46 Surface water hydrographs showing flow during sampling periods for samples 10,12 , and 13 at SS-6

B.47 Diagrammatic representation of the method for calculating flow from stage at $\mathrm{BCK} 12.38$

B.48 Rating curve for BCK 9.47

.. B10-52

B.49 Flowchart outlining sampling activities for BCV Floodplain soils investigation ... . . B10-53

B.50 Locations of Floodplain soils sampling activities in BCV ............. B10-55

B.51 Summary of samples collected for the BCV OU 4 RI field activities by

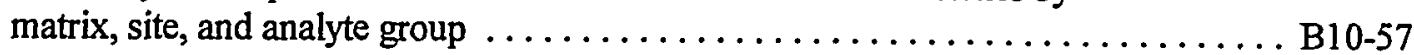

B.52 Summary of samples taken for the BCV OU 1 RIFA by matrix, site, and analyte group...

B.53 Summary of samples taken for the FPSS field activities by matrix, site, and analyte group

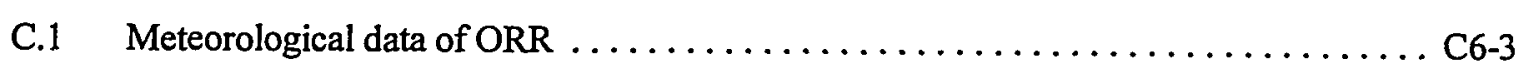

C.2 Map of BCV showing topography, named tributaries, and springs $\ldots \ldots \ldots \ldots \ldots$ C6-5

C.3 Geological map of BCV and surrounding areas $\ldots \ldots \ldots \ldots \ldots \ldots \ldots \ldots \ldots \ldots . . \ldots \ldots$

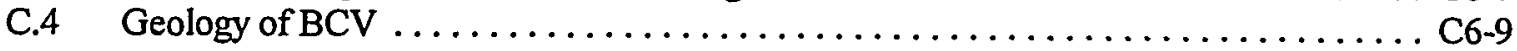

C.5 Along-strike section of Maynardville Limestone in BCV $\ldots \ldots \ldots \ldots \ldots \ldots \ldots$ C6-10

C.6 Structural cross section of the Oak Ridge area ................... C6-11

C.7 Hydraulic head, fractures, and fracture characteristics in Nolichucky

Shale from GW-726 and GW-727 ........................ C6-12

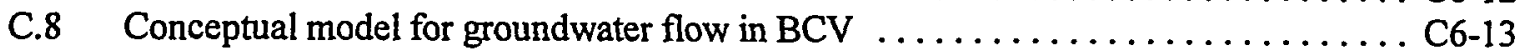

C.9 A schematic showing conceptual shallow groundwater flow for BCV . . . . . . . C6-14

C.10 Water balance model for BCV above BCK $9.47 \ldots \ldots \ldots \ldots \ldots \ldots \ldots \ldots$ C6-15

C.11 BCV groundwater elevations for January 10-13, 1994-groundwater piezometric head in BCV for water table and bedrock intervals during high-flow season . . . . C6-17

C.12 BCV groundwater elevations for August 23-31, 1994-groundwater piezometric head in BCV for water table and bedrock intervals during low-flow season . . . . . . C6-19

C.13 Hydrologic cross section in strike-perpendicular section showing detailed hydraulic head measurements from four coreholes (GW-132,

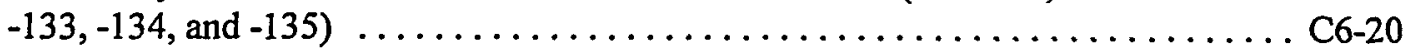

C.14 Hydraulic gradients in the Nolichucky Shale and Maynardville Limestone in BCV

C.15 Water-type regimes in a strike-perpendicular cross section of $\mathrm{BCV} \ldots \ldots \ldots \ldots \ldots$ C6-22

C.16 Piper diagram illustrating groundwater geochemistry in $\mathrm{BCV} \ldots \ldots \ldots \ldots \ldots \ldots$ C6-23

C.17 Reaction path model for groundwater in BCV .................... C6-24

C.18 Stream hydrograph from BCK 9.47 from March 1994 to January $1995 \ldots \ldots$. . . . C6-25

C.19 Variation of head from instantaneous measurement in GW-227 and GW-228 . . . C C6-26

C.20 Hydraulic head monitoring in wells GW-624, -626 , and -629 in the Nolichucky Shale 
C.21 Well hydrographs for GW-725 and GW-726 at BYBY, and for GW-227 and

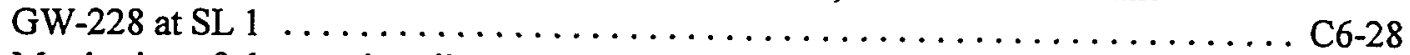

C.22 Monitoring of changes in soil saturation, stream flow, and groundwater at the BCBG for a storm on April 15, 1994 .

C.23 Monitoring of changes in soil saturation, stream flow, and groundwater at the S-3 Site during storms on July 26-28, 1994

C.24 Example well hydrographs for the water table interval of the

Nolichucky Shale

C.25 Hydraulic head monitoring in wells at the Western Picket in the Maynardville Limestone

C.26 Relative magnitudes of $\lambda$ for stream flow, stormflow tubes, and groundwater in $\mathrm{BCV}$

C.27 Identification of gaining and losing reaches in Bear Creek during a high-baseflow period in April 1994

C.28 Identification of gaining and losing reaches in Bear Creek during a low-baseflow period in April 1994

C.29 West-East profiles of Bear Creek showing flow and conductivity during the high and low baseflow spring and seep surveys (low-flow profile - September 1994 and high-flow profile - March 1995)

C.30 Well hydrograph and specific conductivity for GW-045 at depth of

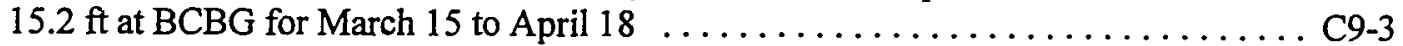

C.31 Well hydrograph and specific conductivity for GW-053 at depth of $39.7 \mathrm{ft} \ldots \ldots \ldots$ C9-4

C.32 Well hydrograph and specific conductivity for GW-076 at depth of

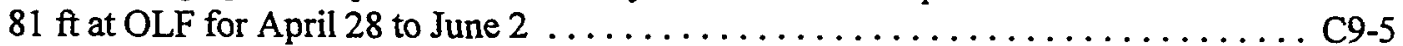

C.33 Well hydrograph for GW-085 at depth of $62 \mathrm{ft}$ at OLF for

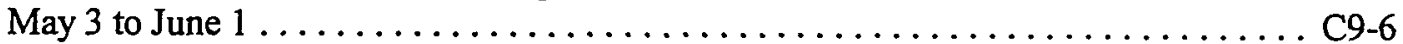

C.34 Well hydrograph and specific conductivity for GW-086 at depth of

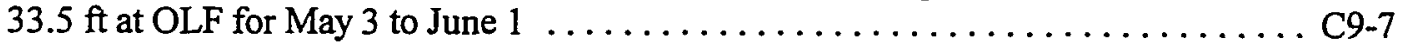

C.35 Well hydrograph and specific conductivity for GW-094 at depth of

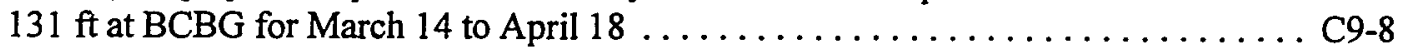

C.36 Well hydrograph and specific conductivity for GW-095 at depth of

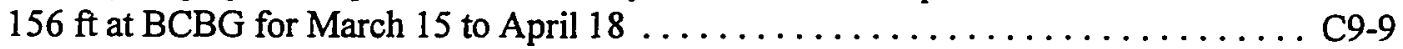

C.37 Well hydrograph and specific conductivity for GW-101 at depth of

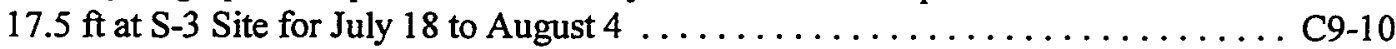

C.38 Well hydrograph for GW-101 at depth of $17.5 \mathrm{ft}$ at S-3 Site for

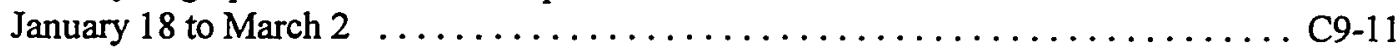

C.39 Well hydrograph for GW-122 at depth of $92 \mathrm{ft}$ at S-3 Site for

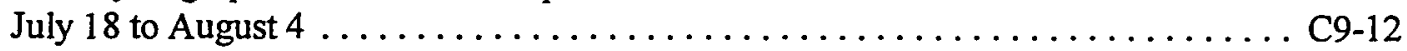

C.40 Well hydrograph for GW-124 at depth of $100 \mathrm{ft}$ at S-3 Site for

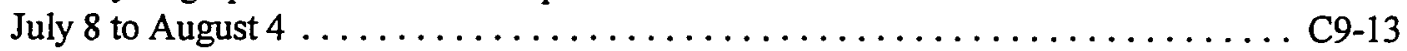

C.41 Well hydrograph for GW-126 at depth of $105 \mathrm{ft}$ at BCBG for

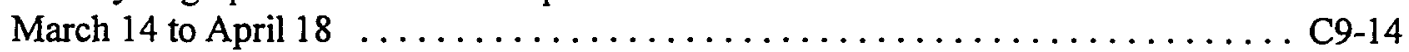

C.42 Well hydrograph for GW-127 at depth of $24.0 \mathrm{ft}$ at S-3 Site for

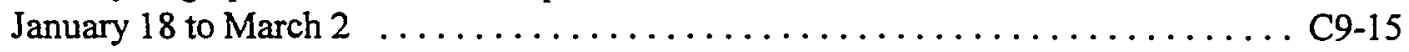

C.43 Well hydrograph and specific conductivity for GW-227 at depth of

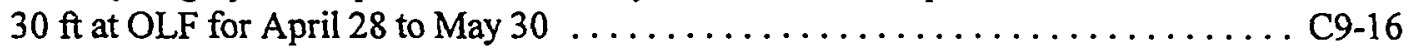

C.44 Well hydrograph and specific conductivity for GW-228 at depth of $80 \mathrm{ft}$ at OLF for April 27 to May 29 
C.45 Well hydrograph for GW-276 at depth of $18.5 \mathrm{ft}$ at S-3 Site for

February 3 to March 2

C.46 Well hydrograph and specific conductivity for GW-345 at depth of

$26 \mathrm{ft}$ at S-3 Site for July 8 to August 4

C.47 Well hydrograph and specific conductivity for GW-346 at depth of $65 \mathrm{ft}$ at S-3 Site for April 29 to June 3

C.48 Well hydrograph and specific conductivity for GW-526 at depth of

$101 \mathrm{ft}$ at S-3 Site for April 28 to June 2

C.49 Well hydrograph and specific conductivity for GW-537 at depth of $24.5 \mathrm{ft}$ at OLF for May 3 to May 30

C.50 Well hydrograph and specific conductivity for GW-616 at depth of $219 \mathrm{ft}$ at S-3 Site for July 8 to August 4

C.51 Well hydrograph, specific conductivity, and temperature for GW-624 for March 15 to April 18

C.52 Well hydrograph and specific conductivity for GW-626 at depth of

$78 \mathrm{ft}$ at BCBG for March 19 to April 18

C.53 Well hydrograph and specific conductivity for GW-629 at depth of $262 \mathrm{ft}$ at BCBG for March 14 to April 18

C.54 Well hydrograph and specific conductivity for GW-651 at depth of $52 \mathrm{ft}$ at BCBG for March 14 to April 18

C.55 Well hydrograph for GW-710 at depth of $539 \mathrm{ft}$ at Western Picket for November 1 to January 4

C.56 Well hydrograph for GW-711 at depth of $616 \mathrm{ft}$ at Western Picket for

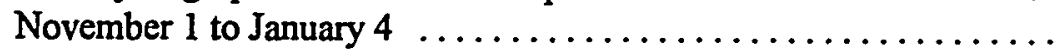

C.57 Well hydrograph for GW-712 at depth of $451 \mathrm{ft}$ at Western Picket for

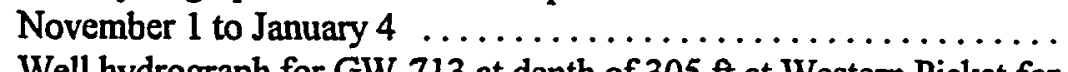

C.58 Well hydrograph for GW-713 at depth of $305 \mathrm{ft}$ at Western Picket for November 1 to January 4

C.59 Well hydrograph for GW-714 at depth of $113 \mathrm{ft}$ at Western Picket for November 3 to January 4

C.60 Well hydrograph for GW-715 at depth of $75 \mathrm{ft}$ at Western Picket for November 3 to January 4

C.61 Well hydrograph and specific conductivity for GW-725 at depth of $132.5 \mathrm{ft}$ at OLF for May 2 to June 3 .

C.62 Well hydrograph and specific conductivity for GW-736 at depth $102 \mathrm{ft}$ at OLF for May 2 to June 2

C.63 Well hydrograph for S3-1 at depth of $11.5 \mathrm{ft}$ at S-3 Site for January 17 to March 2

C.64 Well hydrograph for S3-3 at depth of $6.0 \mathrm{ft}$ at S-3 Site for January 18 to March 2 .

C.65 Well hydrograph for S3-5 at depth of $12.0 \mathrm{ft}$ at S-3 Site for January 18 to March 2 .

C.66 Well hydrograph for S3-6 at depth of $18.8 \mathrm{ft}$ at S-3 Site for

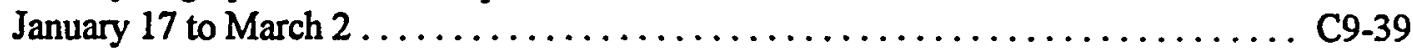

C.67 Well hydrograph for S3-7 at depth of $27.9 \mathrm{ft}$ at S-3 Site for

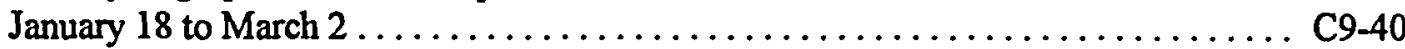

C.68 Well hydrograph for S3-8 at depth of $95 \mathrm{ft}$ at S-3 Site for January 18 to March 2 . 
C.69 Well hydrographs for GW-526 and GW-346 at S-3 Site and for GW-085 and GW-086 at BYBY

C.70 Well hydrographs for GW-045 and GW-095 at BCBG ............... C9-43

C.71 Well hydrographs for GW-094, GW-122, and GW-124 plotted in semi-log space

C.72 Hydrographs from stormflow tubes SFT 1, SFT 2, and SFT 3 from April to October 1994 .

C.73 Hydrographs from stormflow tubes SFT 4, SFT 5, and SFT 6 from April to October 1994 


\section{PLATES}

A.1 Upper Bear Creek and the Y-12 Plant, circa $1947 \ldots \ldots \ldots \ldots \ldots \ldots \ldots \ldots \ldots$. $\ldots \ldots \ldots$

A.2 Upper Bear Creek, circa late 1980 s .......................... A5-3

A.3 Ponds during neutralization and bionitrification, circa $1983 \ldots \ldots \ldots \ldots \ldots \ldots$ A5-5

A.4 Ponds during closure, filling, and structural stabilization,

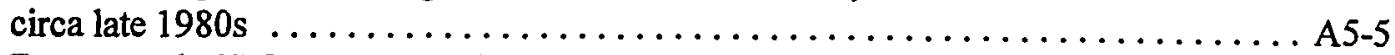

A.5 Foreground: OLF area HCDA in operation, with small percolation pond in SW corner. Background: OLF, SL 1, and NT-3, circa $1980 \mathrm{~s} \ldots \ldots \ldots \ldots \ldots \ldots$. . . . . $5-7$

A.6 Trench, possibly located at BYBY ......................... A5-7

A.7 Burial Grounds, circa 1980s. (Note possible uranium fire in the BG-D area) . . . . A A5-9

A.8 Unidentified trench in BG-A South, circa 1980s. (Note the heat haze

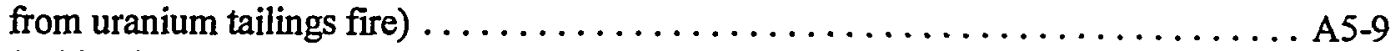

A.9 Unidentified trench in BG-A South, circa 1980s. (Note burn pit in foreground

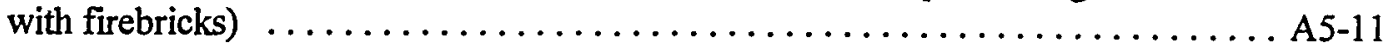

A.10 Unidentified trench, probably located in area $\mathrm{D}, \mathrm{E}$, or $\mathrm{J} \ldots \ldots \ldots \ldots \ldots \ldots \ldots$ A5-11

A.11 ORP-1 (Burial Grounds), circa 1980s. Picture taken after draining the pond

during closure operation. Equipment in background is oil/water separator . . . . A A5-13

B.1 Photograph showing the floodplain soil sample at transect $2 \ldots \ldots \ldots \ldots \ldots \ldots$ B11-3

B.2 Photograph showing the floodplain soil sample at transect $3 \ldots \ldots \ldots \ldots \ldots \ldots$ B11-3 



\section{TABLES}

A.1 Sites considered in this RI report that are listed in the FFA

or have been identified as solid waste management units . . . . . . . . . A6-3

A.2 Chronological list of events at the $S-3$ Ponds $\ldots \ldots \ldots \ldots \ldots \ldots \ldots$ A6-6

A.3 Source term characterization for $S-3$ Site $\ldots \ldots \ldots \ldots \ldots \ldots \ldots \ldots \ldots$ A6-9

A.4 Chronological list of events at the Oil Landfarm . . . . . . . . . . . . A A6-11

A.5 Summary of waste coolant disposals at Y-12 Plant Oil Landfarm . . . . . . . . A6-13

A.6 Summary of waste oil disposals at the Y-12 Plant Oil Landfarm . . . . . . . . . A6-14

A.7 OLF storage pad soil data summary . . . . . . . . . . . . . . A6-15

A.8 OLF soils-in-place analytical results summary . . . . . . . . . . . . A6-17

A.9 Chronological list of events at the Boneyard/Burnyard . . . . . . . . . A A6-18

A.10 Chronological list of events at SL $1 \ldots \ldots \ldots \ldots \ldots \ldots \ldots$ A6-19

A.11 Chronological list of events at the Burial Grounds . . . . . . . . . . A6-20

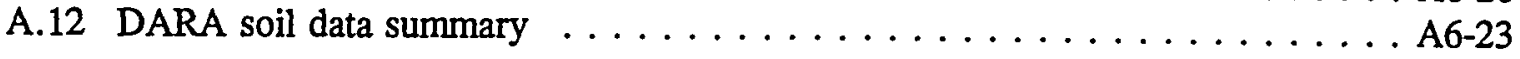

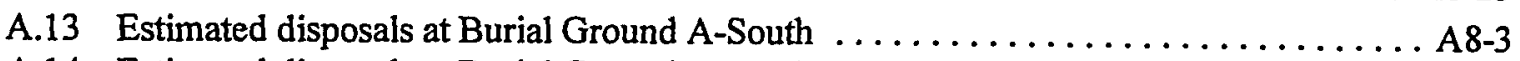

A.14 Estimated disposals at Burial Ground A-North $\ldots \ldots \ldots \ldots \ldots \ldots \ldots \ldots \ldots \ldots \ldots \ldots \ldots$

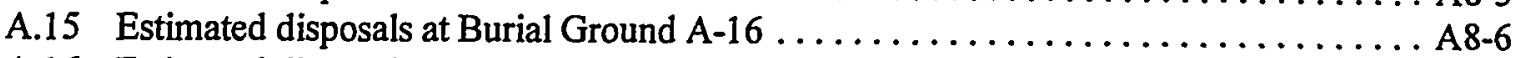

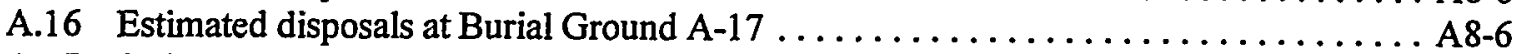

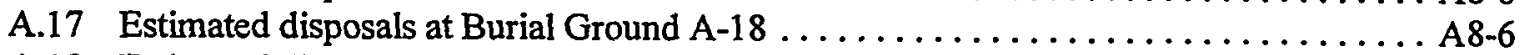

A.18 Estimated disposals at Burial Ground B $\ldots \ldots \ldots \ldots \ldots \ldots \ldots \ldots \ldots \ldots \ldots \ldots \ldots \ldots \ldots \ldots$

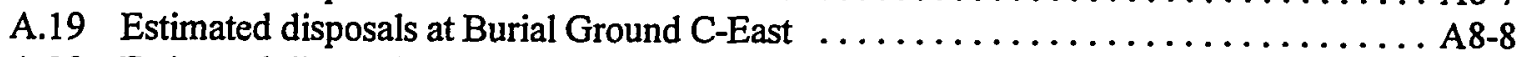

A.20 Estimated disposals at Burial Ground C-West $\ldots \ldots \ldots \ldots \ldots \ldots \ldots \ldots \ldots \ldots \ldots \ldots \ldots$

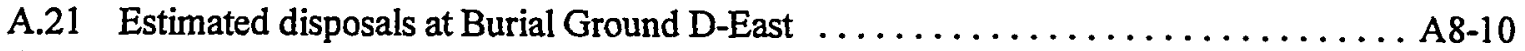

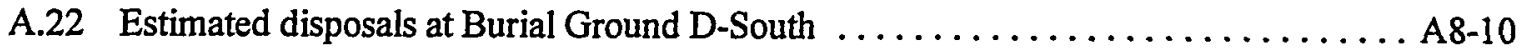

A.23 Estimated disposals at Burial Grounds $\mathrm{D}$-West, $\mathrm{E}$, and $\mathrm{J} \ldots \ldots \ldots \ldots \ldots \ldots \ldots \ldots \ldots$

A.24 Estimated disposals at Burial Ground Walk-In Pit 1 (North) .............. A8-11

A.25 Estimated disposals at Burial Ground Walk-In Pits 2 and 3 (South) $\ldots \ldots \ldots \ldots$. . A8-14

A.26 BG-A - Summary of recorded disposals and removals . . . . . . . . . . . A

A.27 Summary of estimated uranium quantities by Burial Grounds area $\ldots \ldots \ldots \ldots$ A8-16

B.1 Historical data from special studies, subcontractor sampling events, and

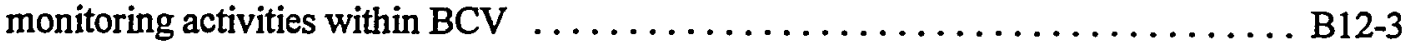

B.2 Summary of number of samples per analyte per project and medium ......... B12-24

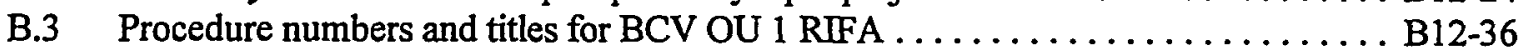

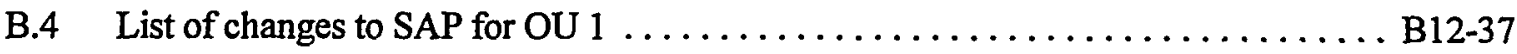

B.5 List of analytes and reported quantitation limits for surface and subsurface

soils in BCV OU 1 ...................................... $12-40$

B.6 Geotechnical and physical parameters for soil samples taken in

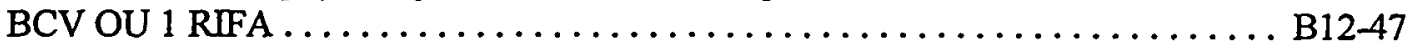

B.7 List of analytes and reported quantitation limits for groundwater and

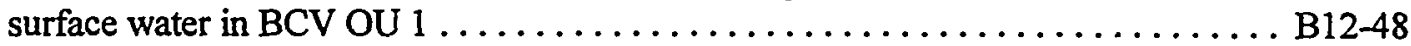

B.8 Groundwater sample intervals for groundwater collected during

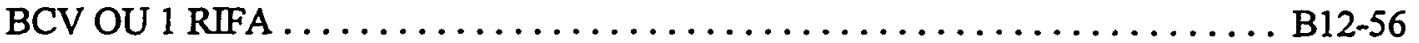

B.9 Technical sampling procedures used during BCV OU 4 RIFA $\ldots \ldots \ldots \ldots \ldots . . \ldots 12-57$

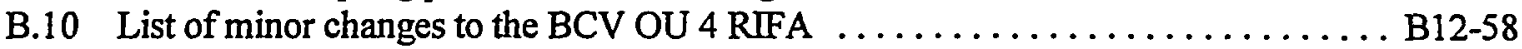

B.11 List of activities completed for BCV OU 4 RIFA $\ldots \ldots \ldots \ldots \ldots \ldots \ldots \ldots \ldots \ldots \ldots \ldots$ 
B.12 List of analytes and reported quantitation limits for surface water

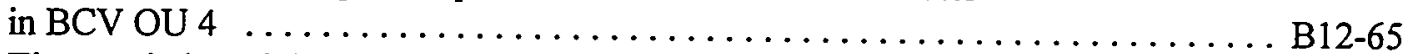

B.13 Time periods and the stage to flow conversions for each surface water site

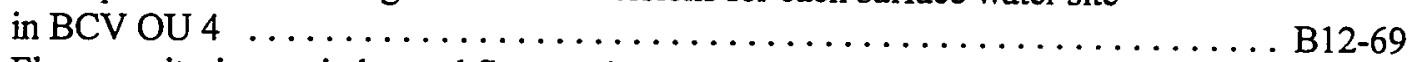

B.14 Flow monitoring periods, total flow, and average flow for the

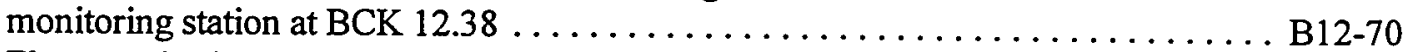

B.15 Flow monitoring periods, total flow, and average flow for the

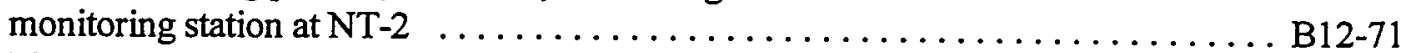

B.16 Flow monitoring periods, total flow, and average flow for the

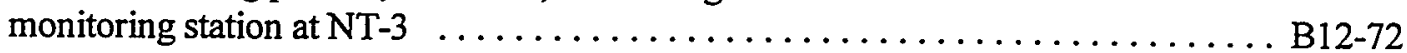

B.17 Flow monitoring periods, total flow, and average flow for the

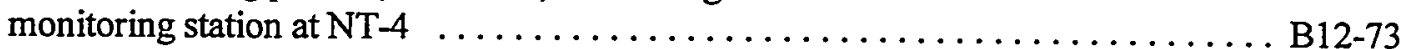

B.18 Flow monitoring periods, total flow, and average flow for the monitoring station at NT-5

B.19 Flow monitoring periods, total flow, and average flow for the monitoring station at NT-6

B.20 Flow monitoring periods, total flow, and average flow for the monitoring station at NT-7

B.21 Flow monitoring periods, total flow, and average flow for the monitoring station at NT-8

B.22 Flow monitoring periods, total flow, and average flow for the monitoring station at BCK 9.47 .

B.23 Flow monitoring periods, total flow, and average flow for the monitoring station at SS-1

B.24 Flow monitoring periods, total flow, and average flow for the monitoring station at SS-4

B.25 Flow monitoring periods, total flow, and average flow for the monitoring station at SS-5

B.26 Flow monitoring periods, total flow, and average flow for the

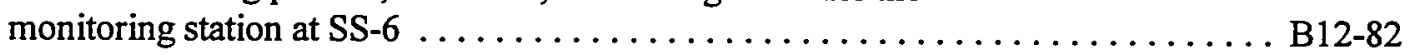

B.27 Rating curve for Bear Creek at BCK $9.47 \ldots \ldots \ldots \ldots \ldots \ldots \ldots \ldots \ldots \ldots \ldots \ldots \ldots . \ldots \ldots$

B.28 List of monitoring wells and monitoring periods for BCV OU 4 RIFA

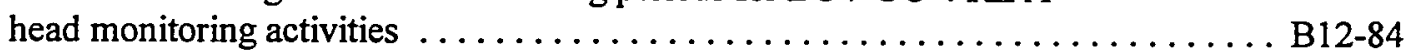

B.29 List of minor changes to the BCV FPSS field activities . . . . . . . . . . . B12-86

B.30 Large-scale characterization sample location and analysis matrix $\ldots \ldots \ldots \ldots \ldots . . . . . .12-88$

B.31 List of analytes and reported quantitation limits for soils and sediment in BCV FPSS ..................................... B12-89

B.32 Fine-scale characterization, stream sediment and soil reference, sample location, and analysis matrices . . . . . . . . . . . . $12-95$

B.33 Technical sampling procedures used in the course of BCV Floodplain

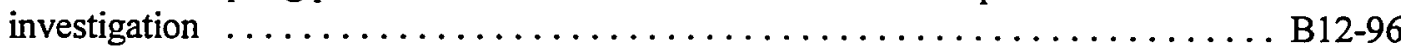

B.34 Technical procedures for collection of BCV biota samples . . . . . . . . . . . B12-97

B.35 Biota samples collected for the BCV RI . . . . . . . . . . . . . . . . B12-98

B.36 Summary of analytical methods used for the GWQR dataset . . . . . . . . . . B 12-99

B.37 Minimum and maximum non-detects for groundwater in the $\mathrm{S}-3$ aggregate ..... B12-101

B.38 Minimum and maximum non-detects for groundwater

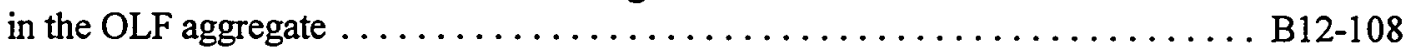

B.39 Minimum and maximum non-detects for groundwater in the BCBG aggregate 
B.40 Minimum and maximum non-detects for groundwater in the Maynardville aggregate . . . . . . . . . . . . . B12-120

B.41 Analyses eliminated for use due to high total suspended solids, sodium, or chloride $\ldots \ldots \ldots \ldots \ldots \ldots \ldots \ldots \ldots \ldots \ldots \ldots \ldots \ldots \ldots \ldots \ldots \ldots \ldots \ldots \ldots, 12-124$

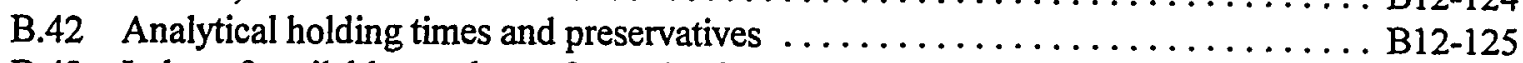

B.43 Index of available numbers of samples from each source and media providing qualitative or quantitative information $\ldots \ldots \ldots \ldots \ldots \ldots$ B12-126

B.44 Audits and surveillances of Bear Creek field activities .............. B12-127

B.45 SPARCC parameter criteria for BCV OU 4, OU 1, and FPSS projects ........ B12-132

B.46 Accuracy in the BCV OU 4, OU 1, and FPSS datasets ............... B12-133

B.47 Overall precision in the BCV RI dataset ........................ B12-134

B.48 BCV OU 4 samples that may have been mis-identified during analysis $\ldots . . .612-135$

B.49 Data usability in the BCV OU 4, OU 1, and FPSS datasets ....... B12-136

C.1 Thickness of zones identified in the Maynardville Limestone $\ldots \ldots \ldots \ldots \ldots \ldots$ C $7-3$

C.2 Valley-wide summary of results from the BCV and Grassy Creek spring and

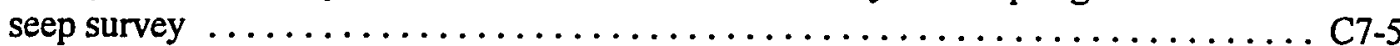

C.3 Vertical hydraulic gradients in the Nolichucky Shale in BCV .............. C10-3

C.4 Analysis of selected well hydrographs in BCV $\ldots \ldots \ldots \ldots \ldots \ldots \ldots \ldots \ldots \ldots, C 10-5$

C.5 Analysis of selected stream hydrographs in BCV $\ldots \ldots \ldots \ldots \ldots \ldots \ldots \ldots . C 10-6$

C.6 Analysis of selected stormflow tube hydrographs in $\mathrm{BCV} \ldots \ldots \ldots \ldots \ldots \ldots \ldots$ C10-7 


\section{ACRONYMS AND ABBREVIATIONS}

\section{APPENDIX A}

$\begin{array}{ll}\text { BCBG } & \text { Bear Creek Burial Grounds } \\ \text { BCV } & \text { Bear Creek Valley } \\ \text { BYBY } & \text { Boneyard/Burnyard } \\ \text { CA } & \text { Characterization Area } \\ \text { CERCLA } & \text { Comprehensive Environmental Response, Compensation, and Liability Act } \\ \text { DARA } & \text { Disposal Area Remedial Action } \\ \text { DOE } & \text { Department of Energy } \\ \text { Energy Systems } & \text { Lockheed Martin Energy Systems, Inc. } \\ \text { EPA } & \text { Environmental Protection Agency } \\ \text { HCDA } & \text { Hazardous Chemical Disposal Area } \\ \text { HWDU } & \text { Hazardous Waste Disposal Unit } \\ \text { MOU } & \text { Memorandum of Understanding } \\ \text { OLF } & \text { Oil Landfarm } \\ \text { ORP } & \text { Oil Retention Pond } \\ \text { ORR } & \text { Oak Ridge Reservation } \\ \text { PCB } & \text { polychlorinated biphenyl } \\ \text { ppb } & \text { parts per billion } \\ \text { ppm } & \text { parts per million } \\ \text { RCRA } & \text { Resource Conservation and Recovery Act } \\ \text { RI } & \text { Remedial Investigation } \\ \text { SL 1 } & \text { Sanitary Landfill 1 } \\ \text { TDEC } & \text { Tennessee Department of Environment and Conservation } \\ \text { WIP } & \text { Walk-In Pits } \\ & \end{array}$

\section{APPENDIX B}

$\begin{array}{ll}\text { ADNCR } & \text { Analytical Data Non-Conformance Report } \\ \text { AFI } & \text { area for further investigation } \\ \text { ASTM } & \text { American Society for Testing and Materials } \\ \text { ATV } & \text { all-terrain vehicle } \\ \text { BCBG } & \text { Bear Creek Burial Grounds } \\ \text { BCK } & \text { Bear Creek Kilometer } \\ \text { BCV } & \text { Bear Creek Valley } \\ \text { BEIDMS } & \text { Bechtel Environmental Information Data Management System } \\ \text { bgs } & \text { below ground surface } \\ \text { BNI } & \text { Bechtel National, Inc. } \\ \text { BSCP } & \text { Background Soil Characterization Project } \\ \text { BYBY } & \text { Boneyard/Burnyard } \\ \text { CA } & \text { Characterization Area } \\ \text { CLP } & \text { Contract Laboratory Program } \\ \text { DQO } & \text { data quality objective } \\ \text { Energy Systems } & \text { Lockheed Martin Energy Systems, Inc. } \\ \text { EPA } & \text { Environmental Protection Agency }\end{array}$




$\begin{array}{ll}\text { FPSS } & \text { floodplain soil/sediment } \\ \text { GFAA } & \text { graphite furnace atomic absorption } \\ \text { GWPP } & \text { Groundwater Protection Program } \\ \text { GWQR } & \text { Groundwater Quality Report } \\ \text { HCDA } & \text { Hazardous Chemical Disposal Area } \\ \text { ICP } & \text { inductively coupled plasma } \\ \text { NCR } & \text { non-conformance report } \\ \text { NT } & \text { North Tributary } \\ \text { OLF } & \text { Oil Landfarm } \\ \text { ORNL } & \text { Oak Ridge National Laboratory } \\ \text { ORP } & \text { Oil Retention Pond } \\ \text { OU } & \text { Operable Unit } \\ \text { PCB } & \text { polychlorinated biphenyl } \\ \text { RI } & \text { Remedial Investigation } \\ \text { RPD } & \text { relative percent difference } \\ \text { SAP } & \text { Sampling and Analysis Plan } \\ \text { SAIC } & \text { Science Applications International Corporation } \\ \text { SL 1 } & \text { Sanitary Landfill 1 } \\ \text { SPARCC } & \text { sensitivity, precision, accuracy, representativeness, completeness } \\ & \text { and comparability } \\ \text { SVOC } & \text { semivolatile organic compound } \\ \text { USGS } & \text { U.S. Geological Survey } \\ \text { USRADS } & \text { Ultrasonic Ranging and Data System } \\ \text { VOC } & \text { volatile organic compound }\end{array}$

\section{APPENDIX C}

$\begin{array}{ll}\text { amsl } & \text { above mean sea level } \\ \text { BCBG } & \text { Bear Creek Burial Grounds } \\ \text { BCHR } & \text { Bear Creek Hydrogeologic Regime } \\ \text { BCK } & \text { Bear Creek Kilometer } \\ \text { BCV } & \text { Bear Creek Valley } \\ \text { bgs } & \text { below ground surface } \\ \text { BYBY } & \text { Boneyard/Burnyard } \\ \text { cfs } & \text { cubic foot/second } \\ \text { GWPP } & \text { Groundwater Protection Program } \\ \text { GWQR } & \text { Groundwater Quality Report } \\ \text { NT } & \text { North Tributary } \\ \text { ORR } & \text { Oak Ridge Reservation } \\ \text { ORRHAGS } & \text { ORR Hydrology and Geology Studies } \\ \text { OU } & \text { Operable Unit } \\ \text { ppb } & \text { parts per billion } \\ \text { RI } & \text { Remedial Investigation } \\ \text { RIFA } & \text { RI Field Activities } \\ \text { SL 1 } & \text { Sanitary Landfill 1 } \\ \text { TDS } & \text { total dissolved solids }\end{array}$




\section{EXECUTIVE SUMMARY}

This Remedial Investigation (RI) Report characterizes the nature and extent of contamination, evaluates the fate and transport of contaminants, and assesses risk to human health and the environment resulting from waste disposal and other U.S. Department of Energy (DOE) operations in Bear Creek Valley (BCV). BCV, which is located within the DOE Oak Ridge Reservation (ORR) (Fig. ES.1), encompasses multiple waste units containing hazardous and radioactive wastes arising from operations at the adjacent Oak Ridge Y-12 Plant (Fig. ES.2). The primary waste units discussed in this RI Report are the S-3 Site, Oil Landfarm (OLF), Boneyard/Burnyard (BYBY), Sanitary Landfill 1 (SL 1), and Bear Creek Burial Grounds (BCBG). These waste units, plus the contaminated media resulting from environmental transport of the wastes from these units, are the subject of this RI.

Consistent with the Watershed Approach to remedial investigation/feasibility study (RI/FS) planning adopted by the Oak Ridge Federal Facility Agreement (FFA) parties, the environmental media and waste sites in BCV have been combined into a single Characterization Area (CA) encompassing the entire Bear Creek watershed. The benefits of this approach have included:

- a significantly reduced site investigation phase, with more reliance on historical data as the basis for remedial action decisions;

- development of more consistent Remedial Goal Options (RGOs) across the multiple source units;

- an increased focus on development of an integrated prioritization for remedial actions, particularly for sites appropriate for near-term actions; and

- an overall reduction in cost and schedule for the RI/FS process.

Accordingly, the BCV RI Report documents and interprets the results of numerous historical field characterization efforts conducted in BCV prior to 1994 as well as three limited RI field projects covering specific portions of the watershed in 1994 and 1995. This interpretation provides a comprehensive evaluation of the conditions at and risks associated with the waste sites, associated floodplain, and groundwater in the valley.

Inherent in the accelerated watershed approach is the heavy reliance on historical data to form the basis of the RI. For BCV, a significant historical data set existed, thus minimal effort was spent by the watershed $R I$ team in gathering additional extent of contamination information. While this -approach greatly reduces the schedule and cost of the $\mathrm{RI}$, it does result in higher levels of uncertainty in the evaluation results. The likelihood of important data gaps in the BCV RI was minimized by adherence to the Data Quality Objective (DQO) process during the planning phase, and by proactive uncertainty management during the data collection and evaluation phases. The resulting FS will accommodate the identified uncertainties through selection of contingent actions that will allow for flexibility within the remedy selection.

This BCV RI Report represents the first major step in the decision-making process for the BCV watershed. The RI results, in concert with the follow-on FS (to be available for public review in April 1997), will form the basis for the Proposed Plan and Record of Decision for all BCV sites. This comprehensive decision document process will meet the objectives of the watershed approach for 

-........ REACH 1 OF BEAR CREEK REACH 2 OF BEAR CREEK NT-3 To BCK -9.40 REACH 3 OF BEAR CREEK
BCK -9.47 to ET-4 REACH 4 OF BEAR CREEK
ET-4 to EFPC GROUNDWATER WELL (individual wells not
G.... labeled unless mentioned in text.) $. \ldots \ldots \ldots . . .$. labeled unless mentioned in text.) TS1. SOIL TRANSECT LOCATION
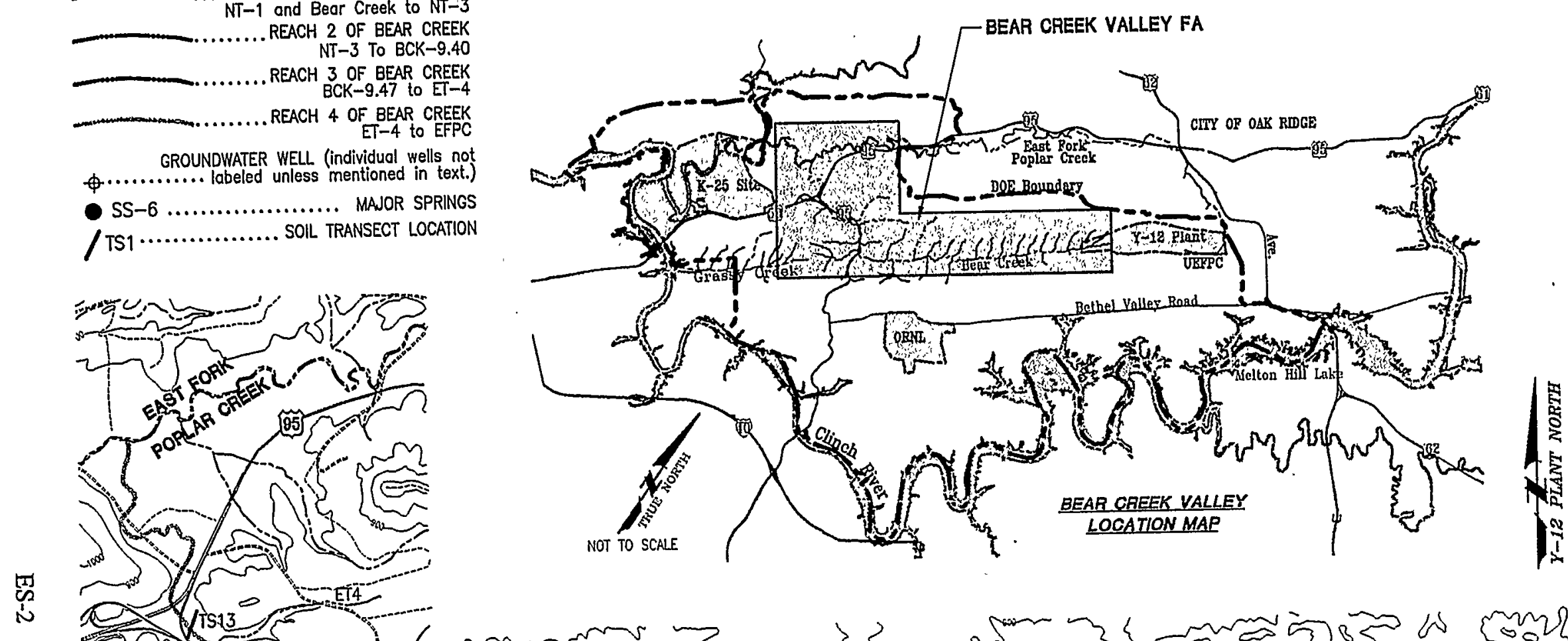

is

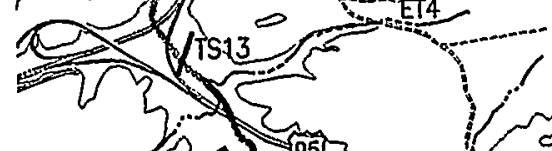

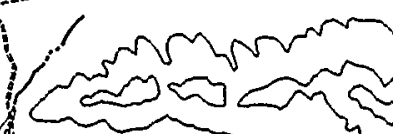

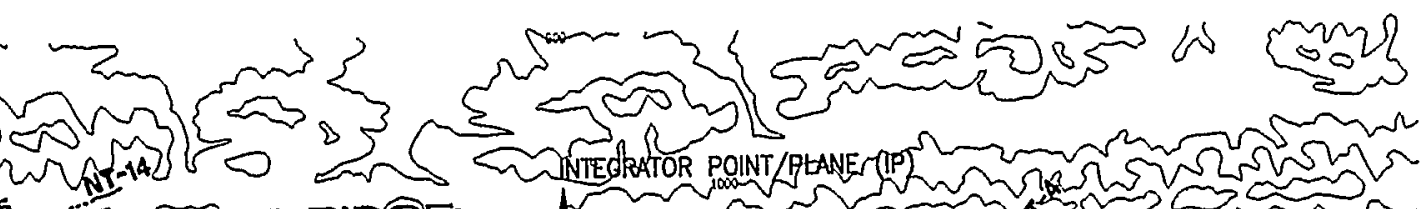
Wh W (n) Figure ES.1. Location map for the Bear Creek Valley Characterization Area showing major geographical and hydrological features. 


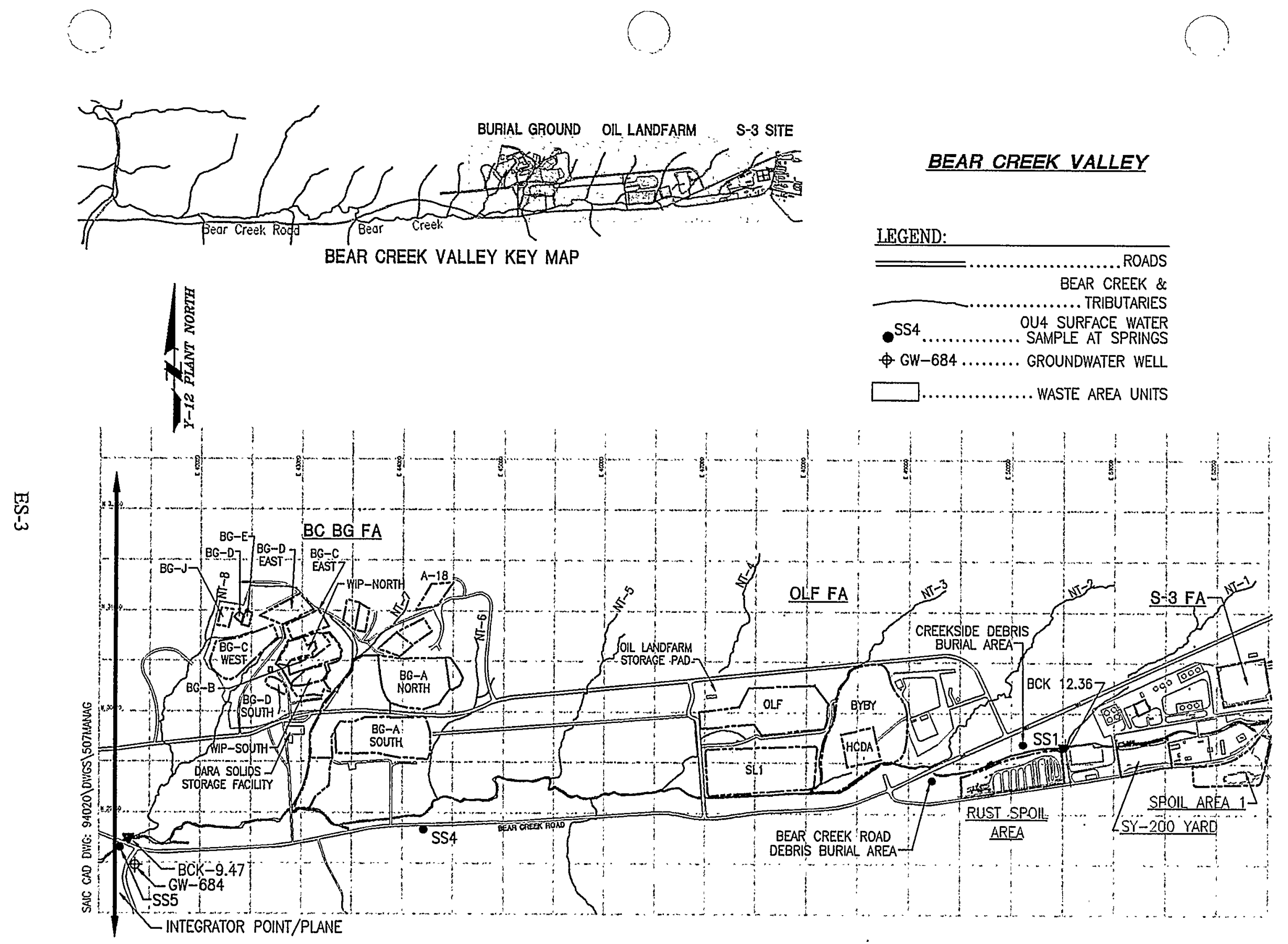

Figure ES.2. Location map for waste areas in the Bear Creek Valley Characterization Area. 
BCV, which include: (1) prioritization of remedial action decisions, (2) expeditious implementation of highest priority remedial actions, and (3) increased cost effectiveness of remedial action by setting watershed Remedial Action Objectives (RAOs) based on an integrated, valley-wide, future land use plan. By conducting the evaluation within the watershed framework, DOE can ensure consistent actions that achieve the RAOs across all the units and cost effectively optimize the extent and type of remedies, regardless of location.

\section{ES.1 MAJOR CONCLUSIONS FOR THE RI REPORT}

The BCV RI Report contains a detailed analysis of environmental data for BCV. The major conclusions from the analysis are conveyed via conceptual models for the nature and extent of contamination and fate and transport of contaminants. Common to each of the major waste units located on the north side of Bear Creek are the following major conclusions:

- There are a number of physical and chemical aspects of the source sites that will complicate cleanup of the sources areas and will limit the ability to allow unrestricted, e.g., residential or industrial, use at these sites (S-3 Site, BYBY, and the BCBG). These are:

- large volumes of buried waste exist at each source area in unlined trenches;

- portions of the waste at each source area are inundated by shallow groundwater;

- groundwater at the sources is contaminated to over $120 \mathrm{~m}(400 \mathrm{ft})$ depth and dense non-aqueous phase liquid (DNAPL) is present; at the S-3 Site and BCBG, contamination in groundwater is a secondary source that is of equal or greater magnitude than the primary waste source; and

- the sources are situated on low permeability, fractured shale rock. Diffusion of contaminated groundwater into the rock pores has resulted in a reservoir of contaminated groundwater that can only be released from the rock at a slow rate.

- Contaminants migrating from the waste sites in BCV converge at Bear Creek Kilometer (BCK) 9.47/South Spring (SS)-5 (Fig. ES.1): more than 99\% of available water from the upper portion of the valley passes through this location as either surface water or groundwater. Thus a north-south line drawn at BCK $9.47 / \mathrm{SS}-5$ is a convenient location to conduct an integrator point/plane (IP) assessment of contaminant fluxes from the waste areas (Note: in some of the FS alternatives, unrestricted land use starts to the west of this line). At the IP, potential risks from exposure to groundwater or surface water exceed $10^{-6}$ or a Hazard Index (HI) $>1$ (Fig ES.3). The chemicals of concern (COCs) at the IP are uranium, nitrate, boron, and fluoride. In addition, applicable or relevant and appropriate requirements (ARARs) for nitrate are exceeded in groundwater at the IP and also most likely for uranium (Note: uranium contamination in GW-684 at the IP does not exceed the ARAR; however, groundwater discharge at SS-5 periodically exceeds the uranium ARAR). Although it is not clear how far the elevated hazard and ARAR exceedances extend to the west, they do not extend as far as Highway 95.

- Contaminated groundwater at waste areas migrates along geological strike to nearby tributaries of Bear Creek [i.e., North Tributary (NT) $-1,-2,-3,-6,-7$, and -8] causing the tributaries and Bear Creek to become contaminated. This is the principal exit pathway for contaminants leaving the waste areas and moving to the IP. Figure ES.3 shows what sources and tributaries contribute the most to contamination at the IP. The S-3 Site (NT-1, NT-2, and Bear Creek above 


\section{Potential Risks and Toxic Effects at the Integrator Plane}

\section{BCK 9.4/SS-5 Aggregate}

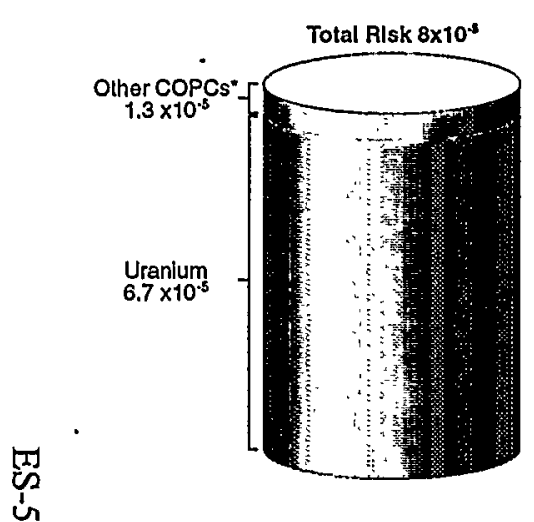

GW 684 Groundwater

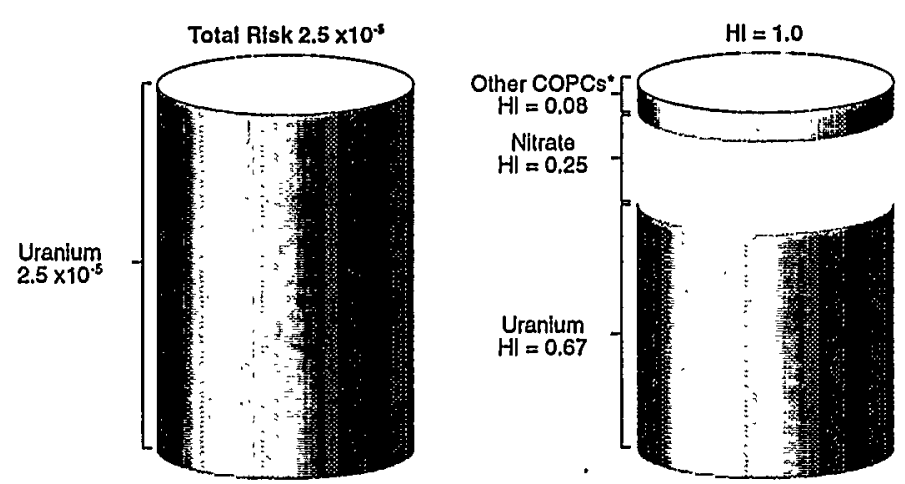

${ }^{*}$ COPCs not listed individually have individual potential risk $<10^{-5}$ or $\mathrm{HI}<0.1$
Relative Contribution of Uranium and Nitrate at the IP from Source Areas

\section{Uranium Flux}

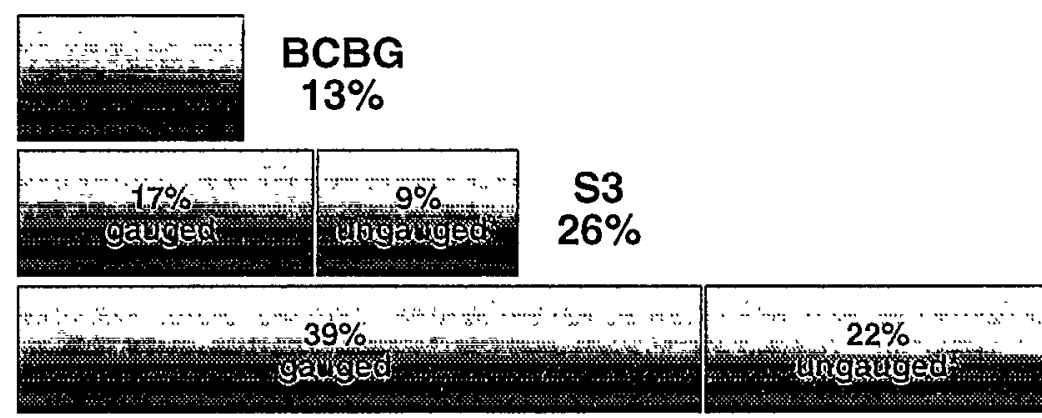

BYBY

$61 \%$

"Assumed distribution of ungauged flux is $70 \%$ BYBY, $30 \%$ S-3 Site.

\section{Nitrate Flux}

\begin{tabular}{|l|l|l|}
\hline $\begin{array}{l}\text { other } \\
6 \%\end{array}$ \\
\hline \hline \begin{tabular}{l|l|} 
NT-1/Bear Creek \\
$54 \%$
\end{tabular} & \begin{tabular}{c|c} 
NT-2 \\
$11 \%$
\end{tabular} & $29 \%$ \\
\hline
\end{tabular}

Figure ES.3. Potential risks and hazards at the Integrator point/plane and the relative magnitude of the sources for nitrate and uranium. 
BCK 12.36) and BYBY (NT-3) sites are currently contributing more than $80 \%$ of the potential hazard at the IP through releases of uranium and, to a lesser extent, nitrate. The total flux from NT-1 and NT-2 is expected to increase in the foreseeable future and may result in a greater hazard at the IP. A 50 to $75 \%$ reduction in the current contaminant flux through tributaries or shallow groundwater at the S-3 Site and BYBY could reduce the total HI at the IP below 0.8 .

- Discharges to surface water from a plume of contaminated groundwater at the S-3 Site are the primary causes of current impacts on the aquatic ecology in Bear Creek, east of BCK 9.47.

- Impacts of contamination at waste areas have been lessened by capping waste areas. In addition, seep collection at BCBG has lessened the downgradient impact of contamination migrating away from this source.

\section{ES.2 BCV HYDROGEOLOGICAL CONCEPTUAL MODEL}

The hydrogeological system in BCV is governed by the valley's geology. Rocks underlying BCV fall into two broad categories: those that are dominated by clastic lithologies (e.g., Nolichucky Shale) and those that are predominantly carbonates (e.g., Maynardville Limestone). The primary permeability of the rocks underlying BCV is very low. The formations are extensively fractured and, in the case of carbonate formations, karstified, creating a secondary porosity that results in substantially increased permeability.

Groundwater flows through fractures or solution conduits, which are well-connected and mostly parallel to geological strike (Fig. ES.4). Fracture aperture width generally decreases with depth, restricting the depth of active groundwater circulation. The shallow interval [top $30 \mathrm{~m}(100 \mathrm{ft})$ ] of the Maynardville Limestone contains a well-connected maze of conduits that is able to transport water rapidly along strike, west in the axis of $\mathrm{BCV}$. Groundwater in this interval is closely connected to flow in Bear Creek. Below $30 \mathrm{~m}(100 \mathrm{ft})$ in this formation, along strike flow occurs through discrete solution conduits and fractures that are not as well-interconnected than those in the shallow interval.

The Nolichucky Shale is the principal clastic formation that forms the northern flank of BCV. Most groundwater flow in the clastic formations occurs during and immediately following precipitation at the water table and shallow bedrock intervals [probably $<15 \mathrm{~m}(50 \mathrm{ft})$ depth]. Flow is predominantly along strike, and discharge is to tributaries of Bear Creek after short flowpaths. During storms, flow in these shallow intervals may be rapid (up to $40 \mathrm{~m} / \mathrm{d}$ ).

As a result of predominantly short and shallow flow paths for groundwater in the clastic formations in $\mathrm{BCV}$, although the largest mass of water (and consequently the largest mass of contaminants) exits BCV via surface water, groundwater is the principal pathway for contaminants leaving the waste units. The main flow and contaminant transport pathways in groundwater at the waste units are along strike with the discharge points at tributaries to Bear Creek. Fluxes in flow paths at the waste units (overland flow, soil interflow, and groundwater flow) have not been quantified but recharge followed by groundwater flow to tributaries constitutes the main water flux pathway. During a 10 -month surface water monitoring program, an estimated $97 \%$ of water available for flow (precipitation and evapotranspiration) exited the section of the valley above BCK 9.47 as surface water flow. 


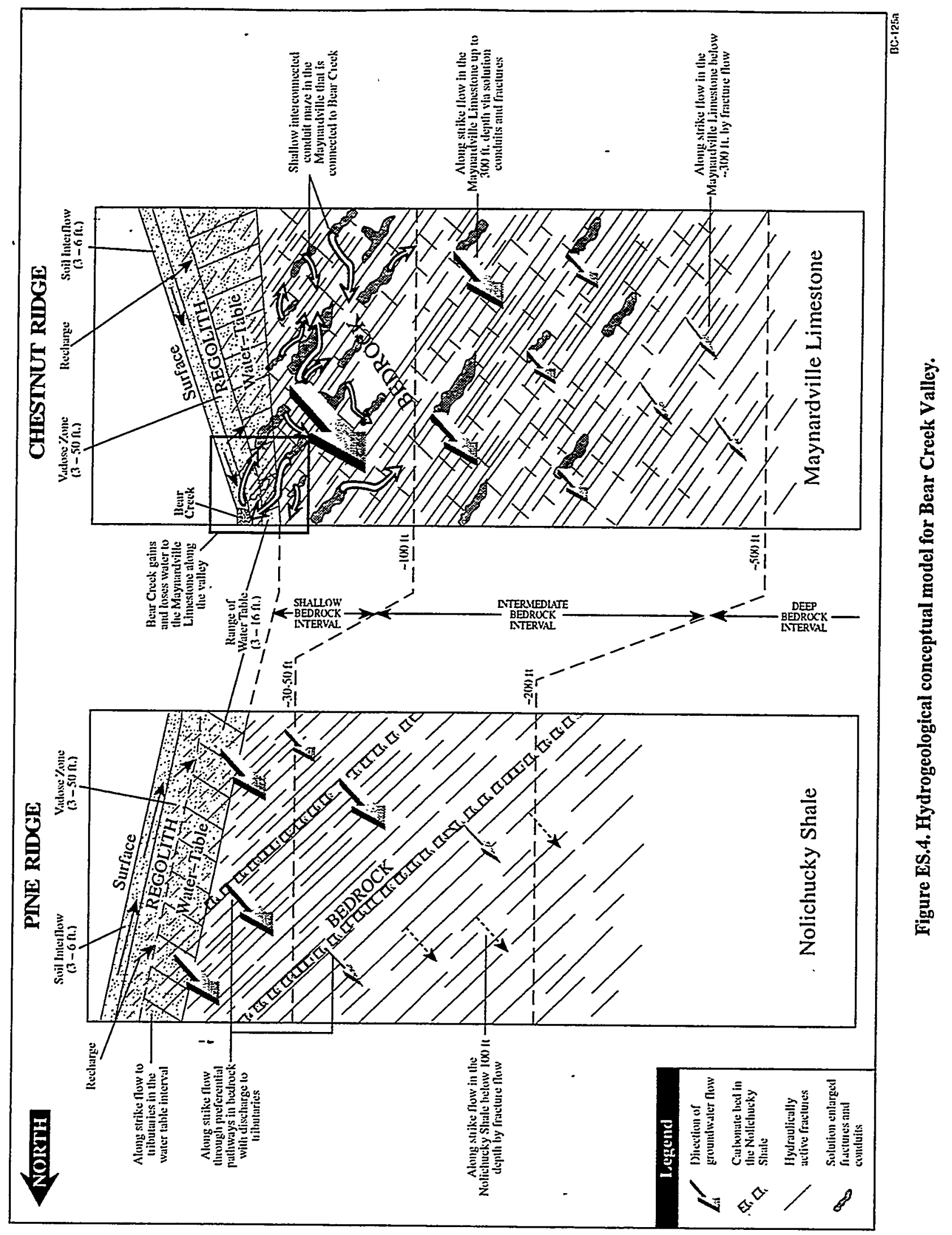

ES-7 


\section{ES.3 NATURE AND EXTENT OF CONTAMINATION}

\section{ES.3.1 Environmental Database}

The environmental database used for the BCV RI includes 75,000 soil, sediment, groundwater, surface water, and biota analyses obtained during the RI field projects conducted during 1994 and 1995 , and 20,000 soil, sediment, groundwater, and surface water analyses obtained from historical field studies conducted in the 1980s and early 1990s. A detailed data quality assessment review demonstrated that the quality of both the recent and historical chemical data is adequate: $<1 \%$ of the recent data were considered unacceptable, and only $1.3 \%$ of the historical chemical data were rejected. Historical radiological data for groundwater were deemed unacceptable for use in the RI and the Human Health Risk Assessment, therefore, additional groundwater samples were taken during the RI to complete the radiological database.

\section{ES.3.2 Waste Sites}

The primary waste sites characterized in this BCV RI report are the S-3 Site, OLF, BYBY, SL 1, and BCBG (Fig. ES.2). Three other primary waste sites within BCV - Spoil Area 1, Rust Spoil Area, and SY-200 Yard - are discussed in the BCV OU 2 RI (Energy Systems 1995). Although these sources were described in the BCV OU 2 RI Report, the watershed approach dictates that their impacts on the environment in BCV are considered in this report. In addition, numerous smaller waste disposal or storage areas throughout BCV, such as the OLF Storage Containment Pad, Bear Creek Road Debris Burial area, and Creekside Debris Burial area, are also considered as potential contaminant sources.

During the $\mathrm{DQO}$ process for $\mathrm{BCV}$, the $\mathrm{RI}$ team decided that direct sampling to characterize the waste materials was not feasible (DQO meeting minutes). Instead, the physical and chemical characteristics of the contaminant sources were derived from interpretation of historical data and information in waste management records: pre-closure sampling data were used to quantify waste contamination at the S-3 Ponds and OLF sites; a detailed waste inventory was used for BCBG; and data from recent (1994) soil sampling were used for BYBY and SL 1. Where possible, current conditions within each source area were estimated to allow modeling of the potential future releases and assessment of current and future risks.

The waste areas in BCV are located in the upper $3.5 \mathrm{~km}$ (2.2 miles) of the valley (east of the IP) (Fig ES.2). Both solid and liquid wastes were disposed of at these sites. Most liquid waste has either infiltrated to groundwater below the waste sites or has migrated in groundwater and surface water away from the source areas. The following volumes of waste, contaminated soil, and contaminated groundwater are estimated to be present in BCV (Note: volume estimates for soils and wastes do not include materials in waste area caps):

$\begin{array}{ll}\text { S-3 Site } & 1,600 \mathrm{~m}^{3} \text { waste and contaminated soils } \\ & 7.1 \times 10^{6} \mathrm{~m}^{3}(5740 \text { acre- } \mathrm{ft}) \text { contaminated groundwater } \\ \text { Oil Landfarm } & 25,000 \mathrm{~m}^{3} \text { waste and contaminated soils } \\ \text { BYBY } & 90,000 \mathrm{~m}^{3} \text { waste and contaminated soils } \\ & 0.4 \times 10^{6} \mathrm{~m}^{3}(320 \text { acre- } \mathrm{ft}) \text { contaminated groundwater }\end{array}$


In addition, there is an estimated $5.7 \times 10^{6} \mathrm{~m}^{3}$ (4600 acre- $\mathrm{ft}$ ) of contaminated groundwater in the Maynardville Limestone, and $<1,000 \mathrm{~m}^{3}$ of contaminated soils and waste materials on the $\mathrm{BCV}$ floodplain.

\section{ES.3.3 Nature and Extent of Contamination in Environmental Media and Wastes}

The data available for the BCV CA were divided into four functional areas (FAs), each of which contains data that are logically interpreted together because of location and/or contaminant source. Three of the FAs - the S-3 FA, the OLF FA, and the BCBG FA - include data that relate to the three primary waste areas (Fig. ES.2). The fourth FA is the Maynardville Limestone and Bear Creek FA, which is located downgradient of the source FAs and acts as an integrated exit pathway for contaminants migrating away from the source units, via groundwater in the Maynardville Limestone or surface water flow in Bear Creek.

\section{S-3 Functional Area}

The S-3 FA includes the soils, groundwater, and surface water at and immediately downgradient of the S-3 Site.

Sources and contaminants. At the S-3 Site FA, primary contaminant sources are (1) a plume of contaminated groundwater derived from infiltration of nitric acid waste water and density-driven flow downward into bedrock, and (2) sludges remaining in place in the former ponds. Thirty years of disposal of concentrated ( 1 molar) nitric acid solutions at the S-3 Site has resulted in a reservoir of contaminated groundwater with high $(>10,000 \mathrm{mg} / \mathrm{L})$ total dissolved solids (TDS) in the Nolichucky Shale at this site. Discharge of groundwater from this contaminated plume results in contaminated surface water with elevated TDS (maximum $>1000 \mathrm{mg} / \mathrm{L}$ ).

Contamination derived from the S-3 Site can be identified in the Maynardville Limestone as far west as Picket $W$ and in surface water at BCK 4.55. Primary contaminants that have migrated away from the S-3 Site include (1) nitrate, uranium, ${ }^{99} \mathrm{Tc}$, barium, boron, cadmium, strontium, acetone, and tetrachloroethene (PCE) in groundwater, and (2) nitrate, cadmium, uranium, and ${ }^{99} \mathrm{Tc}$ in surface water. Contaminant concentrations in groundwater at the S-3 Site exceed ARARs for inorganic and organic chemicals in drinking water.

S-3 Site conceptual model. At the S-3 Site, contaminated groundwater in the Nolichucky Shale is the main source of contaminants to downgradient receptors: more contaminant mass flux is discharging to the creek than is leaching from waste materials that remain in the former ponds. Historically, during operations at the S-3 Ponds, most of the acidic waste water probably migrated rapidly to the main stem of Bear Creek, NT-1, and Upper East Fork Poplar Creek via shallow groundwater flow. At the present time, contaminants in this plume are migrating in shallow and deep groundwater and discharging to Bear Creek, NT-1, and NT-2 (Fig. ES.5). 


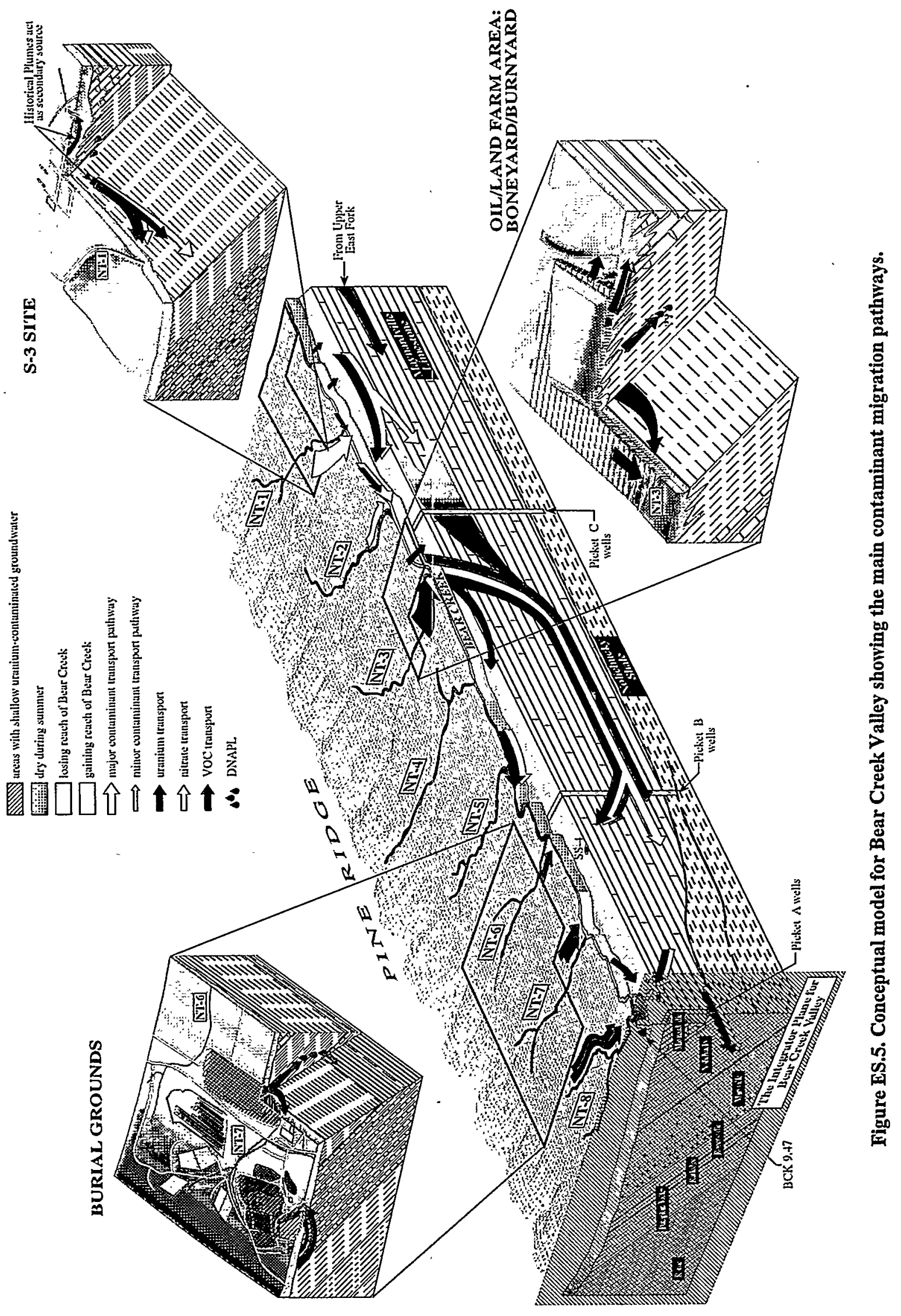

ES-10 
Contaminants have undergone differential retardation that has resulted in different distributions and exit pathways for the primary contaminants: nitrate, metals, uranium, ${ }^{99} \mathrm{Tc}$, and PCE. Uranium and some metals are made relatively immobile by geochemical reactions and have been held up in the residuum and shallow groundwater close to the S-3 Site. The exit pathway for these contaminants is via discharge of shallow groundwater to Bear Creek. Nitrate, ${ }^{99} \mathrm{Tc}, \mathrm{PCE}$, and the more mobile metals have contaminated bedrock groundwater. The main pathway for these contaminants is along strike flow in the intermediate and deep groundwater intervals, followed by upwelling and/or diffusion to the shallow groundwater interval and discharge to NT-1 and NT-2. Nitrate is least retarded and has traveled the farthest from the S-3 Site - its occurrence in groundwater marks the maximum extent of contamination resulting from the S-3 Site.

All contaminants in groundwater at the S-3 Site have been retarded by matrix diffusion. A reservoir of contaminants in the matrix porosity now exists at the S-3 Site, where these contaminants flow and/or diffuse from the rock matrix into the active flow fractures in each pathway.

The maximum concentrations of PCE found at S-3 Site ( $>1 \%$ of PCE solubility) indicate the potential for PCE bearing DNAPL in the bedrock formations beneath the ponds.

The plume of contaminated groundwater derived from the S-3 Site can be traced in the Nolichucky Shale as far west as NT-2. However, although the extent west of the plume in shallow groundwater is well known, no data points exist until downgradient of SL 1 to identify the leading edge of the plume in intermediate and deep groundwater. Increasing concentrations of nitrate in shallow wells near the NT-2 catchment over the past 10 years suggest that the center of mass of the nitrate plume may be moving along strike to the west in groundwater below $30 \mathrm{~m}(100 \mathrm{ft})$ depth. The probable condition is that the plume in deep groundwater extends no further west than the plume in shallow groundwater and that much of the contaminant mass flux in the plume is discharged to NT-2.

\section{Oil Landfarm Functional Area}

The OLF FA encompasses the soils, groundwater, and surface water at and immediately downgradient of four sites: OLF, BYBY, Hazardous Chemicals Disposal Area (HCDA), and SL 1.

Sources and contaminants. Both solid and liquid wastes were disposed of at the OLF FA. There are three primary locations of solid wastes: (1) buried waste materials at BYBY, (2) buried waste materials in the SL 1 trench, and (3) contaminated soils on the former OLF plots. In addition, disposals of liquid wastes at BYBY, HCDA, and OLF have resulted in plumes of volatile organic compound (VOC) -contaminated groundwater.

Contamination at the OLF FA is diverse, including metal, radionuclide, and VOC contamination in groundwater, surface water, soils, and waste materials. Frequently detected contaminants in the OLF FA are as follows:

- At BYBY and HCDA: (1) mercury, beryllium, manganese, nickel, vanadium, PCE, trichloroethene (TCE), 1,2-dichloroethene (DCE), and uranium isotopes in groundwater; (2) mercury, lithium, and uranium isotopes in surface water; and (3) mercury, cadmium, copper, polyaromatic hydrocarbons (PAHs), polychlorinated biphenyls (PCBs), phthalates, uranium isotopes, and ${ }^{99} \mathrm{Tc}$ in soils. 
- At OLF: (1) PCBs and uranium in soils and wastes, and (2) 1,1,1-trichloroethane (TCA), 1,1-dichloroethane (DCA), 1,1-DCE, 1,2-DCE, PCE, and TCE in groundwater. There is no surface water contamination that can be attributed to OLF.

- At SL 1: (1) mercury, copper, nickel, PCB-1254, and ${ }^{235} U$ in soils and wastes, and (2) 1,1-DCA, $1,2-D C E$, and vinyl chloride in groundwater. There is no surface water contamination that can be attributed to SL 1.

OLF FA conceptual model. The conceptual models for both OLF and SL 1 are that soils surrounding the waste sites are relatively uncontaminated. Groundwater below and immediately downgradient of each waste area is contaminated with VOCs as a result of liquid waste disposals.

At BYBY, uranium leaches from waste materials (some of which are most likely inundated with groundwater) and contaminated soils to groundwater, which subsequently discharges to surface water in NT-3. Uranium in groundwater that has leached from fill material in the southern portion of BYBY probably migrates directly to the Maynardville Limestone and Bear Creek via shallow groundwater flow (Fig. ES.5). Fate and transport modeling indicates that most inorganic and radiological contaminants in NT-3 have probably reached peak concentrations; however, the presence of a continuous source (leaching from waste materials) suggests that these peak values would be maintained over several hundred years.

The VOC plume at BYBY is partly located in residuum above the Maynardville Limestone and, like uranium, VOCs probably migrate directly into the Maynardville Limestone or Bear Creek. Although VOCs entering groundwater from 'HCDA or the Burnyard may discharge to surface water in NT-3, the extent of this discharge is low, hence, VOCs volatilize almost immediately.

\section{Bear Creek Burial Grounds Functional Area}

Sources and contaminants. At the BCBG FA, both solid and liquid wastes were disposed of in a series of unlined trenches. The waste trenches are grouped into areas $B G-A,-B,-C,-D,-F$, and Walk-in-Pits (WIP). Uranium dominates the wastes disposed of in each area with a total estimated mass of 18.6 million $\mathrm{Kg}$. Disposals of liquid wastes have also resulted in DNAPL (PCE and TCE) in groundwater that may have reached depths of $180 \mathrm{~m}(600 \mathrm{ft})$. Dissolution of DNAPL results in plumes of VOC-contaminated groundwater.

Contamination in the BCBG FA includes VOCs and metals in groundwater, and VOCs, metals, and radionuclides in surface water, soils, waste materials, and leachate from waste trenches. In general, organic contamination of environmental media at BCBG is more widespread than inorganic and radionuclide contamination. Primary contaminants detected at the BCBG are: (1) boron, PCE, TCE, 1,1,1-TCA, and 1,2-DCE in groundwater; (2) beryllium, 1,1,2-TCA, 1,1-DCE, 1,2-DCA, vinyl chloride, 1,1-DCA, 1,1,1-TCA, chloroethane, and uranium isotopes in surface water; (3) arsenic, vanadium, PCBs, acetone, and toluene in soils surrounding the waste areas; and (4) uranium, beryllium, PCBs, TCE, and PCE in wastes. Contaminant concentrations in groundwater at BCBG exceed ARARs for inorganic and organic chemicals in drinking water at many locations.

Contamination of groundwater and surface water is dominated by VOCs at the BCBG FA. Three groundwater plumes were identified: (1) the BG-A plume is dominated by PCE, TCE, and 1,2-DCE, and includes DNAPL; (2) the WIP plume is dominated by PCE; and (3) the plume at the NT-8 catchment is dominated by $1,2-\mathrm{DCE}$, with lesser concentrations of vinyl chloride. 
Radiological contamination is virtually absent from groundwater wells in the BCBG, but uranium is consistently detected in surface water. Collection of leachate in the NT-7 and NT-8 catchments has significantly reduced the concentration of radiological and other contaminants in surface water.

Radiological contamination occurs in soils in the NT-8 floodplain and is probably related to past deposition of contaminated sediments derived from drainage of the $B G-B,-C$, and $-D$ areas.

BCBG conceptual model. The distribution of contaminants at $B C B G$ reflects the type of waste materials that were disposed. The organic wastes were dense liquids and were disposed of directly into groundwater; uranium is in the solid form and is slowly leaching from trenches. The dominance of the hydrogeologic system by shallow flow restricts inorganic and radionuclide contamination to short flow paths in the shallow groundwater interval, whereas the density-driven flow of DNAPL provides a mechanism for organic contamination to enter the shallow, intermediate, and deep bedrock intervals (Fig. ES.5).

Oils and solvents were disposed of in the BG-A area by pouring the liquids into standpipes in debris- and waste-filled trenches. The bulk of these liquids migrated laterally to surface water and downward to groundwater, ultimately reaching depths of up to $180 \mathrm{~m}(600 \mathrm{ft})$ as DNAPL. Free-phase liquids occur in bedrock and probably remain in the trenches as residual droplets that have adhered to waste materials and minerals. Dissolved VOCs in the BG-A and NT-8 plumes have undergone limited chemical or biological degradation. A plume of dissolved PCE is migrating along strike in the Nolichucky Shale to the west of BG-A South. Fate and transport modeling suggests that a PCE plume may take a few hundred years to migrate along strike as far as NT-8.

\section{Maynardville Limestone and Bear Creek Functional Area}

The Maynardville Limestone and Bear Creek FA includes (1) soils and sediments in the Bear Creek floodplain, (2) groundwater in the Maynardville Limestone, and (3) surface water in the main stem of Bear Creek and in floodplain springs.

Sources and contaminants. The environmental media in this FA represent the downgradient pathways and receptors of contaminants migrating away from the sources on the Nolichucky Shale. The primary sources of contaminant input to Bear Creek and the Maynardville Limestone from the source sites are:

- S-3 Site: nitrate, radionuclides, and high TDS via discharge from NT-1 and NT-2, shallow groundwater discharges to Bear Creek, and shallow groundwater discharges directly to the Maynardville Limestone.

- BYBY: uranium via discharge from NT-3 and direct runoff to the Floodplain, and uranium and VOCs by shallow groundwater discharge into the Maynardville Limestone.

- SL 1: VOCs via shallow groundwater discharge into the Maynardville Limestone.

- BCBG: VOCs and uranium via discharge from NT-7 and NT-8.

- Past releases of TCE and 1,2-DCE from an unknown site east of BYBY FA or Rust Spoil Area. 
- Past releases of TCE and 1,2-DCE from the Fire Training area in the neighboring Upper East Fork Poplar Creek (Fig. ES.1) hydrogeologic regime that may have migrated in karst in the Maynardville Limestone into the Bear Creek hydrogeologic regime at Spoil Area 1.

In addition, the Creekside Debris Burial area and the Bear Creek Road Debris Burial area are two waste areas, first identified during field operations for the BCV RI, with soil contamination on the Floodplain. These sites do not currently contribute to groundwater contamination but may have done so in the past. Primary contaminants in the Maynardville Limestone and Bear Creek FA are:

- nitrate, boron, uranium, strontium, barium, PCE, TCE, 1,2-DCE, and ${ }^{99} \mathrm{Tc}$ in groundwater; concentrations of these contaminants exceed ARARs for drinking water at many locations in the valley upgradient of BCK 9.47;

- barium, cadmium, manganese, uranium, boron, strontium, TCE, 1,2-DCE, and ${ }^{99} \mathrm{Tc}$ in springs and surface water upstream of BCK 9.47;

- nitrate, boron, strontium, and uranium in surface water downstream of BCK 9.47; and

- cadmium, uranium, and PCBs in Floodplain soils and sediments at a few locations [in general, contaminant concentrations are higher in sediments than in soils, and the highest concentrations in soils occur in the top $10 \mathrm{~cm}$ (4 in.) of soil].

Nitrate, uranium, and ${ }^{99} \mathrm{Tc}$ contamination occurs close to the S-3 Site and continues west as far as BCK 9.47 and Picket A. Nitrate contamination in groundwater occurs $2590 \mathrm{~m}(8500 \mathrm{ft})$ west of Picket $A$ in Picket $W$, but uranium and ${ }^{99}$ Tc have not reached this far west. TCE- and 1,2-DCE contaminated groundwater occurs in groundwater wells at the Spoil Area 1 and Rust Spoil Area. Concentrations of TCE and 1,2-DCE in groundwater increase downgradient of Rust Spoil Area at Picket $\mathrm{C}$ and adjacent to BYBY. The furthest west that TCE is detected in groundwater is in Picket $B$; however, discharge to SS-5 is contaminated with trace concentrations of TCE, which may indicate the presence of the leading edge of the TCE plume at Picket A.

Maynardville Limestone conceptual model. At monitoring points downgradient of BYBY (groundwater and surface water), the plumes from the S-3 Site and BYBY source areas are completely commingled (Fig. ES.5). It is only possible to identify BYBY as a contributor to the inorganic and organic Maynardville Limestone contaminant plumes because of the relative concentrations of contaminants in groundwater, surface water, and springs. Progressive changes in relative concentrations of contaminants in groundwater along the valley reflect the inputs to the Bear Creek/Maynardville Limestone system and suggest that after entering Bear Creek contaminants can migrate downward into the Maynardville Limestone (Fig. ES.5).

Surface water in Bear Creek and shallow groundwater in the Maynardville Limestone are closely interrelated and constitute $96 \%$ of water flowing along the valley. Contaminants in these media pathways are quickly diluted by rapid recharge of rainwater and inputs from noncontaminated tributaries. Concentrations of contaminants in the intermediate and deep groundwater pathways [30 to $90 \mathrm{~m}$ (100 to $300 \mathrm{ft})$ depth] are not attenuated as rapidly as those in shallow groundwater because this interval is somewhat isolated from inputs from recharge and tributaries. Plumes of groundwater contaminated above maximum contaminant levels in the 30 to $90 \mathrm{~m}$ (100 to $300 \mathrm{ft}$ ) depth interval are more continuous and extend further along the valley. 
Groundwater contamination at Picket $W$ is attributed both to diffuse contamination as a result of infiltration of contaminated surface water in Bear Creek and along strike migration of contaminated groundwater in intermediate and deep groundwater.

\section{ES.4 CONTAMINANT FATE AND TRANSPORT PATHWAYS}

The principal contaminant sources in BCV are located on the outcrop of the Nolichucky Shale (S-3 Site, BYBY, and BCBG), a carbonate-rich fractured shale with low permeability. Solid and liquid waste disposals have caused shallow groundwater contamination. Leaching of solid materials, particularly uranium, is a current source of shallow groundwater contamination. Where dense liquids were disposed of at the S-3 Site and BCBG, contamination of deep groundwater in the Nolichucky Shale has occurred. Contaminants migrate away from the waste disposal units using the following pathways (Fig. ES.5):

- Contaminated shallow groundwater at sources on the Nolichucky Shale migrates through fractures along geological strike and discharges to tributaries or directly to Bear Creek causing the tributaries and Bear Creek to become contaminated.

- Contaminants in deep groundwater in the Nolichucky Shale also migrate through fractures along strike and discharge to tributaries. However, contaminant pathways in the deep groundwater can underflow proximal tributaries and/or springs and be a source of contamination in neighboring tributary subwatersheds.

- After entering tributaries, contaminants migrate in surface water directly to Bear Creek. Bear Creek intermittently loses and gains water from groundwater in the Maynardville Limestone throughout the length of the valley. Losing reaches of Bear Creek cause groundwater contamination in the Maynardville Limestone. Gaining reaches of Bear Creek are associated with large springs at the base of Chestnut Ridge, some of which have contaminated discharge (SS-1, $-4,-5$, and -6 ).

- Surface water in Bear Creek and shallow groundwater in the Maynardville Limestone constitute $96 \%$ of water flowing along the valley. Contaminants in these media pathways are quickly diluted by rapid recharge of rainwater and inputs from noncontaminated tributaries.

- Deep groundwater in the Maynardville Limestone [30 to $90 \mathrm{~m}$ (100 to $300 \mathrm{ft})$ depth] constitutes $<4 \%$ of water flowing along the valley. Concentrations of contaminants in this and in the deep groundwater pathway are not attenuated as rapidly as those in shallow groundwater; this pathway is an important source of long distance groundwater transport along the valley.

- Contaminant concentrations in shallow groundwater in the Nolichucky Shale and the Maynardville Limestone and in surface water are diluted by recharge during storm events and show seasonal trends of lower concentrations during periods of high rainfall.

Contaminants migrating from the waste sites in BCV converge at BCK 9.47/SS-5 - more than $99 \%$ of available water from the upper portion of the valley passes through this location as either surface water or groundwater. 


\section{ES.4.1 Integrator Point/Plane Assessment}

To determine the contribution of each FA to the valley-wide contaminant flux migrating off site from the BCV CA, an IP assessment was completed at BCK 9.47/SS-5. Using a mass balance calculation, $69 \%$ of uranium measured at BCK 9.47 and SS-5 was measured at monitoring stations in tributaries to Bear Creek (gauged flux on Fig. ES.3). The remaining 31\% was not measured in the $R I$ (engaged flux) but is expected to be derived from migration of uranium directly to Bear Creek and the Maynardville Limestone via shallow groundwater at the BYBY and S-3 Site sources.

Assuming a similar distribution of the engaged flux as the gauged flux, then $\sim 61 \%$ of the uranium found in surface water and groundwater at the IP is derived from BYBY. The S-3 Site is the second major contributor of uranium (26\%), and this site contributes approximately $94 \%$ of the nitrate contamination at the IP. At the IP, $13 \%$ of the uranium is derived from BCBG. VOCs at the IP are mainly derived from BCBG; however, most VOCs (82\%) discharged to surface water at source areas volatilize before reaching BCK 9.47. Boron was not measured in tributaries in the RI but is probably mostly derived from the $B C B G$ where it was reported to be a contaminant in waste liquids that accompanied uranium tailings disposal and is found in the current leachate at BCBG.

Using these flux data, the portion of the total risk to human health and total hazard at the IP contributed by each waste site was calculated (Fig. ES.6). BYBY contributes most to the human health risk to the IP (38.5\%), followed by BCBG (23.0\%), and the S-3 Site (17.4\%). Engaged uranium fluxes contribute $20.7 \%$ of risk at the IP. As discussed above, most of the engaged uranium flux originates in the BYBY (assumed 70\%) and the S-3 Site (assumed 30\%).

\section{ES.4.2 Anticipated Future Changes}

In the absence of remedial action and assuming maintenance of the current leachate collection system at $B C B G$, contaminant concentrations in most pathways are expected to remain at concentrations similar to those currently observed with four exceptions. These exceptions are:

- Concentrations of uranium and some metals in groundwater discharged to NT-1 are expected to increase in the foreseeable future (100 to 200 years). Concentrations of VOCs and nitrate may have peaked in this pathway but are expected to remain close to current levels for the next 100 years.

- Concentrations of nitrate, uranium, and some metals in groundwater discharged to NT-2 are expected to increase in the foreseeable future (100 to 1000 years).

- Along strike migration in the Nolichucky Shale of a plume of PCE-contaminated groundwater at BCBG may result in discharge of contaminated groundwater to NT-8 in the next 100 years. However, it is anticipated that volatilization of most of the VOCs in surface water, as is observed today, will lessen the impact of this discharge.

- Along strike migration in the Maynardville Limestone of a plume of TCE- and 1,2-DCE-contaminated groundwater at BCBG may result in discharge of increasingly contaminated groundwater at SS-5 and BCK 9.47 for the next 500 years. In addition, migration of this plume to BCK 9.47/SS-5 may result in unacceptable risk from use of groundwater at these locations and cause additional groundwater ARARs to be exceeded in the future. 


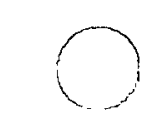

Oak Ridge Reservation

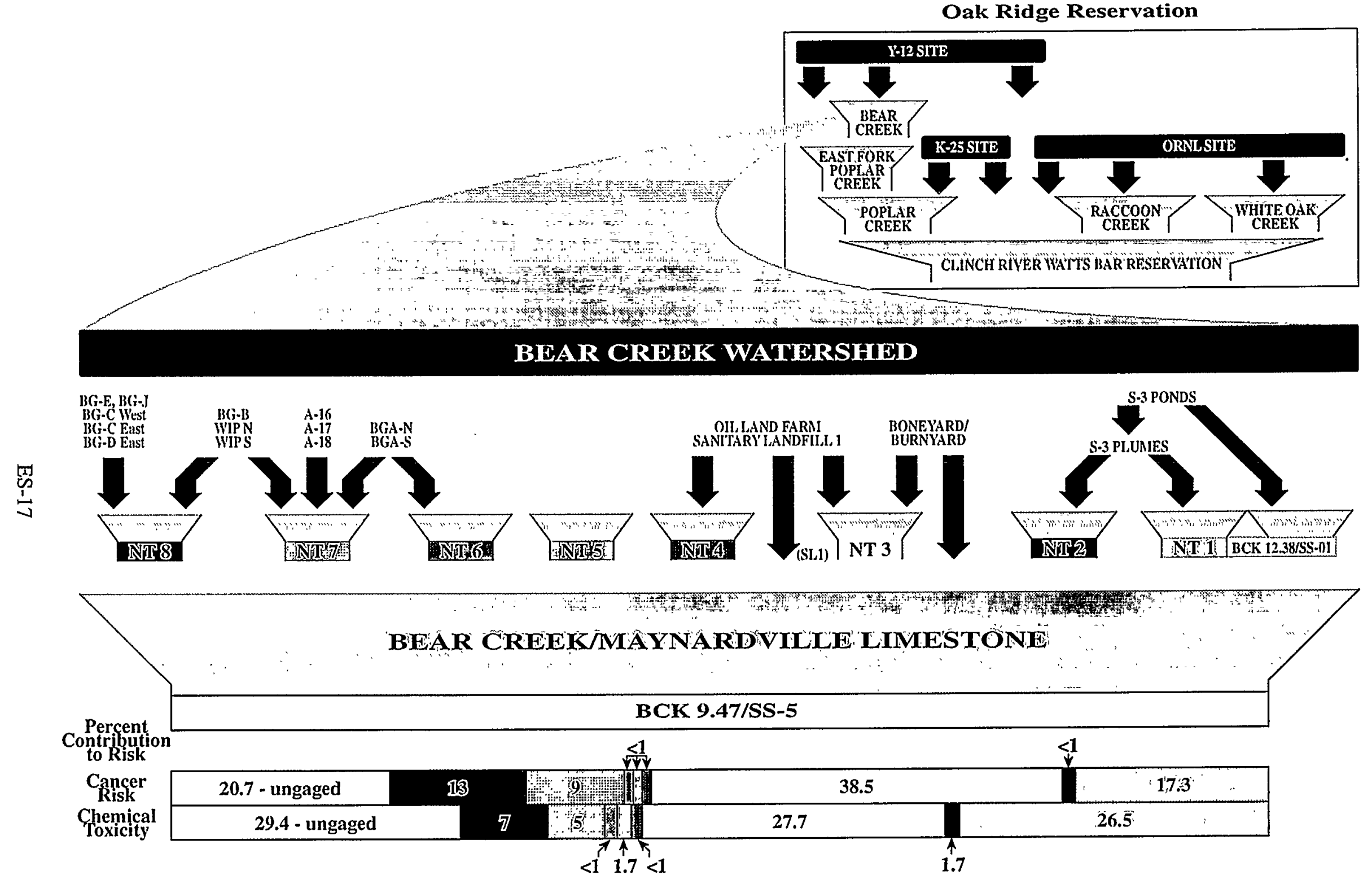

Figure ES.6. Relative contributions from source areas to potential risks and hazards at the IP. 
In the absence of remedial actions, the resulting effect of these changes on contaminant fluxes will be to increase the fluxes of uranium, nitrate, some metals, and VOCs at the IP during the foreseeable future. The leading edge of the nitrate plume in BCV has reached Picket W wells $\sim 2.3 \mathrm{~km}$ west of BCK 9.47 (Fig ES.1). Increased fluxes of contaminants at the IP will most likely result in extension of the plumes of contaminated groundwater west of BCK 9.47 and increased concentrations of contaminants at Picket W.

\section{ES.5 APPLICABLE OR RELEVANT AND APPROPRIATE REQUIREMENTS}

ARARs and to-be-considered guidance that may be applicable to BCV have been identified so that remedial actions planned for BCV can be fully protective of human health and the environment. Chemical-specific guidance for the BCV include:

- Environmental Protection Agency's (EPA's) insufficient yield criterion for groundwater classification;

- Safe Drinking Water Act maximum contaminant levels;

- National Secondary Drinking Water Standards secondary maximum contaminant levels;

- EPA rule for natural attenuation of contaminants in groundwater in cases where active remediation is not appropriate; and

- Tennessee Department of Environment and Conservation ambient water quality criteria.

Chemical-specific ARARs for soils and sediments and location- and action-specific ARARs applicable to sensitive resources are usually invoked during remedial action. Thus, these ARARs will be analyzed and discussed as remedial alternatives are screened in the BCV FS.

\section{ES.6 BASELINE RISK ASSESSMENT}

\section{ES.6.1 Baseline Human Health Risk Assessment}

Conclusions on potential human health risks in BCV are based on four hypothetical land uses for which risks to human health were calculated; these are current hypothetical "unprotected" site maintenance workers at the source areas, future industrial workers, future recreational receptors downstream of BCK 9.47, and future residential receptors (Figs. ES.7 and ES.8).

At BCBG, S-3 Site, and OLF, there is an important distinction between contamination due to buried waste materials and soil contamination resulting from mobilization of contaminants in wastes (secondary contamination). In general, although secondary contamination is present in soils immediately surrounding the wastes, the concentrations of contaminants in these soils are lower and pose potential risks that are orders of magnitude less than those from the neighboring waste materials. Soils surrounding waste units generally pose risks to potential future residents but little risks to potential future industrial or unprotected maintenance workers; whereas exposure to contaminants in wastes poses high risks for potential future residents and future industrial workers. With the exception of BYBY and BG-D, -E, and -J, waste materials are buried and covered with multilayer RCRA caps; therefore, the scenario for exposure of future residents and industrial workers assumes degradation of these caps and eventual uncovering of the wastes. 


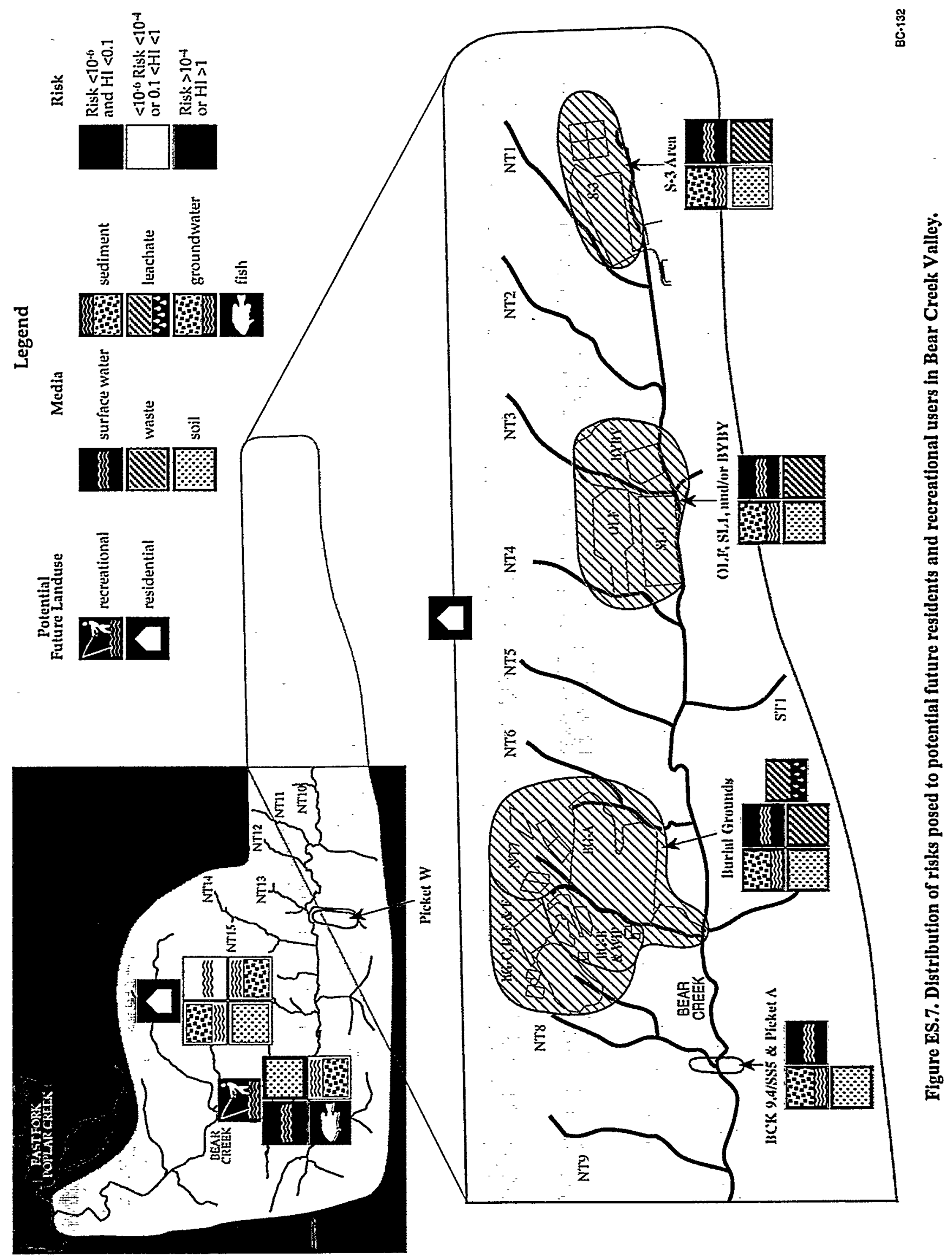

ES-19 


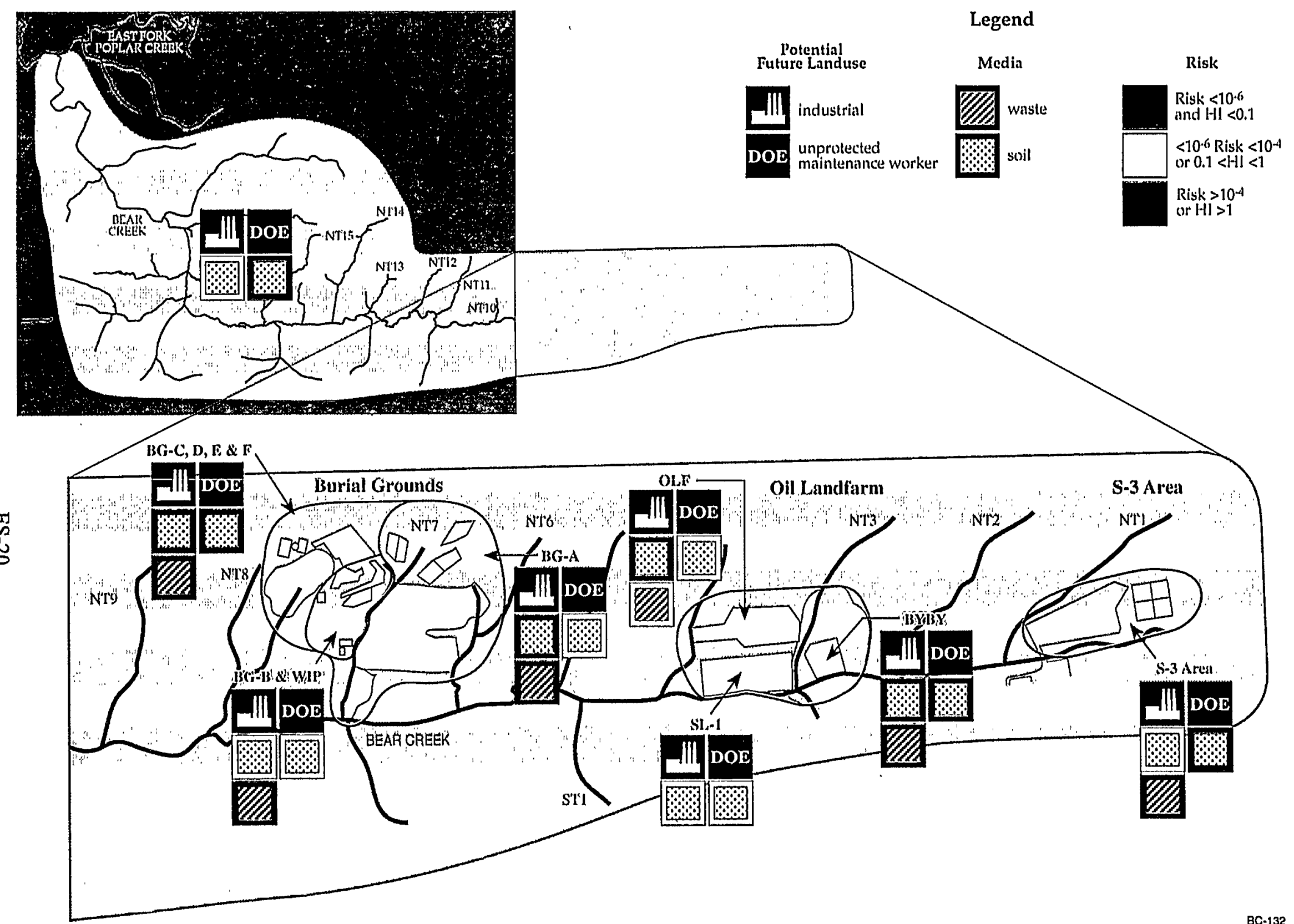

Figure ES.8. Distribution of risks posed to potential future industrial workers and unprotected maintenance workers in Bear Creek Valley. 
Current "unprotected" maintenance worker. Risks from exposures to an unprotected maintenance worker (rather than a worker having the level of protection currently required for access at $\mathrm{BCV}$ sites) were evaluated to provide a conservative estimate of current risk. Assuming that existing caps at the waste areas are maintained, the only risks exceeding $10^{-4}$ identified for an unprotected maintenance worker at any of the BCV sites are through exposure to three chemicals of concern (COCs) ${ }^{234} \mathrm{U},{ }^{235} \mathrm{U}$, and ${ }^{238} \mathrm{U}$ ) found in hot spot soils, where waste material was exposed at the surface, at BYBY, and at BCBG (Fig. ES.8).

Future industrial worker. Risks/hazards to a future industrial worker can occur from exposure to 33 COCs:

- buried and capped wastes at the S-3 Site contain 12 COCs (beryllium, PCB-1248, and radionuclides);

- soils adjacent to the OLF cap contain 4 COCs (arsenic and radionuclides);

- soils at BYBY contain 12 COCs (metals, PAHs, and radionuclides);

- soils adjacent to caps, hot spot soils near BG-D East, and buried wastes at BCBG contain 12 COCs (metals, PCBs, VOCs, and radionuclides); and

- inventoried soils at the Disposal Area Remedial Action (DARA) Solids Storage Unit and the OLF Storage Pad contain 6 COCs (dioxins, PCB-1254, and uranium isotopes) and 4 COCs (beryllium, PCBs, and uranium isotopes), respectively.

Future recreational receptor. Risks to a future recreational user of $B C V$ were evaluated for the BCV Floodplain, starting just west of the BCBG (BCK 9.47) and ending near Highway 95. Only one pathway was estimated to pose potential risks under this scenario: ingestion of fish that have bioaccumulated mercury (i.e., methylmercury) and PCBs (Fig. ES.7). However, there is uncertainty whether the fish analyzed in the assessment were exposed to contamination only from Bear Creek. No COCs associated with exposure to surface water, floodplain soils, and sediments were identified.

Future resident. Although a residential exposure scenario at the source areas is unlikely, it was evaluated to obtain a reasonable maximum exposure estimate of the risk to future human receptors in $\mathrm{BCV}$.

West of BCK 9.47 and Picket A, total pathway risks from aggregated data do not exceed $10^{-4}$ (Fig. ES.7). Two individual locations have COCs associated with them. These are:

- 1 COC, PCB-1254, in soils at SP04 near Highway 95 in the BCV Floodplain;

- 4 COCs, arsenic, chromium, manganese, and PCB-1254 in sediments in Bear Creek near NT-9 and NT-11; and

- 2 COCs, boron and strontium, considered as naturally occurring and not related to activities in $\mathrm{BCV}$, were identified for well GW-711 at Picket W.

In addition, low activities $(<7 \mathrm{pCi} / \mathrm{L})$ of radium, ${ }^{137} \mathrm{Cs}$, and ${ }^{228} \mathrm{Th}$ in groundwater at Picket $\mathrm{W}$ and arsenic, ${ }^{137} \mathrm{Cs}$, and ${ }^{238} \mathrm{U}$ in surface water in Bear Creek downstream of BCK 9.47 pose risk between $10^{-6}$ and $10^{-4}$. However, there is a high degree of uncertainty associated with these radiological data, and the lack of other radionuclides usually associated with contamination in BCV (e.g., $\mathrm{U}$ and ${ }^{99} \mathrm{Tc}$ ) in these wells makes their occurrence at Picket $W$ suspect. 
At the $\mathrm{P}$, total pathway risks are between $10^{-4}$ and $10^{-6}$. Specific risks and hazards are as follows:

- Ingestion of isotopic uranium in groundwater in GW-684 poses a risk between $10^{-6}$ and $10^{-4}$ to future residents. Nitrate and uranium in groundwater in this well also result in a potential $\mathrm{HI}=1$ for future residents.

- Ingestion of PCE, TCE, ${ }^{99} \mathrm{Tc},{ }^{137} \mathrm{Cs},{ }^{237} \mathrm{~Np}$, and isotopic uranium in surface water poses a potential risk between $10^{-6}$ and $10^{-4}$ to future residents. Ingestion of uranium in surface water at the IP also results in an HI > 1 for future residents with boron, fluoride, and nitrate also contributing to the hazard.

- Soils at transect TS4, located at the confluence of NT-8 and Bear Creek (Fig. ES.1), pose a potential risk $>10^{-4}$ to future residents via incidental ingestion or external exposure from beryllium, PCB-1260, or isotopic uranium.

East of BCK 9.47, risks and hazards posed to potential future residents are numerous, and at nearly all locations cumulative pathway risks exceed $10^{-4}$ and/or HIs exceed 1 via exposure to waste, soil, groundwater, or surface water (Fig. ES.7). Potential risks/hazards to future residents can occur from exposure to 94 COCs:

- at the S-3 Site FA: 34 COCs in groundwater, 13 COCs in surface water, 2 COCs in soils, and 17 COCs in buried/capped waste;

- at the OLF FA: $28 \mathrm{COCs}$ in groundwater and $11 \mathrm{COCs}$ in surface water, $10 \mathrm{COCs}$ in OLF soils, 6 COCs in OLF Storage Pad soils, 12 COCs in SL 1 soils, and 22 COCs in BYBY soils;

- at the BCBG FA: $23 \mathrm{COCs}$ in groundwater, $14 \mathrm{COCs}$ in surface water, $41 \mathrm{COCs}$ in leachate, 11 COCs in soils adjacent to caps and in hot spots, 16 COCs in buried waste, 7 COCs in DARA soils; an

- for the Maynardville Limestone and Bear Creek FA: 13 COCs in Bear Creek Road Debris Burial area, and 16 COCs in Creekside Debris Burial area.

In addition to the risk/hazard associated with exposure to chemicals in $B C V$, the $B C B G$ site presents potential physical hazards associated with the burial of pyrophoric and explosive agents. An incompatibility study conducted in 1984 concluded that it is reasonable to expect that excavation at BCBG would foster additional reactions through re-exposure to air and unavoidable mixing as wastes are handled.

\section{ES.6.2 Ecological Risk Assessment}

Ecological risk was estimated for fish, benthic invertebrate, soil invertebrate, and plant communities and representative organisms of populations of small mammals (mice and shrew), piscivores (mink and kingfisher), large herbivores (deer), and predator/scavengers (hawks and fox). The baseline ecological risk assessment identified significant ecological risks from chemicals in water, sediment, soil, and shallow groundwater for one or more receptors. Metals and PCBs are the primary contaminants of potential ecological concern, and source area and floodplain soils, including transects west of 9.47, contribute to these risks (Fig. ES.9).

In characterizing risk to the assessment endpoints established for the BCV baseline ecological risk assessment (e.g. species richness and abundance), a $20 \%$ or greater reduction in one of the 


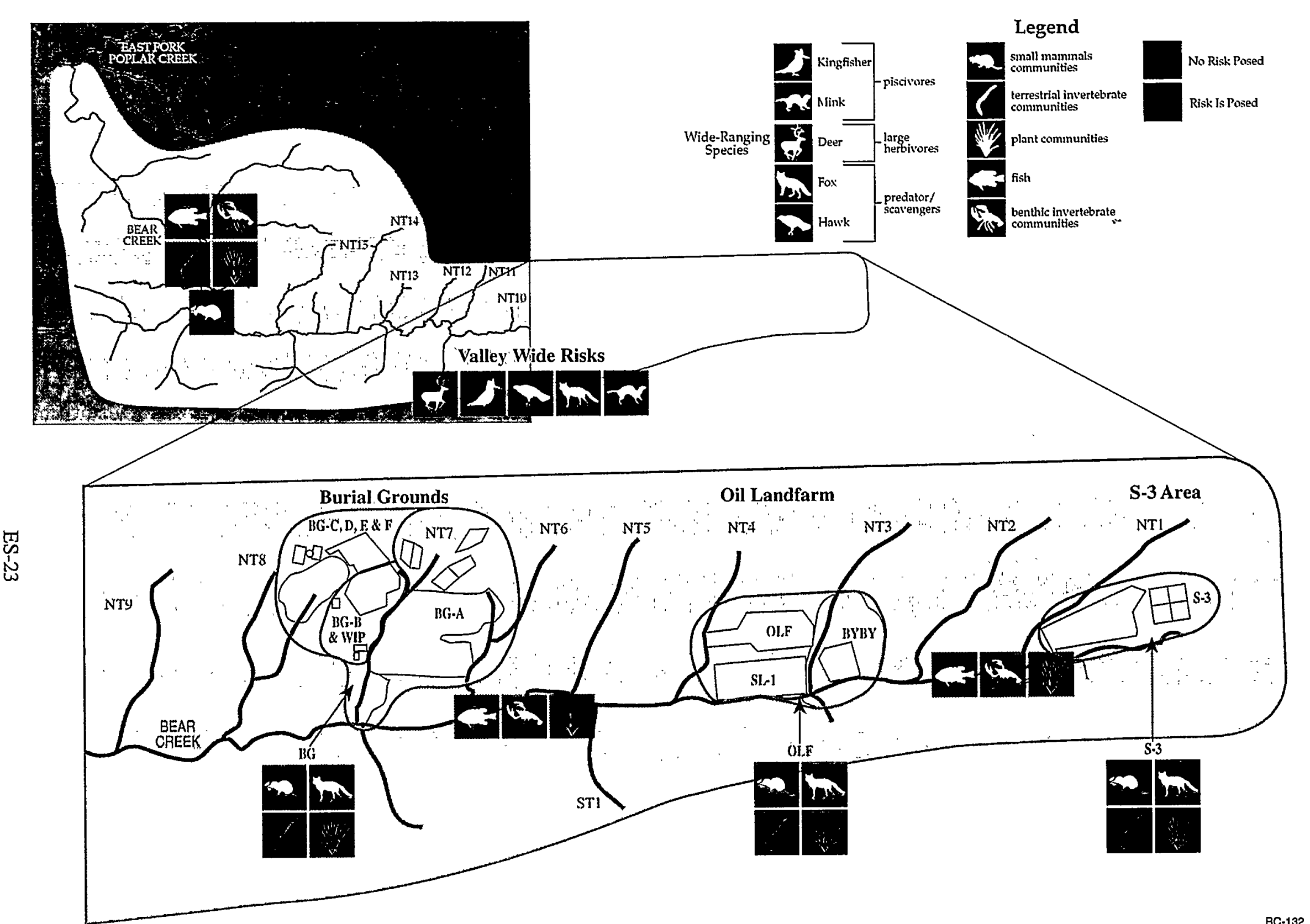

Figure ES.9. Distribution of risks posed to aquatic and terrestrial biota in Bear Creek Valley. 
endpoint properties measured in the field or a $20 \%$ reduction in survivorship, growth, or reproduction in a toxicity test was considered to be potentially significant. The assessment endpoints and their associated risks for the $\mathrm{BCV}$ are:

Reduction in species richness or abundance in fish communities resulting from toxicity. Risks to fish communities were evaluated for Bear Creek, which was divided into four reaches for the baseline ecological risk assessment (Fig. ES.1), and for tributaries NT-2 through NT-8. Both dissolved phase and total concentrations of metals were used in the exposure assessment for fish. The weight of evidence suggests that water from Bear Creek and NT-2 through NT-8 does not pose a significant risk of a $20 \%$ reduction in fish species richness or abundance or in the Tennessee dace population due to a toxic effect.

Reduction in species richness or abundance of benthic macroinvertebrate communities resulting from toxicity. Benthic invertebrates exposed primarily to surface water in erosional areas were evaluated separately from those exposed primarily to fine sediments in depositional areas. For benthic invertebrates in erosional areas, the weight of evidence suggests that water in Reaches 1 and 2 , NT-2, SS-1, and SS-4 poses a significant risk of a $20 \%$ reduction in species richness and abundance due to a toxic effect from high concentrations of calcium, cadmium, manganese, nickel, and uranium. For benthic invertebrates in depositional areas, the weight of evidence suggests that sediment from 3 of 18 sites poses a significant risk due to a toxic effect, probably from manganese and, potentially, selenium and 2,4,5-trichlorophenoxyacetic acid (2,4,5-T). However, it is unlikely that the soft-sediment benthic invertebrate community as a whole is reduced by $20 \%$ in species richness or abundance.

Reduction in production of soil/litter invertebrates resulting from toxicity. Risk to soil invertebrates was evaluated for four source areas (S-3 Site, BYBY, combined SL 1 and OLF, and $B C B G$ ) and for the Bear Creek Floodplain. Risks of a toxic effect to soil invertebrates from mercury and, possibly, chromium, copper, and zinc, are estimated to be significant in the S-3 Site, SL 1/OLF, BYBY, Creekside Debris Burial area, and Bear Creek Road Debris Burial area.

Reduction in production of terrestrial plant communities resulting from toxicity. The plant communities in the BYBY area near HCDA are probably adversely affected by metals in shallow groundwater if they are exposed by root uptake. Soils at isolated locations along two Floodplain transects in Upper Bear Creek (transects TS3 and TS4, Fig. ES.1)) appear to pose a significant risk to plants.

Reduction in abundance or production of terrestrial wildlife populations resulting from toxicity. Risks to wide-ranging species were evaluated for the $\mathrm{BCV}$ as a whole. Risks to small mammals, which have more limited spatial requirements, were evaluated within the source areas and for $\mathrm{BCV}$ as a whole. Among the wide-ranging species, only fox were estimated to be significantly at risk of a $20 \%$ reduction in population production; this risk results from soil contamination by: antimony at BYBY; mercury at S-3 Site, BYBY, OLF, and Floodplain transect TS1; and PCBs in BCBG and Floodplain transects TS4 and TS10. Shrews are estimated to be significantly at risk of a $20 \%$ reduction in population production from high soil concentrations of metals at S-3 Site, BYBY, and OLF and PCBs at BCBG. Shrews are also estimated to be at risk from elevated chromium and PCBs in Floodplain soils in transects west of BCK 9.47. There were no risks to shrew, mouse, deer, hawk, and fox from uptake of radionuclides. 
Reduction in abundance or production of piscivorous wildlife populations resulting from toxicity. Because piscivorous wildlife are highly mobile, risks to piscivores were evaluated for the $\mathrm{BCV}$ as a whole. Kingfishers inhabiting the watershed were estimated to be significantly at risk of a $20 \%$ reduction in population production because of mercury in fish.

\section{ES.6.3 Conclusions about Potential Risk}

At nearly all locations in BCV east of the IP, potential cumulative pathway risks posed to future residents exceed $10^{-4}$ and/or HIs exceed 1 via potential exposure to contaminants in waste, soil, groundwater, or surface water (Fig. ES.7). Cumulative pathway potential risks posed to future industrial workers or unprotected maintenance workers vary between $10^{-6}$ and $10^{-1}$ via exposure to buried waste and contaminated soil at hot spots (Fig. ES.8). Contamination both at the waste areas and in the floodplain poses risks to wide ranging predatory animals, fish-eating wildlife, small mammals, soil invertebrates, and plant communities (Fig. ES.9). Contaminants in surface water upstream of BCK 9.47 and in sediments in NT-2, NT-6, and reach 4 of Bear Creek pose risks to benthic invertebrates (Fig ES.9). In addition, ARARs are exceeded in groundwater at many locations east of the IP.

At the IP, potential human health risks posed from use of groundwater or surface water exceed $10^{-6}$ or an $\mathrm{HI}>1$. The COCs at the IP are uranium, nitrate, boron, and fluoride. In addition, ARARs for nitrate, uranium, and VOCs are most likely exceeded in groundwater.

In the portion of the valley west of the IP, environmental media are contaminated as a result of releases from the waste areas east of the IP, but contamination is slight and poses relatively little risk (Figs. ES.7 to ES.8). West of the IP, the most prevalent contaminants in groundwater and surface water are chloride, fluoride, nitrate, boron, strontium, and uranium, but contamination does not exceed ARARs. For a potential future residential receptor, four $\mathrm{COCs}$ (As, $\mathrm{Cr}, \mathrm{Mn}$, and PCB-1254) were identified in sediments from Bear Creek at two locations, and one COC (PCB-1254) in soils at one location in the Bear Creek floodplain.

\section{ES.7 REMEDIAL GOAL OPTIONS}

Media- and chemical-specific RGOs have been developed for each chemical of concern in BCV. RGOs are target cleanup goals to be used in identifying effective remedial technologies. They are not proposed final cleanup levels. RGOs were calculated for the following three criteria:

- Chemicals of concern identified in the baseline human health risk assessment. For these chemicals of concern, RGOs were calculated to be protective of human health at target risk levels of $10^{-4}, 10^{-5}$, and $10^{-6}$ and target HIs of $0.1,1$, and 3 .

- Chemicals of concern identified in the baseline ecological risk assessment. For these chemicals of concern, RGOs represent benchmarks, probable effects levels, ambient water quality criteria, and naturally occurring background levels.

- Chemicals of concern identified as chemicals that exceed ARARs. For these COCs, RGOs represent the ARAR.

In addition, results of fate and transport modeling were used to identify chemicals that are likely to exceed ARARS or preliminary remediation goals as a result of leaching from soils to groundwater 
or transport to surface water in the future. These chemicals are also considered chemicals of concern, and the RGOs for these chemicals are considered the maximum contaminant level or preliminary remediation goal in the receptor medium.

The ability to meet RGOs for primary risk drivers will be evaluated in the FS. Based on the results of the baseline risk assessments, primary risk drivers include uranium, nitrate, and VOCs in the upper third section of BCV.

\section{ES.8 TECHNICAL CONSIDERATIONS FOR REMEDIAL ACTIONS}

Contamination in groundwater and surface water at, and west of, the IP is derived from migration away from the source sites. A remedial strategy with the goal of reducing contaminant fluxes at the IP to acceptable levels will have two general options: (1) take actions at the IP to mitigate exposures downstream, or (2) take actions upstream and east of the IP that will result in achieving the remedial goals at the IP.

Actions taken at the IP would be groundwater and surface water capture/treatment type actions. Actions taken upstream of the IP would involve interception of contaminant pathways to tributaries (i.e., actions taken closer to the sources) that would result in remediation of nitrate and uranium in contaminated surface water in Bear Creek and groundwater in the Maynardville Limestone. These actions may also be groundwater and surface water treatment actions taken closer to the sources, but could also include source isolation/treatment/removal to mitigate three pathways. In addition, a plume of VOC-contaminated water in the Maynardville Limestone that has no apparent source would also need to be addressed.

The following physical, chemical, and hydrological parameters will need to be addressed to achieve the remedial action objectives for BCV.

\section{ES.8.1 Considerations for Remedial Actions for Groundwater and Surface Water at the Sources}

- Large volumes of contaminated groundwater exist in the Nolichucky Shale at the contaminant sources $\left(7.1 \times 10^{6} \mathrm{~m}^{3}\right.$ at the S-3 Site, $0.4 \times 10^{6} \mathrm{~m}^{3}$ at BYBY, and $4.0 \times 10^{6} \mathrm{~m}^{3}$ at BCBG). Due to the fractured nature of the Nolichucky Shale, $<10 \%$ of this contaminated volume occurs in fractures that are accessible for withdrawal of water. More than $90 \%$ of this volume occurs in the very low permeability matrix and contains the highest concentrations of contaminants. The mechanism for migration of contaminants from the matrix to flowing fractures is by chemical diffusion and is termed matrix diffusion. The result of matrix diffusion is that, if pump and treat technology is used to remediate a plume in fractured bedrock, many times the contaminated volume of water will require pumping before acceptable concentrations can be achieved.

- DNAPL occurs at two locations in the Nolichucky Shale, the S-3 Site and BCBG (Fig. ES.5). The nature of migration of DNAPL in the subsurface means that small droplets of residual DNAPL exist rather than large and identifiable pools of liquids. Thus, identification and extraction of DNAPL is not possible. Dissolution of DNAPL at these sites will, therefore, act as a dispersed source of contamination to groundwater. 
- Some of the solid waste at BYBY, BCBG, and most likely at the S-3 Site is inundated by shallow groundwater and will be a continuing source for groundwater contamination unless it is hydraulically isolated from groundwater.

- Contaminated shallow and deep groundwater in the Nolichucky Shale migrates rapidly through discrete fractures or preferential pathways along geological strike to discharge to tributaries or directly to Bear Creek. Most of the groundwater flux most likely flows through a few discrete fracture zones; however, the specific locations and depths of these fracture zones are not known at this time and may be difficult to ascertain.

- Flow in shallow groundwater and tributaries is "flashy." For example, flow in NT-3 varies from extremes of $0 \mathrm{~L} / \mathrm{s}$ to over $150 \mathrm{~L} / \mathrm{s}(2400 \mathrm{gpm})$. Average baseflow in NT-3 varies from $0 \mathrm{~L} / \mathrm{s}$ in summer to almost $10 \mathrm{~L} / \mathrm{s}(160 \mathrm{gpm})$ during winter months.

ES.8.2 Considerations for Remedial Actions for Groundwater and Surface Water in the Maynardville Limestone

- Water flows through a network of interconnected cavities and fractures up to $150 \mathrm{~m}(500 \mathrm{ft})$ deep in the Maynardville Limestone. Most of the groundwater flux most likely flows through a few discrete cavities, however, the flux through these cavities and the specific locations and depths of these cavities are not known at this time and may be difficult to ascertain.

- The total flux of groundwater flow at the IP was calculated as $54,000 \mathrm{~m}^{3}$ during the 10 -month monitoring period for the $\mathrm{RI}\left(-65,000 \mathrm{~m}^{3} / \mathrm{a}\right.$ or $\left.52.5 \mathrm{acre} \mathrm{ft} / \mathrm{a}\right)$.

- Flow in Bear Creek at BCK 9.47 is flashy and varies from extremes of $<1 \mathrm{~L} / \mathrm{s}(\sim 16 \mathrm{gpm})$ to over $10,000 \mathrm{~L} / \mathrm{s}(16,000 \mathrm{gpm})$. Average baseflow varies from $<1 \mathrm{~L} / \mathrm{s}$ in summer to $100 \mathrm{~L} / \mathrm{s}$ $(1,600 \mathrm{gpm})$ during winter months. Flow in SS-5 is more steady than in Bear Creek and varies from extremes of $<3 \mathrm{~L} / \mathrm{s}(-48 \mathrm{gpm})$ to over $100 \mathrm{~L} / \mathrm{s}(1600 \mathrm{gpm})$. Average baseflow varies from $<3 \mathrm{~L} / \mathrm{s}$ in summer to $10 \mathrm{~L} / \mathrm{s}(160 \mathrm{gpm})$ during winter months.

- Concentrations of contaminants in BCK 9.47 and SS-5 are relatively dilute. For example, at BCK 9.47, uranium ranges from 52 to $152 \mu \mathrm{g} / \mathrm{L}$ and nitrate ranges from $<1 \mathrm{mg} / \mathrm{L}$ to $46.2 \mathrm{mg} / \mathrm{L}$.

\section{ES.8.3 Considerations for Remedial Actions for Soils at Sources}

- Large volumes of buried waste materials exist at the $B C B G$, some of which are potentially pyrophoric or explosive. In addition, large volumes of waste materials and contaminated fill exist at BYBY, SL 1, and the S-3 Site.

- At some locations in BCBG and BYBY, and probably at the S-3 Site, waste materials are inundated by shallow groundwater.

- At some locations in BYBY and BCBG, waste materials occur at the surface of the soil. These locations constitute the most likely areas where direct exposure to waste could occur with unrestricted use.

- Many of the source areas are covered with RCRA caps that limit the possibility of direct exposure to waste materials under the current land use. 


\section{ES.8.4 Consideration for Remedial Actions for Soils/Sediments in the Bear Creek Floodplain}

- The sampling strategy for floodplain soils and sediments was, by intention, biased towards likely sediment accumulation areas. The relatively small number of samples for the area of land that constitutes the Bear Creek floodplain means that volumes of contaminated soils are not well defined. The data indicate that contaminant concentrations are low and soil volumes are small (most likely $<1000 \mathrm{~m}^{3}$ ).

\section{ES.8.5 Relative Importance of Pathways}

For actions taken close to the sources, the relative importance of the pathways with regard to the contaminant mass flux is a consideration for which remedial actions will be most effective from a watershed perspective. The following parameters, therefore, also need to be considered:

- Figure ES.3 shows the potential human health risk/hazard from surface water and groundwater at the IP posed by exposure to the individual COCs. Figure ES.3 also lists the relative proportions of the flux of the two principal COCs, nitrate and uranium, derived from sources in $\mathrm{BCV}$. Based on this ranking of source contributions to the total potential risk/hazard at the IP (refer to Sect. 3.2.7 and Appendix E), most of the potential risk/hazard is from uranium migrating from BYBY and the S-3 Site. In addition, most of ungauged flux is most likely from BYBY and the S-3 Site, further increasing the proportion of uranium flux derived from these sites. Nitrate is the second most important COC at the IP and is $94 \%$ derived from the S-3 Site.

- Reduction of the contaminant mass flux through shallow groundwater and/or surface water discharge in tributaries at BYBY and S-3 Site will reduce the overall mass flux of uranium and nitrate at the IP and achieve a reduction of potential risks and hazards at this location. For example, a reduction of $70 \%$ in the uranium flux from NT-3 and a similar reduction in the ungauged flux derived from this site (assumed to be $70 \%$ of the total ungauged flux) would result in a $43 \%$ reduction in the total uranium flux at the IP. A reduction of $70 \%$ in the contaminant flux from S-3 Site (NT-1 and NT-2) and a similar reduction in the ungauged flux derived from this site (assumed to be $30 \%$ of the total ungauged flux) would result in an $18 \%$ reduction in the total uranium flux at the IP, and a $66 \%$ reduction in the total nitrate flux.

- COCs for ecological receptors in Bear Creek are mainly metals in reaches 1 and 2 that are derived from discharge in NT-1, -2 , and -3 (with the exception of mercury for which no sources have been defined in BCV). It can be expected that actions taken to reduce the contaminant flux in any of these pathways will result in a reduction of ecological impacts in Bear Creek east of the IP and reduce impacts to piscivores in all of $\mathrm{BCV}$.

\section{ES.9 DOCUMENT LAYOUT}

The BCV RI Report is contained in six volumes. Volume 1, the RI Report, summarizes the extensive data analysis and interpretation that have been completed for the RI. The eight chapters of the Report address (1) the strategy used to satisfy the regulatory requirements in BCV; (2) physical and hydrogeological properties of $\mathrm{BCV}$; (3) results of environmental investigations conducted to determine the nature, extent, fate, and transportation of contamination; (4) ARARs; (5) results of baseline human health risk assessment; (6) results of baseline ecological risk assessment; (7) RGOs derived from the RI; and (8) conclusions. 
The RI Report is supported by seven appendices (A through $G$ ), contained in five volumes, that provide detailed analysis and discussion corroborating the information provided and conclusions reached in Volume 1. Volume 2 contains three appendices addressing (A) the operational histories of BCV waste sites and detailed analysis of inventory records of the BCBG; (B) the historical database for BCV and a detailed description of the field activities conducted during 1994 and 1995; and $(\mathrm{C})$ the valley-wide hydrogeological conceptual model for BCV. Volumes 3 through 6 , each containing one appendix, address (D) nature and extent of contamination in BCV; (E) fate and transport of contaminants in $\mathrm{BCV}$; (F) baseline human health risk assessment; and (G) baseline ecological risk assessment. 


\section{APPENDIX A}

WASTE SITES, SOURCE TERMS, AND WASTE INVENTORY 
Appendix A provides detailed information about waste disposal areas encompassed by the Bear Creek Valley (BCV) Characterization Area (CA) Remedial Investigation (RI). This information includes descriptions of waste areas and estimates of the current compositions of the wastes (source terms). These descriptions of the waste areas include the types of wastes disposed of, disposal methods used, timing of disposals, and treatment or clean-up activities that have been completed. Estimates of source terms were calculated in one of two ways: (1) from inventory of waste types and volumes or (2) from historical analytical data for the waste material.

BCV contains the watersheds of three creeks: Bear Creek, Grassy Creek, and Upper East Fork Poplar Creek. The BCV RI focuses primarily on the watershed of Bear Creek and, to a lesser extent, that of Grassy Creek. The Upper East Fork Poplar Creek watershed is covered in a separate RI report.

This appendix, like the overall BCV RI Report, presents a nonclassified analysis of data in the $B C V$. Where possible, declassified summaries of classified material were prepared and included in the appendix. Materials that could not be declassified are available for review by appropriately cleared individuals and have been included in an on-site record; they are not included in the off-site record.

\section{A.1 SITE DESCRIPTION}

BCV encompasses the Oak Ridge Y-12 Plant and its supporting facilities. The main facilities of the Y-12 Plant lie on the valley floor, primarily within the Upper East Fork Poplar Creek watershed (Fig. A.1). Auxiliary facilities, including several waste disposal areas, are located along Chestnut Ridge and in the Bear Creek watershed. The primary waste disposal areas included in the BCV CA and described in this report (Fig. A.2) are:

- S-3 Site,

- Oil Landfarm (OLF),

- Boneyard/Burnyard (BYBY) [including the Hazardous Chemical Disposal Area (HCDA)],

- Sanitary Landfill 1 (SL 1), and

- Bear Creek Burial Grounds (BCBG).

These five waste areas were known sources of contamination in BCV. Many smaller sites in BCV, listed in Table A.1 and identified on Fig. A.2, are known waste disposal or storage sites and may also be source areas.

\section{A.1.1 GEOGRAPHICAL INFORMATION}

About $18 \mathrm{~km}$ (11 miles) long, BCV trends E-W along the center of the Oak Ridge Reservation (ORR). As shown in Fig. A.1, the valley's west end is bounded by the Clinch River at the Grassy Creek Embayment on Watts Bar Lake, and its east end becomes Union Valley at Scarboro Road. BCV is bounded to the north by Pine Ridge and on the south by Chestnut Ridge.

As shown in Fig. A.3, Bear Creek originates in the southeast corner of the former S-3 Ponds (S-3 Site) near the western margin of the Y-12 Plant (Plates A.1 and A.2). The creek flows west 


$$
\text { A1-4 }
$$

for about $8 \mathrm{~km}$ ( 5 miles), turns north through a water gap in Pine Ridge, and flows for $4.5 \mathrm{~km}$ ( 3 miles) to its confluence with Lower East Fork Poplar Creek.

\section{A.1.2 BACKGROUND INFORMATION}

The Oak Ridge Y-12 Plant was built by the U.S. Army Corps of Engineers in 1943 as part of the Manhattan Project. The original mission of the Plant was to separate the fissionable isotope of uranium $\left({ }^{235} \mathrm{U}\right)$ using an electromagnetic separation process. After World War II, this process was discontinued in favor of a more economical gaseous diffusion process conducted at the nearby Oak Ridge K-25 Site (Welch 1989).

Since its inception, the Y-12 Plant has developed into a sophisticated manufacturing and developmental engineering facility. Its mission is to serve as a key manufacturing technology center for developing and demonstrating unique materials, components, and services important to the Department of Energy (DOE) and the nation. Activities have included the reclamation and storage of nuclear materials, manufacture of nuclear materials, manufacture of components for the nation's defense capabilities, support to national security programs, and services provided to other customers as approved by DOE.

\section{A.1.3 OPERATIONAL INFORMATION AND DESCRIPTION OF WASTE AREAS}

The S-3 Ponds, BYBY, OLF, SL 1, and BCBG are the primary contaminant sources in BCV (Fig. A.2). Smaller sites in the Bear Creek watershed, identified as solid waste management units or listed in the Federal Facilities Agreement, are listed in Table A.1 along with a brief description of their status.

The following subsections describe the wastes managed in the five primary contaminant sources as well as information about their generation, disposal methods, and any subsequent treatment or clean-up activities that have been conducted. Where records are available, estimates of the current conditions in the source areas are included. These source data were used as input to the fate and transport modeling (Appendix E) and risk assessment (Appendix F) portions of the RI.

\section{A.1.3.1 S-3 Ponds}

\section{Introduction}

The S-3 Ponds source area consists of four unlined ponds formerly used for industrial waste treatment, which were neutralized, drained, filled, and capped during Resource Conservation and Recovery Act (RCRA) closure in 1988. Operations at the former S-3 Ponds are documented in the RCRA closure reports for the facility, with the primary source being the RCRA Post Closure Permit Application for the Bear Creek Valley Hydrogeologic Regime at the Y-12 Plant (Energy Systems 1992a).

\section{S-3 Ponds Operational History}

The S-3 Ponds, which were formerly a part of the S-3 Waste Management Area, are located adjacent to the west end of the Y-12 Plant (Fig. A.3). Activities at the S-3 Ponds are listed 
chronologically in Table A.2. Constructed in 1951, the four unlined impoundments covered an area of $\sim 120 \times 120 \mathrm{~m}(400 \times 400 \mathrm{ft})$ (Plate A.3). The original pond excavations penetrated residual soil and fill materials but are assumed, based on the depth of bedrock in wells surrounding the site, not to have extended down to the bedrock. Each pond was $\sim 5 \mathrm{~m}(17 \mathrm{ft})$ deep and, while in operation, each pond had a storage capacity of 9.5 million L (2.5 million gal).

Three different types of wastes are known to have been disposed of in the S-3 Ponds: (1) liquid wastes generated by Y-12 Plant operations and other facilities; (2) sludges generated from the in situ neutralization and biodenitrification of the pond waters and sludges generated from the treatment of acid raffinate; and (3) contaminated sediments from two lagoons (known as the "Blue Lagoons") in Upper Bear Creek. Waste products were discharged into the ponds from tank trucks, small containers, and an underground nitric acid pipeline, which was abandoned and plugged in 1983. The liquid wastes generated by the Y-12 Plant consisted primarily of nitric acid, nitrate waste, pickling and plating wastes, and miscellaneous liquid wastes associated with routine clean-up operations (e.g., mop water). Other wastes included dilute acid, machine coolants, caustic solutions, and acids with a $\mathrm{pH}$ of $<2.0$. During the mid-1950s, uranyl nitrate solutions containing small amounts of plutonium were discharged into the ponds. In the 1970s, aerosol cans (very small paint cans such as used for touch-up work) were placed in the northeast pond, and some small amounts (probably $<10 \%$ ) were put in the southeast pond.

From 1951 to 1976 , the ponds received liquid wastes from the uranium operations at the Y-12 Plant. Wastes from areas in the plant handling enriched uranium constituted the largest volumes [about 7.6 million $\mathrm{L}$ ( 2 million gal) of liquid per year]. These liquids were sent to the ponds through the pipeline in small batches [about $760 \mathrm{~L}(200 \mathrm{gal})]$. Of the total waste stream, about 5.7 million L (1.5 million gal) per year were called "condensate" and were 0.1 to $4.0 \%$ nitric acid aqueous solutions. The other stream [about 1.9 million $L(0.5$ million gal) per year] was "raffinate" and was a mixture of about $20 \%$ aluminum nitrite in 1 to $4 \%$ nitric acid aqueous solutions.

During the 1950s to 1970s, the uranium assay in the ponds was monitored carefully. Depleted uranium nitrate solution ( $30 \%$ uranium nitrate aqueous) was pumped through the pipeline to the ponds to maintain an assay of $<0.7 \%{ }^{235} \mathrm{U}$. The ponds generally had an assay of $<0.4 \%{ }^{235} \mathrm{U}$. The volume of this stream was usually 1900 to $3800 \mathrm{~L}$ (500 to 1000 gal) per year and was generated from spent pickle baths used for cleaning depleted uranium metal. The acid cleaning bath also was occasionally used for cleaning copper metal, but this was not a common practice.

In 1976, a recycle and nitrate recovery system was developed and installed for the condensate and raffinate streams. The amounts of nitrate that were being released to the ponds from the plant decreased significantly, but the volumes of waste liquids going to the ponds remained approximately the same. However the amounts of depleted uranium being released did not decrease.

During the late 1970 s, mop waters (soap and water) that had previously been discharged in BCBG were diverted to the S-3 Ponds. This waste stream reportedly did not contain any uranium. In the late 1970 s and early 1980 s, the ponds received sludge from the scrubbing of waste fluoride gas from the K-25 Site. The sludge was a mixture of potassium carbonate, potassium hydroxide, and potassium fluoride with a small amount of ${ }^{99} \mathrm{Tc}$. The sludge contained about $40 \%$ solids and $60 \%$ water. Liquid waste discharges into the ponds were terminated in March 1984. 
While in operation, the now-abandoned nitric acid pipeline also transported liquid wastes originating from sources outside of Oak Ridge Y-12 Plant, including raffinate from DOE's Savannah River Site and Idaho National Engineering Laboratory. The wastes from these facilities contained, at a minimum, the following radionuclides: ${ }^{137} \mathrm{Cs},{ }^{57}$ and ${ }^{60} \mathrm{Co}$, californium, americium, iodine isotopes, ${ }^{237} \mathrm{~Np},{ }^{95} \mathrm{Nb}$, nickel isotopes, ${ }^{238}$ and ${ }^{239} \mathrm{Pu},{ }^{106} \mathrm{Ru},{ }^{90} \mathrm{Sr},{ }^{228,}{ }^{230},{ }^{232},{ }^{234} \mathrm{Th},{ }^{99} \mathrm{Tc},{ }^{95} \mathrm{Zr}$, and uranium daughters. These radionuclides were present in the waste streams in the parts per billion (ppb) range and possibly the low parts per million (ppm) range. The ponds also received liquid waste from the K-25 Site and Oak Ridge National Laboratory in Oak Ridge, but these were transported by truck in small batches (usually in 55-gal drums).

Several studies of water and sludges in the S-3 Ponds (Jeter 1983; Kimbrough and Turner 1987) concluded that, although the pond water chemistry varied from pond to pond and from year to year, it generally remained highly acidic. Nitric acid was the primary acid constituent. Major metallic ion constituents were calcium, magnesium, potassium, aluminum; moderately high concentrations of other trace metals were present. The few organic analyses available for the pond waters indicate that concentrations of organics could have been highly variable over the period of operation.

\section{S-3 Ponds Treatment and Closure}

In situ treatment of wastewater in the S-3 Ponds consisted of (1) neutralization in all four ponds between May and November 1983 and (2) in situ biodenitrification processes from May 1983 to September 1984 (Fig. A.3). This biodenitrification treatment decreased nitrate levels in the pond water to $<50 \mathrm{ppm}$. Nutrients continued to be added to the ponds to maintain the bioreaction, and the sludge was agitated to denitrify residuals.

After denitrification, the contents of the ponds were allowed to settle and form a sludge layer ranging from 0.6 to $1.5 \mathrm{~m}$ ( 2 to $5 \mathrm{ft}$ ) thick. Supernatant liquids were pumped to the S-3 Ponds Treatment Facility (Fig. A.2) for removal of trace metals and organics. Treated effluent was discharged to East Fork Poplar Creek in accordance with a National Pollutant Discharge Elimination System permit. The supernatant treatment began in 1985 and was completed by the spring of 1986.

Immediately before structural stabilization and filling of the S-3 Ponds (Plate A.4) in preparation for facility closure in 1988 (Energy Systems 1988a), sediment that had accumulated in the two Blue Lagoons in Upper Bear Creek was placed in the southwest cell of the S-3 Ponds. Turner and Kamp (1984) characterized this material in place before removal from the lagoons, and each truckload of sediment was sampled and analyzed before it was placed in the ponds (McMahon 1988). The data from the 1988 sampling and characterization have been tabulated in Appendix A of the BCV OU 1 RI Work Plan (DOE 1994a) and are summarized in Table A.3 with the estimated current composition of materials located in the former ponds.

It should be noted that when the given thorium activities for the S-3 Ponds and the uranium activities were "back calculated" (using the isotopes' specific activities) to concentrations (mg/kg), the calculated values do not match the concentrations shown for total thorium and total uranium under the inventory's metals listing. For example, the measured S-3 Ponds ${ }^{232} \mathrm{Th}$ activity alone represents $818.7 \mathrm{mg} / \mathrm{kg}{ }^{232} \mathrm{Th}$. Yet the total thorium metal concentration for the S-3 Ponds was measured at $204 \mathrm{mg} / \mathrm{kg}$. This apparent mismatch is probably due to the use of different analytical methods to measure total metals and isotopic activities. To address these data gaps in a manner most protective of human health, it was decided to calculate activities for three thorium isotopes 
$\left({ }^{228} \mathrm{Th},{ }^{230} \mathrm{Th}\right.$, and $\left.{ }^{232} \mathrm{Th}\right)$ for the Blue Lagoon assuming the same measured isotopic distribution as shown for the S-3 Ponds and by using the Blue Lagoon measured exposure concentration of $10.1 \mathrm{mg} / \mathrm{kg}$. Similarly, the activities for four uranium isotopes $\left({ }^{234} \mathrm{U},{ }^{235} \mathrm{U},{ }^{236} \mathrm{U}\right.$, and $\left.{ }^{237} \mathrm{U}\right)$ were calculated for the S-3 Ponds by assuming the same measured isotopic distribution as shown for the Blue Lagoon and by using the S-3 Ponds measured exposure concentration of $1020 \mathrm{mg} / \mathrm{kg}$.

The S-3 Ponds Hazardous Waste Disposal Unit (HWDU) was granted interim status under TN Rule 1200-1-11-.07(3) in December 1984 and is, therefore, subject to the groundwater monitoring requirements described in TN Rule 1200-1-11-.05. Before this date, groundwater monitoring at the S-3 Ponds was conducted in accordance with two DOE monitoring programs: historical and characterization monitoring. Characterization monitoring was conducted at the S-3 Ponds from 1983 to 1986 in response to the Memorandum of Understanding (MOU) signed by DOE, the Environmental Protection Agency (EPA), and the Tennessee Department of Environment and Conservation (TDEC). The historical program was initiated in 1975 to monitor groundwater quality in and around waste disposal sites in the BCBG. The program was expanded in the early 1980 s to include other sites, including the S-3 Ponds.

Continued investigations were performed between 1986 and 1989 to support RCRA groundwater monitoring requirements. Groundwater quality assessment monitoring was performed in lieu of RCRA detection monitoring in accordance with a formal Groundwater Quality Assessment Plan issued in 1987 (Geraghty and Miller 1987).

The 1988 RCRA closure of the S-3 Ponds Site included installing a multilayered cap and covering the site with asphalt to create a parking lot. TDEC granted final closure certification of the S-3 Ponds in November 1990 and issued a RCRA postclosure permit for the S-3 Ponds HWDU on September 30, 1991 (Energy Systems 1992b). The permit was appealed by DOE and Martin Marietta Energy Systems, Inc. (Energy Systems) on October 30, 1991. A revised application was submitted to TDEC in November 1992 (Energy Systems 1992b). The 1992 version satisfied the appeal, and in April 1993 a "consent order" related to the RCRA postclosure permit for the S-3 Site was signed by TDEC, DOE, and Energy Systems. With the consent order, the parties agreed to proceed with the Comprehensive Environmental Response, Compensation, and Liability Act (CERCLA) as the lead regulatory program and RCRA as an applicable or relevant and appropriate requirement. The consent order was further used as a model for all remaining postclosure permits.

\section{A.1.3.2 Oil Landfarm}

\section{Introduction}

The OLF source area consists of a former landfarming plot that was used for the biological degradation of industrial waste oil and machine coolants. It was closed as a landfill with a multilayered engineered cap in 1990. Operations at the OLF are documented in the RCRA closure reports for the facility, with the primary source being the RCRA Postclosure Permit Application for the Bear Creek Valley Hydrogeologic Regime at the Y-12 Plant (Energy Systems 1992a). Primary sources concerning sampling and analysis of soils at the OLF are Herbes (1989) for characterization of soils before excavation and closure and Bohrman (1989) for characterization of soils after excavation. 


\section{OLF Operational History}

The OLF is located $\sim 2.4 \mathrm{~km}$ (1.5 miles) west of the Y-12 Plant and north of SL 1 and Bear Creek Road (Plate A.5). Activities at the site are listed chronologically in Table A.4. Between 1973 and 1982 the facility was used for biological degradation of waste oil and machine coolants through landfarming, a process involving the application of waste oils and coolants to nutrient-adjusted soil during the dry months of the year (April to October). After application, the plots were cultivated frequently to maintain aerobic conditions to enhance biodegradation of the wastes. During its 9 years of operation, the OLF received $\sim 3.8$ million L (1 million gal) of liquid wastes (Turner et al. 1991), including:

- waste oils,

- coolants,

- mop waters,

- tanker oils from the K-25 Site,

- wastes from cooling towers,

- oils from the Oil Retention Ponds (ORPs) in BCBG, and

- unidentified miscellaneous liquid wastes.

The oils and coolants disposed of at the OLF are known to have been contaminated with beryllium compounds, depleted uranium, polychlorinated biphenyls (PCBs), tetrachloroethene, and 1,1,1-trichloroethane.

The composition and volume of liquid waste applied to the OLF varied from plot to plot (BNI 1983). For example, beryllium-contaminated oil, tanker oils, and coolants were applied to Plots $1 / 2$ through $15 / 16$ (Fig. A.4) as follows:

- Beryllium-contaminated oils

- Tanker oils

- Coolants
Plots $1 / 2(50 \%$ of total), $7 / 8(25 \%)$, and $9 / 10(25 \%)$ Plots $3 / 4$ and $5 / 6$ (with lighter applications to other plots)

Plots $3 / 4,5 / 6,11 / 12,13 / 14$, and $15 / 16$ (with lighter applications to other plots)

In general, the east plots received greater volumes of total liquid waste than the west plots, which in turn received greater volumes than the north plots.

Tables A.5 and A.6 summarize the types and amounts of waste oils and waste coolants disposed of in the plots during the operating period (Union Carbide 1984). Although waste oils typically consisted of crankcase, hydraulic, gear, vacuum pump, mineral, and machine coolant oils, the oils disposed of during 1974 and 1975 included $~ 57,000 \mathrm{~L}(15,000 \mathrm{gal})$ of oil skimmed from the surface of ORP-1, located in the BCBG (see Sect. A.1.3.5). The machine coolants included nonsoluble oils and water-soluble mixtures consisting of $\sim 5 \%$ oil and $95 \%$ water.

The typical composition of waste oils and coolants disposed of in the OLF plots is considered representative of that of the waste oils and coolants generated at the Y-12 Plant, which is summarized in Appendix A of the BCV OU 1 RI Work Plan (DOE 1994a). The waste oils contained uranium concentrations ranging from $\sim 20$ to $80 \mathrm{ppm}$ as well as elevated concentrations of calcium, iron, sodium, silicon, phosphorous, chlorine, zinc, and lead. The coolants show a similar composition, except that barium concentration in the coolants are 10 to 50 times higher 
than those in the oils. Waste disposed of during 1980 also included $3800 \mathrm{~L}$ (1000 gal) of dye penetrant, which could act as a potential artifact in future dye-tracer studies.

Before 1979, waste oils and coolants were not specifically analyzed for contaminants before they were applied to the OLF. However, analytical results for samples of oil collected from the surface of one ORP in the BCBG and applied to the OLF in 1979 indicated the presence of PCBs. Thereafter, oils were analyzed for uranium, beryllium, thorium, and PCBs before being applied to the OLF. The Y-12 Plant established a maximum permissible concentration level of $5 \mathrm{mg} / \mathrm{L}$ PCBs in waste oils to be landfarmed. Oils containing $>5 \mathrm{mg} / \mathrm{L}$ of PCBs were shipped for commercial disposal if uranium concentrations were less than permissible limits established for such disposal. If uranium concentrations were greater than the established permissible limits, waste oils containing $>5 \mathrm{mg} / \mathrm{L}$ of $\mathrm{PCBs}$ were placed in storage for future incineration at the $\mathrm{K}-25$ Site Toxic Substances Control Act Incinerator.

In December 1981, the analyses of wastes to be landfarmed were expanded to include chlorinated hydrocarbons. A maximum permissible concentration of $3 \%$ was established for chlorinated solvents in the waste oils. Since 1981, sampling and analysis of waste oils for chlorinated solvents have shown that landfarmed waste oils have contained concentrations of $<3 \%$ chlorinated hydrocarbons.

\section{OLF Treatment and Closure}

In 1984, TDEC issued an order requiring DOE to permit or close the OLF site under RCRA, although the actual "closure" wasn't initiated until 1988. In March 1994, DOE resubmitted the postclosure permit application with a modification to add the OLF to the BCV permit (Energy Systems 1994). Between 1984 and 1988, preparations for closure included extensive soil sampling, involving collection of 200 soil samples in a randomized block design, to delineate the extent of soils contaminated with $>25 \mu \mathrm{g} / \mathrm{g}$ PCB (Herbes 1989). PCB concentrations above this action level were identified in several areas of the OLF plots; the highest concentration measured was $60.5 \mu \mathrm{g} / \mathrm{g}$. Ten depth profiles revealed that the PCB contamination was principally confined to the upper 6 in. of soil, with concentrations declining by more than $90 \%$ between the surface ( 0 - to 6-in. interval) and the 12- to 18-in. interval. The highest PCB concentrations were found in the east and west plots (Herbes 1989). Analysis of the same soil samples for uranium showed that uranium concentrations were also highest in the east and west plots and that they declined rapidly with soil depth. The highest mean uranium concentration observed was $204 \mu \mathrm{g} / \mathrm{g}$ (in Plot 7/8). Lowest concentrations were between 13 and $27 \mu \mathrm{g} / \mathrm{g}$ and occurred in the north plot group.

Soils found to be contaminated with $>25 \mu \mathrm{g} / \mathrm{g}$ PCB were excavated in 1989, before construction of the OLF cap, and placed on the OLF soils contaminant pad (Fig. A.2), and post-excavation sampling was conducted to confirm that the $<25 \mu \mathrm{g} / \mathrm{g}$ standard had been attained (Bohrman 1989). Table A.7 provides a summary of geotechnical and chemical analysis of soils placed on this storage pad, and Table A.8 lists the results of postevacuation confirmatory sampling of soils-in-place at the OLF. Note that although the soils-in-place samples were not analyzed for metals, it is expected that the concentrations of metal contaminants in the in-place samples would be equal to or less than the concentrations of metal contaminants in the evacuated soils placed in the OLF soils contaminant pad. Details of the current nature and extent of PCB and uranium soil contamination below the OLF cap were calculated using data from the Herbes 1989 and Bohrman 1989 reports. 
The OLF HWDU was granted interim status under TN Rule 1200-1-11-.07(3) in December 1984 and is, therefore, subject to the groundwater monitoring requirements described in TN Rule 1200-1-11-.05. Before this date, groundwater monitoring at the OLF was conducted in accordance with two DOE groundwater monitoring programs. Historical monitoring at the site was conducted from 1975 to 1987 as part of a program to identify groundwater contamination sources at the Y-12 Plant. Characterization monitoring began in 1983 in response to the MOU signed by DOE, EPA, and TDEC and continued until 1986.

Groundwater quality data collected during historical and characterization monitoring verified the presence of contaminants in groundwater at the OLF. Therefore, interim status assessment monitoring was implemented at the site in lieu of detection monitoring, as required under TN Rule 1200-1-11-.05(6)(a)4. Assessment monitoring was initiated at the OLF in January 1986.

TDEC acceptance of certification of final closure of the OLF was granted in November 1990. The site was closed as an HWDU and is subject to postclosure care under TN Rule 1200-1-11-.06(7)(g) and (h). Pursuant to TN Rule 1200-1-11-.06(1)(c), a postclosure permit modification adding the OLF site to the BCV postclosure permit was issued in June 1995, thus groundwater monitoring requirements under TN Rule 1200-1-11-.06 apply to this site (Energy Systems 1994).

\section{A.1.3.3 Boneyard/Burnyard}

The BYBY, located east of the OLF, consists of three sites: Boneyard, Burnyard, and HCDA (Fig. A.5 and Plate A.5). Information concerning operations at this site is sparse. The primary source documents used for this section are the RCRA Postclosure Permit Application for the Bear Creek Valley Hydrogeologic Regime at the Y-12 Plant (Energy Systems 1992a), and the Remedial Investigation Work Plan for Bear Creek (Turner et al. 1991). Activities at the BYBY are listed chronologically in Table A.9.

The Boneyard, which consisted of a series of unlined earthen trenches, was an active waste disposal site from the mid-1940s to the mid-1970s. Site wastes have been characterized as ranging from ignitable and radioactive to inert. They are known to have included organics, metals, debris, acids, and beryllium, but the total quantity of material is unknown. The primary waste that went to the Boneyard in the late 1950 s to the late 1960 s was depleted uranium metal chips. These were placed into an open pit and were burned without being covered. Some waste oil or waste paper was used to start the burning, which was usually done once a week.

Magnesium chips were disposed of in the southwest corner of the Boneyard, south of the gravel road. The metal chips were placed in burn pans in unlined earthen trenches, and ignitable waste solvents were used to initiate the burn. The residue remaining in the trenches was covered with soil and compacted until the trenches were filled, after which they were covered with topsoil and seeded with grass. The remaining land in the Boneyard was used to dispose of construction spoil material such as concrete and rebar.

The Burnyard consisted of two trenches $\sim 90 \mathrm{~m}$ (300 ft) long and $12 \mathrm{~m}$ (40 ft) wide (Plate A.6). The site is no longer visible because the HCDA was built on top of it and subsequently capped (Fig. A.5). An active waste site from 1943 to 1968, the Burnyard is estimated to have received $-90 \mathrm{~m}^{3}\left(350 \mathrm{yd}^{3}\right)$ per month $\left[1000 \mathrm{~m}^{3}\left(4000 \mathrm{yd}^{3}\right)\right.$ per year] of sanitary refuse, including solids, liquids, and sludges, from plant operations. The waste materials, which may have contained empty pesticide containers, metal shavings, solvents, oils, and laboratory 


\section{A1-11}

chemicals, were placed in unlined earthen trenches and burned. Oils and other flammable liquids, possibly transformer oils containing PCBs, were used to start and sustain combustion. Dioxin/furan contamination could have resulted from this burning of PCBs at relatively low temperatures. After the trenches became filled, they were covered with soil. No collection or treatment systems, other than burning, are known to have been used on this site.

The HCDA is located on top of the former Burnyard site (Fig. A.5 and Plate A.5). The site is estimated to have received $<3.8 \mathrm{~m}^{3}\left(5 \mathrm{yd}^{3}\right)$ of solid, liquid, and gaseous waste materials a year from 1975 to 1981 (Turner et al. 1991). The material was broadly characterized as ignitable, reactive, corrosive, toxic, highly flammable, or in some instances inert (Energy Systems 1987b).

Generally, the HCDA received wastes from two sources that posed safety hazards within the Y-12 Plant: (1) gas cylinders with leaking or damaged valves and (2) laboratory chemicals considered to be reactive or explosive. Gas cylinders containing noncorrosive gases were allowed to leak into the atmosphere or were bled off to expedite the process. Those containing corrosive gases were bled through neutralizing slurries. Empty gas cylinders were either destroyed or transported to another location for repair. The lab chemicals included acids, bases, organics, water-reactive compounds, and explosive compounds such as picric acid, benzoyl peroxide, and ether. Bottles of chemicals were broken under water spray in a concrete vessel that was open to the atmosphere. After the explosion or chemical reaction had taken place, the effluent was discharged into a small unlined surface impoundment and allowed to percolate through the soil (Plate A.5). The chemical residue remaining in the concrete vessel was removed periodically and transported to the BCBG (Energy Systems 1987b).

In 1989, the HCDA was covered with a cap of RCRA multilayer type construction (Energy Systems 1991); however, no actions to remediate soils were conducted before capping. This cap is not included in the BCV postclosure permit.

\section{A.1.3.4 Sanitary Landfill 1}

SL 1 is located $\sim 1.3 \mathrm{~km}(0.8$ mile) west of the Y-12 Plant, just north of Bear Creek and immediately south of the OLF (Fig. A.5 and Plate A.5). Little recorded information exists for the SL 1 site. The principal references for operational information are the same as those for BYBY: Energy Systems (1987b) and Turner et al. (1991). SL 1 was used between 1968 and 1983 for the disposal of combustible and decomposable solid wastes. The landfill was permitted for materials such as paper and cardboard, plastics, rubber, wood, brush, animal bedding, organic garbage, textile products, and asphalt roofing materials. Although administrative controls were used to exclude the disposal of toxic chemicals and other contaminated materials, some of these materials may have been disposed of in the landfill. Events at SL 1 are listed chronologically in Table A.10.

The trench at SL 1 was excavated to a depth of $-6 \mathrm{~m} \mathrm{(20} \mathrm{ft)} \mathrm{and} \mathrm{backfilled} \mathrm{to} \sim 4.5 \mathrm{~m} \mathrm{(15 \textrm {ft } )}$ above grade. About $27,000 \mathrm{~m}^{3}\left(35,315 \mathrm{yd}^{3}\right)$ of refuse were disposed of at the landfill during its 15 years of operation. SL 1 was closed in 1985 by grading the site to promote drainage, capping it with $0.6 \mathrm{~m}(2 \mathrm{ft}$ ) of clay and topsoil, and establishing a vegetation cover (Energy Systems 1987b). 


\section{A.1.3.5 Bear Creek Burial Grounds}

\section{Introduction}

The BCBG were used from about 1955 to 1991 to dispose of industrial wastes that were composed of or contaminated with uranium. Most of the available information about the operations at the BCBG was compiled from the waste inventory records (see Supporting Information for Appendix A) and the RCRA closure documents for this facility (Energy Systems 1988b).

During the early years of Y-12 Plant operation, the Maintenance Division was responsible for waste disposal, including waste disposals at the BCBG. Waste materials disposed of in the BCBG came not only from the Y-12 Plant but also from Oak Ridge National Laboratory, K-25 Site, and facilities outside Oak Ridge.

Materials delivered to the BCBG were segregated and disposed of in particular areas. Initially, there were only two areas: Burial Ground 1 and Burial Ground 2 (BG-1 and BG-2). These areas were later subdivided, with BG-1 becoming Burial Ground $A$ (BG-A) and BG-2 being divided into multiple areas: BG-B, $-\mathrm{C},-\mathrm{D},-\mathrm{E}$, and $-\mathrm{J}$ (Figs. A.6 and A.7).

Trenches were dug in each area as needed, with each trench receiving its own identification number. For example, the number BG-A3E referred to the east end of trench \#3 in the A area. Several areas were set aside for particular materials: carbon foam (BG-A8FOAM), aerosol cans (BG-A11AERCAN), asbestos (BG-A12ASBP), crucible oxides (BG-BCRUCOX and BGCCRUCOX), depleted uranium alloys (BG-BDEPUCPD), depleted uranium (BG-BD38 and BG-CD38), and thorium (BG-BTHOR).

\section{$B C B G$ Operational Information}

The BCBG, located $\sim 3.2 \mathrm{~km}$ ( 2 miles) west of the Y-12 Plant (Fig. A.2 and Plate A.7), consist of:

- $\quad$ several principal waste disposal units designated as BG-A, -B, -C, -D, -E, and -J;

- Walk-In Pits (WIP);

- Uranium Vaults (Fig. A.8); and

- ORP-1 and -2 .

Each waste disposal unit consisted of a series of trenches, 4.2 to $7.5 \mathrm{~m}$ (14 to $25 \mathrm{ft}$ ) deep (Energy Systems 1988b), which were used for disposal of solid and liquid wastes (Figs. A.6 and A.7). Events at the BCBG are listed chronologically in Table A.11.

A detailed inventory of waste materials in the BCBG has been constructed and is summarized here. Further details are contained in Supporting Information for Appendix A. Most of the wastes disposed of at the BCBG were composed of or contaminated with uranium (Fig. A.9). These wastes included:

- uranium-contaminated waste material,

- large pieces of uranium metal (machined parts),

- uranium tailings and chips generated by milling the machined parts, and

- uranium saw fines generated by fabrication methods. 
In general, the contaminated material and tailings were placed in the A trenches (Plates A.8 and A.9), and the large uranium parts/pieces were placed in $E$ and $J$ trenches. Some of the tailings were also placed in 1-B trenches, as well as in the $\mathrm{C}$ to $\mathrm{J}$ trenches. The locations at which these various uranium forms were disposed of are discussed in more detail in Sect. A.6 of Supporting Information for Appendix A.

Unpublished reports and photographs (Plates A.7 and A.8) indicate that, after disposal, uranium tailings exposed to air often oxidized rapidly, causing uranium fires. The most pyrophoric form of uranium disposed of in the BCBG, saw fines and chips, was disposed of in the WIP in a manner that prevented rapid oxidation and subsequent fires. In addition, photographs also reveal that wastes in many branches were submerged (Plates A.9 and A.10).

Mercury, which is a known potential contaminant throughout the $Y-12$ complex, is also found in the BCBG. Because actual quantities of mercury disposed of at $\mathrm{Y}-12$ were not routinely recorded, no estimates of mercury masses or concentrations have been attempted in this review.

Before 1968, oils (including those contaminated with PCBs) were burned for disposal in the BCBG. PCBs were also used in the plant in transformers and as a coolant component for the $\mathrm{M}$-Wing and the Z-oil system. These original coolants, as well as subsequent non-PCB coolant change-out fluids, were deposited in the BCBG. Waste oils and coolants, which contained varying amounts of organic compounds (potentially with PCB content), were used to bathe uranium chips before disposal.

Actual quantities and identities of materials deposited in the BCBG have a high degree of uncertainty. Small amounts of unrecorded material may also have been buried in these areas.

\section{Area $A$}

Area A-South was the initial disposal site within the BCBG and was operational for about 6 years before other areas were opened.

Uranium is a major contaminant in every BCBG area. Area A was targeted primarily for waste types identified as containing depleted uranium contamination. A wide variety of contaminated debris and wastes were deposited in Area A, and small amounts of waste contaminated with enriched uranium may also have been disposed of here. Areas A-16 through A-18 are relatively recent burial sites designated strictly for uranium-contaminated trash; they are assumed to contain no other waste types. Other radioactive materials disposed in Area A-North include a one-time disposal of thorium-contaminated sludge from outside the $\mathrm{Y}-12$ complex and technetium.

Area $\mathrm{A}$ also received nonradioactive wastes. Large quantities of waste oils and machine coolants were deposited in the trenches of A-South and A-North, either directly in the trenches or as burn residues. Disposal records available for the purposes of this report quantitatively documented the disposal of PCB materials only in relation to BCBG Areas A-North and A-South as well as WIP \#1 (North). Specific PCB compounds cited are Therminol-FR-0 and Pyranol, manufactured by Monsanto and General Electric, respectively. The PCB concentration in Therminol-FR-0 during the 1960s was $80 \%$ Aroclor-1242, while Pyranol, a component in transformer oil during the 1960s, was manufactured as an Aroclor series (1242-1260) containing 45 to $100 \%$ PCBs, depending on the particular Aroclor (Mappes 1995). 


\section{A1-14}

The Isolation Area of A-South received thousands of gallons of organic solvent wastes and fuel-contaminated waters (gasoline/water mixtures) between 1970 and 1979. Similar quantities may have been discarded throughout the A-South area before 1970. Area A-North contains a segregated location for asbestos-containing materials. Such segregation was not implemented until 1978; therefore, asbestos-containing waste materials are assumed to have been deposited throughout Area A before 1978.

\section{Areas $B, D, E$, and $J$}

These areas were designated for disposal of uranium chip, metal, and oxide wastes. Almost $70 \%$ of the total uranium deposited in the BCBG is estimated to have been placed in these areas (Supporting Information, Sect. A.7.3). Although Area E is physically small, a relatively high percentage of the total BCBG uranium has been assigned to the area because of the reported type and size of uranium-containing objects deposited there. Area D designated trenches actually appear in three separate geographical locations of the BCBG and thus are addressed separately in the inventory review tables (D-East, D-West, and D-South). Area D-West, Area E, and Area J trenches form a geographically contiguous group and were combined to estimate uranium concentrations. An estimated quantity of thorium is also assumed to be deposited in Area B.

\section{Area $C$}

Area $\mathrm{C}$ was designated for the disposal of industrial wastes contaminated with beryllium, enriched uranium, thorium, and technetium. Indications are that only a minor amount of material potentially contaminated with enriched uranium was deposited in this area. However, review records contained definite reference to amounts of materials, metals, chips, and oxides contaminated with depleted uranium being deposited in Area $\mathrm{C}$. Therefore, in addition to estimates for beryllium and thorium, this review has assumed a uranium contribution to the waste inventory of Area $C$. Records also indicated that lithium compounds were deposited in the $C$ area (Supporting Information, Tables A.19 and A.20).

\section{Walk-In Pits}

Three WIP locations are mentioned in inventory information (see Supporting Information for Appendix A). The records indicate that these pits were contiguous with Area B and that WIP 1 (North) received most of the recorded material (78\% of the recorded entries other than uranium saw fines). These areas were used for the disposal of laboratory and industrial chemicals of all types; however, uranium metal saw fines were a primary contribution to these locations. About $15 \%$ of the total BCBG uranium has been assumed to be uranium material in these areas.

As indicated in the BCBG waste inventory (see Supporting Information for Appendix A), there is an extensive list of chemicals that could have been placed in these areas. The quantities of most of these miscellaneous chemical deposits are assumed to be relatively small (on the order of milliliters). However, many common solvents (acetone, alcohols, carbon tetrachloride, cyclohexane, methyl ethyl ketone, methyl isobutyl ketone, toluene, and xylenes), which were listed on inventories for these sites without associated quantities, may have been discarded in significant amounts. Several compounds, such as picric acid, ether, and chromic acid, were deposited in these WIP locations because they were old, partially crystallized or radioactively contaminated reagents, constituting an explosive hazard. 


\section{Oil Retention Ponds}

ORP-1 and -2 were constructed to prevent downstream transport of oil in NT-6 and NT-7 (Fig. A.2 and Plate A.11). Although overflow of mop water from standpipes had occurred previously, oil was first observed seeping from the west ends of trenches in BG-A into NT-7 and from the soil surface above the oil disposal pits between 1969 and 1971. At this time, oil disposal in the BG-A South trenches was discontinued (Bailey 1979). To prevent oil transport down NT-7 to Bear Creek, ORP-1, with maximum dimensions of $55 \mathrm{~m}$ (180 ft) in length, $34 \mathrm{~m} \mathrm{(110} \mathrm{ft)} \mathrm{in}$ width, and $2 \mathrm{~m}(6 \mathrm{ft})$ in depth, was constructed at the southwest corner of BG-A in May 1971. The pond was equipped with underflow pipes to permit water discharge while retaining floating oils in the impoundment. Simultaneously, a drainage ditch was constructed about 18 to $30 \mathrm{~m}$

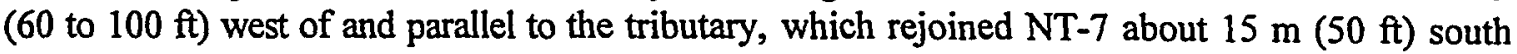
of the pond, to divert uncontaminated surface runoff around the pond. A sump was later dug at the western end of one of the trenches east of ORP-1 to collect oil, which was pumped into the pond. This sump has been backfilled with dirt (Bailey 1979). A pipe was also installed between the end of a second trench and the pond to permit direct oil transfer to the pond (Bailey 1979).

ORP-2 was constructed in a similar fashion to ORP-1, but located northeast of BCBG A North (Fig. A.2). It was capped at the same time as BCBG-A.

\section{BCBG Treatment and Closure}

Areas $A, B, C, D, E, J$, and WIP

BG-A and BG-C West were closed in place as landfills and covered with a RCRA cap in 1989. BG-B and the WIP North and South were covered with a RCRA cap in 1994 and closed. Although BG-B did not receive RCRA wastes, it was covered with a RCRA cap due to its location between WIP North and South. BG-C East also did not receive RCRA-regulated wastes, and was closed in 1994 with a .6-m (2-ft) clay cover.

The BCBG were granted interim status in December 1984 and, therefore, are subject to the groundwater monitoring requirements described in TN Rule 1200-1-11-.05. Before this date, groundwater monitoring at the site was conducted in accordance with two DOE monitoring programs. Historical monitoring at the site was conducted from 1975 until 1987 as part of a program to identify groundwater contamination sources at the Y-12 Plant. Characterization monitoring at the BCBG began in 1983 in response to the MOU signed by DOE, EPA, and TDEC and continued until 1986.

Groundwater quality data collected during historical and characterization monitoring verified the presence of contaminants in groundwater at the $\mathrm{BCBG}$. Therefore, interim status assessment monitoring was implemented at the site in lieu of detection monitoring. TDEC granted approval in November 1990 for the final closure of BG-A. The site was closed as an HWDU and is subject to postclosure care. BCBG C West was certified in May 1993 (Energy Systems 1992c), and the WIP and BCBG B were certified by the State of Tennessee in February 1995.

In April 1995, DOE submitted a postclosure permit application modification to add the WIP to the BCV permit, and in September 1995, TDEC issued a revised postclosure permit incorporating the WIP (Energy Systems 1995). 


\section{Oil Retention Ponds}

In $1974, \sim 57,000 \mathrm{~L}(15,000 \mathrm{gal})$ of oil were removed from the surface of ORP-1 and sent to the Oil Landfarm (Sect. A.1.3.2). An additional 19,000 L (5000 gal) were removed in early 1975 and sprayed onto nearby trees. In 1979, another $68,000 \mathrm{~L}(18,000 \mathrm{gal})$ of oil were removed (Battelle 1986). Oil seepage was observed on a steep slope above NT-6 at the eastern end of trenches A-14 and A-15 before 1972 (Bailey 1979). In May 1972, a smaller impoundment, ORP-2, was constructed on NT-6 in the northeast corner of BG-A. No significant oil accumulation was reported on the surface of ORP-2 from 1975 to closure of the pond in 1989 (Battelle 1986).

Both ORPs were closed and capped under an approved RCRA closure plan in 1989. During closure operations, $3060 \mathrm{~m}^{3}$ (4,000 $\left.\mathrm{yd}^{3}\right)$ of sludge, sediment, and soil were excavated from ORP-1, ORP-2, and NT-7 (Collins 1990a) (Plate A.11). This waste was placed in the Disposal Area Remedial Action (DARA) facility located to the west of ORP-1 (Fig. A.2). A total of 980 screening samples (rapid turnaround) were taken during excavation to guide removal activities. A total of 287 certification samples of remaining soils were taken, and all but one of the contaminated areas in ORP-1, ORP-2, and NT-7 were certified to have $<25 \mu \mathrm{g} / \mathrm{g}$ PCBs. In one area, the seepage area (Seep 1, Fig. A.6) to the west of BG-A North, higher than anticipated concentrations of PCBs were encountered during excavation $(1,200 \mu \mathrm{g} / \mathrm{g})$. This area was closed without achieving the $25 \mu \mathrm{g} / \mathrm{g}$ acceptance criteria. Table A.12 gives a summary of the analytical results from the soil samples taken from soils stored in the DARA facility. The ponds and the section of NT-7 north of ORP-1 were then covered with an engineered multilayered cap. The portion of NT-7 below ORP-1 was capped with a clay cap at this time. A new channel was constructed for NT-7, and this tributary was rerouted $\sim 15 \mathrm{~m}(50 \mathrm{ft})$ to the west of its original course.

Seepage zones from adjacent burial areas have been observed on all three tributaries draining the BCBG: NT-6, NT-7, and NT-8 (Fig. A.8), and seepage collection systems were installed on NT-7 and -8 catchments during closure of the BG-A and BG-C, and just before the initiation of WIP closure, respectively. Collection system A, located on NT-7, collects an average of $2 \mathrm{~L} / \mathrm{min}$ (0.5 gpm) from Seep 1 (Fig. A.8). Collection system B, known as the Leachate Collection System (Seeps 2, 3, and 4), is located on NT-8. Flow in system B is variable and may reach $76 \mathrm{~L} / \mathrm{min}$ $(20 \mathrm{gpm})$ in rainy weather, whereas flow in system A shows little variation. 


\section{A.2 RELEASES}

Numerous releases of hazardous and/or radioactive chemicals to the environment occurred during operation of the waste disposal sites in BCV. These releases were the result of either working practices that were approved at the time (such as injection of waste oils into standpipes in the BCBG) or accidental releases. The instances of releases through working practices are described in this Appendix, and the released contaminants are described in detail in Appendix D. 


\section{A.3 REFERENCES}

Bailey, J. K. 1979. History: Y-12 Oil Disposal, Y-12 File Report, Union Carbide Corporation, Oak Ridge Y-12 Plant, Oak Ridge, Tennessee.

Bailey, J. K. 1983a. Bear Creek Burial Grounds Inventory, Y/DS-171, Parts 1 through 10, Martin Marietta Energy Systems, Inc., Oak Ridge Y-12 Plant, Oak Ridge, Tennessee.

Bailey, J. K. 1983b. Waste Disposal Notes, Y-12 File Report, Union Carbide Corp., Oak Ridge Y-12 Plant, Oak Ridge, Tennessee.

Bailey, J. K. 1995. Fax transmittal to J. H. Moyer dated May 9, subject: Information relating to PCB contamination in the Bear Creek Valley Burial Grounds.

Battelle (Battelle, Inc.). 1986. Geologic Report and RCRA Closure Plan for Oil Retention Ponds, DOE Y-12 Plant, Oak Ridge, Tennessee, Columbus, Ohio.

Battelle PNL. 1994. PEIS Solid Waste Report for Y-12, Y-12-S0001-001, February.

BNI (Bechtel National, Inc.). 1983. Preliminary Characterization and Remedial Action Plan for the Y-12 Plant Oil Landfarm, Y/Sub/83-47974C/1, prepared for Martin Marietta Energy Systems, Inc., Oak Ridge Y-12 Plant, Oak Ridge, Tennessee, October.

Bohrman, D. E. 1989. Oil Landfarm Summary of Closure Under Rules Governing Hazardous Waste Management in Tennessee, Y/TS-394/2, Martin Marietta Energy Systems, Inc., Oak Ridge Y-12 Plant, Oak Ridge, Tennessee, November.

Collins, E. T. 1990a. Oil Retention Ponds (T-008, T-009) Summary of Closure Under Rules Governing Hazardous Waste Management in Tennessee, Y/TS-392/2, Martin Marietta Energy Systems, Inc., Oak Ridge Y-12 Plant, Oak Ridge, Tennessee, May.

Collins, E. T. 1990b. Bear Creek Burial Ground C-West Summary of Closure Under Rules Governing Hazardous Waste Management in Tennessee, Y/TS-395/3, Martin Marietta Energy Systems, Inc., Oak Ridge Y-12 Plant, Oak Ridge, Tennessee, December.

DOE (Department of Energy). 1988. Historical Radionuclide Releases from Current DOE Oak Ridge Operations Office Facilities, OR-890, May.

DOE. 1993. Remedial Investigation Work Plan for Bear Creek Valley Operable Unit I (S-3 Ponds, Boneyard/Burnyard, Oil Landfarm, Sanitary Landfill I, and the Burial Grounds, Including Oil Retention Ponds 1 and 2) at the Oak Ridge Y-12 Plant, Oak Ridge, Tennessee, DOE/OR/01-1161/V1\&D1.

DOE. 1994a. Remedial Investigation Work Plan for Bear Creek Valley Operable Unit 1 (S-3 Ponds, Boneyard/Burnyard, Oil Landfarm, Sanitary Landfill 1, and the Burial Grounds, Including Oil Retention Ponds 1 and 2) at the Oak Ridge Y-12 Plant, Oak Ridge, Tennessee, Volumes 1. Main Text and 2. Appendices, DOE/OR/01-1161/V1\&D2, V2\&D2, March. 
DOE. 1994b. Preliminary Assessment Report for the Study Areas and Proposed No Further Investigation Sites for the Y-12 Plant at Oak Ridge, Tennessee, Y/ER-164/R0, April.

Energy Systems (Lockheed Martin Energy Systems, Inc.). 1987a. Post-Closure Permit Application for the S-3 Ponds Hazardous Waste Disposal Unit at the Y-12 Plant, Y/Sub/87-00206C/12, Oak Ridge Y-12 Plant, Oak Ridge, Tennessee.

Energy Systems. 1987b. Post-Closure Permit Application for the Oil Landfarm Hazardous Waste Disposal Unit at the Y-12 Plant, Y/Sub/87-00206C/10, Oak Ridge Y-12 Plant, Oak Ridge, Tennessee.

Energy Systems. 1988a. Revised RCRA Closure Plan for the S-3 Ponds, Y/TS-393, Oak Ridge Y-12 Plant, Oak Ridge, Tennessee, February.

Energy Systems. 1988b. Post-Closure Permit Application for the Burial Grounds Hazardous Waste Disposal Unit at the Y-12 Plant, Y/Sub/87-00206C/11/R2, Oak Ridge Y-12 Plant, Oak Ridge, Tennessee.

Energy Systems. 1991. Oak Ridge Reservation Environmental Report for 1990, ES/ESH-18/V1\&V2, Oak Ridge, Tennessee, September.

Energy Systems. 1992a. RCRA Postclosure Permit Application for the Bear Creek Hydrogeologic Regime at the Y-12 Plant, Oak Ridge Y-12 Plant, Oak Ridge, Tennessee, November.

Energy Systems. 1992b. Post-Closure Permit Application for the Bear Creek Hydrogeologic Regime at the Y-12 Plant: S-3 Ponds, Y/ER/Sub/91-ALV96/1.

Energy Systems. 1992c. Post-Closure Permit Application for the Bear Creek Hydrogeologic Regime at the Y-12 Plant: Bear Creek Burial Grounds, Y/ER/Sub/91-ALV96/3, Rev. 2.

Energy Systems. 1992d. Environmental Restoration Remedial Action Surveillance and Maintenance Program Plan, Oak Ridge Y-12 Plant, Oak Ridge, Tennessee.

Energy Systems. 1993. Pages Excerpted from Documents Pertaining to Bear Creek Burial Grounds Inventory, Y/SA-839, Oak Ridge Y-12 Plant, Oak Ridge, Tennessee, August.

Energy Systems. 1994. Post-Closure Permit Application for the Bear Creek Hydrogeologic Regime at the Y-12 Plant: Oil Landfarm Hazardous Disposal Unit, Y/ER/Sub/91-ALV96/2, Rev. 2.

Energy Systems. 1995. Post-Closure Permit Application for the Bear Creek Hydrogeologic Regime at the Y-12 Plant: Walk In Pits, Y-12/ER/Sub/91-ALV96/3, Rev. 2, Addendum.

Energy Systems. 1996. Interviews with J. K. Bailey and C. Smith of Y-12 Waste Management conducted by N.A. Luedtke, Science Applications International Corporation, and J. A. Moyer, Lockheed Martin Energy Systems.

Geraghty and Miller. 1987. Proposed RCRA Groundwater Quality Assessment Plan for the S-3 Ponds Hazardous-Waste Disposal Unit at the Y-12 Plant, Y/Sub/87-00206C/4, prepared for Martin Marietta Energy Systems, Inc., Oak Ridge Y-12 Plant, Oak Ridge, Tennessee. 
Herbes, S. E. 1989. PCBs, Uranium, and Oil/Grease in Soil at the Oak Ridge Y-12 Plant Oil Landfarm: Results of a 1985-1986 Sampling and Analysis Program, Y/TS-538, Martin Marietta Energy Systems, Inc., Oak Ridge Y-12 Plant, Oak Ridge, Tennessee.

Jeter, I. W. 1983. The Chemical and Radiological Characterization of the S-3 Ponds, Y/MA-6400, Union Carbide Corporation Nuclear Division, Oak Ridge Y-12 Plant, Oak Ridge, Tennessee.

Kimbrough, C. W. and R. R. Turner. 1987. Field Notebook: Sampling and Analysis of Sludges in the S-3 Ponds at the Y-12 Plant, Y/TS-294, Martin Marietta Energy Systems, Inc., Oak Ridge National Laboratory, Oak Ridge, Tennessee.

McCauley, L. L. 1984. Inventory of Existing Contamination in the Y-12 Plant Bear Creek Valley Oil Landfarm Area, Y/A-166, Martin Marietta Energy Systems, Inc., Oak Ridge Y-12 Plant, Oak Ridge, Tennessee.

McMahon, L. W. 1988. Sampling and Analysis to Support Excavation of Blue Lagoon Sediment Build-up, Y/TS-481, Martin Marietta Energy Systems, Inc., Oak Ridge Y-12 Plant, Oak Ridge, Tennessee.

Mappes, G. 1995. Personal communication of Gary Mappes (Monsanto, St. Louis) to J. H. Moyer (Oak Ridge National Laboratory, Oak Ridge) on May 22, 1995.

Mynatt, F. 1991. Letter dated February 1, 1991 to R.R. Nelson. (SWIMS). Subject: Historical Radionuclide Release Report Update.

Turner, R. R. and G. E. Kamp. 1984. Characterization and Remedial Alternatives for Sediments in Upper Bear Creek, Y/TS-56, Martin Marietta Energy Systems, Inc., Oak Ridge Y-12 Plant, Oak Ridge, Tennessee.

Turner, R. R., M.A. Bogle, R. B. Clapp, K. Dearstone, R. B. Dreier, T.O. Eary, S. E. Herbes, J. M. Loar, P.D. Parr, and G. R. Southworth. 1991. Remedial Investigation Work Plan for Bear Creek (Y02-S600) at the Oak Ridge Y-12 Plant, Oak Ridge, Tennessee, ES/ER-19\&D2 (Y/ER/Sub-90/99928/2), Martin Marietta Energy Systems, Inc., Oak Ridge Y-12 Plant, Oak Ridge, Tennessee, June.

Union Carbide (Union Carbide Corporation-Nuclear Division). 1984. Inventory of Existing Contamination in the Y-12 Plant Bear Creek Valley Oil Landfarm Area, Y/IA-166, Oak Ridge Y-12 Plant, Oak Ridge, Tennessee, January 31.

Welch, S. H. 1989. RCRA Facility Investigation Plan General Document Y-12 Plant, Oak Ridge, Tennessee, Y/TS-352, Vol. 1 (Rev. 1), Martin Marietta Energy Systems, Inc., Oak Ridge Y-12 Plant, Oak Ridge, Tennessee, April. 
A4-1

\section{A.4 FIGURES}





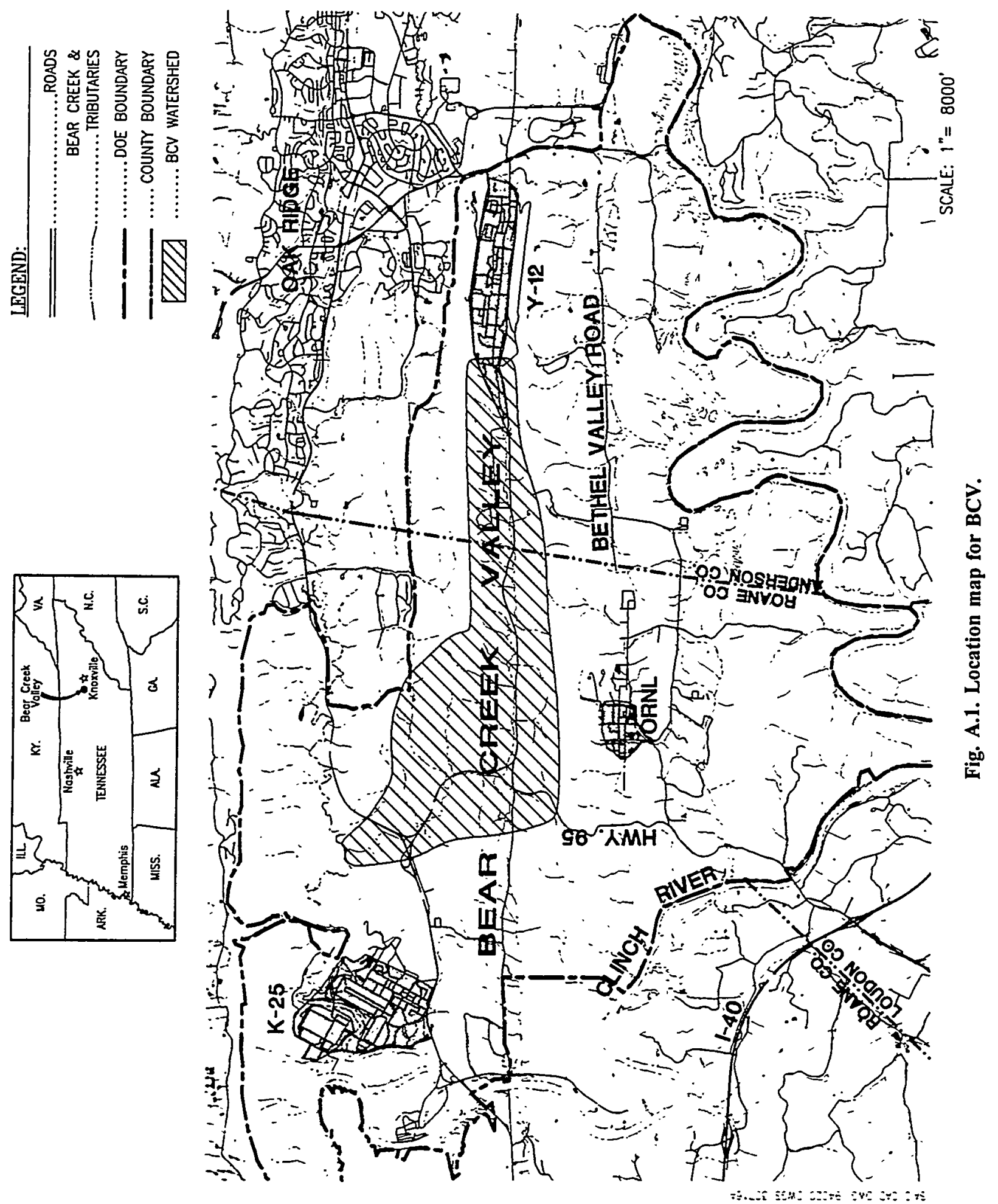



A4-5

(1)

(2)

(3)

4

5. . INIERIM REACTNE WASTE TREATMENT AREA

(6)

7

(8)

(9) WASTE OL/SOLVENT STORAGE FAC.

9.... AND TRANSFORMER FLUID STORAGE FAC.

(10)

(11)

(12...... HAZARDOUS CHEMICAL DISPOSAL AREA

(13)

ABANDONED NITRIC ACID PIPELINE

S-3 TREATMENT FACILITY

S-3 SITE

SPOIL AREA 1

..RUST SPOIL AREA UQUID ORGANIC WASTE
STORAGE FACILTT (OD1O)

OIL LANDFARM
(14.)

(15)

(16)

(17)

(18)

19. DARA LOUID STORAGE AND TREATMENT UNTT

(20)

(21)

(22)

(23)

(24)

(25)

(26) .DARA SOLD STORAGE FACILITY .. NaK BURN FACILITY M.K. FERGUSSON LAYDOWN AREA BEAR CREEK ROAD STTE . DEBRIS BURIAL AREA CREEKSIDE DEBRIS BURIAL AREA MERCURY CONTAMINATED CONSTRUCTION BONEYARD/BURNYARD

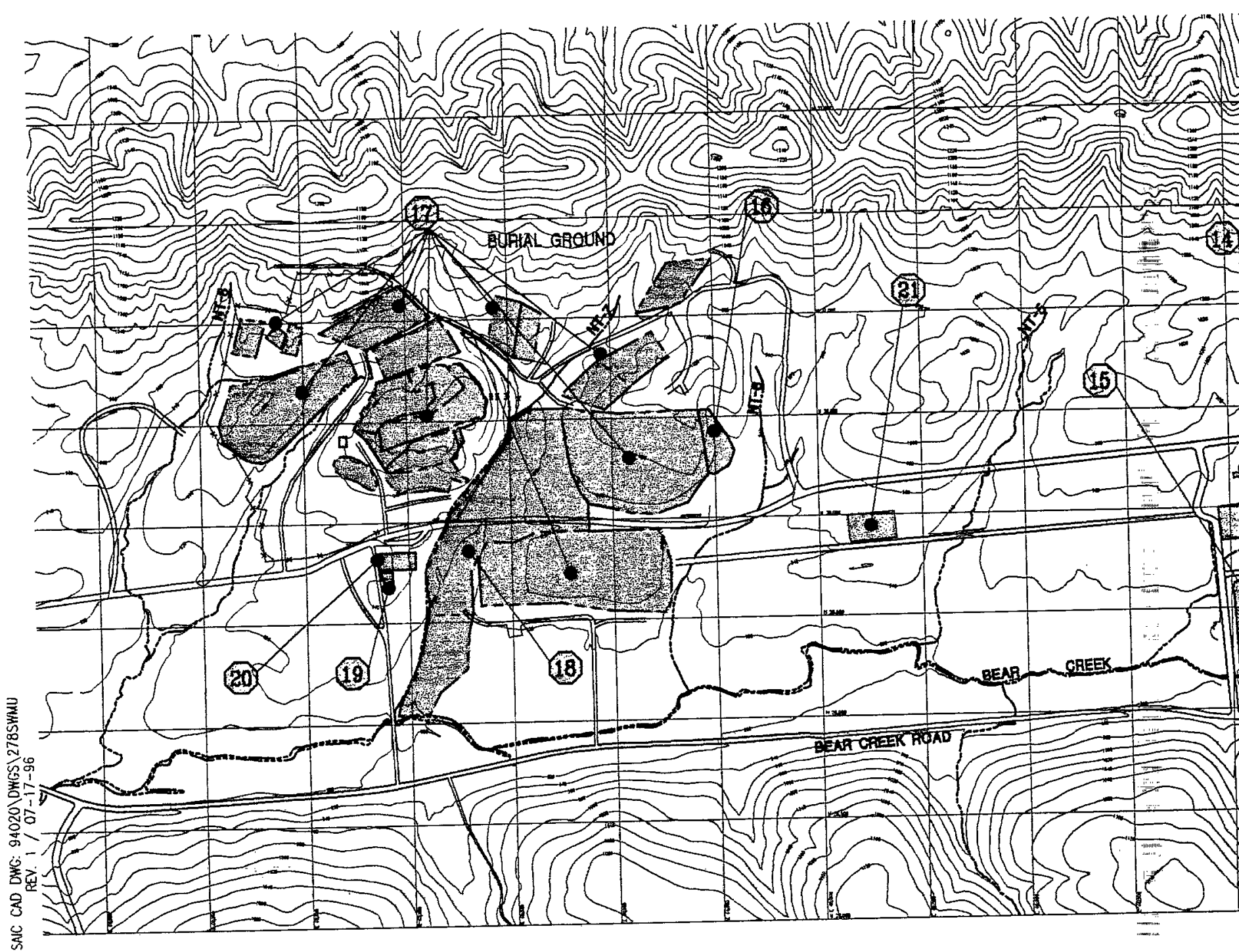

Fig. A.2. Locations of waste storage area 

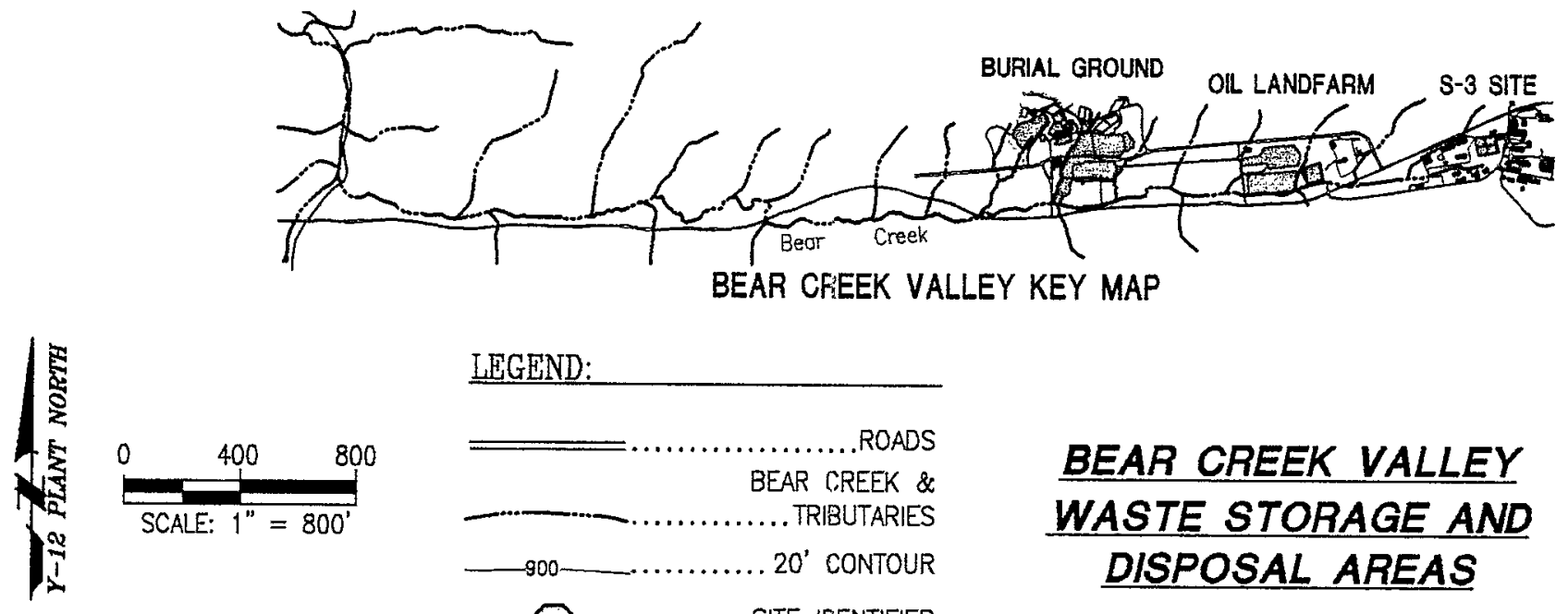

LEGEND:

ROADS

BEAR CREEK \&

.. TRIBUTARIES

900 _...........20 20' CONTOUR

(22) …........ SITE IDENTIFIER

\section{BEAR CREEK VALLEY WASTE STORAGE AND DISPOSAL AREAS}

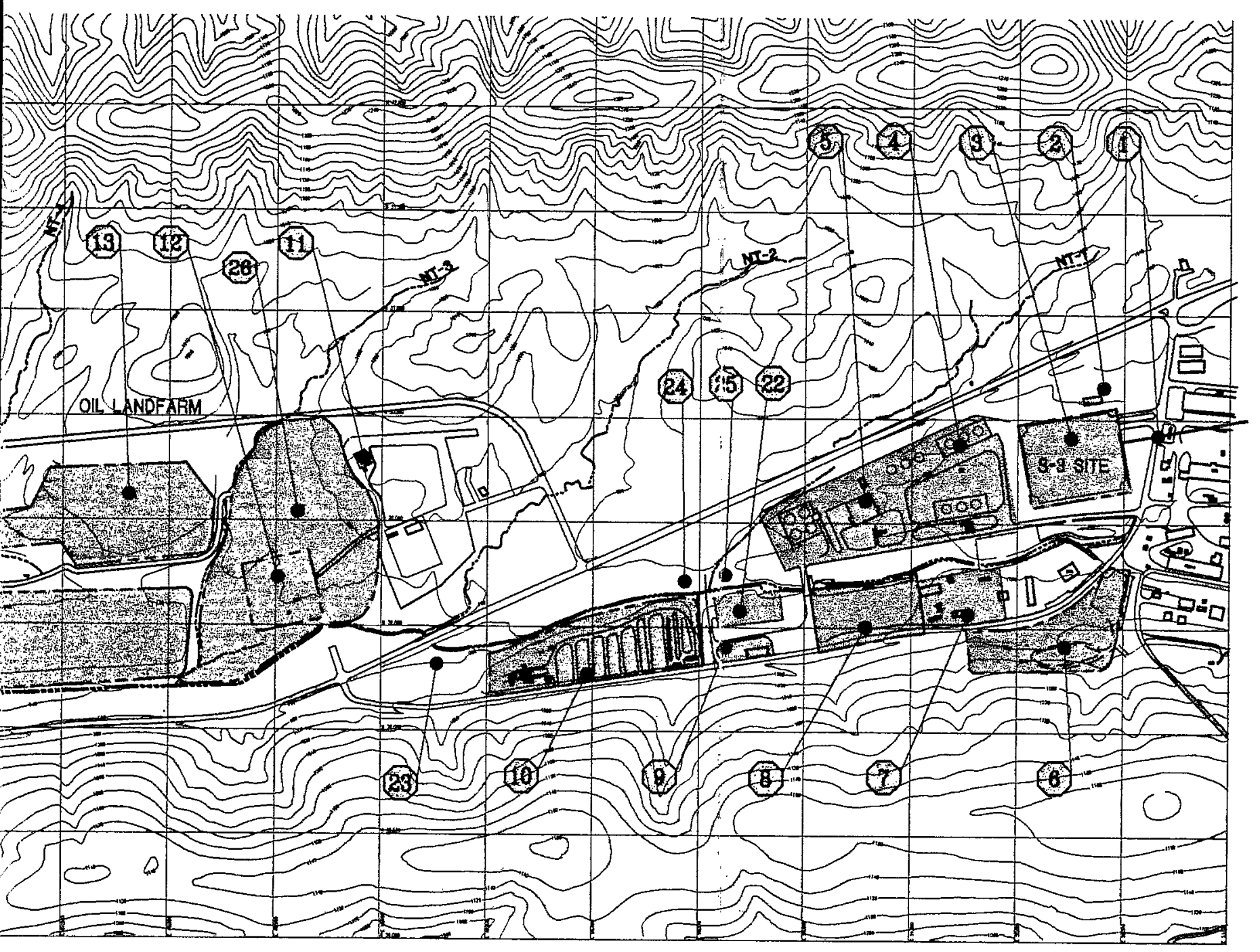

$=$
$=$
$=$
$=$

treatment and storage facilities in BCV. 


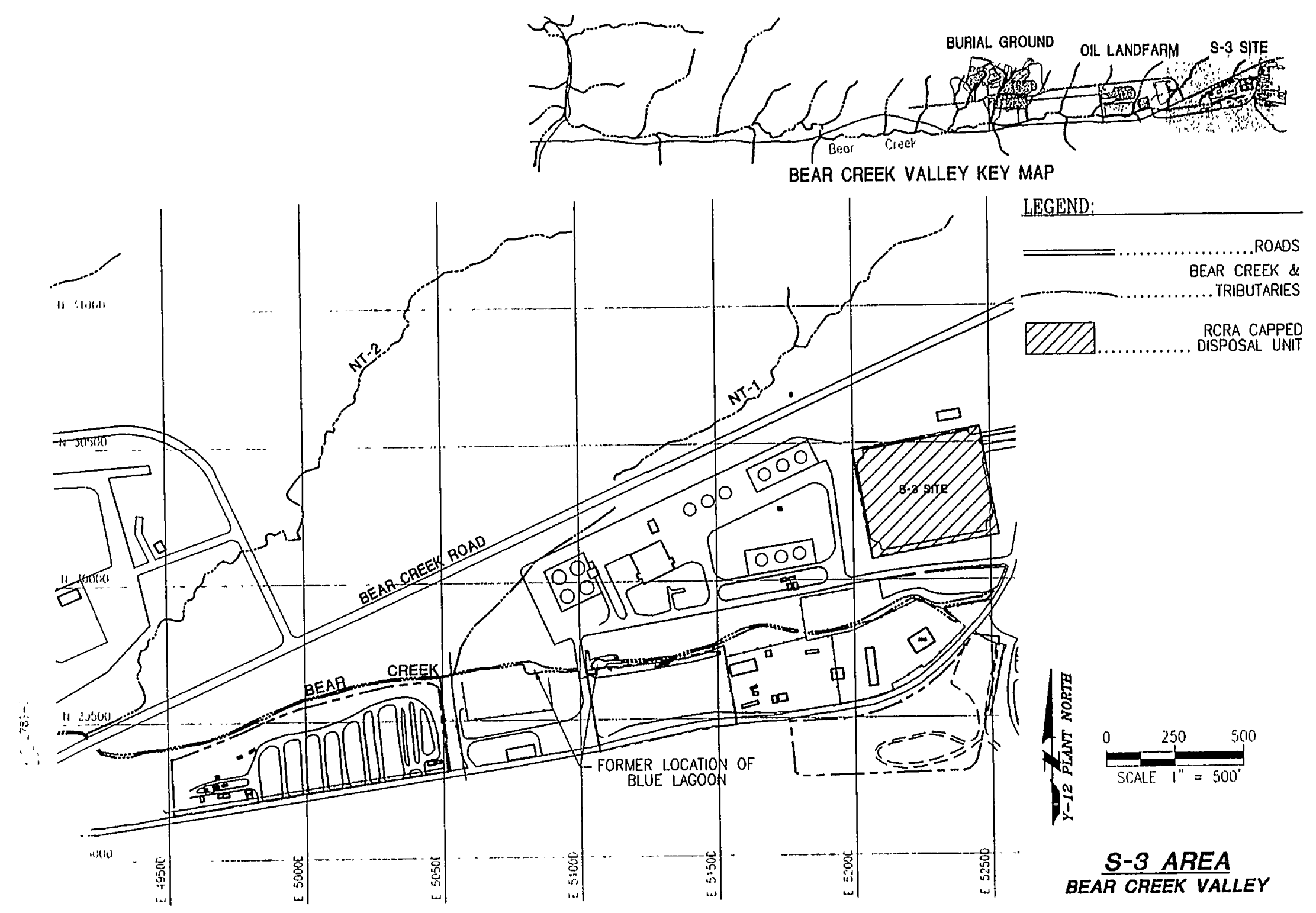

Fig. A.3. Map of the S-3 Site. 


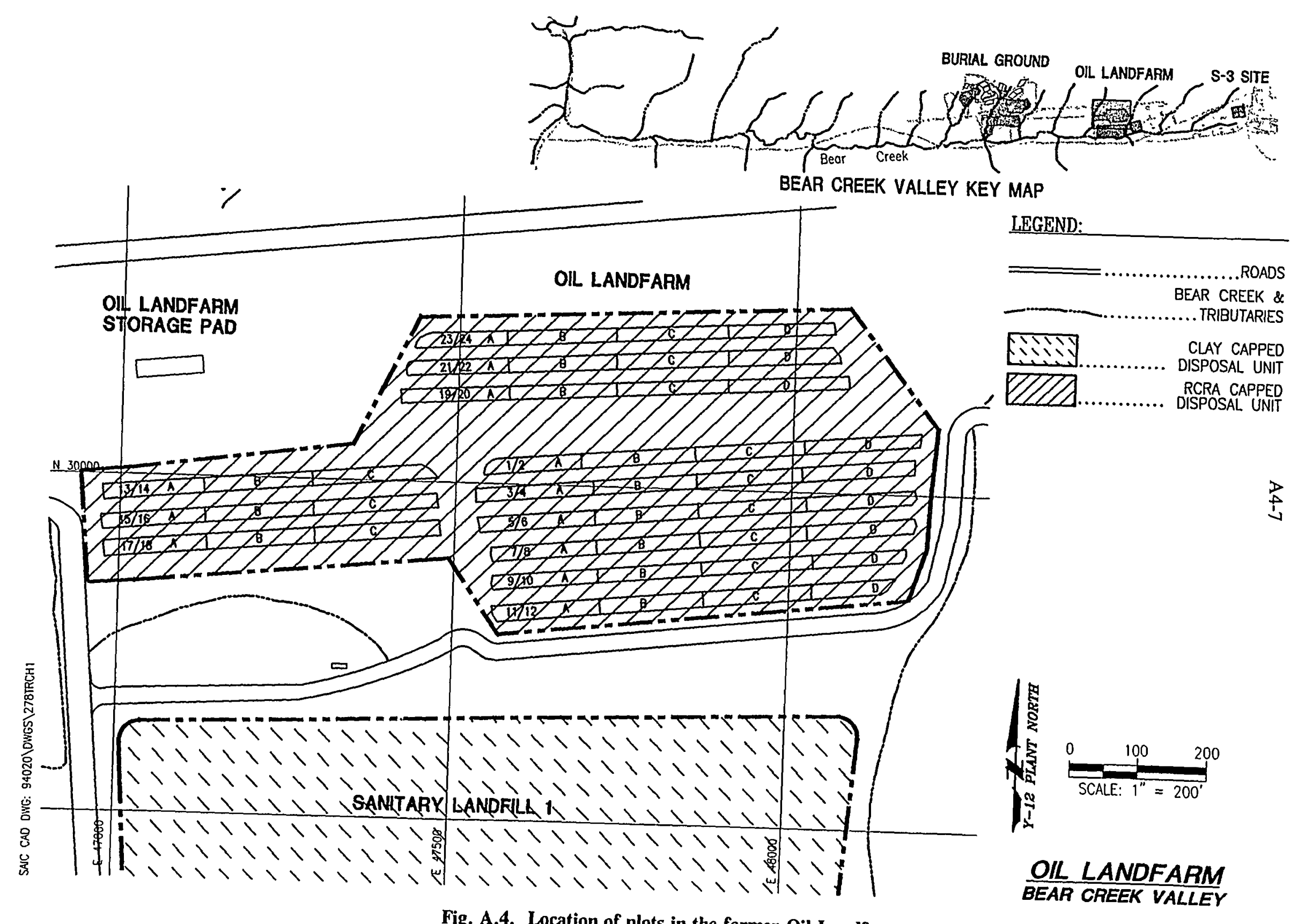

Fig. A.4. Location of plots in the former Oil Landfarm. 
A4-8

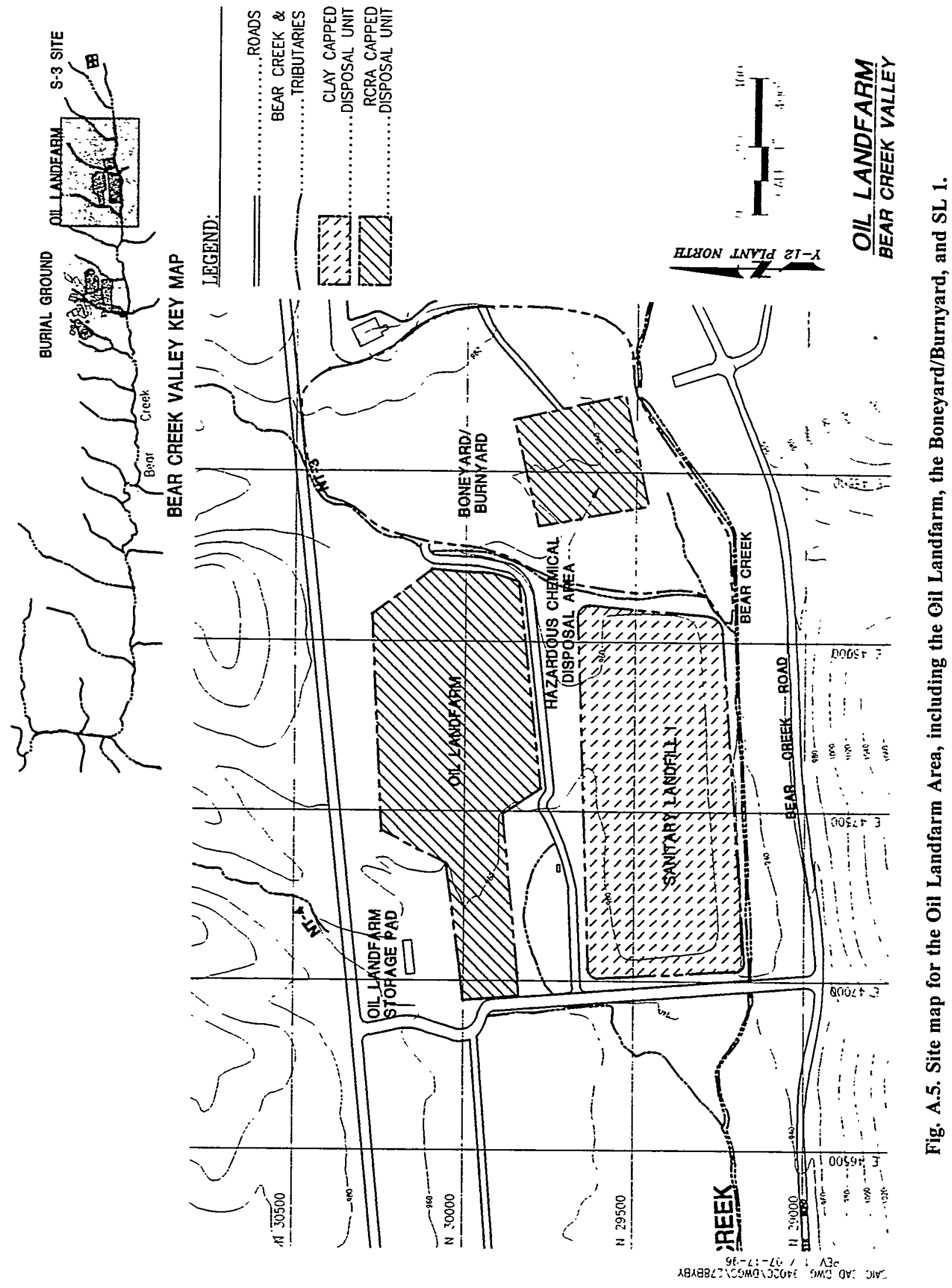




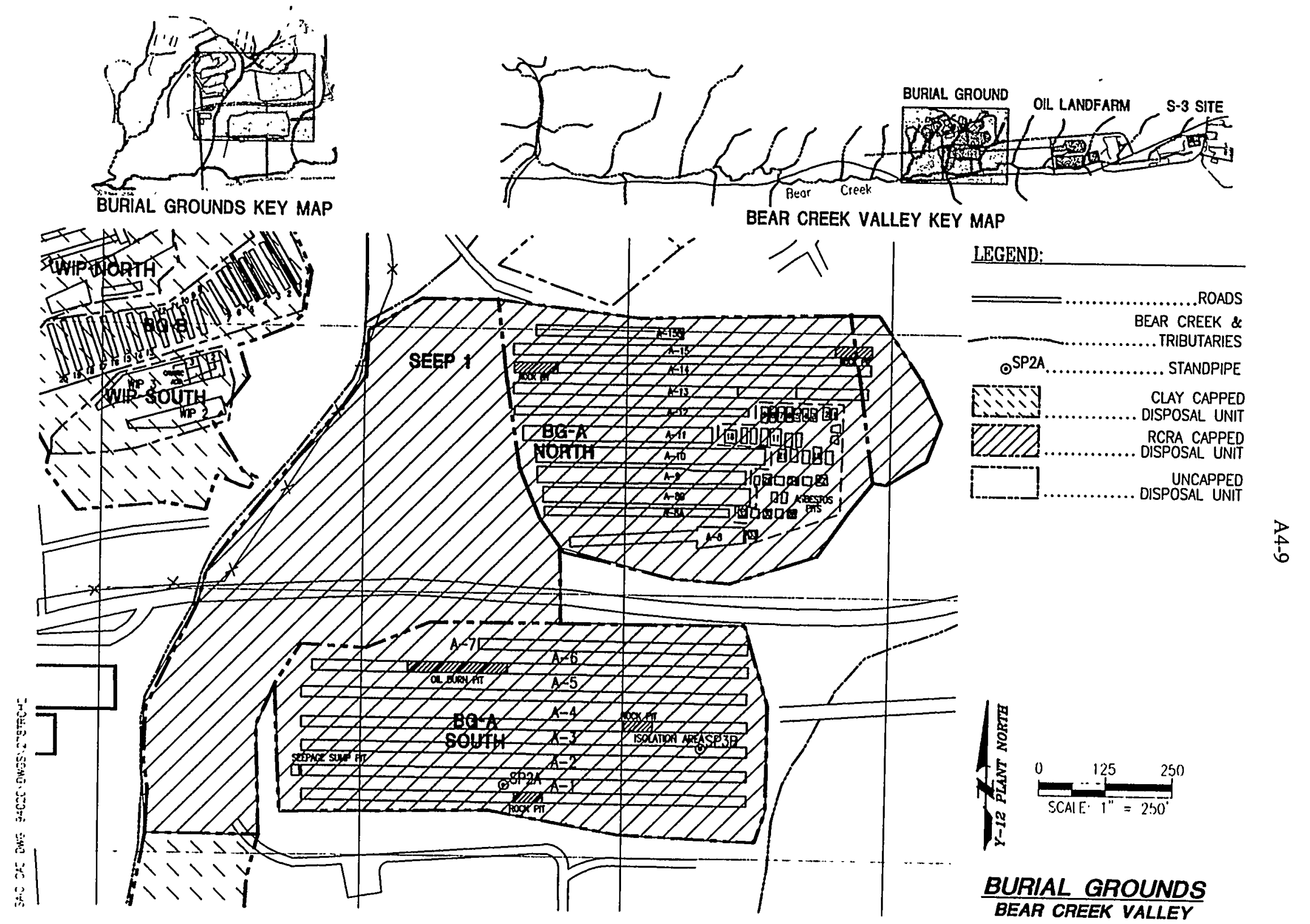

Fig. A.6. Locations of trenches, oil disposal pits, standpipes, and the isolation area in BG-A North and BG-A South. 


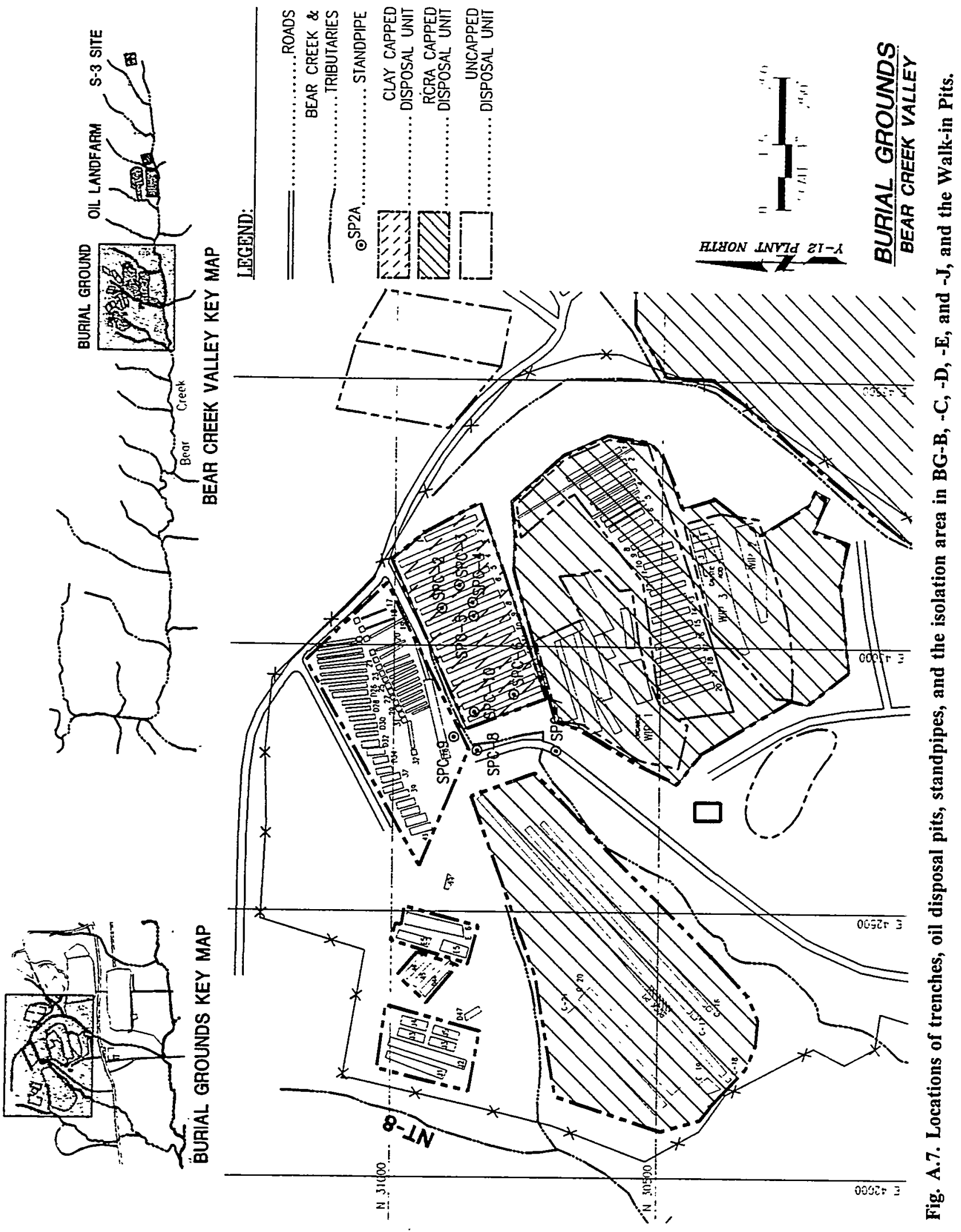

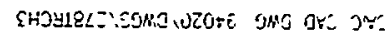




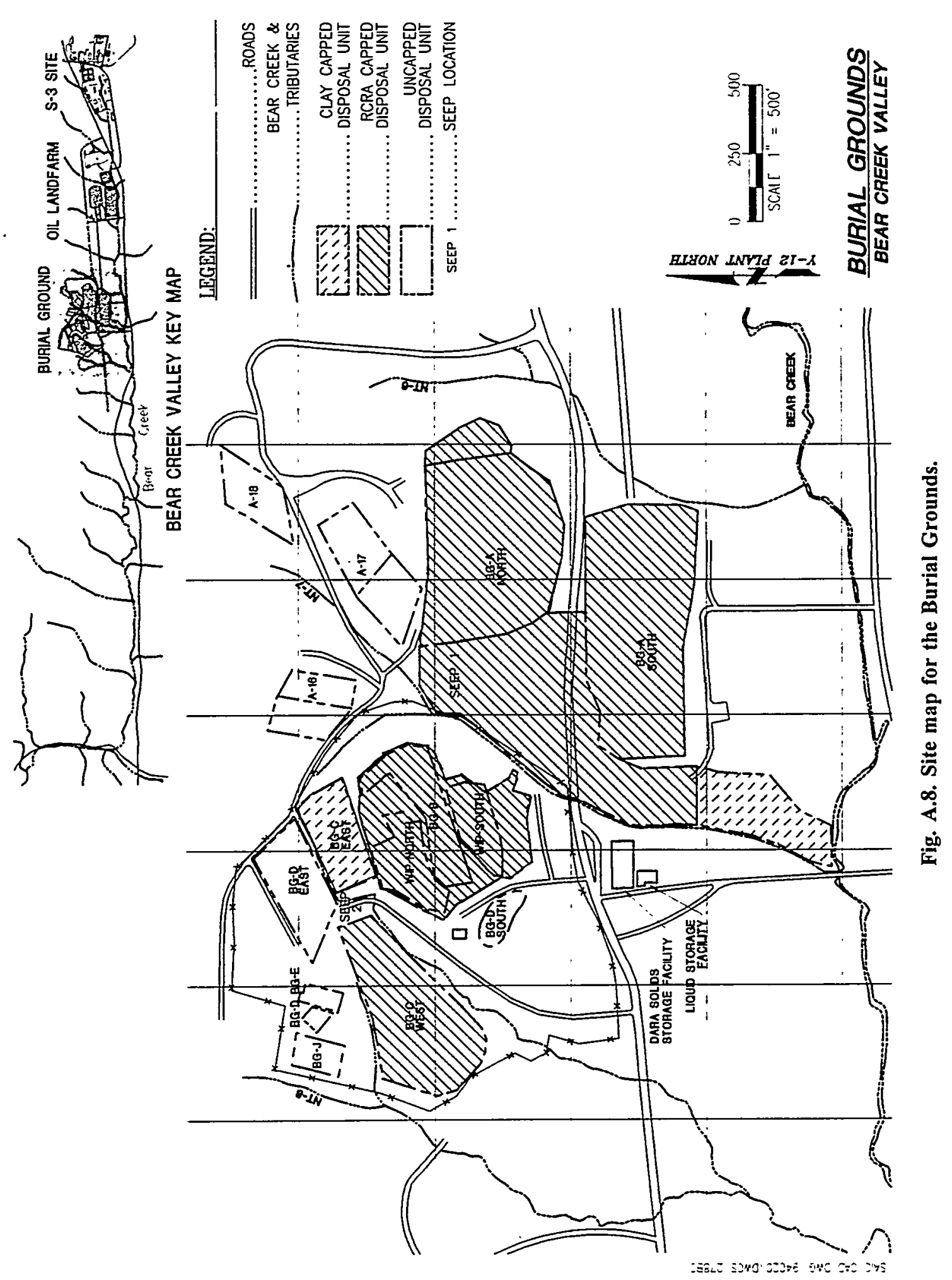




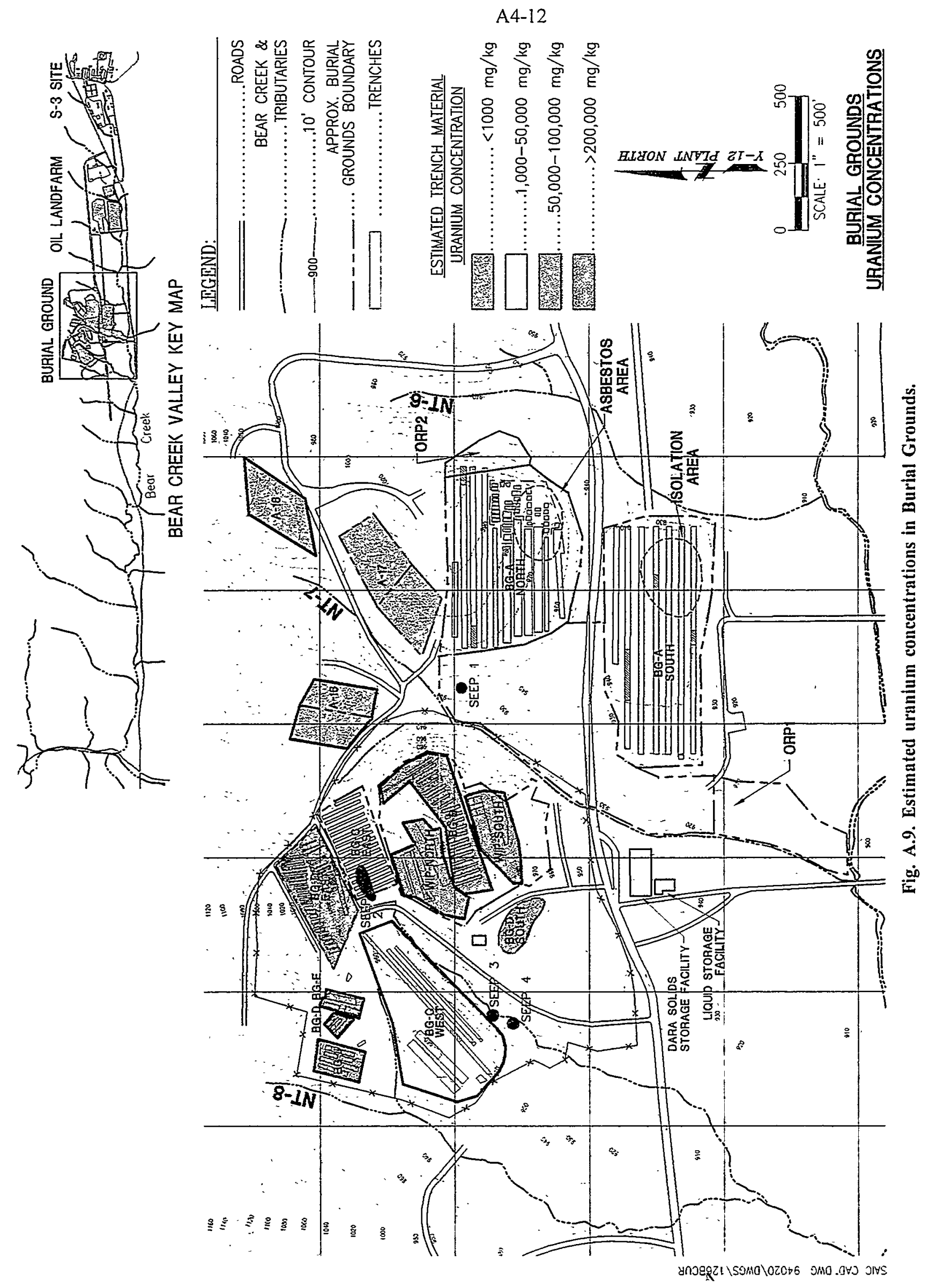


A5-1

A5. PLATES 
. 


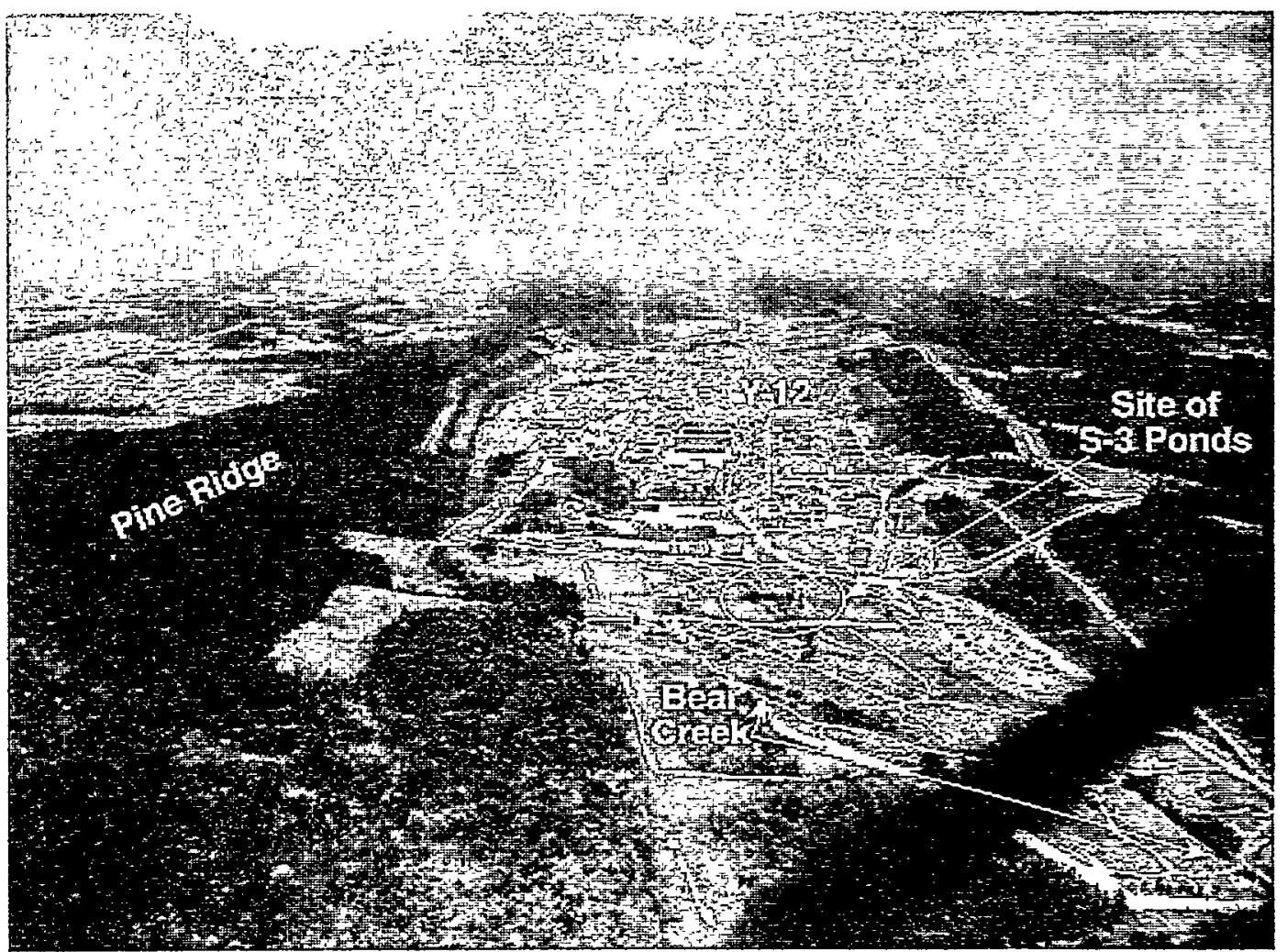

Plate A.1. Upper Bear Creek and the Y-12 Plan, circa 1947.

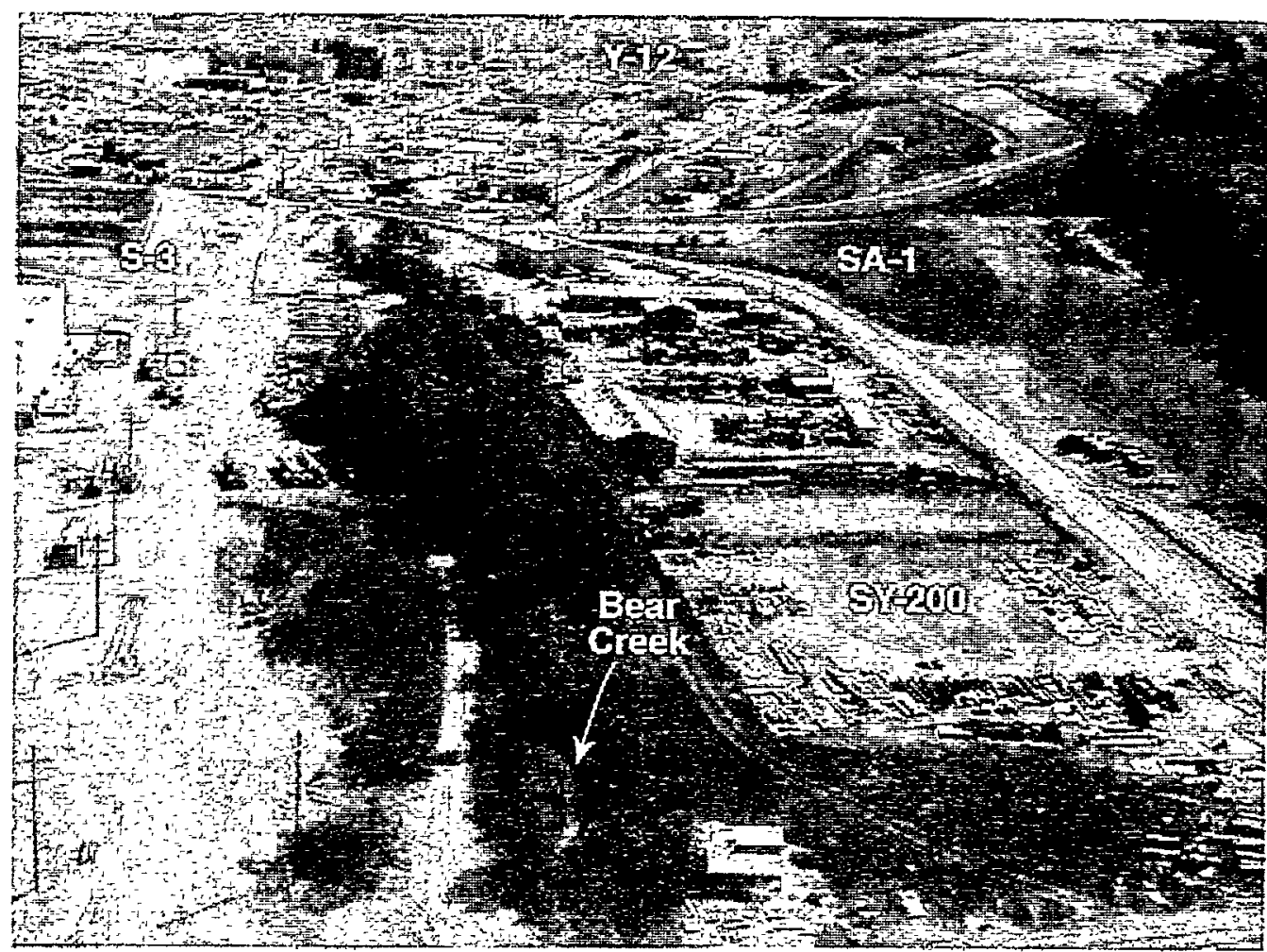

Plate A.2. Upper Bear Creek, circa late 1980s. 


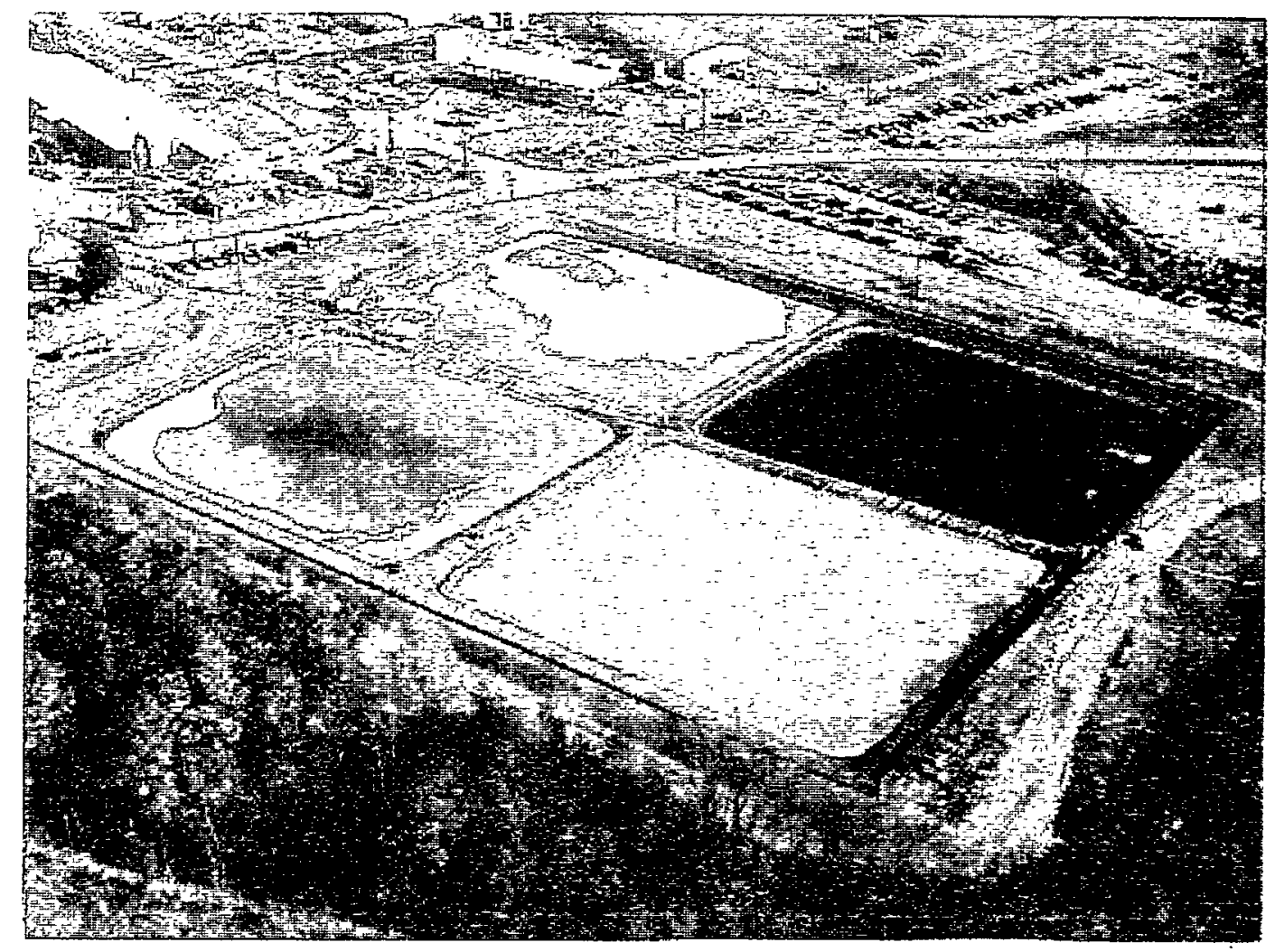

Plate A.3. Ponds during neutralization and bionitrification, circa 1983.

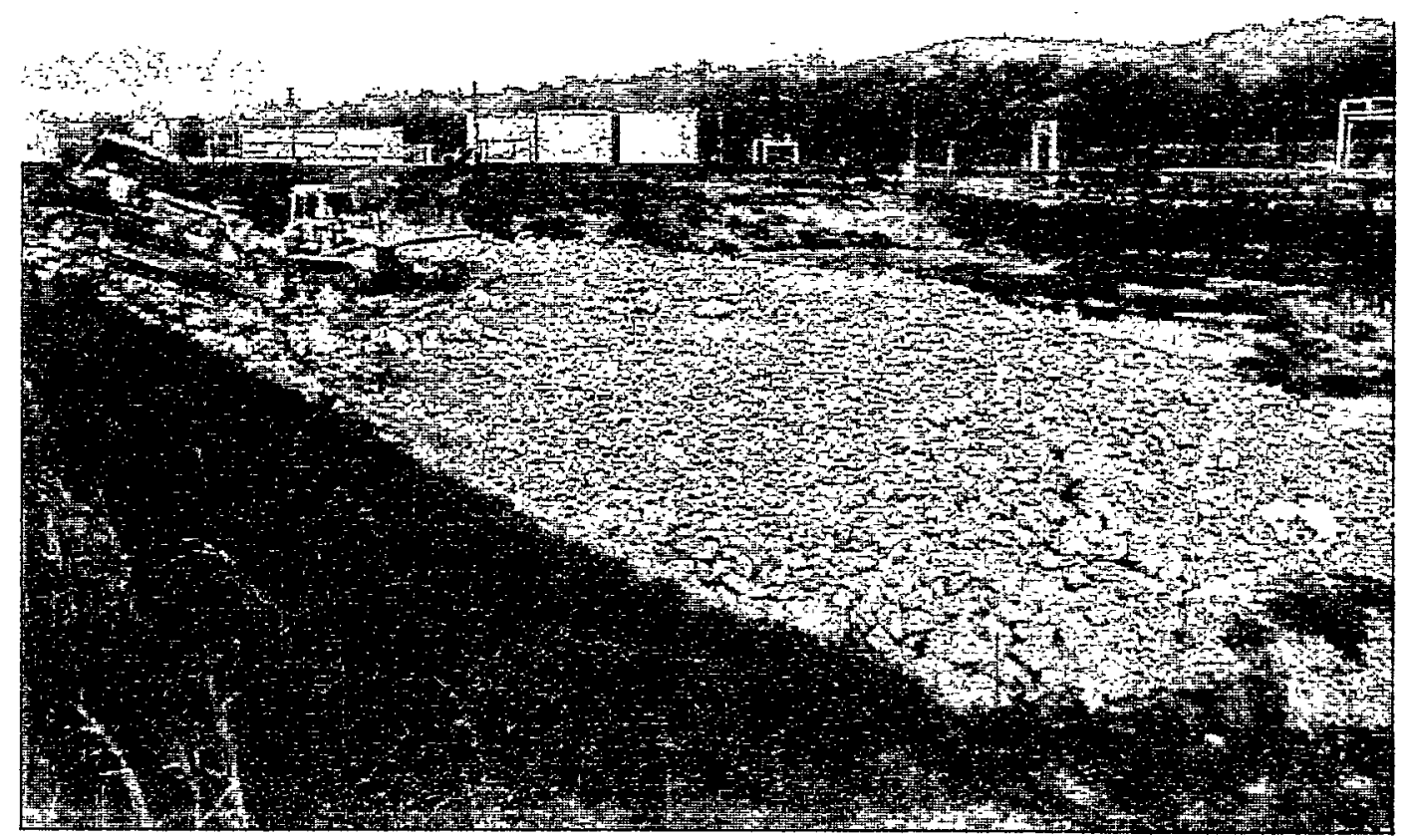

Plate A.4. Ponds during closure, filling, and structural stabilization, circa late 1980s. 


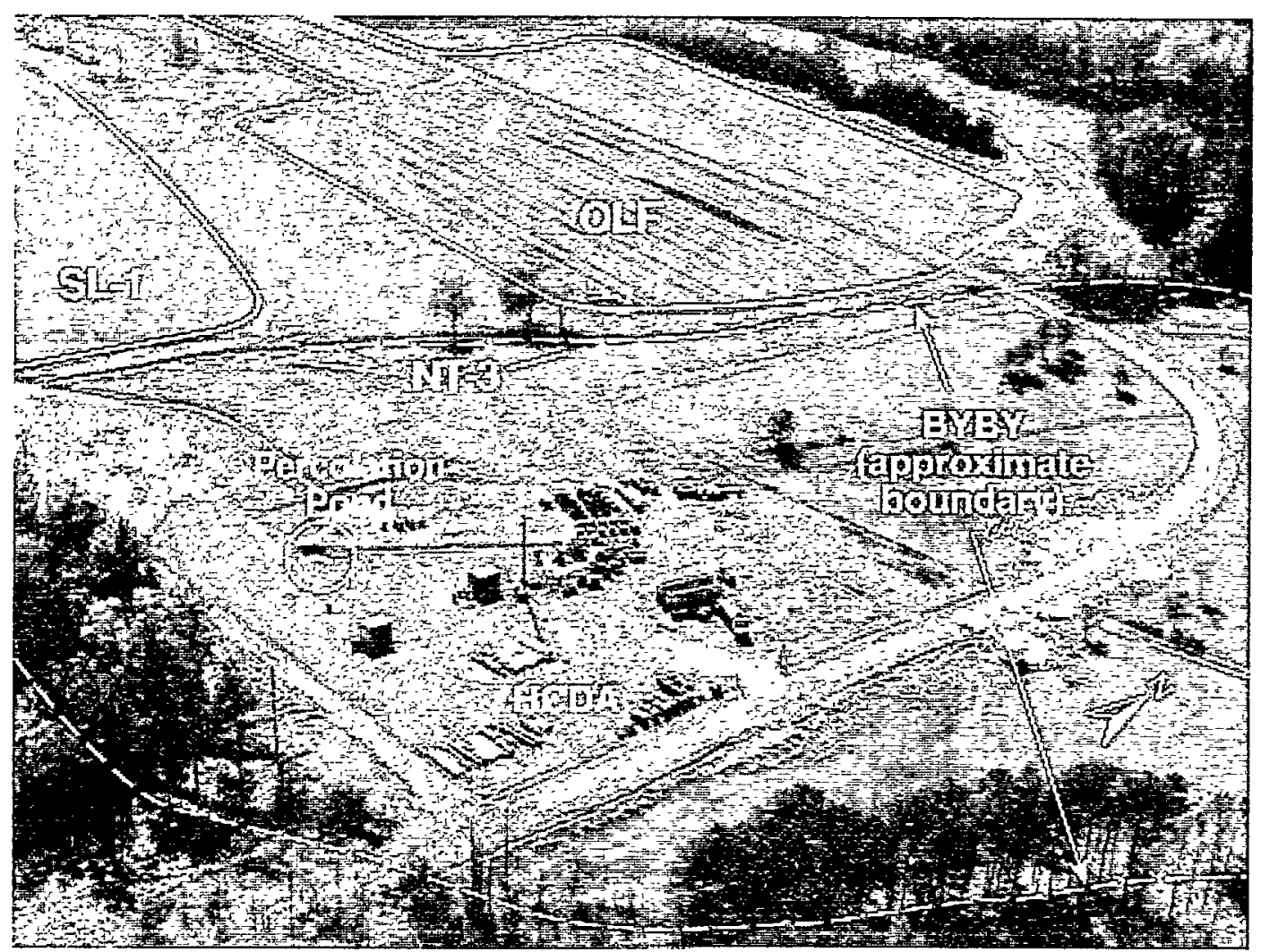

Plate A.5. Foreground: OLF Area HCDA in operation, with small percolation pond in SW corner. Background: OLF, SL 1, and NT-3, circa 1980 s.

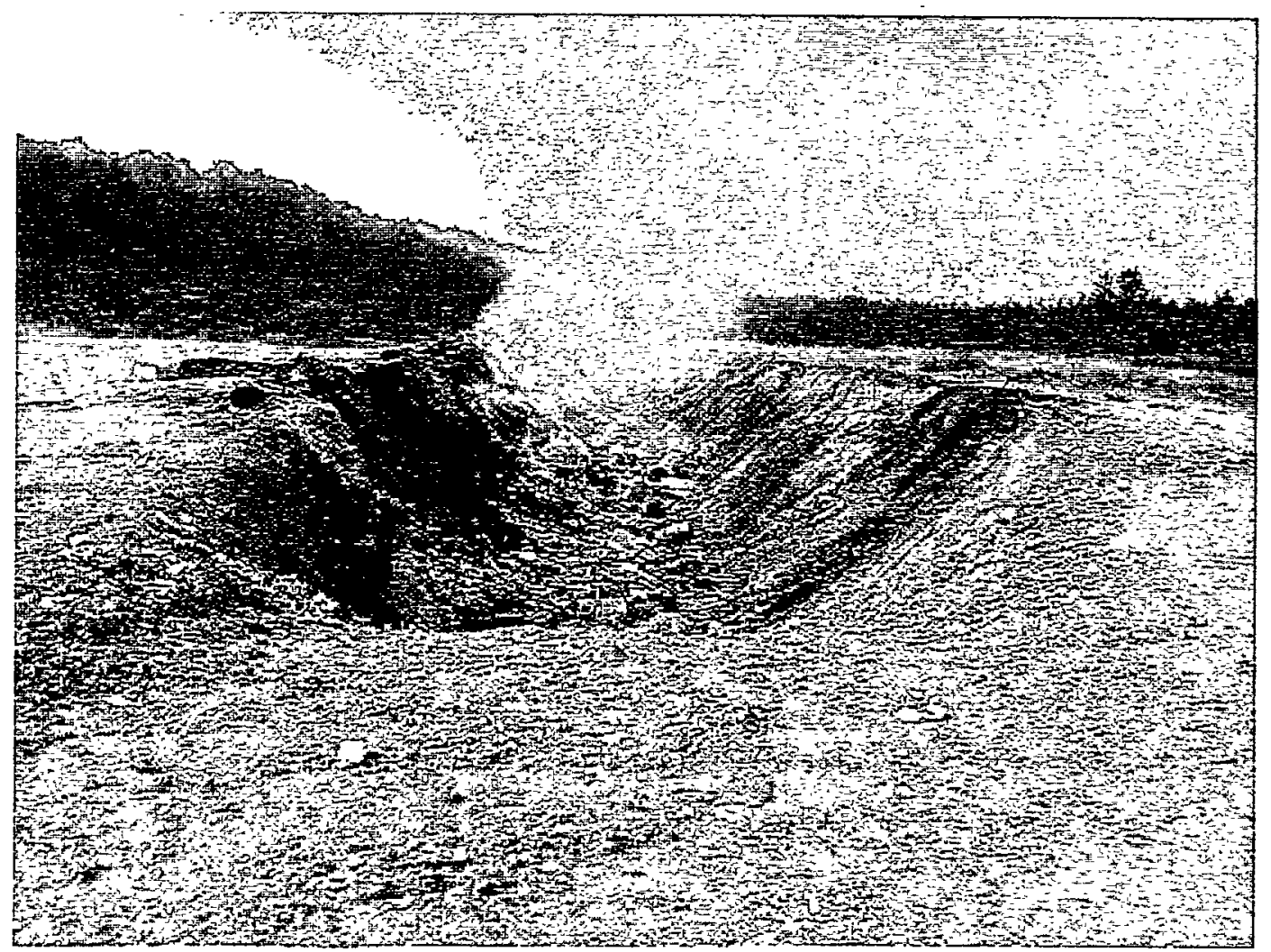

Plate A.6. Trench, possibly located at BYBY. 



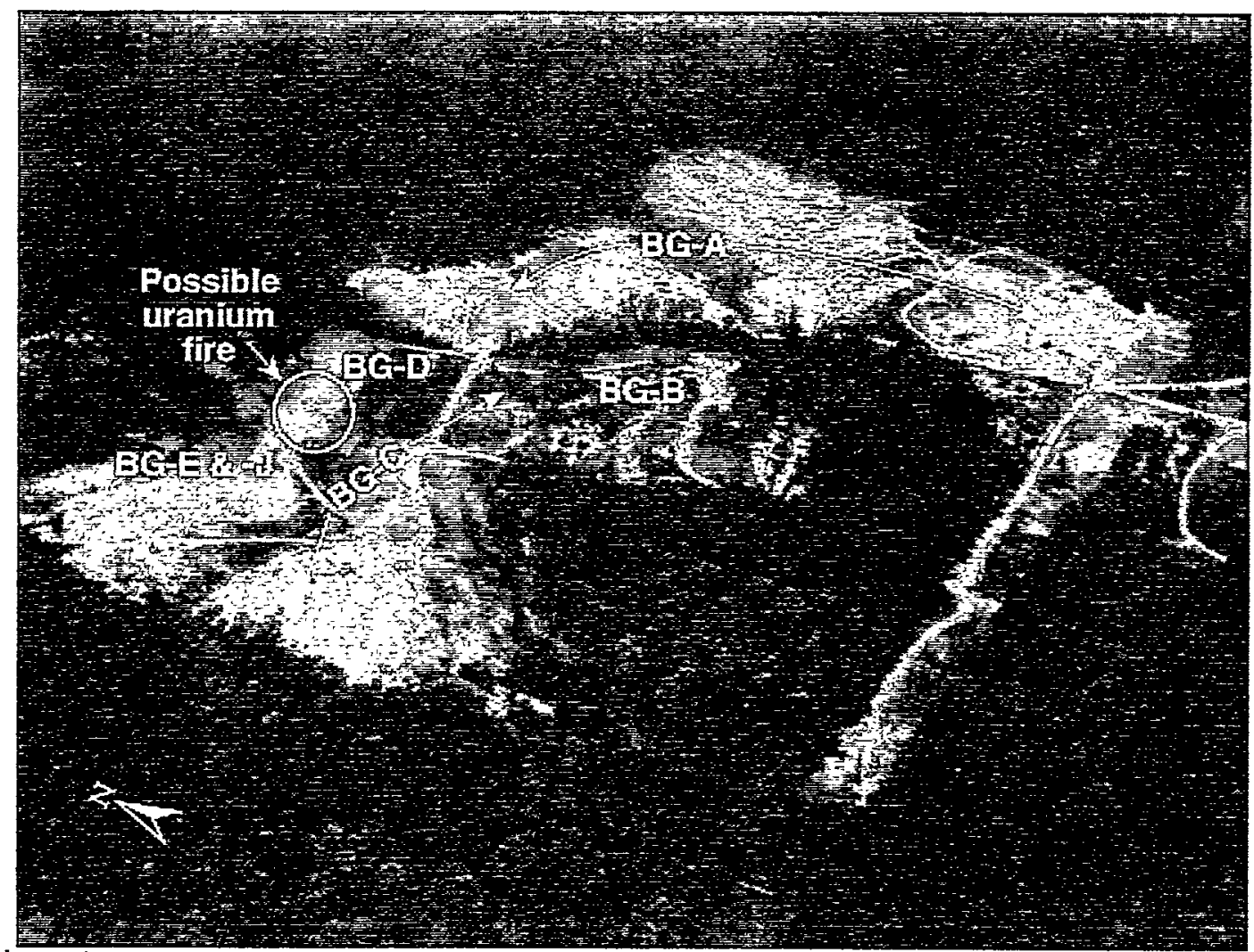

Plate A.7. Burial Grounds, circa 1980s. (Note possible uranium fire in the BG-D area)

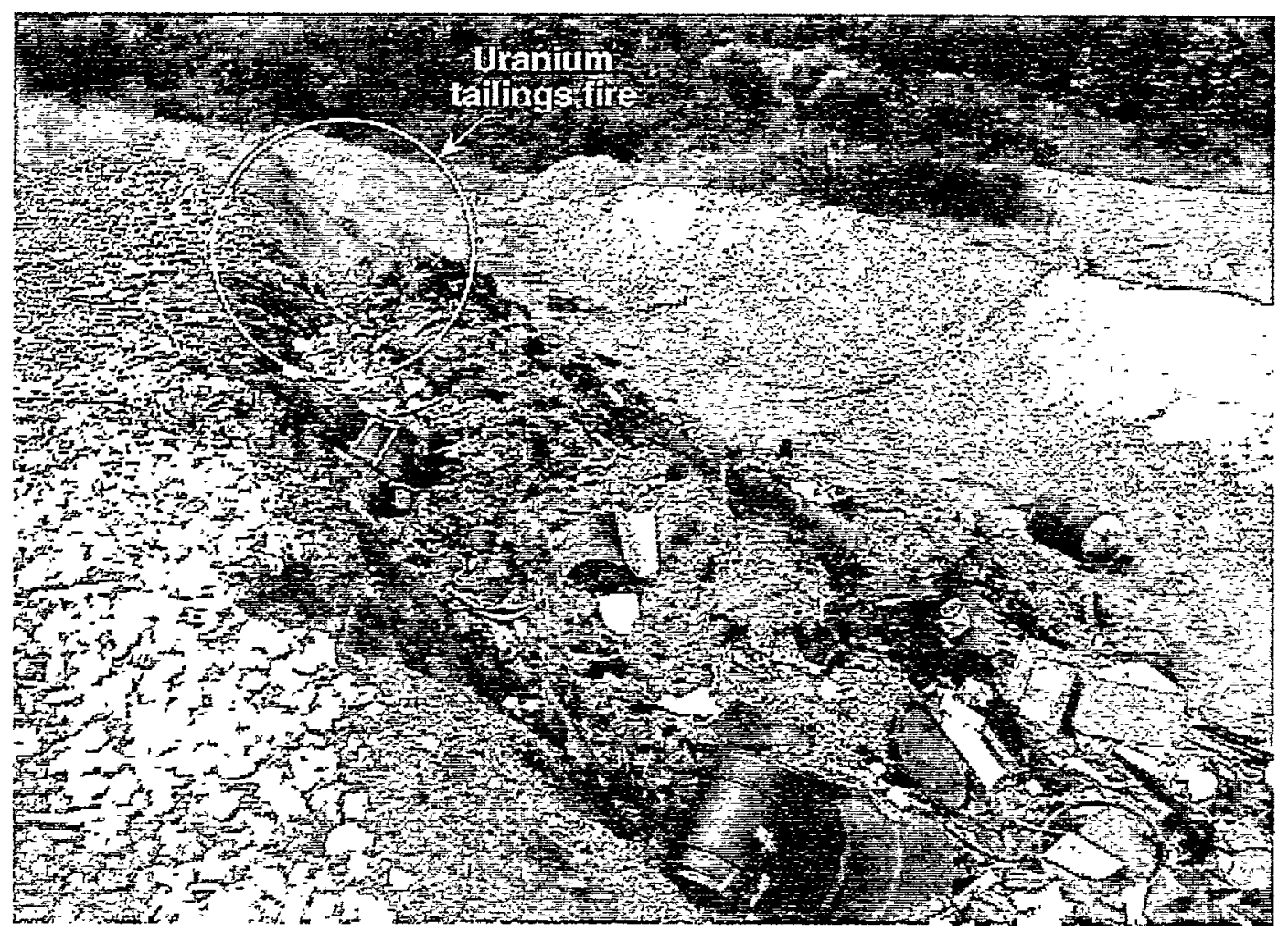

Plate A.8. Unidentified trench in BG-A South, circa 1980s. (Note the heat haze from uranium tailings fire) 


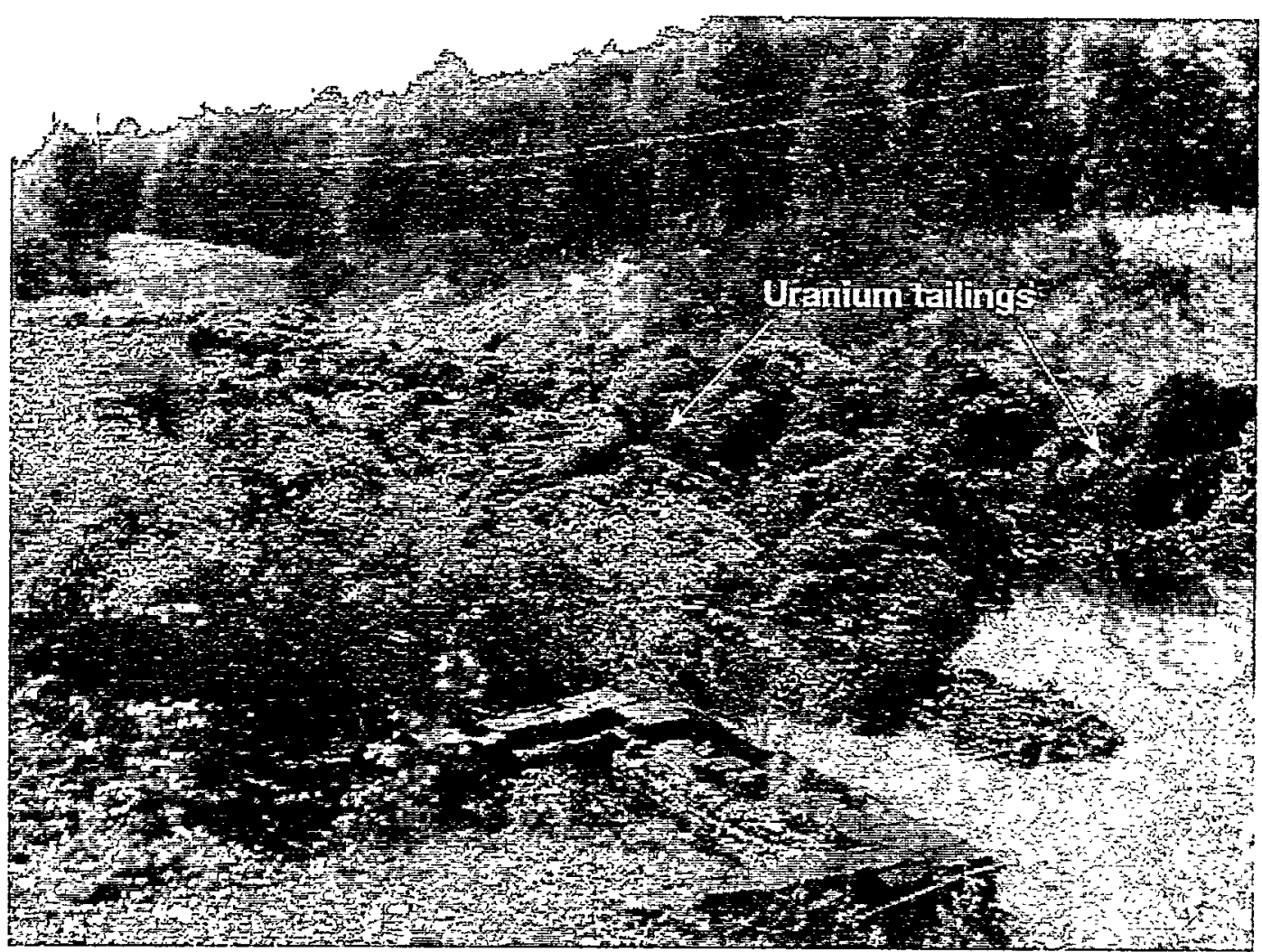

Plate A.9. Unidentified trench in BG-A South, circa 1980s. (Note burn pit in foreground with firebricks)

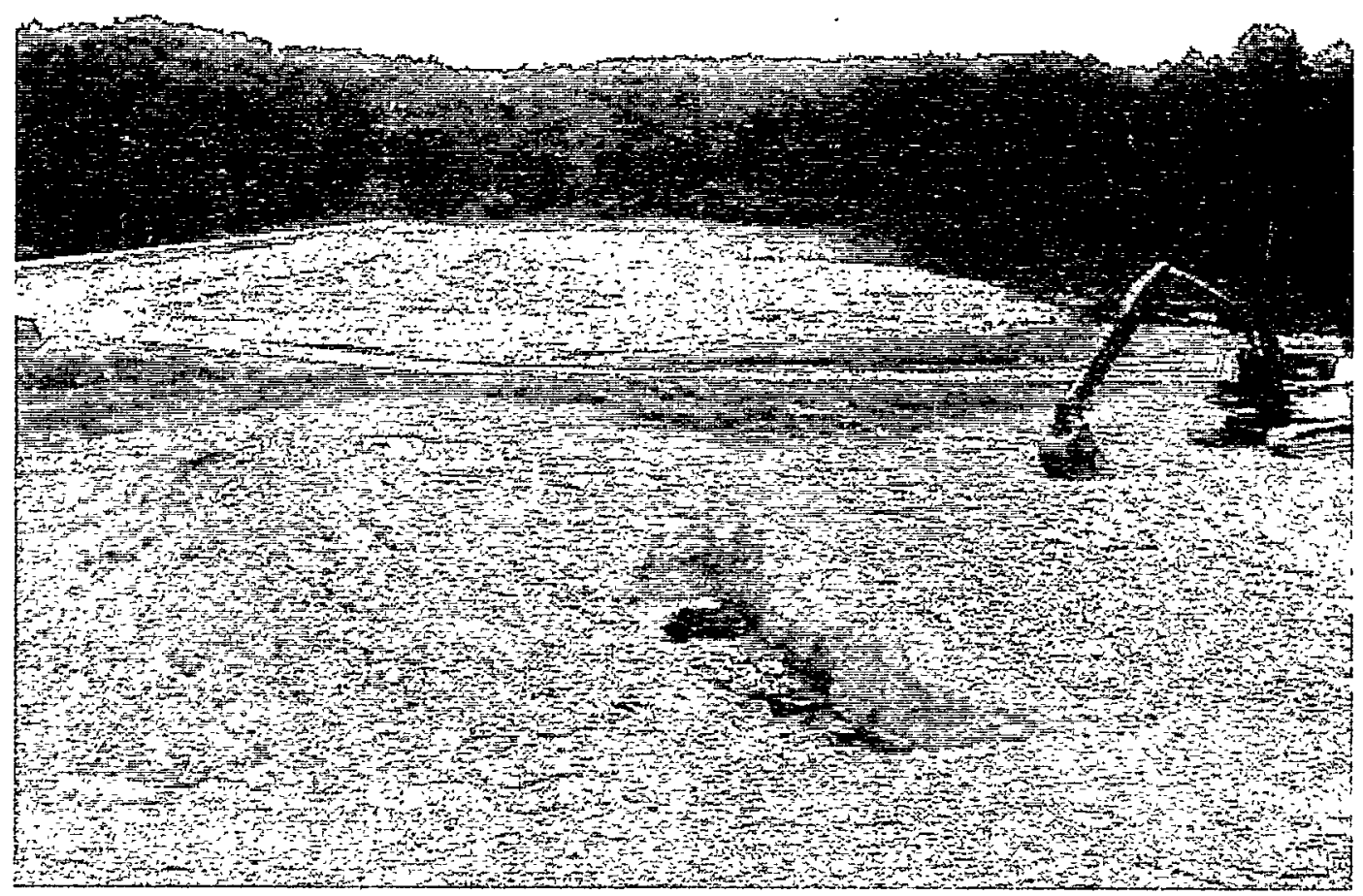

Plate A.10. Unidentified trench, probably located in area $\mathrm{D}, \mathrm{E}$, or $\mathrm{J}$. 



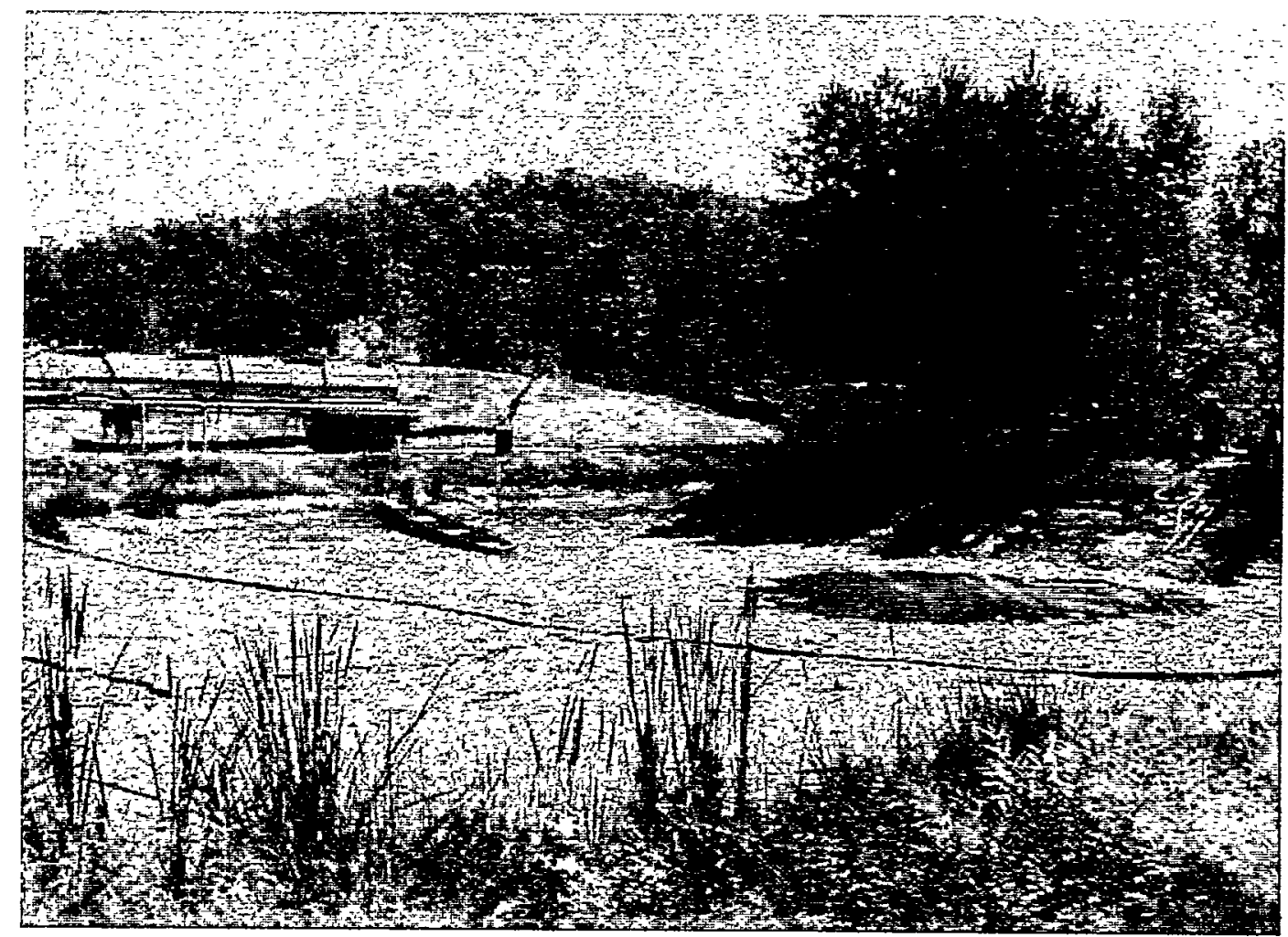

Plate A.11. ORP 1 (Burial Grounds), circa 1980s. Picture taken after draining the pond during closure operation. Equipment in background is oil/water separator. 




\section{A6-3}

Table A.1. Sites considered in this RI report that are listed in the FFA or have been identified as solid waste management units

\begin{tabular}{l}
\hline \multicolumn{1}{c}{ Site $^{a}$} \\
\hline Bear Creek Burial Grounds \\
(Fig. A.2 \#17) \\
HCDA/Boneyard Burnyard \\
(Fig. A.2 \#12) \\
Sanitary Landfill 1 \\
(Fig. A.2 \#15) \\
Bear Creek Groundwater, \\
Creek Sediments, and \\
Floodplain Soils \\
S-3 Ponds (Fig. A.2 \#3) \\
Oil Retention Pond 1 \\
(Fig. A.2 \#18) \\
Oil Retention Pond 2 \\
(Fig. A.2 \#16) \\
Oil Landfarm (Fig. A.2 \#13) \\
Oil Landfarm Soil \\
Containment Pad \\
(Fig. A.2 \#14)
\end{tabular}

DARA Solids Storage Facility (Fig. A.2 \#20)

Status/service history
FFA Area of Concern in BCV CA
FFA Area of Concern in BCV CA
FFA Area of Concern in BCV CA

FFA Area of Concern in BCV CA

FFA Area of Concern in BCV CA

FFA Area of Concern in BCV CA

FFA Area of Concern in BCV CA

FFA Area of Concern in BCV CA

FFA Area of Concern in BCV CA. The site is used as a storage facility for contaminated soils from the closure of the Oil Landfarm. Site contains soils that are contaminated with PCBs, organics, and uranium. A RCRA Part $B$ permit application has been submitted.

FFA Area of Concern in BCV CA. Bldg. 9720-60 is designed to dewater soils by gravity flow to sumps. Collected liquids are pumped to the DARA Liquid Storage

Facility-a RCRA Permit by Rule Unit. The soil and liquids were products of the excavation and closure of the oil retention ponds and associated tributaries. Radioactive mixed waste, PCBs, uranium, and organic are among the contaminants present at this site. Site has had a RCRA permit application submitted.

Operable Unit (ANAP). Received CERCLA NFA ROD 9/12/94. Also located in UEFPC CA.

Pipeline (ANAP) (Fig. A.2 \#1)

Rust Spoil Area (Fig. A.2 \#10)
FFA Area of Concern in BCV CA originally part of Bear Creek OU 2 but incorporated into $\mathrm{BCV} C A$ due to minor groundwater contamination.
YS-600

YT-004

YT-008

YT-009

YT-014

YS-050

Reference

YD-024

YD-024-HC

YD-101

YS-051

YS-601

YD-106 
Table A.1 (continued)

\begin{tabular}{l}
\hline Site $^{a}$ \\
\hline Spoil Area 1 (Fig. A.2 \#6) \\
SY-200 Yard (Fig. A.2 \#8) \\
Contaminated Construction \\
Spoil Pile (Fig. A.2 \#25)
\end{tabular}

Spoil Pile (Fig. A.2 \#25)

S-3 (or Decant) Treatment Facility (Fig. A.2 \#2)

Waste Oil/Solvent Storage Facility (Fig. A.2 \#9)

Liquid Organic Waste Storage Facility (Fig. A.2 \#11)

DARA Liquids Storage and Treatment Unit (Fig. A.2 \#19)

Rust Engineering Storage Yard (Fig. A.2 \#7)

\section{Status/service history \\ Reference}

YD-107

Operable Unit (BCV OU 2) SA-1 and SY-200 yard (below) were included in BCV OU 2 , and received a "status quo" ROD of maintaining existing caps on these sites. The ROD is due to EPA and TDEC April 1996. There is no groundwater contamination associated with SA-1 or SY-200 Yard.

Operable Unit (BCV OU 2) (see above). YD-125

FFA Area of Concern in BCV CA - This soil was excavated during construction of the first tank farm for WETF. It has low levels of mercury contamination, similar to other soil in the area.

FFA Area of Concern in BCV CA. Formerly operated under RCRA Permit by Rule - Treatment of denitrified supernatant from S3 Ponds; denitrified supernatant from West End Treatment Facility tanks from 1985 to 1989 . No longer in operation.

Active Waste Management Area (Alias OD-9) - The site is designed to store organics, PCBs, PCB-contaminated waste oil containing various concentrations of organic solvents and uranium. The site has a current RCRA permit.

Active Waste Management Area (Alias OD-10) - Used for storage of various chlorinated and non-chlorinated organics and PCBs. The site has a current RCRA permit.

Active Waste Management Area operated under RCRA Permit by Rule [Accumulation Area AA-137, Alias LSF Diked Area (YS826)] - Liquids collected from dewatering soils within the DARA soils storage facility are pumped to this DARA liquid storage facility. The liquids go through an oil/water separator and then are tankered to the GWTF adjacent to WETF. These liquids/soils originated from excavation and closure of the oil retention ponds and associated tributaries (Trib 7), and from the seep collection trench (Trib 8).

Active Process Storage Area - Storage of various types of concrete finishing and coating compounds from 1975 to present.
YT-044 YS-052

YS-027 (Y/TS-473)

YS-039

YS-040

YS-401 
Table A.1 (continued)

\begin{tabular}{|c|c|c|}
\hline Site $^{a}$ & Status/service history & Reference \\
\hline $\begin{array}{l}\text { West End Treatment Facility } \\
\text { (Fig. A.2 \#4) }\end{array}$ & $\begin{array}{l}\text { Active Waste Management Area [Also } \\
\text { includes 9616-7, GWTF - Accumulation } \\
\text { Area AA-133 (YS-822) and Groundwater } \\
\text { Treatment Facility (YT-053) (RCRA Permit } \\
\text { by Rule Unit)] - Treatment of nitrate- } \\
\text { bearing wastes including biodenitrification } \\
\text { sludge, plating solutions, mopwaters, } \\
\text { evaporator condensates, acids, caustics, and } \\
\text { heavy metals including depleted and } \\
\text { enriched uranium from } 1985 \text { to present. }\end{array}$ & YT-007 \\
\hline $\begin{array}{l}\text { Interim Reactive Waste } \\
\text { Treatment Area (Fig. A.2 \#5) }\end{array}$ & $\begin{array}{l}\text { Active Waste Management Area (Interim } \\
\text { Status IT-42) - This site treats water that } \\
\text { may be contaminated with volatile and } \\
\text { nonvolatile organics from the water stored } \\
\text { at DARA Liquid Storage Facility (YS-052). }\end{array}$ & YT-150 \\
\hline $\begin{array}{l}\text { NaK Burn Facility } \\
\text { (Fig. A.2 \#21) }\end{array}$ & $\begin{array}{l}\text { Former Waste Management Area. Area } \\
\text { where NaK alloys were ignited. Located } \\
\text { between NT-5 and NT- } 6 \text {. }\end{array}$ & \\
\hline $\begin{array}{l}\text { 9720-58 Transformer Fluid } \\
\text { Storage Facility (Fig. A.2 \#9) }\end{array}$ & $\begin{array}{l}\text { Active Waste Management Area. RCRA } \\
\text { Permitted Storage Facility. This facility } \\
\text { stores PCB-contaminated waste and } \\
\text { equipment. }\end{array}$ & YS- \\
\hline $\begin{array}{l}\text { M.K. Ferguson Laydown Area } \\
\text { (Fig. A.2 \#22) }\end{array}$ & $\begin{array}{l}\text { Active Process Storage Area. } \\
\text { Radiologically contaminated demarcated } \\
\text { area }\end{array}$ & \\
\hline Above Grade Storage Pads & $\begin{array}{l}\text { Active Waste Management Area. Currently } \\
\text { active under a state agreement }\end{array}$ & \\
\hline $\begin{array}{l}\text { Johnson Controls } 90-\text { Day } \\
\text { Accumulation Area }\end{array}$ & $\begin{array}{l}\text { Active Waste Management Area. RCRA } \\
\text { 90-day Accumulation Area }\end{array}$ & YS- \\
\hline $\begin{array}{l}\text { Bear Creek Road Debris Burial } \\
\text { Area (Fig. A.2 \#23) }\end{array}$ & $\begin{array}{l}\text { New found site on Bear Creek Floodplain. } \\
\text { History unknown. Decision on inclusion in } \\
\text { FFA is pending. }\end{array}$ & \\
\hline $\begin{array}{l}\text { Creekside Debris Burial Area } \\
\text { (Fig. A.2 \#24) }\end{array}$ & $\begin{array}{l}\text { New found site on Bear Creek Floodplain. } \\
\text { History unknown. Decision on inclusion in } \\
\text { FFA is pending. }\end{array}$ & \\
\hline
\end{tabular}

${ }^{a}$ Locations of sites identified on Fig. A.2.

Source: DOE 1994b. 
Table A.2. Chronological list of events at the S-3 Ponds

\begin{tabular}{|c|c|c|}
\hline Year & Event & Reference \\
\hline 1951 & $\begin{array}{l}\text { The S-3 Ponds were constructed. They } \\
\text { consisted of four unlined surface } \\
\text { impoundments with a total storage capacity of } \\
38 \text { million L ( } 10 \text { million gal) }\end{array}$ & Energy Systems 1992d \\
\hline Mid-1950s & $\begin{array}{l}\text { Uranyl nitrate solutions containing small } \\
\text { amounts of plutonium were discharged } \\
\text { into ponds }\end{array}$ & \\
\hline $1951-1983$ & $\begin{array}{l}\text { Primary waste disposed of in S-3 Ponds } \\
\text { consisted of nitric acid, nitrate waste, pickling } \\
\text { and plating wastes, and miscellaneous liquid } \\
\text { wastes associated with routine cleanup } \\
\text { operations. Other wastes included dilute acid, } \\
\text { machine coolants, depleted uranium, } \\
\text { technetium, caustic solutions, biodenitrification } \\
\text { sludges, and acids with pH of }<2.0\end{array}$ & \\
\hline 1976 & $\begin{array}{l}\text { The nitric acid recovery system } \\
\text { became operational }\end{array}$ & \\
\hline 1983 & $\begin{array}{l}\text { Annual liquid waste entering the ponds was } \\
\text { reported to be } \sim 10.3 \text { million } L \\
\text { ( } 2.7 \text { million gal) }\end{array}$ & \\
\hline 1983 & $\begin{array}{l}\text { The underground nitric acid pipeline used to } \\
\text { transport waste to the S-3 Ponds was plugged } \\
\text { and abandoned }\end{array}$ & Energy Systems $1987 a$ \\
\hline March 1983 & $\begin{array}{l}\text { All waste discharges into the ponds were } \\
\text { terminated }\end{array}$ & \\
\hline 1983 & $\begin{array}{l}\text { Characterization monitoring at the S-3 Ponds } \\
\text { began in response to a Memorandum of } \\
\text { Understanding (MOU) signed by DOE, EPA, } \\
\text { and TDEC }\end{array}$ & $\begin{array}{l}\text { Jeter } 1983 \text { and Turner } \\
\text { et al. } 1991\end{array}$ \\
\hline 1983 & $\begin{array}{l}\text { In situ treatment of wastewater in the ponds } \\
\text { began }\end{array}$ & \\
\hline May-November 1983 & Liquid in all four ponds was neutralized & \\
\hline $\begin{array}{l}\text { May } 1983- \\
\text { September } 1984\end{array}$ & $\begin{array}{l}\text { Biodentrification of liquids occurred. Nitrate } \\
\text { levels in the pond water decreased } \\
\text { to } \sim 100 \mathrm{ppm}\end{array}$ & \\
\hline September 1984 & $\begin{array}{l}\text { In situ treatment of wastewater was completed. } \\
\text { Nitrate levels were maintained below } 50 \mathrm{ppm}\end{array}$ & \\
\hline December 1984 & $\begin{array}{l}\text { S-3 Ponds HWDU }{ }^{a} \text { was granted interim status } \\
\text { under TN Rule } 1200-1-11-.07(3)\end{array}$ & \\
\hline
\end{tabular}


Table A.2 (continued)

\begin{tabular}{|c|c|c|}
\hline Year & Event & Reference \\
\hline 1985 & $\begin{array}{l}\text { Supernatant treatment to remove trace metals } \\
\text { and organics began. The supernatant was } \\
\text { pumped to the S-3 Ponds Treatment Facility } \\
\text { where processes that included pH adjustment, } \\
\text { precipitation, coagulation, flocculation, carbon } \\
\text { absorption, filtration and chlorination were } \\
\text { conducted. The treated effluent was discharged } \\
\text { to EFPC in accordance with an NPDES } \\
\text { permit }\end{array}$ & \\
\hline January 1986 & $\begin{array}{l}\text { Assessment monitoring was initiated at the S-3 } \\
\text { Ponds }\end{array}$ & \\
\hline Spring 1986 & $\begin{array}{l}\text { Supernatant treatment processes were } \\
\text { completed }\end{array}$ & \\
\hline March 1987 & $\begin{array}{l}\text { The formalized Groundwater Quality } \\
\text { Assessment Plan for the site was submitted to } \\
\text { TDEC }\end{array}$ & $\begin{array}{l}\text { Geraghty and Miller } \\
1987\end{array}$ \\
\hline 1988 & $\begin{array}{l}\text { Sediment from the two "lagoons" in upper } \\
\text { Bear Creek was placed in the southwest cell of } \\
\text { the S-3 Ponds. The sediment was characterized } \\
\text { in place and after being disposed (Turner and } \\
\text { Kamp 1984). Data are reported in McMahon } \\
1988\end{array}$ & Energy Systems 1988a \\
\hline February 1988 & RCRA Closure Plan was revised & Energy Systems 1988a \\
\hline 1988 & $\begin{array}{l}\text { The S- } 3 \text { Ponds were closed with a multilayered } \\
\text { RCRA cap. Currently, the site is covered with } \\
\text { asphalt and used as a parking lot }\end{array}$ & \\
\hline November 15,1990 & $\begin{array}{l}\text { Final closure of the S-3 Ponds was accepted by } \\
\text { TDEC }\end{array}$ & \\
\hline September 30, 1991 & $\begin{array}{l}\text { TDEC issued a RCRA postclosure permit for } \\
\text { the S-3 Ponds }\end{array}$ & \\
\hline October 31, 1991 & $\begin{array}{l}\text { DOE and Energy Systems appealed permit on } \\
\text { basis of inapplicability of RCRA Corrective } \\
\text { Actions toward an NPL with an FFA in place. } \\
\text { As a result, all subsequent postclosure permit } \\
\text { applications were put on hold pending } \\
\text { determination of appeal. }\end{array}$ & \\
\hline November 30, 1992 & $\begin{array}{l}\text { DOE resubmits postclosure permit application } \\
\text { with reference to CERCLA for any } \\
\text { groundwater remediation. }\end{array}$ & \\
\hline
\end{tabular}




\section{A6-8}

Table A.2 (continued)

\begin{tabular}{lll}
\hline Year & \multicolumn{1}{c}{ Event } & Reference \\
\hline April 1993 & DOE, TDEC, and Energy Systems go before \\
& state board with consent order signed by all \\
& parties agreeing to CERCLA reference, and \\
& agree to use S-3 Site postclosure permit \\
& application language as a model for all \\
& subsequent applications. \\
\hline
\end{tabular}

${ }^{a}$ HWDU $=$ Hazardous Waste Disposal Unit.

${ }^{b} \mathrm{NPDES}=$ National Pollutant Discharge Elimination System. 
Table A.3. Source term characterization for S-3 Site

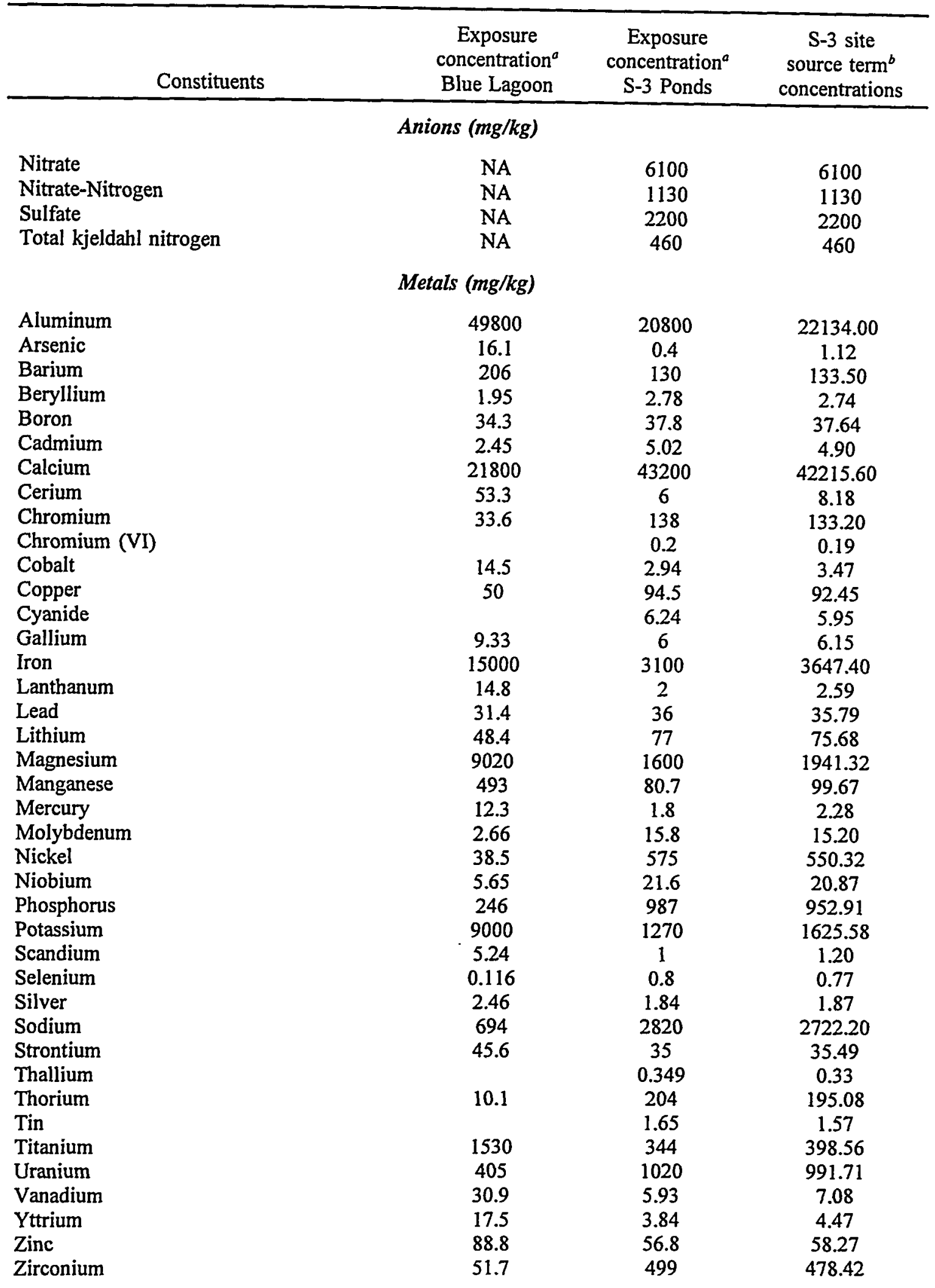


Table A.3 (continued)

\begin{tabular}{|c|c|c|c|}
\hline Constituents & $\begin{array}{c}\text { Exposure } \\
\text { concentration }^{a} \\
\text { Blue Lagoon }\end{array}$ & $\begin{array}{c}\text { Exposure } \\
\text { concentration }^{a} \\
\text { S-3 Ponds }\end{array}$ & $\begin{array}{c}\mathrm{S}-3 \text { site } \\
\text { source term } \\
\text { concentrations }\end{array}$ \\
\hline \multicolumn{4}{|c|}{ Organics $(\mu \mathrm{g} / \mathrm{kg})$} \\
\hline 1,1,2-Trichloroethane & 0 & 79 & 75.37 \\
\hline 1,1,2,2-Tetrachloroethane & 0 & 402 & 383.51 \\
\hline 1,1,2-Trichloro-1,2,2-trifluoroethane & 32.4 & 3 & 4.35 \\
\hline 1-(2-Butoxyethoxy)-Ethanol & 0 & 1100 & 1049.40 \\
\hline 2-Butoxyethanol & 0 & 2400 & 2289.60 \\
\hline 2-(2-Butoxyethoxy)-Ethanol & 0 & 2000 & 1908.00 \\
\hline 2-Hexanol & 0 & 310 & 295.74 \\
\hline 3-(1,1-Dimethylethyl)-Phenol & 0 & 6330 & 6038.82 \\
\hline Acetone & 499 & 0 & 22.95 \\
\hline Aroclor 1248 & 0 & 5940 & 5666.76 \\
\hline Diethylphthalate & 0 & 548 & 522.79 \\
\hline Methylene chloride & 10.6 & 0 & 0.49 \\
\hline Phenol & 0 & 7700 & 7345.80 \\
\hline Phosphoric acid & 0 & 810 & 772.74 \\
\hline Tetrachloroethene & 5.54 & 831 & 793.03 \\
\hline Toluene & 5.97 & 0 & 0.27 \\
\hline Trichloroethene & 6.13 & 0 & 0.28 \\
\hline Trichlorofluoromethane & 8.29 & 0 & 0.38 \\
\hline \multicolumn{4}{|c|}{ Radionuclides ( $p C i / g$ ) } \\
\hline Alpha activity & 202 & 960 & 925.13 \\
\hline Beta activity & 310 & 1980 & 1903.18 \\
\hline Americium-241 & 0.17 & & 0.01 \\
\hline Cesium-137 & 0 & 5 & 4.77 \\
\hline Neptunium-237 & 0.506 & 10.3 & 9.85 \\
\hline Plutonium-238 & 1.25 & 26.5 & 25.34 \\
\hline Plutonium-239/240 & 0.104 & 2.66 & 2.54 \\
\hline Ruthenium-106 & & 34.9 & 33.29 \\
\hline Stronium-90 & 0.377 & 13.5 & 12.90 \\
\hline Technetium-99 & 61.1 & 7880 & 7520.33 \\
\hline Tritium & 15.1 & & 0.69 \\
\hline Thorium-228 & $3.48^{c}$ & 280 & 267.28 \\
\hline Thorium-230 & $7.02^{c}$ & 570 & 544.10 \\
\hline Thorium-232 & $1.13^{c}$ & 91.7 & 87.53 \\
\hline Uranium-234 & 77.1 & $126.31^{c}$ & 124.05 \\
\hline Uranium-235 & 4.92 & $8.21^{c}$ & 8.06 \\
\hline Uranium-236 & 4.89 & $7.81^{c}$ & 7.68 \\
\hline Uranium-238 & 207 & $338.30^{c}$ & 332.26 \\
\hline
\end{tabular}

a Exposure concentrations represent $95 \%$ upper confidence limit of the mean.

b Source terms for S-3 Site represent weighted average (based on $95.4 \%$ S-3 Ponds sludge and $4.6 \%$ Blue Lagoon sludge) of exposure concentrations for the S-3 Ponds and the Blue Lagoon.

c Activities for Blue Lagoon and S-3 Ponds are calculated (not measured) on the basis of the isotopic distributions shown for thorium in the S-3 Ponds and for uranium in the Blue Lagoon, respectively. 
Table A.4. Chronological list of events at the Oil Landfarm

\begin{tabular}{|c|c|c|}
\hline Year & Event & Reference \\
\hline 1973 & $\begin{array}{l}\text { Landfarming activities began at the site. Waste oils } \\
\text { and coolants that contained beryllium compounds, } \\
\text { depleted uranium, PCBs, and chlorinated organic } \\
\text { compounds, mop waters, tanker oils from the } \\
\text { K-25 Site, wastes from cooling towers and the } \\
\text { Burial Grounds, and unidentified miscellaneous } \\
\text { liquid wastes were disposed of at the site }\end{array}$ & Energy Systems 1991 \\
\hline $1974-1975$ & $\begin{array}{l}57,000 \mathrm{~L}(15,000 \mathrm{gal}) \text { of oil skimmed from the } \\
\text { surface of the Oil Retention Pond }-1 \text { in } \mathrm{BG}-\mathrm{A} \text { were } \\
\text { disposed of in the Landfarm. An additional } 19,000 \mathrm{~L} \\
(5,000 \text { gal) were removed and sprayed onto nearby } \\
\text { trees }\end{array}$ & \\
\hline 1975 & $\begin{array}{l}\text { Historical monitoring at the site began as part } \\
\text { of DOE monitoring programs }\end{array}$ & \\
\hline 1979 & $\begin{array}{l}\text { Analyses of waste were implemented before } \\
\text { application to the Landfarm. The analytical results } \\
\text { for oil samples collected from the surface of one of } \\
\text { the ponds in the Burial Grounds indicated the } \\
\text { presence of PCBs }\end{array}$ & \\
\hline 1979 & $\begin{array}{l}\text { Oils were analyzed for uranium, beryllium, thorium, } \\
\text { and PCBs. Permissible concentration levels of } \\
5 \mathrm{mg} / \mathrm{L} \text { were established for PCBs. Waste oils } \\
\text { containing PCBs at concentrations }>5 \mathrm{mg} / \mathrm{L} \text { and } \\
\text { uranium concentration levels greater than permissible } \\
\text { limits were placed in storage for incineration at the } \\
\mathrm{K}-25 \text { Site TSCA incinerator. An additional } 68,000 \mathrm{~L} \\
\text { (18,000 gal) of oil were removed from ORP-1 }\end{array}$ & Battelle 1986 \\
\hline 1981 & $\begin{array}{l}\text { Analyses of waste were expanded to include } \\
\text { chlorinated hydrocarbons with a maximum } \\
\text { permissible concentration of } 3 \% \text { in waste oils }\end{array}$ & \\
\hline 1982 & $\begin{array}{l}\text { Landfarm activities ceased. Approximately } \\
3.8 \text { million } L \text { ( } 1 \text { million gal) of liquid waste were } \\
\text { disposed of during the operational history. A total of } \\
2.2 \text { million } L(583,500 \text { gal) of waste coolant and } \\
1.6 \text { million } L(430,800 \text { gal) of waste oil were } \\
\text { reported to be disposed of at the site (Union Carbide } \\
1984 \text { ) }\end{array}$ & Turner et al. 1991 \\
\hline 1983 & $\begin{array}{l}\text { Groundwater characterization monitoring } \\
\text { began in response to the MOU signed by DOE, EPA, } \\
\text { and TDEC }\end{array}$ & \\
\hline 1983 & $\begin{array}{l}\text { Core samples from perimeter monitoring wells were } \\
\text { analyzed for organic contaminants }\end{array}$ & \\
\hline September 1983 & $\begin{array}{l}\text { Composite soil samples were collected from plots } \\
1-12,13-18 \text {, and } 19-24 \text { and analyzed for VOCs, acid- } \\
\text { and base-neutral extractables, inductively coupled } \\
\text { plasma metals, and pesticide/PCBs }\end{array}$ & \\
\hline
\end{tabular}


Table A.4 (continued)

\begin{tabular}{|c|c|c|}
\hline Year & Event & Reference \\
\hline $1983-1984$ & $\begin{array}{l}\text { Water and sediment samples were collected } \\
\text { at tributaries NT-3 and NT-4. Levels of VOCs, } \\
\text { phenols, and beryllium were all below detection } \\
\text { limits }\end{array}$ & Turner et al. 1991 \\
\hline December 1984 & $\begin{array}{l}\text { Oil Landfarm was granted interim status under } \\
\text { TN Rule 1200-1-11.07(3) }\end{array}$ & \\
\hline 1985 & $\begin{array}{l}\text { A total of } 200 \text { soil samples were collected in a } \\
\text { randomized block design to delineate areas } \\
\text { containing PCB levels }>25 \mu \mathrm{g} / \mathrm{g} \text {. Samples were also } \\
\text { analyzed for uranium }\end{array}$ & Herbes 1989 \\
\hline January 1986 & DOE characterization monitoring ended & \\
\hline January 1986 & $\begin{array}{l}\text { Interim status assessment monitoring was initiated at } \\
\text { the site in lieu of detection monitoring as required } \\
\text { under TN Rule } 1200-1-11-.05(6) \text { (a) } 4 \text { due to the } \\
\text { detection of contaminants in groundwater }\end{array}$ & \\
\hline $1986-1987$ & $\begin{array}{l}\text { Groundwater samples from three monitoring wells } \\
\text { bordering the Oil Landfarm were analyzed for total } \\
\text { and dissolved toxic metals and gross radioactivity }\end{array}$ & \\
\hline 1987 & DOE historical monitoring at the site ended & \\
\hline February 1988 & RCRA Closure Plan was revised & \\
\hline 1989 & $\begin{array}{l}305.8 \mathrm{~m}^{3}\left(400 \mathrm{yd}^{3}\right) \text { of soils with PCB concentrations } \\
>25 \mathrm{\mu} / \mathrm{g} \text { excavated from soils at Oil Landfarm and } \\
\text { placed in the OLF Soils Containment Pad }\end{array}$ & Bohrman 1989 \\
\hline November 1990 & $\begin{array}{l}\text { Oil Landfarm was closed as a landfill with a } \\
\text { multilayered engineered cap pursuant } \\
\text { to TN Rule } 1200-1-11.05(14)(\mathrm{e})\end{array}$ & Bohrman 1989 \\
\hline December 1990 & $\begin{array}{l}\text { Final RCRA closure for the site was certified } \\
\text { by TDEC }\end{array}$ & Bohrman 1989 \\
\hline March 31, 1994 & $\begin{array}{l}\text { As a result of agreements made during issuance of } \\
\text { the S-3 portion of the BCV Hydrogeologic Regime } \\
\text { postclosure permit application, DOE resubmits OLF } \\
\text { postclosure permit application to TDEC }\end{array}$ & \\
\hline June 30,1995 & $\begin{array}{l}\text { TDEC issues modification to } \mathrm{BCV} \text { permit adding } \\
\text { OLF section }\end{array}$ & \\
\hline
\end{tabular}


A6-13

Table A.5. Summary of waste coolant disposals at the Y-12 Plant Oil Landfarm

\begin{tabular}{|c|c|c|c|c|}
\hline $\begin{array}{c}\text { Calendar } \\
\text { year }\end{array}$ & $\begin{array}{c}\text { No. of } \\
\text { disposals }\end{array}$ & $\begin{array}{c}\text { Volume } \\
\text { (gal) }\end{array}$ & $\begin{array}{c}\text { Active plots } \\
\text { (acres) }\end{array}$ & Description \\
\hline \multirow[t]{2}{*}{1973} & $\begin{array}{c}12 \\
8\end{array}$ & $\begin{array}{l}34,800 \\
22,500\end{array}$ & $\begin{array}{l}0.9 \\
0.9\end{array}$ & $\begin{array}{l}\text { Coolants } \\
\text { Coolants and mop } \\
\text { waters }\end{array}$ \\
\hline & 2 & 9,700 & 0.9 & $\begin{array}{l}\text { Water } \\
\text { contaminated } \\
\text { with nitrate }\end{array}$ \\
\hline 1974 & $\begin{array}{c}22 \\
6\end{array}$ & $\begin{array}{r}104,000 \\
21,000\end{array}$ & $\begin{array}{l}1.6 \\
1.6\end{array}$ & $\begin{array}{l}\text { Coolants } \\
\text { Coolants and mop } \\
\text { waters }\end{array}$ \\
\hline 1975 & 21 & 97,500 & 2.0 & Coolants \\
\hline 1976 & $\begin{array}{c}25 \\
3\end{array}$ & $\begin{array}{r}107,000 \\
9,400\end{array}$ & $\begin{array}{l}2.0 \\
2.0\end{array}$ & $\begin{array}{l}\text { Coolants } \\
\text { Water }\end{array}$ \\
\hline 1977 & 23 & 114,000 & 1.6 & Coolants \\
\hline 1978 & 15 & 62,600 & 1.4 & Coolants \\
\hline 1979 & NA & NA & 1.4 & No disposals \\
\hline 1980 & 1 & 1,000 & 1.4 & Dye penetrant \\
\hline 1981 & NA & NA & 1.4 & No disposals \\
\hline 1982 & NA & $\mathrm{NA}$ & 1.4 & No disposals \\
\hline TOTAL & 138 & 583,500 & & \\
\hline
\end{tabular}

Source: Union Carbide 1984. 
A6-14

Table A.6. Summary of waste oil disposals at the Y-12 Plant Oil Landfarm

\begin{tabular}{|c|c|c|c|c|c|}
\hline $\begin{array}{c}\text { Calendar } \\
\text { year }\end{array}$ & Origin & $\begin{array}{c}\text { No. of } \\
\text { disposals }\end{array}$ & $\begin{array}{l}\text { Volume } \\
\text { (gal) }\end{array}$ & $\begin{array}{l}\text { Active plots } \\
\text { (acres) }\end{array}$ & Description \\
\hline 1973 & $\mathrm{Y}-12$ & 11 & 42,800 & 0.4 & Waste oil \\
\hline 1974 & $Y-12$ & 14 & 53,300 & 1.0 & Waste oil \\
\hline 1975 & $Y-12$ & 4 & 14,600 & 1.0 & Waste oil \\
\hline \multirow[t]{2}{*}{1976} & $Y-12$ & 9 & 25,600 & 1.0 & Waste oil \\
\hline & $\mathrm{NR}^{a}$ & 5 & 17,700 & 1.0 & No record \\
\hline 1977 & NR & 5 & 14,000 & 1.4 & No record \\
\hline \multirow[t]{2}{*}{1978} & $Y-12$ & 12 & 36,000 & 1.7 & Waste oil \\
\hline & ORGDP & 1 & 1,000 & 1.7 & Mineral oil \\
\hline \multirow[t]{2}{*}{1979} & $Y-12$ & 4 & 16,500 & 2.6 & Waste oil \\
\hline & ORGDP & 16 & 63,900 & 2.6 & Waste oil \\
\hline \multirow[t]{3}{*}{1980} & $Y-12$ & 22 & 72,400 & 2.6 & Waste oil \\
\hline & $Y-12$ & 5 & 17,800 & 2.6 & Mineral oil \\
\hline & ORGDP & 7 & 22,300 & 2.6 & Waste oil \\
\hline 1981 & $\mathrm{NA}^{b}$ & $\mathrm{NA}$ & $\mathrm{NA}$ & 2.6 & No disposals \\
\hline 1982 & $\mathrm{Y}-12$ & 9 & 32,900 & 2.6 & Waste oil \\
\hline TOTAL & & 124 & 430,800 & & \\
\hline
\end{tabular}

${ }^{a} \mathrm{NR}=$ no record.

${ }^{b} \mathrm{NA}=$ not applicable.

Source: Union Carbide 1984. 
A6-15

Table A.7. OLF storage pad soil data summary

\begin{tabular}{|c|c|c|c|c|c|}
\hline Analysis & Units & Minimum & Maximum & Mean & $\mathrm{N}$ \\
\hline Aluminum & ppm & 9600 & 18000 & 13882.5 & 40 \\
\hline Antimony & ppm & 2.2 & 34733 & 870.78 & 40 \\
\hline Arsenic & ppm & 2.2 & 2.8 & 2.51 & 40 \\
\hline Barium & ppm & 5.2 & 160 & 86.96 & 40 \\
\hline Beryllium & ppm & 0.71 & 13 & 4.66 & 40 \\
\hline Boron & $\mathrm{ppm}$ & 3.5 & 5.7 & 4.13 & 40 \\
\hline Cadmium & $\mathrm{ppm}$ & 0.22 & 0.46 & 0.28 & 40 \\
\hline Calcium & $\mathrm{ppm}$ & 1600 & 26000 & 6340 & 40 \\
\hline Chlorides & $\mathrm{ppm}$ & 5 & 402 & 110.33 & 40 \\
\hline Chromium & $\mathrm{ppm}$ & 15 & 37 & 21.7 & 40 \\
\hline Cobalt & $\mathrm{ppm}$ & 7 & 14 & 9.65 & 40 \\
\hline Copper & $\mathrm{ppm}$ & 9 & 25 & 14.93 & 40 \\
\hline Cyanide & $\mathrm{ppm}$ & 0.5 & 0.5 & 0.5 & 40 \\
\hline Fluorides & $\mathrm{ppm}$ & 5 & 24 & 13.28 & 40 \\
\hline Iron & $\mathrm{ppm}$ & 14000 & 29000 & 18650 & 40 \\
\hline Lead & $\mathrm{ppm}$ & 7.1 & 33 & 15.42 & 40 \\
\hline Lithium & $\mathrm{ppm}$ & 660 & 830 & 750.75 & 40 \\
\hline Magnesium & $\mathrm{ppm}$ & 8.9 & 9400 & 3292.72 & 40 \\
\hline Manganese & $\mathrm{ppm}$ & 64 & 970 & 343.8 & 40 \\
\hline Mercury & $\mathrm{ppm}$ & 0.09 & 0.73 & 0.39 & 40 \\
\hline Molybdenum & $\mathrm{ppm}$ & 1.8 & 2.2 & 2.01 & 40 \\
\hline Nickel & ppm & 11 & 23 & 14.88 & 40 \\
\hline PCBs & $\mathrm{ppm}$ & 0.17 & 92.5 & 15.56 & 40 \\
\hline Phosphates & $\mathrm{ppm}$ & 5 & 490 & 107.8 & 40 \\
\hline Phosphorus & ppm & 150 & 1100 & 404.25 & 40 \\
\hline Selenium & $\mathrm{ppm}$ & 2.2 & 3 & 2.52 & 40 \\
\hline Silicon & $\mathrm{ppm}$ & 1300 & 2100 & 1725 & 40 \\
\hline Silver & $\mathrm{ppm}$ & 0 & 0.28 & 0.24 & 40 \\
\hline Sodium & $\mathrm{ppm}$ & 220 & 280 & 250.75 & 40 \\
\hline Strontium & $\mathrm{ppm}$ & 5.2 & 22 & 9.83 & 40 \\
\hline Tin & $\mathrm{ppm}$ & 2.2 & 2.8 & 2.51 & 40 \\
\hline Titanium & $\mathrm{ppm}$ & 97 & 160 & 127.18 & 40 \\
\hline Uranium & $\mathrm{ppm}$ & 16 & 151 & 66.13 & 40 \\
\hline Uranium 234 & $\mathrm{pCi} / \mathrm{g}$ & 9.18 & 32.4 & 20.81025 & 40 \\
\hline
\end{tabular}


A6-16

Table A.7 (continued)

\begin{tabular}{cccccc}
\hline Analysis & Units & Minimum & Maximum & Mean & $\mathrm{N}$ \\
\hline Uranium 235 & $\mathrm{pCi} / \mathrm{g}$ & 0.351 & 2.7 & 1.38915 & 40 \\
Uranium 238 & $\mathrm{pCi} / \mathrm{g}$ & 5.13 & 45.9 & 20.12175 & 40 \\
Uranium Total & $\mathrm{pCi} / \mathrm{g}$ & 14.9 & 80.35 & 42.32 & 40 \\
Vanadium & $\mathrm{ppm}$ & 15 & 26 & 19.85 & 40 \\
Water & $\mathrm{wt}$ & 16 & 30 & 23.03 & 40 \\
Zinc & $\mathrm{ppm}$ & 24 & 49 & 37.15 & 40 \\
Zirconium & $\mathrm{ppm}$ & 3.1 & 8 & 5.45 & 40 \\
Ash & $\mathrm{wt}$ & 62.9 & 73.7 & 68.7 & 40 \\
Flash Point & ${ }^{\circ} \mathrm{C}$ & 85 & 99 & 96.15 & 40 \\
Site > 20 mesh & & 19 & 64 & 41.15 & 40 \\
Specific Gravity & - & 1.5 & 2.7 & 1.89 & 40 \\
\hline
\end{tabular}


A6-17

Table A.8. OLF soils-in-place analytical results summary

\begin{tabular}{lccccc}
\hline \multicolumn{1}{c}{ Analysis } & Unit & Phase I light $^{a}$ & Phase I dark $^{a}$ & Phase II $^{b}$ & Verification $^{c}$ \\
\hline Oil and grease & $\%$ & 5.2 & 12.3 & 3.5 & \\
PCB-1254 & $\mathrm{mg} / \mathrm{kg}$ & 8.4 & 5.5 & 4.2 & \\
PCB-1260 & $\mathrm{mg} / \mathrm{kg}$ & $\mathrm{ND}$ & 10.8 & 5.3 & \\
Percent solids & $\%$ & 82.5 & 82.3 & 80.5 & \\
Total Uranium & $\mathrm{mg} / \mathrm{kg}$ & 48.6 & 63.3 & 74.5 & \\
Total PCBs & $\mathrm{mg} / \mathrm{kg}$ & & & & 8.3 \\
\hline
\end{tabular}

${ }^{a}$ Phase I = Initial comparison of light versus dark stained areas.

${ }^{b}$ Phase II = Investigation by plot of entire OLF area.

${ }^{c}$ Verification $=$ Confirmatory samples collected at each soil removal site.

ND - not detected. 


\section{A6-18}

Table A.9. Chronological list of events at the Boneyard/Burnyard

\begin{tabular}{|c|c|c|}
\hline Year & Event & Reference \\
\hline 1943 & $\begin{array}{l}\text { The Boneyard was used as a disposal site for waste from } \\
\text { the Y-12 Plant. Burning and disposal of debris and } \\
\text { sanitary, metallic, chemical, and radioactive wastes are } \\
\text { known to have occurred. In the southwest corner } \\
\text { of the Boneyard, metal chips were placed in pans } \\
\text { in unlined earthen trenches and burned. The residue } \\
\text { remaining in the trench was covered with topsoil } \\
\text { and compacted until the trench was filled. The trench was } \\
\text { then covered with topsoil and seeded with grass }\end{array}$ & Energy Systems 1991 \\
\hline 1943 & $\begin{array}{l}\text { The Burnyard received } \sim 1000 \mathrm{~m}^{3}\left(4000 \mathrm{yd}^{3} / \mathrm{year}\right) \\
\text { of sanitary refuse from plant operations including solids, } \\
\text { liquids, and sludges. The wastes were placed } \\
\text { in two unlined earthen trenches and burned. When filled, } \\
\text { the trenches were covered with soil }\end{array}$ & \\
\hline 1968 & Disposal of waste at the Burnyard was discontinued & \\
\hline 1970 & Disposal of waste at the Boneyard site was discontinued & \\
\hline $1975-1981$ & $\begin{array}{l}\text { A Hazardous Chemical Disposal Area was established on } \\
22 \text { acres in the southeastern portion of Boneyard/Burnyard } \\
\text { on top of the Burnyard. The area was used } \\
\text { to burn or neutralize liquid and gaseous wastes. The } \\
\text { material was broadly characterized as ignitable, reactive, } \\
\text { corrosive, toxic, highly flammable, or in some instances } \\
\text { inert }\end{array}$ & $\begin{array}{l}\text { Energy Systems } 1991 \\
\text { Energy Systems } 1987 \mathrm{~b}\end{array}$ \\
\hline 1985 & $\begin{array}{l}\text { An investigation conducted by Bechtel National, Inc. on } \\
\text { sediment samples collected downstream of the Boneyard } \\
\text { indicated levels of mercury, uranium, several polynuclear } \\
\text { aromatic hydrocarbons, and phthalates }\end{array}$ & Energy Systems $1987 \mathrm{~b}$ \\
\hline 1989 & $\begin{array}{l}\text { The Hazardous Chemical Disposal Area was covered with } \\
\text { a RCRA-type cap }\end{array}$ & Energy Systems 1991 \\
\hline
\end{tabular}




\section{A6-19}

Table A.10. Chronological list of events at SL 1

\begin{tabular}{|c|c|c|}
\hline Year & Event & Reference \\
\hline $1968-1983$ & $\begin{array}{l}\text { The site was used for the disposal of combustible and } \\
\text { decomposable solid wastes. A total of }-27,000 \mathrm{~m}^{3} \\
\left(35,315 \mathrm{yd}^{3}\right) \text { of refuse was disposed of at the landfill }\end{array}$ & \\
\hline 1983 & Waste disposal at the site was terminated & \\
\hline 1985 & $\begin{array}{l}\text { The site was closed by grading, capping with } 0.6 \mathrm{~m} \\
(2 \mathrm{ft}) \text { of clay, and establishing a vegetative cover }\end{array}$ & \\
\hline
\end{tabular}


Table A.11. Chronological list of events at the Burial Grounds

\begin{tabular}{|c|c|}
\hline Year & Event \\
\hline August 1955 & $\begin{array}{l}\text { Disposal at the Burial Grounds began with the disposal } \\
\text { of solid waste in Unit A. The Burial Grounds consisted } \\
\text { of waste disposal units A, B, C, D, E, and J. Each unit } \\
\text { consisted of a series of trenches, } 4.3 \text { to } 7.6 \mathrm{~m} \text { (14 } \\
\text { to } 25 \mathrm{ft} \text { ) deep, that were used for the disposal of liquid } \\
\text { and solid wastes }\end{array}$ \\
\hline July 1959 & $\begin{array}{l}\text { Large volumes of solvent-contaminated water and oils } \\
\text { began being disposed of in BG-A }\end{array}$ \\
\hline 1959-1979 & $\begin{array}{l}\text { An estimated } 2.3 \text { million L ( } 600,000 \text { gal) of mop water } \\
\text { were disposed of annually in BG-A }\end{array}$ \\
\hline 1961 & $\begin{array}{l}\text { A surface tank was installed in BG-A to hold waste oils } \\
\text { and coolants; accumulations were burned. Liquids that did } \\
\text { not burn were drained into trenches. An estimated } 684,000 \\
\text { L ( } 180,000 \text { gal) of oil and coolants were disposed of by } \\
\text { this method }\end{array}$ \\
\hline 1962 & $\begin{array}{l}\text { BG-B was opened and used for disposal of depleted } \\
\text { uranium metal and oxides }\end{array}$ \\
\hline 1962 & $\begin{array}{l}\text { BG-C was opened for the disposal of asbestos beryllium, } \\
\text { beryllium oxide, lithium, technetium, thorium, and solid } \\
\text { waste contaminated with these materials. Other materials } \\
\text { contaminated with enriched uranium were also disposed of } \\
\text { in BG-C }\end{array}$ \\
\hline 1966 & $\begin{array}{l}\text { The WIP were established in the Burial Grounds. The area } \\
\text { was used to dispose of chemicals and uranium metal saw } \\
\text { fines }\end{array}$ \\
\hline 1968 & $\begin{array}{l}\text { Burning of waste oils and coolants was terminated } \\
\text { in BG-A }\end{array}$ \\
\hline 1968 & BG-B reached waste disposal capacity \\
\hline 1968 & $\begin{array}{l}\text { BG-D was opened. The area was used to replace BG-B } \\
\text { and received depleted uranium metals and oxides waste }\end{array}$ \\
\hline 1969-1971 & $\begin{array}{l}\text { Oil was first observed seeping from the ends } \\
\text { of trenches in BG-A into Tributary NT-7 and from the soil } \\
\text { surface above the oil disposal pits }\end{array}$ \\
\hline January 1969 & $\begin{array}{l}\text { Oil and coolants were poured into standpipes that were } \\
\text { installed in the trenches }\end{array}$ \\
\hline $1970-1981$ & $\begin{array}{l}\text { Approximately } 380,000 \mathrm{~L}(100,000 \mathrm{gal}) \text { of waste solvents } \\
\text { were poured into rock piles and into waste-filled trenches } \\
\text { in the southern part of } \mathrm{BG}-\mathrm{A}\end{array}$ \\
\hline May 1971 & $\begin{array}{l}\text { ORP-1 was constructed with dimensions of } 55 \mathrm{~m} \\
(180 \mathrm{ft}) \text { long, } 34 \mathrm{~m}(110 \mathrm{ft}) \text { wide, and } 2 \mathrm{~m}(6 \mathrm{ft}) \text { deep }\end{array}$ \\
\hline $1971-1972$ & $\begin{array}{l}\text { Approximately } 497,403 \mathrm{~L}(131,400 \mathrm{gal}) \text { of oil and mop } \\
\text { waters were sumped into a standpipe in the northeast } \\
\text { corner of BG-D. }\end{array}$ \\
\hline
\end{tabular}

Turner et al. 1991

Turner et al. 1991, Battelle 1994

Turner et al. 1991

Turner et al. 1991

Turner et al. 1991

Fig. A.7

Turner et al. 1991

Bailey 1979

Bailey 1983b 
Table A.11 (continued)

\begin{tabular}{|c|c|}
\hline Year & Event \\
\hline May 1972 & $\begin{array}{l}\text { ORP- } 2 \text { was constructed on Tributary NT- } 6 \text { at the northeast } \\
\text { corner of BG-A }\end{array}$ \\
\hline $1974-1975$ & $\begin{array}{l}\text { Approximately } 57,000 \mathrm{~L}(15,000 \mathrm{gal}) \text { of oil were skimmed } \\
\text { and removed from the surfaces of ORP-1 for disposal on } \\
\text { the Oil Landfarm }\end{array}$ \\
\hline 1975 & $\begin{array}{l}\text { Approximately } 132,450 \mathrm{~L}(35,000 \mathrm{gal}) \text { of oil were } \\
\text { collected from ORP-2 and placed on the OLF plots }\end{array}$ \\
\hline 1975 & $\begin{array}{l}\text { Since } 1975 \text {, no significant accumulation of oil has } \\
\text { occurred on surface of ORP-2 }\end{array}$ \\
\hline $1975-1987$ & $\begin{array}{l}\text { Historical monitoring at the site began as part } \\
\text { of a program to identify groundwater contamination } \\
\text { sources at } Y-12 \text { Plant }\end{array}$ \\
\hline 1979 & $\begin{array}{l}\text { There were } 68,400 \mathrm{~L}(18,000 \mathrm{gal}) \text { of oil removed } \\
\text { from ORP-1 }\end{array}$ \\
\hline 1979 & The disposal of mop water in BG-A was terminated \\
\hline 1979 & Oil disposal ceased in the Burial Grounds \\
\hline 1980 & $\begin{array}{l}\text { Trenches and disposal areas in the Burial Grounds that } \\
\text { received hazardous wastes were designated and given } \\
\text { interim status }\end{array}$ \\
\hline 1980,1982 & $\begin{array}{l}\text { A series of soil cores were collected along transects from } \\
\text { the perimeter of ORP-1 for PCB analysis }\end{array}$ \\
\hline 1981 & $\begin{array}{l}\text { After 1981, the WIP were used for disposal } \\
\text { of uranium metal saw-fines, organics, and laboratory } \\
\text { wastes }\end{array}$ \\
\hline 1983 & $\begin{array}{l}\text { Water and sediment samples collected from sites } \\
\text { in NT-6 and NT-7 were analyzed for VOCs, metals, } \\
\text { cyanide, phenols, and a number of conventional water } \\
\text { quality parameters. Several VOCs principally including } \\
1,1 \text {-dichloroethane, tetrachloroethylene (PCE), trans-1,2- } \\
\text { dichloroethylene, and trichloroethylene (TCE) were found } \\
\text { in the sediments of ORP-1 and in both water and } \\
\text { sediments of NT-7 downstream of the pond. VOCs were } \\
\text { not detected in a water sample collected north } \\
\text { of ORP-1, which indicated that the VOC source differed } \\
\text { from that of PCBs }\end{array}$ \\
\hline $\begin{array}{l}\text { September } \\
1983\end{array}$ & $\begin{array}{l}\text { Sediment samples collected from ORP-1 and NT-7 } \\
\text { downstream of the pond did not show elevated levels of } \\
\text { toxic metals, cyanide, or phenols in comparison } \\
\text { to the control site on NT-7 upstream of the Burial Grounds }\end{array}$ \\
\hline $\begin{array}{l}\text { September } \\
1983\end{array}$ & $\begin{array}{l}\text { Samples from ORP-1 were found to contain PCBs ranging } \\
\text { from } 3 \text { to } 31 \mathrm{mg} / \mathrm{L}\end{array}$ \\
\hline 1983,1984 & $\begin{array}{l}\text { Concentrations of PCBs in NT-7 channel sediments } \\
\text { at the confluence with Bear Creek were reported } \\
\text { to range from } 5.2 \text { to } 28.2 \mathrm{mg} / \mathrm{g}\end{array}$ \\
\hline
\end{tabular}

Bailey 1983

Bailey 1983

Turner et al. 1991

Turner et al. 1991

McCauley 1984 
Table A.11 (continued)

\begin{tabular}{|c|c|c|}
\hline Year & Event & Reference \\
\hline $\begin{array}{c}\text { December } \\
1984\end{array}$ & $\begin{array}{l}\text { The Burial Grounds were granted interim status and } \\
\text { therefore became subject to the groundwater monitoring } \\
\text { requirements described in TN Rule 1200-1-11-.05 }\end{array}$ & \\
\hline $1985-1988$ & $\begin{array}{l}\text { Extensive sediment sampling throughout the tributary } \\
\text { system showed that PCBs were present in concentrations } \\
\text { of several hundred milligrams per gram in surface } \\
\text { sediments of NT-7 between ORP-1 and the visible area of } \\
\text { oil seepage at the west end of Burial Trench A-14 but } \\
\text { declined below } 25 \mathrm{mg} / \mathrm{g} \text { by a depth of } 60 \mathrm{~cm} \text { ( } 24 \text { in.) }\end{array}$ & \\
\hline October 1985 & $\begin{array}{l}\text { Five cores were collected from the bottom of ORP- } 1 \text { and } \\
\text { subdivided into } 15-\mathrm{cm} \text { ( } 6 \text {-in.) intervals for analysis. } \\
\text { Concentrations of PCBs in surface sediments ranged as } \\
\text { high as } 710 \mathrm{mg} / \mathrm{g} \text { but declined to } 3 \mathrm{mg} / \mathrm{g} \text { or less at a depth } \\
\text { of } 67.5 \mathrm{~cm}(27 \mathrm{in} .)\end{array}$ & Herbes 1989 \\
\hline $\begin{array}{c}\text { February } \\
1988\end{array}$ & RCRA Closure Plan was revised & \\
\hline 1989 & $\begin{array}{l}3060 \mathrm{~m}^{3}\left(4,000 \mathrm{yd}^{3}\right) \text { of sludge and soils were excavated } \\
\text { and placed in DARA Soil Storage Facility from ORP-1, } \\
\text { ORP-2, and NT-7. An engineered cap was constructed } \\
\text { over each pond and NT-7 under an approved RCRA } \\
\text { closure plan. A new channel was constructed for NT- } 7 \text {, } \\
\text { and this tributary was rerouted } \sim 15 \mathrm{~m} \text { ( } 50 \mathrm{ft}) \text { west of its } \\
\text { original course }\end{array}$ & Collins $1990 \mathrm{a}$ \\
\hline 1989 & $\begin{array}{l}\text { BG-A and BG-C west were closed in place as a landfill } \\
\text { and covered with an engineered cap under RCRA }\end{array}$ & Collins $1990 \mathrm{~b}$ \\
\hline $\begin{array}{c}\text { November } \\
1990\end{array}$ & TDEC granted approval for the final closure of BG-A & \\
\hline 1993 & WIP and BG-B closure plan approved & \\
\hline Fall 1993 & Trib 8 collection system complete & \\
\hline May 1994 & WIP closure complete & \\
\hline $\begin{array}{c}\text { February } \\
1995\end{array}$ & WIP closure certified by State of Tennessee & \\
\hline April 1995 & $\begin{array}{l}\text { DOE submits postclosure permit application modification } \\
\text { to add WIP to } B C V \text { permit }\end{array}$ & \\
\hline $\begin{array}{c}\text { September } \\
1995\end{array}$ & $\begin{array}{l}\text { TDEC issues revised BCV Hydrogeologic Regime } \\
\text { postclosure permit incorporating WIP }\end{array}$ & \\
\hline
\end{tabular}


Table A.12. DARA soil data summary

\begin{tabular}{|c|c|c|c|c|c|c|}
\hline Chemical & Units & N Sample & $\mathrm{N}>$ Quan. Limit & Min & $\operatorname{Max}$ & Average \\
\hline \multicolumn{7}{|c|}{ Detected Constituents } \\
\hline 1,2,4,5-Tetrachlorobenzene & $\mathrm{mg} / \mathrm{kg}$ & 32 & 1 & 0.19 & 25 & 6.511 \\
\hline 2,4-Dimethylphenol & $\mathrm{mg} / \mathrm{kg}$ & 32 & 12 & 0.19 & 5.1 & 1.06 \\
\hline Acetone & $\mathrm{mg} / \mathrm{kg}$ & 21 & 10 & 0.012 & 0.36 & 0.071 \\
\hline Anthracene & $\mathrm{mg} / \mathrm{kg}$ & 32 & 1 & 0.26 & 5.1 & 1.507 \\
\hline Antimony & $\mathrm{mg} / \mathrm{l}$ & 32 & 7 & 0.012 & 0.018 & 0.013 \\
\hline Barium & $\mathrm{mg} / \mathrm{l}$ & 32 & 1 & 5 & 5.1 & 5 \\
\hline Benao(a)anthracene & $\mathrm{mg} / \mathrm{kg}$ & 32 & 1 & 0.4 & 5.1 & 1.481 \\
\hline Cadmium & $\mathrm{mg} / \mathrm{l}$ & 32 & 1 & 0.01 & 0.012 & 0.01 \\
\hline Carbon disulfide & $\mathrm{mg} / \mathrm{l}$ & 21 & 5 & 0.003 & 0.01 & 0.007 \\
\hline Chloroethane & $\mathrm{mg} / \mathrm{kg}$ & 21 & 1 & 0.006 & 0.043 & 0.014 \\
\hline Chrysene & $\mathrm{mg} / \mathrm{kg}$ & 32 & 1 & 0.4 & 5.1 & 1.486 \\
\hline Ethyl ether & $\mathrm{mg} / \mathrm{kg}$ & 21 & 2 & 0.005 & 0.21 & 0.068 \\
\hline Fluoranthene & $\mathrm{mg} / \mathrm{kg}$ & 32 & 2 & 0.23 & 5.1 & 1.468 \\
\hline Lead & $\mathrm{mg} / \mathrm{l}$ & 32 & 1 & 0.05 & 0.41 & 0.061 \\
\hline Methanol & $\mathrm{mg} / \mathrm{l}$ & 32 & 3 & 0.5 & 3.87 & 0.725 \\
\hline Methyl isobutyl ketone & $\mathrm{mg} / \mathrm{kg}$ & 21 & 2 & 0.012 & 0.043 & 0.016 \\
\hline Naphthalene & $\mathrm{mg} / \mathrm{kg}$ & 32 & 1 & 0.21 & 5.1 & 1.505 \\
\hline Pentachlorobenzene & $\mathrm{mg} / \mathrm{kg}$ & 32 & 3 & 0.071 & 25 & 5.518 \\
\hline Pentachlorodibenzo-p-dioxins & $\mu \mathrm{g} / \mathrm{kg}$ & 32 & 2 & 0.04 & 0.39 & 0.137 \\
\hline Phenanthrene & $\mathrm{mg} / \mathrm{kg}$ & 32 & 6 & 0.079 & 5.1 & 0.852 \\
\hline Pyrene & $\mathrm{mg} / \mathrm{kg}$ & 32 & 5 & 0.14 & 5.1 & 0.889 \\
\hline
\end{tabular}


Table A.12 (continued)

\begin{tabular}{|c|c|c|c|c|c|c|}
\hline Chemical & Units & N Sample & $N>$ Quan. Limit & Min & $\operatorname{Max}$ & Average \\
\hline Tetrachlorodibenzo-p-dioxins & $\mu \mathrm{g} / \mathrm{kg}$ & 32 & 2 & 0.067 & 2.4 & 0.275 \\
\hline Trichlorofluoromethane & $\mathrm{mg} / \mathrm{kg}$ & 21 & 2 & 0.001 & 0.021 & 0.007 \\
\hline bis(2-Ethylhexyl)phthalate & $\mathrm{mg} / \mathrm{kg}$ & 32 & 13 & 0.073 & 5.1 & 1.25 \\
\hline \multicolumn{7}{|c|}{ Analytical Results } \\
\hline 1,2,4-Trichlorobenze & $\mathrm{mg} / \mathrm{kg}$ & 32 & 19 & 0.057 & 4.9 & 0.423 \\
\hline Aroclor- 1254 & $\mathrm{mg} / \mathrm{kg}$ & 32 & 32 & 14.5 & 103 & 49.963 \\
\hline Ethyl benzene & $\mathrm{mg} / \mathrm{kg}$ & 21 & 11 & 0.002 & 0.021 & 0.007 \\
\hline Hexachlorodibenzo-furans & $\mu \mathrm{g} / \mathrm{kg}$ & 32 & 27 & 0.098 & 2.92 & 1.065 \\
\hline Hexachlorodibenzo-p-dioxins & $\mu \mathrm{g} / \mathrm{kg}$ & 32 & 22 & 0.017 & 2.65 & 0.194 \\
\hline Methylene chloride & $\mathrm{mg} / \mathrm{kg}$ & 21 & 21 & 0.005 & 0.3 & 0.26 \\
\hline Nickel & $\mathrm{mg} / \mathrm{l}$ & 32 & 32 & 0.012 & 0.069 & 0.03 \\
\hline Pentachlorodibenzo-furans & $\mu \mathrm{g} / \mathrm{kg}$ & 32 & 31 & 0.17 & 3.41 & 0.799 \\
\hline Tetrachlorodibenzo-furans & $\mu \mathrm{g} / \mathrm{kg}$ & 32 & 32 & 0.12 & 6067 & 2.074 \\
\hline Toluene & $\mathrm{mg} / \mathrm{kg}$ & 21 & 11 & 0.004 & 0.062 & 0.011 \\
\hline Total Uranium & $\mathrm{pCi} / \mathrm{gm}$ & & & 9.78 & 199.55 & 47.24 \\
\hline Uranium-234 & $\mathrm{pCi} / \mathrm{gm}$ & 32 & 32 & 5.527 & 114.2 & 26.59 \\
\hline Uranium-235 & $\mathrm{pCi} / \mathrm{gm}$ & 32 & 32 & 0.241 & 4.911 & 1.031 \\
\hline Uranium-236 & $\mathrm{pCi} / \mathrm{gm}$ & 32 & 32 & 0.099 & 3.532 & 0.0603 \\
\hline Uranium-238 & $\mathrm{pCi} / \mathrm{gm}$ & 32 & 32 & 3.913 & 76.91 & 18.9 \\
\hline Xylene & $\mathrm{mg} / \mathrm{kg}$ & 21 & 13 & 0.001 & 0.024 & 0.01 \\
\hline
\end{tabular}





\section{A.7.1 INTRODUCTION}

During planning for the BCV RI, DOE, Energy Systems, and the regulators agreed that a detailed waste analysis, resulting in development of a waste inventory, would be conducted in lieu of sampling in the BCBG. Factors contributing to this decision included:

- existing caps prevented sampling of large areas of the BCBG;

- direct sampling of the wastes could be potentially dangerous because of the presence of pyrophoric materials; and

- collection of representative, statistically valid samples would have required an extensive, costly sampling program (involving millions of samples) because of the tremendous variability of waste materials in the BCBG.

The purpose of developing the waste inventories was to identify the primary waste types, waste quantities, and potential source term quantities of chemicals to support the human health risk assessment and contaminant plume modeling phases of the BCV RI. The inventories provide suspected locations of waste disposals and estimates of waste quantities and should not be interpreted as presenting actual disposal history. Additionally, it should be noted that this inventory may not be complete; data gaps exist from the probability that nonradioactive waste inventory estimates were poorly maintained or never recorded and that other hazardous materials weren't recorded. There were also uncertainties associated with the waste inventory documents (e.g., the volume estimates varied, etc.). Nonetheless, the information presented in this section provides useful estimates for the modeling and human health risk assessment phases of the RI.

As noted in the introduction to Appendix A, classified information is not included in the BCV RI Report or its appendixes. Classified elements and compounds potentially present in the BCBG are addressed in the separate Classified Operable Unit Assessment.

\section{A.7.2 WASTE DISPOSAL RECORDS}

Disposals at the BCBG between the 1950s and 1980 can be categorized according to the following three distinct disposal practices:

- Blanket Disposals (accounting for about two-thirds of the wastes delivered to BCBG). Operating areas in the Y-12 Plant initiated "blanket requests" to the Maintenance Division for routine pickups of their waste. A separate blanket request was required for each type of waste, and each request was valid only for the period of time (months or years) during which that particular type of waste was being generated. About 350 blanket requests have been active at one time or another since the early 1960 s.

- Debris Disposals (accounting for about one-third of the wastes delivered to BCBG). Onetime disposals were made of materials that pose no particular hazard. These materials included cans, bottles, boxes, glass, discarded equipment, and other miscellaneous items that are generated routinely during industrial operations.

- Hazardous Disposals (accounting for a small proportion of the total wastes). Nonroutine disposals of hazardous (e.g., toxic, explosive, reactive) materials were made several times a 
day. UNC-2109 forms (i.e., Request for Hazardous Materials Disposal forms) or UNC-6538 forms (i.e., Request for Classified Materials Disposal forms), which describe the hazards and handling requirements involved in the disposal, as determined by the requester, were submitted to the Maintenance Division with each disposal.

The Y-12 Plant records maintained for these disposals provided a basis for developing a $\mathrm{BCBG}$ waste inventory for use in the BCV RI. These records included:

- Activity Reports - In 1963 the Maintenance Division's Activity Reports began recording the number of blanket disposals made each month. These reports show that about 50,000 blanket disposals were made from 1963-1983.

- Kardex Blanket File - Of the 50,000 blanket disposals recorded on the Activity Reports, about $40,000(80 \%)$ are described on Kardex Blanket File cards. The Kardex Blanket File cards for the remaining $10,000(20 \%)$ blanket disposals have not been located. Although the amounts of waste disposed of via these 10,000 disposals are unknown, the types of wastes are assumed to have been similar to those listed on the existing cards. Only the data provided on the recovered Kardex Blanket files were included in the BCBG waste inventory used for the BCV RI. Because blanket disposals account for about two-thirds of the total BCBG disposals, the available blanket disposal data included in the inventory represent about half (80\% of two-thirds) of the wastes disposed of at the BCBG since 1963.

- Requests for Hazardous/Classified Disposals (forms 2109s/6538s) - Hazardous disposals make up a very small amount of the total material sent to the BCBG (Energy Systems 1993). The great variety of materials found through tabulation of $2109 \mathrm{~s}$ and $6538 \mathrm{~s}$ does not lend itself to a summary inventory such as that presented for blanket disposals. However, the number of 2109s found corresponds closely with the number of individual hazardous disposals mentioned in the Maintenance Division's Activity Reports, so the records presented in this area are essentially complete for the time period covered.

- Nuclear Materials Control and Accountability Waybill Records - These records document the movement of accountable nuclear materials such as uranium. In general, disposals documented in this system are also recorded in the various Maintenance Division records. However, a type of waybill known as a " 741 " allows separate identification of material that was shipped to the Y-12 Plant from other installations for disposal since 1977.

- Waste Management Inventory-Manifest System - In 1983 a classified inventory of waste materials delivered to the BCBG between the 1950s and 1980 was developed (Bailey 1983). A declassified version of the classified inventory was prepared (Energy Systems 1993), and all disposal information was collected in a computerized database known as the Waste Management Inventory-Manifest System.

The BCBG waste inventory developed and used for the $B C B G$ is based on review of (1) 50,000 disposals tabulated from existing records, (2) 15,000 disposals included in the Waste Management Inventory-Manifest System, and (3) hundreds of pages of historical text. Despite the available documentation, the inventory is incomplete: many records were routinely discarded under approved procedures, and many items of information were never recorded. The primary data gaps are: 
- No records have been found detailing the composition of disposals made in the initial trenches of Burial Ground 1. (These trenches later became Burial Ground A, trenches \#1 through \#5.)

- An inventory of materials placed in the B and C areas during the early 1960 s comes from an engineering drawing (E-CV-62373). Data from 1960 to 1964 are not accounted for in any other data source. Data after 1964 probably overlap with other reported information, but the extent of this overlap is impossible to determine.

\section{A.7.3 INVENTORY REVIEW}

The $\mathrm{BCBG}$ have been segmented into seven primary areas for presentation of this inventory review: Area-A, Area-B, Area-C, Area-D, Area-E, Area-J, and WIP. Inventory data are summarized, by area or sub-area, in Tables 1 through 15 . Each table presents the primary waste constituents, estimated inventory mass $(\mathrm{Kg})$, estimated concentration $(\mathrm{mg} / \mathrm{Kg})$, general physical form of the material, assumptions leading to the mass and concentration estimates, and a source reference for the estimates. Brief narratives regarding each area are presented in Sect. A.1.3.5.

Reference documentation used as resource material in compiling this information includes a 10-volume, classified waste inventory summary (up to 1982), computerized waste inventory records (1982 through 1989), personnel interviews, and additional classified and nonclassified records and documents (Energy Systems 1983 through 1988).

Tables A.13 through A.17 provide the inventory estimates and primary constituent concerns for Area A. Areas B, D, E, and J are dominated by uranium disposals, as shown in Tables A.18, A.21, A.22, and A.23. Area $C$ was designed for the disposal of beryllium, enriched uranium, thorium, and technetium contaminated industrial wastes, with inventory estimates presented in Tables A.19 and A.20. The WIP were used for the disposal of a wide variety of laboratory and industrial chemicals, as indicated in Tables A.24 and A.25.

\section{A.7.4 PRIMARY ASSUMPTIONS}

As described in Sect. A.4, a detailed waste inventory analysis was conducted in lieu of sampling in the BCBG. To obtain equivalent concentrations needed for the risk assessment, a number of assumptions about the waste inventory had to be made. The primary assumptions implemented in this review and accumulation of data are itemized in the following subsections.

\section{A.7.4.1 General Assumptions}

- All concentrations have been derived based on the assumption that the quantity of contaminant is distributed equally throughout the trenched area of each location.

- Trench weights have been determined based on the volume of the trench, an assumed soil density of $2.2 \mathrm{~g} / \mathrm{cc}$, and an assumed void volume of $40 \%$ (based on close-pack spherical particles). The assumed weight of uranium was then added to this mass to obtain a total weight for trench material in the area. 
- For those wastes identified through inventory records in gallons, the general assumption has been made that there are $8 \mathrm{lb} / \mathrm{gal}$ and $2.2 \mathrm{lb} / \mathrm{Kg}$. Actual compound densities, when they were considered, are noted.

\section{A.7.4.2 Disposal Area Volume Estimates}

- These estimates are calculated from trench dimensions provided in Appendix B of the RI Work Plan for Bear Creek OU 1 (DOE 1993):

$\begin{array}{lrr}\text { Area A South } & 61,122 \mathrm{yd}^{3} & 1,650,300 \mathrm{ft}^{3} \\ \text { Area A North } & 86,095 \mathrm{yd}^{3} & 2,324,600 \mathrm{ft}^{3} \\ \text { Area A16 } & 44,000 \mathrm{yd}^{3} & 1,188,000 \mathrm{ft}^{3} \\ \text { Area A17 } & 68,000 \mathrm{yd}^{3} & 1,836,000 \mathrm{ft}^{3} \\ \text { Area A18 } & 34,000 \mathrm{yd}^{3} & 918,000 \mathrm{ft}^{3} \\ \text { Area B } & 14,468 \mathrm{yd}^{3} & 390,600 \mathrm{ft}^{3} \\ \text { Area C East } & 11,546 \mathrm{yd}^{3} & 311,700 \mathrm{ft}^{3} \\ \text { Area C West } & 30,100 \mathrm{yd}^{3} & 812,700 \mathrm{ft}^{3} \\ \text { Area D East } & 10,670 \mathrm{yd}^{3} & 288,100 \mathrm{ft}^{3} \\ \text { Area D West } & 1,100 \mathrm{yd}^{3} & 29,700 \mathrm{ft}^{3} \\ \text { Area D South } & 85 \mathrm{yd}^{3} & 2,300 \mathrm{ft}^{3} \\ \text { Area E } & 3,516 \mathrm{yd}^{3} & 94,900 \mathrm{ft}^{3} \\ \text { Area J } & 5,278 \mathrm{yd}^{3} & 142,500 \mathrm{ft}^{3} \\ \text { WIP North } & 21,404 \mathrm{yd}^{3} & 577,900 \mathrm{ft}^{3} \\ \text { WIP South } & 13,692 \mathrm{yd}^{3} & 369,700 \mathrm{ft}^{3}\end{array}$

\section{A.7.4.3 Uranium Assumptions}

- Uranium is assumed to be in the form of $\mathrm{UO}_{2}$, with a density of $10.96 \mathrm{~g} / \mathrm{cc}$ and a percent uranium of 88.15. Other options, not used, are uranium as $\mathrm{U}_{3} \mathrm{O}_{8}$, with a density of $8.30 \mathrm{~g} / \mathrm{cc}$ and a percent uranium of 84.09 , and pure uranium metal with a density of $19.05 \mathrm{~g} / \mathrm{cc}$.

- The Y-12 Kardex Blanket File disposal records were used to estimate the total mass of uranium buried in the entire BCBG. Nineteen of these disposal records, encompassing major bulk uranium types (e.g., chips, saw fines, alloy, parts) over a 17-year period, totaled $26.2 \times 10^{6} \mathrm{lb}$ of uranium materials. This volume is equivalent to $11.9 \times 10^{6} \mathrm{Kg}$ as $\mathrm{UO}_{2}$ or $10.5 \times 10^{6} \mathrm{Kg}$ as uranium. A per-year estimate of $620,000 \mathrm{Kg} / \mathrm{year}$ of uranium, multiplied by a 30-year site history, provides an estimate of $18.6 \times 10^{6} \mathrm{Kg}$ of uranium sent to the BCBG.

- Uranium chips (material varying from fine metallic filings to machine shop turnings and large chunks of metal) went primarily to Areas B, D, and J, when these areas were open.

- Area E received uranium metal parts.

- Areas D-West, $\mathrm{E}$, and $\mathrm{J}$ form a geographically contiguous group of trenches and have been combined to estimate a uranium concentration for that area. Area D-West comprises trenches D-44, $-45,-46$, and -47 . 


\section{A7-7}

- Although Areas C-East and C-West had been designated for thorium and beryllium disposals, a certain amount of depleted uranium-contaminated material and uranium metals were also deposited in these areas according to Kardex Blanket File records and other inventory records, it is assumed some enriched uranium was also deposited in this area as well.

- WIP areas are assumed to contain uranium saw fines. As with any fine particle metallic material, these were and potentially still are, highly combustible and explosive.

- Disposal Areas A-16 through A-18 contain contaminated wastes and debris from more recent year activities (about 1985 through 1991). As a result of increased awareness, recycling, and reuse, the quantities of uranium contained in these materials are assumed to be significantly lower than for other Area A locations.

- Mop water contains $\sim 80$ ppm uranium (Turner et al. 1991).

- Machine coolant/waste oil contains $\sim 40 \mathrm{ppm}$ uranium (Turner et al. 1991).

- The contribution of each burial ground to the total uranium deposited in the BCBG is assumed to be:

\section{Assumed percentage by weight (\%)}

$\begin{array}{lr}\text { Area A South } & 5.0 \\ \text { Area A North } & 5.0 \\ \text { Area A16-A18 } & 0.5 \\ \text { Area B } & 33.0 \\ \text { Area C East, West } & 5.0 \\ \text { Area D East, West, South } & 20.0 \\ \text { Area E } & 6.5 \\ \text { Area J } & 10.0 \\ \text { Walk-In North } & 9.0 \\ \text { Walk-In South } & 6.0\end{array}$

- For risk assessment purposes, a natural uranium isotopic distribution should be assumed for all uranium forms in the BCBG.

\section{A.7.4.4 Thorium Assumptions}

- Most thorium metals and contaminated materials were disposed of in Area C, with a smaller amount being associated with Area B, Area A-North, and WIP North. Before these areas were opened, thorium waste was not knowingly taken to the BCBG.

- Historical release reports indicate $18.4 \mathrm{Ci}$ of thorium was deposited in the BCBG, and the assumption has been made that these disposals are distributed as follows:

Area C-East $\quad 37.5 \%$

Area C-West $57.5 \%$

Area B 
- A one-time thorium sludge disposal of $276 \mathrm{Kg}$ of thorium was made to Area A North.

- WIP North has a recorded inventory estimate for thorium.

- Thorium should be assumed to be ${ }^{232} \mathrm{Th}$, the thorium isotope that is most abundant and has the longest half-life.

\section{A.7.4.5 Technetium Assumptions}

- Most technetium was disposed of in Area C-West (80\%), with the remaining $20 \%$ being associated with Area A-North. Before these areas were opened, technetium waste was not knowingly taken to the BCBG.

- Historical release reports indicate that $10.7 \mathrm{Ci}$ of technetium was deposited in the BCBG, and the assumption has been made that these disposals are distributed according to the above percentages.

- Technetium is assumed to be ${ }^{99} \mathrm{Tc}$.

\section{A.7.4.6 Beryllium Assumptions}

- All beryllium oxide and contaminated debris disposals went to Areas C-East and C-West from 1962 through 1989. Kardex Blanket File records divided beryllium disposals into two categories: beryllium oxide and beryllium-contaminated materials.

- Quantities of solid and scrap beryllium material in three Kardex Blanket File records over a 15-year period of time were totaled and then divided by 15 to obtain an estimated average yearly disposal rate of $1,650 \mathrm{Kg}$ beryllium per year.

- Area $C$ is assumed to have received this material over a 28-year time period, yielding a total beryllium mass of 28 years times $1,650 \mathrm{Kg} /$ year.

- Beryllium-contaminated debris contains $0.05 \%$ beryllium by weight. Quantities of beryllium-contaminated debris in eight Kardex Blanket File records over a 15-year period of time were totaled and then divided by 15 to obtain the estimated average yearly disposal rate of $90 \mathrm{Kg}$ beryllium per year.

- Area $C$ is assumed to have received this material over a 28-year time period, yielding a total beryllium mass of 28 years times $90 \mathrm{Kg} /$ year.

- These two estimates are then added to obtain an estimated $48,700 \mathrm{Kg}$ of beryllium deposited in Area C.

- Mop water contains $\sim 0.04$ ppm beryllium (Turner et al. 1991).

- Machine coolant/waste oil contains $\sim 12 \mathrm{ppm}$ beryllium (Turner et al. 1991). 


\section{A.7.4.7 Lithium Assumptions}

- Lithium disposals are recorded for Areas A and C.

- Estimates from Kardex Blanket File records indicate $12,000 \mathrm{Kg}$ of lithium disposed of in Area C.

- Exact lithium compound composition can not be determined; however, most of the compound types disposed of can be assumed to have oxidized and hydrolyzed. Therefore, the lithium is assumed to be in the form of $\mathrm{LiOH}$.

- Mop water contains $\sim 2$ ppm lithium (Turner et al. 1991).

- Machine coolant/waste oil contains $\sim 4.5$ ppm lithium (Turner et al. 1991).

\section{A.7.4.8 Asbestos Assumptions}

- Asbestos was not recognized as a hazardous substance until the mid-1970s. Therefore, its disposal before that time was not documented or quantitated and cannot be determined.

- Based on Kardex Blanket File records, $20,000 \mathrm{Kg} /$ year of asbestos is assumed to have been taken to Area A-North between 1977 and 1990 (13 years).

- The location in Area A-North designated as the Asbestos Area has been assumed to include A-8E pit \#s 22 through 27, A-9E pit \#s 28 through 33, and A-10E pit \#s 17 through 21. The estimated volume of these pits is $95,100 \mathrm{ft}^{3}$.

\section{A.7.4.9 PCB Assumptions}

- $\quad$ Recorded disposals and removals for Area BG-A are summarized in Table A.26.

- Unless specified in the disposal records (Bailey 1995), PCB disposals to Area A were assumed to be divided equally between Areas A-South and A-North.

- Recorded oil removals from BG-A were considered in calculating the PCB at the site. Because PCBs sorb well to soil particulates, $85 \%$ of any unit volume of PCBs is assumed to have remained, only $15 \%$ being present in the removed liquids.

- Volumes of waste oils/coolants disposed of in Area A were adjusted to reflect that PCB-containing oils burned during the 1950 s and until 1968 or 1969 . About $25 \%$ of the volume of waste oils and coolants described in the chemical inventory tables is assumed to have been disposed of by burning. This value represents the assumption that $50 \%$ of the oils/coolants burned from 1958 through 1968 remained (and that $50 \%$ of the original PCB remained as well).

- Many potential sources and disposals of PCB-containing wastes were never documented. Therefore, estimates for PCBs are considered minimum contents. Records of Z-oil system disposals could not be identified to estimate this source of PCB disposal. Significant amounts of PCB-containing liquids may have been disposed of in the $\mathrm{BCBG}$, which are unaccounted for in this report. 
- $\quad$ Pyranol (trade name for PCB oil) transformer oil contains 50\% PCBs.

- All Therminol (trade name for PCB oil) disposals were considered to be disposals of Therminol-FR-0.

- The following densities were assumed for all PCB estimations:

Aroclor-1242

non-PCB component of transformer oil

non-PCB component of Therminol

non-PCB component of other oils

$$
\begin{aligned}
& \text { density }=1.41 \mathrm{~g} / \mathrm{cc} \\
& \text { density }=1.2 \mathrm{~g} / \mathrm{cc} \\
& \text { density }=0.82 \mathrm{~g} / \mathrm{cc} \\
& \text { density }=1.2 \mathrm{~g} / \mathrm{cc}
\end{aligned}
$$

\section{A.7.4.10 Mop Water Assumptions}

- Equal distribution of mop water disposal between Areas A-South and A-North is assumed.

- Disposal of an estimated 600,000 gal/year is assumed, based on records between 1971 through 1978. Records were not kept for previous years.

- The same quantity is assumed for all years up to 1979 , when liquid disposal ended (20 years).

\section{A.7.5 TOTAL URANIUM ESTIMATE COMPARISONS}

A comparison to disposal estimates acquired and reported under the SWIMS (Mynatt 1991) program provides a level of confidence to the order of magnitude estimated through this review. Table A.27 and Fig. A.9 present the total uranium estimated by this review $\left(18.6 \times 10^{6} \mathrm{Kg}\right.$ as uranium) and compare that total to a 1989 historical release report total $\left(17.3 \times 10^{6} \mathrm{Kg}\right)$ (DOE 1988). 
A8-1

A8. SUPPORTING INFORMATION FOR APPENDIX A-TABLES 
. 
A8-3

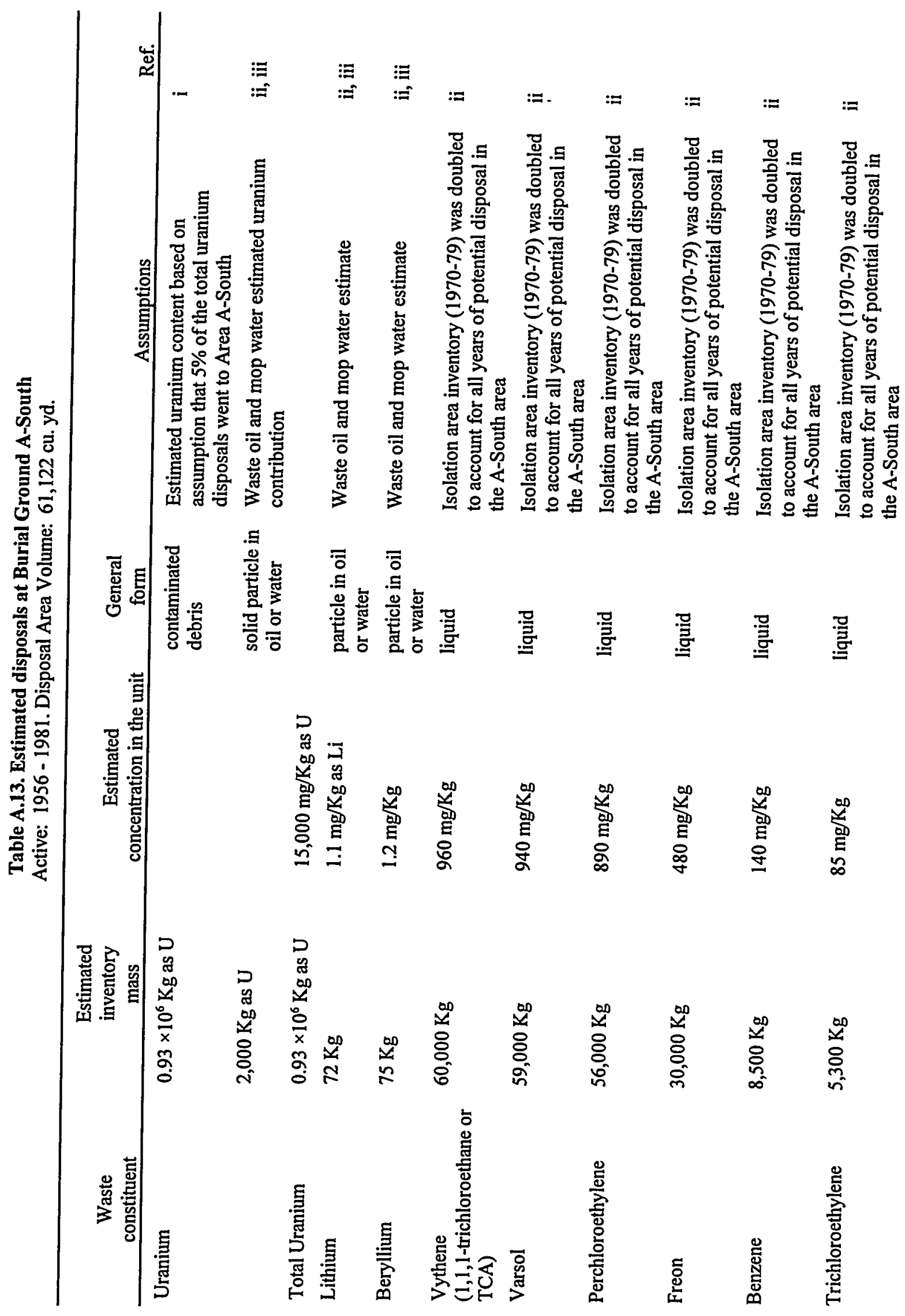


Table A.13 (continued)

\begin{tabular}{|c|c|c|c|c|c|}
\hline $\begin{array}{c}\text { Waste } \\
\text { constituent }\end{array}$ & $\begin{array}{c}\text { Estimated } \\
\text { inventory } \\
\text { mass }\end{array}$ & $\begin{array}{l}\text { Estimated } \\
\text { concentration in the unit }\end{array}$ & $\begin{array}{l}\text { General } \\
\text { form }\end{array}$ & Assumptions & Ref. \\
\hline Methyl ethyl ketone & $3,900 \mathrm{Kg}$ & $62 \mathrm{mg} / \mathrm{Kg}$ & liquid & $\begin{array}{l}\text { Isolation area inventory (1970-79) was doubled } \\
\text { to account for all years of potential disposal in } \\
\text { the A-South area }\end{array}$ & ii \\
\hline Alcohol $^{a}$ & $24,000 \mathrm{Kg}$ & $380 \mathrm{mg} / \mathrm{Kg}$ & liquid & $\begin{array}{l}\text { Isolation area inventory }(1970-79) \text { was doubled } \\
\text { to account for all years of potential disposal in } \\
\text { the A-South area }\end{array}$ & ii \\
\hline Fuel-water ${ }^{b}$ & $57,000 \mathrm{Kg}$ & & liquid & $\begin{array}{l}\text { Isolation area inventory }(1970-79) \text { was doubled } \\
\text { to account for all years of potential disposal in } \\
\text { the A-South area }\end{array}$ & ii \\
\hline PCBs & $1,400 \mathrm{Kg}$ & $21 \mathrm{mg} / \mathrm{Kg}$ & liquid & $\begin{array}{l}\text { Estimate based on recorded inventory } \\
\text { information }\end{array}$ & $\mathrm{iv}, \mathrm{v}$ \\
\hline \multicolumn{6}{|l|}{ Asbestos $^{c}$} \\
\hline Waste oils and coolants ${ }^{d}$ & $1,700,000 \mathrm{gal}$ & & liquid & $\begin{array}{l}\text { Estimate based on inventory from 1969-79 } \\
\text { doubled to cover 1958-79 }\end{array}$ & ii \\
\hline Mop waters & $6,000,000 \mathrm{gal}$ & & liquid & $\begin{array}{l}\text { Estimate } 600,000 \mathrm{gal} / \mathrm{yr} \text { disposal from } 59-79 \text {. } \\
\text { Assume equal distribution of mop water } \\
\text { disposal between A-South and A-North }\end{array}$ & ii \\
\hline
\end{tabular}

a Assume this to be methanol.

$b$ Assume a gasoline/water mixture, with primary contaminants of Benzene, Toluene, Ethylbenzene, Xylene.

c Asbestos was not recognized as a hazardous substance until the mid-1970s, therefore, its disposal prior to that time was not documented or quantitated and cannot be determined.

d These comprise system coolant oils and liquids, machine oils, vehicle oils, etc. - on the entire spectrum of industrial oil and coolant materials that may have been employed at the plant.

Sources:

i. Energy Systems 1996.

ii. Battelle 1994.

iii. Tumer et al 1991.

iv. Bailey 1995.

v. Mappes 1995. 
Table A.14. Estimated disposals at Burial Ground A-North

Active: 1969 - 1981. Disposal Area Volume: 86,095 cu. yd.

\begin{tabular}{|c|c|c|c|c|c|}
\hline $\begin{array}{c}\text { Waste } \\
\text { constituent }\end{array}$ & $\begin{array}{c}\text { Estimated } \\
\text { inventory } \\
\text { mass }\end{array}$ & $\begin{array}{c}\text { Estimated } \\
\text { concentration in the unit }\end{array}$ & $\begin{array}{c}\text { General } \\
\text { form }\end{array}$ & Assumptions & Ref. \\
\hline \multirow[t]{2}{*}{ Uranium } & $0.93 \times 10^{6} \mathrm{Kg}$ as $\mathrm{U}$ & & $\begin{array}{l}\text { contaminated } \\
\text { debris }\end{array}$ & $\begin{array}{l}\text { Estimated uranium content based on } \\
\text { assumption that } 5 \% \text { of the total uranium } \\
\text { disposals went to Area A-North }\end{array}$ & $\mathbf{i}$ \\
\hline & $1,800 \mathrm{Kg}$ as $\mathrm{U}$ & & $\begin{array}{l}\text { solid particle in } \\
\text { oil or water }\end{array}$ & $\begin{array}{l}\text { Waste oil and mop water estimated uranium } \\
\text { contribution }\end{array}$ & ii, iii \\
\hline Total Uranium & $0.93 \times 10^{6} \mathrm{Kg}$ as $\mathrm{U}$ & $11,000 \mathrm{mg} / \mathrm{Kg}$ as $\mathrm{U}$ & & & \\
\hline Lithium & $53 \mathrm{Kg}$ as $\mathrm{Li}$ & $0.6 \mathrm{mg} / \mathrm{Kg}$ as $\mathrm{Li}$ & $\begin{array}{l}\text { solid particle in } \\
\text { oil or water }\end{array}$ & Waste oil and mop water estimate & ii, iii \\
\hline Thorium & $280 \mathrm{Kg}$ as Th & $3.1 \mathrm{mg} / \mathrm{Kg}$ as $\mathrm{Th}$ & sludge material & One time large volume sludge disposal & $\mathbf{i}$ \\
\hline Beryllium & $27 \mathrm{Kg}$ as $\mathrm{Be}$ & $0.3 \mathrm{mg} / \mathrm{Kg}$ as $\mathrm{Be}$ & $\begin{array}{l}\text { solid particle in } \\
\text { oil or water }\end{array}$ & Waste oil and mop water estimate & $\mathrm{ii}, \mathrm{iii}$ \\
\hline Technetium & $0.13 \mathrm{Kg}$ & $0.0014 \mathrm{mg} / \mathrm{Kg}$ & & Estimate based on total Tc-99 of $10.7 \mathrm{Ci}$ & iv, i \\
\hline Asbestos & $260,000 \mathrm{Kg}$ & $73,000 \mathrm{mg} / \mathrm{Kg}$ & debris & $\begin{array}{l}\text { Kardex blanket estimate of } 20,000 \mathrm{Kg} / \mathrm{yr} \text { from } \\
1977-90 \text {. Asbestos disposal area of } 95,100 \mathrm{ft}^{3} \\
\text { assumed }\end{array}$ & $v$ \\
\hline PCBs & $110,000 \mathrm{Kg}$ & $1,300 \mathrm{mg} / \mathrm{Kg}$ & liquid & $\begin{array}{l}\text { Estimate based on recorded inventory } \\
\text { information }\end{array}$ & vi, vii \\
\hline Waste oils and coolants ${ }^{a}$ & $590,000 \mathrm{gal}$ & & liquid & Estimate based on inventory from 1971-79 & ii \\
\hline Mop waters & $6,000,000 \mathrm{gal}$ & & liquid & $\begin{array}{l}\text { Assume equal distribution of mop waters } \\
\text { between A-North and A-South }\end{array}$ & ii \\
\hline
\end{tabular}

a These comprise system coolant oils and liquids, machine oils, vehicle oils, etc. and represent the entire spectrum of industrial oil and coolant materials that may have been employed at the plant.

Sources:

i. Energy Systems 1996.

ii. Battelle 1994.

iii. Turner et al. 1991.

iv. DOE 1988.

v. Bailey 1983.

vi. Bailey 1995.

vii. Mappes 1995. 
Table A.15. Estimated disposals at Burial Ground A-16

Active: 1983 - 1987. Disposal Area Volume: $44,000 \mathrm{yd}^{3}$

\begin{tabular}{ccccc}
$\begin{array}{c}\text { Waste } \\
\text { constituent }\end{array}$ & $\begin{array}{c}\text { Estimated } \\
\text { inventory } \\
\text { mass }\end{array}$ & $\begin{array}{c}\text { Estimated } \\
\text { concentration in the unit }\end{array}$ & $\begin{array}{c}\text { General } \\
\text { form }\end{array}$ & Assumptions \\
\hline Uranium & $27,000 \mathrm{Kg}$ as $\mathrm{U}$ & $610 \mathrm{mg} / \mathrm{Kg}$ as $\mathrm{U}$ & $\begin{array}{l}\text { contaminated } \\
\text { debris }\end{array}$ & $\begin{array}{l}\text { Estimated uranium content based on } \\
\text { assumption that } 0.5 \% \text { of the total uranium } \\
\text { disposals went to Areas A16-A 18 }\end{array}$ \\
\hline
\end{tabular}

Table A.16. Estimated disposals at Burial Ground A-17

Active: 1983 - 1987. Disposal Area Volume: $68,000 \mathrm{yd}^{3}$

\begin{tabular}{lcccc}
\hline $\begin{array}{c}\text { Waste } \\
\text { constituent }\end{array}$ & $\begin{array}{c}\text { Estimated } \\
\text { inventory } \\
\text { mass }\end{array}$ & $\begin{array}{c}\text { Estimated } \\
\text { concentration in the unit }\end{array}$ & $\begin{array}{c}\text { General } \\
\text { form }\end{array}$ & Assumptions \\
\hline Uranium & $42,000 \mathrm{Kg}$ as $\mathrm{U}$ & $610 \mathrm{mg} / \mathrm{Kg}$ as $\mathrm{U}$ & $\begin{array}{l}\text { contaminated } \\
\text { debris }\end{array}$ & $\begin{array}{l}\text { Estimated uranium content based on } \\
\text { assumption that } 0.5 \% \text { of the total uranium } \\
\text { disposals went to Area A16-A18 }\end{array}$ \\
\hline
\end{tabular}

Table A.17. Estimated disposals at Burial Ground A-18

Active: 1988 - 1991. Disposal Area Volume: $34,000 \mathrm{yd}^{3}$

\begin{tabular}{llcll}
\hline $\begin{array}{c}\text { Waste } \\
\text { constituent }\end{array}$ & $\begin{array}{c}\text { Estimated } \\
\text { inventory } \\
\text { mass }\end{array}$ & $\begin{array}{c}\text { Estimated } \\
\text { concentration in the unit }\end{array}$ & $\begin{array}{c}\text { General } \\
\text { form }\end{array}$ & Assumptions \\
\hline Uranium & $21,000 \mathrm{Kg}$ as U & $610 \mathrm{mg} / \mathrm{Kg}$ as U & $\begin{array}{l}\text { contaminated } \\
\text { debris }\end{array}$ & $\begin{array}{l}\text { Estimated uranium content based on } \\
\text { assumption that } 0.5 \% \text { of the total uranium } \\
\text { disposals went to Area A16-A18 }\end{array}$ \\
\hline
\end{tabular}

Source:

i. Energy Systems 1996. 
Table A.18. Estimated disposals at Burial Ground B

Active: 1962 - 1968. Disposal Area Volume: $14,468 \mathrm{yd}^{3}$

\begin{tabular}{|c|c|c|c|c|c|}
\hline $\begin{array}{c}\text { Waste } \\
\text { constituent }\end{array}$ & $\begin{array}{l}\text { Estimated } \\
\text { inventory } \\
\text { mass }\end{array}$ & $\begin{array}{c}\text { Estimated } \\
\text { concentration in the unit }\end{array}$ & $\begin{array}{l}\text { General } \\
\text { form }\end{array}$ & Assumptions & Ref. \\
\hline Total Uranium & $6.14 \times 10^{6} \mathrm{Kg}$ as U & $300,000 \mathrm{mg} / \mathrm{Kg}$ as $\mathrm{U}$ & metallic chips & $\begin{array}{l}\text { Estimated uranium content based on } \\
\text { assumption that } 33.0 \% \text { of the total uranium . } \\
\text { disposals went to Area B }\end{array}$ & i \\
\hline Thorium & $0.84 \times 10^{4} \mathrm{Kg}$ & $410 \mathrm{mg} / \mathrm{Kg}$ as $\mathrm{Th}$ & saw fines & $\begin{array}{l}\text { Estimated based on assumption that } 5.0 \% \text { of a } \\
\text { total } 18.4 \mathrm{Ci} \text { of thorium was equally distributed } \\
\text { in Area } \mathrm{B}\end{array}$ & $\mathrm{ii}, \mathrm{i}$ \\
\hline $\mathrm{PCB}^{a}$ & & & & & \\
\hline
\end{tabular}

a Existing disposal records are inadequate to provide relevant quantities and concentrations for this area of the Burial Grounds. It is recommended available groundwater and surface water analysis be employed to develop risk assessment estimates for PCB contamination.

Sources:

i. Energy Systems 1996.

ii. DOE 1988. 
Table A.19. Estimated disposals at Burial Ground C-East

Active: 1962 - 1989. Disposal Area Volume: East $=11,546 \mathrm{yd}^{3}$; West $=30,100 \mathrm{yd}^{3} ;$ Total $=41,646 \mathrm{yd}^{3}$

\begin{tabular}{|c|c|c|c|c|c|}
\hline $\begin{array}{c}\text { Waste } \\
\text { constituent }\end{array}$ & $\begin{array}{c}\text { Estimated } \\
\text { inventory } \\
\text { mass } \\
\end{array}$ & $\begin{array}{l}\text { Estimated } \\
\text { concentration in the unit }\end{array}$ & $\begin{array}{c}\text { General } \\
\text { form }\end{array}$ & Assumptions & Ref. \\
\hline Uranium & $0.25 \times 10^{6} \mathrm{Kg}$ as U & $21,000 \mathrm{mg} / \mathrm{Kg}$ as $\mathrm{U}$ & $\begin{array}{l}\text { debris and } \\
\text { chips }\end{array}$ & $\begin{array}{l}\text { Estimated uranium content based on } \\
\text { assumption that } 5.0 \% \text { of the total uranium } \\
\text { disposals went to Area } C^{a}\end{array}$ & $\mathrm{i}$ \\
\hline \multicolumn{6}{|l|}{ Asbestos $^{b}$} \\
\hline Lithium & $3,400 \mathrm{Kg}$ as $\mathrm{Li}$ & $280 \mathrm{mg} / \mathrm{Kg}$ as $\mathrm{Li}$ & compounds & Estimate from Y/DS-171, Parts $4 \& 5$ & i \\
\hline \multirow[t]{2}{*}{ Beryllium } & $13,000 \mathrm{Kg}$ as $\mathrm{Be}$ & & $\begin{array}{l}\text { metallic } \\
\text { materials } \\
\text { (chips) }\end{array}$ & $\begin{array}{l}\text { Kardex blanket estimate of } 1,650 \mathrm{Kg} / \text { year } \\
\text { estimated for } 28 \text { years. }\end{array}$ & i \\
\hline & $700 \mathrm{Kg}$ as $\mathrm{Be}$ & & $\begin{array}{l}\text { contam. } \\
\text { material }\end{array}$ & $\begin{array}{l}\text { Kardex blanket estimate of } 90 \mathrm{Kg} / \text { year } \\
\text { assuming material contamination of } 0.05 \% \mathrm{Be} \text {. }\end{array}$ & i \\
\hline Total Beryllium & $14,000 \mathrm{Kg}$ as $\mathrm{Be}$ & $1,100 \mathrm{mg} / \mathrm{Kg}$ as $\mathrm{Be}$ & & & \\
\hline Thorium & $6.33 \times 10^{4} \mathrm{Kg}$ & $5,300 \mathrm{mg} / \mathrm{Kg}$ as $\mathrm{Th}$ & chips & $\begin{array}{l}\text { Estimated based on assumption that } 37.5 \% \text { of a } \\
\text { total } 18.4 \mathrm{Ci} \text { of thorium was equally distributed } \\
\text { in Area } \mathrm{C} \text {-East }\end{array}$ & ii, iii \\
\hline
\end{tabular}

a A volume proportional distribution has been assumed between sections east and west.

$b$ Asbestos was not recognized as a hazardous substance until the mid-1970s, therefore, its disposal prior to that time was not documented or quantitated and cannot be determined. Sources:

i. Bailey 1983.

ii. DOE 1988.

iii. Energy Systems 1996. 
Table A.20. Estimated disposals at Burial Ground C-West

Active: 1962 - 1989. Disposal Area Volume: East $=11,546 \mathrm{yd}^{3} ;$ West $=30,100 \mathrm{yd}^{3} ;$ Total $=41,646 \mathrm{yd}^{3}$

\begin{tabular}{|c|c|c|c|c|c|}
\hline $\begin{array}{c}\text { Waste } \\
\text { constituent }\end{array}$ & $\begin{array}{c}\text { Estimated } \\
\text { inventory } \\
\text { mass }\end{array}$ & $\begin{array}{l}\text { Estimated } \\
\text { concentration in the unit }\end{array}$ & $\begin{array}{c}\text { General } \\
\text { form }\end{array}$ & Assumptions & Ref. \\
\hline Uranium & $0.68 \times 10^{6} \mathrm{Kg}$ as $\mathrm{U}$ & $22,000 \mathrm{mg} / \mathrm{Kg}$ as $\mathrm{U}$ & $\begin{array}{l}\text { debris and } \\
\text { chips }\end{array}$ & $\begin{array}{l}\text { Estimated uranium content based on } \\
\text { assumption that } 5.0 \% \text { of the total uranium } \\
\text { disposals went to Area } C^{a}\end{array}$ & $\mathrm{i}$ \\
\hline \multicolumn{6}{|l|}{ Asbestos $^{b}$} \\
\hline Lithium & $8,600 \mathrm{Kg}$ as $\mathrm{Li}$ & $280 \mathrm{mg} / \mathrm{Kg}$ as $\mathrm{Li}$ & compounds & Estimate from Y/DS-171, Parts $4 \& 5$. & $i$ \\
\hline Thorium & $9.71 \times 10^{4} \mathrm{Kg}$ as $\mathrm{Th}$ & $3,100 \mathrm{mg} / \mathrm{Kg}$ as $\mathrm{Th}$ & $\begin{array}{l}\text { contam. debris } \\
\text { and solid } \\
\text { material } \\
\text { (chips) }\end{array}$ & $\begin{array}{l}\text { Estimated based on assumption that } 57.5 \% \text { of a } \\
\text { total } 18.4 \mathrm{Ci} \text { of thorium was equally distributed } \\
\text { in Area } \mathrm{C} \text {-West }\end{array}$ & ii, iii \\
\hline \multirow[t]{2}{*}{ Beryllium } & $33,000 \mathrm{Kg}$ as $\mathrm{Be}$ & & $\begin{array}{l}\text { metallic } \\
\text { materials } \\
\text { (chips) }\end{array}$ & $\begin{array}{l}\text { Kardex blanket estimate of } 1,650 \mathrm{Kg} / \text { year } \\
\text { estimated for } 28 \text { years. }\end{array}$ & $\mathrm{i}$ \\
\hline & $1,800 \mathrm{Kg}$ as $\mathrm{Be}$ & & $\begin{array}{l}\text { contam. } \\
\text { material }\end{array}$ & $\begin{array}{l}\text { Kardex blanket estimate of } 90 \mathrm{Kg} / \mathrm{year} \\
\text { assuming material contamination of } 0.05 \% \mathrm{Be} \text {. }\end{array}$ & $\mathbf{i}$ \\
\hline Total Beryllium & $35,000 \mathrm{Kg}$ as $\mathrm{Be}$ & $1,100 \mathrm{mg} / \mathrm{Kg}$ as $\mathrm{Be}$ & & & \\
\hline Technetium & $0.50 \mathrm{Kg}$ & $0.016 \mathrm{mg} / \mathrm{Kg}$ & & $\begin{array}{l}\text { Estimated based on assumption that } 80 \% \text { of a } \\
\text { total } 10.7 \mathrm{Ci} \text { of technetium was equally } \\
\text { distributed in Area C-West }\end{array}$ & $\mathrm{ii}, \mathrm{iii}$ \\
\hline
\end{tabular}

a A volume proportional distribution has been assumed between sections east and west.

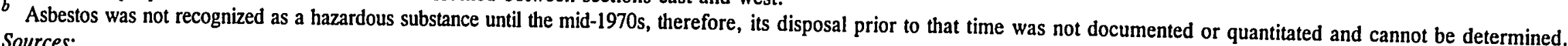

i. Bailey 1983.

ii. DOE 1988.

iii. Energy Systems 1996. 
Table A.21. Estimated disposals at Burial Ground D-East

Active: $1968-1989$. Disposal Area Volume: $10,670 \mathrm{yd}^{3}$

\begin{tabular}{|c|c|c|c|c|c|}
\hline $\begin{array}{c}\text { Waste } \\
\text { constituent }\end{array}$ & $\begin{array}{c}\text { Estimated } \\
\text { inventory } \\
\text { mass }\end{array}$ & $\begin{array}{c}\text { Estimated } \\
\text { concentration in the unit }\end{array}$ & $\begin{array}{l}\text { General } \\
\text { form }\end{array}$ & Assumptions & Ref. \\
\hline Total Uranium & $3.35 \times 10^{6} \mathrm{Kg}$ as U & $240,000 \mathrm{mg} / \mathrm{Kg}$ as U & metallic chips & Uranium estimates $^{a}$ & $\mathrm{i}$ \\
\hline \multicolumn{6}{|c|}{$\begin{array}{l}\text { Table A.22. Estimated disposals at Burial Ground D-South } \\
\text { Active: } 1988-1990 \text {. Disposal Area Volume: } 85 \mathrm{yd}^{3}\end{array}$} \\
\hline $\begin{array}{c}\text { Waste } \\
\text { constituent }\end{array}$ & $\begin{array}{c}\text { Estimated } \\
\text { inventory } \\
\text { mass } \\
\end{array}$ & $\begin{array}{l}\text { Estimated } \\
\text { concentration in the unit }\end{array}$ & $\begin{array}{l}\text { General } \\
\text { form }\end{array}$ & Assumptions & Ref. \\
\hline Total Uranium & $0.03 \times 10^{6} \mathrm{Kg}$ as U & $240,000 \mathrm{mg} / \mathrm{Kg}$ as $\mathrm{U}$ & metallic chips & Uranium estimates $^{a}$ & $\mathrm{i}$ \\
\hline
\end{tabular}

Table A.23. Estimated disposals at Burial Grounds D-West, E, and $\mathbf{J}$

Active: 1983 - 1990. Disposal Area Volume: "D-West" =1,100 $\mathrm{yd}^{3} ; " \mathrm{E} "=3,516 \mathrm{yd}^{3} ; " \mathrm{~J} "=5,278 \mathrm{yd}^{3}$

\begin{tabular}{|c|c|c|c|c|c|}
\hline $\begin{array}{c}\text { Waste } \\
\text { constituent }\end{array}$ & $\begin{array}{c}\text { Estimated } \\
\text { inventory } \\
\text { mass }\end{array}$ & $\begin{array}{c}\text { Estimated } \\
\text { concentration in the unit }\end{array}$ & $\begin{array}{c}\text { General } \\
\text { form }\end{array}$ & Assumptions & Ref. \\
\hline Uranium Area D-West & $0.35 \times 10^{6} \mathrm{Kg}$ as U & & metallic chips & Uranium estimates $^{a}$ & $\mathrm{i}$ \\
\hline Uranium Area E & $1.21 \times 10^{6} \mathrm{Kg}$ as U & & metallic blocks & $\begin{array}{l}\text { Estimated uranium content based on } \\
\text { assumption that } 6.5 \% \text { of the total uranium } \\
\text { disposals went to Area } E\end{array}$ & $\mathrm{i}$ \\
\hline Uranium Area J & $1.86 \times 10^{6} \mathrm{Kg}$ as U & & metallic chips & $\begin{array}{l}\text { Estimated uranium content based on } \\
\text { assumption that } 10.0 \% \text { of the total uranium } \\
\text { disposals went to Area J }\end{array}$ & $\mathrm{i}$ \\
\hline Total Uranium & $3.34 \times 10^{6} \mathrm{Kg}$ as U & $260,000 \mathrm{mg} / \mathrm{Kg}$ as $\mathrm{U}$ & & $\begin{array}{l}\text { Areas are geographically contiguous and have } \\
\text { been considered as one unit }\end{array}$ & $\mathrm{i}$ \\
\hline
\end{tabular}

a Estimated uranium content based on assumption that $20.0 \%$ of the total uranium disposals went to Area D and Area D disposals were proportionally distributed between east, west, and south by volume.

Source:

i. Energy Systems 1996. 
Table A.24. Estimated disposals at Burial Ground Walk-In Pit 1 (North)

Active: 1966 - 1989. Disposal Area Volume: $21,404 \mathrm{yd}^{3}$

\begin{tabular}{|c|c|c|c|c|c|}
\hline $\begin{array}{c}\text { Waste } \\
\text { constituent }\end{array}$ & $\begin{array}{c}\text { Estimated } \\
\text { inventory } \\
\text { mass }\end{array}$ & $\begin{array}{c}\text { Estimated } \\
\text { concentration in the unit }\end{array}$ & $\begin{array}{c}\text { General } \\
\text { form }\end{array}$ & Assumptions & Ref. \\
\hline Total Uranium & $1.67 \times 10^{6} \mathrm{Kg}$ & $72,000 \mathrm{mg} / \mathrm{Kg}$ as $\mathrm{U}$ & metallic fines & $\begin{array}{l}\text { Estimated uranium content based on } \\
\text { assumption that } 9.0 \% \text { of the total uranium } \\
\text { disposals went to WIP North }\end{array}$ & $\mathbf{i}$ \\
\hline Acetic acid & $14 \mathrm{Kg}$ & $0.6 \mathrm{mg} / \mathrm{Kg}$ & liquid & Inventory accounting & ii \\
\hline Acetone $^{a}$ & & & & & $\mathbf{i}$ \\
\hline Alcohols $^{b}$ & & & & & $\mathbf{i}$ \\
\hline Alizarin & $0.03 \mathrm{Kg}$ & $0.001 \mathrm{mg} / \mathrm{Kg}$ & solid & Inventory accounting & $\mathbf{i}$ \\
\hline Aluminum & $7 \mathrm{Kg}$ & $0.3 \mathrm{mg} / \mathrm{Kg}$ & solid & Inventory accounting & $\mathfrak{i}$ \\
\hline $\begin{array}{l}\text { Ammonia } \\
\text { compounds }^{c}\end{array}$ & $11 \mathrm{Kg}$ & $0.5 \mathrm{mg} / \mathrm{Kg}$ & solid & Inventory accounting & $\mathrm{i}$ \\
\hline Arsenic & $0.1 \mathrm{Kg}$ & $.004 \mathrm{mg} / \mathrm{Kg}$ & solid & Inventory accounting & $\mathrm{i}$ \\
\hline Asbestos $^{d}$ & & & & & $\mathrm{i}$ \\
\hline Benzene & $3,000 \mathrm{Kg}$ & $130 \mathrm{mg} / \mathrm{Kg}$ & liquid & Inventory accounting & $\mathrm{i}$ \\
\hline Benzidine & $730 \mathrm{Kg}$ & $31 \mathrm{mg} / \mathrm{Kg}$ & liquid & Inventory accounting & $\mathbf{i}$ \\
\hline Beryllium & $610 \mathrm{Kg}$ & $26 \mathrm{mg} / \mathrm{Kg}$ & solid & Inventory accounting & $\mathbf{i}$ \\
\hline Bromine & $23 \mathrm{Kg}$ & $1.0 \mathrm{mg} / \mathrm{Kg}$ & liquid & Inventory accounting & $\mathrm{i}$ \\
\hline $\begin{array}{l}\text { Carbon } \\
\text { tetrachloride }\end{array}$ & & & & & $\mathrm{i}$ \\
\hline Chloroform & $0.25 \mathrm{Kg}$ & $0.01 \mathrm{mg} / \mathrm{Kg}$ & liquid & Inventory accounting & $\mathrm{i}$ \\
\hline Chromium compounds $^{e}$ & $100 \mathrm{Kg}$ as $\mathrm{Cr}$ & $4.4 \mathrm{mg} / \mathrm{Kg}$ & liquid & Inventory accounting & $\mathbf{i}$ \\
\hline Cyanide & $0.48 \mathrm{Kg}$ & $0.02 \mathrm{mg} / \mathrm{Kg}$ & liquid & Inventory accounting & $\mathrm{i}$ \\
\hline Cyclohexane $^{a}$ & & & & & i \\
\hline
\end{tabular}


Table A.24 (continued)

\begin{tabular}{|c|c|c|c|c|c|}
\hline $\begin{array}{c}\text { Waste } \\
\text { constituent }\end{array}$ & $\begin{array}{c}\text { Estimated } \\
\text { inventory } \\
\text { mass }\end{array}$ & $\begin{array}{c}\text { Estimated } \\
\text { concentration in the unit }\end{array}$ & $\begin{array}{c}\text { General } \\
\text { form }\end{array}$ & Assumptions & Ref. \\
\hline DDT & $110 \mathrm{Kg}$ & $4.9 \mathrm{mg} / \mathrm{Kg}$ & liquid & Inventory accounting & $\mathrm{i}$ \\
\hline Epoxys $^{f}$ & $2,200 \mathrm{Kg}$ & $95 \mathrm{mg} / \mathrm{Kg}$ & liquid & Inventory accounting & $\mathrm{i}$ \\
\hline Ether ${ }^{g}$ & $14 \mathrm{Kg}$ & $0.6 \mathrm{mg} / \mathrm{Kg}$ & liquid & Inventory accounting & $\mathrm{i}$ \\
\hline Ethyl alcohol & $2.6 \mathrm{Kg}$ & $0.1 \mathrm{mg} / \mathrm{Kg}$ & liquid & Inventory accounting & $\mathrm{i}$ \\
\hline Formaldehyde & $10 \mathrm{Kg}$ & $0.4 \mathrm{mg} / \mathrm{Kg}$ & liquid & Inventory accounting & $\mathrm{i}$ \\
\hline Hydrazine & $2.2 \mathrm{Kg}$ & $0.09 \mathrm{mg} / \mathrm{Kg}$ & liquid & Inventory accounting & $\mathbf{i}$ \\
\hline Lead & $140 \mathrm{Kg}$ & $6.0 \mathrm{mg} / \mathrm{Kg}$ & solid & Inventory accounting & $\mathbf{i}$ \\
\hline $\begin{array}{l}\text { Lithium } \\
\text { compounds }\end{array}$ & $68 \mathrm{Kg}$ & $2.9 \mathrm{mg} / \mathrm{Kg}$ & solid & Inventory accounting & $\mathrm{i}$ \\
\hline Mercuric chloride & $400 \mathrm{Kg}$ & $17 \mathrm{mg} / \mathrm{Kg}$ & solid & Inventory accounting & $\mathrm{i}$ \\
\hline $\mathrm{MEK}^{a}$ & & & & & $\mathrm{i}$ \\
\hline $\mathrm{MIBK}^{a}$ & & & & & $\mathrm{i}$ \\
\hline Nickel & $120 \mathrm{Kg}$ & $5.2 \mathrm{mg} / \mathrm{Kg}$ & solid & Inventory accounting & $\mathrm{i}$ \\
\hline Phenol & $1,100 \mathrm{Kg}$ & $47 \mathrm{mg} / \mathrm{Kg}$ & liquid & Inventory accounting & $\mathrm{i}$ \\
\hline Picric acid' & & & & & $\mathrm{i}$ \\
\hline PCBs & $40 \mathrm{Kg}$ & $1.7 \mathrm{mg} / \mathrm{Kg}$ & liquid & Inventory accounting with estimations & iii, iv \\
\hline Thorium & $14,000 \mathrm{Kg}$ & $580 \mathrm{mg} / \mathrm{Kg}$ & saw fines & Inventory accounting & $\mathrm{i}$ \\
\hline Toluene $^{a}$ & & & & & $\mathrm{i}$ \\
\hline Trichloroethane & $180 \mathrm{Kg}$ & $7.7 \mathrm{mg} / \mathrm{Kg}$ & liquid & Inventory accounting & $\mathrm{i}$ \\
\hline Waste oils & $1,800 \mathrm{Kg}$ & $77 \mathrm{mg} / \mathrm{Kg}$ & liquid & Inventory accounting & $\mathrm{i}$ \\
\hline Xylene $^{a}$ & & & & & $\mathrm{i}$ \\
\hline
\end{tabular}




\section{Table A.24 (continued)}

a These various common laboratory solvents were listed in records without associated quantities. They have been included here to identify their potential presence and will be dealt with qualitatively in further evaluations.

Methanol can be assumed.

c Ammonium bifluoride and ammonium fluoride are recorded in the inventory.

d Asbestos was not recognized as a hazardous substance until the mid-1970s, therefore, its disposal prior to that time was not documented or quantitated and cannot be determined.

c This can be assumed to be Hexavalent chromium. Compounds were probably of a chromic acid type and were placed in the WIP due to their highly oxidative and explosive nature.

$f$ Assume these epoxys are comprised of a polyolefin oxidized with peracetic acid.

$g$ Assume this to be partially crystallized ethyl ether with explosive potential.

$h$ Exact lithium compound composition cannot be determined, however, it can be assumed most of the compound types disposed would have oxidized and hydrolyzed. Therefore, the assumption can be made that the lithium is $\mathrm{LiOH}$.

Initially, picric acid residues were disposed of in WIP North as an explosive waste; later, when space became limited they were taken to WIP South. Amount could not be estimated from existing information. Sources:

i. Energy Systems 1996.

ii. Bailey 1983.

iii. DOE 1988.

iv. Mappes 1995. 
Table A.25. Estimated disposals at Burial Ground Walk-In Pits 2 and 3 (South) Active: 1966-1989. Disposal Area Volume: $13,692 \mathrm{yd}^{3}$

\begin{tabular}{|c|c|c|c|c|c|}
\hline $\begin{array}{c}\text { Waste } \\
\text { constituent } \\
\end{array}$ & $\begin{array}{c}\text { Estimated } \\
\text { inventory } \\
\text { mass }\end{array}$ & $\begin{array}{c}\text { Estimated } \\
\text { concentration in the unit }\end{array}$ & $\begin{array}{c}\text { General } \\
\text { form }\end{array}$ & Assumptions & Ref. \\
\hline Total Uranium & $1.12 \times 10^{6} \mathrm{Kg}$ & $75,000 \mathrm{mg} / \mathrm{Kg}$ as $\mathrm{U}$ & metallic fines & $\begin{array}{l}\text { Estimated uranium content based on } \\
\text { assumption that } 6.0 \% \text { of the total uranium } \\
\text { disposals went to WIP South }\end{array}$ & $\mathrm{i}$ \\
\hline Mixed acids $^{a}$ & $1200 \mathrm{Kg}$ & $80 \mathrm{mg} / \mathrm{Kg}$ & liquid & Inventory accounting & ii \\
\hline Chromium $^{b}$ & $700 \mathrm{Kg}$ & $47 \mathrm{mg} / \mathrm{Kg}$ & solids & Inventory accounting & ii \\
\hline Mercury & $31 \mathrm{Kg}$ & $2 \mathrm{mg} / \mathrm{Kg}$ & solids & Inventory accounting & ii \\
\hline
\end{tabular}

a Mixture includes hydrochloric acid, nitric acid, picric acid (potentially partially crystallized), plus others. Since the exact mixture is unknown, the most toxic acid should be assumed for risk assessment.

$b$ This can be assumed to be Hexavalent chromium. Compounds were probably of a chromic acid type and were placed in the WIP due to their highly oxidative and explosive nature.

Sources:

i. Energy Systems 1996.

ii. Bailey 1983. 
A8-15

Table A.26. BG-A - Summary of recorded PCB disposals and removals

\begin{tabular}{|c|c|c|}
\hline Area & Disposals $^{a, b}$ & Removal $^{c}$ \\
\hline \multirow[t]{6}{*}{ A-North } & $\begin{array}{l}\text { 131,440 gal oil (1971-1972), assumed: } 16 \% \mathrm{PCB} \\
\text { (equivalent of } 20 \% \text { Therminol) }\end{array}$ & $\begin{array}{l}35,000 \text { gal collected oil (1975) sent to } \\
\text { Oil Landfarm plots }\end{array}$ \\
\hline & $\begin{array}{l}220 \text { gal M-Wing coolant (known: } 20 \% \\
\text { Therminol, } 10 \% \text { mineral oil, } 70 \% \text { PCE) }\end{array}$ & \\
\hline & $\begin{array}{l}97.5 \text { gal transformer oil (1971) (Pyranol) } \\
\text { (assumed: 50\% PCBs) }\end{array}$ & \\
\hline & $\begin{array}{l}385 \text { gal M-Wing coolant (1970) (known: } 30 \% \\
\text { PCE, } 10 \% \text { mineral oil, } 60 \% \text { Therminol) }\end{array}$ & \\
\hline & $\begin{array}{l}990 \text { gal M-Wing coolant with Therminol (1971) } \\
\text { (assumed: } 10 \% \text { mineral oil, } 70 \% \text { PCE, } 20 \% \\
\text { Therminol) }\end{array}$ & \\
\hline & $\begin{array}{l}4.9 E+05 \text { gal waste oils/coolants (1969-1979) } \\
\text { (includes above) }\end{array}$ & \\
\hline \multirow[t]{4}{*}{ A-South } & $\begin{array}{l}220 \text { gal M-Wing coolant (known: } 20 \% \\
\text { Therminol, } 10 \% \text { mineral oil, } 70 \% \text { PCE) }\end{array}$ & $\begin{array}{l}15,000 \text { gal (1974) to Oil Landfarm } \\
\text { plots }\end{array}$ \\
\hline & $\begin{array}{l}385 \text { gal M-Wing coolant }(1970) \text { (known: } 30 \% \\
\text { PCE, } 10 \% \text { mineral oil, } 60 \% \text { Therminol) }\end{array}$ & $\begin{array}{l}18,000 \text { gal }(1979) \text { to underground } \\
\text { storage tanks }\end{array}$ \\
\hline & $\begin{array}{l}97.5 \text { gal transformer oil (1971) (Pyranol) } \\
\text { (assumed: 50\% PCBs) }\end{array}$ & \\
\hline & $\begin{array}{l}\text { 1.28E+06 gal oils/coolants (1969-1979) } \\
\text { (includes above) }\end{array}$ & \\
\hline
\end{tabular}

a Volumes were calculated using the assumption that (unless specified) "drums" cited in records are 55 gal.

b Non-PCB component of Therminol assumed to have the same density as mineral oil $(0.822 \mathrm{~g} / \mathrm{cc})$, and the non-PCB portion of the total waste oils/coolants disposed in each area was assumed to have a density of $1.2 \mathrm{~g} / \mathrm{cc}$.

c 5000 gallons of oil were removed from ORP-1 in 1975; because they were sprayed on trees adjacent to the pond, this volume was not considered as a removal.

PCE - perchloroethene 
A8-16

Table A.27. Summary of estimated uranium quantities by Burial Grounds area ${ }^{a}$

\begin{tabular}{lccc}
\hline \multicolumn{1}{c}{ Area } & $\begin{array}{c}\text { Assumed \% of total } \\
\text { Kardex estimated }\end{array}$ & $\begin{array}{c}\text { Estimated Uranium } \\
\text { mass }(\mathrm{Kg})\end{array}$ & $\begin{array}{c}\text { Estimated Uranium } \\
\text { concentration }(\mathrm{mg} / \mathrm{Kg})\end{array}$ \\
\hline A-South & 5.0 & $0.93 \times 10^{6}$ & 15,000 \\
A-North & 5.0 & $0.93 \times 10^{6}$ & 11,000 \\
A-16 thru 18 & 0.5 & $0.09 \times 10^{6}$ & 610 \\
B & 33.0 & $6.14 \times 10^{6}$ & 300,000 \\
C & 5.0 & East $0.25 \times 10^{6}$ & 21,000 \\
& & West $0.68 \times 10^{6}$ & 22,000 \\
D & 20.0 & East $3.35 \times 10^{6}$ & 240,000 \\
& & South $0.03 \times 10^{6}$ & 240,000 \\
& & West $0.35 \times 10^{6}$ & 260,000 \\
E & 6.5 & $1.21 \times 10^{6}$ & 260,000 \\
J & 10.0 & $1.86 \times 10^{6}$ & 260,000 \\
Walk-In North & 9.0 & $1.67 \times 10^{6}$ & 72,000 \\
Walk-In South & 6.0 & $1.12 \times 10^{6}$ & 75,000
\end{tabular}

$18.6 \times 10^{6} \mathrm{Kg}$ as uranium

Kardex File Total Estimate

Nineteen Kardex Blankets over a 17-year period totaled $26.2 \times 10^{6} \mathrm{lbs}$ of uranium type materials. This is equivalent to $11.9 \times 10^{6} \mathrm{Kg}$ as $\mathrm{UO}_{2}$ or $10.5 \times$ $10^{6} \mathrm{Kg}$ as U. A per-year estimate then becomes $620,000 \mathrm{Kg} / \mathrm{year}$ of uranium, multiplied by a 30 -year site history provides a total estimate of $18.6 \times 10^{6} \mathrm{Kg}$ as uranium.

Comparison (DOE 1988) $\quad 17.3 \times 10^{6} \mathrm{Kg}$ of uranium

The "Historical Radionuclide Releases, May 1988 " reports a total of $19.3 \times 10^{6}$ $\mathrm{Kg}$ buried, corrected for overestimates of uranium mass due to water weight (1.5 $\times 10^{6} \mathrm{Kg}$ ) and uranium transported to X-10 Site $(522,000 \mathrm{Kg})$, provides the final estimate above uranium. This includes pre-1972 liquid materials containing uranium that were not actually placed in the landfill but were transferred off-site or to S-3 Ponds, which were considered as solid material entering the landfill.

${ }^{a}$ Reference is also made to Fig. A.9. 


\section{APPENDIX B}

\section{DESCRIPTION OF THE FIELD ACTIVITIES}

AND REPORT DATABASE 



\section{B.1 INTRODUCTION}

An extensive database of environmental data for the Bear Creek Valley (BCV) Characterization Area (CA) was derived from (1) recent remedial investigation (RI) field activities conducted during 1994 and 1995 and from (2) historical field studies conducted during the 1980s and early 1990s. The extent and quality of this environmental database are summarized in this appendix. This appendix also presents information about the number and location of samples collected, the analytes examined in those samples, and the extent of data validation or data quality review. The focus is on the type and extent of environmental sampling in $\mathrm{BCV}$, rather than the results of analyses.

This appendix is subdivided into six sections. Section B.2 summarizes the historic database, and Sect. B.3, B.4, and B.5 describe the sampling activities conducted during 1994 and 1995 for:

- BCV Operable Unit (OU) 1 - field activities addressing the source waste sites;

- $\quad$ BCV OU 4 - field activities addressing the main hydrological pathways for contaminant migration in $\mathrm{BCV}$;

- floodplain soil/sediment (FPSS) investigation - field activities addressing secondary contamination in the BCV floodplain and pathways to ecological receptors within the valley; and

- biota sampling - addressing transfer of contaminants from physical media to plants and animals.

An evaluation of the data quality is presented in Sect. B.6 for the historic groundwater data and in Sect. B.7 for the data from the three recent field activities. 
B2-1

\section{B.2 SUMMARY OF HISTORICAL DATA FOR BCV}

Historical data for the $1995 \mathrm{BCV}$ RI are defined as those data collected within the BCV before 1994 and not as part of the recently completed OU 1, OU 4, or FPSS investigations. This definition encompasses historical characterization and monitoring activities, ongoing monitoring activities, and special investigations. The types of historical data that exist include physical and chemical analyses of the primary environmental media (surface water, groundwater, soil, sediment waste) plus biological, ecological, geological, and meteorological data for a host of sites within the valley. Also included are the waste disposal records maintained from the 1950s to 1980, which were used to develop the waste inventory for the Bear Creek Burial Grounds (BCBG) (Supporting Information for Appendix A, Sect. A.6).

Literally thousands of samples have been collected from the BCV CA during the last 40 years as part of nearly 100 studies. Although some monitoring was conducted as early as the $1950 \mathrm{~s}$ and 1960 s, most of the historical data have been generated since 1982. These investigations have been conducted by the Oak Ridge Y-12 Plant, Oak Ridge National Laboratory (ORNL), Tennessee Valley Authority, U.S. Geological Survey (USGS), and companies under subcontract to Union Carbide or Lockheed Martin Energy Systems, Inc. (Energy Systems).

Table B.1 lists the historical studies that were reviewed for the BCV RI Report. The studies for which data are included in the BCV RI electronic database are shaded entries (although in some cases, only some of the data were captured). The electronic historical database includes results from more than 10,000 samples. Of particular note for their excellent summaries of historical sampling events and data collected from Bear Creek are:

- 1991 BCV RI Work Plan (Turner et al. 1991), which provide the most comprehensive coverage available;

- $\quad$ sampling history for the Oil Landfarm (OLF) area (Herbes 1989); and

- $\quad$ sampling history for the Oil Retention Ponds (ORPs)-1 and -2 (Herbes 1988).

The methodologies used in the historical studies for BCV vary widely. Sampling and analytical methods, including quality control measures, have changed over the years as techniques and protocols have evolved. In some cases, documentation of procedures is unavailable. Differing sampling designs, study goals, and companies performing the work also add variability to the historical data record for BCV. For the most part, however, the historical data that exist for Bear Creek and its environs were collected and analyzed by trained technicians using approved procedures. Furthermore, as noted by Turner et al. (1991), a general concordance of results over the years lends credibility to the historical data for this site.

The following subsections summarize the sources of historical data for BCV by medium:

- groundwater,

- soil,

- floodplain soil/sediment,

- surface water, and

- other. 
Sources of historical data are identified by reference citation and/or a number (\#) correlating to the numbers in Table B.1, which presents the details (sampling stations, dates, types of analyses performed) about each study. Table B.2 lists the frequency of analytes for each project and each medium in the historic database. Figure B.1 shows the locations of historic data sampling points in $\mathrm{BCV}$.

\section{B.2.1 GROUNDWATER}

More than 300 groundwater monitoring wells and piezometers, ranging from shallow water table wells to deep bedrock wells, have been installed in the BCV watershed; screened intervals exist in the shallow and deep groundwater aquifers and for most of the formations present in BCV. Most of the wells are located near the waste disposal sites in upper Bear Creek (Fig. B.1).

Most of the wells in BCV were installed by $\mathrm{Y}-12$ Plant subcontractors as part of the Groundwater Protection Program (GWPP); others were installed and monitored by the USGS. A substantial amount of groundwater data was made available from as early as 1983, when Bechtel National, Inc. (BNI) was subcontracted to install a group of wells near the waste sites (\#20). The Roy F. Weston company also conducted an extensive groundwater sampling and analysis campaign in 1987-88, including Appendix IX analyses (\#40) that have been validated to the extent possible, documented, and are available in the Bechtel Environmental Information Data Management System (BEIDMS). The Weston data are well documented and considered to be of good quality, but only a portion has been previously published (Turner et al. 1991).

The Y-12 Plant Groundwater Monitoring Program electronic database dates back to 1986. The data obtained under this program include water level measurements and a suite of organic and inorganic chemical analytical results (\#41). Radiological analytical results are more sporadic, and the radionuclides reported vary.

\section{B.2.2 SOL}

Historical soils data for $\mathrm{BCV}$ are derived primarily from cores that were sampled during drilling of groundwater wells or sampling of the OLF prior to closure. Not all of the well cores have been sampled, but McCauley (1985) includes data for $\sim 50$ boreholes. Sampling at the OLF was restricted to the individual treatment plots but included more than 300 composite samples (Herbes 1989; Bohrman 1989; \#39 and \#51). Some soil samples were collected by Y-12 Plant Waste Management from the excavated soils stored at the OLF Storage Pad (\#61) and the Disposal Area Remedial Action facility (\#69). These samples received the most comprehensive analyses, including analysis using Toxicity Characteristic Leaching Procedures. A number of surface and subsurface soil samples have also been collected in upper Bear Creek around the Rust Spoil Area (Energy Systems 1995; \#57, \#66), Storage Yard 200 (Energy Systems 1995; \#54, \#66), Spoil Area I (Energy Systems 1995; \#58, \#66), and the soil pile excavated during construction of the West End Tank Farm in 1984 (Turner 1988; \#35).

\section{B.2.3 FLOODPLAIN SOIL/SEDIMENT}

Stream sediments and floodplain soils of Bear Creek and its tributaries have also been sampled extensively. Stream sediments were included in the sampling campaigns of BNI and the 
Roy F. Weston company in the early 1980 s (Geraghty and Miller 1985; \#21, \#40). Areas in and around the BCBG are the most intensively characterized; hundreds of samples were collected to characterize the North Tributary (NT)-7, NT-8, and the ORP sites during remediation. Sediment samples from other tributaries and for Bear Creek are less extensive. However, reference samples of sediment were also collected at Grassy Creek, NT-2, and NT-14 for use as background values in various studies.

Floodplain soil samples (as opposed to in-stream sediments) have been collected more sporadically, generally as part of larger investigations. Available data are limited to several sites in lower Bear Creek; the Blue Lagoon area in upper Bear Creek; the bridge site near Bear Creek Kilometer (BCK) 9.42; and areas of NT-6, -7 , and -8 that drain the BCBG.

\section{B.2.4 SURFACE WATER}

Limited surface water data are available from as early as the 1960s (McMaster 1967). Sampling during the 1970 s, especially in the headwaters, was associated primarily with the monitoring and eventual closure of the former S-3 Pond, which was completed in 1984. In the early 1980 s, surface water was sampled in and around the waste disposal sites by Roy F. Weston (\#40), BNI (\#19), and the Y-12 Plant (\#41). In addition to general chemistry, these samples were analyzed for a suite of analytical parameters. Surface water monitoring of Bear Creek has continued since that time, and sampling and analysis of both Bear Creek and its tributaries have been the focus of numerous special investigations, including an NT-8 study (Bogle and Turner 1993; \#59), National Pollutant Discharge Elimination System monitoring (\#3), and Environmental Sciences Division flow monitoring project (Clapp et al. 1990; \#25).

In addition, surface water from the former ORPs was sampled and analyzed for a variety of contaminants during the 1980 s (\#16, \#36, \#50, \#53). These ponds were eventually drained and excavated. The most recent study in the historical surface water dataset is a 1994 seep-and-spring survey conducted by the USGS (SAIC Project File 1995e; \#71). Although the surveyors for this study did not collect samples for laboratory analysis, they did measure field parameters at more than 700 seeps, springs, and stream locations along Bear Creek, Grassy Creek, and their tributaries.

\section{B.2.5 OTHER STUDIES}

Other types of studies conducted within the Bear Creek watershed include meteorological monitoring, sampling of the waste sludge in the former S-3 Ponds (Kimbrough and Turner 1987; \#26), leachate collection at BG-C (\#64), sampling of liquids in standpipes in the burial trenches (McCauley 1985; \#22), ecological and biological sampling, endangered species surveys, dye tracer tests, and various geological studies.

Water and sediment at the former S-3 Ponds were sampled in the 1970s and 1980s before the ponds were neutralized in 1983, as were the sludges resulting from the neutralization process (Kimbrough and Turner 1987; \#26). Sediment from Blue Lagoon, a ponded area in Bear Creek just downstream of the ponds, was excavated in the late 1980s and transferred to the southwest cell of the S-3 Ponds just before they were closed. This sediment was sampled during the excavation and analyzed for contamination by the Y-12 Laboratory (McMahon 1988; \#49). 
The meteorology data for the vicinity of BCV date back to the 1950s, and rain gauges were installed in the valley during the 1980s. The rain gauges and meteorological monitoring stations provide information on the rainfall, solar radiation, and wind patterns within BCV and the surrounding areas.

Ecological and biological data have been collected primarily by ORNL, most notably by the Biological Monitoring and Abatement Program, which focuses on stream ecology and toxicity (Hinzman et al. 1995; \#30). Other ecological monitoring activities have included mapping and characterization of wetlands and other sensitive areas and documentation of endangered species populations. 


\section{B.3 BCV OU 1 RI FIELD ACTIVITIES}

\section{B.3.1 SUMMARY OF FIELD INVESTIGATIONS}

The BCV OU 1 field activity addressing the source sites in BCV was implemented in the Fall of 1994. It included sampling of surface and subsurface soils, groundwater, and/or surface water at the following sites:

- S-3 Site (Fig. B.2),

- OLF (Fig. B.3),

- Boneyard/Burnyard (BYBY) [including the Hazardous Chemical Disposal Area (HCDA)],

- Sanitary Landfill 1 [SL 1 (Fig. B.3)], and

- $\quad \mathrm{BCBG}$, including BG-A, $-\mathrm{B},-\mathrm{C},-\mathrm{D},-\mathrm{E}$, and -J; ORP-1 and -2 ; and Walk-in Pits (Fig. B.4).

In addition, radiation and geophysical surveys were conducted at various sites, and groundwater head monitoring was conducted at the S-3 Site.

The rationale and procedures for collecting environmental samples and field data are presented in the BCV OU 1 RI Work Plan (DOE 1994a) and Environmental Technical Support for Bear Creek Valley Operable Unit 1 Remedial Investigation Field Activities Manual (SAIC 1994a). This manual includes procedures consistent with those in Environmental Surveillance Procedures, Quality Control Program (Kimbrough, Long, and McMahon 1990) and investigation-specific procedures developed for sampling and field data collection methods not addressed by published Energy Systems procedures. Field procedures used during the RI and referred to in Sect. B.3 are referenced by procedure numbers correlating with those listed, along with the corresponding titles presented in SAIC (1994a), in Table B.3.

\section{B.3.2 DEVIATION FROM THE SAMPLING AND ANALYSIS PLAN}

Modifications to the original sampling and analysis plan (SAP) made during the course of the RI changed the scope of work for the field activities. Most of these changes to the SAP were made to accommodate site-specific conditions (e.g., change in sample location). These modifications are summarized in Table B.4.

\section{B.3.3 SITE SAMPLING ACTIVITIES}

The unique disposal histories of the various BCV OU 1 sites required the development of the site-specific sampling schemes presented in the RI Work Plan (DOE 1994a). The sampling schemes were designed to incorporate each applicable medium and to achieve the data quality objectives (DQOs) set forth in the RI Work Plan. The following sections summarize the field activities by sampling type: surface soil radiation surveys, geophysical surveys, surface soil, subsurface soil, groundwater, surface water, stormflow monitoring, and groundwater head monitoring. 


\section{B.3.3.1 Surface Soil Radiation Surveys}

Radiation surveys were conducted to define areas of elevated activity in surface soils. Survey results were used in part to optimize sampling locations.

The Ultrasonic Ranging and Data System (USRADS) survey technology used for the surveys provides precise and real-time geographical location of collected data. The system includes a (1) movable base station containing a host microcomputer and a master receiver and (2) data pack consisting of electronic data gathering and positioning instrumentation. The data pack interfaces between the sensor meters and the master receiver located at the base station. The USRADS software automatically and instantaneously correlates the collected data to the actual location of the surveyor. The location and corresponding data value(s) are then plotted on a grid map displayed on the host microcomputer.

The USRADS equipment was mounted either in a backpack carried by the surveyor or on an all-terrain vehicle (ATV) driven by the surveyor. The instrumentation in the backpack carried by the surveyor included:

1. A Model 44-2, 2.5- $\times 2.5-\mathrm{cm}(1-\times 1$-in.) sodium iodide detector probe (NaI scintillation crystal) coupled to a Ludlum Model 3 count rate meter for near-surface $\gamma$ detection.

2. A Ludlum Model 44-9 open-window Geiger-Mueller pancake detector, mounted as close as possible to the surface, coupled with a Ludlum Model 3 count rate meter for near-surface $\beta$ detection.

3. A Bicron MicroRem Model Tissue Equivalent Survey Meter, carried $\sim 1 \mathrm{~m}(3 \mathrm{ft})$ above the ground surface, to detect low-level, tissue-equivalent dose rates in $\mu \mathrm{rem} / \mathrm{h}$.

The instrumentation for the ATV, which was used to survey the larger, open areas, was equipped with the following instrumentation:

1. Three Ludlum Model 3 Survey Meters equipped with Ludlum Model 44-2, 2.5-cm (1-in.) $\mathrm{Nal}$ scintillation crystal probes, spaced $30.5 \mathrm{~cm}$ (12 in.) apart, for near-surface $\gamma$ detection.

2. Two Ludlum Model 12 ratemeters with Model 43-37 Gas Flow Proportional Floor Monitors, spaced equally across a $1-\mathrm{m}(3-\mathrm{ft})$ frame, for near-surface $\beta / \gamma$ detection.

3. One Bicron MicroRem Model Tissue Equivalent Survey Meter for low-level, tissueequivalent dose-rate measurement.

In either configuration, the radiological instruments were used to record data during a single pass over each survey grid. For the surveyor-carried surveys, the $\gamma$ and $\beta$ ground surface probes were held about 15.2 to $30.5 \mathrm{~cm}$ (6 to 12 in.) above the ground surface and swung in a $1-\mathrm{m}$ (3-ft) path across the survey transect. The surveyor traversed each survey grid at a rate of $1 \mathrm{~m} / \mathrm{s}(3 \mathrm{ft} / \mathrm{s})$ on parallel transects spaced $\sim 1 \mathrm{~m}(3 \mathrm{ft})$ on center. For the surveys conducted with the ATV, the vehicle traveled at $\sim 6.5 \mathrm{~km} / \mathrm{h}(4 \mathrm{mph})$ on parallel transects spaced $\sim 1 \mathrm{~m}(3 \mathrm{ft})$ on center.

Radiation surveys were conducted at three of the BCV OU 1 areas: BYBY, SL 1, and BCBG. 


\section{B3-3}

BYBY. Radiation surveys were conducted at the BYBY to identify areas of elevated activity in surface soils to target subsequent sampling activities. The large aerial coverage (Fig. B.3) and low topographic relief of the site required the use of the ATV. Vegetation in the area was cut back to allow the instrument to be suspended low enough to allow readings to be taken about 15.2 to $30.5 \mathrm{~cm}$ ( 6 to $12 \mathrm{in}$.) above the ground surface.

SL 1. A surveyor carrying a backpack surveyed the northern, western, and southern perimeters of the SL 1 capped area. Figure B.3 shows the extent of coverage of the radiological survey.

BCBG. Radiation surveys using both backpack- and ATV-mounted instruments were conducted at BCBG and on the Bear Creek floodplain in the vicinity of BCBG. Figure B.4 shows the extent of coverage of the radiological survey.

\section{B.3.3.2 Geophysical Surveys}

Geophysical surveys were conducted with a Geonics EM-31 terrain conductivity meter and a Geometrics G-822L Cesium Vapor Magnetometer. The EM-31 simultaneously measured two components of the induced magnetic field: a quadrature-phase component giving the ground conductivity and an in-phase component sensitive to metallic objects. The sensors were oriented

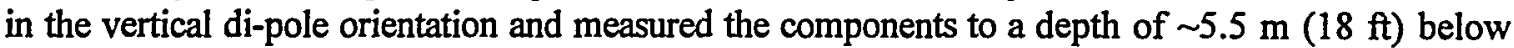
the surface. The Geometrics G-822L Cesium Vapor Magnetometer used a directly locked oscillator that was proportional to the earth's magnetic field and was tolerant to noise and gradient changes. According to manufacturer specifications, the instrument is capable of detecting buried drums at

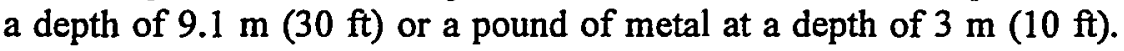

The EM-31 was connected to the USRADS equipment to allow output signals from the quadrature- and in-phase modes to be recorded simultaneously with geographic data from USRADS. The EM-31 was carried by the surveyor at a height of $\sim 1 \mathrm{~m}(3 \mathrm{ft})$ above ground surface on parallel paths spaced $\sim 3 \mathrm{~m}$ (10 ft) apart, first in a north-south direction and then in an east-west direction. Readings were usually taken about 15.2 to $30.5 \mathrm{~cm}$ (6 to $12 \mathrm{in}$.) above the ground surface.

The surveyor walked the G-822L surveys on $\sim 1-\mathrm{m}$ (3-ft) paths on center, swinging the instrument from side to side and holding the probe $\sim 15.2 \mathrm{~cm}(6 \mathrm{in}$.) above the ground surface. The data collected by the GL-822L were output via RS-232 connections to the USRADS datapack, which immediately transmitted the data and location to the host computer.

Geophysical surveys were conducted in only one BCV OU 1 area: the BYBY.

BYBY. The BYBY surveys were conducted to define anomalies associated with buried objects and, consequently, the trenches. The survey data were subsequently used to determine optimal sampling locations for determining the nature and extent of contamination in the BYBY. The extent of the geophysical survey coverage is shown in Fig. B.3.

\section{B.3.3.3 Surface Soil Sampling}

Surface soil was collected for chemical analysis from the S-3, BYBY, SL-1, OLF, and BCBG sites to aid in determining the nature, extent, and likely contribution of surface erosion to contamination within the OU. Hand augers and scoops were used to collect soil samples from 
$<1 \mathrm{ft}$ below ground surface (bgs). Surface radiation surveys were used to direct sampling activities, and levels of activity were monitored and recorded during sampling.

Surface soil samples were initially submitted for laboratory-based screening analyses of metals, polychlorinated biphenyls (PCBs), and uranium. These screening analyses were not validated. Screening results were reviewed by Energy Systems and Science Applications International Corporation (SAIC) project management to determine concentration and contaminant distribution. This evaluation was used to select those locations requiring additional analytical data collection with validation. The selected locations were resampled, and the collected samples were analyzed for metals, organics, semivolatiles, pesticides, and radioactivity (Table B.5).

Surface soil sampling was conducted at all five BCV OU 1 areas: S-3 Site, BYBY, SL 1, OLF, and BCBG.

S-3 Site. Surface soil samples were collected from four locations (SS3-01 through -04) at the S-3 Site and submitted for screening analysis (Fig. B.2). The results of screening analysis showed no concentrations of contaminants sufficient to warrant further sampling for more detailed analyses.

BYBY. Surface soil samples were taken at 27 locations (SBY-01 through -26 and -28 ) at the BYBY for screening analysis (Fig. B.3). Based on the results of screening analysis, six locations were resampled for more complete analysis (SBY-13, -16, -17, -20, -21, and -22) (Table B.5). An additional sample (SBY-27) was taken from material in a half-buried and ruptured drum located south of the BYBY, which exhibited radioactive contamination $(>400,000 \mathrm{cpm})$. Because of its radioactive nature, this sample was submitted to the $\mathrm{Y}-12$ Laboratory for analysis rather than to an off-site laboratory.

SL 1. Surface soil samples were taken at 14 locations (SSL-01 through -14) at the SL 1 for screening analysis (Fig. B.3). Results of the screening analysis showed that only SSL-13 required resampling for more complete analysis.

OLF. Surface soil samples were collected at two locations (SOL-1 and SOL-2) at the OLF (Fig. B.3) for screening analysis. The results of screening analysis showed no concentrations of contaminants sufficient to warrant further sampling for more detailed analyses.

BCBG. Surface soil samples were collected from 44 locations at BCBG (Fig. B.4). Screening analysis was performed on 41 of the samples (SBG-01 through -41). Of these locations, five were resampled for more complete analysis (SBG-07, $-11,-20,-25$, and -33). Surface soil samples from SBG-43 and -44 were each sampled for screening analysis and for complete analysis during one event due to time constraints and the need to have analyses consistent with previous sampling. The sample collected at SBG-42 came from an area of soil with yellow discoloration and high $\beta$ and $\gamma$ radiation $(>400,000 \mathrm{cpm})$ that was discovered during reconnaissance of the area. Because of its radioactive nature, this sample was submitted to the $\mathrm{Y}-12$ Laboratory for analysis rather than to an off-site laboratory.

\section{B.3.3.4 Subsurface Soil Sampling}

Depending on the sample site and the soil lithology, subsurface soil samples were collected using Geoprobe ${ }^{\text {sut }}$ sampling techniques, hollow-stem auger and split barrel samplers, and Little Beaver ${ }^{\text {nt/ }} /$ hand auger sampling techniques. 
Subsurface soil samples were analyzed for metals, volatile organic compounds (VOCs), PCBs, and radioactivity (Table B.5). At the BYBY site and selected locations at the BCBG, samples were also analyzed for semivolatile organic compounds (SVOCs) (dioxins and furans). Subsurface soil samples.were also collected, using Shelby tubes for geotechnical analysis. These samples were analyzed for percent moisture, grain size diameter, hydraulic conductivity, mineral composition, distribution coefficient, shear strength, total organic carbon, and cation exchange capacity. Soil samples were analyzed for the list of parameters in Table B.5, and the Shelby tubes were analyzed for the list of parameters in Table B-6.

To ensure worker health and safety during field activities, environmental monitoring was conducted from within the breathing zone and for sample media. During the subsurface soil sampling, the presence and concentrations of VOCs, mercury vapor, combustible gases, and radioactivity were monitored and recorded.

S-3 Site. Subsurface soil samples were collected continuously at ten locations (S3-01 through -10) from the surface to auger refusal using a hollow-stem auger and split barrel samplers (Fig. B.2). Shelby tube samples were collected through the hollow-stem auger from two borings (S3-02 and -07).

BYBY. Continuous subsurface soil samples were collected from nine locations at the BYBY (BYBY-01 through -09) using Geoprobe ${ }^{\text {Tu }}$ sampling techniques (Fig. B.3). Sample depth intervals are shown on the lithologic logs for each boring (Supporting Information for this appendix). Shelby tubes were collected through a hollow-stem auger at two locations (BY-05 and -07).

SL 1. Subsurface soil samples were taken from two locations at SL 1 (SL1-01 and -02) using Geoprobe $^{\mathrm{nt}}$ sampling techniques (Fig. B.3). Sample depth intervals are shown on the lithologic logs presented in the Supporting Information for this appendix. Soil samples and Shelby tube samples were analyzed for the parameters listed in Table B.6.

OLF. Subsurface soil samples were taken from five locations at the OLF (OLF-01 through -05) using Geoprobe ${ }^{\text {nt }}$ sampling techniques (Fig. B.3). Sample depth intervals are shown on the lithologic logs presented in the Supporting Information for this appendix. Shelby tubes were collected through a hollow-stem auger at two locations (OLF-03 and -04). Soil samples and Shelby tube samples were analyzed for the parameters listed in Table B.6.

BCBG. Subsurface soil samples were taken from 15 locations at BCBG (BG-01 through BG-15) (Fig. B.4). Geoprobe ${ }^{\text {TM }}$ sampling techniques were used at 12 of these locations (BG-01 through $-06,-08$, and -10 through -14). A Little Beaver $r^{\text {nh }}$ power auger and hand-bucket augers were used to collect samples from BG-07, -15 , and -16 because of difficulty in accessing these sites with a mechanical drilling rig. Sample depth intervals are shown on the lithologic logs presented in the Supporting Information for this appendix. Shelby tubes were collected through a hollow-stem auger at four locations (BG-02, -06, -11, and -15).

\section{B.3.3.5 Groundwater}

Groundwater samples were collected using Geoprobe ${ }^{\text {nu }}$ groundwater sampling techniques from each Geoprobe ${ }^{\text {Th }}$ sample location at which groundwater was identified during the subsurface soil sampling activities. The samples were analyzed for VOCs and SVOCs, metals, pesticides, and radioactivity (Table B.7). Temperature, $\mathrm{pH}$, and conductivity of each sample were measured at 
time of collection along with organic vapor concentration in the breathing zone, which was measured for health and safety concerns.

Wet zones were identified during subsurface soil sampling and targeted for groundwater sampling in a Geoprobe ${ }^{\mathrm{TM}}$ hole adjacent to the soil sampling hole. The Geoprobe ${ }^{\mathrm{TH}}$ groundwater sampling system used a $0.6-\mathrm{m}(2-\mathrm{ft})$ screen that was deployed from the bottom of the pushrods. It was often necessary to retract the pushrods $0.6 \mathrm{~m}(2 \mathrm{ft})$ to sample water because of slow recharge or slight differences in water levels from soil sample stations to the adjacent groundwater station.

Groundwater was sampled at three BCV OU 1 areas: BYBY, SL 1, and BCBG.

BYBY. Groundwater grab samples were taken from seven of the nine Geoprobe ${ }^{\text {Tu }}$ borings at BYBY (BYBY-01 through -06 and BYBY-09) (Fig. B.3). Sample intervals ranged from 2 to $10.8 \mathrm{~m}$ (7 to $35.5 \mathrm{ft}$ ) bgs across the site (Table B.8). No water was encountered in the other two sample stations (BYBY-07 and BYBY-08).

SL 1. One groundwater sample was taken from the 3.7 to $4.3 \mathrm{~m}$ (12 to $14 \mathrm{ft}$ ) bgs interval (Table B.8) of boring SL1-01 (Fig. B.3). Boring SL1-02 was not sampled because no groundwater was encountered.

BCBG. Groundwater was collected from seven locations in the BCBG (BG-01 through -05, -12 , and -13) (Fig. B.4). Stations BG-07 and -15 were inaccessible by groundwater sampling equipment. No water was encountered at BG-06, $-08,-10,-11$, or -14 . The sample intervals ranged from 2.4 to $9.8 \mathrm{~m}(8$ to $32 \mathrm{ft}$ ) bgs (Table B.8).

\section{B.3.3.6 Surface Water}

Surface water samples were obtained using a dipper. Before sample collection, each location was scanned for surface radioactivity to ensure worker health and safety, and temperature, $\mathrm{pH}$, and conductivity of each sample were measured at time of collection. The collected samples were analyzed for VOCs and SVOCs, metals, PCBs, pesticides, and radioactivity (Table B.7).

Surface water samples were taken after a rainfall event at two locations in the upper reaches of NT-8 (SW-01 and SW-02) in BCBG (Fig. B.4). These locations were selected because they were likely to have received surface runoff from multiple sources within the $B C B G$.

\section{B.3.3.7 Stormflow Monitoring}

Stormflow tubes were installed at ten locations within the BCBG (SF-01 to SF-10) to establish the existence of flow in the shallow subsurface zone (Fig. B.4). Water level measurements in each stormflow tube were taken once a week for a period of 8 weeks. When applicable, measurements were obtained as soon as possible after a rain event during each week.

\section{B.3.3.8 Groundwater Head Monitoring}

Groundwater levels in selected wells and temporary piezometers were monitored continuously. Groundwater head measurements were recorded every $30 \mathrm{~min}$ for $\sim 6$ weeks using data loggers and pressure transducers. 
Temporary piezometers were installed at the S-3 Site in borings S3-01, -03, -05, -06, -07, and -08 by placing a slotted polyvinyl chloride pipe in the hole after withdrawing the auger and filling the annulus space with drill cuttings. Groundwater levels were measured in each of these temporary piezometers and in monitoring wells GW-101, -127, and -276. Monitoring well GW-276 was monitored for a shorter period ( $\sim 4$ weeks) because a scheduled, quarterly sampling of the well could not be completed with the head monitoring equipment in place. 


\section{B.4 BCV OU 4 FIELD ACTIVITIES}

\section{B.4.1 SUMIMARY OF FIELD INVESTIGATIONS}

The BCV OU 4 field activities addressing the hydrology of BCV and the exit pathways from the source sites to potential off-site receptors included (1) sampling surface water at tributaries draining from the source sites into Bear Creek and (2) monitoring groundwater head, stormflow, and surface water flow to refine the hydrologic conceptual model for BCV. OU 4 sampling locations are shown in Fig. B.5.

The collection of environmental samples and field data followed procedures outlined in the BCV OU 4 RI Work Plan (DOE 1993) and presented in Environmental Technical Support for Bear Creek Valley Operable Unit 4 Remedial Investigation Field Activities Manual (SAIC 1994b) (Table B.9). This manual includes procedures consistent with those in Environmental Surveillance Procedures, Quality Control Program (Kimbrough, Long, and McMahon 1990) and investigation-specific procedures developed for sampling and field data collection methods not addressed by published Energy Systems procedures.

The work plan for the BCV OU 4 RI was approved on September 29, 1993, and field activities began on March 1, 1994.

\section{B.4.2 DEVLATIONS FROM THE SAMPLING ANALYSIS PLAN}

Modifications to the original SAP, made after a review of preliminary data, changed the scope of work for the field activities. The major modifications to the BCV OU 4 SAP included:

- The original SAP included sampling of groundwater from 25 wells in BCV. The decision was later made not to sample groundwater because sufficient data for defining groundwater chemistry and contaminants are available from the annual sampling of monitoring wells in BCV for the Groundwater Quality Report (GWQR) (e.g., HSW 1995) (DOE 1994b - BCV DQO meeting minutes).

- Although the SAP identified 14 stream and spring sample sites, sampling equipment was available for only 6 of the 14 sites at the project start. Therefore, 6 priority sites were identified and monitored from project start, with the 8 remaining sites equipped and brought on line for sampling during May 1994.

- The original SAP called for surface water sampling to be conducted by using flow-proportional samplers to take weekly composites of surface water. However, experience in taking the initial two samples at each site revealed that taking composites over a 7-d period would not be practical and, furthermore, might bias the database towards high-flow periods.

The flow-proportional samplers, which take a volume of sample that is proportional to the total volume of water that has passed through the site, automatically switched off once the sample containers were full. To gain a representative sample of one week's flow, a field team had to set the sample rate at the start of each sample so that the sampler would operate for the whole week. In cases where water flow was higher than predicted when programming the 
sampler, the sampler would switch off before the end of the week period. Conversely, in cases where flow was lower than anticipated, an insufficient sample would be taken. Most often, the samplers filled up and switched off during storm events before the end of the week sampling period. Unfortunately, weather forecasting could only give the sample teams the probable weather condition for $5 \mathrm{~d}$ in advance, which was insufficient to project total flow through the samplers for a full week. The sample strategy was therefore changed to obtain representative samples during different periods of the hydrograph: stormflow, storm regression, and baseflow. Sample periods were generally shorter than 1 week and ranged from 1 to $6 \mathrm{~d}$, depending on the conditions and the targeted sample period. This change in strategy also resulted in fewer samples being needed to define the flux of contaminants at each site. The total number of sample events was therefore changed from the original 28 to 21 .

- The SAP called for three tracer tests - one at each of the main waste sites in - BCV to be conducted. After obtaining additional expert opinion suggesting that the tracer tests would probably not work because there was little likelihood that any tracer would be identified in the monitoring wells, the sample strategy was changed to eliminate the tracer tests (DOE 1994b).

- The SAP called for three pressure pulse tests - one at each of the main waste sites in $\mathrm{BCV}$ - to be conducted. The same expert opinion that questioned the value of the tracer tests also suggested that the pulse tests should not be conducted. As a result, the sample strategy was changed to complete only one of the pulse tests (DOE 1994b).

- The SAP did not address lithium. However, because new data made available during the RI showed the potential toxicity of lithium, it was added to the list of analytes for the seven surface water sample events after September 1994.

Other minor modifications to the original SAP are summarized in Table B.10.

\section{B.4.2.1 Comprehensive Radiological Characterization Monitoring}

In addition to the modifications to the original SAP discussed above, a Statement of Work was issued July 14, 1995 (revised July 24, 1995) by Energy Systems to conduct groundwater sampling and analysis of radiochemical parameters in support of the ongoing RI in BCV. This task involved sampling and analysis of groundwater from selected wells and springs within the Bear Creek Hydrogeologic Regime for radiochemical parameters of concern to determine the nature and extent of radiogenic contamination and to perform a baseline human health risk assessment.

Radiochemical contaminants of potential concern were identified during a review and evaluation of the Y-12 Plant GWPP historical analytical database, radiological waste inventory data for the sludges in the S-3 Ponds and wastes in the BCBG, and radionuclides detected as part of the BCV OU 1 and OU 4 sampling events. The contaminants of potential concern selected include ${ }^{241} \mathrm{Am},{ }^{137} \mathrm{Cs},{ }^{3} \mathrm{H},{ }^{237} \mathrm{~Np},{ }^{238} \mathrm{Pu},{ }^{2391240} \mathrm{Pu},{ }^{223,224,226} \mathrm{Ra},{ }^{228} \mathrm{Ra}$, total $\mathrm{Sr},{ }^{99} \mathrm{Tc},{ }^{228,230,232} \mathrm{Th},{ }^{233 / 234} \mathrm{U}$, ${ }^{235} \mathrm{U},{ }^{238} \mathrm{U}$, gross $\alpha$, and gross $\beta$.

Sampling locations were selected to determine the nature and extent of radiogenic contamination to the degree necessary to evaluate risk to human health and to evaluate the feasibility of implementing various remedial alternatives. Sampling locations are shown on Fig. B.6 and include source areas (the S-3 Site, BYBY, and BCBG), exit pathways for 
contaminant migration (Bear Creek and the Maynardville Limestone), and background locations upgradient of any waste disposal sites.

\section{B.4.3 SITE SAMPLING ACTIVITIES}

Table B.11 lists the sampling activities conducted for BCV OU 4. Tables B.12 to B.28 list additional parameters for the BCV OU 4 activities that are referenced in Table B.11. The following subsections briefly describe the RI sampling activities by OU 4 sample group: surface water sampling, continuous surface water monitoring, continuous stormflow monitoring, and continuous groundwater monitoring.

\section{B.4.3.1 Surface Water Sampling}

A continuous automatic sampler was used in conjunction with a bubbler-flow meter to take flow-proportional samples for inorganic and radiological analyte groups. VOC samples cannot be taken using these samplers because of their volatility; instead, VOC samples were taken as grab samples when the flow-proportional samples were retrieved from the automatic sampler.

The flow-proportional samples were composited into a 15-L nalgene carboy packed with ice each day that the sampler was in operation. Samples were taken after completion of the sample program in each sampler was completed. Duplicate samples were taken by installing a second complete automatic sampler at one site in BCV for each sample event and programming the samplers for the same parameters. The duplicate site was changed for each sample event. Equipment rinsates were taken by rinsing a nalgene collection bottle at intervals specified in the work plan. No equipment rinsates were taken for VOC samples because the sample bottle was dipped directly in the stream and no sampling equipment was used. Samples were analyzed for the analytes listed in Table B.12.

As discussed in Sect. B.4.2, the total number of samples collected at each surface water monitoring site was reduced from the SAP-specified number because insufficient equipment was available to sample all sites from the start of the project. The 14 sample sites in BCV comprised of 9 surface water sampling sites (NT-1 through NT-8 and BCK-S3) and 5 surface water sampling sites at springs (SS-1, -4, -5, -6, and -8) (Fig. B.6) were sampled between 12 and 22 times. Each sample represents a unique sampling period, which depended on stream flow at that site. Table B.13 lists the total period over which flow was monitored at each site. Tables B.14 through B.26 list the time periods of sampling for each site, and Figs. B.7 through B.46 show the flow hydrographs for each sample. The one exception to this strategy occurred at SS-8, where the shape of the channel prohibited flume installation or continuous recording of flow. Instead, samples were taken for a fixed time period with fixed time intervals.

Surface water samples were analyzed for inorganics, organics, and radionuclides according to the list of analytes in Table B.12. Although all samples were analyzed for gross $\alpha$, gross $\beta$, and isotopic uranium, only those samples that had gross $\alpha$ activities $>15 \mathrm{pCi} / \mathrm{L}$ and gross $\beta$ activities $>50 \mathrm{pCi} / \mathrm{L}$ were to be analyzed for other isotopes to determine the isotopic nature of the radiological contamination. However, because more samples than anticipated had results greater than the specified screening values, only a representative number of samples were analyzed for isotopes other than uranium. 


\section{B4-4}

Two additional grab samples of surface water were obtained at sites without flow composite samplers (Table B.11). Although these sites were not included in the original SAP, they were added later because the RI technical team determined that samples from the sites were necessary to evaluate the nature and extent of contamination. This decision was based on results from sampling surface water at the planned sites. The two grab samples were performed on April 12, 1994, at BCK S3 and on December 20, 1994, at SS-6b. They were analyzed for the same analytes that the composite surface water samples were analyzed for (Table B.12). The locations of the two grab sample sites are shown on Fig. B.6.

\section{B.4.3.2 Continuous Monitoring of Surface Water}

Surface water stage was recorded continuously for the specified sampling period at each surface water sampling site, except for SS-8 (Table B.11) where the shape of the stream channel prevented flume installation. The stage at each site was measured using a bubbler-flow meter. Portable H-type flumes were installed at each site, except for BCK 9.4 and BCK 12.36. At BCK 9.4, where the stream channel is too large for a portable flume, a rating curve developed by USGS was used to calculate flow. BCK 12.36, where the stream is contained in two culvert pipes, required monitoring the stage in each pipe separately and combining the two flows to derive the total. Flow was calculated for each pipe using the Manning equation for a round pipe (slope $=0.001$ and radius $=2.5 \mathrm{ft}$ ) and a roughness coefficient for corrugated steel pipe (Fig. B.47). Table B.13 lists (1) the time periods over which surface water flow was recorded at each site and (2) the stage-to-flow conversion calculation for each site. The rating curve for BCK 9.47 is listed in Table B.27 and illustrated in Fig. B.48.

Conductivity and temperature were measured at NT-2, NT-3, and SS-6. Although these measurements were not included in the original SAP, they were added later to investigate the relationship between flow rates and concentration. The two parameters were monitored using a probe placed in the tributary or spring, and data were recorded using a datalogger.

Sampling operations at NT-2 revealed that a major outfall from a contaminated groundwater plume occurs in NT-2. The RI technical team decided that the location of the sample site in NT-2 relative to the contaminated groundwater discharge needed to be determined to ensure that the samples from NT-2 were representative of tributary conditions. The location was delineated by measuring the conductivity at 25 locations spaced $15.2 \mathrm{~m}(50 \mathrm{ft})$ apart along NT-2.

\section{B.4.3.3 Continuous Monitoring of Stormflow}

Stormflow tubes were installed at six locations in upper BCV following the construction details in Moore (1992). Water level in these tubes was recorded continuously using a Druck PDCR 940 pressure transducer and an Omnidata Easylogger ${ }^{\mathrm{TM}} 900$ Series datalogger (Table B.11). The sites were visited every 2 weeks to download data and check the calibration of the pressure transducer. Additional visits to each site were made to ensure that battery levels were sufficient for logger operation. The water level in each tube was monitored from March 16 to October 6, 1994.

\section{B.4.3.4 Continuous Monitoring of Groundwater}

Piezometric head, conductivity, and temperature were monitored in each well for the three well groupings located at each of the main waste areas in the valley (Table B.11). Piezometric head was monitored using a pressure transducer that was suspended in the well a distance below 


\section{B4-5}

the water table equal to about half of the pressure transducer's range, thus giving maximum allowance for rising or falling groundwater head. The sites were visited each week to download data, check the calibration of the pressure transducer, and verify that groundwater head had remained within the range of the transducer. Table B.28 lists the monitoring wells in each group and the time frame for monitoring each well. 


\section{B.5 FIELD DATA COLLECTION - FLOODPLAIN SOILS AND SEDIMENTS}

\section{B.5.1 SUMMARY OF FIELD INVESTIGATIONS}

The BCV FPSS field activity addressed the potential impact of contaminant releases from numerous upstream sources and future releases due to erosion of the sediments and soil. Implemented in the Spring of 1995, the investigation consisted of four parts:

- large-scale characterization of floodplain sediments,

- fine-scale characterization of floodplain sediments,

- ecological sampling, and

- $\quad$ stream sediment sampling.

Figure B.49 is a flow chart that outlines the sampling activities for the Bear Creek floodplain investigation.

The BCV FPSS investigation was performed in accordance with the Soil Sampling and Analysis Plan for the Bear Creek Valley Floodplain at the Oak Ridge Y-12 Plant, Oak Ridge, Tennessee (DOE 1995a) and its procedures presented in the Environmental Technical Support Bear Creek Valley Operable Unit 1 and Floodplain Soil Sampling Field Technical Procedures, Rev. 5 (SAIC 1995a). This manual includes procedures consistent with those in the Environmental Surveillance Procedures, Quality Control Program (Kimbrough, Long, and McMahon 1990) and investigation-specific procedures developed for sampling and field data collection methods not addressed by published Energy Systems procedures.

All sample locations for the various media were surveyed by a certified land surveyor, recorded on the BCV map, and marked with a stake and flagging (Fig. B.50). In addition, all locations identified during the field screenings as areas for further investigation (AFIs) were staked, flagged with a unique identifier, and photographed so that they could easily be relocated during the subsequent ecological sampling. Stream sediment sampling locations were marked on the adjacent stream bank and supporting field notes were taken to ensure relocation.

In addition to samples specified in the SAP, three samples identified by Energy Systems Environmental Restoration were taken to further characterize floodplain soils. Other minor changes to the SAP were made during implementation to account for field conditions. These changes are detailed in the field change orders for this project and are summarized in Table B.29.

\section{B.5.2 BACKGROUND DETERMINATIONS (REFERENCE SAMPLES AND VALUES)}

Reference activities and concentrations were established for the list of analytes to provide a basis of comparison with BCV FPSS analytical results. A number of different types of samples were collected outside the Bear Creek floodplain to serve as reference samples. 


\section{B.5.2.1 Floodplain Soil Screening Reference Samples}

Soil screening during the large- and fine-scale characterizations involved PCB, radiometric, and VOC screening techniques. The screening reference value for PCBs was originally set to satisfy risk assessment needs $(0.05 \mathrm{ppm})$, but was reduced to the analytical detection limit of the selected field screening method $(0.5 \mathrm{ppm})$. The screening reference value for $\gamma$ radiation was determined by locating 10 sites outside of the Bear Creek floodplain but within geologic and soil units similar to those of the floodplain (e.g., sites along tributaries to Bear Creek that did not drain waste disposal sites) (Fig. B.50). Three locations at each reference site were sampled to yield a total of 30 measurements. Each sample was collected from depths of 0.0 to $81.0 \mathrm{~cm}(0.0$ to 32.0 in.) bgs and homogenized before screening. The reference value for $\gamma$ radiation used for comparison purposes during subsequent sampling was the $95 \%$ upper confidence level arithmetic average of all readings from all sites.

\section{B.5.2.2 Floodplain Soil Radiological and Chemical Reference Values}

The reference values against which soil radiological and chemical analyses were compared came from the Background Soil Characterization Project (BSCP) (Energy Systems 1993e) for soils of similar type and origin. These reference values were only for inorganic elements and compounds and radionuclides. Organic analytes are assumed not to occur naturally and, therefore, have no reference concentrations.

\section{B.5.2.3 Ecological Reference Samples}

Soil samples were collected from BSCP sites ORR-11, -23 , and -33 for toxicity and geotechnical analysis to supplement the historical chemical and radiological data attained during the BSCP (Energy Systems 1993e). Samples were collected in accordance with procedures described in later sections.

\section{B.5.2.4 Stream Sediment Reference Samples}

Three stream sediment samples were collected for chemical, radiological, and geotechnical analysis from areas in Bear Creek tributaries NT-11, -13 , and -15 not affected by contamination (Fig. B.50). They were collected in accordance with the procedures described in later sections, composited in equal amounts for sediment toxicity testing, and analyzed for the full radiological and chemical analyte list.

\section{B.5.3 SOIL SAMPLING}

\section{B.5.3.1 Large-Scale Characterization of the Bear Creek Floodplain}

The large-scale characterization of floodplain soil was conducted using a sequenced approach:

- Soil samples were collected with a backsaver ${ }^{\text {rd }}$ sampler along the length of Bear Creek, beginning at BCK 12.10 and ending at the intersection between White Wing Road and Oak Ridge Turnpike, and screened. Results of the field screening analyses were compared with predetermined screening criteria (sampling action levels). If a screening sample from any borehole exceeded a sampling action level, that borehole location was classified as an AFI. 
- After the initial screening survey was complete, the sampling strategy team evaluated the screening data to identify those AFIs that needed to be sampled in more detail. Additional soil samples were taken from each AFI, as described below, and submitted for more complete radiological and chemical analysis and toxicity testing. Additional screening tests for uranium were conducted on a split from each sample sent for further analysis.

- After laboratory analytical data were returned, the sampling strategy team used toxicological benchmarks to identify the biota samples to be collected within the vicinity of a subset of the AFIs.

Details of this approach are presented in the following subsections. The large-scale characterization sample location and analysis matrix is shown in Table B.30.

Floodplain soil screening. Thirteen transects in depositional areas of the Bear Creek floodplain were designated for sampling (Fig. B.50). These transects were located in areas of the floodplain most likely to have accumulated sediment and therefore contaminants. The locations were selected by field geologists and were based upon both floodplain morphology and previous sampling experience in BCV. Each transect consisted of a total of six sample locations: one in the creek berms on either side of Bear Creek and two more in the backmarsh on either side of the creek (where adequate floodplain existed on both sides of creek). The backmarsh locations were spaced evenly over the entire width of the floodplain. Each sample location was sampled at three different depth intervals: 0 to $10 \mathrm{~cm}$ ( 0 to 4 in.), 10 to $41 \mathrm{~cm}$ (4 to $16 \mathrm{in}$.), and 41 to $81 \mathrm{~cm}$ (16 to 32 in.) bgs or to sampler refusal, whichever came first.

Samples collected from each interval were homogenized, field-screened for VOCs and for $\gamma$-radiation, and sent to the Y-12 Laboratory for PCB screening. VOCs were screened using a hand-held photoionization detector to detect head-space concentrations of an undisturbed sample, and $\gamma$-radiation was screened using a sodium iodide $(\mathrm{NaI})$ scintillator.

The screening level constituents and values that were selected during the development of the SAP were:

- $\quad$ PCBs - $0.5 \mathrm{ppm}$,

- VOCs $-0.5 \mathrm{mg} / \mathrm{kg}$, and

- $\quad \beta / \gamma$ radioactivity - the lesser of two standard deviations or $100 \mathrm{cpm}$ above background.

The PCB field screening criterion was originally set at $0.5 \mathrm{ppm}$, the detection limit on the lowest PCB screening method available. The screening level was mistakenly changed to $0.05 \mathrm{ppm}$ by team members familiar with human health risk needs and not field screening methods. When the disconnect between the field screening capabilities and risk needs was identified, the project team decided that all AFI and confirmatory samples collected for laboratory analysis would be analyzed for PCBs using a CLP method having a detection level $\leq 0.05 \mathrm{ppm}$.

The radiological sampling action level was defined as $247 \mathrm{cpm}$, which is the lesser of two standard deviations or $100 \mathrm{cpm}$ above the average activity of radiological control samples of uncontaminated soil of similar origin to those found in the Bear Creek floodplain (i.e., local background).

Samples from locations with PCB concentrations $>0.5 \mathrm{ppm}$ (the PCB sampling action level), $\gamma$ radiation $>247 \mathrm{cpm}$, and/or VOC levels $>5 \mathrm{mg} / \mathrm{kg}$ (based on detector resolution) were classified 
as AFIs. These areas were included in a second round of sampling, with samples from depth intervals exceeding the sampling action levels sent for laboratory radiological and chemical analysis (Table B.30).

AFI floodplain soil samples. The sampling strategy team identified the 14 AFIs that needed to be sampled and analyzed in more detail (Table B.30). (The SAP had limited this sampling and analysis effort to a maximum of 26 AFIs, with a maximum of two AFIs located on one transect.)

Sampling crews then returned to the 14 locations classified as AFIs to perform additional sampling. These AFIs were located by referring to the BCV map (Fig. B.50), photographs taken of the locations (e.g., Plates B.1 and B.2), and stakes and flagging used to delineate the AFI during the screening effort. For each AFI, only those depth intervals that exceeded the sampling action levels were sampled.

Sample collection at each AFI required collecting enough adjacent soil samples to provide a sufficient sample volume for laboratory analysis and toxicity testing (Table B.30). Because of the large volume of sample needed from the $0-$ to $10-\mathrm{cm}(0-$ to $4-\mathrm{in}$.) and $10-$ to $41-\mathrm{cm}$ (4- to 16-in.) intervals, multiple samples were collected immediately adjacent to [within a $0.3-\mathrm{m}$ (1-ft) radius of] the location where the sampling action level was exceeded until an adequate sample volume was recovered. The samples were completely homogenized before collection of individual analytical samples.

Sampling began by clearing the forest litter, grasses, and forbs from the ground surface. Initially, samples were collected from the 0 - to $10-\mathrm{cm}(0-$ to 4 -in.) deep interval using a hand auger. Samples for VOC analysis were taken directly from the first auger bucket from each interval sampled. The remaining sample was homogenized and the resulting sample was split: one split was sent for laboratory radiological and chemical analysis, and the other split was used for toxicity testing. Roots, rocks, and invertebrates were removed from the sample and returned to the sample location.

Following sampling of the initial $0-$ to $10-\mathrm{cm}(0-$ to 4 -in.) interval, two more intervals were sampled at each AFI, as appropriate: $10-$ to $41-\mathrm{cm}$ (4- to 16-in.) interval and 41- to $81-\mathrm{cm}$ (16- to 32-in.) interval. The 10- to $41-\mathrm{cm}$ (4- to 16-in.) interval was homogenized and split as described for the $0-$ to $10-\mathrm{cm}(0-$ to $4-\mathrm{in}$.) interval. One split was sent to a laboratory for more complete radiological and chemical analysis, and the other split was composited proportionally with a split from the 0 - to $10-\mathrm{cm}(0-$ to $4-\mathrm{in}$.) interval [composite was based on volume such that one part from the 0 -to $10-\mathrm{cm}(0-$ to 4 -in.) interval and three parts from the $10-$ to $41-\mathrm{cm}$ (4- to 16-in.) interval were combined to yield a sample representative of the 0 - to $41-\mathrm{cm}(0-$ to 16 -in.) interval] and homogenized for use in toxicity testing. The $41-$ to $81-\mathrm{cm}$ (16- to 32-in.) interval was sampled only when the sampling action level was exceeded in that interval during screening and if the $0-$ to $10-\mathrm{cm}(0-$ to 4 -in.) and $10-$ to $41-\mathrm{cm}$ (4- to 16-in.) interval of the same boring did not exceed sampling action levels. The $41-\mathrm{cm}$ to $81-\mathrm{cm}(16-$ to $32-\mathrm{in}$.) interval was not tested for toxicity but was homogenized and submitted to the laboratory for more detailed radiological and chemical analyses.

The analytes for chemical analysis and the isotopes whose activities were determined during radiological analysis are listed in Table B.31. Gamma radiation field screening analyses were performed on splits from all soil samples that were sent to the laboratory for analysis to allow correlation of laboratory results with the field screening techniques. In addition, an aliquot of each sample sent for laboratory radiological and chemical analysis was sent to a geotechnical laboratory 
for analysis of moisture content, $\mathrm{pH}$, particle size distribution, and organic content using American Society for Testing and Materials (ASTM) or Methods of Soil Analysis procedures.

Toxicity testing was conducted on a maximum of two samples per transect from 11 AFIs. Toxicity tests were not performed on transects TS11 and TS12 because no contaminants were found above background concentrations in these transects. Sample locations for toxicity tests were determined after a review of screening data with emphasis on PCB results. PCBs were used to select the toxicity test sampling locations because they are more toxic to earthworms and vegetation than radionuclides or VOCs. If no samples in a transect exceeded the detection limit for the PCB screening test, then selection of samples for toxicity testing was based on radiological results. Concern for VOCs in toxicity tests is minimal. The procedures for toxicity testing are described in two separate addendums to the Soil Sampling and Analysis Plan for the Bear Creek Valley Floodplain at the Oak Ridge Y-12 Plant, Oak Ridge, Tennessee (DOE 1995a). Samples to be tested for toxicity to earthworms and plants were sieved coarsely (i.e., through a 1-cm mesh or screen) to remove pebbles, twigs, etc.

Biota sampling at AFIs. Biota were sampled at the AFIs to determine the degree of bioaccumulation of contaminants in small mammals and the potential for accumulation or biomagnification into higher trophic levels. Chemical analyses of soil samples were used to identify locations where small mammals, earthworms, and vegetation would be collected and the contaminants for which they would be analyzed.

Benchmarks for exposure of small mammals to soil contaminants were derived by assuming that contaminants are ingested directly and are transferred from soil to food. Exposure parameters for white-footed mouse (Peromyscus leucopus) and short-tailed shrew (Blarina brevicauda) included daily soil and food ingestion rates (Sample and Suter 1994) and soil-to-plant and soil-toearthworm uptake factors taken from the Reservation-wide ERA (DOE 1995b). Toxicity benchmarks (Opresko, Sample, and Suter 1994) were used to compute soil exposure benchmark concentrations. Observed soil concentrations were compared to the calculated exposure benchmarks to identify sites in the AFIs where small mammals were exposed to potentially toxic contaminant concentrations. Any site where a contaminant concentration exceeded background and a screening benchmark for mice or shrews became a candidate for small mammals sampling. Because of the relatively large ranges of small mammals, only one trapping system was set up per soil transect. Small mammals were collected at transects G01 (5 individuals), G02 (5 individuals), G03 (3 individuals), G04 (4 individuals), and G07 (3 individuals).

Soil exposure benchmarks for earthworms were taken from Will and Suter (1994). Sites that exceeded background and the benchmark value for a contaminant became candidates for earthworm sampling. A team of scientists reviewed the screening results to determine the maximum number of samples to be taken and the optimal sampling locations. Because one purpose of sampling was to develop site-specific bio-uptake factors, sampling sites were chosen to provide as wide a range of soil exposure concentrations as possible. Earthworm samples were collected at transects G01 (2 samples), G02 (1 sample), G03 (2 samples), G04 (2 samples), G07 (2 samples), and G09 (1 sample). Plants were sampled in the vicinity of AFIs where earthworm samples were collected. Browse, canopy, and herbaceous vegetation (two samples of each for every earthworm sample collected) were collected at each site.

Reference samples of small mammals (16), earthworms (3), and plants (9 each of browse, canopy, and herbaceous vegetation) were collected at sites where the soil was similar to that in the AFIs. 
Biota were analyzed only for contaminant groups (e.g., inorganics, PCBs) for which at least one soil exposure benchmark was exceeded. Plants were analyzed for inorganics and radionuclides, whereas earthworms and small mammals were analyzed for inorganics, radionuclides, and PCBs.

Confirmatory samples. Confirmatory sampling was conducted at $15 \%$ of the sample locations not classified as AFIs (Fig. B.50, Table B.30). Locations and intervals to be sampled were determined by the sampling strategy team on the basis of the field screening and analytical data. Of the confirmatory samples, $50 \%$ were collected from the $0-$ to $41-\mathrm{cm}$ (0- to $16-\mathrm{in}$.) interval, represented by a composite sample from the 0 - to $10-\mathrm{cm}(0-$ to $4-\mathrm{in}$.) and $10-$ to $41-\mathrm{cm}$ (4- to $16-$ in.) interval, and $50 \%$ from the $41-$ to $81-\mathrm{cm}$ (16- to 32-in.) interval. The sampling plan for the confirmatory soils was identical to that for sampling the AFIs. Biota sampling at confirmatory locations was conducted when the laboratory radiological or chemical analyses of soils demonstrated that toxicological benchmarks for small mammals had been exceeded.

Additional floodplain soil samples. In addition to samples defined in the SAP, three additional samples identified by Energy Systems Environmental Restoration were taken to further characterize floodplain soils:

- a stream sample taken from a quiescent pool in the tributary draining the White Wing Gap Scrapyard,

- $\quad$ surface soil composite collected from previously unknown source area adjacent to the Rust Spoil Area (subsequently named the Bear Creek Road Debris Burial Area), and

- $\quad$ surface soil composite collected from previously unknown source area adjacent to West End Tank Farm (subsequently named the Creekside Debris Burial Area) (Appendix A, Table A.1).

All three samples were analyzed only for chemical and radiological constituents. No toxicity, geochemical, or $\gamma$ screening analyses were performed. Because of the high radiological readings for the composite from the Bear Creek Road Debris Burial, just west of Rust Soil Area, the composite was diluted with lower-activity soil from the same area at a ratio of one part elevated-activity soil to four parts lower-activity soil to enable shipment to the laboratory.

\section{B.5.3.2 Fine-Scale Characterization of the Bear Creek Floodplain}

The fine-scale characterization of the Bear Creek floodplain was conducted because, at location BCK 4.70, the two primary contaminants, uranium and PCBs, were found to be concentrated near the creek's berm and within discrete strata in the floodplain (Turner et al. 1991) (Fig. B.50). To confirm this finding and to characterize the extent to which the pattern exits throughout the whole floodplain, the fine-scale characterization strategy was devised. In addition to defining the locations of contaminants in the soil column, this characterization was also valuable in confirming the findings of the large-scale characterization and in providing information for understanding the mechanisms for contaminant transport and deposition. The sampling strategy team had the option of reevaluating and modifying the characterization strategy if laboratory results indicated that uranium and PCBs were not the only contaminants of potential concern. Table B.32 shows the fine-scale and stream sediment sample locations and analysis matrix.

The investigation began at BCK 4.70 with a hand-dug, sediment profile excavation into the floodplain in the vicinity of coring sites W1 and W2 (Turner et al. 1991). Excavation dimensions 
were $3 \times 1 \times 1 \mathrm{~m}(9.8 \times 3.3 \times 3.3 \mathrm{ft})$. Each layer was described in sufficient detail to allow layers of similar type and origin to be recognized. Characteristics included in the profile description were color; relative amounts of coarse, fine, and organic material; depth in the profile; and general descriptions of overlying and underlying layers. Discrete layers were then sampled and screened for $\gamma$ radioactivity, PCBs, and VOCs, as in the large-scale characterization. If any layer exceeded the sampling action levels for $\gamma$ radiation, PCBs, or VOCs, then sufficient sample for radiological and chemical analysis was collected from the exposed excavation walls.

After the sediment profile excavation at BCK 4.70 was completed, a modified version of the excavation was used to investigate 17 locations in the Bear Creek floodplain between BCK 1.0 and BCK 11.09 (Fig. B.50, Table B.32). A soil sample was taken on or proximal to the berm to a depth equal to the bottom of the creek channel, a maximum of $1 \mathrm{~m}(3.3 \mathrm{ft})$, or sampler refusal, whichever came first. Sample layers were inspected for similarities to those recognized as contaminant-bearing layers during the sediment profile characterization at BCK 4.70. Any layers that matched the physical descriptions were screened for $\gamma$ radiation, PCBs, and VOCs. If any layer exceeded the sampling action levels, then sufficient sample was collected from the layer for laboratory analysis of the radiological and chemical constituents. In addition, the sample location was classified and subsequently investigated as an AFI. This investigation included soil samples for chemical and radiological analysis [0 to $10 \mathrm{~cm}$ ( 0 to $4 \mathrm{in}$.), 10 to $41 \mathrm{~cm}$ (4 to $16 \mathrm{in}$.), and 41 to $81 \mathrm{~cm}$ (16 to $32 \mathrm{in}$.) as appropriate], toxicity tests, and biota samples for ecological testing.

All soil sampling for the BCV FPSS investigation was conducted using applicable, media-specific standard operating procedures provided or approved by $\mathrm{Y}-12$ Plant Environmental Restoration and consistent with the Energy Systems Environmental Surveillance Procedures, Quality Control Program (Kimbrough, Long, and McMahon 1990). Any deviations from these operation procedures were documented on a field change order form as outlined in the Field Quality Assurance Project Plan for the SAP.

Soil screening samples were collected with a 3.2-cm (1.25-in.) inside-diameter backsaver ${ }^{\text {Tw }}$ sampler. Bulk soil sampling in the floodplain was conducted using a 7.6-cm (3-in.) hand auger in accordance with Energy Systems procedures (Kimbrough et al. 1990). Additional technical procedures used during the course of the BCV FPSS investigation are presented in Table B.33.

\section{B.5.4 BEAR CREEK STREAM SEDIMENT CHARACTERIZATION}

Whole sediment samples from 17 locations along Bear Creek and from tributaries and springs that feed Bear Creek were collected from specified locations in the field and analyzed for specified constituents (Fig. B.50, Table B.31). They were also tested at the ORNL Environmental Sciences Division Aquatic Toxicology Laboratory for toxicity to surrogate benthic invertebrates. Sample splits were sent to a second laboratory for bulk sediment characteristics. Data obtained from the toxicity tests were used in the BCV Environmental Risk Assessment as one of several lines of evidence to evaluate the ecological condition of $\mathrm{BCV}$.

All stream sediment sampling for the BCV FPSS investigation was conducted using, as applicable, media-specific standard operating procedures provided or approved by Y-12 Plant Environmental Restoration and consistent with the Energy Systems Environmental Surveillance Procedures, Quality Control Program (Kimbrough, Long, and McMahon 1990) and with Region IV Environmental Compliance Branch Standard Operating Procedures and Quality Assurance 
Manual (EPA 1991). Any deviations from the standard operating procedures were documented on a field change order form as outlined in the Field Quality Assurance Project Plan for the SAP.

Specifically, stream sediment sampling in Bear Creek was conducted using a 1-L, hand-operated Ponar-style dredge. Sampling was conducted in accordance with Energy Systems procedure ESP-304-1 (Kimbrough, Long, and McMahon 1990). Additional information for stream sediment sampling procedures using the Ponar dredge can be found in SOP-29 of the Environmental Sciences Division Toxicology Laboratory Quality Assurance Manual-Collection of Surface Sediment Samples. Other technical procedures to be used during the course of the BCV FPSS investigation are presented in Table B.33.

One 3-L sample volume was collected at each designated stream sediment sampling site. In the field, large gravel and debris were removed from the whole sediment samples that were homogenized. One 1-L split portion (for toxicity testing) was placed into labeled 1-L, high-density polyethylene sample containers covered with $2.5 \mathrm{~cm}$ (1 in.) of stream water and placed on ice. Another 1-L split portion (for bulk analysis) was placed into containers with volumes appropriate for use in laboratory analysis and stored on ice. All samples were shipped on ice to either the laboratory for chemical and radiological analysis or to the Environmental Sciences Division Aquatic Toxicology Laboratory for toxicity testing. In addition, a 1-L sample split was sent to a geotechnical laboratory for analysis of moisture content, $\mathrm{pH}$, particle size distribution, and organic content using ASTM or Methods of Soil Analysis procedures.

\section{B.5.5 SOURCE TERM ECOLOGICAL CHARACTERIZATION}

Comprehensive characterization of the full ecological impact of any potential contaminants in $\mathrm{BCV}$ required an investigation of the impact of potential source areas. Most of the source areas for the Bear Creek drainage reside in OU 1. The RI for OU 1 was conducted during the Fall of 1994, prior to the BCV FPSS. Hence, by the time the BCV FPSS investigation was under way, many source soil samples had been collected and sent to the laboratory for radiological and chemical analyses.

Biota were sampled at the source areas to determine the degree of bioaccumulation of contaminants in small mammals and the potential for accumulation or biomagnification into higher trophic levels. Chemical analyses of soil samples were used to identify locations where small mammals, earthworms, and vegetation would be collected and the contaminants for which they would be analyzed. Identification of potential locations was carried out as described in Sect. B.5.3.1 (Biota sampling at AFIs), and included evaluation of the accessibility of potential sites. No intrusive sampling was done in capped sections of the source areas.

Small mammals were collected at the BYBY site BY17 (4 individuals). Earthworm samples were collected at BYBY sites BY17 (1 sample) and BY22 (1 sample). Plants were sampled in the vicinity of AFIs where earthworm samples were collected. Browse, canopy, and herbaceous vegetation (two samples of each for every earthworm sample collected) were collected at each site. Reference samples of small mammals (16), earthworms (3), and plants ( 9 each of browse, canopy, and herbaceous vegetation) were collected at sites where the soil was similar to that in the AFIs.

Biota were analyzed only for contaminant groups (e.g., inorganics, PCBs) for which at least one soil exposure benchmark was exceeded. Plants were analyzed for inorganics and 
radionuclides, whereas earthworms and small mammals were analyzed for inorganics, radionuclides, and PCBs.

Other sample locations in OU 1 that were identified by this screening process were not sampled for biota. Screening benchmarks for earthworms and mice were not exceeded at the S-3 Ponds, OLF, or SL 1; at the BCBG area, benchmarks were not exceeded for mice and were exceeded at only one location for earthworms. In the case of the S-3 functional area, the soil boring location had subsequently been converted to a gravel parking area, which did not provide suitable habitat for plants or small mammals. Samples that exceeded screening benchmarks for shrews at locations in the BCBG functional area and at most locations in the BYBY functional area were not taken because access to those locations had been restricted because of potential radiological hazards to site workers. Toxicity testing was not done on soils from the source areas because of health and safety concerns for laboratory personnel. 


\section{B.6 FIELD DATA COLLECTION — BIOTA SAMPLING}

BCV biota sampling addressed the impact of contaminant releases from numerous sources on biota in source areas and in the BCV floodplain. The data were also used to evaluate potential exposure of herbivores, insectivores, omnivores, and wide-ranging predators to contaminants in their food.

\section{B.6.1 PROCEDURES}

Any site where a contaminant concentration exceeded background and a screening benchmark for mice or shrews became a candidate for terrestrial biota sampling. Benchmarks for exposure of small mammals to soil contaminants were derived by assuming that contaminants are ingested directly and are transferred from soil to food. Exposure parameters for white-footed mouse (Peromyscus leucopus) and short-tailed shrew (Blarina brevicauda) included daily soil and food ingestion rates (Sample and Suter 1994) and soil-to-plant and soil-to-earthworm uptake factors taken from the Reservation-wide ERA (DOE 1995b). Toxicity benchmarks (Opresko, Sample, and Suter 1994) were used to compute soil exposure benchmark concentrations. Observed soil concentrations were compared to the calculated exposure benchmarks to identify sites in the AFIs where small mammals were exposed to potentially toxic contaminant concentrations. Because of the relatively large ranges of small mammals, only one trapping system was set up per soil transect.

The collection of biota samples and field data followed procedures outlined in the BCV OU 4 RI Work Plan (DOE 1993) and presented in Environmental Technical Support for Bear Creek Valley Operable Unit 4 Remedial Investigation Field Activities Manual (SAIC 1994b). This manual includes procedures consistent with those in Environmental Surveillance Procedures, Quality Control Program (Kimbrough, Long, and McMahon 1990) and investigation-specific procedures developed for sampling and field data collection methods not addressed by published Energy Systems procedures. Procedures used to sample biota are listed in Table B.34.

\section{B.6.1.1 Small Mammals}

Small mammals were collected using snap-traps or Sherman live traps set along transects identified as AFIs. Traps were baited with peanut butter and rolled oats and were checked daily. The number of samples collected at each transect is presented in Table B.35.

The species, age, and sex of each sample were determined, and body measurements (weight, tail length, head/body length) were taken. Whole-body samples were washed with nonionic detergent to remove external contamination and were thoroughly rinsed with deionized water. Samples were stored at $-20^{\circ} \mathrm{C}$ in a freezer prior to submission for laboratory analysis.

\section{B.6.1.2 Earthworms}

Earthworms were sampled by using a mustard solution (Gunn 1992) as an expellant (Bechtel 1994). This method is nonintrusive, minimizes personnel exposure to contaminants, and is not as labor intensive as hand sorting. A mustard and water suspension was applied slowly to the ground surface using a watering can to obtain even spread and minimal ponding. Surfacing earthworms were collected with forceps until no additional earthworms emerged ( $\sim 20$ to $25 \mathrm{~min}$ ). 
Earthworms were rinsed in the field with deionized water to remove soil and expellant, and put in a Petri dish that was then sealed and put in a cooler. All earthworms were kept moist, intact, and alive, and handling was minimized. Parameters recorded for each earthworm included sample location, sample site, date collected, total weight of earthworms collected at each site (measured in the laboratory), presence of clitellum, and general physical condition including overt signs of lesions or other abnormalities. In addition, a running total of earthworms collected since the time expellant was added (in 2-min intervals) was recorded. All earthworms were maintained in the laboratory for $3 \mathrm{~d}$ to allow voiding of intestinal contents (depuration) before being analyzed for radiological and chemical parameters.

\section{B.6.1.3 Vegetation Sampling}

Vegetation collected included tree foliage, herbaceous ground cover (i.e., grasses and forbs) and woody browse plants [e.g., Japanese honeysuckle (Lonicera japonica)]. Vegetation was collected from the same locations as earthworms. One composite sample of each type of vegetation was collected at each location. Leaves from a given tree were counted as a single sample. Ground cover and woody browse were sampled by compositing both leaves and stems at each sampling point.

Vegetation samples were rinsed with deionized water in the laboratory to remove external contamination, air dried, and stored at $-20^{\circ} \mathrm{C}$ in a freezer prior to submission for laboratory analysis.

\section{B.6.1.4 Fish Sampling}

Field data collection for fish was not done as a part of the RI. Instead, historical data reported by the Bear Creek Biological Monitoring Program (Hinzman et al. 1995) were used. Sampling locations for this study are shown in Fig. B.50.

\section{B.6.2 SOURCE TERM ECOLOGICAL CHARACTERIZATION}

Comprehensive characterization of the full ecological impact of any potential contaminants in $\mathrm{BCV}$ required an investigation of the impact of potential source areas. Most of the source areas for the Bear Creek drainage reside in OU 1. The RI for OU 1 was conducted during the Fall of 1994, prior to the BCV FPSS. Hence, by the time the BCV FPSS investigation was under way, many source soil samples had been collected and sent to the laboratory for radiological and chemical analyses.

Biota were sampled at the source areas to determine the degree of bioaccumulation of contaminants in small mammals, earthworms, and plants and the potential for accumulation or biomagnification into higher trophic levels. Chemical analyses of soil samples were used to identify locations where small mammals, earthworms, and vegetation would be collected and the contaminants for which they would be analyzed. Identification of potential locations was carried out as described in Sect. B.5.3.1 (AFI floodplain soil samples), and included evaluation of the accessibility of potential sites. No intrusive sampling was done in capped sections of the source areas.

The numbers of samples and the locations at which they were taken are presented in Table B.35, and sample locations are also indicated in Figure B.3. Small mammals were collected 
at the BYBY site BY17 (4 individuals). Earthworm samples were collected at BYBY sites BY17 (1 sample) and BY22 (1 sample). Plants were sampled in the vicinity of AFIs where earthworm samples were collected. Browse, canopy, and herbaceous vegetation (two samples of each for every earthworm sample collected) were collected at each site.

Biota were analyzed only for contaminant groups (e.g., inorganics, PCBs) for which at least one soil exposure benchmark was exceeded. Plants were analyzed for inorganics and radionuclides, whereas earthworms and small mammals were analyzed for inorganics, radionuclides, and PCBs.

Other sample locations in OU 1 that were identified by this screening process were not sampled for biota. Screening benchmarks for earthworms and mice were not exceeded at the S-3 Ponds, OLF, or SL 1; at the BCBG area, benchmarks were not exceeded for mice and were exceeded at only one location for earthworms. In the case of the S-3 functional area, the soil boring location had subsequently been converted to a gravel parking area, which did not provide suitable habitat for plants or small mammals. Samples that exceeded screening benchmarks for shrews at locations in the BCBG functional area and at most locations in the BYBY functional area were not taken because access to those locations had been restricted because of potential radiological hazards to site workers. Toxicity testing was not done on soils from the source areas because of health and safety concerns for laboratory personnel.

\section{B.6.3 BIOTA SAMPLING AT FLOODPLAIN AFIs}

Biota were sampled at the floodplain AFIs to determine the degree of bioaccumulation of contaminants in small mammals and the potential for accumulation or biomagnification into higher trophic levels. Chemical analyses of soil samples were used to identify locations where small mammals, earthworms, and vegetation would be collected and the contaminants for which they would be analyzed.

The numbers of samples and the locations at which they were taken are presented in Table B.35, and sample locations are also indicated in Figure B.50. Small mammals were collected at transects T01 (5 individuals), T02 (5 individuals), T03 (3 individuals), T04 (4 individuals), and T07 ( 3 individuals).

Soil exposure benchmarks for earthworms were taken from Will and Suter (1994). Sites that exceeded background and the benchmark value for a contaminant became candidates for earthworm sampling. A team of scientists reviewed the screening results to determine the maximum number of samples to be taken and the optimal sampling locations. Because one purpose of sampling was to develop site-specific bio-uptake factors, sampling sites were chosen to provide as wide a range of soil exposure concentrations as possible. Earthworm samples were collected at transects T01 (2 samples), T02 (1 sample), T03 (2 samples), T04 (2 samples), T07 (2 samples), and T09 (1 sample). Plants were sampled in the vicinity of AFIs where earthworm samples were collected. Browse, canopy, and herbaceous vegetation (two samples of each for every earthworm sample collected) were collected at each site.

Biota were analyzed only for contaminant groups (e.g., inorganics, PCBs) for which at least one soil exposure benchmark was exceeded. Plants were analyzed for inorganics and radionuclides, whereas earthworms and small mammals were analyzed for inorganics, radionuclides, and PCBs. 


\section{B.6.4 ECOLOGICAL REFERENCE SAMPLES}

Soil samples were collected from BSCP sites ORR-11, -23 , and -33 for toxicity and geotechnical analysis to supplement the historical chemical and radiological data attained during the BSCP (Energy Systems 1993e). Samples were collected in accordance with procedures described in later sections.

Reference samples of small mammals (16), earthworms (3), and plants (9 each of browse, canopy, and herbaceous vegetation) were collected at sites where the soil was similar to that in the AFIs. 


\section{B.7 GWQR DATA QUALITY ASSESSMENT}

\section{B.7.1 PURPOSE}

This section of the RI report serves two purposes:

- document acceptance criteria for groundwater analytical results developed during BCV RI planning, identifying specific areas of uncertainty relative to these criteria; and

- assess the level of confidence associated with the GWPP groundwater geochemistry database, identifying specific areas of uncertainty (e.g., holding times, reporting units, and analytical method types).

The largest area of uncertainty in the GWPP data in BEIDMS is caused by the lack of laboratory quality control data and associated usability flags that would more adequately confirm data quality. These data would include such items as laboratory control samples, surrogate spike results, and matrix spike results. This uncertainty, however, can be largely overcome by using the available data in an informed manner. The massive volumes of data obtained through long-term monitoring over multiple years and the general consistency of results reduce the uncertainty.

\section{B.7.2 SCOPE}

This data quality assessment focuses on the Y-12 Plant groundwater data for 1986 through 1994, published in the annual GWQRs (e.g., HSW 1995).

\section{B.7.3 RI DATA QUALITY OBJECTIVES}

Objectives for data quality for BCV RI are summarized below. Data not meeting these criteria were determined to be unusable for the RI. As a result, 2,000 of 147,750 (1.3\%) data records from the Y-12 Plant groundwater database have been eliminated from consideration. This dataset meets overall completeness objectives, except for radiochemical isotopic data. While areas of uncertainty exist, overall data quality is acceptable and is described in Sect. B.7.4.

\section{B.7.3.1 Screening Criteria}

To initiate the data screening process, certain steps were taken to eliminate non-representative data:

- Mis-identified data. Information derived from GWPP documents and individuals who participated in GWPP sampling activities show two mis-identified samples: 931108-106 from SS-6 and 931108-110 from BCK 9.4. These two samples are reported to have been switched in the laboratory and thus were eliminated from the RI dataset.

- Well location. Based on their locations, 266 monitoring wells located in the BCV hydrogeological regime were identified for use in the BCV RI. 
- Rule of four. Characterization of current conditions in the Bear Creek hydrology requires use of data that are as complete and recent as possible. Thus, a screening criterion known as the rule of four was applied to data collected from each well.

GWPP sampling strategy from 1986 to 1990 involved quarterly sampling of all wells located within or near the source of the contaminant plume. After 1990, sampling focused on wells located at the periphery of the contaminant plumes, with few wells located in the center of plumes being sampled.

The rule of four selects data in the following manner: if a well was sampled at least four times since 1990, only those data collected since 1990 were considered during the investigation; if a well was sampled less than four times since 1990, all available data from those wells were used. Appendix D, Table D.6, lists all wells identified for use in the BCV $\mathrm{RI}$ along with the range of sampling dates available, well depth, and the source of data used in the investigation (1990 through 1994 or all available).

After this initial data screening process was completed, more specific criteria were used to eliminate (1) additional nonrepresentative and/or potentially inaccurate data and (2) data that do not meet sensitivity requirements established for the BCV RI. These criteria include:

- ICP vs. GFAA. The GWQR dataset contains metals values determined by inductively coupled plasma (ICP) methodologies and graphite furnace atomic absorption (GFAA) methodologies. A decision was made to retain only one set of metals data, as described in Sect. B.7.4.3, for inclusion in the BCV RI working dataset.

- Elevated detection limits. Nondetected values for diluted samples having quantitfication limits greater than five times the associated method detection limit were determined to be unusable for the BCV RI. Application of this criterion eliminated a total of 897 inorganic records $(\sim 1.3 \%)$ and 755 organic records $(0.9 \%)$.

- High suspended solids or interfering elements. Results from wells with high total suspended solids, high sodium, and/or high chloride, as determined by GWQR, were also eliminated from consideration (See Sect. B.7.4).

- Dissolved vs. total. Where the percent difference between dissolved (filtered) metals concentrations and total (unfiltered) metals concentrations was $\geq 10 \%$, metals data for that element were omitted.

- Charge balance. For the purposes of the BCV RI, an acceptance limit for ionic charge balance of $20 \%$ was determined. Any record with a calculated charge balance $>20 \%$ was not considered during the investigation.

- Radiochemical screening criteria. Radiochemical counting uncertainties or minimum detectable activities exceeding the corresponding analytical value were determined to be unusable for the RI. Procedures used to collect historical radiological data as a best management plan did not specify the count times and associated minimum detectable activities/counting errors that were suitable for baseline risk assessment. Consequently, $80 \%$ of historical radiochemical data were determined unusable for the RI. In addition, the remaining data collected (H\&R Technical Associates, Inc. 1995) were intended to provide a radiochemical review of selected isotopic data to determine if all isotopes of concern were 
being evaluated. This did not require screening or validation as part of the evaluation and was therefore not useable in the RI.

Based on the above data, the decision was made to eliminate all radiochemical data from consideration and retain only gross $\alpha$ and gross $\beta$ determinations that meet the above criteria. A supplemental sampling program was designed and implemented to provide new radiochemical isotopic data for use in the RI.

\section{B.7.4 DATA UNCERTAINTY}

This section uses sensitivity, precision, accuracy, representativeness, completeness, and comparability (SPARCC) parameters to assess data uncertainty and usability relative to the criteria presented in Sect. B.7.3. The assessment is limited by available information and can provide only a general overview of data quality. Individual results should be evaluated for their usability by comparing them to other relevant data and considering the cautions noted in this report.

Most of the uncertainty associated with the GWPP data can be attributed to the fact that the intended purpose of the GWPP data was monitoring, not RI support. Data collected for the GWPP did not undergo CLP-type data validation and are not stored with their corresponding laboratory quality control data.

\section{B.7.4.1 Sensitivity}

Determination of minimum detectable values allows an investigation to assess the relative confidence that can be placed in a value relative to the magnitude or level of analyte concentration observed. The closer a measured value comes to the minimum detectable concentration, the less confidence and more variation the measurement will have.

\section{Sensitivity-based RI Criteria}

Applicable sensitivity-based criteria established for acceptable data include the "five times" rule, which eliminates from consideration any data that are reported as a "less than" or "non-detected" value for which the associated number exceeds five times the associated quantitation limit.

Of the 897 inorganic results eliminated from consideration according to this criterion, more than half (460) were from the S-3 aggregate ( $5 \%$ of the S-3 data). These elevated quantitation limits occurred primarily in sulfate data from wells GW-244, -245, -246, $-247,-276,-277$, and -346. Antimony, beryllium, chloride, cobalt, copper, iron, molybdenum, nickel, sulfate, thorium, and vanadium in wells GW-101, $-243,-345,-526,-537$, and -615 were also eliminated based on this criterion.

Another 227 inorganic results were omitted from consideration in the BCBG aggregate based on this criterion. These results occurred primarily in wells GW-117, $-118,-119,-626,-625$, and -705. An additional 22 results were eliminated from the OLF aggregate, and 188 from the Maynardville groundwater aggregate (Table D.6), predominantly from wells GW-710 and -711.

A total of $755(0.9 \%)$ nondetected organic values were considered unusable by the investigation based on the "five times" criterion. Of the 755 values, 236 were from well GW-243 
at the S-3 Site. Contaminant levels associated with this source would require dilution of samples to bring particular analytes into the quantitation range of the laboratory instrument, thus raising the associated detection limits for other analytes. follows:

Within the BCBG aggregate, 18 organic data values were omitted from consideration, as

- one sample each from GW-014, -288 , and -289 ;

- two samples each from GW-027, $-046,-259$, and -624 ;

- three samples from GW-626; and

- four samples from GW-623.

Other organic data eliminated from consideration based on this criterion included 27 results in the OLF aggregate (sample 891206-037 from GW-376) and 21 results primarily from GW-225 (sample 911102-025) in the Maynardville aggregate.

Application of sensitivity-derived criteria also resulted in the elimination of all GWPP radiochemical isotopic data from consideration during the $\mathrm{RI}$. If an associated gross $\alpha$ or gross $\beta$ minimum detectable activity level exceeded a sample value, data were further rejected for use in the investigation.

\section{Blanks}

Overall project sensitivity can be further evaluated by reviewing field blank information. These actual sample analyses may provide a comprehensive look at the combined sampling and analysis sensitivity attained by the project. Quality control blanks for the program, collected from 1991 to 1993, included (1) equipment rinsate blanks, (2) trip blanks, (3) field blanks, and (4) laboratory volatile blanks. Data for these types of samples analytical detection levels cannot be assumed for all results, and some data may require higher detection levels to be assigned. As a result, positively reported data associated with contaminated blanks were evaluated for false positive results.

Equipment rinsate samples were collected by pouring water over decontaminated sampling equipment. These samples were then analyzed for VOCs, metals, and radiochemical parameters. These blank samples were not analyzed for SVOCs, pesticide/PCBs, or indicator parameters (e.g., alkalinity, anions, pH). For a complete list of methods by year, refer to GWQR reports (e.g., HSW 1995) and Table B.36. VOC analytes were not detected in these rinsates at significant or consistent levels, indicating the decontamination process was effective for these compounds. Metals contaminants that were routinely identified included aluminum, boron, calcium, iron, magnesium, manganese, silicon, sodium, strontium, and zinc. These constituents were recognized to be associated with the deionized water used as the source for the rinsate samples. The deionized source was located in an active laboratory facility at the Oak Ridge K-25 Site where columns were not changed frequently enough to maintain high-quality deionized water. This problem was resolved in 1993 when the source unit was moved to a "clean area," and a more stringent maintenance schedule was instituted. Equipment rinsates were planned to be collected during each sampling event consisting of no more than 10 wells (generally). Equipment rinsates were collected at a rate of 13 to $17 \%$ across the three years, which would seem to be consistent with the RI DQOs. 
Trip blanks were to be sent with each batch of samples for VOC analysis. In 1991, 271 trip blanks were collected across 238 dates; in 1992, 258 trip blanks were collected across 237 sampling dates; and in 1993, 250 trip blanks were collected across 217 sampling dates. These data indicate that a sufficient number of trip blanks were collected during these three years to document contamination during transport of samples.

Field quality control samples appear to have been collected at rates that provide an adequate description of potential artifact contamination. The current dataset contains flags that indicate the presence of volatiles contamination.

Laboratory volatile blanks are presumed to have been required at a rate of at least 1 in 20 ( $1 / 20$ ) environmental samples, or $5 \%$. Such blanks were actually reported at a rate of 23 to $27 \%$, indicating that some sample delivery groups contained $<20$ samples.

\section{Data Usability}

\section{Nondetected analytes}

Nondetected analytes or data that are flagged " $<$ " or " $U$ " must be used accordingly. Both flags mean "less than" the associated value; for example, a value reported " $<20.0$ " or " $20.0 \mathrm{U}$ " would be interpreted "less than" 20 or as not detected within the detection limit of 20 . The inability to detect a particular analyte in a sample, however, does not necessarily mean the analyte is not present. Each analytical method has a method detection limit; concentrations below this limit cannot be detected with any confidence. For a complete list of analytes and detection limits, refer to Tables B.37, B.38, B.39, and B.40. Thus, although undetected, an analyte could be present in a concentration less than the detection limit. In the above example $(<20.0$ or $20.0 \mathrm{U})$, the analyte could be present at less than 20 units. This concept becomes especially important when an "action" or "trigger" level (the level at which contamination is considered to be present) is exceeded by the associated value. If the associated value (e.g., $<20.0)$ is greater than an "action" level (e.g., 10.0), contamination may or may not be present above the action level.

In the statistical analysis of data, such values can be treated several ways. They can be considered " 0 ," or $1 / 2$ the detection limit, or even the detection limit. In calculating statistics for the groundwater aggregates, nondetects were set to $1 / 2$ the detection limit except for radionuclide analyses. Regardless of the statistical use, the user must interpret individual data points according to the above information.

\section{Positive identification}

For a single sample to be considered positive, the Environmental Protection Agency (EPA) recommends that the value of the reported concentration should be significantly greater than any reported in the background samples or field quality assurance samples. EPA further defines "significant" as follows:

- For constituents present only in environmental samples and not detected in background samples or quality assurance samples (field or lab), a "three times" detection limit rule is used.

- If the background sample contains the constituent of concern, a concentration of at least five times background is required in the sample. 
- Where quality control has uncommon contaminants, use a "five times" rule; for common contaminants, use a "ten times" rule.

Where a value meets any of these three criteria, it is considered positively identified. If not, EPA guidance uses a "three times" rule, wherein a value must exceed three times the analytical detection limit.

As a concentration approaches the analytical detection limit, the confidence associated with those values diminishes. As with human vision, one simply cannot "see" anything smaller or farther than a particular standard; as the limit of vision is approached, vision becomes less accurate and less precise. Therefore, a value very close to the analytical method detection limit is not as accurate as one several times larger.

Further, analytical methods are limited by matrix interferences, matrix heterogeneity, analytical precision, analytical accuracy, and many other factors. For this reason, an analytical value cannot be interpreted as an "absolute" number. A value reported as an analytical concentration could have an associated analytical error of as much as two to five times the method detection limit. Therefore, where a method detection limit is 10 , a reported value of 15 should be considered to be between 0 and 65; however, as the reported value approaches 50 (for a detection limit of 10), confidence in a positive identification increases.

\section{B.7.4.2 Precision}

Precision is defined as the reproducibility or degree of agreement among duplicate measurements under a given set of conditions. The closer the measurements approach one another, the more precise the measurement. The level of precision is generally determined by calculating the relative percent difference (RPD) between two measurements. Field duplicates are collected to assess the precision of sample collection procedures, matrices, and analytical procedures. Similarly, analytical laboratory precision can be measured by the analysis of sub-samples of an aliquot. Sample homogeneity, analytical method performance, and the quantity of the analyte being measured all contribute to this measure of analytical precision.

Contribution to variability resulting from the combination of environmental media, sampling consistency, and analytical precision is measured by analyzing field duplicate samples. Field duplicate samples are samples collected at the same time and from the same point (e.g., well) as the original sample. EPA data validation guidelines call for the estimation of all associated data where laboratory precision exceeds $20 \%$. When field duplicate pairs are simultaneously collected from a single well, precision usually approaches laboratory precision. As indicated above, the quantity of the analyte being measured contributes to the measure of precision. For this reason, criteria apply only where both the original and duplicate samples are $>5$ times the quantitation limit goal.

The GWPP dataset contains 15,201 field duplicate pairs. Of these data, 1130 pairs (7\%) exceed $20 \%$ RPD. More than $70 \%$ of these values with $20 \%$ RPD are associated with the following metals analytes: aluminum, manganese, boron, iron, and zinc. Four wells (GW-190, $-255,-191$, and -262 ) account for $45 \%$ of the values with $>20 \%$ RPD. Radiochemical analytical precision is calculated without considering analytical counting uncertainty. 
The precision of organic and radiochemical GWPP data was concluded to be acceptable without qualification, and the precision of inorganic GWPP data was concluded to be largely acceptable, with the possible exception of the four wells noted above.

\section{B.7.4.3 Accuracy}

Accuracy is a measure of the difference between a measured value and its true value. Analytical accuracy is evaluated by measuring the agreement between an analytical result and its known or true value. This is generally determined through the use of laboratory control samples, matrix spike analysis, and performance evaluation samples. Factors that contribute to analytical accuracy include method accuracy, analyst error, instrument accuracy, and sample-specific matrix interferences. Any combination of these factors can and frequently does cause a result to be significantly biased, yielding a measured value that is either higher or lower than the actual value.

\section{Accuracy-based RI Criteria}

Accuracy-based criteria established during the BCV RI prompted the decision to (1) eliminate either the GFAA or ICP data where both existed and (2) eliminate data for which the associated charge balance exceeded 20\% (Sect. B.7.3).

\section{ICP versus GFAA}

Although ICP values were generally comparable to available GFAA data, the ICP values for arsenic, cadmium, chromium, lead, selenium, and silver were excluded from the working dataset and replaced by GFAA values. Conversely, the GFAA values for barium and beryllium were excluded from consideration and were replaced by ICP values.

Chromium values reported by ICP are consistently higher than comparable GFAA data. Several factors may contribute to this anomaly. ICP methods are used more routinely than GFAA methods. Additionally, chromium is not completely soluble in nitric acid, which is the sole reagent used to prepare aqueous samples that are to be analyzed by GFAA. Samples to be analyzed by ICP are prepared using both nitric and hydrochloric acids. Therefore, the ICP data would be expected to be higher.

Determining which set of data (ICP vs. GFAA) is the most accurate for assigning chromium values is hampered by the lack of calibration and matrix spike data. However, based on the above discussion and the fact that the use of ICP data in this case yields the higher values, the use of ICP chromium data is believed to be more conservative than the use of GFAA data. It should be noted that prior to 1994 , matrix interference may have produced falsely elevated or repressed values for ICP chromium, lead, and cadmium.

\section{Charge balance}

The calculation of charge balance is applicable for checking the correctness of analyses of water samples for which relatively complete mineral analyses are made. Theoretically, the sum of the anions, expressed in me/L, must equal exactly the sum of the cations, in me/L, in any sample. In practice, the sums are seldom equal because of unavoidable variations in the analysis. This inequality increases as the ionic concentrations increase. If values of differences of the sums fall outside acceptable limits, at least one of the determinations should be rechecked (APHA 1975). 
GWPP samples having an unusually high or low charge balance have zeros reported for one or more parameters (usually calcium, magnesium, potassium, or sulfate) or high nitrate values. As nitrate is a contaminant of concern in the BCV regime, these samples should not be considered "out of balance." Where no value was reported, the calculation includes a zero value. This can sometimes throw the charge seemingly out of balance when, in fact, not enough information is known to establish a charge balance for that sample. No trends were observed that would suggest a need to eliminate a whole block of data from use. However, the user is encouraged to note those samples for which charge balance was determined to be "out of balance" and to consider individual cation or anion values that may seem to be significantly biased based on the history of that analyte in that well.

A total of 175 records $(\sim 0.2 \%$ of the database) were eliminated from consideration during the BCV RI as a result of charge balance results as follows: 18 from the OLF groundwater aggregate, 68 from the Maynardville groundwater aggregate, 41 from the BCBG groundwater aggregate, and 48 from the S-3 Site groundwater aggregate.

\section{Laboratory data reporting}

Accuracy of analytical data can be greatly affected by laboratory data reporting in addition to the analysis of samples. Accurate reporting and use of data include consideration of data quality flags, units of measure, and other factors.

Data quality flags. Data reported by a laboratory usually contain flags to indicate those samples that failed laboratory quality control requirements. All electronic datasets were searched for the presence of such laboratory flags. The only laboratory flags available for these data are the $>$ and < symbols, indicating "greater than" and "less than" the corresponding value. Data with these flags should be used appropriately.

Units of measure. Also indicated as crucial to accurate data reporting are the analytical units of measure. In a dataset that has been collected over a long period, parameters are often reported in different units during different time periods. Units should always be noted by the user during data interpretation. Datasets for 1986 through 1994 were checked for consistency in reporting units and were found to be standard throughout the database with the following exceptions:

- Some radioisotopes are reported in $\mathrm{bq} / \mathrm{L}$ as well as $\mathrm{pCi} / \mathrm{L}$.

- 1994 conductivity units have two spellings: $\mu \mathrm{mho} / \mathrm{cm}$ and $\mu \mathrm{mhos} / \mathrm{cm}$.

\section{Other data}

Radiochemical data have been reported in many different ways during the life of the GWPP. Various data have been reported with the "<" flag, with associated uncertainty, and with negative (less than zero) values. The appropriate and accurate use of radiochemical data depends in part upon these reporting techniques. The user should be aware of these differences in reporting techniques during data interpretation, particularly in association with statistical calculations.

The analysis of water samples for nitrogen can be reported in several ways. Data can be calculated as nitrate, nitrite, nitrogen, or both nitrate and nitrite. In any given year, data may have been reported under as many as three different parameters. All, however, were performed by the same ion chromatography method (EPA 300.0). These data should be used with appropriate caution for interpretation according to the intended analyte. 
Isotopic uranium is reported as ${ }^{234} \mathrm{U} /{ }^{235} \mathrm{U}$ and ${ }^{235} \mathrm{U}$ alone. Although isotopic separation is possible, it is not easily or usually done unless specifically requested. Such data should be treated appropriately. Either ${ }^{234} \mathrm{U}$ or ${ }^{235} \mathrm{U}$ or both could occur in the BCV since ${ }^{23} \mathrm{U}$ occurs naturally at about $0.71 \%,{ }^{235} \mathrm{U}$ was generated by $\mathrm{Y}-12$ Plant uranium enrichment activities during or after World War II, and both have long half-lives.

\section{B.7.4.4 Representativeness}

Representativeness, which expresses the degree to which data accurately reflect the analyte or parameter of interest for the environmental site, is the qualitative term most concerned with the proper design of the sampling program (EPA 1987). Factors that affect the representativeness of analytical data include proper preservation, analytical holding times, use of standard sampling and analytical methods, and determination of matrix or analyte interferences.

\section{RI Criteria Associated with Representativeness}

Factors considered during the BCV RI include (1) total versus dissolved analyses and (2) elevated concentration of potential interferant.

\section{Total $v s$. dissolved analyses}

GWPP metals samples were collected in duplicate, with one fraction being filtered in the field before preservation. Because the dissolved fraction is a subset of the total fraction, analysis is expected to yield equal or higher results in the total fraction. Where the dissolved fraction was greater and the percent difference exceeded $10 \%$, the total vs dissolved comparisons were considered unacceptable for the BCV RI because the values are suspected of being erroneously reported. A total of 108 data points $(\sim 0.1 \%$ of the database) were considered unusable for this reason. Of these 108 data points, 35 came from the S-3 Site aggregate, 44 from the Maynardville aggregate, and 29 from the $B C B G$ aggregate.

\section{Elevated concentrations of interferant}

Data for samples with elevated concentrations of total suspended solids, sodium, or chloride were eliminated from consideration in the BCV RI as discussed in Sect. B.7.3. Eliminated analyses are listed in Table B.41. Total analytical results for samples with high levels of suspended solids might indicate a high concentration of a contaminant of concern in the water sample when, in fact, the contaminant is not present in the water but in suspended material. In this case, the use of dissolved, rather than total, data is desirable.

The presence of certain metals and cations (e.g., sodium, chloride, magnesium, calcium, potassium) in high concentrations can interfere with the analysis of other metals by ICP. This problem can be overcome by using interelement correction factors in the calculation of metals results.

\section{Analytical Holding Time and Methods}

The purpose of an environmental field investigation is to collect data that are representative of the site at the time of the investigation. Therefore, the preservation of environmental samples and completion of the required analyses according to standard analytical methods in a timely manner are critical. For analytical methods, refer to the GWQR reports (e.g., HSW 1995). 
Samples are preserved by adding chemical preservative, controlling sample exposure to environmental factors such as light and air, and controlling the temperature at which the samples are stored. Protocol for sample preservation has been established for the GWPP, and routine assessments are conducted to ensure compliance. Therefore, sample preservation is not considered a source of uncertainty.

Table B.42 lists appropriate preservatives and analytical holding times for VOC, SVOC, pesticide/PCB, metals, cyanide, and radiochemical analyses. Analytical holding time is measured from the time of sample collection to the time of preparation and/or analysis. GWPP data in BEIDMS include the date of collection for all samples, but have only a date of analysis for volatile analyses. This information can be used to determine that all volatile analyses were performed within the routine analytical holding time of $14 \mathrm{~d}$. However, data are not available to evaluate the analytical holding time of other parameters. Holding times are not likely to have been excessive for metals or radiochemical analyses. However, they could possibly have been exceeded for SVOC, pesticide/PCB, and mercury analyses. This lack of data introduces further uncertainty into the GWPP dataset.

The lack of holding time and preservation information, while introducing some uncertainty, does not present an unacceptable amount of uncertainty. The rejection of data for these reasons is rare and, therefore, unlikely to have affected a significant portion of samples.

\section{Statistical Outliers}

A value considered to be statistically "out of range" is not necessarily analytically inaccurate. Individual data points that seem suspect should be evaluated against other data from the same well under similar conditions to determine the data usability.

The effects of matrix interferant in water samples, while not as severe as in soil samples, can severely impact the representativeness of a dataset. As discussed in reference to analytical accuracy, data for measuring these effects were not available at the time of this review. Therefore, an unknown amount of uncertainty is introduced into the representativeness of the dataset. Apparent outliers might be compared to data, such as the BCV OU 2, OU 4, OU 1, or FPSS data, which have undergone a thorough CLP-type data validation process, including evaluation of matrix spike and laboratory control samples.

\section{B.7.4.5 Completeness}

Completeness of a dataset is an assessment of the quantity of samples collected and analyzed and the resulting data considered to be usable. Usable data are defined as those data that pass individual scrutiny during a review process (usually a data validation effort) and are accepted for unrestricted application to a human health risk assessment or equivalent applications.

The GWPP generated an abundance of data, a subset of which was selected for use in the BCV RI. Stations GW-196, -197, -237 , and -509 were determined to have insufficient data and were eliminated from the data set. For other stations not having a minimum of four data points from 1990 through 1994, all available data were included in the RI. These and other criteria described in Sect. B.7.3 resulted in the rejection of 2000 of 147,750 (1.3\%) GWPP data points. In addition to this $1.3 \%$, all isotopic radiochemical data were rejected. 


\section{B.7.4.6 Comparability}

Comparability is a qualitative term relative to a project dataset as an individual. A dataset comparable to other relevant datasets would possess narrowly defined sampling methods, site audits/surveillances, use of standard sampling devices, uniform training, documentation of sampling, standard analytical protocols/procedures, quality control checks with standard control limits, and universally accepted data reporting units to ensure comparability to other datasets.

Although sampling and analysis protocols may have changed as techniques have improved, the GWPP maintains standards and controls that provide data comparability. A more detailed review of comparability is provided in the BCV integrating data quality assessment (Sect. B.8).

\section{B.7.5 CONCLUSIONS}

The 1986 through 1994 GWPP dataset is judged adequate for use in the BCV RI, however, several specific areas of uncertainty, such as holding times, reporting units, and reporting analytical method types, are noted. The primary cause for rejecting $1.3 \%$ of the GWPP data for use in the BCV RI was elevated quantitation limits. Other causes for rejected data include a preference of methodology, elevated concentrations of interferant, unacceptable charge balance information, and unacceptable total comparisons with dissolved analyses.

The 1994 values for the benzene, ethylbenzene, toluene, and xylene parameters, as well as chromium values produced by GFAA methodologies, should also be rejected. Other data may be considered usable with caution as described herein. 


\section{B.8 BCV INTEGRATING DATA QUALITY ASSESSMENT}

\section{B.8.1 PURPOSE}

The purpose of this integrating data quality assessment is to evaluate quality assurance/quality control results associated with the BCV RI dataset to confirm that data used in the RI report meet the stated objectives. This assessment included evaluations of field collection activities and laboratory analysis. The effect of field collection activities on analytical data was assessed by examining completeness, field quality control sample results, and quality assurance program findings. The effect of laboratory analysis on data quality was assessed by examining quality assurance program findings and evaluating SPARCC parameter results and goals.

Both quantitative measures and qualitative assessments were performed to characterize these data as having sufficient quality to satisfy stated objectives. As demonstrated in the following subsections, this assessment concluded that data originating from the BCV OU 4, BCV OU 1, and BCV FPSS field investigations can withstand scientific scrutiny (for its intended purposes), are technically defensible, and are of a known and acceptable precision and accuracy. Further, these data were compared to the previously assessed GWPP data to provide a comprehensive discussion of all data used for the BCV RI.

\section{B.8.2 SCOPE}

For purposes of this discussion of the integration data quality assessment, the available data and their sources have been categorized into quantitative and qualitative information. Table B.43 presents an index of the available numbers of samples from each source and medium providing qualitative or quantitative information.

Data from BCV OU 4, BCV OU 1, and BCV FPSS field investigations are evaluated against established, project-specific SPARCC criteria. General data quality are then summarized, noting areas that merit caution relative to data usability.

The GWPP groundwater data, which were also used to characterize the nature and extent of contamination in the BCV, have been previously evaluated (Sect. B.6) and thus are noted only for summary purposes.

\section{B.8.3 DATA ACCEPTABUITY}

More than 75,000 discrete soil, sediment, groundwater, and surface water analyses were accumulated for use in the BCV RI during the OU 4, OU 1, and FPSS field investigations. Of these, only 672 are considered to have sufficient problems with data quality to merit being flagged unacceptable $(R)$.

The acceptability of analytical data to a project is determined by the criteria established for that project. In all BCV RI field investigations, CLP data validation criteria were selected as the criteria for comparison during the analytical data validation effort. Application of these criteria resulted in the rejection of $<1 \%$ of all collected data for all three field investigations for use

during the analytical data validation process. These data, which include those that failed CLP or 
project-specific criteria, are flagged with an "R." Following is an assessment of the impact of these rejections on each of the three projects.

\section{$B C V$ OU 4}

Less than $1 \%$ of OU 4 surface water data were rejected during the data validation effort. These rejected data are primarily radiochemical data exhibiting severe matrix interferences. The rejected radiochemical data include 12 of 255 total gross $\alpha$ values $(>150 \%), 18$ of 255 total gross $\beta$ values, and 17 of 255 dissolved gross $\beta$ values. The rejected values, which must be considered extremely positively biased, can be used for qualitative purposes only; they are unacceptable for quantitative use.

Matrix interferences also affected individual isotopic analyses. Of $10^{241} \mathrm{Am}$ values, 2 were rejected because chemical recovery was $<20 \%$. Additionally, 1 out of 46 isotopic thorium values was rejected because of low surrogate recovery. Other values for isotopic thorium and isotopic uranium were also rejected because chemical recovery was $<20 \%$.

Some of these data should be eliminated from consideration entirely, while others can be used for qualitative purposes only. Data that can be used on a limited basis include total gross $\beta$ values for SB1020 and SN3020 and dissolved gross $\beta$ for SB1021. In all of these cases, the values are sufficiently elevated to warrant the interpretation of gross $\beta$ activity, even though the laboratory control sample and matrix spike recovery were extremely elevated. Additionally, the SN3002 total gross $\alpha$ value may be used for qualitative purposes. Again, the associated value is elevated and may be considered indicative of some level of gross $\beta$ contamination, regardless of the extremely high matrix spike value.

Several isotopic uranium values, which have been qualified "R," may also be usable for limited purposes: SN3019, ${ }^{233,234} \mathrm{U}$ and ${ }^{238} \mathrm{U}$; SN3020, total and dissolved ${ }^{23} \mathrm{U}$; and SN3020, total and dissolved ${ }^{238} \mathrm{U}$. As with the gross values discussed above, reported values are sufficiently elevated to warrant the interpretation of some radiochemical contamination, although quantitation of those values is impossible because of matrix interferences.

\section{$B C V O U 1$}

About $1.5 \%$ of all the BCV OU 1 data were rejected for use during the data validation effort. These data were predominantly BCBG soil data, rejected primarily because of antimony results exhibiting extremely poor accuracy. All pesticide/PCB data in three samples were rejected because of poor surrogate recovery.

\section{BCV FPSS}

Less than 1\% (40 data points) of all FPSS data were flagged as unusable during the analytical data validation effort. Three of the rejected data points were reference points for antimony, which were considered critical to the BCV RI. However, existing nonrejected data were sufficient to calculate background values; therefore, the RI was not impacted as a result of the rejected antimony reference points. 
The other 37 rejected data points were for:

- antimony,

- N-nitrosodiphenylamine, and

- americium, curium, and uranium.

All antimony soil and sediment data were qualified because of poor matrix spike recovery. Although matrix interferences to antimony are common in soil and sediments, recovery was sufficiently poor (18.8 to $50.4 \%$ ) to warrant rejection of some and estimation of most associated antimony data points. In general, soil antimony data should be considered extremely negatively biased, and the 8 of 46 soils and 5 of 26 sediment samples qualified with an "R" should be considered unusable for any purpose. Associated antimony values are reported as non-detects. Values reported as non-detects in conjunction with a negative analytical bias result in inconclusive data, which should not be used for any purpose.

The rejection of three organic soil data points is associated with variation in instrument calibration. These rejected data points were all non-detected values for $\mathrm{N}$-nitrosodiphenylamine, which is not a contaminant of concern in the BCV.

Rejected radiochemical data include seven uranium, two curium, and one americium soil data points. Poor surrogate recovery in these analyses warrants the rejection of these data for all purposes.

The only significant impact of rejected data in the FPSS dataset is that associated with the soil/sediment antimony data.

\section{Summary of Data Acceptability}

The overall quality of all OU 4, OU 1 , and FPSS data is acceptable: $<1 \%(672 / 78,455)$ of the data were found (through the analytical data validation process) to have sufficient quality problems to preclude their use for any purpose. The overall impact of rejected data to the BCV $\mathrm{RI}$ is minimal, with the relatively largest impact being radiochemical and metals data for soils and sediments. By far the greatest challenge to data interpretation is not insufficient or unacceptable data, but, rather, the appropriate use of available data. Therefore, this assessment will focus on data that, because of their quality, present a challenge to data usability.

\section{B.8.4 QUALITY ASSURANCE PROGRAM}

Each field investigation project establishes a project-specific quality assurance program that provides procedures and criteria that ensure an endproduct of data of known and defensible quality. Such procedures/criteria include DQOs, analytical methodologies, laboratory deliverables, data review, field change order documentation, Non-Conformance Report (NCR)/Analytical Data Non-Conformance Report (ADNCR) documentation, and others. DQOs generally include acceptance criteria for SPARCC parameters. Following is a description of the quality assurance programs and their project-specific criteria and/or procedures. 


\section{B.8.4.1 Sample Collection Activities}

Quality assurance of sample collection activities for each field investigation includes audits and surveillances. These audits/surveillances include thorough internal and external reviews of adherence to established procedures for sample collection, chain of custody, field instrument calibration, preventive maintenance, and other activities. Field investigations supporting this RI report were subjected to ten internal surveillances and three client (Energy Systems and/or Department of Energy) audits. Table B.44 summarizes project audits and surveillances for each field investigation supporting this RI.

\section{B.8.4.2 Laboratory Deliverables}

Project quality assurance plans for the three field investigations outlined requirements for laboratory instrument preventive maintenance, zero calibration, data reduction, and reporting. Each project required the analytical laboratory to provide comprehensive deliverables, including data summary forms (EPA CLP-type forms or their equivalent), raw data, and instrument calibration information necessary for a thorough review of all data. This type of deliverable is equivalent to the former EPA Level IV data deliverable. Each project also required analytical laboratories to provide electronic data deliverables, thus eliminating the need for extensive data entry and the associated potential for data error.

\section{B.8.4.3 Analytical Data Review}

Data were reviewed for accuracy and precision during the laboratory data generation phase of the projects and then by SAIC analytical chemists during the data validation/evaluation process. The data validation approach used for all three projects involved a comprehensive review of $10 \%$ of the data and a summary review of the remaining $90 \%$. The summary review did not include an evaluation of matrix spike data. Therefore, appropriate use of the data required conclusions to be drawn on the basis of this assessment and other available information, as well as the data validation qualifiers in the dataset. Only the BCV OU 4 dataset was flagged for poor sensitivity associated with field quality control blank samples.

\section{B.8.4.4 Data Quality Objectives}

Each project established objectives for data quality using SPARCC parameters, as summarized in Table B.45. Section B.8.5 compares data quality to these established objectives.

\section{B.8.4.5 Quality Assurance Reports}

Quality assurance reports such as SAIC's NCR/ADNCRs, corrective action reports, and field change orders were used to document deviations from established procedures or criteria. Copies of individual reports were routed through the project organization as appropriate.

A total of 40 field change orders and 134 NCR/ADNCRs were generated during these investigations. ADNCRs document nonconformance issues related to analytical data, while NCRs document all other types of nonconformance issues. All NCR/ADNCRs have been satisfactorily concluded. All problems, as well as their root causes and corrections, where applicable, are documented in the project file. 


\section{B.8.5 DATA EVALUATION}

\section{B.8.5.1 Completeness}

The combined recent and historical BCV RI database includes analytical data for groundwater, surface water, surface soil, sediment, subsurface soil, waste, and biota. The primary BCV studies are the BCV OU 4, BCV OU 1, BCV FPSS, and GWPP. The BCV OU 1 and FPSS field investigations established individual project completeness objectives requiring $90 \%$ of all planned samples to produce valid analytical data. Background or reference locations were considered critical to both projects and required $100 \%$ completeness. Specific goals were not defined for the BCV OU 4 and GWPP investigations.

\section{BCV OU 4}

The BCV OU 4 project was evaluated during implementation as an ongoing process. Some originally planned segments were eliminated, and others were added to accommodate the evolving approach to a valley-wide investigation (Fig. B.51). Evaluation of established completeness goals is not appropriate under these circumstances. However, based on the interpretation of data in Appendices $\mathrm{C}, \mathrm{D}$, and $\mathrm{E}$, the amount of data collected meets project needs.

\section{$B C V O U 1$}

The BCV OU 1 field activity investigated four separate areas: BYBY, OLF, S-3 Ponds, and SL 1. Project-specific criteria for the BCV OU 1 field investigation called for $90 \%$ of all planned data to be collected and validated for all four areas.

A total of 349 samples were planned for the OU 1 project. Of these, 295 (85\%) were collected, with $<2 \%$ (458/31,151 data points) then being rejected during the data validation process. Planned versus collected samples are summarized in Fig. B.52.

Because of the uncollected samples, each site except for SL 1 was $<90 \%$ complete. Twelve locations are not represented by any data: BG-09 (soil) and BG-06, -07, -08, -09, -10, -11, -14, $-15, \mathrm{BY}-07, \mathrm{BY}-08$, and SL1-02 (all groundwater).

\section{BCV FPSS}

The same completeness criteria established for BCV OU 1 were applied to BCV FPSS. Of all planned samples, 83\% (364/437) were collected (Fig. B.53). Uncollected samples included 16 sediment samples and 57 soil samples. All surface water and reference samples were collected.

Less than $1 \%$ (40 data points) of all data were then flagged as unusable during the data validation effort. The 40 rejected data points were primarily metals soils/sediment data. Three of the 40 points were reference points for antimony. These antimony and other rejected metals data were considered unacceptable because of extremely poor accuracy.

\section{Summary of BCV RI Data Completeness}

The compilation of these datasets creates a summary dataset that represents multiple media in the $\mathrm{BCV}$ regime and provides adequate data from which to draw conclusions about the extent of contamination related to each source. 


\section{B.8.5.2 Accuracy}

Laboratory control samples, matrix spike analysis, and performance evaluation samples were used to assess the accuracy of data resulting from the BCV OU $1, \mathrm{BCV}$ OU 4, and FPSS investigations. Data validation of matrix spikes was limited to those data packages that were comprehensively reviewed as described in Sect. B.8.2.

\section{$B C V$ OU 4}

All organic and inorganic laboratory control samples indicate the non-radiochemical laboratory analytical processes were in control. However, data for several metals and radiochemical parameters had to be qualified because of poor accuracy, suggesting that their stable chemistry analyses were inhibited by matrix interferants.

\section{Organic data}

Out of the 253 chloroethane values, $170(67 \%)$ are qualified as estimated because of poor laboratory instrument calibration. This qualification indicates that the instrument used for analysis of these samples was not operating properly, introducing a degree of uncertainty for these data.

\section{Inorganic data}

Inorganic analytes that merit close attention to potential bias include mercury, cyanide, antimony, aluminum, iron, lithium, and silver. Mercury matrix spike recoveries ranged from $55 \%$ to $137 \%$; cyanide recoveries ranged from $41 \%$ to $110 \%$; and antimony, aluminum, iron, lithium, and silver recoveries ranged from $<1 \%$ to $144 \%$. All of these analytes have associated unacceptable matrix spike values in at least some cases and a tendency towards low matrix spike/matrix spike duplicate recovery. This pattern indicates a potential for negative bias in these data.

\section{Radiochemical data}

Of $33{ }^{234} \mathrm{U}$ data points, 15 (45\%) were qualified as estimated because of high matrix spike recoveries, and $17(52 \%)$ were estimated because of low matrix spike recoveries. Therefore, almost all ${ }^{234} \mathrm{U}$ data that were evaluated based on matrix spike recoveries are considered to be highly variable and potentially biased.

Radiochemical data were also estimated because of laboratory control samples and surrogate recovery. Of $24{ }^{238} \mathrm{Pu}$ and ${ }^{239} \mathrm{Pu} /{ }^{240} \mathrm{Pu}$ data points, 5 were qualified as estimated because of low surrogate recovery. These data should be considered negatively biased. Of $41{ }^{90} \mathrm{Sr}$ values, 12 are considered estimated because of low laboratory control samples recovery, as are 12 of $36{ }^{99} \mathrm{Tc}$ values. Again, these data should be considered low estimates of true values.

\section{$B C V$ OU 1}

\section{Groundwater}

As with OU 4, OU 1 stable chemistry laboratory control samples data indicate that analytical processes were in control, but apparent matrix interferences resulted in qualification of some data. Of 15 groundwater samples, 4 were qualified as estimated because of elevated recovery for 
aluminum and depressed recovery for antimony in the matrix spike. Therefore, aluminum values are considered positively biased, and antimony negatively biased.

Additionally, 7/9 groundwater data points for 2,4-dinitrophenol are considered to be inaccurate (flagged as estimated) because of fluctuations in the calibration of the analytical instrument.

Soil

Soil data were qualified because of poor matrix spike recovery for antimony as well as poor laboratory control samples recovery for radiochemical parameters and fluctuations in analytical instrument calibration.

All OU 1 antimony soil data should be considered negatively biased. A significant portion of all radiochemical soil data is qualified "UJ" (estimated) because of low laboratory control samples recovery. These data should be considered negatively biased.

Two organic analytes (2,4-dinitrophenol and chloroethane) exhibit significant fluctuations in calibration information that may cause data to be of less than desirable accuracy. Of the 75 2,4-dinitrophenol soils data points, 70 are qualified "UJ," and of the 205 chloroethane soil data points, 46 are qualified "UJ."

\section{Surface water}

Similar to the soil data, $15 / 16$ surface water chloroethane data points are qualified as estimated because of poor calibration of the analytical instrument.

\section{BCV FPSS}

\section{Process control}

Laboratory control soil sample data for barium, potassium, and sodium indicate analytical processes may not have been in control for these analyses. Analyte recovery for these parameters ranged from $92 \%$ (lowest value for all three analytes) to $133 \%$ for barium, $232 \%$ for potassium, and $632 \%$ for sodium. Because potassium, barium, and sodium are common elements that occur in most soil samples at quite variable concentrations, these analytical variations will cause minimal impact on data confidence.

\section{Matrix spikes}

Matrix spike recovery for mercury, lithium, manganese, and antimony exceeded the project criterion of $\pm 20 \%$. In most cases, recoveries ranged from $<80 \%$ to $>120 \%$. This broad range of analyte recovery indicates a similarly broad range of accuracy in these analytes.

This tendency is particularly exaggerated in antimony soil data. All antimony soil data were qualified because of poor recovery in the matrix spike. Recovery was sufficiently poor ( $18.8 \%$ to $50.4 \%$ ) to warrant the rejection of some associated antimony data points. Soil antimony data should be considered extremely negatively biased, and those qualified with an " $R$ " should be considered unusable for any purpose. 


\section{B8-8}

\section{Serial dilutions}

Serial dilutions are performed during ICP analysis to further evaluate potential matrix interferences. When analyzed at a 10-fold dilution, interferants are expected to be significantly reduced or eliminated. Therefore, diluted results, when multiplied by the appropriate dilution factor, should agree within $10 \%$. In 34 out of 46 FPSS soil samples, associated serial dilution results fail to agree within $10 \%$ of the original value for zinc, suggesting the presence of a matrix interferant, and are thus qualified as estimated. In all cases, the diluted sample had a higher value for zinc than the original. Therefore, zinc soil values for FPSS should be considered negatively biased.

\section{Summary of BCV RI Data Accuracy}

Accuracy in the BCV dataset is summarized in Table B.46, which presents an overall perception of data accuracy based on that portion of data receiving comprehensive validation. The table also indicates those analyte data that have poor accuracy and little confidence and whether they have been flagged in the data set.

Most problems seem to be attributable to matrix interferences in metals data. Exceptions would be the negatively biased cyanide data and ${ }^{234} U$ in the surface water. Uranium-234 matrix spike recovery resulted in the qualification of $32 / 33$ surface water data points.

\section{B.8.5.3 Precision}

Field duplicate samples, collected along with environmental samples during the BCV OU 1 , BCV OU 4, and FPSS investigations, were analyzed to assess analytical precision. Assessment results are presented in following paragraphs.

\section{$B C V$ OU 4}

\section{Organic and inorganic data precision}

Field duplicates indicate acceptable overall precision for all organic and inorganic analytes, except for total and dissolved aluminum, total iron, and total manganese. The average RPD for each of these analytes exceeds $35 \%$. Of the 255 total and 255 dissolved aluminum values, $50(19.6 \%)$ total and $80(31 \%)$ dissolved values are qualified as estimated because of poor precision. Of the 255 total iron values, 70 are similarly qualified, and of the 255 total manganese values, 78 are flagged with a "J." Therefore, these analytes should be used with caution throughout the OU 4 dataset.

\section{Radiochemical data precision}

OU 4 gross $\alpha$ data must also be used with caution. Of 255 total and 255 dissolved gross $\alpha$ data points, 53 total and 52 dissolved data points are qualified "J" because of a poor laboratory duplicate error ratio. Additionally, 71/255 ${ }^{235} \mathrm{U}$ values are considered estimated because of poor laboratory precision.

\section{$B C V$ OU I}

Precision of analytical data is consistently acceptable across the BCV OU 1 project. 
BCV FPSS

Soil

Inorganic field duplicate RPDs for soil samples range from $3.6 \%$ (mercury) to $88.7 \%$ (cadmium). Laboratory duplicates for arsenic and manganese fail to meet CLP criteria. However, very few samples required qualification for these reasons. Overall precision of soil data is acceptable.

\section{Sediment}

Sediment sample RPDs for inorganic parameters range from $0.75 \%$ (magnesium) to $49.93 \%$ (lead). Analytes for which the average RPD exceeds $20 \%$ include aluminum, arsenic, cadmium, chromium, cobalt, iron, lead, lithium, manganese, mercury, and potassium. Where this criterion is exceeded, data are qualified as estimated. All organic RPDs for sediment field duplicates are acceptable.

Precision of radiochemical field duplicates was evaluated by calculating the duplicate error ratio. Precision is considered acceptable where the duplicate error ratio is $<1$. In the only sediment duplicate pair, the duplicate error ratios for ${ }^{99} \mathrm{Tc},{ }^{228} \mathrm{Th},{ }^{230} \mathrm{Th},{ }^{232} \mathrm{Th},{ }^{234} \mathrm{U},{ }^{235} \mathrm{U}$, and ${ }^{238} \mathrm{U}$ fail this criterion. Although sediment data for these analytes are not qualified because of field precision, they should be considered estimated.

\section{Summary of BCV RI Data Precision}

The overall impact of poor precision on the BCV RI dataset is summarized in Table B.47, which shows that precision-related factors did not contribute significantly to poor data quality. Radiochemical precision is affected only in sediment and surface water data. Of these, all surface water data points, which are considered estimated because of laboratory precision, are qualified. The user is cautioned in the use of ${ }^{99} \mathrm{Tc},{ }^{228} \mathrm{Th},{ }^{230} \mathrm{Th},{ }^{232} \mathrm{Th},{ }^{234} \mathrm{U},{ }^{235} \mathrm{U}$, and ${ }^{238} \mathrm{U}$ sediment data because, although not qualified, they may be significantly impacted by poor precision.

Inorganic data affected by poor precision include (1) very few arsenic and manganese soil values; (2) aluminum, arsenic, cadmium, chromium, cobalt, iron, lead, lithium, manganese, mercury, and potassium sediment values; (3) aluminum, iron, and manganese in OU 4 surface waters; and (4) dissolved aluminum in OU 4 and OU 1 surface water.

\section{B.8.5.4 Sensitivity}

Required sensitivities vary across the three BCV projects, in some cases significantly so. In addition to this variability in sensitivity, the requested detection limits were not always obtained. Such is the case with ${ }^{99} \mathrm{Tc}$ data for NT-3 surface water samples. These data have associated minimum detectable activities (sensitivity) of $\sim 50$ to $60 \mathrm{pCi} / \mathrm{L}$, which far exceeds the requested project detection limit of $1 \mathrm{pCi} / \mathrm{L}$. Although the reported activities for the NT-3 surface water samples are all less than the $50-$ to $60-\mathrm{pCi} / \mathrm{L}$ minimum detectable activity, they nevertheless exceed the requested $1-\mathrm{pCi} / \mathrm{L}$ detection limit in some cases. Therefore, these data should be rejected for all use.

Another reason detection limits may exceed those required by the project is that contamination in the laboratory method blank may have caused the elevation of that detection 
limit during data validation. Contamination in an associated laboratory blank can result in a " $U$ " qualifier being applied to a result, thus adjusting the reported detection limit to the associated value. For example, a value reported as $27 \mu \mathrm{g} / \mathrm{L}$ for which the laboratory detection limit is $5 \mu \mathrm{g} / \mathrm{L}$ and in which the associated blank for that analyte reports $20 \mu \mathrm{g} / \mathrm{L}$ might be flagged " $\mathrm{U}$." In this case, the detection limit has effectively been adjusted from 5 to $27 \mu \mathrm{g} / \mathrm{L}$. A significant portion of acetone and methylene chloride data is affected in this manner. Additionally, metals, including dissolved aluminum, iron, copper, cadmium, lithium, and sodium, are also frequently affected. Di-n-butylphthalate and ${ }^{234} \mathrm{U}$ complete the list of parameters significantly affected by method blank contamination.

\section{$B C V$ OU 4}

In the BCV OU 4 project, dissolved aluminum data were qualified because of laboratory blank contamination in 80/255 surface water samples. Contamination in associated blanks with dissolved iron and total copper qualified an additional 90 and 95 samples, respectively. Organic blank contamination for this project resulted in elevating 74/253 methylene chloride surface water detection limits. Radiochemical contamination of blanks with ${ }^{234} U$ resulted in $9 / 33$ samples being qualified as estimated.

\section{BCV OU 1}

The only parameter for which a significant portion of data had elevated detection limits because of associated laboratory method blank contamination was di-n-butylphthalate. Of 75 soil data points, 66 were so qualified.

\section{BCV FPSS}

Metals contamination of associated laboratory method blanks led to the adjustment of detection limits for cadmium, lithium, and sodium soil samples, resulting in qualification of $10 / 46$ cadmium soil data points, $11 / 46$ lithium soil data points, and 12/46 sodium soil data points. Organic contamination of soil blanks resulted in $24 / 46$ acetone soil data points and $46 / 46(100 \%)$ methylene chloride soil data points receiving adjusted detection limits.

Sediment data were also qualified for metals and organic blank contamination in a significant portion of samples. Laboratory method blank contamination resulted in 11/26 cadmium samples and $8 / 26$ sodium samples being qualified "U." Of 26 herbicide samples, 19 were qualified "U" for all three herbicide parameters. An additional 16/26 acetone and 26/26 (100\%) methylene chloride sediment data points also were so qualified.

Further, a significant number of radiochemical data are estimated because of contamination in an associated laboratory method blank. As a result, $19 / 46{ }^{243} \mathrm{Cm}$ soils, $59 / 72{ }^{228} \mathrm{Th}$ soils and sediments, $14 / 46{ }^{230} \mathrm{Th}$ soils, and $21 / 72{ }^{232} \mathrm{Th}$ soils and sediments are considered estimated.

\section{Summary of BCV RI Data Sensitivity}

Laboratory blank contamination resulted in elevated detection limits and/or qualification of data as either estimated or not detected for some data points in all BCV datasets. Analyses affected were primarily organics and metals, but radiochemical results for ${ }^{234} \mathrm{U},{ }^{99} \mathrm{Tc},{ }^{243} \mathrm{Cm}$, and isotopic thorium were also impacted. Field blank results indicate that sample handling and 
equipment decontamination procedures were effective in preventing sample contamination during field activities for all three BCV projects.

\section{Field Blank Contamination}

Overall project sensitivity can be evaluated by reviewing the three types of field quality control blanks used for the BCV OU 1, BCV OU 4, and FPSS projects:

- Trip blanks - No contamination of trip blanks, which would indicate that artifacts had been introduced into samples during shipment, was significantly detected for the three BCV projects.

- Field blanks - Field blanks collected during the BCV RI field investigations included samples of (1) the potable water source used during decontamination and (2) analyte-free water used as the final water rinse of the process. Field blanks indicate that the decontamination process used for all three BCV RI projects was effective.

- Equipment rinsate blanks - BCV OU 4 and FPSS project equipment rinsates indicate that the decontamination of field equipment was successful. Equipment rinsate EQR020 from the BCV OU 1 project, however, had $91.7 \mu \mathrm{g} / \mathrm{L}$ cyanide present. Sample S07011, which was collected immediately after this rinsate with the same equipment, had $1.4 \mathrm{mg} / \mathrm{kg}$ cyanide. Therefore, any contamination introduced through the sampling equipment was not significant.

\section{B.8.5.5 Representativeness}

Sample preservation techniques, analytical holding times, and sampling and analytical methods used for the BCV OU 1, BCV OU 4, and FPSS projects, along with matrix or analyte interferences, were assessed to determine representativeness of the BCV RI data.

\section{$B C V$ OU 4}

\section{Holding times}

Of 253 OU 4 VOC analyte samples, 15 are estimated because of insufficient preservation. These data are considered to be negatively biased.

\section{Statistical outliers}

The statistical analysis of data suggests that some BCV OU 4 data points significantly exceed the rest of the population of values for that analyte and matrix and thus are not representative of conditions in the BCV.:

- The filtered ${ }^{235} U$ value for $\mathrm{SN} 3010(98 \mathrm{pCi} / \mathrm{L})$ is not representative of conditions at the BCV OU 4 NT-3 site. This dissolved data point should be eliminated from consideration, based on several factors: (1) the duplicate SN3110 filtered sample values were not high, (2) the gross rad counts of the sample and duplicate were not high, and (3) the total (unfiltered) ${ }^{235} \mathrm{U}$ value was $7.4 \mathrm{pCi} / \mathrm{L}$.

- SB9115 2-butanone also has a field duplicate for which the associated 2-butanone value is $24 \mu \mathrm{g} / \mathrm{L}$. Other values for this analyte at this station, coupled with the discrepancy in the two 
B8-12

surface water field duplicates for which precision is expected to approach $20 \%$, suggest this value is questionable. Therefore, SB9115 2-butanone should not be used for any purpose.

- Lead in SS8009 should also be eliminated from consideration because of potential nonrepresentativeness of data. A dissolved value of $37.1 \mu \mathrm{g} / \mathrm{L}$ is associated with a total value of $2 \mu \mathrm{g} / \mathrm{L}$. Furthermore, the next highest value at that station is $11.4 \mu \mathrm{g} / \mathrm{L}$.

\section{Samples possibly mis-identified during analysis}

Evaluation of gross and total isotopic analyses, along with total and dissolved analyses, suggests that data from four samples (SS6008, SN5008, SB9017, and SN3016) may be mislabeled. All four samples were sent simultaneously to a single laboratory for analysis of total gross $\alpha$, total gross $\beta$, total isotopic uranium, dissolved gross $\alpha$, dissolved gross $\beta$, and dissolved isotopic uranium. Data for these samples are presented in Table B.48.

Total isotopic uranium results reported for SS6008 and SN5008 are more consistent with gross values and dissolved $U$ values reported for the other two samples, and vice versa. Other data at the locations substantiate the theory that the samples were mislabeled. Because the theory cannot be proven or disproven, total isotopic uranium data for all four samples were eliminated from consideration during data interpretation.

\section{Calculated charge balance}

Calculation of ionic charge balance provides a general geochemical check of cations and anions in solution. Of 20 OU 4 samples, 6 have a calculated charge balance exceeding $20 \%$. However, these results seem to be attributable to the turbidity of samples rather than the validity of the data itself. Therefore, no BCV RI data should be excluded from consideration based on charge balance information.

\section{$B C V O U 1$}

All indications point to a high degree of representativeness in the BCV OU 1 dataset, especially in aqueous samples. This finding is supported by acceptable charge balance ratios for all aqueous samples, comparable conductivity measurements between the field and laboratory, and agreement between most total/dissolved analyses. The only exception is for ${ }^{212} \mathrm{~Pb}$ in sample $\mathrm{B} 01511$, which showed a dissolved value eight times that of the total. Because these ${ }^{212} \mathrm{~Pb}$ values may not be representative of actual conditions at $\mathrm{BCV}$, neither should be included in data interpretation.

\section{BCV FPSS}

Project data seem to be generally representative of conditions in the $\mathrm{BCV}$, with the following exceptions:

- W00221 and W00321 copper values are highly questionable and should not be used for any purpose. In both cases, the copper values for the total analyses are non-detects $(0.7 \mathrm{U})$, while the dissolved analysis is $\sim 5$ times the detection limit ( 3.4 and $4.6 \mu \mathrm{g} / \mathrm{L}$, respectively). 
- Analyses of several soil samples for pesticides/PCBs and/or SVOC analytes were performed outside of analytical holding time. As a result, 11/46 pesticides/PCBs and 13/46 SVOC soil data points are estimated.

- Exceedance of analytical holding times also leads to the estimation of $1 / 26$ herbicide, $3 / 26$ pesticide/SVOC, and 1/26 VOC sediment samples during the validation effort. These data should be considered negatively biased and, therefore, not completely representative of conditions at the BCV floodplains.

\section{Summary of BCV RI Data Representativeness}

Overall representativeness of the BCV RI dataset is judged to be very good. Analysis outside holding times and insufficient preservation resulted in qualification of $15 / 253$ surface water VOC samples, 24/92 soil SVOC or pesticide/PCB samples, and 5/78 sediment VOC or pesticide/herbicide samples. These data are qualified as estimated and considered to be negatively biased. Other factors affecting representativeness resulted in the elimination of a total of only 11 results from consideration.

\section{B.8.5.6 Comparability}

Each of the three BCV projects evaluated, as well as the GWPP data source for groundwater, used narrowly defined sampling methods, which were audited both internally and by Energy Systems/Department of Energy. Additionally, the projects used standard sampling devices, uniform training, documentation of sampling, standard analytical methods, quality control checks with standard control limits, and universally accepted data reporting units.

\section{Analytes}

Analyte lists were not common across all projects. Project-specific analytes are presented in the discussion of each project (Sects. B.3, B.4, and B.5).

\section{Reporting of nitrogen}

The analysis of water samples for nitrogen can be reported in several ways. Data can be calculated as nitrate, nitrite, nitrogen, or both nitrate and nitrite. In any given year, GWPP data may have been reported under as many as three different parameters. All, however, were analyzed using the same ion chromatography method (EPA 300.0). Current BCV RI data (OU 4, OU 1, and FPSS) are consistently reported as nitrogen as nitrate and were analyzed using the EPA 353.2 colorimetry method. Although the methodologies are not consistent, data are expected to be comparable in quality. However, these data should be used with appropriate caution to ensure that they are interpreted in terms of the intended analyte.

\section{Reporting of isotopic uranium}

Isotopic uranium is reported as ${ }^{234} \mathrm{U} /{ }^{35} \mathrm{U}$ and ${ }^{235} \mathrm{U}$ alone. Although isotopic separation is possible, it is not easily or usually done unless specifically requested. Either ${ }^{234} \mathrm{U}$ or ${ }^{235} \mathrm{U}$ or both could occur in the BCV because ${ }^{234} \mathrm{U}$ occurs naturally at about $0.71 \%$. The reader should treat such data appropriately. 


\section{B.8.6 CONCLUSIONS}

More than 75,000 discrete soil, sediment, groundwater, and surface water analyses were accumulated for use in the BCV RI during the three BCV field investigations. Overall quality of all OU 4, OU 1, and FPSS data are acceptable, with $<1 \%(672 / 78,455)$ of the data having sufficient quality problems to be considered unacceptable.

Those data whose quality presents a challenge to data usability are summarized in Table B.49 and are discussed in the following subsections, which present the data by matrix.

\section{B.8.6.1 Soil}

Soil and sediment data present the greatest challenge to data usability because of the heterogeneity and matrix-related interferences inherent to these matrices. The OU 1 and FPSS projects combine to produce 41,282 discrete data points of which $<1 \%$ are considered unusable.

The only inhibitors to usability of organic soil data are the 11/46 FPSS pesticide/PCB values, which should be considered negatively biased because analytical holding times were exceeded.

Additionally, two copper values from BCV OU 1 (samples W00221 and W00321) should be eliminated from consideration because they were not representative of actual conditions at OU 1 .

\section{B.8.6.2 Sediment}

BCV RI sediment values were obtained from the FPSS and OU 1 investigations. Matrixrelated interferences and inherent heterogeneity contributed to variability in sediment metals data. Arsenic and manganese data precisions at FPSS are generally poor. Additionally, zinc values are generally positively biased across both projects, while antimony at both sites and selenium and silver from the FPSS are generally biased low.

Sediment organic data are affected as follows: one herbicide and VOC sample, as well as three pesticides and SVOC samples, have been negatively impacted because analytical holding times were exceeded. These values are usable but should be considered negatively biased.

Remaining challenges to usability of sediment data in the BCV RI are attributable to matrix heterogeneity. Technetium-99, isotopic thorium, and isotopic uranium radiochemical data are of poor precision. Metals data similarly affected include aluminum, arsenic, cadmium, chromium, cobalt, iron, lead, lithium, manganese, mercury, and potassium. These radiochemical and metals parameters should be considered estimates of true concentrations in the FPSS samples.

\section{B.8.6.3 Groundwater}

Minimal challenges to data usability are associated with BCV RI groundwater data provided by OU 1 . The exceptions are aluminum values, which are positively biased, and antimony data, which are negatively biased. Data should be used accordingly.

\section{B.8.6.4 Surface Water}

BCV RI surface water data were obtained from the OU 4 and OU 1 field investigations. 
A single organic value (SB9115, 2-butanone) should be eliminated from data interpretation because it far exceeds any other 2-butanone value at that station or in the corresponding field duplicate sample (SB9015). Additionally, 15/253 OU 4 VOC samples are negatively biased due to insufficient preservation.

Inorganic data precision and accuracy merit some caution. Total (OU 4) and dissolved (OU 1) aluminum, iron (OU 4), and manganese (OU 4) are of poor precision and thus exhibit a high degree of variability. Additionally, mercury, cyanide, antimony, aluminum, iron, lithium, and silver are generally biased low in the OU 4 dataset.

The lead value for SS8009 should be eliminated from consideration. The dissolved value for this analyte is $37.1 \mu \mathrm{g} / \mathrm{L}$, while the total is only $2 \mu \mathrm{g} / \mathrm{L}$. Further, the next highest lead value at the SS-8 station is $11.4 \mu \mathrm{g} / \mathrm{L}$.

Challenges to radiochemical data quality include gross $\alpha$, isotopic uranium, isotopic thorium, and ${ }^{99} \mathrm{Tc}$ data. Total and dissolved gross $\alpha$ and ${ }^{23} \mathrm{U}$ values at OU 4 exhibit poor precision. The accuracy of ${ }^{234} \mathrm{U}$ data from OU 4 is in question. Data should be considered according to data validation flags.

The sample $\mathrm{B} 01511^{212} \mathrm{~Pb}$ result seems to be nonrepresentative of actual conditions at BCV OU 1 and should therefore be eliminated from consideration. Likewise, SS6008, SN5008, SB9017, and SN3016 isotopic uranium values are not usable for any purpose as these data do not seem to be representative of actual conditions at OU 4 . Finally, ${ }^{99} \mathrm{Tc}$ data from NT-3 are unusable because of poor sensitivity. 
B9-1

\section{B.9 REFERENCES}

APHA (American Public Health Association). 1975. Standard Methods for the Analysis for Water and Wastewater.

Anonymous. 1983. Bear Creek Characterization Study, December 1981 through March 1983, Oak Ridge Y-12 Plant, Oak Ridge, Tennessee.

Bailey, J. K. 1980. Compliance with PCB Regulations-Y-12 Burial Ground Pond, Memorandum to M. Sanders, Union Carbide Corporation, Inc., Oak Ridge Y-12 Plant, February 21.

BNI (Bechtel National, Incorporated). 1983. Preliminary Characterization and Remedial Action Plan for the Y-12 Plant Oil Landfarm, Y/Sub/83-47974C/1, prepared for Martin Marietta Energy Systems, Inc., Oak Ridge Y-12 Plant, Oak Ridge, Tennessee, October.

Bohrman, D. E. 1989. Oil Landfarm Summary of Closure under Rules Governing Hazardous Waste Management in Tennessee, Y/TS-394/2, Martin Marietta Energy Systems, Inc., Oak Ridge Y-12 Plant, Oak Ridge, Tennessee, November.

Bogle, M. A., R. R. Turner, and S. D. Easterling. 1991. Characterization of Contamination Along the Upper Reaches of the East Fork of Tributary 8 at Burial Ground C in Bear Creek Valley, Y/TS-720, Martin Marietta Energy Systems, Inc., Oak Ridge Y-12 Plant, Oak Ridge, Tennessee, February.

Bogle, M. A. and R. R. Turner. 1993. Comparison of water quality at BCK-12.46 and BCK-11.97 in upper Bear Creek, February 1989-June 1992, Y/TS-945, Martin Marietta Energy Systems, Inc., Oak Ridge Y-12 Plant, Oak Ridge, Tennessee, May.

Burson, Z. G. 1976. Aerial Radiological Surveys of ERDA's Oak Ridge Facilities and Vicinity (Survey Period: 1973-1974), EG\&G-1183-1682, Las Vegas, Nevada.

Clapp, R. B., D. K. Cox, J.R. Jones, W. C. Kyker, J. A. Watts, and B.J. Fredrick. 1990. Surface Water Discharge Data for the Bear Creek Watershed, Oak Ridge, Tennessee, 1984-1988, Y/TS-407, Martin Marietta Energy Systems, Inc., prepared for Y-12 HSEAD, Oak Ridge, Tennessee, October.

Collins, E. T. 1990. Water Sample results from Upper West Forks Tributary 7 and Tributary 8, Internal Martin Marietta Energy Systems, Inc., Correspondence to Distribution, Oak Ridge Y-12 Plant, Oak Ridge, Tennessee, July.

DOE (Department of Energy). 1993. Remedial Investigation Work Plan for Bear Creek Valley Operable Unit 4 (Shallow Groundwater in Bear Creek Valley) at the Oak Ridge Y-12 Plant, Oak Ridge, Tennessee, DOE/OR/01-1115\&D3, September.

DOE. 1994a. Remedial Investigation Work Plan for Bear Creek Valley Operable Unit 1 (S-3 Ponds, Boneyard/Burnyard, Oil Landfarm, Sanitary Landfill 1, and the Burial Grounds, Including Oil Retention Ponds 1 and 2) at the Oak Ridge Y-12 Plant, Oak Ridge, Tennessee, Volumes 1. Main Text and 2. Appendices, DOE/OR/01-1161/V1\&D2, V2\&D2, March. 
DOE. 1994b. Bear Creek Valley Data Quality Objectives Meeting Minutes.

DOE. 1995a. Soil Sampling and Analysis Plan for the Bear Creek Valley Floodplain at the Oak Ridge Y-12 Plant, Oak, Ridge, Tennessee, DOE/OR/01-1322\&D2, March.

DOE. 1995b. Preliminary Assessment of the Ecological Risks to Wide-Ranging Wildlife Species on the Oak Ridge Reservation, DOE/OR/01-1407\&D1.

Dreier, R. B., T. O. Early, and H. L. King. 1993. Results and Interpretation of Groundwater Data Obtained from Multiport-Instrumented Coreholes (GW-131 through GW-135); Fiscal Years 1990-1991, Y/TS-803, Martin Marietta Energy Systems, Inc., Oak Ridge National Laboratory, Oak Ridge, Tennessee.

Dreier, R. B. and A. Caldanaro. 1993. Installation Summary for the DNAPL Characterization Multiport Wells, GW-726, GW-727, GW-729, GW-730, and GW-790, Y/ER-117, Martin Marietta Energy Systems, Inc., Oak Ridge National Laboratory, Oak Ridge, Tennessee.

Energy Systems (Lockheed Martin Energy Systems, Inc.) 1987a. Environmental Surveillance of the U.S. Department of Energy Oak Ridge Reservation and Surrounding Environs During 1986. ES/ESH-1/V1 \& V2, Oak Ridge, Tennessee.

Energy Systems. 1987b. Analytical Results: Groundwater Samples Collected from Selected Wells at the Y-12 Plant Site, Y/TS-218/2, Oak Ridge Y-12 Plant, Oak Ridge, Tennessee.

Energy Systems. 1990. Oak Ridge Y-12 Plant Groundwater Protection Program Management Plan, Y/TS-633, Oak Ridge Y-12 Plant, Oak Ridge, Tennessee.

Energy Systems. 1993a. Resource Management Plan for the Oak Ridge Reservation: Volume 29: Rare Plants on the Oak Ridge Reservation, ORNL/NERP-7, Oak Ridge National Laboratory, Oak Ridge, Tennessee.

Energy Systems. 1993b. Resource Management Plan for the Oak Ridge Reservation: Volume 30: Oak Ridge National Environmental Research Park Natural Areas and Reference Areas-Oak Ridge Reservation Environmentally Sensitive Sites Containing Special Plants, Animals, and Communities, ORNL/NERP-8, Oak Ridge National Laboratory, Oak Ridge, Tennessee.

Energy Systems. 1993c. Remedial Investigation Work Plan for Bear Creek Valley Operable Unit 2 (Rust Spoil Area, SY-200 Yard, Spoil Area 1) at the Oak Ridge Y-12 Plant, Oak Ridge, Tennessee, DOE/OR-1060\&D3, ES/ER-43/\&D3, Y/ER/Sub/91/99069/1, Oak Ridge Y-12 Plant, Oak Ridge, Tennessee, May.

Energy Systems. 1993d. Oak Ridge Environmental Report for 1992. Volume 1: Narrative. ES/ESH-31/N1, Oak Ridge, Tennessee, September.

Energy Systems. 1993e. Annual Report on the Background Soil Characterization Project on the Oak Ridge Reservation, Oak Ridge, Tennessee: Results of Phase I Investigation, DOE/OR/01-1136 (ES/ER/TM-43), Oak Ridge, Tennessee, May. 
Energy Systems. 1995. Remedial Investigation Report on Bear Creek Valley Operable Unit 2 (Rust Spoil Area, Spoil Area 1, and SY-200 Yard) at the Oak Ridge Y-12 Plant, Oak Ridge, Tennessee, DOE/OR/01/1273/V1\&D2/A1, Oak Ridge Y-12 Plant, Oak Ridge, Tennessee, April.

ERDA (Energy Research and Development Administration). 1975. Preliminary Draft Environmental Analysis Oak Ridge Operations, Vol. VI, Section 2.5.5.

EPA (Environmental Protection Agency). 1987. Data Quality Objectives for Remedial Response Activities Development Process, EPA/540/G-87/003.

EPA. 1991. Region IV Environmental Compliance Branch Standard Operating Procedures and Quality Assurance Manual.

Evaldi, R. D. 1984. Streamflow and Specific Conductance Data for Selected Sites, February 15 through April 9, 1984, Near the Y-12 Plant, the Oak Ridge Reservation, Tennessee, USGS Open File Report 84-625.

Evaldi, R. D. 1985. Streamflow and Specific Conductance Data for Bear Creek, August 13, 1985, Oak Ridge Reservation, Tennessee, USGS Open File Report 85-682.

Francke, H.C. 1973. Nitrate Effluents and Their Effect on the Environment as Related to the Y-12 Plant, Y/DA-5085, Union Carbide Corporation Nuclear Division, Oak Ridge Y-12 Plant, Oak Ridge, Tennessee.

Geraghty and Miller, Inc. 1985. Remedial Alternatives for the Bear Creek Valley Waste Disposal Area, Y/Sub/85-00206C/3, prepared for Martin Marietta Energy Systems, Inc., Oak Ridge Y-12 Plant, Oak Ridge, Tennessee.

Geraghty and Miller, Inc. 1987. Hydrogeologic Investigation of the S-3 Pond Area at the Y-12 Plant, Y/Sub/87-00206C/18, prepared for Martin Marietta Energy Systems, Inc., Oak Ridge Y-12 Plant, Oak Ridge, Tennessee.

Geraghty and Miller. 1989. Tracer Study of the Hydrologic System of Upper Bear Creek, Y-12 Plant, Oak Ridge, Tennessee, Y/Sub/89-00206C/4, prepared for Martin Marietta Energy Systems, Inc., Oak Ridge Y-12 Plant, Oak Ridge, Tennessee.

H\&R Technical Associates, Inc. 1995. Letter Report: Radiological Analysis of Oak Ridge Y-12 Plant Groundwater Data, Y/Sub/95-TK532C/1, prepared for Lockheed Martin Energy Systems, Inc., Oak Ridge Y-12 Plant, Oak Ridge, Tennessee, June 22.

Haase, C. S. and H. L. King. 1990. Report and Preliminary Assessment of the Occurrence of Dense Nonaqueous Phase Liquids in the Bear Creek Burial Grounds Hazardous Waste Disposal Unit at the Oak Ridge Y-12 Plant, Y/TS-629, Martin Marietta Energy Systems, Inc., Oak Ridge Y-12 Plant, Oak Ridge, Tennessee.

Hatcher, R. D., P. J. Lemiszki, R. B. Dreier, R. H. Ketelle, R. R. Lee, D. A. Leitzke, W. M. McMaster, J. L. Foreman, and S. Y. Lee. 1992. Status Report on the Geology of the Oak Ridge Reservation, ORNL/TM-12074, Martin Marietta Energy Systems, Inc., Oak Ridge National Laboratory, Oak Ridge, Tennessee. 
Herbes, S. E. 1988. PCB Contamination in the Sediments of the Oil Retention Ponds and Associated Tributary Channels at the Burial Grounds of the Oak Ridge Y-12 Plant, Y/TS-431, Martin Marietta Energy Systems, Inc., Oak Ridge Y-12 Plant, Oak Ridge, Tennessee.

Herbes, S. E. 1989. PCBs, Uranium, and Oil/Grease in Soil at the Oak Ridge Y-12 Oil Landfarm: Results of 1985 - 1986 Sampling and Analysis Program, Y/TS-538, Martin Marietta Energy Systems, Inc., Oak Ridge Y-12 Plant, Oak Ridge, Tennessee.

Hinzman, R. L., J. J. Beauchamp, C. F. Cada, S. W. Christiansen, M. J. Peterson, T. L. Phipps, W. K. Roy, E. M. Schilling, J. G. Smith, M. R. Smith, G. R. Southworth, A. J. Stewart, L. F. Wicker, and J. A. Wojtowicz. 1995. Report on the Biological Monitoring Program for Bear Creek at the Oak Ridge Y-12 Plant, Oak Ridge, Tennessee, 1989-1994, Draft, ORNL/TM-12334, Martin Marietta Energy Systems, Inc., Oak Ridge National Laboratory, Oak Ridge, Tennessee.

Hoffman, F. O., B. G. Blaylock, K .E. Couser, K. L. Daniels, C. C. Travis, and C. W. Weber. 1984. Preliminary Screening of Contaminants in Sediments, ORNL/TM-9370, Martin Marietta Energy Systems, Inc., Oak Ridge National Laboratory, Oak Ridge, Tennessee.

HSW (HSW Environmental Consultants, Inc.). 1991. Groundwater Quality Assessment for the Bear Creek Hydrogeologic Regime at the Y-12 Plant, 1990: Data Interpretations and Proposed Modifications, Y/Sub/91-YP507C/1 Part 2, prepared for Martin Marietta Energy Systems, Inc., Oak Ridge Y-12 Plant, Oak Ridge, Tennessee.

HSW. 1992. Groundwater Quality Assessment for the Bear Creek Hydrogeologic Regime at the Y-12 Plant: 1991 Groundwater Quality Data Interpretations and Proposed Program Modifications, Y/Sub/92-YP507C/1/P1\&P2, prepared for Martin Marietta Energy Systems, Inc., Oak Ridge Y-12 Plant, Oak Ridge, Tennessee, August.

HSW. 1995. Calendar Year 1994 Groundwater Quality Report for the Bear Creek Hydrogeologic Regime at the Y-12 Plant: 1994 Groundwater Quality Data Interpretations and Proposed Program Modifications, Y/Sub/95-EAQ10C/1/P2, prepared for Martin Marietta Energy Systems, Inc., Oak Ridge Y-12 Plant, Oak Ridge, Tennessee, August.

Jeter, I. W. and Napier, J. M. 1978. Chemical Analysis of the S-3 Disposal Ponds (April 1978), Y/DA-7794, Union Carbide Corporation-Nuclear Division, Oak Ridge Y-12 Plant, Oak Ridge, Tennessee.

Jeter, I. W. 1983. The Chemical and Radiological Characterization of the S-3 Ponds, Y/MA-6400, Union Carbide Corporation-Nuclear Division, Oak Ridge Y-12 Plant, Oak Ridge, Tennessee.

Kimbrough, C. W. and R. R. Turner. 1987. Field Notebook: Sampling and Analysis of Sludges in the S-3 Ponds at the Y-12 Plant, Y/TS-294, Martin Marietta Energy Systems, Inc., Environmental Sciences Division, Oak Ridge National Laboratory, Oak Ridge, Tennessee.

Kimbrough, C. W. 1988. Characterization of the Tributary 7 Oil Retention Pond No. 1 and Associated Seep in Bear Creek Watershed, Y/TS-458, Martin Marietta Energy Systems, Inc., Oak Ridge Y-12 Plant, Oak Ridge, Tennessee, August. 
Kimbrough, C. W., L. W. Long, and L. W. McMahon. 1990. Environmental Surveillance Procedures Quality Control Program, ESH/Sub/87-21706/1, Rev. 1, Martin Marietta Energy Systems, Inc., Oak Ridge K-25 Site, Oak Ridge, Tennessee, January.

Lowery, J. F. 1987. Water Resources Data for Tennessee, Water Year 1986, Report USGS/WRG/HD-86/216, USUS, Nashville, Tennessee.

McCauley, L. L. 1984a. Sediment Assessment and Inventory of Existing Contamination and Biological Data of Two Oil Retention Ponds in the Y-12 Plant, Bear Creek Valley Waste Disposal Area, Y/IA-165, Martin Marietta Energy Systems, Inc., Oak Ridge Y-12 Plant, Oak Ridge, Tennessee.

McCauley, L. L. 1984b. Inventory of Existing Contamination in the Y-12 Plant Bear Creek Valley Oil Landfarm Area, UCC-ND Report Y/IA-166, Martin Marietta Energy Systems, Inc., Oak Ridge Y-12 Plant, Oak Ridge, Tennessee, January.

McCauley, L. L. 1985. Analytical Results for Water, Sediment, and Soil Samples Collected in the Y-12 Plant Bear Creek Valley Waste Disposal Areas, Y/TS-112, Martin Marietta Energy Systems, Inc., Oak Ridge Y-12 Plant, Oak Ridge, Tennessee.

McClain, G. R. 1972. Preliminary Aquatic Survey of East Fork Poplar Creek, 1972. Report to Pollution Control Branch, U.S. Atomic Energy Commission, Oak Ridge, Tennessee, 18 pp.

McElhaney, R .J. 1982. PCB in Fish from East Fork Poplar Creek and Bear Creek, Memorandum from R.J. McElhaney, Y-12 Plant, to W. Van Winkle, Environmental Sciences Division, Oak Ridge National Laboratory, Oak Ridge, Tennessee, September 22.

McMahon, L. W. 1988. Sampling and Analysis to Support Excavation of Blue Lagoon Sediment Build-up, Y/TS-481, Martin Marietta Energy Systems, Inc., Oak Ridge Y-12 Plant, Oak Ridge, Tennessee.

McMaster, W. M. 1967. "Hydrologic Data for the Oak Ridge Area, Tennessee," U.S. Geological Survey-Water Supply Paper No. 1838-N, U.S. Government Printing Office, Washington, D.C.

Moore, E. K. 1992. Hydrograph Analysis in Fractured Rock Terrace, Groundwater, Vol. 30, no. 3, pp. 390-395.

Napier, J. M., C. W. Hancher, G. E. Harris, M. E. Johnson, and B. C. Padgett. 1988. Treatability Studies for Waters in Oil Pond No. 1, Oil Pond No. 2, and the Oil Seep, Y/DZ-392, Martin Marietta Energy Systems, Inc., Oak Ridge Y-12 Plant, Oak Ridge, Tennessee.

Opresko, D. M., B. E. Sample, and G. W. Suter II. 1994. Toxicological Benchmarks for Wildlife: 1994 Revision, ES/ER/TM-86/R1, Environmental Sciences Division, Oak Ridge National Laboratory, Oak Ridge, Tennessee.

Pulliam, Pamela J. 1985a. Water-quality Data for 34 Sites, April and June 1984, Near the Y-12 Plant, The Oak Ridge Reservation, Tennessee, U.S. Geological Survey Open File Report 85-165. 
Pulliam, Pamela J., 1985b. Water Quality Data for 35 Sites, September, 1984, Near the Y-12 Plant, The Oak Ridge Reservation, Tennessee, U.S. Geological Survey Open File Report 85-553.

Reece, J. H. 1973. Preliminary Aquatic Survey of East Fork Poplar Creek and Bear Creek, 1973, Report to Environmental Protection Branch, U.S. Atomic Energy Commission, Oak Ridge, Tennessee, $26 \mathrm{pp}$.

Rosensteel, B. A. and C. C. Trettin. 1993. Identification and Characterization of Wetlands in the Bear Creek Watershed, Y/TS-1016, Martin Marietta Energy Systems, Inc., Oak Ridge National Laboratory, Oak Ridge, Tennessee.

SAIC (Science Applications International Corporation). 1985. SAIC Project File. Project information consisting of hard copy of lab data sheets received from Chris Smith, Lockheed Martin Energy Systems, Inc.

SAIC. 1994a. Environmental Technical Support for Bear Creek Valley Operable Unit 1 Remedial Investigation Field Activities Manual, prepared for RI Field Team.

SAIC. 1994b. Environmental Technical Support for Bear Creek Valley Operable Unit 4 Remedial Investigation Field Activities Manual, prepared for RI Field Team.

SAIC. 1995a. SAIC Project File. Environmental Technical Support, Bear Creek Valley Operable Unit 1 and Floodplain Soil Sampling Field Technical Procedures, Rev. 5.

SAIC. 1995b. SAIC Project File. Project information consisting of diskette and letter received from Roger Clapp, Lockheed Martin Energy Systems, Inc.

SAIC. 1995c. SAIC Project File. Project information consisting of hard copy of printed data summary received from Chris Smith, Lockheed Martin Energy Systems, Inc.

SAIC. 1995d. SAIC Project File. Project information consisting of paper and electronic copies of survey results received from Chemrad, Inc.

SAIC. 1995e. SAIC Project File. Project information consisting of electronic files received from John Robinson, USGS.

Sample, B. E. and G. W. Suter II. 1994. Estimating Exposure of Terrestrial Wildlife to Contaminants, ER/ES/TM-125, Environmental Sciences Division, Oak Ridge National Laboratory, Oak Ridge, Tennessee.

Southworth, G. R., J. A. Burris, J. M. Loar, M. G. Ryon, J. G. Smith, A. J. Stewart, and J. A. Burris. 1992. Ecological Effects of Contaminants and Remedial Actions in Bear Creek ORNL/TM1 1977, ESD Publication No. 3810, Martin Marietta Energy Systems, Inc., Oak Ridge National Laboratory, Oak Ridge, Tennessee.

TVA (Tennessee Valley Authority). 1986. Instream Contaminant Study: Task 5 Summary Report, ZZ-86-06-08, prepared for U.S. Department of Energy, Oak Ridge, Tennessee, under Interagency Agreement No. DE-AI05-85OR. 
Taylor, P. A. 1981. Sampling of Oil Farm Plots. Memorandum to M. Sanders, December 16.

Turner, R. R. and G. E. Kamp. 1984. Characterization and Remedial Alternatives for Sediments in Upper Bear Creek, Y/TS-56, Martin Marietta Energy Systems, Inc., Oak Ridge Y-12 Plant, Oak Ridge, Tennessee.

Turner, R. R. 1988. Sampling and Analysis of Soil from 1985 Tank Farm Excavations Near S-3 Ponds, Y-12 Plant, Oak Ridge, Tennessee, Y/TS-473, Martin Marietta Energy Systems, Inc., Oak Ridge Y-12 Plant, Oak Ridge, Tennessee, September.

Turner, R. R., M. A. Bogle, R. B. Clapp, K. Dearstone, R. B. Dreier, T. O. Early, S. E. Herves, J. M. Loar, P. D. Parr, and G. R. Southworth. 1991. Remedial Investigation Work Plan for Bear Creek (Y02-S600) at the Oak Ridge Y-12 Plant, ES/ER-19\&D2, Y/ER/Sub-90/99928/2, Martin Marietta Energy Systems, Inc., Oak Ridge Y-12 Plant, Oak Ridge, Tennessee.

U.S. Atomic Energy Commission (USAEC). 1953. A Meteorological Survey of the Oak Ridge Area. Final Report Covering the Period 1948-1952, ORO-99, Weather Bureau, Oak Ridge, Tennessee.

Van Winkle, W., R. W. Counts, J. E. Dorsey, J. W. Eldwood, V. W. Lowe, Jr., R. McElhaney, S. D. Schlotzhauer, F. G. Taylor, Jr., and R. R. Turner. 1984. Mercury Contamination in East Fork Poplar Creek and Bear Creek, ORNL/TM-8894, ESD-2051, Martin Marietta Energy Systems, Inc., Oak Ridge National Laboratory, Oak Ridge, Tennessee.

Walker, B. A. and Saylor, R. E., eds., Low Level Waste Disposal Development and Demonstration (LLWDDD) Program. 1988. Data Package for the Low-Level Waste Disposal Development and Demonstration Program Environmental Impact Statement, ORNL/TM-10939/V1\&V2, Martin Marietta Energy Systems, Inc., Oak Ridge National Laboratory, Oak Ridge, Tennessee.

Will, M. E. and G. W. Suter II. 1994. Toxicological Benchmarks for Screening Potential Contaminants of Concern for Effects on Soil and Litter Invertebrates and Heterotrophic Process, ES/ER/TM-126, Martin Marietta Energy Systems, Inc., Oak Ridge National Laboratory, Oak Ridge, Tennessee.

Y-12 HSEAD (Health, Safety, Environmental, and Accountability Division). 1984a. Preliminary Assessment of Existing Contamination in Bear Creek Valley Watershed Area and Potential Remedial Actions for Mitigating Its Impact on Bear Creek, Y/TS-51/1, Martin Marietta Energy Systems, Inc., Oak Ridge Y-12 Plant, Oak Ridge, Tennessee.

Y-12 HSEAD. 1984b. Appendices: Preliminary Assessment of Existing Contamination in Bear Creek Valley Watershed Area and Potential Remedial Actions for Mitigating its Impact on Bear Creek, Y/TS-51/2, Martin Marietta Energy Systems, Inc., Oak Ridge Y-12 Plant, Oak Ridge, Tennessee, June.

Y-12 HSEAD. 1987. Post-Closure Permit Application for the Oil Landfarm Hazardous Waste Disposal Unit at the Y-12 Plant, Y/Sub/87-00206C/10, Martin Marietta Energy Systems, Inc., Oak Ridge Y-12 Plant, Oak Ridge, Tennessee. 
B10-1

\section{B.10 FIGURES}




\section{Notice}

Page(s) size did not permit electronic reproduction. Information may be purchased by the general public from the National Technical Information Service, U.S. Department of Commerce, Springfield, VA 22161 (1800-553-6847). DOE and DOE contractors may purchase information by contacting DOE's Office of Scientific and Technical Information, P.O. Box 62, Oak Ridge, TN 37831-0062, Attn: Information Services (1865-576-8401). 
B10-5

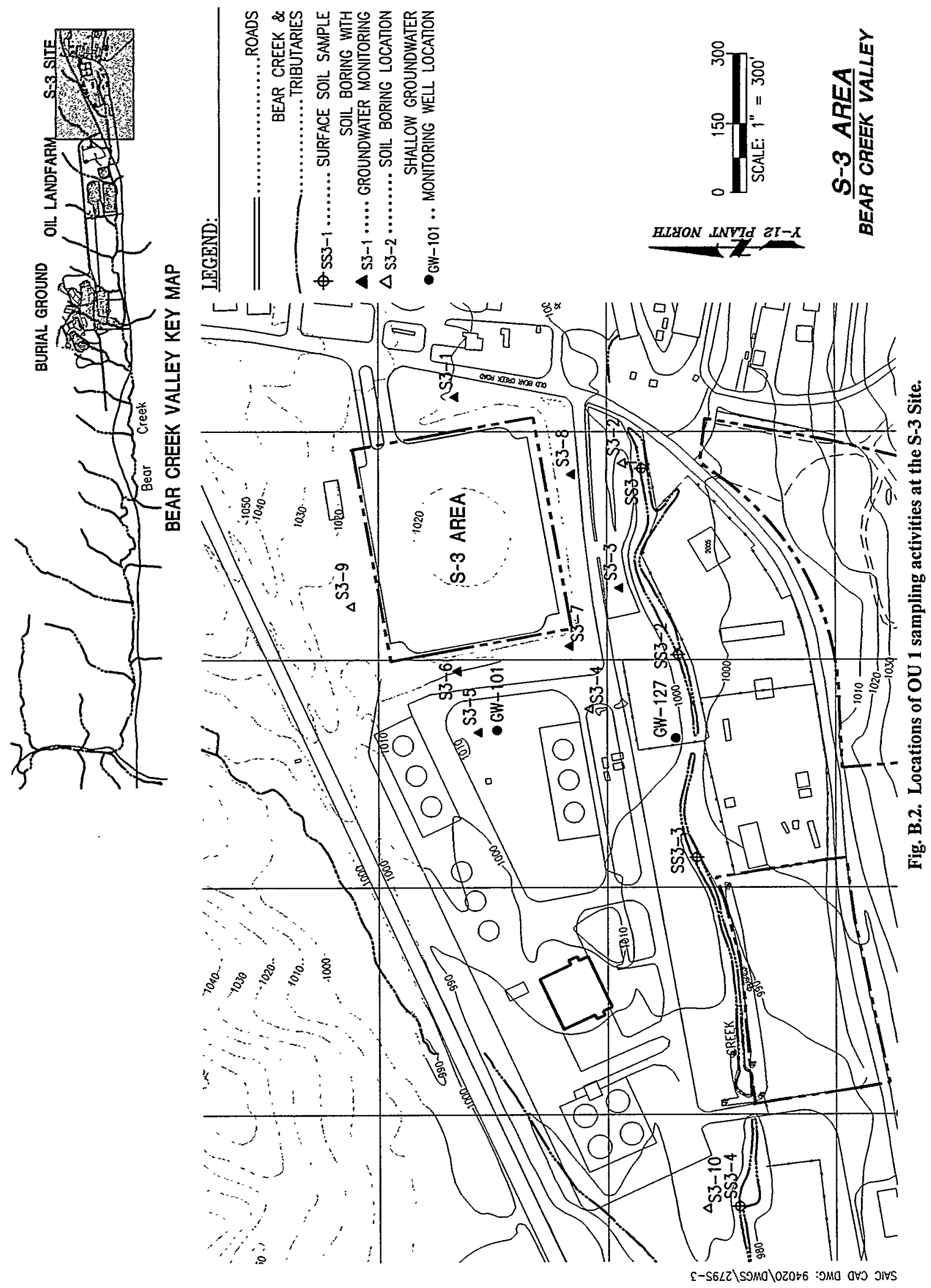



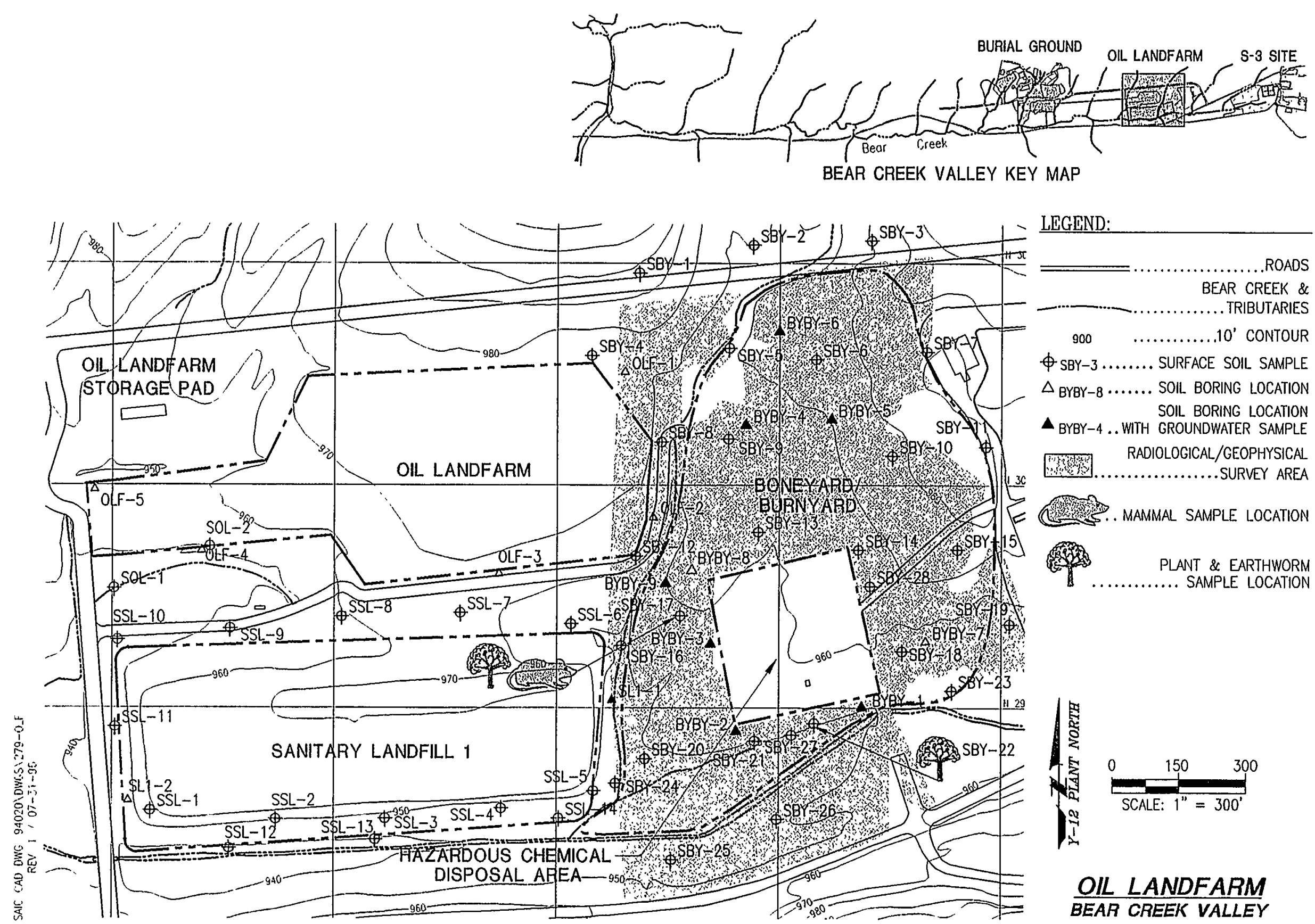

LEGEND:

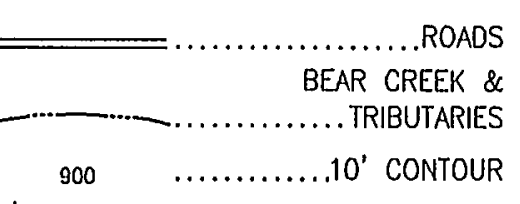
\$ SBY-3 ....... SURFACE SOIL SAMPLE $\triangle$ BYBY-8...... SOLL BORING LOCATION SOIL BORING LOCATION $\triangle$ BYBY-4 .. WTH GROUNDWATER SAMPLE RADIOLOGICAL/GEOPHYSICAL M................. SURVEY AREA

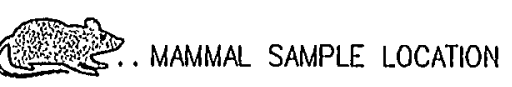
PLANT \& EARTHWORM

Fig. B.3. Locations of OU 1 sampling activities at BYBY, Oil Landfarm, and SL 1.

OIL LANDFARM BEAR CREEK VALLEY

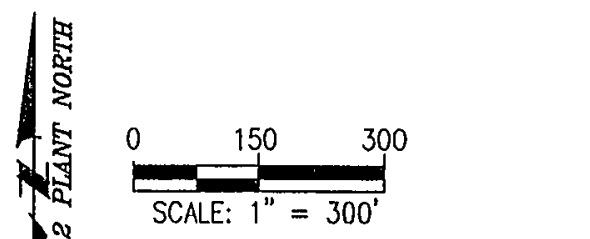


B10-7

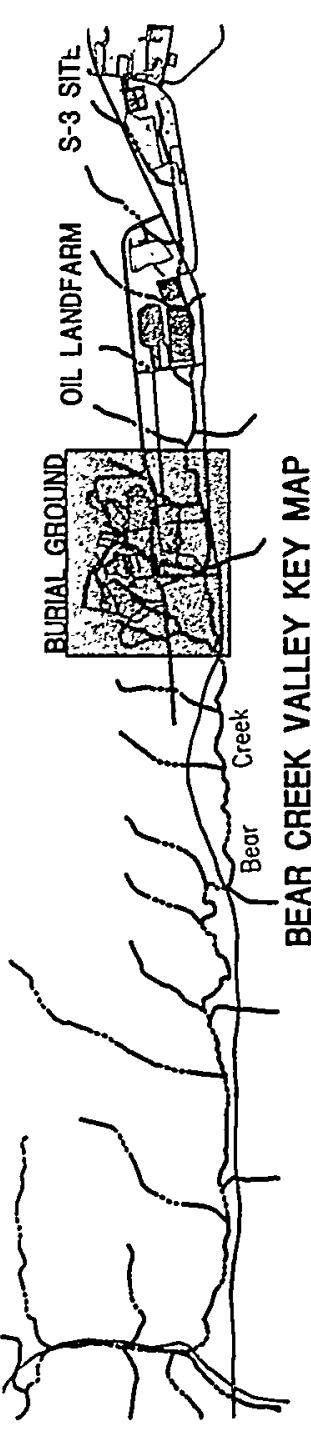

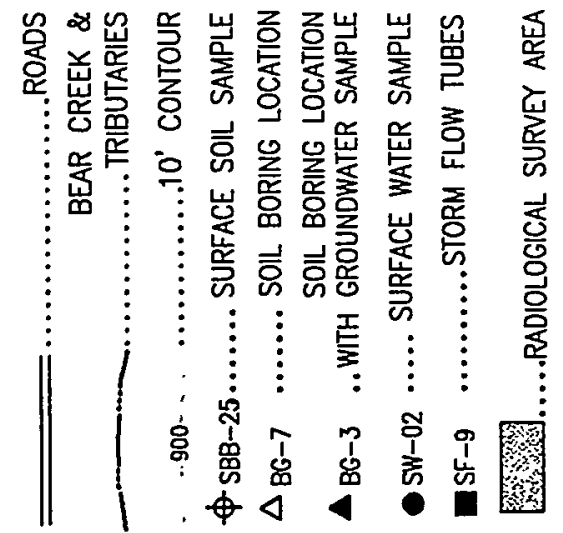
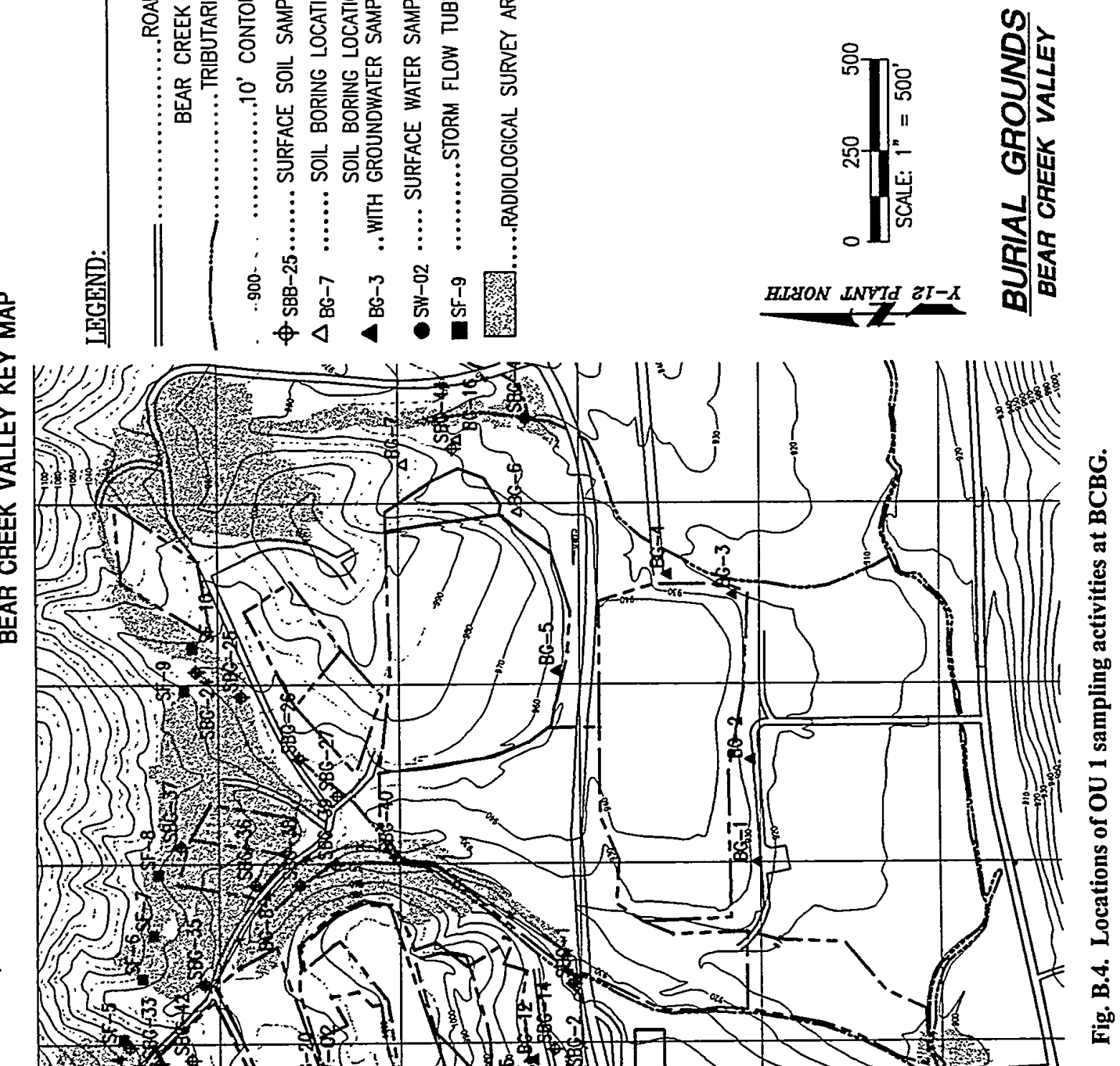

B10-9
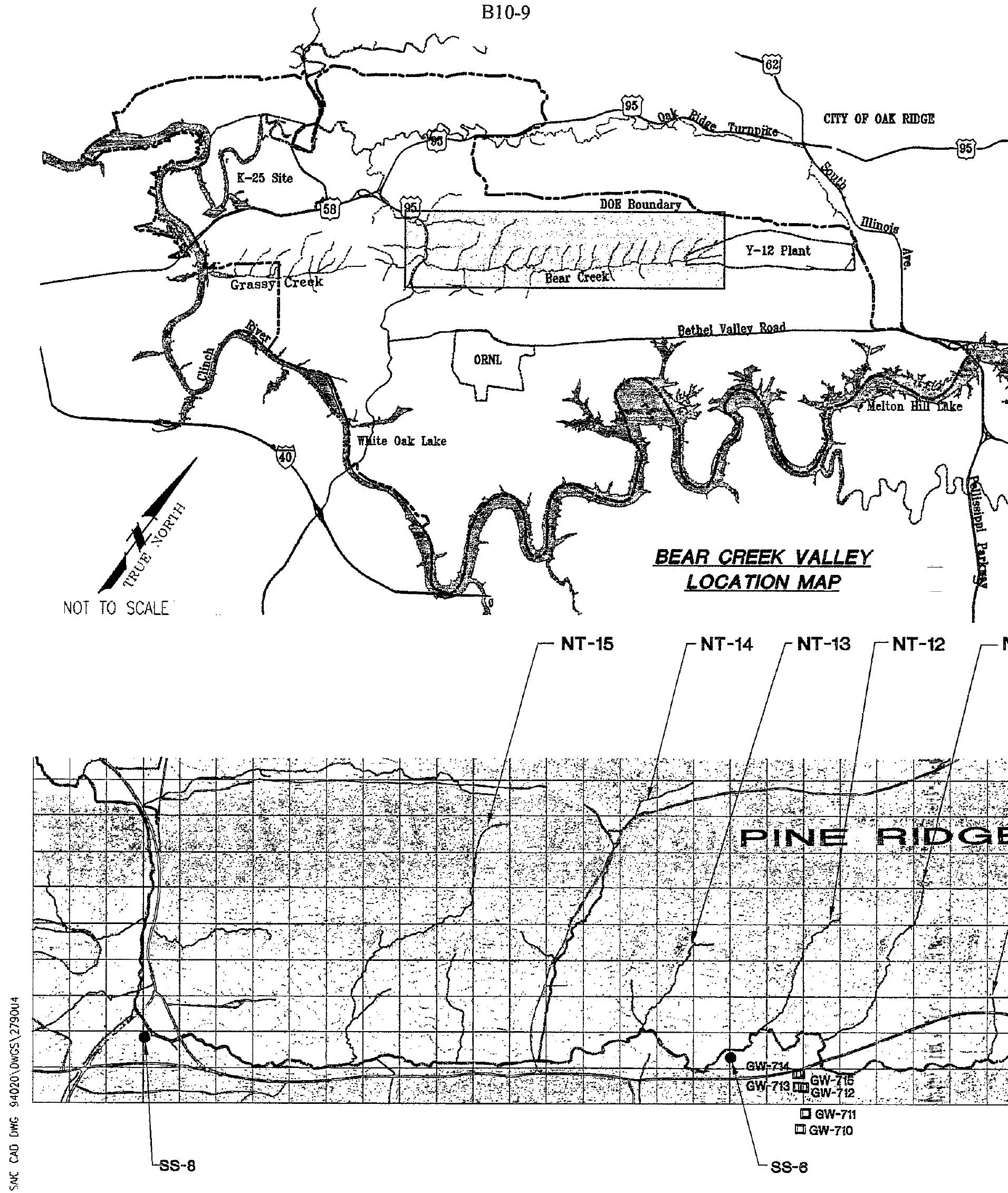

Fig. B.5. Locations of OU 


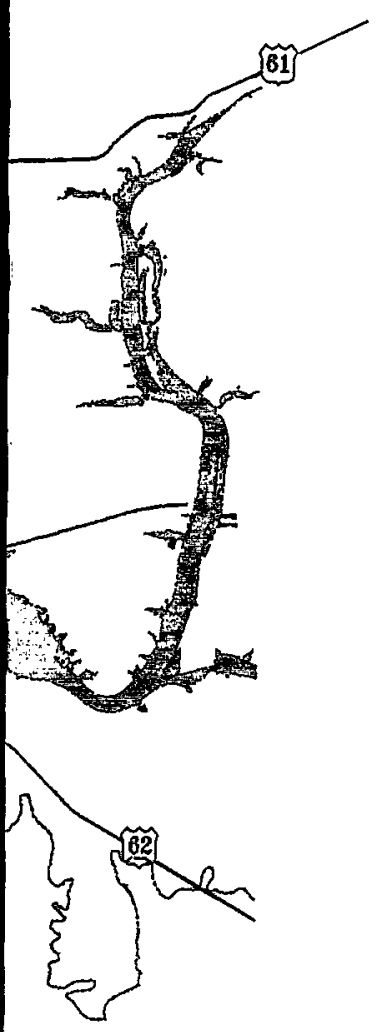

\section{BEAR CREEK \\ VALLEY}
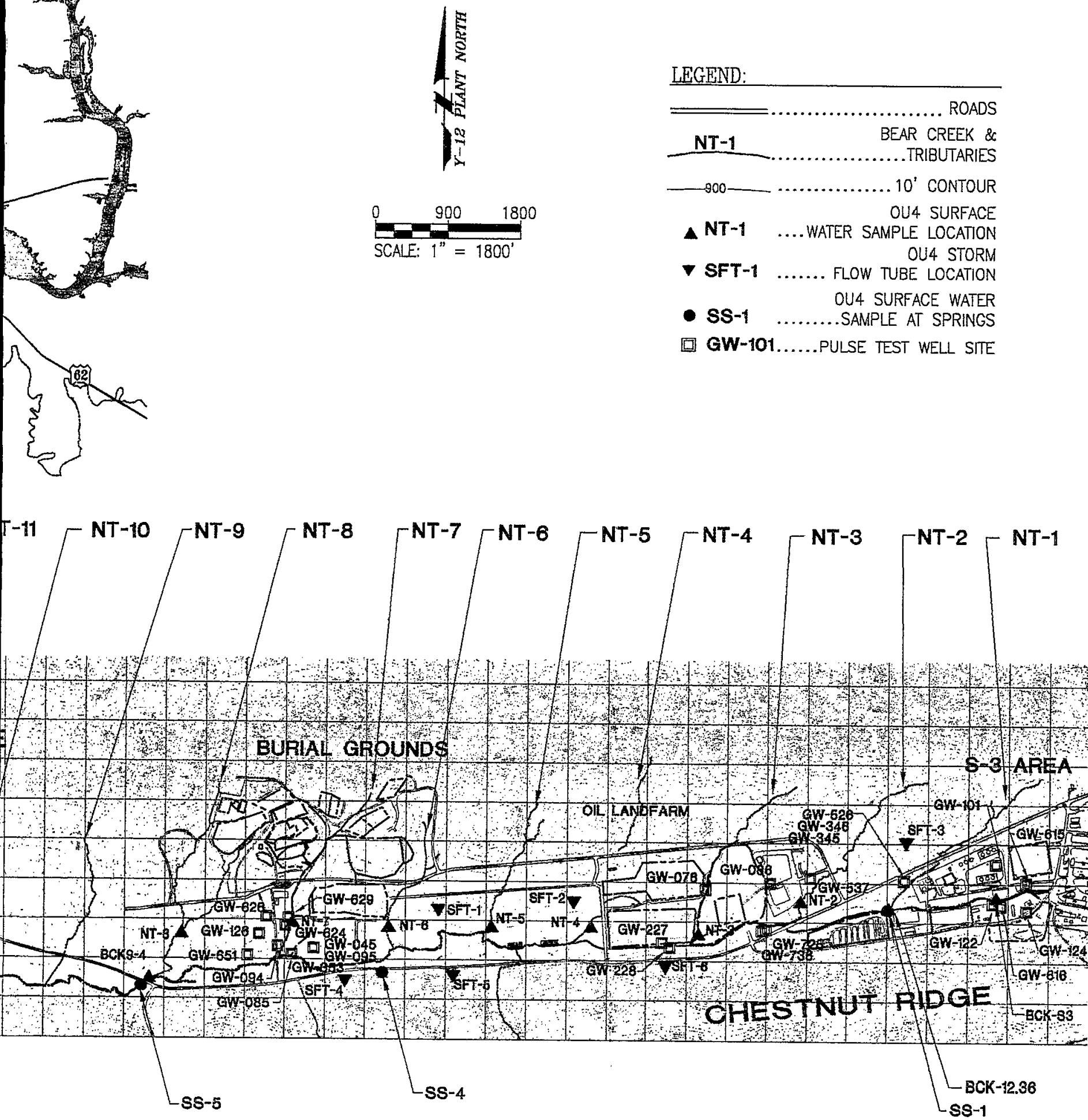

sampling activities in BCV. 

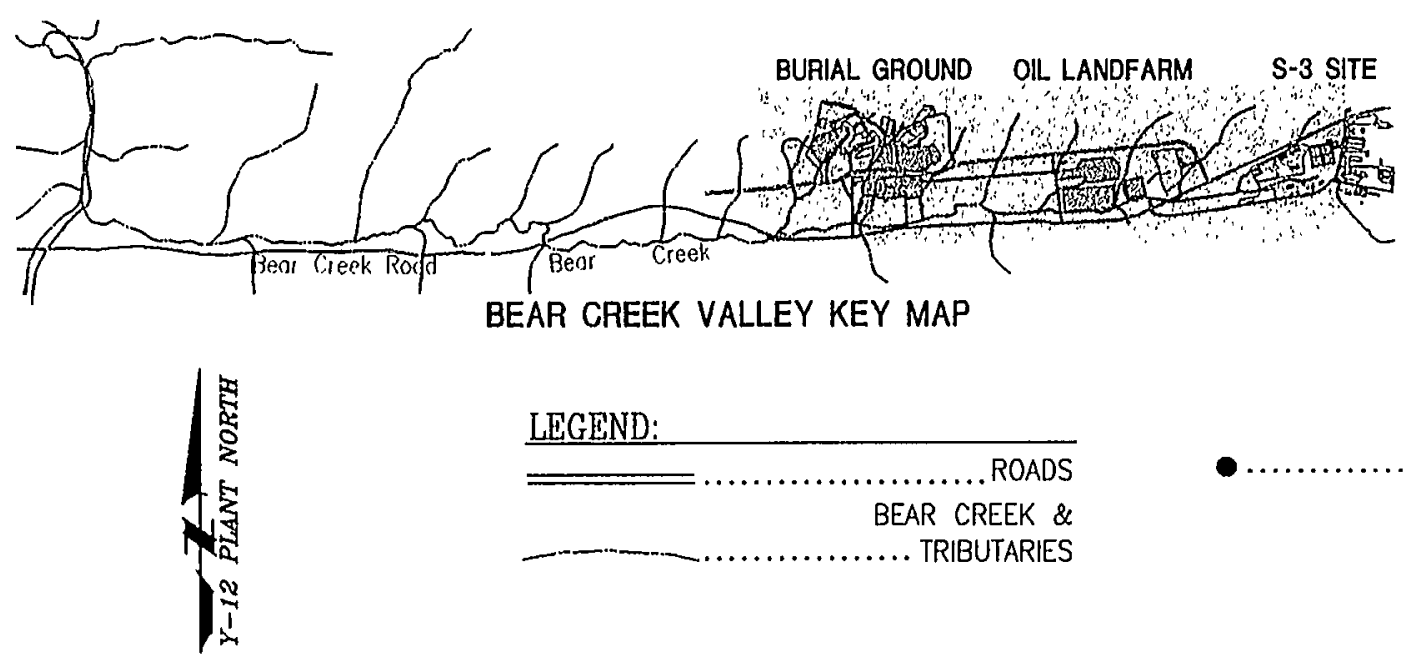

BEAR CREEK VALLEY KEY MAP

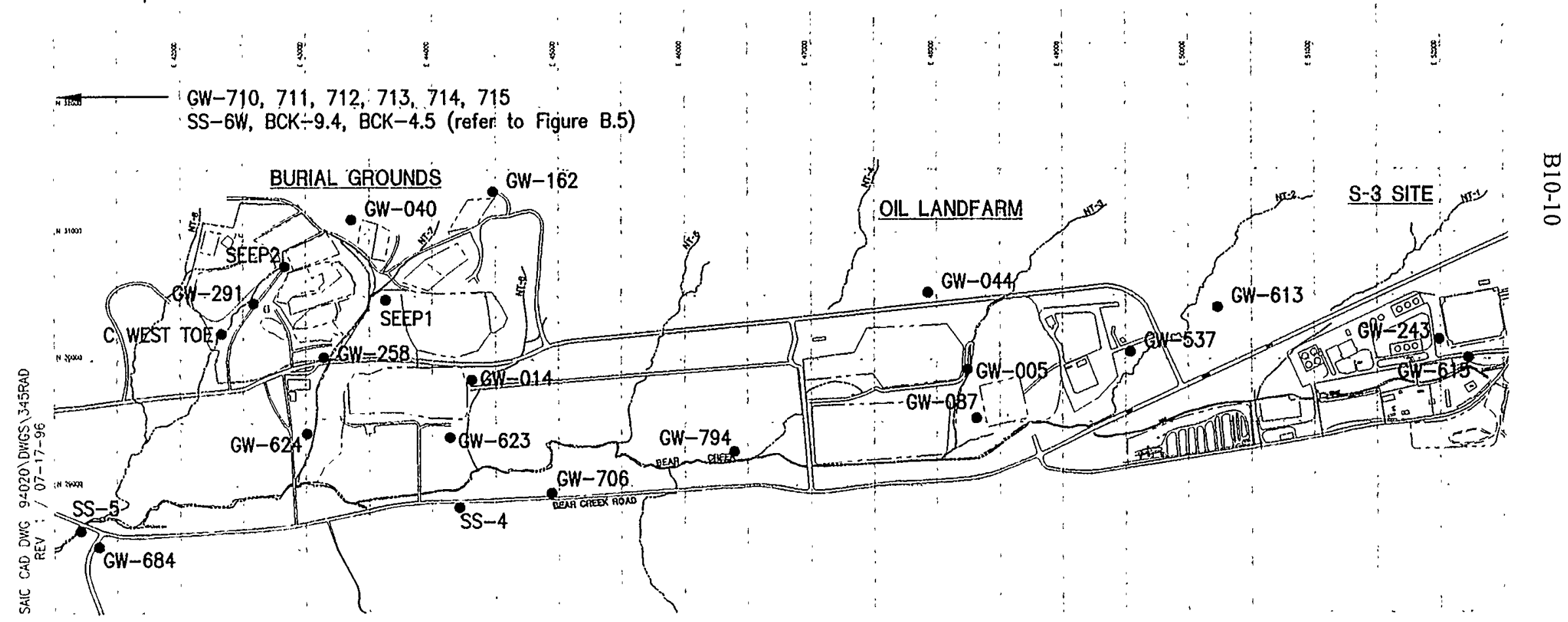

Fig. B.6. Surface water and groundwater sampling locations for August 1995 radiological sampling task in BCV. 

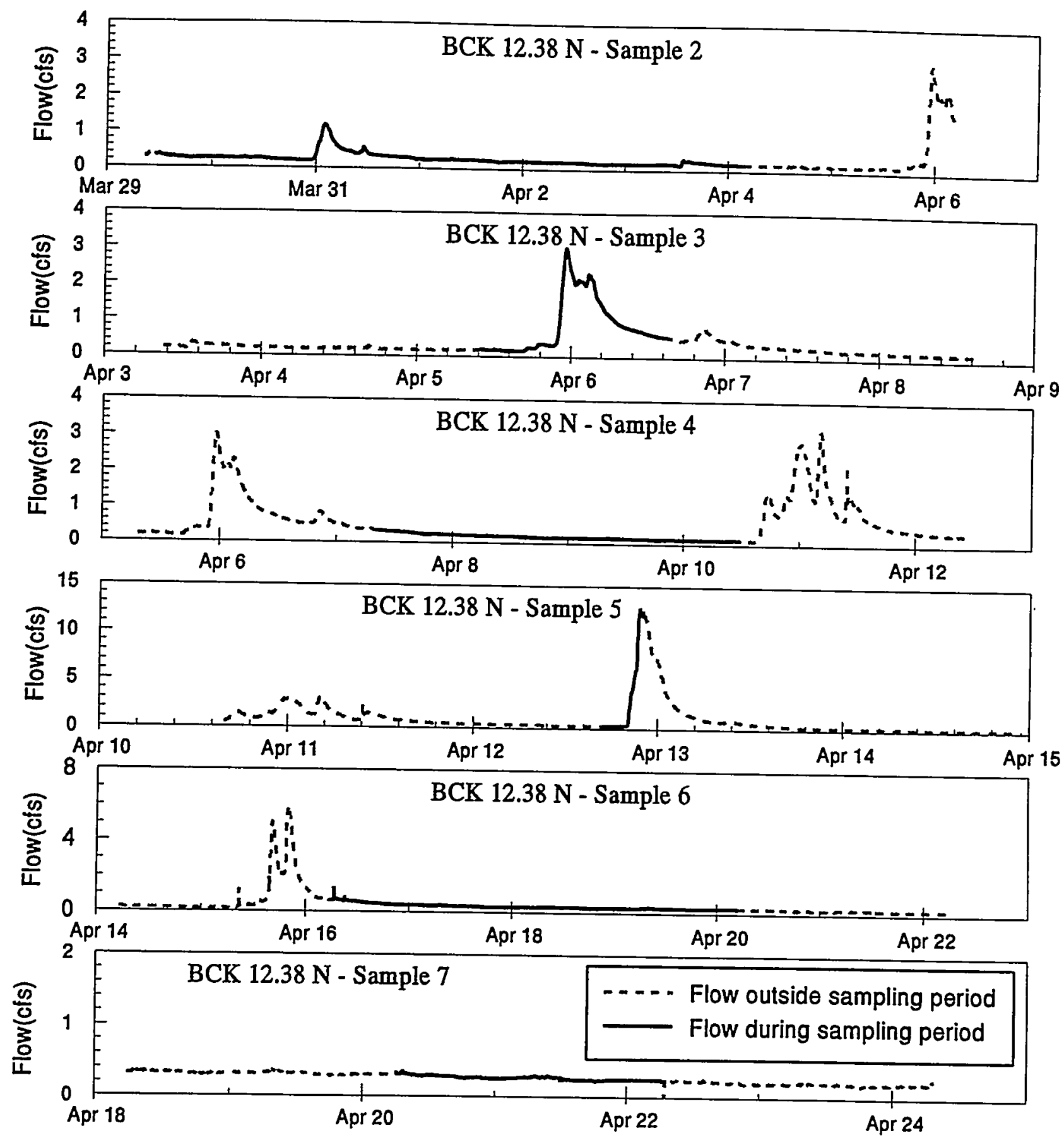

Fig. B.7. Surface water hydrographs showing flow during sampling periods for samples 2 through 7 at BCK $12.38 \mathrm{~N}$ Tunnel. 

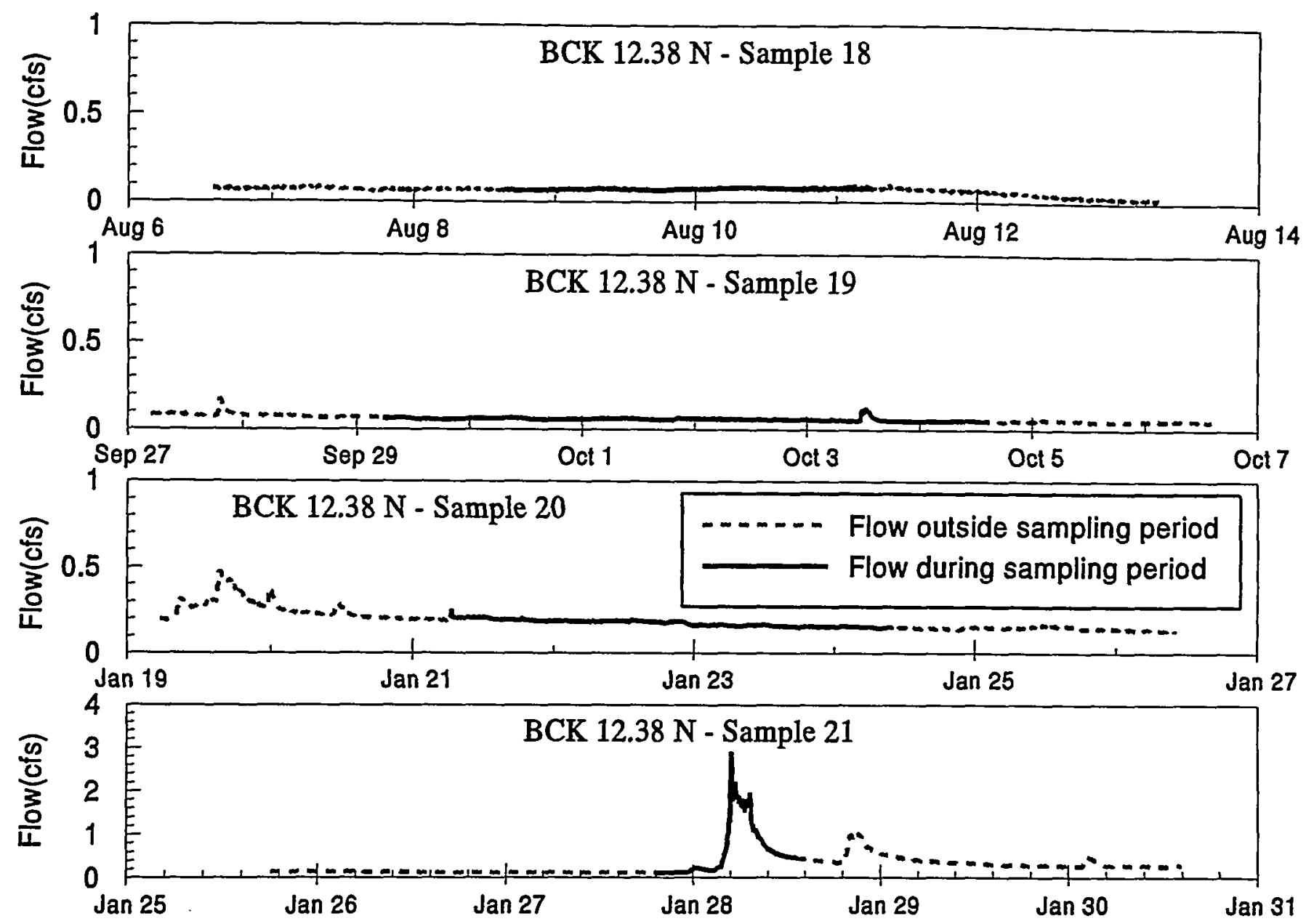

Fig. B.9. Surface water hydrographs showing flow during sampling periods for samples 18 through 21 at BCK $12.38 \mathrm{~N}$ Tunnel. 

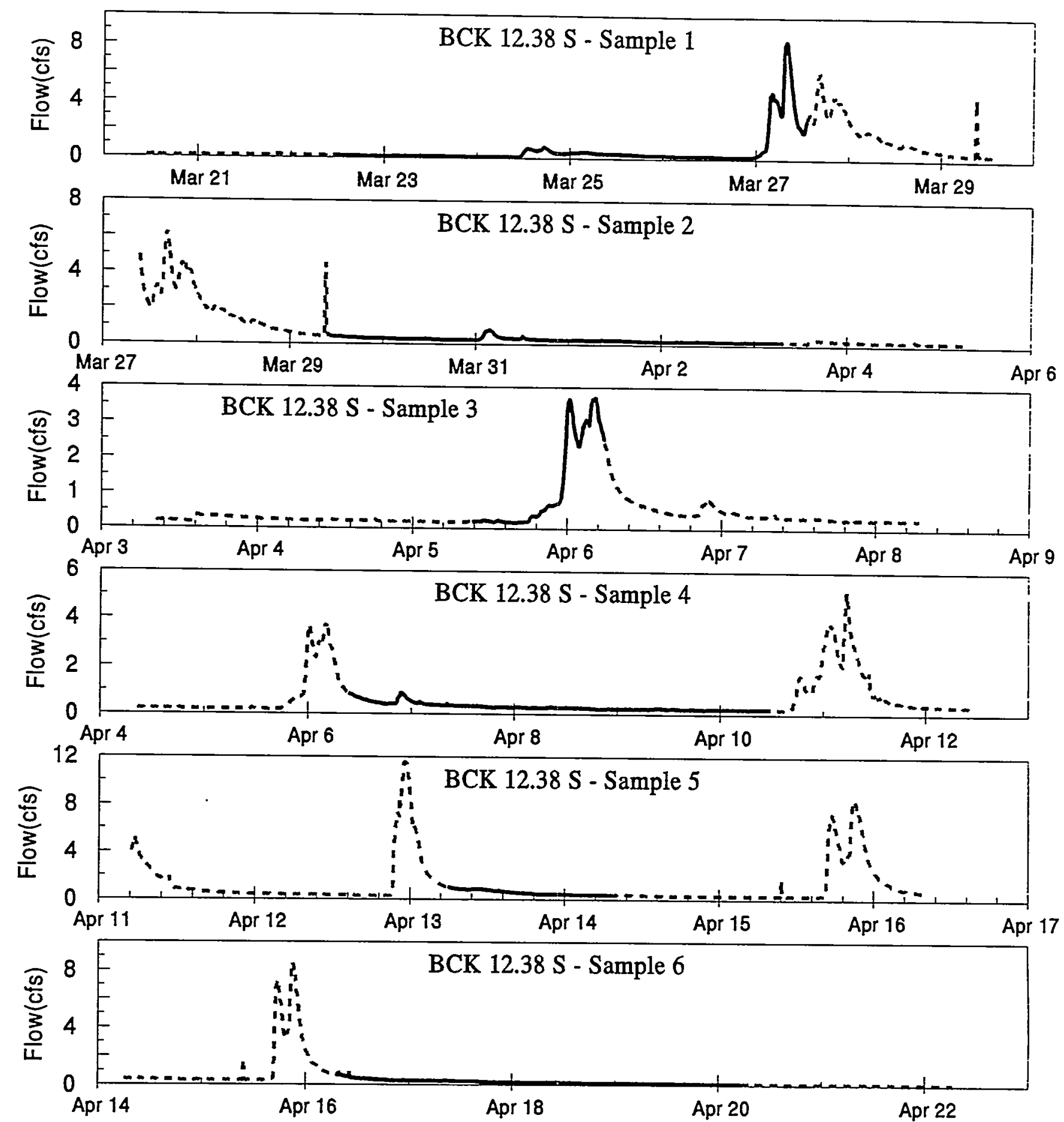

Fig. B.10. Surface water hydrographs showing flow during sampling periods for samples 1 through 6 at BCK $12.38 \mathrm{~S}$ Tunnel. 

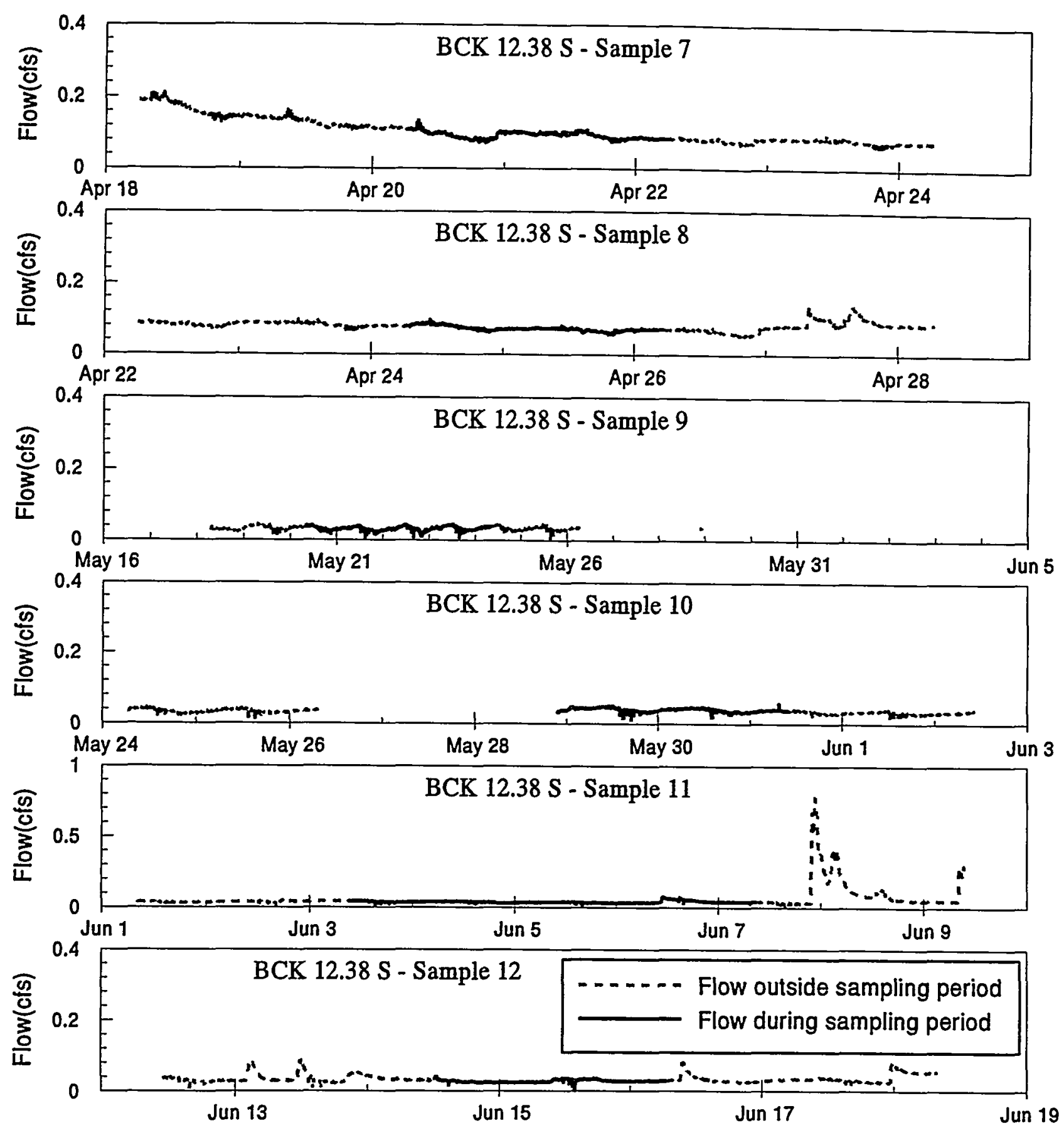

Fig. B.11. Surface water hydrographs showing flow during sampling periods for samples 7 through 12 at BCK $12.38 \mathrm{~S}$ Tunnel. 

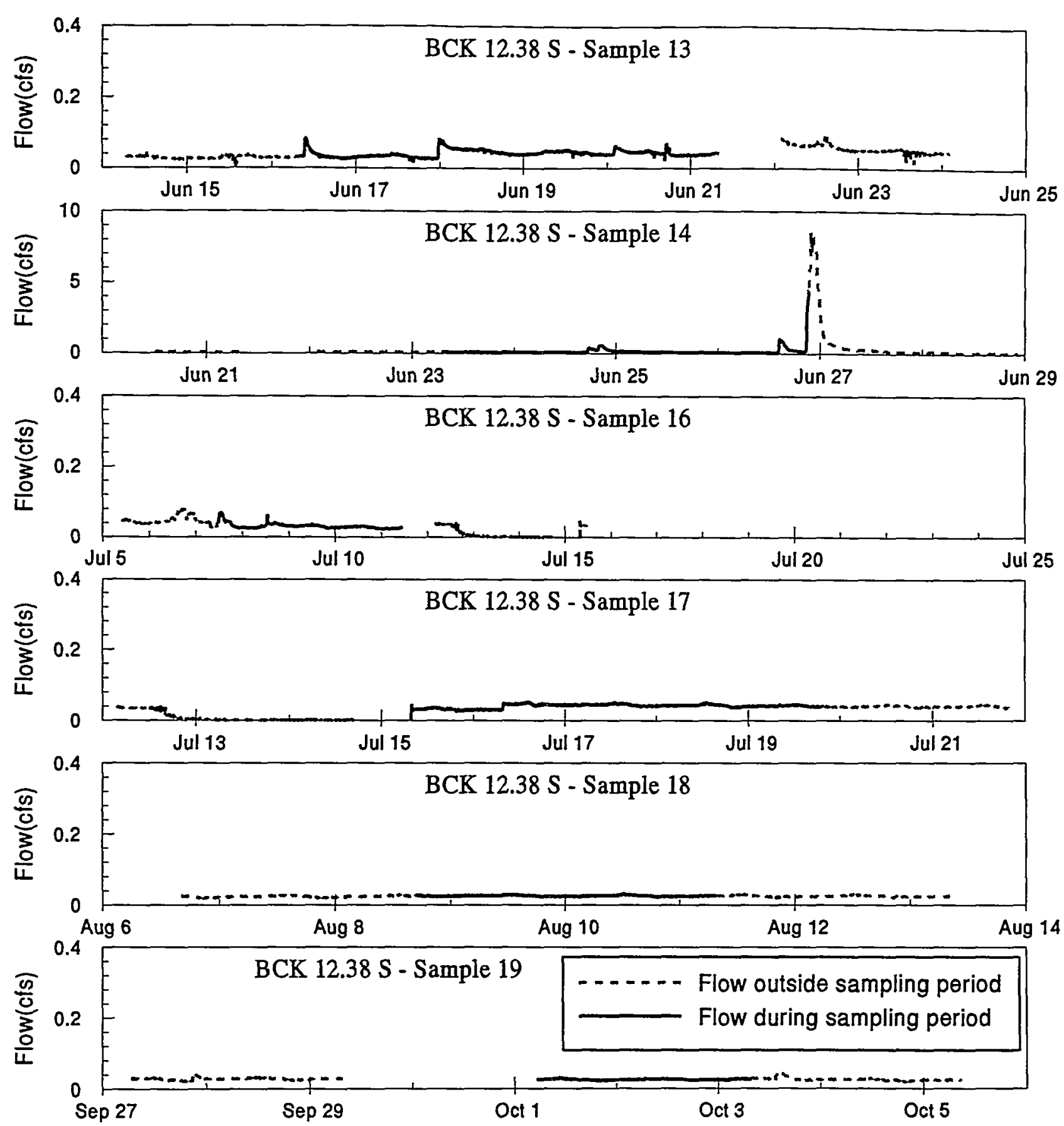

Fig. B.12. Surface water hydrographs showing flow during sampling periods for samples 13, 14, 16, through 19 at BCK $12.38 \mathrm{~S}$ Tunnel. 

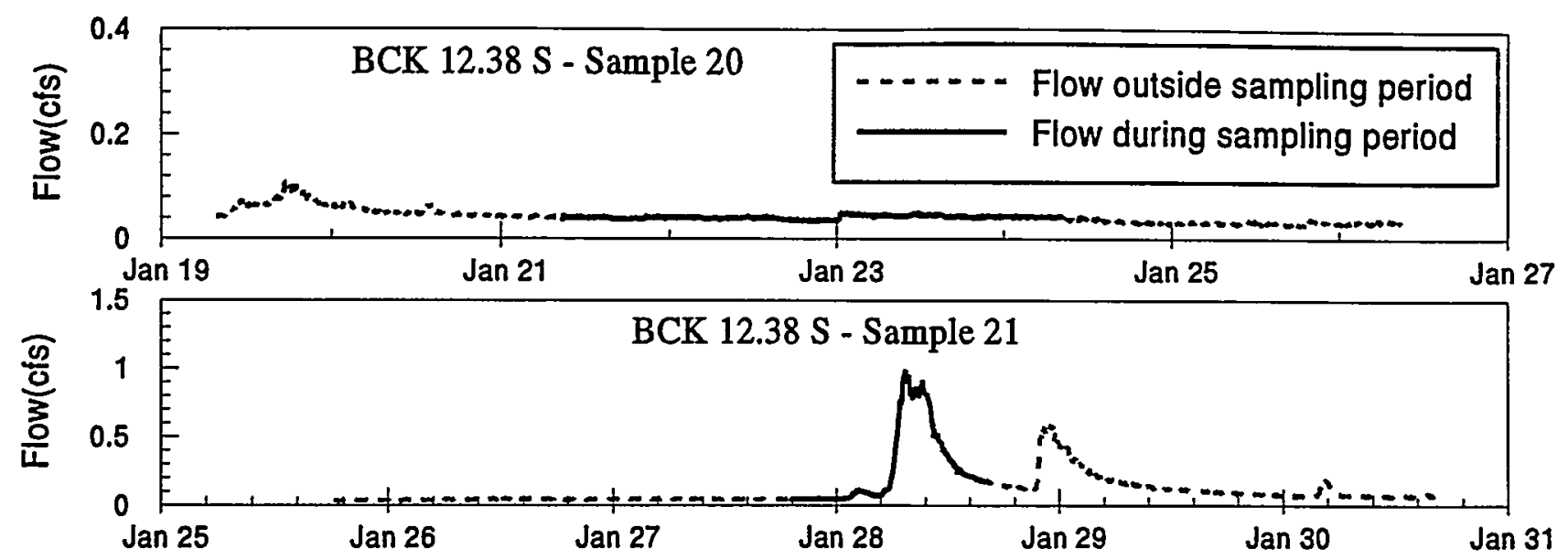

Fig. B.13. Surface water hydrographs showing flow during sampling periods for samples 20 and 21 at BCK $12.38 \mathrm{~S}$ Tunnel. 


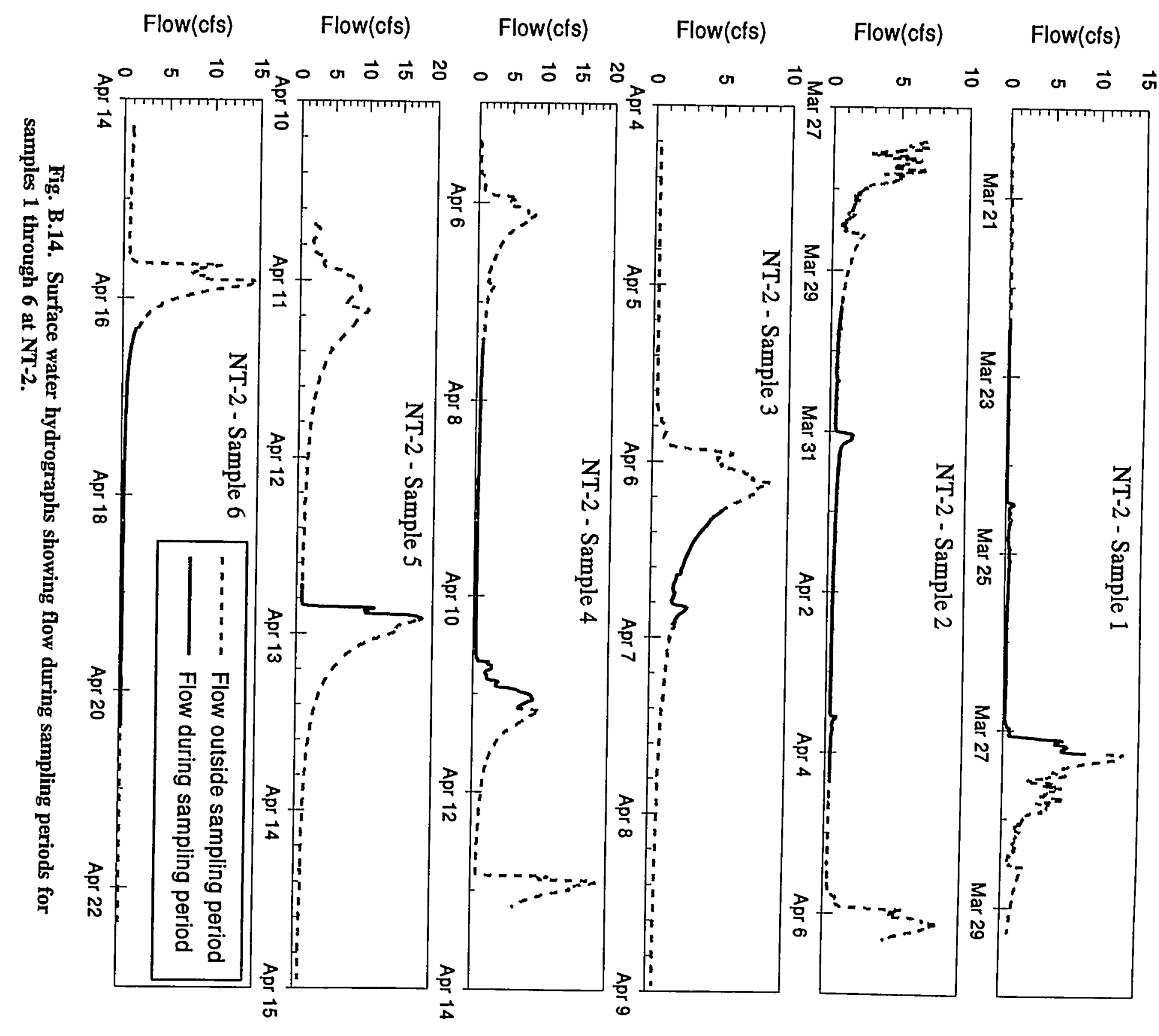

$\underset{\infty}{\stackrel{\infty}{0}}$ 

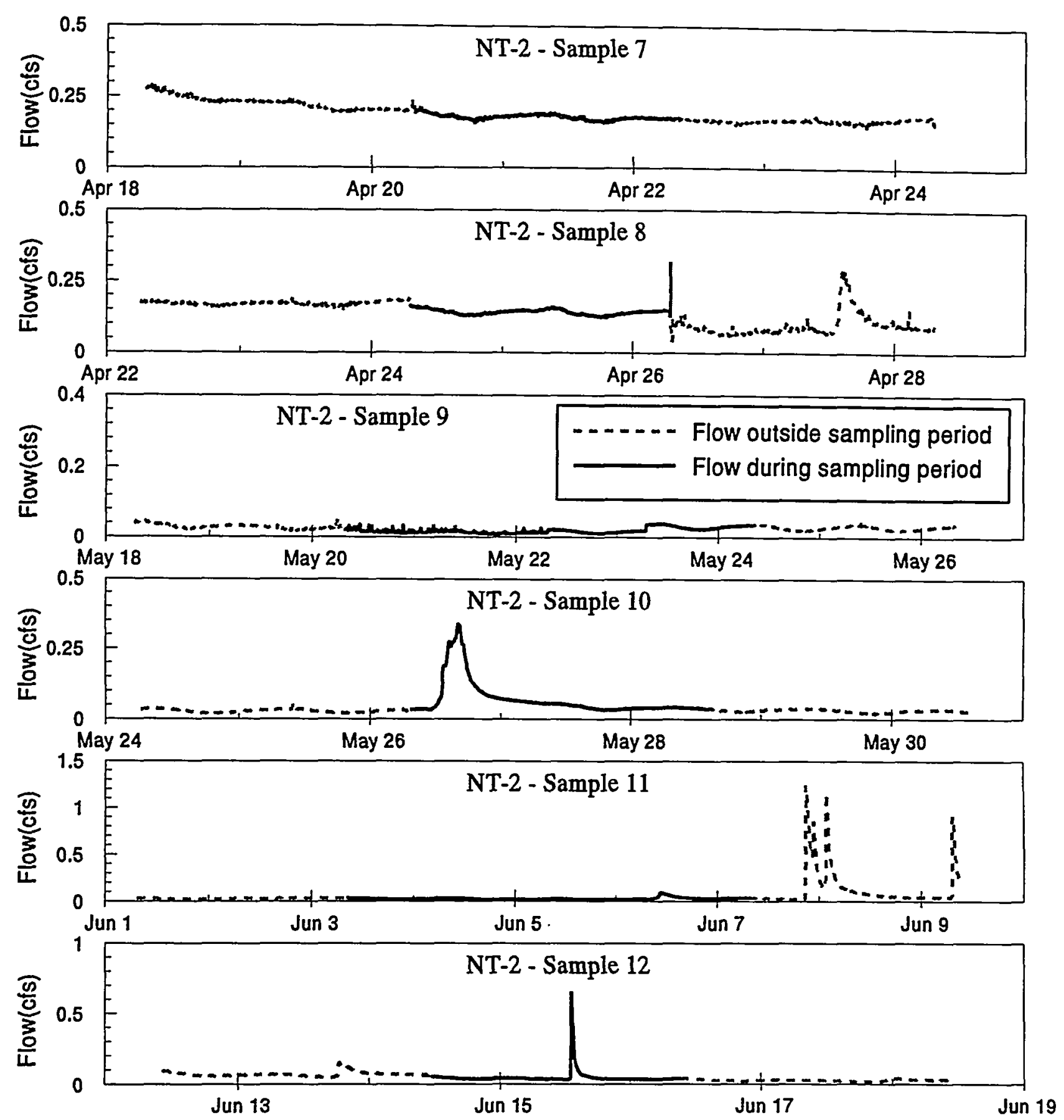

Fig. B.15. Surface water hydrographs showing flow during sampling periods for samples 7 through 12 at NT-2. 

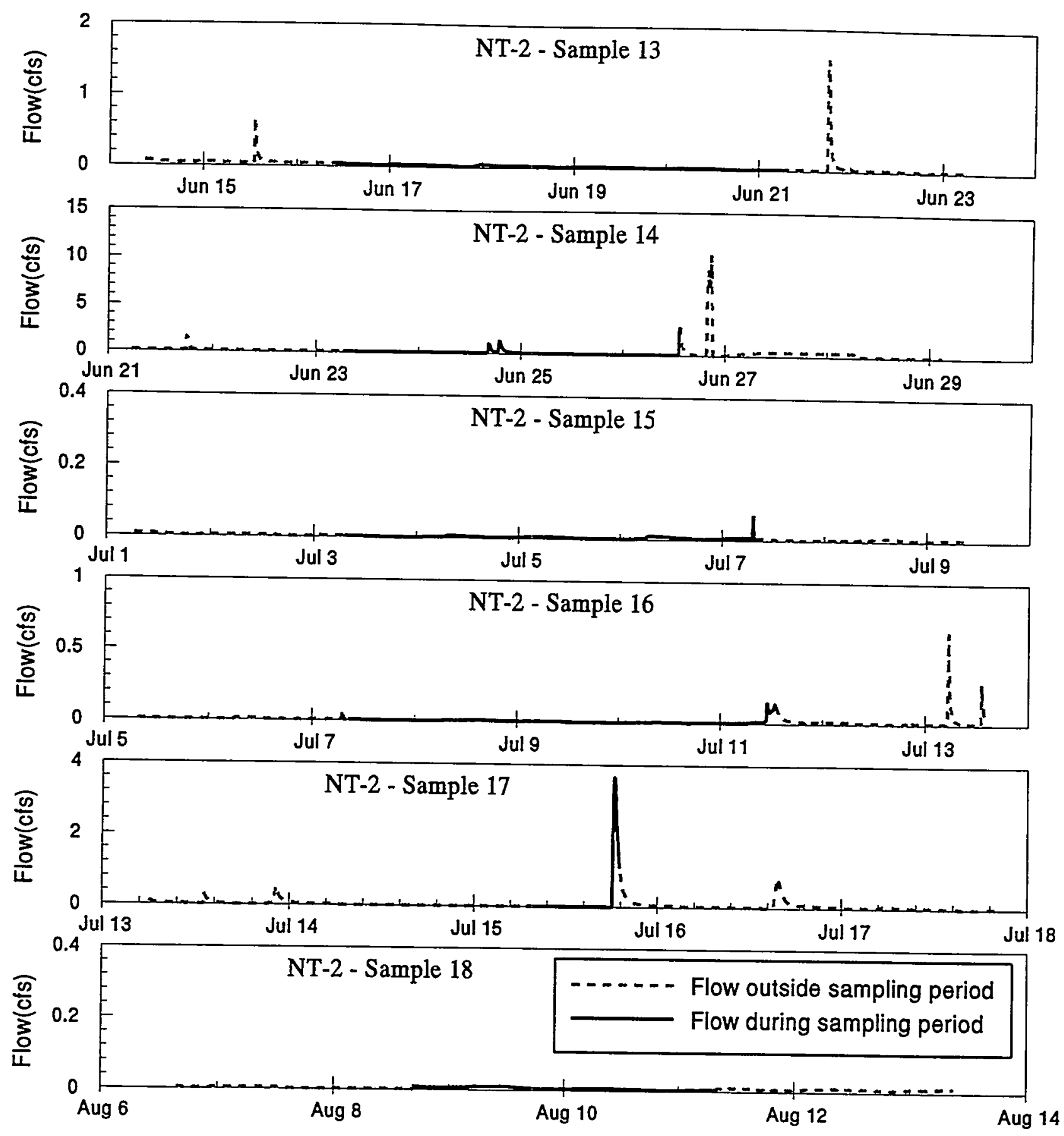

Fig. B.16. Surface water hydrographs showing flow during sampling periods for samples 13 through 18 at NT-2. 

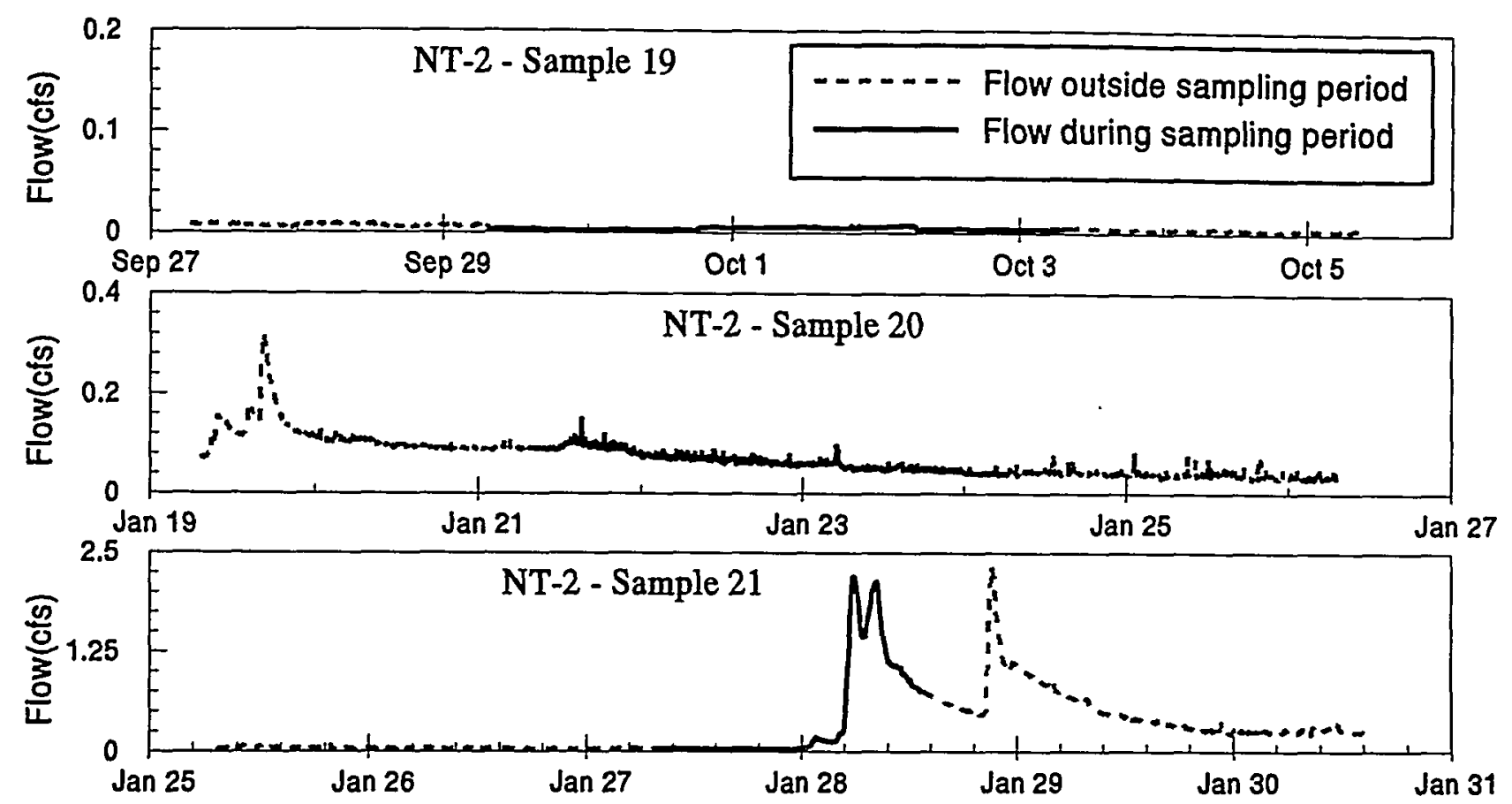

Fig. B.17. Surface water hydrographs showing flow during sampling periods for samples 19 through 21 at NT-2. 

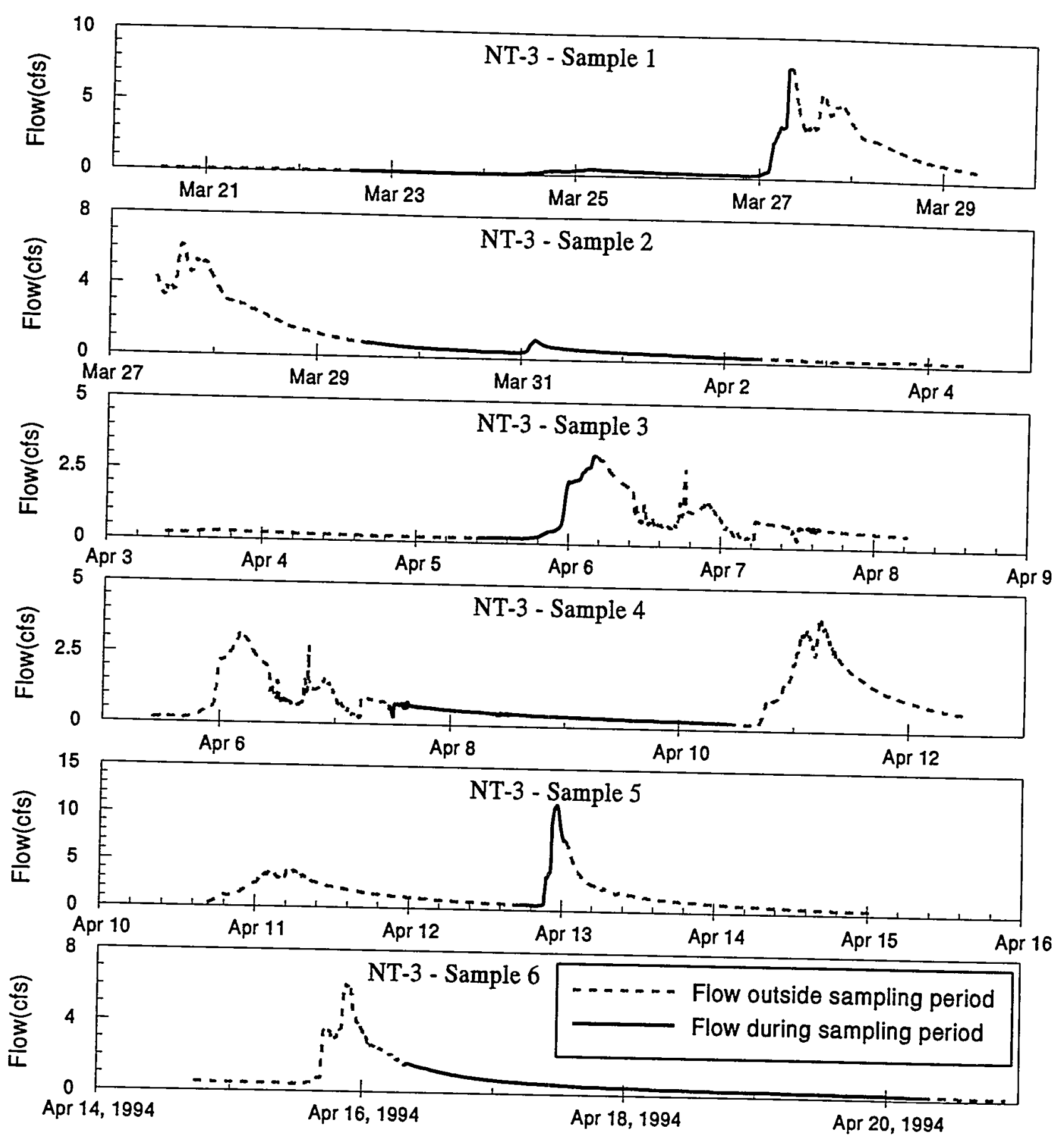

Fig. B.18. Surface water hydrographs showing flow during sampling periods for samples 1 through 6 at NT-3. 

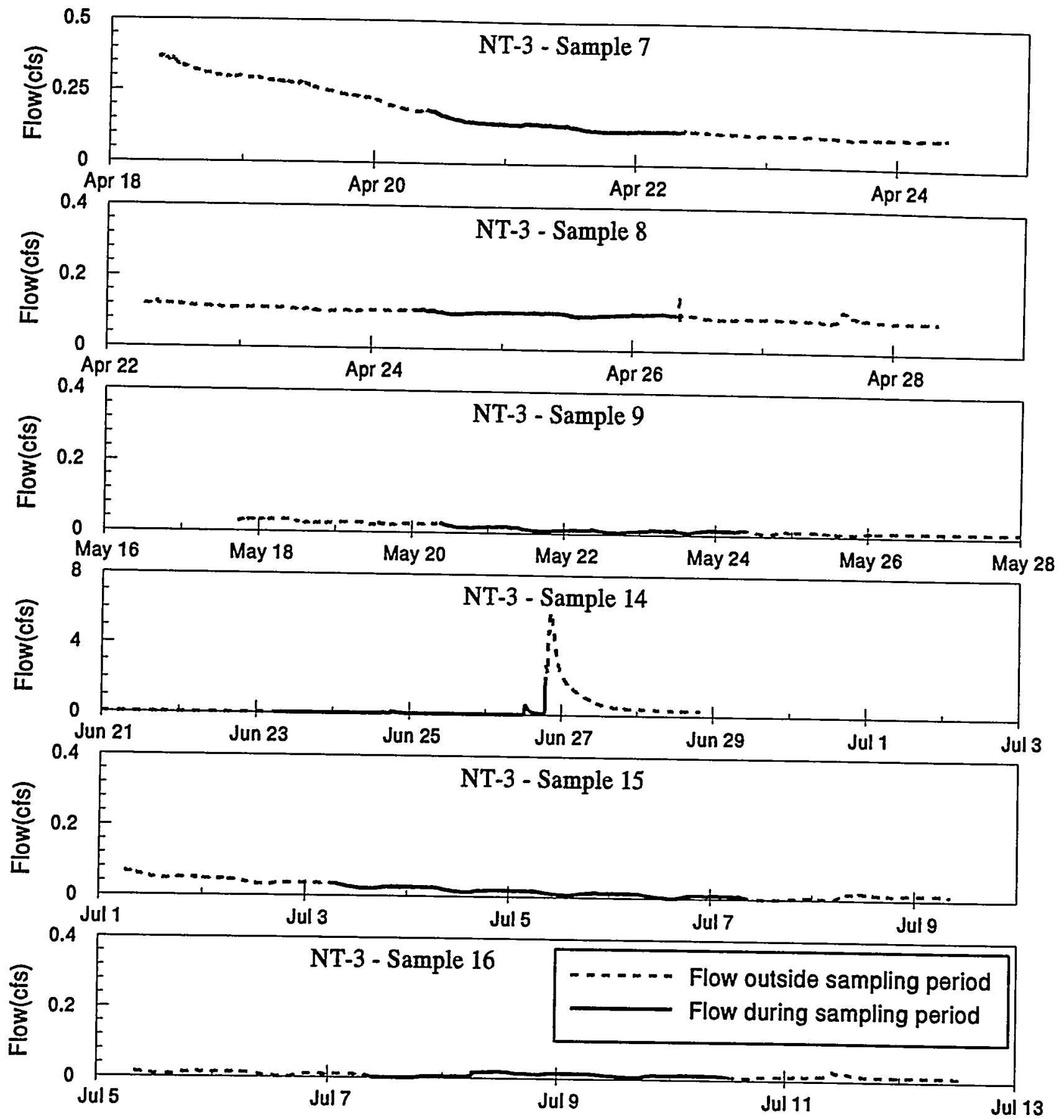

Fig. B.19. Surface water hydrographs showing flow during sampling periods for samples 7 through 9 and 14 through 16 at NT-3. 

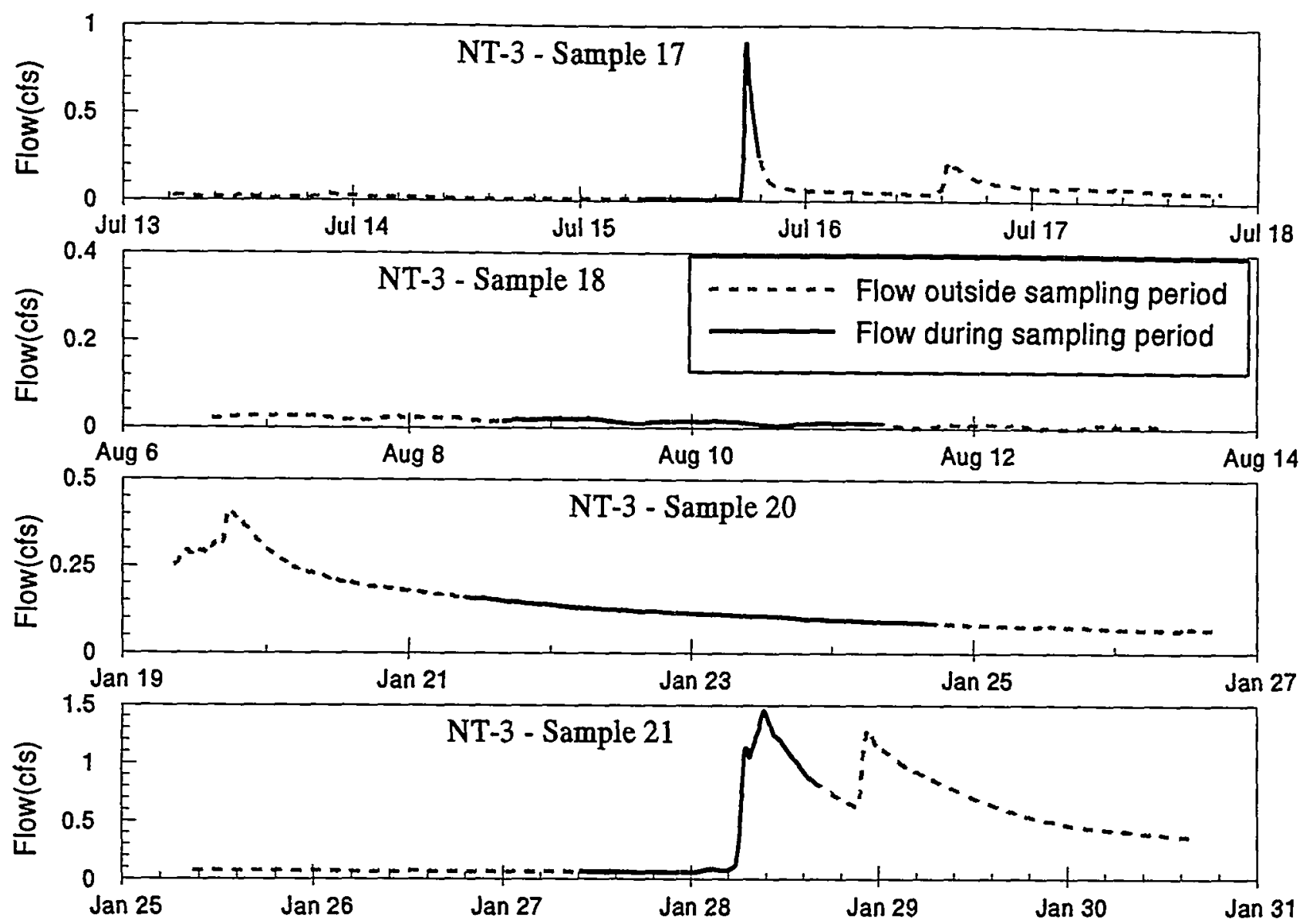

Fig. B.20. Surface water hydrographs showing flow during sampling periods for samples 17, 18, 20, and 21 at NT-3. 
B10-25
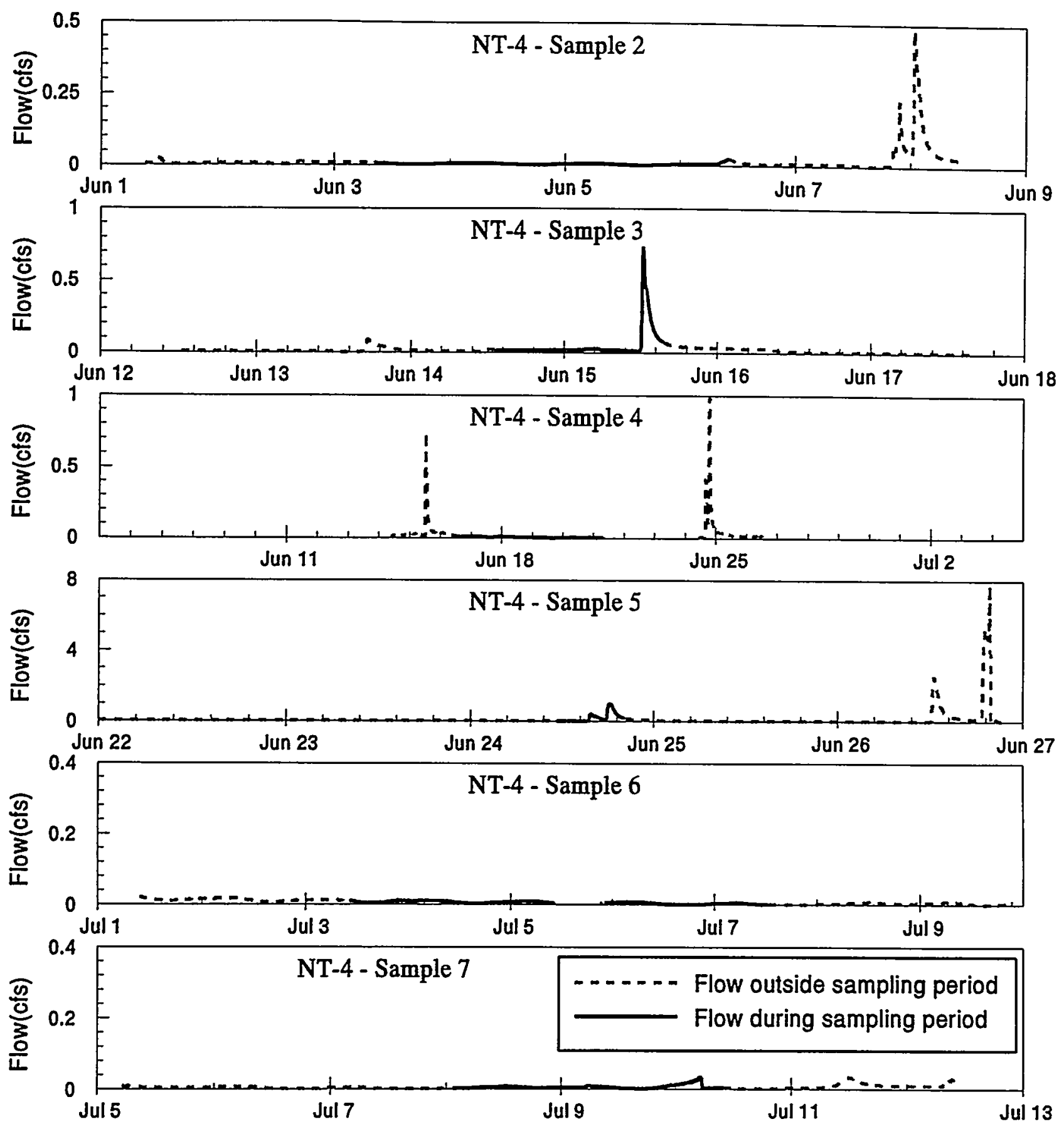

Fig. B.21. Surface water hydrographs showing flow during sampling periods for samples 2 through 7 at NT-4. 

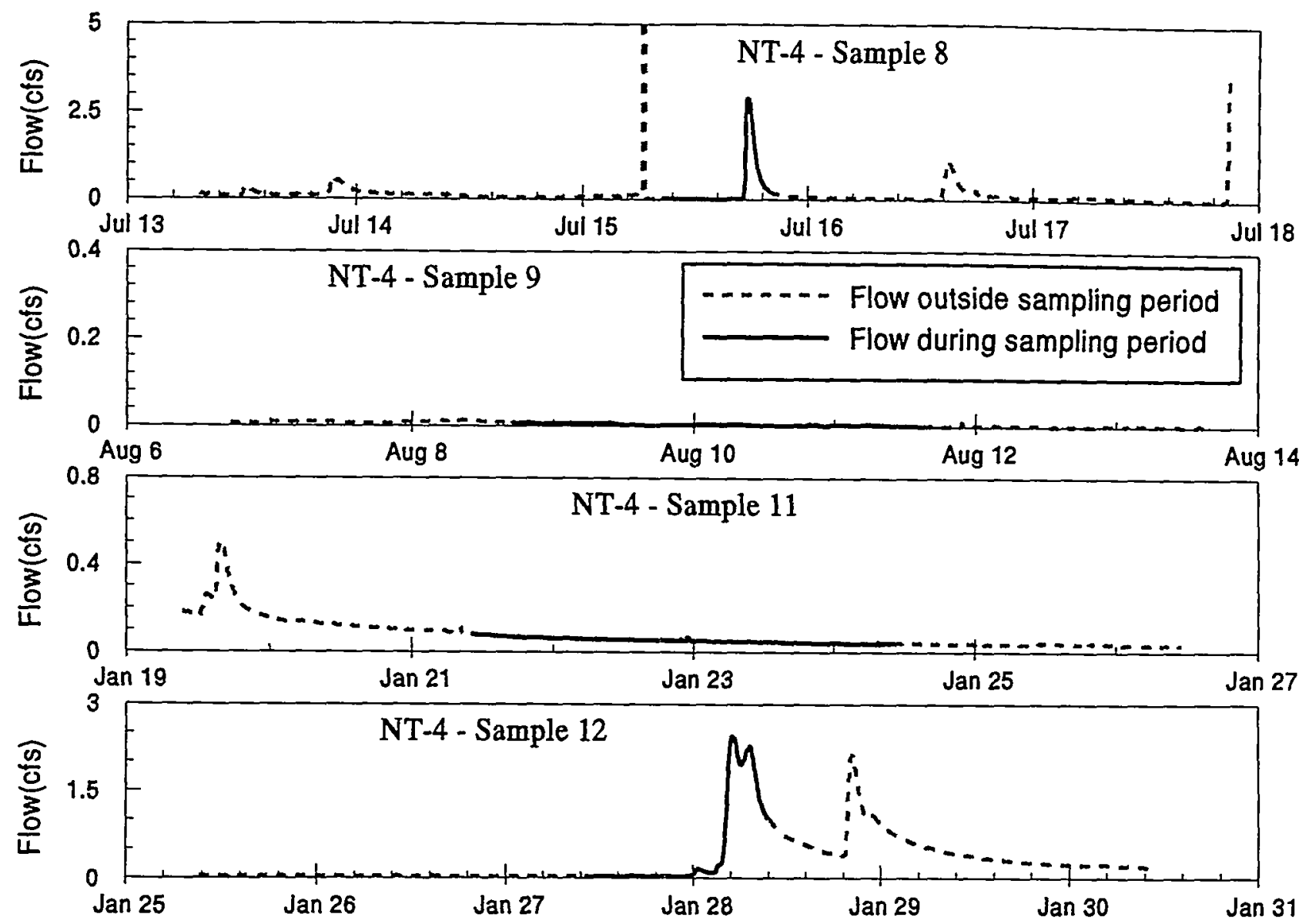

Fig. B.22. Surface water hydrographs showing flow during sampling periods for samples 8 through 12 at NT-4. 


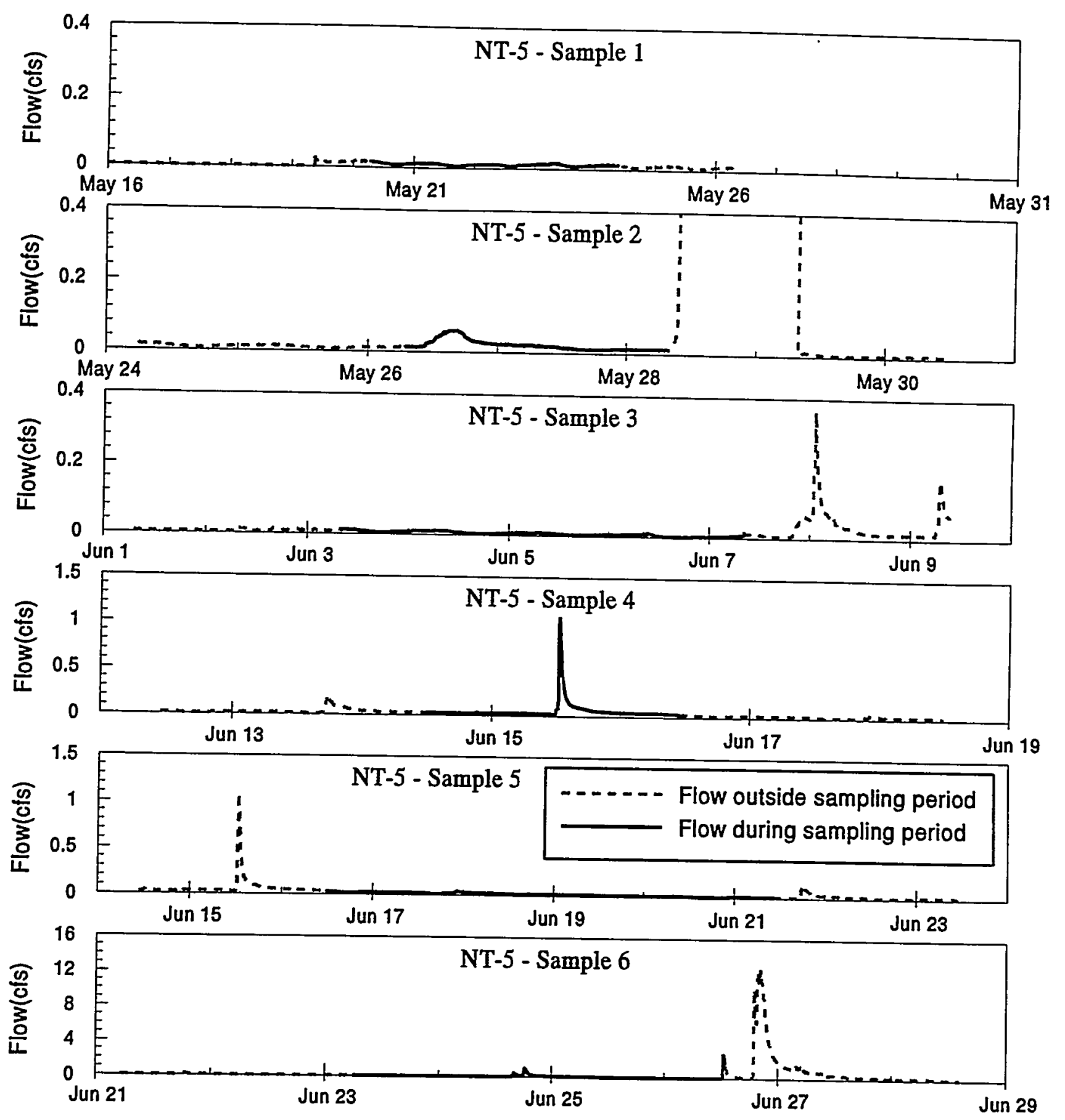
Fig. B.23. Surface water hydrographs showing flow during sampling periods for
samples 1 through 6 at NT-5. 

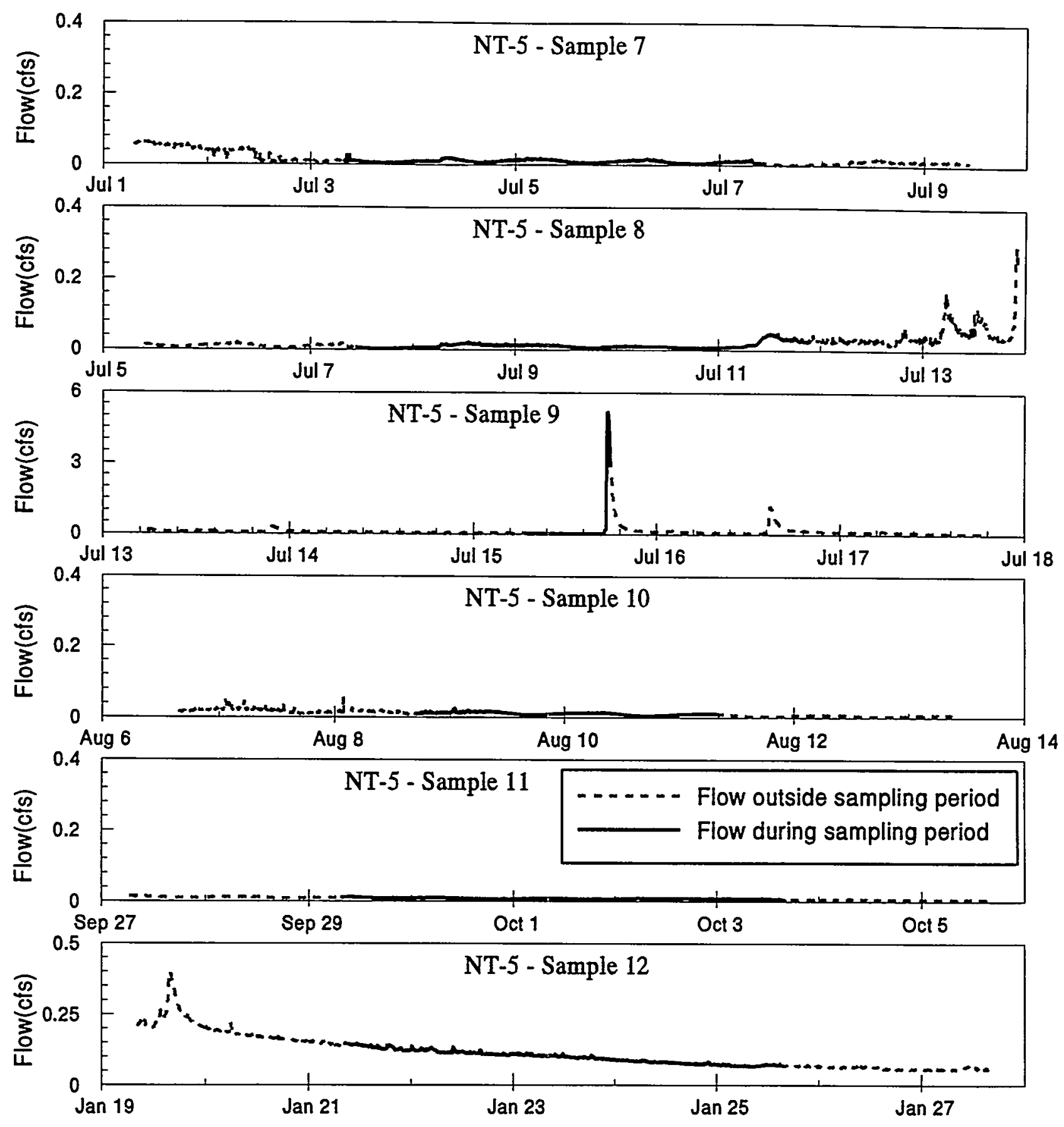

Fig. B.24. Surface water hydrographs showing flow during sampling periods for samples 7 through 12 at NT-5. 
B10-29

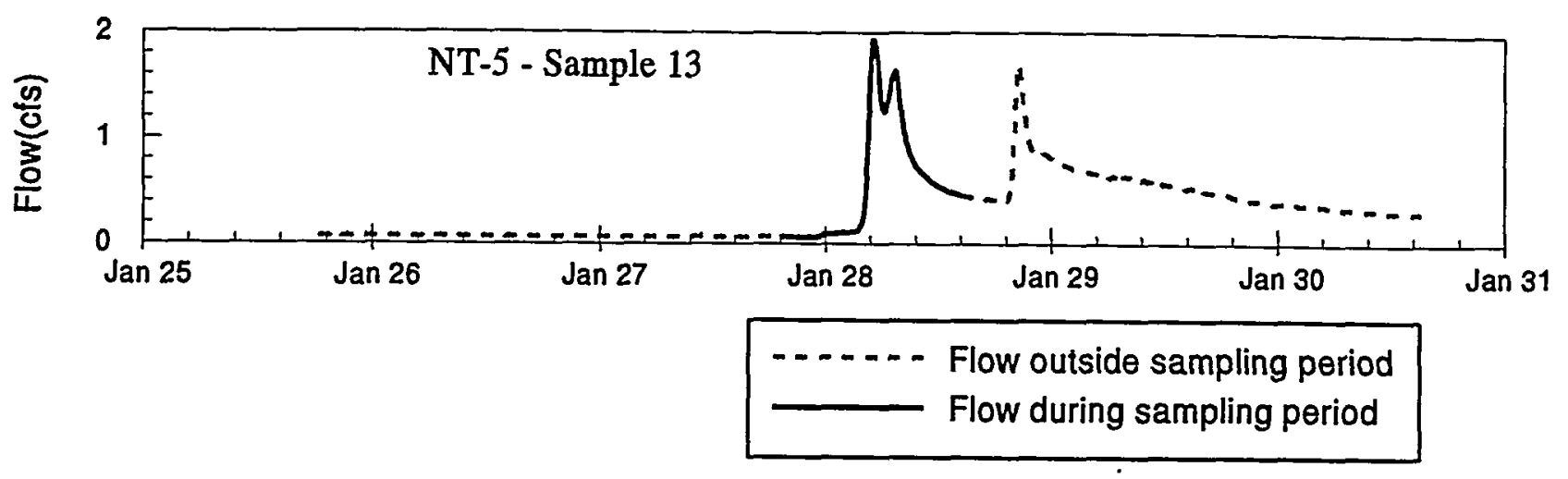

Fig. B.25. Surface water hydrographs showing flow during sampling periods for sample 13 at NT-5. 
B10-30
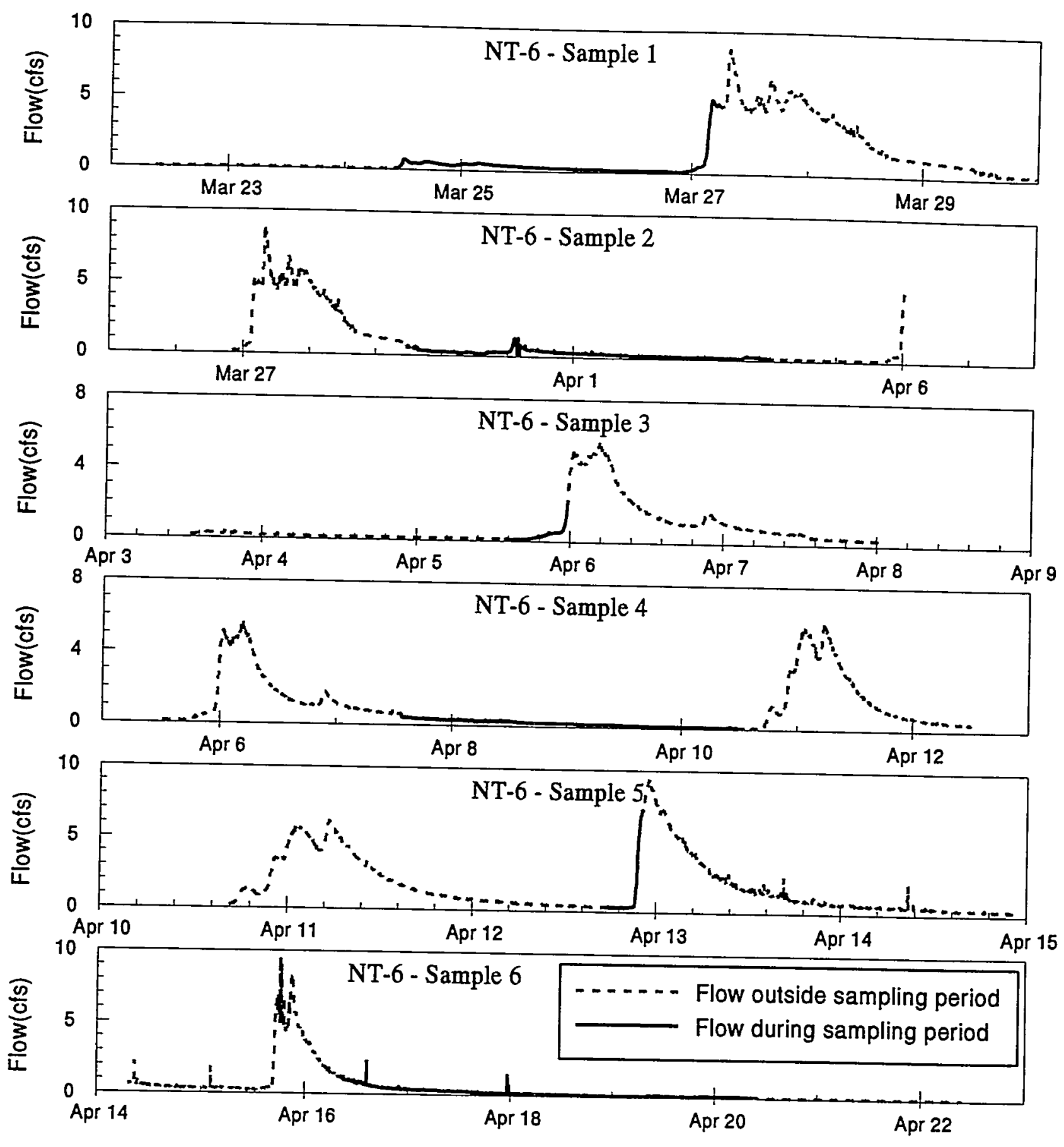

Fig. B.26. Surface water hydrographs showing flow during sampling periods for samples 1 through 6 at NT-6. 

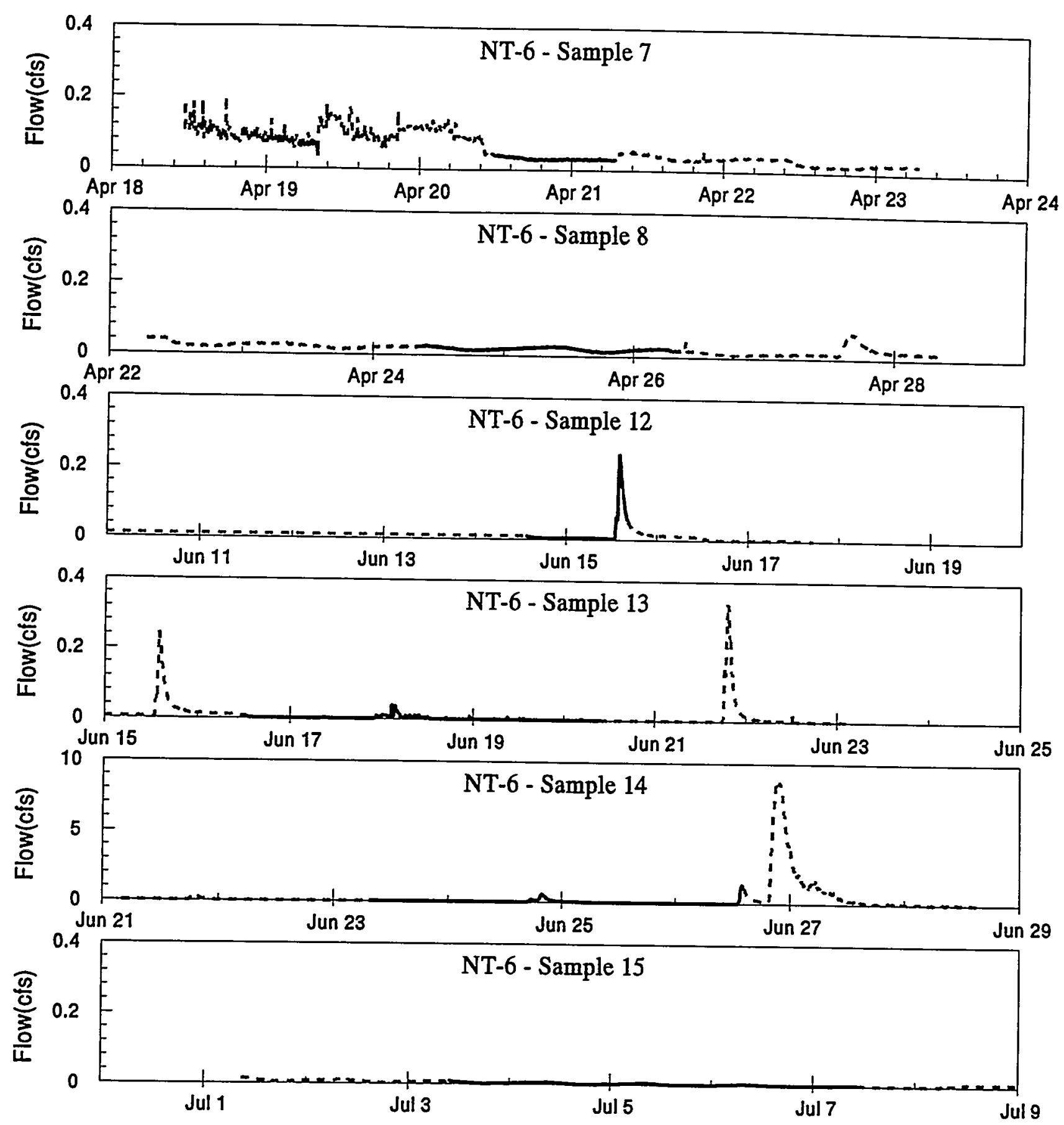

Fig. B.27. Surface water hydrographs showing flow during sampling periods for samples 7, 8, and 12 through 15 at NT-6. 
B10-32

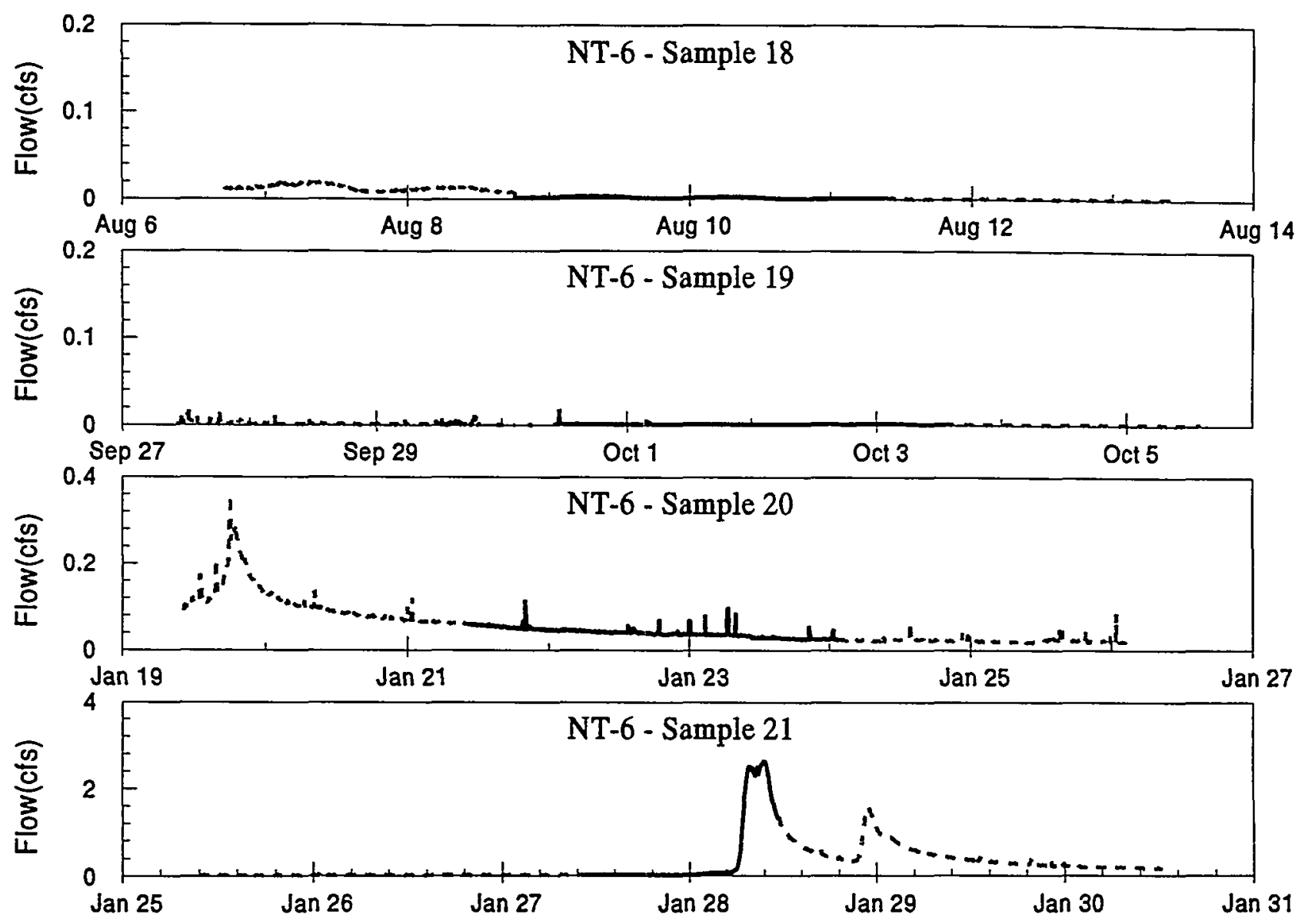

Fig. B.28. Surface water hydrographs showing flow during sampling periods for samples 18 through 21 at NT-6. 

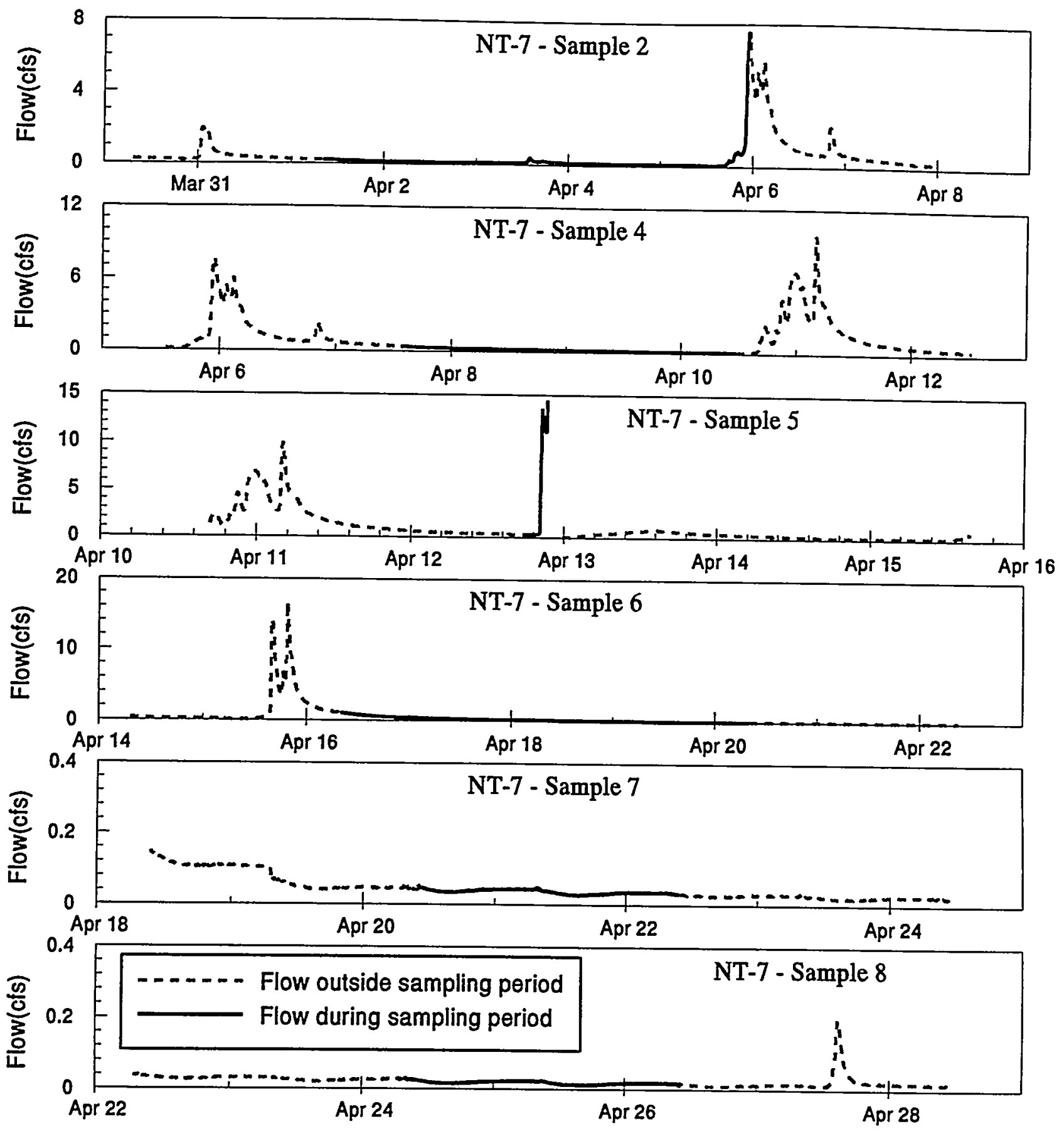

Fig. B.29. Surface water hydrographs showing flow during sampling periods for samples 2 and 4 through 8 at NT-7. 
B10-34
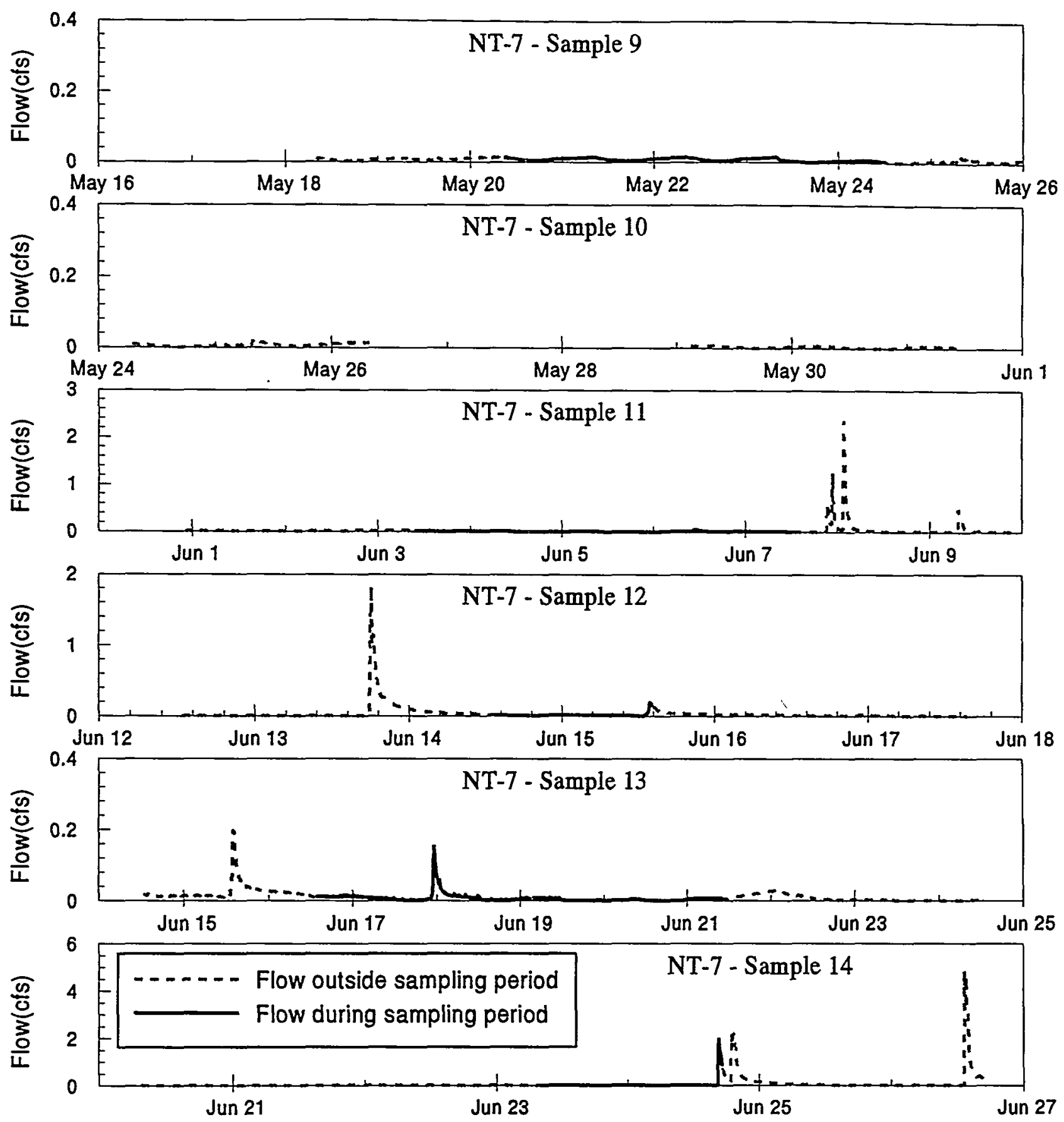

Fig. B.30. Surface water hydrographs showing flow during sampling periods for samples 9 through 14 at NT-7. 

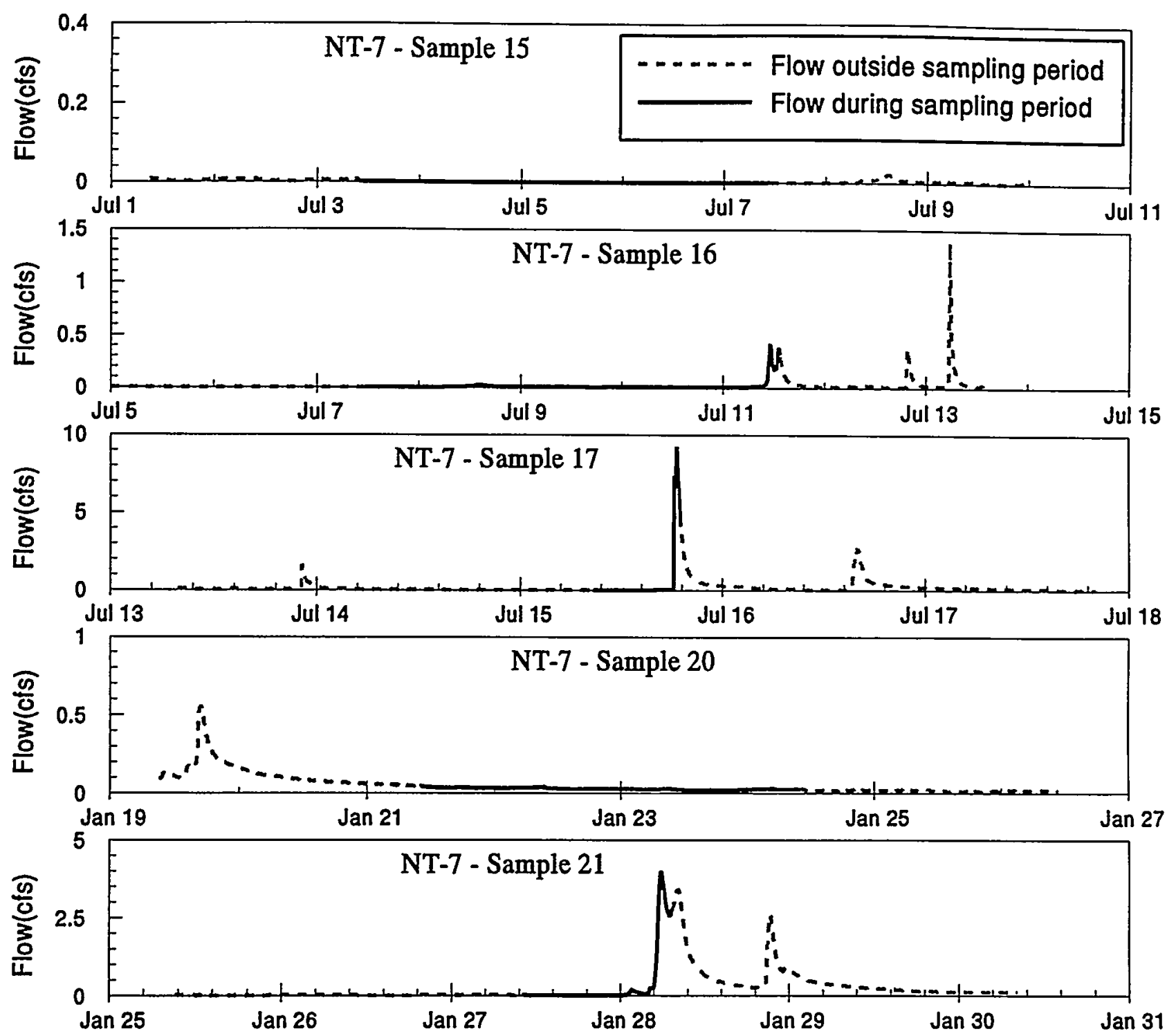

Fig. B.31. Surface water hydrographs showing flow during sampling periods for samples 15 through 17, and 20 and 21 at NT-7. 
B10-36
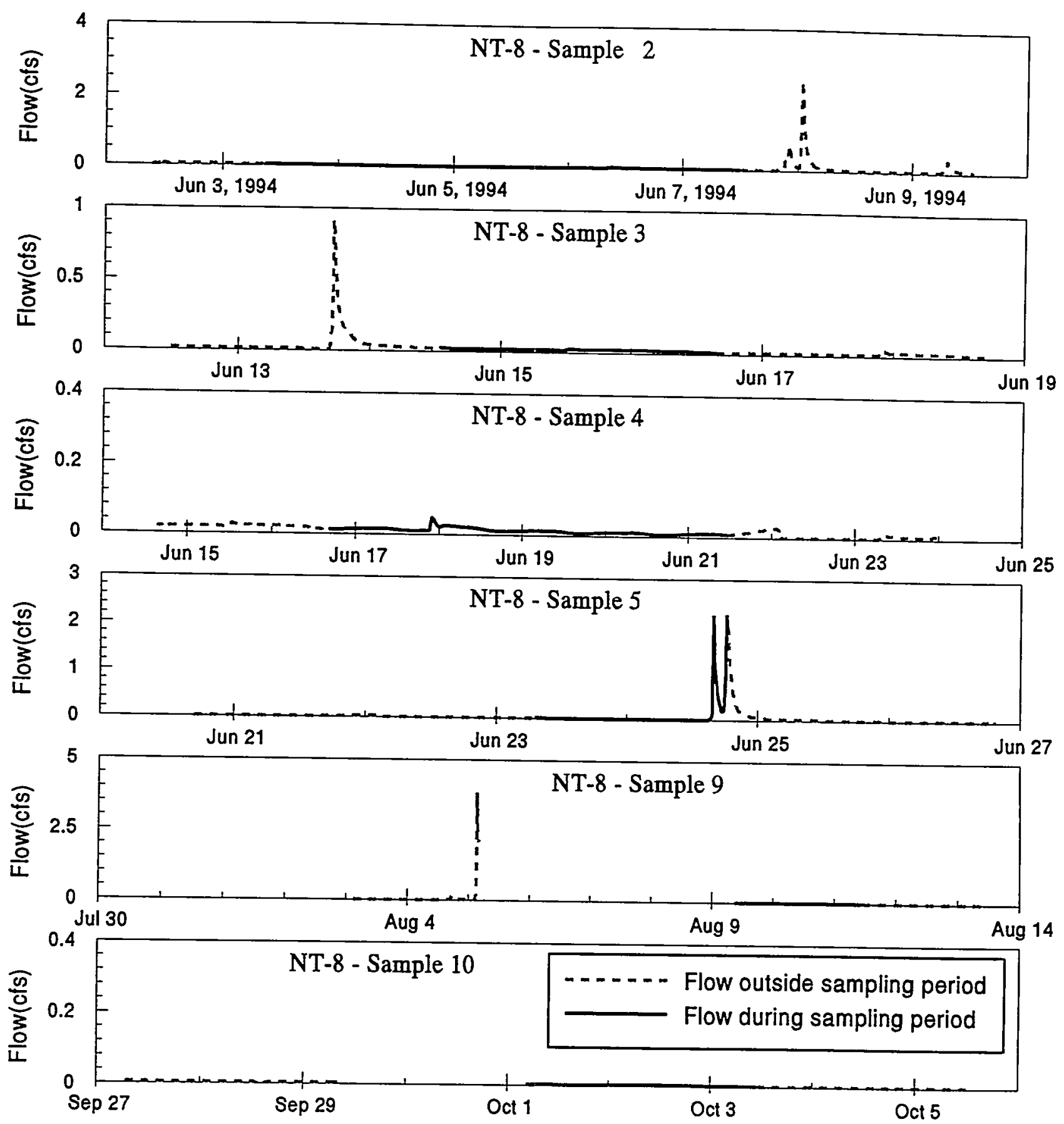

Fig. B.32. Surface water hydrographs showing flow during sampling periods for samples 2 through 5, and 9 and 10 at NT-8. 
B10-37

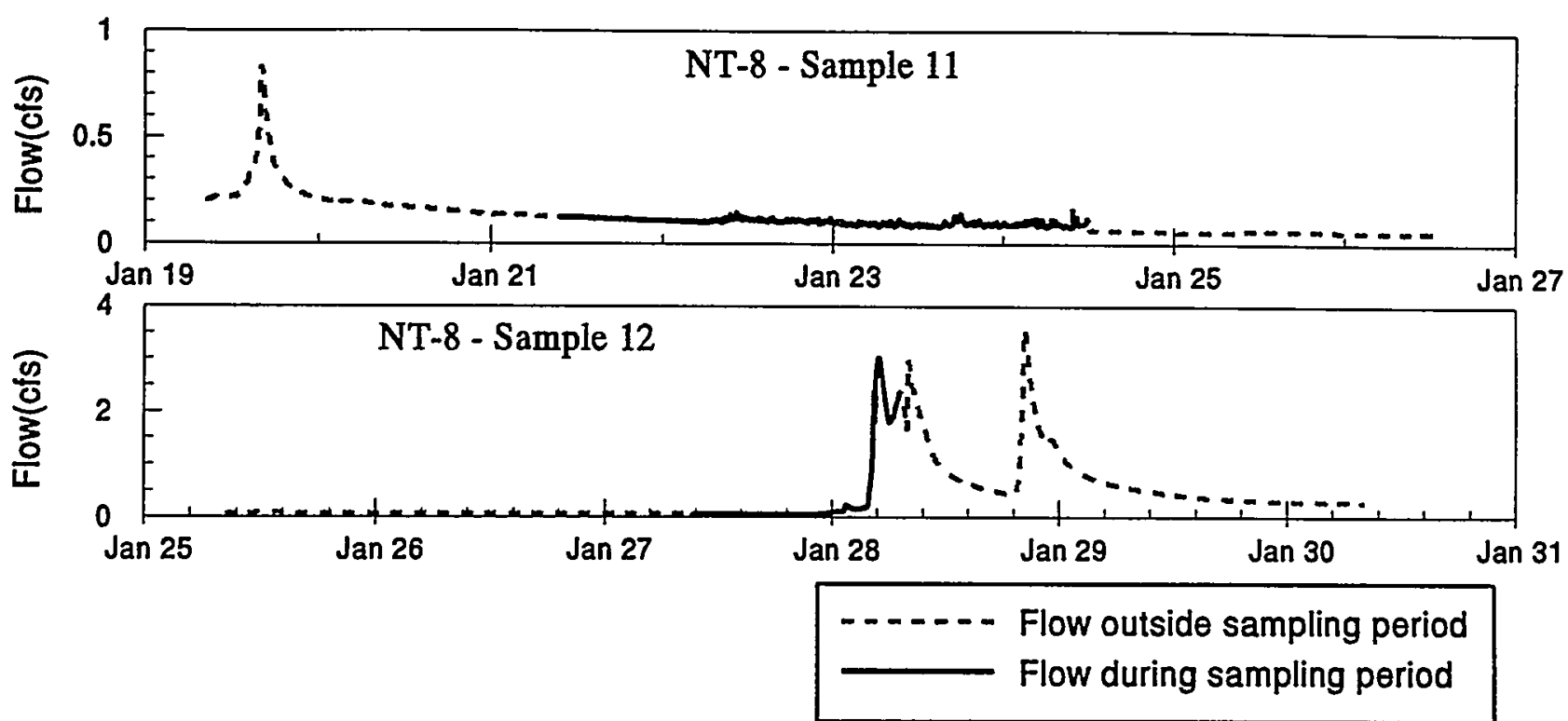

Fig. B.33. Surface water hydrographs showing flow during sampling periods for samples 11 and 12 at NT-8. 

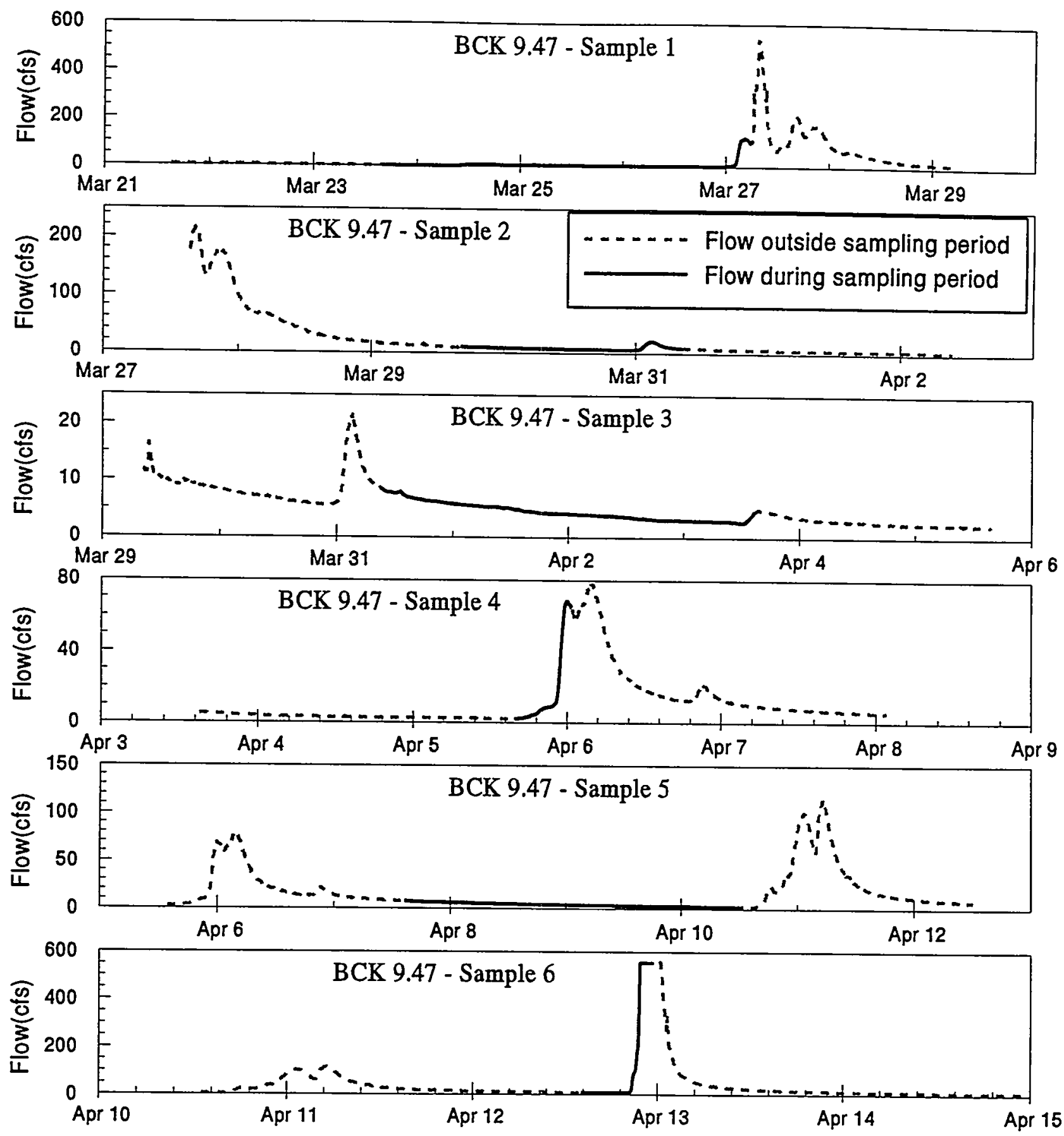

Fig. B.34. Surface water hydrographs showing flow during sampling periods for samples 1 through 6 at BCK 9.47. 
B10-39
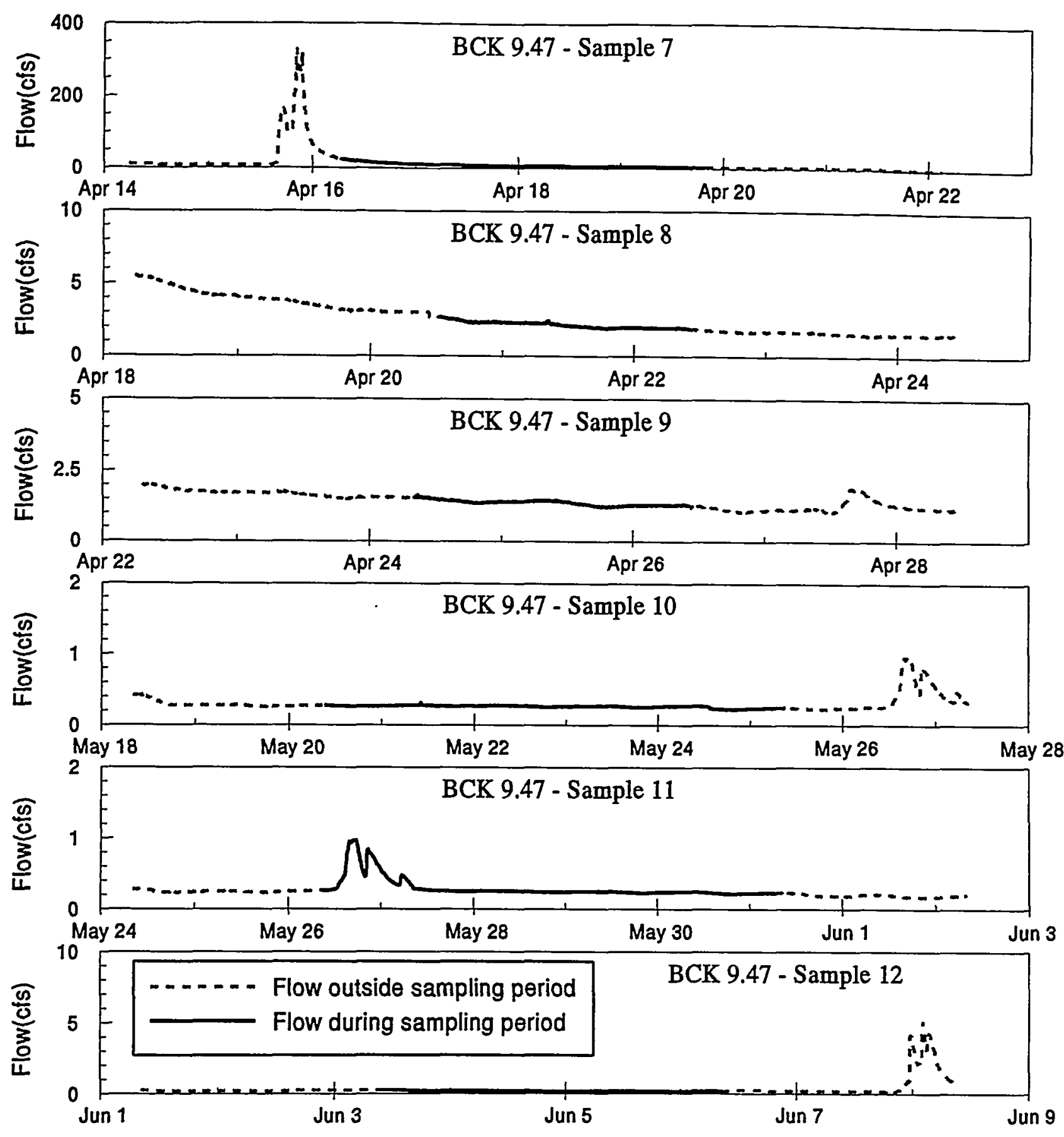

Fig. B.35. Surface water hydrographs showing flow during sampling periods for samples 7 through 12 at BCK 9.47. 

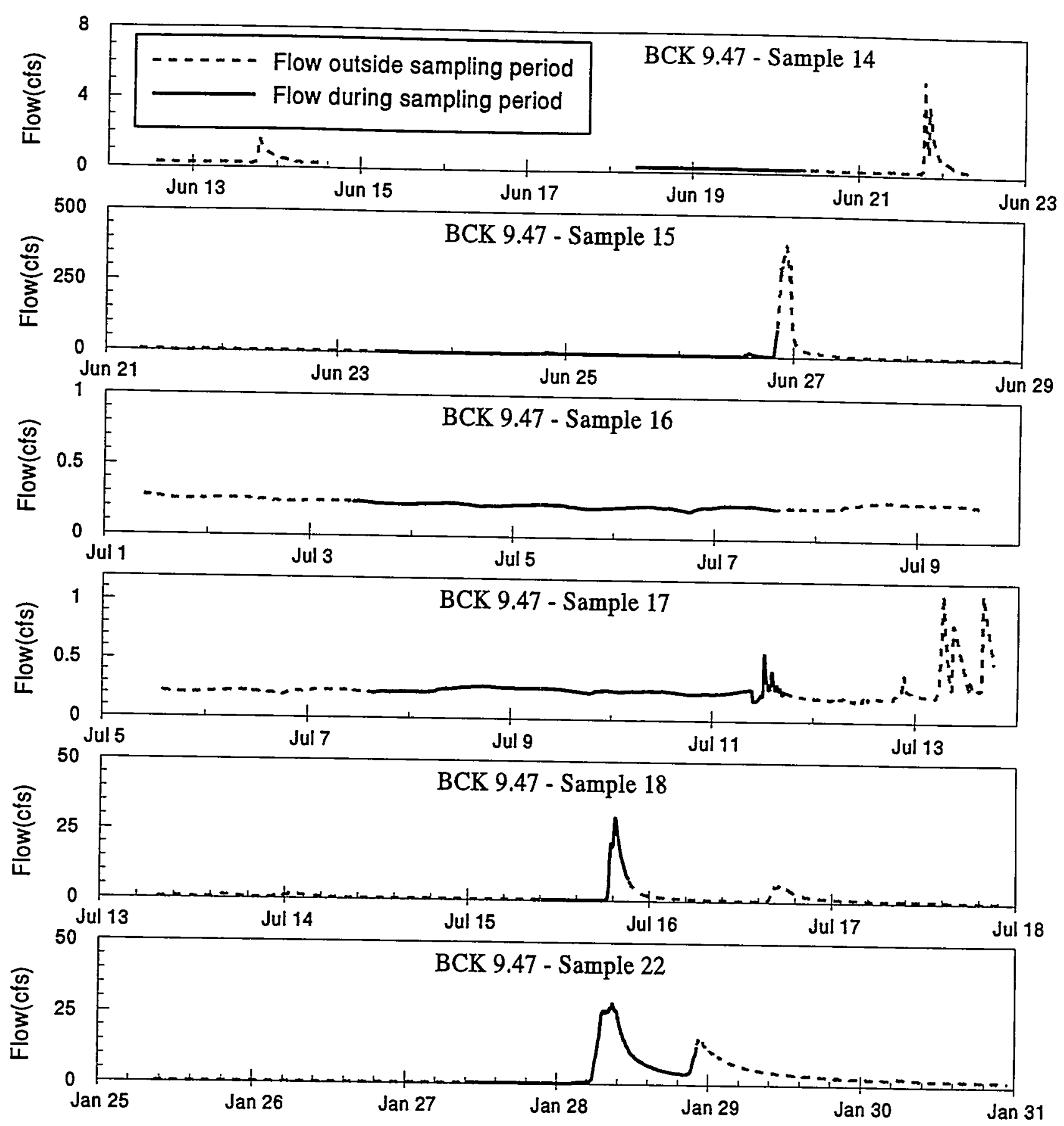

Fig. B.36. Surface water hydrographs showing flow during sampling periods for samples 14 through 18, and 22 at BCK 9.47. 

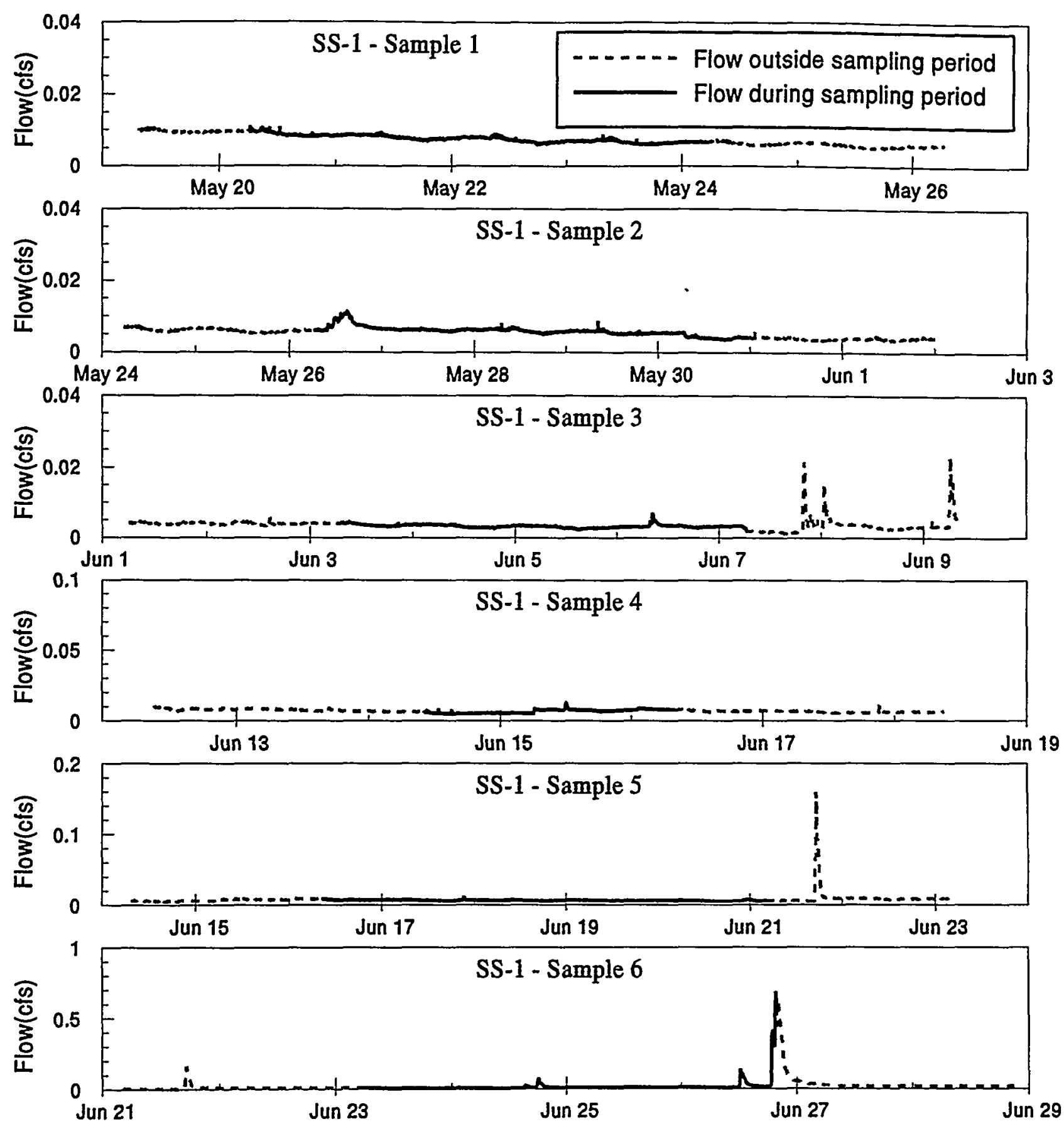

Fig. B.37. Surface water hydrographs showing flow during sampling periods for samples 1 through 6 at SS-1. 

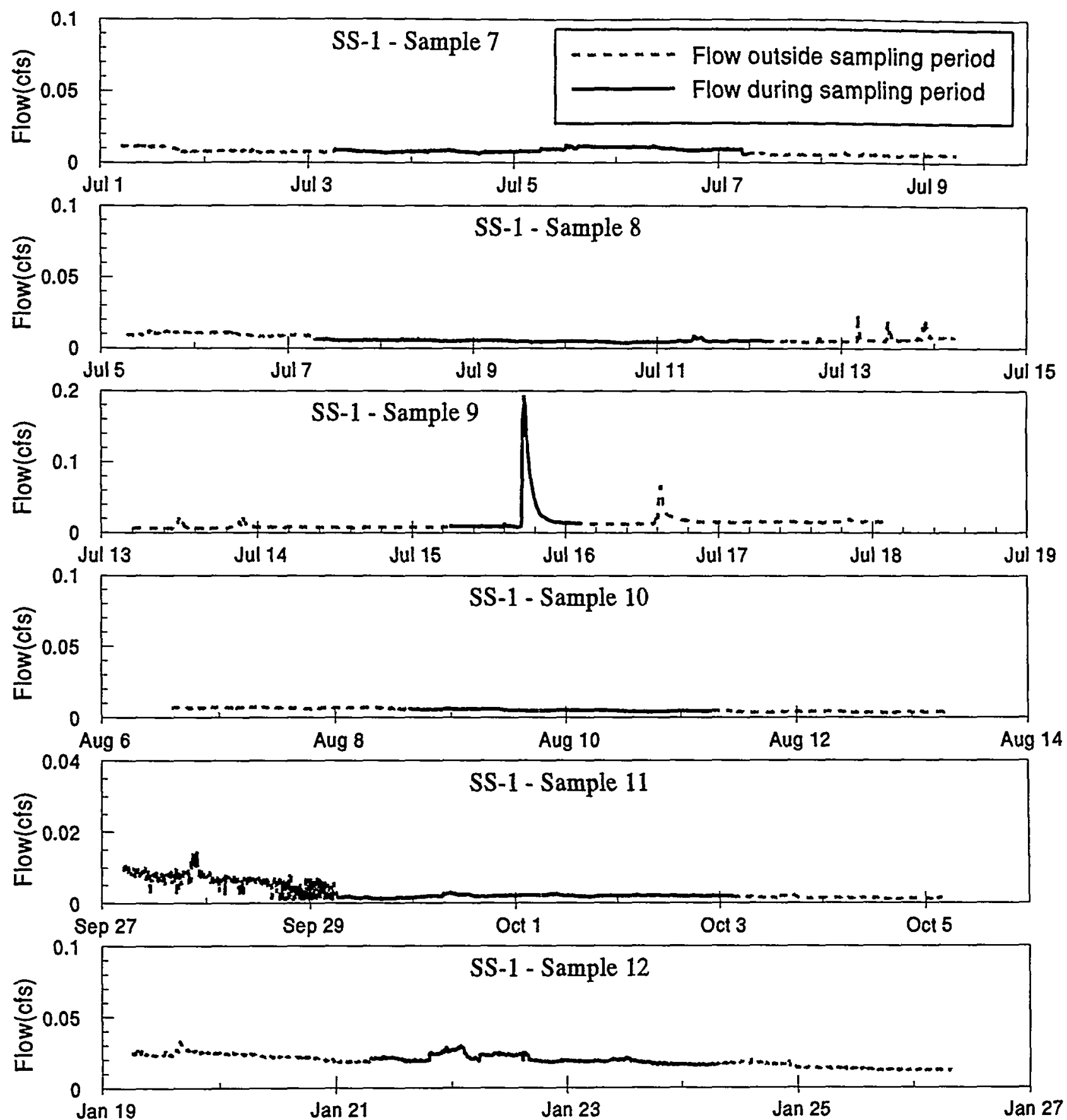

Fig. B.38. Surface water hydrographs showing flow during sampling periods for samples 7 through 12 at SS-1. 
B10-43

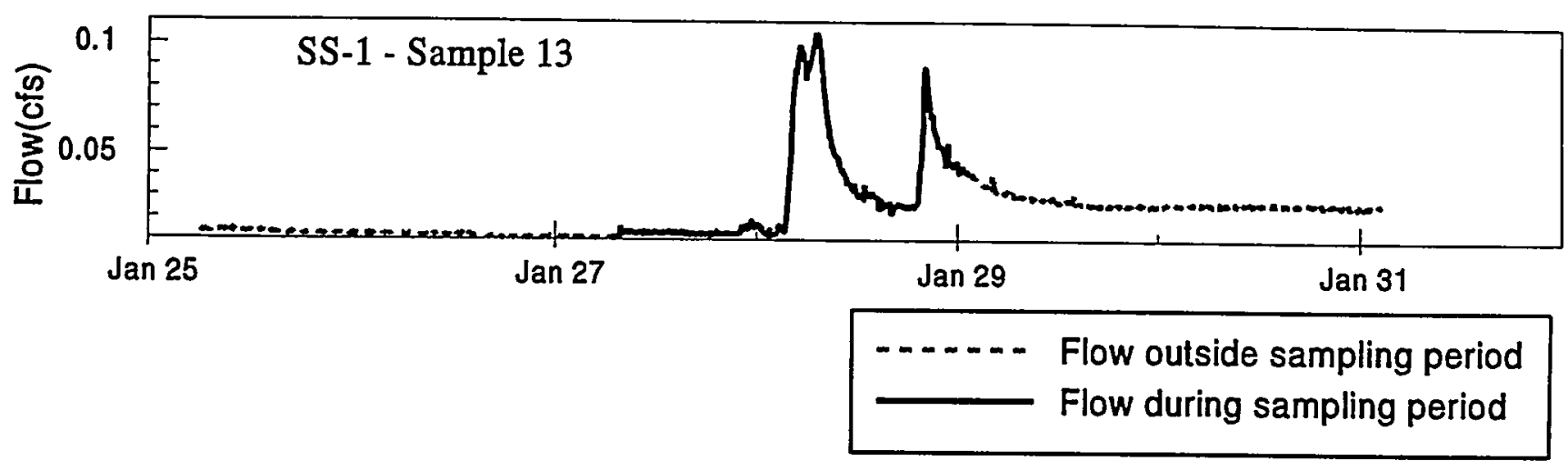

Fig. B.39. Surface water hydrographs showing flow during sampling periods for sample 13 at SS-1. 

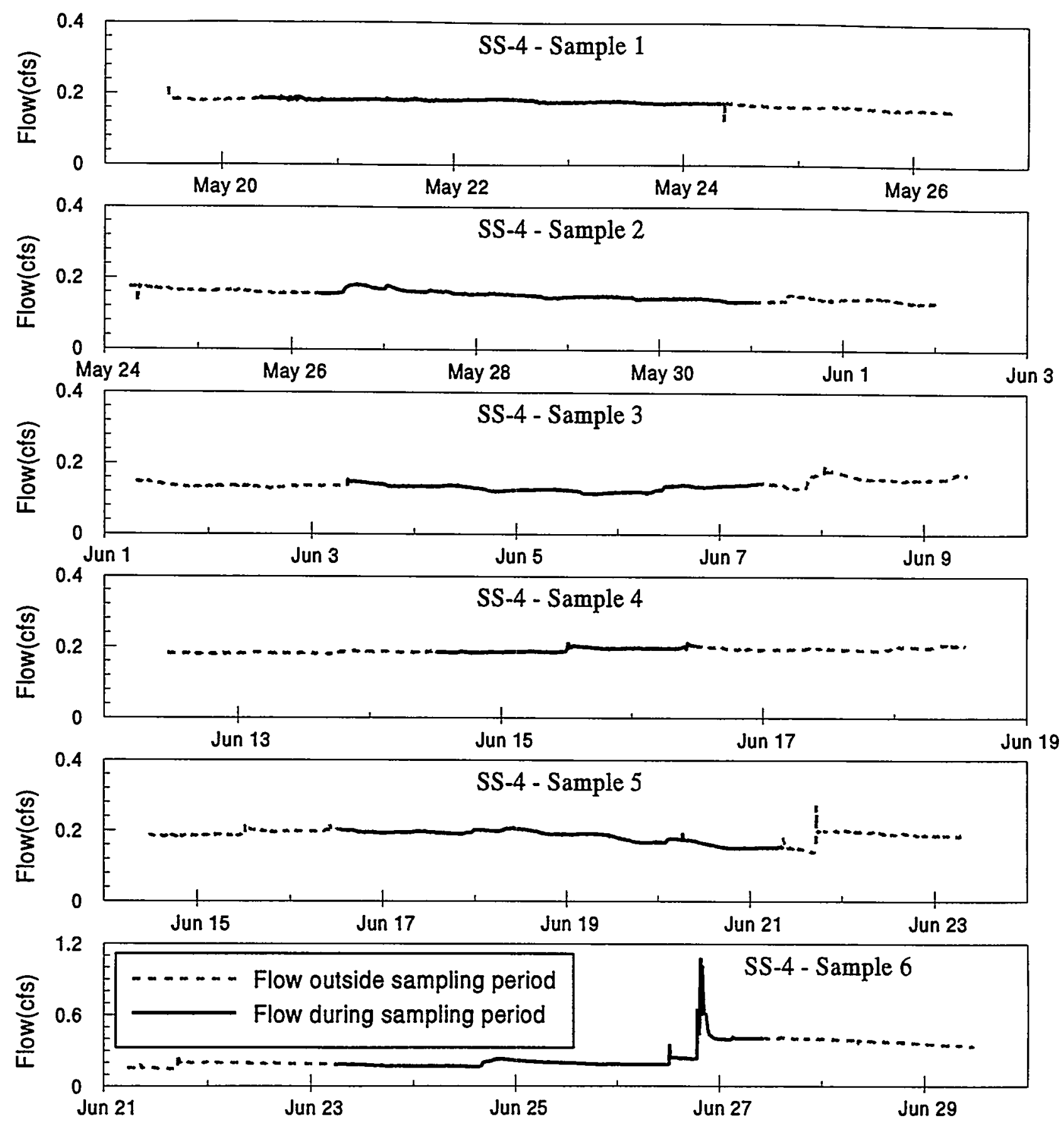

Fig. B.40. Surface water hydrographs showing flow during sampling periods for samples 1 through 6 at SS-4. 

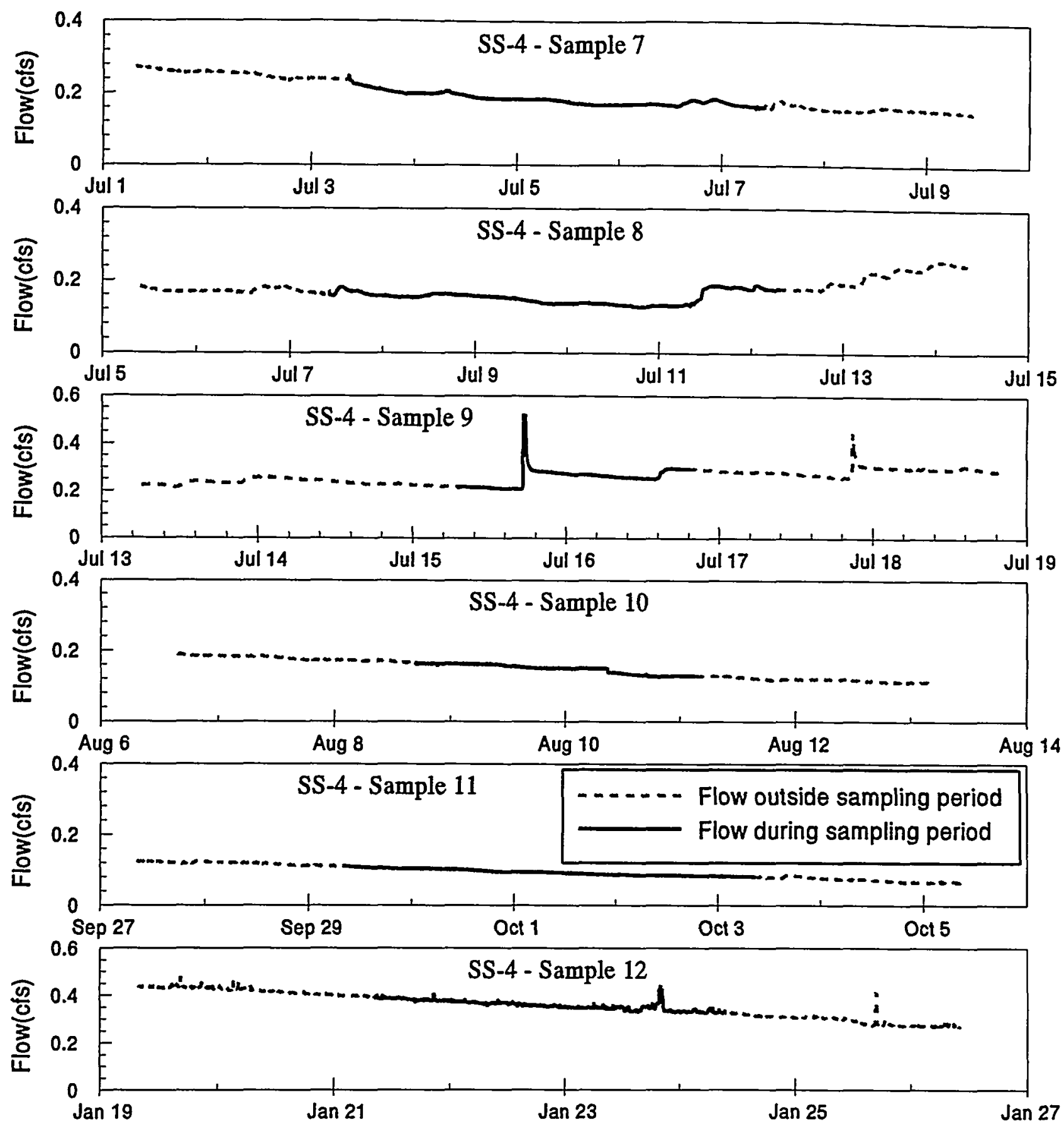

Fig. B.41. Surface water hydrographs showing flow during sampling periods for samples 7 through 12 at SS-4. 


\section{B10-46}

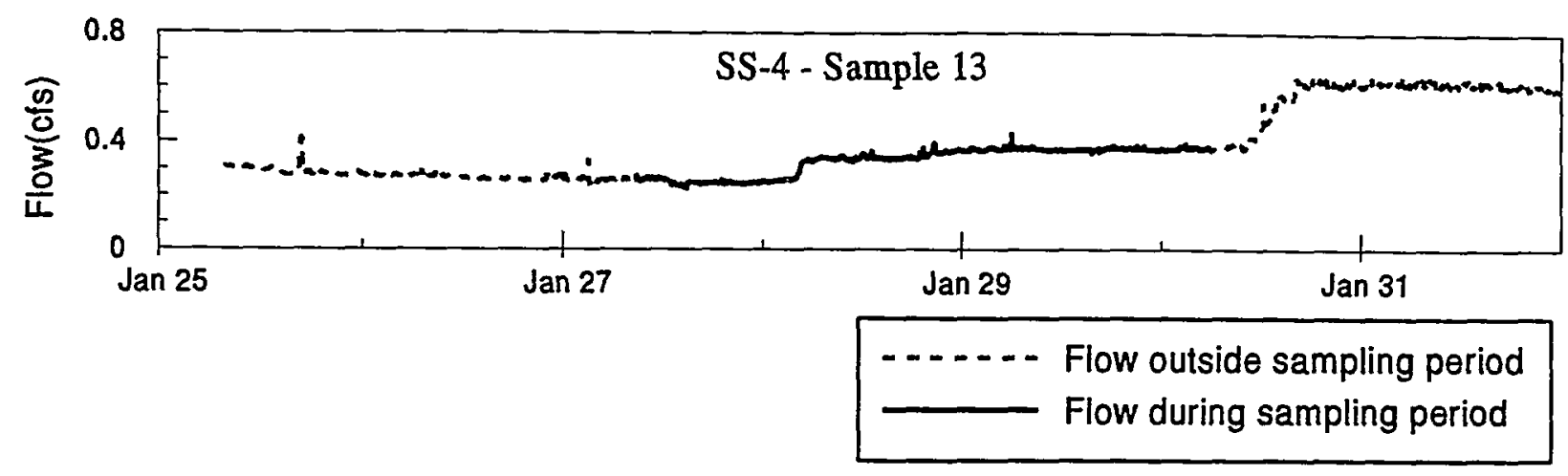

Fig. B.42. Surface water hydrographs showing flow during sampling periods for sample 13 at SS-4. 

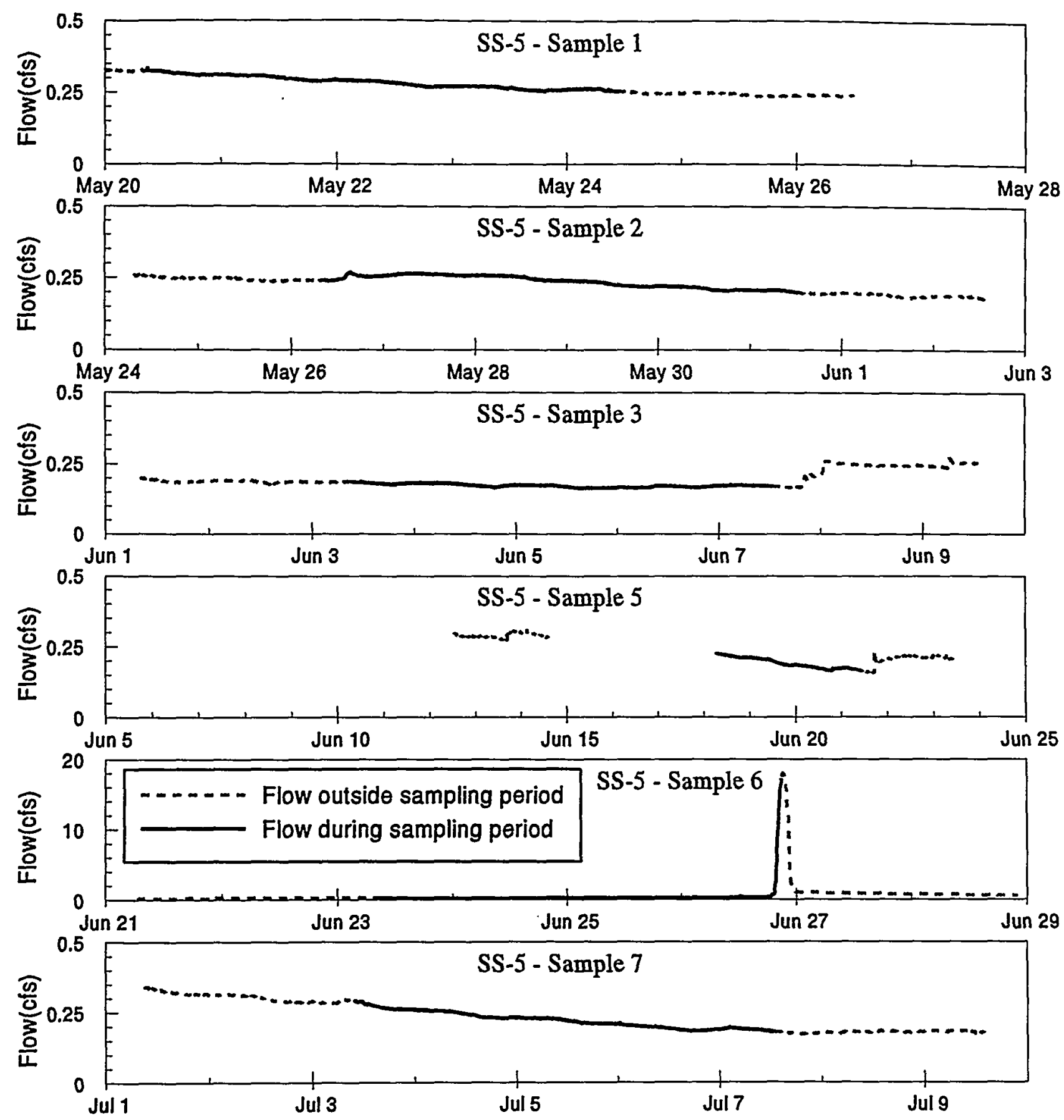

Fig. B.43. Surface water hydrographs showing flow during sampling periods for samples 1 through 3 and 5 through 7 at SS-5. 

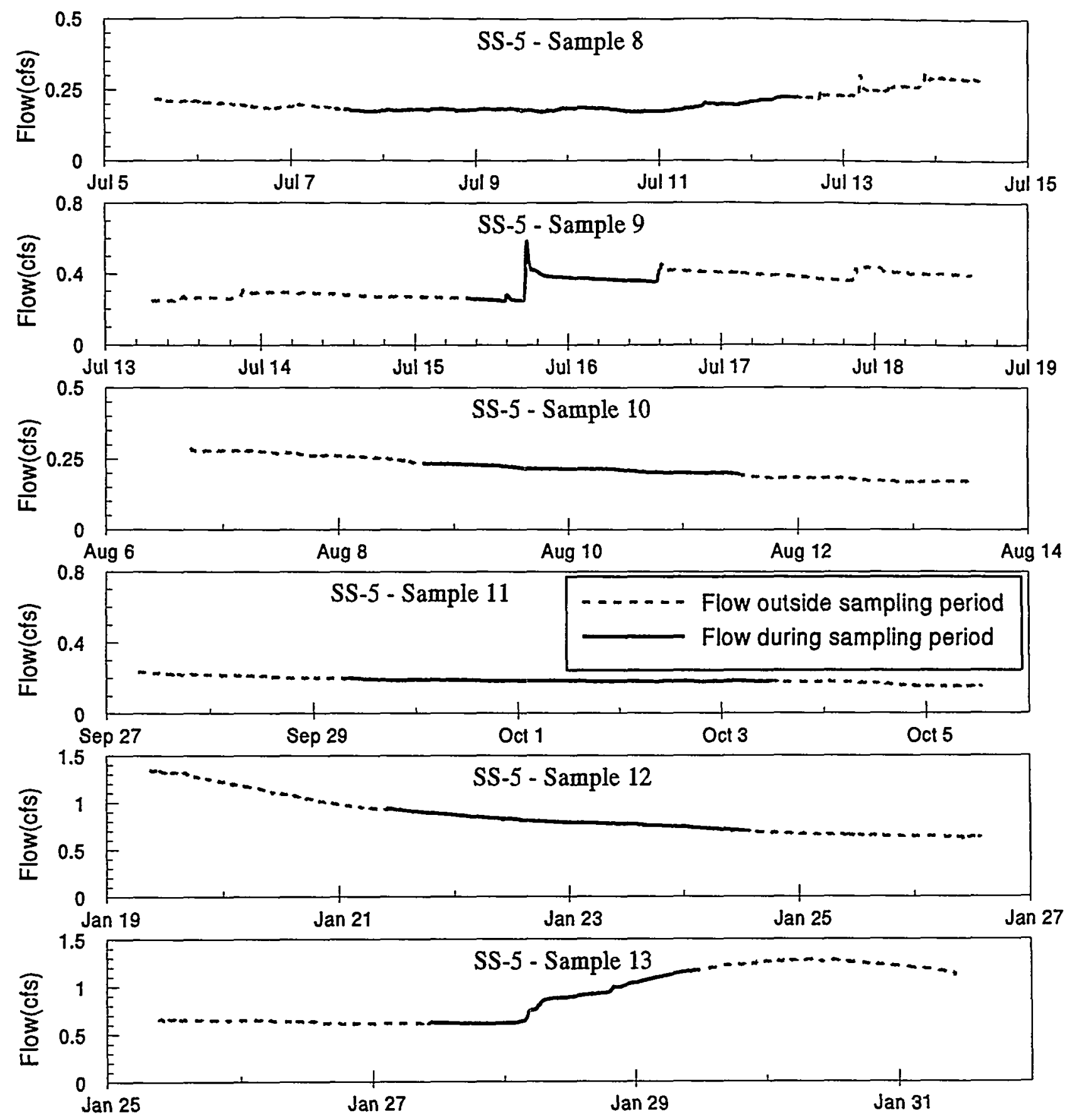

Fig. B.44. Surface water hydrographs showing flow during sampling periods for samples 8 through 13 at SS-5. 
B10-49
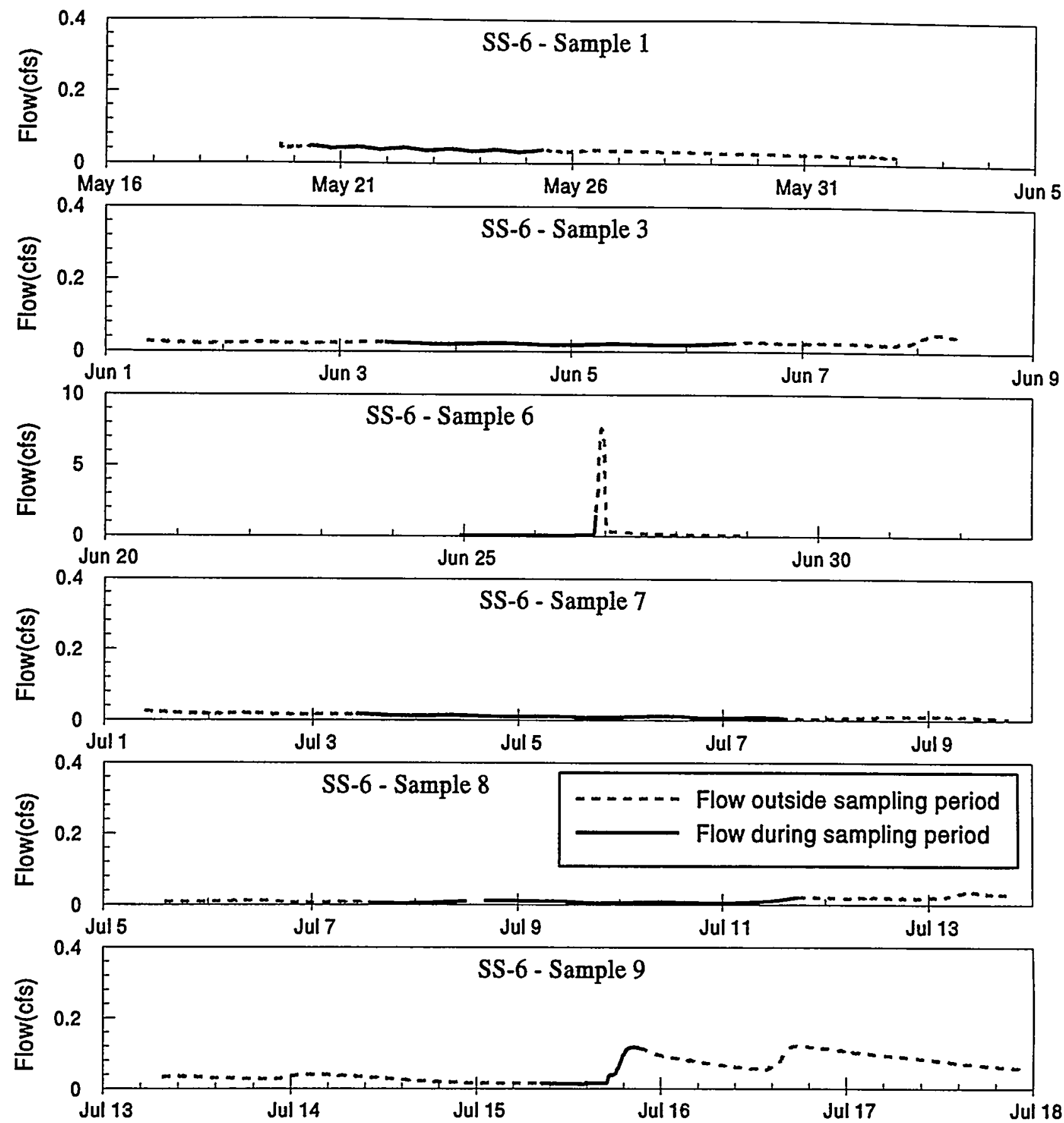

Fig. B.45. Surface water hydrographs showing flow during sampling periods for samples 1, 3, and 6 through 9 at SS-6. 

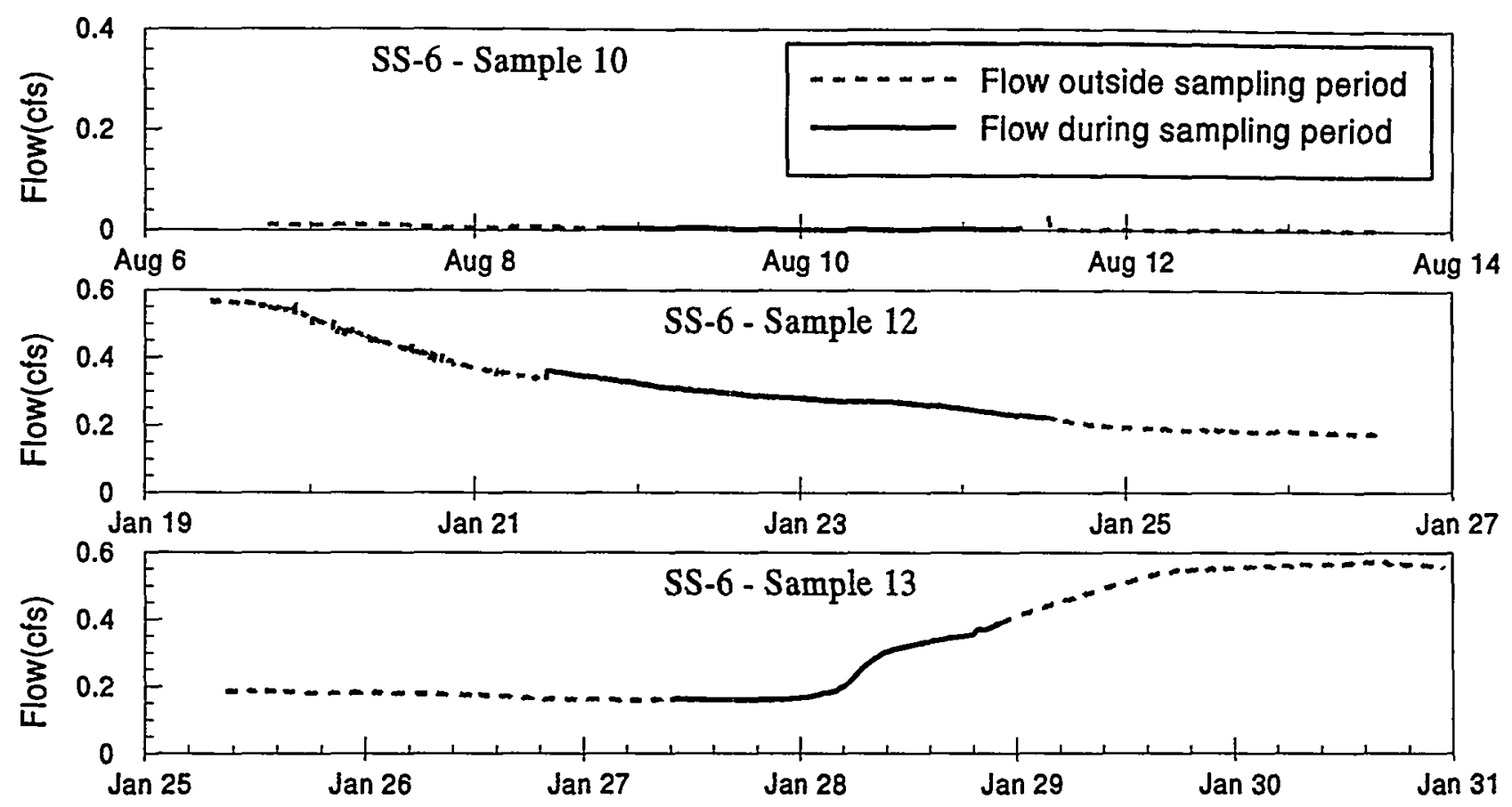

Fig. B.46. Surface water hydrographs showing flow during sampling periods for samples 10, 12, and 13 at SS-6. 


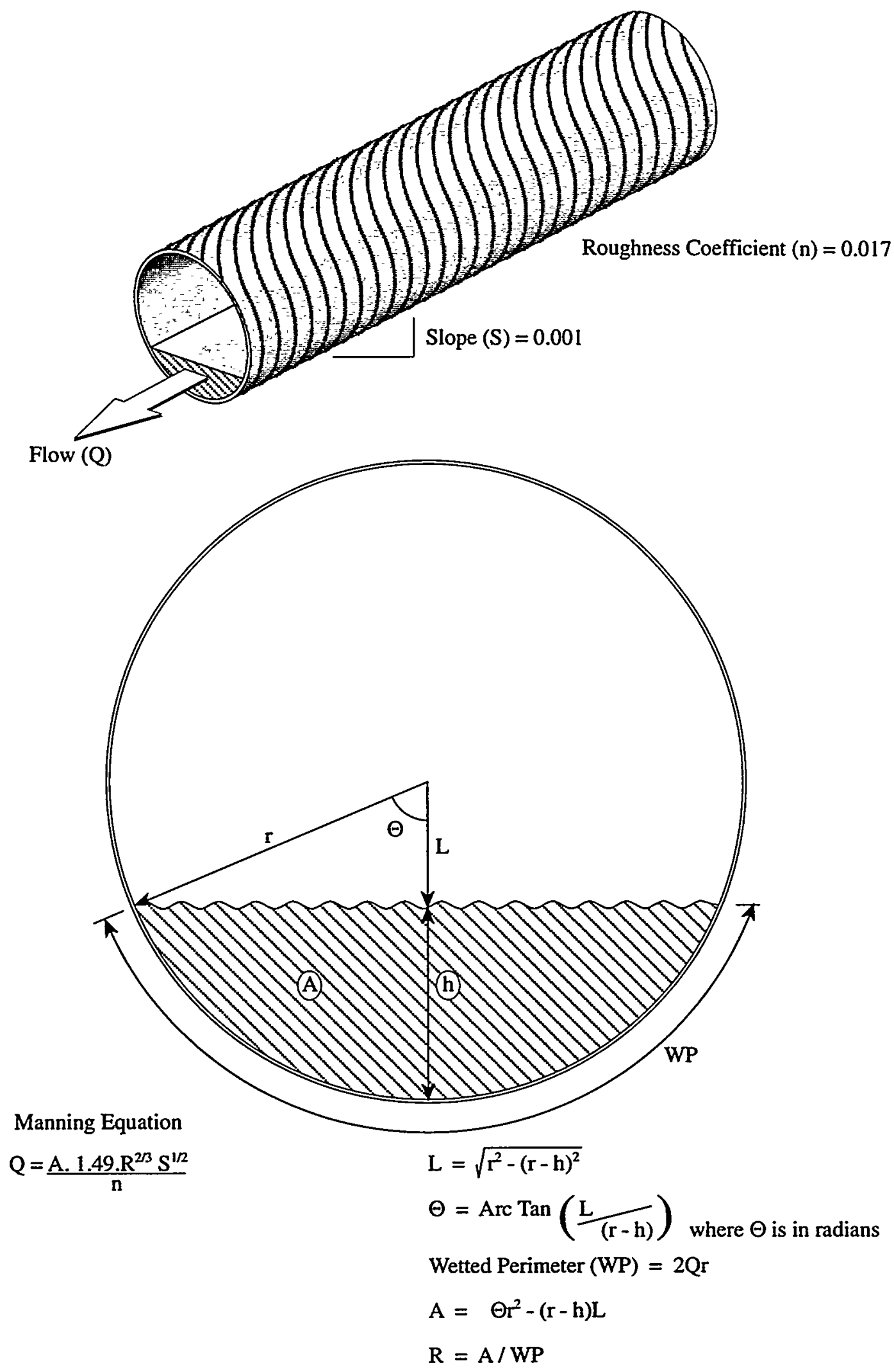

Fig. B.47. Diagrammatic representation of the method for calculating flow from stage at $B C K$ 12.38. 
B10-52

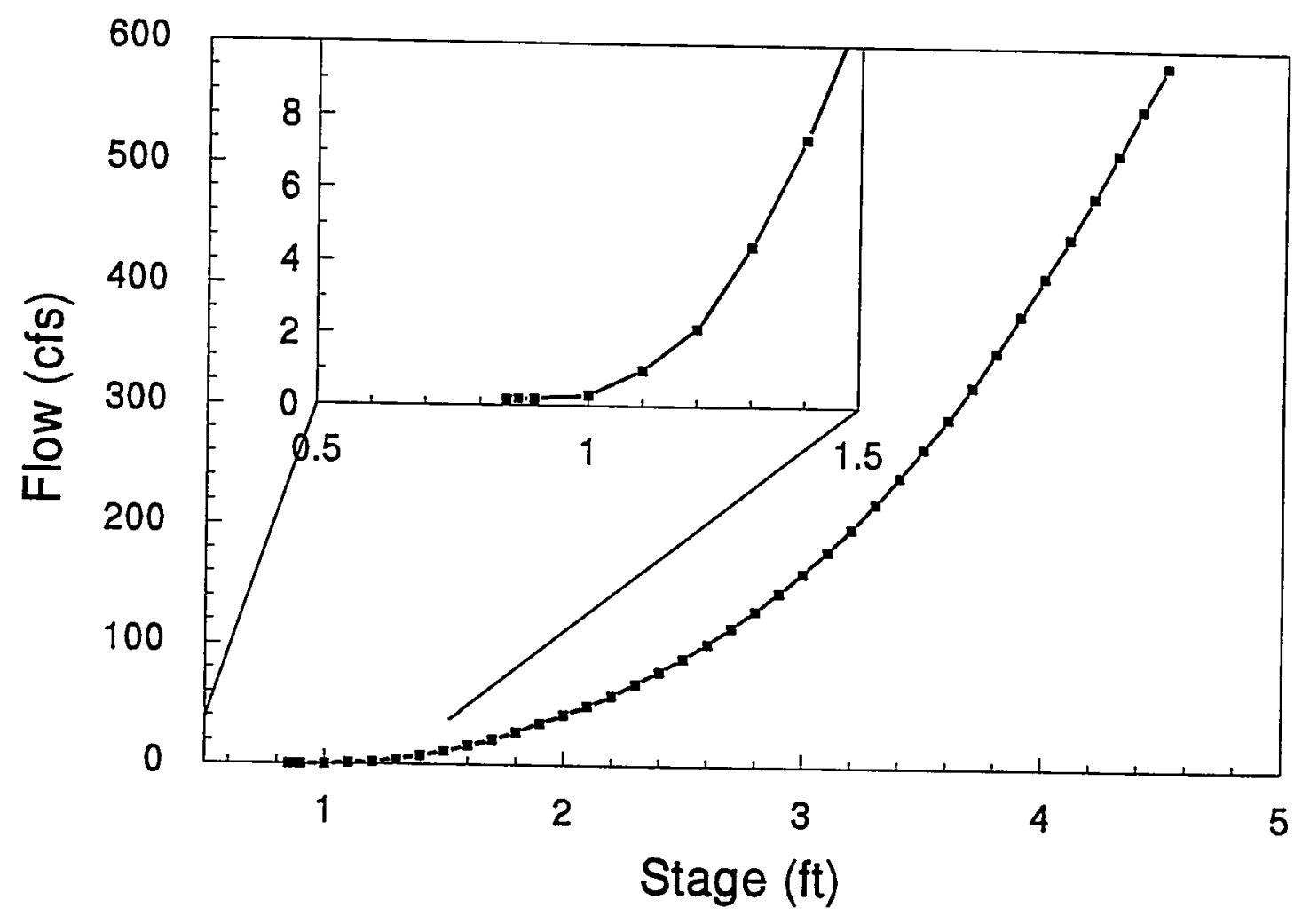

Fig. B.48. Rating curve for BCK 9.47. 


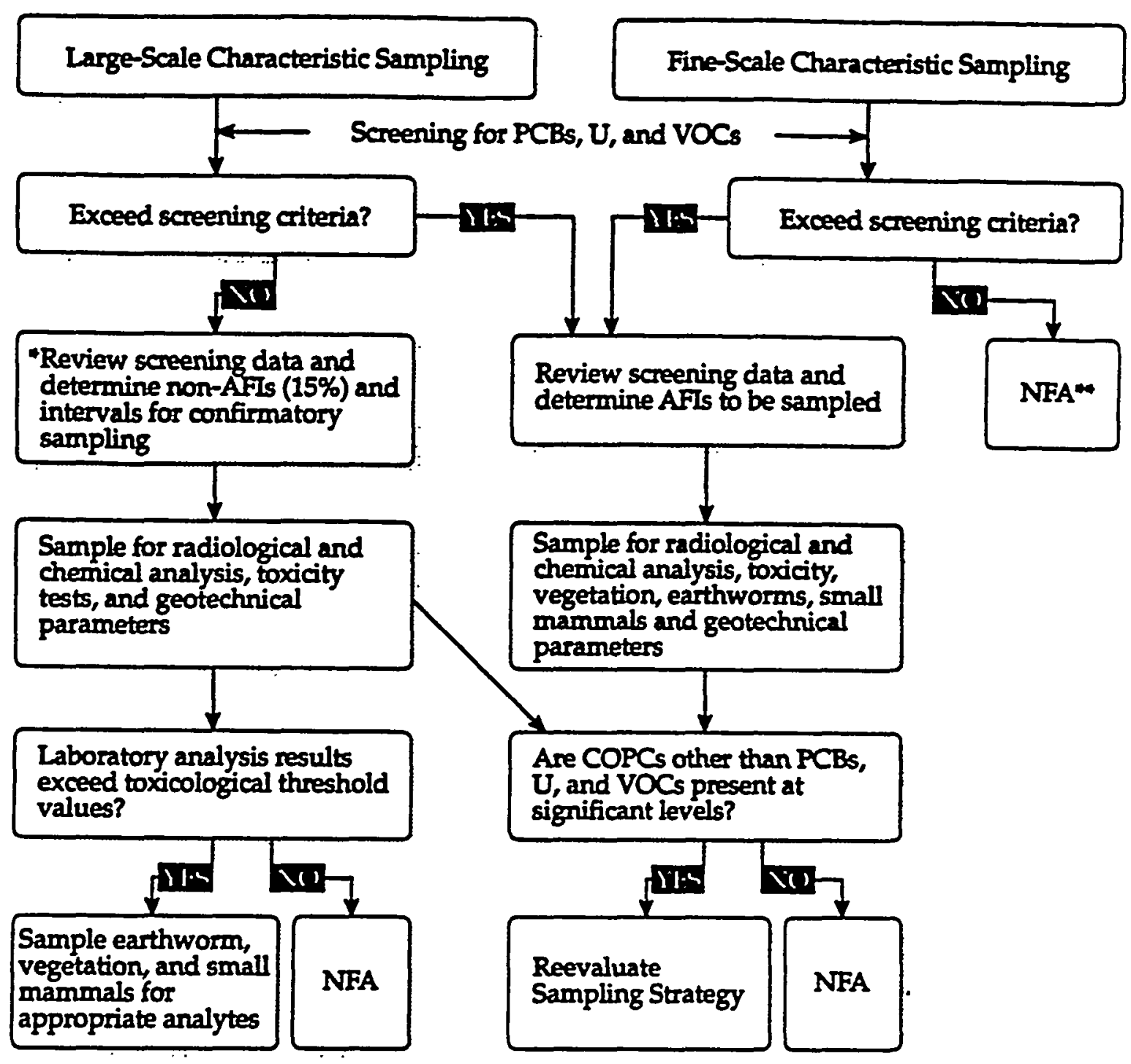

"Review of data will occur as data packages arrive from the analytical laboratory.

Reevaluation of the sampling strategy may occur any time during the sampling activities.

No further action

Fig. B.49. Flowchart outlining sampling activities for BCV Floodplain soils investigation. 
Notice

Page(s) size did not permit electronic reproduction. Information may be purchased by the general public from the National Technical Information Service, U.S. Department of Commerce, Springfield, VA 22161 (1800-553-6847). DOE and DOE contractors may purchase information by contacting DOE's Office of Scientific and Technical Information, P.O. Box 62, Oak Ridge, TN 37831-0062, Attn: Information Services (1865-576-8401). 

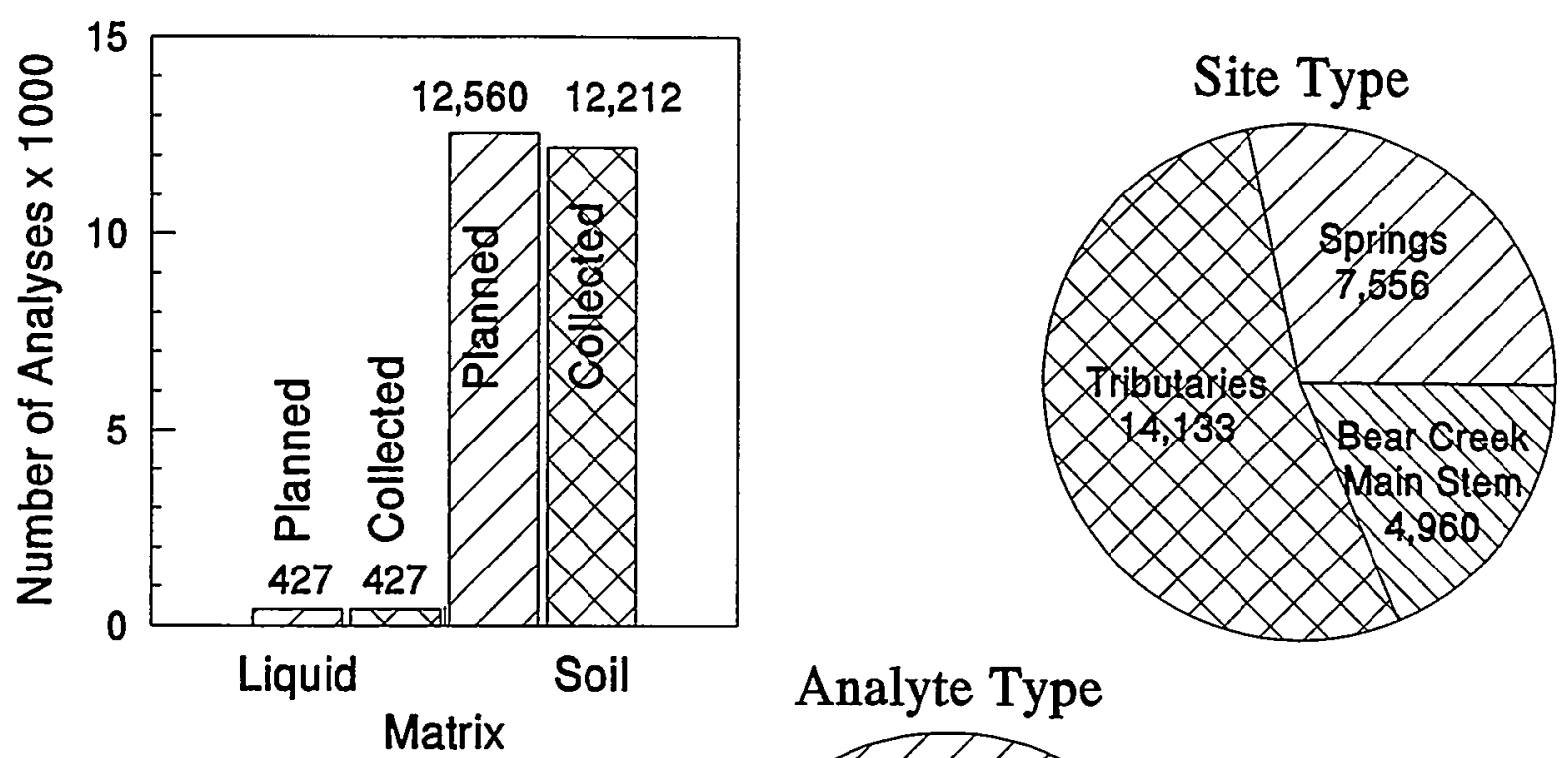

\section{Analyte Type}

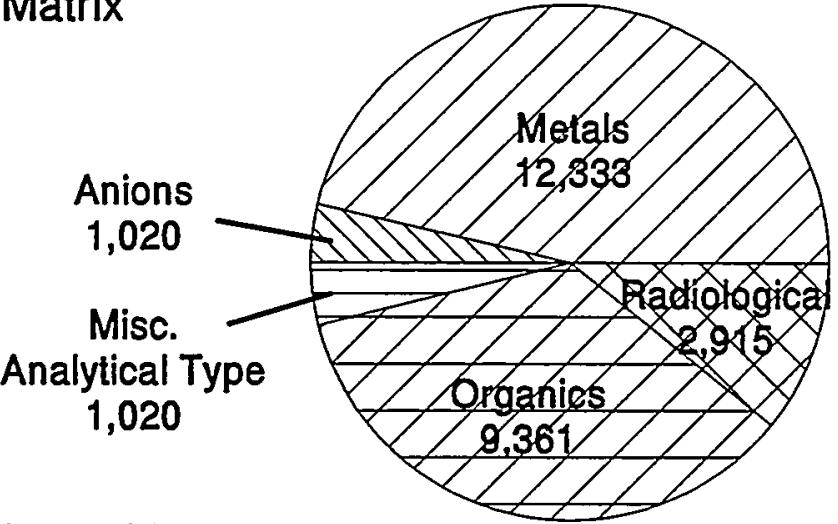

Rejected Data
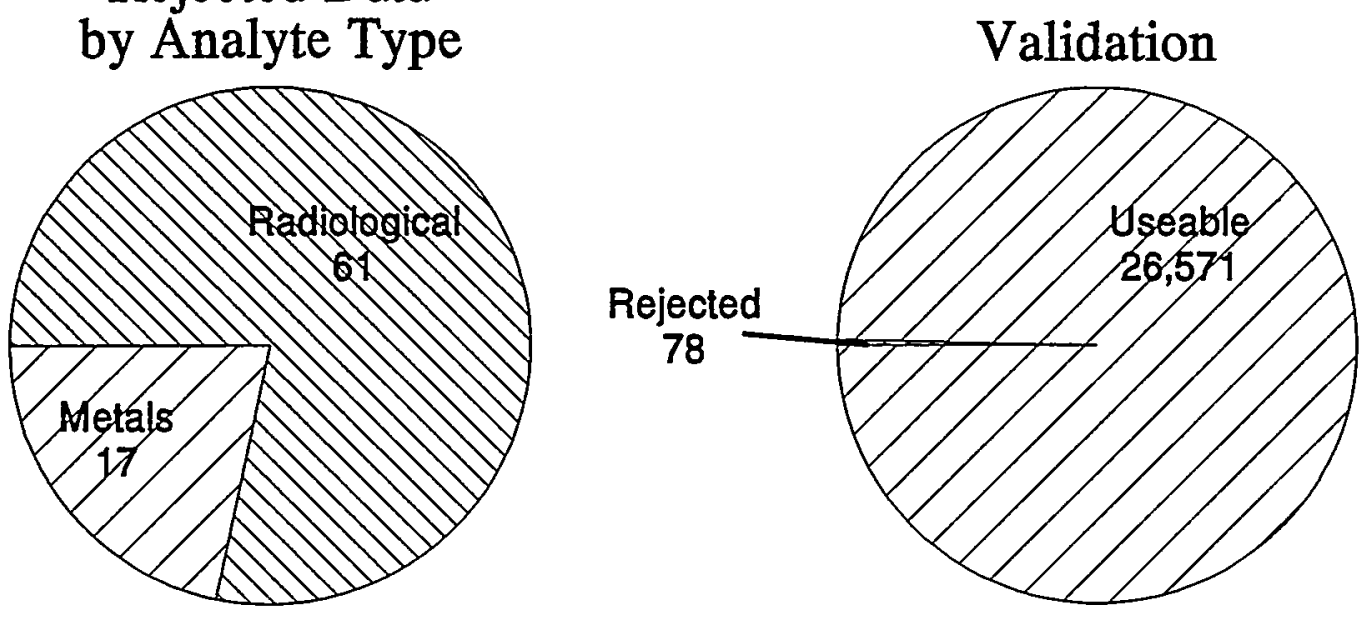

Fig. B.51. Summary of samples collected for the BCV OU 4 RI field activities by matrix, site, and analyte group. 


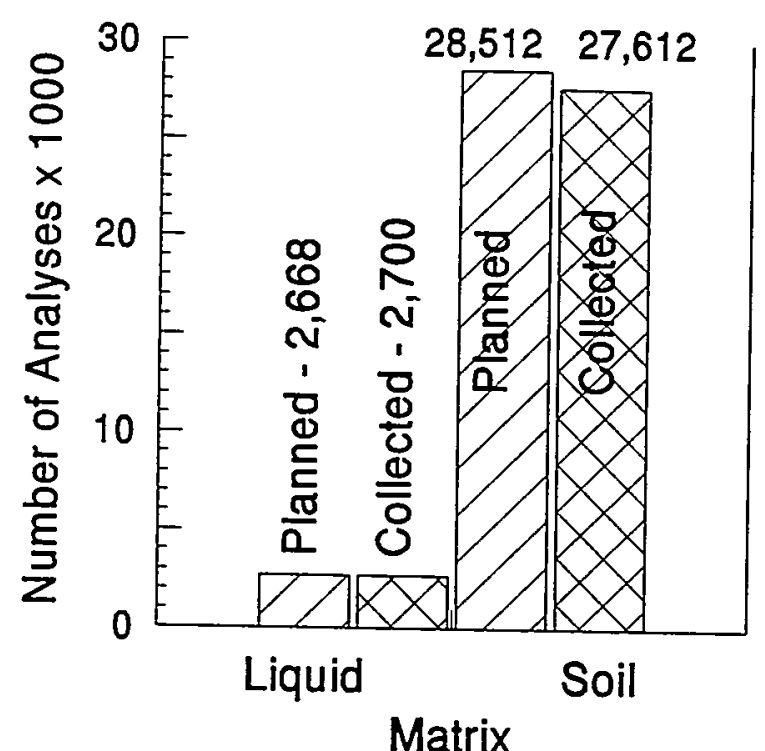

\section{Analyte Type}

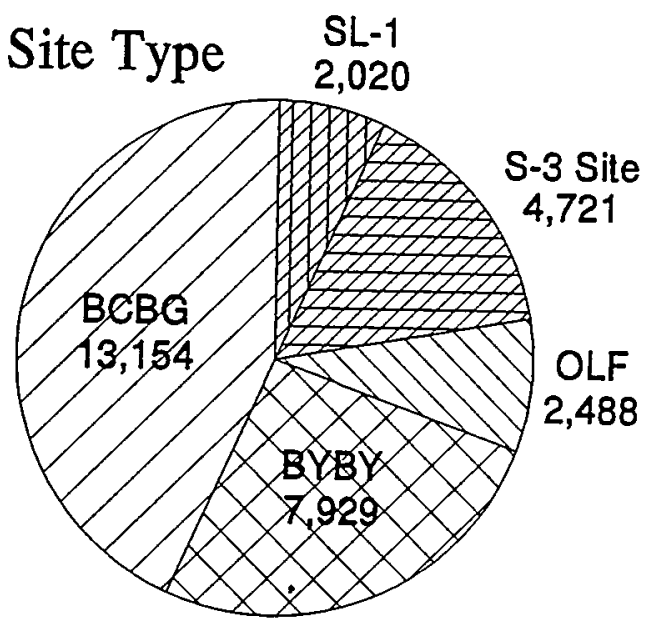

Rejected Data by Analyte Type

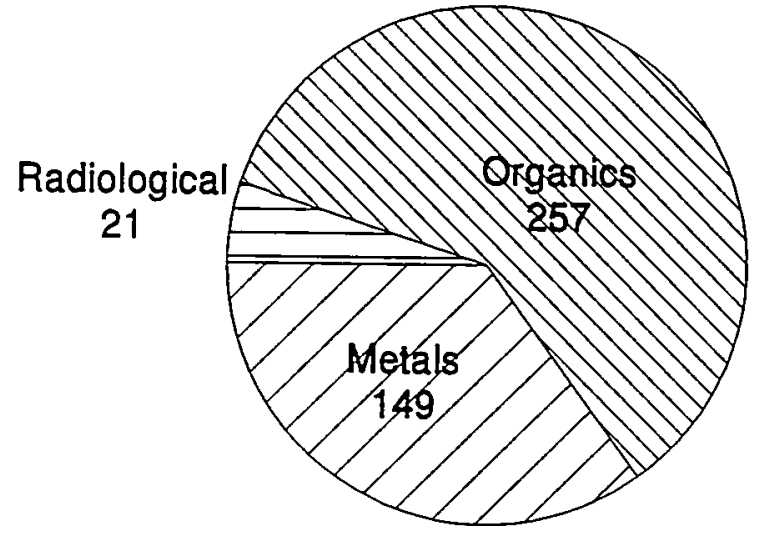

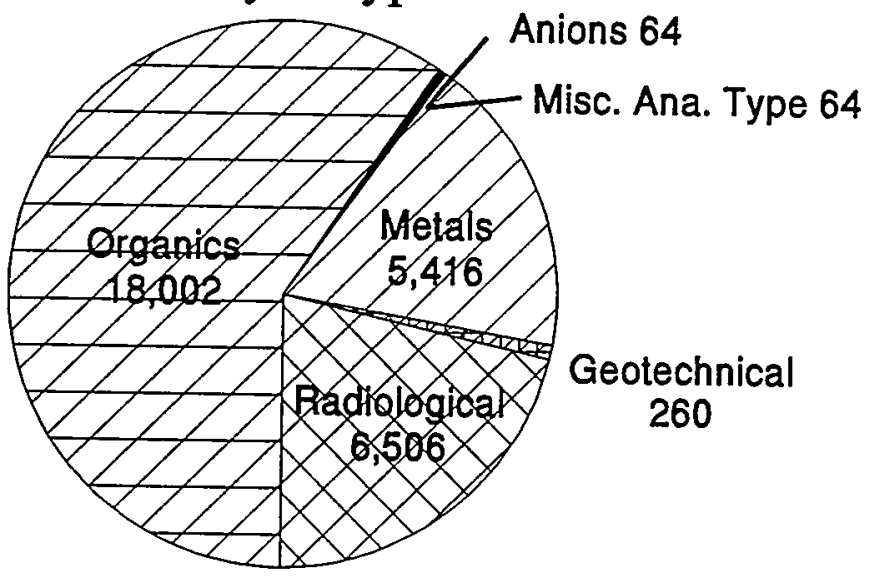

Validation

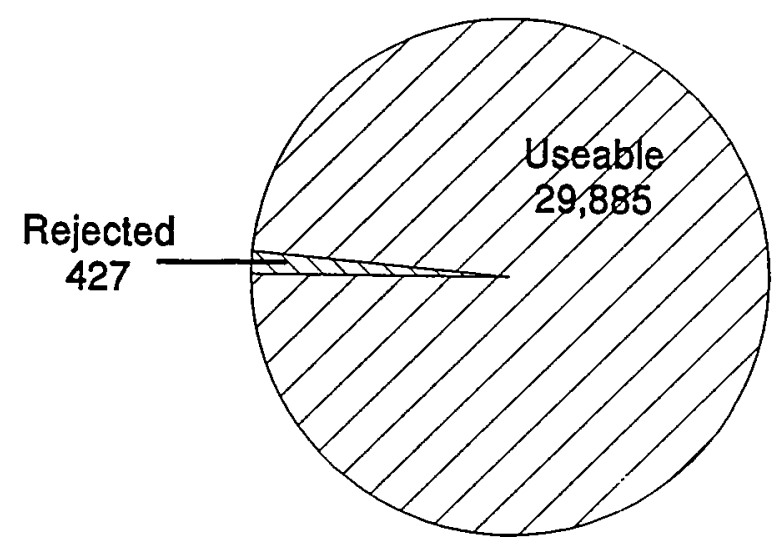

Fig. B.52. Summary of samples taken for the BCV OU 1 RIFA by matrix, site, and analyte group. 

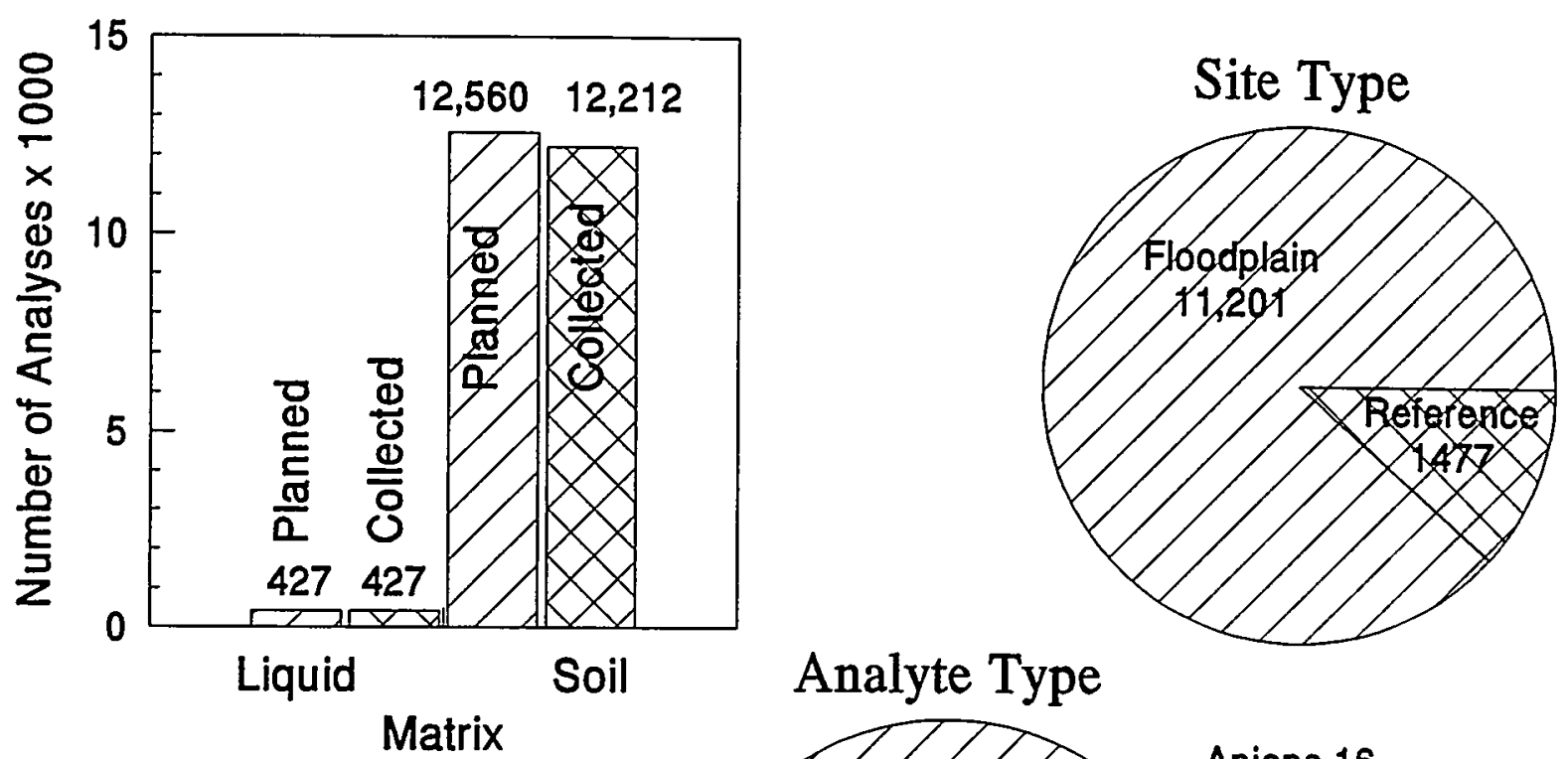

\section{Analyte Type}

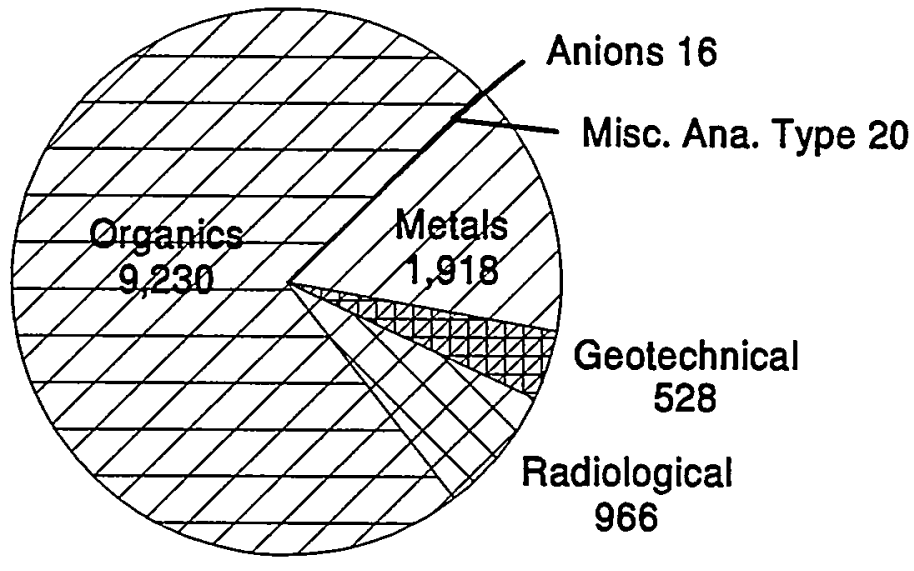

Rejected Data

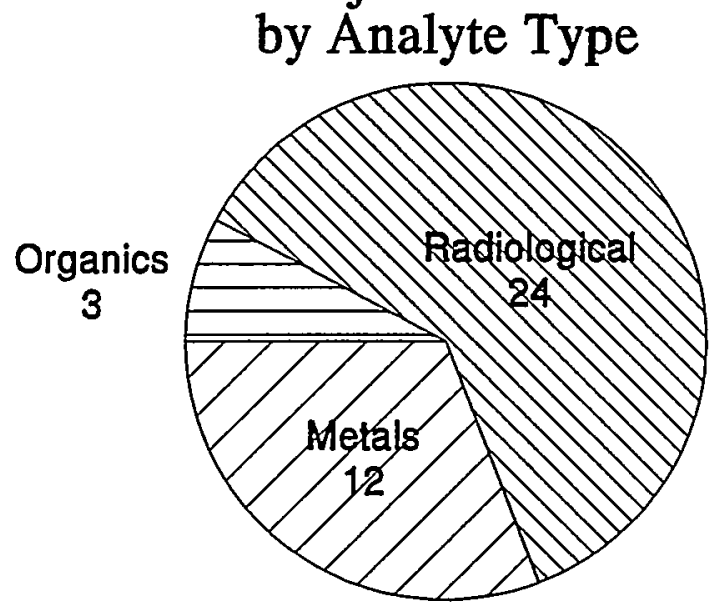

Validation

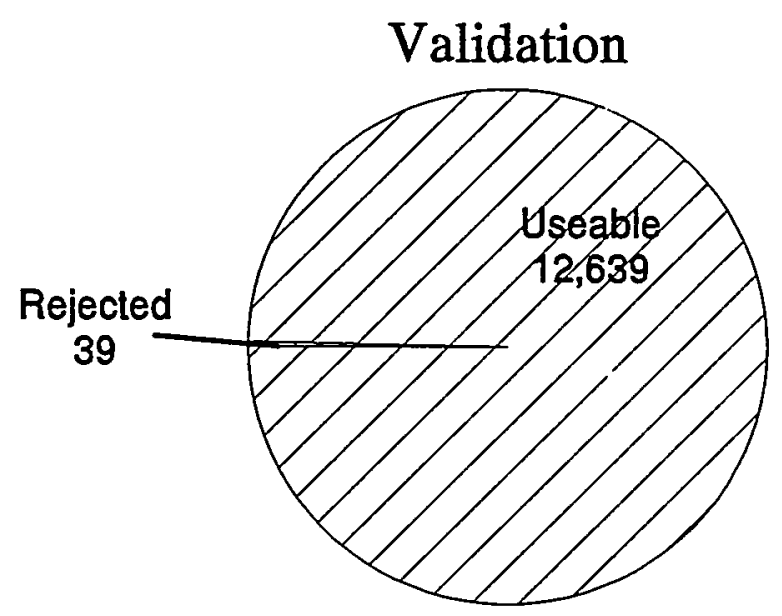

Fig. B.53. Summary of samples taken for the FPSS field activities by matrix, site, and analyte group. 
B11-1

\section{B.11 PLATES}





\section{B1 1-3}
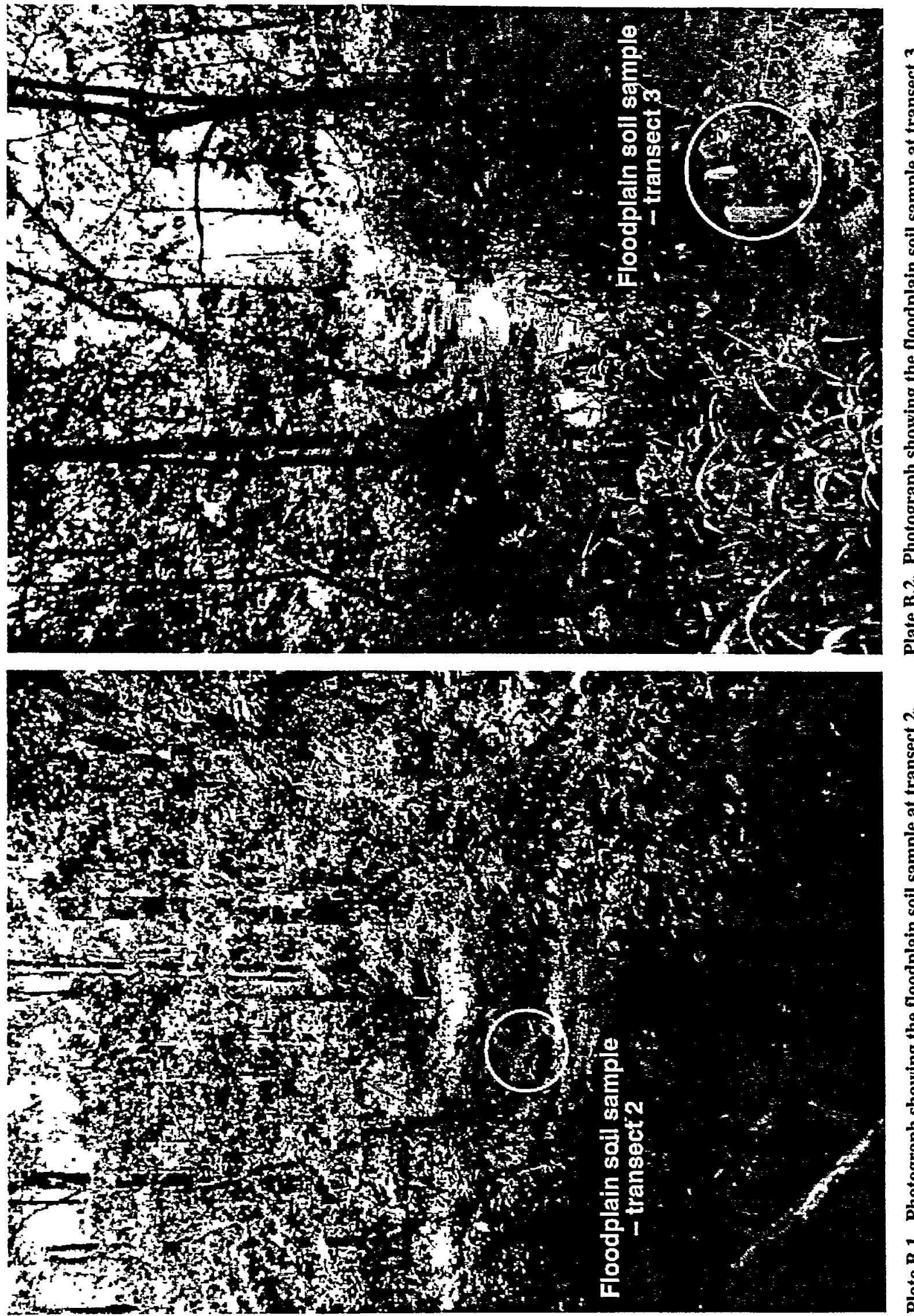

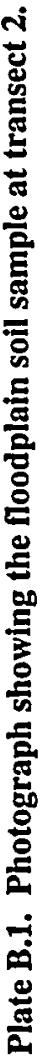


B12-1

B.12 TABLES 
Table B.1. Historical data from special studies, subcontractor sampling events, and monitoring activities within BCV. Datasets captured for use in this RI are highlighted

\begin{tabular}{|c|c|c|c|c|c|c|c|}
\hline No. & Description of study & Dates & $\begin{array}{l}\text { Number } \\
\text { of } \\
\text { samples }\end{array}$ & $\begin{array}{c}\text { Media } \\
\text { sampled }\end{array}$ & $\begin{array}{l}\text { Sampling } \\
\text { stations }\end{array}$ & $\begin{array}{l}\text { Analyses } \\
\text { performed }\end{array}$ & $\begin{array}{c}\text { Selected references to } \\
\text { these data }\end{array}$ \\
\hline 1. & Early meteorological data & $\begin{array}{l}\text { Beginning } \\
\text { in } 1948\end{array}$ & $\mathrm{NA}^{a}$ & NA & $\begin{array}{l}\text { Oak Ridge } \\
\text { Townsite: } \\
\text { (011) } \\
\text { BCV: (008, } \\
018) \\
\text { Pine Ridge, } \\
\text { K-25, X-10 }\end{array}$ & $\begin{array}{l}\text { Extensive } \\
\text { meteorological } \\
\text { monitoring } \\
\text { including } \\
\text { radioactivity }\end{array}$ & USAEC 1953 \\
\hline 2. & $\begin{array}{l}\text { U.S. Geologic Survey } \\
\text { (USGS) hydrologic } \\
\text { monitoring of Bear Creek } \\
\text { and its tributaries }\end{array}$ & $\begin{array}{l}1958 \text { to } \\
\text { present }\end{array}$ & NA & Surface water & $\begin{array}{l}03538256 \\
03538260 \\
035382672 \\
035382673 \\
035382677 \\
03538270 \\
03538272 \\
03538273 \\
03538275\end{array}$ & Flow & $\begin{array}{l}\text { McMaster 1967; } \\
\text { Lowery 1987; } \\
\text { Clapp et al. 1990; } \\
\text { Turner et al. } 1991\end{array}$ \\
\hline 3. & $\begin{array}{l}\text { National Pollution Discharge } \\
\text { Elimination System } \\
\text { (NPDES) monitoring by } \\
\text { Y-12 at BCK }-4.55\end{array}$ & $\begin{array}{l}1971 \text { to } \\
\text { present }\end{array}$ & $\mathrm{ND}^{b}$ & Surface water & NPDES-304 & $\begin{array}{l}\text { Flow, anions, } \\
\text { inorganics, } \\
\text { miscellaneous } \\
\text { constituents }^{c}\end{array}$ & $\begin{array}{l}\text { Environmental } \\
\text { Surveillance Reports } \\
\text { e.g., Energy } \\
\text { Systems 1987a; } \\
\text { Energy Systems 1993d }\end{array}$ \\
\hline
\end{tabular}


Table B.1 continued

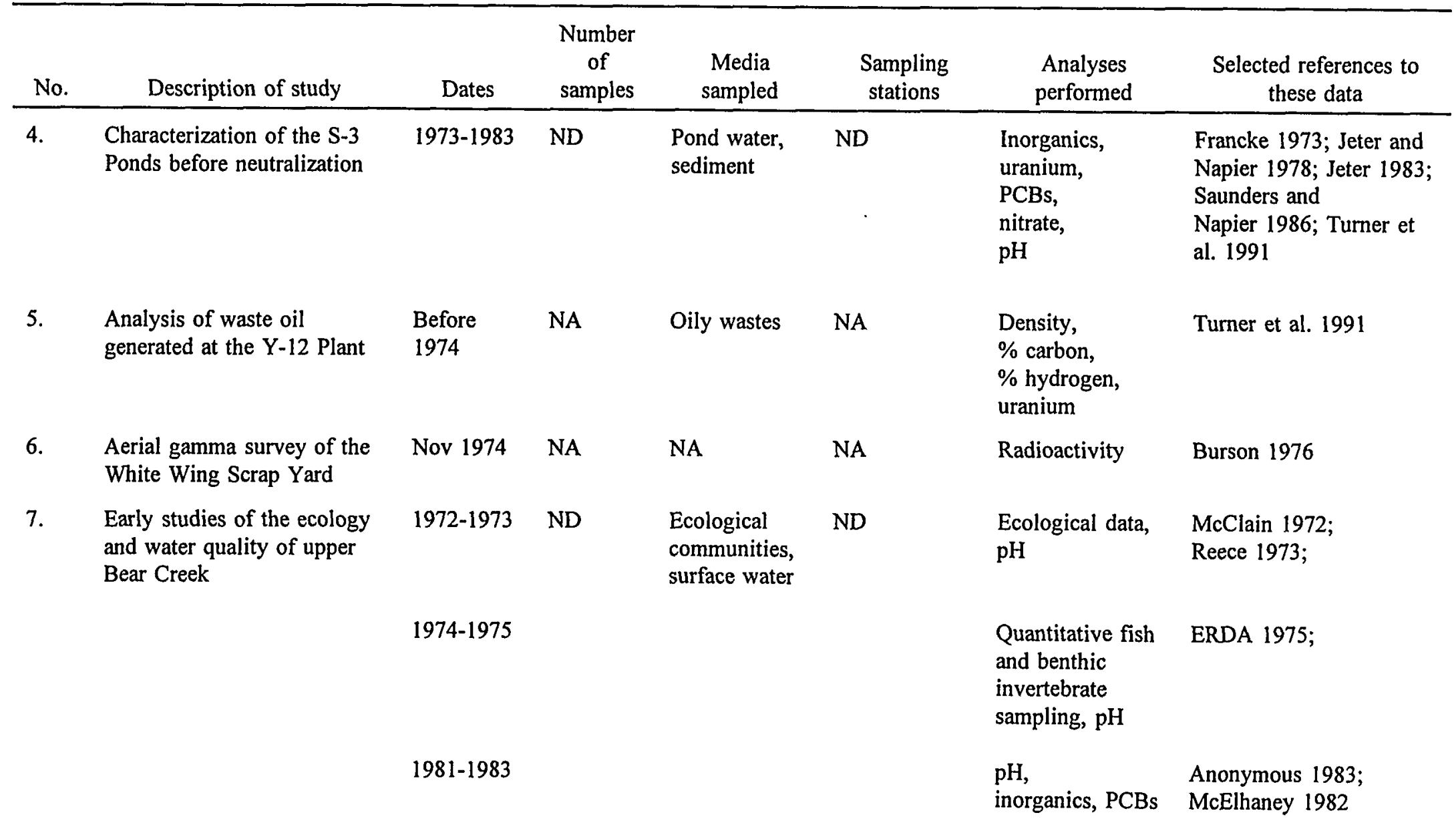


Table B.1 continued

\begin{tabular}{|c|c|c|c|c|c|c|c|}
\hline No. & Description of study & Dates & $\begin{array}{c}\text { Number } \\
\text { of } \\
\text { samples }\end{array}$ & $\begin{array}{c}\text { Media } \\
\text { sampled }\end{array}$ & $\begin{array}{c}\text { Sampling } \\
\text { stations }\end{array}$ & $\begin{array}{l}\text { Analyses } \\
\text { performed }\end{array}$ & $\begin{array}{c}\text { Selected references to } \\
\text { these data }\end{array}$ \\
\hline \multirow[t]{3}{*}{8.} & $\begin{array}{l}\text { Analysis of oily wastes sent } \\
\text { to the Oil Landfarm }\end{array}$ & $\begin{array}{l}\text { Before } \\
1979\end{array}$ & NA & Oily wastes & NA & Inorganics & Turner et al. 1991 \\
\hline & & After 1979 & NA & Oily wastes & NA & Inorganics, PCBs & \\
\hline & & $\begin{array}{l}\text { Dec } 1981- \\
1982\end{array}$ & NA & Oily wastes & NA & $\begin{array}{l}\text { Inorganics, } \\
\text { PCBs, } \\
\text { chlorinated } \\
\text { hydrocarbons }\end{array}$ & \\
\hline 9. & $\begin{array}{l}\text { Soil samples from transects } \\
\text { on the perimeter of Oil } \\
\text { Retention Pond } 1 \text { (ORP-1) }\end{array}$ & $\begin{array}{l}1980 \\
1982\end{array}$ & $\begin{array}{l}14 \\
19\end{array}$ & Soil cores & ND & PCBs & $\begin{array}{l}\text { Bailey } 1980 ; \\
\text { Herbes } 1988\end{array}$ \\
\hline 10. & $\begin{array}{l}\text { Meteorological data collected } \\
\text { by the National Oceanic and } \\
\text { Atmospheric Administration } \\
\text { (NOAA) }\end{array}$ & $\begin{array}{l}\text { 1980- } \\
\text { present }\end{array}$ & NA & NA & $\mathrm{NA}$ & $\begin{array}{l}\text { Precipitation, } \\
\text { temperature, } \\
\text { relative } \\
\text { humidity, wind } \\
\text { speed and } \\
\text { direction }\end{array}$ & Energy Systems 1993d \\
\hline 11. & $\begin{array}{l}\text { Station } 8 \text { ambient air } \\
\text { monitoring by Y-12 near the } \\
\text { plant's west end }\end{array}$ & $\begin{array}{l}\text { Early ' } 80 \mathrm{~s} \\
\text { to present }\end{array}$ & ND & Air & 8 & $\begin{array}{l}\text { Gross } \alpha, \text { gross } \beta \text {, } \\
\text { isotopic } U \text {, } \\
\text { mercury }\end{array}$ & $\begin{array}{l}\text { Turner et al. 1991; } \\
\text { Energy Systems 1993d }\end{array}$ \\
\hline 12. & $\begin{array}{l}\text { Y-12 Plant Lab analysis of } \\
\text { soil from the Oil Landfarm }\end{array}$ & $\begin{array}{l}\text { Oct } 1981 \\
\text { Nov } 1982\end{array}$ & $\begin{array}{l}45 \\
3\end{array}$ & $\begin{array}{l}\text { Soil } \\
\text { composites }\end{array}$ & $\begin{array}{l}\text { Plots } 1 / 2 \text {, } \\
3 / 4,5 / 6 \text {, } \\
\text { OF-East } \\
\text { OF-Middle } \\
\text { OF-West }\end{array}$ & $\begin{array}{l}\text { Oil and grease, } \\
\text { total carbon, } \\
\text { PCBs, } \\
\text { inorganics, } \\
\text { nitrates, } \\
\text { uranium }\end{array}$ & $\begin{array}{l}\text { Taylor 1981; } \\
\text { BNI 1983; } \\
\text { Geraghty and } \\
\text { Miller 1985; } \\
\text { Herbes } 1989\end{array}$ \\
\hline
\end{tabular}


Table B.1 continued

\begin{tabular}{|c|c|c|c|c|c|c|c|}
\hline No. & Description of study & Dates & $\begin{array}{l}\text { Number } \\
\text { of } \\
\text { samples }\end{array}$ & $\begin{array}{l}\text { Media } \\
\text { sampled }\end{array}$ & $\begin{array}{l}\text { Sampling } \\
\text { stations }\end{array}$ & $\begin{array}{l}\text { Analyses } \\
\text { performed }\end{array}$ & $\begin{array}{l}\text { Selected references to } \\
\text { these data }\end{array}$ \\
\hline \multirow{2}{*}{13.} & & & 15 & Sediment & $\begin{array}{l}7.40,2.80 \\
2.75,0.55 \\
0.4, \text { L2 }\end{array}$ & & $\begin{array}{l}\text { TVA 1986; } \\
\text { Turner et al. } 1991\end{array}$ \\
\hline & & & 26 & Aquatic biota & & & \\
\hline 14. & $\begin{array}{l}\text { Preliminary screening of } \\
\text { contaminants in Bear Creek } \\
\text { sediments }\end{array}$ & Oct 1983 & $\begin{array}{l}3 \\
(\mathrm{BC}-\mathrm{FP}-1 \\
=12 \\
\text { cores) }\end{array}$ & $\begin{array}{l}\text { Floodplain } \\
\text { soil, sediment }\end{array}$ & $\begin{array}{l}\text { BCK-4.68 } \\
\text { (BC-FP-1) } \\
\text { BC-1 } \\
\text { BC-2 }\end{array}$ & $\begin{array}{l}\text { Organics, } \\
\text { inorganics, } \\
\text { radionuclides }\end{array}$ & $\begin{array}{l}\text { Hoffman et al. 1984; } \\
\text { Geraghty and } \\
\text { Miller } 1985\end{array}$ \\
\hline 15. & $\begin{array}{l}\text { Weekly surface water } \\
\text { monitoring at BCK-12.46 } \\
\text { and BCK-11.97 }\end{array}$ & $\begin{array}{l}\text { July } 1983 \\
\text { to present } \\
\text { (11.97 est } \\
\text { Feb 1989) }\end{array}$ & ND & Surface water & $\begin{array}{l}\text { BCK-12.46 } \\
\text { BCK-11.97 } \\
(\mathrm{BCK}-12.36 \\
3 / 88-5 / 88)\end{array}$ & $\begin{array}{l}\text { Inorganics, } \\
\text { PCBs, VOCs, } \\
\text { rads, TSS, TDS, } \\
\text { DO, pH }\end{array}$ & $\begin{array}{l}\text { Turner et al. 1991; } \\
\text { Bogle and Turner } 1993\end{array}$ \\
\hline 16. & $\begin{array}{l}\text { Subsurface water samples } \\
\text { collected from beneath the } \\
\text { surface oil layer on ORP-1 }\end{array}$ & Sept 1983 & 2 & Pond water & $10 \mathrm{~A}, 16 \mathrm{~A}$ & $\begin{array}{l}\text { PCBs, phenols, } \\
\text { inorganics, } \\
\text { cyanide, uranium }\end{array}$ & $\begin{array}{l}\text { McCauley 1984a; } \\
\text { McCauley } 1985\end{array}$ \\
\hline 17. & $\begin{array}{l}\text { Composite study of "dark" } \\
\text { and "light" areas within the } \\
\text { Oil Landfarm to investigate } \\
\text { correlations between PCB } \\
\text { contamination and soil color. }\end{array}$ & Sept 1983 & 5 & $\begin{array}{l}\text { Soil } \\
\text { composites }\end{array}$ & $\begin{array}{l}\text { 01D, 01L, } \\
13 \mathrm{~L}, 13 \mathrm{D}, \\
\text { 19L } \\
\text { SEDGRAB }\end{array}$ & $\begin{array}{l}\text { Organics, } \\
\text { inorganics, } \\
\text { pesticides, } \\
\text { PCBs }\end{array}$ & $\begin{array}{l}\text { BNI 1983; Herbes 1989; } \\
\text { McCauley } 1985\end{array}$ \\
\hline
\end{tabular}


Table B.1 continued

\begin{tabular}{|c|c|c|c|c|c|c|c|}
\hline No. & Description of study & Dates & $\begin{array}{c}\text { Number } \\
\text { of } \\
\text { samples }\end{array}$ & $\begin{array}{c}\text { Media } \\
\text { sampled }\end{array}$ & $\begin{array}{l}\text { Sampling } \\
\text { stations }\end{array}$ & $\begin{array}{l}\text { Analyses } \\
\text { performed }\end{array}$ & $\begin{array}{c}\text { Selected references to } \\
\text { these data }\end{array}$ \\
\hline 18. & $\begin{array}{l}\text { Background samples } \\
\text { collected for comparison to } \\
\text { Bear Creek data during the } \\
\text { early } 1980 \text { s }\end{array}$ & 1983-1986 & $\begin{array}{l}14 \\
14\end{array}$ & $\begin{array}{l}\text { Surface water, } \\
\text { sediment }\end{array}$ & $\begin{array}{l}\text { GCK-1.4 } \\
\text { GCK-2.4 } \\
\text { NT-2 }\end{array}$ & $\begin{array}{l}\text { Inorganics, } \\
\text { radionuclides, } \\
\text { VOCs, PCBs, } \\
\text { pesticides, } \\
\text { miscellaneous } \\
\text { constituents }^{d}\end{array}$ & Turner et al. 1991 \\
\hline 19. & $\begin{array}{l}\text { Monitoring of Bear Creek } \\
\text { Valley surface water and } \\
\text { sediment in the early } 1980 \text { s } \\
\text { (BNI) }\end{array}$ & $1983-1984$ & 26 & $\begin{array}{l}\text { Surface water, } \\
\text { sediment } \\
\text { Surface water, } \\
\text { sediment }\end{array}$ & $\begin{array}{l}\text { Oil Landfarm: } \\
\text { 1-16 } \\
\text { Burial } \\
\text { Grounds: 1A- } \\
\text { 26A }\end{array}$ & $\begin{array}{l}\text { Inorganics, } \\
\text { organics } \\
\text { PCBs, } \\
\text { radionuclides, } \\
\text { anions, } \\
\text { miscellaneous } \\
\text { constituents }^{e}\end{array}$ & $\begin{array}{l}\text { BNI 1984; } \\
\text { McCauley 1984b; } \\
\text { McCauley 1985; } \\
\text { Y-12 HSEAD 1984a; } \\
\text { Y-12 HSEAD 1984b; } \\
\text { Y-12 HSEAD 1987 }\end{array}$ \\
\hline 20. & $\begin{array}{l}\text { Analysis of soil cores from } \\
\text { groundwater wells installed } \\
\text { by BNI (S-3 Ponds, Burial } \\
\text { Grounds, Oil Landfarm) }\end{array}$ & 1983-1984 & 732 & Soil cores & $\begin{array}{l}\text { GW-1... } \\
\text { GW-53A, } \\
\text { GW-100... } \\
\text { GW-103 }\end{array}$ & $\begin{array}{l}\text { Organics, } \\
\text { inorganics, } \\
\text { pesticides, } \\
\text { PCBs, } \\
\text { miscellaneous } \\
\text { constituents }\end{array}$ & BNI 1983; Herbes 1989 \\
\hline
\end{tabular}


Table B.1 continued

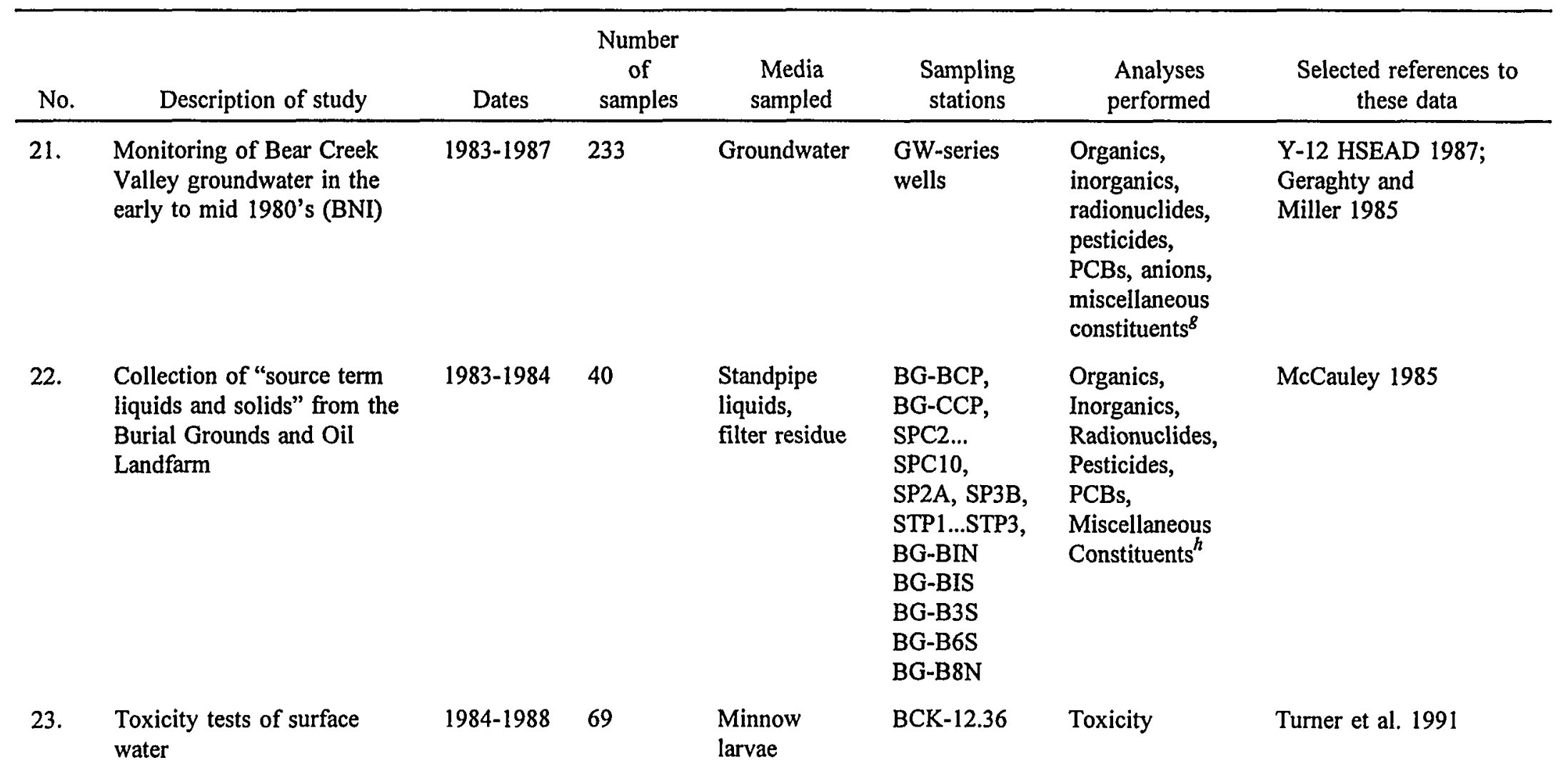


Table B.1 continued

\begin{tabular}{|c|c|c|c|c|c|c|c|}
\hline No. & Description of study & Dates & $\begin{array}{c}\text { Number } \\
\text { of } \\
\text { samples }\end{array}$ & $\begin{array}{l}\text { Media } \\
\text { sampled }\end{array}$ & $\begin{array}{l}\text { Sampling } \\
\text { stations }\end{array}$ & $\begin{array}{l}\text { Analyses } \\
\text { performed }\end{array}$ & $\begin{array}{c}\text { Selected references to } \\
\text { these data }\end{array}$ \\
\hline 24. & $\begin{array}{l}\text { Weekly water levels } \\
\text { measured at monitoring wells } \\
\text { in BCV (wells not shown on } \\
\text { Plate B.1) }\end{array}$ & $1984-1988$ & 16,981 & Groundwater & $\begin{array}{l}\text { Y-12 } \\
\text { monitoring } \\
\text { wells: } \\
\text { 1000-series, } \\
\text { GW-001... } \\
\text { GW-338, } \\
\text { USGS\#1 } \\
\text { USGS\#2 } \\
\text { USGS\#3 }\end{array}$ & Water level & DOE 1995a \\
\hline
\end{tabular}


B12-10

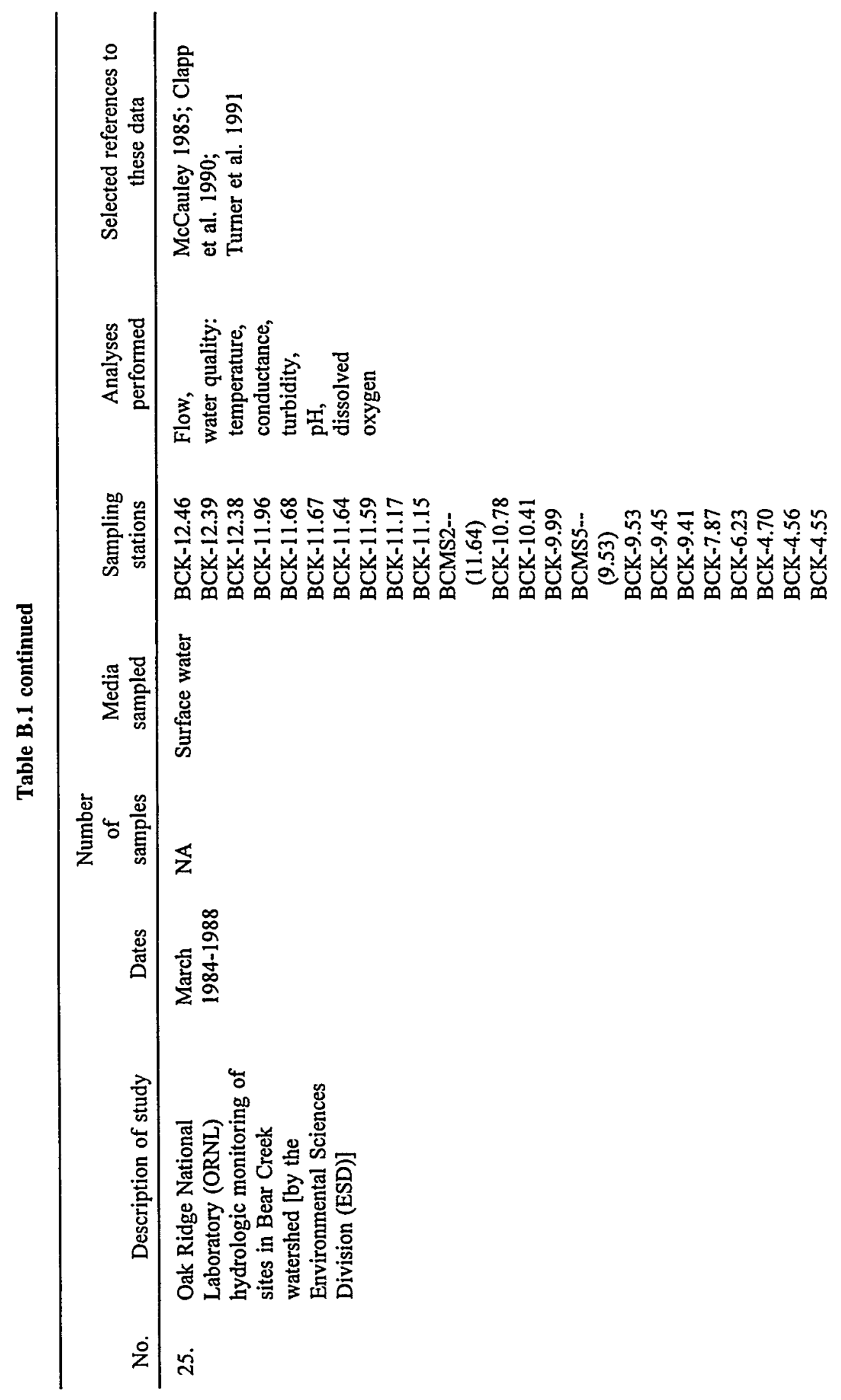


Table B.1 continued

\begin{tabular}{|c|c|c|c|c|c|c|c|}
\hline No. & Description of study & Dates & $\begin{array}{l}\text { Number } \\
\text { of } \\
\text { samples }\end{array}$ & $\begin{array}{l}\text { Media } \\
\text { sampled }\end{array}$ & $\begin{array}{l}\text { Sampling } \\
\text { stations }\end{array}$ & $\begin{array}{l}\text { Analyses } \\
\text { performed }\end{array}$ & $\begin{array}{l}\text { Selected references to } \\
\text { these data }\end{array}$ \\
\hline 26. & $\begin{array}{l}\text { S-3 Pond characterization } \\
\text { after neutralization of pond } \\
\text { waters }\end{array}$ & 1984 & $\begin{array}{l}4 \\
\text { Compo- } \\
\text { sites }\end{array}$ & Sludge & $\begin{array}{l}\text { NW, NE, } \\
\text { SW, SE }\end{array}$ & $\begin{array}{l}\text { Organics, } \\
\text { inorganics, } \\
\text { TCLP, } \\
\text { anions, } \\
\text { permeability, } \\
\text { radionuclides }\end{array}$ & $\begin{array}{l}\text { Kimbrough and } \\
\text { Turner } 1987\end{array}$ \\
\hline 27. & $\begin{array}{l}\text { Characterization of sediments } \\
\text { in upper Bear Creek, } \\
\text { including two samples from } \\
\text { the "Blue Lagoon" area }\end{array}$ & 1984 & 4 & Sediment & $\begin{array}{l}\text { UBC-2 UBC- } \\
3 \text { UBC-4 } \\
\text { UBC-FPI }\end{array}$ & $\begin{array}{l}\text { Organics, } \\
\text { inorganics, } \\
\text { PCBs, } \\
\text { radionuclides }\end{array}$ & $\begin{array}{l}\text { Turner and Kamp 1984; } \\
\text { McMahon } 1988\end{array}$ \\
\hline 28. & $\begin{array}{l}\text { Y-12 Plant study of } \\
\text { sediments in Bear Creek and } \\
\text { tributary channels to } \\
\text { investigate contaminant } \\
\text { transport away from the } \\
\text { disposal areas }\end{array}$ & $\begin{array}{l}\text { March and } \\
\text { September } \\
1984\end{array}$ & 31 & $\begin{array}{l}\text { Sediment } \\
\text { surface water }\end{array}$ & $\begin{array}{l}\text { BCK-11.5, } \\
2.8,4.8,7.5, \\
\text { GCK-1.4, 2.4, } \\
\text { SPR-1... } \\
\text { SPR-4, } \\
1-1 \\
2-1 \ldots 2-5 \\
3-1 \ldots .3-3 \\
4-1 \ldots 4-3 \\
6-1 . .6-3 \\
7-1 \ldots .7-3 \\
8-1 \ldots 8-8 \\
9-1\end{array}$ & $\begin{array}{l}\text { PCBs, VOCs, } \\
\text { inorganics, } \\
\text { radionuclides }\end{array}$ & $\begin{array}{l}\text { McCauley 1985; } \\
\text { Herbes } 1988\end{array}$ \\
\hline
\end{tabular}


Table B.1 continued

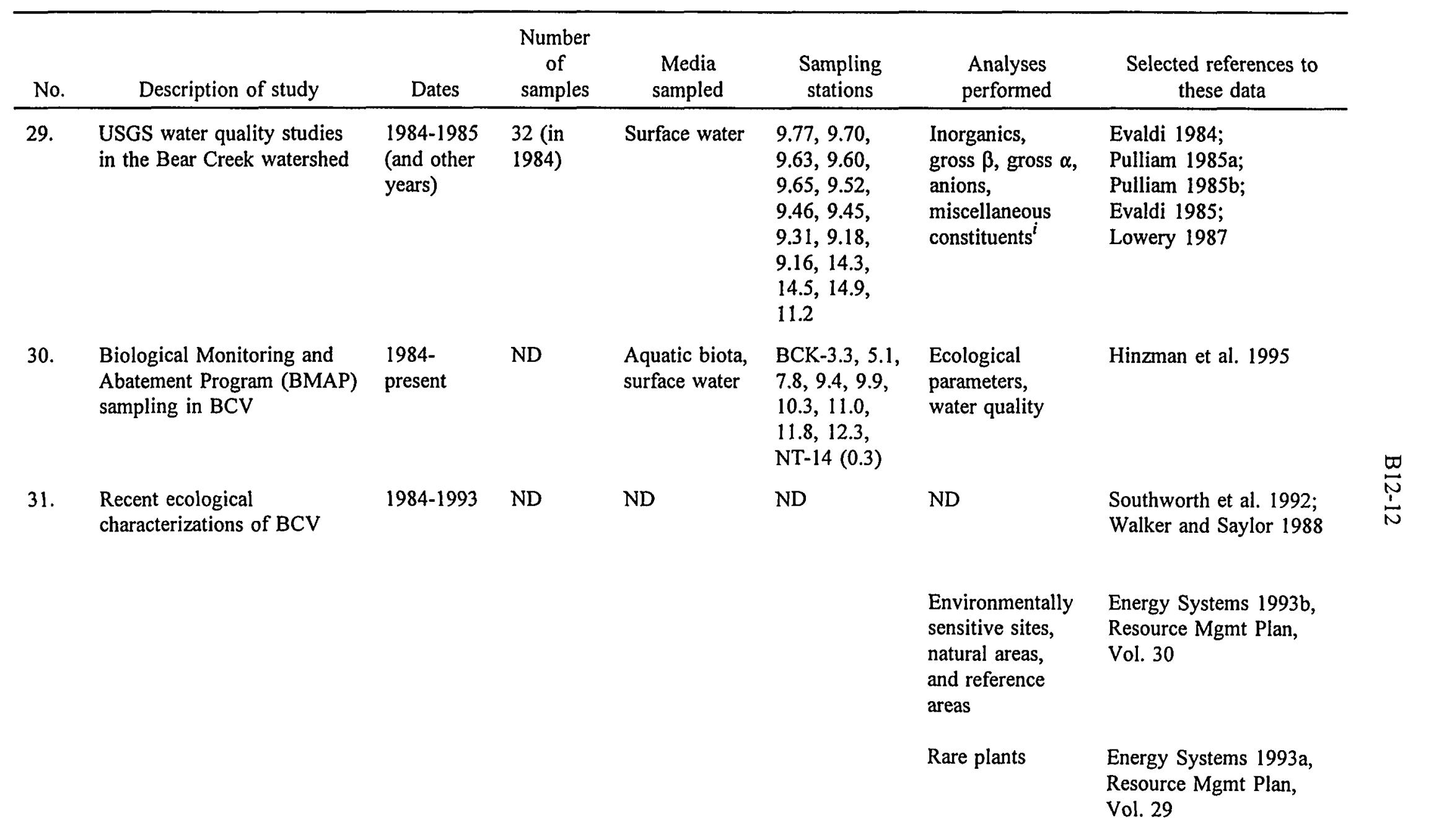


Table B.1 continued

\begin{tabular}{|c|c|c|c|c|c|c|c|}
\hline No. & Description of study & Dates & $\begin{array}{l}\text { Number } \\
\text { of } \\
\text { samples }\end{array}$ & $\begin{array}{l}\text { Media } \\
\text { sampled }\end{array}$ & $\begin{array}{l}\text { Sampling } \\
\text { stations }\end{array}$ & $\begin{array}{l}\text { Analyses } \\
\text { performed }\end{array}$ & $\begin{array}{c}\text { Selected references to } \\
\text { these data }\end{array}$ \\
\hline 32. & $\begin{array}{l}\text { ORNL ESD preliminary } \\
\text { evaluation of contaminants in } \\
\text { Bear Creek and East Fork } \\
\text { Poplar Creek floodplains }\end{array}$ & Ápril 1985 & 104 & $\begin{array}{l}\text { Sediment, } \\
\text { floodplain soil }\end{array}$ & $\begin{array}{l}\text { BCK-1.05 } \\
\text { BCK-4.70 } \\
\text { BCK-9.91 } \\
\text { BCK-11.09 } \\
\text { BCK-12.10 }\end{array}$ & $\begin{array}{l}\text { Radionuclides, } \\
\text { inorganics }\end{array}$ & Turner et al. 1991 \\
\hline 33. & $\begin{array}{l}\text { Soil samples collected by } \\
\text { R. R. Turner from NT-7 and } \\
\text { surrounding area }\end{array}$ & April 1985 & 5 & Soil & $\begin{array}{l}\text { RRT-1 } \ldots \\
\text { RRT-5 }\end{array}$ & PCBs & Herbes 1988 \\
\hline 34. & $\begin{array}{l}\text { Y-12 subsampling and } \\
\text { analysis of archived soil } \\
\text { cores from wells installed in } \\
\text { Burial Ground } A\end{array}$ & April 1985 & 16 & Soil & $\begin{array}{l}\text { GW-14 } \\
G W-15 \\
G W-16 \\
G W-18 \\
G W-20 \\
G W-21 \\
G W-22 \\
G W-46 \\
G W-47 \\
G W-53 A\end{array}$ & $\begin{array}{l}\text { PCBs, } \\
\text { radionuclides, } \\
\text { inorganics }\end{array}$ & $\begin{array}{l}\text { Herbes 1988; } \\
\text { Turner et al. } 1991\end{array}$ \\
\hline
\end{tabular}


Table B.1 continued

\begin{tabular}{|c|c|c|c|c|c|c|c|}
\hline No. & Description of study & Dates & $\begin{array}{l}\text { Number } \\
\text { of } \\
\text { samples }\end{array}$ & $\begin{array}{c}\text { Media } \\
\text { sampled }\end{array}$ & $\begin{array}{l}\text { Sampling } \\
\text { stations }\end{array}$ & $\begin{array}{l}\text { Analyses } \\
\text { performed }\end{array}$ & $\begin{array}{l}\text { Selected references to } \\
\text { these data }\end{array}$ \\
\hline 35. & $\begin{array}{l}\text { Soil sampling from spoils } \\
\text { pile created during } \\
\text { construction of the West End } \\
\text { Tank Farm (located just west } \\
\text { of the Tank Farm) }\end{array}$ & May 1985 & 31 & soil & $\begin{array}{l}\text { Base, } \\
\text { perimeter, } \\
10 \mathrm{~A} . . .10 \mathrm{E}, \\
30 \mathrm{~A} . . .30 \mathrm{C}, \\
65 \mathrm{~A} . . .65 \mathrm{D}, \\
145 \mathrm{~A} . .145 \mathrm{C}, \\
220 \mathrm{~A} . .220 \mathrm{C} \text {, } \\
275 \mathrm{~A} . .275 \mathrm{C}, \\
320 \mathrm{~A} . . .320 \mathrm{E}, \\
350 \mathrm{~A} . . .350 \mathrm{C}\end{array}$ & $\begin{array}{l}\text { Radionuclides, } \\
\text { inorganics, } \\
\text { EP toxicity, total } \\
\text { uranium }\end{array}$ & Turner 1988 \\
\hline 36. & $\begin{array}{l}\text { Soil study at ORP-1 (west } \\
\text { pond) and ORP-2 (east } \\
\text { pond), including depth } \\
\text { profiles of contamination }\end{array}$ & July 1985 & 72 & Soil & $\begin{array}{l}\text { East Pond, } \\
\text { Transects 1-3: } \\
\text { e.g., E1E1 } \\
\text { West Pond, } \\
\text { Transects 1-6: } \\
\text { e.g., W1E1 }\end{array}$ & $\%$ solids, PCBs & Herbes 1988 \\
\hline 37. & Sediment study at ORP- 1 & Oct 1985 & 24 & Sediment & Cores $1-5$ & $\%$ solids, PCBs & Herbes 1988 \\
\hline 38. & $\begin{array}{l}\text { Sediment and soil samples } \\
\text { collected at the bridge site } \\
\text { near BCK-9.42 }\end{array}$ & Nov 1985 & 6 & $\begin{array}{l}\text { Sediment, } \\
\text { floodplain soil }\end{array}$ & $\begin{array}{l}\mathrm{C} 1, \mathrm{C} 2, \mathrm{C} 3 \\
\mathrm{C} 4, \mathrm{C} 5, \mathrm{C} 6\end{array}$ & $\begin{array}{l}\text { Inorganics, } \\
\text { radionuclides, } \\
\text { PCBs }\end{array}$ & Turner et al. 1991 \\
\hline
\end{tabular}


Table B.1 continued

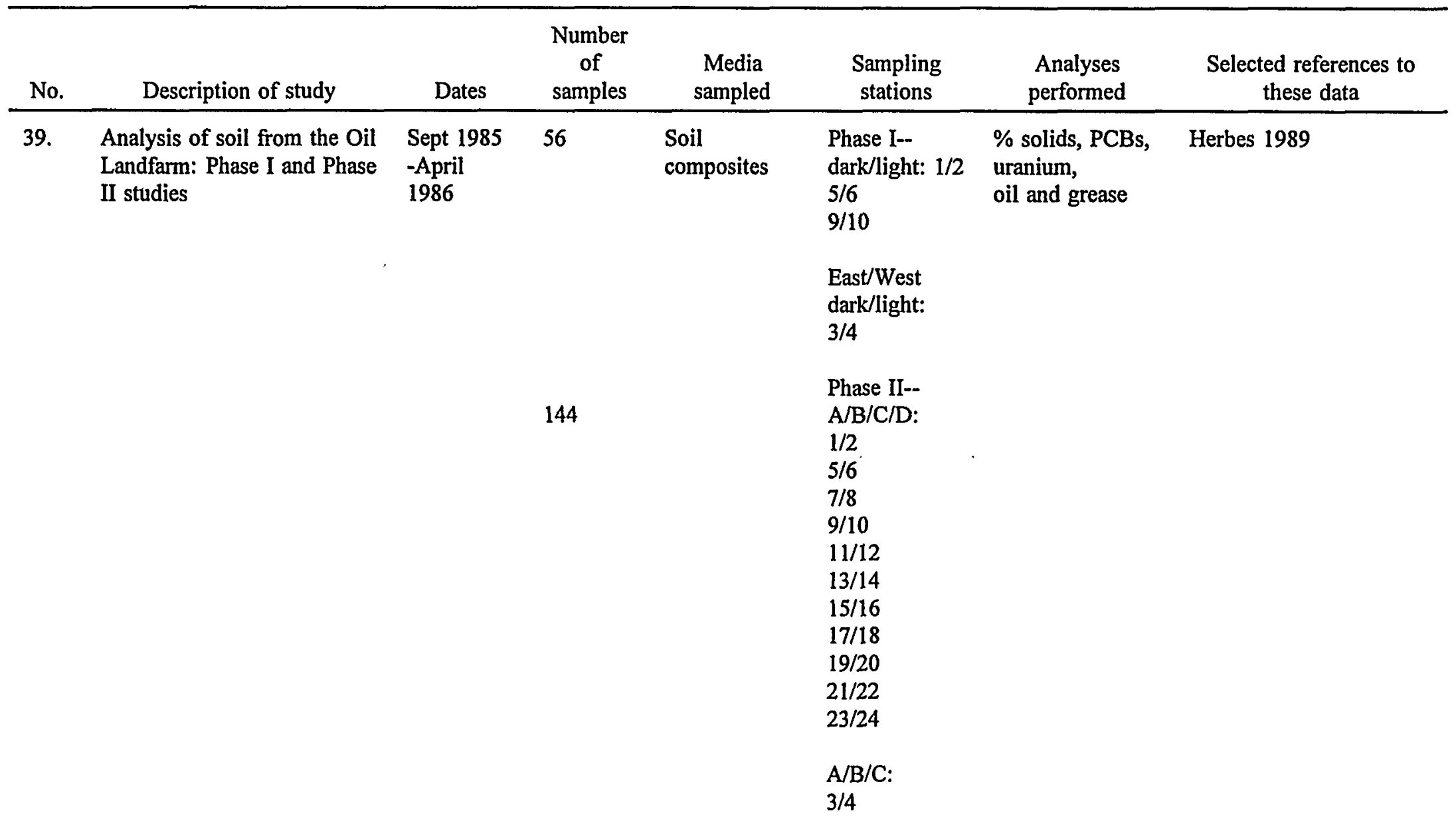


Table B.1 continued

\begin{tabular}{|c|c|c|c|c|c|c|c|}
\hline No. & Description of study & Dates & $\begin{array}{l}\text { Number } \\
\text { of } \\
\text { samples }\end{array}$ & $\begin{array}{l}\text { Media } \\
\text { sampled }\end{array}$ & $\begin{array}{l}\text { Sampling } \\
\text { stations }\end{array}$ & $\begin{array}{l}\text { Analyses } \\
\text { performed }\end{array}$ & $\begin{array}{l}\text { Selected references to } \\
\text { these data }\end{array}$ \\
\hline 40. & $\begin{array}{l}\text { Extensive sampling of } \\
\text { groundwater, surface water, } \\
\text { and sediment in BCV by the } \\
\text { Roy F. Weston company } \\
\text { (wells not shown on Plate } \\
\text { B.1) }\end{array}$ & $1985-1987$ & ND & $\begin{array}{l}\text { Surface water } \\
\text { groundwater, } \\
\text { spring water, } \\
\text { sediment }\end{array}$ & $\begin{array}{l}\text { (Partial } \\
\text { listing:) } \\
\text { NT-7 } \\
\text { GW-103 } \\
\text { GW-225 } \\
\text { SS-1-5,7,8 } \\
\text { BCK 5.15 } \\
\text { BCK-9.43 } \\
\text { BCK-12.46 }\end{array}$ & $\begin{array}{l}\text { Pesticides, } \\
\text { PCBs, } \\
\text { inorganics, } \\
\text { organics }\end{array}$ & $\begin{array}{l}\text { Turner et al. } 1991 \text {; } \\
\text { Southworth et al. 1992; } \\
\text { Geraghty and } \\
\text { Miller } 1987\end{array}$ \\
\hline 41. & $\begin{array}{l}\text { Y-12 groundwater } \\
\text { monitoring program data } \\
\text { (wells not shown on Plate } \\
\text { B.1) }\end{array}$ & $\begin{array}{l}\text { 1985- } \\
\text { present }\end{array}$ & ND & $\begin{array}{l}\text { Groundwater, } \\
\text { surface water }\end{array}$ & $\begin{array}{l}\text { GW-series } \\
\text { wells, } \\
\text { Tribs: NT-1, } \\
\text { NT-13, } \\
\text { Bear Crk: } \\
\text { BCK-0.63, } \\
4.55,9.40 \text {, } \\
11.97,12.36 \text {, } \\
\text { Springs: } \\
\text { SS1, SS4, } \\
\text { SS5, SS6, } \\
\text { SS8 }\end{array}$ & $\begin{array}{l}\text { Anions, organics, } \\
\text { inorganics, } \\
\text { radionuclides, } \\
\text { pesticides, } \\
\text { PCBs }\end{array}$ & $\begin{array}{l}\text { Energy Systems 1987b; } \\
\text { Energy Systems 1990; } \\
\text { Annual Groundwater } \\
\text { Quality Assessment } \\
\text { Reports, e.g., HSW 1991 } \\
\text { or 1992; } \\
\text { Bogle and Turner } 1993\end{array}$ \\
\hline 42. & $\begin{array}{l}\text { Groundwater quality } \\
\text { assessment program } \\
\text { investigation using three } \\
\text { wells around the Oil } \\
\text { Landfarm }\end{array}$ & $1986-1987$ & 3 & Groundwater & ND & $\begin{array}{l}\text { Total and } \\
\text { dissolved } \\
\text { inorganics, } \\
\text { radionuclides }\end{array}$ & Turner et al. 1991 \\
\hline
\end{tabular}
wells around the Oil andfarm 
Table B.1 continued

\begin{tabular}{|c|c|c|c|c|c|c|c|}
\hline No. & Description of study & Dates & $\begin{array}{c}\text { Number } \\
\text { of } \\
\text { samples }\end{array}$ & $\begin{array}{c}\text { Media } \\
\text { sampled }\end{array}$ & $\begin{array}{l}\text { Sampling } \\
\text { stations }\end{array}$ & $\begin{array}{l}\text { Analyses } \\
\text { performed }\end{array}$ & $\begin{array}{l}\text { Selected references to } \\
\text { these data }\end{array}$ \\
\hline 43. & $\begin{array}{l}\text { Soil and sediment samples } \\
\text { collected from Bear Creek } \\
\text { tributaries NT-6, NT-7, and } \\
\text { NT-8 }\end{array}$ & April 1986 & 84 & $\begin{array}{l}\text { Floodplain } \\
\text { soil, } \\
\text { sediment }\end{array}$ & $\begin{array}{l}\text { NT6, transects } \\
1-8 \text {, } \\
\text { W,C,E } \\
\text { NT7, transects } \\
1-12 \text {, } \\
\text { W,C,E } \\
\text { NT8, transects } \\
1-5 \text { W,C,E }\end{array}$ & $\begin{array}{l}\% \text { solids, PCBs, } \\
\text { uranium }\end{array}$ & Herbes 1988 \\
\hline 44. & $\begin{array}{l}\text { Study of contamination in } \\
\text { seeps near the Oil Retention } \\
\text { Ponds }\end{array}$ & April 1986 & 33 & Soil & $\begin{array}{l}\text { S1-1...S1-6 } \\
\text { S2-1...S2-9 } \\
\text { S3-1..S3-6 } \\
\text { S4-1...S4-6 }\end{array}$ & $\begin{array}{l}\text { PCBs, } \\
\text { oil and grease, } \\
\text { uranium }\end{array}$ & Herbes 1988 \\
\hline 45. & $\begin{array}{l}\text { Depth profiles of sediment } \\
\text { contamination in tributaries } \\
\text { NT- } 6 \text { and NT-7 }\end{array}$ & Sept 1986 & $\begin{array}{l}19 \\
23\end{array}$ & Sediment & $\begin{array}{l}\text { E1, E2, } \\
\text { W, C }\end{array}$ & $\begin{array}{l}\text { PCBs, mercury, } \\
\text { uranium }\end{array}$ & Herbes 1988 \\
\hline 46. & $\begin{array}{l}\text { Soil samples from transects } \\
\text { parallel to Tribs } 6 \text { and } 7 \text {, } \\
\text { between the ends of BG-A } \\
\text { trenches and the stream } \\
\text { channels: potential seep } \\
\text { positions in Burial Ground A }\end{array}$ & Nov 1986 & 78 & $\begin{array}{l}\text { Floodplain } \\
\text { soil, Sediment }\end{array}$ & $\begin{array}{l}\text { T1-1.T1-16 } \\
\text { T2-1.T2-12 } \\
\text { T3-1...T3-5 } \\
\text { T4-1...T4-6 }\end{array}$ & $\begin{array}{l}\% \text { solids, PCBs, } \\
\text { Uranium }\end{array}$ & Herbes 1988 \\
\hline
\end{tabular}


Table B.1 continued

\begin{tabular}{|c|c|c|c|c|c|c|c|}
\hline No. & Description of study & Dates & $\begin{array}{l}\text { Number } \\
\text { of } \\
\text { samples }\end{array}$ & $\begin{array}{l}\text { Media } \\
\text { sampled }\end{array}$ & $\begin{array}{l}\text { Sampling } \\
\text { stations }\end{array}$ & $\begin{array}{l}\text { Analyses } \\
\text { performed }\end{array}$ & $\begin{array}{l}\text { Selected references to } \\
\text { these data }\end{array}$ \\
\hline 47. & $\begin{array}{l}\text { Surface water monitoring at } \\
\text { six sites at the Low Level } \\
\text { Waste Disposal Development } \\
\text { Demonstration (LLWDDD) } \\
\text { site in west Bear Creek }\end{array}$ & 1987 & 24 & Surface water & $\begin{array}{l}\text { FL-270 } \\
\text { FL-272 } \\
\text { FL-273 } \\
\text { FL-672 } \\
\text { FL-673 } \\
\text { FL-677 }\end{array}$ & $\begin{array}{l}\text { Flow, } \\
\text { inorganics, } \\
\text { anions, } \\
\text { gross } \alpha, \\
\text { gross } \beta, \\
\text { total uranium }\end{array}$ & Walker and Saylor 1988 \\
\hline 48. & $\begin{array}{l}\text { Golden and Associates } \\
\text { hydrogeologic } \\
\text { characterization of west Bear } \\
\text { Creek LLWDDD area }\end{array}$ & 1987 & $\begin{array}{l}45 \text { piezo- } \\
\text { meters }\end{array}$ & NA & ND & ND & Walker and Saylor 1988 \\
\hline 49. & $\begin{array}{l}\text { Characterization of sediment } \\
\text { excavated from two lagoons } \\
\text { (Blue Lagoon) and placed in } \\
\text { the SW cell of the S-3 Ponds }\end{array}$ & $1987-1988$ & 54 & $\begin{array}{l}\text { Sediment, } \\
\text { water }\end{array}$ & $\begin{array}{l}\text { Trucks and } \\
\text { Tankers (from } \\
\text { the Blue } \\
\text { Lagoon) }\end{array}$ & $\begin{array}{l}\text { Organics, } \\
\text { inorganics, } \\
\text { radionuclides }\end{array}$ & McMahon 1988 \\
\hline 50. & $\begin{array}{l}\text { Characterization of Trib } 7 \\
\text { seep, ORP-1, and ORP-2 }\end{array}$ & $1987-1988$ & ND & Surface water & $\begin{array}{l}\text { ORP-1, ORP- } \\
2, \text { Seep } 1\end{array}$ & $\begin{array}{l}\text { PCBs, VOAs, } \\
\text { inorganics }\end{array}$ & Napier et al. 1988 \\
\hline 51. & $\begin{array}{l}\text { Confirmatory samples } \\
\text { collected from the Oil } \\
\text { Landfarm after excavation of } \\
\text { PCB-contaminated areas } \\
\text { (where } 80 \% \text { confidence limit } \\
>25 \mathrm{ppm} \text { ) }\end{array}$ & 1988 & 186 & Soil & $\begin{array}{l}\text { EA1- } \\
001 \ldots .012 \\
\text { EA2- } \\
001 \ldots 012 \\
\text { EA3- } \\
001 \ldots 080 \\
\text { EA4- } \\
001 \ldots 006 \\
\text { EA5- } \\
001 \ldots 034 \\
\text { EA6- } \\
001 \ldots 042\end{array}$ & PCBs & Bohrman 1989 \\
\hline
\end{tabular}


Table B.1 continued

\begin{tabular}{|c|c|c|c|c|c|c|c|}
\hline No. & Description of study & Dates & $\begin{array}{l}\text { Number } \\
\text { of } \\
\text { samples }\end{array}$ & $\begin{array}{c}\text { Media } \\
\text { sampled }\end{array}$ & $\begin{array}{l}\text { Sampling } \\
\text { stations }\end{array}$ & $\begin{array}{l}\text { Analyses } \\
\text { performed }\end{array}$ & $\begin{array}{l}\text { Selected references to } \\
\text { these data }\end{array}$ \\
\hline 52. & $\begin{array}{l}\text { Post-excavation core study of } \\
\text { Blue Lagoon area soils }\end{array}$ & $\begin{array}{l}\text { April-June } \\
1988\end{array}$ & 32 & Soil cores & $\begin{array}{l}\text { EBL-1...19 } \\
\text { WBL-1...13 }\end{array}$ & $\begin{array}{l}\text { Inorganics, } \\
\text { radionuclides, } \\
\text { VOCs }\end{array}$ & $\begin{array}{l}\text { McMahon 1988; } \\
\text { Turner et al. } 1991\end{array}$ \\
\hline 53. & $\begin{array}{l}\text { Follow-up sampling from } \\
\text { ORP-1 and the Trib } 7 \text { seep }\end{array}$ & June 1988 & 6 & $\begin{array}{l}\text { Pond water, } \\
\text { seep water } \\
\text { soil }\end{array}$ & $\begin{array}{l}1,2,3,4 \\
1 \\
1\end{array}$ & $\begin{array}{l}\text { PCBs, VOAs, } \\
\text { total uranium, } \\
\text { inorganics }\end{array}$ & Kimbrough 1988 \\
\hline \multirow[t]{3}{*}{54.} & $\begin{array}{l}\text { Storage Yard } 200 \text { (SY-200) } \\
\text { soil characterization }\end{array}$ & July 1986 & $\begin{array}{l}4 \\
2\end{array}$ & $\begin{array}{l}\text { Surface soil, } \\
\text { subsurface } \\
\text { soil }\end{array}$ & $\begin{array}{l}\mathrm{EP}-1 \ldots \mathrm{EP}-3 \\
1,2\end{array}$ & $\begin{array}{l}\text { Mercury, TCLP } \\
\text { metals, PCBs }\end{array}$ & $\begin{array}{l}\text { Energy Systems } 1993 \mathrm{c} \\
\text { (OU } 2 \text { RI) }\end{array}$ \\
\hline & & Jan 1988 & 15 & Soil cores & B-1...B-5 & $\begin{array}{l}\text { Gross } \alpha, \\
\text { gross } \beta \text {, } \\
\text { gamma, PCBs, } \\
\text { selected metals, } \\
\text { TCLP metals }\end{array}$ & (OU $2 \mathrm{RI})$ \\
\hline & & Jan 1989 & 22 & $\begin{array}{l}\text { Soil } \\
\text { composites } \\
\text { from } \\
\text { excavated } \\
\text { berm material }\end{array}$ & $1,2 \ldots .22$ & $\begin{array}{l}\text { Thorium, } \\
\text { uranium, } \%{ }^{235} \mathrm{U} \text {, } \\
\text { mercury }\end{array}$ & \\
\hline 55. & $\begin{array}{l}\text { Dye tracer study in upper } \\
\text { Bear Creek to investigate } \\
\text { hydrogeology }\end{array}$ & Oct 1988 & $\mathrm{NA}$ & Water & $\begin{array}{l}\text { MS-1... } \\
\text { MS-13 }\end{array}$ & $\begin{array}{l}\text { Flow, water } \\
\text { quality }^{j}\end{array}$ & $\begin{array}{l}\text { Geraghty and } \\
\text { Miller } 1989\end{array}$ \\
\hline
\end{tabular}


Table B.1 continued

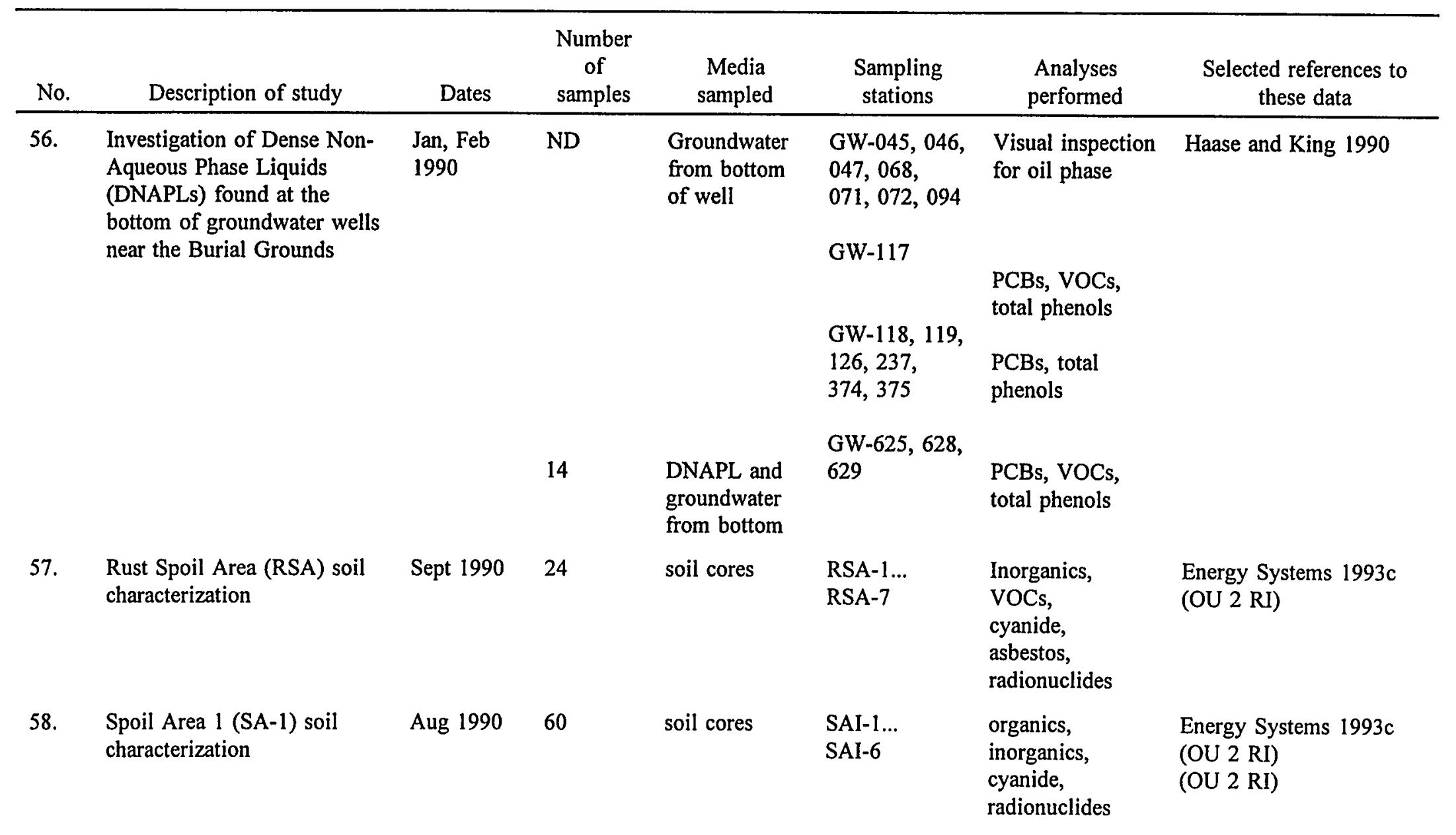


Table B.1 continued

\begin{tabular}{|c|c|c|c|c|c|c|c|}
\hline No. & Description of study & Dates & $\begin{array}{c}\begin{array}{c}\text { Number } \\
\text { of } \\
\text { samples }\end{array} \\
\end{array}$ & $\begin{array}{c}\text { Media } \\
\text { sampled }\end{array}$ & $\begin{array}{c}\text { Sampling } \\
\text { stations }\end{array}$ & $\begin{array}{c}\text { Analyses } \\
\text { performed }\end{array}$ & $\begin{array}{c}\text { Selected references to } \\
\text { these data }\end{array}$ \\
\hline 59. & $\begin{array}{l}\text { Characterization of Trib. } 8 \\
\text { soils, sediment, and surface } \\
\text { water prior to remediation }\end{array}$ & Jan 1990 & 100 & $\begin{array}{l}\text { Sediment, } \\
\text { floodplain } \\
\text { soil, } \\
\text { surface water }\end{array}$ & $\begin{array}{l}\text { P1...P23 } \\
\text { S1...S10 } \\
\text { W1...W9 }\end{array}$ & $\begin{array}{l}\text { Organics, } \\
\text { inorganics, } \\
\text { radionuclides, } \\
\text { PCBs, } \\
\% \text { moisture }\end{array}$ & Bogle et al. 1991 \\
\hline 60. & $\begin{array}{l}\text { Groundwater data from deep, } \\
\text { multi-port instrumented } \\
\text { (Westbay) wells }\end{array}$ & $\begin{array}{l}\text { 1990- } \\
\text { present }\end{array}$ & ND & Groundwater & $\begin{array}{l}\text { GW-131.. } \\
\text { GW-135, } \\
\text { GW-722, } \\
\text { GW-726, } \\
\text { GW-727, } \\
\text { GW-730, } \\
\text { GW-790 }\end{array}$ & $\begin{array}{l}\text { Hydraulic head, } \\
\text { anions, } \\
\text { inorganics, } \\
\text { organics }\end{array}$ & $\begin{array}{l}\text { Dreier et al. 1993; } \\
\text { Dreier and } \\
\text { Caldanaro } 1993\end{array}$ \\
\hline 61. & $\begin{array}{l}\text { Characterization data from } \\
\text { soils stored at the Oil } \\
\text { Landfarm Storage Pad } \\
\text { (excavated from the Oil } \\
\text { Landfarm plots) }\end{array}$ & 1990 & 40 & $\begin{array}{l}\text { Soil } \\
\text { composites }\end{array}$ & $1-40$ & $\begin{array}{l}\text { Inorganics, } \\
\text { anions, PCBs, } \\
\text { cyanide, organics }\end{array}$ & SAIC Project File 1985 \\
\hline 62. & $\begin{array}{l}\text { Water samples from the } \\
\text { upper west forks of NT-7 } \\
\text { and NT-8 in preparation for } \\
\text { future closure activities }\end{array}$ & April 1990 & 8 & Surface water & $\begin{array}{l}1,2,3,4 \\
\text { on each } \\
\text { tributary }\end{array}$ & $\begin{array}{l}\text { TSS, } \mathrm{pH}, \\
\text { conductivity, } \\
\text { inorganics, } \\
\text { PCBs, VOAs, } \alpha \text {, } \\
\beta, \text { gamma, Total } \\
\mathrm{U}, \%{ }^{235} \mathrm{U}\end{array}$ & Collins 1990 \\
\hline 63. & $\begin{array}{l}\text { Geology and soil description } \\
\text { of BCV }\end{array}$ & 1992 & NA & NA & NA & $\begin{array}{l}\text { Geological } \\
\text { survey }\end{array}$ & $\begin{array}{l}\text { Hatcher et al. 1992; } \\
\text { Energy Systems 1993d }\end{array}$ \\
\hline
\end{tabular}


Table B.1 continued

\begin{tabular}{|c|c|c|c|c|c|c|c|}
\hline No. & Description of study & Dates & $\begin{array}{l}\text { Number } \\
\text { of } \\
\text { samples }\end{array}$ & $\begin{array}{c}\text { Media } \\
\text { sampled }\end{array}$ & $\begin{array}{l}\text { Sampling } \\
\text { stations }\end{array}$ & $\begin{array}{l}\text { Analyses } \\
\text { performed }\end{array}$ & $\begin{array}{l}\text { Selected references to } \\
\text { these data }\end{array}$ \\
\hline 64. & $\begin{array}{l}\text { Analysis of leachate } \\
\text { collected from the Burial } \\
\text { Ground C leachate collection } \\
\text { system installed at several } \\
\text { seeps draining burial trenches }\end{array}$ & 1993 & ND & Leachate & $\begin{array}{l}\text { Trib 8: } \\
\text { Seeps 2, 3, } 4 \\
\text { and C-West } \\
\text { Toe Slope } \\
\text { Trib 7: } \\
\text { Seep 1 }\end{array}$ & $\begin{array}{l}\text { Organics, } \\
\text { inorganics, } \\
\text { radionuclides, } \\
\text { pesticides, } \\
\text { PCBs }\end{array}$ & SAIC Project File 1995a \\
\hline 65. & $\begin{array}{l}\text { ORNL ESD rainfall data } \\
\text { from a rain gage located at } \\
\text { the Burial Grounds }\end{array}$ & 1993-1995 & hourly & Precipitation & BUR & Rainfall & SAIC Project File 1995b \\
\hline 66. & $\begin{array}{l}\text { Operable Unit } 2 \text { Remedial } \\
\text { Investigation (RSA, SAI, } \\
\text { SY-200) }\end{array}$ & 1993 & 285 & Soil & $\begin{array}{l}\text { SB-1...SB-64, } \\
\text { SS01...SS09 }\end{array}$ & $\begin{array}{l}\text { Organics, } \\
\text { inorganics, } \\
\text { radionuclides }\end{array}$ & Energy Systems 1995 \\
\hline 67. & $\begin{array}{l}\text { Wetlands delineation in Bear } \\
\text { Creek Valley }\end{array}$ & 1993 & NA & NA & NA & Wetlands survey & $\begin{array}{l}\text { Rosensteel and Trettin } \\
1993\end{array}$ \\
\hline 68. & $\begin{array}{l}\text { NPDES monitoring by Y-12 } \\
\text { of effluent from ORP-1 }\end{array}$ & ND & ND & Surface water & NPDES-305 & ND & Turner et al. 1991 \\
\hline 69. & $\begin{array}{l}\text { Characterization data from } \\
\text { soils stored at DARA } \\
\text { (excavated from Trib. } 7 \text { and } \\
\text { the Oil Retention Ponds) }\end{array}$ & ND & 32 & Soil & ND & $\begin{array}{l}\text { TCLP and non- } \\
\text { TCLP: } \\
\text { organics, } \\
\text { inorganics, } \\
\text { cyanide, } \\
\text { radionuclides, } \\
\text { PCBs, } \\
\text { herbicides, } \\
\text { dioxin/furans }\end{array}$ & SAIC Project File 1995c \\
\hline
\end{tabular}


Table B.1 continued

\begin{tabular}{|c|c|c|c|c|c|c|c|}
\hline No. & Description of study & Dates & $\begin{array}{c}\text { Number } \\
\text { of } \\
\text { samples }\end{array}$ & $\begin{array}{l}\text { Media } \\
\text { sampled }\end{array}$ & $\begin{array}{l}\text { Sampling } \\
\text { stations }\end{array}$ & $\begin{array}{l}\text { Analyses } \\
\text { performed }\end{array}$ & $\begin{array}{l}\text { Selected references to } \\
\text { these data }\end{array}$ \\
\hline 70. & $\begin{array}{l}\text { Radiological and geophysical } \\
\text { surveys of the Burial } \\
\text { Grounds and BYBY areas by } \\
\text { CHEMRAD }\end{array}$ & 1994 & NA & NA & NA & $\begin{array}{l}\text { EM-31, } \\
\text { pancake } \\
\text { probe, } \\
\text { NaI Probe, } \\
\text { magnetometer }\end{array}$ & SAIC Project File 1995d \\
\hline 71. & $\begin{array}{l}\text { USGS seep and spring } \\
\text { survey (sites not shown on } \\
\text { Plate B.1) }\end{array}$ & 1994 & $\begin{array}{l}\text { approx. } \\
1400\end{array}$ & Surface water & $\begin{array}{l}01005 \ldots \\
22060 \\
(\mathrm{~N}=702)\end{array}$ & $\begin{array}{l}\text { Flow, water } \\
\text { quality }^{k}\end{array}$ & SAIC Project File 1995e \\
\hline
\end{tabular}

a NA: Not Applicable.

${ }^{b}$ ND: Not Determined.

${ }^{c} \mathrm{pH}$, Conductivity, Temperature, Dissolved Oxygen (DO), Surfactants, Oil and Grease, Biological Oxygen Demand (BOD), Chemical Oxygen Demand (COD), Turbidity, Total Suspended Solids (TSS), Total Dissolved Solids (TDS).

${ }^{d} \mathrm{pH}$, Conductivity, Temperature, BOD, COD, TSS, Redox, Alkalinity, Ammonia-N, Total Kjeldahl Nitrogen, Nitrate, Phosphate, Sulfate.

e pH, Conductivity, Temperature, BOD, COD, TSS, Redox, Alkalinity, Ammonia-N, Total Kjeldahl Nitrogen, Nitrate, Oil and Grease, Total Organic Carbon (TOC), Dissolved Organic Carbon (DOC), Particulate Organic Carbon (POC).

$f$ Ammonia-N, Nitrate-N, Ortho Phosphate, Cation Exchange Capacity (CEC), TOC.

8 Water Level, pH, Conductivity, Temperature, COD, TSS, TDS, Redox, Alkalinity, Ammonia-N, Total Kjeldahl Nitrogen, Nitrate, Phosphate, Sulfate, Turbidity, Conductance, Hardness, Coliform, Phenols, TOC, Total Organic Halides (TOH)

${ }^{h} \mathrm{pH}$, Conductivity, Temperature, BOD, COD, TSS, Redox, Alkalinity, Ammonia-N, Total Kjeldahl Nitrogen, Nitrate, Oil and Grease, Plate Counts, Total Organic Carbon (TOC), Dissolved Organic Carbon (DOC).

1 Total Carbon, Dissolved Carbon, Alkalinity, Nitrogen, TDS, Oil and Grease.

j Specific Conductance, $\mathrm{pH}$, Temperature.

${ }^{k} \mathrm{pH}, \mathrm{DO}$, Temperature, Conductivity. 


\begin{tabular}{|c|c|c|c|c|c|c|c|c|c|c|c|c|c|}
\hline & Media Sampled & 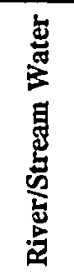 & 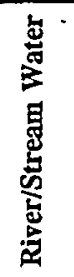 & 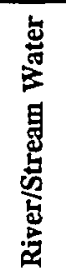 & 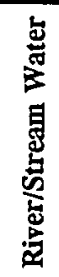 & 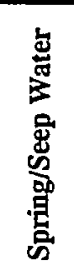 & 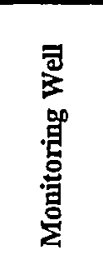 & 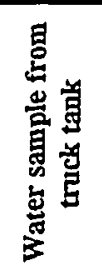 & ตี & $\begin{array}{l}\text { 嵑 } \\
\text { 意 } \\
\text { 员 }\end{array}$ & 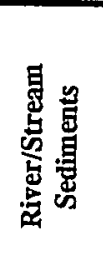 & 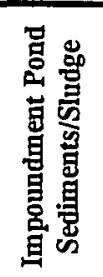 & 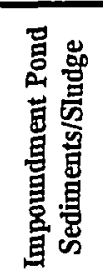 \\
\hline & Project & 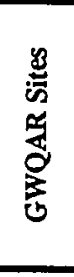 & 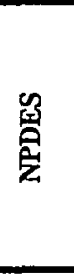 & 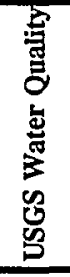 & $\begin{array}{l}\infty \\
\text { [్ }\end{array}$ & 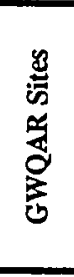 & 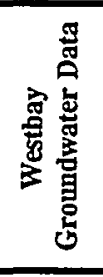 & 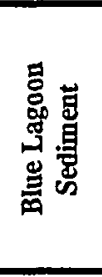 & $\begin{array}{l}\infty \\
\text { 葛 }\end{array}$ & 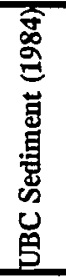 & $\begin{array}{l}\infty \\
\stackrel{R}{E}\end{array}$ & 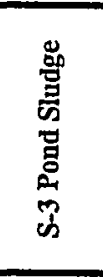 & 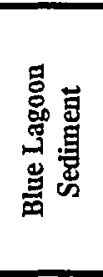 \\
\hline \multicolumn{14}{|l|}{ Anions } \\
\hline ALKALINITY (CO3) & & 70 & & & & 70 & & & & & & & \\
\hline ALKALINITY (HCO3) & & 70 & & & & 70 & & & & & & & \\
\hline BROMIDE & & & & & & & 11 & & & & & & \\
\hline CHLORIDE & & 70 & 56 & 26 & & 70 & 74 & & & & & & \\
\hline CONDUCTIVITY & & 70 & & & & 70 & & & & & & & \\
\hline DISSOLVED SOLIDS & & 70 & & & & 70 & & & & & & & \\
\hline FLUORIDE & & 70 & 56 & & & 70 & 74 & & & & & & \\
\hline NH3 AS N & & & & 11 & & & & & & & & & \\
\hline NITRATE & & & & & & & 74 & & & & & 4 & \\
\hline NITRATE AS N & & 70 & & & & 70 & & & & & & & \\
\hline NITRATE AS NITROGEN & & & 230 & & & & & & & & & & \\
\hline NITRATE, AS NITROGEN & & & & & & & & 1 & & & & & \\
\hline NITRATE-NITROGEN & & & & & & & & & & & & 5 & \\
\hline NITRATE/NITRITE (NO3/NO2-N) & & & & 11 & & & & & & & & & \\
\hline NITROGEN, NO2/NO3 & & & & 15 & & & & & & & & & \\
\hline NITROGEN, TOTAL & & & & 11 & & & & & & & & & \\
\hline PH & & 70 & & & & 70 & & & & & & & \\
\hline SULFATE & & 70 & 56 & 26 & & 70 & 72 & & & & & 5 & \\
\hline SUSPENDED SOLIDS & & 70 & & & & 70 & & & & & & & \\
\hline TURBIDITY & & 70 & & & & 70 & & & & & & & \\
\hline \multicolumn{14}{|l|}{ Inorganics } \\
\hline ALUMINUM & & 139 & 56 & & 10 & 140 & $\overline{74}$ & $T$ & 79 & 6 & $\pi$ & $\overline{6}$ & 52 \\
\hline ANTIMONY & & 139 & & & & 140 & 14 & & & 6 & & & \\
\hline ARSENIC & & 139 & 56 & 11 & 10 & 140 & 73 & 1 & 79 & 6 & 11 & 5 & 53 \\
\hline BARIUM & & 139 & 56 & 26 & 10 & 140 & 74 & 1 & 79 & 6 & 11 & 6 & 53 \\
\hline BERYLLIUM & & 139 & 56 & 26 & 10 & 140 & & 1 & 79 & 12 & 11 & 6 & 52 \\
\hline BORON & & 139 & 56 & & 10 & 140 & 74 & 1 & 79 & 6 & 11 & 6 & 51 \\
\hline
\end{tabular}




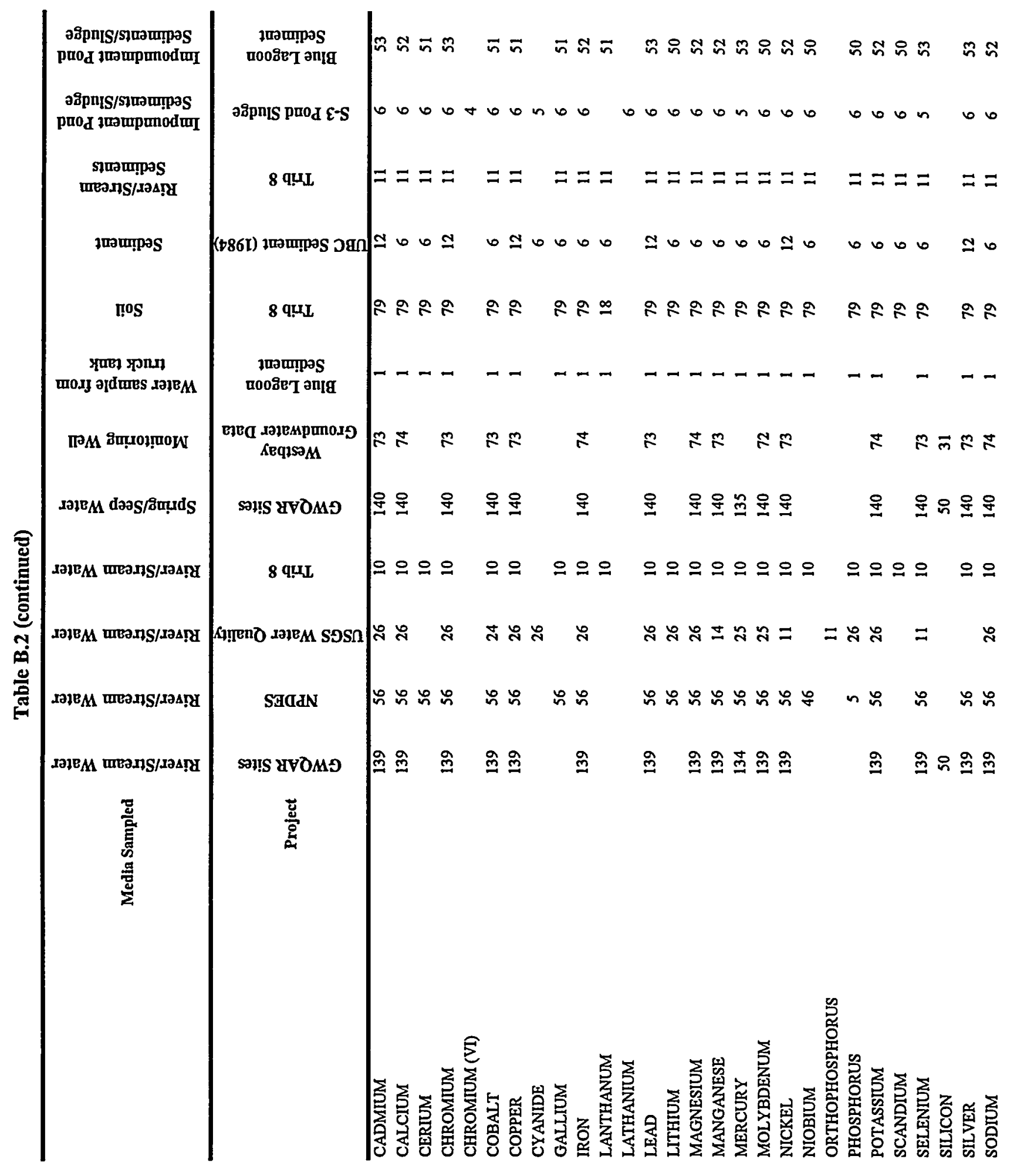


Table B.2 (continued)

\begin{tabular}{|c|c|c|c|c|c|c|c|c|c|c|c|c|}
\hline Media Sampled & 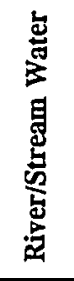 & 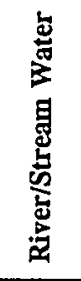 & 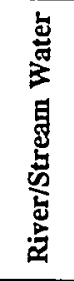 & 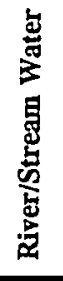 & 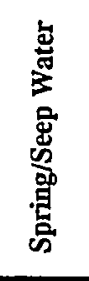 & 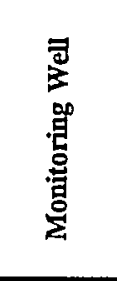 & 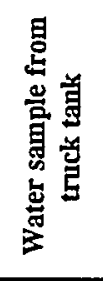 & \%ั้ & 鴶 & 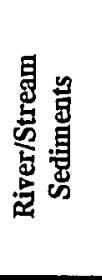 & 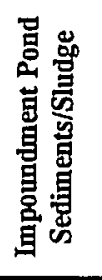 & 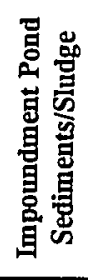 \\
\hline Project & 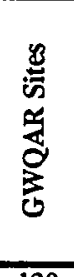 & $\begin{array}{l}\text { 楒 } \\
\text { 甚 }\end{array}$ & 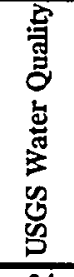 & $\begin{array}{l}\infty \\
\text { 苂 }\end{array}$ & 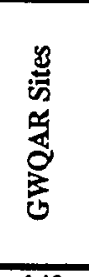 & 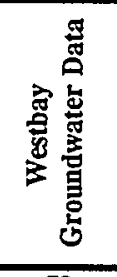 & 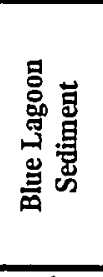 & $\stackrel{\infty}{\mathbb{E}}$ & 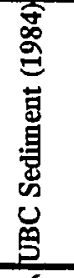 & 冓 & 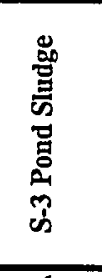 & 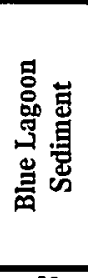 \\
\hline STRONTIUM & 139 & 56 & 24 & 10 & 140 & 73 & 1 & 79 & 6 & 11 & 6 & 52 \\
\hline THALLIUM & & 56 & & & & & & & 6 & & 5 & \\
\hline $\begin{array}{l}\text { THORIUM } \\
\text { TIN }\end{array}$ & 139 & 56 & & 10 & 140 & 73 & 1 & 79 & 6 & 11 & $\begin{array}{l}6 \\
5\end{array}$ & 50 \\
\hline TITANIUM & & 56 & & 10 & & & 1 & 79 & 6 & 11 & 6 & 50 \\
\hline URANIUM & & & 7 & & & & & & & & 5 & \\
\hline VANADIUM & 139 & 56 & 25 & 10 & 140 & 73 & 1 & 79 & 6 & 11 & 6 & 50 \\
\hline YTTRIUM & & & & & & & 1 & 79 & 6 & 11 & 6 & 50 \\
\hline ZINC & 139 & 56 & 25 & 10 & 140 & 72 & 1 & 79 & 12 & 11 & 6 & 50 \\
\hline ZIRCONIUM & & 56 & & 10 & & & 1 & 79 & 6 & 11 & 6 & 52 \\
\hline \multicolumn{13}{|l|}{ Miscellaneous } \\
\hline ALKALINITY & & & 17 & & & 74 & & & & & & \\
\hline ALPHA RADIOACTIVITY & & & & & & & & & & & 5 & \\
\hline ALUMNUM & & & & & & 1 & & & & & & \\
\hline ARSENIC & & & & & & & & & & & 5 & \\
\hline BARIUM & & & & & & & & & & & 5 & \\
\hline BETA RADIOACTIVITY & & & & & & & & & & & 5 & \\
\hline BIOLOGICAL OXYGEN DEMAND (BOD) & & 229 & & & & & & & & & & \\
\hline CADMIUM & & & & & & & & & & & 5 & \\
\hline CHEMICAL OXYGEN DEMAND (COD) & & 230 & & & & & & & & & & \\
\hline CHROMIUM & & & & & & & & & & & 5 & \\
\hline CONDUCTIVITY & 69 & & & & 70 & & & & & & & \\
\hline DISSOLVED OXYGEN & 69 & & & & 70 & & & & & & & 2 \\
\hline ENDRIN & & & & & & & & & & & 5 & \\
\hline IRON & & & & & & 1 & & & & & & \\
\hline LEAD & & & & & & & & & & & 5 & \\
\hline LINDANE & & & & & & & & & & & 5 & \\
\hline MERCURY & & & & & & & & & & & 5 & \\
\hline
\end{tabular}




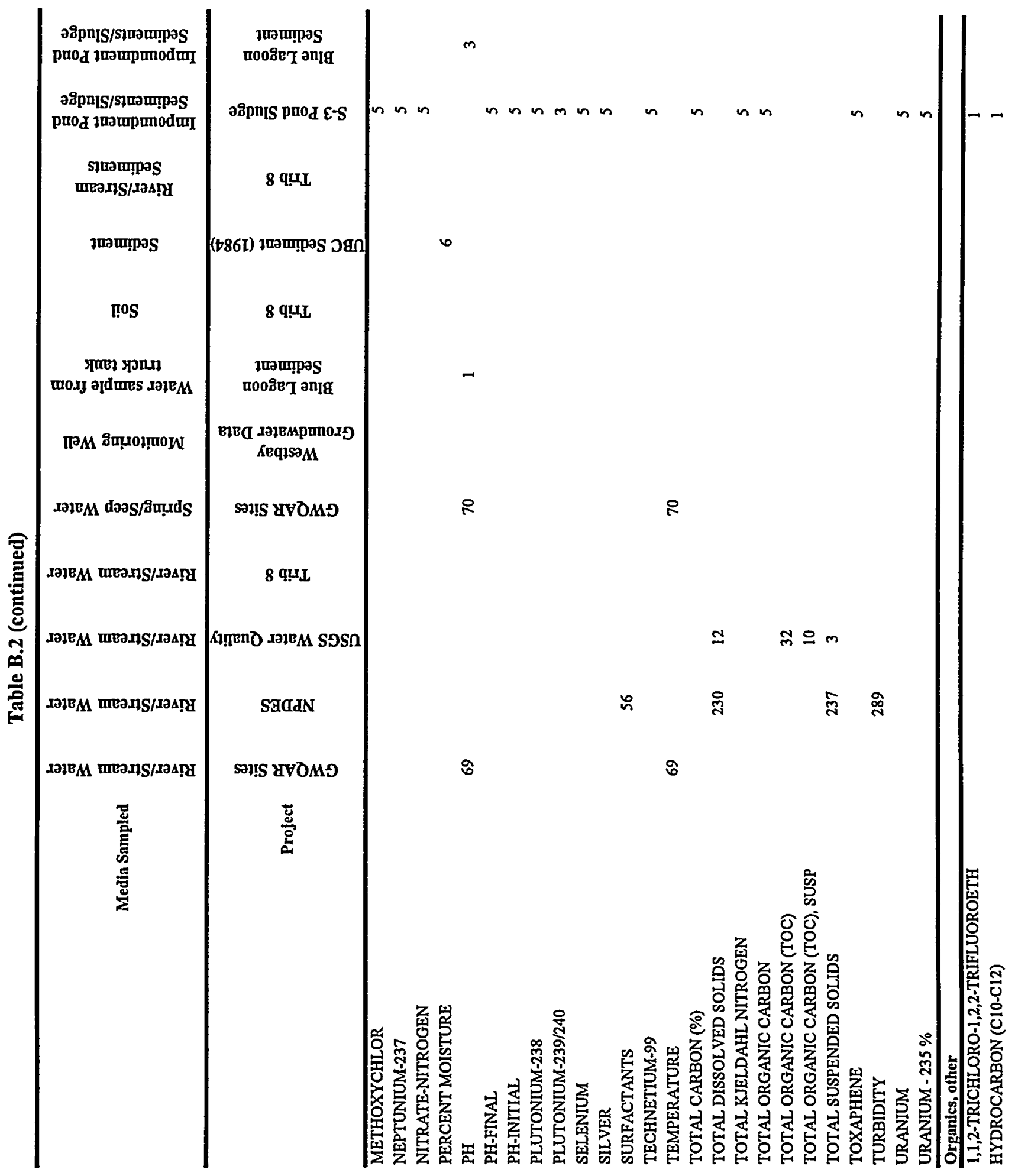




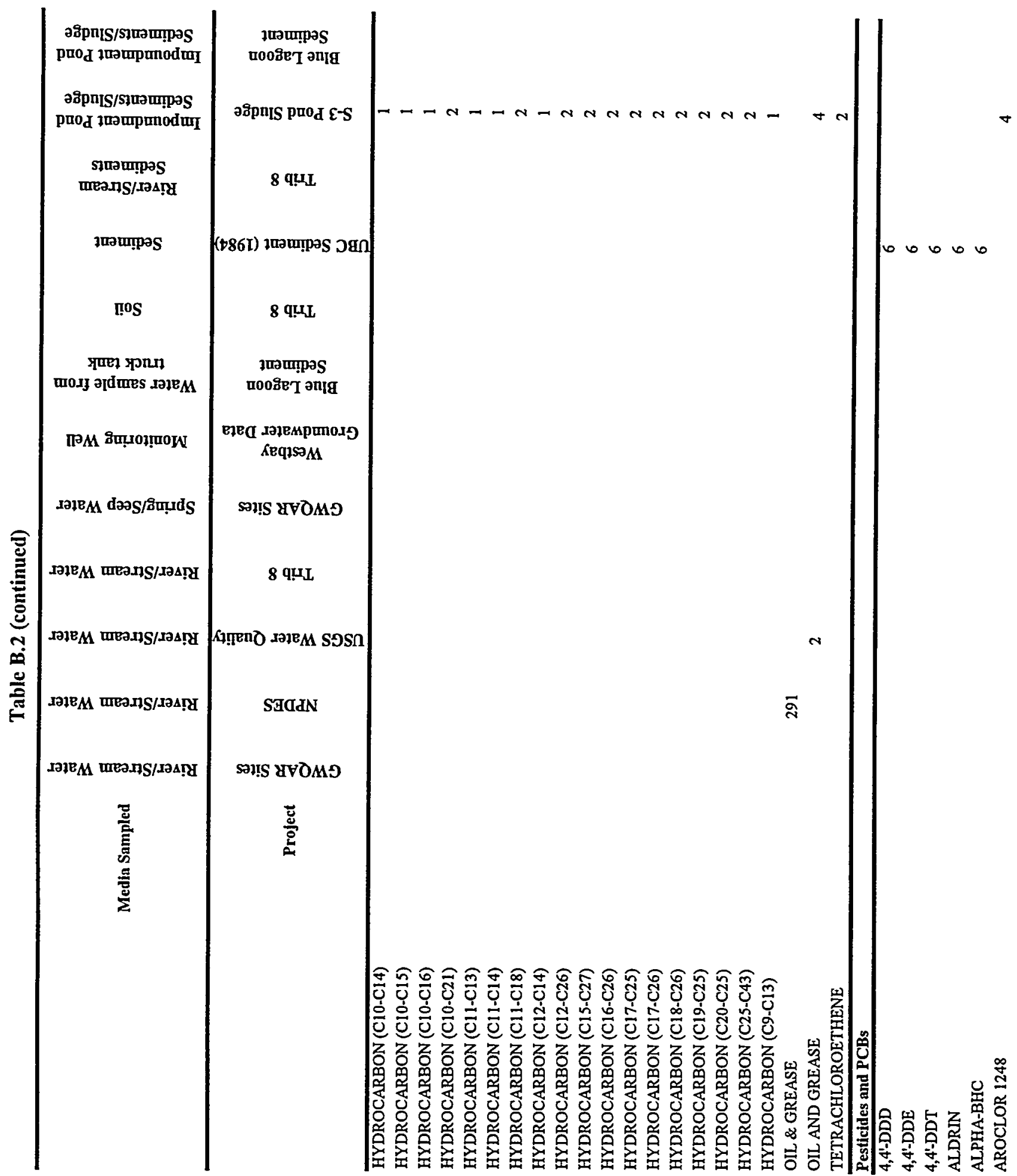


B12-29

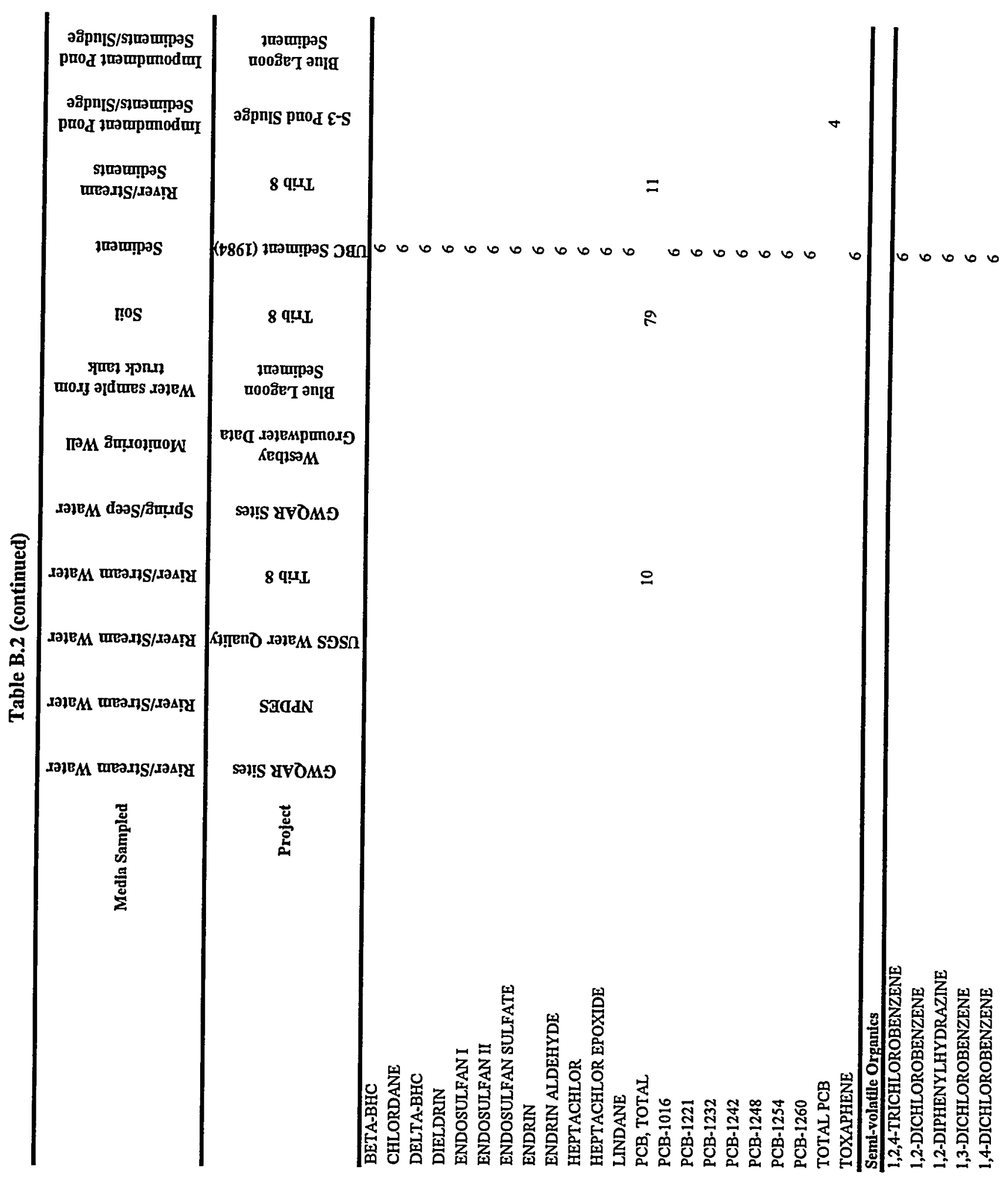


Table B.2 (continued)

\begin{tabular}{|c|c|c|c|c|c|c|c|c|c|c|c|c|}
\hline Media Sampled & 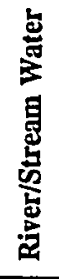 & 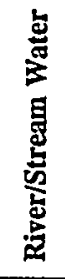 & 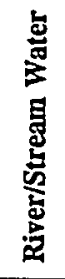 & 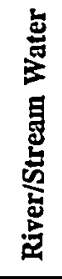 & 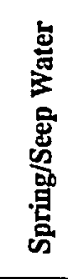 & 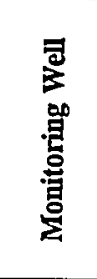 & 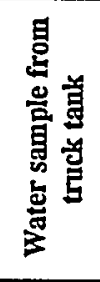 & 居 & $\begin{array}{l}\text { 崫 } \\
\text { 密 } \\
\text { 心 }\end{array}$ & 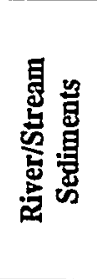 & 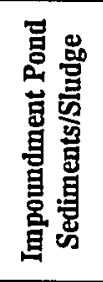 & 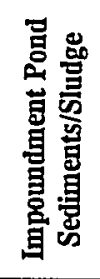 \\
\hline Project & 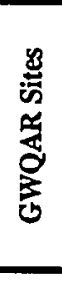 & $\begin{array}{l}\text { 喢 } \\
\text { 帘 }\end{array}$ & 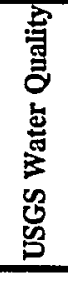 & $\begin{array}{l}\infty \\
\text { 官 } \\
\text { E }\end{array}$ & 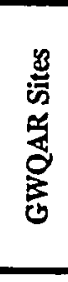 & 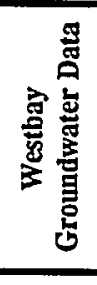 & 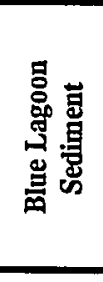 & ${ }_{\vec{E}}^{\infty}$ & 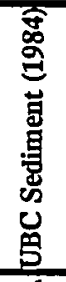 & 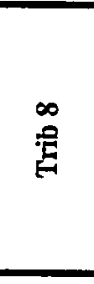 & 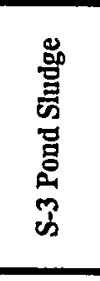 & 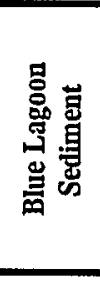 \\
\hline BENZO(GHI)PERYLENE & & & & & & & & & 6 & & & \\
\hline BENZO(K)FLUORANTHENE & & & & & & & & & 6 & & & \\
\hline BIS(2-CHLOROETHOXY)METHANE & & & & & & & & & 6 & & & \\
\hline BIS(2-CHLOROETHYL) ETHER & & & & & & & & & 6 & & & \\
\hline BIS(2-CHLOROISOPROPYL) ETHER & & & & & & & & & 6 & & & \\
\hline BIS(2-ETHYLHEXYL)PHTHALATE & & & & & & & & & 6 & & & \\
\hline BUTYLBENZYLPHTHALATE & & & & & & & & & 6 & & & \\
\hline CHRYSENE & & & & & & & & & 6 & & & \\
\hline DI-N-BUTYLPHTHALATE & & & & & & & & & 6 & & & \\
\hline DI-N-OCTYLPHTHALATE & & & & & & & & & 6 & & & \\
\hline DIBENZ(A,H)ANTHRACENE & & & & & & & & & 6 & & & \\
\hline DIETHYL PHTHALATE & & & & & & & & & & & 5 & \\
\hline DIETHYLPHTHALATE & & & & & & & & & 6 & & & \\
\hline DIMETHYLPHTHALATE & & & & & & & & & 6 & & & \\
\hline DIPHENYLAMINE & & & & & & & & & 6 & & & \\
\hline FLUORANTHENE & & & & & & & & & 6 & & & \\
\hline FLUORENE & & & & & & & & & 6 & & & \\
\hline HEXACHLOROBENZENE & & & & & & & & & 6 & & & \\
\hline HEXACHLOROBUTADIENE & & & & & & & & & 6 & & & \\
\hline HEXACHLOROCYCLOPENTADIENE & & & & & & & & & 6 & & & \\
\hline HEXACHLOROETHANE & & & & & & & & & 6 & & & \\
\hline INDENO(1,2,3-CD)PYRENE & & & & & & & & & 6 & & & \\
\hline ISOPHORONE & & & & & & & & & 6 & & & \\
\hline N-NITROSO-DI-N-PROPYLAMINE & & & & & & & & & 6 & & & \\
\hline N-NITROSODIMETHYLAMINE & & & & & & & & & 6 & & & \\
\hline NAPHTHALENE & & & & & & & & & 6 & & & \\
\hline NITROBENZENE & & & & & & & & & 6 & & & \\
\hline O-CRESOL, 4,6-DINITRO & & & & & & & & & 6 & & & \\
\hline
\end{tabular}


Table B.2 (continued)

\begin{tabular}{|c|c|c|c|c|c|c|c|c|c|c|c|c|}
\hline Media Sampled & 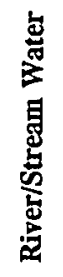 & 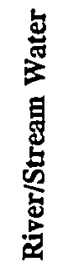 & 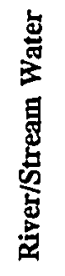 & 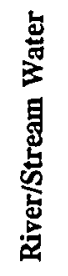 & 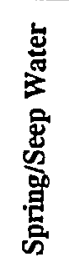 & 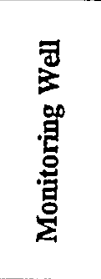 & 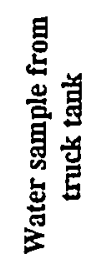 & हี & $\begin{array}{l}\text { 芫 } \\
\text { 营 } \\
\text { 心 }\end{array}$ & 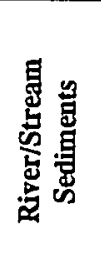 & 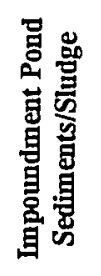 & 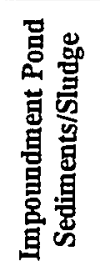 \\
\hline Project & 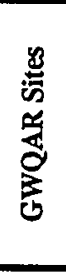 & 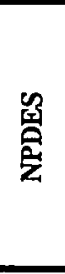 & 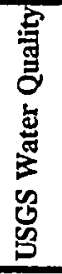 & $\begin{array}{l}\infty \\
\text { 总 }\end{array}$ & 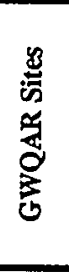 & 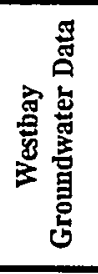 & 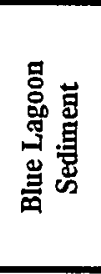 & ${ }_{\text {胥 }}^{\infty}$ & 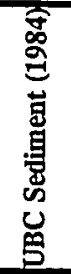 & $\begin{array}{l}\infty \\
\text { 疋 }\end{array}$ & 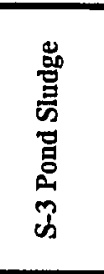 & 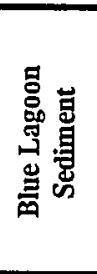 \\
\hline OCTAMETHYL-CYCLOTETRASILOZANE & & & & & & & & & & & 2 & \\
\hline PENTACHLOROPHENOL & & & & & & & & & 6 & & & \\
\hline PHENANTHRENE & & & & & & & & & 6 & & & \\
\hline PHENOL & & & & & & & & & 6 & & 5 & \\
\hline PHOSOPHORIC ACID & & & & & & & & & & & 2 & \\
\hline PYRENE & & & & & & & & & 6 & & & \\
\hline TRIPHENYLESTER & & & & & & & & & & & 2 & \\
\hline UNIDENTIFIED (POSSIBLE SILANE) & & & & & & & & & & & 5 & \\
\hline UNIDENTIFIED METHYLESTER & & & & & & & & & & & 4 & \\
\hline 1,1'-THIOBIS-ETHANE & & & & 1 & & & & & & & & \\
\hline 1,1,1-TRICHLOROETHANE & 71 & & & 10 & 69 & 52 & & 79 & 6 & 11 & & 49 \\
\hline 1,1,2,2-TETRACHLOROETHANE & 71 & & & 10 & 69 & 52 & & 79 & 6 & 11 & 5 & 49 \\
\hline 1,1,2-TRICHLORO-1,2,2-TRIFLUOROETH & & & & 10 & & & & 79 & & 1 & & 38 \\
\hline 1,1,2-TRICHLOROETHANE & 71 & & & 10 & 69 & 52 & & 79 & 6 & 11 & 1 & 48 \\
\hline 1,1-DICHLOROETHANE & 71 & & & 10 & 69 & 52 & & 79 & 6 & 11 & & 49 \\
\hline 1,1-DICHLOROETHENE & 71 & & & 10 & 69 & 52 & & 79 & 6 & 11 & & 49 \\
\hline 1,2-DICHLOROETHANE & 71 & & & 10 & 69 & 52 & & 79 & 6 & 11 & & 49 \\
\hline 1,2-DICHLOROETHENE & & & & & & 52 & & & & & & \\
\hline 1,2-DICHLOROETHENE (TOTAL) & 71 & & & & 69 & & & & & & & \\
\hline 1,2-DICHLOROPROPANE & 71 & & & 10 & 69 & 52 & & 79 & 6 & 11 & & 49 \\
\hline 2-BUTANONE & 71 & & & 10 & 69 & 52 & & 79 & & 4 & & 5 \\
\hline 2-CHLOROETHYLVINYL ETHER & & & & 10 & & & & 79 & 6 & 11 & & 49 \\
\hline 2-HEXANONE & 71 & & & & 69 & 52 & & & & & & \\
\hline 2-PROPANOL & & & & & & & & 1 & & & & \\
\hline 2-PROPENYL BENZENE & & & & & & & & 2 & & & & \\
\hline 3-CHLORO-1-BUTYNE & & & & 1 & & & & & & & & \\
\hline 4-METHYL-2-PENTANONE & 71 & & & 10 & 69 & 52 & & 79 & & 1 & & \\
\hline ACETONE & 71 & & & 10 & 69 & 52 & & 79 & & & & 14 \\
\hline
\end{tabular}


Table B.2 (continued)

\begin{tabular}{|c|c|c|c|c|c|c|c|c|c|c|c|c|c|}
\hline & Media Sampled & 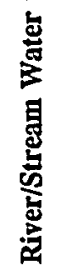 & 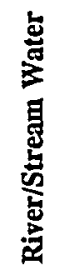 & 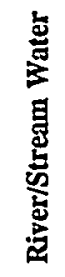 & 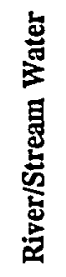 & 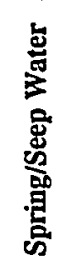 & 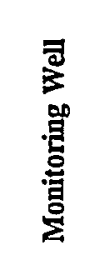 & 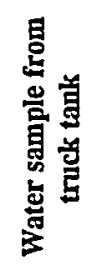 & 局 & 葍 & 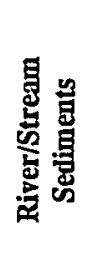 & 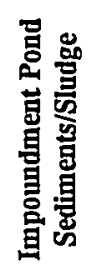 & 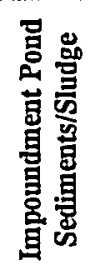 \\
\hline & Project & 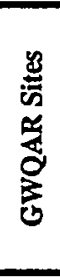 & 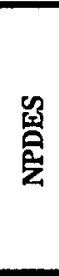 & 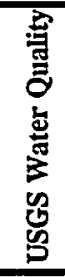 & $\begin{array}{l}\infty \\
\vec{E}\end{array}$ & 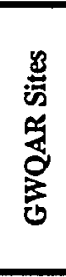 & 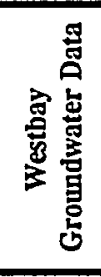 & 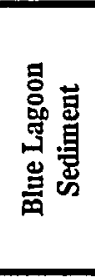 & $\begin{array}{l}\infty \\
\text { 峟 }\end{array}$ & 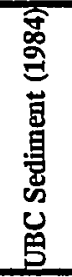 & $\begin{array}{l}\infty \\
\text { :्E }\end{array}$ & 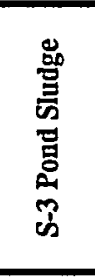 & 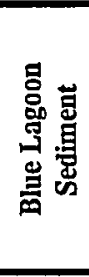 \\
\hline ACROLEIN & & & & & & & & & & 6 & & & \\
\hline ACRYLONITRILE & & & & & & & & & & 6 & & & \\
\hline ALL OTHER VOLATILES TOTAL & & & & & & & & & & & & 5 & \\
\hline BENZENE & & 71 & & & 10 & 69 & 52 & & 79 & 6 & 11 & & 48 \\
\hline BROMODICHLOROMETHANE & & 71 & & & 10 & 69 & 52 & & 79 & 6 & 11 & & 47 \\
\hline BROMOFORM & & 71 & & & 10 & 69 & 52 & & 79 & 6 & 11 & & 48 \\
\hline BROMOMETHANE & & 71 & & & 10 & 69 & 52 & & 79 & 6 & 11 & & 49 \\
\hline CARBON DISULFIDE & & 71 & & & & 69 & 52 & & & & & & \\
\hline CARBON TETRACHLORIDE & & 71 & & & 10 & 69 & 52 & & 79 & 6 & 11 & & 48 \\
\hline CHLOROBENZENE & & 71 & & & 10 & 69 & 52 & & 79 & 6 & 11 & & 49 \\
\hline CHLOROETHANE & & 71 & & & 10 & 69 & 52 & & 79 & 6 & 11 & & 49 \\
\hline CHLOROFORM & & 71 & & & 10 & 69 & 52 & & 79 & 6 & 11 & & 49 \\
\hline CHLOROMETHANE & & 71 & & & 10 & 69 & 52 & & 79 & 6 & 11 & & 49 \\
\hline CIS-1,2-DICHLOROETHENE & & & & & 7 & & & & 43 & & & & \\
\hline CIS-1,3-DICHLOROPROPENE & & 71 & & & 10 & 69 & 52 & & 79 & 6 & 11 & & 49 \\
\hline DIBROMOCHLOROMETHANE & & 71 & & & 10 & 69 & 52 & & 79 & 6 & 10 & & 49 \\
\hline DIBROMODICHLOROMETHANE & & & & & & & & & & & 1 & & \\
\hline DIETHYL DISULFIDE & & & & & 2 & & & & & & 3 & & \\
\hline ETHYL METHYL BENZENE & & & & & 2 & & & & & & & & \\
\hline ETHYLBENZENE & & 71 & & & 10 & 69 & 52 & & 79 & 6 & 11 & & 49 \\
\hline ISOPHORONE & & & & & & & & & & & & & 2 \\
\hline METHYLENE CHLORIDE & & 71 & & & 10 & 69 & 52 & & 79 & 6 & 11 & & 49 \\
\hline STYRENE & & 71 & & & & 69 & 52 & & & & & & \\
\hline SUBSTITUTED BENZENES & & & & & & & & & 1 & & 4 & & \\
\hline TETRACHLOROETHENE & & 71 & & & 10 & 69 & 52 & & 79 & 6 & 11 & 5 & 49 \\
\hline TOLUENE & & 71 & & & 10 & 69 & 52 & & 79 & 6 & 11 & & 49 \\
\hline TOTAL XYLENES & & 71 & & & & 69 & & & & & & & \\
\hline TRANS-1,2-DICHLOROETHENE & & & & & 10 & & & & 79 & 6 & 11 & & 49 \\
\hline
\end{tabular}


B12-34

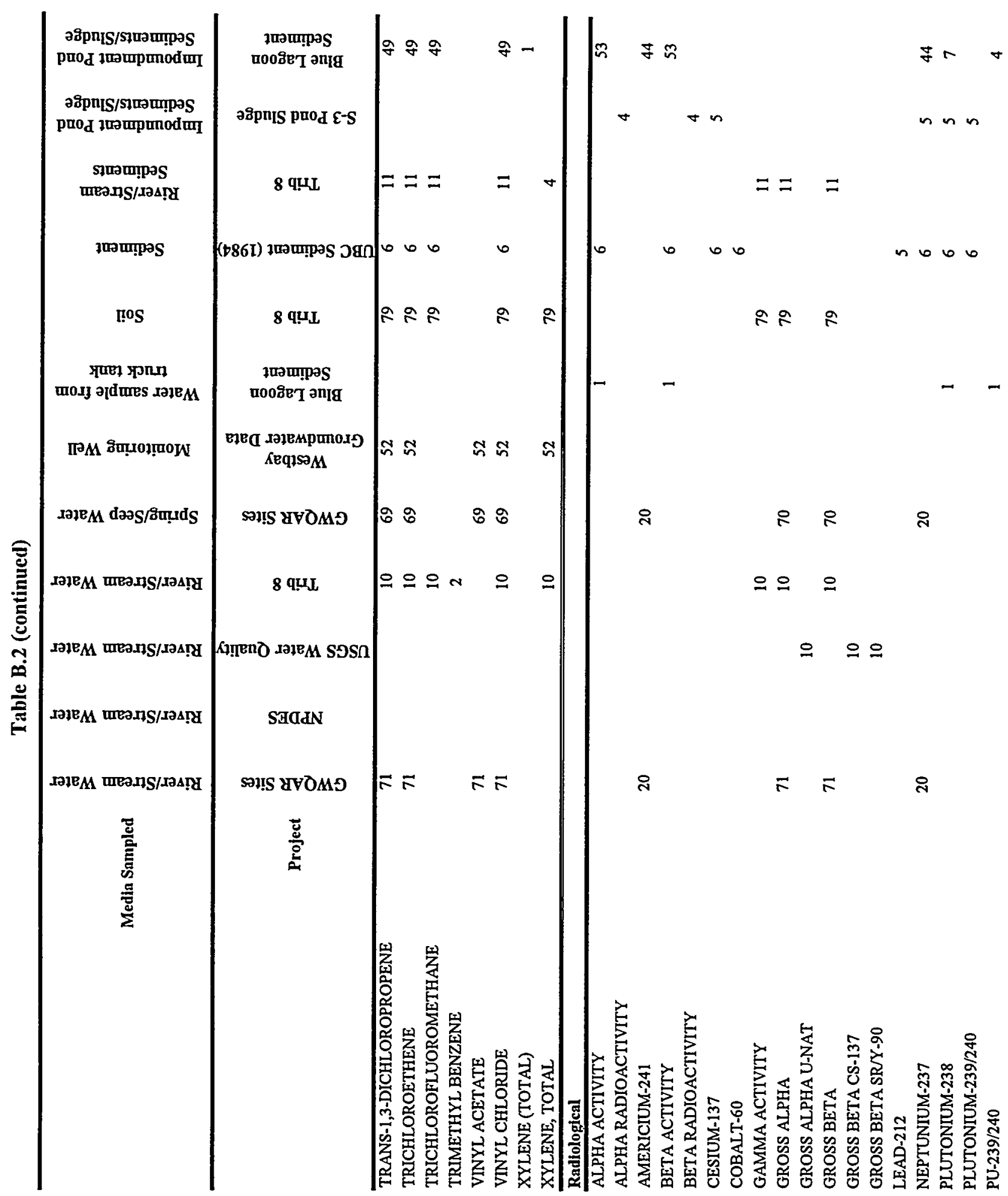


Table B.2 (continued)

\begin{tabular}{|c|c|c|c|c|c|c|c|c|c|c|c|c|}
\hline Media Sampled & 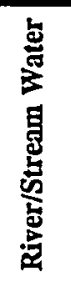 & 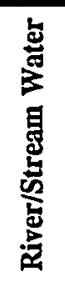 & 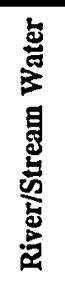 & 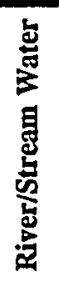 & 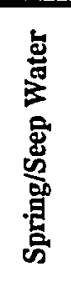 & 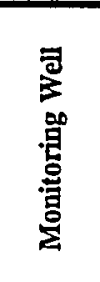 & 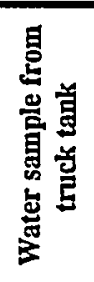 & 菅 & $\begin{array}{l}\text { 㟧 } \\
\text { 葛 }\end{array}$ & 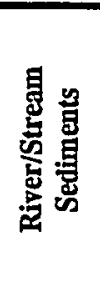 & 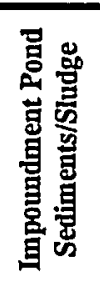 & 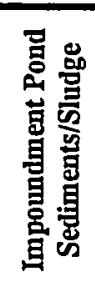 \\
\hline Project & 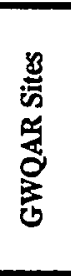 & 岕 & 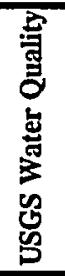 & $\begin{array}{l}\infty \\
\text { 定 }\end{array}$ & $\sum_{0}^{8}$ & 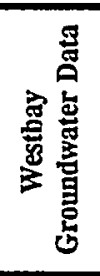 & 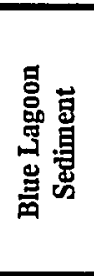 & $\begin{array}{l}\infty \\
\text { 窞 }\end{array}$ & 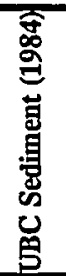 & 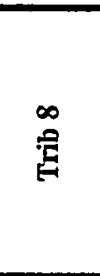 & 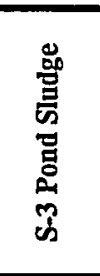 & 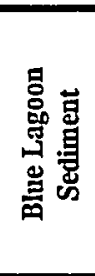 \\
\hline RUTHIUM-106 & & & & & & & & & & & 5 & \\
\hline STRONTIUM-90 & 24 & & & & 24 & & 1 & & & & 5 & 52 \\
\hline TECHNETIUM-99 & 24 & & & & 24 & & 1 & & 5 & & 5 & 52 \\
\hline THALLIUM-208 & & & & & & & & & 4 & & & \\
\hline THORIUM-228 & & & & & & & & & & & 4 & \\
\hline THORIUM-230 & & & & & & & & & & & 4 & \\
\hline THORIUM-232 & & & & & & & & & & & 4 & \\
\hline TOTAL URANIUM (FLUOROMETRIC) & 139 & & & & 140 & & & & & & & \\
\hline TRITIUM & 24 & & & & 24 & & 1 & & & & & 52 \\
\hline U-235 & & & & 10 & & & & 79 & & 11 & & \\
\hline U-238 & & & & & & & & 79 & & & & \\
\hline URANIUM & & & 18 & 10 & & & & 79 & 6 & 11 & & \\
\hline URANIUM - $235 \%$ & & & & & & & & & & & 5 & \\
\hline URANIUM, TOTAL & & & & & & & 1 & & & & & 51 \\
\hline URANIUM-234 & 50 & & & & 50 & & 1 & & 6 & & & 53 \\
\hline URANIUM-235 & 45 & & & & 45 & & 1 & & 6 & & & 53 \\
\hline URANIUM-236 & & & & & & & 1 & & & & & 51 \\
\hline URANIUM-238 & 50 & & & & 50 & & 1 & & 6 & & & 53 \\
\hline ZIRCONIUM-95 & & & & & & & & & & & 4 & \\
\hline ZR95/NB95 & & & & & & & & & 3 & & & \\
\hline
\end{tabular}


Table B.3. Procedure numbers and titles for BCV OU 1 RIFA

\begin{tabular}{|c|c|c|c|}
\hline $\begin{array}{c}\text { Procedure } \\
\text { number }\end{array}$ & Subject activity & $\begin{array}{c}\text { Issue } \\
\text { date }\end{array}$ & Revision \\
\hline \multicolumn{4}{|c|}{ Activity series 301 : surface water sampling } \\
\hline ESP-301-1 & Water sampling using a dipper & $8 / 30 / 88$ & 0 \\
\hline ESP-301-4 & Grab sampling with Kemmerer bottles & $8 / 30 / 88$ & 0 \\
\hline ESP-301-5 & Stream flow measurements & $8 / 30 / 88$ & 0 \\
\hline \multicolumn{4}{|c|}{ Activity series 302: groundwater sampling } \\
\hline ESP-302-1 & Water level measurements using a water level indicator & $8 / 29 / 88$ & 0 \\
\hline ESP-302-5 & Using a bladder pump & $8 / 29 / 88$ & 0 \\
\hline FTP-352 & Groundwater sampling procedures: using a hydropunch & $6 / 30 / 93$ & 0 \\
\hline FTP-357 & $\begin{array}{l}\text { Groundwater sampling using micropurge and low flow } \\
\text { sampling }\end{array}$ & TBA & \\
\hline FTP-616 & $\begin{array}{l}\text { Installation, development, and abandonment of temporary } \\
\text { piezometers }\end{array}$ & TBA & \\
\hline \multicolumn{4}{|c|}{ Activity series 303 : soil sampling } \\
\hline ESP-303-1 & Soil sampling with a spade and scoop & $8 / 30 / 88$ & 0 \\
\hline ESP-303-2 & Soil sampling with an auger & $9 / 01 / 88$ & 0 \\
\hline ESP-303-3 & Soil sampling with a trier & $8 / 31 / 88$ & 0 \\
\hline ESP-303-4 & Penetration testing and split-barrel sampling & $8 / 24 / 88$ & 0 \\
\hline ESP-303-5 & Subsurface soil sampling with shelby tubes & $8 / 30 / 88$ & 0 \\
\hline FTP-551 & Soil sampling by direct push & TBA & \\
\hline \multicolumn{4}{|c|}{ Activity series 304: sediment sampling } \\
\hline ESP-304-1 & Streambeds & $8 / 29 / 88$ & 0 \\
\hline \multicolumn{4}{|c|}{ Activity series 307: field measurements } \\
\hline FTP-880 & $\begin{array}{l}\text { Field measurement procedures: } \mathrm{pH} \text {, temperature, and } \\
\text { conductance }\end{array}$ & $8 / 29 / 88$ & 0 \\
\hline ESP-307-5 & Oxidation/reduction potential of water & $8 / 29 / 88$ & 0 \\
\hline FTP-750 & Field measurement procedures: organic vapor detection & $8 / 29 / 88$ & 0 \\
\hline FTP-451 & $\begin{array}{l}\text { Field measurement procedures: operation of radiation } \\
\text { survey instruments }\end{array}$ & $1 / 31 / 90$ & 0 \\
\hline FTP-701 & $\begin{array}{l}\text { Field measurement procedures: using a proton } \\
\text { magnetometer }\end{array}$ & TBA & \\
\hline FTP-710 & Field measurement procedures: using the EM-31 & TBA & \\
\hline
\end{tabular}


Table B.4. List of changes to SAP for OU 1

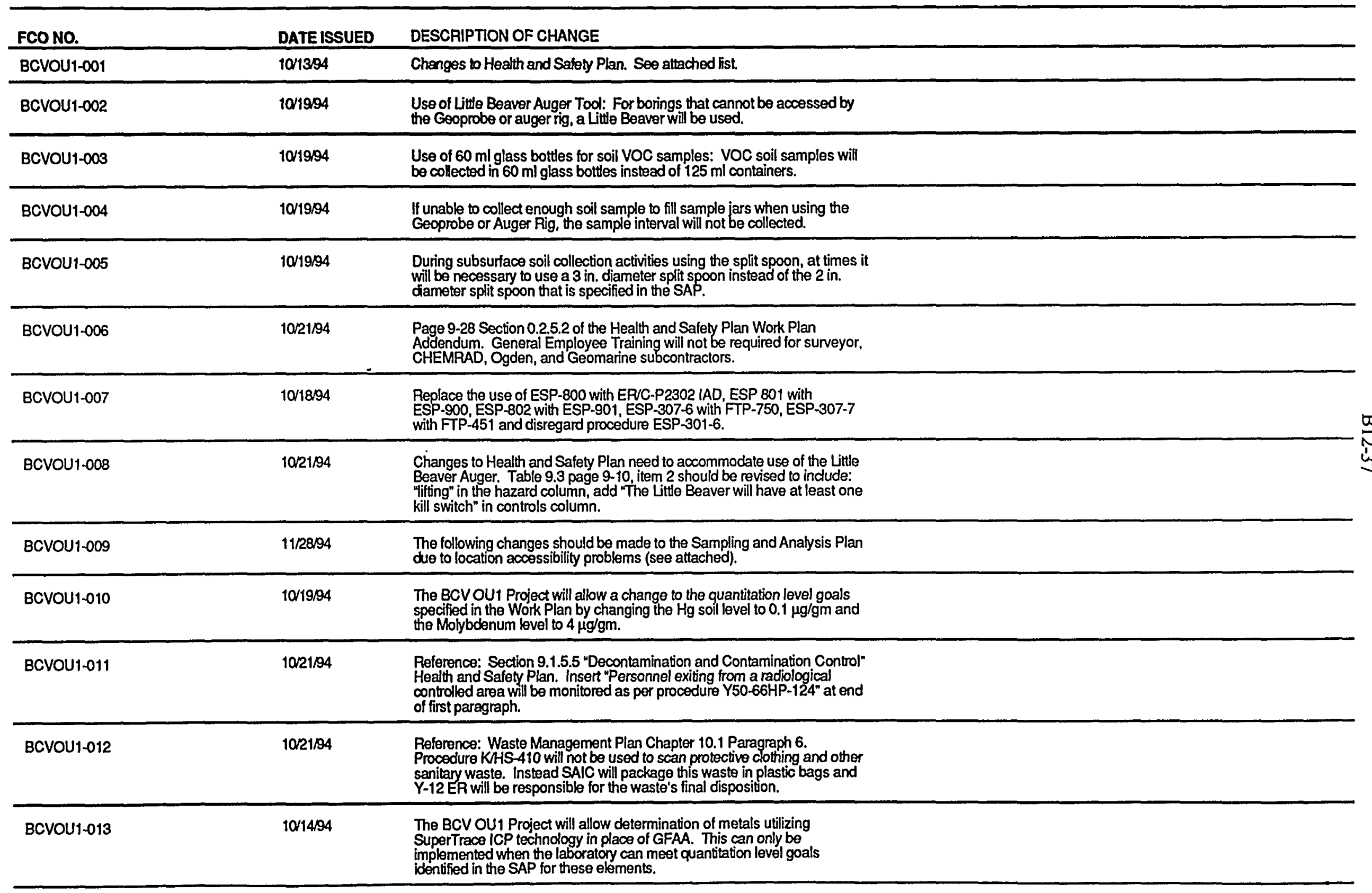




\begin{tabular}{|c|c|c|}
\hline FCONO. & DATE ISSUED & DESCRIPTION OF CHANGE \\
\hline BCVOU1-014 & $11 / 394$ & $\begin{array}{l}\text { Waive Hazwoper zoning requirement for groundwater sampling in } \\
\text { boreholes previously soil probed. Sites covered: SL-01;SL-02; OLF-01. }\end{array}$ \\
\hline BCVOU1-015 & $11 / 1 / 94$ & $\begin{array}{l}\text { Site Heaith \& Salety Officer (SHSO) may waive equipment/personnel } \\
\text { rad/con surveys at job completion and during job provided no HP } \\
\text { measurements are above general area background on samples, geoprobe } \\
\text { equipment. }\end{array}$ \\
\hline BCVOU1-016 & $11 / 3 / 94$ & $\begin{array}{l}\text { Waive Hazwoper zoning requirement on SL-01, SL-02, OLF-01 Geoprobe } \\
\text { sites for water sampling (groundwater). }\end{array}$ \\
\hline BCVOU1-017 & $11 / 3 / 94$ & $\begin{array}{l}\text { Will take VOA water samples from geoprobe boreholes using the tubing } \\
\text { water is pumped through. Tubing extends into borehole and is connected to } \\
\text { peristaltic pump. Water will be drawn through tubing, up to pump and } \\
\text { tubing will then be disconnected from pump, water captured by putting } \\
\text { thumb/finger over tubing, tubing removed from borehole, VOAs filled by } \\
\text { letting waler out of tubing. }\end{array}$ \\
\hline BCVOU1-018 & $11 / 15 / 94$ & $\begin{array}{l}\text { Change work plan from "borehole will be abandoned to } 4 \mathrm{ft} \text { of surface" to } \\
\text { "boreholes will be abandoned to about } 4 \mathrm{ft} \text { of surface." }\end{array}$ \\
\hline BCVOU1-019 & $11 / 15 / 94$ & $\begin{array}{l}\text { Not necessary to scan geoprobe borehole location with Mercury Vapor } \\
\text { analyzer on } 11 / 15 / 94 \text {. }\end{array}$ \\
\hline BCVOU1-020 & $11 / 1594$ & $\begin{array}{l}\text { Collect one trip blank per day instead of one trip blank per crew. All vOA } \\
\text { samples will be shipped to lab in same cooler as trip blank. Trip[ blanks } \\
\text { will be altemated between teams daily. }\end{array}$ \\
\hline BCVOU1-021 & $11 / 14 / 94$ & $\begin{array}{l}\text { Replace FTP-616 with BCV OU1-615. Delete references to the following } \\
\text { procedures in the QAPjP and/or the Health and Safely Plan in the Work } \\
\text { Plan Addendum: ESP-302-5, ESP-303-3, ESP-304-1, ESP-307-5, FTP } 352 \text {, } \\
\text { FTP 357, FTP 551, FTP 701 and FTP 710. }\end{array}$ \\
\hline BCVOU1-022 & $11 / 15 / 94$ & $\begin{array}{l}\text { Reference: Waste Management Plan Chapter 10, page 10-1, paragraph } 6 \text {. } \\
\text { Delete the use of procedure KNSS-410. SAIC Health and Safety Officer will } \\
\text { scan protective dothing and other sanitary waste prior to leaving the } \\
\text { sampling location and before bagging the PPE and sanitary waste. (This } \\
\text { FCO affects FCO BCV OU1-012.) }\end{array}$ \\
\hline BCVOU1-023 & $11 / 1594$ & $\begin{array}{l}\text { If unable to collect enough soil sample to fill sample jars when } \\
\text { homogenizing a } 4 \text { ft interval using the geoprobe or auger rig then a } 6 \mathrm{ft} \\
\text { interval will be homogenized. If there is still not enough sample then the } \\
\text { sample jars will be filled following the analyte priority list. (This FCO } \\
\text { affects BCV OU1-004.) }\end{array}$ \\
\hline BCVOU1-024 & $11 / 1694$ & $\begin{array}{l}\text { Boring locations around S } 3 \text { Ponds may have to be moved due to overhead } \\
\text { and underground obstructions. Mitch Guinn will assist and concur on any } \\
\text { moved boreholes. }\end{array}$ \\
\hline BCVOU1-025 & $11 / 1694$ & $\begin{array}{l}\text { Piezometers are being installed around } S 03 \text { ponds and boreholes are being } \\
\text { backfilled with soil cuttings. top } 5 \text { feet of borehole will be backfilled with } \\
\text { bentonite to prvent surface water going down borehole. }\end{array}$ \\
\hline
\end{tabular}


Table B.4. (continued)

\begin{tabular}{|c|c|c|}
\hline FCONO. & DATEISSUED & DESCRIPTION OF CHANGE \\
\hline BCVOU1-026 & $11 / 2894$ & $\begin{array}{l}\text { Clarification for BCV OU1 Addendum to RI Work Plan Chapter } 8 \text { page 8-2. } \\
\text { Calibration of field screening instruments (such as pH and conductivity } \\
\text { metors should be done once in the moming and once in the aftemoon when } \\
\text { using the equipment all day. However, if only using the instruments once } \\
\text { during the day, it is only necessary to calibrate it immediately before use. } \\
\text { All H\&S monitoring equipment (H Nus, Radmeters, etc.) will only be } \\
\text { required to be calibratod onc per day before use. }\end{array}$ \\
\hline BCVOU1-027 & $11 / 23 / 94$ & $\begin{array}{l}\text { Waive Hazwoper zoning requirements [(e.g., support zone, CR2 zone, } \\
\text { exclusion zone) since previous field monitoring indicated no contaminants } \\
\text { present] for pushing Shelby tubes; area to be marked as "construction } \\
\text { area". Area will be "Hazwoper" zoned if any field monitoring results } \\
\text { indicate contaminants present. }\end{array}$ \\
\hline BCVOU1-028 & $11 / 23 / 94$ & $\begin{array}{l}\text { Change the Waste Management Plan. Al soil boring S-3 } 8 \text { and S-3-7 all the } \\
\text { soil would not go back down the borehole. Because the soil at S-3-8 was } \\
\text { found to have a low pH ( }(3) \text { and the soil at S-3-7 was found to have high } \\
\text { beta/gamma readings ( } 500 \text { cpm), a decision was made not to spread the } \\
\text { remaining soil on top of the ground around the borehole. Steve Walker } \\
\text { requested that we dig a hole next to the boreholes and bury the excess soil } \\
\text { and cover it with the soil removed from the hole that was dug. }\end{array}$ \\
\hline BCVOU1-029 & $11 / 29 / 94$ & $\begin{array}{l}\text { Increase the type and number of Field Blanks (FB) to be collected on the } \\
\text { project. See the attactied definition for the type of tield blank to be collected. } \\
\text { The field blanks will be collected at a frequency of } 1 / 20 \text { or } 5 \% \text { per area (BG, } \\
\text { S-3 Ponds, (SL-1, BY/By and the Oil Landfarm). This increase is being } \\
\text { implemented al the request of Hugh Newsom and was approved by Judy } \\
\text { Hodgins. Collecting the additional samples will cause an increase to the } \\
\text { analytical costs. However, the cost is unkown by this requestor because } \\
\text { the laboratory is subcontracted directly to Energy Systems. }\end{array}$ \\
\hline BCVOU1-030 & $12 / 1 / 94$ & $\begin{array}{l}\text { Waive Hazwoper zoning requirement for sites in the Burial } \\
\text { Ground, Boneyard / Burnyard and Oil Landfarm Area. These } \\
\text { sites have previously been drilled / probed with only } \\
\text { background radiological contaimnation detected, } 0 \% \text { LEL, .000 } \\
\mathrm{m}^{3} / \mathrm{m}^{3} \mathrm{Hg} \text {, and ) ppm PID readings. The SHSO will continue to } \\
\text { perform real-time monitoring and will post the area as a } \\
\text { "Hazwoper site" (e.g., exclusion zone, contamination reduction } \\
\text { zone, support zone) as conditions warrent. }\end{array}$ \\
\hline BCVOU1-031 & $11 / 18 / 94$ & $\begin{array}{l}\text { Addendum to BCV OU1 Health and Safety Plan and Sampling and Analysis } \\
\text { Plan. This should indude the sampling of one opened } 55 \text { gallon drum } \\
\text { radiologically contaminated (e.g., } 100,000 \text { pm beta gamma, } 0 \text { opm alpha). } \\
\text { Sample to be collected and shipped to Y-12 laboratory. SAIC will collect tie } \\
\text { additional sample and Steve Walker will transport the sample to the Y-12 } \\
\text { Exclusion Area. PAdiochemical laboratory; qualified (Rad worker II, Resp. } \\
\text { Qualified)SAIC personnel will perform sampling/packaging. }\end{array}$ \\
\hline BCVOU1-032 & 26195 & $\begin{array}{l}\text { Will monitor water level in GW-276 for approximately } 5 \text { weeks versus } 8 \\
\text { weeks as outined in Work Plan. }\end{array}$ \\
\hline
\end{tabular}


B12-40

Table B.5. List of analytes and reported quantitation limits for surface and subsurface soils in BCV OU 1

\begin{tabular}{|c|c|c|}
\hline Analyte & Minimum quantitation limit ${ }^{\mathrm{a}}$ & Maximum quantitation limit $^{\mathrm{a}}$ \\
\hline & Inorganics (mg/kg) & \\
\hline \multicolumn{3}{|l|}{ Aluminum } \\
\hline \multicolumn{3}{|l|}{ Antimony } \\
\hline Arsenic & 0.38 & 0.38 \\
\hline \multicolumn{3}{|l|}{ Barium } \\
\hline Beryllium & 0.12 & 2.20 \\
\hline \multicolumn{3}{|l|}{ Boron } \\
\hline Cadmium & 0.27 & 0.57 \\
\hline Calcium & 35.70 & 263.00 \\
\hline \multicolumn{3}{|l|}{ Chromium } \\
\hline \multicolumn{3}{|l|}{ Cobalt } \\
\hline Copper & 3.70 & 24.70 \\
\hline Cyanide & 0.48 & 57.30 \\
\hline \multicolumn{3}{|l|}{ Iron } \\
\hline \multicolumn{3}{|l|}{ Lead } \\
\hline \multicolumn{3}{|l|}{ Magnesium } \\
\hline \multicolumn{3}{|l|}{ Manganese } \\
\hline Mercury & 0.04 & 0.08 \\
\hline Molybdenum & 0.49 & 16.20 \\
\hline \multicolumn{3}{|l|}{ Nickel } \\
\hline \multicolumn{3}{|l|}{ Potassium } \\
\hline Selenium & 0.48 & 4.10 \\
\hline Silver & 0.47 & 3.70 \\
\hline Sodium & 20.60 & 811.00 \\
\hline Thallium & 0.33 & 0.72 \\
\hline Tin & 1.90 & 16.60 \\
\hline \multicolumn{3}{|l|}{ Vanadium } \\
\hline Zinc & 7.10 & 7.10 \\
\hline
\end{tabular}




$$
\text { B12-41 }
$$

Table B.5 (continued)

\begin{tabular}{|c|c|c|}
\hline Analyte & Minimum quantitation limit ${ }^{\mathrm{a}}$ & Maximum quantitation limit ${ }^{\mathrm{a}}$ \\
\hline \multicolumn{3}{|c|}{ Pesticides/PCBs/Dioxins ( $\mu \mathrm{g} / \mathrm{kg}$ ) } \\
\hline 2378-TCDD (pg/g) & 2.15 & 5.40 \\
\hline Aroclor-1016 & 38.00 & 43.00 \\
\hline Aroclor- 1221 & 76.00 & 87.00 \\
\hline Aroclor-1232 & 38.00 & 43.00 \\
\hline Arocior- 1242 & 38.00 & 43.00 \\
\hline Aroclor- 1248 & 38.00 & 43.00 \\
\hline Aroclor- 1254 & 38.00 & 43.00 \\
\hline Aroclor- 1260 & 38.00 & 43.00 \\
\hline 4,4'-DDD & 3.30 & 42.00 \\
\hline 4,4'-DDE & 3.30 & 42.00 \\
\hline $4,4^{\prime}-\mathrm{DDT}$ & 3.30 & 42.00 \\
\hline Aldrin & 1.70 & 21.00 \\
\hline Aroclor-1016 & 33.00 & 420.00 \\
\hline Aroclor-1221 & 67.00 & 850.00 \\
\hline Aroclor-1232 & 33.00 & 420.00 \\
\hline Aroclor-1242 & 33.00 & 420.00 \\
\hline Aroclor-1248 & 33.00 & 420.00 \\
\hline Aroclor- 1254 & 33.00 & 47.00 \\
\hline Aroclor- 1260 & 33.00 & 420.00 \\
\hline Dieldrin & 3.30 & 42.00 \\
\hline Endosulfan I & 1.70 & 21.00 \\
\hline Endosulfan II & 3.30 & 42.00 \\
\hline Endosulfan sulfate & 3.30 & 42.00 \\
\hline Endrin & 3.30 & 42.00 \\
\hline Endrin aldehyde & 3.30 & 42.00 \\
\hline Endrin ketone & 3.30 & 42.00 \\
\hline Heptachlor & 1.70 & 21.00 \\
\hline Heptachlor epoxide & 1.70 & 21.00 \\
\hline Toxaphene & 170.00 & 2100.00 \\
\hline$\alpha-\mathrm{BHC}$ & 1.70 & 21.00 \\
\hline$\alpha$-Chlordane & 1.70 & 21.00 \\
\hline
\end{tabular}


B12-42

Table B.5 (continued)

\begin{tabular}{|c|c|c|}
\hline Analyte & Minimum quantitation limit & Maximum quantitation limit ${ }^{2}$ \\
\hline$\beta-B H C$ & 1.70 & 21.00 \\
\hline$\triangle-\mathrm{BHC}$ & 1.70 & 21.00 \\
\hline$\gamma$-BHC (Lindane) & 1.70 & 21.00 \\
\hline$\gamma$-Chlordane & 1.70 & 21.00 \\
\hline p,p'-Methoxychlor & 17.00 & 210.00 \\
\hline \multicolumn{3}{|c|}{ Semivolatile Organics $(\mu \mathrm{g} / \mathrm{kg})$} \\
\hline 1,2,4-Trichlorobenzene & 360.00 & 2000.00 \\
\hline 1,2-Dichlorobenzene & 360.00 & 2000.00 \\
\hline 1,3-Dichlorobenzene & 360.00 & 2000.00 \\
\hline 1,4-Dichlorobenzene & 360.00 & 2000.00 \\
\hline 2,2'-oxybis(1-Chloropropane) & 360.00 & 2000.00 \\
\hline 2,4,5-Trichlorophenol & 900.00 & 4900.00 \\
\hline 2,4,6-Trichlorophenol & 360.00 & 2000.00 \\
\hline 2,4-Dichlorophenol & 360.00 & 2000.00 \\
\hline 2,4-Dimethylphenol & 360.00 & 2000.00 \\
\hline 2,4-Dinitrophenol & 900.00 & 4900.00 \\
\hline 2,4-Dinitrotoluene & 360.00 & 2000.00 \\
\hline 2,6-Dinitrotoluene & 360.00 & 2000.00 \\
\hline 2-Chloronaphthalene & 360.00 & 2000.00 \\
\hline 2-Chlorophenol & 360.00 & 2000.00 \\
\hline 2-Methylnaphthalene & 360.00 & 750.00 \\
\hline 2-Methylphenol & 360.00 & 2000.00 \\
\hline 2-Nitroaniline & 900.00 & 4900.00 \\
\hline 2-Nitrophenol & 360.00 & 2000.00 \\
\hline 3,3'-Dichlorobenzidine & 360.00 & 2000.00 \\
\hline 3-Nitroaniline & 900.00 & 4900.00 \\
\hline 4,6-Dinitro-2-methylphenol & 900.00 & 4900.00 \\
\hline 4-Bromophenyl-phenylether & 360.00 & 2000.00 \\
\hline 4-Chloro-3-methylphenol & 360.00 & 2000.00 \\
\hline 4-Chloroaniline & 360.00 & 2000.00 \\
\hline 4-Chlorophenyl-phenylether & 360.00 & 2000.00 \\
\hline 4-Methylphenol & 360.00 & 2000.00 \\
\hline
\end{tabular}


B12-43

Table B.5 (continued)

\begin{tabular}{|c|c|c|}
\hline Analyte & Minimum quantitation limit $^{\mathbf{z}}$ & Maximum quantitation limit \\
\hline 4-Nitroaniline & 900.00 & 4900.00 \\
\hline 4-Nitrophenol & 900.00 & 4900.00 \\
\hline Acenaphthene & 360.00 & 750.00 \\
\hline Acenaphthylene & 360.00 & 2000.00 \\
\hline Anthracene & 360.00 & 750.00 \\
\hline Benzo(a)anthracene & 360.00 & 750.00 \\
\hline Benzo(a)pyrene & 360.00 & 750.00 \\
\hline Benzo(b)fluoranthene & 360.00 & 750.00 \\
\hline Benzo(g,h,i)perylene & 360.00 & 750.00 \\
\hline Benzo(k)fluoranthene & 360.00 & 750.00 \\
\hline Butylbenzylphthalate & 360.00 & 2000.00 \\
\hline Carbazole & 360.00 & 750.00 \\
\hline Chrysene & 360.00 & 750.00 \\
\hline Di-n-butylphthalate & 82.00 & 2000.00 \\
\hline Di-n-octylphthalate & 360.00 & 4000.00 \\
\hline Dibenzo(a,h)anthracene & 360.00 & 750.00 \\
\hline Dibenzofuran & 360.00 & 750.00 \\
\hline Diethylphthalate & 360.00 & 4000.00 \\
\hline Dimethylphthalate & 360.00 & 2000.00 \\
\hline Fluoranthene & 360.00 & 750.00 \\
\hline Fluorene & 360.00 & 750.00 \\
\hline Hexachlorobenzene & 360.00 & 4000.00 \\
\hline Hexachlorobutadiene & 360.00 & 4000.00 \\
\hline Hexachlorocyclopentadiene & 360.00 & 4000.00 \\
\hline Hexachloroethane & 360.00 & 4000.00 \\
\hline Indeno(1,2,3-c,d)pyrene & 360.00 & 750.00 \\
\hline Isophorone & 360.00 & 4000.00 \\
\hline N-Nitroso-di-n-propylamine & 360.00 & 4000.00 \\
\hline N-Nitrosodiphenylamine & 360.00 & 4000.00 \\
\hline Naphthalene & 360.00 & 750.00 \\
\hline Nitrobenzene & 360.00 & 4000.00 \\
\hline Pentachlorophenol & 900.00 & 9800.00 \\
\hline
\end{tabular}




$$
\text { B12-44 }
$$

Table B.5 (continued)

\begin{tabular}{|c|c|c|}
\hline Analyte & Minimum quantitation limit ${ }^{\mathrm{a}}$ & Maximum quantitation limit $^{\mathrm{a}}$ \\
\hline Phenanthrene & 360.00 & 750.00 \\
\hline Phenol & 360.00 & 2000.00 \\
\hline Pyrene & 360.00 & 750.00 \\
\hline bis(2-Chloroethoxy)methane & 360.00 & 2000.00 \\
\hline bis(2-Chloroethyl)ether & 360.00 & 4000.00 \\
\hline bis(2-Ethylhexyl)phthalate & 360.00 & 2000.00 \\
\hline \multicolumn{3}{|c|}{ Volatile Organics $(\mu \mathrm{g} / \mathrm{kg})$} \\
\hline 1,1,1-Trichloroethane & 5.00 & 33.00 \\
\hline 1,1,2,2-Tetrachloroethane & 5.00 & 33.00 \\
\hline 1,1,2-Trichloroethane & 5.00 & 33.00 \\
\hline 1,1-Dichloroethane & 5.00 & 33.00 \\
\hline 1,1-Dichloroethene & 5.00 & 33.00 \\
\hline 1,2-Dichloroethane & 5.00 & 33.00 \\
\hline 1,2-Dichloroethene & 5.00 & 33.00 \\
\hline 1,2-Dichloropropane & 5.00 & 33.00 \\
\hline 2-Butanone & 10.00 & 66.00 \\
\hline 2-Hexanone & 10.00 & 66.00 \\
\hline 4-methyl-2-Pentanone & 6.00 & 23.00 \\
\hline Acetone & 11.00 & 170.00 \\
\hline Benzene & 5.00 & 33.00 \\
\hline Bromodichloromethane & 5.00 & 33.00 \\
\hline Bromoform & 5.00 & 33.00 \\
\hline Bromomethane & 10.00 & 66.00 \\
\hline Carbon disulfide & 5.00 & 33.00 \\
\hline Carbon tetrachloride & 5.00 & 33.00 \\
\hline Chlorobenzene & 5.00 & 33.00 \\
\hline Chloroethane & 10.00 & 66.00 \\
\hline Chloroform & 5.00 & 33.00 \\
\hline Chloromethane & 10.00 & 66.00 \\
\hline Dibromochloromethane & 5.00 & 33.00 \\
\hline Ethylbenzene & 5.00 & 33.00 \\
\hline Methylene chloride & 5.00 & 85.00 \\
\hline
\end{tabular}




\section{B12-45}

Table B.5 (continued)

\begin{tabular}{|c|c|c|}
\hline Analyte & Minimum quantitation limit ${ }^{\mathbf{a}}$ & Maximum quantitation limit ${ }^{2}$ \\
\hline Styrene & 5.00 & 33.00 \\
\hline Tetrachloroethene & 5.00 & 12.00 \\
\hline Toluene & 6.00 & 33.00 \\
\hline Trichloroethene & 5.00 & 33.00 \\
\hline Trichlorotrifluoromethane & 10.00 & 66.00 \\
\hline Vinyl chloride & 10.00 & 66.00 \\
\hline Xylene, Total & 5.00 & 33.00 \\
\hline cis-1,3-Dichloropropene & 5.00 & 33.00 \\
\hline \multirow[t]{2}{*}{ trans-1,3-Dichloropropene } & 5.00 & 33.00 \\
\hline & Radionuclides ( $\mathrm{pCi} / \mathrm{g}$ ) & \\
\hline \multicolumn{3}{|l|}{ Antimony-125 } \\
\hline \multicolumn{3}{|l|}{ Americium-241 } \\
\hline \multicolumn{3}{|l|}{ Bismuth-212 } \\
\hline \multicolumn{3}{|l|}{ Cerium-144 } \\
\hline \multicolumn{3}{|l|}{ Cesium-134 } \\
\hline \multicolumn{3}{|l|}{ Cesium-137 } \\
\hline \multicolumn{3}{|l|}{ Chromium-51 } \\
\hline \multicolumn{3}{|l|}{ Cobalt -57} \\
\hline \multicolumn{3}{|l|}{ Cobalt-58 } \\
\hline \multicolumn{3}{|l|}{ Cobalt -60} \\
\hline \multicolumn{3}{|l|}{ Gross $\alpha$} \\
\hline \multicolumn{3}{|l|}{ Gross $\beta$} \\
\hline \multicolumn{3}{|l|}{ Iron-59 } \\
\hline \multicolumn{3}{|l|}{ Manganese-54 } \\
\hline \multicolumn{3}{|l|}{ Lead-212 } \\
\hline \multicolumn{3}{|l|}{ Neptunium-237 } \\
\hline \multicolumn{3}{|l|}{ Niobium-95 } \\
\hline \multicolumn{3}{|l|}{ Potassium-40 } \\
\hline \multicolumn{3}{|l|}{ Plutonium-238 } \\
\hline \multicolumn{3}{|l|}{ Plutonium-239/240 } \\
\hline Ruthenium-106 & & \\
\hline Thallium-208 & & \\
\hline
\end{tabular}


B12-46

Table B.5 (continued)

\begin{tabular}{l}
\multicolumn{1}{c}{ Analyte } \\
\hline Sodium -22 \\
Strontium-90 \\
Technetium-99 \\
Thorium-228 \\
Thorium-230 \\
Thorium-232 \\
Uranium-234 \\
Uranium-235 \\
Uranium-238 \\
Zinc-65 \\
Zirconium-95
\end{tabular}

${ }^{2}$ Parameters which were never reported as less than the quantitation limit have no statistics for minimum or maximum quantitation limit 
Table B.6. Geotechnical and physical parameters for soil samples taken in BCV OU 1 RIFA

\begin{tabular}{ll}
\hline \multicolumn{1}{c}{ Analytical parameter } & \multicolumn{1}{c}{ Analytical method } \\
\hline Permeability & SW 846 Method 9100 \\
Hydraulic conductivity & SW 846 Method 9100 \\
Porosity & EM 1110-2-1906 \\
Grain size (sieve) & ASTM D422 \\
Grain size (hydrometer) & ASTM D422 \\
Mineral composition & X-ray diffraction/electron spectroscopy \\
Bulk density & ASTM D4531-86 \\
Cation exchange capacity & SW 846 Method 9081 \\
pH & SW 846 Method 9045 \\
Total organic carbon (bulk) & SW 846 Method $9060^{\circ}$ \\
Total organic carbon $(<75 \mu \mathrm{m})$ & SW 846 Method $9060^{\circ}$ \\
Distribution coefficient & ASTM Method 4646 \\
Moisture content & ASTM D4959-89 \\
Atterburg limits & ASTM D4318-84 \\
Shear strength & ASTM D4318-84 \\
\hline
\end{tabular}

a As modified for solid media per laboratory-specific methodology. Laboratory method will be submitted for review and approval. 


\section{B12-48}

Table B.7. List of analytes and reported quantitation limits for groundwater and surface water in BCV OU 1

\begin{tabular}{|c|c|c|}
\hline Analyte & Minimum quantitation limit ${ }^{\mathrm{a}}$ & Maximum quantitatic \\
\hline & Anions (mg/l) & \\
\hline \multicolumn{3}{|l|}{ Chloride } \\
\hline Fluoride & 0.05 & 0.05 \\
\hline Nitrate/Nitrite (NO3/NO2-N) & 0.10 & 0.10 \\
\hline \multicolumn{3}{|l|}{ Sulfate } \\
\hline & Inorganics (total, $\mu g / l)$ & \\
\hline \multicolumn{3}{|l|}{ Aluminum } \\
\hline Antimony & 0.90 & 0.90 \\
\hline Arsenic & 1.70 & 1.70 \\
\hline \multicolumn{3}{|l|}{ Barium } \\
\hline Beryllium & 0.30 & 1.50 \\
\hline Cadmium & 1.40 & 3.30 \\
\hline \multicolumn{3}{|l|}{ Calcium } \\
\hline Chromium & 1.70 & 9.90 \\
\hline Cobalt & 2.30 & 6.10 \\
\hline Copper & 4.60 & 53.90 \\
\hline Cyanide & 10.00 & 10.00 \\
\hline \multicolumn{3}{|l|}{ Iron } \\
\hline Lead & 3.90 & 3.90 \\
\hline \multicolumn{3}{|l|}{ Magnesium } \\
\hline \multicolumn{3}{|l|}{ Manganese } \\
\hline Mercury & 0.20 & 0.20 \\
\hline Molybdenum & 2.40 & 45.80 \\
\hline Nickel & 3.50 & 3.50 \\
\hline \multicolumn{3}{|l|}{ Potassium } \\
\hline Selenium & 2.50 & 4.00 \\
\hline Silver & 2.40 & 2.40 \\
\hline Thallium & 1.70 & 1.70 \\
\hline Tin & 9.90 & 9.90 \\
\hline
\end{tabular}


B12-49

Table B.7 (continued)

\begin{tabular}{|c|c|c|}
\hline Analyte & Minimum quantitation limit ${ }^{\mathrm{a}}$ & Maximum quantitation limit $^{\mathrm{a}}$ \\
\hline Vanadium & 2.30 & 8.10 \\
\hline Zinc & 6.40 & 53.40 \\
\hline \multicolumn{3}{|c|}{ Inorganics (dissolved, $\mu \mathrm{g} /$ ))- surface water only } \\
\hline Aluminum & 22.40 & 22.40 \\
\hline \multicolumn{3}{|l|}{ Arsenic } \\
\hline \multicolumn{3}{|l|}{ Barium } \\
\hline Beryllium & 0.30 & 0.30 \\
\hline Cadmium & 1.40 & 1.40 \\
\hline \multicolumn{3}{|l|}{ Calcium } \\
\hline Chromium & 1.70 & 1.70 \\
\hline Cobalt & 2.30 & 2.30 \\
\hline Copper & 3.10 & 5.20 \\
\hline Iron & 12.40 & 12.40 \\
\hline \multicolumn{3}{|l|}{ Magnesium } \\
\hline Manganese & 1.20 & 1.20 \\
\hline Mercury & 0.20 & 0.20 \\
\hline Molybdenum & 2.40 & 2.40 \\
\hline Nickel & 3.50 & 3.50 \\
\hline \multicolumn{3}{|l|}{ Potassium } \\
\hline \multicolumn{3}{|l|}{ Selenium } \\
\hline Silver & 2.40 & 2.40 \\
\hline \multicolumn{3}{|l|}{ Thallium } \\
\hline Tin & 9.90 & 9.90 \\
\hline Vanadium & 2.30 & 2.30 \\
\hline Zinc & 6.30 & 6.30 \\
\hline \multicolumn{3}{|c|}{ Pesticides/PCBs $(\mu g / l)$} \\
\hline 4,4'-DDD & 0.10 & 0.19 \\
\hline $4,4^{\prime}-\mathrm{DDE}$ & 0.10 & 0.19 \\
\hline $4,4^{\prime}-\mathrm{DDT}$ & 0.10 & 0.19 \\
\hline Aldrin & 0.05 & 0.09 \\
\hline Aroclor-1016 & 0.98 & 1.90 \\
\hline Aroclor-1221 & 1.90 & 3.80 \\
\hline
\end{tabular}


B12-50

Table B.7 (continued)

\begin{tabular}{|c|c|c|}
\hline Analyte & Minimum quantitation limit ${ }^{\mathrm{a}}$ & Maximum quantitation limit ${ }^{\mathrm{a}}$ \\
\hline Aroclor-1232 & 0.98 & 1.90 \\
\hline Aroclor-1242 & 0.98 & 1.90 \\
\hline Aroclor-1248 & 0.98 & 1.90 \\
\hline Aroclor- 1254 & 0.98 & 1.90 \\
\hline Aroclor- 1260 & 0.98 & 1.90 \\
\hline Dieldrin & 0.10 & 0.19 \\
\hline Endosulfan I & 0.05 & 0.09 \\
\hline Endosulfan II & 0.10 & 0.19 \\
\hline Endosulfan sulfate & 0.10 & 0.19 \\
\hline Endrin & 0.10 & 0.19 \\
\hline Endrin aldehyde & 0.10 & 0.19 \\
\hline Endrin ketone & 0.10 & 0.19 \\
\hline Heptachlor & 0.05 & 0.09 \\
\hline Heptachlor epoxide & 0.05 & 0.09 \\
\hline Toxaphene & 4.80 & 9.40 \\
\hline$\alpha-\mathrm{BHC}$ & 0.05 & 0.09 \\
\hline$\alpha$-Chlordane & 0.05 & 0.09 \\
\hline$\beta$-BHC & 0.05 & 0.09 \\
\hline$\Delta-\mathrm{BHC}$ & 0.05 & 0.09 \\
\hline$\gamma$-BHC (Lindane) & 0.05 & 0.09 \\
\hline$\gamma$-Chlordane & 0.05 & 0.09 \\
\hline p,p'-Methoxychlor & 0.48 & 0.94 \\
\hline \multicolumn{3}{|c|}{ Semi-volatile organics $(\mu \mathrm{g} / \mathrm{l})$} \\
\hline 1,2,4-Trichlorobenzene & 10.00 & 17.00 \\
\hline 1,2-Dichlorobenzene & 10.00 & 17.00 \\
\hline 1,3-Dichlorobenzene & 10.00 & 17.00 \\
\hline 1,4-Dichlorobenzene & 10.00 & 17.00 \\
\hline 2,2'-Oxybis(1-Chloropropane) & 10.00 & 17.00 \\
\hline 2,4,5-Trichlorophenol & 25.00 & 42.00 \\
\hline 2,4,6-Trichlorophenol & 10.00 & 17.00 \\
\hline 2,4-Dichlorophenol & 10.00 & 17.00 \\
\hline 2,4-Dimethylphenol & 10.00 & 17.00 \\
\hline
\end{tabular}


B12-51

Table B.7 (continued)

\begin{tabular}{|c|c|c|}
\hline Analyte & Minimum quantitation limit $^{2}$ & Maximum quantitation limit \\
\hline 2,4-Dinitrophenol & 25.00 & 42.00 \\
\hline 2,4-Dinitrotoluene & 10.00 & 17.00 \\
\hline 2,6-Dinitrotoluene & 10.00 & 17.00 \\
\hline 2-Chloronaphthalene & 10.00 & 17.00 \\
\hline 2-Chlorophenol & 10.00 & 17.00 \\
\hline 2-Methylnaphthalene & 10.00 & 17.00 \\
\hline 2-Methylphenol & 10.00 & 17.00 \\
\hline 2-Nitroaniline & 25.00 & 42.00 \\
\hline 2-Nitrophenol & 10.00 & 17.00 \\
\hline 3,3'-Dichlorobenzidine & 10.00 & 17.00 \\
\hline 3-Nitroaniline & 25.00 & 42.00 \\
\hline 4,6-Dinitro-2-methylphenol & 25.00 & 42.00 \\
\hline 4-Bromophenyl-phenylether & 10.00 & 17.00 \\
\hline 4-Chloro-3-methylphenol & 10.00 & 17.00 \\
\hline 4-Chloroaniline & 10.00 & 17.00 \\
\hline 4-Chlorophenyl-phenylether & 10.00 & 17.00 \\
\hline 4-Methylphenol & 10.00 & 17.00 \\
\hline 4-Nitroaniline & 25.00 & 42.00 \\
\hline 4-Nitrophenol & 25.00 & 42.00 \\
\hline Acenaphthene & 10.00 & 17.00 \\
\hline Acenaphthylene & 10.00 & 17.00 \\
\hline Anthracene & 10.00 & 17.00 \\
\hline Benzo(a)anthracene & 10.00 & 17.00 \\
\hline Benzo(a)pyrene & 10.00 & 17.00 \\
\hline Benzo(b)fluoranthene & 10.00 & 17.00 \\
\hline Benzo(g,h,i)perylene & 10.00 & 17.00 \\
\hline Benzo(k)fluoranthene & 10.00 & 17.00 \\
\hline Butylbenzylphthalate & 10.00 & 17.00 \\
\hline Carbazole & 10.00 & 17.00 \\
\hline Chrysene & 10.00 & 17.00 \\
\hline Di-n-butylphthalate & 10.00 & 17.00 \\
\hline Di-n-octylphthalate & 10.00 & 17.00 \\
\hline
\end{tabular}


B12-52

Table B.7 (continued)

\begin{tabular}{|c|c|c|}
\hline Analyte & Minimum quantitation limit ${ }^{\mathrm{a}}$ & Maximum quantitation limit ${ }^{\mathrm{a}}$ \\
\hline Dibenzo(a,h)anthracene & 10.00 & 17.00 \\
\hline Dibenzofuran & 10.00 & 17.00 \\
\hline Diethylphthalate & 10.00 & 17.00 \\
\hline Dimethylphthalate & 10.00 & 17.00 \\
\hline Fluoranthene & 10.00 & 17.00 \\
\hline Fluorene & 10.00 & 17.00 \\
\hline Hexachlorobenzene & 10.00 & 17.00 \\
\hline Hexachlorobutadiene & 10.00 & 17.00 \\
\hline Hexachlorocyclopentadiene & 10.00 & 17.00 \\
\hline Hexachloroethane & 10.00 & 17.00 \\
\hline Indeno(1,2,3-c,d)pyrene & 10.00 & 17.00 \\
\hline Isophorone & 10.00 & 17.00 \\
\hline N-Nitroso-di-n-propylamine & 10.00 & 17.00 \\
\hline N-Nitrosodiphenylamine & 10.00 & 17.00 \\
\hline Naphthalene & 10.00 & 17.00 \\
\hline Nitrobenzene & 10.00 & 17.00 \\
\hline Pentachlorophenol & 25.00 & 42.00 \\
\hline Phenanthrene & 10.00 & 17.00 \\
\hline Phenol & 10.00 & 17.00 \\
\hline Pyrene & 10.00 & 17.00 \\
\hline Bis(2-Chloroethoxy)methane & 10.00 & 17.00 \\
\hline Bis(2-Chloroethyl)ether & 10.00 & 17.00 \\
\hline Bis(2-Ethylhexyl)phthalate & 10.00 & 17.00 \\
\hline
\end{tabular}


B12-53

Table B.7 (continued)

\begin{tabular}{|c|c|c|}
\hline Analyte & Minimum quantitation limit ${ }^{\mathrm{a}}$ & Maximum quantitation limit $^{2}$ \\
\hline \multicolumn{3}{|c|}{ Volatile Organics $(\mu \mathrm{g} / \mathrm{l})$} \\
\hline 1,1,1-Trichloroethane & 5.00 & 14.00 \\
\hline 1,1,2,2-Tetrachloroethane & 5.00 & 5.00 \\
\hline 1,1,2-Trichloroethane & 5.00 & 5.00 \\
\hline 1,1-Dichloroethane & 5.00 & 5.00 \\
\hline 1,1-Dichloroethene & 5.00 & 5.00 \\
\hline 1,2-Dichloroethane & 5.00 & 5.00 \\
\hline 1,2-Dichloroethene & 5.00 & 5.00 \\
\hline 1,2-Dichloropropane & 5.00 & 5.00 \\
\hline 2-Butanone & 10.00 & 10.00 \\
\hline 2-Hexanone & 10.00 & 10.00 \\
\hline 4-Methyl-2-Pentanone & 10.00 & 10.00 \\
\hline Acetone & 10.00 & 150.00 \\
\hline Benzene & 5.00 & 5.00 \\
\hline Bromodichloromethane & 5.00 & 5.00 \\
\hline Bromoform & 5.00 & 5.00 \\
\hline Bromomethane & 10.00 & 10.00 \\
\hline Carbon disulfide & 5.00 & 5.00 \\
\hline Carbon tetrachloride & 5.00 & 5.00 \\
\hline Chlorobenzene & 5.00 & 5.00 \\
\hline Chloroethane & 10.00 & 10.00 \\
\hline Chloroform & 5.00 & 5.00 \\
\hline Chloromethane & 10.00 & 10.00 \\
\hline Dibromochloromethane & 5.00 & 5.00 \\
\hline Ethylbenzene & 5.00 & 5.00 \\
\hline Methylene chloride & 5.00 & 58.00 \\
\hline Styrene & 5.00 & 5.00 \\
\hline Tetrachloroethene & 5.00 & 5.00 \\
\hline Toluene & 5.00 & 5.00 \\
\hline Trichloroethene & 5.00 & 5.00 \\
\hline Trichlorotrifluoromethane & 10.00 & 10.00 \\
\hline Vinyl chloride & 10.00 & 10.00 \\
\hline
\end{tabular}




\section{B12-54}

Table B.7 (continued)

\begin{tabular}{lcc}
\hline \multicolumn{1}{c}{ Analyte } & Minimum quantitation limit $^{\mathrm{a}}$ & Maximum quantitation limit $^{\mathrm{a}}$ \\
\hline Xylene, total & 5.00 & 5.00 \\
Cis-1,3-Dichloropropene & 5.00 & 5.00 \\
Trans-1,3-Dichloropropene & 5.00 & 5.00
\end{tabular}

\section{Radionuclides (pCi/l)}

Antimony-125

Americium-241

Bismuth-212

Cerium-144

Cesium-134

Cesium-137

Chromium-51

Cobalt-57

Cobalt-58

Cobalt- 60

Gross $\alpha$

Gross $\beta$

Iron-59

Manganese-54

Lead-212

Neptunium-237

Niobium-95

Potassium-40

Plutonium-238

Plutonium-239/240

Ruthenium-106

Thallium-208

Sodium-22

Strontium-90

Technetium-99

Thorium-228

Thorium-230 
B12-55

Table B.7 (continued)

\begin{tabular}{l}
\multicolumn{1}{c}{ Analyte } \\
\hline Thorium-232 \\
Uranium-234 \\
Uranium-235 \\
Uranium-238 \\
Zinc-65 \\
Zirconium-95
\end{tabular}

'Parameters which were never reported as less than the quantitation limit have no statistics for minimum or maximum quantitation limit 


\section{B12-56}

Table B.8. Groundwater sample intervals for groundwater collected during BCV OU 1 RIFA

\begin{tabular}{|c|c|}
\hline Sample ID & Sample interval (ft bgs) \\
\hline \multicolumn{2}{|c|}{$B Y B Y$} \\
\hline Y01616 & 16 to 18 \\
\hline Y02616 & 30 to 32 \\
\hline Y03616 & 33.5 to 35.5 \\
\hline Y04616 & 7 to 9 \\
\hline Y05616 & 18 to 20 \\
\hline Y06616 & 12.5 to 15.5 \\
\hline Y09616 & 9 to 12 \\
\hline \multicolumn{2}{|c|}{$O L F$} \\
\hline L01611 & 12 to 14 \\
\hline \multicolumn{2}{|c|}{$B C B G$} \\
\hline B01611 & 16 to 18 \\
\hline B02611 & 30 to 32 \\
\hline $\mathrm{B} 03611$ & 18 to 22 \\
\hline B04611 & 8 to 13 \\
\hline B05611 & 23 to 26.5 \\
\hline B12611 & 30 to 34 \\
\hline B13611 & 10 to 14.5 \\
\hline
\end{tabular}




\section{B12-57}

Table B.9. Technical sampling procedures used during BCV OU 4 RIFA

\begin{tabular}{llcc}
\hline $\begin{array}{c}\text { Procedure } \\
\text { number }\end{array}$ & \multicolumn{1}{c}{$\begin{array}{c}\text { Subject activity } \\
\text { Groundwater sampling } \\
\text { ESP-302-1 }\end{array}$} & Water level measurements using a water level indicator & Revision \\
\hline ESP-302-2 & Guidelines for well pumping & $9 / 26 / 94$ & 0 \\
ESP-302-3 & Using a bailer $\quad 9 / 26 / 94$ & 0 \\
ESP-302-4 & Using a gas-driven piston pump & $9 / 26 / 94$ & 0 \\
& $\quad$ Surface water sampling & $9 / 26 / 94$ & 0 \\
ESP-301-1 & Water sampling with a dipper & & \\
\hline
\end{tabular}




\section{Table B.10. List of minor changes to the BCV OU 4 RIFA}

\section{FCONO.}

DESCRIPTION OF CHANGE

OU4-001

Modifications to Appendix C (Environmental Restoration Program Sito

Specific Health and Safety Plan of the Remedial Investigation Work Plan

Specific Health and Safely Plany of the Remedial Investigation

DOEOPV01-1115\&D3). The attacted modfications show the revisions to

the Hazard Evaluation, Personal Protective Equipment, Training,

Monitoring, and spill response aspects of this plan.

OU4-002

Clarify the identities of Site Health and Safety Officer as described in

section 10.1 of the Remedial Investigation Work Plan for Bear Creek Valley

Operable Unit 4 (DOE/ORD1-1115\&D3). The stream water sampling task

performed by $Y-12$ personnel will be performed under the oversight of $Y-12$

health and safety personnel. In other words, Y-12 will supply an SHSO(s),

as needed, for this task. SAIC observers will comply with the

requirements of these $Y-12$ health and safety personnel. For the installation

of storm flow tubes performed by SAIC personnel and groundwater

sampling performed by $Y-12$ personnel will be carried out under the direct

oversight of SAIC health and safety personnel. Tasks that do not involve

any potential for significant hazard (site survey, data downloading, trace

testing) will be performed under general oversight of an SAIC SHSO bu

the SHSO will not be present at all times. The primary SAIC SHSO will be

Gary Seaver. The altemate SAIC SHSOs are Mike Crenshaw and Steve

Davis or other suitably trained personnel.

Modify section 10.7 of the Remedial Investigation Work Plan for Bear Creek Valley Operable Unit 4 (DOE/OR/01-1115\&D3) to require that

on-site workers use a buddy system.

OU4-004

Replace the use of ESP-800 Packaging Environmental Samples for

Transportation throughout the BC

Analysis through the K-25 and Y -12 Environmental Restoration Programs.

OU4-005

Change Field Blank Frequency to: [Surface Water - one per lot number of

ASTM water, one rinsate water at the start, middle, and end of sampling]

[Groundwater - one per lot number of ASTM water, one per event of rinsate

water] [Bromide - one per twenty ASTM water]. Change Equipment

Rinsate Blank Frequency to: [Surface water - one for grab sample

equipment per twenty samples, one for filtration equipment per twenty

samples, six initially from the dedicated samplers, two at the midpoint from

the dedicated samplers, two at the end from the dedicated samplers.]

Groundwater - one per twenty samples per event, two per event from the

filtration equipment.

OU4-006

Change the metals CRDL's to the following:

Thallium from $2 \mathrm{ppb}$ to $3 \mathrm{ppb}$

Arsenic from $2 \mathrm{ppb}$ to $3 \mathrm{ppb}$ 
Table B.10. (continued)

\begin{tabular}{|c|c|}
\hline FCO NO. & DESCRIPTION OF CHANGE \\
\hline OU4-008 & $\begin{array}{l}\text { Modification to Appendix C (Environmental Restoration Program Site } \\
\text { Specific Health and Safety Plan) of the Remedial lnvestigation Work Plan } \\
\text { (RIWP) for Bear Creek Valley Operable Unit } 4 \text { (BCV OU } 4 \text {, } \\
\text { bOEOORD1-1115 \& D3). Task } 7.2 \text { will also include intrusive in addition to } \\
\text { non-intrusive types of work. Intrusive work will be associated with the } \\
\text { installation and removal of stormflow tubes. }\end{array}$ \\
\hline OU4-009 & $\begin{array}{l}\text { Modify the Bear Creek Valley OU4 Work Plan to reduce groundwater } \\
\text { sampling from four quarters to two events. The list of wells remains the } \\
\text { same. }\end{array}$ \\
\hline OU4-010 & $\begin{array}{l}\text { Modification of the Sampling Plan in BCV OU4 RI Work Plan } \\
\text { (DOEORVO1-1115 \& D3). Add a surface water sampling point in the } \\
\text { uppermost reach of Bear Creek near the S-3 Ponds, at a new BCK } 12.5 \text {. } \\
\text { The sampling type at this location will be a grab sample, and sampling will } \\
\text { be camied out twice, once at high flow and once at low flow conditions. } \\
\text { Surface water will be analyzed for the same parameters as surface water } \\
\text { samples are being analyzed for in the current plan. }\end{array}$ \\
\hline OU4-011 & $\begin{array}{l}\text { Change to NCR reporting process as contained in section } 8 \text { of the RIWP: } \\
\text { When an NCR is recognized and documented on the NCR form, that form } \\
\text { will be submitted to the SAIC NCR Coordinator and the Y-12 ER BCV OU } 4 \\
\text { Project Management and QAS will be notified. The NCR Coordinator will } \\
\text { enter the infomation into the NCR database. }\end{array}$ \\
\hline OU4-012 & $\begin{array}{l}\text { Substitute GW- } 651 \text { for } \mathrm{GW}-118 \text { as a monitoring point for the pulse test } \\
\text { being performed at the Burial Grounds. }\end{array}$ \\
\hline OU4-013 & $\begin{array}{l}\text { Substitute GW- } 629 \text { for GW-117 as a monitoring point for the pulse test to } \\
\text { be performed at the Burial Grounds. }\end{array}$ \\
\hline OU4-014 & $\begin{array}{l}\text { Bear Creek Valley OU4 RIFA Work Plan states that handling of waste will } \\
\text { be described in procedure ESP-1000. Procedure ESP-1000 is not the most } \\
\text { current procedure, and will be replaced by ESP-105. }\end{array}$ \\
\hline OU4-015 & $\begin{array}{l}\text { Variances during the field sampling program from approved operating } \\
\text { procedures in the BCV OU4 AI Work Plan, SAP, AAPjP, or H\&S plan will } \\
\text { be documented through filing of a "Field Change Order (FCO)" accoroing } \\
\text { to procedure ER/C-P1719 "Controlling and Documenting Field Changes to } \\
\text { Approved Field Sampling Plans." }\end{array}$ \\
\hline OU4-016 & $\begin{array}{l}\text { Replace procedure TP-307-8 (LWA 1990) with ESP-307-1, ESP-307-2, } \\
\text { and ESP-307-8. }\end{array}$ \\
\hline OU4-018 & $\begin{array}{l}\text { Allow for the taking of surface water VOA grab samples by immersing the } \\
\text { sample container in the stream. A project specific procedure for this } \\
\text { sampling procedure will be generated, and will serve as an altemate } \\
\text { method to ESP-301-1, "Water Sampling Using a Dipper." }\end{array}$ \\
\hline
\end{tabular}




\begin{tabular}{|c|c|}
\hline FCO NO. & DESCRIPTION OF CHANGE \\
\hline OU4-019 & $\begin{array}{l}\text { Add procedure number ESP-308-1, "Composite Procedures" to the BCV } \\
\text { OU4 RIFA Procedure Manual. }\end{array}$ \\
\hline OU4-020 & $\begin{array}{l}\text { Change the well list for the Oil Landfarm Pulse Test. The Work Plan well } \\
\text { list was GW-073, GW-097, GW-098, GW-120, GW-225, GW-226, } \\
\text { GW-229, GW-368, GW-369 and GW-601. The revised list of Wells is as } \\
\text { follows: GW-537, GW-086, GW-085, GW-076, GW-225, GW-226, } \\
\text { GW-725, GW-736, GW-346 and GW-526. }\end{array}$ \\
\hline OU4-021 & $\begin{array}{l}\text { Metals analytes originally to be analyzed by GFAA will now be analyzed by } \\
\text { ICP Trace per APO approval of this methodology. quantitation limit goals } \\
\text { will not change. }\end{array}$ \\
\hline OU4-022 & Change mercury quantitation limit goal from $0.1 \mu \mathrm{g} /$ to $0.2 \mu \mathrm{g} /$. \\
\hline OU4-023 & $\begin{array}{l}\text { Change procedure number BCV OU4-353, Section } 6.3 \text { : During calibration } \\
\text { of pressure transducer, the deeper set point as outlined in } 6.3 .6 \text { should be } \\
\text { performed before the shallower set point outtined in } 6.3 .5 \text {. Also, it is not } \\
\text { necessary for transducer to equilibrate for a minimum of } 5 \text { minutes. The } \\
\text { transducers equilibrate in less than } 2 \text { minutes. Section } 6.4 .14 \text {. Delete this } \\
\text { section. Once the sensors have been installed, it is impossible to cap the } \\
\text { well. These changes are being incorporated in Revision } 1 \text { of this procedure. }\end{array}$ \\
\hline OU4-024 & $\begin{array}{l}\text { Procedure number BCV OU4-353, Section } 6.4 .12 \text { - For installations at } \\
\text { monitoring wells, excess cable will be coiled and hung from an } \\
\text { approximately } 1 \text { ft length of PVC pipe horizontally secured to the top of the } \\
\text { well casing. The data logger will be located on the concrete pad that } \\
\text { supports the casing stick-up. If the data logger is placed more than } 10 \mathrm{ft} \\
\text { from the well the sensors are installed in, but within the area secured by the } \\
\text { well's protective posts, the cables will be run through PVC pipe for the } \\
\text { length between the data logger and the well head. If the data logger must be } \\
\text { installed outside the area secured by the protective posts, the cable will be } \\
\text { buried in a } 6 \text { in. trench and flags placed along trench pathway. }\end{array}$ \\
\hline OU4-025 & $\begin{array}{l}\text { Modifications to section 7.4.5.3, Ecological data, on page 7-26 and Table } 7.5 \\
\text { on page 7.36 of the Remedial Investigation Work Plan (RIWP) for Bear } \\
\text { Creek Valley Operable Unit } 4 \text { (BCV OU4, DOE/ORV1-1115\&D3). Water } \\
\text { and fish samples from the Biological Monitoring and Abatement Program } \\
\text { (BMAP) reference site on Hinds Creek will be collected to provide } \\
\text { supplemental ecological data for the risk assessment. Water samples will } \\
\text { be collected for two toxicity tests and fish samples will be collected during } \\
\text { one sampling event. }\end{array}$ \\
\hline OU4-026 & $\begin{array}{l}\text { Modification to Table } 7.4 \text { (Numbers of samples and quality control for } \\
\text { water quality samples) on page } 7-26 \text { of the Remedial Investigation Work } \\
\text { Plan (RIWP) for Bear Creek Valley Operable Unit } 4 \text { (BCV OU4 } \\
\text { DOEROAO1-1115\&D3). Modificatons include the elimination of field } \\
\text { blanks and equipment rinsate blanks. The QC requirements for the toxicity } \\
\text { testing will include one field split sample trom a randomly selected test site } \\
\text { tor each of the two test periods. }\end{array}$ \\
\hline
\end{tabular}


Table B.10. (continued)

\begin{tabular}{|c|c|}
\hline FCO NO. & DESCRIPTION OF CHANGE \\
\hline OU4-027 & $\begin{array}{l}\text { A duplicalo ISCO water sampler at NT-3 did not collect enough water for a } \\
\text { duplicate sample that was scheduled to be taken at that site. There was } \\
\text { sufficient water collected by the dedicated sampler at the site to provide } \\
\text { sample volume for both the regular sample and the duplicats. The } \\
\text { duplicate sample was, therefore, a split sample. The sampling event } \\
\text { occurred on } 711994 \text {. (After review this FCO was deemed unecessany and } \\
\text { was cancelled) }\end{array}$ \\
\hline OU4-028 & $\begin{array}{l}\text { Modify the Bear Creek Valley OU4 Field Quality Assurance Project Plan } \\
\text { Section } 8.4 \text { Sample Custody Procedures, paragraph } 3 \text {, last sentence and } \\
\text { the Laboratory Quality Assurance Project Plan Section 9.4, first paragraph, } \\
\text { last sentence to read: "The BCV OU } 4 \text { project manager will be responsible } \\
\text { for ensuring that the original or a copy of the chain-ol-custody form is } \\
\text { submitted to the Document Management Center." }\end{array}$ \\
\hline OU4-029 & $\begin{array}{l}\text { Revise the list of wells to be monitored at the } S-3 \text { Pond Site for water level } \\
\text { elevation, temperature, and conductivity. The wells to be monitored will be: } \\
\text { GW-101, GW-122, GW-124, GW-345, GW-526, GW-615, GW-616. }\end{array}$ \\
\hline OU4-030 & $\begin{array}{l}\text { Change to required field apparel wom by SAIC field personnel involved in } \\
\text { surface water sampling. This change will allow wearing of shorts or } \\
\text { similar hot weather clothing as an option to company issued coveralls. } \\
\text { Field personnel handling preservatives (acids and bases) must wear a } \\
\text { chemical resistant apron in addition to splash prevention PPE originally } \\
\text { specified in the project Health and Safety Plan. }\end{array}$ \\
\hline OU4-031 & $\begin{array}{l}\text { Stormflow tubes will be downloaded and calibrated on a biweekly schedule } \\
\text { as opposed to weekly. In the week between the downloads, battery levels } \\
\text { and instrument checks will be performed to confirm datalogger operation. }\end{array}$ \\
\hline
\end{tabular}

OU4-032

Table 7.4 (Numbers of samples and quality control for water quality samples) on page 7-26 of the Remedial Investigation Work Plan (RIWP) for Bear Creek Valley Operable Unit 4 (BCV OU4, DOE/ORV01-1115\&D3) indicates numbers of environmental and quality control samples for the following categories:

Surface water/springs, Groundwater, Groundwater Tracer Test, and Ecological. (Continued on page 2). 
Table B.10. (continued)

\begin{tabular}{ll}
\hline FCO NO. & DESCRIPTION OF CHANGE \\
\hline OU4-033 & Change procedure number BCV OU4-353 Sections 1.0 and 2.0: \\
& The Hydrolab H20@ G Multiprobe which is used on BCV OU4 to \\
& measure and record specific conductance (conductivity) and \\
& temperature of groundwater in wells can also be used to record \\
& these parameters in surface water bodies such as streams, \\
& springs, and ponds. There is no change to the procedure with \\
& the exception of the following: In Section 6.4 where there is a \\
& reference to a well, add "or stream, spring, or pond sample \\
& site". Section 6.4 .4 and 6.4 .9 do not apply. Add to 6.4 .10 "If \\
& installing a probe into a stream, pond or spring, locate the \\
probe such that the sensor is covered with water."
\end{tabular}


Table B.11. List of activities completed for BCV OU 4 RIFA

\begin{tabular}{|c|c|c|c|c|c|}
\hline Group & Media & $\begin{array}{l}\text { Analysis } \\
\text { type }\end{array}$ & Sample type & Stations & Comments \\
\hline 1 & $\begin{array}{l}\text { Surface } \\
\text { water }\end{array}$ & Chemistry & $\begin{array}{l}\text { Flow proportional } \\
\text { composite }\end{array}$ & $\begin{array}{l}\text { NT-2, NT-3, NT-4, NT-5, } \\
\text { NT-6, NT-7, NT-8, } \\
\text { BCK 12.36, BCK 9.4, SS-1, } \\
\text { SS-4, SS-5, SS-6, SS-8 }\end{array}$ & $\begin{array}{l}\text { Filtered and unfiltered inorganics, volatile } \\
\text { organics, anions, and filtered and unfiltered } \\
\text { radiological. See Table B.12 for a } \\
\text { detailed list of analytes. }\end{array}$ \\
\hline 2 & $\begin{array}{l}\text { Surface } \\
\text { water }\end{array}$ & Chemistry & Grab & $\mathrm{BCK}-\mathrm{S} 3, \mathrm{SS}-6 \mathrm{~b}$ & $\begin{array}{l}\text { Filtered and unfiltered inorganics, volatile } \\
\text { organics, anions, and filtered and unfiltered } \\
\text { radiological. See Table B.12 for a } \\
\text { detailed list of analytes. }\end{array}$ \\
\hline 3 & $\begin{array}{l}\text { Surface } \\
\text { water }\end{array}$ & Chemistry & Continuous & NT-2, NT-3, SS-6 & Conductivity and temperature. \\
\hline 4 & $\begin{array}{l}\text { Surface } \\
\text { water }\end{array}$ & Chemistry & Grab & NT-2 & Conductivity profile. \\
\hline 5 & $\begin{array}{l}\text { Surface } \\
\text { water }\end{array}$ & Flow & Continuous & $\begin{array}{l}\text { NT-2, NT-3, NT-4, NT-5, } \\
\text { NT-6, NT-7, NT-8, } \\
\text { BCK 12.36, BCK 9.4, SS-1, } \\
\text { SS-4, SS-5, SS-6 }\end{array}$ & $\begin{array}{l}\text { See Table B. } 13 \text { for a list of monitoring } \\
\text { periods. }\end{array}$ \\
\hline 6 & Stormflow & Water level & Continuous & $\begin{array}{l}\text { SFT-1, SFT-2, SFT-3, SFT-4, } \\
\text { SFT-5, SFT-6 }\end{array}$ & $\begin{array}{l}\text { Monitored between March and October } \\
1994 .\end{array}$ \\
\hline 7 & Groundwater & Chemistry & Continuous & $\begin{array}{l}\text { GW-045, GW-053, GW-094, } \\
\text { GW-095, GW-126, GW-624, } \\
\text { GW-626, GW-629, GW-651. }\end{array}$ & $\begin{array}{l}\text { Conductivity and temperature. Burial } \\
\text { Grounds group of wells. See Table B.28 } \\
\text { for a list of monitoring periods. }\end{array}$ \\
\hline 8 & Groundwater & Water level & Continuous & $\begin{array}{l}\text { GW-045, GW-053, GW-094, } \\
\text { GW-095, GW-126, GW-624, } \\
\text { GW-626, GW-629, GW-651. }\end{array}$ & $\begin{array}{l}\text { Burial Grounds group of wells. See } \\
\text { Table B. } 28 \text { for a list of monitoring } \\
\text { periods. }\end{array}$ \\
\hline
\end{tabular}


Table B.11 continued

\begin{tabular}{|c|c|c|c|c|c|}
\hline Group & Media & $\begin{array}{l}\text { Analysis } \\
\text { type }\end{array}$ & Sample type & Stations & Comments \\
\hline 9 & Groundwater & Chemistry & Continuous & $\begin{array}{l}\text { GW-076, GW-085, GW-086, } \\
\text { GW-227, GW-228, GW-346, } \\
\text { GW-526, GW-537, GW-725, } \\
\text { GW-736. }\end{array}$ & $\begin{array}{l}\text { Conductivity and temperature. Oil } \\
\text { Landfarm group of wells. See Table B.28 } \\
\text { for a list of monitoring periods. }\end{array}$ \\
\hline 10 & Groundwater & Water level & Continuous & $\begin{array}{l}\text { GW-076, GW-085, GW-086, } \\
\text { GW-227, GW-228, GW-346, } \\
\text { GW-526, GW-537, GW-725, } \\
\text { GW-736. }\end{array}$ & $\begin{array}{l}\text { Oil Landfarm group of wells. See } \\
\text { Table B. } 28 \text { for a list of monitoring } \\
\text { periods. }\end{array}$ \\
\hline 11 & Groundwater & Chemistry & Continuous & $\begin{array}{l}\text { GW-101, GW-122, GW-124, } \\
\text { GW-345, GW-526, GW-615, } \\
\text { GW-616. }\end{array}$ & $\begin{array}{l}\text { Conductivity and temperature. S-3 Site } \\
\text { group of wells. See Table B.28 for a list } \\
\text { of monitoring periods. }\end{array}$ \\
\hline 12 & Groundwater & Water level & Continuous & $\begin{array}{l}\text { GW-101, GW-122, GW-124, } \\
\text { GW-345, GW-526, GW-615, } \\
\text { GW-616. }\end{array}$ & $\begin{array}{l}\text { S-3 Site group of wells. See Table B.28 } \\
\text { for a list of monitoring periods. }\end{array}$ \\
\hline 13 & Groundwater & Water level & Continuous & $\begin{array}{l}\text { GW-710, GW-711, GW-712, } \\
\text { GW-714. }\end{array}$ & $\begin{array}{l}\text { Western Picket group of wells. See } \\
\text { Table B. } 28 \text { for a list of monitoring } \\
\text { periods. }\end{array}$ \\
\hline
\end{tabular}


B12-65

Table B.12. List of analytes and reported quantitation limits for surface water in BCV OU 4

\begin{tabular}{|c|c|c|}
\hline Analyte & Minimum quantitation limit ${ }^{2}$ & Maximum quantitation limit $^{\mathrm{a}}$ \\
\hline \multicolumn{3}{|c|}{ Anions $(m g / l)$} \\
\hline Chloride & 1.00 & 1.00 \\
\hline Fluoride & 0.10 & 0.10 \\
\hline Nitrate/Nitrite (NO3/NO2-N) & 0.10 & 0.10 \\
\hline Sulfate & 5.00 & 20.00 \\
\hline \multicolumn{3}{|c|}{ Inorganics (dissolved, $\mu \mathrm{g} / \mathrm{l}$ ) } \\
\hline Aluminum & 16.50 & 235.00 \\
\hline Antimony & 1.30 & 2.90 \\
\hline Arsenic & 1.50 & 2.60 \\
\hline Barium & 49.10 & 173.00 \\
\hline Beryllium & 0.30 & 0.80 \\
\hline Cadmium & 0.80 & 11.80 \\
\hline \multicolumn{3}{|l|}{ Calcium } \\
\hline Chromium & 1.70 & 7.80 \\
\hline Cobalt & 2.10 & 7.20 \\
\hline Copper & 2.10 & 14.80 \\
\hline Iron & 4.80 & 260.00 \\
\hline Lead & 0.70 & 4.00 \\
\hline Lithium & 1.10 & 8.70 \\
\hline \multicolumn{3}{|l|}{ Magnesium } \\
\hline Manganese & 0.90 & 13.20 \\
\hline Mercury & 0.10 & 0.20 \\
\hline Molybdenum & 3.60 & 3.60 \\
\hline Nickel & 2.80 & 21.30 \\
\hline Selenium & 2.10 & 5.20 \\
\hline Silver & 2.40 & 4.10 \\
\hline Sodium & 1450.00 & 8020.00 \\
\hline Thallium & 1.70 & 3.70 \\
\hline Tin & 13.30 & 13.30 \\
\hline Vanadium & 2.10 & 17.10 \\
\hline Zinc & 2.00 & 19.70 \\
\hline \multicolumn{3}{|c|}{ Inorganics (total, $\mu \mathrm{g} / \mathrm{l}$ ) } \\
\hline Aluminum & 17.00 & 700.00 \\
\hline
\end{tabular}


B12-66

Table B.12 (continued)

\begin{tabular}{|c|c|c|}
\hline Analyte & Minimum quantitation limit ${ }^{\mathrm{a}}$ & Maximum quantitation limit $^{2}$ \\
\hline Antimony & 1.30 & 1.80 \\
\hline Arsenic & 1.50 & 2.60 \\
\hline Barium & 118.00 & 125.00 \\
\hline Beryllium & 0.30 & 0.61 \\
\hline Cadmium & 0.80 & 8.90 \\
\hline \multicolumn{3}{|l|}{ Calcium } \\
\hline Chromium & 1.70 & 11.40 \\
\hline Cobalt & 2.10 & 8.40 \\
\hline Copper & 2.10 & 26.30 \\
\hline Cyanide & 10.00 & 10.00 \\
\hline Iron & 6.30 & 357.00 \\
\hline Lead & 1.00 & 1.50 \\
\hline Lithium & 1.10 & 1.50 \\
\hline \multicolumn{3}{|l|}{ Magnesium } \\
\hline Manganese & 3.80 & 56.70 \\
\hline Mercury & 0.10 & 0.20 \\
\hline Molybdenum & 3.60 & 7.80 \\
\hline Nickel & 2.80 & 34.40 \\
\hline Potassium & 4910.00 & 4910.00 \\
\hline Selenium & 2.10 & 3.30 \\
\hline Silver & 2.40 & 4.10 \\
\hline Sodium & 2010.00 & 8030.00 \\
\hline Thallium & 1.70 & 3.30 \\
\hline $\operatorname{Tin}$ & 13.30 & 13.30 \\
\hline Vanadium & 2.10 & 18.60 \\
\hline Zinc & 3.60 & 58.00 \\
\hline \multicolumn{3}{|c|}{ Volatile Organics $(\mu g / l)$} \\
\hline 1,1,1-Trichloroethane & 5.00 & 5.00 \\
\hline 1,1,2,2-Tetrachloroethane & 5.00 & 10.00 \\
\hline 1,1,2-Trichloroethane & 5.00 & 10.00 \\
\hline 1,1-Dichloroethane & 5.00 & 5.00 \\
\hline 1,1-Dichloroethene & 5.00 & 5.00 \\
\hline 1,2-Dichlorobenzene & 5.00 & 10.00 \\
\hline
\end{tabular}


B12-67

Table B.12 (continued)

\begin{tabular}{|c|c|c|}
\hline Analyte & Minimum quantitation limit $^{\mathbf{a}}$ & Maximum quantitation limit ${ }^{\mathrm{a}}$ \\
\hline 1,2-Dichloroethane & 5.00 & 10.00 \\
\hline 1,2-Dichloroethene & 5.00 & 5.00 \\
\hline 1,2-Dichloropropane & 5.00 & 10.00 \\
\hline 1,3-Dichlorobenzene & 5.00 & 10.00 \\
\hline 1,4-Dichlorobenzene & 5.00 & 10.00 \\
\hline 2-Butanone & 5.00 & 10.00 \\
\hline 2-Hexanone & 5.00 & 10.00 \\
\hline 4-methyl-2-Pentanone & 4.00 & 10.00 \\
\hline Acetone & 5.00 & 41.00 \\
\hline Benzene & 5.00 & 10.00 \\
\hline Bromodichloromethane & 5.00 & 10.00 \\
\hline Bromoform & 5.00 & 10.00 \\
\hline Bromomethane & 5.00 & 10.00 \\
\hline Carbon disulfide & 5.00 & 10.00 \\
\hline Carbon tetrachloride & 5.00 & 10.00 \\
\hline Chlorobenzene & 5.00 & 10.00 \\
\hline Chloroethane & 5.00 & 10.00 \\
\hline Chloroform & 5.00 & 5.00 \\
\hline Chloromethane & 5.00 & 12.00 \\
\hline Dibromochloromethane & 5.00 & 10.00 \\
\hline Ethylbenzene & 5.00 & 10.00 \\
\hline Methylene chloride & 3.00 & 23.00 \\
\hline Styrene & 5.00 & 10.00 \\
\hline Tetrachloroethene & 5.00 & 5.00 \\
\hline Toluene & 5.00 & 10.00 \\
\hline Trichloroethene & 5.00 & 5.00 \\
\hline Trichlorofluoromethane & 5.00 & 10.00 \\
\hline Vinyl chloride & 5.00 & 5.00 \\
\hline Xylene, total & 5.00 & 10.00 \\
\hline cis-1,3-Dichloropropene & 5.00 & 10.00 \\
\hline \multirow{2}{*}{ trans-1,3-Dichloropropene } & 5.00 & 10.00 \\
\hline & Radionuclides (pCi/l) & \\
\hline
\end{tabular}

Americium-241 


\section{B12-68}

Table B.12 (continued)

\begin{tabular}{|c|c|c|}
\hline Analyte & Minimum quantitation limit ${ }^{\mathrm{a}}$ & Maximum quantitation limit ${ }^{\mathrm{a}}$ \\
\hline \multicolumn{3}{|l|}{ Curium-243 } \\
\hline \multicolumn{3}{|l|}{ Curium-244 } \\
\hline \multicolumn{3}{|l|}{ Cesium-137 } \\
\hline \multicolumn{3}{|l|}{ Plutinium-238 } \\
\hline \multicolumn{3}{|c|}{ Plutonium-239/240 } \\
\hline \multicolumn{3}{|l|}{ Strontium-90 } \\
\hline \multicolumn{3}{|l|}{ Technetium-99 } \\
\hline \multicolumn{3}{|l|}{ Thorium-228 } \\
\hline \multicolumn{3}{|l|}{ Thorium-230 } \\
\hline \multicolumn{3}{|l|}{ Thorium-232 } \\
\hline \multicolumn{3}{|l|}{ Uranium-234 } \\
\hline \multicolumn{3}{|l|}{ Uranium-235 } \\
\hline Uranium-238 & & \\
\hline
\end{tabular}

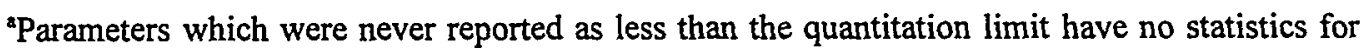
minimum or maximum quantitation limit 
Table B.13. Time periods and the stage to flow conversions for each surface water site in BCV OU 4

\begin{tabular}{|c|c|c|c|c|}
\hline \multirow{2}{*}{$\frac{\text { Site }}{\text { BCK } 12.6^{b}}$} & \multicolumn{2}{|c|}{$\begin{array}{l}\text { Monitoring period } \\
\text { Start End }\end{array}$} & \multirow{2}{*}{$\begin{array}{l}\text { Flow measurement } \\
\text { method } \\
5 \text {-ft diameter } \\
\text { corrugated pipe }\end{array}$} & \multirow{2}{*}{$\begin{array}{l}\text { Flow calculations }^{a} \\
\text { Manning }^{c}\end{array}$} \\
\hline & $3 / 29 / 94$ & $1 / 30 / 95$ & & \\
\hline NT-2 & $3 / 22 / 94$ & $1 / 30 / 95$ & 1.5-ft H-flume & $\mathrm{Q}(\mathrm{cfs})=2.11 \times \mathrm{h}^{2.31}$ \\
\hline NT-3 & $3 / 22 / 94$ & $1 / 30 / 95$ & $1.0-\mathrm{ft}$ H-flume & $\mathrm{Q}(\mathrm{cfs})=1.95 \times \mathrm{h}^{2.31}$ \\
\hline NT-4 & $5 / 31 / 94$ & $1 / 30 / 95$ & 1.0 -ft H-flume & $\mathrm{Q}(\mathrm{cfs})=1.95 \times \mathrm{h}^{2.31}$ \\
\hline NT-5 & $5 / 19 / 94$ & $1 / 30 / 95$ & 1.5-ft H-flume & $Q(\mathrm{cfs})=2.11 \times \mathrm{h}^{2.31}$ \\
\hline NT-6 & $3 / 22 / 94$ & $1 / 30 / 95$ & 2.0-ft H-flume & $\mathrm{Q}(\mathrm{cfs})=2.23 \times \mathrm{h}^{2.31}$ \\
\hline NT-7 & $3 / 29 / 94$ & $1 / 30 / 95$ & 2.0-ft H-flume & $\mathrm{Q}(\mathrm{cfs})=2.23 \times \mathrm{h}^{2.31}$ \\
\hline NT-8 & $6 / 2 / 94$ & $1 / 30 / 95$ & 2.0-ft H-flume & $\mathrm{Q}(\mathrm{cfs})=2.23 \times \mathrm{h}^{2.31}$ \\
\hline BCK 9.4 & $3 / 22 / 94$ & $1 / 30 / 95$ & Open channel & Rating curve $^{d}$ \\
\hline SS-1 & $5 / 19 / 94$ & $1 / 30 / 95$ & 1.0-ft H-flume & $\mathrm{Q}(\mathrm{cfs})=1.95 \times \mathrm{h}^{2.31}$ \\
\hline SS-4 & $5 / 19 / 94$ & $1 / 30 / 95$ & 2.0-ft H-flume & $\mathrm{Q}(\mathrm{cfs})=2.23 \times \mathrm{h}^{2.31}$ \\
\hline SS-5 & $5 / 19 / 94$ & $1 / 30 / 95$ & 1.5-ft H-flume & $\mathrm{Q}(\mathrm{cfs})=2.11 \times \mathrm{h}^{2.31}$ \\
\hline SS-6 & $5 / 19 / 94$ & $1 / 30 / 95$ & 1.0-ft H-flume & $\mathrm{Q}(\mathrm{cfs})=1.95 \times \mathrm{h}^{2.31}$ \\
\hline SS-8 & $5 / 19 / 94$ & $1 / 30 / 95$ & NA & \\
\hline
\end{tabular}

${ }^{a}$ For $\mathrm{H}$-flumes the stage to flow conversion is an empirical formula supplied by the manufacturer.

${ }^{b}$ At this site, flow is through two 5 -ft diameter corrugated pipes.

${ }^{c}$ Manning equation was used to calculate flow from stage:

$$
Q=\frac{1.49 \times A \times R^{2 / 3} \times S^{1 / 2}}{n}
$$

where:

$$
\begin{aligned}
& \mathrm{Q}=\text { the flow, } \\
& \mathrm{A}=\text { the cross-sectional area of flow, } \\
& \mathrm{R}=\text { the hydraulic radius defined as the ratio of } \mathrm{A} \text { to the total length of the wetted perimeter (see } \\
& \\
& \text { Fig. B.47), } \\
& \mathrm{S}=\text { the slope }(0.001), \\
& \mathrm{n}=\text { the Manning roughness coefficient }(0.017) .
\end{aligned}
$$

${ }^{d}$ The USGS-supplied rating curve for BCK 9.41 was used to convert stage to flow. See Table B.27 for the rating curve.

h - stream stage

cfs - cubic feet/second 
Table B.14. Flow monitoring periods, total flow, and average flow for the monitoring station at BCK 12.38

\begin{tabular}{|c|c|c|c|c|c|c|c|}
\hline Sample \# & Start Date & Start Time & End Date & End Time & Total Flow (cf) & Average Flow (cfs) & Average Flow $(\mathrm{L} / \mathrm{s})$ \\
\hline $1^{*}$ & 22-MAR-94 & $12: 00$ & 27-MAR-94 & $13: 15$ & 253436.97 & 1.16 & 32.89 \\
\hline 2 & 29-MAR-94 & $10: 25$ & 04-APR-94 & $03: 30$ & 241285.65 & 0.53 & 15.14 \\
\hline 3 & 05-APR-94 & $09: 20$ & 06-APR-94 & $14: 35$ & 177524.43 & 2.05 & 58.16 \\
\hline 4 & 07-APR-94 & $08: 25$ & 10-APR-94 & $10: 35$ & 118874.98 & 0.45 & 12.76 \\
\hline 5 & 12-APR-94 & $16: 55$ & 14-APR-94 & $07: 10$ & 112591.01 & 3.71 & 105.02 \\
\hline 6 & 16-APR-94 & $06: 05$ & 20-APR-94 & $05: 25$ & 197048.35 & 0.58 & 16.40 \\
\hline 7 & 20-APR-94 & $06: 40$ & 22-APR-94 & $06: 20$ & 61170.08 & 0.36 & 10.15 \\
\hline 8 & 24-APR-94 & $05: 45$ & 26-APR-94 & $06: 05$ & 48441.85 & 0.28 & 7.96 \\
\hline 9 & 20-MAY-94 & $06: 45$ & 24-MAY-94 & $07: 05$ & 42982.92 & 0.13 & 3.57 \\
\hline 10 & 26-MAY-94 & $07: 35$ & 31-MAY-94 & 09:05 & 48636.82 & 0.17 & 4.70 \\
\hline 11 & 03-JUN-94 & 08:00 & 07-JUN-94 & $08: 30$ & 41526.31 & 0.12 & 3.43 \\
\hline 12 & 14-JUN-94 & $12: 05$ & 16-JUN-94 & $06: 40$ & 4241.20 & 0.06 & 1.57 \\
\hline 13 & 16-JUN-94 & $07: 50$ & 21-JUN-94 & $07: 10$ & 49350.90 & 0.13 & 3.81 \\
\hline 14 & 23-JUN-94 & $07: 05$ & 26-JUN-94 & $21: 20$ & 40228.64 & 0.26 & 7.31 \\
\hline 15 & 03-JUL-94 & $07: 35$ & 07-JUL-94 & $07: 20$ & 14702.48 & 0.11 & 3.25 \\
\hline 16 & 07-JUL-94 & $11: 20$ & 12-JUL-94 & $07: 10$ & 10587.53 & 0.06 & 1.69 \\
\hline 17 & 15-JUL-94 & $05: 45$ & 19-JUL-94 & $18: 45$ & 56393.01 & 0.26 & 7.37 \\
\hline 18 & 08-AUG-94 & $15: 00$ & 11-AUG-94 & $07: 35$ & 22756.93 & 0.10 & 2.85 \\
\hline 19 & 29-SEP-94 & $05: 40$ & 04-ОСТ-94 & $13: 10$ & 35849.39 & 0.08 & 2.39 \\
\hline 20 & 21-JAN-95 & $06: 30$ & 24-JAN-95 & $08: 55$ & 57613.82 & 0.22 & 6.14 \\
\hline 21 & 27-JAN-95 & 19:05 & 28-JAN-95 & $16: 00$ & 60365.13 & 0.88 & 24.97 \\
\hline
\end{tabular}

* During this period only the north tunnel was operational. The average flow for the north tunnel was doubled to estimate the average flow for both tunnels 
Table B.15. Flow monitoring periods, total flow, and average flow for the monitoring station at NT-2

\begin{tabular}{|c|c|c|c|c|c|c|c|}
\hline Sample \# & Start Date & Start Time & End Date & End Time & Total Flow (cf) & Average Flow (cfs) & Average Flow $(\mathrm{L} / \mathrm{s})$ \\
\hline 1 & 22-MAR-94 & $10: 10$ & 27-MAR-94 & $06: 05$ & 180294.40 & 0.43 & 12.24 \\
\hline 2 & 29-MAR-94 & $11: 00$ & 04-APR-94 & $06: 55$ & 235526.48 & 0.47 & 13.24 \\
\hline 3 & 06-APR-94 & $06: 30$ & 06-APR-94 & $22: 20$ & 154557.65 & 2.71 & 76.79 \\
\hline 4 & 07-APR-94 & $10: 10$ & 11-APR-94 & 03:05 & 330169.67 & 1.03 & 29.21 \\
\hline 5 & 12-APR-94 & $17: 20$ & 12-APR-94 & $22: 05$ & 95666.90 & 5.59 & 158.44 \\
\hline 6 & 16-APR-94 & $07: 25$ & 20-APR-94 & $07: 30$ & 123039.57 & 0.36 & 10.07 \\
\hline 7 & 20-APR-94 & $07: 50$ & 22-APR-94 & $07: 15$ & 30369.47 & 0.18 & 5.04 \\
\hline 8 & 24-APR-94 & $07: 00$ & 26-APR-94 & $06: 30$ & 24332.81 & 0.14 & 4.03 \\
\hline 9 & 20-MAY-94 & $07: 35$ & 24-MAY-94 & $07: 00$ & 6345.59 & 0.02 & 0.52 \\
\hline 10 & 26-MAY-94 & $07: 20$ & 28-MAY-94 & $14: 15$ & 13881.01 & 0.07 & 1.99 \\
\hline 11 & 03-JUN-94 & $08: 25$ & 07-JUN-94 & $07: 45$ & 8947.09 & 0.03 & 0.74 \\
\hline 12 & 14-JUN-94 & $11: 25$ & $16-J U N-94$ & 09:20 & 7505.47 & 0.05 & 1.29 \\
\hline 13 & 16-JUN-94 & 09:55 & 21-JUN-94 & $06: 00$ & 8867.61 & 0.02 & 0.60 \\
\hline 14 & 23-JUN-94 & $06: 25$ & 26-JUN-94 & $13: 20$ & 16729.11 & 0.06 & 1.67 \\
\hline 15 & 03-JUL-94 & $07: 25$ & 07-JUL-94 & 08:00 & 1014.06 & 0.00 & 0.08 \\
\hline 16 & 07-JUL-94 & $08: 35$ & 11-JUL-94 & $13: 00$ & 2500.54 & 0.01 & 0.20 \\
\hline 17 & 15-JUL-94 & $06: 55$ & 15-JUL-94 & $19: 05$ & 9000.82 & 0.21 & 5.82 \\
\hline 18 & 08-AUG-94 & $16: 30$ & 11-AUG-94 & $07: 45$ & 1286.69 & 0.01 & 0.16 \\
\hline 19 & 29-SEP-94 & $07: 25$ & 03-ОСТ-94 & $08: 30$ & 1302.11 & 0.00 & 0.11 \\
\hline 20 & 21-JAN-95 & $08: 10$ & 24-JAN-95 & $06: 35$ & 16689.87 & 0.07 & 1.86 \\
\hline 21 & 27-JAN-95 & $08: 25$ & 28-JAN-95 & $13: 25$ & 45733.39 & 0.44 & 12.41 \\
\hline
\end{tabular}


Table B.16. Flow monitoring periods, total flow, and average flow for the monitoring station at NT-3

\begin{tabular}{|c|c|c|c|c|c|c|c|}
\hline Sample \# & Start Date & Start Time & End Date & End Time & Total Flow (cf) & Average Flow (cfs) & Average Flow (L/s) \\
\hline 1 & 22-MAR-94 & $13: 20$ & 27-MAR-94 & $07: 55$ & 142396.62 & 0.35 & 9.78 \\
\hline 2 & 29-MAR-94 & $11: 30$ & 02-APR-94 & $07: 10$ & 160015.81 & 0.48 & 13.73 \\
\hline 3 & 05-APR-94 & $09: 55$ & 06-APR-94 & $04: 25$ & 58375.01 & 0.88 & 24.82 \\
\hline 4 & 07-APR-94 & $11: 15$ & 10-APR-94 & $10: 35$ & 104611.75 & 0.41 & 11.54 \\
\hline 5 & 12-APR-94 & $17: 25$ & 13-APR-94 & $00: 35$ & 98120.51 & 3.80 & 107.70 \\
\hline 6 & 16-APR-94 & $07: 40$ & 20-APR-94 & $06: 50$ & 170090.48 & 0.50 & 14.06 \\
\hline 7 & 20-APR-94 & $09: 40$ & 22-APR-94 & $08: 05$ & 22610.47 & 0.14 & 3.83 \\
\hline 8 & 24-APR-94 & $07: 40$ & 26-APR-94 & $07: 20$ & 17405.67 & 0.10 & 2.87 \\
\hline 9 & 20-MAY-94 & $08: 50$ & 24-MAY-94 & $07: 45$ & 3927.76 & 0.01 & 0.33 \\
\hline $10^{*}$ & 26-MAY-94 & $08: 00$ & 31-MAY-94 & $08: 05$ & & 0.01 & 0.28 \\
\hline $11^{*}$ & 03-JUN-94 & $09: 40$ & 06-JUN-94 & $09: 00$ & & 0.00 & 0.02 \\
\hline $12 *$ & 15-JUN-94 & $08: 30$ & 16-JUN-94 & $09: 20$ & & 0.05 & 1.35 \\
\hline $13^{*}$ & 16-JUN-94 & $10: 00$ & 21-JUN-94 & $06: 55$ & & 0.02 & 0.71 \\
\hline 14 & 23-JUN-94 & $05: 45$ & 26-JUN-94 & $18: 55$ & 8429.96 & 0.03 & 0.78 \\
\hline 15 & 03-JUL-94 & 07:00 & 07-JUL-94 & $07: 15$ & 5215.68 & 0.02 & 0.43 \\
\hline 16 & 07-JUL-94 & $08: 45$ & 10-JUL-94 & $11: 55$ & 2659.26 & 0.01 & 0.28 \\
\hline 17 & 15-JUL-94 & $06: 10$ & 15-JUL-94 & $19: 05$ & 3803.10 & 0.08 & 2.32 \\
\hline 18 & 08-AUG-94 & $15: 50$ & 11-AUG-94 & $07: 05$ & 3073.31 & 0.01 & 0.38 \\
\hline $19 *$ & 30-SEP-94 & $04: 40$ & 03-OCT-94 & $09: 15$ & & 0.00 & 0.06 \\
\hline 20 & 21-JAN-95 & $09: 25$ & 24-JAN-95 & $16: 20$ & 32594.57 & 0.11 & 3.25 \\
\hline 21 & 27-JAN-95 & $09: 50$ & 28-JAN-95 & $15: 25$ & 42303.46 & 0.40 & 11.25 \\
\hline
\end{tabular}

* Flow not recorded electronically. Average flow calulated from field printouts. 
Table B.17. Flow monitoring periods, total flow, and average flow for the monitoring station at NT-4

\begin{tabular}{cllllrrr}
\hline Sample \# & Start Date & Start Time & End Date & End Time & Total Flow (cf) & Average Flow (cfs) & Average Flow (L/s) \\
\hline 1 & 26-MAY-94 & $08: 55$ & 28-MAY-94 & $06: 40$ & & 0.02 & 0.62 \\
2 & 03-JUN-94 & $09: 55$ & 06-JUN-94 & $10: 05$ & 867.14 & 0.00 & 0.09 \\
3 & 14-JUN-94 & $13: 20$ & 15-JUN-94 & $15: 35$ & 4525.49 & 0.05 & 1.36 \\
4 & 16-JUN-94 & $10: 15$ & 24-JUN-94 & $11: 10$ & 1587.48 & 0.00 & 0.11 \\
5 & 24-JUN-94 & $11: 20$ & 24-JUN-94 & $20: 20$ & 6610.73 & 0.21 & 5.83 \\
6 & 03-JUL-94 & $10: 25$ & 07-JUL-94 & $12: 35$ & 1524.67 & 0.00 & 0.14 \\
7 & 08-JUL-94 & $01: 30$ & 10-JUL-94 & $10: 00$ & 1200.11 & 0.01 & 0.17 \\
8 & 15-JUL-94 & $08: 30$ & 15-JUL-94 & $19: 55$ & 12419.89 & 0.30 & 8.56 \\
9 & 08-AUG-94 & $18: 15$ & 11-AUG-94 & $15: 10$ & 786.36 & 0.00 & 0.09 \\
$10 *$ & 29-SEP-94 & $9: 15$ & 03-OCT-94 & $09: 45$ & & 0.00 & 0.05 \\
11 & 21-JAN-95 & $10: 20$ & 24-JAN-95 & $10: 05$ & 13403.69 & 0.05 & 1.47 \\
12 & 27-JAN-95 & $10: 10$ & 28-JAN-95 & $09: 35$ & 40738.75 & 0.48 & 13.69 \\
\hline
\end{tabular}

* Flow not recorded electronically. Average flow calulated from field printouts. 
Table B.18. Flow monitoring periods, total flow, and average flow for the monitoring station at NT-5

\begin{tabular}{|c|c|c|c|c|c|c|c|}
\hline Sample \# & Start Date & Start Time & End Date & End Time & Total Flow (cf) & Average Flow (cfs) & Average Flow (L/s) \\
\hline 1 & 20-MAY-94 & $07: 30$ & 24-MAY-94 & $07: 15$ & 3557.82 & 0.01 & 0.29 \\
\hline 2 & 26-MAY-94 & $06: 55$ & 28-MAY-94 & $06: 35$ & 3731.71 & 0.02 & 0.62 \\
\hline 3 & 03-JUN-94 & $08: 05$ & 07-JUN-94 & $08: 25$ & 1831.58 & 0.01 & 0.15 \\
\hline 4 & 14-JUN-94 & $11: 55$ & 16-JUN-94 & $11: 00$ & 9769.09 & 0.06 & 1.63 \\
\hline 5 & 16-JUN-94 & $11: 40$ & 21-JUN-94 & $10: 25$ & 7262.76 & 0.02 & 0.48 \\
\hline 6 & 23-JUN-94 & $06: 00$ & 26-JUN-94 & $12: 55$ & 16424.33 & 0.06 & 1.64 \\
\hline 7 & 03-JUL-94 & $08: 05$ & 07-JUL-94 & $09: 30$ & 3258.30 & 0.01 & 0.26 \\
\hline 8 & 07-JUL-94 & $10: 35$ & 11-JUL-94 & $21: 10$ & 4381.96 & 0.01 & 0.32 \\
\hline 9 & 15-JUL-94 & $06: 40$ & 15-JUL-94 & 18:00 & 9515.60 & 0.23 & 6.60 \\
\hline 10 & 08-AUG-94 & $16: 40$ & 11-AUG-94 & $08: 00$ & 2526.17 & 0.01 & 0.31 \\
\hline 11 & 29-SEP-94 & $07: 30$ & 03-OCT-94 & $14: 35$ & 2846.25 & 0.01 & 0.22 \\
\hline 12 & 21-JAN-95 & 09:15 & 25-JAN-95 & $15: 05$ & 36550.13 & 0.10 & 2.82 \\
\hline 13 & 27-JAN-95 & $19: 20$ & 28-JAN-95 & $14: 25$ & 38180.64 & 0.56 & 15.74 \\
\hline
\end{tabular}


Table B.19. Flow monitoring periods, total flow, and average flow

for the monitoring station at NT-6

\begin{tabular}{|c|c|c|c|c|c|c|c|}
\hline Sample \# & Start Date & Start Time & End Date & End Time & Total Flow (cf) & Average Flow (cfs) & Average Flow (L/s) \\
\hline 1 & 24-MAR-94 & $10: 05$ & 27-MAR-94 & $05: 45$ & 111672.11 & 0.46 & 12.98 \\
\hline 2 & 29-MAR-94 & $14: 00$ & 03-APR-94 & $23: 30$ & 116192.13 & 0.25 & 7.06 \\
\hline 3 & 05-APR-94 & $13: 50$ & 05-APR-94 & $23: 40$ & 11702.88 & 0.33 & 9.36 \\
\hline 4 & 07-APR-94 & $13: 20$ & 10-APR-94 & $11: 35$ & 52369.41 & 0.21 & 5.86 \\
\hline 5 & 12-APR-94 & $17: 35$ & 12-APR-94 & $22: 15$ & 22592.23 & 1.34 & 38.08 \\
\hline 6 & 16-APR-94 & 08:00 & 20-APR-94 & $08: 45$ & 81509.69 & 0.23 & 6.63 \\
\hline 7 & 20-APR-94 & $12: 00$ & 21-APR-94 & $06: 00$ & 2026.61 & 0.03 & 0.89 \\
\hline 8 & 24-APR-94 & $07: 45$ & 26-APR-94 & $07: 20$ & 3245.71 & 0.02 & 0.54 \\
\hline $9 *$ & 20-MAY-94 & $10: 55$ & 24-MAY-94 & $09: 25$ & & 0.00 & 0.07 \\
\hline $10 *$ & 26-MAY-94 & 09:15 & 26-MAY-94 & $19: 00$ & & 0.07 & 2.09 \\
\hline $11 *$ & 03-JUN-94 & $11: 45$ & 06-JUN-94 & 09:30 & & 0.00 & 0.00 \\
\hline 12 & 14-JUN-94 & $13: 25$ & 15-JUN-94 & $16: 15$ & 1743.89 & 0.02 & 0.51 \\
\hline 13 & 16-JUN-94 & $13: 00$ & 20-JUN-94 & 09:15 & 606.37 & 0.00 & 0.05 \\
\hline 14 & 23-JUN-94 & $07: 45$ & 26-JUN-94 & $14: 15$ & 9753.97 & 0.03 & 0.98 \\
\hline 15 & 03-JUL-94 & $09: 45$ & 07-JUL-94 & $10: 20$ & 637.01 & 0.00 & 0.05 \\
\hline $16^{*}$ & 07-JUL-94 & $11: 05$ & 11-JUL-94 & $00: 50$ & & 0.00 & 0.08 \\
\hline $17^{*}$ & 15-JUL-94 & 08:10 & 15-JUL-94 & $18: 45$ & & 0.12 & 3.33 \\
\hline 18 & 08-AUG-94 & $18: 05$ & 11-AUG-94 & 09:30 & 290.93 & 0.00 & 0.04 \\
\hline 19 & 29-SEP-94 & $11: 15$ & 03-OCT-94 & $13: 10$ & 215.92 & 0.00 & 0.02 \\
\hline 20 & 21-JAN-95 & $10: 55$ & 24-JAN-95 & 01:35 & 8943.70 & 0.04 & 1.12 \\
\hline 21 & 27-JAN-95 & $10: 30$ & 28-JAN-95 & $11: 25$ & 39609.71 & 0.44 & 12.51 \\
\hline
\end{tabular}

* Flow not recorded electronically. Average flow calulated from field printouts. 
Table B.20. Flow monitoring periods, total flow, and average flow for the monitoring station at NT-7

\begin{tabular}{|c|c|c|c|c|c|c|c|}
\hline Sample \# & Start Date & Start Time & End Date & End Time & Total Flow (cf) & Average Flow (cfs) & Average Flow (L/s) \\
\hline $1^{*}$ & 22-MAR-94 & $17: 15$ & 27-MAR-94 & $04: 15$ & & 0.70 & 19.77 \\
\hline 2 & 01-APR-94 & $08: 20$ & 05-APR-94 & $13: 05$ & 39762.11 & 0.11 & 3.10 \\
\hline 3 & 05-APR-94 & $15: 15$ & 05-APR-94 & $23: 10$ & 34411.20 & 1.19 & 33.84 \\
\hline 4 & 07-APR-94 & $13: 55$ & 10-APR-94 & $11: 35$ & 38381.72 & 0.15 & 4.33 \\
\hline 5 & 12-APR-94 & $17: 45$ & 12-APR-94 & $23: 45$ & 45241.64 & 3.51 & 99.32 \\
\hline 6 & 16-APR-94 & $08: 15$ & 20-APR-94 & $08: 05$ & 76150.63 & 0.22 & 6.25 \\
\hline 7 & 20-APR-94 & $10: 30$ & 22-APR-94 & $09: 50$ & 6340.44 & 0.04 & 1.05 \\
\hline 8 & 24-APR-94 & $07: 50$ & 26-APR-94 & $09: 50$ & 3218.91 & 0.02 & 0.51 \\
\hline 9 & 20-MAY-94 & $09: 10$ & 24-MAY-94 & $10: 55$ & 2492.08 & 0.01 & 0.20 \\
\hline $10^{*}$ & 26-MAY-94 & $08: 45$ & 26-MAY-94 & $17: 50$ & & 0.22 & 6.35 \\
\hline 11 & 03-JUN-94 & $09: 35$ & 07-JUN-94 & $12: 35$ & 1117.53 & 0.00 & 0.09 \\
\hline 12 & 14-JUN-94 & $13: 40$ & 15-JUN-94 & $14: 10$ & 1538.14 & 0.02 & 0.49 \\
\hline 13 & 16-JUN-94 & $13: 30$ & 21-JUN-94 & $09: 50$ & 2826.10 & 0.01 & 0.19 \\
\hline 14 & 23-JUN-94 & $07: 50$ & 24-JUN-94 & $17: 20$ & 4487.48 & 0.04 & 1.05 \\
\hline $15^{*}$ & 03-JUL-94 & $10: 05$ & 07-JUL-94 & $10: 40$ & & 0.00 & 0.00 \\
\hline 16 & 07-JUL-94 & $11: 15$ & 11-JUL-94 & $13: 25$ & 4272.96 & 0.01 & 0.34 \\
\hline 17 & 15-JUL-94 & $08: 45$ & 15-JUL-94 & $19: 05$ & 20452.27 & 0.55 & 15.57 \\
\hline $18 *$ & 08-AUG-94 & $18: 45$ & 11-AUG-94 & $10: 25$ & & 0.00 & 0.00 \\
\hline $19 *$ & 29-SEP-94 & $09: 05$ & 03-OCT-94 & $12: 05$ & & 0.00 & 0.00 \\
\hline 20 & 21-JAN-95 & $10: 05$ & 24-JAN-95 & $09: 50$ & 7292.24 & 0.03 & 0.80 \\
\hline 21 & 27-JAN-95 & $10: 00$ & 28-JAN-95 & $07: 20$ & 27016.95 & 0.35 & 9.96 \\
\hline
\end{tabular}

* Flow not recorded electronically. Average flow calulated from field printouts. 
Table B.21. Flow monitoring periods, total flow, and average flow

for the monitoring station at NT-8

\begin{tabular}{clllllr}
\hline Sample \# & Start Date & Start Time & End Date & End Time & Total Flow (cf) & Average Flow (cfs) Average Flow (L/s) \\
\hline $1^{*}$ & 26-MAY-94 & $09: 00$ & Timed - 40 min & & & \\
2 & 03-JUN-94 & $08: 45$ & 07-JUN-94 & $11: 55$ & 4745.58 & 0.01 \\
3 & 14-JUN-94 & $12: 55$ & 16-JUN-94 & $15: 40$ & 3408.42 & 0.02 \\
4 & 16-JUN-94 & $16: 25$ & 21-JUN-94 & $11: 10$ & 4864.57 & 0.01 \\
5 & 23-JUN-94 & $07: 05$ & 24-JUN-94 & $18: 25$ & 8853.25 & 0.07 \\
$6^{*}$ & 03-JUL-94 & $09: 30$ & 07-JUL-94 & $12: 55$ & & 0.33 \\
$7^{*}$ & 07-JUL-94 & $13: 30$ & 11-JUL-94 & $19: 30$ & & \\
$8^{*}$ & 15-JUL-94 & $07: 55$ & 16-JUL-94 & $18: 35$ & & \\
9 & 08-AUG-94 & $17: 55$ & 11-AUG-94 & $11: 00$ & 557.16 & 0.00 \\
10 & 29-SEP-94 & $07: 40$ & 03-OCT-94 & $10: 55$ & 503.89 & 0.00 \\
11 & 21-JAN-95 & $09: 25$ & 24-JAN-95 & $12: 05$ & 27724.78 & 0.07 \\
12 & 27-JAN-95 & $09: 15$ & 28-JAN-95 & $06: 55$ & 27013.97 & 0.07 \\
\hline
\end{tabular}

* Flowmeter malfunction resulted in no flow record for this time period 
Table B.22. Flow monitoring periods, total flow, and average flow for the monitoring station at BCK 9.47

\begin{tabular}{|c|c|c|c|c|c|c|c|}
\hline Sample \# & Start Date & Start Time & End Date & End Time & Total Flow (cf) & Average Flow (cfs) & Average Flow (L/s) \\
\hline 1 & 23-MAR-94 & $16: 15$ & 27-MAR-94 & 05:05 & 1765423.56 & 5.78 & 163.71 \\
\hline 2 & 29-MAR-94 & $16: 15$ & 31-MAR-94 & $08: 30$ & 1215668.05 & 8.39 & 237.60 \\
\hline 3 & 31-MAR-94 & 09:15 & 03-APR-94 & $14: 45$ & 1251661.04 & 4.49 & 127.05 \\
\hline 4 & 05-APR-94 & $15: 55$ & 06-APR-94 & $00: 40$ & 567102.64 & 18.00 & 509.85 \\
\hline 5 & 07-APR-94 & $14: 35$ & 10-APR-94 & $11: 15$ & 987316.38 & 3.99 & 113.11 \\
\hline 6 & 12-APR-94 & $14: 05$ & 12-APR-94 & $22: 30$ & 2369073.41 & 77.42 & 2192.55 \\
\hline 7 & 16-APR-94 & 06:45 & 19-APR-94 & $19: 45$ & 2267823.13 & 7.41 & 209.88 \\
\hline 8 & 20-APR-94 & 13:00 & 22-APR-94 & 10:05 & 350530.77 & 2.16 & 61.16 \\
\hline 9 & 24-APR-94 & 08:05 & 26-APR-94 & $10: 25$ & 246698.33 & 1.36 & 38.56 \\
\hline 10 & 20-MAY-94 & 09:10 & 25-MAY-94 & 07:15 & 112261.45 & 0.26 & 7.48 \\
\hline 11 & 26-MAY-94 & 09:20 & 31-MAY-94 & $06: 55$ & 126110.03 & 0.30 & 8.44 \\
\hline 12 & 03-JUN-94 & $09: 15$ & 06-JUN-94 & $08: 45$ & 46951.82 & 0.18 & 5.17 \\
\hline $13 *$ & 15-JUN-94 & $12: 10$ & 16-JUN-94 & $16: 35$ & & & \\
\hline 14 & 16-JUN-94 & $17: 10$ & 20-JUN-94 & $06: 35$ & 42128.92 & 0.25 & 7.05 \\
\hline 15 & 23-JUN-94 & 07:55 & 26-JUN-94 & $20: 35$ & 380563.23 & 1.25 & 35.36 \\
\hline 16 & 03-JUL-94 & $10: 15$ & 07-JUL-94 & $13: 35$ & 80121.76 & 0.22 & 6.35 \\
\hline 17 & 07-JUL-94 & $15: 00$ & 11-JUL-94 & $17: 25$ & 88519.77 & 0.25 & 7.07 \\
\hline 18 & 15-JUL-94 & $08: 25$ & 15-JUL-94 & $21: 15$ & 178234.89 & 3.86 & 109.26 \\
\hline $19 *$ & 08-AUG-94 & $18: 45$ & 11-AUG-94 & $12: 30$ & & & \\
\hline 20 & 29-SEP-94 & 08:45 & 03-OCT-94 & $13: 40$ & 63262.05 & 0.17 & 4.93 \\
\hline 21 & 21-JAN-95 & $10: 25$ & 24-JAN-95 & $12: 20$ & 98860.27 & 0.54 & 15.25 \\
\hline 22 & 27-JAN-95 & $09: 40$ & 28-JAN-95 & $22: 10$ & 688576.14 & 5.24 & 148.41 \\
\hline
\end{tabular}

* Flowmeter malfunction resulted in no flow record for this time period 
Table B.23. Flow monitoring periods, total flow, and average flow for the monitoring station at SS-1

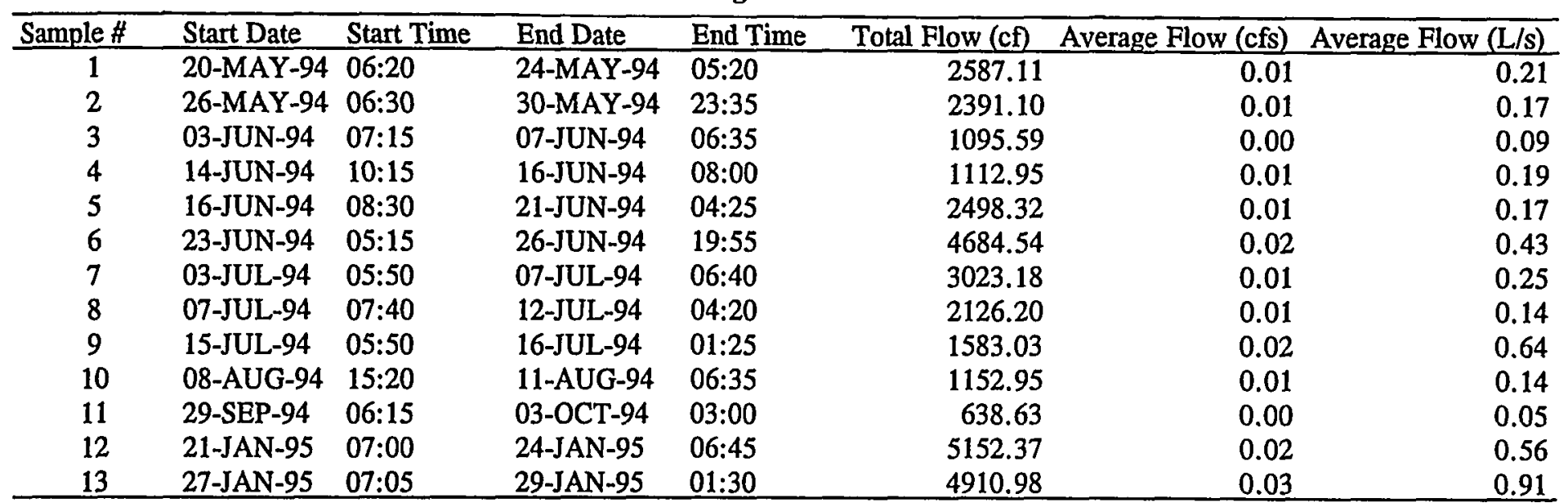


Table B.24. Flow monitoring periods, total flow, and average flow for the monitoring station at SS-4

\begin{tabular}{|c|c|c|c|c|c|c|c|}
\hline Sample \# & Start Date & Start Time & End Date & End Time & Total Flow (cf) & Average Flow (cfs) & Average Flow $(\mathrm{L} / \mathrm{s})$ \\
\hline 1 & 20-MAY-94 & $07: 45$ & 24-MAY-94 & $07: 40$ & 62033.50 & 0.18 & 5.09 \\
\hline 2 & 26-MAY-94 & $07: 25$ & 31-MAY-94 & $00: 35$ & 62377.25 & 0.15 & 4.34 \\
\hline 3 & 03-JUN-94 & $08: 15$ & 07-JUN-94 & $08: 50$ & 45364.00 & 0.13 & 3.69 \\
\hline 4 & 14-JUN-94 & $12: 10$ & 16-JUN-94 & $11: 50$ & 33095.95 & 0.19 & 5.46 \\
\hline 5 & 16-JUN-94 & $12: 35$ & 21-JUN-94 & $07: 30$ & 75927.90 & 0.18 & 5.20 \\
\hline 6 & 23-JUN-94 & $06: 25$ & 27-JUN-94 & $10: 25$ & 82996.93 & 0.23 & 6.53 \\
\hline 7 & 03-JUL-94 & $08: 35$ & 07-JUL-94 & $09: 45$ & 64137.49 & 0.18 & 5.19 \\
\hline 8 & 07-JUL-94 & $10: 35$ & 12-JUL-94 & $07: 35$ & 64468.59 & 0.15 & 4.33 \\
\hline 9 & 15-JUL-94 & $07: 05$ & 16-JUL-94 & $19: 10$ & 33620.77 & 0.26 & 7.33 \\
\hline 10 & 08-AUG-94 & $16: 45$ & 11-AUG-94 & $03: 15$ & 31376.52 & 0.15 & 4.22 \\
\hline 11 & 29-SEP-94 & $09: 25$ & 03-OCT-94 & $08: 50$ & 32001.93 & 0.09 & 2.64 \\
\hline 12 & 21-JAN-95 & $08: 45$ & 24-JAN-95 & $09: 05$ & 93191.22 & 0.36 & 10.14 \\
\hline 13 & 27-JAN-95 & $08: 45$ & 30-JAN-95 & $05: 40$ & 81838.63 & 0.33 & 9.34 \\
\hline
\end{tabular}


Table B.25. Flow monitoring periods, total flow, and average flow for the monitoring station SS-5

\begin{tabular}{cllllrrr}
\hline Sample \# & Start Date & Start Time & End Date & End Time & Total Flow (cf) & Average Flow (cfs) & Average Flow (L/s) \\
\hline 1 & 20-MAY-94 & $08: 35$ & 24-MAY-94 & $11: 00$ & 100482.64 & 0.28 & 8.03 \\
2 & 26-MAY-94 & $08: 25$ & 31-MAY-94 & $13: 00$ & 106123.63 & 0.24 & 6.71 \\
3 & 03-JUN-94 & $09: 00$ & 07-JUN-94 & $12: 45$ & 62245.43 & 0.17 & 4.91 \\
$4^{*}$ & 14-JUN-94 & $14: 00$ & 16-JUN-94 & $15: 00$ & & 0.30 & 8.42 \\
$5^{*}$ & 16-JUN-94 & $15: 40$ & 21-JUN-94 & $10: 05$ & & 0.24 & 6.81 \\
6 & 23-JUN-94 & $07: 25$ & 26-JUN-94 & $21: 00$ & 120253.08 & 0.39 & 11.05 \\
7 & 03-JUL-94 & $09: 55$ & 07-JUL-94 & $13: 05$ & 79003.76 & 0.22 & 6.27 \\
8 & 07-JUL-94 & $13: 55$ & 12-JUL-94 & $11: 15$ & 77770.33 & 0.18 & 5.21 \\
9 & 15-JUL-94 & $08: 05$ & 16-JUL-94 & $14: 15$ & 36998.24 & 0.34 & 9.65 \\
10 & 08-AUG-94 & $18: 20$ & 11-AUG-94 & $11: 50$ & 50204.00 & 0.21 & 6.03 \\
11 & 29-SEP-94 & $08: 20$ & 03-OCT-94 & $11: 55$ & 65654.59 & 0.18 & 5.19 \\
12 & 21-JAN-95 & $09: 45$ & 24-JAN-95 & $12: 40$ & 217218.80 & 0.81 & 22.81 \\
13 & 27-JAN-95 & $10: 10$ & 29-JAN-95 & $10: 35$ & 146734.43 & 0.84 & 23.84 \\
\hline
\end{tabular}

* Flow not recorded electronically. Average flow calulated from field printouts. 
Table B.26. Flow monitoring periods, total flow, and average flow for the monitoring station at SS-6

\begin{tabular}{|c|c|c|c|c|c|c|c|}
\hline Sample \# & Start Date & Start Time & End Date & End Time & Total Flow (cf) & Average Flow (cfs) & Average Flow $(\mathrm{L} / \mathrm{s})$ \\
\hline 1 & 20-MAY-94 & $09: 10$ & 25-MAY-94 & $07: 15$ & 15990.89 & 0.04 & 1.07 \\
\hline $2 *$ & 26-MAY-94 & $09: 20$ & 31-MAY-94 & $06: 45$ & & 0.04 & 1.22 \\
\hline 3 & 03-JUN-94 & $09: 20$ & 06-JUN-94 & $08: 45$ & 5106.53 & 0.02 & 0.56 \\
\hline $4^{*}$ & 15-JUN-94 & $14: 10$ & 16-JUN-94 & $17: 25$ & & 0.03 & 0.77 \\
\hline $5^{*}$ & 16-JUN-94 & $17: 10$ & 20-JUN-94 & $06: 30$ & & 0.02 & 0.68 \\
\hline 6 & 23-JUN-94 & 09:55 & 26-JUN-94 & $22: 35$ & 5147.79 & 0.03 & 0.88 \\
\hline 7 & 03-JUL-94 & $10: 15$ & 07-JUL-94 & $13: 30$ & 3659.84 & 0.01 & 0.29 \\
\hline 8 & 07-JUL-94 & $15: 05$ & 11-JUL-94 & $17: 25$ & 2498.64 & 0.01 & 0.21 \\
\hline 9 & 15-JUL-94 & $08: 25$ & 15-JUL-94 & $21: 15$ & 1692.93 & 0.04 & 1.04 \\
\hline 10 & 08-AUG-94 & $18: 45$ & 11-AUG-94 & $12: 35$ & 357.52 & 0.00 & 0.05 \\
\hline $11^{*}$ & 29-SEP-94 & $08: 45$ & 03-ОCT-94 & $13: 35$ & & 0.00 & 0.00 \\
\hline 12 & 21-JAN-95 & $10: 25$ & 24-JAN-95 & $12: 20$ & 75874.48 & 0.29 & 8.08 \\
\hline 13 & 27-JAN-95 & $09: 40$ & 28-JAN-95 & $22: 10$ & 31216.19 & 0.24 & 6.73 \\
\hline
\end{tabular}

* Flow not recorded electronically. Average flow calulated from field printouts. 
B12-83

Table B.27. Rating curve for Bear Creek at BCK 9.47

\begin{tabular}{|c|c|c|c|}
\hline Stage (ft) & Flow (cfs) & Stage (ft) & Flow (cfs) \\
\hline 0.0 & 0.000 & 2.6 & 101.6 \\
\hline 0.85 & 0.155 & 2.7 & 114.8 \\
\hline 0.87 & 0.171 & 2.8 & 129.1 \\
\hline 0.9 & 0.177 & 2.9 & 144.7 \\
\hline 1.0 & 0.285 & 3.0 & 161.5 \\
\hline 1.1 & 0.98 & 3.1 & 179.6 \\
\hline 1.2 & 2.16 & 3.2 & 199.0 \\
\hline 1.3 & 4.43 & 3.3 & 219.9 \\
\hline 1.4 & 7.40 & 3.4 & 242.2 \\
\hline 1.5 & 11.12 & 3.5 & 266.0 \\
\hline 1.6 & 15.72 & 3.6 & 291.5 \\
\hline 1.7 & 20.90 & 3.7 & 318.5 \\
\hline 1.8 & 26.99 & 3.8 & 347.2 \\
\hline 1.9 & 34.37 & 3.9 & 377.7 \\
\hline 2.0 & 42.05 & 4.0 & 410.0 \\
\hline 2.1 & 49.61 & 4.1 & 442.5 \\
\hline 2.2 & 58.07 & 4.2 & 476.7 \\
\hline 2.3 & 67.50 & 4.3 & 512.7 \\
\hline 2.4 & 77.95 & 4.4 & 550.0 \\
\hline 2.5 & 89.45 & 4.5 & 586.0 \\
\hline
\end{tabular}




\section{B12-84}

Table B.28. List of monitoring wells and monitoring periods for BCV OU 4 RIFA head monitoring activities

\begin{tabular}{|c|c|c|c|c|c|c|}
\hline Well & $\begin{array}{l}\text { Depth } \\
\text { (ft bgs) }\end{array}$ & Formation & $\begin{array}{l}\text { Start } \\
\text { monitoring }\end{array}$ & $\begin{array}{l}\text { End } \\
\text { monitoring }\end{array}$ & $\begin{array}{l}\text { Pressure head } \\
\text { measurement }\end{array}$ & $\begin{array}{l}\mathrm{K} / \mathrm{T}^{a} \\
\text { measurement }\end{array}$ \\
\hline \multicolumn{7}{|c|}{$B C B G$} \\
\hline GW-045 & 15.2 & $\mathrm{Cn}$ & $3 / 15 / 94$ & $4 / 18 / 95$ & $\mathrm{X}$ & $\mathrm{X}$ \\
\hline GW-053 & 39.7 & $\mathrm{Cm}$ & $3 / 15 / 94$ & $4 / 18 / 95$ & $\mathrm{X}$ & $X$ \\
\hline GW-094 & 131 & $\mathrm{Cm}$ & $3 / 14 / 94$ & $4 / 18 / 95$ & $X$ & $X$ \\
\hline GW-095 & 156 & $\mathrm{Cm}$ & $3 / 15 / 94$ & $4 / 18 / 95$ & $X$ & $X$ \\
\hline GW-126 & 105 & $\mathrm{Cn}$ & $3 / 14 / 94$ & $4 / 18 / 95$ & $X$ & $X$ \\
\hline GW-624 & 27.2 & $\mathrm{Cn}$ & $3 / 15 / 94$ & $4 / 18 / 95$ & $X$ & $X$ \\
\hline GW-626 & 78 & $\mathrm{Cn}$ & $3 / 19 / 94$ & $4 / 18 / 95$ & $X$ & $X$ \\
\hline GW-629 & 262.3 & $\mathrm{Cn}$ & $3 / 14 / 94$ & $4 / 18 / 95$ & $X$ & $X$ \\
\hline GW-651 & 52 & $\mathrm{Cm}$ & $3 / 14 / 94$ & $4 / 18 / 95$ & $\mathrm{X}$ & $\mathrm{X}$ \\
\hline \multicolumn{7}{|c|}{$O L F$} \\
\hline GW-076 & 81 & $\mathrm{Cn}$ & $4 / 28 / 94$ & $6 / 2 / 94$ & $\mathrm{X}$ & $\mathrm{X}$ \\
\hline GW-085 & 62 & $\mathrm{Cn}$ & $5 / 3 / 94$ & $6 / 1 / 94$ & $X$ & \\
\hline GW-086 & 33.5 & $\mathrm{Cn}$ & $5 / 3 / 94$ & $6 / 1 / 94$ & $X$ & $\mathrm{X}$ \\
\hline GW-227 & 30 & $\mathrm{Cm}$ & $4 / 28 / 94$ & $5 / 30 / 94$ & $X$ & $X$ \\
\hline GW-228 & 80 & $\mathrm{Cm}$ & $4 / 27 / 94$ & $5 / 29 / 94$ & $X$ & $\mathrm{X}$ \\
\hline GW-346 & 65 & $\mathrm{Cn}$ & $4 / 29 / 94$ & $6 / 3 / 94$ & $X$ & $X$ \\
\hline GW-526 & 101 & $\mathrm{Cn}$ & $4 / 28 / 94$ & $6 / 2 / 94$ & $\mathrm{X}$ & $\mathrm{X}$ \\
\hline GW-537 & 24.5 & $\mathrm{Cn}$ & $5 / 3 / 94$ & $5 / 30 / 94$ & $\mathrm{X}$ & $X$ \\
\hline GW-725 & 132.5 & $\mathrm{Cm}$ & $5 / 2 / 94$ & $6 / 3 / 94$ & $X$ & $X$ \\
\hline GW-736 & 102 & $\mathrm{Cm}$ & $5 / 2 / 94$ & $6 / 2 / 94$ & $X$ & $X$ \\
\hline \multicolumn{7}{|c|}{ S-3 Site Group } \\
\hline GW-101 & 17.5 & $\mathrm{Cn}$ & $7 / 18 / 94$ & $8 / 4 / 94$ & $\mathrm{X}$ & $\mathrm{X}$ \\
\hline GW-122 & 92 & $\mathrm{Cm}$ & $7 / 8 / 94$ & $8 / 4 / 94$ & $\mathrm{X}$ & $\mathrm{X}$ \\
\hline GW-124 & 100 & $\mathrm{Cm}$ & $7 / 5 / 94$ & $8 / 4 / 94$ & $\mathrm{X}$ & $\mathrm{X}$ \\
\hline GW-345 & 26 & $\mathrm{Cn}$ & $7 / 8 / 94$ & $8 / 4 / 94$ & $\mathrm{X}$ & $\mathrm{X}$ \\
\hline GW-526 & 101 & $\mathrm{Cn}$ & $7 / 8 / 94$ & $8 / 4 / 94$ & $\mathrm{X}$ & $\mathrm{X}$ \\
\hline
\end{tabular}


B12-85

Table B.28 continued

\begin{tabular}{lllllcc}
\hline Well & $\begin{array}{l}\text { Depth } \\
\text { (ft bgs) }\end{array}$ & Formation & $\begin{array}{l}\text { Start } \\
\text { monitoring }\end{array}$ & $\begin{array}{l}\text { End } \\
\text { monitoring }\end{array}$ & $\begin{array}{l}\text { Pressure head } \\
\text { measurement }\end{array}$ & $\begin{array}{l}\mathrm{K} / \mathrm{T}^{a} \\
\text { measurement }\end{array}$ \\
\hline GW-615 & 222 & $\mathrm{Cn}$ & $7 / 8 / 94$ & $8 / 4 / 94$ & $\mathrm{X}$ & $\mathrm{X}$ \\
GW-616 & 219 & $\mathrm{Cn}$ & $\begin{array}{c}7 / 8 / 94 \\
\text { Western Picket }\end{array}$ & $8 / 4 / 94$ & $\mathrm{X}$ & $\mathrm{X}$ \\
& & & $11 / 1 / 94$ & $1 / 4 / 95$ & $\mathrm{X}$ & \\
GW-710 & 539 & $\mathrm{Cm}$ & $11 / 1 / 94$ & $1 / 4 / 95$ & $\mathrm{X}$ & \\
GW-711 & 616 & $\mathrm{Cm}$ & $11 / 1 / 94$ & $1 / 4 / 95$ & $\mathrm{X}$ & \\
GW-712 & 451 & $\mathrm{Cm}$ & $11 / 1 / 94$ & $1 / 4 / 95$ & $\mathrm{X}$ & \\
GW-713 & 305 & $\mathrm{Cm}$ & $11 / 3 / 94$ & $1 / 4 / 95$ & $\mathrm{X}$ & \\
GW-714 & 113 & $\mathrm{Cm}$ & $11 / 3 / 94$ & $1 / 4 / 95$ & $\mathrm{X}$ & \\
GW-715 & 75 & $\mathrm{Cm}$ & & &
\end{tabular}

${ }^{a}$ Indicates that water conductivity and temperature were monitored.

Cn - Nolichucky Shale

$\mathrm{Cm}$ - Maynardville Limestone

bgs - below ground surface 
Table B.29. List of minor changes to the BCV FPSS field activities

\begin{tabular}{|c|c|c|}
\hline FCO NO. & DATE ISSUED & DESCRIPTION OF CHANGE \\
\hline BCVFPSS-001 & $3 / 27 / 95$ & $\begin{array}{l}\text { Change (PPE requirement) for shoes from stoel-toe boots to "Filod Boots" } \\
\text { in Bear Creek Valley Flood Plain Soil Sampling Health and Safety Plan for } \\
\text { field toam members. }\end{array}$ \\
\hline BCVFPSS-002 & $3 / 28 / 95$ & $\begin{array}{l}\text { Add the use of Procedure No. ESP-900, Cleaning and Decontaminating } \\
\text { sample containers and sampling devices, to the BCV FPSS SAP in Section } \\
4 \text {, Table 4.1. In addition, in Attachment } 2 \text { of the procedure in Section } 11.4 \\
\text { delete the requirement to have the equipment air ory for } 24 \text { hours. }\end{array}$ \\
\hline FPSS-003 & 3/28/95 & $\begin{array}{l}\text { Delete the requirement to grout the upper } 4 \mathrm{ft} \text { of each borehole in Table } 9.1 \\
\text { under waste stream. }\end{array}$ \\
\hline FPSS-004 & $4 / 3 / 95$ & $\begin{array}{l}\text { 1. Pages } 8 \text { - } 14 \text { of Section } 8 \text { in the Health \& Safety Plan - Section } 8.1 .8 \\
\text { Emergency Preparedness - change the location of nearest plant phone from } \\
\text { the green trialer at SL-1 to west end guard portal at Bear Creek Rd. } 2 \text {. } \\
\text { Change Table } 8.3 \text { from respiratory protection for site visitor from " } V " \text { to } \\
\text { "X" } \mathrm{X} \text {. Clanify Section } 8.1 .5 \text { on page } 8-8 \text { for admin contracts - chemicals } \\
\text { will be brought on site within their original containers, however some } \\
\text { chemicals may need to be in an aliquot type container. These containers } \\
\text { will be labeled using the Hazardous Materials Identification Diamond. }\end{array}$ \\
\hline FPSS-006 & $4 / 11 / 95$ & $\begin{array}{l}\text { When transporting environmental samples collected on Bear Creek to the } \\
\text { Y-12 laboratory for analysis on the BCV FPSS Project, it will not be } \\
\text { necessary to line the cooler with vermiculite, tape the cooler shut with } \\
\text { strapping tape and custody seals, or to have Y-12 survey technicians } \\
\text { conduct readiological surveys to green tag the cooler and sample as stated } \\
\text { in procedure no. ERVC-P2302 IAD, Rev. O. }\end{array}$ \\
\hline FPSS-007 & $4 / 21 / 95$ & $\begin{array}{l}\text { Change the screening level criteria for PCB's from } 0.05 \mathrm{mg} / \mathrm{kg} \text { (ppm) to } 0.5 \\
\mathrm{ppm} \text { (mg/kg) throughout the BCV Floodplain Sampling and Analysis Plan. }\end{array}$ \\
\hline FPSS-008 & $5 / 8 / 95$ & $\begin{array}{l}\text { Delete isopropanol rinse from decontamination procedure for the Ponar } \\
\text { dredge. }\end{array}$ \\
\hline FPSS-009 & $5 / 4 / 95$ & $\begin{array}{l}\text { Modifications to screen 4.5, Stream Sediment Sampling, on } \\
\text { page 4-3 and section 6.6, Stream Sediment Toxicity Testing, } \\
\text { on page 6-3 of the Soil Sampling and Analysis Plan for Bear } \\
\text { Creek Valley Floodplain at the Oak Ridge Y-12 Plant (DOE/ } \\
\text { OR/ 01-1322 \&D1) are detailed in the attached document: } \\
\text { Addendum to the Soil Sampling and Analysis Plan for the Bear } \\
\text { Creek Valley Floodplain at the Oak Ridge Y-12 Plant. Details } \\
\text { concerning sediment sampling, toxicity testing, data analysis } \\
\text { and data quality assurance issues are specified for the } \\
\text { sediment sampling and sediment toxicity testing sections. } \\
\text { Specific criteria for data quality assurance and quality control are detailed. }\end{array}$ \\
\hline
\end{tabular}


Table B.29. (continued)

\begin{tabular}{|c|c|c|}
\hline FCONO. & DATE ISSUED & DESCRIPTION OF CHANGE \\
\hline FPSS-010 & $5 / 395$ & $\begin{array}{l}\text { Modifications to section 4.1, Floodplain Sediment Sampling, on page 4-1 } \\
\text { and section 6.5, Floodplain Sodiment Toxicity Testing, on page 6-2 of the } \\
\text { Soll Sampling and Analysis Plan for Bear Creek Valley Floodplain at the } \\
\text { Oak Ridge Y-12 Plant (DOEORV1-13228D1); an addendum to the } \\
\text { Remedial Investigation Work Plan (RIWP). Details concerning sampling, } \\
\text { testing, and data quality assurance issues are provided for the sediment } \\
\text { sampling and sediment toxicity testing sections. Specific criteria for data } \\
\text { quality assurance and quality control are detailed. A complete description of } \\
\text { the aforementioned changes can be found in the attached addendum. }\end{array}$ \\
\hline FPSS-011 & $5 / 1295$ & $\begin{array}{l}\text { The procecture that will be used for the measurement of the physical } \\
\text { parameters in the field are SAIC's FTP-451, FTP-750, FTP-753 and } \\
\text { FTP-880. This change is being written to clarify and specity which } \\
\text { procedures will be used. In section } 7.2 .3 \text { of the BCV SAP, } \\
\text { bOE/ORV 1-1322\&D2, the use of which SAIC procedures is not clearly } \\
\text { identified. }\end{array}$ \\
\hline FPSS-012 & $6 / 12 / 95$ & $\begin{array}{l}\text { 2- Chloroaniline should be changed to } 4 \text { - Chloroaniline, as listed in CLP } \\
\text { OLM } 3.0 \text { and as listed in previous Bear Creek projects. }\end{array}$ \\
\hline
\end{tabular}


Table B.30. Large-scale characterization sample location and analysis matrix

\begin{tabular}{|c|c|c|c|c|c|c|c|c|c|c|c|c|c|c|c|c|c|c|}
\hline \multirow{3}{*}{\begin{tabular}{|} 
Sample \\
Location and \\
Depth \\
Transect: 1
\end{tabular}} & \multicolumn{6}{|c|}{\begin{tabular}{|c|}
$\begin{array}{c}\text { Floodplain } \\
\text { Soil } \\
\text { Screening }\end{array}$ \\
Station Number \\
\end{tabular}} & \multicolumn{6}{|c|}{$\begin{array}{l}\text { Floodplain Soil } \\
\text { Sampling } \\
\text { AFIs }\end{array}$} & \multicolumn{6}{|c|}{$\begin{array}{c}\text { Confirmatory } \\
\text { Soil Sampling } \\
\text { Station Number }\end{array}$} \\
\hline & 1 & 2 & 3 & 4 & 5 & & 1 & 2 & 3 & 4 & 5 & 6 & 1 & 2 & 3 & 14 & 5 & 3 \\
\hline & & & & & & & & & & & & & & & & & & \\
\hline $0-4$ in & $\bar{s}$ & $\mathbf{s}$ & s & $\mathbf{s}$ & st & S) & & C,G,Sr & & & & $\overline{C, G, S r}$ & & & & & & \\
\hline $4-16$ in & Is & & 5 & s & s) & s. & & $\mathrm{C}, \mathrm{G}, \mathrm{Sr}$ & & & & $\overline{C, G, S r}$ & & & & & & \\
\hline $0-16$ in Comp & & & & & & & & $\mathrm{T}, \mathrm{B}$ & & & & $T, \bar{B}$ & & & & & & \\
\hline $16-32$ in & Is & & s & s) & S. & s & & & & & & & & & & & & \\
\hline$\frac{\text { Transect } 2}{0-4 \text { in }}$ & Is & S & $\mathbf{S}$ & st & $\mathbf{s}$ & $\mathbf{S}$ & & & & & & & & & & & & \\
\hline $4-16$ in & $\bar{s}$ & S & st & S & St & s. & & & & & & & & & $\frac{\mathrm{C}, \mathrm{G}, \mathrm{Sr}}{\mathrm{C}, \mathrm{G}, \mathrm{Sr}}$ & & & \\
\hline $0-16$ in Comp & & & & & & & & & & & & & & & $\mathrm{T}, \mathrm{B}$ & & & \\
\hline $16-32$ in & & & s] & s) & st & 5 & & & & & & & & & & & & \\
\hline Transect: 3 & & 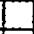 & & & & & & & & & & & & & & & & \\
\hline $0-4$ in & $\mathbf{s}$ & Is & s] & s) & s. & S! & & & $\mathrm{C}, \mathrm{G}, \mathrm{SI}_{\mathbf{S}}$ & $\mathrm{C}, \mathrm{G}, \mathrm{Sr}$ & & & & & & & & \\
\hline $4-16$ in & Is & $\mathbf{s}$ & s] & $\mathbf{S}$ & s| & & & & $\mathrm{C}, \mathrm{G}, \mathrm{Sr}$ & $\mathrm{C}, \mathrm{G}, \mathrm{Sr}$ & & & & & & & & \\
\hline $0-16$ in Comp & & & & & & & & & $\mathrm{T}, \mathrm{B}$ & $\overline{T, B}$ & & & & & & & & \\
\hline $16-32$ in & & $\bar{s}$ & & St & st & s & & & & & & & & & & & & \\
\hline Transect: 4 & & & & & & & & & & & & & & & & & & \\
\hline $0-4$ in & s & S & s & s) & st & & $\overline{C, G, S r}$ & $\mathrm{C}, \mathrm{G}, \mathrm{Sr}$ & & & & & & & & & & \\
\hline $4-16$ in & s & 5 & s & S & st & 3 & $\overline{C, G, S I}$ & $\mathrm{C}, \mathrm{G}, \mathrm{Sr}$ & & & & & & & & & & \\
\hline $0-16$ in Comp & & & & & & & T.B & $\bar{T}, \bar{B}$ & & & & & & & & & & \\
\hline $16-32$ in & 5 & S & s & st & st & s. & & & & & & & & & & & & \\
\hline Transect: 5 & & & & & & & & & & & & & & & & & & \\
\hline $0-4$ in & Is & S & st & S & S] & 5 & $\mathrm{C,G,Sr}$ & & & & & & & & & & & \\
\hline $4-16$ in & $\mathbf{s}$ & $\mathbf{S}$ & s! & $\mathbf{s}$ & s| & 5 & $\mathbf{C , G , S r}$ & & & & & & & & & & & \\
\hline $0-16$ in Comp & & 5 & & & & & $\mathrm{T,B}$ & & & & & & & & & & & \\
\hline $16-32$ in & 5 & 5 & s & S1 & s| & 5 & & & & & & & & & & & & \\
\hline Transect: 6 & & & & & & & & & & & & & & & & & & \\
\hline $0-4$ in & 5 & 5 & s & S & s] & 3 & & & C, G,S & $\mathrm{C}, \mathrm{G}, \mathrm{SI}$ & & & & & & & & \\
\hline $4-16$ in & $\mathbf{S}$ & $\mathbf{s}$ & S & si & s] & & & & C,G,Sr & C,G,Sr & & & & & & & & \\
\hline $0-16$ in Comp & & & & & & & & & $\mathrm{T}, \mathrm{B}$ & $T, \bar{B}$ & & & & & & & & \\
\hline $16-32$ in & Is & $\mathbf{S}$ & S! & s) & S! & & & & $\mathrm{C}, \mathrm{G}, \mathrm{S}_{\mathbf{T}}$ & $\mathrm{C}, \overline{\mathrm{G}}, \mathrm{Sr}$ & & & & & & & & \\
\hline Transect: 7 & & & & & & & & & & & & & & & & & & \\
\hline $0-4$ in & 5 & s & s & s & & & C,G,ST & & C.G.Sr & & & & & & & & & \\
\hline $4-16$ in & $\mathrm{s}$ & s & s & $s$ & & & C.G.SI & & $\mathrm{C}, \mathrm{G}, \mathrm{Sr}$ & & & & & & & & & \\
\hline $0-16$ in Comp & & & & & & & $\overline{T, B}$ & & T.B & & & & & & & & & \\
\hline $16-32$ in & $\mathbf{S}$ & $\mathbf{s}$ & $\mathbf{s}$ & $\mathbf{s}$ & & & & & & & & & & & & & & \\
\hline Transect: 8 & & & & & & & & & & & & & & & & & & \\
\hline $0-4$ in & $\mathrm{S}$ & S & S & S| & St & S) & & & & & & & & & & & & C,G,Sr \\
\hline $4-16$ in & S & $\mathbf{s}$ & s & s] & s| & & & & & & & & & & & & & $\mathbf{C , G , S t}$ \\
\hline $0-16$ in Comp & & & & & & & & & & & & & & & & & & $\mathrm{T}, \overline{\mathrm{B}}$ \\
\hline $16-32$ in & $S$ & S & S & s] & St & S) & & & & & & & & & & & & \\
\hline Transect: 9 & & & & & & & & & & & & & & & & & & \\
\hline $0-4$ in & S & S & S & st & St & 5 & & & & & & & & $\mathrm{C}, \mathrm{G}, \mathrm{Sr}$ & & & & \\
\hline $4-16$ in & $\mathrm{s}$ & s & s & s| & & & & & & & & & & $\mathbf{C , G , S r}$ & & & & \\
\hline $0-16$ in Comp & & & & & & & & & & & & & & $\mathrm{T}, \mathrm{B}$ & & & & \\
\hline $16-32$ in & IS & $\mathbf{S}$ & S) & $\mathbf{S |}$ & s) & & & & & & & & & & & & & \\
\hline Transect: 10 & & & & & & & & & & & & & & & & & & \\
\hline $0-4$ in & Is & S & S & st & & & & & $\mathrm{C}, \mathrm{G}, \mathrm{S}_{\mathrm{T}}$ & & & & & & & & & \\
\hline $4-16$ in & IS & $\mathbf{s}$ & S & s| & & & & & $\mathrm{C}, \mathrm{G}, \mathrm{Sr}$ & & & & & & & & & \\
\hline $0-16$ in Comp & & & & & & & & & $\mathrm{T}, \mathrm{B}$ & & & & & & & & & \\
\hline $16-32$ in & s & 5 & S & St & s| & 5 & & & & & $\mathrm{C}, \mathrm{G}, \mathrm{Sr}$ & & & & & & & \\
\hline Transect: 11 & & & & & & & & & & & & & & & & & & \\
\hline $0-4$ in & IS & S & S & st & ST & & & & & & & & & & & & & \\
\hline $4-16$ in & 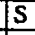 & $\mathbf{S}$ & S & $\mathbf{s}$ & S1 & & & & & & & & & & & & & \\
\hline $0-16$ in Comp & & & & & & & & & & & & & & & & & & \\
\hline $16-32$ in & IS & 5 & S & S| & & st & & & & & & & $\mathrm{C}, \mathrm{G}, \mathrm{Sr}$ & & & & & \\
\hline Transect: 12 & & & & & & & & & & & & & & & & & & \\
\hline $0-4$ in & s & S & S & S| & s] & & & & & & & & & & & & & \\
\hline $4-16$ in & IS & S & S & s & S1 & & & & & & & & & & & & & \\
\hline $0-16$ in Comp & & & & & & & & & & & & & & & & & & \\
\hline $16-32$ in & $\mathbf{S}$ & & S! & $\mathbf{S}$ & & & & & & & & & & & C, G,Sr & & & \\
\hline Transect: 13 & & & & & & & & & & & & & & & & & & \\
\hline $0-4$ in & S & $\mathbf{S}$ & s & S! & & S! & & C.G.Sr & & & & & & & & & & \\
\hline $4-16$ in & $\mathbf{s}$ & $\mathrm{S}$ & s & $s$ & s) & & & $\mathrm{C}, \mathrm{G}, \mathrm{Sr}$ & & & & & & & & & & \\
\hline $0-16$ in Comp & & & & & & & & $T, B$ & & & & & & & & & & \\
\hline $16-32$ in & $\mathrm{s}$ & S & $\mid \mathbf{s}$ & $\underline{|S|}$ & & S & & & & & & & & & & & & \\
\hline
\end{tabular}

$S$ - PCB, VOC, RAD Screen

Sr - Rad Screen only

T - Toxicity

B- Biota

C - Organic/norganic and Radiological Analysis

G - Geotechnical Analysis 


\section{B12-89}

Table B.31. List of analytes and reported quantitation limits for soils and sediment in BCV FPSS

\begin{tabular}{|c|c|c|}
\hline Analyte & Minimum quantitation limit ${ }^{2}$ & Maximum quantitation limit ${ }^{\mathrm{a}}$ \\
\hline & Inorganics (mg/kg) & \\
\hline \multicolumn{3}{|l|}{ Aluminum } \\
\hline Antimony & 0.44 & 1.00 \\
\hline Arsenic & 0.94 & 1.00 \\
\hline \multicolumn{3}{|l|}{ Barium } \\
\hline Beryllium & 0.36 & 0.63 \\
\hline Cadmium & 0.07 & 0.84 \\
\hline \multicolumn{3}{|l|}{ Calcium } \\
\hline \multicolumn{3}{|l|}{ Chromium } \\
\hline \multicolumn{3}{|l|}{ Copper } \\
\hline Cyanide & 0.57 & 1.40 \\
\hline \multicolumn{3}{|l|}{ Iron } \\
\hline \multicolumn{3}{|l|}{ Lead } \\
\hline Lithium & 4.90 & 13.00 \\
\hline \multicolumn{3}{|l|}{ Magnesium } \\
\hline Manganese & 0.93 & 0.93 \\
\hline Mercury & 0.10 & 0.26 \\
\hline \multicolumn{3}{|l|}{ Nickel } \\
\hline \multicolumn{3}{|l|}{ Potassium } \\
\hline Selenium & 1.10 & 1.50 \\
\hline Silver & 0.12 & 0.27 \\
\hline Sodium & 149.00 & 306.00 \\
\hline Thallium & 1.00 & 2.50 \\
\hline \multicolumn{3}{|l|}{ Vanadium } \\
\hline \multicolumn{3}{|l|}{ Zinc } \\
\hline \multicolumn{3}{|c|}{ Herbicides $(\mu \mathrm{g} / \mathrm{kg})$} \\
\hline $2,4,5-\mathrm{T}$ & 25.00 & 65.00 \\
\hline 2,4,5-TP (Silvex) & 25.00 & 150.00 \\
\hline $2,4-D$ & 99.00 & 610.00 \\
\hline
\end{tabular}


B12-90

Table B.31 (continued)

\begin{tabular}{|c|c|c|}
\hline Analyte & Minimum quantitation limit $^{\mathrm{a}}$ & Maximum quantitation limit ${ }^{\mathrm{a}}$ \\
\hline \multicolumn{3}{|c|}{ Pesticides/PCBs ( $\mu \mathrm{g} / \mathrm{kg})$ : } \\
\hline $4,4^{\prime}-\mathrm{DDD}$ & 3.60 & 26.00 \\
\hline 4,4'-DDE & 3.60 & 26.00 \\
\hline $4,4^{\prime}-\mathrm{DDT}$ & 3.60 & 26.00 \\
\hline Aldrin & 1.90 & 13.00 \\
\hline Aroclor-1016 & 36.00 & 260.00 \\
\hline Aroclor -1221 & 73.00 & 530.00 \\
\hline Aroclor- 1232 & 36.00 & 260.00 \\
\hline Aroclor- 1242 & 36.00 & 260.00 \\
\hline Aroclor-1248 & 36.00 & 260.00 \\
\hline Aroclor- 1254 & 40.00 & 260.00 \\
\hline Aroclor- 1260 & 36.00 & 260.00 \\
\hline Dieldrin & 3.60 & 26.00 \\
\hline Endosulfan I & 1.90 & 13.00 \\
\hline Endosulfan II & 3.60 & 26.00 \\
\hline Endosulfan sulfate & 3.60 & 26.00 \\
\hline Endrin & 3.60 & 26.00 \\
\hline Endrin aldehyde & 3.60 & 26.00 \\
\hline Endrin ketone & 3.60 & 26.00 \\
\hline Heptachlor & 1.90 & 13.00 \\
\hline Heptachlor epoxide & 1.90 & 13.00 \\
\hline Methoxychlor & 19.00 & 130.00 \\
\hline Toxaphene & 190.00 & 1300.00 \\
\hline alpha $\alpha-B H C$ & 1.90 & 13.00 \\
\hline$\alpha$-Chlordane & 1.90 & 13.00 \\
\hline$\beta-B H C$ & 1.90 & 13.00 \\
\hline$\triangle-\mathrm{BHC}$ & 1.90 & 13.00 \\
\hline$\gamma$-BHC (Lindane) & 1.90 & 13.00 \\
\hline$\gamma$-Chlordane & 1.90 & 13.00 \\
\hline
\end{tabular}


B12-91

Table B.31 (continued)

\begin{tabular}{|c|c|c|}
\hline Analyte & Minimum quantitation limit ${ }^{\mathbf{a}}$ & Maximum quantitation limit ${ }^{\mathbf{a}}$ \\
\hline \multicolumn{3}{|c|}{ Semivolatile Organics ( $\mu \mathrm{g} / \mathrm{kg}$ ) } \\
\hline 1,2,4-Trichlorobenzene & 330.00 & 800.00 \\
\hline 1,2-Dichlorobenzene & 330.00 & 800.00 \\
\hline 1,3-Dichlorobenzene & 330.00 & 800.00 \\
\hline 1,4-Dichlorobenzene & 330.00 & 800.00 \\
\hline 2,2'-oxybis(1-Chloropropane) & 330.00 & 800.00 \\
\hline 2,4,5-Trichlorophenol & 830.00 & 2000.00 \\
\hline 2,4,6-Trichlorophenol & 330.00 & 800.00 \\
\hline 2,4-Dichlorophenol & 330.00 & 800.00 \\
\hline 2,4-Dimethylphenol & 330.00 & 800.00 \\
\hline 2,4-Dinitrophenol & 830.00 & 2000.00 \\
\hline 2,4-Dinitrotoluene & 330.00 & 800.00 \\
\hline 2,6-Dinitrotoluene & 330.00 & 800.00 \\
\hline 2-Chloronaphthalene & 330.00 & 800.00 \\
\hline 2-Chlorophenol & 330.00 & 800.00 \\
\hline 2-Methylnaphthalene & 330.00 & 800.00 \\
\hline 2-Methylphenol & 330.00 & 800.00 \\
\hline 2-Nitroaniline & 830.00 & 2000.00 \\
\hline 2-Nitrophenol & 330.00 & 800.00 \\
\hline 3,3'-Dichlorobenzidine & 330.00 & 800.00 \\
\hline 3-Nitroaniline & 830.00 & 2000.00 \\
\hline 4,6-Dinitro-2-methylphenol & 830.00 & 2000.00 \\
\hline 4-Bromophenyl-phenylether & 330.00 & 800.00 \\
\hline 4-Chloro-3-methylphenol & 330.00 & 800.00 \\
\hline 4-Chloroaniline & 330.00 & 800.00 \\
\hline 4-Chlorophenyl-phenylether & 330.00 & 800.00 \\
\hline 4-Methylphenol & 330.00 & 800.00 \\
\hline 4-Nitroaniline & 830.00 & 2000.00 \\
\hline 4-Nitrophenol & 830.00 & 2000.00 \\
\hline Acenaphthene & 330.00 & 800.00 \\
\hline Acenaphthylene & 330.00 & 800.00 \\
\hline Anthracene & 330.00 & 800.00 \\
\hline
\end{tabular}


B12-92

Table B.31 (continued)

\begin{tabular}{|c|c|c|}
\hline Analyte & Minimum quantitation limit ${ }^{\mathrm{a}}$ & Maximum quantitation limit ${ }^{\mathrm{a}}$ \\
\hline Benzo(a)anthracene & 330.00 & 800.00 \\
\hline Benzo(a)pyrene & 330.00 & 800.00 \\
\hline Benzo(b)fluoranthene & 330.00 & 800.00 \\
\hline Benzo(g,h,i)perylene & 330.00 & 800.00 \\
\hline Benzo(k)fluoranthene & 330.00 & 800.00 \\
\hline Butylbenzylphthalate & 330.00 & 800.00 \\
\hline Carbazole & 330.00 & 800.00 \\
\hline Chrysene & 330.00 & 800.00 \\
\hline Di-n-butylphthalate & 110.00 & 800.00 \\
\hline Di-n-octylphthalate & 330.00 & 800.00 \\
\hline Dibenzo(a,h)anthracene & 330.00 & 800.00 \\
\hline Dibenzofuran & 330.00 & 800.00 \\
\hline Diethylphthalate & 330.00 & 800.00 \\
\hline Dimethylphthalate & 330.00 & 800.00 \\
\hline Fluoranthene & 330.00 & 800.00 \\
\hline Fluorene & 330.00 & 800.00 \\
\hline Hexachlorobenzene & 330.00 & 800.00 \\
\hline Hexachlorobutadiene & 330.00 & 800.00 \\
\hline Hexachlorocyclopentadiene & 330.00 & 800.00 \\
\hline Hexachloroethane & 330.00 & 800.00 \\
\hline Indeno(1,2,3-c,d)pyrene & 330.00 & 800.00 \\
\hline Isophorone & 330.00 & 800.00 \\
\hline N-Nitroso-di-n-propylamine & 330.00 & 800.00 \\
\hline N-Nitrosodiphenylamine & 330.00 & 800.00 \\
\hline Naphthalene & 330.00 & 800.00 \\
\hline Nitrobenzene & 330.00 & 800.00 \\
\hline Pentachlorophenol & 830.00 & 2000.00 \\
\hline Phenanthrene & 330.00 & 800.00 \\
\hline Phenol & 330.00 & 800.00 \\
\hline Pyrene & 330.00 & 800.00 \\
\hline bis(2-Chloroethoxy)methane & 330.00 & 800.00 \\
\hline bis(2-Chloroethyl)ether & 330.00 & 800.00 \\
\hline
\end{tabular}


B12-93

Table B.31 (continued)

\begin{tabular}{|c|c|c|}
\hline Analyte & Minimum quantitation limit ${ }^{\mathrm{a}}$ & Maximum quantitation limit ${ }^{\mathbf{a}}$ \\
\hline bis(2-Ethylhexyl)phthalate & 330.00 & 800.00 \\
\hline \multicolumn{3}{|c|}{ Volatile Organics $(\mu \mathrm{g} / \mathrm{kg})$} \\
\hline 1,1,1-Trichloroethane & 6.00 & 12.00 \\
\hline 1,1,2,2-Tetrachloroethane & 6.00 & 12.00 \\
\hline 1,1,2-Trichloroethane & 6.00 & 12.00 \\
\hline 1,1-Dichloroethane & 6.00 & 12.00 \\
\hline 1,1-Dichloroethene & 6.00 & 12.00 \\
\hline 1,2-Dichloroethane & 6.00 & 12.00 \\
\hline 1,2-Dichloroethene & 6.00 & 12.00 \\
\hline 1,2-Dichloropropane & 6.00 & 12.00 \\
\hline 2-Butanone & 6.00 & 12.00 \\
\hline 2-Hexanone & 6.00 & 12.00 \\
\hline 4-methyl-2-Pentanone & 6.00 & 12.00 \\
\hline Acetone & 6.00 & 83.00 \\
\hline Benzene & 6.00 & 12.00 \\
\hline Bromodichloromethane & 6.00 & 12.00 \\
\hline Bromoform & 6.00 & 12.00 \\
\hline Bromomethane & 6.00 & 12.00 \\
\hline Carbon disulfide & 6.00 & 12.00 \\
\hline Carbon tetrachloride & 6.00 & 12.00 \\
\hline Chlorobenzene & 6.00 & 12.00 \\
\hline Chloroethane & 6.00 & 12.00 \\
\hline Chloroform & 6.00 & 12.00 \\
\hline Chloromethane & 6.00 & 12.00 \\
\hline Dibromochloromethane & 6.00 & 12.00 \\
\hline Ethylbenzene & 6.00 & 12.00 \\
\hline Methylene chloride & 6.00 & 97.00 \\
\hline Styrene & 6.00 & 12.00 \\
\hline Tetrachloroethene & 6.00 & 12.00 \\
\hline Toluene & 6.00 & 12.00 \\
\hline Trichloroethene & 6.00 & 12.00 \\
\hline Vinyl chloride & 6.00 & 12.00 \\
\hline
\end{tabular}


B12-94

Table B.31 (continued)

\begin{tabular}{lcc}
\hline \multicolumn{1}{c}{ Analyte } & Minimum quantitation limit $^{\mathrm{a}}$ & Maximum quantitation limit $^{\mathbf{2}}$ \\
\hline Xylene, total & 6.00 & 12.00 \\
cis-1,3-Dichloropropene & 6.00 & 12.00 \\
trans-1,3-Dichloropropene & 6.00 & 12.00 \\
& Radionuclides $(\mathrm{pCi} / \mathrm{g})$ & \\
Americium-241 & & \\
Cesium-137 & & \\
Curium-243 & \\
Curium-244 & \\
Plutonium-238 & \\
Plutonium-239/240 & \\
Strontium-90 & \\
Technetium-99 & \\
Thorium-228 & \\
Thorium-230 & \\
Thorium-232 & \\
Uranium-234 & \\
Uranium-235 & \\
Uranium-238 & \\
\hline
\end{tabular}

aparameters which were never reported as less than the quantitation limit have no statistics for minimum or maximum quantitation limit 
Table B.32. Fine-scale characterization, stream sediment and soil reference, sample location, and analysis matrices

\begin{tabular}{|c|c|c|c|c|c|c|c|c|}
\hline \multicolumn{3}{|c|}{ Fine-scale characterization } & \multicolumn{2}{|c|}{$\begin{array}{l}\text { Stream sediment } \\
\text { characterization }\end{array}$} & \multicolumn{2}{|c|}{ Stream sediment reference } & \multicolumn{2}{|c|}{$\begin{array}{l}\text { Floodplain soil radiological and } \\
\text { chemical references }\end{array}$} \\
\hline Sample location & $\begin{array}{l}\text { Initial sample } \\
\text { analyses }\end{array}$ & $\begin{array}{c}\text { AFI } \\
\text { analyses }\end{array}$ & $\begin{array}{l}\text { Sample } \\
\text { location }\end{array}$ & $\begin{array}{c}\text { Sample } \\
\text { analyses }\end{array}$ & Sample location & Sediment analyses & Sample location & Sample analyses \\
\hline \multicolumn{3}{|c|}{ Sediment profile excavation } & 1 & $\mathrm{C}, \mathrm{G}, \mathrm{T}$ & 1 & C, G & 1 & \\
\hline 1 & $s$ & & 2 & C, G, T & 2 & C, G & $0-16$ in. comp & $G, T, B$ \\
\hline 2 & $s$ & & 3 & C, G, T & 3 & C,,$G$ & 2 & \\
\hline 3 & $\mathbf{s}$ & & 4 & C, G, T & $1,2,3$ comp & $\mathrm{T}$ & $0-16$ in. comp & G, T, B \\
\hline 4 & S, C & & 5 & C, G, T & & & 3 & \\
\hline 5 & S & & 6 & C, G, T & & & $0-16$ in. comp & G, T, B \\
\hline \multicolumn{3}{|c|}{ Fine-scale sediment } & 7 & $\mathrm{C}, \mathrm{G}, \mathrm{T}$ & & & & \\
\hline 1 & & & 8 & C, G, T & & & & \\
\hline 2 & & & 9 & C, G, T & & & & \\
\hline 3 & & & 10 & C, G, T & & & & \\
\hline 4 & $\mathbf{S}$ & & 11 & $\mathrm{C}, \mathrm{G}, \mathrm{T}$ & & & & \\
\hline 5 & & & 12 & C, G, T & & & & \\
\hline $5: 0-4$ in. & & $\mathrm{C}, \mathrm{G}, \mathrm{Sr}$ & 13 & C, G, T & & & & \\
\hline $5: 4-16$ in. & & $\mathrm{C}, \mathrm{G}, \mathrm{Sr}$ & 14 & $\mathrm{C}, \mathrm{G}, \mathrm{T}$ & & & & \\
\hline 5: $10-28 \mathrm{in.}$ & $\mathbf{S}$ & $\mathrm{C}, \mathrm{G}$ & 15 & C, G, T & & & & \\
\hline $5: 0-16$ in. comp & & $\mathrm{T}, \mathrm{B}$ & 16 & $\mathrm{C}, \mathrm{G}, \mathrm{T}$ & & & & \\
\hline 6 & & & 17 & C, G, T & & & & \\
\hline 7 & $S$ & & & & & & & \\
\hline 8 & $\mathbf{S}$ & & & & & & & \\
\hline \multicolumn{9}{|l|}{9} \\
\hline \multicolumn{9}{|l|}{10} \\
\hline \multicolumn{9}{|l|}{11} \\
\hline 11: $16-32$ in. & & $\mathrm{C}, \mathrm{Sr}$ & & & & & & \\
\hline 11: $18-34$ in. & $\mathbf{s}$ & C & & & & & & \\
\hline 12 & $s$ & & & & & & & \\
\hline 13 & $S$ & & & & & & & \\
\hline 14 & $s$ & & & & & & & \\
\hline 15 & $S$ & & & & & & & \\
\hline 16 & S & & & & & & & \\
\hline 17 & $s$ & & & & & & & \\
\hline
\end{tabular}


Table B.33. Technical sampling procedures used in the course of BCV Floodplain investigation

\begin{tabular}{|c|c|c|c|}
\hline $\begin{array}{c}\text { Procedure } \\
\text { number }^{a}\end{array}$ & Subject activity & $\begin{array}{c}\text { Issue } \\
\text { date }\end{array}$ & Revision \\
\hline \multicolumn{4}{|c|}{ Soil sampling } \\
\hline ESP-303-1 & Soil sampling with a spade and scoop & $8 / 30 / 88$ & 0 \\
\hline ESP-303-2 & Soil sampling with an auger & $9 / 1 / 88$ & 0 \\
\hline TP-303-8 & $\begin{array}{l}\text { Subsoil sampling with a } \mathrm{MC} \text { backsaver soil sampling } \\
\text { system }\end{array}$ & $10 / 2 / 91$ & 1 \\
\hline \multicolumn{4}{|c|}{ Stream sampling } \\
\hline ESP-304-1 & Sediment sampling procedures: stream beds & $10 / 29 / 90$ & 1 \\
\hline \multicolumn{4}{|c|}{ Biota sampling } \\
\hline TP-309-9 & Terrestrial vegetation sampling collection & $5 / 8 / 92$ & 0 \\
\hline TP-309-9 & Terrestrial small mammal sampling & $10 / 15 / 91$ & 0 \\
\hline $\mathrm{K}-901-1062$ & Terrestrial subsurface macroinvertebrate collection & $9 / 14 / 94$ & 0 \\
\hline
\end{tabular}

${ }^{a}$ SAIC 1995a. Environmental Technical Support, Bear Creek Valley Operable Unit One and Floodplain Soil Sampling Field Technical Procedures. 


\section{B12-97}

Table B.34. Technical procedures for collection of BCV biota samples

\begin{tabular}{llll}
\hline Procedure number & Subject activity & Issue date & Revision \\
\hline TP-309-3 & Terrestrial small mammal sampling & $10 / 15 / 91$ & 0 \\
K-901-1062 & $\begin{array}{l}\text { Terrestrial subsurface macroinvertebrate } \\
\text { collection }\end{array}$ & $9 / 14 / 94$ & 0 \\
TP-309-9 & Terrestrial vegetation sample collection & $5 / 8 / 92$ & 0 \\
\hline
\end{tabular}


Table B.35. Biota samples collected for the BCV RI

\begin{tabular}{|c|c|c|c|c|c|}
\hline Location & Small mammals & Earthworm & Herbiage & Browse & Canopy \\
\hline BYBY (BY17) & 4 individuals & 1 composite & 1 composite & 1 composite & 1 composite \\
\hline BYBY (BY22) & & 1 composite & 1 composite & 1 composite & 1 composite \\
\hline Transect 1 & 5 individuals & & & & \\
\hline TS012 & & 1 composite & 1 composite & 1 composite & 1 composite \\
\hline TS016 & & 1 composite & 1 composite & 1 composite & 1 composite \\
\hline Transect 2 & 5 individuals & & & & \\
\hline $\mathrm{TS} 023$ & & 1 composite & 1 composite & 1 composite & 1 composite \\
\hline Transect 3 & 3 individuals & & & & \\
\hline $\mathrm{TS} 033$ & & 1 composite & 1 composite & 1 composite & 1 composite \\
\hline TS034 & & 1 composite & 1 composite & 1 composite & 1 composite \\
\hline Transect 4 & 4 individuals & & & & \\
\hline $\mathrm{TS} 041$ & & 1 composite & 1 composite & 1 composite & 1 composite \\
\hline $\mathrm{TS} 042$ & & 1 composite & 1 composite & 1 composite & 1 composite \\
\hline Transect 7 & 3 individuals & & & & \\
\hline TS071 & & 1 composite & 1 composite & 1 composite & 1 composite \\
\hline $\mathrm{TS} 073$ & & I composite & 1 composite & 1 composite & 1 composite \\
\hline Transect 9, TS092 & & 1 composite & 1 composite & 1 composite & 1 composite \\
\hline
\end{tabular}


Table B.36. Summary of analytical methods used for the GWQR dataset

\begin{tabular}{|c|c|c|c|c|c|c|c|c|}
\hline Parameter & $\begin{array}{l}\text { Method } \\
1986\end{array}$ & $\begin{array}{l}\text { Method } \\
1987\end{array}$ & $\begin{array}{l}\text { Method } \\
1988\end{array}$ & $\begin{array}{l}\text { Method } \\
1989\end{array}$ & $\begin{array}{l}\text { Method } \\
1990\end{array}$ & $\begin{array}{l}\text { Method } \\
1991\end{array}$ & $\begin{array}{l}\text { Method } \\
1992\end{array}$ & $\begin{array}{l}\text { Method } \\
1993\end{array}$ \\
\hline VOA & EPA 8240 & EPA 8240 & EPA 8240 & EPA 8240 & EPA 8240 & EPA 8240 & EPA 8240 & EPA 8240 \\
\hline SVOA & EPA 8270 & EPA 8270 & EPA 8270 & EPA 8270 & EPA 8270 & EPA 8270 & EPA 8270 & EPA 8270 \\
\hline Pesticides/PCBs & EPA 8080 & EPA 8080 & EPA 8080 & EPA 8080 & EPA 8080 & EPA 8080 & EPA 8080 & EPA 8080 \\
\hline Alkalinity & TP-1822 & SM-403 & SM-403 & SM-403 & SM-403 & SM-403 & SM-403 & SM-2320B \\
\hline Alkalinity & TP-1822 & SM-403 & SM-403 & SM-403 & SM-403 & SM-403 & SM-403 & SM-2320B \\
\hline Ammonia & EPA 350.3 & EPA 350.3 & EPA 350.3 & EPA 350.3 & EPA 350.3 & & & \\
\hline Chloride & EPA 300.0 & EPA 300.0 & EPA 300.0 & EPA 300.0 & EPA 300.0 & EPA 300.0 & EPA 300.0 & EPA 300.0 \\
\hline Conductivity & EPA 120.1 & EPA 120.0 & EPA 120.0 & EPA 120.1 & EPA 120.1 & & EPA 9050 & EPA 9050 \\
\hline Fluoride & TP-1835 & EPA 340.2 & EPA 340.2 & EPA 340.2 & EPA 340.2 & & EPA 340.2 & EPA 340.2 \\
\hline Kjeldahl & EPA 351.3 & EPA 351.1 & EPA 351.3 & EPA 351.3 & EPA 351.3 & & & \\
\hline Nitrate & EPA 300.0 & EPA 300.0 & & & & & & \\
\hline Nitrate as $\mathrm{N}$ & EPA 300.0 & EPA 300.0 & EPA 300.0 & EPA 300.0 & EPA 300.0 & & EPA 300.0 & EPA 300.0 \\
\hline Nitrite & EPA 300.0 & & & & & & & \\
\hline $\mathrm{pH}$ & EPA 150.0 & EPA 150.1 & EPA 150.1 & EPA 150.1 & EPA 150.1 & EPA 9040 & EPA 9040 & EPA 9040 \\
\hline Phenols & EPA 420.1 & EPA 420.1 & EPA 420.1 & EPA 420.1 & EPA 420.1 & EPA 9065 & & \\
\hline Sulfate & EPA 300.0 & EPA 300.0 & EPA 300.0 & EPA 300.0 & EPA 300.0 & EPA 300.0 & EPA 300.0 & EPA 300.0 \\
\hline Suspended & TP-1818 & EPA 160.2 & EPA 160.2 & EPA 160.2 & EPA 160.2 & EPA 160.2 & EPA 160.2 & EPA 160.2 \\
\hline Total & SM-909 & SM-909 & SM-909 & SM-909 & SM-909 & & & \\
\hline Total & TP-1837 & TP-183708 & TP-183708 & TP- 183708 & TP-183708 & EC-1910 & EC-1910 & EC-1910 \\
\hline Turbidity & EPA 180.1 & EPA 180.1 & EPA 180.1 & EPA 180.1 & EPA 180.1 & EPA $180.1 ?$ & EPA 180.1 & EPA 180.1 \\
\hline
\end{tabular}


Table B.36 continued

\begin{tabular}{lllllllll}
\hline & $\begin{array}{l}\text { Method } \\
\text { Parameter }\end{array}$ & $\begin{array}{l}\text { Method } \\
1986\end{array}$ & $\begin{array}{l}\text { Method } \\
1988\end{array}$ & $\begin{array}{l}\text { Method } \\
1989\end{array}$ & $\begin{array}{l}\text { Method } \\
1990\end{array}$ & $\begin{array}{l}\text { Method } \\
1991\end{array}$ & $\begin{array}{l}\text { Method } \\
1992\end{array}$ & $\begin{array}{l}\text { Method } \\
1993\end{array}$ \\
\hline Metals & EPA 6010 & EPA 6010 & EPA 6010 & EPA 6010 & EPA 6010 & EPA 6010 & EPA 6010 & EPA 6010 \\
Total & EPA 415.1 & EPA 415.1 & EPA 415.1 & EPA 415.1 & EPA 415.1 & & & \\
Gross & TP-1602 & EPA 900.0 & EPA 900.0 & EPA 300.0 & EPA 300.0 & EPA 9310 & EPA 9310 & EPA 9310 \\
Nitrite & & EPA 300.0 & EPA 300.0 & EPA 300.0 & EPA 300.0 & & & \\
Total & & EPA 415.2 & EPA 415.2 & EPA 415.2 & EPA 415.2 & & & EPA 160.1 \\
Dissolved & & & & EPA 160.1 & EPA 160.1 & & At X-10 & At X-10 \\
Petroleum & & & & & At X-10 & At X-10 & At \\
\hline
\end{tabular}


B12-101

Table B.37. Minimum and maximum non-detects for groundwater in the S-3 aggregate ${ }^{a}$

\begin{tabular}{|c|c|c|c|}
\hline Analyte & Units & $\begin{array}{c}\text { Minimum } \\
\text { non-detect }\end{array}$ & $\begin{array}{l}\text { Maximum } \\
\text { non-detect }\end{array}$ \\
\hline \multicolumn{4}{|c|}{ Inorganics } \\
\hline Aluminum & $\mathrm{mg} / \mathrm{L}$ & 0.02 & 0.04 \\
\hline Ammonia nitrogen & $\mathrm{mg} / \mathrm{L}$ & 0.2 & 0.2 \\
\hline Antimony & $\mathrm{mg} / \mathrm{L}$ & 0.05 & 0.25 \\
\hline Arsenic & $\mathrm{mg} / \mathrm{L}$ & 0.005 & 0.005 \\
\hline Barium & $\mathrm{mg} / \mathrm{L}$ & . & • \\
\hline Beryllium & $\mathrm{mg} / \mathrm{L}$ & 0.0003 & 0.0006 \\
\hline Boron & $\mathrm{mg} / \mathrm{L}$ & 0.004 & 0.02 \\
\hline Cadmium & $\mathrm{mg} / \mathrm{L}$ & 0.002 & 0.01 \\
\hline Calcium & $\mathrm{mg} / \mathrm{L}$ & . & . \\
\hline Chloride & $\mathrm{mg} / \mathrm{L}$ & 1 & 5 \\
\hline Chromium & $\mathrm{mg} / \mathrm{L}$ & 0.01 & 0.01 \\
\hline Cobalt & $\mathrm{mg} / \mathrm{L}$ & 0.005 & 0.025 \\
\hline Copper & $\mathrm{mg} / \mathrm{L}$ & 0.004 & 0.02 \\
\hline Fluoride & $\mathrm{mg} / \mathrm{L}$ & 0.1 & 0.1 \\
\hline Iron & $\mathrm{mg} / \mathrm{L}$ & 0.004 & 0.01 \\
\hline Kjeldahl nitrogen & $\mathrm{mg} / \mathrm{L}$ & 0.1 & 0.2 \\
\hline Lead & $\mathrm{mg} / \mathrm{L}$ & 0.004 & 0.02 \\
\hline Lithium & $\mathrm{mg} / \mathrm{L}$ & . & . \\
\hline Magnesium & $\mathrm{mg} / \mathrm{L}$ & . & . \\
\hline Manganese & $\mathrm{mg} / \mathrm{L}$ & 0.001 & 0.005 \\
\hline Mercury & $\mathrm{mg} / \mathrm{L}$ & 0.0002 & 0.00026 \\
\hline Molybdenum & $\mathrm{mg} / \mathrm{L}$ & 0.01 & 0.05 \\
\hline Nickel & $\mathrm{mg} / \mathrm{L}$ & 0.01 & 0.05 \\
\hline Niobium & $\mathrm{mg} / \mathrm{L}$ & 0.007 & 0.007 \\
\hline Nitrate & $\mathrm{mg} / \mathrm{L}$ & 0.2 & 0.5 \\
\hline Nitrite & $\mathrm{mg} / \mathrm{L}$ & 6.7 & 100 \\
\hline Potassium & $\mathrm{mg} / \mathrm{L}$ & 0.6 & 0.6 \\
\hline Selenium & $\mathrm{mg} / \mathrm{L}$ & 0.005 & 0.03 \\
\hline Silicon & $\mathrm{mg} / \mathrm{L}$ & . & . \\
\hline Silver & $\mathrm{mg} / \mathrm{L}$ & 0.01 & 0.01 \\
\hline Sodium & $\mathrm{mg} / \mathrm{L}$ & . & . \\
\hline
\end{tabular}


B12-102

Table B.37 (continued)

\begin{tabular}{|c|c|c|c|}
\hline Analyte & Units & $\begin{array}{c}\text { Minimum } \\
\text { non-detect }\end{array}$ & $\begin{array}{l}\text { Maximum } \\
\text { non-detect }\end{array}$ \\
\hline Strontium & $\mathrm{mg} / \mathrm{L}$ & . & . \\
\hline Sulfate & $\mathrm{mg} / \mathrm{L}$ & 1 & 5 \\
\hline Thallium & $\mathrm{mg} / \mathrm{L}$ & 0.01 & 0.01 \\
\hline Thorium & $\mathrm{mg} / \mathrm{L}$ & 0.2 & 1 \\
\hline Tin & $\mathrm{mg} / \mathrm{L}$ & 0.01 & 0.01 \\
\hline Titanium & $\mathrm{mg} / \mathrm{L}$ & 0.003 & 0.003 \\
\hline Total Uranium & $\mathrm{mg} / \mathrm{L}$ & 0.001 & 0.001 \\
\hline Vanadium & $\mathrm{mg} / \mathrm{L}$ & 0.005 & 0.025 \\
\hline Zinc & $\mathrm{mg} / \mathrm{L}$ & 0.001 & 0.004 \\
\hline Zirconium & $\mathrm{mg} / \mathrm{L}$ & 0.005 & 0.005 \\
\hline \multicolumn{4}{|c|}{ Organics } \\
\hline 1,1,1-Trichloroethane & $\mu \mathrm{g} / \mathrm{L}$ & 0.8 & 10 \\
\hline 1,1,2,2-Tetrachloroethane & $\mu \mathrm{g} / \mathrm{L}$ & 5 & 10 \\
\hline 1,1,2-Trichloroethane & $\mu \mathrm{g} / \mathrm{L}$ & 5 & 10 \\
\hline 1,1-Dichloroethane & $\mu \mathrm{g} / \mathrm{L}$ & 5 & 10 \\
\hline 1,1-Dichloroethene & $\mu \mathrm{g} / \mathrm{L}$ & 5 & 10 \\
\hline 1,2,4-Trichlorobenzene & $\mu \mathrm{g} / \mathrm{L}$ & 5 & 10 \\
\hline 1,2-Dichlorobenzene & $\mu \mathrm{g} / \mathrm{L}$ & 5 & 10 \\
\hline 1,2-Dichloroethane & $\mu \mathrm{g} / \mathrm{L}$ & 5 & 10 \\
\hline 1,2-Dichloroethene & $\mu \mathrm{g} / \mathrm{L}$ & 5 & 10 \\
\hline 1,2-Dichloropropane & $\mu \mathrm{g} / \mathrm{L}$ & 5 & 10 \\
\hline 1,3-Dichlorobenzene & $\mu \mathrm{g} / \mathrm{L}$ & 5 & 10 \\
\hline 1,4-Dichlorobenzene & $\mu \mathrm{g} / \mathrm{L}$ & 5 & 10 \\
\hline 2,4,5-Trichlorophenol & $\mu \mathrm{g} / \mathrm{L}$ & 25 & 50 \\
\hline 2,4,6-Trichlorophenol & $\mu \mathrm{g} / \mathrm{L}$ & 5 & 10 \\
\hline $2,4-D$ & $\mu \mathrm{g} / \mathrm{L}$ & 1 & 1 \\
\hline 2,4-Dichlorophenol & $\mu \mathrm{g} / \mathrm{L}$ & 5 & 10 \\
\hline 2,4-Dimethylphenol & $\mu \mathrm{g} / \mathrm{L}$ & 5 & 10 \\
\hline 2,4-Dinitrophenol & $\mu \mathrm{g} / \mathrm{L}$ & 25 & 50 \\
\hline 2,4-Dinitrotoluene & $\mu \mathrm{g} / \mathrm{L}$ & 5 & 10 \\
\hline 2,6-Dinitrotoluene & $\mu \mathrm{g} / \mathrm{L}$ & 5 & 10 \\
\hline 2-Butanone & $\mu \mathrm{g} / \mathrm{L}$ & 6 & 10 \\
\hline
\end{tabular}


B12-103

Table B.37 (continued)

\begin{tabular}{|c|c|c|c|}
\hline Analyte & Units & $\begin{array}{c}\text { Minimum } \\
\text { non-detect }\end{array}$ & $\begin{array}{l}\text { Maximum } \\
\text { non-detect }\end{array}$ \\
\hline 2-Chloroethylvinyl ether & $\mu \mathrm{g} / \mathrm{L}$ & 10 & 10 \\
\hline 2-Chloronaphthalene & $\mu \mathrm{g} / \mathrm{L}$ & 5 & 10 \\
\hline 2-Chlorophenol & $\mu \mathrm{g} / \mathrm{L}$ & 5 & 10 \\
\hline 2-Hexanone & $\mu \mathrm{g} / \mathrm{L}$ & $10^{\circ}$ & 10 \\
\hline 2-Methyl-4,6-Dinitrophenol & $\mu \mathrm{g} / \mathrm{L}$ & 25 & 50 \\
\hline 2-Methylnaphthalene & $\mu \mathrm{g} / \mathrm{L}$ & 5 & 10 \\
\hline 2-Methylphenol & $\mu \mathrm{g} / \mathrm{L}$ & 5 & 10 \\
\hline 2-Nitrobenzenamine & $\mu \mathrm{g} / \mathrm{L}$ & 25 & 50 \\
\hline 2-Nitrophenol & $\mu \mathrm{g} / \mathrm{L}$ & 5 & 10 \\
\hline 3,3'-Dichlorobenzidine & $\mu \mathrm{g} / \mathrm{L}$ & 10 & 20 \\
\hline 3-Nitrobenzenamine & $\mu \mathrm{g} / \mathrm{L}$ & 25 & 50 \\
\hline 4,4'-DDD & $\mu \mathrm{g} / \mathrm{L}$ & 0.1 & 0.1 \\
\hline 4,4'-DDE & $\mu \mathrm{g} / \mathrm{L}$ & 0.1 & 0.1 \\
\hline 4,4'-DDT & $\mu \mathrm{g} / \mathrm{L}$ & 0.1 & 0.1 \\
\hline 4-Bromophenyl phenyl ether & $\mu \mathrm{g} / \mathrm{L}$ & 5 & 10 \\
\hline 4-Chloro-3-Methylphenol & $\mu \mathrm{g} / \mathrm{L}$ & 5 & 10 \\
\hline 4-Chlorobenzenamine & $\mu \mathrm{g} / \mathrm{L}$ & 5 & 10 \\
\hline 4-Chlorophenylphenyl ether & $\mu \mathrm{g} / \mathrm{L}$ & 5 & 10 \\
\hline 4-Methyl-2-Pentanone & $\mu \mathrm{g} / \mathrm{L}$ & 1 & 10 \\
\hline 4-Methylphenol & $\mu \mathrm{g} / \mathrm{L}$ & 5 & 10 \\
\hline 4-Nitrobenzenamine & $\mu \mathrm{g} / \mathrm{L}$ & 25 & 50 \\
\hline 4-Nitrophenol & $\mu \mathrm{g} / \mathrm{L}$ & 25 & 50 \\
\hline Acenaphthene & $\mu \mathrm{g} / \mathrm{L}$ & 5 & 10 \\
\hline Acenaphthylene & $\mu \mathrm{g} / \mathrm{L}$ & 5 & 10 \\
\hline Acetone & $\mu \mathrm{g} / \mathrm{L}$ & 1 & 10 \\
\hline Aldrin & $\mu \mathrm{g} / \mathrm{L}$ & 0.05 & 0.05 \\
\hline$\alpha-\mathrm{BHC}$ & $\mu \mathrm{g} / \mathrm{L}$ & 0.05 & 0.05 \\
\hline$\alpha$-Chlordane & $\mu \mathrm{g} / \mathrm{L}$ & 0.5 & 0.5 \\
\hline Aniline & $\mu \mathrm{g} / \mathrm{L}$ & 10 & 10 \\
\hline Anthracene & $\mu \mathrm{g} / \mathrm{L}$ & 5 & 10 \\
\hline Benzene & $\mu \mathrm{g} / \mathrm{L}$ & 5 & 10 \\
\hline Benzenemethanol & $\mu \mathrm{g} / \mathrm{L}$ & 5 & 10 \\
\hline
\end{tabular}


B12-104

Table B.37 (continued)

\begin{tabular}{|c|c|c|c|}
\hline Analyte & Units & $\begin{array}{c}\text { Minimum } \\
\text { non-detect }\end{array}$ & $\begin{array}{l}\text { Maximum } \\
\text { non-detect }\end{array}$ \\
\hline Benzidine & $\mu \mathrm{g} / \mathrm{L}$ & 80 & 80 \\
\hline Benzo(a)anthracene & $\mu \mathrm{g} / \mathrm{L}$ & 5 & 10 \\
\hline Benzo(a)pyrene & $\mu \mathrm{g} / \mathrm{L}$ & 5 & 10 \\
\hline Benzo(b)fluoranthene & $\mu \mathrm{g} / \mathrm{L}$ & 5 & 10 \\
\hline Benzo(ghi)perylene & $\mu \mathrm{g} / \mathrm{L}$ & 5 & 10 \\
\hline Benzo(k)fluoranthene & $\mu \mathrm{g} / \mathrm{L}$ & 5 & 10 \\
\hline Benzoic Acid & $\mu \mathrm{g} / \mathrm{L}$ & 25 & 50 \\
\hline$\beta-\mathrm{BHC}$ & $\mu \mathrm{g} / \mathrm{L}$ & 0.05 & 0.05 \\
\hline Bis(2-chloroethoxy)methane & $\mu \mathrm{g} / \mathrm{L}$ & 5 & 10 \\
\hline Bis(2-chloroethyl) Ether & $\mu \mathrm{g} / \mathrm{L}$ & 5 & 10 \\
\hline Bis(2-chloroisopropyl)ether & $\mu \mathrm{g} / \mathrm{L}$ & 5 & 10 \\
\hline Bis(2-ethylhexyl)phthalate & $\mu \mathrm{g} / \mathrm{L}$ & 5 & 10 \\
\hline Bromodichloromethane & $\mu \mathrm{g} / \mathrm{L}$ & 5 & 10 \\
\hline Bromoform & $\mu \mathrm{g} / \mathrm{L}$ & 5 & 10 \\
\hline Bromomethane & $\mu \mathrm{g} / \mathrm{L}$ & 10 & 10 \\
\hline Butylbenzylphthalate & $\mu \mathrm{g} / \mathrm{L}$ & 5 & 10 \\
\hline Carbon Disulfide & $\mu \mathrm{g} / \mathrm{L}$ & 5 & 10 \\
\hline Carbon Tetrachloride & $\mu \mathrm{g} / \mathrm{L}$ & 5 & 10 \\
\hline Chlorobenzene & $\mu \mathrm{g} / \mathrm{L}$ & 5 & 10 \\
\hline Chloroethane & $\mu \mathrm{g} / \mathrm{L}$ & 10 & 10 \\
\hline Chloroform & $\mu \mathrm{g} / \mathrm{L}$ & 0.8 & 10 \\
\hline Chloromethane & $\mu \mathrm{g} / \mathrm{L}$ & 10 & 10 \\
\hline Chrysene & $\mu \mathrm{g} / \mathrm{L}$ & 5 & 10 \\
\hline Cis-1,3-dichloropropene & $\mu \mathrm{g} / \mathrm{L}$ & 5 & 10 \\
\hline$\triangle-\mathrm{BHC}$ & $\mu \mathrm{g} / \mathrm{L}$ & 0.05 & 0.05 \\
\hline Di-n-butylphthalate & $\mu \mathrm{g} / \mathrm{L}$ & 5 & 10 \\
\hline Di-n-octylphthalate & $\mu \mathrm{g} / \mathrm{L}$ & 5 & 10 \\
\hline Dibenzo(a,h)anthracene & $\mu \mathrm{g} / \mathrm{L}$ & 5 & 10 \\
\hline Dibenzofuran & $\mu \mathrm{g} / \mathrm{L}$ & 5 & 10 \\
\hline Dibromochloromethane & $\mu \mathrm{g} / \mathrm{L}$ & 5 & 10 \\
\hline Dieldrin & $\mu \mathrm{g} / \mathrm{L}$ & 0.1 & 0.1 \\
\hline Diethylphthalate & $\mu \mathrm{g} / \mathrm{L}$ & 5 & 10 \\
\hline
\end{tabular}


B12-105

Table B.37 (continued)

\begin{tabular}{|c|c|c|c|}
\hline Analyte & Units & $\begin{array}{l}\text { Minimum } \\
\text { non-detect }\end{array}$ & $\begin{array}{l}\text { Maximum } \\
\text { non-detect }\end{array}$ \\
\hline Dimethylbenzene & $\mu \mathrm{g} / \mathrm{L}$ & 5 & 10 \\
\hline Dimethylphthalate & $\mu \mathrm{g} / \mathrm{L}$ & 5 & 10 \\
\hline Endosulfan I & $\mu \mathrm{g} / \mathrm{L}$ & 0.05 & 0.05 \\
\hline Endosulfan II & $\mu \mathrm{g} / \mathrm{L}$ & 0.1 & 0.1 \\
\hline Endosulfan Sulfate & $\mu \mathrm{g} / \mathrm{L}$ & 0.1 & 0.1 \\
\hline Endrin & $\mu \mathrm{g} / \mathrm{L}$ & 0.1 & 0.1 \\
\hline Endrin Ketone & $\mu \mathrm{g} / \mathrm{L}$ & 0.1 & 0.1 \\
\hline Ethylbenzene & $\mu \mathrm{g} / \mathrm{L}$ & 0.7 & 10 \\
\hline Fluoranthene & $\mu \mathrm{g} / \mathrm{L}$ & 5 & 10 \\
\hline Fluorene & $\mu \mathrm{g} / \mathrm{L}$ & 5 & 10 \\
\hline$\gamma$-BHC & $\mu \mathrm{g} / \mathrm{L}$ & 0.05 & 0.05 \\
\hline$\gamma$-Chlordane & $\mu \mathrm{g} / \mathrm{L}$ & 0.5 & 0.5 \\
\hline Heptachlor & $\mu \mathrm{g} / \mathrm{L}$ & 0.05 & 0.05 \\
\hline Heptachlor Epoxide & $\mu \mathrm{g} / \mathrm{L}$ & 0.05 & 0.05 \\
\hline Hexachlorobenzene & $\mu \mathrm{g} / \mathrm{L}$ & 5 & 10 \\
\hline Hexachlorobutadiene & $\mu \mathrm{g} / \mathrm{L}$ & 5 & 10 \\
\hline Hexachlorocyclopentadiene & $\mu \mathrm{g} / \mathrm{L}$ & 5 & 10 \\
\hline Hexachloroethane & $\mu \mathrm{g} / \mathrm{L}$ & 5 & 10 \\
\hline Indeno(1,2,3-cd)pyrene & $\mu \mathrm{g} / \mathrm{L}$ & 5 & 10 \\
\hline Isophorone & $\mu \mathrm{g} / \mathrm{L}$ & 5 & 10 \\
\hline Methoxychlor & $\mu \mathrm{g} / \mathrm{L}$ & 0.5 & 0.5 \\
\hline Methylene Chloride & $\mu \mathrm{g} / \mathrm{L}$ & 1 & 16 \\
\hline N-nitroso-di-n-propylamine & $\mu \mathrm{g} / \mathrm{L}$ & 5 & 10 \\
\hline $\mathrm{N}$-nitrosodimethylamine & $\mu \mathrm{g} / \mathrm{L}$ & 10 & 10 \\
\hline N-nitrosodiphenylamine & $\mu \mathrm{g} / \mathrm{L}$ & 5 & 10 \\
\hline Naphthalene & $\mu \mathrm{g} / \mathrm{L}$ & 5 & 10 \\
\hline Nitrobenzene & $\mu \mathrm{g} / \mathrm{L}$ & 5 & 10 \\
\hline PCB-1016 & $\mu \mathrm{g} / \mathrm{L}$ & 0.5 & 0.5 \\
\hline PCB-1221 & $\mu \mathrm{g} / \mathrm{L}$ & 0.5 & 0.5 \\
\hline PCB-1232 & $\mu \mathrm{g} / \mathrm{L}$ & 0.5 & 0.5 \\
\hline PCB-1242 & $\mu \mathrm{g} / \mathrm{L}$ & 0.5 & 0.5 \\
\hline PCB-1248 & $\mu \mathrm{g} / \mathrm{L}$ & 0.5 & 0.5 \\
\hline
\end{tabular}


B12-106

Table B.37 (continued)

\begin{tabular}{|c|c|c|c|}
\hline Analyte & Units & $\begin{array}{l}\text { Minimum } \\
\text { non-detect }\end{array}$ & $\begin{array}{l}\text { Maximum } \\
\text { non-detect }\end{array}$ \\
\hline PCB-1254 & $\mu \mathrm{g} / \mathrm{L}$ & 1 & 1 \\
\hline PCB-1260 & $\mu \mathrm{g} / \mathrm{L}$ & 1 & 1 \\
\hline Pentachlorophenol & $\mu \mathrm{g} / \mathrm{L}$ & 25 & 50 \\
\hline Phenanthrene & $\mu \mathrm{g} / \mathrm{L}$ & 5 & 10 \\
\hline Phenol & $\mu \mathrm{g} / \mathrm{L}$ & 5 & 10 \\
\hline Phenols & $\mathrm{mg} / \mathrm{L}$ & 0.001 & 0.03 \\
\hline Pyrene & $\mu \mathrm{g} / \mathrm{L}$ & 5 & 10 \\
\hline Silvex & $\mu \mathrm{g} / \mathrm{L}$ & 0.1 & 0.1 \\
\hline Styrene & $\mu \mathrm{g} / \mathrm{L}$ & 5 & 10 \\
\hline Tetrachloroethene & $\mu \mathrm{g} / \mathrm{L}$ & 5 & 10 \\
\hline Toluene & $\mu \mathrm{g} / \mathrm{L}$ & 0.6 & 10 \\
\hline Toxaphene & $\mu \mathrm{g} / \mathrm{L}$ & 1 & 1 \\
\hline Trans-1,2-dichloroethene & $\mu \mathrm{g} / \mathrm{L}$ & 5 & 10 \\
\hline Trans-1,3-dichloropropene & $\mu \mathrm{g} / \mathrm{L}$ & 5 & 10 \\
\hline Trichloroethene & $\mu \mathrm{g} / \mathrm{L}$ & 5 & 10 \\
\hline Vinyl acetate & $\mu \mathrm{g} / \mathrm{L}$ & 10 & 10 \\
\hline Vinyl chloride & $\mu \mathrm{g} / \mathrm{L}$ & 10 & 10 \\
\hline \multicolumn{4}{|c|}{$R A D S$} \\
\hline \multicolumn{4}{|l|}{ Americium-241 } \\
\hline \multicolumn{4}{|l|}{ Cesium-137 } \\
\hline \multicolumn{4}{|l|}{ Gross $\alpha$} \\
\hline \multicolumn{4}{|l|}{ Gross $\beta$} \\
\hline \multicolumn{4}{|l|}{ Neptunium-237 } \\
\hline \multicolumn{4}{|l|}{ Plutonium-238 } \\
\hline \multicolumn{4}{|l|}{ Plutonium-239/240 } \\
\hline \multicolumn{4}{|l|}{ Radium-228 } \\
\hline \multicolumn{4}{|l|}{ Technetium-99 } \\
\hline \multicolumn{4}{|l|}{ Thorium-228 } \\
\hline \multicolumn{4}{|l|}{ Thorium-230 } \\
\hline \multicolumn{4}{|l|}{ Thorium-232 } \\
\hline Total Radioactive Strontium & & & \\
\hline Total Radium $\alpha$ & & & \\
\hline
\end{tabular}


B12-107

Table B.37 (continued)

\begin{tabular}{|c|c|c|c|}
\hline Analyte & Units & $\begin{array}{c}\text { Minimum } \\
\text { non-detect }\end{array}$ & $\begin{array}{l}\text { Maximum } \\
\text { non-detect }\end{array}$ \\
\hline \multicolumn{4}{|l|}{ Tritium } \\
\hline \multicolumn{4}{|l|}{ Uranium-234 } \\
\hline \multicolumn{4}{|l|}{ Uranium-235 } \\
\hline Uranium-238 & & & \\
\hline
\end{tabular}

a Refer to Table D.6 in Appendix D for a list of wells and sample dates for this aggregate. 
Table B.38. Minimum and maximum non-detects for groundwater in the OLF aggregate ${ }^{a}$

\begin{tabular}{|c|c|c|c|}
\hline Analyte & Units & $\begin{array}{l}\text { Minimum } \\
\text { non-detect }\end{array}$ & $\begin{array}{l}\text { Maximum } \\
\text { non-detect }\end{array}$ \\
\hline \multicolumn{4}{|c|}{ Inorganics } \\
\hline Aluminum & $\mathrm{mg} / \mathrm{l}$ & 0.02 & 0.02 \\
\hline Antimony & $\mathrm{mg} / \mathrm{l}$ & 0.05 & 0.05 \\
\hline Arsenic & $\mathrm{mg} / \mathrm{l}$ & 0.005 & 0.005 \\
\hline Barium & $\mathrm{mg} / \mathrm{l}$ & . & . \\
\hline Beryllium & $\mathrm{mg} / \mathrm{l}$ & 0.0003 & 0.0003 \\
\hline Boron & $\mathrm{mg} / \mathrm{l}$ & 0.004 & 0.004 \\
\hline Cadmium & $\mathrm{mg} / 1$ & 0.002 & 0.002 \\
\hline Calcium & $\mathrm{mg} / \mathrm{l}$ & . & . \\
\hline Chloride & $\mathrm{mg} / \mathrm{l}$ & 1 & 1 \\
\hline Chromium & $\mathrm{mg} / \mathrm{l}$ & 0.01 & 0.01 \\
\hline Cobalt & $\mathrm{mg} / \mathrm{l}$ & 0.005 & 0.005 \\
\hline Copper & $\mathrm{mg} / \mathrm{l}$ & 0.004 & 0.004 \\
\hline Fluoride & $\mathrm{mg} / \mathrm{l}$ & 0.1 & 0.2 \\
\hline Iron & $\mathrm{mg} / \mathrm{l}$ & 0.004 & 0.005 \\
\hline Lead & $\mathrm{mg} / \mathrm{l}$ & 0.004 & 0.004 \\
\hline Lithium & $\mathrm{mg} / \mathrm{l}$ & 0.004 & 0.004 \\
\hline Magnesium & $\mathrm{mg} / \mathrm{l}$ & . & . \\
\hline Manganese & $\mathrm{mg} / \mathrm{l}$ & 0.001 & 0.001 \\
\hline Mercury & $\mathrm{mg} / \mathrm{l}$ & 0.0002 & 0.00026 \\
\hline Molybdenum & $\mathrm{mg} / \mathrm{l}$ & 0.01 & 0.01 \\
\hline Nickel & $\mathrm{mg} / 1$ & 0.01 & 0.01 \\
\hline Niobium & $\mathrm{mg} / 1$ & 0.007 & 0.007 \\
\hline Nitrate & $\mathrm{mg} / 1$ & 0.1 & 1 \\
\hline Potassium & $\mathrm{mg} / \mathrm{l}$ & 0.6 & 0.6 \\
\hline Selenium & $\mathrm{mg} / \mathrm{l}$ & 0.005 & 0.005 \\
\hline Silicon & $\mathrm{mg} / 1$ & - & . \\
\hline Silver & $\mathrm{mg} / \mathrm{l}$ & 0.01 & 0.01 \\
\hline Sodium & $\mathrm{mg} / \mathrm{l}$ & . & . \\
\hline Strontium & $\mathrm{mg} / \mathrm{l}$ & . & . \\
\hline Sulfate & $\mathrm{mg} / \mathrm{l}$ & 1 & 1 \\
\hline
\end{tabular}


B12-109

Table B.38 (continued)

\begin{tabular}{|c|c|c|c|}
\hline Analyte & Units & $\begin{array}{l}\text { Minimum } \\
\text { non-detect }\end{array}$ & $\begin{array}{l}\text { Maximum } \\
\text { non-detect }\end{array}$ \\
\hline Thallium & $\mathrm{mg} / \mathrm{l}$ & 0.01 & 0.01 \\
\hline Thorium & $\mathrm{mg} / \mathrm{l}$ & 0.2 & 0.2 \\
\hline Titanium & $\mathrm{mg} / \mathrm{l}$ & 0.003 & 0.003 \\
\hline Total Uranium & $\mathrm{mg} / \mathrm{l}$ & 0.001 & 0.001 \\
\hline Vanadium & $\mathrm{mg} / \mathrm{l}$ & 0.005 & 0.005 \\
\hline Zinc & $\mathrm{mg} / \mathrm{l}$ & 0.001 & 0.002 \\
\hline Zirconium & $\mathrm{mg} / \mathrm{l}$ & 0.005 & 0.005 \\
\hline \multicolumn{4}{|c|}{ Organics } \\
\hline 1,1,1-Trichloroethane & $\mu \mathrm{g} / 1$ & 0.8 & 10 \\
\hline 1,1,2,2-Tetrachloroethane & $\mu \mathrm{g} / 1$ & 5 & 10 \\
\hline 1,1,2-Trichloroethane & $\mu \mathrm{g} / 1$ & 5 & 10 \\
\hline 1,1-Dichloroethane & $\mu \mathrm{g} / 1$ & 5 & 10 \\
\hline 1,1-Dichloroethene & $\mu \mathrm{g} / 1$ & 5 & 10 \\
\hline 1,2,4-Trichlorobenzene & $\mu \mathrm{g} / 1$ & 10 & 10 \\
\hline 1,2-Dichlorobenzene & $\mu \mathrm{g} / \mathrm{l}$ & 10 & 10 \\
\hline 1,2-Dichloroethane & $\mu \mathrm{g} / \mathrm{l}$ & 5 & 10 \\
\hline 1,2-Dichloroethene & $\mu \mathrm{g} / \mathrm{l}$ & 5 & 10 \\
\hline 1,2-Dichloropropane & $\mu \mathrm{g} / \mathrm{l}$ & 5 & 10 \\
\hline 1,3-Dichlorobenzene & $\mu \mathrm{g} / \mathrm{l}$ & 10 & 10 \\
\hline 1,4-Dichlorobenzene & $\mu \mathrm{g} / \mathrm{l}$ & 10 & 10 \\
\hline 2,4,5-Trichlorophenol & $\mu \mathrm{g} / \mathrm{l}$ & 50 & 50 \\
\hline 2,4,6-Trichlorophenol & $\mu \mathrm{g} / \mathrm{l}$ & 10 & 10 \\
\hline $2,4-D$ & $\mu \mathrm{g} / 1$ & 1 & 1 \\
\hline 2,4-Dichlorophenol & $\mu \mathrm{g} / \mathrm{l}$ & 10 & 10 \\
\hline 2,4-Dimethylphenol & $\mu \mathrm{g} / 1$ & 10 & 10 \\
\hline 2,4-Dinitrophenol & $\mu \mathrm{g} / \mathrm{l}$ & 50 & 50 \\
\hline 2,4-Dinitrotoluene & $\mu \mathrm{g} / 1$ & 10 & 10 \\
\hline 2,6-Dinitrotoluene & $\mu \mathrm{g} / 1$ & 10 & 10 \\
\hline 2-Butanone & $\mu \mathrm{g} / \mathrm{l}$ & 3 & 20 \\
\hline 2-Chloroethylvinyl ether & $\mu \mathrm{g} / \mathrm{l}$ & 10 & 10 \\
\hline 2-Chloronaphthalene & $\mu \mathrm{g} / 1$ & 10 & 10 \\
\hline
\end{tabular}


B12-110

Table B.38 (continued)

\begin{tabular}{|c|c|c|c|}
\hline Analyte & Units & $\begin{array}{l}\text { Minimum } \\
\text { non-detect }\end{array}$ & $\begin{array}{l}\text { Maximum } \\
\text { non-detect }\end{array}$ \\
\hline 2-Chlorophenol & $\mu \mathrm{g} / 1$ & 10 & 10 \\
\hline 2-Hexanone & $\mu \mathrm{g} / 1$ & 10 & 20 \\
\hline 2-Methyl-4,6-Dinitrophenol & $\mu \mathrm{g} / 1$ & 50 & 50 \\
\hline 2-Methylnaphthalene & $\mu \mathrm{g} / 1$ & 10 & 10 \\
\hline 2-Methylphenol & $\mu \mathrm{g} / 1$ & 10 & 10 \\
\hline 2-Nitrobenzenamine & $\mu \mathrm{g} / \mathrm{l}$ & 50 & 50 \\
\hline 2-Nitrophenol & $\mu \mathrm{g} / 1$ & 10 & 10 \\
\hline 3,3'-Dichlorobenzidine & $\mu \mathrm{g} / 1$ & 20 & 20 \\
\hline 3-Nitrobenzenamine & $\mu \mathrm{g} / \mathrm{l}$ & 50 & 50 \\
\hline 4,4'-DDD & $\mu \mathrm{g} / 1$ & 0.1 & 0.1 \\
\hline 4,4'-DDE & $\mu \mathrm{g} / 1$ & 0.1 & 0.1 \\
\hline 4,4'-DDT & $\mu \mathrm{g} / 1$ & 0.1 & 0.1 \\
\hline 4-Bromophenyl phenyl ether & $\mu \mathrm{g} / 1$ & 10 & 10 \\
\hline 4-Chloro-3-Methylphenol & $\mu \mathrm{g} / 1$ & 10 & 10 \\
\hline 4-Chlorobenzenamine & $\mu \mathrm{g} / 1$ & 10 & 10 \\
\hline 4-Chlorophenylphenyl ether & $\mu \mathrm{g} / 1$ & 10 & 10 \\
\hline 4-Methyl-2-Pentanone & $\mu \mathrm{g} / 1$ & 1 & 20 \\
\hline 4-Methylphenol & $\mu \mathrm{g} / 1$ & 10 & 10 \\
\hline 4-Nitrobenzenamine & $\mu \mathrm{g} / 1$ & 50 & 50 \\
\hline 4-Nitrophenol & $\mu \mathrm{g} / 1$ & 50 & 50 \\
\hline Acenaphthene & $\mu \mathrm{g} / 1$ & 10 & 10 \\
\hline Acenaphthylene & $\mu \mathrm{g} / \mathrm{l}$ & 10 & 10 \\
\hline Acetone & $\mu \mathrm{g} / \mathrm{l}$ & 1 & 49 \\
\hline Aldrin & $\mu \mathrm{g} / 1$ & 0.05 & 0.05 \\
\hline$\alpha-\mathrm{BHC}$ & $\mu \mathrm{g} / 1$ & 0.05 & 0.05 \\
\hline$\alpha$-Chlordane & $\mu \mathrm{g} / \mathrm{l}$ & 0.5 & 0.5 \\
\hline Anthracene & $\mu \mathrm{g} / \mathrm{l}$ & 10 & 10 \\
\hline Benzene & $\mu \mathrm{g} / 1$ & 5 & 10 \\
\hline Benzenemethanol & $\mu \mathrm{g} / 1$ & 10 & 10 \\
\hline Benzo(a)anthracene & $\mu \mathrm{g} / \mathrm{l}$ & 10 & 10 \\
\hline Benzo(a)pyrene & $\mu \mathrm{g} / 1$ & 10 & 10 \\
\hline
\end{tabular}


B12-111

Table B.38 (continued)

\begin{tabular}{|c|c|c|c|}
\hline Analyte & Units & $\begin{array}{l}\text { Minimum } \\
\text { non-detect }\end{array}$ & $\begin{array}{l}\text { Maximum } \\
\text { non-detect }\end{array}$ \\
\hline Benzo(b)fluoranthene & $\mu \mathrm{g} / 1$ & 10 & 10 \\
\hline Benzo(ghi)perylene & $\mu \mathrm{g} / \mathrm{l}$ & 10 & 10 \\
\hline Benzo(k)fluoranthene & $\mu \mathrm{g} / 1$ & 10 & 10 \\
\hline Benzoic acid & $\mu \mathrm{g} / \mathrm{l}$ & 50 & 50 \\
\hline$\beta$-BHC & $\mu \mathrm{g} / \mathrm{l}$ & 0.05 & 0.05 \\
\hline Bis(2-chloroethoxy)methane & $\mu \mathrm{g} / \mathrm{l}$ & 10 & 10 \\
\hline Bis(2-chloroethyl)ether & $\mu \mathrm{g} / \mathrm{l}$ & 10 & 10 \\
\hline Bis(2-chloroisopropyl)ether & $\mu \mathrm{g} / \mathrm{l}$ & 10 & 10 \\
\hline Bis(2-ethylhexyl)phthalate & $\mu \mathrm{g} / 1$ & 10 & 10 \\
\hline Bromodichloromethane & $\mu \mathrm{g} / \mathrm{l}$ & 5 & 10 \\
\hline Bromoform & $\mu \mathrm{g} / \mathrm{l}$ & 5 & 10 \\
\hline Bromomethane & $\mu \mathrm{g} / 1$ & 10 & 20 \\
\hline Butylbenzylphthalate & $\mu \mathrm{g} / \mathrm{l}$ & 10 & 10 \\
\hline Carbon Disulfide & $\mu \mathrm{g} / \mathrm{l}$ & 5 & 10 \\
\hline Carbon Tetrachloride & $\mu \mathrm{g} / \mathrm{l}$ & 5 & 10 \\
\hline Chlorobenzene & $\mu \mathrm{g} / 1$ & 5 & 10 \\
\hline Chloroethane & $\mu \mathrm{g} / 1$ & 10 & 20 \\
\hline Chloroform & $\mu \mathrm{g} / 1$ & 0.8 & 10 \\
\hline Chloromethane & $\mu \mathrm{g} / \mathrm{l}$ & 10 & 20 \\
\hline Chrysene & $\mu \mathrm{g} / \mathrm{l}$ & 10 & 10 \\
\hline Cis-1,3-Dichloropropene & $\mu \mathrm{g} / \mathrm{l}$ & 5 & 10 \\
\hline$\Delta$-BHC & $\mu \mathrm{g} / 1$ & 0.05 & 0.05 \\
\hline Di-n-butylphthalate & $\mu \mathrm{g} / 1$ & 10 & 10 \\
\hline Di-n-octylphthalate & $\mu \mathrm{g} / 1$ & 10 & 10 \\
\hline Dibenzo(a,h)anthracene & $\mu \mathrm{g} / 1$ & 10 & 10 \\
\hline Dibenzofuran & $\mu \mathrm{g} / 1$ & 10 & 10 \\
\hline Dibromochloromethane & $\mu \mathrm{g} / \mathrm{l}$ & 5 & 10 \\
\hline Dieldrin & $\mu \mathrm{g} / \mathrm{l}$ & 0.1 & 0.1 \\
\hline Diethylphthalate & $\mu \mathrm{g} /$ & 10 & 10 \\
\hline Dimethylbenzene & $\mu \mathrm{g} / 1$ & 5 & 10 \\
\hline Dimethylphthalate & $\mu \mathrm{g} / \mathrm{l}$ & 10 & 10 \\
\hline
\end{tabular}


B12-112

Table B.38 (continued)

\begin{tabular}{|c|c|c|c|}
\hline Analyte & Units & $\begin{array}{l}\text { Minimum } \\
\text { non-detect }\end{array}$ & $\begin{array}{l}\text { Maximum } \\
\text { non-detect }\end{array}$ \\
\hline Endosulfan I & $\mu \mathrm{g} / \mathrm{l}$ & 0.05 & 0.05 \\
\hline Endosulfan II & $\mu \mathrm{g} / 1$ & 0.1 & 0.1 \\
\hline Endosulfan Sulfate & $\mu \mathrm{g} / 1$ & 0.1 & 0.1 \\
\hline Endrin & $\mu \mathrm{g} /$ & 0.1 & 0.1 \\
\hline Endrin Ketone & $\mu \mathrm{g} / 1$ & 0.1 & 0.1 \\
\hline Ethylbenzene & $\mu \mathrm{g} / 1$ & 5 & 10 \\
\hline Fluoranthene & $\mu \mathrm{g} / 1$ & 10 & 10 \\
\hline Fluorene & $\mu \mathrm{g} / 1$ & 10 & 10 \\
\hline$\gamma-\mathrm{BHC}$ & $\mu \mathrm{g} / 1$ & 0.05 & 0.05 \\
\hline$\gamma$-Chlordane & $\mu \mathrm{g} / 1$ & 0.5 & 0.5 \\
\hline Heptachlor & $\mu \mathrm{g} / 1$ & 0.05 & 0.05 \\
\hline Heptachlor Epoxide & $\mu \mathrm{g} / 1$ & 0.05 & 0.05 \\
\hline Hexachlorobenzene & $\mu \mathrm{g} / 1$ & 10 & 10 \\
\hline Hexachlorobutadiene & $\mu \mathrm{g} / 1$ & 10 & 10 \\
\hline Hexachlorocyclopentadiene & $\mu \mathrm{g} / 1$ & 10 & 10 \\
\hline Hexachloroethane & $\mu \mathrm{g} / 1$ & 10 & 10 \\
\hline Indeno(1,2,3-cd)pyrene & $\mu \mathrm{g} / 1$ & 10 & 10 \\
\hline Isophorone & $\mu \mathrm{g} / 1$ & 10 & 10 \\
\hline Methoxychlor & $\mu \mathrm{g} / 1$ & 0.5 & 0.5 \\
\hline Methylene Chloride & $\mu \mathrm{g} / \mathrm{l}$ & 0.6 & 17 \\
\hline N-nitroso-di-n-propylamine & $\mu \mathrm{g} / 1$ & 10 & 10 \\
\hline $\mathrm{N}$-nitrosodiphenylamine & $\mu \mathrm{g} / 1$ & 10 & 10 \\
\hline Naphthalene & $\mu \mathrm{g} / 1$ & 10 & 10 \\
\hline Nitrobenzene & $\mu \mathrm{g} / 1$ & 10 & 10 \\
\hline PCB-1016 & $\mu \mathrm{g} / 1$ & 0.5 & 0.5 \\
\hline PCB-1221 & $\mu \mathrm{g} / 1$ & 0.5 & 0.5 \\
\hline PCB-1232 & $\mu \mathrm{g} / 1$ & 0.5 & 0.5 \\
\hline PCB-1242 & $\mu \mathrm{g} / 1$ & 0.5 & 0.5 \\
\hline PCB-1248 & $\mu \mathrm{g} / 1$ & 0.5 & 0.5 \\
\hline PCB-1254 & $\mu \mathrm{g} / 1$ & 1 & 1 \\
\hline PCB- 1260 & $\mu \mathrm{g} / \mathrm{l}$ & 1 & 1 \\
\hline
\end{tabular}


B12-113

Table B.38 (continued)

\begin{tabular}{|c|c|c|c|}
\hline Analyte & Units & $\begin{array}{c}\text { Minimum } \\
\text { non-detect }\end{array}$ & $\begin{array}{l}\text { Maximum } \\
\text { non-detect }\end{array}$ \\
\hline Pentachlorophenol & $\mu \mathrm{g} / \mathrm{l}$ & 50 & 50 \\
\hline Phenanthrene & $\mu \mathrm{g} / 1$ & 10 & 10 \\
\hline Phenol & $\mu \mathrm{g} / \mathrm{l}$ & 10 & 10 \\
\hline Phenols & $\mathrm{mg} / \mathrm{l}$ & 0.001 & 0.03 \\
\hline Pyrene & $\mu \mathrm{g} / \mathrm{l}$ & 10 & 10 \\
\hline Silvex & $\mu \mathrm{g} / 1$ & 0.1 & 0.1 \\
\hline Styrene & $\mu \mathrm{g} / 1$ & 5 & 10 \\
\hline Tetrachloroethene & $\mu \mathrm{g} / 1$ & 5 & 10 \\
\hline Toluene & $\mu \mathrm{g} / 1$ & 0.7 & 10 \\
\hline Toxaphene & $\mu \mathrm{g} / \mathrm{l}$ & 1 & 1 \\
\hline Trans-1,2-Dichloroethene & $\mu \mathrm{g} / \mathrm{l}$ & 5 & 5 \\
\hline Trans-1,3-Dichloropropene & $\mu \mathrm{g} / \mathrm{l}$ & 5 & 10 \\
\hline Trichloroethene & $\mu \mathrm{g} / \mathrm{l}$ & 5 & 10 \\
\hline Vinyl acetate & $\mu \mathrm{g} / \mathrm{l}$ & 10 & 20 \\
\hline Vinyl chloride & $\mu \mathrm{g} / \mathrm{l}$ & 10 & 20 \\
\hline \multicolumn{4}{|c|}{$R A D S$} \\
\hline \multicolumn{4}{|l|}{ Americium-241 } \\
\hline \multicolumn{4}{|l|}{ Cesium-137 } \\
\hline \multicolumn{4}{|l|}{ Gross $\alpha$} \\
\hline \multicolumn{4}{|l|}{ Gross $\beta$} \\
\hline \multicolumn{4}{|l|}{ Neptunium-237 } \\
\hline \multicolumn{4}{|l|}{ Plutonium-238 } \\
\hline \multicolumn{4}{|l|}{ Plutonium-239/240 } \\
\hline \multicolumn{4}{|l|}{ Radium-228 } \\
\hline \multicolumn{4}{|l|}{ Technetium-99 } \\
\hline \multicolumn{4}{|l|}{ Thorium-228 } \\
\hline \multicolumn{4}{|l|}{ Thorium-230 } \\
\hline \multicolumn{4}{|l|}{ Thorium-232 } \\
\hline \multicolumn{4}{|l|}{ Total Radioactive Strontium } \\
\hline Total Radium $\alpha$ & & & \\
\hline Tritium & & & \\
\hline
\end{tabular}


B12-114

Table B.38 (continued)

\begin{tabular}{llll}
\hline Analyte & Units & $\begin{array}{c}\text { Minimum } \\
\text { non-detect }\end{array}$ & $\begin{array}{c}\text { Maximum } \\
\text { non-detect }\end{array}$ \\
\hline Uranium-234 & & & \\
Uranium-235 & & & \\
Uranium-238 & & & \\
\hline
\end{tabular}

- Refer to Table D.6 in Appendix D for a list of wells and sample dates for this aggregate. 


\section{B12-115}

Table B.39. Minimum and maximum non-detects for groundwater in the BCBG aggregate ${ }^{a}$

\begin{tabular}{|c|c|c|c|}
\hline Analyte & Units & $\begin{array}{c}\text { Minimum } \\
\text { non-detect }\end{array}$ & $\begin{array}{l}\text { Maximum } \\
\text { non-detect }\end{array}$ \\
\hline \multicolumn{4}{|c|}{ Inorganics } \\
\hline Aluminum & $\mathrm{mg} / \mathrm{L}$ & 0.02 & 0. \\
\hline Antimony & $\mathrm{mg} / \mathrm{L}$ & 0.05 & 0.25 \\
\hline Arsenic & $\mathrm{mg} / \mathrm{L}$ & 0.005 & 0.005 \\
\hline Barium & $\mathrm{mg} / \mathrm{L}$ & . & . \\
\hline Beryllium & $\mathrm{mg} / \mathrm{L}$ & 0.0003 & 0.000 \\
\hline Boron & $\mathrm{mg} / \mathrm{L}$ & 0.003 & 0.004 \\
\hline Cadmium & $\mathrm{mg} / \mathrm{L}$ & 0.002 & 0.002 \\
\hline Calcium & $\mathrm{mg} / \mathrm{L}$ & . & . \\
\hline Chloride & $\mathrm{mg} / \mathrm{L}$ & 1 & 5 \\
\hline Chromium & $\mathrm{mg} / \mathrm{L}$ & 0.01 & 0.05 \\
\hline Cobalt & $\mathrm{mg} / \mathrm{L}$ & 0.004 & 0.025 \\
\hline Copper & $\mathrm{mg} / \mathrm{L}$ & 0.004 & 0.02 \\
\hline Fluoride & $\mathrm{mg} / \mathrm{L}$ & 0.1 & 0.1 \\
\hline Iron & $\mathrm{mg} / \mathrm{L}$ & 0.004 & 0.005 \\
\hline Lead & $\mathrm{mg} / \mathrm{L}$ & 0.004 & 0.02 \\
\hline Lithium & $\mathrm{mg} / \mathrm{L}$ & 0.001 & 0.001 \\
\hline Magnesium & $\mathrm{mg} / \mathrm{L}$ & . & . \\
\hline Manganese & $\mathrm{mg} / \mathrm{L}$ & 0.001 & 0.001 \\
\hline Mercury & $\mathrm{mg} / \mathrm{L}$ & 0.0002 & 0.0002 \\
\hline Molybdenum & $\mathrm{mg} / \mathrm{L}$ & 0.01 & 0.05 \\
\hline Nickel & $\mathrm{mg} / \mathrm{L}$ & 0.01 & 0.05 \\
\hline Niobium & $\mathrm{mg} / \mathrm{L}$ & 0.007 & 0.007 \\
\hline Nitrate & $\mathrm{mg} / \mathrm{L}$ & 0.11 & 1 \\
\hline Potassium & $\mathrm{mg} / \mathrm{L}$ & 0.6 & 0.6 \\
\hline Selenium & $\mathrm{mg} / \mathrm{L}$ & 0.005 & 0.005 \\
\hline Silicon & $\mathrm{mg} / \mathrm{L}$ & . & - \\
\hline Silver & $\mathrm{mg} / \mathrm{L}$ & 0.01 & 0.01 \\
\hline Sodium & $\mathrm{mg} / \mathrm{L}$ & . & . \\
\hline Strontium & $\mathrm{mg} / \mathrm{L}$ & - & - \\
\hline Sulfate & $\mathrm{mg} / \mathrm{L}$ & 0.2 & 1 \\
\hline
\end{tabular}


B12-116

Table B.39 (continued)

\begin{tabular}{|c|c|c|c|}
\hline Analyte & Units & $\begin{array}{c}\text { Minimum } \\
\text { non-detect }\end{array}$ & $\begin{array}{l}\text { Maximum } \\
\text { non-detect }\end{array}$ \\
\hline Thallium & $\mathrm{mg} / \mathrm{L}$ & 0.01 & 0.01 \\
\hline Thorium & $\mathrm{mg} / \mathrm{L}$ & 0.2 & 1 \\
\hline Titanium & $\mathrm{mg} / \mathrm{L}$ & 0.003 & 0.003 \\
\hline Total uranium & $\mathrm{mg} / \mathrm{L}$ & 0.001 & 0.001 \\
\hline Vanadium & $\mathrm{mg} / \mathrm{L}$ & 0.004 & 0.025 \\
\hline Zinc & $\mathrm{mg} / \mathrm{L}$ & 0.001 & 0.002 \\
\hline Zirconium & $\mathrm{mg} / \mathrm{L}$ & 0.001 & 0.005 \\
\hline \multicolumn{4}{|c|}{ Organics } \\
\hline 1,1,1-Trichloroethane & $\mu \mathrm{g} / \mathrm{L}$ & 0.8 & 25 \\
\hline 1,1,2,2-Tetrachloroethane & $\mu \mathrm{g} / \mathrm{L}$ & 1 & 25 \\
\hline 1,1,2-Trichloroethane & $\mu \mathrm{g} / \mathrm{L}$ & 5 & 25 \\
\hline 1,1-Dichloroethane & $\mu \mathrm{g} / \mathrm{L}$ & 5 & 25 \\
\hline 1,1-Dichloroethene & $\mu \mathrm{g} / \mathrm{L}$ & 5 & 25 \\
\hline 1,2-Dichloroethane & $\mu \mathrm{g} / \mathrm{L}$ & 5 & 25 \\
\hline 1,2-Dichloroethene & $\mu \mathrm{g} / \mathrm{L}$ & 5 & 25 \\
\hline 1,2-Dichloropropane & $\mu \mathrm{g} / \mathrm{L}$ & 5 & 25 \\
\hline $2,4,5-\mathrm{T}$ & $\mu \mathrm{g} / \mathrm{L}$ & 0.1 & 0.1 \\
\hline 2,4-D & $\mu \mathrm{g} / \mathrm{L}$ & 1 & 1 \\
\hline 2-Butanone & $\mu \mathrm{g} / \mathrm{L}$ & 2 & 50 \\
\hline 2-Chloroethylvinyl ether & $\mu \mathrm{g} / \mathrm{L}$ & 10 & 10 \\
\hline 2-Hexanone & $\mu \mathrm{g} / \mathrm{L}$ & 1 & 50 \\
\hline 4,4'-DDD & $\mu \mathrm{g} / \mathrm{L}$ & 0.1 & 0.1 \\
\hline 4,4'-DDE & $\mu \mathrm{g} / \mathrm{L}$ & 0.1 & 0.1 \\
\hline $4,4^{\prime}-\mathrm{DDT}$ & $\mu \mathrm{g} / \mathrm{L}$ & 0.1 & 0.1 \\
\hline 4-Methyl-2-Pentanone & $\mu \mathrm{g} / \mathrm{L}$ & 1 & 50 \\
\hline Acetone & $\mu \mathrm{g} / \mathrm{L}$ & 1 & 50 \\
\hline Aldrin & $\mu \mathrm{g} / \mathrm{L}$ & 0.05 & 0.05 \\
\hline$\alpha-B H C$ & $\mu \mathrm{g} / \mathrm{L}$ & 0.05 & 0.05 \\
\hline$\alpha$-Chlordane & $\mu \mathrm{g} / \mathrm{L}$ & 0.5 & 0.5 \\
\hline Benzene & $\mu \mathrm{g} / \mathrm{L}$ & 5 & 25 \\
\hline$\beta$-BHC & $\mu \mathrm{g} / \mathrm{L}$ & 0.05 & 0.05 \\
\hline
\end{tabular}


B12-117

Table B.39 (continued)

\begin{tabular}{|c|c|c|c|}
\hline Analyte & Units & $\begin{array}{c}\text { Minimum } \\
\text { non-detect }\end{array}$ & $\begin{array}{l}\text { Maximum } \\
\text { non-detect }\end{array}$ \\
\hline Bromodichloromethane & $\mu \mathrm{g} / \mathrm{L}$ & 5 & 25 \\
\hline Bromoform & $\mu \mathrm{g} / \mathrm{L}$ & 5 & 25 \\
\hline Bromomethane & $\mu \mathrm{g} / \mathrm{L}$ & 10 & 50 \\
\hline Carbon Disulfide & $\mu \mathrm{g} / \mathrm{L}$ & 1 & 25 \\
\hline Carbon Tetrachloride & $\mu \mathrm{g} / \mathrm{L}$ & 5 & 25 \\
\hline Chlorobenzene & $\mu \mathrm{g} / \mathrm{L}$ & 5 & 25 \\
\hline Chloroethane & $\mu \mathrm{g} / \mathrm{L}$ & 10 & 50 \\
\hline Chloroform & $\mu \mathrm{g} / \mathrm{L}$ & 0.8 & 25 \\
\hline Chloromethane & $\mu \mathrm{g} / \mathrm{L}$ & 10 & 50 \\
\hline Cis-1,3-Dichloropropene & $\mu \mathrm{g} / \mathrm{L}$ & 5 & 25 \\
\hline$\Delta-\mathrm{BHC}$ & $\mu \mathrm{g} / \mathrm{L}$ & 0.05 & 0.05 \\
\hline Dibromochloromethane & $\mu \mathrm{g} / \mathrm{L}$ & 5 & 25 \\
\hline Dieldrin & $\mu \mathrm{g} / \mathrm{L}$ & 0.1 & 0.1 \\
\hline Dimethylbenzene & $\mu \mathrm{g} / \mathrm{L}$ & 5 & 25 \\
\hline Endosulfan I & $\mu \mathrm{g} / \mathrm{L}$ & 0.05 & 0.05 \\
\hline Endosulfan II & $\mu \mathrm{g} / \mathrm{L}$ & 0.1 & 0.1 \\
\hline Endosulfan Sulfate & $\mu \mathrm{g} / \mathrm{L}$ & 0.1 & 0.1 \\
\hline Endrin & $\mu \mathrm{g} / \mathrm{L}$ & 0.1 & 0.1 \\
\hline Endrin Ketone & $\mu \mathrm{g} / \mathrm{L}$ & 0.1 & 0.1 \\
\hline Ethylbenzene & $\mu \mathrm{g} / \mathrm{L}$ & 5 & 25 \\
\hline$\gamma$-BHC & $\mu \mathrm{g} / \mathrm{L}$ & 0.05 & 0.05 \\
\hline$\gamma$-Chlordane & $\mu \mathrm{g} / \mathrm{L}$ & 0.5 & 0.5 \\
\hline Heptachlor & $\mu \mathrm{g} / \mathrm{L}$ & 0.05 & 0.05 \\
\hline Heptachlor epoxide & $\mu \mathrm{g} / \mathrm{L}$ & 0.05 & 0.05 \\
\hline Methoxychlor & $\mu \mathrm{g} / \mathrm{L}$ & 0.5 & 0.5 \\
\hline Methylene chloride & $\mu \mathrm{g} / \mathrm{L}$ & 0.6 & 25 \\
\hline PCB-1016 & $\mu \mathrm{g} / \mathrm{L}$ & 0.5 & 0.5 \\
\hline PCB-1221 & $\mu \mathrm{g} / \mathrm{L}$ & 0.5 & 0.5 \\
\hline PCB-1232 & $\mu \mathrm{g} / \mathrm{L}$ & 0.5 & 0.5 \\
\hline PCB-1242 & $\mu \mathrm{g} / \mathrm{L}$ & 0.5 & 0.5 \\
\hline PCB-1248 & $\mu \mathrm{g} / \mathrm{L}$ & 0.5 & 0.5 \\
\hline
\end{tabular}


B12-118

Table B.39 (continued)

\begin{tabular}{|c|c|c|c|}
\hline Analyte & Units & $\begin{array}{c}\text { Minimum } \\
\text { non-detect }\end{array}$ & $\begin{array}{l}\text { Maximum } \\
\text { non-detect }\end{array}$ \\
\hline PCB-1254 & $\mu \mathrm{g} / \mathrm{L}$ & 1 & 1 \\
\hline PCB- 1260 & $\mu \mathrm{g} / \mathrm{L}$ & 1 & 1 \\
\hline Phenols & $\mathrm{mg} / \mathrm{L}$ & 0.001 & 0.05 \\
\hline Silvex & $\mu \mathrm{g} / \mathrm{L}$ & 0.1 & 0.1 \\
\hline Styrene & $\mu \mathrm{g} / \mathrm{L}$ & 5 & 25 \\
\hline Technical Chlordane & $\mu \mathrm{g} / \mathrm{L}$ & 0.5 & 0.5 \\
\hline Tetrachloroethene & $\mu \mathrm{g} / \mathrm{L}$ & 5 & 10 \\
\hline Toluene & $\mu \mathrm{g} / \mathrm{L}$ & 0.3 & 25 \\
\hline Toxaphene & $\mu \mathrm{g} / \mathrm{L}$ & 1 & 1 \\
\hline Trans-1,2-Dichloroethene & $\mu \mathrm{g} / \mathrm{L}$ & 5 & 5 \\
\hline Trans-1,3-Dichloropropene & $\mu \mathrm{g} / \mathrm{L}$ & 5 & 25 \\
\hline Trichloroethene & $\mu \mathrm{g} / \mathrm{L}$ & 5 & 25 \\
\hline Vinyl acetate & $\mu \mathrm{g} / \mathrm{L}$ & 2 & 50 \\
\hline Vinyl chloride & $\mu \mathrm{g} / \mathrm{L}$ & 10 & 50 \\
\hline \multicolumn{4}{|c|}{$R A D S$} \\
\hline \multicolumn{4}{|l|}{ Americium-241 } \\
\hline \multicolumn{4}{|l|}{ Cesium-137 } \\
\hline \multicolumn{4}{|l|}{ Gross $\alpha$} \\
\hline \multicolumn{4}{|l|}{ Gross $\beta$} \\
\hline \multicolumn{4}{|l|}{ Neptunium-237 } \\
\hline \multicolumn{4}{|l|}{ Plutonium-238 } \\
\hline \multicolumn{4}{|l|}{ Plutonium-239/240 } \\
\hline \multicolumn{4}{|l|}{ Radium-228 } \\
\hline \multicolumn{4}{|l|}{ Technetium-99 } \\
\hline \multicolumn{4}{|l|}{ Thorium-228 } \\
\hline \multicolumn{4}{|l|}{ Thorium-230 } \\
\hline \multicolumn{4}{|l|}{ Thorium-232 } \\
\hline \multicolumn{4}{|l|}{ Total Radioactive Strontium } \\
\hline \multicolumn{4}{|l|}{ Total Radium $\alpha$} \\
\hline \multicolumn{4}{|l|}{ Tritium } \\
\hline Uranium-234 & & & \\
\hline
\end{tabular}


B12-119

Table B.39 (continued)

\begin{tabular}{llll}
\hline Analyte & Units & $\begin{array}{c}\text { Minimum } \\
\text { non-detect }\end{array}$ & $\begin{array}{c}\text { Maximum } \\
\text { non-detect }\end{array}$ \\
\hline Uranium-235 & & & \\
Uranium-238 & & \\
\hline
\end{tabular}

- Refer to Table D.6 in Appendix D for a list of wells and sample dates for this aggregate. 
B $12-120$

Table B.40. Minimum and maximum non-detects for groundwater in the Maynardville aggregate ${ }^{a}$

\begin{tabular}{|c|c|c|c|}
\hline Analyte & Units & $\begin{array}{c}\text { Minimum } \\
\text { non-detect }\end{array}$ & $\begin{array}{l}\text { Maximum } \\
\text { non-detect }\end{array}$ \\
\hline \multicolumn{4}{|c|}{ Inorganics } \\
\hline Aluminum & $\mathrm{mg} / \mathrm{l}$ & 0.02 & 0.1 \\
\hline Ammonia Nitrogen & $\mathrm{mg} / \mathrm{l}$ & 0.2 & 0.2 \\
\hline Antimony & $\mathrm{mg} / 1$ & 0.05 & 0.25 \\
\hline Arsenic & $\mathrm{mg} / \mathrm{l}$ & 0.005 & 0.005 \\
\hline Barium & $\mathrm{mg} / \mathrm{l}$ & . & . \\
\hline Beryllium & $\mathrm{mg} / \mathrm{l}$ & 0.0003 & 0.0006 \\
\hline Boron & $\mathrm{mg} / \mathrm{l}$ & 0.004 & 0.004 \\
\hline Cadmium & $\mathrm{mg} / \mathrm{l}$ & 0.002 & 0.003 \\
\hline Calcium & $\mathrm{mg} / 1$ & . & . \\
\hline Chloride & $\mathrm{mg} / \mathrm{l}$ & 1 & 1 \\
\hline Chromium & $\mathrm{mg} / 1$ & 0.01 & 0.05 \\
\hline Cobalt & $\mathrm{mg} / \mathrm{l}$ & 0.005 & 0.025 \\
\hline Copper & $\mathrm{mg} / \mathrm{l}$ & 0.004 & 0.02 \\
\hline Fluoride & $\mathrm{mg} / 1$ & 0.1 & 0.1 \\
\hline Iron & $\mathrm{mg} / \mathrm{l}$ & 0.004 & 0.005 \\
\hline Kjeldahl Nitrogen & $\mathrm{mg} / 1$ & 0.05 & 0.06 \\
\hline Lead & $\mathrm{mg} / \mathrm{l}$ & 0.004 & 0.02 \\
\hline Lithium & $\mathrm{mg} / 1$ & 0.004 & 0.004 \\
\hline Magnesium & $\mathrm{mg} / \mathrm{l}$ & . & . \\
\hline Manganese & $\mathrm{mg} / \mathrm{l}$ & 0.001 & 0.001 \\
\hline Mercury & $\mathrm{mg} / \mathrm{l}$ & 0.0002 & 0.00026 \\
\hline Molybdenum & $\mathrm{mg} / \mathrm{l}$ & 0.01 & 0.05 \\
\hline Nickel & $\mathrm{mg} / \mathrm{l}$ & 0.01 & 0.05 \\
\hline Niobium & $\mathrm{mg} / \mathrm{l}$ & 0.007 & 0.007 \\
\hline Nitrate & $\mathrm{mg} / \mathrm{l}$ & 0.11 & 1 \\
\hline Nitrite & $\mathrm{mg} / \mathrm{l}$ & 1 & 10 \\
\hline Potassium & $\mathrm{mg} / \mathrm{l}$ & 0.6 & 0.6 \\
\hline Selenium & $\mathrm{mg} / \mathrm{l}$ & 0.005 & 0.005 \\
\hline Silicon & $\mathrm{mg} / \mathrm{l}$ & . & . \\
\hline Silver & $\mathrm{mg} / \mathrm{l}$ & 0.01 & 0.01 \\
\hline Sodium & $\mathrm{mg} / \mathrm{l}$ & . & . \\
\hline
\end{tabular}


B12-121

Table B.40 (continued)

\begin{tabular}{|c|c|c|c|}
\hline Analyte & Units & $\begin{array}{l}\text { Minimum } \\
\text { non-detect }\end{array}$ & $\begin{array}{l}\text { Maximum } \\
\text { non-detect }\end{array}$ \\
\hline Strontium & $\mathrm{mg} / \mathrm{l}$ & . & . \\
\hline Sulfate & $\mathrm{mg} / \mathrm{l}$ & 1 & 5 \\
\hline Thallium & $\mathrm{mg} / \mathrm{l}$ & 0.01 & 0.01 \\
\hline Thorium & $\mathrm{mg} / \mathrm{l}$ & 0.2 & 1 \\
\hline Tin & $\mathrm{mg} / \mathrm{l}$ & 0.01 & 0.01 \\
\hline Titanium & $\mathrm{mg} / 1$ & 0.003 & 0.003 \\
\hline Total uranium & $\mathrm{mg} / \mathrm{l}$ & 0.001 & 0.003 \\
\hline Vanadium & $\mathrm{mg} / \mathrm{l}$ & 0.005 & 0.025 \\
\hline Zinc & $\mathrm{mg} / \mathrm{l}$ & 0.001 & 0.004 \\
\hline Zirconium & $\mathrm{mg} / \mathrm{l}$ & 0.005 & 0.005 \\
\hline \multicolumn{4}{|c|}{ Organics } \\
\hline 1,1,1-Trichloroethane & $\mu \mathrm{g} / \mathrm{l}$ & 0.8 & 25 \\
\hline $1,1,2,2$-Tetrachloroethane & $\mu \mathrm{g} / 1$ & 2 & 25 \\
\hline 1,1,2-Trichloroethane & $\mu \mathrm{g} / 1$ & 5 & 25 \\
\hline 1,1-Dichloroethane & $\mu \mathrm{g} / \mathrm{l}$ & 5 & 25 \\
\hline 1,1-Dichloroethene & $\mu \mathrm{g} / \mathrm{l}$ & 5 & 25 \\
\hline 1,2-Dichloroethane & $\mu \mathrm{g} / 1$ & 5 & 25 \\
\hline 1,2-Dichloroethene & $\mu \mathrm{g} / 1$ & 5 & 25 \\
\hline 1,2-Dichloropropane & $\mu \mathrm{g} / \mathrm{l}$ & 5 & 25 \\
\hline 2-Butanone & $\mu \mathrm{g} / 1$ & 2 & 50 \\
\hline 2-Chloroethylvinyl ether & $\mu \mathrm{g} / \mathrm{l}$ & 10 & 10 \\
\hline 2-Hexanone & $\mu \mathrm{g} / \mathrm{l}$ & 1 & 50 \\
\hline 4-Methyl-2-Pentanone & $\mu \mathrm{g} / 1$ & 1 & 50 \\
\hline Acetone & $\mu \mathrm{g} / 1$ & 1 & 50 \\
\hline Benzene & $\mu \mathrm{g} / 1$ & 2 & 25 \\
\hline Bromodichloromethane & $\mu \mathrm{g} / 1$ & 5 & 25 \\
\hline Bromoform & $\mu \mathrm{g} / \mathrm{l}$ & 5 & 25 \\
\hline Bromomethane & $\mu \mathrm{g} / 1$ & 10 & 50 \\
\hline Carbon disulfide & $\mu \mathrm{g} / 1$ & 2 & 25 \\
\hline Carbon tetrachloride & $\mu \mathrm{g} / 1$ & 5 & 10 \\
\hline Chlorobenzene & $\mu \mathrm{g} / \mathrm{l}$ & 5 & 25 \\
\hline Chloroethane & $\mu \mathrm{g} / 1$ & 10 & 50 \\
\hline
\end{tabular}


B12-122

Table B.40 (continued)

\begin{tabular}{|c|c|c|c|}
\hline Analyte & Units & $\begin{array}{c}\text { Minimum } \\
\text { non-detect }\end{array}$ & $\begin{array}{l}\text { Maximum } \\
\text { non-detect }\end{array}$ \\
\hline Chloroform & $\mu \mathrm{g} / \mathrm{l}$ & 0.6 & 25 \\
\hline Chloromethane & $\mu \mathrm{g} / 1$ & 10 & 50 \\
\hline Cis-1,3-Dichloropropene & $\mu \mathrm{g} / 1$ & 5 & 25 \\
\hline Dibromochloromethane & $\mu \mathrm{g} / 1$ & 5 & 25 \\
\hline Dimethylbenzene & $\mu \mathrm{g} / \mathrm{l}$ & 5 & 25 \\
\hline Ethylbenzene & $\mu \mathrm{g} / \mathrm{l}$ & 1 & 25 \\
\hline Methylene chloride & $\mu \mathrm{g} / 1$ & 0.5 & 25 \\
\hline Phenols & $\mathrm{mg} / \mathrm{l}$ & 0.001 & 0.05 \\
\hline Styrene & $\mu \mathrm{g} / \mathrm{l}$ & 5 & 25 \\
\hline Tetrachloroethene & $\mu \mathrm{g} / \mathrm{l}$ & 4 & 20 \\
\hline Toluene & $\mu \mathrm{g} / \mathrm{l}$ & 0.4 & 25 \\
\hline Trans-1,2-Dichloroethene & $\mu \mathrm{g} / \mathrm{l}$ & 5 & 10 \\
\hline trans-1,3-Dichloropropene & $\mu \mathrm{g} / \mathrm{l}$ & 5 & 25 \\
\hline Trichloroethene & $\mu \mathrm{g} / \mathrm{l}$ & 4 & 10 \\
\hline Vinyl acetate & $\mu \mathrm{g} / \mathrm{l}$ & 10 & 50 \\
\hline Vinyl chloride & $\mu \mathrm{g} / \mathrm{l}$ & 10 & 50 \\
\hline \multicolumn{4}{|c|}{$R A D S$} \\
\hline
\end{tabular}

Americium-241

Cesium-137

Gross $\alpha$

Gross $\beta$

Neptunium-237

Plutonium-238

Plutonium-239/240

Radium-228

Technetium-99

Thorium-228

Thorium-230

Thorium-232

Total Radioactive Strontium

Total Radium $\alpha$

Tritium 


\section{B12-123}

Table B.40 (continued)

\begin{tabular}{llll}
\hline Analyte & Units & $\begin{array}{c}\text { Minimum } \\
\text { non-detect }\end{array}$ & $\begin{array}{c}\text { Maximum } \\
\text { non-detect }\end{array}$ \\
\hline Uranium-234 & & & \\
Uranium-235 & & & \\
Uranium-238 & & & \\
\hline
\end{tabular}

- Refer to Table D.6 in Appendix D for a list of wells and sample dates for this aggregate. 
B12-124

Table B.41. Analyses eliminated for use due to high total suspended solids, sodium, or chloride

\begin{tabular}{cl}
\hline Well & Analysis \\
\hline GW-005 & Aluminum, iron, cadmium, lead, mercury, strontium, uranium \\
GW-040 & Aluminum, iron \\
GW-042 & Cadmium \\
GW-071 & Boron \\
GW-075 & Boron \\
GW-085 & Strontium \\
GW-117 & Aluminum, iron \\
GW-118 & Molybdenum \\
GW-119 & Molybdenum, strontium \\
GW-211 & Strontium \\
GW-343 & Aluminum, iron \\
GW-344 & Strontium \\
GW-371 & Strontium \\
GW-531 & Aluminum, iron \\
GW-537 & Barium, strontium \\
GW-623 & Boron \\
GW-705 & Boron, copper, iron, lead, manganese, zinc \\
\hline
\end{tabular}




\section{B12-125}

Table B.42. Analytical holding times and preservatives

\begin{tabular}{lcl}
\hline Parameter & Analytical holding time & Preservative \\
\hline Volatile organic analytes & $14 \mathrm{~d}$ & $\mathrm{HCl}$ to $\mathrm{pH}<$ \\
& & $\mathrm{Cool}$ to $4^{\circ} \mathrm{C}$ \\
Semivolatile organic analytes & $7 \mathrm{~d}^{a}$ & $\mathrm{Cool} \mathrm{to} 4^{\circ} \mathrm{C}$ \\
& $40 \mathrm{~d}^{b}$ & \\
Pesticides/PCBs & $7 \mathrm{~d}^{d}$ & $\mathrm{Cool} \mathrm{to} 4^{\circ} \mathrm{C}$ \\
& $40 \mathrm{~d}^{b}$ & \\
Metals (except mercury) & $180 \mathrm{~d}$ & $\mathrm{HNO}_{3}$ to $\mathrm{pH}<2$ \\
Mercury & $28 \mathrm{~d}$ & $\mathrm{HNO}_{3}$ to $\mathrm{pH}<2$ \\
& & $\mathrm{Cool}^{\circ}$ to $4^{\circ} \mathrm{C}$ \\
Radiochemical parameters & $180 \mathrm{~d}$ & $\mathrm{HNO}_{3}$ to $\mathrm{pH}<2$ \\
\hline
\end{tabular}

- Represents holding times from sampling to extraction.

b Represents holding times from sampling to analysis. 
B12-126

Table B.43. Index of available numbers of samples from each source and media providing qualitative or quantitative information

\begin{tabular}{lllllll} 
& \multicolumn{5}{c}{ Media } \\
\cline { 2 - 6 } Data source & Groundwater & Surface water & Soil & Sediment & Waste & Biota \\
\hline BCV OU 1 & QN(16) & QN(2) & QN(277) & QN(1) & \\
BCV OU 4 & & QN(231) & & & & \\
Floodplain soil & & & QN(276) & QN(23) & QL & \\
Ecological & & & & & & $\mathrm{QN}^{b} / \mathrm{QL}$ \\
Historical & $\mathrm{QN}(5000)$ & $\mathrm{QN}(450) ; \mathrm{QL}$ & QL & QL & QL & \\
\hline
\end{tabular}

a Approximate number of samples shown in parentheses.

${ }^{b}$ In progress.

QL - Qualitative

QN - Quantitative 
Table B.44. Audits and surveillances of Bear Creek field activities

\begin{tabular}{|c|c|c|c|}
\hline Audit/surveillance & Project & $\begin{array}{l}\text { Type of audit/surveillance } \\
\text { and activity observed }\end{array}$ & Findings/issues \\
\hline ETS-94-017 & BCV OU 1 & QA-Soil sampling and documentation & None. \\
\hline ETS-93-009 & BCV OU 2 & $\begin{array}{l}\text { QA-Soil sampling, sample packaging and } \\
\text { shipment, chain-of-custody implementation, } \\
\text { decontamination of sampling devices, } \\
\text { operation of safety equipment. }\end{array}$ & $\begin{array}{l}\text { To ensure that adequate sample volumes are collected, as often } \\
\text { as possible, 3-in. diameter spoons should be used. } \\
\text { To reduce the chance of cross-contamination between collected } \\
\text { samples and clean sampling equipment, at least one additional } \\
\text { table should be obtained for the storage of clean equipment. } \\
\text { One table should be dedicated solely to sample collection. } \\
\text { To ensure traceability of instrument readings to the instruments, } \\
\text { all information pertaining to screening instruments required in } \\
\text { the Cooler Shipping Log should be obtained and recorded. }\end{array}$ \\
\hline ETS-93-010 & BCV OU 2 & $\begin{array}{l}\text { QA-Decontamination pad, calibration for } \\
\text { HNU organic vapor meter and MX-261 } \\
\text { combustible gas meter. }\end{array}$ & None. \\
\hline ETS-93-015 & BCV OU 2 & QA-Groundwater sampling. & None. \\
\hline ETS-93-016 & BCV OU 2 & QA-Sediment sampling. & None. \\
\hline Sept. 20, 1993 & BCV OU 2 & $\begin{array}{l}\text { QA-Assess implementation of requirements } \\
\text { of work plan; hollow stem auger split spoon } \\
\text { sampling, equipment decontamination. }\end{array}$ & $\begin{array}{l}\text { Unapproved substitution of High Performance Liquid } \\
\text { Chromatography (HPLC) water in place of American Society for } \\
\text { Testing and Materials (ASTM) Type II water used in the final } \\
\text { rinse for decontaminating sampling equipment. }\end{array}$ \\
\hline ETS-94-005 & BCV OU 2 & $\begin{array}{l}\text { QA-Field crew decontamination of sampling } \\
\text { equipment. }\end{array}$ & None. \\
\hline ETS-94-006 & $\mathrm{BCV}$ OU 2 & $\begin{array}{l}\text { QA-Soil sample collection using shelby } \\
\text { tubes, well installation. }\end{array}$ & None. \\
\hline ETS-94-007 & BCV OU 2 & QA-Surface water sampling using a dipper. & None. \\
\hline
\end{tabular}


Table B.44 continued

\begin{tabular}{llll}
\hline Audit/surveillance & Project & $\begin{array}{l}\text { Type of audit/surveillance } \\
\text { and activity observed }\end{array}$ & Findings/issues \\
\hline ETS-94-008 & BCV OU 4 & QA-Installation of stormflow tubes. & $\begin{array}{l}\text { From the procedure, it is unclear as to whether sand poured in } \\
\text { the annular space is to act as a true sand pack, or to just provide } \\
\text { support for the tube. If the sand is to act as a true pack, an } \\
\text { alternative method of emplacement may be required. Theoretical } \\
\text { calculations of the amount of sand needed to fill the annular } \\
\text { space and measures of actual amounts used may provide an } \\
\text { indication of sand "pack" quality. }\end{array}$ \\
BCV OU 4 & QA-Collection of surface water sampling & $\begin{array}{l}\text { Currently, the rate at which "flow-paced" samples are collected } \\
\text { is determined and programmed in the field by Energy Systems } \\
\text { using a dipper and automatic sampler. }\end{array}$ & $\begin{array}{l}\text { Field Team Members based on anticipated stream flow } \\
\text { conditions. It is recommended that a field change order be } \\
\text { written to document that this is the required methodology. }\end{array}$
\end{tabular}

It is recommended that a field change order be written to allow for the collection of VOC fractions by the dipping method. If the dipping method is used, however, great care must be taken to insure that the preservative is not lost from the sample container during sample collection.

Currently there is no compositing procedure in the projectspecific procedures manual. It is recommended that the procedure used for compositing be added to the procedures manual.

ETS-94-011

ETS-94-012
BCV OU 4

BCV OU 4
QA-Ensure presence of required records onsite; assess sample packaging and shipment ensure required completion of sample tags, labels, and chain-of-custody forms; ensure proper completion of logbooks pertaining to surface water sample shipping.

QA-Setup of the decontamination line, performance of the decontamination procedure, and the completion of decontamination logbook.
None.

None. 


\section{Table B.44 continued}

\begin{tabular}{|c|c|c|c|}
\hline Audit/surveillance & Project & $\begin{array}{l}\text { Type of audit/surveillance } \\
\text { and activity observed }\end{array}$ & Findings/issues \\
\hline Y-12/ER-94-006 & BCV OU 4 & QA-Sample collection and decontamination. & $\begin{array}{l}\text { There is no assurance now that all procedures have been } \\
\text { reviewed and approved for use by Y- } 12 \text { ER because the } \\
\text { procedures manual, which was updated by the } 2 / 23 / 94 \text { sheet } \\
\text { stating that all procedures were reviewed and approved for use } \\
\text { by Y- } 12 \mathrm{ER} \text {, is out-of-date. }\end{array}$ \\
\hline
\end{tabular}

it is the subject of a field change or file the change orders with the appropriate procedure(s).

Field change logs are not being kept up-to-date.

Original chain-of-custody forms are not returned from the analytical labs; thus, the original records are not available for project archiving.

ER/Y-95-002 BCV FPSS QA-Maintaining Temperate Cooler log, calibration of field measurement instrumentation, project management.
The cooler log on $3 / 30 / 95$ indicates a time gap in checking the cooler temperature of 2 hours and 18 minutes (occurred between $11: 50$ and 14:08).

Positive response verification checks were not performed as often as specified in the above requirements.

Discrepancies appear to exist in COC versus field logbooks about times when samples were delivered to the Y-12 Plant laboratory.

Legibility of logs is not maintained through the copying process.

Apparent incorrect date entries made in the temperature cooler $\log$. 
Table B.44 continued

\begin{tabular}{|c|c|c|c|c|}
\hline Audit/surveillance & Project & $\begin{array}{l}\text { Type of audit/surveillance } \\
\text { and activity observed }\end{array}$ & Findings/issues & \\
\hline \multirow[t]{3}{*}{$\begin{array}{l}\mathrm{ER} / \mathrm{Y}-95-002 \\
\text { (continued) }\end{array}$} & & & $\begin{array}{l}\text { Copies of Project Nonconformance Reports are not being } \\
\text { provided to the Y-12 ER Quality staff in a timely manner. }\end{array}$ & \\
\hline & & & $\begin{array}{l}\text { Field Change Requests are not being filed to provide project } \\
\text { specific directions, i.e., to progress from purposely generic and } \\
\text { vague directions from the Sampling and Analysis Plan. }\end{array}$ & \\
\hline & & & $\begin{array}{l}\text { Complete information is not being provided via the logs when an } \\
\text { unscheduled event (and/or variations from the norm) occurs, or } \\
\text { what the final resolution was (e.g., } 3 / 30 / 95 \text { failure of counter). }\end{array}$ & \\
\hline ER/Y-95-005 & $\begin{array}{l}\text { BCV Floodplain } \\
\text { SS }\end{array}$ & QA-Data handling. & None. & \\
\hline \multirow[t]{2}{*}{ ETS-95-008 } & $\begin{array}{l}\text { BCV Floodplain } \\
\text { SS }\end{array}$ & $\begin{array}{l}\text { QA-Subsoil sampling using a JMC } \\
\text { Backsaver soil sampler. }\end{array}$ & $\begin{array}{l}\text { Clarification to Procedure ER/C-P2302 as written should specify } \\
\text { the type of glove to be worn during sampling, depending on } \\
\text { anticipated site conditions. }\end{array}$ & \\
\hline & & & $\begin{array}{l}\text { It was stressed that a sampling spoon be used only for the } \\
\text { sample depth interval taken from that spoon. Sample spoons } \\
\text { from associated overlying sample intervals will be used if a } \\
\text { boring has to be deepened before a sample is taken. This will } \\
\text { ensure that, if additional sample is needed for analysis from the } \\
\text { intermediate or lowest sample interval, the spoon for that sample } \\
\text { will not have been used to remove overlying soil. }\end{array}$ & 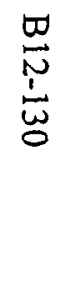 \\
\hline ETS-95-010 & $\begin{array}{l}\text { BCV Floodplain } \\
\text { SS }\end{array}$ & $\begin{array}{l}\text { QA-Observe control and documentation of } \\
\text { field changes to approved Field Sampling } \\
\text { Plans. }\end{array}$ & None. & \\
\hline
\end{tabular}


Table B.44 continued

\begin{tabular}{|c|c|c|c|}
\hline Audit/surveillance & Project & $\begin{array}{l}\text { Type of audit/surveillance } \\
\text { and activity observed }\end{array}$ & Findings/issues \\
\hline ETS-95-011 & BCV FPSS & $\begin{array}{l}\text { QA-Sample classification, packaging, } \\
\text { marking, and shipping. }\end{array}$ & $\begin{array}{l}\text { By definition in the procedure, transportation of environmental } \\
\text { screening samples within the plant boundary is considered as an } \\
\text { off-site shipment and the requirements for shipment are the same } \\
\text { as if the samples were being sent to an off-site, contracted } \\
\text { laboratory. Based on this, deficiencies were observed and } \\
\text { documented on the attached Procedures Checklist. These } \\
\text { samples are hand-carried and in custody of the sampling team } \\
\text { until transfer to the Y-12 Analytical Laboratory. }\end{array}$ \\
\hline ETS-95-012 & BCV FPSS & $\begin{array}{l}\text { QA-Manual chain-of-custody and field } \\
\text { logbook procedures. }\end{array}$ & $\begin{array}{l}\text { A deficiency was noted in the designation of } Q C \text { samples (in } \\
\text { particular the duplicate samples). No duplicate samples are } \\
\text { being taken during initial screening sampling at the transverses. }\end{array}$ \\
\hline ETS-95-013 & BCV FPSS & $\begin{array}{l}\text { QA-Observe decontamination procedures of } \\
\text { sampling devices and equipment. }\end{array}$ & $\begin{array}{l}\text { A final rinse with organic-free water, as listed on the attached } \\
\text { Procedure Checklist, was not done. Sufficient time was allowed } \\
\text { for the isopropanol from the previous rinse to evaporate before } \\
\text { the sampling equipment was used. This is consistent with the } \\
\text { requirements of ESP-801. }\end{array}$ \\
\hline
\end{tabular}

ASTM - American Society for Testing and Materials

FPSS - Floodplain soil/sediment

HPLC - High Performance Liquid Chromatography

QA - Quality assurance

QC - Quality control 
B12-132

Table B.45. SPARCC parameter criteria for BCV OU 4, OU 1, and FPSS projects

\begin{tabular}{|c|c|c|c|}
\hline Parameter & BCV OU 4 & BCV OU 1 & BCV FPSS \\
\hline Sensitivity & - & - & - \\
\hline Precision & $\begin{array}{l}\text { No criteria } \\
\text { established }\end{array}$ & $\begin{array}{l}\text { Laboratory duplicates } \\
\pm 20 \% \mathrm{RPD} \text { for } \\
\mathrm{rad} / \text { inorganic } \\
\pm \text { lab criteria for organic }\end{array}$ & $\begin{array}{l}\text { Laboratory duplicates } \\
\quad \pm 20 \% \text { RPD for } \\
\text { rad/inorganic } \\
\pm \text { lab criteria for organic }\end{array}$ \\
\hline Accuracy & $\begin{array}{l}\text { No criteria } \\
\text { established }\end{array}$ & $\begin{array}{c} \pm 20 \% \text { recovery for } \\
\mathrm{rad} / \text { inorganic } \\
\pm \text { lab criteria for organic }\end{array}$ & $\begin{array}{l} \pm 20 \% \text { recovery for } \\
\mathrm{rad} / \text { inorganic }\end{array}$ \\
\hline Representativeness & - & \multicolumn{2}{|c|}{ Qualitative parameters } \\
\hline Comparability & - & - & - \\
\hline Completeness & $\begin{array}{l}\text { No criteria } \\
\text { established }\end{array}$ & $\begin{array}{c}95 \% \text { collection } \\
90 \% \text { overall } \\
100 \% \text { at background } \\
\text { locations }\end{array}$ & $\begin{array}{c}95 \% \text { collection } \\
90 \% \text { overall } \\
100 \% \text { at background } \\
\text { locations }\end{array}$ \\
\hline
\end{tabular}

RPD - Relative percent difference

FPSS - Floodplain soil/sediment 
B12-133

Table B.46. Accuracy in the BCV OU 4, OU 1, and FPSS datasets

\begin{tabular}{llll}
\hline Matrix & Organic & Inorganic & Radiochemical \\
\hline Soil & $\begin{array}{l}\text { No significant } \\
\text { problems with } \\
\text { accuracy of data }\end{array}$ & $\begin{array}{l}\text { - Zinc biased high (FPSS) } \\
\text { - Antimony biased low (OU 1 } \\
\text { and FPSS) } \\
\text { - Selenium biased low (FPSS) } \\
\text { - Silver biased low (FPSS) }\end{array}$ & $\begin{array}{l}\text { No significant problems } \\
\text { with accuracy of data }\end{array}$ \\
& & No significant problems with \\
accuracy of data & \\
Gediment & - Aluminum biased high (OU 1) & \\
& & - Antimony biased low (OU 1) & \\
Surface water & & Mercury, cyanide, antimony, & - 234U poor accuracy. \\
& & aluminum, iron, lithium, silver & Data can be biased in \\
& & biased low (OU 4) &
\end{tabular}


Table B.47. Overall precision in the BCV RI dataset

\begin{tabular}{|c|c|c|c|}
\hline Media & Organic & Inorganic & Radiochemical \\
\hline Soil & $\begin{array}{l}\text { Precision } \\
\text { considered } \\
\text { acceptable. }\end{array}$ & $\begin{array}{l}\text { Overall precision acceptable. Very } \\
\text { few arsenic and manganese values } \\
\text { qualified (FPSS) due to poor } \\
\text { precision. }\end{array}$ & $\begin{array}{l}\text { Precision considered } \\
\text { acceptable. }\end{array}$ \\
\hline Sediment & & $\begin{array}{l}\text { Minimal effects on precision } \\
\text { indicated for aluminum, arsenic, } \\
\text { cadmium, chromium, cobalt, iron, } \\
\text { lead, lithium, manganese, mercury, } \\
\text { and potassium. Data qualified as } \\
\text { necessary. (FPSS) }\end{array}$ & $\begin{array}{l}{ }^{99} \mathrm{Tc},{ }^{228} \mathrm{Th},{ }^{230} \mathrm{Th},{ }^{232} \mathrm{Th}, \\
{ }^{234} \mathrm{U},{ }^{235} \mathrm{U} \text {, and }{ }^{238} \mathrm{U} \text { FPSS } \\
\text { sediment data of poor } \\
\text { precision and not qualified } \\
\text { in the dataset. }\end{array}$ \\
\hline Groundwater & & Precision considered acceptable. & $\begin{array}{l}\text { Precision considered } \\
\text { acceptable. }\end{array}$ \\
\hline Surface water & & $\begin{array}{l}\text { Poor overall precision for OU } 4 \\
\text { aluminum, iron, manganese, and } \\
\text { dissolved aluminum. } \\
\text { Dissolved aluminum precision } \\
\text { estimated in OU } 1 \text { data as well. }\end{array}$ & $\begin{array}{l}\text { Total and dissolved } \\
\text { gross } \alpha \text { for OU } 4 \\
\text { estimated due to poor } \\
\text { precision } \\
{ }^{235} \text { U OU } 4 \text { values } \\
\text { estimated due to poor } \\
\text { laboratory precision. }\end{array}$ \\
\hline
\end{tabular}

FPSS - Floodplain soil/sediment 
B12-135

Table B.48. BCV OU 4 samples that may have been mis-identified during analysis

\begin{tabular}{llllllllllll}
\hline & \multicolumn{2}{c}{$\begin{array}{c}\text { Gross } \alpha \\
(\mathrm{pCi} / \mathrm{L})\end{array}$} & \multicolumn{2}{c}{$\begin{array}{c}{ }^{233} \mathrm{U} /{ }^{34} \mathrm{U} \\
(\mathrm{pCi} / \mathrm{L})\end{array}$} & \multicolumn{2}{c}{$\begin{array}{c}{ }^{235} \mathrm{U} \\
(\mathrm{pCi} / \mathrm{L})\end{array}$} & \multicolumn{2}{c}{$\begin{array}{c}{ }^{238} \mathrm{U} \\
(\mathrm{pCi} / \mathrm{L})\end{array}$} & \multicolumn{2}{c}{$\begin{array}{c}\text { Gross } \beta \\
(\mathrm{pCi} / \mathrm{L})\end{array}$} \\
Sample & Total & Dsivd & Total & Dslvd & Total & Dslvd & Total & Dslvd & Total & Dlvd \\
\hline SS6008 & 1.9 & -2 & 25.5 & .4 & 2.05 & -.03 & 50.3 & 0.5 & 2.89 & 0.8 \\
SN5008 & 1.54 & -3 & 35.6 & 0.2 & 4.96 & 0.2 & 71.3 & 0.3 & 1.36 & -7 \\
SB9017 & 107 & 59.5 & 0.36 & 26 & 0.29 & .96 & 0.37 & 56 & 61.3 & 60.2 \\
SN3016 & 766 & 450 & 0.68 & 181 & 0.12 & 14 & 0.88 & 41 & 214 & 254 \\
\hline
\end{tabular}


Table B.49. Data usability in the BCV OU 4, OU 1, and FPSS datasets

\begin{tabular}{|c|c|c|c|}
\hline Matrix & Organic & Inorganic & Radiochemical \\
\hline Soil & $\begin{array}{l}\text { - } 11 / 46 \text { pesticide/PCB values } \\
\text { negatively biased due to exceedance } \\
\text { of analytical holding time (FPSS) } \\
\text { - Di-n-butylphthalate (OU 1) poor } \\
\text { sensitivity } \\
\text { - } \mathrm{MeCl}_{2} \text { and acetone sensitivity } \\
\text { (FPSS) }\end{array}$ & $\begin{array}{l}\text { - Arsenic, cadmium, lithium, sodium, } \\
\text { and manganese data poor sensitivity } \\
\text { (FPSS) } \\
\text { - Zinc generally biased high (FPSS) } \\
\text { - Antimony generally biased low (OU } 1 \\
\text { and FPSS) } \\
\text { - Selenium generally biased low (FPSS) } \\
\text { - Silver generally biased low (FPSS) } \\
\text { - W00221 and W00321 copper non- } \\
\text { representative of OU } 1\end{array}$ & $\begin{array}{l}\text { - } \mathrm{B} 01511{ }^{212} \mathrm{~Pb} \text { non-representative of } \\
\text { OU } 1 \\
\text { - }{ }^{243} \mathrm{Cm},{ }^{228} \mathrm{Th},{ }^{230} \mathrm{Th},{ }^{232} \mathrm{Th} \text { poor } \\
\text { sensitivity (FPSS) }\end{array}$ \\
\hline Sediment & $\begin{array}{l}\text { 1/26 herbicides and VOAs, } 3 / 26 \\
\text { pesticides and SVOAs negatively } \\
\text { biased due to exceedance of } \\
\text { analytical holding time (FPSS) } \\
\text { - Herbicides, acetone, and } \mathrm{MeCl}_{2} \text { poor } \\
\text { sensitivity (FPSS) }\end{array}$ & $\begin{array}{l}\text { Aluminum, arsenic, cadmium, } \\
\text { chromium, cobalt, iron, lead, lithium, } \\
\text { manganese, mercury, potassium } \\
\text { precision caused FPSS data to be } \\
\text { estimated } \\
\text { - Cadmium and sodium poor sensitivity } \\
\text { (FPSS) }\end{array}$ & $\begin{array}{l}{ }^{99} \mathrm{Tc} \text {, isotopic thorium, isotopic } \\
\text { uranium FPSS data of poor } \\
\text { precision } \\
{ }^{228} \mathrm{Th},{ }^{232} \mathrm{Th} \text { poor sensitivity (FPSS) }\end{array}$ \\
\hline Groundwater & $\begin{array}{l}\text { No significant, unqualified challenges } \\
\text { to data usability. }\end{array}$ & $\begin{array}{l}\text { - Aluminum positively biased (OU 1) } \\
\text { - Antimony generally biased negatively } \\
\text { (OU 1) }\end{array}$ & $\begin{array}{l}\text { No significant, unqualified challenges } \\
\text { to data usability }\end{array}$ \\
\hline
\end{tabular}


Table B.49 continued

\begin{tabular}{|c|c|c|c|}
\hline Matrix & Organic & Inorganic & Radiochemical \\
\hline Surface water & $\begin{array}{l}\text { - } 15 / 243 \text { VOAs negatively biased due } \\
\text { to insufficient preservation (OU 4) } \\
\text { - SB9115 2-butanone value considered } \\
\text { non-representative of OU } 4 \\
\text { - } \mathrm{MeCl}_{2} \text { poor sensitivity (OU 4) }\end{array}$ & $\begin{array}{l}\text { Mercury, cyanide, antimony, } \\
\text { aluminum, iron, lithium, and silver } \\
\text { generally biased low (OU 4) } \\
\text { - Aluminum, iron, manganese, and } \\
\text { dissolved aluminum OU } 4 \text { data of poor } \\
\text { precision } \\
\text { Dissolved aluminum OU } 1 \text { data of poor } \\
\text { precision } \\
\text { - SS8009 lead not representative of OU } 4 \\
\text { - Dissolved aluminum and dissolved iron } \\
\text { poor precision (OU 4) }\end{array}$ & $\begin{array}{l}\text { - Total and dissolved gross } \alpha \\
\text { estimated due to poor precision } \\
\text { (OU 4) } \\
\text { - SS6008, SN5008, SB9017, and } \\
\text { SN3016 isotopic uranium values } \\
\text { unusable } \\
\text { - SN3009, and SN3010 non- } \\
\text { representative }{ }^{235} \mathrm{U} \text { values (OU 4) } \\
\text { - }{ }^{234} \mathrm{U} \text { generally poorly accurate and } \\
\text { poor sensitivity for OU } 4 \text { samples } \\
\text { - }{ }^{234} \mathrm{U} \text { OU } 4 \text { data estimated due to } \\
\text { poor precision } \\
\text { - }{ }^{99} \mathrm{Tc} \text { sensitivity poor at NT3. Data } \\
\text { considered unusable. }\end{array}$ \\
\hline
\end{tabular}


B13-1

\section{B.13 SUPPORTING INFORMATION FOR APPENDIX B-LITHOLOGIC LOGS}





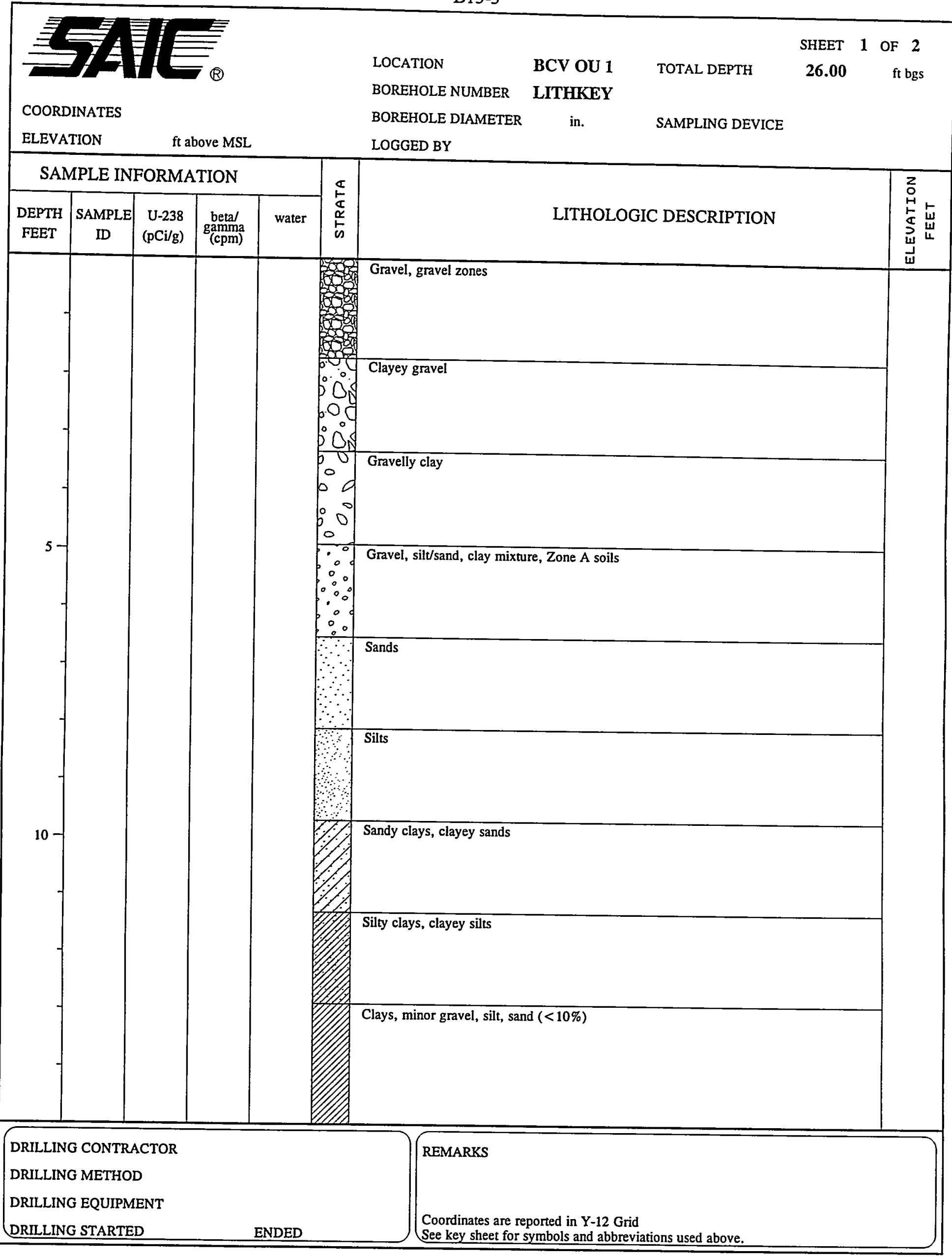


B13-4

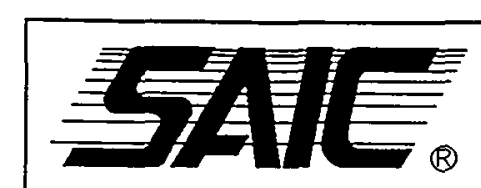

COORDINATES

ELEVATION

ft above MSL

\section{LOCATION \\ BOREHOLE NUMBER}

BOREHOLE DIAMETER

LOGGED BY

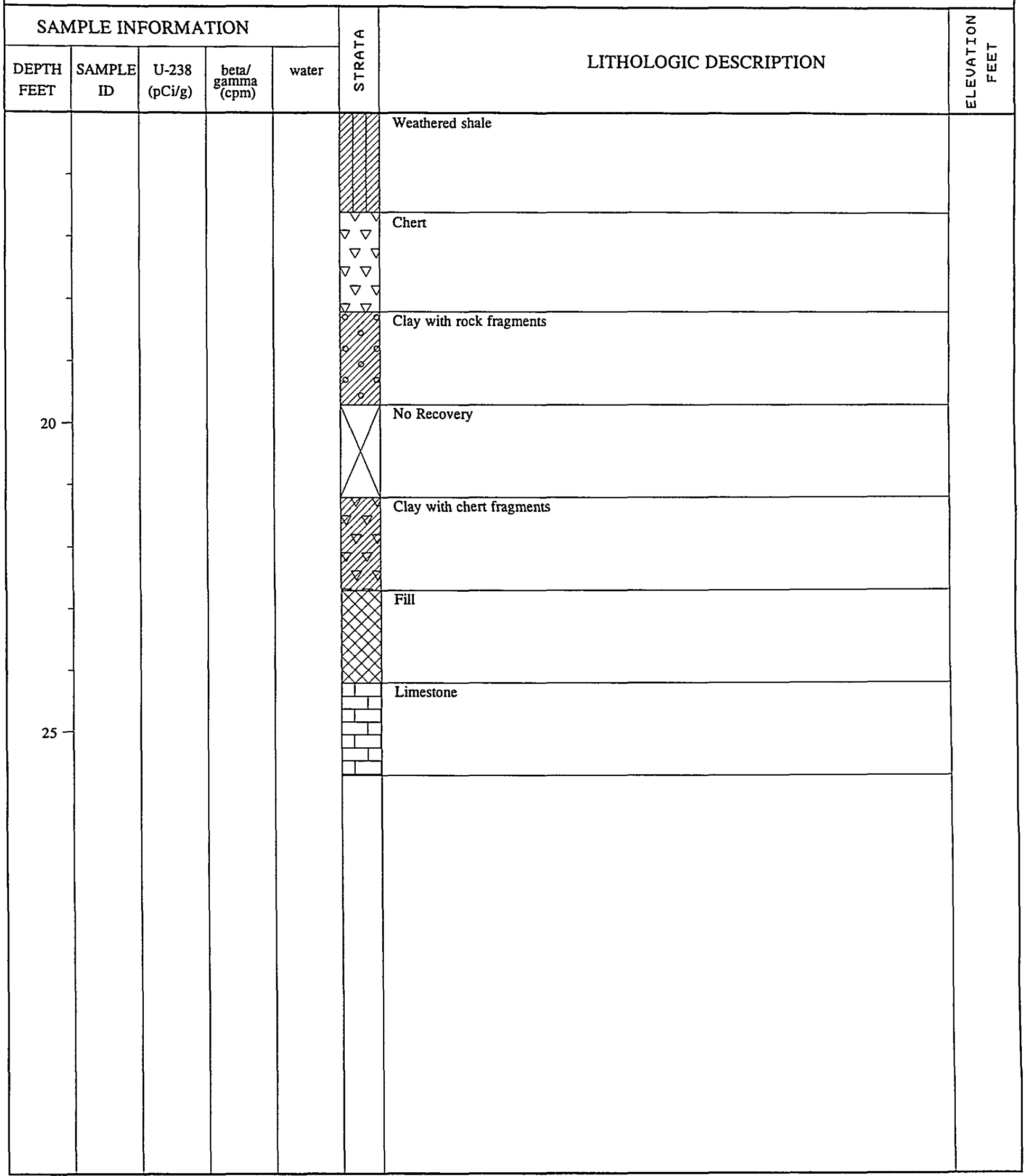




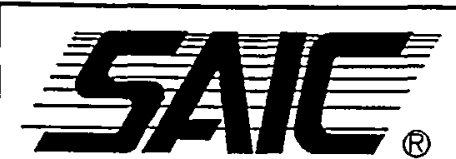

COORDINATES N 30,427.20 E 52,537.40

ELEVATION $1010.80 \mathrm{ft}$ above MSL

\section{LOCATION}

BOREHOLE NUMBER

BOREHOLE DIAMETER 8 in.

SAMPLING DEVICE S-3IN

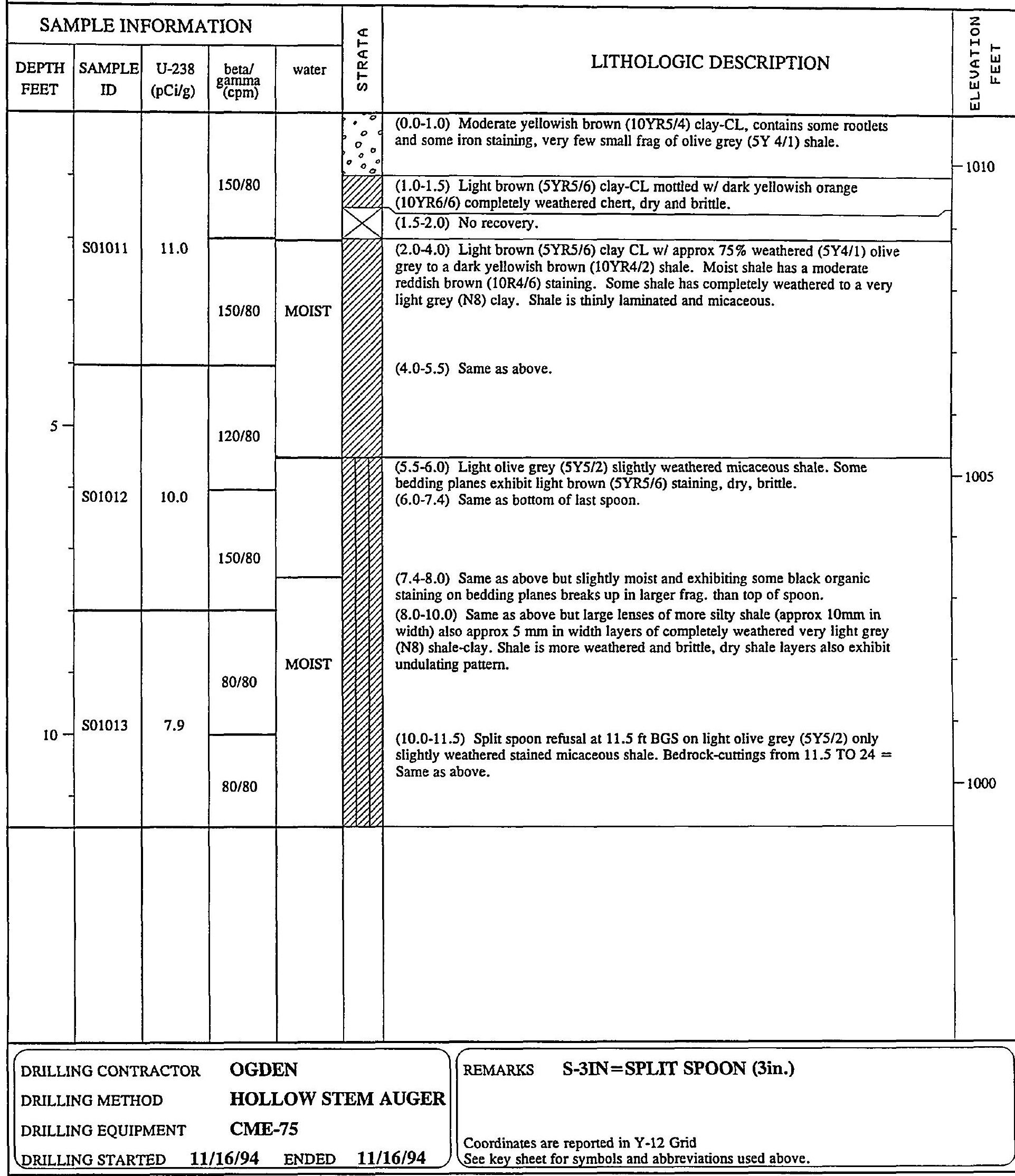




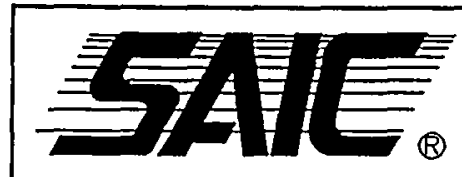

COORDINATES N 30,062.00 E 52,391.80

ELEVATION $1001.80 \mathrm{ft}$ above MSL
LOCATION

BOREHOLE NUMBER

BOREHOLE DIAMETER 8 in. LOGGED BY S.L. ABSTON
SHEET

2 OF 2

BCV OU 1 TOTAL DEPTH

15.40

ft bgs

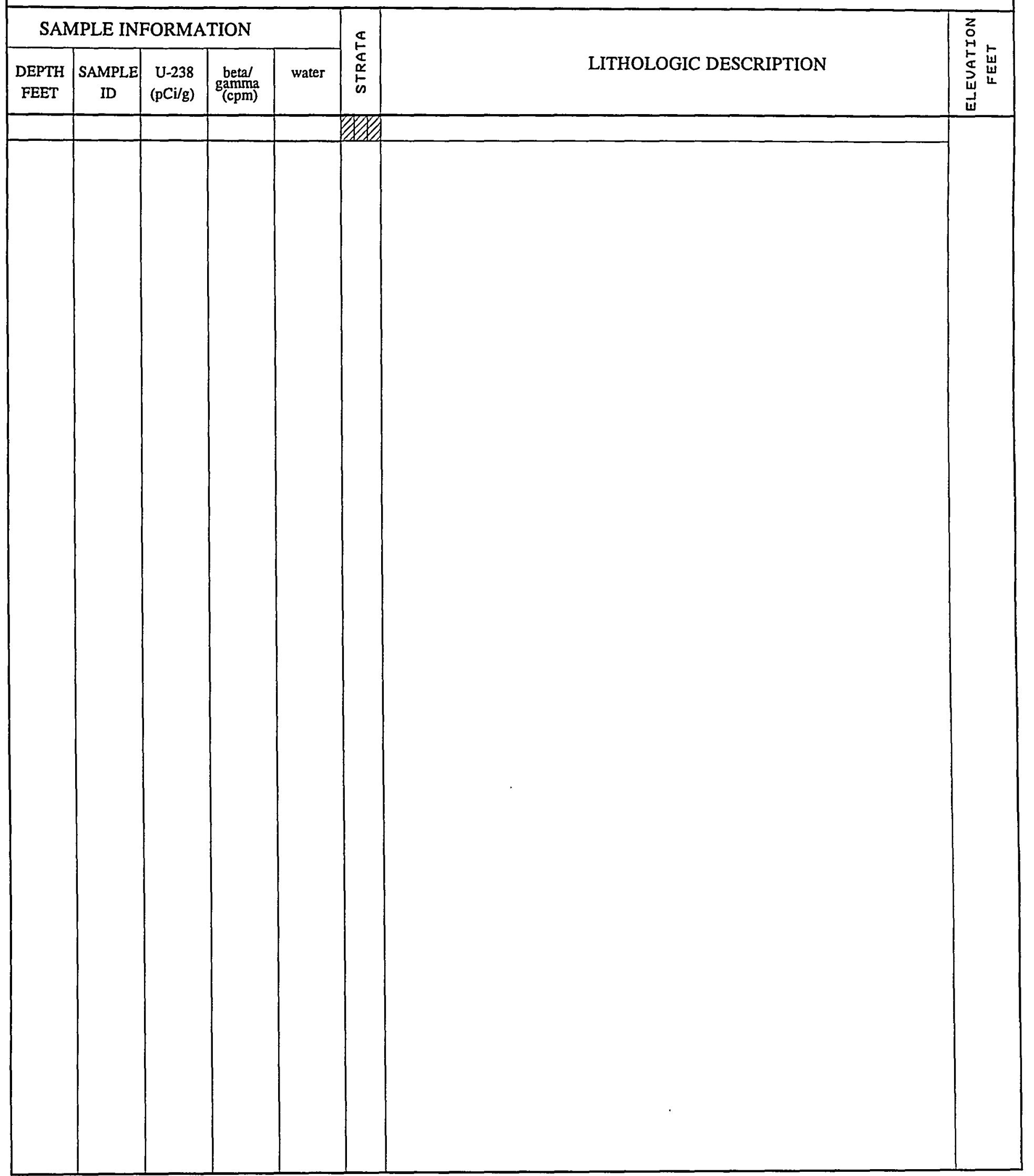




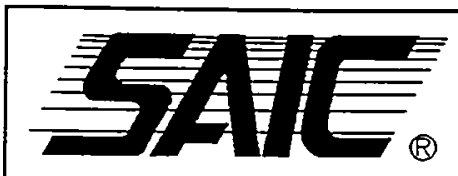

COORDINATES N 30,069.40 E 52,118.40

ELEVATION $1006.50 \mathrm{ft}$ above MSL

\section{LOCATION}

BOREHOLE NUMBER

\section{BCV OU 1}

S3-03

BOREHOLE DIAMETER 8 in.
SHEET 1 OF 1

7.50 ft bgs

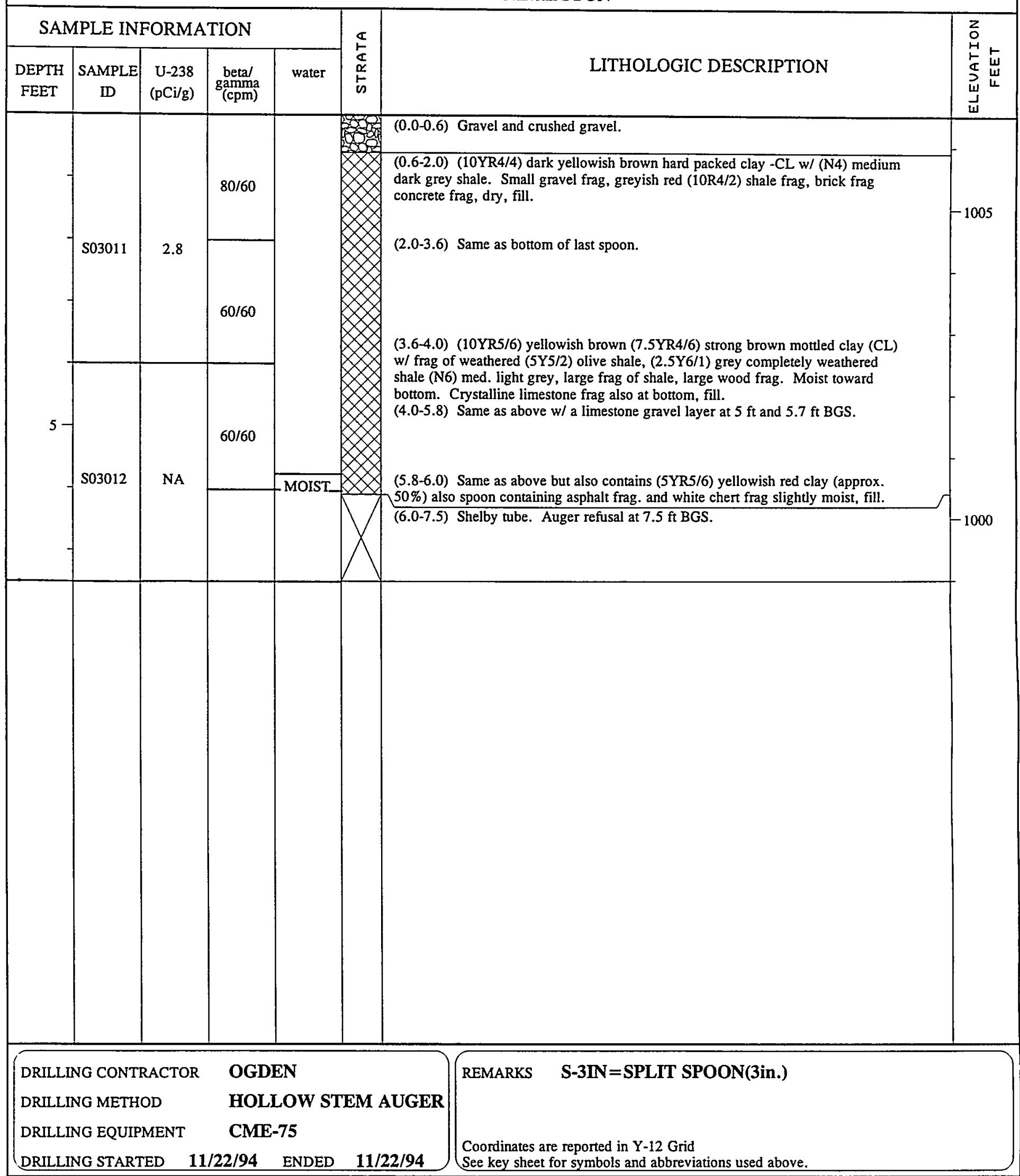




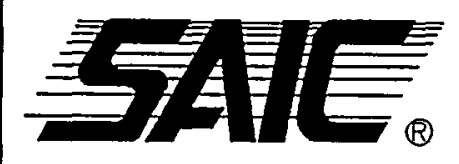

COORDINATES N 30,136.50 E 51,853.40

ELEVATION $1004.50 \mathrm{ft}$ above MSL
LOCATION

BOREHOLE NUMBER
BCV OU 1

S3-04
SHEET 1 OF 2

22.90 ft bgs

\section{BOREHOLE DIAMETER 8 in. SAMPLING DEVICE S-3IN}

LOGGED BY S.L. ABSTON

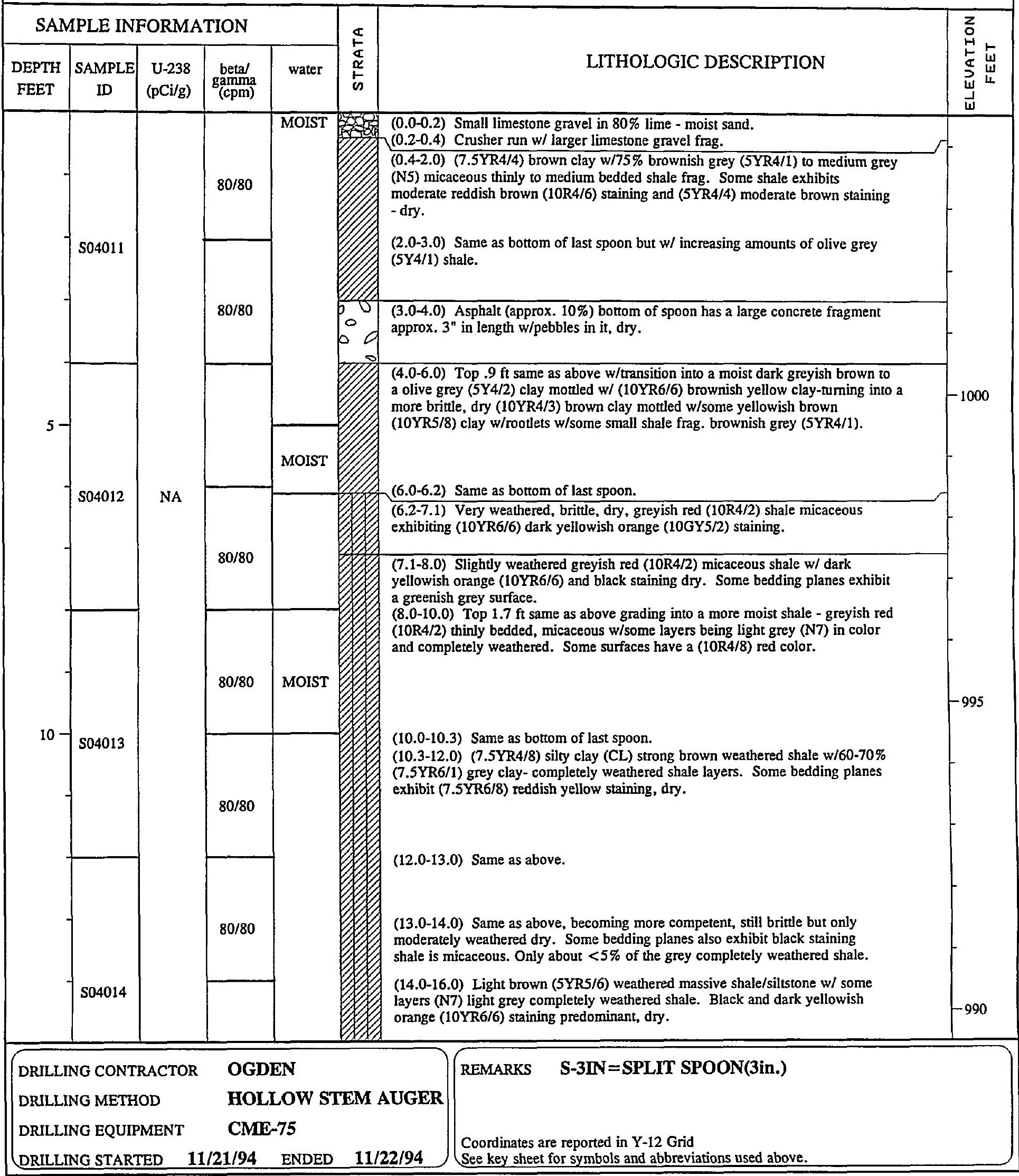


B13-10

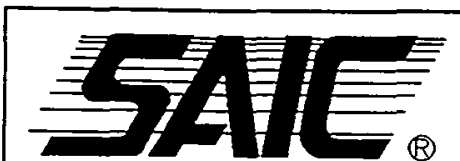

COORDINATES N 30,136.50 E 51,853.40

ELEVATION $1004.50 \mathrm{ft}$ above MSL
SHEET 2 OF 2

LOCATION

BCV OU 1

TOTAL DEPTH

22.90

ft bgs

BOREHOLE NUMBER S3-04

BOREHOLE DIAMETER 8 in.

SAMPLING DEVICE

S-3IN

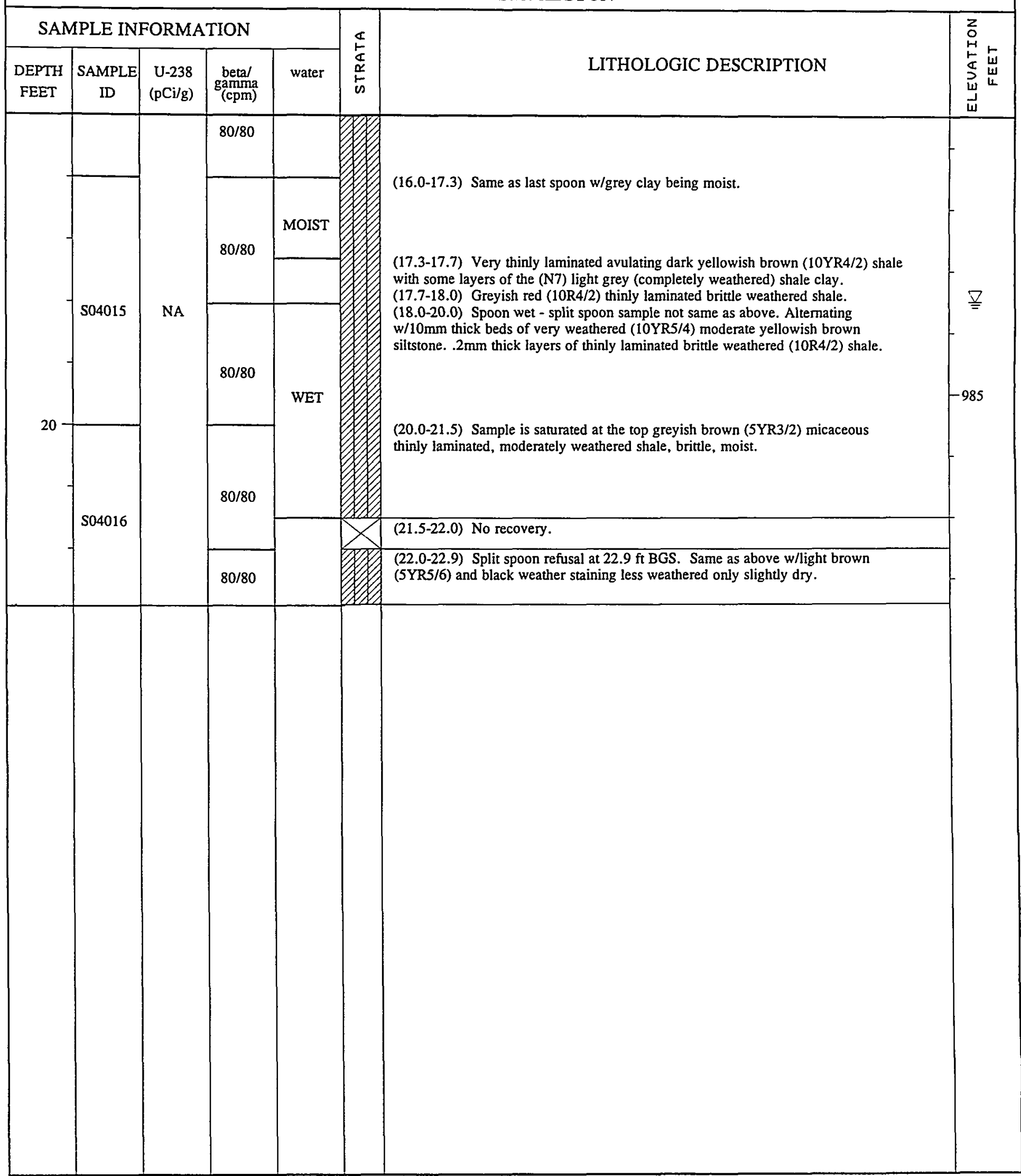


B13-11

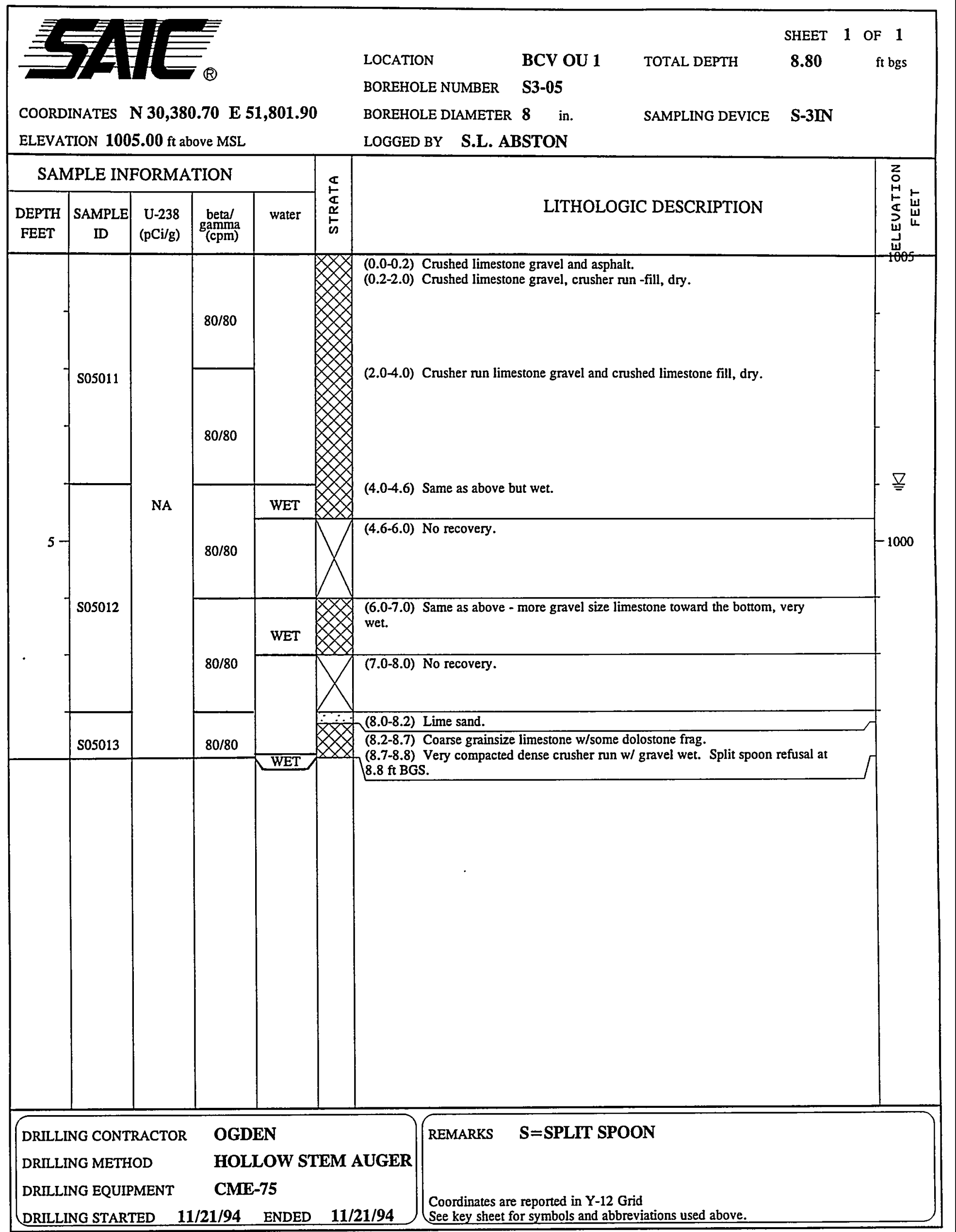




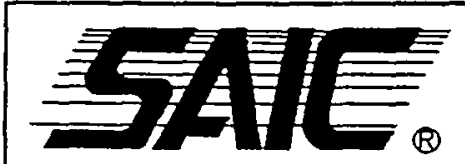

COORDINATES N 30,424.60 E 51,936.50

ELEVATION $1011.60 \mathrm{ft}$ above MSL
SHEET 1 OF 2

LOCATION

BCV OU 1 TOTAL DEPTH

18.80

fi hes

\section{BOREHOLE NUMBER S3-06}

BOREHOLE DLAMETER 8 in. SAMPLING DEVICE S-3IN

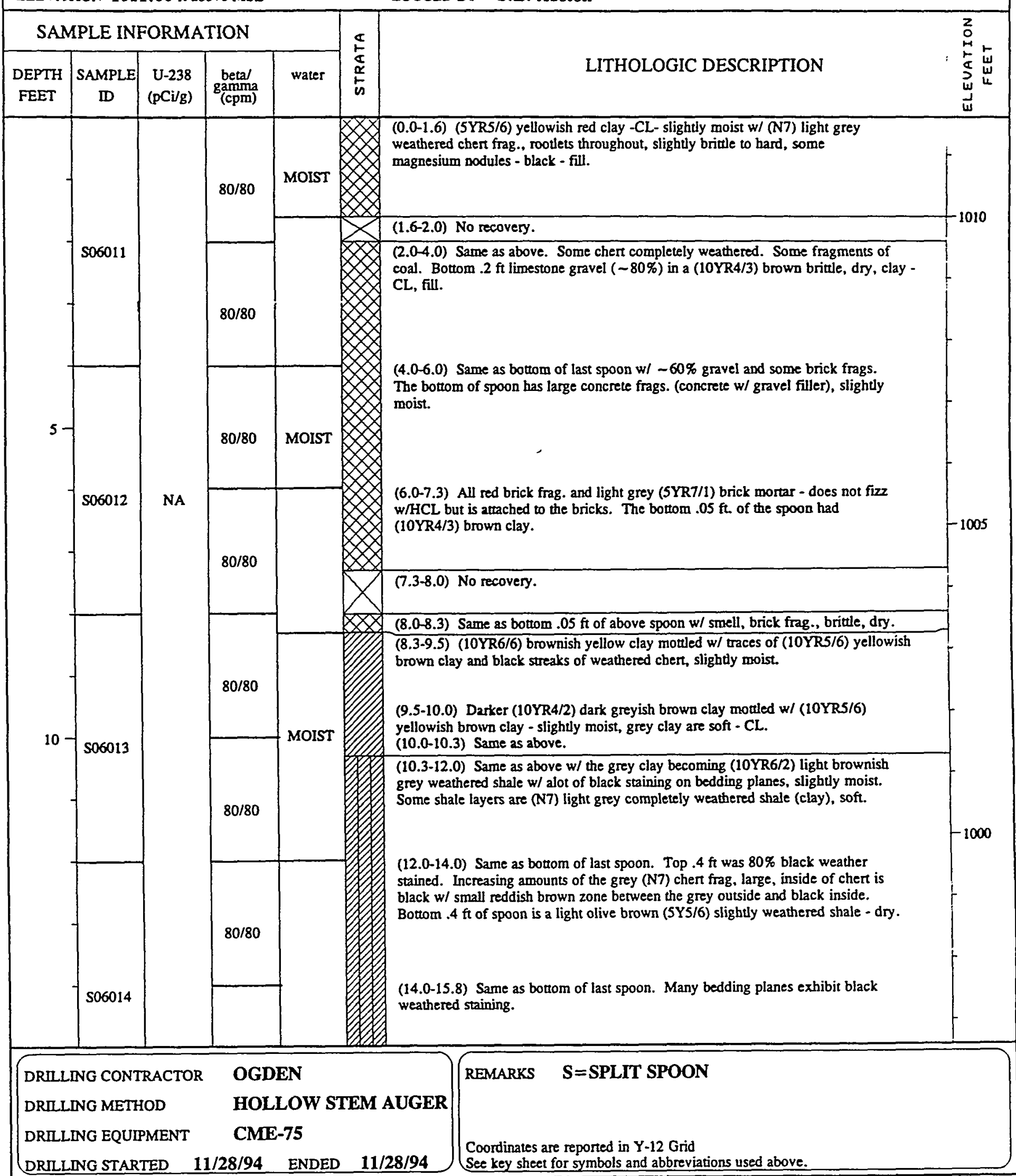




\section{B13-13}

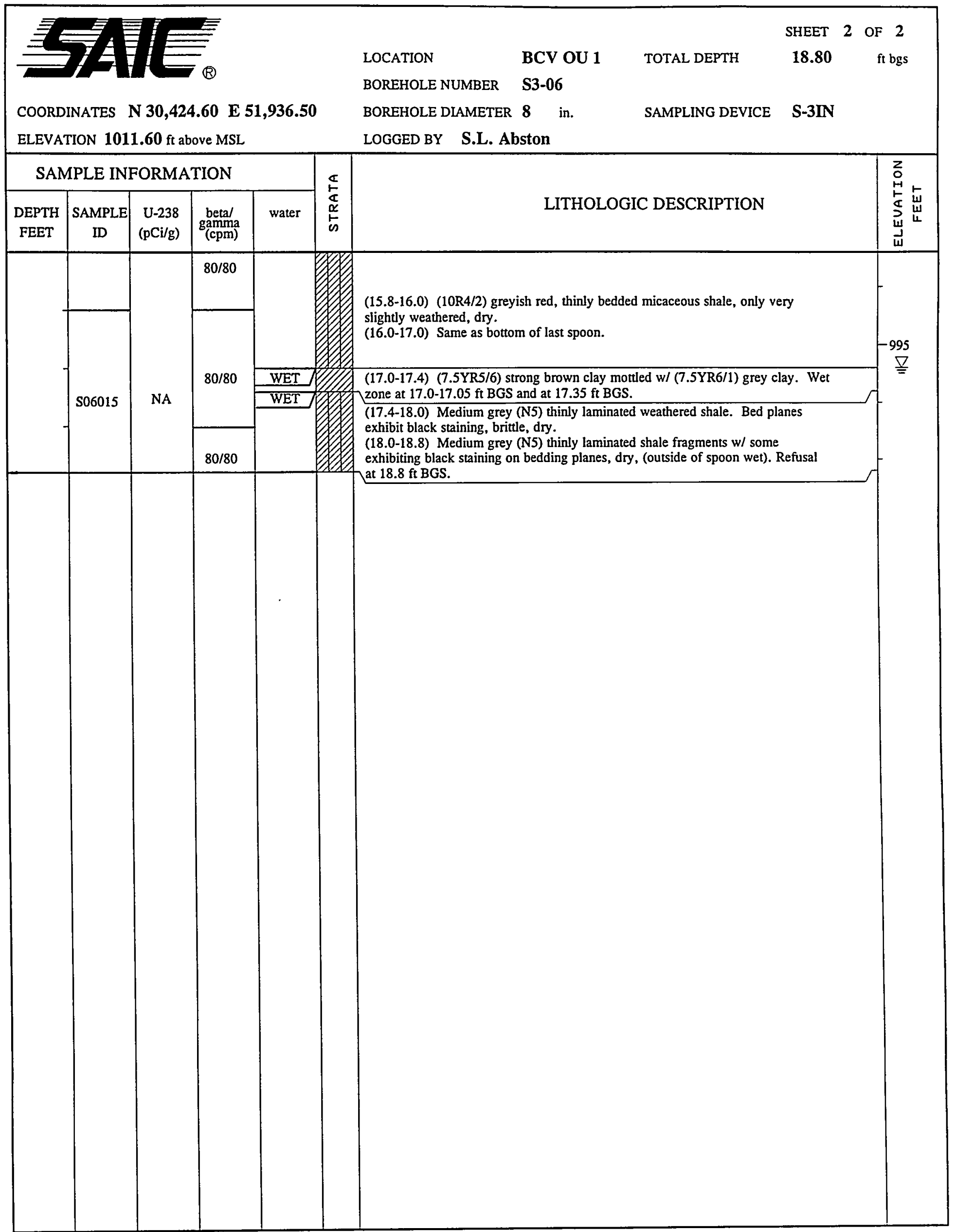




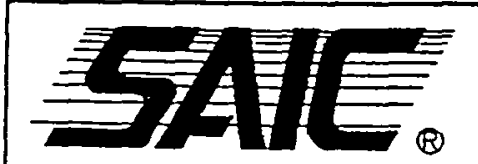

COORDINATES N 30,178.90 E 51,991.30

ELEVATION $1008.10 \mathrm{ft}$ above MSL

\section{LOCATION}

BOREHOLE NUMBER
SHEET 1 OF 2

27.90 fi bgs

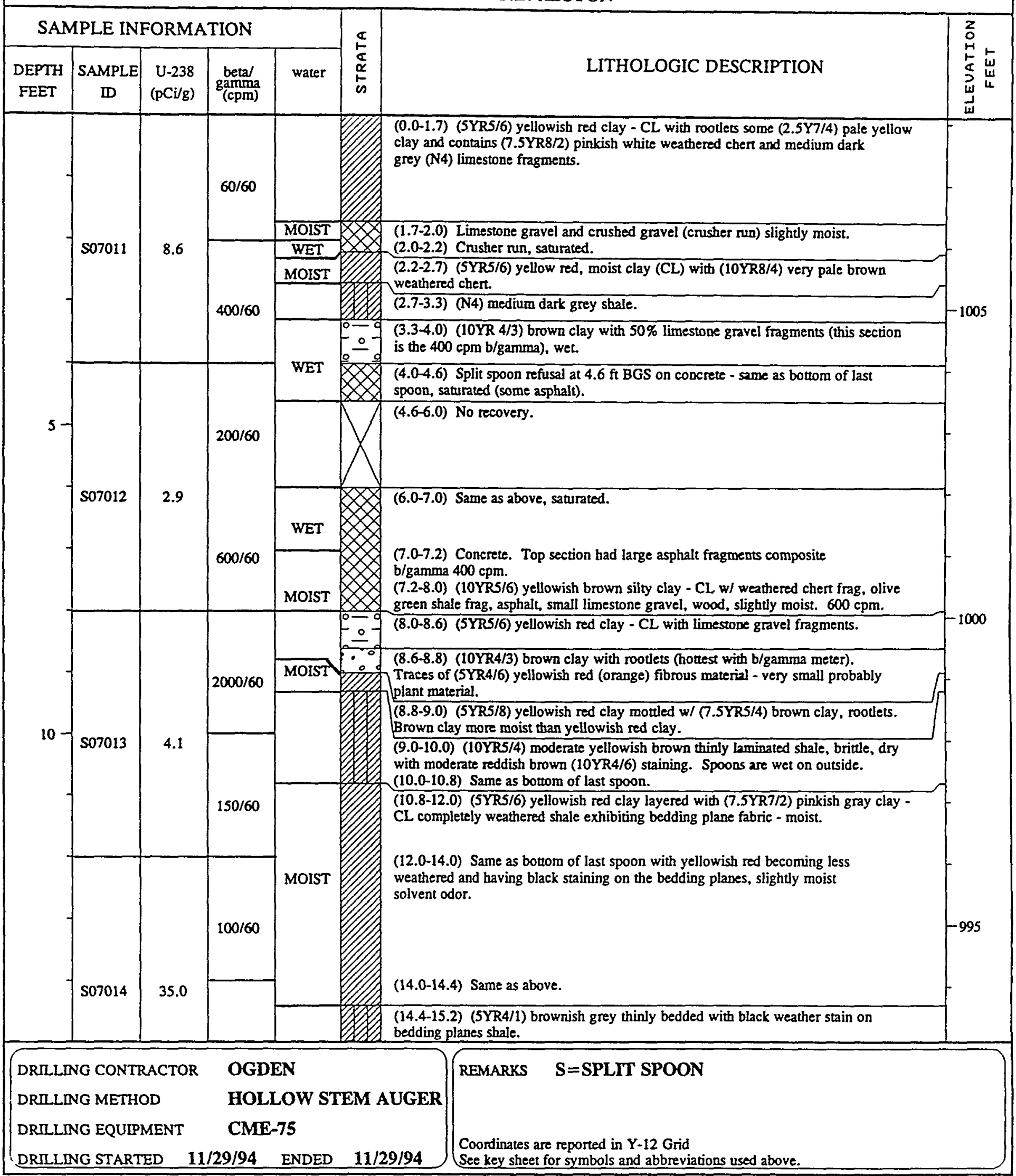


B13-15

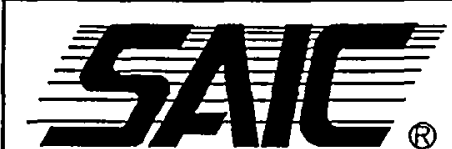

COORDINATES N 30,178.90 E 51,991.30

ELEVATION $1008.10 \mathrm{ft}$ above MSL
SHEET

2 of 2

LOCATION

BCV OU 1

TOTAL DEPTH

27.90

ft bgs

BOREHOLE NUMBER S3-07

BOREHOLE DIAMETER 8 in.

SAMPLING DEVICE

S-3IN

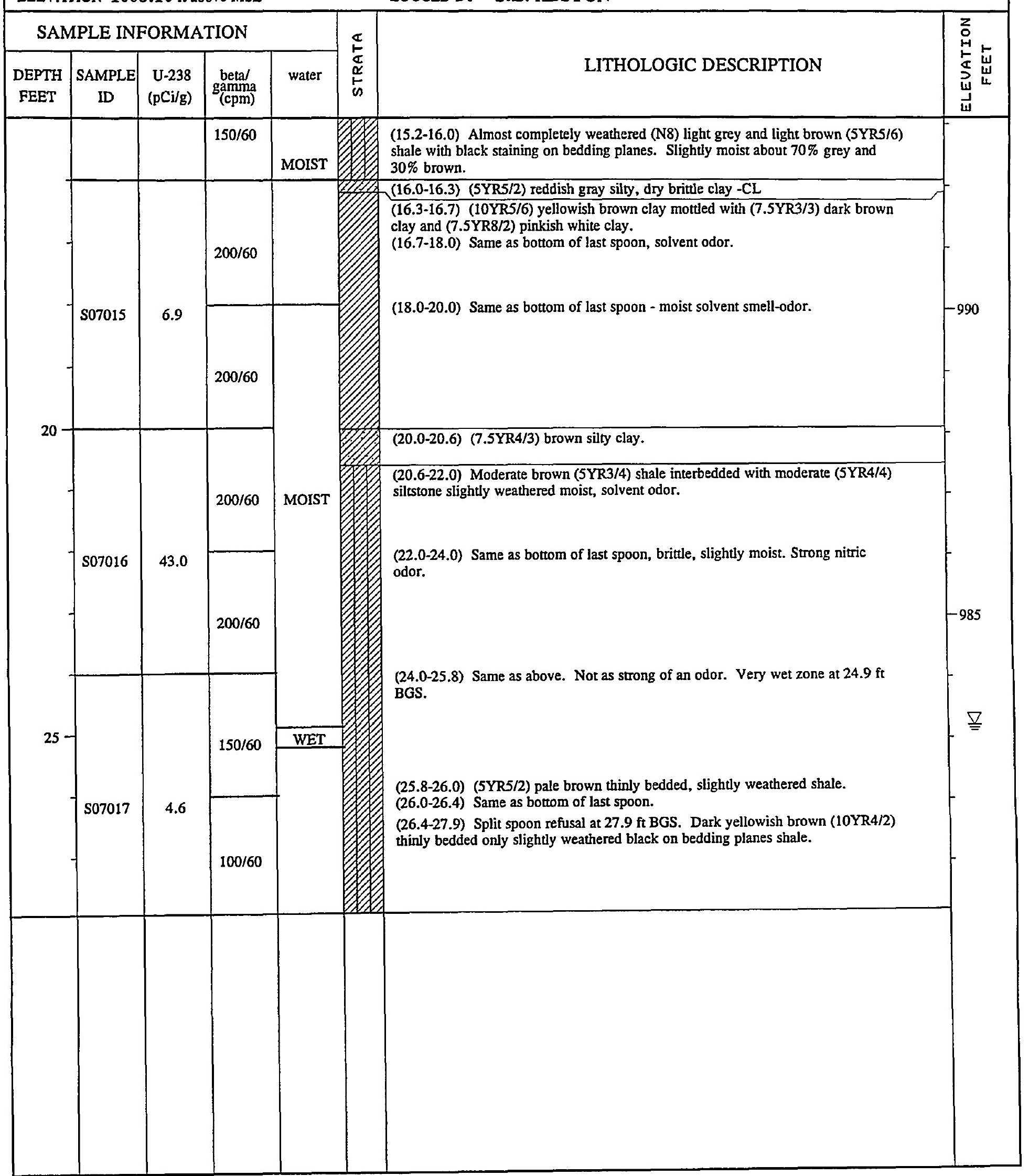


B13-16

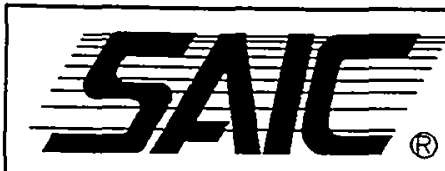

COORDINATES N 30,173.30 E 52,368.30
LOCATION

BOREHOLE NUMBER
BCV OU 1 TOTAL DEPTH

SHEET

12.00

S3-08
SAMPLING DEVICE S-3IN

ELEVATION $1006.00 \mathrm{ft}$ above MSL

BOREHOLE DIAMETER 8 in.

\section{in.} LOGGED BY S.L. ABSTON

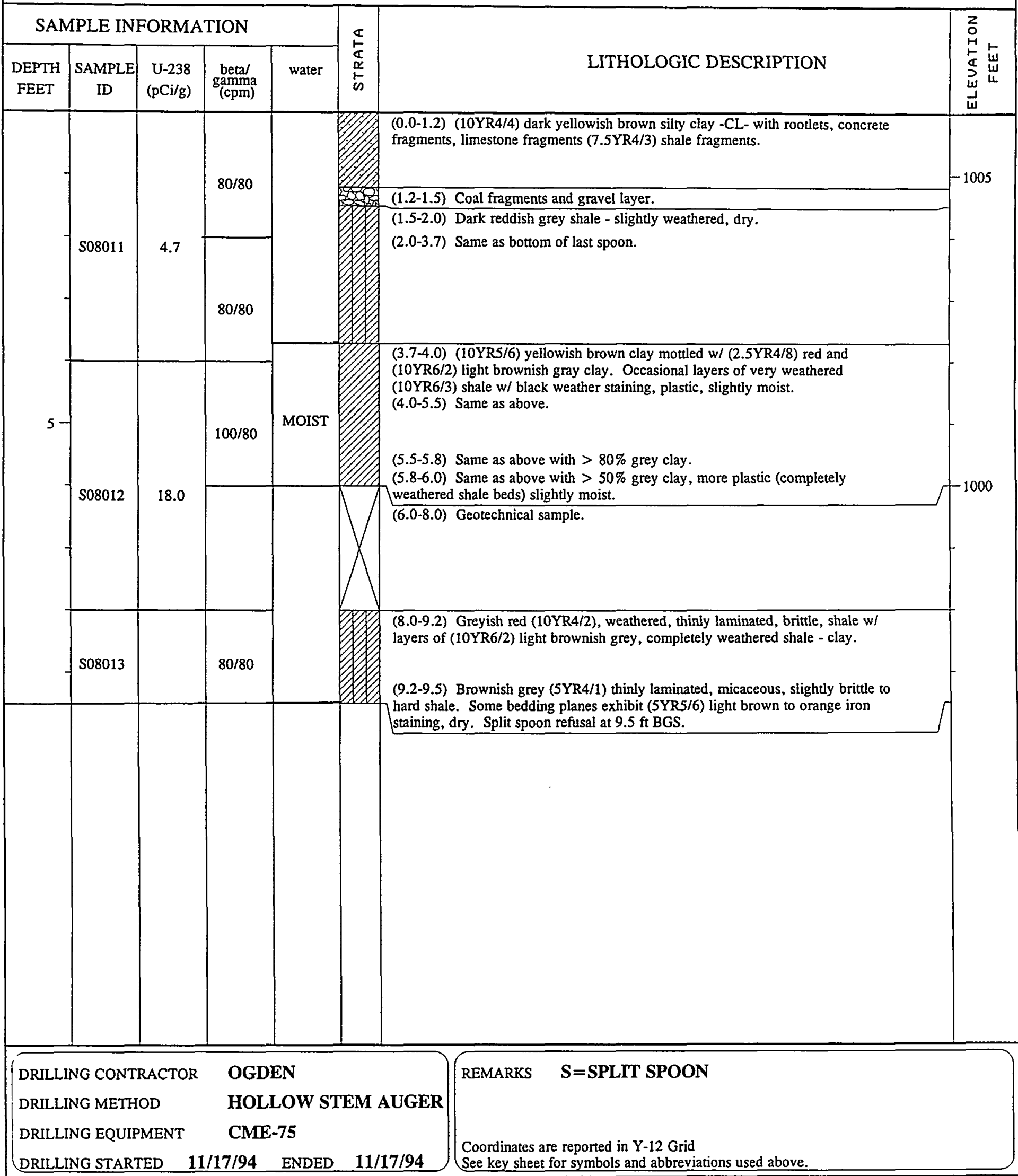




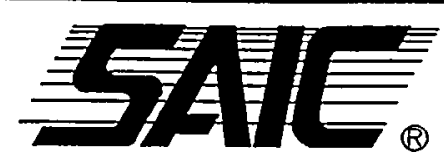

(B)

COORDINATES N 30,656.50 E 52,080.10

ELEVATION $1018.00 \mathrm{ft}$ above MSL
LOCATION

BOREHOLE NUMBER

BCV OU 1

S3-09

BOREHOLE DIAMETER 8 in.
SHEET 1 OF 1 $\mathbf{1 6 . 0 0}$ ft bgs

in. SAMPLING DEVICE S-3IN

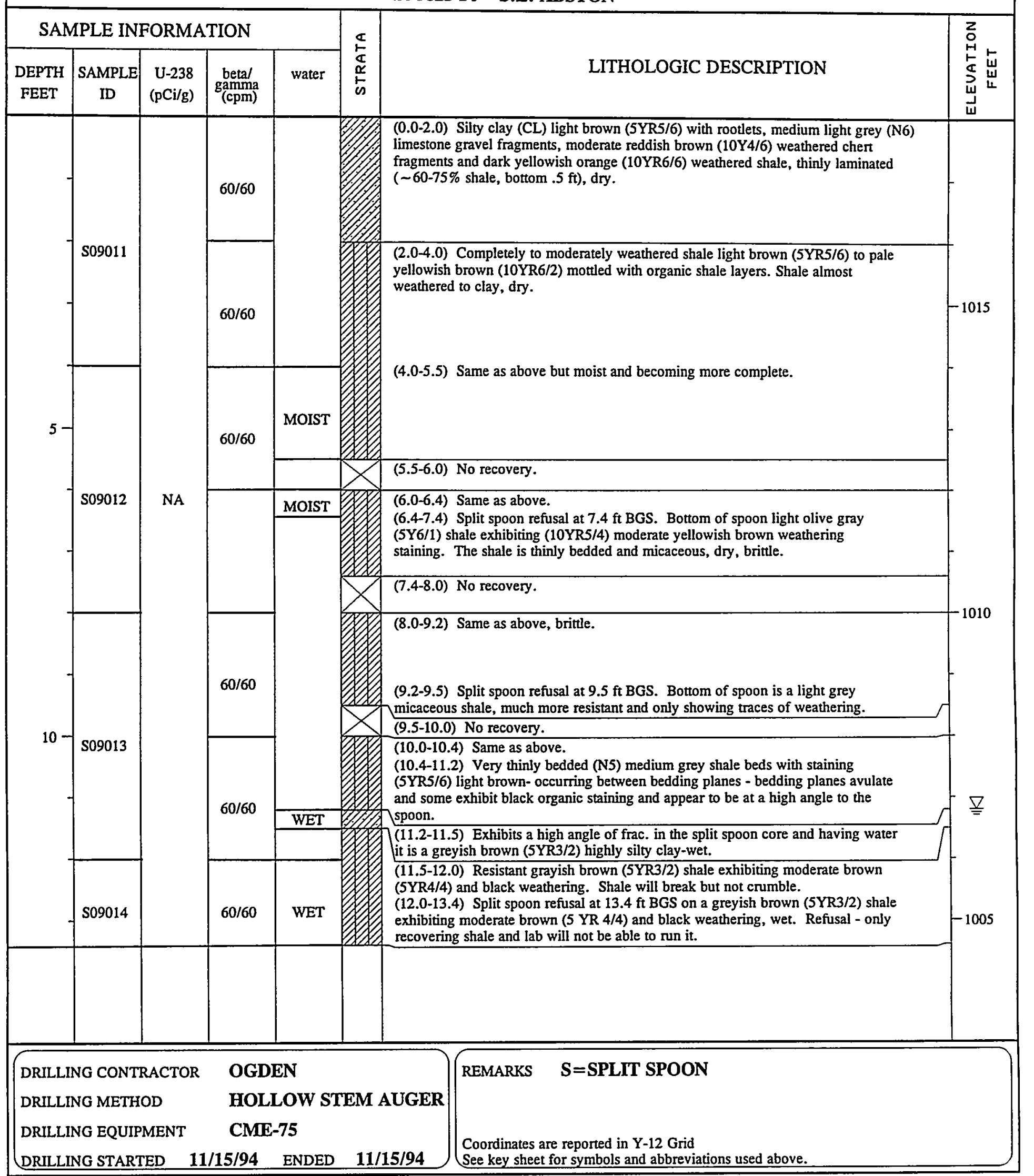




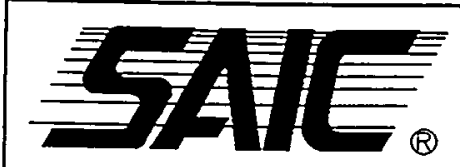

COORDINATES N 29,781.00 E 50,793.00

ELEVATION $981.00 \mathrm{ft}$ above MSL
LOCATION

BOREHOLE NUMBER

12.00 ft bgs

BCV OU 1 TOTAL DEPTH $\quad \mathbf{1 2 . 0 0} \quad \mathrm{ft}$ bgs

BOREHOLE DIAMETER 8 in. SAMPLING DEVICE S-3IN LOGGED BY S.L. ABSTON

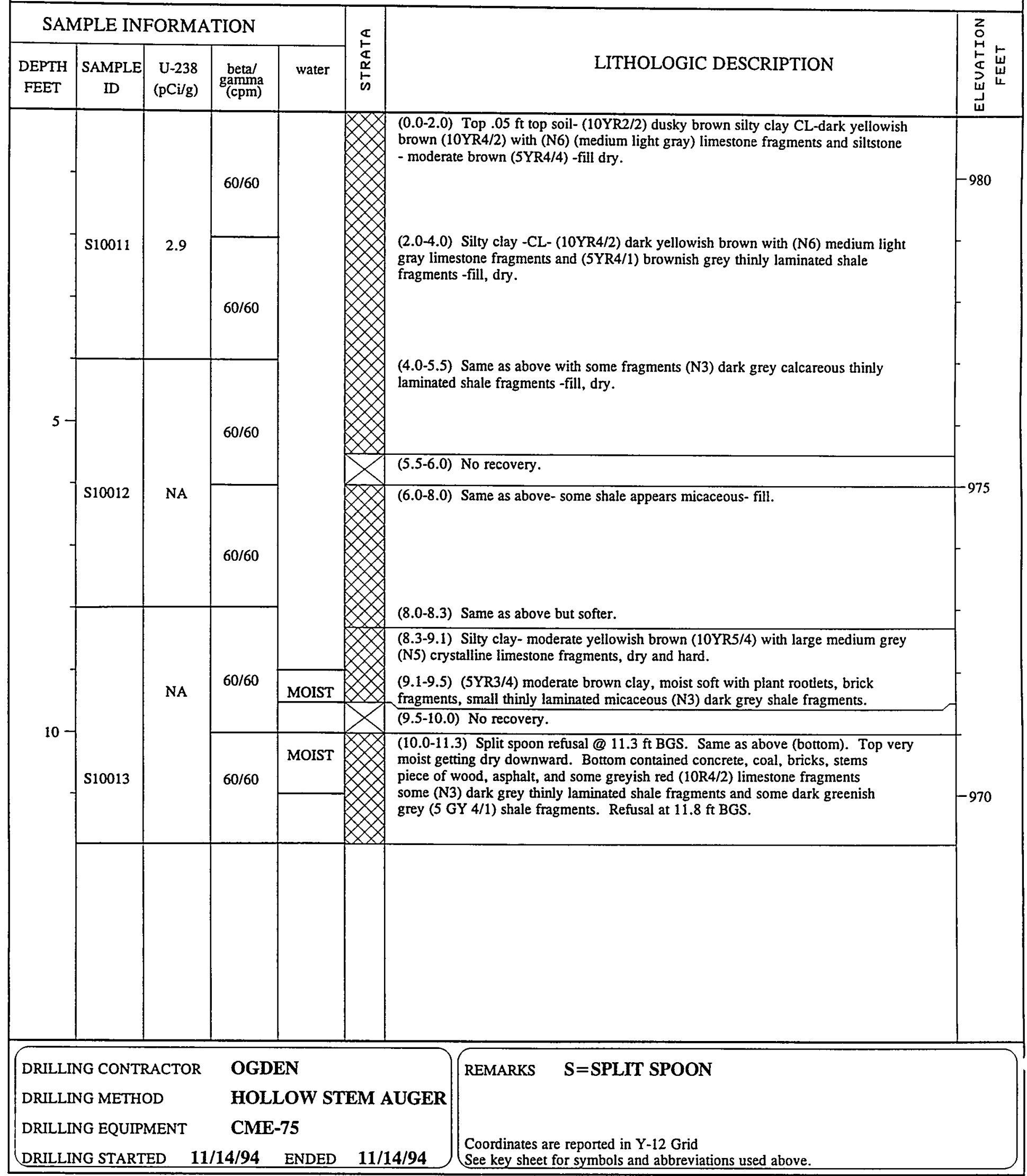




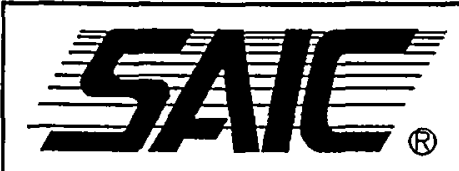

COORDINATES N 29,638.60 E 43,459.60

ELEVATION $923.30 \mathrm{ft}$ above MSL
SHEET 1 OF 3

LOCATION BCV OU 1 TOTAL DEPTH $35.00 \quad \mathrm{ft}$ bgs

BOREHOLE NUMBER BG-01

BOREHOLE DIAMETER 1.25 in.

SAMPLING DEVICE PROBE

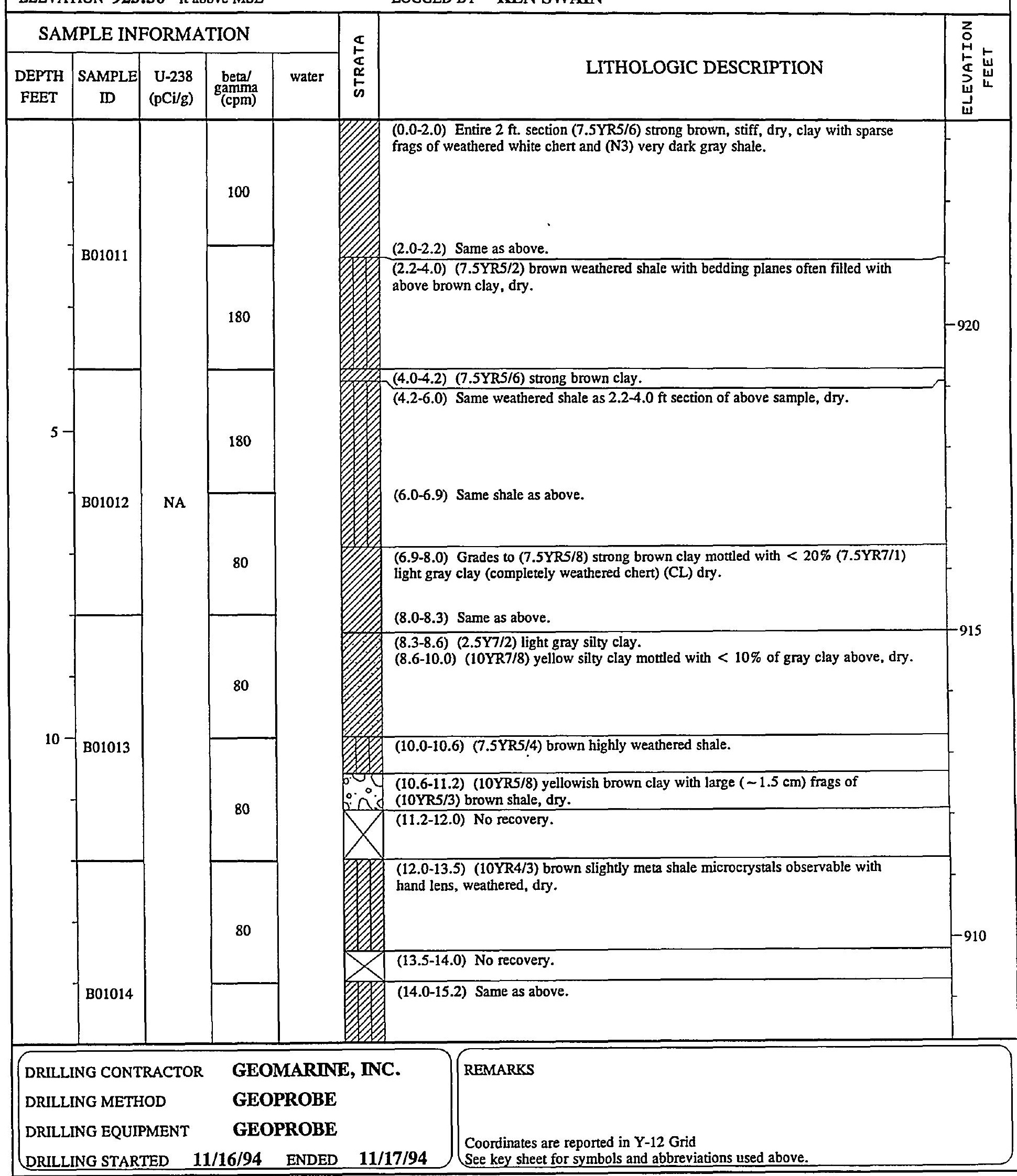


B13-20

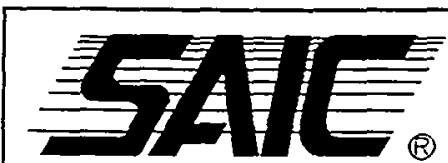

COORDINATES N 29,638.60 E 43,459.60

ELEVATION $923.30 \mathrm{ft}$ above MSL

\section{LOCATION}

BOREHOLE NUMBER

BCV OU 1

BG-01

BOREHOLE DIAMETER $1.25 \mathrm{in}$. LOGGED BY KEN SWAIN

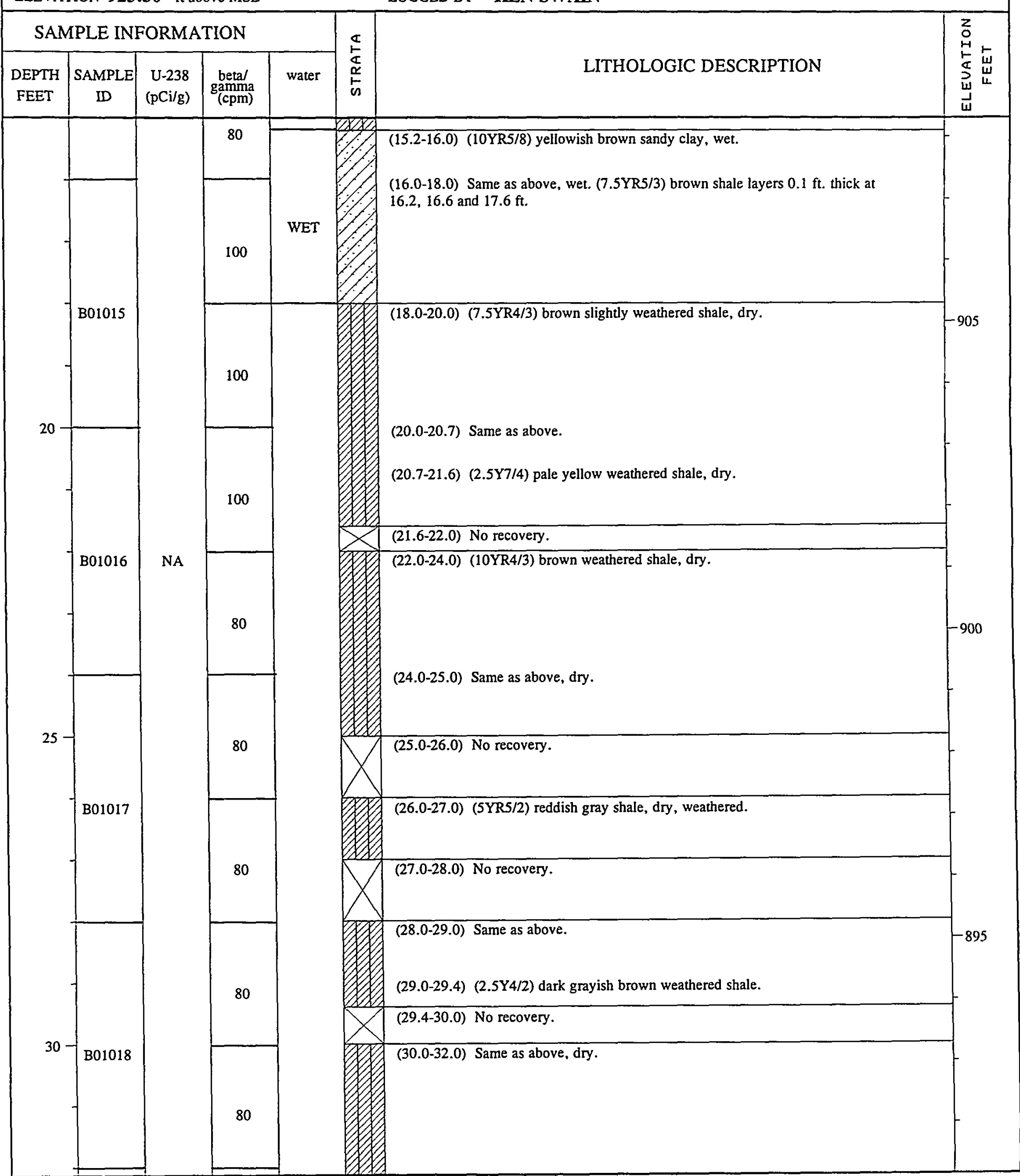



COORDINATES $\mathbf{N} 29,638.60$ E 43,459.60 ELEVATION $923.30 \mathrm{ft}$ above MSL
SHEET 3 OF 3

35.00 ft bgs

$\begin{array}{lllll}\text { LOCATION } & \text { BCV OU } 1 & \text { TOTAL DEPTH } & \mathbf{3 5 . 0 0} & \mathrm{ft} \text { bgs }\end{array}$

BOREHOLE NUMBER BG-01

BOREHOLE DLAMETER $\mathbf{1 . 2 5}$ in.

SAMPLING DEVICE

PROBE

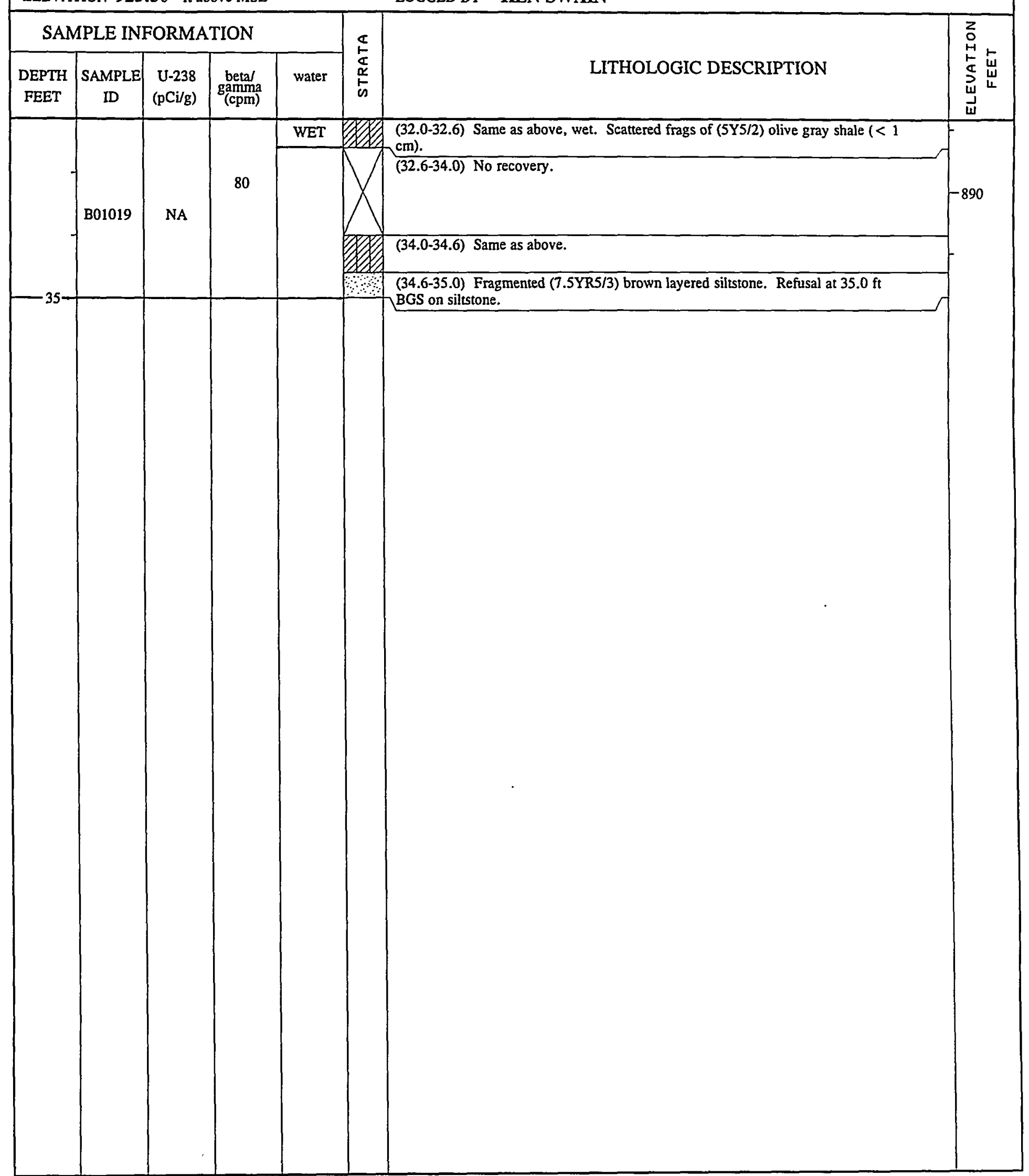


B13-22

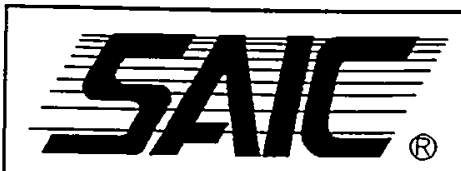

COORDINATES N 29,655.00 E 43,746.60 ELEVATION $926.70 \mathrm{ft}$ above MSL

\section{LOCATION}

BOREHOLE NUMBER

\section{BCV OU 1}

BG-02

BOREHOLE DIAMETER $\mathbf{1 . 2 5} \mathrm{in}$. LOGGED BY KEN SWAIN
SHEET 1 OF 3

37.00 ft bgs

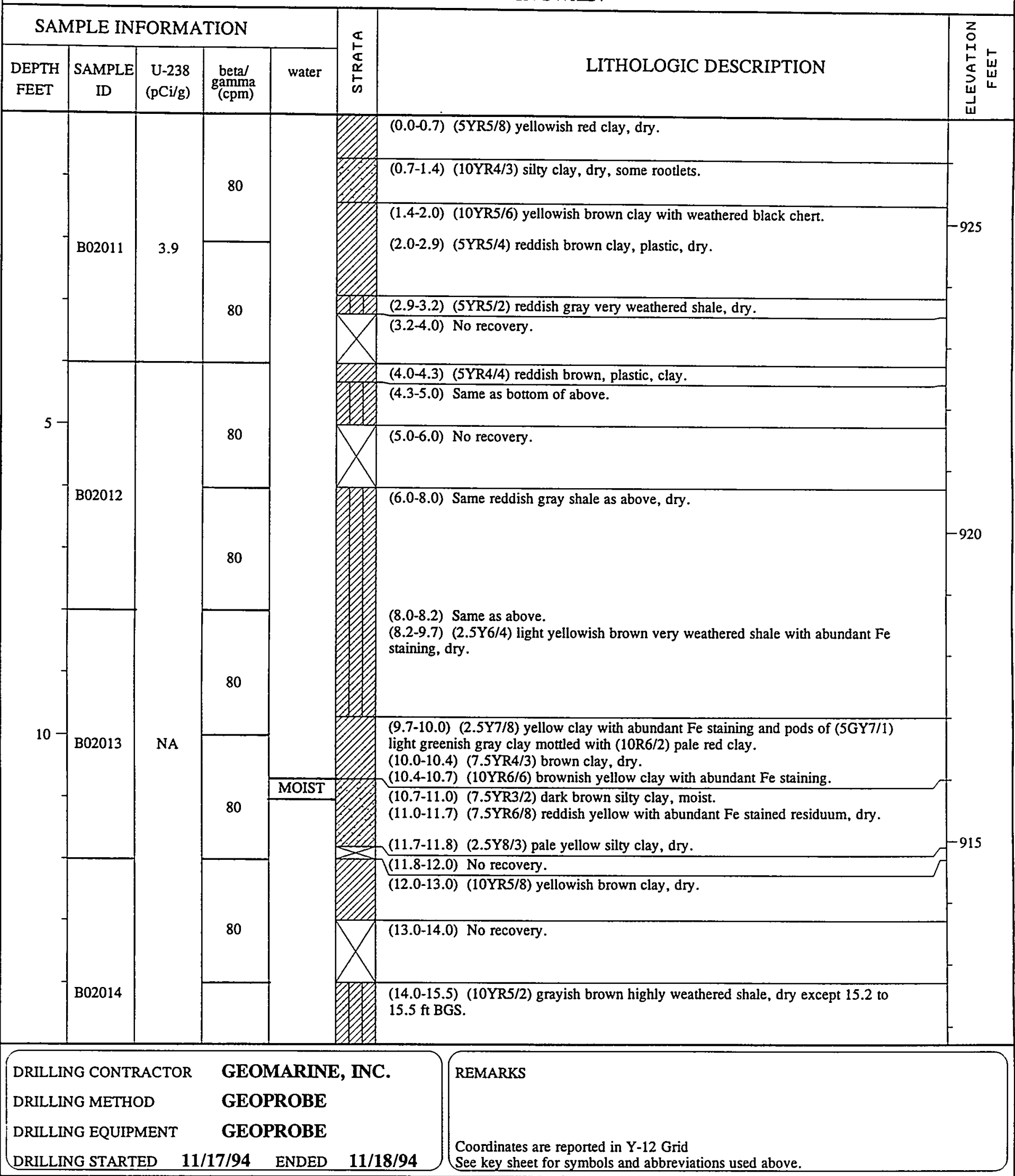




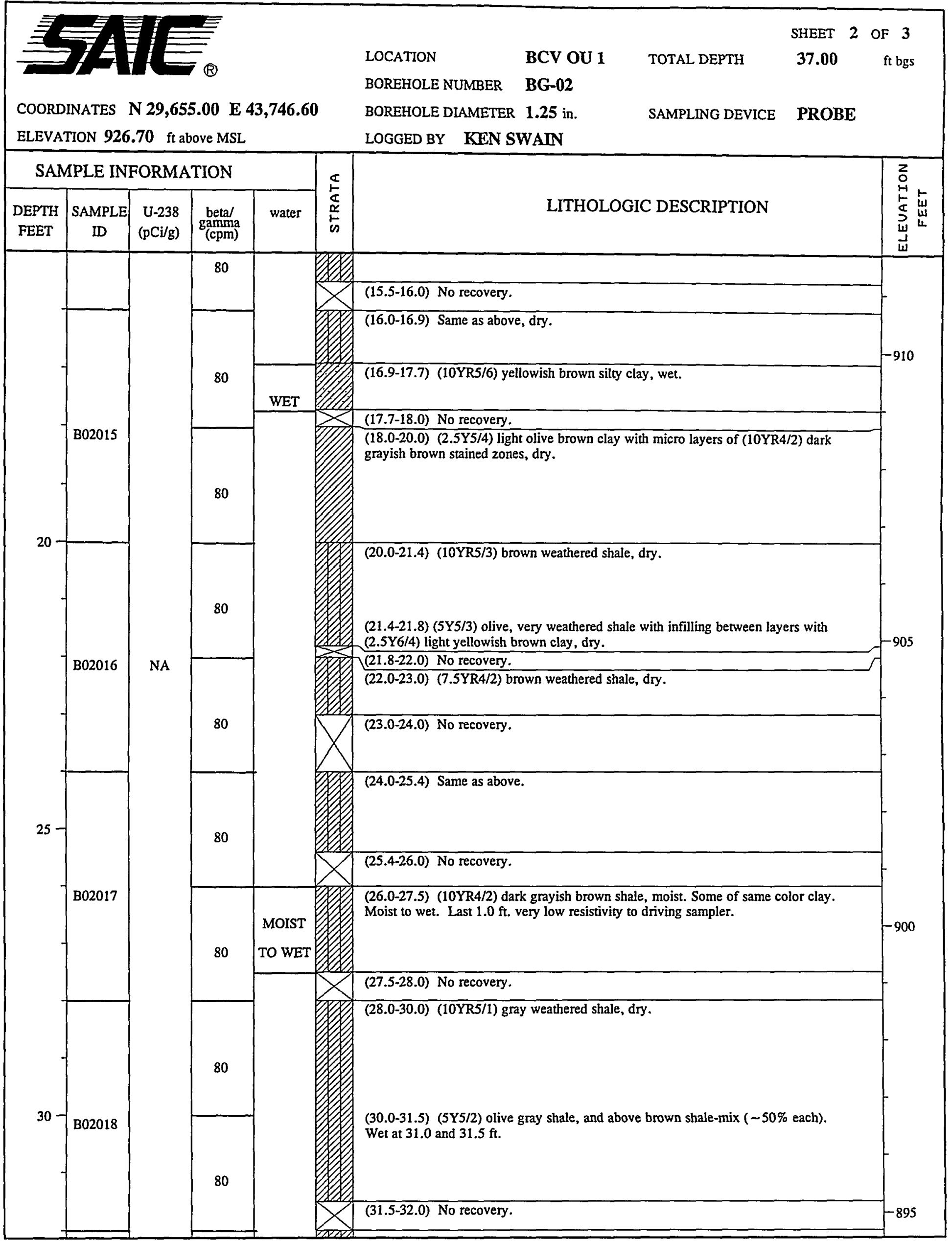


B13-24

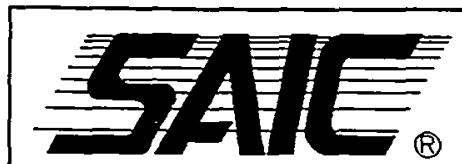

(R)

COORDINATES N 29,655.00 E 43,746.60

ELEVATION $926.70 \mathrm{ft}$ above MSL

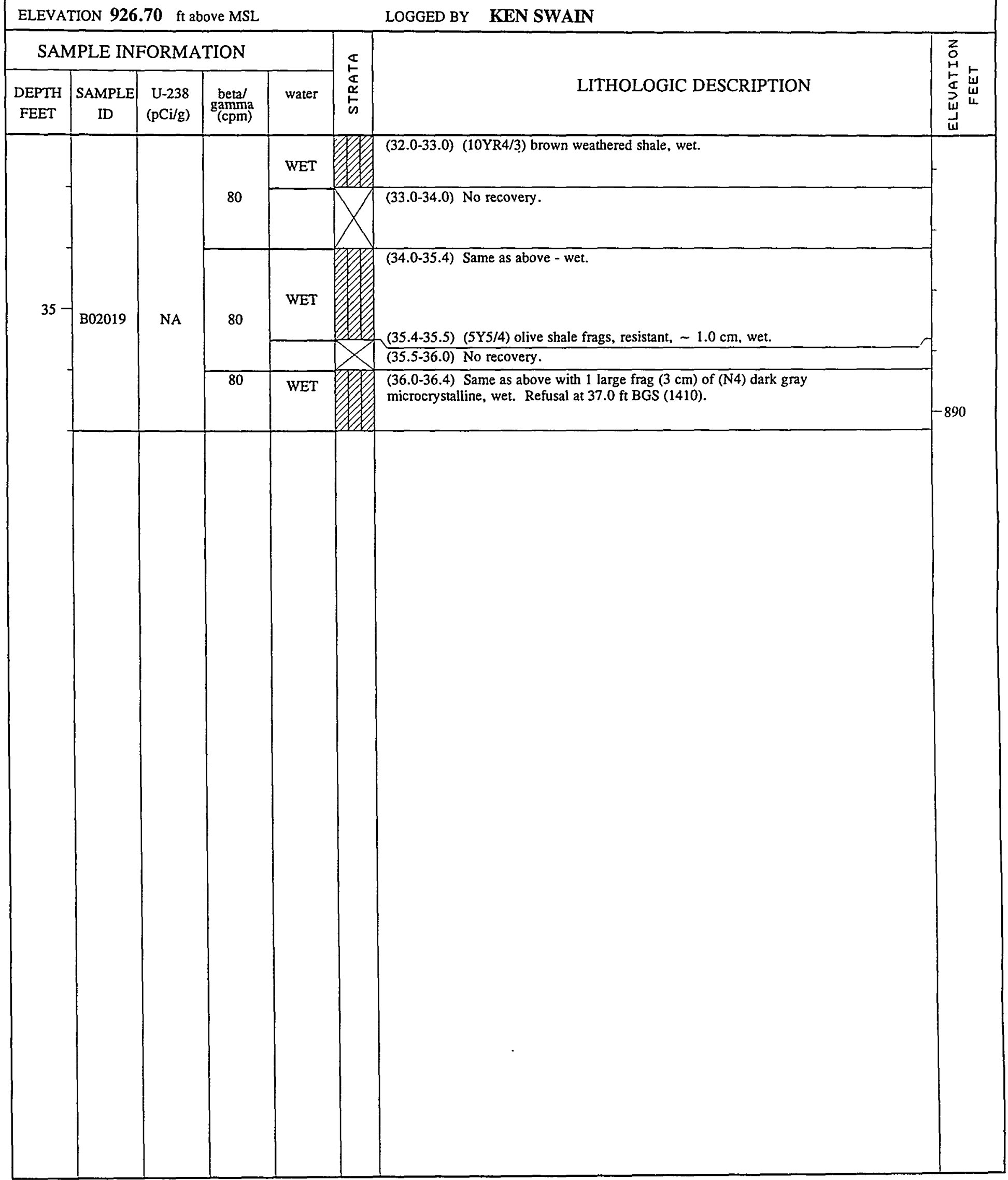




\section{SAIE.}

COORDINATES N 29,701.80 E 44,208.10

ELEVATION $925.90 \mathrm{ft}$ above MSL

\section{LOCATION}

BOREHOLE NUMBER

BCV OU 1

BG-03

BOREHOLE DIAMETER 1.25 in. LOGGED BY KEN SWAIN
SHEET 1 OF 2

20.25 ft bgs

TOTAL DEPTH

SAMPLING DEVICE PROBE

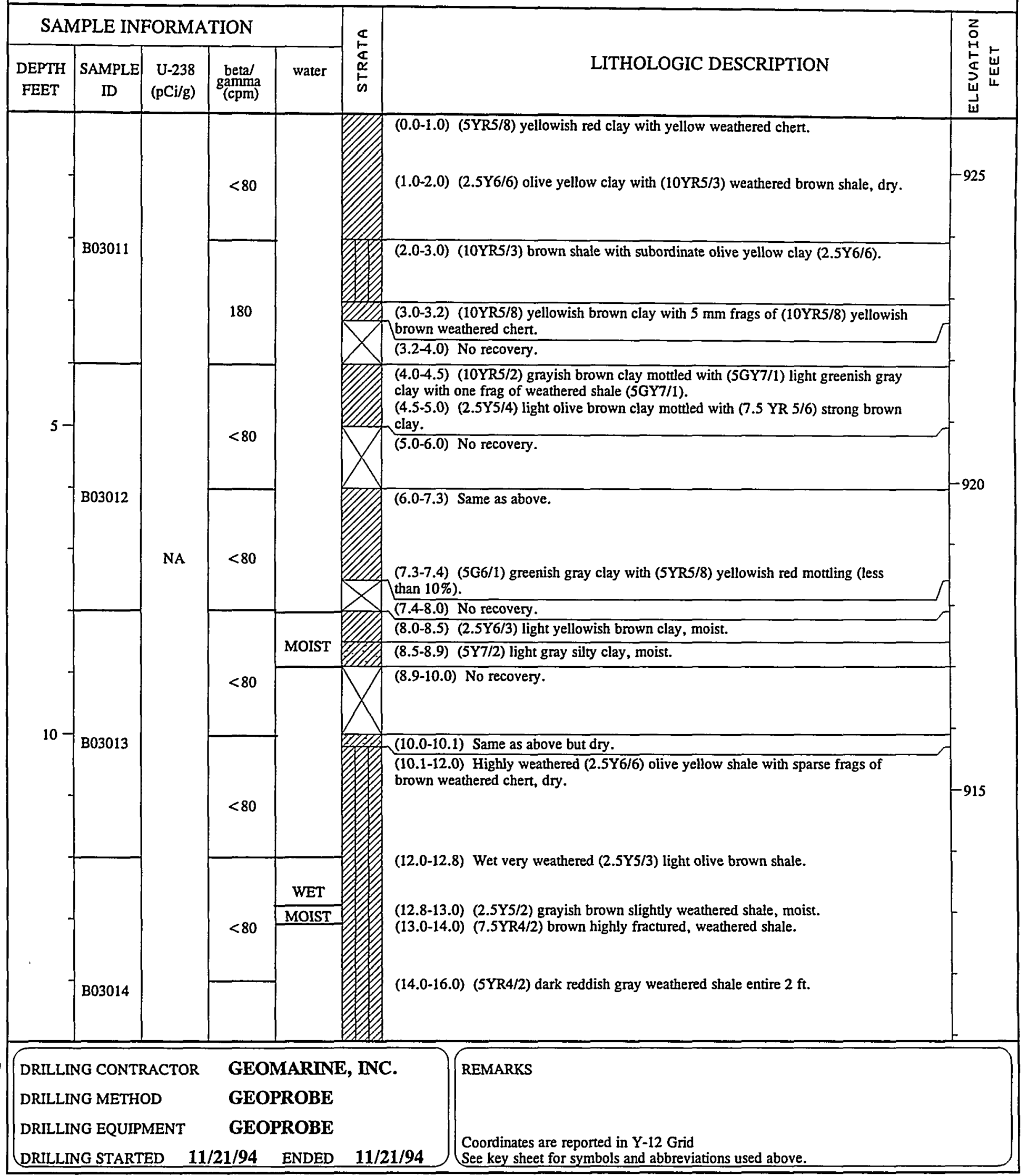


B13-26

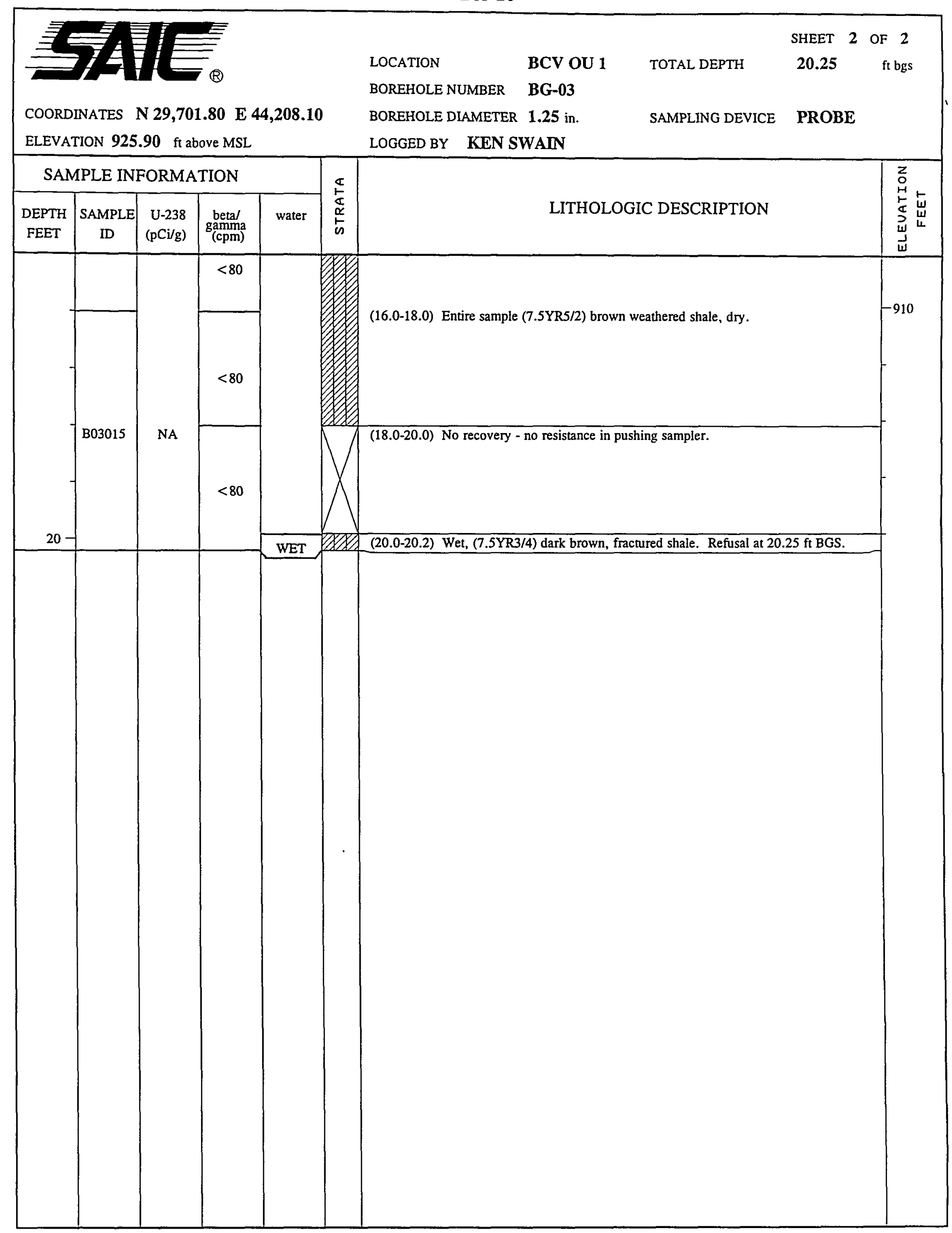




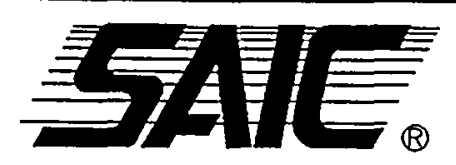

COORDINATES N 29,882.90 E 44,264.40

ELEVATION $926.40 \mathrm{ft}$ above MSL
LOCATION

BOREHOLE NUMBER

BOREHOLE DIAMETER 1.25 in. LOGGED BY KEN SWAIN
SHEET 1 OF 1

$12.50 \quad \mathrm{ft} b g s$

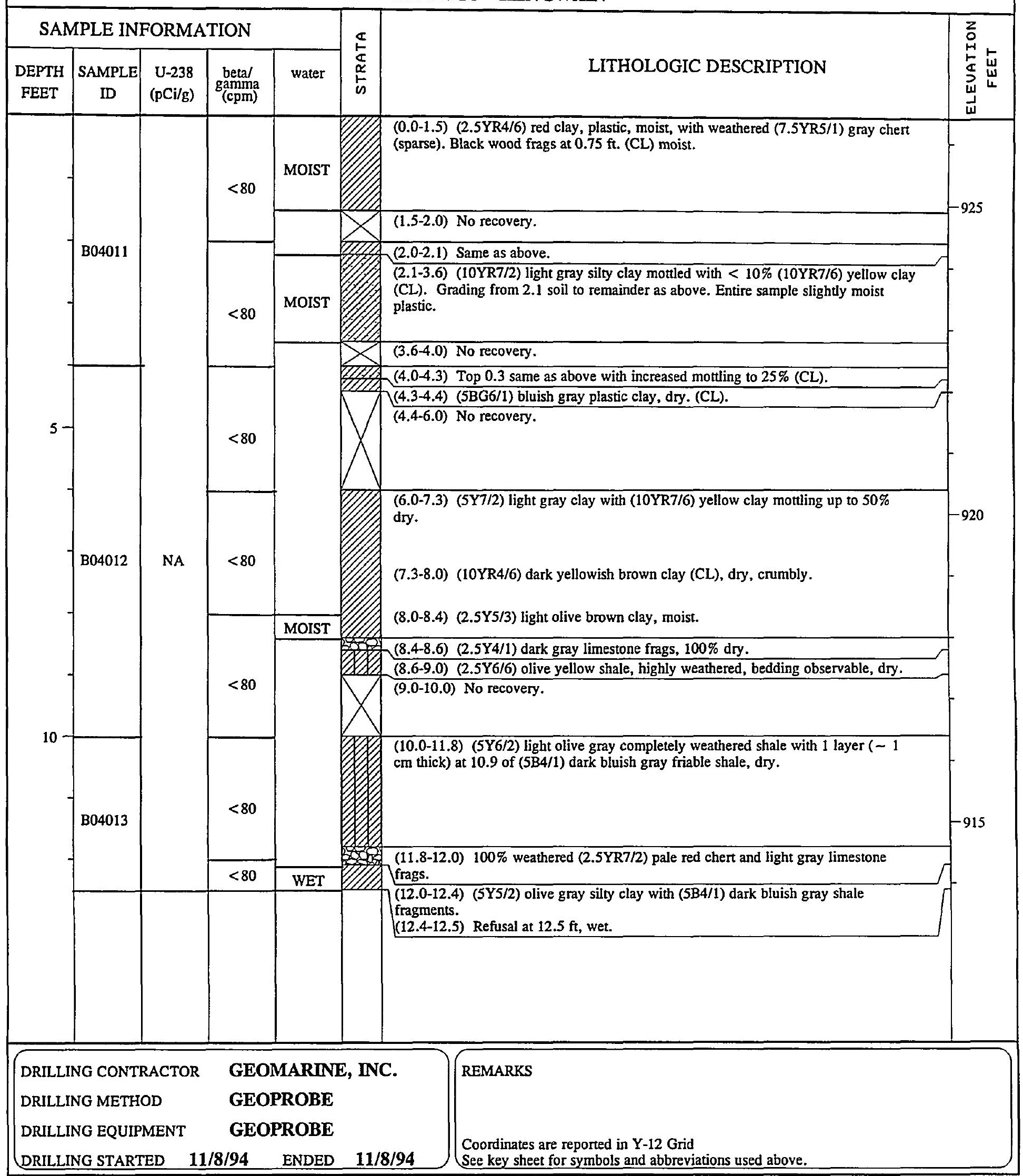




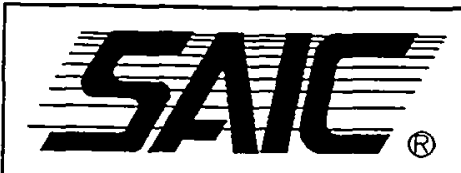

COORDINATES N 30,192.20 E 43,998.00

ELEVATION $952.10 \mathrm{ft}$ above MSL
LOCATION

BOREHOLE NUMBER

\section{BCV OU 1}

BG-05

BOREHOLE DIAMETER 1.25 in. LOGGED BY KEN SWAIN
SHEET 1 OF 2

26.50 ft bgs

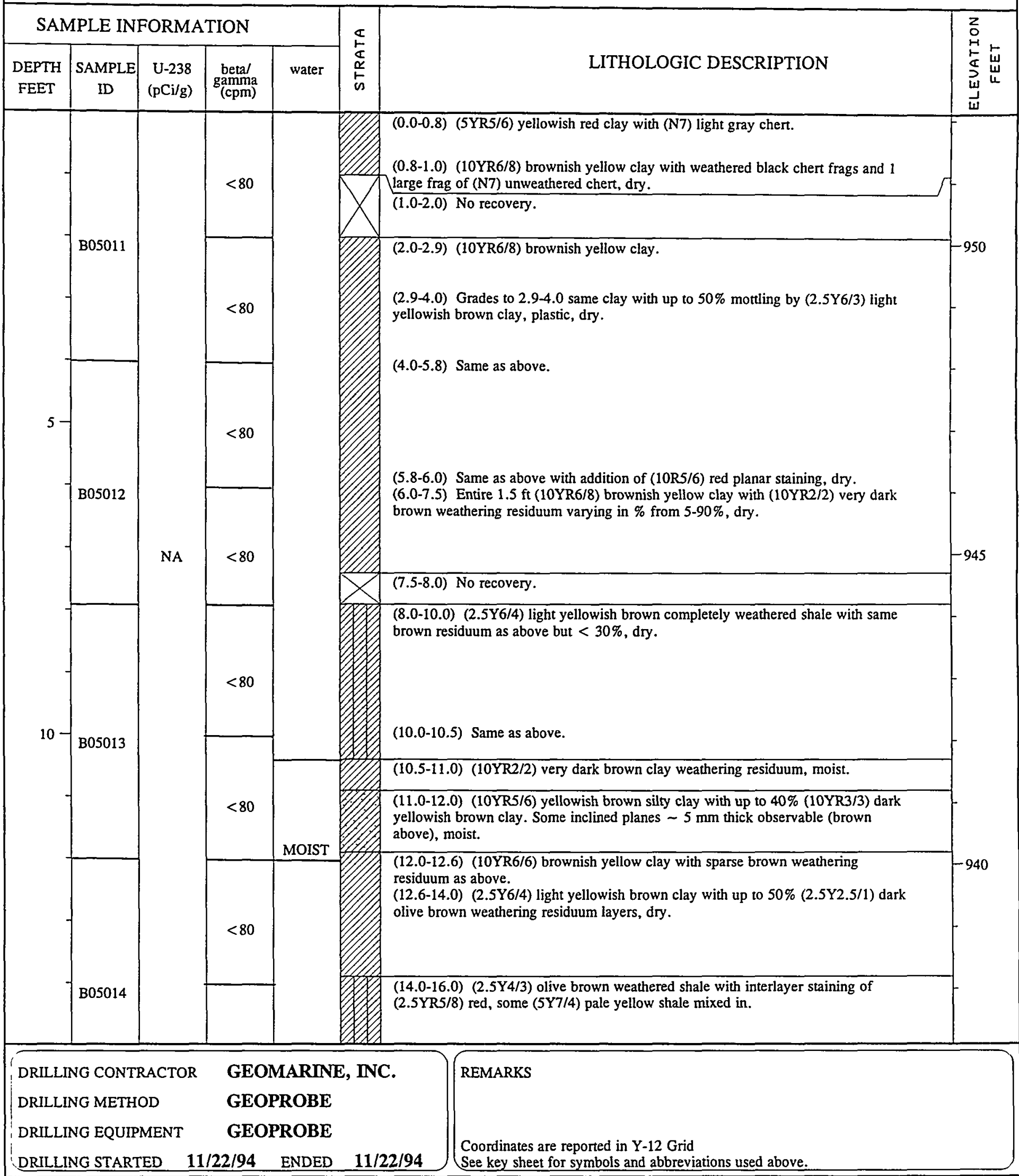




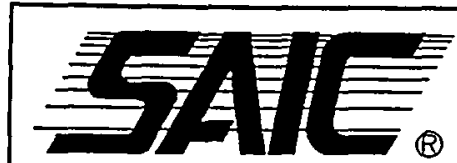

COORDINATES N 30,192.20 E 43,998.00

ELEVATION $952.10 \mathrm{ft}$ above MSL
SHEET 2 OF 2

LOCATION

BCV OU 1

TOTAL DEPTH

26.50

ft bgs

BOREHOLE NUMBER BG-05

BOREHOLE DIAMETER 1.25 in.

SAMPLING DEVICE

PROBE

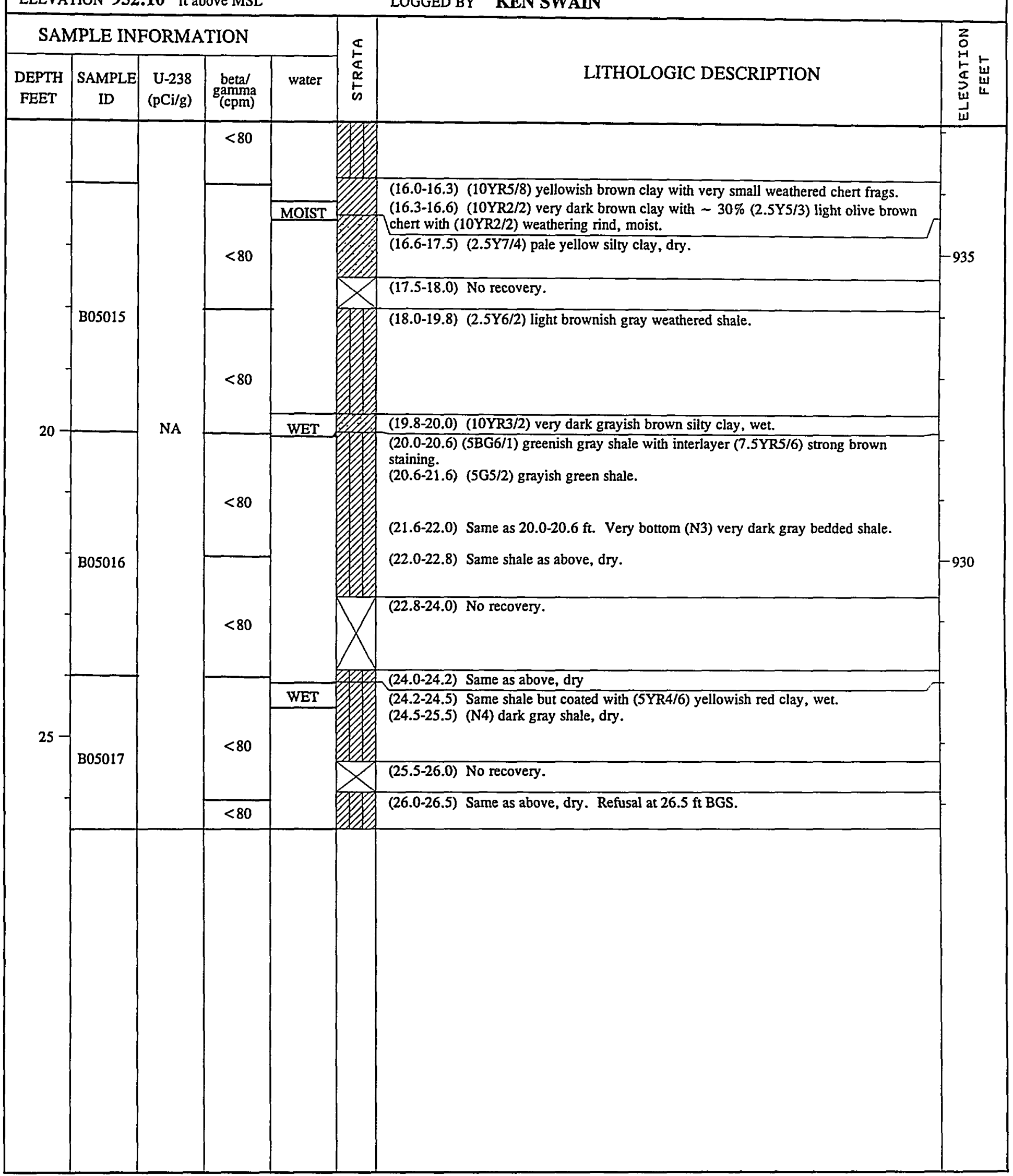




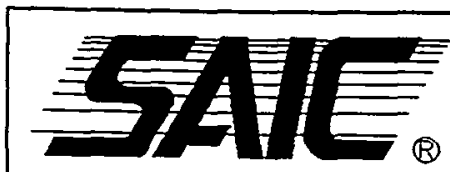

COORDINATES $\mathbf{N} 30,298.00$ E 44,437.80

ELEVATION $955.30 \mathrm{ft}$ above MSL
SHEET 1 OF 2

LOCATION

BCV OU 1 TOTAL DEPTH

24.60

ft bgs

BOREHOLE NUMBER BG-06

BOREHOLE DIAMETER 1.25 in. SAMPLING DEVICE PROBE LOGGED BY KEN SWAIN

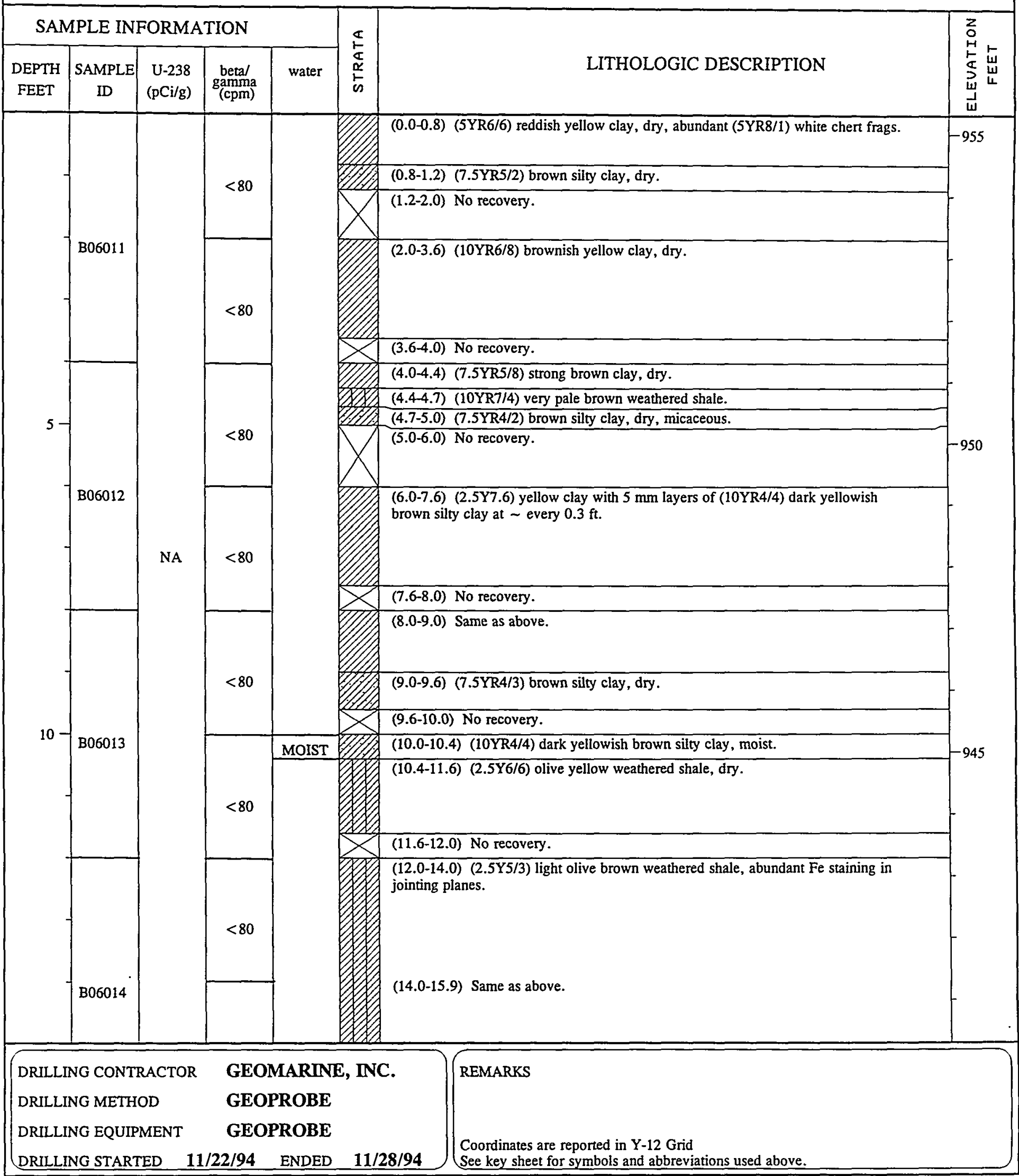




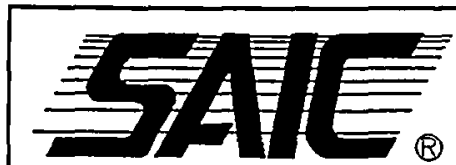

(B)

COORDINATES N 30,298.00 E 44,437.80

ELEVATION $955.30 \mathrm{ft}$ above MSL
SHEET 2 OF 2

$\begin{array}{lllll}\text { LOCATION } & \text { BCV OU } 1 & \text { TOTAL DEPTH } & 24.60 & \text { ft bgs } \\ \text { BOREHOLE NUMBER } & \text { BG-06 } & & & \end{array}$

BOREHOLE DIAMETER 1.25 in.

SAMPLING DEVICE

PROBE

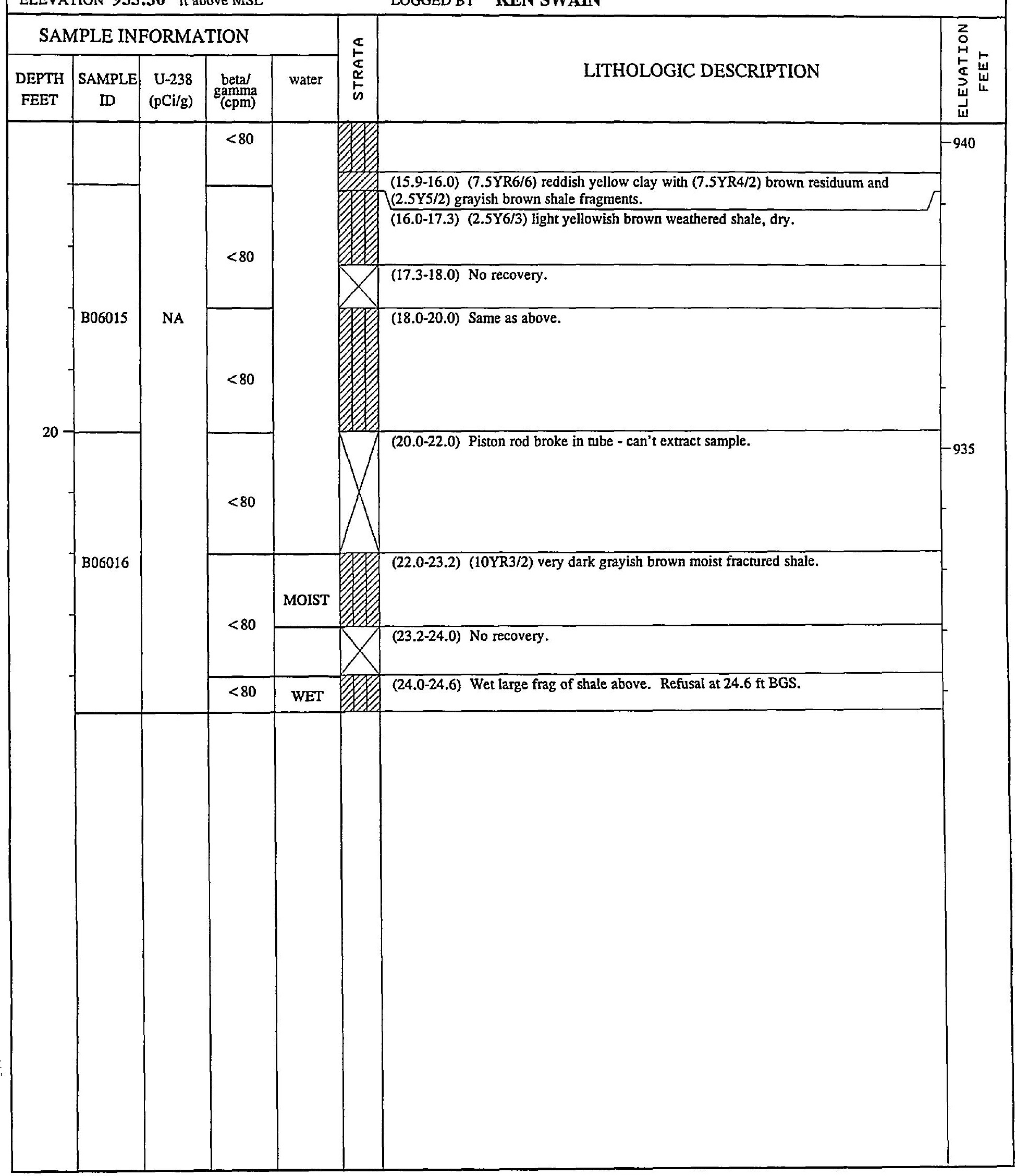


B13-32

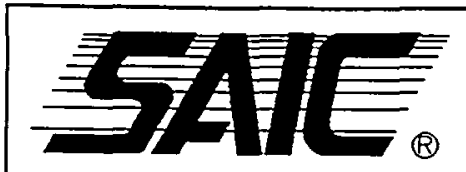

COORDINATES N 30,614.40 E 44,569.90

ELEVATION $975.40 \mathrm{ft}$ above MSL
LOCATION

BOREHOLE NUMBER
SHEET

1 OF 1

BCV OU 1 TOTAL DEPTH

$\mathbf{1 2 . 0 0} \mathrm{ft}$ bgs

DERE DIAMETER 6 in.

SAMPLING DEVICE BUCKET

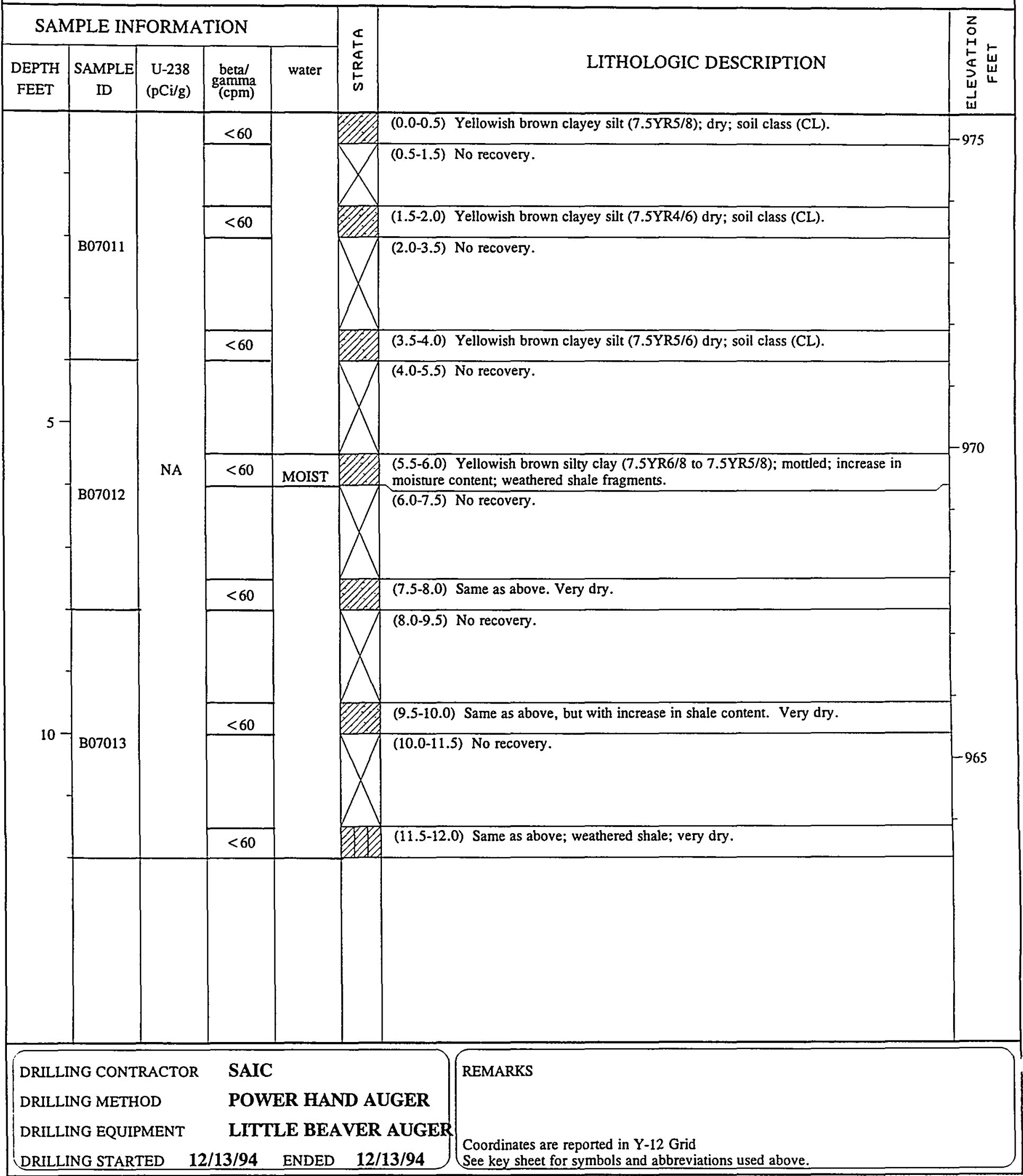




\section{FAIE}

COORDINATES N 31,013.60 E 43,360.20

ELEVATION $960.60 \mathrm{ft}$ above MSL

\section{LOCATION}

BOREHOLE NUMBER

\section{BCV OU 1}

BG-08

BOREHOLE DIAMETER 1.25 in.

LOGGED BY KEN SWAIN
SHEET 1 OF 1

$\mathbf{1 4 . 5 0}$ ft bgs

\section{SAMPLING DEVICE PROBE}

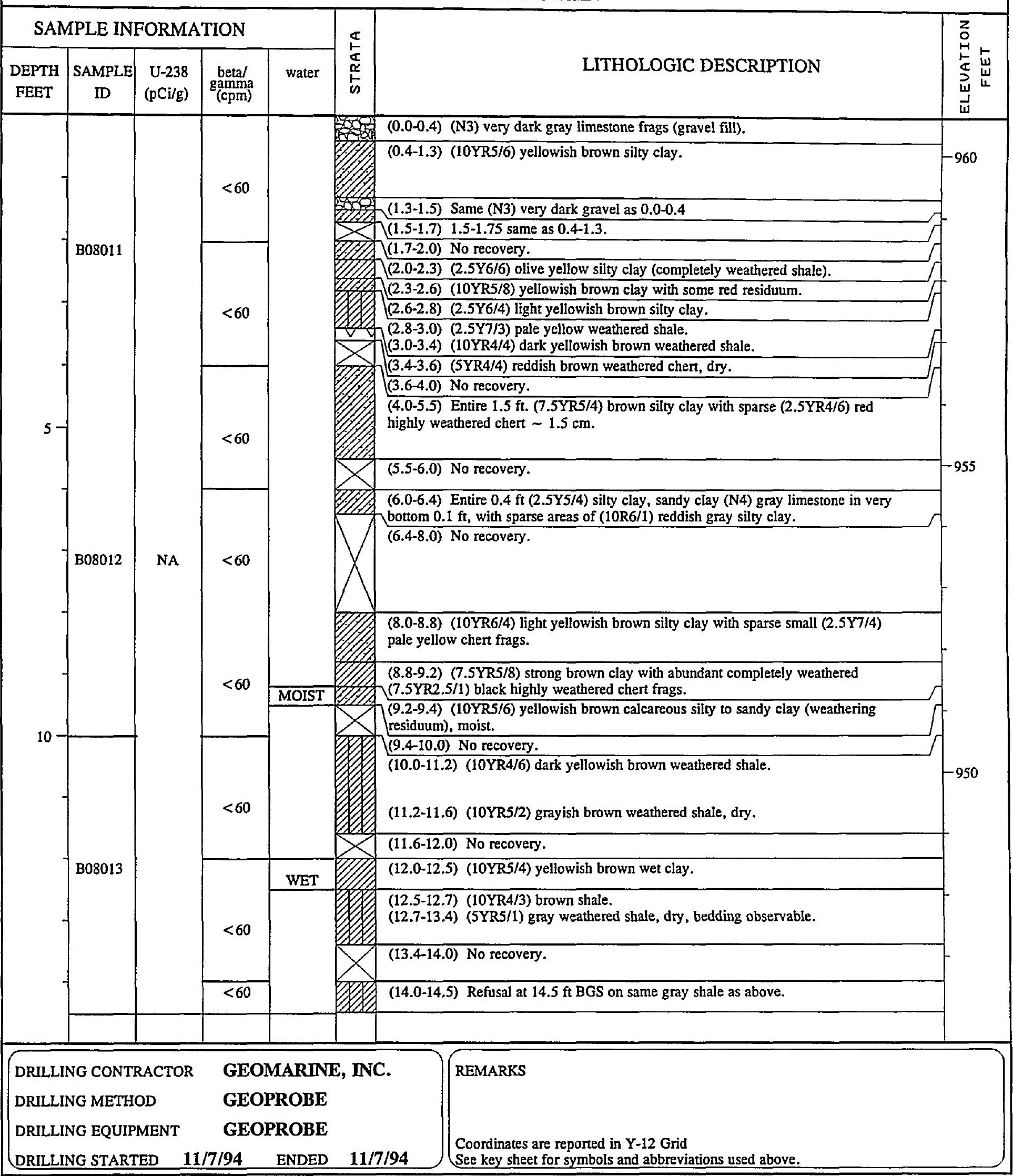




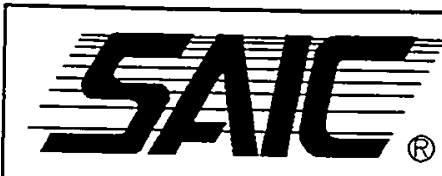

\section{(8)}

COORDINATES N 30,935.60 E 42,739.00

ELEVATION $972.50 \mathrm{ft}$ above MSL

\section{LOCATION}

BOREHOLE NUMBER

BOREHOLE DIAMETER 1.25 in.
SHEET 1 OF 2

$30.00 \quad \mathrm{ft}$ bgs

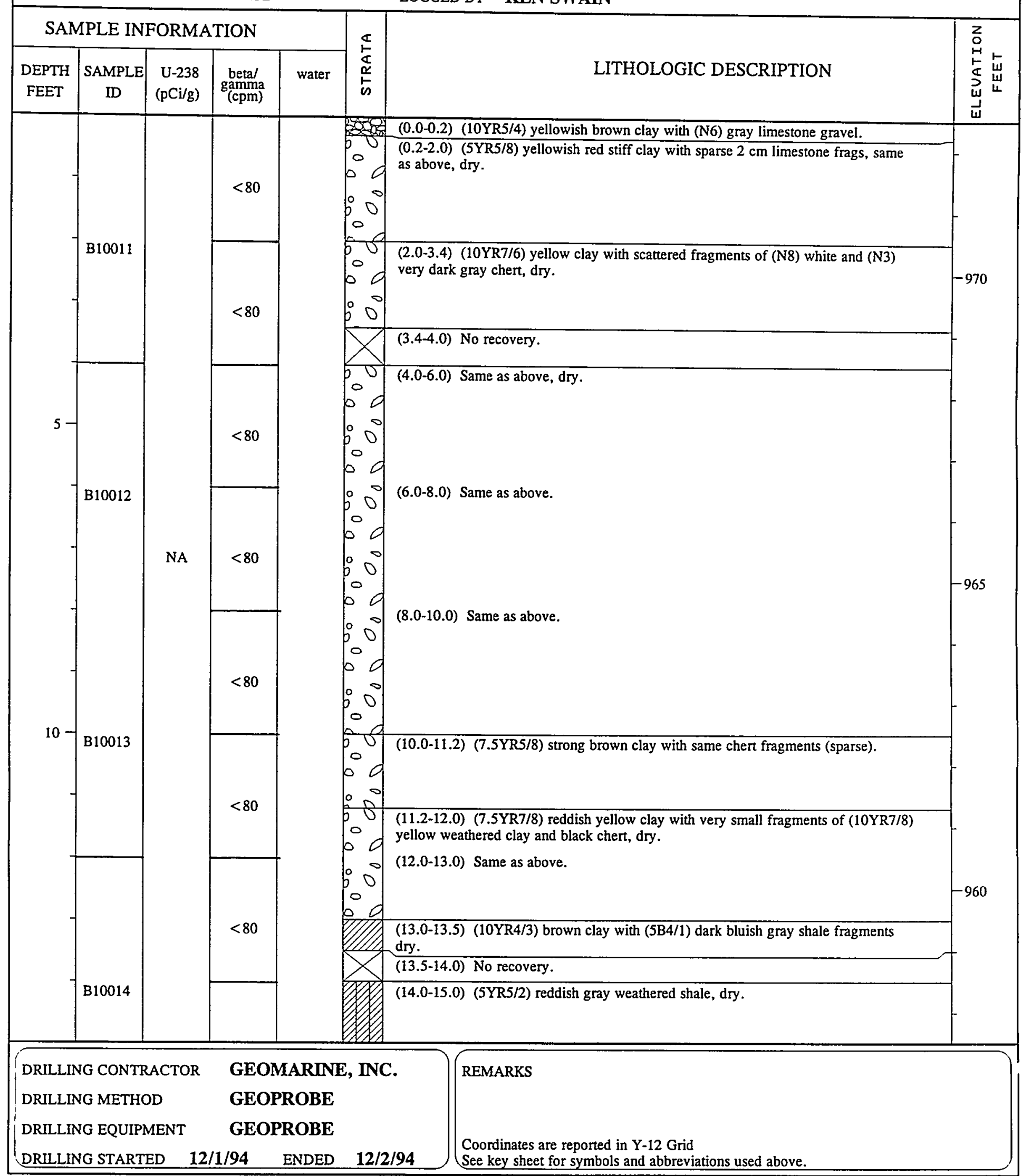


B13-35

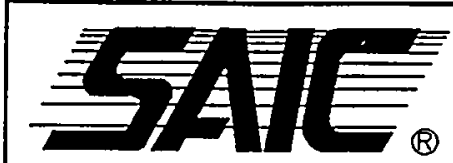

(B)
LOCATION

BOREHOLE NUMBER LOGGED BY KEN SWAIN
SHEET 2 OF 2

BCV OU 1 TOTAL DEPTH $\quad \mathbf{3 0 . 0 0}$ ft bgs

COORDINATES N 30,935.60 E 42,739.00

ELEVATION $972.50 \mathrm{ft}$ above MSL
BG-10

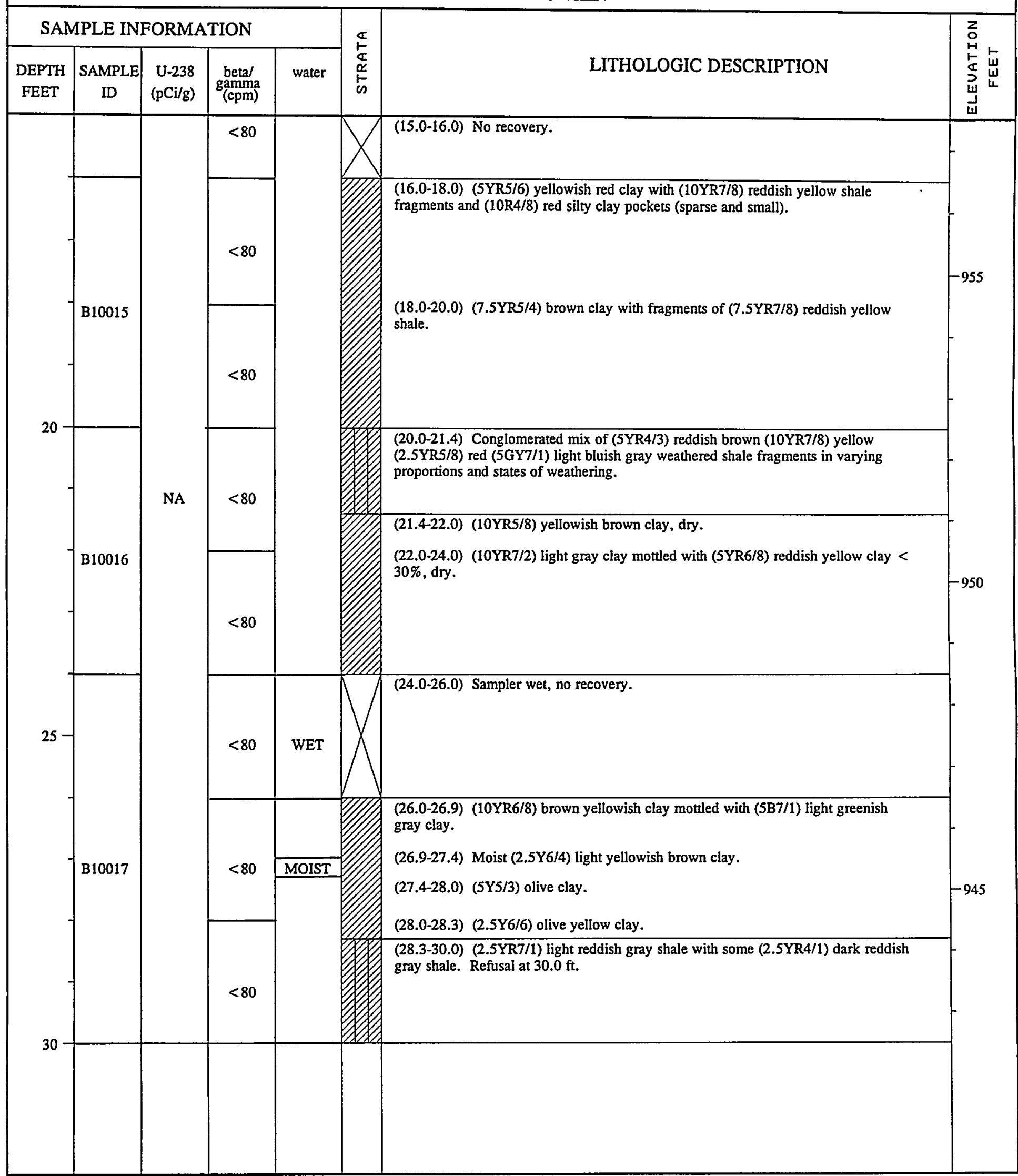




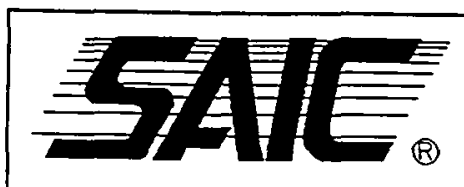

(B)

COORDINATES N 30,559.90 E 42,691.30

ELEVATION $989.40 \mathrm{ft}$ above MSL

\section{LOCATION}

BOREHOLE NUMBER

\section{BCV OU 1}

BG-11

BOREHOLE DIAMETER $1.25 \mathrm{in}$. LOGGED BY KEN SWAIN
SHEET 1 OF 2

15.90 ft bgs

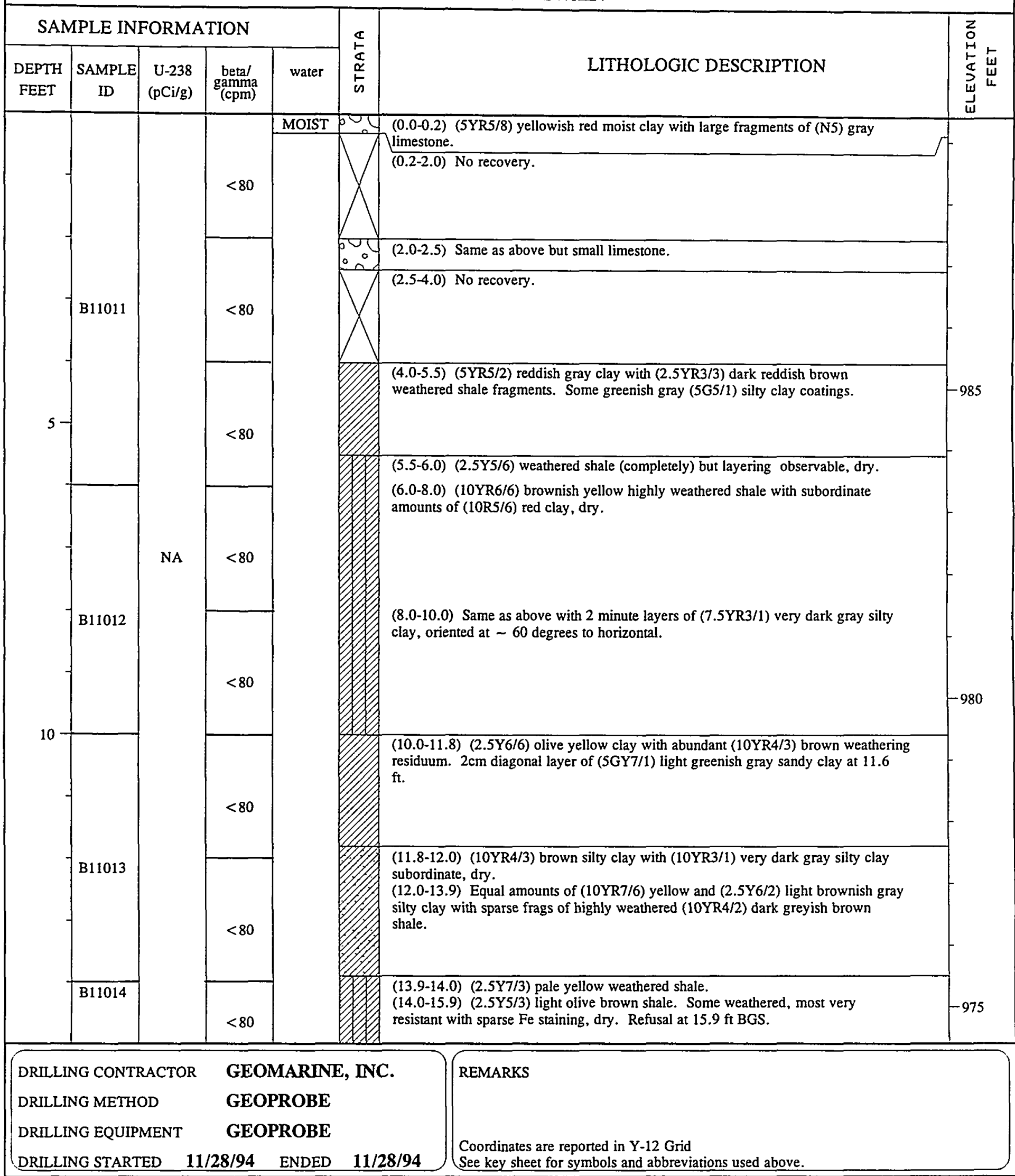





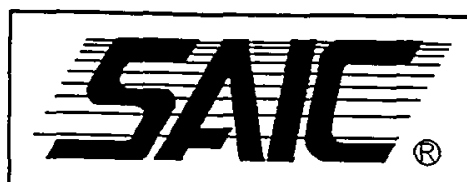

COORDINATES N 30,264.50 E 42,913.30

ELEVATION $957.90 \mathrm{ft}$ above MSL

\section{LOCATION}

BOREHOLE NUMBER

BCV OU 1 TOTAL DEPTH

SHEET 1 OF 3

BOREHOLE DIAMETER 1.25 in.

LOGGED BY KEN SWAIN

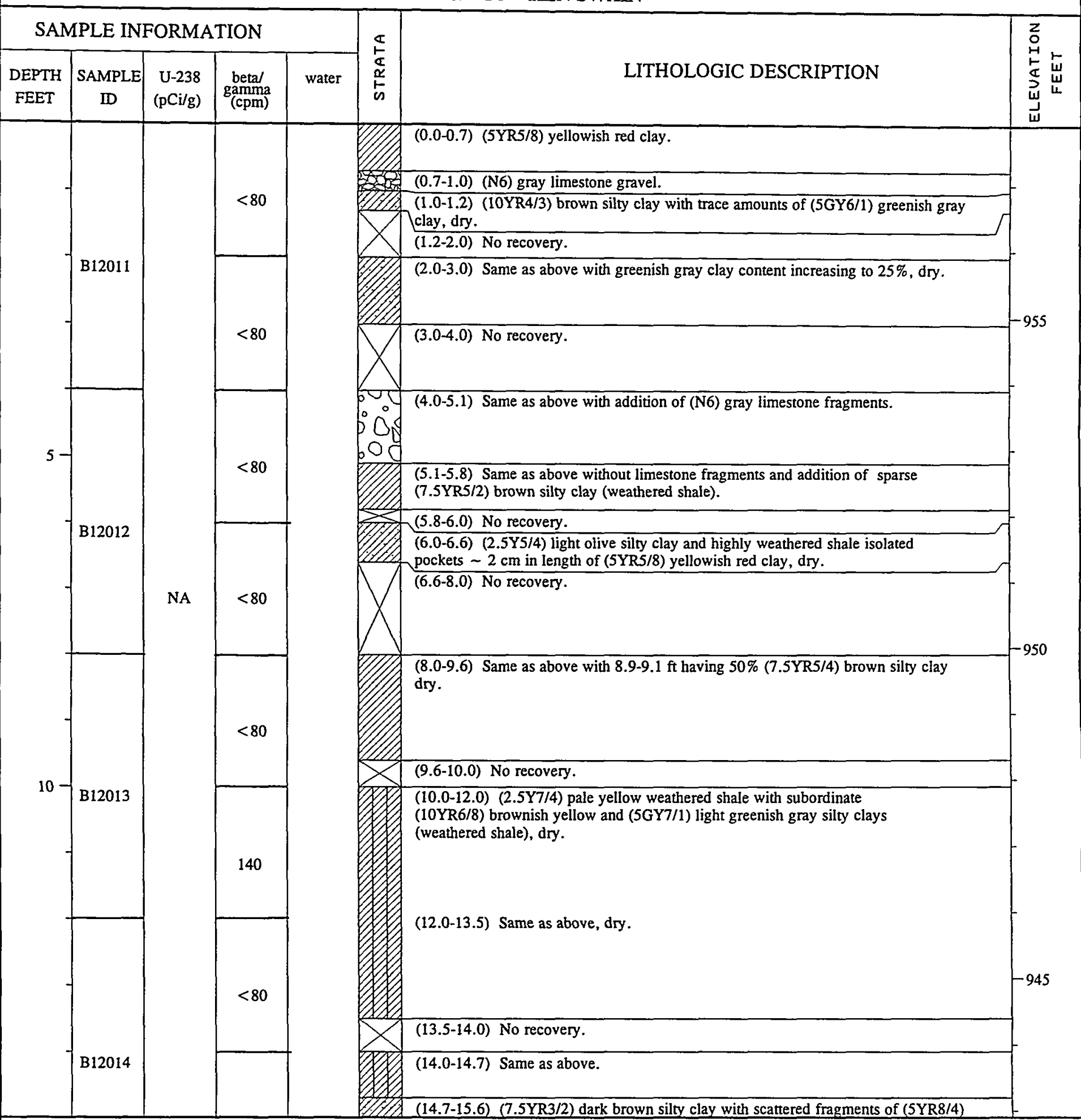

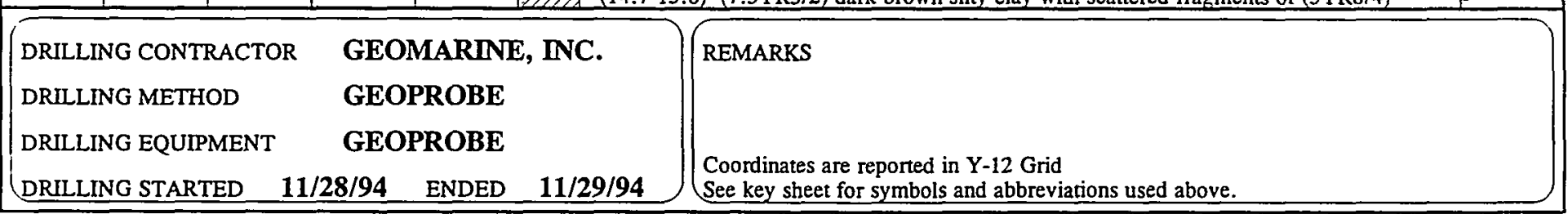




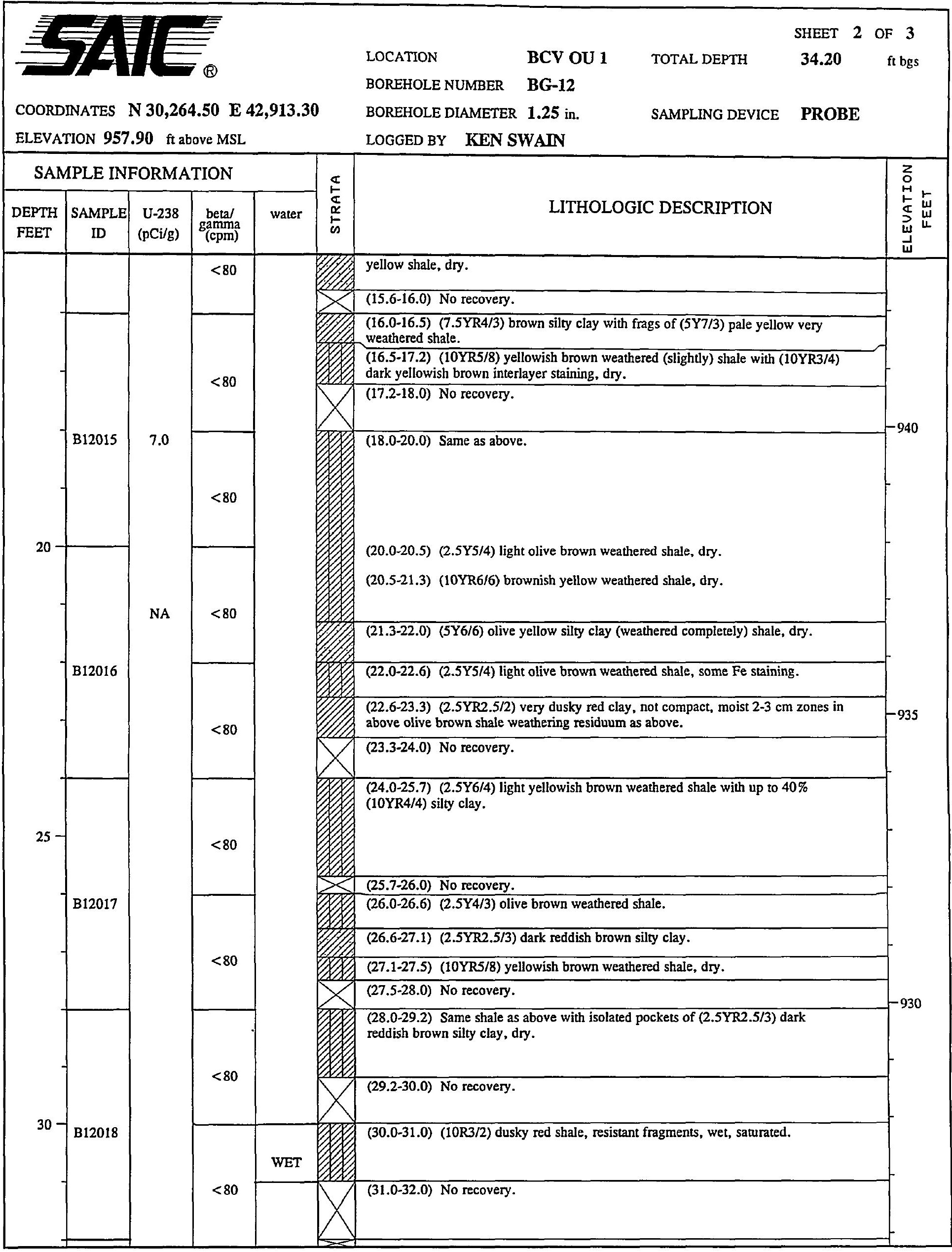


B13-40

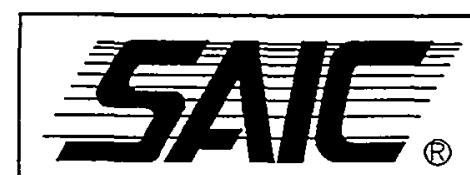

\section{(8)}

COORDINATES N 30,264.50 E 42,913.30

ELEVATION $957.90 \mathrm{ft}$ above MSL
SHEET 3 OF 3

LOCATION

BCV OU 1 TOTAL DEPTH

34.20

ft bgs

BOREHOLE NUMBER BG-12

BOREHOLE DIAMETER 1.25 in.

SAMPLING DEVICE PROBE

LOGGED BY KEN SWAN

\begin{tabular}{|c|c|c|c|c|c|c|c|}
\hline \multicolumn{5}{|c|}{ SAMPLE INFORMATION } & \multirow[b]{2}{*}{ Es } & \multirow[b]{2}{*}{ LITHOLOGIC DESCRIPTION } & \multirow{2}{*}{ 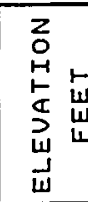 } \\
\hline $\begin{array}{l}\text { DEPTH } \\
\text { FEET }\end{array}$ & $\begin{array}{c}\text { SAMPLE } \\
\text { ID }\end{array}$ & $\begin{array}{r}\mathrm{U}-238 \\
(\mathrm{pCi} / \mathrm{g})\end{array}$ & $\underset{(\mathrm{cpm})}{\text { beta/ }}$ & water & & & \\
\hline & B12019 & NA & $<80$ & & & $\begin{array}{l}(32.0-33.2)(5 Y 4 / 3) \text { olive shale with sparse interlayer filling with }(10 \mathrm{R} 3 / 2) \text { dusky } \\
\text { red shale with residuum. } \\
\\
(33.2-33.3) \text { Fractured shale same color as filling above. .M } \mathrm{M}=\mathrm{CL}-\mathrm{ML} \\
(33.3-34.0) \text { No recovery. } \\
(34.0-34.2) \text { Refusal at } 34.2 \mathrm{ft} \text { BGS. }\end{array}$ & -925 \\
\hline
\end{tabular}




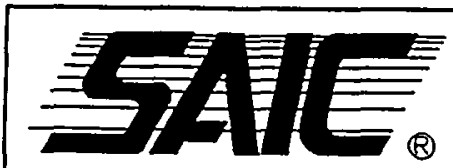

COORDINATES $\mathbf{N}$ 30,335.20 E 42,212.30

ELEVATION $929.70 \mathrm{ft}$ above MSL
LOCATION

BOREHOLE NUMBER

BCV OU 1

BG-13

BOREHOLE DIAMETER 1.25 in. LOGGED BY KEN SWAIN
SHEET 1 OF 1

$14.50 \quad \mathrm{ft}$ bgs

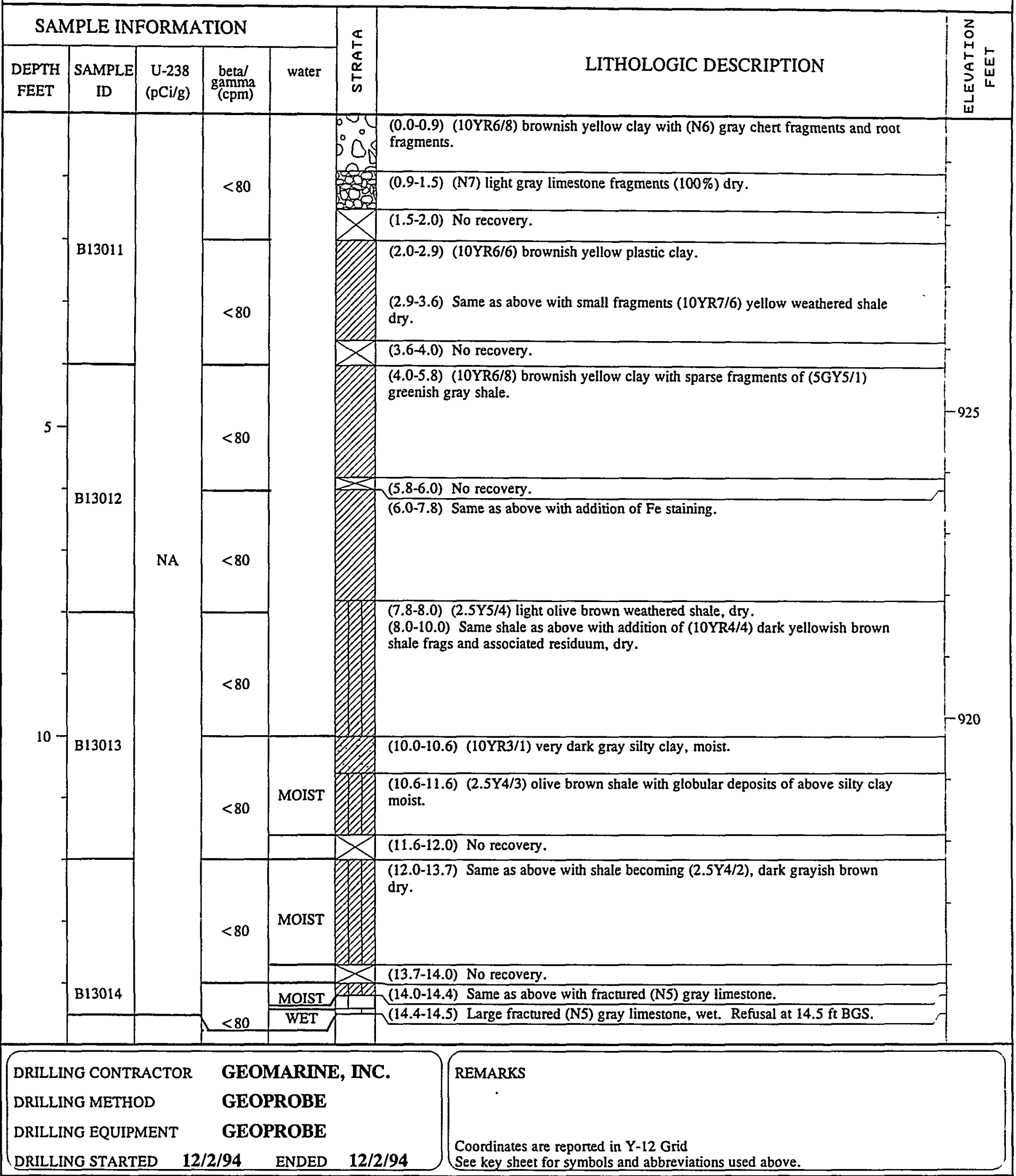




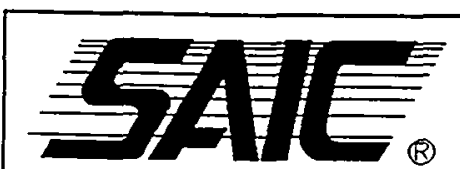

COORDINATES N 30,388.10 E $\mathbf{4 2 , 1 5 1 . 0 0}$

ELEVATION $946.00 \mathrm{ft}$ above MSL

$\begin{array}{lllc} & \text { BCV OU } 1 & \text { TOTAL DEPTH } & \mathbf{2 5 . 5 0} \\ \text { LOCATION } & \text { BCET } 1 \\ \text { BOREHOLE NUMBER } & \text { BG-14 } & & \\ \text { BOREHOLE DIAMETER } & \mathbf{1 . 2 5} \text { in. } & \text { SAMPLING DEVICE } & \text { PROBE } \\ \text { LOGGED BY } & \text { KEN SWAIN } & & \end{array}$

SAMPLE INFORMATION

\begin{tabular}{|c|c|c|c|c|}
\hline $\begin{array}{c}\text { DEPTH } \\
\text { FEET }\end{array}$ & $\begin{array}{c}\text { SAMPLE } \\
\text { ID }\end{array}$ & $\begin{array}{c}\text { U-238 } \\
\text { (pCi/g) }\end{array}$ & $\begin{array}{c}\text { beta/ } \\
\text { gamma } \\
\text { (cpm) }\end{array}$ & water \\
\hline
\end{tabular}

\begin{tabular}{|l|l|l|l|l|} 
FEET & ID & $(\mathrm{pCi} / \mathrm{g})$ & $\underset{(\mathrm{cpm})}{\mathrm{gamma}}$ & \\
\hline & & & &
\end{tabular}

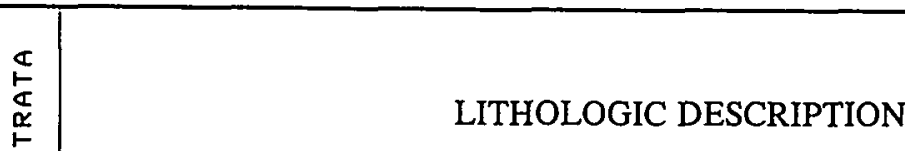

$(0.0-1.8)(7.5 Y R 6 / 8)$ reddish yellow clay, stiff, dry.

एवि

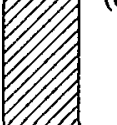

(1.8-2.0) (5YR7/3) pale yellow clay (weathered shale).

(2.0-3.6) (10YR5/8) yellowish brown stiff clay, dry.

$(3.6-4.0)$ Same as $1.8-2.0 \mathrm{ft} \mathrm{BGS}$.

(4.0-6.0) (5GY7/1) light greenish grey shale with interbed staining of (7.5YR6/8) reddish yellow, dry.

(10.0-11.9) Same as above.

(8.0-10.0) Grading from above to (5Y7/3) pale yellow silty clay (CL) with same

(7.5YR6/8) reddish yellow staining, no observable bedding, dry.

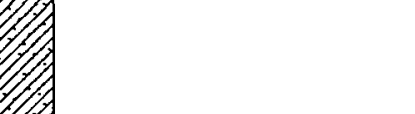

(11.9-12.0) Bedding (5BG6/1) greenish gray shale, highly weathered, dry.

(12.0-14.0) Top $1 \mathrm{ft}$. same as above grading into (2.5Y6/6) olive yellow clay

(weathered shale) with sparse (5YR4/6) yellowish red Fe staining.

\section{(14.0-14.8) (2.5Y5/6) light olive brown clay.}

(14.8-15.6) (5GY7/1) light greenish gray clay with 20\% (10YR6/8) brownish yellow 


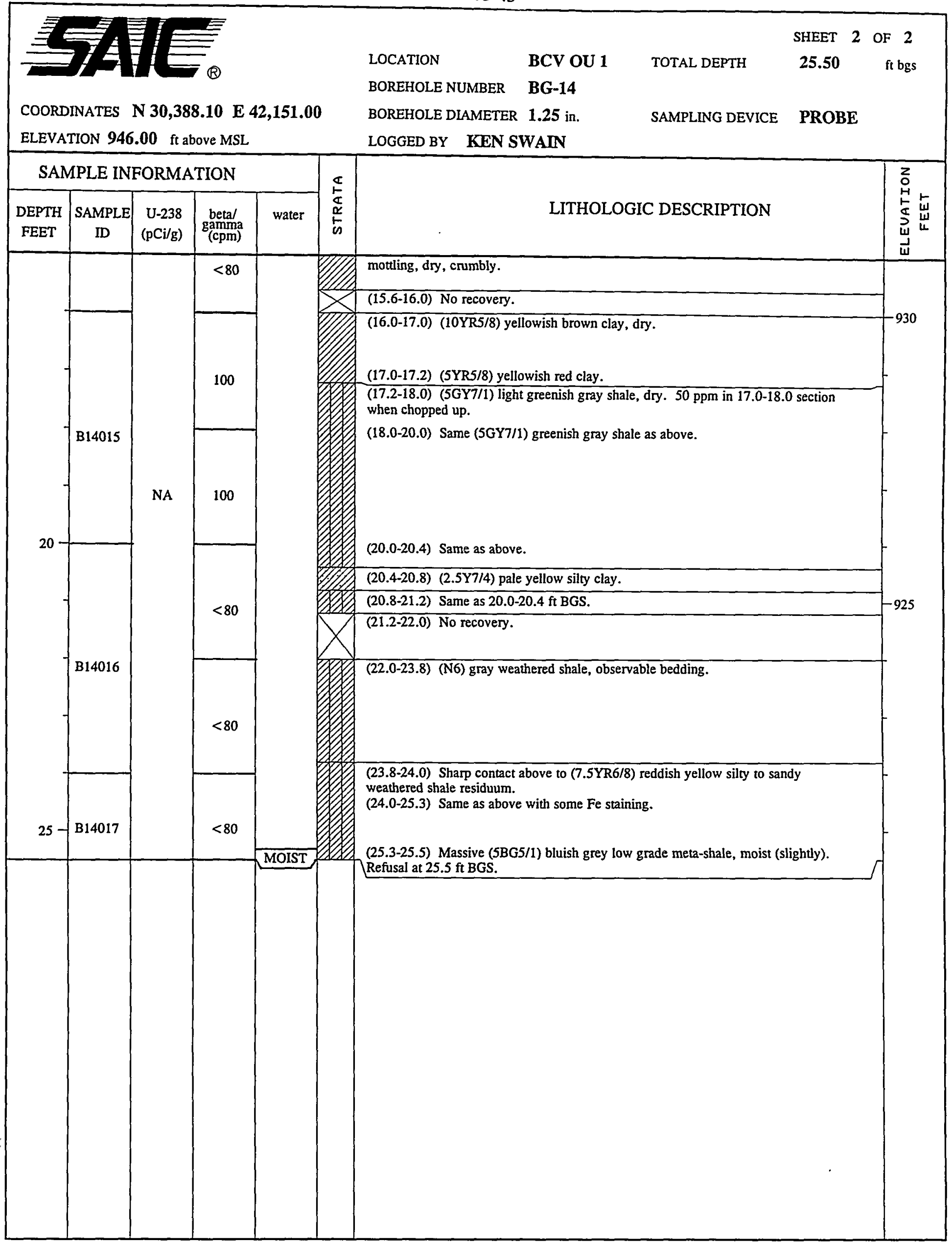


B13-44

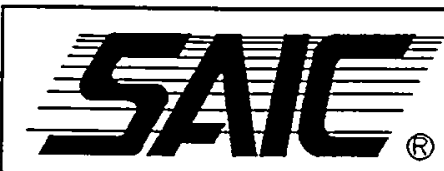

COORDINATES N 30,802.40 E 41,986.30

ELEVATION 941.00 ft above MSL
LOCATION

BOREHOLE NUMBER

BOREHOLE DIAMETER 6
SHEET 1 OF 1

$\begin{array}{llll}\text { BCV OU } 1 & \text { TOTAL DEPTH } & \mathbf{6 . 5 0} & \mathrm{ft} \text { bgs }\end{array}$

BG-15

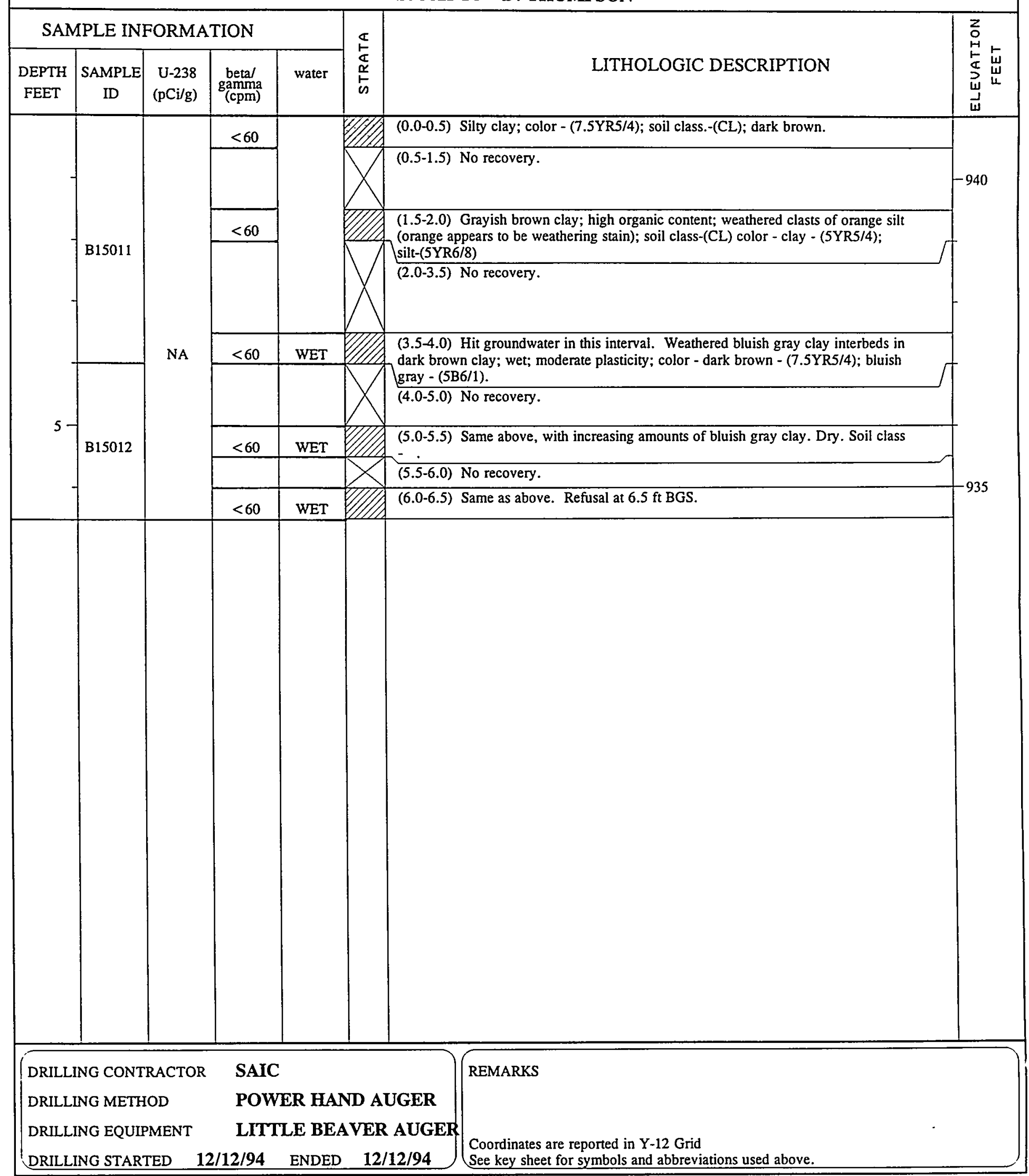




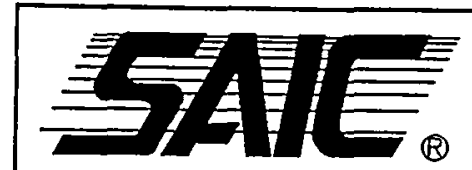

COORDINATES N 30,463.50 E 44,638.20

ELEVATION $943.60 \mathrm{ft}$ above MSL
LOCATION

BOREHOLE NUMBER

BCV OU 1

BG-16

BOREHOLE DIAMETER 6 in.

LOGGED BY

\section{THOMPSON}

SHEET 1 OF 1

$\mathbf{7 . 5 0}$ ft bgs

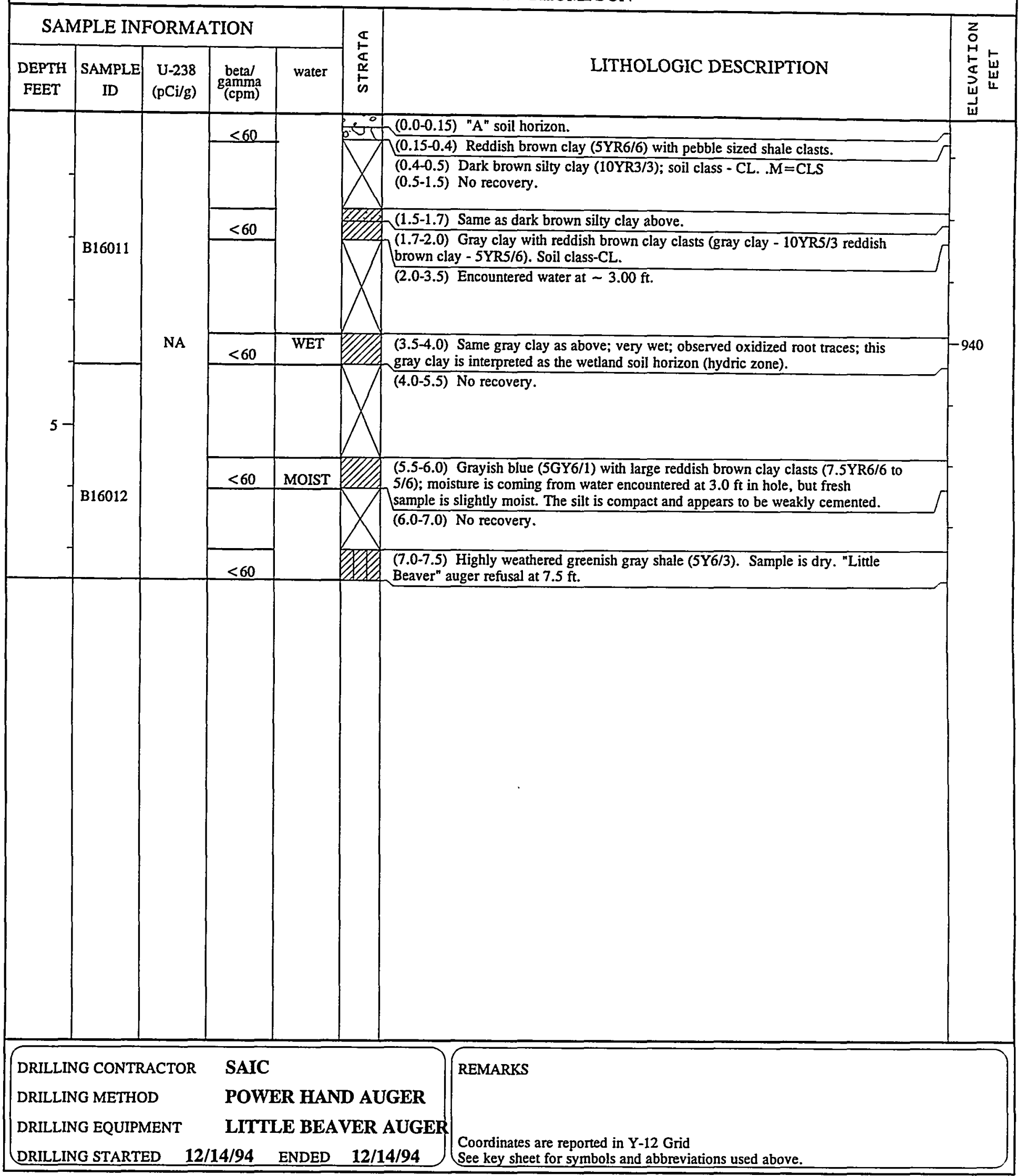




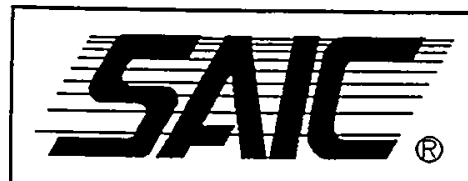

COORDINATES N 29,632.80 E 48,082.70

ELEVATION 953.00 ft above MSL
LOCATION

BOREHOLE NUMBER

\section{BCV OU 1}

SL1-01

BOREHOLE DIAMETER 1.25 in. LOGGED BY KEN SWAIN
SHEET 1 OF 2

$\mathbf{1 6 . 0 0}$ ft bgs

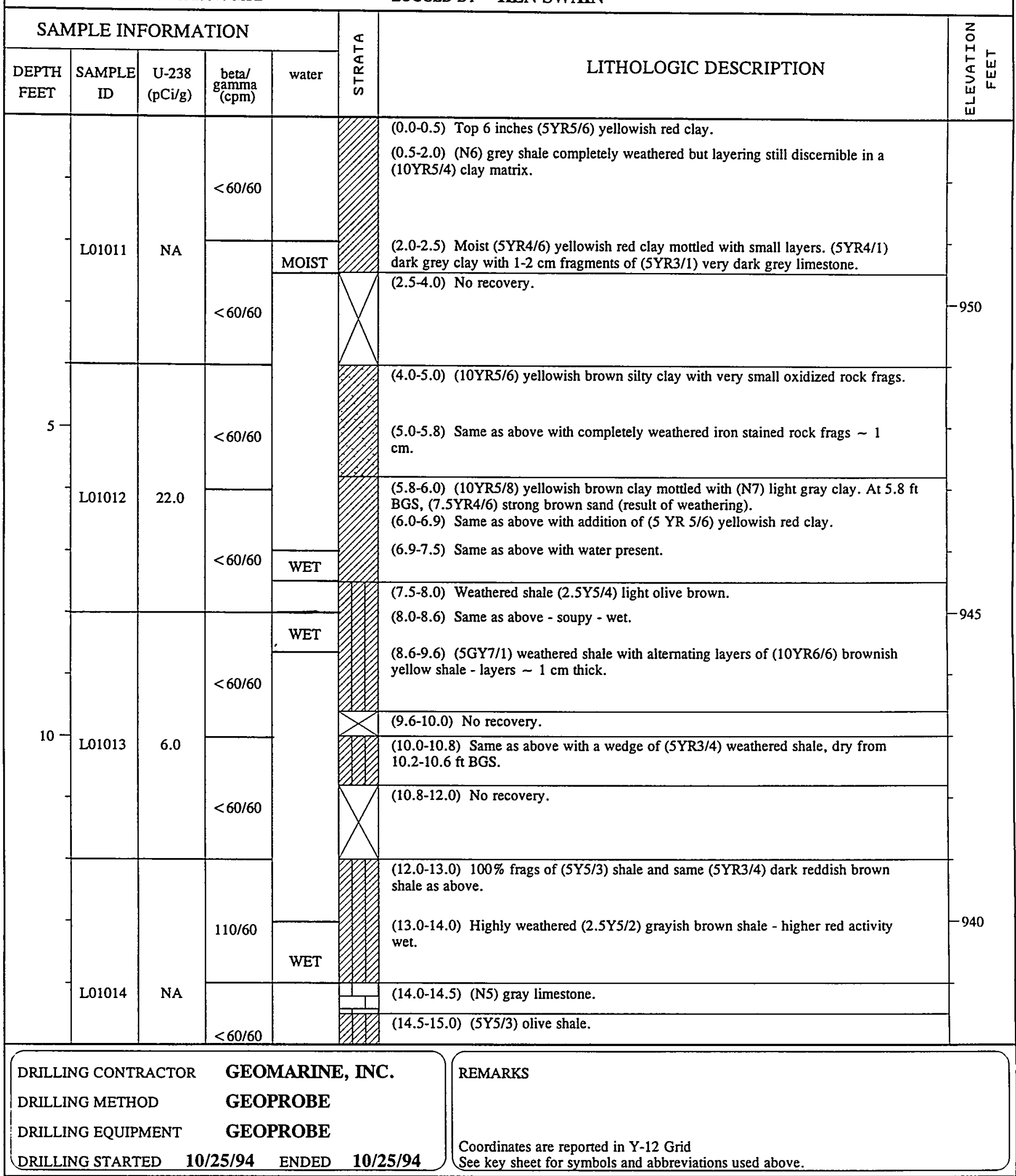


B13-47

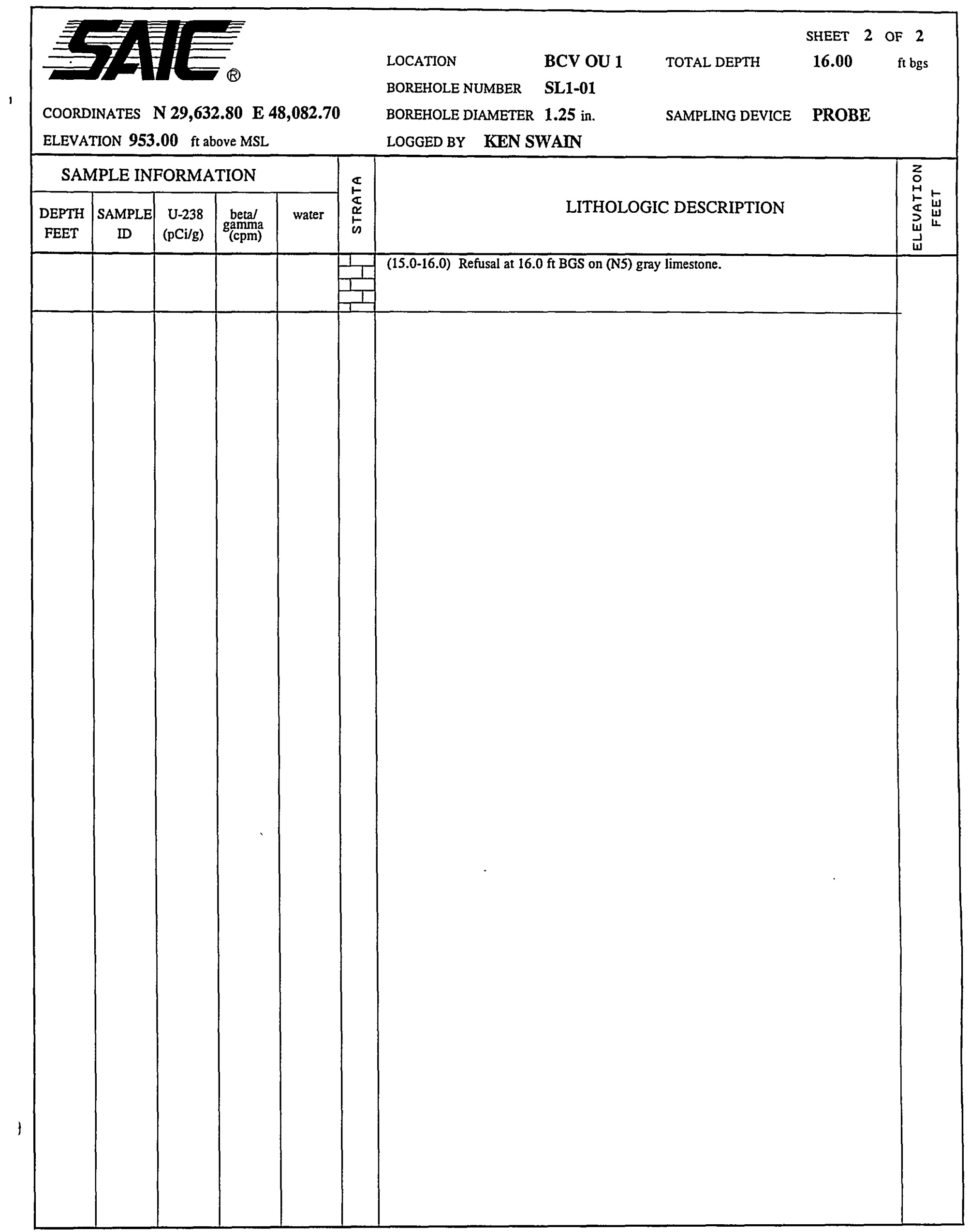


B13-48

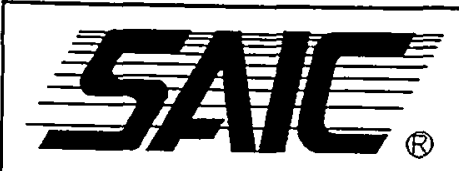

COORDINATES N 29,409.90 E 46,994.50

ELEVATION 948.50 ft above MSL

\section{LOCATION}

BOREHOLE NUMBER

BOREHOLE DIAMETER $\mathbf{1 . 2 5}$ in

26.00

$\mathrm{ft}$ bgs

LOGGED BY KEN SWAIN

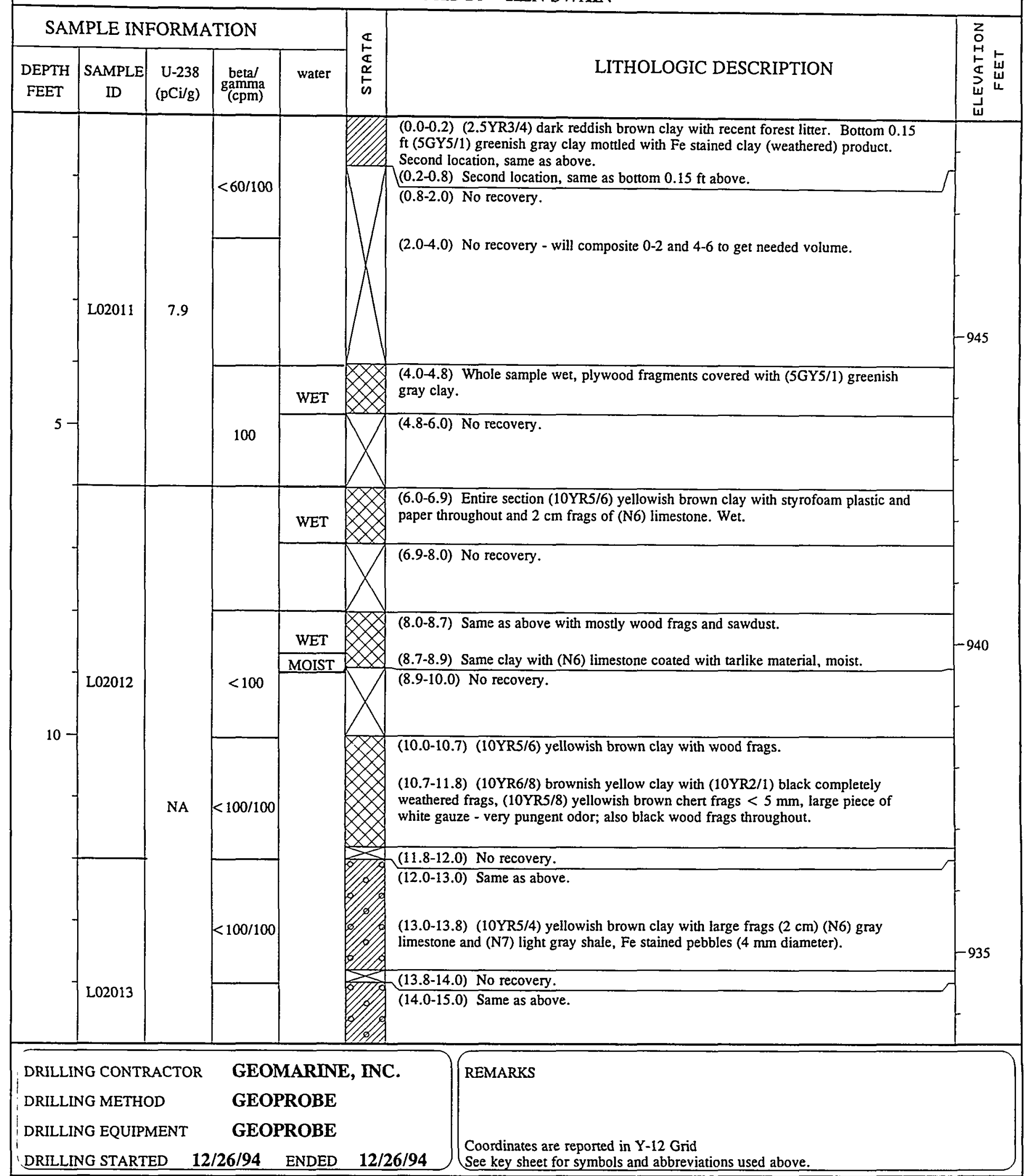




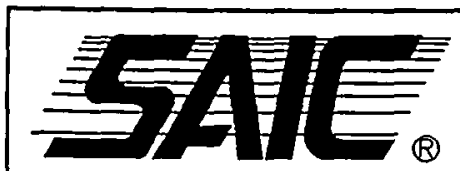

COORDINATES N 29,409.90 E 46,994.50

ELEVATION $948.50 \mathrm{ft}$ above MSL
SAMPLE INFORMATION

DEPTH

DEPTH

FEET

\section{LOCATION}

BOREHOLE NUMBER

BOREHOLE DIAMETER 1.25 in.

LOGGED BY KEN SWAIN
SHEET 2 OF 2

BCV OU 1 TOTAL DEPTH $26.00 \quad$ ft bgs

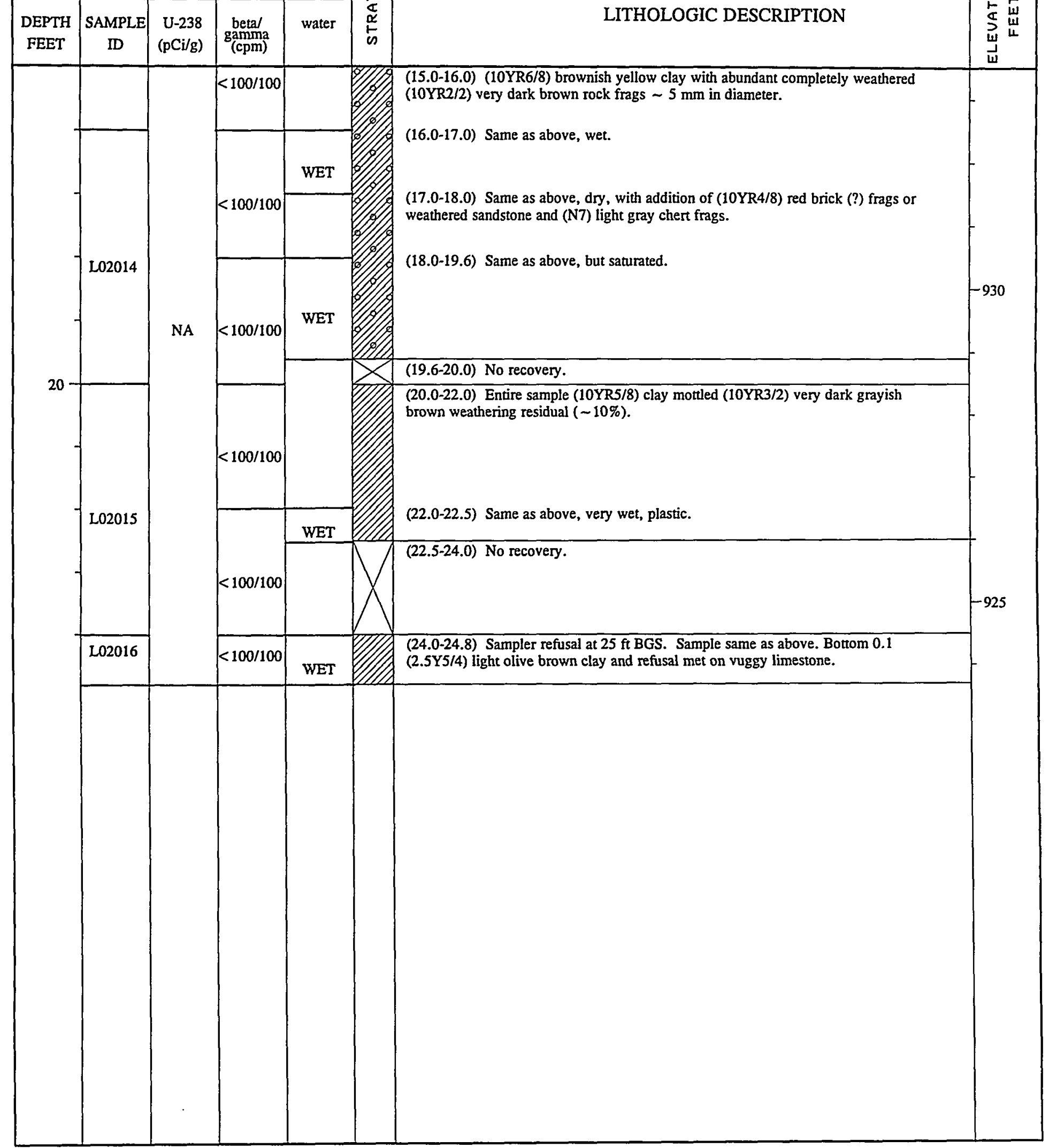




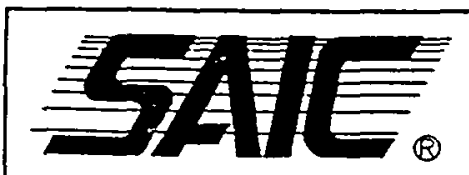

COORDINATES N 30,368.40 E 48,113.40 ELEVATION $973.60 \mathrm{ft}$ above MSL

\section{LOCATION}

BOREHOLE NUMBER
SHEET 1 OF 2

BCV OU 1 TOTAL DEPTH $\quad 16.00 \quad f$ bgs

BOREHOLE DLAMETER 1.25 in.

SAMPLING DEVICE PROBE

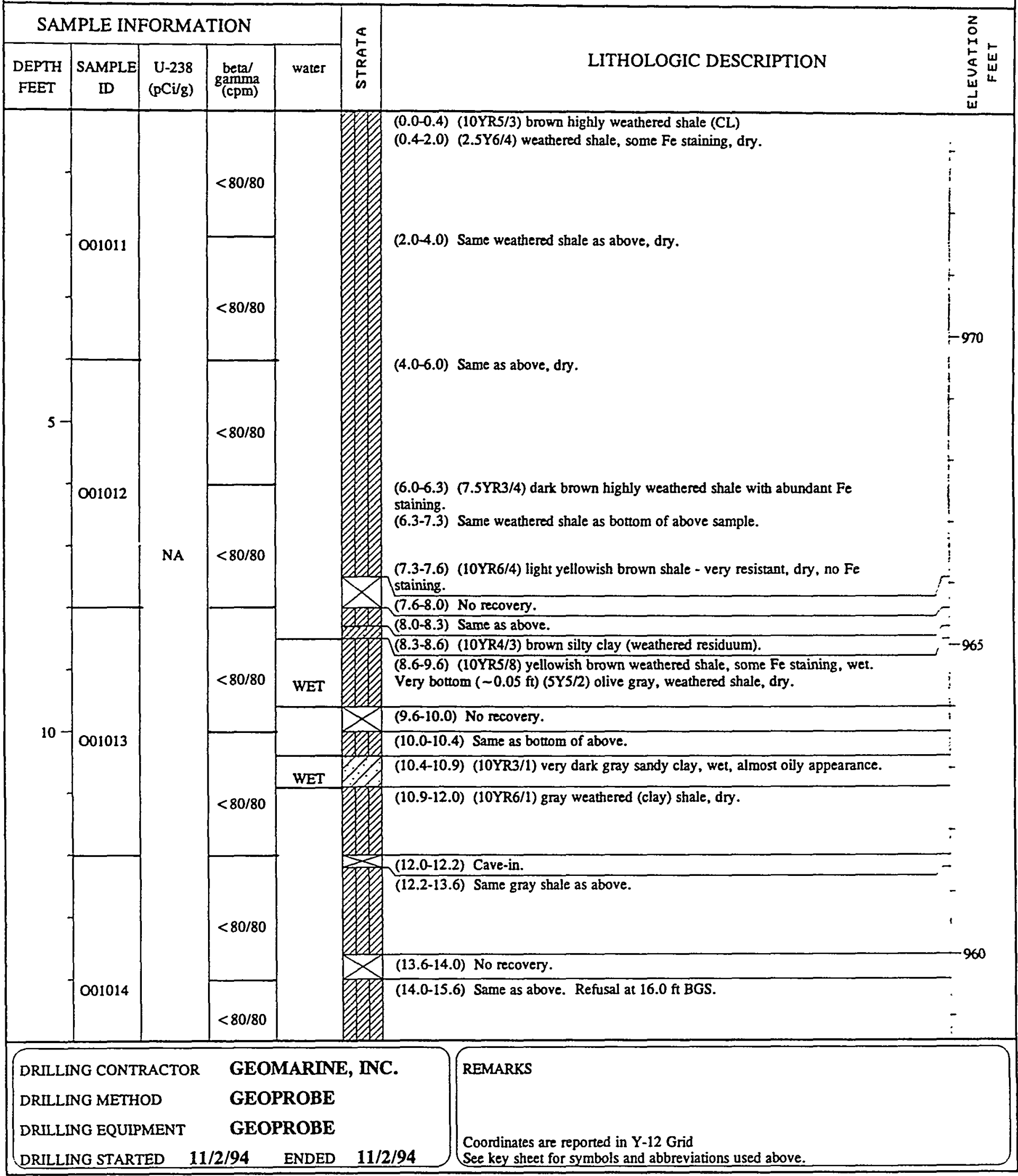



B13-52

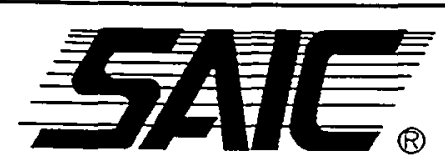

COORDINATES

N 30,042.90 E 48,176.80

ELEVATION $963.10 \mathrm{ft}$ above MSL
SHEET 1 OF 2

LOCATION

BCV OU 1

TOTAL DEPTH

21.60

ft bgs

BOREHOLE NUMBER OLF-02

BOREHOLE DIAMETER $\mathbf{1 . 2 5}$ in.

SAMPLING DEVICE PROBE

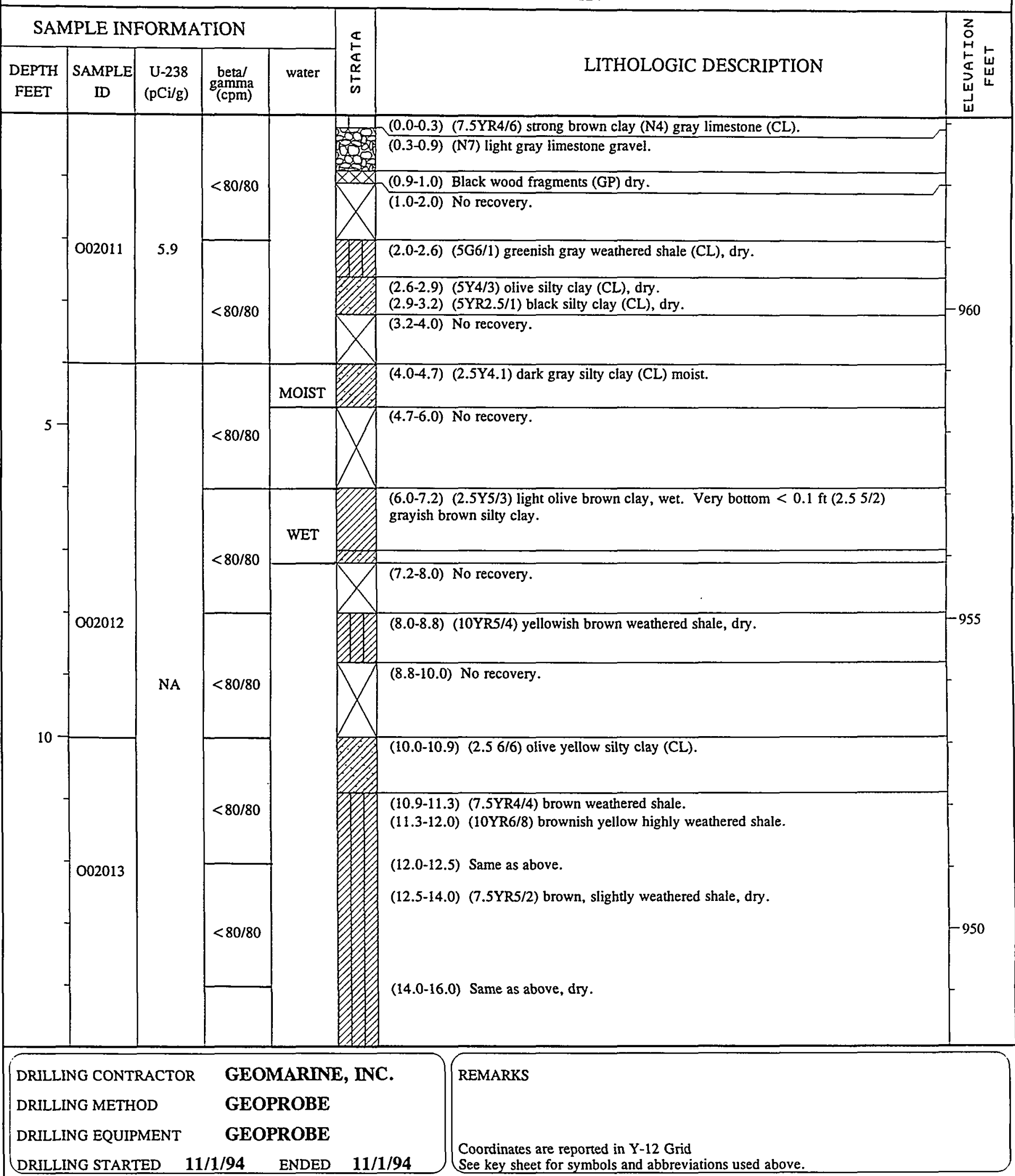




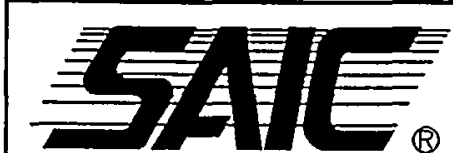

COORDINATES N 30,042.90 E 48,176.80

ELEVATION $963.10 \mathrm{ft}$ above MSL
SHEET 2 OF 2

BCV OU 1

TOTAL DEPTH

21.60

ft bgs

BOREHOLE NUMBER OLF-02

BOREHOLE DLAMETER 1.25 in.

SAMPLING DEVICE PROBE LOGGED BY KEN SWAIN

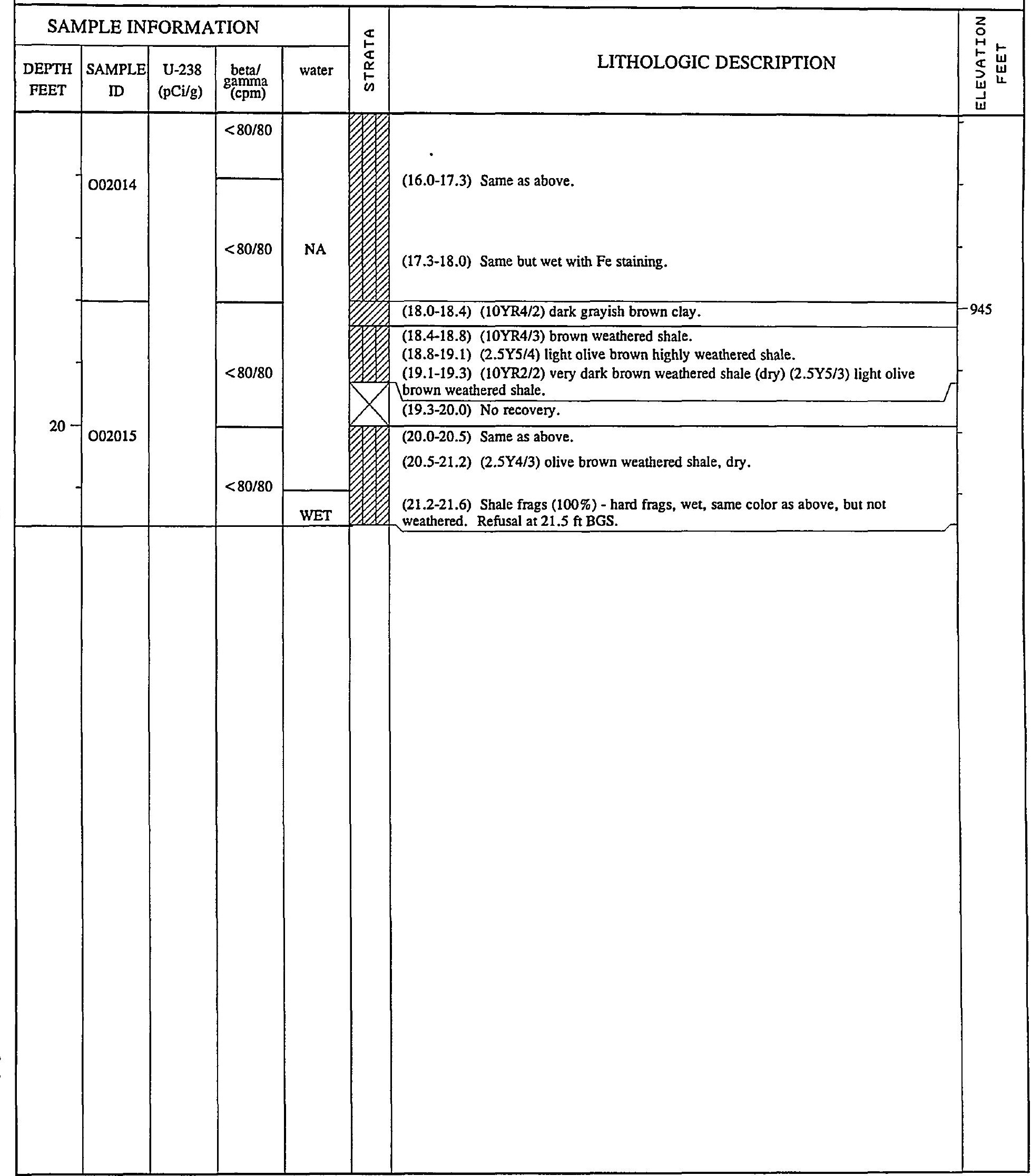


B13-54

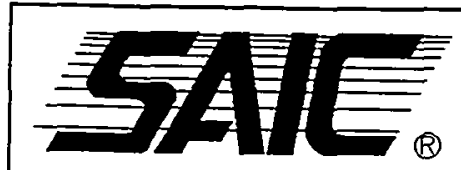

COORDINATES $\mathbf{N} 29,916.70$ E 47,829.00

ELEVATION $964.70 \mathrm{ft}$ above MSL

\section{LOCATION}

BOREHOLE NUMBER

BOREHOLE DIAMETER $\mathbf{1 . 2 5}$ in. LOGGED BY KEN SWAIN
SHEET 1 OF 2

$27.80 \quad \mathrm{ft}$ bgs

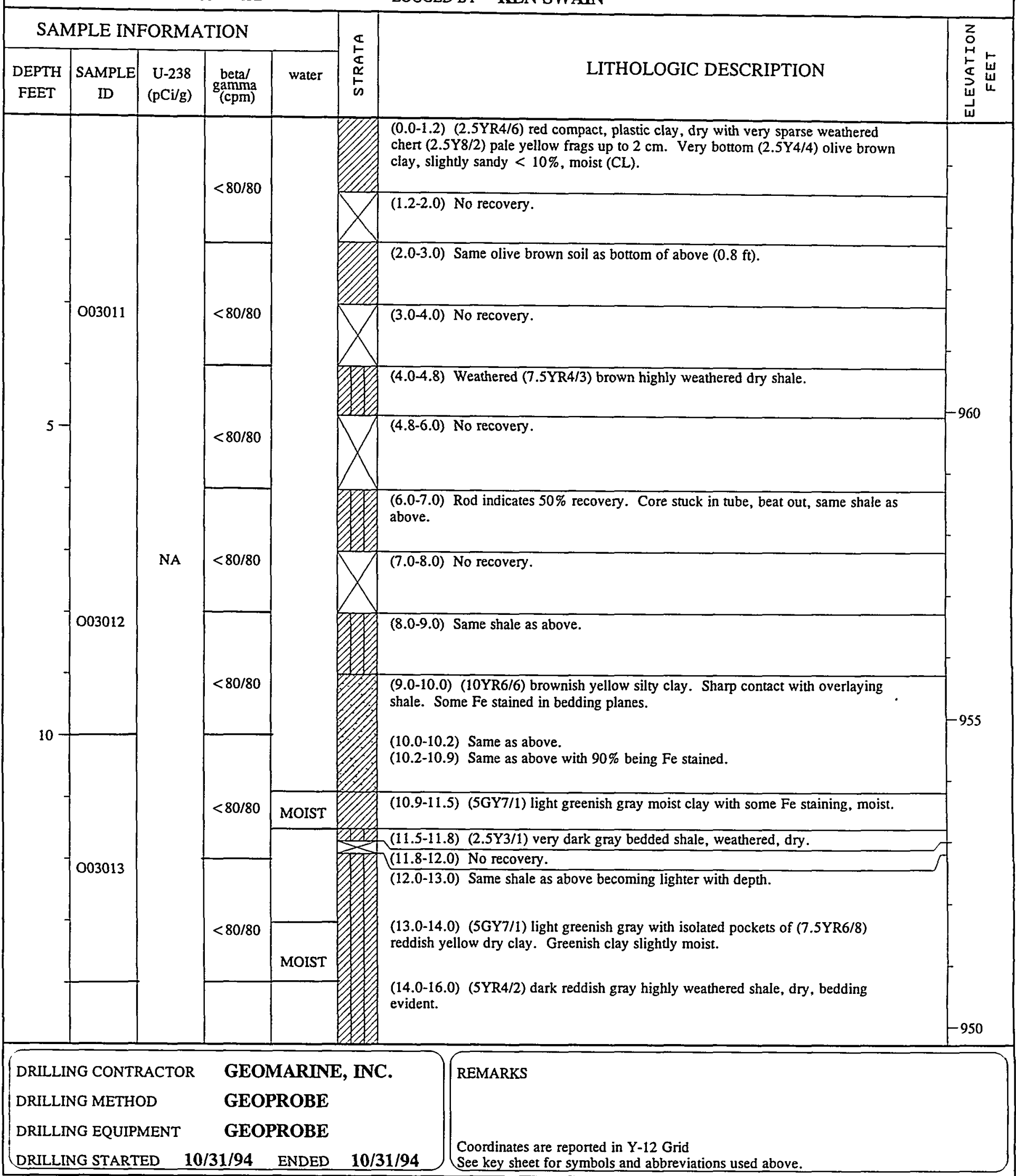


B13-55

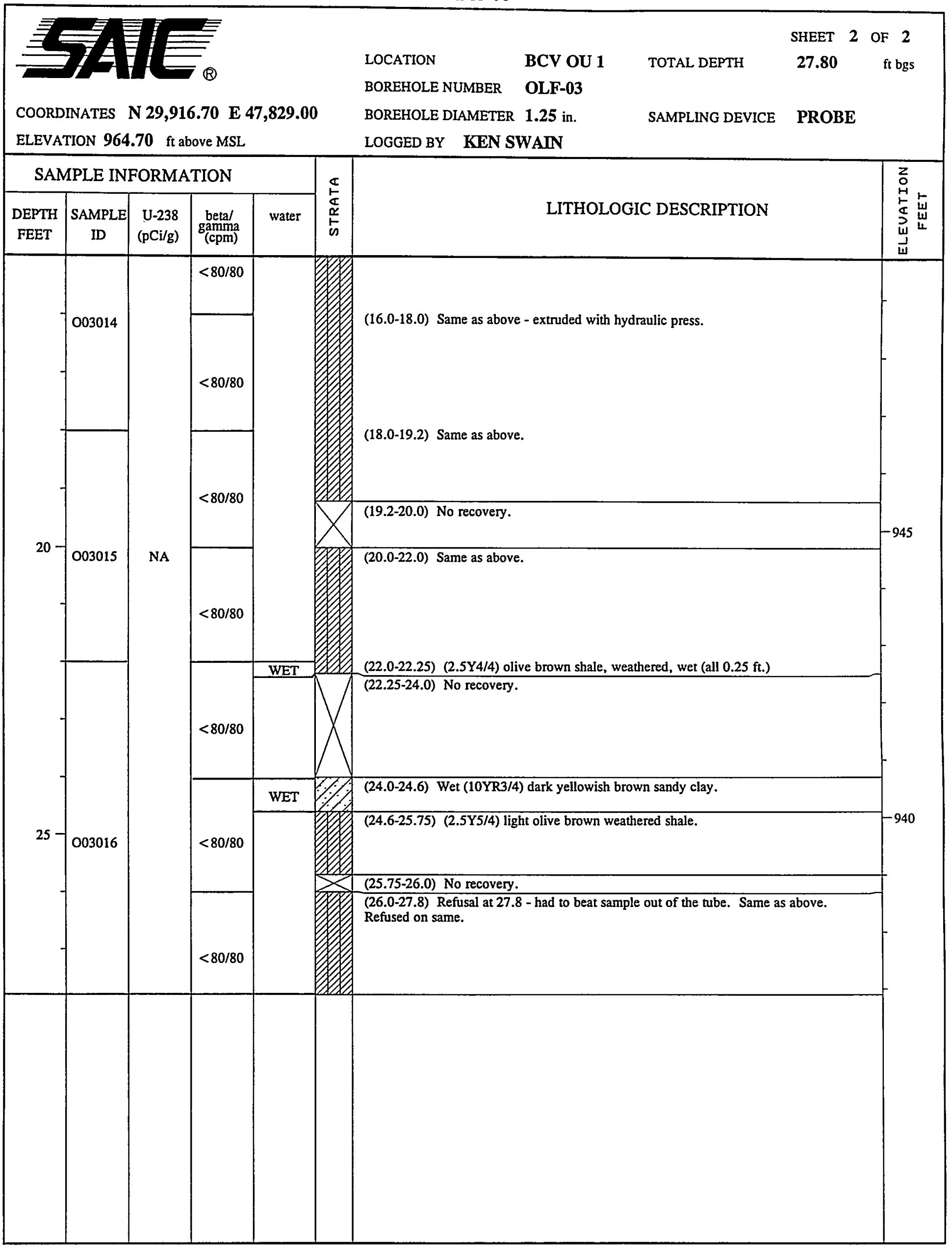




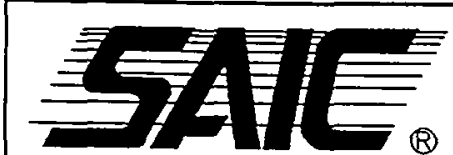

R)

COORDINATES N 29,971.30 E 47,160.80

ELEVATION $951.10 \mathrm{ft}$ above MSL

\section{LOCATION}

BOREHOLE NUMBER OLF-04

BOREHOLE DIAMETER 1.25 in.

TOTAL DEPTH

15.00

ft bgs

LOGGED BY KEN SWAIN

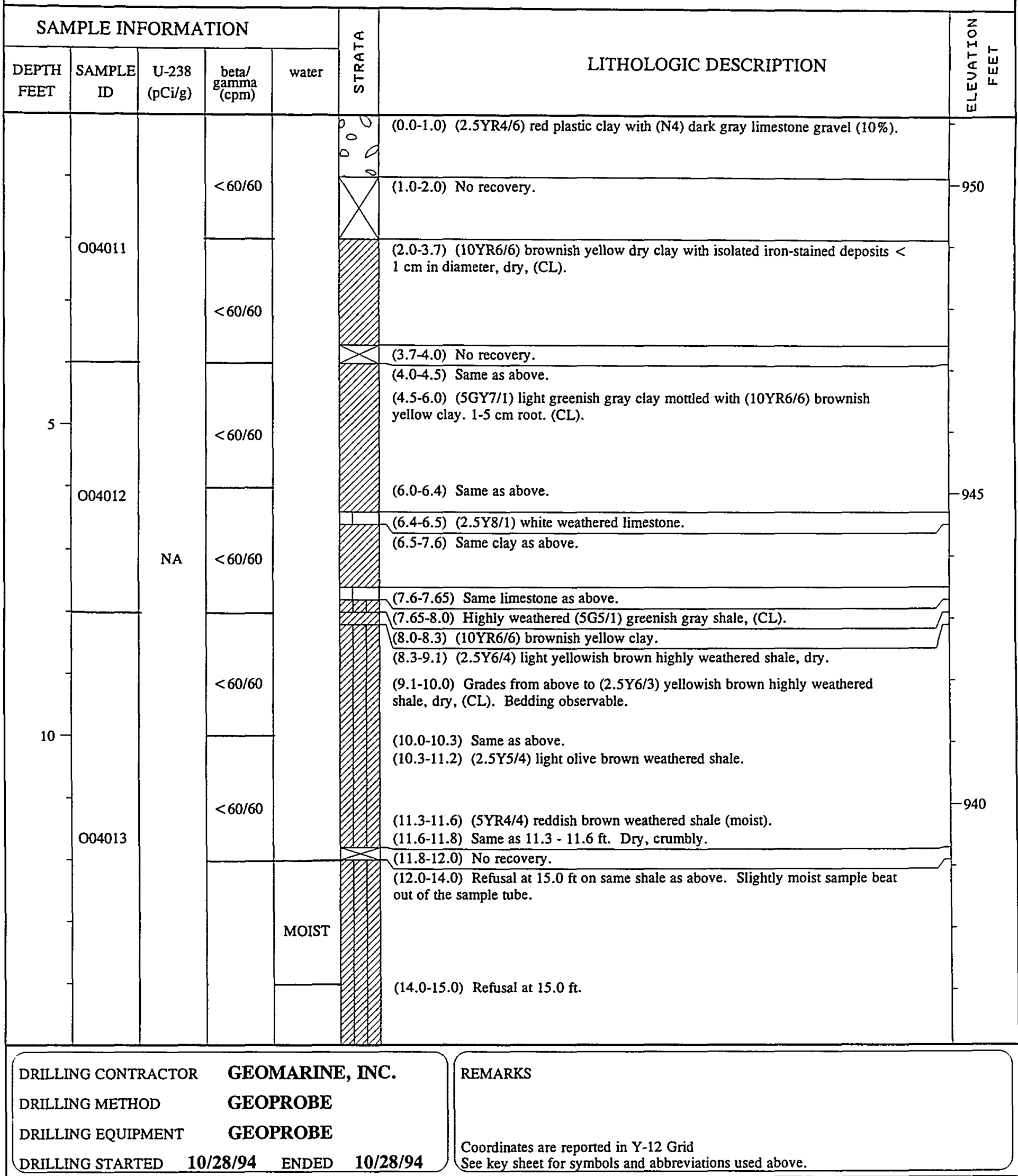




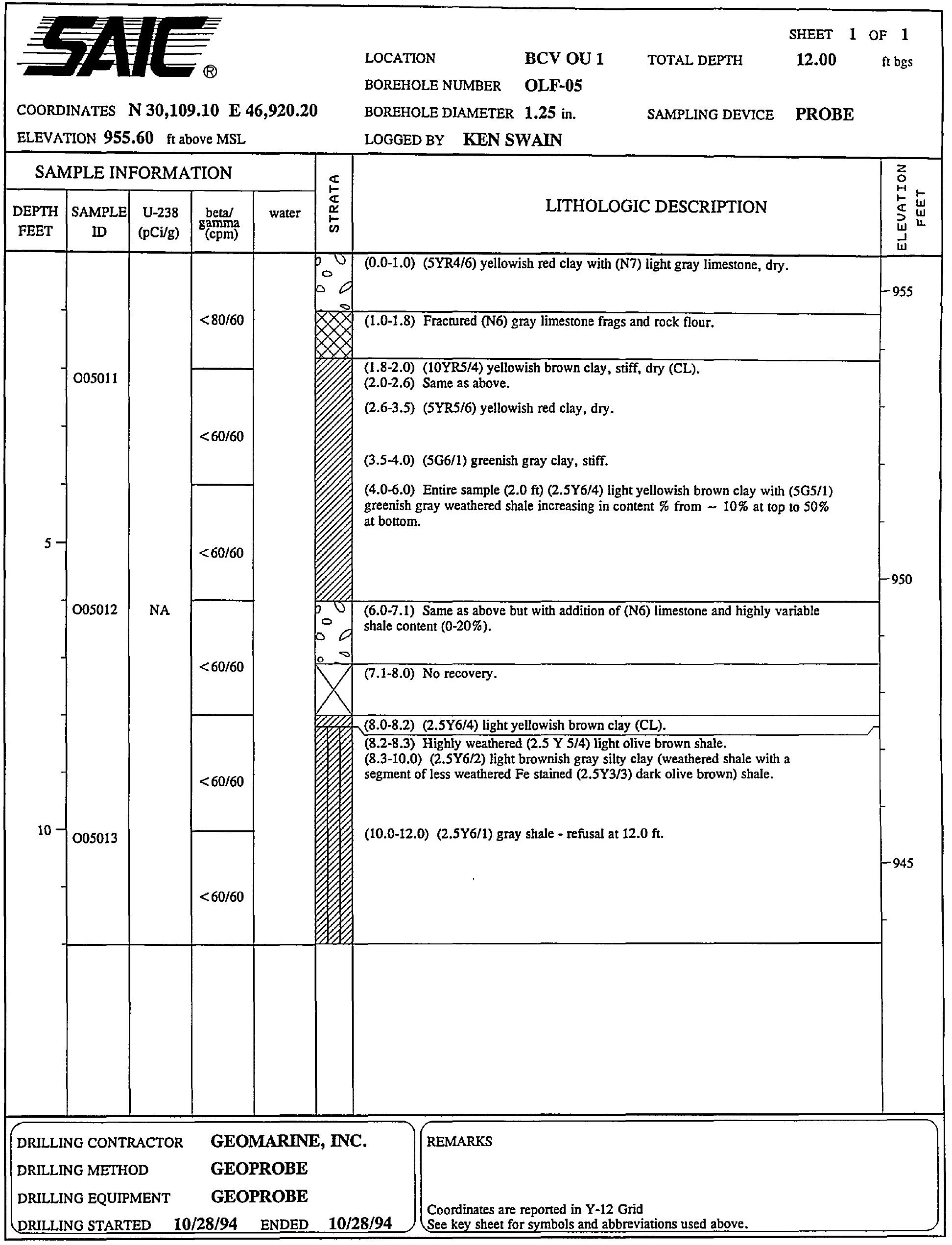


B13-58

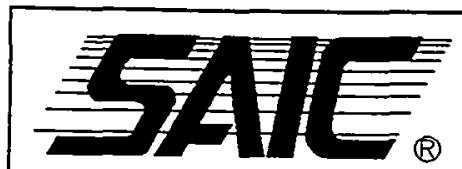

COORDINATES $\mathbf{N}$ 29,614.00 E 48,644.90

ELEVATION $957.50 \mathrm{ft}$ above MSL
SHEET 1 OF 2

LOCATION

BCV OU 1

TOTAL DEPTH

$\mathbf{1 7 . 0 0} \mathrm{ft}$ bgs

BOREHOLE NUMBER BY-01

BOREHOLE DIAMETER 1.25 in. SAMPLING DEVICE PROBE

LOGGED BY KEN SWAIN

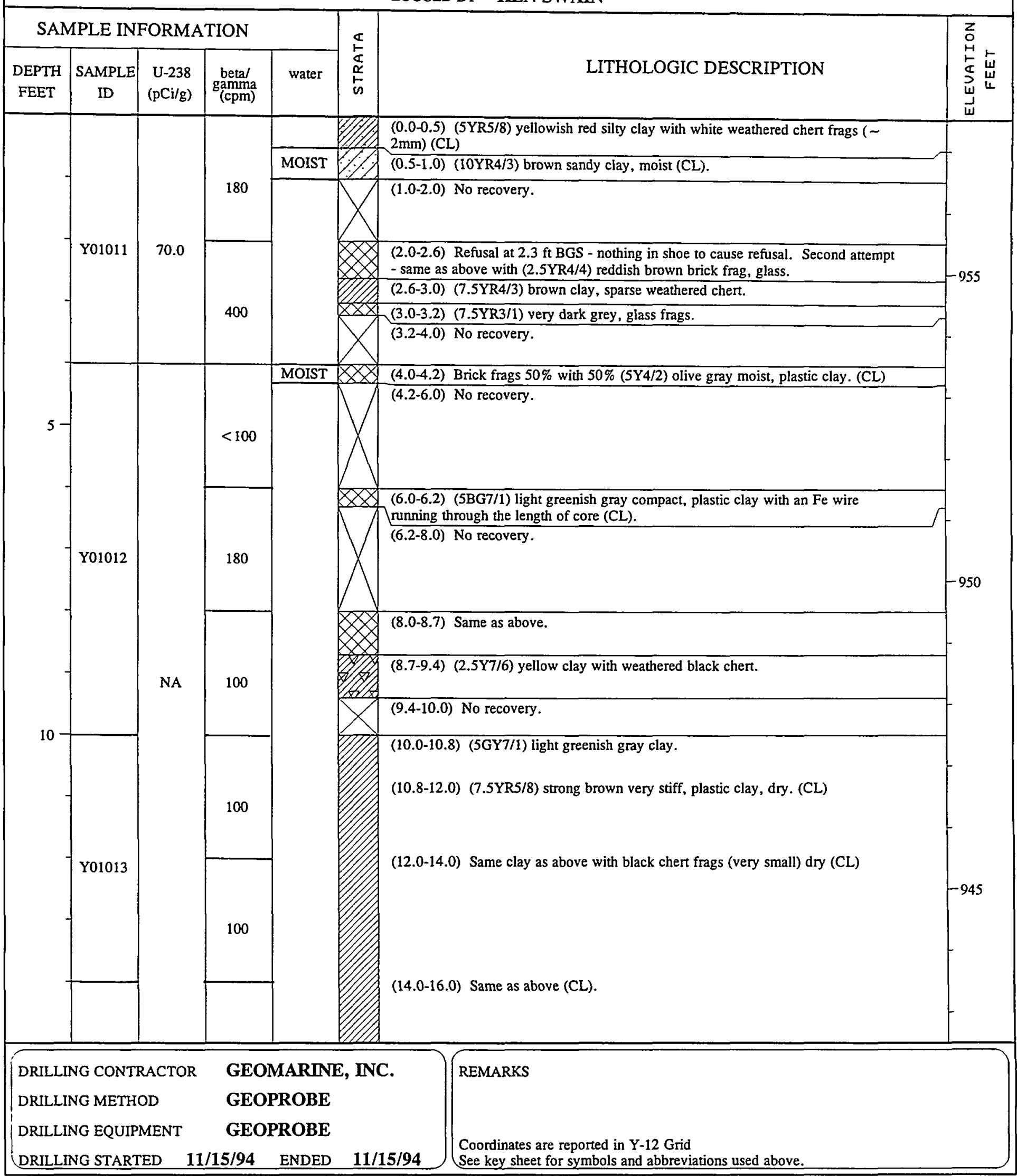


B13-59

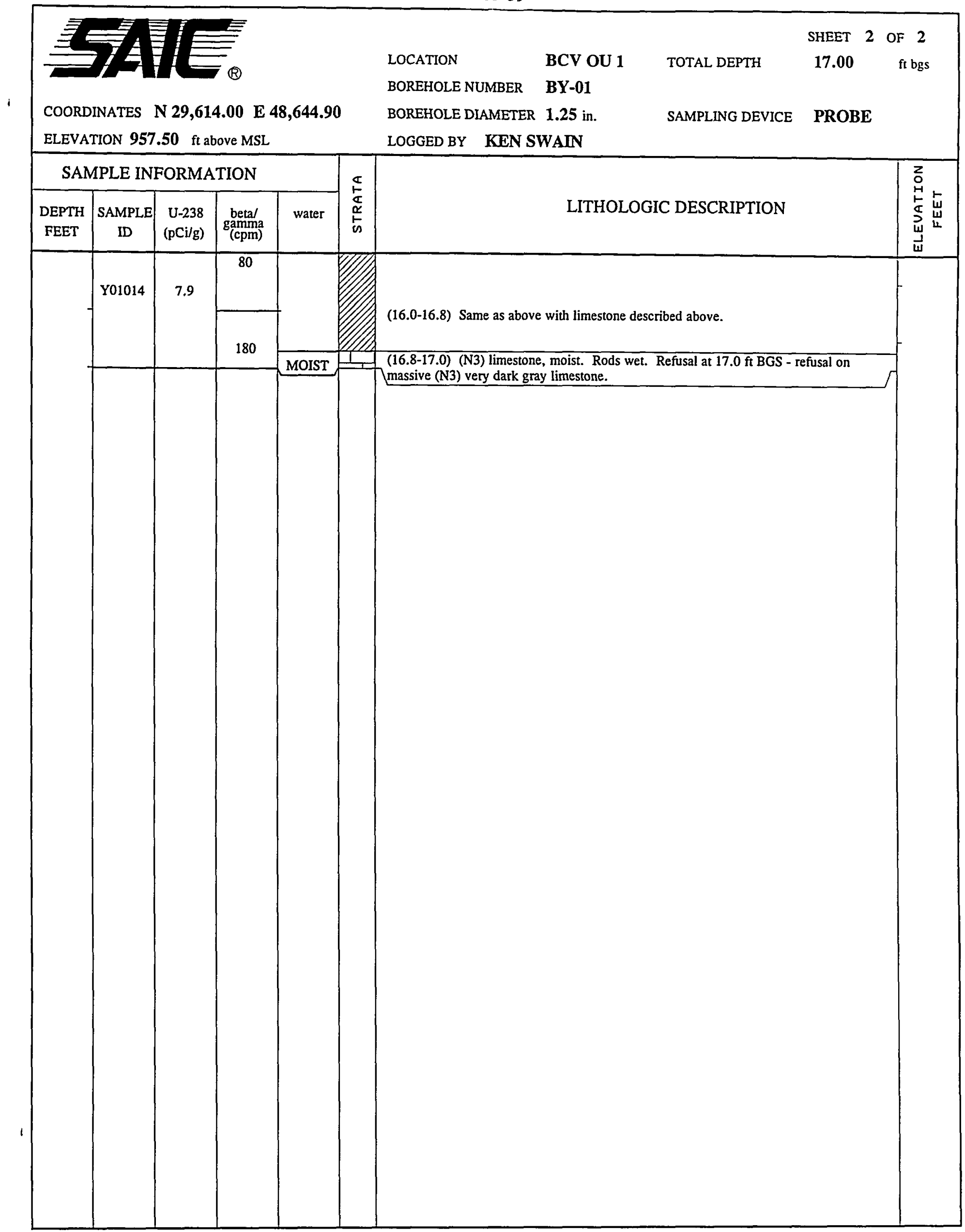




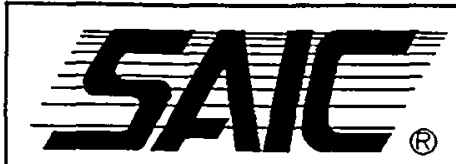

(2)

COORDINATES $\mathrm{N} 29,560.60 \mathrm{E} 48,361.70$

ELEVATION $957.10 \mathrm{ft}$ above MSL

\section{LOCATION}

BOREHOLE NUMBER
SHEET 1 OF 2

$\mathbf{1 7 . 0 0}$ ft bgs

BOREHOLE DIAMETER 1.25 in. SAMPLING DEVICE PROBE

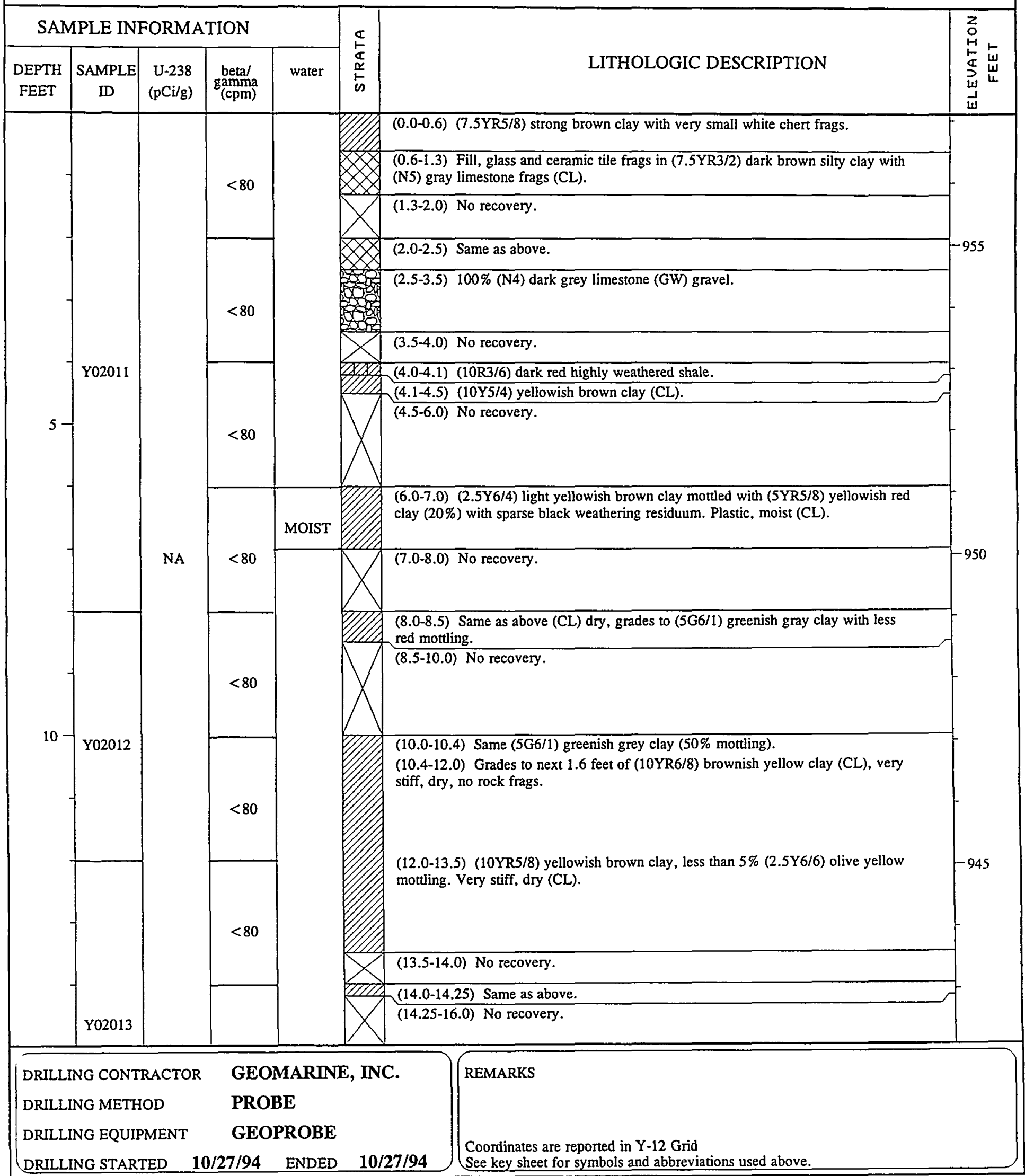


B13-61

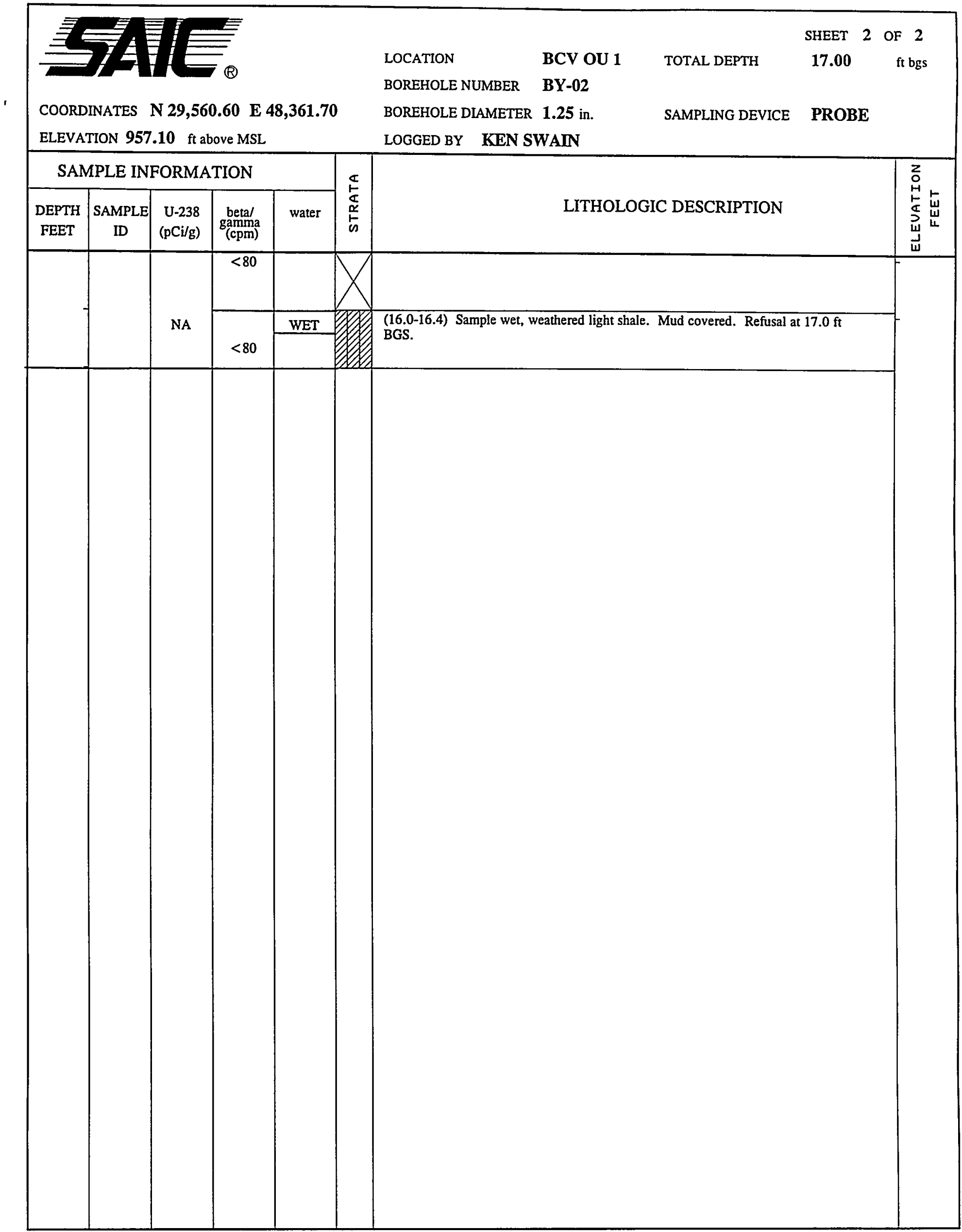


B13-62

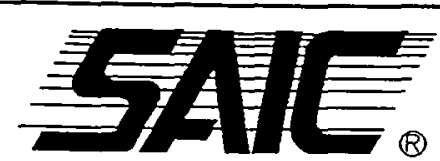

COORDINATES $\mathbf{N} 29,757.10$ E 48,305.30

\section{LOCATION}

BOREHOLE NUMBER
SHEET 1 OF 2

$\mathbf{1 8 . 6 0} \quad \mathrm{ft}$ bgs

ELEVATION $959.30 \mathrm{ft}$ above MSL

BOREHOLE DIAMETER 1.25 in

LOGGED BY KEN SWAIN

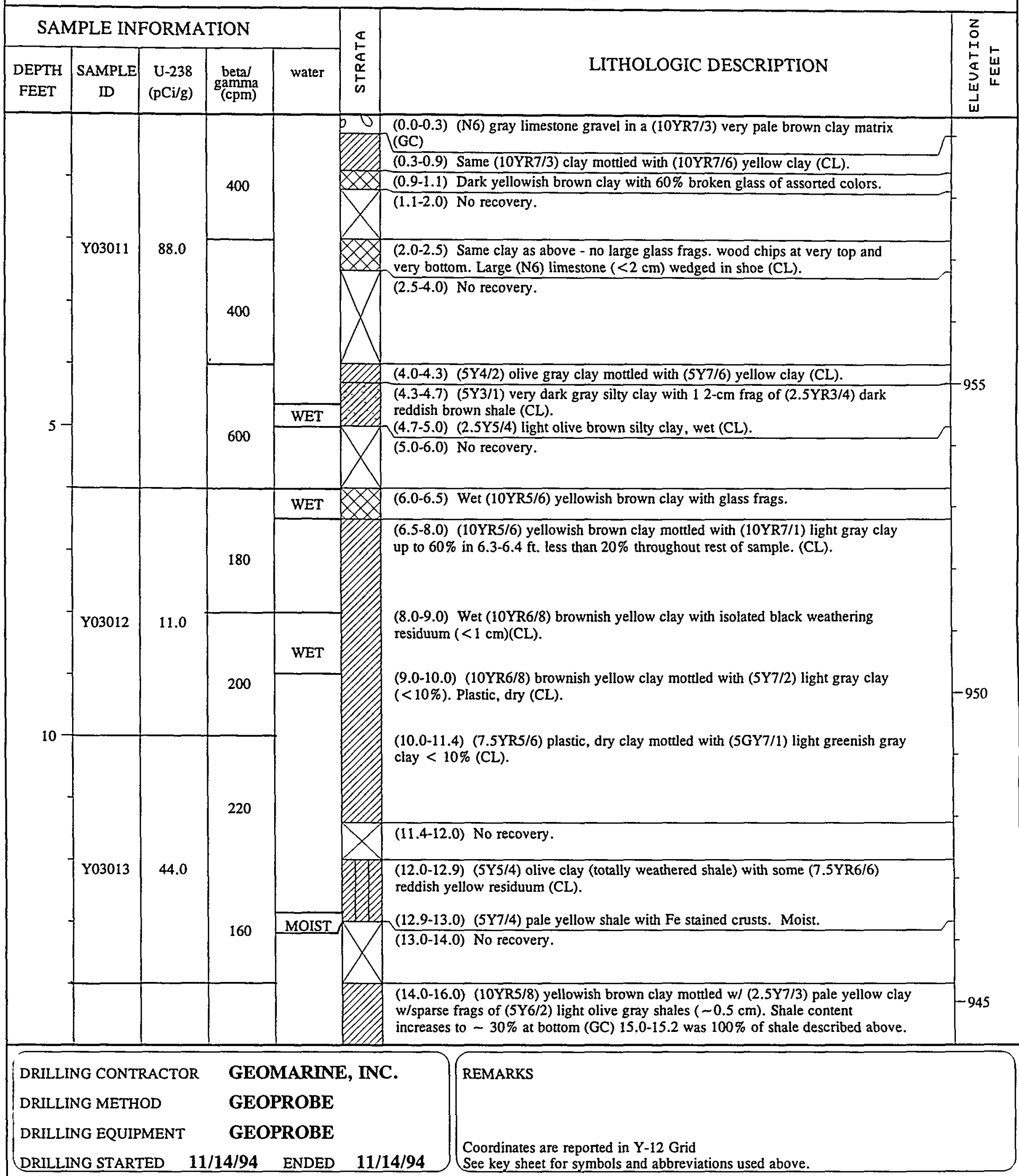




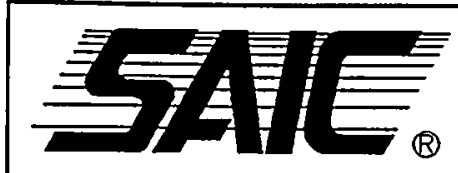

Q

COORDINATES N 29,757.10 E 48,305.30

ELEVATION $959.30 \mathrm{ft}$ above MSL

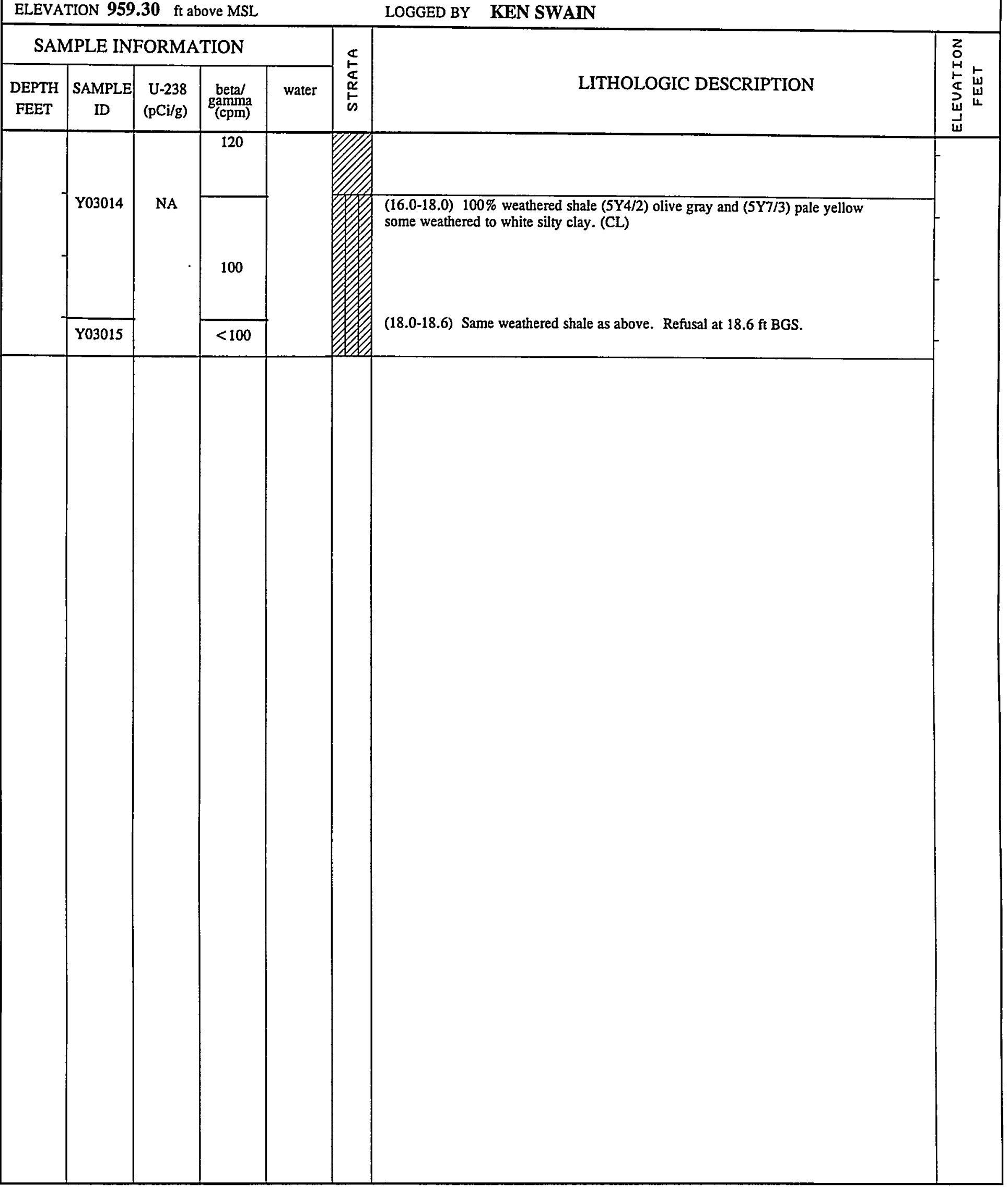

LOCATION

BCV OU 1

BOREHOLE NUMBER

BY-03

BOREHOLE DIAMETER 1.25 in.

SHEET

2 of 2

18.60

$\mathrm{ft}$ bgs

TOTAL DEPTH

SAMPLING DEVICE PROBE 


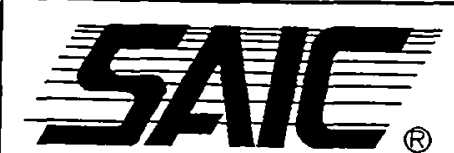

COORDINATES N 30,247.70 E 48,385.30

ELEVATION $969.70 \mathrm{ft}$ above MSL
SHEET 1 OF 1

LOCATION

BCV OU 1 TOTAL DEPTH

14.20

ft bgs

\section{BOREHOLE NUMBER BY-04}

BOREHOLE DIAMETER 1.25 in.

SAMPLING DEVICE PROBE

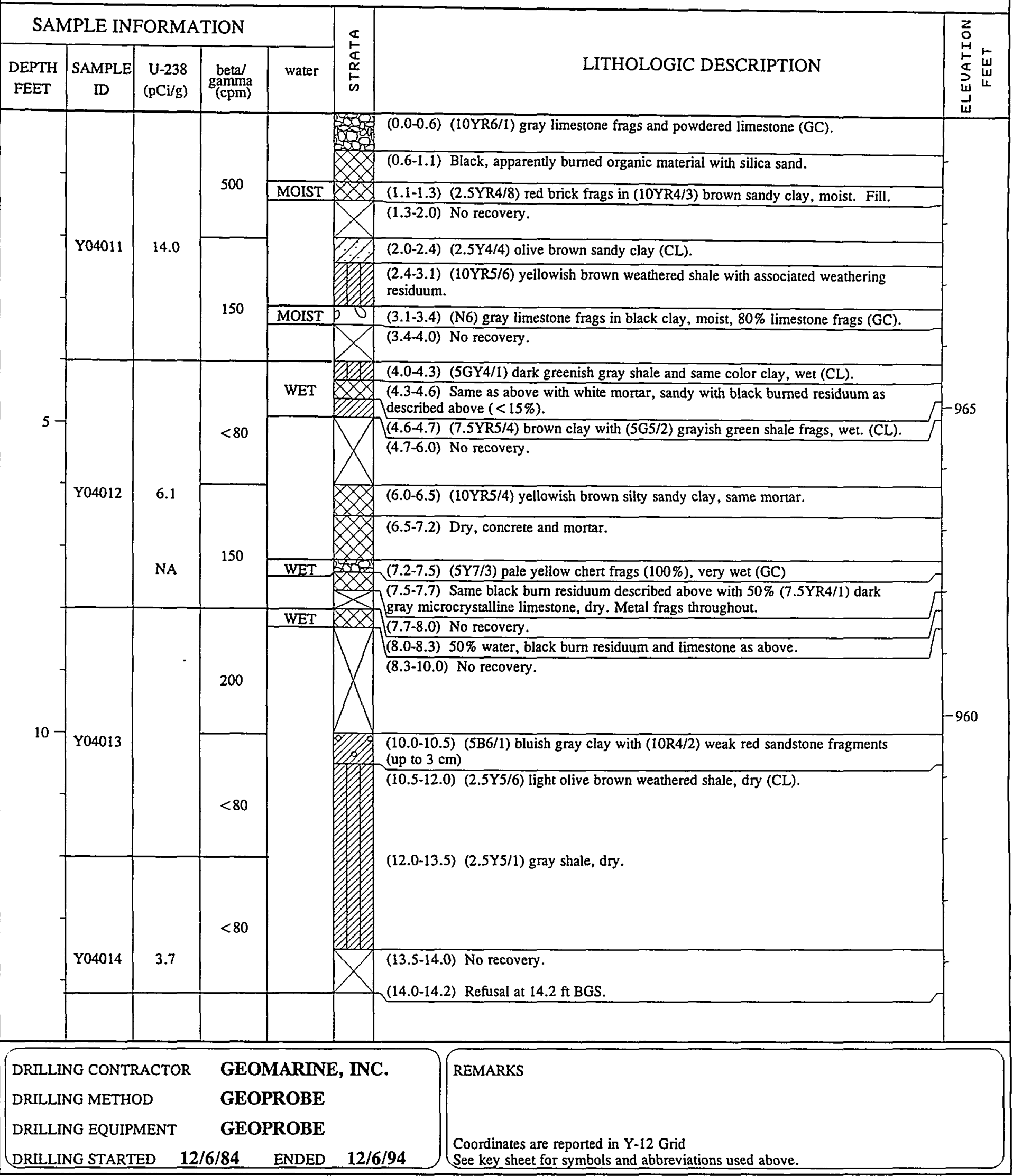




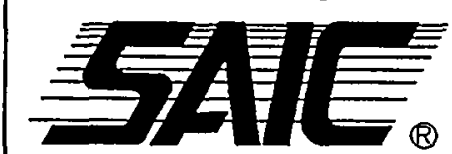

(R)

COORDINATES $\mathbf{N} 30,259.60$ E 48,578.20

ELEVATION $973.90 \mathrm{ft}$ above MSL
SHEET 1 OF 2

LOCATION

BCV OU 1

TOTAL DEPTH

20.00

ft bgs

BOREHOLE NUMBER BY-05

BOREHOLE DIAMETER 1.25 in.

SAMPLING DEVICE

PROBE

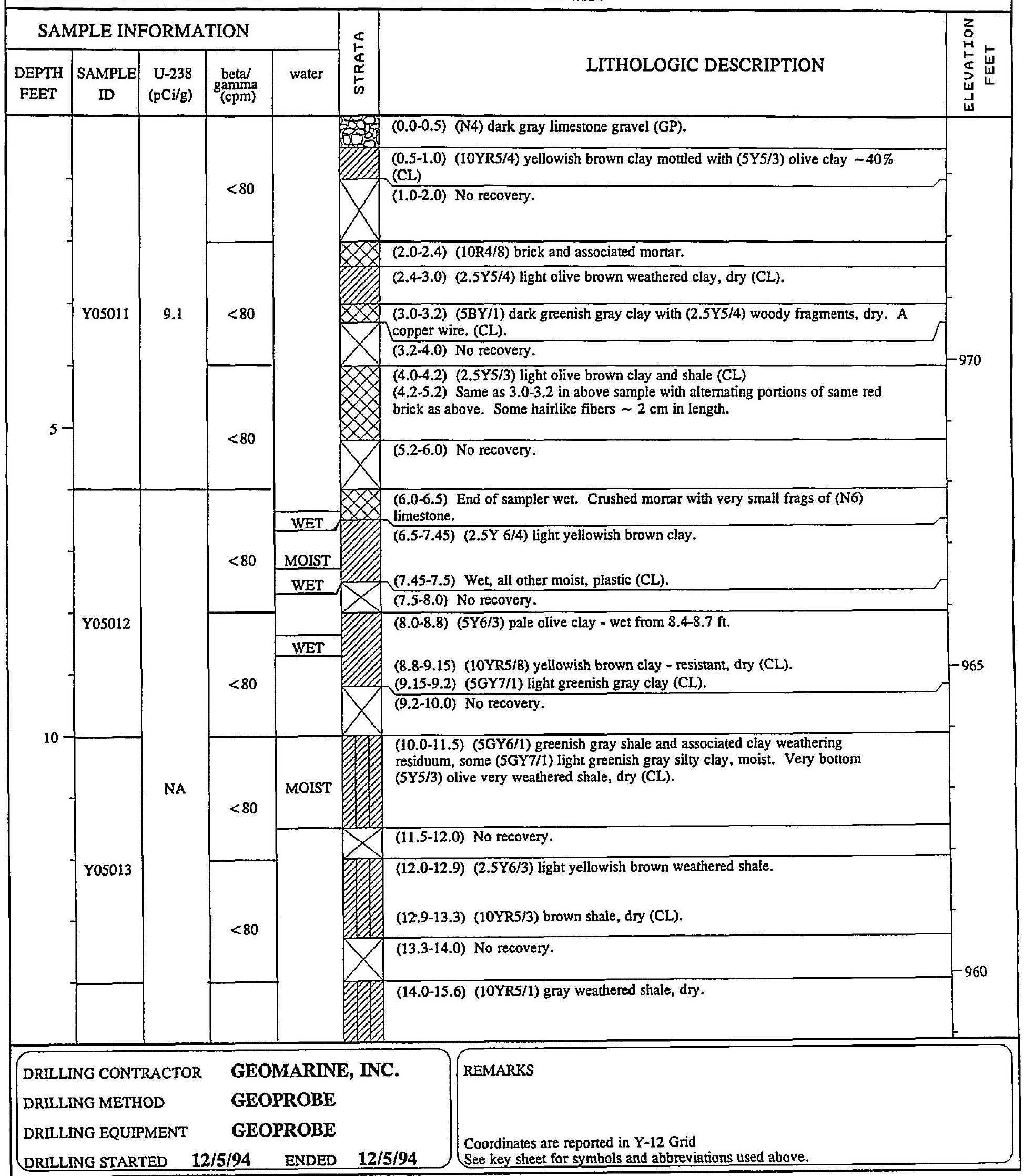


B13-66

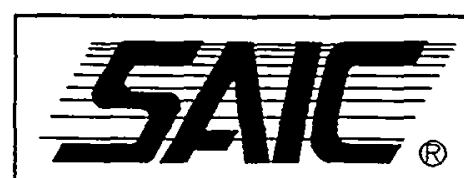

COORDINATES N 30,259.60 E 48,578.20

ELEVATION $973.90 \mathrm{ft}$ above MSL

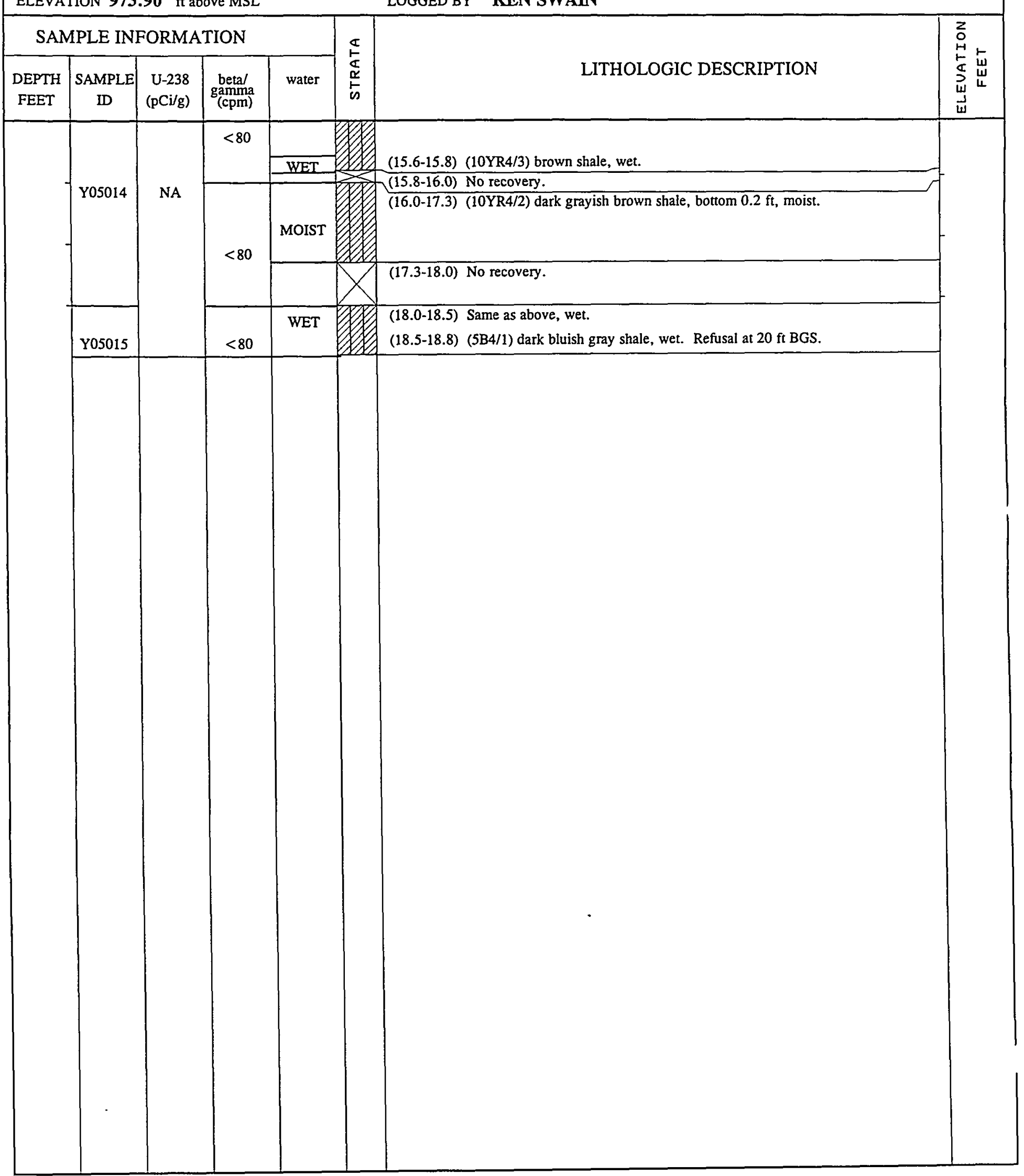

SHEET 2 OF 2

$\begin{array}{lllll}\text { LOCATION } & \text { BCV OU } 1 & \text { TOTAL DEPTH } & \mathbf{2 0 . 0 0} & \text { ft bgs }\end{array}$

BOREHOLE NUMBER BY-05

BOREHOLE DIAMETER 1.25 in. SAMPLING DEVICE PROBE

LOGGED BY KEN SWAIN 


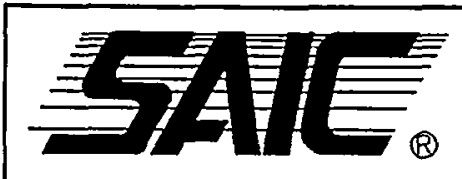

COORDINATES N 30,458.70 E 48,460.80

ELEVATION $976.80 \mathrm{ft}$ above MSL
SHEET 1 OF 2

LOCATION

BCV OU 1

BOREHOLE NUMBER BY-06

BOREHOLE DLAMETER 1.25 in. LOGGED BY KEN SWAIN

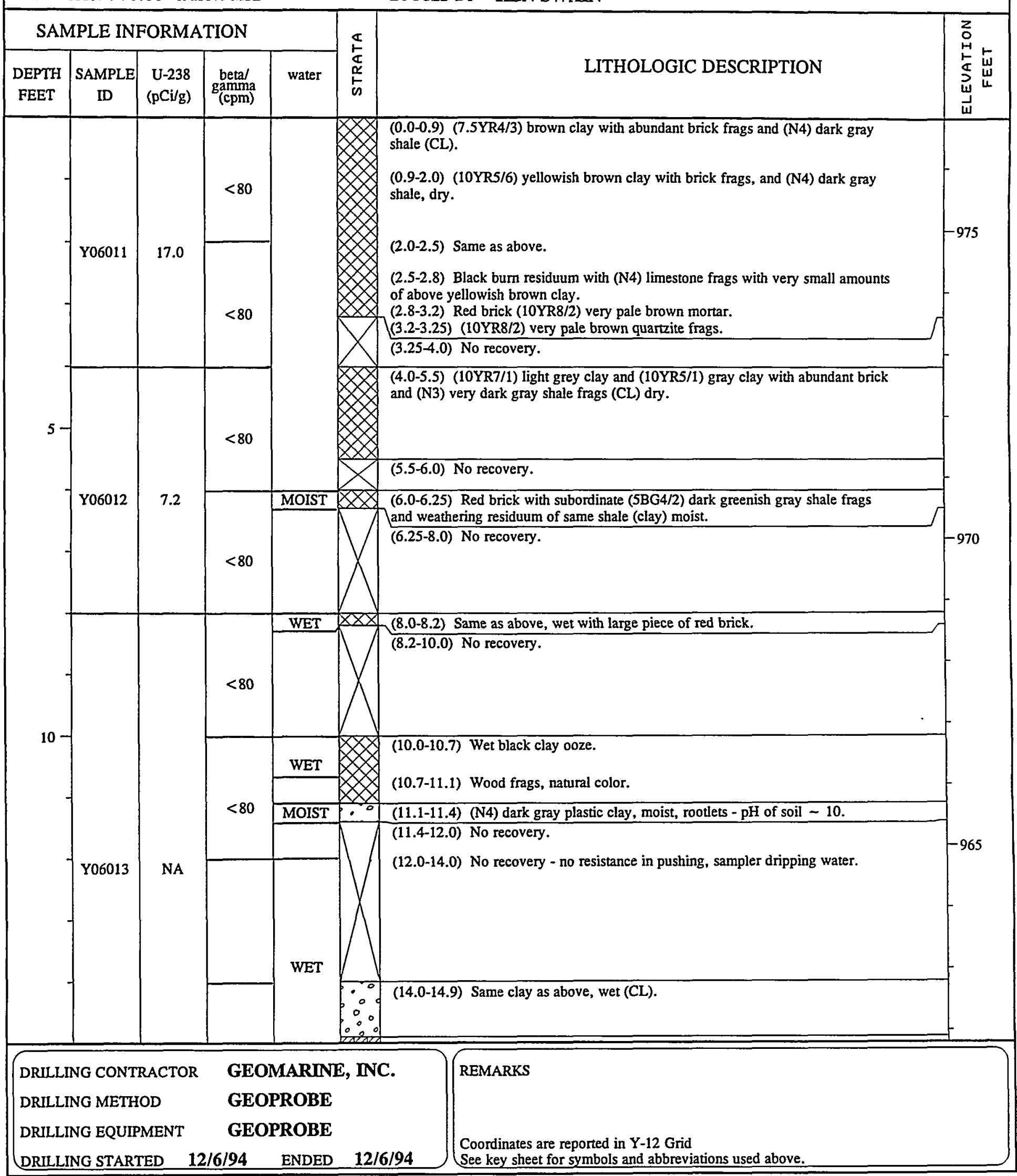




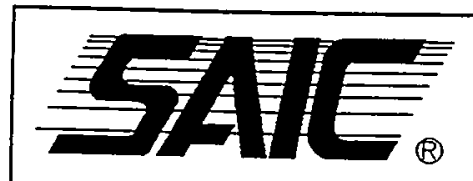

COORDINATES N 30,458.70 E $\mathbf{4 8 , 4 6 0 . 8 0}$

ELEVATION $976.80 \mathrm{ft}$ above MSL

\section{BY-06}

BCV OU

BOREHOLE NUMBER

BOREHOLE DIAMETER 1.25 in. LOGGED BY KEN SWAIN
SHEET 2 OF 2

16.60 ft bgs

SAMPLING DEVICE PROBE

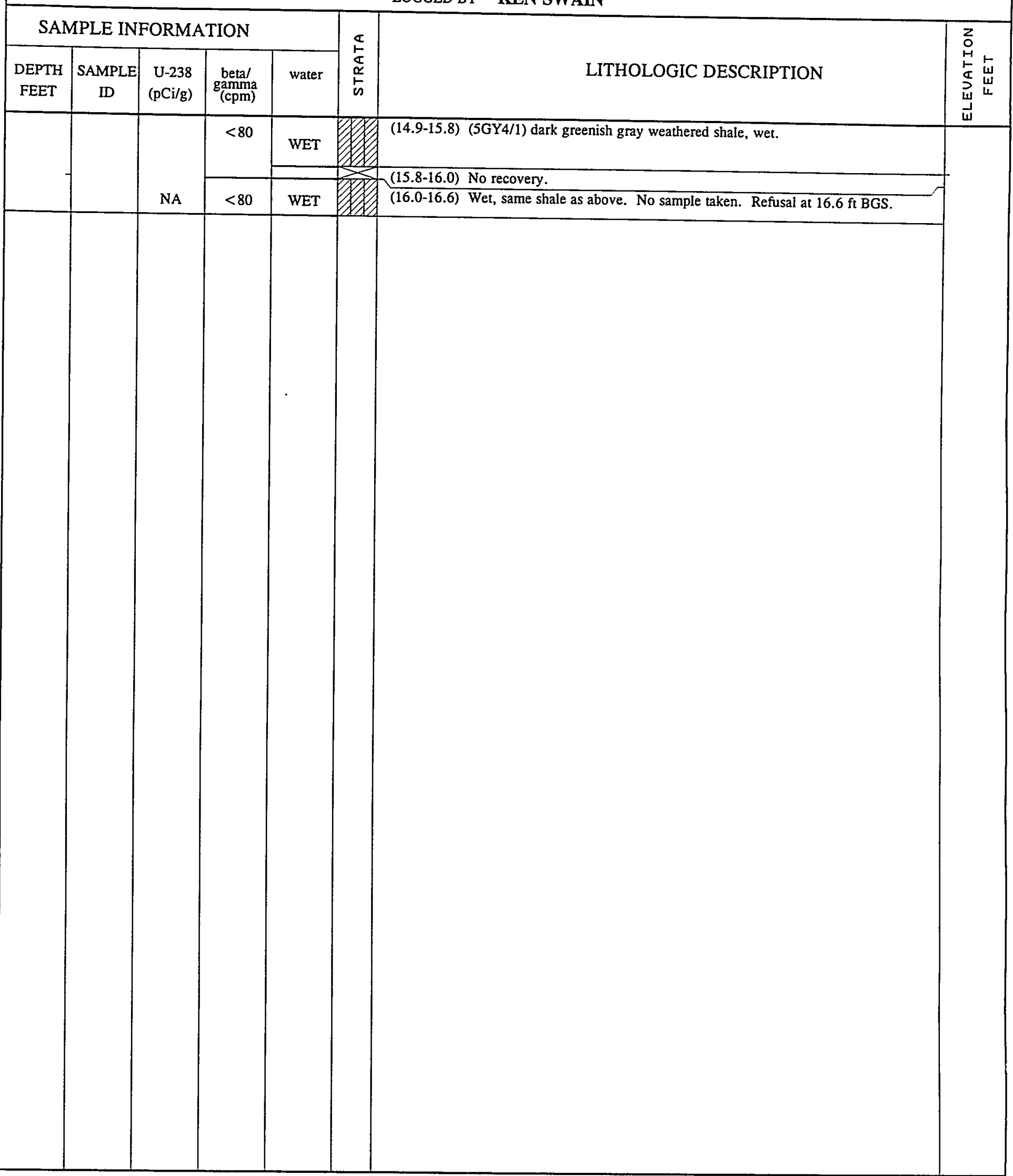




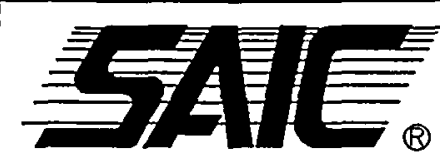

1
LOCATION

BOREHOLE NUMBER

BOREHOLE DIAMETER 1.25 in. LOGGED BY KEN SWAIN

SHEET 1 OF 2

$23.90 \quad f t$ bgs

COORDINATES N 29,760.40 E 48,788.80

BCV OU 1 TOTAL DEPTH

23.90

$f t$ bgs

ELEVATION $961.90 \mathrm{ft}$ above MSL

\section{SAMPLING DEVICE PROBE}

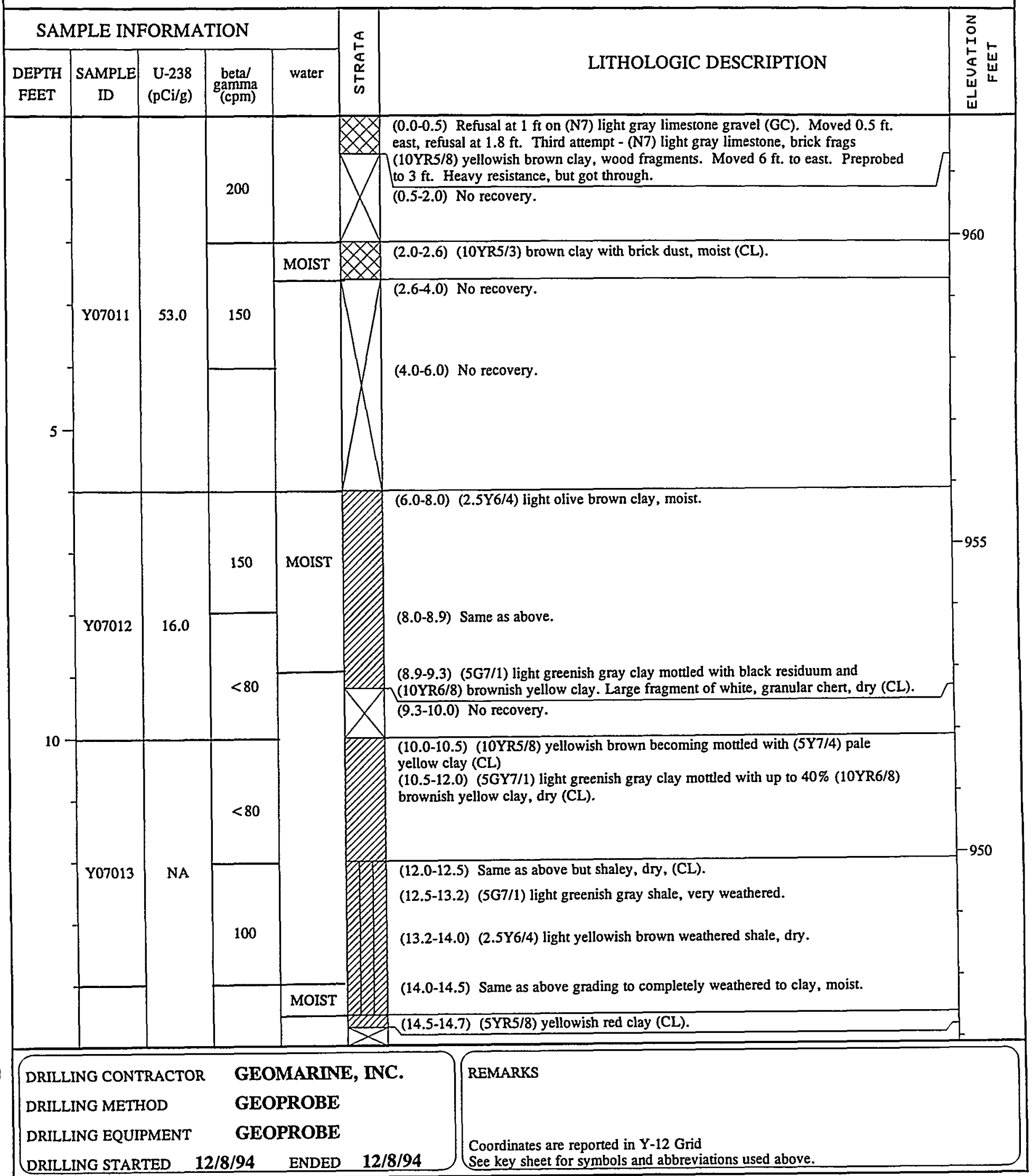




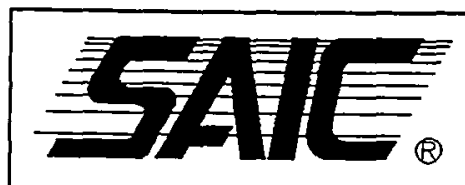

COORDINATES N 29,760.40 E 48,788.80

ELEVATION $961.90 \mathrm{ft}$ above MSL
SHEET 2 OF 2

LOCATION

BCV OU 1

TOTAL DEPTH

23.90

ft bgs

BOREHOLE NUMBER BY-07

BOREHOLE DIAMETER 1.25 in.

SAMPLING DEVICE

PROBE

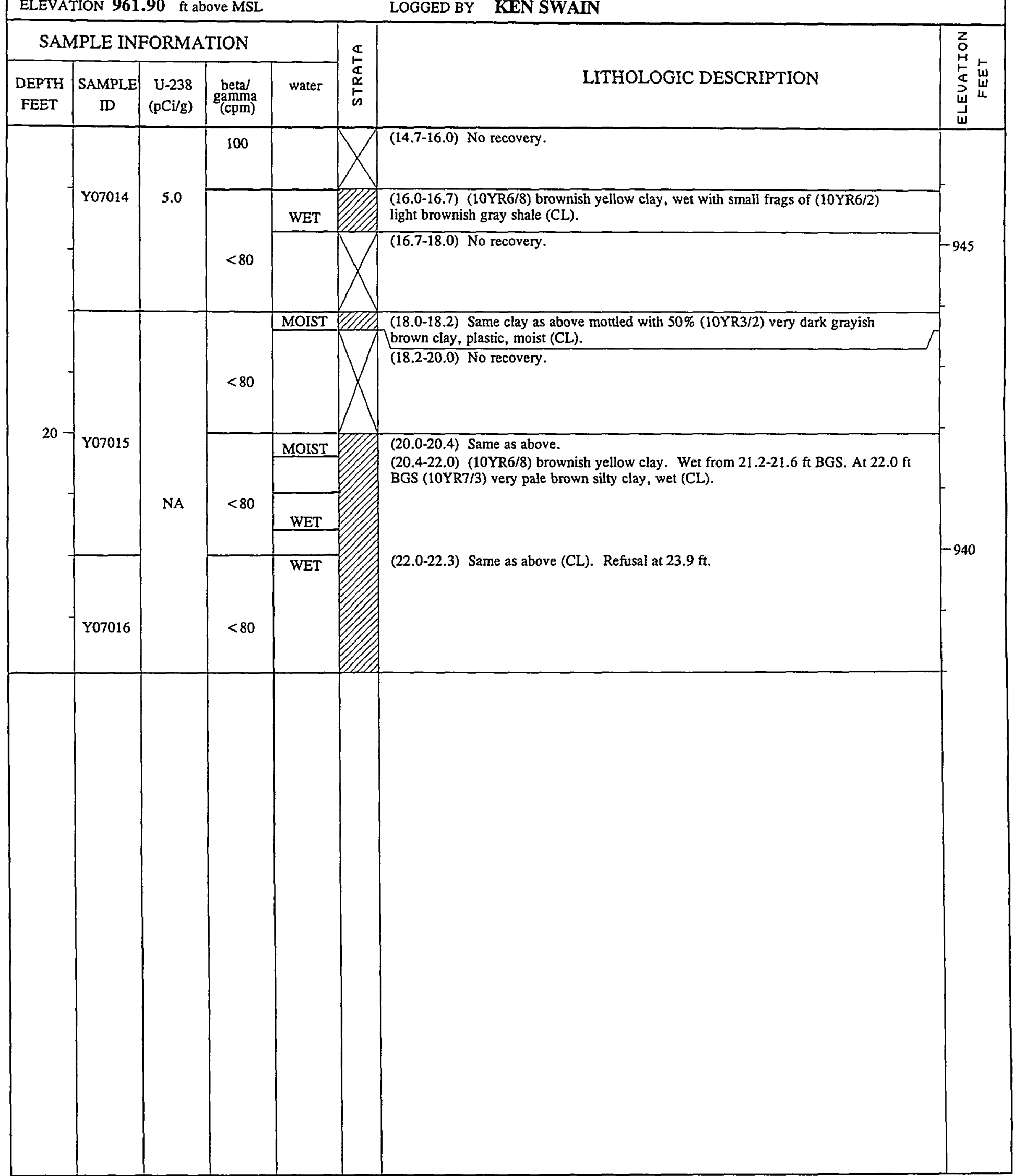




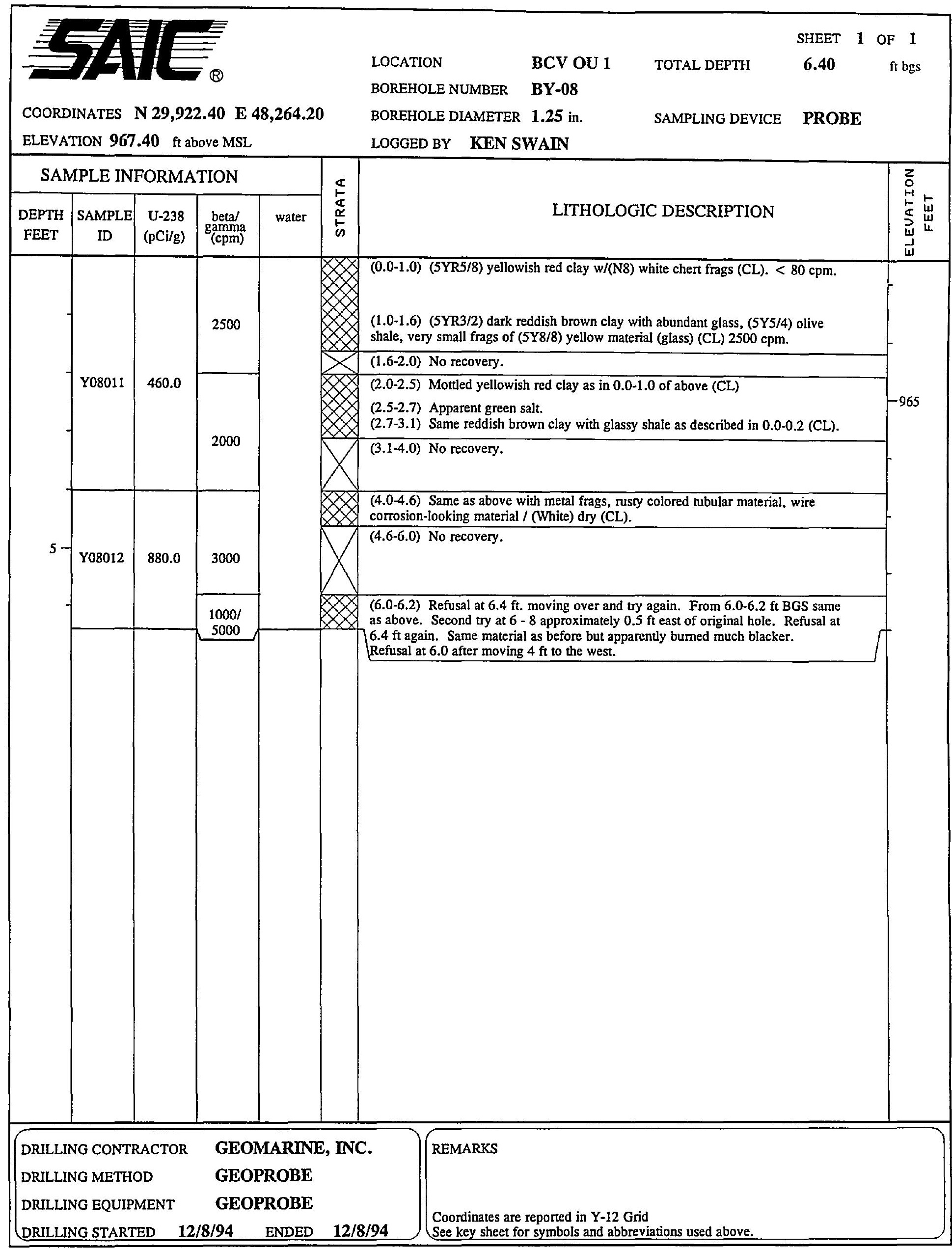




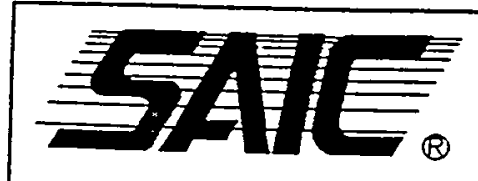

COORDINATES N 29,893.60 E 48,204.70

ELEVATION $963.00 \mathrm{ft}$ above MSL

\begin{tabular}{|c|c|c|c|c|}
\hline \multicolumn{5}{|c|}{ SAMPLE INFORMATION } \\
\hline $\begin{array}{c}\text { DEPTH } \\
\text { FEET }\end{array}$ & SAMPLE & U-238 & $\begin{array}{c}\text { betal } \\
\text { ID }\end{array}$ & water \\
(pCi/g) & (cpm) & \\
\hline
\end{tabular}

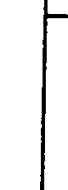

\section{LOCATION}

BOREHOLE NUMBER

BCV OU 1

BY-09

BOREHOLE DIAMETER 1.25 in.

\begin{tabular}{lll} 
LOGGED BY KEN SWAIN & SAMPLEIG DEVICE & PROBE \\
\hline
\end{tabular}

SHEET 1 OF 2

16.00 fi bes

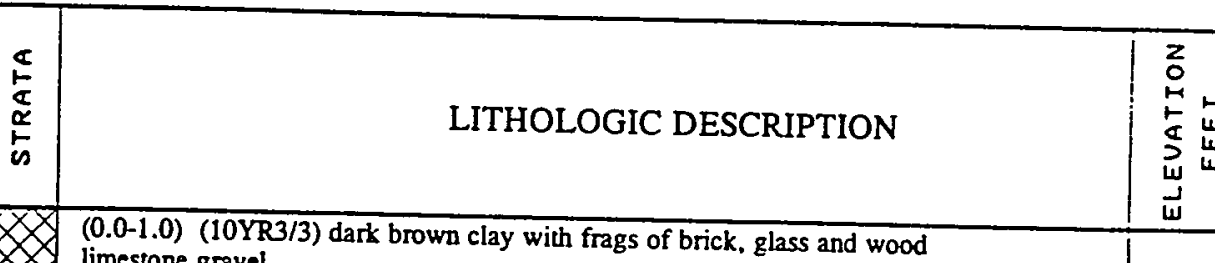

dari brown clay with frags of brick. glass and wood

出

$(1.0-2.0)$ No recovery.

(2.0-2.6) Wet, same material.

(2.6-4.0) No recovery.

(4.0-6.0) Wet, no recovery - 1 piece of magnesium turning on outside of sampler.

(6.0-8.0) Water, no soil again.

(8.0-8.6) Wet, black organic burn residuum, wood and shale frags - color undeterminable due to black mud covering, wet.

(8.6-10.0) No recovery.

300

10

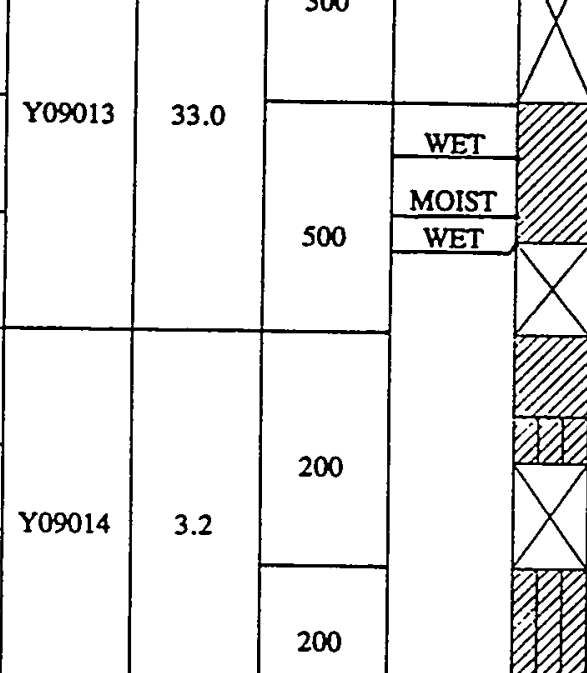

(10.0-11.0) (5Y4/1) dark gray clay, moist (CL). Top $0.6 \mathrm{ft}$ wet, rest feels moist.

(11.0-11.2) A sharp contact (10YR4/4) dark yellowish brown clay, wet (CL). (11.2-12.0) No recovery.

(12.0-12.7) (10YR4/3) brown highly weathered clay, dry (CL).

(12.7-12.9) (5GY6/1) greenish gray highly weathered shale.

(12.9-13.0) Same shale, less weathered, with (2.5Y4/2) dari grayish brown

interlayer staining.

(13.0-14.0) No recovery.

(14.0-15.8) (5YR4/2) dark reddish gray shale, dry. Refusal at $16.0 \mathrm{ft}$.

DRILLING CONTRACTOR GEOMARINE, INC. DRILLING METHOD DRILLING EQUIPMENT GEOPROBE DRILLING STARTED
REMARKS

Coordinates are reported in Y-12 Grid

See key sheet for symbols and abbreviations used above. 



\section{APPENDIX C \\ CHARACTERIZATION OF HYDROGEOLOGIC SETTING}





\section{$\mathrm{Cl}-3$}

The purpose of this appendix is to describe the hydrogeologic conceptual model for Bear Creek Valley (BCV). This conceptual model is one of the principal components of the conceptual site models for contaminant transport in BCV, development of which is one of the goals of this Remedial Investigation $(\mathrm{RI})$. The hydrogeologic conceptual model is a presentation of the working hypothesis, or theory, governing the physical aspect of water movement in BCV. In this respect, the hydrogeologic conceptual model provides the technical basis for interpreting the nature and extent of contamination (Appendix D) and the fate and transport of contaminants (Appendix E). It is important to note that hydrogeologic conditions at individual sites in BCV may vary from the generalized model but still retain the main components of the model (refer to Appendix D for individual site hydrogeologic conditions). Understanding the close interaction among the main components of the hydrogeologic conceptual model in a localized area is, therefore, the key to understanding groundwater flow at a site within that area.

In developing the hydrogeologic conceptual model, data collected during the RI Field Activities (RIFA) in BCV were combined with a wealth of past and ongoing studies that have been carried out in BCV or elsewhere on the Oak Ridge Reservation (ORR). Interest in contaminant transport associated with the waste disposal sites in BCV motivated the Oak Ridge Y-12 Plant to develop a large database of environmental data from studies of the disposal areas and of potential exit pathways. Ongoing work is summarized each year in the Groundwater Quality Report (GWQR) (e.g., HSW 1995). These studies include quarterly water level measurements summarized in the annual GWQR, data from RIs conducted in BCV during 1994 and 1995 (Appendix B), data from numerous previous studies carried out in BCV between 1984 and 1994 (e.g., Golder and Associates 1988a; Geraghty and Miller 1986), the Exit Pathway Monitoring Program (Shevenell et al. 1992), and other more specific studies carried out by the Environmental Sciences Division at Oak Ridge National Laboratory for the Groundwater Protection Program (GWPP) or the ORR Hydrology and Geology Studies (ORRHAGS) program (e.g., Dreier et al. 1993; Goldstrand 1995; Moline and Schreiber 1995, draft). Using these data, the resulting conceptual model builds on the previous theories and hypotheses for groundwater movement on the ORR (e.g., Solomon et al. 1992; Moore and Toran 1992).

Sections C.1 and C.2 of this appendix briefly describe the climate and topographical components of the hydrogeologic conceptual model, Sect. C.3 discusses the geological component, and Sect. C. 4 presents the hydrogeological component. Conclusions of this appendix are also summarized into Section 2 of the RI Report.

\section{C.1 CLIMATE}

The climate of the region surrounding the Oak Ridge area is broadly classified as humid continental. The Cumberland Mountains to the northwest have a moderating influence by shielding the region from cold air masses that frequently extend far south over the plains of the central United States during the winter months. In the summer months, tropical air masses from the south provide warm and humid conditions that often produce thunderstorms; however, anticyclonic circulation around high-pressure systems centered in the western Gulf of Mexico can bring dry air from the southwestern United States into the region, which causes occasional periods of drought (Energy Systems 1994). 


\section{C.1.1 TEMPERATURE}

The National Climatic Data Center calculates the area's "normal" temperatures each decade using climate data from a recent 30-year period. Recent climate normals (1963 through 1992 base period) were obtained from the Atmospheric Turbulence and Diffusion Laboratory of the National Oceanographic and Atmospheric Administration in Oak Ridge, which is the Center's source for local climate data. According to these data, the annual mean air temperature for the Oak Ridge area is $13.9^{\circ} \mathrm{C}\left(57.1^{\circ} \mathrm{F}\right)$. The coldest month is usually January, with temperatures averaging about $2.0^{\circ} \mathrm{C}$ $\left(35.6^{\circ} \mathrm{F}\right.$ ) but occasionally falling as low as $-27^{\circ} \mathrm{C}\left(-17^{\circ} \mathrm{F}\right)$ (Fig. C.1). July is typically the hottest month of the year, with average temperatures of $24.7^{\circ} \mathrm{C}\left(76.5^{\circ} \mathrm{F}\right)$ but occasionally rising to $41^{\circ} \mathrm{C}$ $\left(105^{\circ} \mathrm{F}\right)$. Diurnal temperature changes are relatively consistent from month to month, ranging from 10 to $15^{\circ} \mathrm{C}\left(18\right.$ to $\left.27^{\circ} \mathrm{F}\right)$ (Site \& Facilities Planning Department 1994).

\section{C.1.2 WINDS}

The Oak Ridge area has relatively light winds compared to other parts of the United States. The Cumberland Mountains and Plateau to the northwest and west, combined with the local valley and ridge topography, divert severe storms and minimize air movement and wind impact. However, wind speed characteristics vary greatly over short distances in the Oak Ridge area, depending on the measuring site's location with respect to individual valley bottoms or ridges. According to a preliminary analysis of wind data from the Oak Ridge Site Survey (Eckman et al. 1992), ridge-top and valley sites in the Oak Ridge area (excluding the Cumberland Plateau) experience wind speeds $<5 \mathrm{~m} / \mathrm{s}$ (11.2 mph) over $90 \%$ of the time. Also, many valley-bottom sites experience winds $<2 \mathrm{~m} / \mathrm{s}$ (4.5 mph) over $70 \%$ of the time and calm winds about 25 to $30 \%$ of the time (Site \& Facilities Planning Department 1994).

Prevailing wind directions in the Oak Ridge area are oriented parallel to the direction of the local ridge and valley terrain. Prevailing winds are either up-valley (northeasterly) day-time winds or down-valley (southwesterly) night-time winds (Energy Systems 1994). The general wind characteristics for Oak Ridge described above are observed in BCV, where prevailing winds are oriented along the valley with an average wind speed of $1.5 \mathrm{~m} / \mathrm{s}(3.4 \mathrm{mph})$ (Fig. C.1).

\section{C.1.3 PRECIPITATION}

Detailed discussions of precipitation patterns for BCV can be found in Sect. 2.2 of Ecological Effects of Contaminants and Remedial Actions in Bear Creek (Southworth et al. 1992). Average precipitation in the Oak Ridge area varies by as much as $30 \%$, depending on the location relative to local terrain. In the Oak Ridge area there is a rain shadow effect caused by the higher Cumberland Plateau to the west. The net result is slightly above average precipitation in the northwest portion of the Oak Ridge area and somewhat below average precipitation in the southeast portion (Site \& Facilities Planning Department 1994).

The 40-year annual average precipitation for Oak Ridge is $137 \mathrm{~cm}$ (53.75 in.), including about $26 \mathrm{~cm}$ (10.4 in.) of snowfall (Fig. C.1). Precipitation in 1993 was $126 \mathrm{~cm}$ (49.6 in.), about $11 \mathrm{~cm}$ ( 4.3 in.) below the annual average. Precipitation in the region is greatest in the winter and spring months (January through April) and least during the fall months (September through November), when high-pressure systems are most frequent (Energy Systems 1994). 


\section{C.2 TOPOGRAPHY}

The ORR lies within the Valley and Ridge Physiographic Province, which is characterized by steep-sided parallel ridges with broad intervening valleys, generally oriented in a northeast-southwest direction. BCV is bordered by Pine Ridge on the northwest and by Chestnut Ridge on the southeast (Fig. C.2). Topographic relief from the crest of Pine Ridge to the floor of BCV ranges from 79 to $91 \mathrm{~m}$ (260 to $300 \mathrm{ft}$ ); relief from the crest of Chestnut Ridge to the floor of BCV ranges from 85 to $122 \mathrm{~m}$ ( 280 to $400 \mathrm{ft})$. The average elevation of the ridges is $\sim 335 \mathrm{~m}(1100 \mathrm{ft})$ above mean sea level (amsl), while elevation of the floor of BCV ranges from 244 to $305 \mathrm{~m}$ (800 to $1000 \mathrm{ft}$ ) amsl. 


\section{C.3 BCV HYDROGEOLOGIC CONCEPTUAL MODEL - GEOLOGY}

The hydrogeologic system in BCV is governed by its main geologic features, including:

- lithology that is interbedded shale, sandstone, and limestone;

- geologic structure characterized by tilted stratigraphy, faults, and fractures; and

- geomorphology dominated by parallel ridges and valleys.

The key geologic features affecting transmission of groundwater in BCV are identified below and discussed in the following subsections. Further detailed reviews are available in Hatcher et al. (1992) and Solomon et al. (1992).

- The geology of BCV displays an inclined layer-cake-style stratigraphy. This stratigraphy is observed on a regional scale, where predominantly carbonate rock groups (Knox Group and the Maynardville Limestone) are interbedded with predominantly clastic groups (Conasauga Group and the Rome Formation). Interbedding is also observed on the scale of outcrops, where clastic beds are interlayered with carbonate beds (Figs. C.3 and C.4). This layering structure results in anisotropy of permeability and hydraulic conductivity, which exerts a strong influence on flow directions.

- The primary permeability of the rocks underlying BCV is very low. However, diagenesis, fracturing, and solution weathering of bedrock has resulted in secondary porosity and permeability through which most fluid movement occurs (Solomon et al. 1992; Shevenell 1994b; Goldstrand et al. 1995). In addition, orientations of well-connected fractures or solution conduits are predominantly parallel to geological strike and/or bedding planes, enhancing the effect of anisotropy caused by layering. As a result, groundwater flow paths parallel to geological strike and bedding predominate.

- Fracture aperture width generally decreases with depth in all formations and thus restricts the depth of active groundwater circulation. Hydraulically active fractures, and thus active groundwater circulation, occur at greater depths in the Knox Group and the Maynardville Limestone than in the Conasauga Group.

- Residuum (weathered bedrock) of variable thickness covers most of BCV. Thickest on the ridges of the Knox Group, it is thinner in the valleys and nearly disappears in stream channels. Residuum on the ridges formed by the Rome Formation has variable thickness. When the residuum occurs over clastic formations, it probably retains relict structures from the bedrock and maintains some of the hydraulic anisotropy.

- The surface morphology of the ORR is characterized by parallel ridges and intervening valleys formed by differential erosion of the steeply dipping resistant and less resistant rock units. Knox Group and Rome Formation rocks represent the competent units that, more resistant to erosion than the Conasauga Group, today constitute the ridge-forming units that define $\mathrm{BCV}$.

\section{C.3.1 BCV STRATIGRAPHY}

The geology of the ORR is characterized by a folded and faulted assemblage of shales and limestones. This assemblage represents the deposition of a $\sim 2.5-\mathrm{km}(1.6-\mathrm{mile})$ layer of marine and 
near-shore sediments during the entire Cambrian and Ordovician periods. BCV is underlain by rocks of three regionally important stratigraphic units: the Rome Formation, the Conasauga Group, and the Knox Group (Fig. C.4). For general descriptions of the stratigraphy of geological units in the ORR, see Hatcher et al. (1992) for an overview of the ORR geology; Haase et al. (1985) for the Conasauga Group and Rome Formation; and Lee and Ketelle (1987) for the Knox Group. Following are brief descriptions of these units.

\section{Rome Formation}

The Rome Formation crops out at the Y-12 Plant on Pine Ridge and dips beneath BCV. The oldest rock unit exposed in the ORR, it ranges in thickness from 122 to $183 \mathrm{~m}$ (400 to $600 \mathrm{ft}$ ). Maroon, green, and/or yellow-brown micaceous shale is the most common lithology in the Rome Formation. The formation consists of siltstone, sandstone, dolomitic sandstone, and dolomite interbedded with shale. Sandstones and siltstones are more abundant in the upper Rome Formation, which is capped by a 3- to 6-m (10- to 20-ft) thick sandstone bed. Some dolomite and dolomitic sandstone beds in the upper Rome Formation are laterally continuous.

\section{Conasauga Group}

The Conasauga Group outcrops above the Rome Formation on the southern flank of Pine Ridge. The average thickness of the Conasauga Group is $567 \mathrm{~m}(1860 \mathrm{ft})$. The Group is traditionally subdivided in central East Tennessee into the (1) Middle Cambrian Pumpkin Valley Shale, Rutledge Limestone [Friendship Formation in Hatcher et al. (1992)]; (2) Rogersville Shale, Maryville Limestone [Dismal Gap Formation in Hatcher et al. (1992)]; and (3) Upper Cambrian Nolichucky Shale, Maynardville Limestone.

Except for the Maynardville Limestone, the Conasauga in BCV is a monotonous sequence of shale, siltstone, and thin-bedded limestone. Some formations, however, include laterally continuous limestone beds up to several meters thick. Where karstification has enlarged fractures in the limestone beds, strata-bound, high-permeability zones may exist. The Maynardville Limestone is the uppermost member of the Conasauga Group, a massively bedded limestone and dolomite formation with extensive karstification.

The following are brief descriptions of the six formations in the Conasauga Group.

Pumpkin Valley Shale. Oldest of the Conasauga Group formations, the Pumpkin Valley Shale is predominantly an olive and maroon, massive, clay and shale unit with thin beds of siltstone and sandstone. The Pumpkin Valley Shale is gradational with the underlying Rome Formation but lacks the sandstone that is characteristic of the Rome Formation. Two members of the Pumpkin Valley Shale have been identified (Law Engineering 1975), the upper one being richer in shale than the lower one. The lower member exhibits units that are commonly bioturbated or have wavy parallel stratification. The Pumpkin Valley Shale exhibits low hydraulic conductivity (DuBuchanne and Richardson 1956), and the lack of continuous limestone beds also precludes the possibility of extensive karst development in this formation. The formation is $\sim 94$ to $109 \mathrm{~m}$ (308 to $358 \mathrm{ft}$ ) thick (Hatcher et al. 1992).

Rutledge Limestone [on the ORR referred to as the Friendship Formation by Hatcher et al. (1992)]. Predominantly a clastic unit ( $75 \%$ shale) with some limestone, the Rutledge Limestone in $\mathrm{BCV}$ ranges in thickness from 31 to $45 \mathrm{~m}$ (102 to $148 \mathrm{ft}$ ). The formation consists of light-grey to white, medium- to thin-bedded limestones and micritic limestones interbedded with mudstones and shales that become more calcareous higher in the succession. Some limestone beds are persistent and 
serve as marker beds within the lower Conasauga Group. Increased amounts of limestone distinguish the Rutledge Limestone from the overlying and underlying formations. Although limestone is a minor lithology in this formation, laterally continuous beds may provide groundwater flow paths where karst has formed.

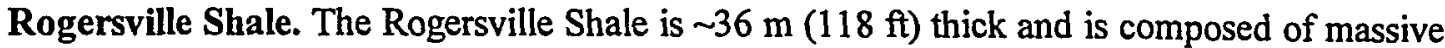
to medium-bedded, noncalcareous mudstones, interbedded with brown shales. The shales and mudstones contain subordinate units of glauconitic and/or calcareous siltstones. A limestone-rich interval known as the Craig Limestone member, which outcrops throughout much of eastern Tennessee, occurs in the upper portion of the Rogersville Shale. Clastic sediments dominate the Rogersville Shale, and karst formation is probably not common, except possibly for the Craig Limestone member.

Maryville Limestone [referred to as the Dismal Gap Formation by Hatcher et al. (1992)]. The Maryville Limestone, ranging in thickness from 47 to $85 \mathrm{~m}$ (154 to $279 \mathrm{ft}$ ), consists of calcareous shales and shaley siltstones ( $\sim 60$ to $70 \%)$ interbedded with light- to dark-grey, fine- to coarse-crystalline limestone ( 30 to $40 \%)$. This formation is informally divided into two members (Haase et al. 1985). The lower member consists of medium- to thin-bedded calcareous mudstone interbedded with pelloidal or oolitic calcareous siltstones. Limestones appear as discrete beds, 5 to $20 \mathrm{~cm}$ ( 2 to $8 \mathrm{in}$.) thick in coarsening upward cycles. Several relatively limestone-rich horizons ranging from 6 to $12 \mathrm{~m}$ ( 20 to $39 \mathrm{ft}$ ) thick, which are characteristic of the Maryville Limestone, occur throughout the lower member. The upper member of the Maryville Limestone is characterized by the presence of distinctive, flat, limestone-pebble conglomerates. In places, the intraclastic limestones are glauconitic or oolite-rich. The limestone units in this formation offer the potential for karst formation. Bedding in the clastic units is commonly wavy, which may result in poor development of bedding parallel fractures.

Nolichucky Shale (Foreman et al. 1991; Rothschild et al. 1984). The Nolichucky Shale, which is $\sim 190 \mathrm{~m}$ (620 ft) thick, consists of shale interbedded with intraclastic limestone, thick fossiliferous limestone, and oolitic limestone. Shale is the dominant lithology, occurring in 2.5- to 3-m (8- to $10-\mathrm{ft}$ ) thick beds that are laterally continuous. Like all shales in the Conasauga Group on the ORR, the Nolichucky Shale has good fissility, and horizontal laminae are well preserved. The occasional limestone beds in the Nolichucky Shale may provide preferential flow paths for groundwater where karst has occurred.

Maynardville Limestone (Shevenell et al. 1992). The youngest formation of the Conasauga Group, the Maynardville Limestone, consists primarily of light-gray to tan, medium- to thin-bedded limestone with subordinate amounts of dolostone. Extensive study of the Maynardville Limestone during the Exit Pathway Monitoring Program in BCV (Shevenell et al. 1992) subdivided the Maynardville into seven different, informal lithologic zones (with zone 7 being stratigraphically highest) based on lithology and geophysical characteristics (Fig. C.5). Comparison with the stratigraphic nomenclature for the Maynardville Limestone shows that zones 4 through 7 correspond to the Chances Branch member, zones 2 and 3 correspond to the Low Hollow member, and zone 1 corresponds to the upper Nolichucky Shale.

In BCV, the thickness of the Maynardville Limestone varies from 67 to $136 \mathrm{~m}$ ( 220 to $445 \mathrm{ft}$ ). Thickest at the northeast end of the Y-12 Plant close to Scarboro Road, the formation thins considerably in BCV adjacent to the Bear Creek Burial Grounds (BCBG) (Table C.1 and Fig. C.5) (Shevenell et al. 1992). Zone 2, which varies considerably in thickness, is apparently absent opposite the $\mathrm{BCBG}$; this absence reflects an overall thinning of the Maynardville Limestone along strike at the $\mathrm{BCBG}$. The pinching out of zone 2 at the $\mathrm{BCBG}$ also appears to be accompanied by a thickening 
of the upper Nolichucky Shale in this section and has been interpreted as an along-strike facies change (Shevenell et al. 1992).

\section{Knox Group}

The Knox Group underlies and forms Chestnut Ridge, the southern boundary of BCV. On the ORR, the Knox Group is divided into five separate units: the Copper Ridge Dolomite, the Chepultepec Dolomite, the Longview Dolomite, the Kingsport Formation, and the Mascot Dolomite. Total thickness of the Knox Group ranges between 600 and $900 \mathrm{~m}$ (1970 and $2950 \mathrm{ft}$ ), with the Copper Ridge Dolomite making up roughly one-third of the total.

The Knox Group is composed of a series of medium- to thick-bedded, massive, grey, green, and pink dolomite. The Copper Ridge and Longview Formation dolomites are siliceous, and these formations tend to be ridge formers in East Tennessee. All formations within the group contain subordinate amounts of chert, some in nodular form that characteristically remain in the soils after weathering of the dolomite matrix. The Knox Group, along with the Maynardville Limestone from the Conasauga Group, forms the regionally important Knox aquifer (Solomon et al. 1992). Although the dolomite lithologies have little primary matrix porosity, extensive karst formation (Shevenell and Beauchamp 1994) and dedolimization (Goldstrand et al. 1995) have resulted in the development of secondary porosity and permeability. Sinkholes are common at outcrop, and springs and seeps are common features at the upper and lower geologic contacts.

\section{Residuum}

Overlying the bedrock on the ORR is unconsolidated material that consists of weathered bedrock (referred to as residuum), man-made fill, alluvium, and colluvium. With the exception of the areas close to the S-3 Site and Rust Spoil Area, most of the unconsolidated material in BCV west of the Y-12 Plant is residuum. The depths to unweathered bedrock differ throughout the ORR because of the different thicknesses of fill and alluvium and the particular weathering characteristics of the bedrock units. The total thickness of these materials typically ranges from 3 to $15 \mathrm{~m}$ (10 to $50 \mathrm{ft}$ ) (Hoos and Bailey 1986).

Overlying the bedrock throughout the ORR except in scattered outcrop areas, the residuum ranges from silty to sandy clay overlying shale units to a slightly sandy clay overlying limestone units. Predominant colors are shades of brown, orange, and grey. With increasing depth, the colors darken and the clay grades to weathered rock that has retained its structural characteristics (saprolite). Bedding planes and joint surfaces in the weathered bedrock commonly are marked by dark reddishbrown and yellow-brown oxide coloration, indicative of a high degree of weathering by circulating groundwater. Although hydraulic conductivities for residuum materials are low $\left(10^{-7}-10^{-4} \mathrm{~cm} / \mathrm{s}\right.$; Moore 1988) because of the high proportion of clay minerals, conduits or preferential flow paths may exist that are related to this relict bedrock structure.

\section{C.3.2 STRUCTURAL GEOLOGY OF THE ORR}

According to Hatcher et al. (1992), the deformation that is characteristic of the geology of the ORR was created by compressional stresses during the Appalachian orogeny. A result of these tectonic forces is that, today, the rocks in the subsurface at BCV typically dip $\sim 45^{\circ}$ to the southeast except where interrupted locally by folds (Fig. C.4). 
The stratigraphic section of the ORR is stacked along three major thrust faults - the Kingston, White Oak Mountain, and Copper Creek faults (Hatcher et al. 1992) - and therefore tends to be repetitive (Fig. C.6). All three faults parallel regional strike and dip because of detachment along lithologic planes of weakness during faulting. Y-12 Plant and BCV are underlain by the White Oak Mountain thrust sheet, which in turn is underlain by the White Oak Mountain thrust fault. This fault has not been historically active.

\section{C.3.3 BCV BEDROCK STRUCTURES}

Formation of secondary porosity and permeability is a major factor in groundwater movement through the formations underlying BCV. Bedrock structural features, such as fractures and solution cavities, provide the pathways for groundwater flow. These formations have little primary porosity or permeability.

Fractures. Because of the large-scale faulting and folding characteristic of ORR geology, all lithologic units in BCV are highly fractured. The most pervasive structural features are extensional, hybrid, and shear fractures. Corehole studies of fractures in bedrock along a transect across BCV near the head of Bear Creek (Lutz and Dreier 1988; Dreier and Davidson 1994) demonstrate the existence of several major fracture sets that are dominated by a strike-parallel set. Most fractures in ORR bedrock constitute a single cubic system (three orthogonal sets) of extension fractures (Dreier et al. 1987; Sledz and Huff 1981). One fracture set is formed by bedding planes, which have an average strike of $\sim \mathrm{N} 55^{\circ} \mathrm{E}$; although variable, the dip commonly is $\sim 30$ to $40^{\circ} \mathrm{SE}$ (Stockdale 1951). Two other fracture sets generally parallel strike and dip; at shallow depths, these sets are commonly angled $\sim 50$ to $60^{\circ}$ below the horizon. These three fracture sets may occur in any locality, and other extension and shear fractures may also be present.

Fractures are abundant on rock outcrops. In general, fracture spacing is a function of lithology and bed thickness. Fractures in more massively bedded formations tend to have longer trace lengths and are more widely spaced. Dreier et al. (1987) measured an average fracture density of $\sim 200 / \mathrm{m}$ $(60 / \mathrm{ft})$ in saprolite of the Maryville Limestone and Nolichucky Shale. At the other extreme, Sledz and Huff (1981) measured a minimum of 5 fractures per meter (1.5 fractures per foot) in fresh rock. Fewer open fractures occur at deeper levels. As described by Haase et al. (1985), fracture frequency is variable, but most fractures observed in cores occur within limestone or sandstone layers $>0.5 \mathrm{~m}$ $(1.6 \mathrm{ft})$ thick, and many are filled or partly filled with secondary minerals.

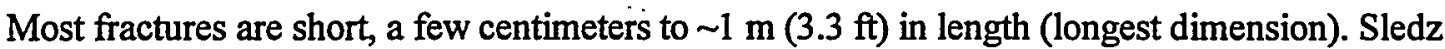
and Huff (1981) found that fracture length at outcrop is relatively uniform [ $12 \mathrm{~cm}(5 \mathrm{in})$.$] in shale$ but increases with bed thickness in siltstone. Haase et al. (1985) observed numerous fractures $\sim 0.1$ to $1.5 \mathrm{~m}(0.3$ to $5 \mathrm{ft})$ long in limestone and sandstone units of the Conasauga Group and the Rome Formation. In limestone, typical fracture spacings range from $<5 \mathrm{~cm}$ ( 2 in.) for very thin beds to $>3 \mathrm{~m}$ $(10 \mathrm{ft})$ for very thick to massive beds. The size of fracture planes may be only a few square meters for thin to very thin beds, but pervious bedding-plane fractures may be $10^{3}$ to $10^{6} \mathrm{~m}^{2}$ for medium to massive beds (Ford and Williams 1989).

Detailed logging of core from wells at the BCBG has provided information on the relative changes in densities of open (hydraulically active) fractures in the Nolichucky Shale compared to depth and lithology (Dreier and Davidson 1994). This information was supported by estimates of

spacings for hydraulically active fractures from resistivity, temperature, and flow meter logs of the

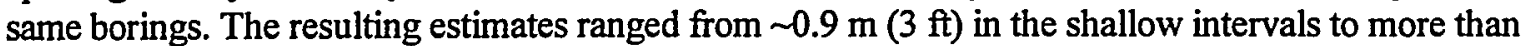
$6 \mathrm{~m}(20 \mathrm{ft}$ ) in the deep intervals (Fig. C.7). The combination of hydrological data and fracture logging 
in Dreier and Davidson (1994) also shows that changes in the vertical hydraulic gradient can be correlated to changes in the spacing of hydraulically active fractures. In the Nolichucky Shale, a strong vertical hydraulic gradient exists in well GW-726 over the upper $76 \mathrm{~m}(250 \mathrm{ft})$, where fracture spacings are $\sim 0.9 \mathrm{~m}$ ( $3 \mathrm{ft}$ ) (Fig. C.7). Below this level, however, fracture spacings increase and the vertical head gradient decreases significantly, becoming flat with increasing fracture spacing (GW-727, Fig. C.7).

In addition to small-scale deformation features such as the fracture sets discussed above, large-scale features, such as fracture zones and faults, that would provide enhanced groundwater flow paths probably exist in the subsurface and influence groundwater flow in BCV. There are a number of lines of evidence that such faults exist; for example, the nearly parallel southerly flow of most tributaries draining the southern slope of Pine Ridge is characteristic of surface expressions arising from parallel fracture zones in the subsurface. The following cumulative evidence suggests the location of one such fracture zone at the BCBG:

- Goldstrand (1995) cites repeated sections of zone 5 of the Maynardville observed in well GW-790 as direct evidence for faulting. These sections, occurring between 55 and $65 \mathrm{~m}$ (180 and $212 \mathrm{ft}$ ) below ground surface (bgs), are associated with abundant cavities that have been demonstrated to be connected to cavities in GW-728, $-29 \mathrm{~m}(95 \mathrm{ft})$ to the north of GW-790.

- Dreier and Koerber (1990) have identified major fault zones at Y-12 Plant by connecting ridge offsets across BCV. Many of these ridge offsets are coincident with valleys on Chestnut Ridge and tributaries on Pine Ridge. One such offset occurs at the BCBG and is associated with a valley in Chestnut Ridge.

$\therefore \quad$ The occurrence of major springs in BCV is associated with zones of major discharge from intermediate and deep groundwater flow paths (Fig. C.8) in the valley floor. These zones occur at five discrete locations along the valley (SS-2, $-4,-5,-6$, and -8 ; refer to Sect. C.4.5) and are probably related to structures that cut across formations that allow deep groundwater to come to the surface.

Cavities and Solution Openings. Fractures are often enlarged by solution. This effect is extensive in the Maynardville Limestone and the Knox Group; in BCV, only these formations display highly developed and well-connected cavity systems. Many of the smaller limestone or dolomite beds with in the predominantly clastic formations, such as the Nolichucky Shale, also exhibit solution openings and cavities at shallow depth.

Cavities in rocks underlying the ORR in the Chickamauga Group were first described by Stockdale (1951, p. 41). Since then, cavities have been reported in most other formations with limestone units (Shevenell and Beauchamp 1994). A general principle of cavity occurrence is that the largest cavities are found in the purest and most massively bedded limestones. Cavities in the Conasauga Group have been reported in the Maryville Limestone, Nolichucky Shale, and Maynardville Limestone.

In BCV, $66 \%$ of wells drilled in the Maynardville Limestone and Copper Ridge Dolomite intercepted at least one cavity and 38\% intercepted two (Shevenell and Beauchamp 1994). During drilling of the Maynardville Exit Pathway Picket Wells (Pickets A, B, C, and W; Fig. C.5), numerous cavities and water-bearing fractures were intercepted (Shevenell et al. 1992). Although no obvious correlation was found between stratigraphic zone and the occurrence of water-bearing zones and cavities in general, most water-bearing zones were intercepted in zones 2 and 6 , and cavities were 
more common in zone 6 (Shevenell et al. 1992; Shevenell and Beauchamp 1994; Goldstrand and Dreier 1993). Regardless of stratigraphic zone, $60 \%$ of cavities were encountered at depths of $<30 \mathrm{~m}$ $(100 \mathrm{ft})$ and nearly all were encountered above $90 \mathrm{~m}(300 \mathrm{ft})$.

Cavities encountered in the Maynardville Limestone range in size from $<0.3 \mathrm{~m}(1 \mathrm{ft})$ to $>3 \mathrm{~m}$ $(10 \mathrm{ft})$ (Shevenell and Beauchamp 1994). In the Maynardville Limestone, $52 \%$ of measurable cavities were between 0.3 and $1.5 \mathrm{~m}$ ( 1 and $5 \mathrm{ft})$ in height, with $12 \%>1.2 \mathrm{~m}(5 \mathrm{ft})$ and $16 \%<0.3 \mathrm{~m}(1 \mathrm{ft})$ (20\% were of unknown height). In the Chestnut Ridge Formation, cavities are generally larger, with

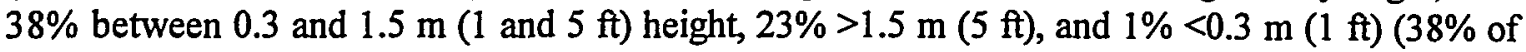
unknown size).

In addition to creating cavities and solution-enlarged fractures in the carbonate formations, water-rock chemical interaction in the Maynardville Limestone and Copper Ridge Dolomite has increased matrix porosity of these formations. Two diagenetic processes - dissolution of evaporite minerals and dedolimitization (Saunders and Toran 1994b) - have produced matrix porosities in these formations of between 1.3 and $2.1 \%$ in the Copper Ridge Dolomite and zone 6 of the Maynardville Limestone, and between 0.5 and $0.8 \%$ in zones 2 to 5 of the Maynardville Limestone (Goldstrand et al. 1995).

\section{C.3.4 FORMATION HYDRAULIC CHARACTERISTICS}

Hydraulic tests in BCV have been conducted by a number of researchers over the past decade (Law Engineering, Inc. 1983; Geraghty and Miller 1986; Lozier et al. 1987; Golder and Associates $1988 \mathrm{a}$ and b; King and Haase 1988) and have included pumping tests, slug tests, packer tests, and tracer tests. Results of these tests show that the Nolichucky Shale is anisotropic and heterogeneous and that semiconfined conditions exist to a depth of $\sim 31 \mathrm{~m}(100 \mathrm{ft})$. Using the results from these tests, transmissivities calculated for the Nolichucky Shale range from $9.29 \times 10^{-7}$ to $1.49 \times 10^{-4} \mathrm{~m}^{2} / \mathrm{s}$ and storage coefficients range from $10^{-4}$ to $10^{-3}$. Consistent with the dominance of strike-parallel fracture directions, pumping test results show that transmissivity in the strike-parallel direction is several times larger than in any other direction. Transmissivities calculated from hydraulic testing conducted in well GW-734, an open hole well in Maynardville Limestone, yielded transmissivities ranging from $6.12 \times 10^{-5}$ to $5.87 \times 10^{-4} \mathrm{~m}^{2} / \mathrm{s}$ (Shevenell $1994 \mathrm{~b}$ ). 


\section{C.4 BCV HYDROGEOLOGIC CONCEPTUAL MODEL - HYDROLOGY}

The hydraulic component of the hydrogeologic conceptual model for BCV is presented here as the hypothesis that best describes the main observations of hydraulic parameters in BCV. Figures C.8 and C.9 depict the hydrogeologic conceptual model for the BCV; Fig. C.8 shows the overall model, and Fig. C.9 shows details of the shallow system.

One of the main points raised by the conceptual model is that although the largest mass of water (and consequently the largest mass of contaminants) exits BCV via surface water, groundwater is the principal pathway for contaminants leaving the waste units. The main flow and contaminant transport pathways in groundwater at the waste units is along strike with the discharge points at tributaries to Bear Creek. For the 10-month monitoring period of BCV Operable Unit (OU) 4 RIFA, it is estimated that $97 \%$ of water available for flow (precipitation - evapotranspiration) exited the upper section of the valley [above Bear Creek Kilometer (BCK) 9.47] as surface water flow (Sect. C.4.1; Fig. C.10). In addition, of water available for flow in the predominantly clastic formations outcropping on Pine Ridge, $94 \%$ exited these formations via surface water in tributaries, and $6 \%$ via subsurface flow. Fluxes in flow paths at the waste units (overland flow, soil interflow, and groundwater flow) have not been quantified; however, hydraulic monitoring data show that overland flow and soil interflow are only important during storm events and recharge followed by groundwater flow to tributaries constitutes the main water flux pathway.

Hydrogeology differs significantly between predominantly clastic formations (such as the Nolichucky Shale) and carbonate formations (such as the Maynardville Limestone), to the extent that they can almost be treated as separate hydraulic entities. In BCV, the contact between the Maynardville Limestone and the Nolichucky Shale roughly corresponds to the axis of the valley (Fig. C.3) and marks a major transition from predominantly clastic formations in the Conasauga Group to carbonate dominant formations in the overlying Knox Group.

Flow in the predominantly clastic formations is mainly by way of fracture flow (Solomon et al. 1992; Moline and Schreiber 1995, draft). More than $95 \%$ of flow occurs through the shallow interval [ $<30 \mathrm{~m}(100 \mathrm{ft})]$ of the formations, principally in the water table interval at the bedrock/residuum interface (Sect. C.4.2). In this interval of the groundwater regime, flow rates can be very rapid (up to $40 \mathrm{~m} / \mathrm{d}$; Sanford and Solomon 1995; McKay et al. 1995) and may be even greater during transient storm events. The transient response of surface water streams to precipitation shows that both interflow through soils and groundwater flow through the water table interval are probably major components of the total flow during storm events.

Flow in the carbonate formations has components of both fracture flow and flow through solution-enlarged cavities and conduits (Shevenell 1994b). Although most flow in the carbonate dominant formations probably occurs in the shallow bedrock interval [ $<30 \mathrm{~m}(100 \mathrm{ft})$ depth], components of groundwater flow occur in deeper intervals [ $>30 \mathrm{~m}(100 \mathrm{ft})$ depth] (Solomon et al. 1992). The shallow interval [ $<30 \mathrm{~m}$ (100 ft) depth] of the Maynardville Limestone in BCV is dominated by a maze-like system of interconnected cavities and solution-enlarged fractures. Bear Creek can be considered as one of the primary conduits for flow in this cavity system.

The dynamic nature of the hydrology of $\mathrm{BCV}$ is extremely important, both for predominantly clastic and carbonate formations. The nature, rate, and direction of groundwater flow are transient and vary based on the climatological conditions. Variations occur on different scales: an annual cyclic variation resulting from seasonal climatic effects (Sect. C.4.3) and a short-term variation 
resulting from the response to individual storm events (Sect. C.4.4). Head in groundwater wells and baseflow in streams relate both to the amount of precipitation and the rate of evapotranspiration. In general, flow in streams is greatest and groundwater elevations are highest during late winter and early spring because annual precipitation is greatest during this time period and moisture demand from plants is at a minimum. Conversely, during the summer and fall, precipitation is usually relatively low and evapotranspiration is high. During this time, flow in most tributaries to Bear Creek ceases, and groundwater elevations fall to their lowest levels.

Additional key features of the hydraulic component of the hydrogeologic conceptual model are as follows:

\section{Flow in Predominantly Clastic Formations}

- Although there are no clearly defined abrupt hydrogeologic changes in the clastic formations with depth, a general hydrogeologic stratigraphy can be defined that separates these formations into shallow-, intermediate-, and deep-flow regimes (Fig C.8; Solomon et al. 1992). The boundary between shallow and intermediate intervals is defined by a consistent change in

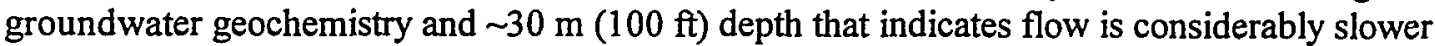
below this depth (Haase 1991; Dreier et al. 1993). The boundary between intermediate and deep intervals is poorly defined and is indicated by a change in groundwater geochemistry that has been observed between 100 and $150 \mathrm{~m}$ (328 and $492 \mathrm{ft}$ ) depth (Solomon 1992; Haase 1991; Dreier et al. 1993). The deep interval probably relates to the base of effective flow in the clastic formations.

- Most flow occurs in the predominantly clastic formations in the shallow interval. This interval includes the water table interval that usually occurs close to the bedrock/residuum interface, where a high conductivity zone is hypothesized to exist. Most flow in the shallow interval is probably through this high conductivity zone or through other preferential flow pathways in the bedrock. Flow in the shallow interval is oriented predominantly along geological strike, with discharge occurring at the tributaries to Bear Creek.

- Geochemistry indicates that greater groundwater residence times and, thus, slower flow generally occur below $30 \mathrm{~m}$ (100 ft) in the intermediate interval (Sect. C.4.2). However, the distribution of contaminant plumes in $\mathrm{BCV}$ indicates that more rapid flow than predicted by major ion geochemistry may occur in an along strike direction along preferential pathways in this interval [nitrate from the S-3 Site has migrated $\sim 1 \mathrm{~km}(0.62$ mile) or more since 1950; refer to Appendix D].

- An upward hydraulic gradient occurs almost everywhere in the bedrock of the predominantly clastic formations that outcrop on the southern flank of Pine Ridge (Sect. C.4.2). This upward hydraulic gradient is a function of the anisotropy of the geological formations and the average $45^{\circ}$ dip of the beds. Pressure head in bedrock is partially controlled by the elevation of the recharge zone, which correlates approximately to the elevation at outcrop of each stratigraphic zone. The elevations at outcrop of stratigraphic zones in the Nolichucky shale increases with depth, thus creating an upward hydraulic gradient.

- During rainfall events, the hydrological system in the predominantly clastic formations responds in changing ways to the influx of water (Sect. C.4.4):

- The shallow portions of the soil profile become saturated, transmitting water laterally downslope to springs and seeps in the banks of streams as interflow. 


\section{C4-3}

- Fractures in the residuum also become saturated, transmitting water rapidly to the shallow groundwater table. As a result, the elevation of the water table rises rapidly during rainfall events.

- The elevated water table increases the rate of groundwater flow in the water table interval and, subsequently, groundwater discharge to streams increases.

- During the heaviest precipitation events, flow in streams increases very rapidly as overland flow enters the stream channels.

- After precipitation has ceased, flow in streams reflects the rate of drainage from three reservoirs of water: overland flow, soil interflow, and groundwater flow. These components of the hydrologic system drain at varying rates: overland flow is the most rapid, stormflow is intermediate, and groundwater discharge declines at the slowest rate and reaches near pre-precipitation levels within a few days.

- Although flow through the porous matrix constitutes a minor component of flow volume in all formations, it plays an important role in contaminant migration because matrix diffusion will significantly slow down contaminant transport rates.

\section{Flow in Carbonate Formations}

- The Maynardville Limestone outcrops along the southern side of the BCV floor. This formation and Copper Ridge Dolomite act as a hydraulic drain for the valley. Flow in these formations is predominantly along strike, parallel to the maximum hydraulic gradient.

- The hydrostratigraphy in the carbonate formations is less well defined than that in the clastic formations (Fig C.8; Solomon et al. 1992). The definitions of shallow, intermediate, and deep regimes are not rigid and rely on cumulative evidence from cavity occurrence (Shevenell et al. 1992; Shevenell and Beauchamp 1994), hydraulic and geochemical responses during storms (Shevenell 1994b; Sect. C.6.2 in Supporting Information for Appendix C), and the distribution of contaminant plumes (Appendix D).

- The shallow interval includes groundwater to $30 \mathrm{~m}(100 \mathrm{ft})$ depth. Flow in this interval occurs through a maze of interconnected solution conduits and cavities (Sect. C.3.3) and is closely associated with flow in Bear Creek (Sect C.4.5). The channel of Bear Creek can be considered conceptually as one of the main hydraulic conduits in this conduit system. In this interval, groundwater flow is relatively rapid and, during storm events, recharge to this interval occurs as a quickflow. Contaminants are easily flushed through this interval, and dilution effects that arise from rainfall/recharge and quickflow mean that contaminant plumes tend to attenuate rapidly along strike.

- The intermediate interval occurs between $\sim 30$ and $100 \mathrm{~m}$ (100 and $328 \mathrm{ft})$. Solution cavities and solutionally enlarged fractures exist in the Maynardville Limestone in this interval. This zone is known to have high flow rates where solution features have been encountered during drilling. Because of its depth, this zone is isolated from dilution effects seen in shallower zones and constitutes an important contaminant transport pathway.

- In the deep interval [ $>100 \mathrm{~m}(328 \mathrm{ft})$ depth], the flow through fractures dominates groundwater movement, and as fracture density decreases with depth, flow zones become less frequent.

- Bear Creek displays losing and gaining reaches where groundwater is recharged and discharged to the surface, respectively (Sect. C.4.5). Major gaining reaches along strike are associated with large springs in the floodplain of Bear Creek, which may be sites of upwelling groundwater 


\section{C4-4}

from deep flowpaths in the Maynardville Limestone. The locations of these springs may be controlled by large-scale geologic structure, such as across strike faults, or thinning of the Maynardville Limestone due to stratigraphic changes or faulting.

The features of the hydraulic component of the hydrogeological conceptual model listed above are discussed in detail in the following sections. Detailed analyses of hydraulic data taken during the BCV OU 4 RIFA are presented in the Supporting Information to this appendix.

\section{C.4.1 WATER BALANCE MODEL FOR BCV}

The detailed water balance of the upper section of the Bear Creek catchment in BCV (above BCK 9.47) establishes the dominant role that surface water flow plays in the overall mass flux of water out of the valley. The water balance model has been completed for only that portion of BCV that is upgradient of BCK 9.47 for a 10-month monitoring period between March 1994 and February 1995. This is the portion of the valley for which there is intensive flow monitoring provided from the RIFA (Appendix B, Sect. B.4).

The water balance attempts to balance the total volume of water entering this section of BCV (inflow) with the total volume of water flowing along strike in BCV at BCK 9.47 and SS-5 (outflow) for the 10-month monitoring period (Sect. C.6.5 in Supporting Information for Appendix C) using water fluxes that were measured during the RI (gaged) or have been calculated (ungaged). Inflow is by way of a single component: rainfall (gaged). The conceptual model for BCV has four outflow fluxes: evapotranspiration (ungaged), flow in BCV at BCK 9.47 (gaged), flow in SS-5 (gaged), and along strike flow in groundwater over a plane at BCK 9.47 (ungaged). Gaged fluxes were measured and have relatively little uncertainty associated with their values; for example, flow monitoring of the tributaries and Bear Creek provided data necessary to accurately define the surface water component of the water balance model with little uncertainty.

Of the parameters of the water balance model shown in Fig. C.10, the values of ungaged fluxes were derived in the following ways (refer to Supporting Information for Appendix C):

- Along strike flow in groundwater was estimated from the site-wide groundwater flow model for BCV (Jacobs Engineering 1995, in preparation).

- Evapotranspiration was calculated by a process of elimination, and the value obtained was compared to results of modeling evapotranspiration using the HELP model (Schroeder et al. 1994). It assumed that there is no net change in the volume of groundwater in this portion of $\mathrm{BCV}$ during the period of calculation. Evapotranspiration then becomes the only unquantified value in equation 1 on Fig. C.10. The total evapotranspiration flux over this 10 -month period was calculated as $2.78 \times 10^{6} \mathrm{~m}^{3}$, which compares favorably with the modeled flux of $3.10 \times 10^{6} \mathrm{~m}^{3}$. The $\sim 10 \%$ variance between these two values is a reasonable margin of error to expect from mass balance modeling of this type and suggests that the results of overall water balance model are reasonable.

- Across strike flow of groundwater was derived by a process of elimination using a water balance model for only the predominantly clastic formations (Fig. C.10). This model assumed that all available water for the siliceous formations (precipitation - evapotranspiration) either moves along strike (modeled) or flows into Bear Creek and/or the Maynardville Limestone. This parameter then becomes the only unquantified value in equation 2 on Fig. C.10. 
Surface water flow leaving the upper section of the valley during the 10 -month monitoring period constituted $40.5 \%$ of precipitation (flow at BCK 9.47 and SS-5 combined; Fig. C.10) or $97 \%$ of the water available for flow (precipitation - evapotranspiration). For the predominantly clastic formations underlying the southern flank of Pine Ridge, $94 . \%\left(1.087 \times 10^{6} \mathrm{~m}^{3}\right)$ of available water left as surface water flow in tributaries. Only $6 \%\left(0.069 \times 10^{6} \mathrm{~m}^{3}\right)$ of available water left these formations as groundwater and, of this amount, $0.6 \%\left(0.007 \times 10^{6} \mathrm{~m}^{3}\right)$ left by way of along strike flow and $5.4 \%$ $\left(0.062 \times 10^{6} \mathrm{~m}^{3}\right)$ entered the Maynardville Limestone as ungaged subsurface flow. Thus, the model estimates that, during this 10 -month period, $99.4 \%$ of water falling on the predominantly clastic formations in BCV flowed out of these formations into either Bear Creek or the Maynardville Limestone.

For the $94 \%$ of available water that flows in tributaries along the flank of Pine Ridge to Bear Creek, the pathways for water to arrive at the tributaries vary and include overland flow, soil interflow, and groundwater flow. These components of the total flow in the tributaries have not been quantitatively itemized in this water balance, but are discussed in more detail in the following sections. Of the $5.4 \%$ of precipitation falling on the flank of Pine Ridge that flows into the Maynardville Limestone, the depth at which this groundwater is flowing is not known; however, most probably flows through the shallow system into the Maynardville Limestone, with only a very small proportion of groundwater in the bedrock of the Nolichucky Shale flowing across strike into the Maynardville Limestone.

Of the total available water for Bear Creek and the Maynardville Limestone (precipitation-evapotranspiration plus inflow from the siliceous formations), 80.8\% $\left(1.616 \times 10^{6} \mathrm{~m}^{3}\right)$ leaves at BCK 9.47 via surface water flow, and an additional $16.2 \%\left(0.323 \times 10^{6} \mathrm{~m}^{3}\right)$ leaves as discharge to the surface water at SS-5. Only $2.7 \%\left(0.054 \times 10^{6} \mathrm{~m}^{3}\right)$ of flow along strike in BCV at BCK 9.47 is via groundwater flow in the Maynardville Limestone.

\section{C.4.2 GROUNDWATER FLOW CHARACTERISTICS}

The direction of groundwater movement generally is controlled by the potentiometric gradient and the permeability of the medium. In a completely isotropic aquifer, the flow direction of groundwater should be normal to the equipotential contours of the aquifer. However, in anisotropic formations such as those in the Conasauga and Knox Groups, flow directions are strongly controlled by the orientation of the bedding planes, fractures, and joints as well as by the distribution of solution cavities. Thus, a map of potentiometric contours based on observed head differences in wells in BCV indicates only the general direction of groundwater flow.

Tracer studies, potentiometric data, and geochemical data have been used to determine flow paths in BCV. These data are discussed in the following sections.

\section{C.4.2.1 Tracer Studies}

Tracer tests have revealed that groundwater flow directions in the shallow bedrock of the predominantly clastic formations may be oriented parallel to strike and almost perpendicular to the prevailing hydraulic gradient (Lee et al. 1992). In addition, tracer migration may undergo rapid and transient changes in direction during storm events, the net result of which may be increased dispersion and possible differing wet- and dry-season flow paths. Moline and Schreiber (1995, draft) report variations in hydraulic characteristics within individual wells located in shallow bedrock of the Nolichucky Shale in BCV that were equipped with multiport monitoring devices. Preliminary 
results of this ongoing study suggest that, although flow dynamics are complex, groundwater flow is strongly controlled by lithology and bedding orientation.

In a tracer study conducted on the Nolichucky Shale in BCV (Lee et al. 1992), the rhodamine tracer, which was injected into the top $0.3 \mathrm{~m}(1 \mathrm{ft})$ of the water table, traveled only in the shallow water table interval. The initial breakthrough of this dye indicated a velocity of $5 \mathrm{~m} / \mathrm{d}$; however, after the initial breakthrough, the tracer test recorded migration rates of 0.04 to $0.09 \mathrm{~m} / \mathrm{d}$ for the more concentrated plume. This pattern was interpreted as (1) rapid migration of the dye in transmissive fractures accompanied by diffusion of most of the tracer into poorly connected fractures, followed by (2) slow release of the tracer to the active fractures by matrix diffusion.

Recent work by Sanford and Solomon (1995), McKay et al. (1995), and Sanford et al. (1994) at the same site as the 1989 study (Lee et al. 1992) indicates that over the past 5 years the 10 parts per billion ( $\mathrm{ppb}$ ) contour for the dye tracer has hardly moved from the position in which it was located 3 months after the tracer injection. Analysis of residuum conducted during installation of new monitoring wells at this site indicates that the highest concentrations of dye are located at the centerline of the plume in an apparently laterally continuous zone $\sim 1.5 \mathrm{~m}(5 \mathrm{ft})$ thick.

Results of a noble gas tracer study in the water table interval of BCV at the same site support the concept of a very active fracture-flow system at the water table (Sanford and Solomon 1995; McKay et al. 1995; Sanford et al. 1994). Using neon and helium as tracers and a passive gas sampling methodology to allow sampling of groundwater under ambient conditions, these studies recorded migration rates of up to $4 \mathrm{~m} / \mathrm{d}$ in the shallow water table interval, very similar to those estimated from the initial release of the rhodamine dye tracer. Helium has a greater diffusivity than neon, and data from Sanford and Solomon (1995) indicate that the tracer plume is relatively enriched in neon resulting from the greater tendency for helium to diffuse into the matrix. In addition to noble gas tracers at this site, McKay et al. (1995) experimented with colloid tracers, which would not be expected to diffuse into the matrix to any great extent. Migration rates for these colloids appear to have reached $45 \mathrm{~m} / \mathrm{d}$ at this site. These data indicate that migration rates in the water table interval depend on the characteristics of the migrating species and can be highly heterogenous, varying by as much as four orders of magnitude.

\section{C.4.2.2 Potentiometric Data}

Water level data are collected, at a minimum, each time monitoring wells are sampled as part of the Y-12 Plant compliance program. Recent results reveal a groundwater piezometric surface (Figs. C.11 and C.12) sloping in from recharge areas on ridges to discharge along Bear Creek (e.g., HSW 1995). The piezometric surface indicates a groundwater divide just east of the S-3 and Spoil Area 1 sites. This divide is the eastern boundary of the Bear Creek Hydrogeologic Regime (BCHR).

Dreier et al. (1993) present detailed hydraulic head measurements from four deep coreholes (GW-132, $-133,-134$, and -135 ), the locations of which form a transect across BCV in the vicinity of the S-3 Site. Westbay ${ }^{\mathrm{TM}}$ multiport samplers installed in each of the coreholes allowed hydraulic head measurements, hydraulic testing, and water sampling in discrete intervals within the groundwater system. Figure C.13 is a hydrologic cross-section of hydraulic head contours across the head of the BCHR, which shows topographically driven recharge from adjacent ridges and convergent flow to the Maynardville Limestone in the axis of the valley (Note that these data also show a pressure bulge with in the Nolichucky Shale at the S-3 Site, which is attributed to pond waste water that infiltrated from the S-3 Site when the ponds were active). 
The hydraulic head distributions in well pairs in the Nolichucky Shale (Fig. C.14), combined with the studies Dreier et al. (1993; Fig. C.13) and Dreier and Davidson (1994; Fig C.7), indicate that on a valley-wide scale, vertical upward hydraulic gradients predominate in the Nolichucky Shale in the intermediate, deep, and shallow bedrock intervals [depths ranging from 14 to $152 \mathrm{~m} \mathrm{(45} \mathrm{to}$ $500 \mathrm{ft}$ )]. Hydraulic gradient vary from -0.22 and 0.35 (negative indicates downward gradients); however, downward gradients are only observed in wells between the water table interval and shallow bedrock wells, indicating local recharge to the shallow system. Water level data from the Maynardville Limestone indicate variable gradients ranging from -0.15 to 0.1 with predominantly downward gradients (Fig. C.14).

The predominance of vertically upward hydraulic gradients in the Nolichucky Shale is probably caused by the strong anisotropy of the formation, where conductivity oriented parallel to bedding planes may be one or two orders of magnitude greater than that across strike. Bedding in the Conasauga Group dips uniformly to the south, and recharge most likely flows downward in bedrock, parallel to dip. Pressure head at depth is, therefore, partly controlled by the elevation of the recharge zone, or outcrop of that stratigraphic zone, which is topographically higher up on Pine Ridge with increasing depth in the Nolichucky Shale.

\section{C.4.2.3 Geochemical Data}

Large-scale groundwater flow in BCV was studied using patterns of groundwater geochemistry observed at the BCBG by Haase (1991) and data from a series of deep [ $>305 \mathrm{~m}(1000 \mathrm{ft})$ ] groundwater wells installed at the S-3 Site with multiport sampling devices (Dreier et al. 1993; Toran and Saunders 1992a and b; Saunders and Toran 1994a and b).

Haase (1991) reported three distinct groundwater geochemical facies in BCV and concluded that the major ion geochemistry of groundwater in BCV is a function of residence time and flow path length. Dreier et al. (1993) identify these facies in the deep multiport well transect of BCV and an additional facies (Figs. C.15 and C.16). Toran and Saunders (1992b) and Saunders and Toran (1994b) interpret the data from Dreier et al. (1993) to determine the mechanisms controlling chemical evolution of groundwater in BCV (Fig. C.17). A more rigorous cluster analysis of groundwater types completed as part of the BCV RI (Sect. 3.2; HSW 1995) confirmed the findings of the previous studies. The four identified groundwater facies were described as follows:

- Calcium/magnesium bicarbonate $\left(\mathrm{Ca} / \mathrm{Mg} \mathbf{H C O}_{3}\right)$ : Groundwater from this facies type generally has total dissolved solids (TDS) $<300 \mathrm{mg} / \mathrm{L}$; has $\mathrm{Ca} / \mathrm{Mg}$ ratios usually close to 1 , but ranging from 0.50 to 14 (expressed as milliequivalents); and is usually saturated or slightly oversaturated with respect to calcite and dolomite (Toran and Saunders 1992b). This groundwater facies type generally occurs in water table and shallow bedrock wells in the predominantly clastic formations and in most wells in the carbonate formations in BCV (HSW 1995).

- Sodium bicarbonate $\left(\mathrm{Na}-\mathrm{HCO}_{3}\right)$ : Groundwater from this facies type typically has TDS $>400 \mathrm{mg} / \mathrm{L}$, very low $\mathrm{Ca}$ and $\mathrm{Mg}$ concentrations, and $\mathrm{pH}$ up to 9 . It is usually saturated with respect to calcite and undersaturated to saturated with respect to dolomite, and occurs in wells in the siliceous dominant formations screened $<30 \mathrm{~m}$ (100 ft) depth (HSW 1995). This facies type has been interpreted as being derived from $\mathrm{Ca} / \mathrm{Mg} \mathrm{HCO}_{3}$ type groundwater by water-rock interaction with minerals in the shale formations. Toran and Saunders (1992b) suggested that the observed water types could be derived solely by mineral dissolution and precipitation reactions and that cation exchange reactions may not be important in deriving the bulk chemistry of this facies type (Fig. C.17). 
- Calcium/magnesium sulfate $\left(\mathrm{Ca} / \mathrm{Mg}-\mathrm{SO}_{4}\right)$ : Groundwater from this facies type typically has TDS $>2000 \mathrm{mg} / \mathrm{L}$, has $\mathrm{pH}<8$, and is usually supersaturated with respect to calcite and dolomite. This groundwater facies type was identified in the multiport sampling wells installed at the S-3 Site (Dreier et al. 1993; Saunders and Toran 1994b). Building on the identification of gypsum nodules in core from these wells (Dreier et al. 1993), Saunders and Toran (1994b) interpret this facies type as being derived from dedolomitization reactions in discrete zones of the Maynardville Limestone and Copper Ridge Dolomite Formations resulting from dissolution of gypsum.

- Sodium/calcium chloride/bicarbonate ( $\left.\mathrm{Na} / \mathrm{Ca}-\mathrm{Cl} / \mathrm{HCO}_{3}\right)$ : This facies type exhibits high TDS

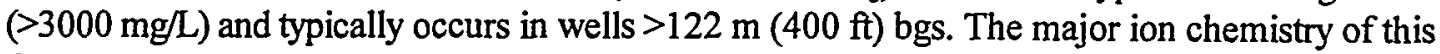
facies type varies; however, high concentrations of sodium and chloride are characteristic of this facies type. Toran and Saunders (1992b) interpret this facies type as resulting from the mixing of groundwater with a deeper brine, either by advective flow or by chemical diffusion. Identification of precipitates of barite $\left(\mathrm{BaSO}_{4}\right)$ and celestite $\left(\mathrm{SrSO}_{4}\right)$ in core from the multiport wells supports this hypothesis of Sr- and Ba-rich brines [brines with high concentrations of $\mathrm{Ba}$ and $\mathrm{Sr}$ are observed in Melton Valley (Switek et al. 1987)] mixing with a sulfate-rich groundwater.

In general, in the predominantly clastic formations, $\mathrm{Ca} / \mathrm{Mg} \mathrm{HCO}$ type groundwater is associated with shorter residence time and shorter flow paths than the $\mathrm{Na}-\mathrm{HCO}_{3}$ type groundwater. The consistent change from $\mathrm{Ca} / \mathrm{Mg} \mathrm{HCO}$ type groundwater to $\mathrm{Na}-\mathrm{HCO}_{3}$ type groundwater at 30 to $61 \mathrm{~m}$ (100 to $200 \mathrm{ft}$ ) in the predominantly clastic formations implies the existence of a distinctly younger water type in a more active flow system at depths $<30 \mathrm{~m}$ (100 ft) compared to an older, less active, water type below $30 \mathrm{~m}$ (100 ft). For the carbonate formations, $\mathrm{Ca} / \mathrm{Mg} \mathrm{HCO}_{3}$ type groundwater occurs at all depths, except for (1) gypsum-rich zones, where $\mathrm{Ca} / \mathrm{Mg} \mathrm{SO}_{4}$ groundwater dominates, and (2) the deepest wells, where $\mathrm{Na}-\mathrm{Cl}$ groundwater occurs.

\section{C.4.3 TRANSIENT RESPONSES TO ANNUAL CHANGE}

Piezometric head in groundwater wells and baseflow in tributaries and Bear Creek show seasonal changes in magnitude that relate both to the amount of precipitation and the rate of evapotranspiration (Figs. C.18 and C.19). In general, flow in streams is greatest and groundwater elevations are highest during late winter and early spring. This is because annual precipitation is greatest during this time period and moisture demand from plants is at a minimum. Conversely, during the summer and fall, precipitation is usually relatively low and evapotranspiration is high. During this time, flow in most tributaries to Bear Creek ceases and groundwater elevations fall to a minimum.

Detailed monitoring of groundwater wells in BCV during 1994 recorded both periods of rising groundwater levels and declining groundwater levels. Figure C.20 shows the piezometric head in three wells screened at the water table interval (GW-624), the shallow bedrock (GW-626), and deep bedrock (GW-629) intervals of the Nolichucky Shale during March and April 1994. These records show steadily increasing groundwater pressure at all depths in the Nolichucky Shale during a period of high rainfall. During this time period, BCV experienced a number of large storms [over $36 \mathrm{~cm}$ (14 in.) precipitation during one month], and rapid recharge shallow groundwater during each storm results in rapid changes in GW-624, as discussed above. The two deeper wells in this well group also display slight immediate changes in water level. In addition, the pressure head in these wells increases fairly uniformly by $-0.60 \mathrm{~m}(2 \mathrm{ft})$ over the period of monitoring in response to the period of heavy rain. 
The converse effect can be observed in wells screened in the Maynardville Limestone that were monitored during May 1994. The hydrographs from wells GW-227, $-228,-725$, and -736 show a continuous declining trend over this period of monitoring [Fig. C.21; the greatest fall in head was recorded in GW-228 at $2.6 \mathrm{~m}(8.5 \mathrm{ft})$ and the smallest change in GW-725 of $0.98 \mathrm{~m}(3.2 \mathrm{ft})]$. This time period contains three precipitation events [a total of $5.6 \mathrm{~m}(2.2 \mathrm{in}$.$) ], and these wells show little$ or no response to these events. The period of monitoring for these wells coincided with the time period of increasing water demand from plants during the leafing-out period.

\section{C.4.4 TRANSIENT RESPONSES TO STORMS}

Stream flow in Bear Creek and its tributaries is highly responsive to precipitation. At all tributary sites monitored during the OU $4 \mathrm{RIFA}$, flow in the stream channel increased rapidly after precipitation commenced in the valley (e.g., Figs. C.22 and C.23). After precipitation ceased, flow in the streams rapidly declined to baseflow within 2 or $3 \mathrm{~d}$. This effect is termed quickflow (Shevenell 1994b). Understanding how quickflow operates in BCV is important to conceptualizing contaminant migration pathways in the valley. Quickflow during storms has a strong influence on contaminant migration from sources to tributaries draining Pine Ridge, and may also promote along-strike migration of contaminants in the Maynardville Limestone.

Three main components of the BCV hydrologic system (surface water flow, groundwater piezometric head, and soil saturation) were monitored during the BCV OU 4 RIFA to determine their responses to precipitation. Results and analysis of this monitoring are presented and discussed in the Supporting Information for this appendix. In general, during precipitation events, the components of the hydrogeologic regime showed these following responses (Figs. C.22 and C.23):

- first, water level in stormflow tubes increases immediately and ceases rising when precipitation ceases, indicating soil saturation and probable interflow during storms;

- then, flow in streams responds similarly to stormflow tubes by increasing immediately as precipitation starts and falling as precipitation ceases; and

- finally, the pressure head in shallow groundwater wells increases almost immediately during precipitation events and continues rising in some wells for up to $2 \mathrm{~d}$ after cessation of rainfall (Fig. C.23).

Figures C.22 and C.23 each show an example of the responses in these components to storms in BCV: Fig. C.23 from close to the S-3 Site during the summer low flow period and Fig. C.22 from the BCBG during the winter/spring high flow period. In each example, all components respond to precipitation rapidly and in almost the same sequence: first, soil saturation; then, surface water; and lastly, groundwater.

In addition, analysis of the regression hydrographs from streams, groundwater wells, and stormflow tubes provides an indication of the relative change that occurs in each of these components after precipitation has ceased. The regression section of the hydrograph depends on the rate of change of storage in the basin after a storm has stopped. In BCV, three types of water storage are included in the hydrogeologic conceptual model: overland flow, soil saturation, and groundwater. When plotted on semi-logarithmic axes, the slope of the regression curve $(\lambda)$ is indicative of the rate of change of water storage in the hydrogeologic system upgradient of the monitoring point and indicates the flow pathways that are operating from soils to tributary streams (refer to Supporting Information for Appendix C). 


\section{C.4.4.1 Soil Saturation, Interflow, and Surface Runoff}

Stormflow tubes were first to respond to precipitation, with soil becoming saturated (and the tubes starting to collect water) between 1 and $3.5 \mathrm{~h}$ after precipitation starts. At the BCBG, groundwater piezometric head and surface water start to rise almost simultaneously about $30 \mathrm{~min}$ after the stormflow tube reacts (Fig. C.23). At the S-3 Site, surface water starts to rise about $1 \mathrm{~h}$ after the stormflow tube and about $1 \mathrm{~h}$ before groundwater (Fig. C.22). This indicates that, before interflow or recharge begin, the upper layers of the soil need to reach a level of saturation that allows for flow through the soil.

The rapid response of stormflow tubes has been observed in previous studies (Moore 1988) and was hypothesized to result in interflow in the uppermost layers of the soil (Moore and Toran 1992). Moore $(1988,1992)$ and Solomon et al. (1992) suggested that a large proportion of flow on the ORR occurs as interflow through the soil and upper regolith, and referred to this process as stormflow. The stormflow zone corresponds approximately to the root zone, and infiltration tests indicate that this zone may be as much as 1000 times more permeable than the underlying vadose zone (Moore 1988). The rapid response to precipitation in shallow groundwater wells in BCV indicates that stormflow plays a lesser role in water movement in BCV and that flow in shallow groundwater accounts for a larger portion of the water flow.

\section{C.4.4.2 Transient Response in Tributaries Draining Pine Ridge}

Tributaries to Bear Creek draining Pine Ridge show rapid increases in flow during storm events. During the two storm events depicted in Figs. C.22 and C.23, surface water flow starts increasing slightly soon after rainfall and coincident with the stormflow tubes. However, after 30 to $60 \mathrm{~min}$, surface water flow increases rapidly, which is interpreted as the start of overland runoff and soil interflow reaching the stream channels.

For tributaries in BCV, the rising limbs of hydrographs are very steep, and little delay occurs between peak rainfall intensity and peak discharge in the streams. In one extreme case, the level in

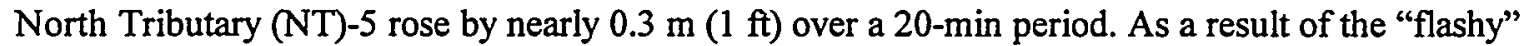
nature of runoff in $\mathrm{BCV}$, the flow hydrographs show a wide range in flow over short periods, with flow most of the time at baseflow level (e.g., as shown in the annual hydrograph for BCK 9.47, Fig. C.18), representing groundwater discharge.

This rapid response to precipitation is typical of streams draining low conductivity formations and can be explained by a combination of overland flow, soil interflow, and rapid shallow groundwater flow that operates only during, and immediately following, storms (Bras 1990).

For many storms in BCV, three segments of the surface water regression hydrograph with different linear slopes $(\lambda)$ were identified in many storm hydrographs plotted on semi-logarithmic axes (Supporting Information for this appendix) and probably relate to different rates of drainage from the three components of the hydrogeologic conceptual model. These are:

- The steepest slope on the regression curve (a) occurs immediately after precipitation ceases and is interpreted as being derived predominantly from water drainage from surface water bodies (i.e., streams channels and ponded water). The mean values for $\lambda$ for this initial segment of the regression curve range from 0.596 to $1.26 \mathrm{~h}^{-1}$. In general, the highest values for $\lambda$ for this segment of the hydrographs tend to coincide with the most intense precipitation events, probably as a result of greater ponding and surface runoff during the most intense rainfall. Due to the rate of decline of flow during this segment of the regression curve, this period is short-lived, ranging 
from 1 to $6 \mathrm{~h}$ after cessation of precipitation for BCV tributaries and main stem. In some instances, where rainfall intensity is insufficient to saturate soils, this section of the regression curve is missing.

- The intermediate slopes in the regression curves (b) are interpreted as resulting from the decline in runoff and from the flow in the streams being dominated by runoff derived from soil drainage and quickflow drainage. The mean values for $\lambda$ for this segment of the regression curve range from $0.061 \mathrm{~h}^{-1}$ to $0.167 \mathrm{~h}^{-1}$. The section of the regression curve where soil drainage and quickflow dominate the flow in the streams in BCV lasts from 8 to $24 \mathrm{~h}$, depending on the intensity of the storm.

- The lowest slopes in the regression curves (c) are interpreted as resulting from the decline in runoff derived from groundwater discharge alone. The mean values for $\lambda$ for this segment of the regression curve range from $0.010 \mathrm{~h}^{-1}$ to $0.038 \mathrm{~h}^{-1}$. This segment of the regression curve may continue for a number of days and is usually truncated by the next precipitation event or by the stream drying up.

\section{C.4.4.3 Groundwater in Predominantly Clastic Formations}

Shallow groundwater in the clastic formations responds rapidly to precipitation. During the two storm events depicted in Figs. C.22 and C.23, water levels in the shallow wells start increasing rapidly between 0.5 and $2 \mathrm{~h}$ after the stormflow tubes react, which is interpreted as the start recharge to groundwater after the soils reach close to saturation. The reaction to precipitation in GW-345 at the S-3 Site is delayed relative to that of GW-624 at the BCBG. The differences between these sites probably reflect the difference in the time of year during which the monitoring occurred. In addition, GW-624 generally shows more rapid and sharper responses to precipitation, indicating a well-connected fracture network.

Rapid transient response of groundwater pressure head in the Nolichucky Shale has been observed in this study (refer to Supporting Information for Appendix C) and elsewhere in BCV (Moline and Schreiber 1995, draft; Sanford et al. 1994). Rapid pressure responses to precipitation were observed in shallow wells with screened intervals $<10 \mathrm{~m}$ (33 ft) depth [e.g., GW-127 at $7.3 \mathrm{~m}$ (24 ft) or GW-624 at $5.2 \mathrm{~m} \mathrm{(17} \mathrm{ft);} \mathrm{Fig.} \mathrm{C.24;} \mathrm{Supporting} \mathrm{Information,} \mathrm{Sect.} \mathrm{C.6.3].} \mathrm{The} \mathrm{transient}$ pressure response to precipitation in some shallow wells was accompanied by rapid changes in specific conductivity, indicating that newly recharged rainwater occurs in these wells a short time after initiation of rainfall. Pressure responses were observed in deeper wells, but, although the initial responses were rapid, the responses were smaller and slower to reach peak pressure than that

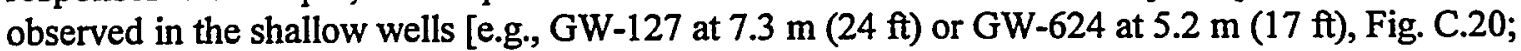
Supporting Information, Sect. C.6.3]. The deeper wells did not show specific conductivity response to precipitation.

The response of groundwater in the clastic formations can be explained by rapid recharge to the water table during the storm event and transmission of a pressure pulse to deeper intervals of the formations. The magnitude and rapidity of the observed rises in the water table imply that recharge occurs along discrete permeable features in the residuum that become saturated during rain events (Solomon et al. 1992). This creates localized and temporarily perched water tables where fractures are saturated even though surrounding pores may remain unsaturated and contain trapped air. During recharge events, flow paths in the vadose zone are probably complex and may be controlled by the orientation of structures, such as relict fractures. 


\section{C.4.4.4 Groundwater in Carbonate Formations}

Rapid transient response of groundwater pressure head in the Maynardville Limestone has been observed by a previous study (Shevenell 1994b) and in this study (Fig. C.25; refer to Supporting Information for this appendix). Pressure pulses from precipitation events have been observed in wells as deep as $164.3 \mathrm{~m}$ (539 ft) (GW-710; Fig. C.25). The transient pressure response to precipitation in

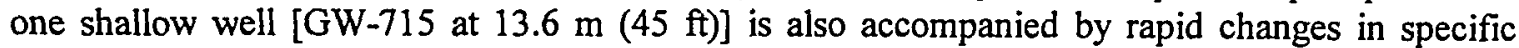
conductivity, indicating that newly recharged rainwater occurs in this well a short time after initiation of rainfall (Shevenell 1994b). Data taken during the BCV OU 4 RIFA from deeper wells or wells without observed cavities in the Maynardville Limestone [e.g., GW-094 at $39.1 \mathrm{~m}(128 \mathrm{ft})$ or GW-651 at $15.8 \mathrm{~m}$ (52 ft), Supporting Information, Sect. C.6.3] show similar pressure responses during storm events but do not have the accompanying specific conductivity change.

Shevenell (1994a) concluded that quickflow in response to precipitation occurred in the Maynardville Limestone and Copper Ridge Dolomite through cavities and fractures. The data from Shevenell (1994b) and this study (refer to Supporting Information for Appendix C) indicate that during precipitation a pressure pulse is transmitted rapidly through the carbonate dominant formations in BCV throughout the fracture and cavity network. The fracture and cavity network is vertically well-connected and pressure pulses are rapidly transmitted to depths $>152 \mathrm{~m}(500 \mathrm{ft})$. The differences in responses by specific conductivity between shallow and deep wells indicate that water recharges rapidly and enters the cavity system in the most shallow [ $30 \mathrm{~m}(100 \mathrm{ft})]$ intervals of these formations within a few hours after precipitation begins. Although these pressure pulses may induce a temporary change in the rate of flow in the deeper bedrock [ $>30 \mathrm{~m}(100 \mathrm{ft})]$ intervals, recharge water takes longer to reach these intervals.

The contrast between the transition of pressure pulses in the clastic formations and carbonate formations is striking. The pressure pulse in clastic formation at depths $>10 \mathrm{~m}$ (33 ft) is subdued and diffuse, whereas the pulse in the Maynardville Limestone at depths over $152 \mathrm{~m}(500 \mathrm{ft})$ is relatively sharp. This is indicative of the much better connectivity of fractures and cavities in the carbonate formations than those in the clastic formations. However, the sharp rises in groundwater pressure head in shallow wells in the clastic formations indicate that fractures and/or cavities in this interval of the clastic formations may be well-connected.

\section{C.4.4.5 Combined Hydrograph Analysis}

Surface water, groundwater, and stormflow tubes all show multiple sloped hydrographs. Figure C.26 shows the ranges of slopes (or $\lambda$ values) derived from hydrographs in both the Nolichucky Shale and the Maynardville Limestone. The slopes of hydrographs fall into four categories based on the values for $\lambda$, with an approximate order of magnitude difference between the $\lambda$ values for each category. The categories can be associated with the probable type of flow that, for a time period after a storm, dominates the flow in the tributaries. These are overland flow, soil interflow, groundwater baseflow surge or quickflow, and groundwater baseflow. The characteristics of flow from these four components are:

- Overland flow with $\lambda$ values ranging from 0.596 to $1.26 \mathrm{~h}^{-1}$. As would be expected, the overland flow component is seen only in surface water hydrographs.

- Soil interflow with $\lambda$ values ranging from 0.058 to $0.208 \mathrm{~h}^{-1}$. This component of the hydrographs is seen in both surface water and stormflow tube hydrographs, indicating that surface water flow is dominated by soil interflow for a period of time after overland flow has ceased. 
- Quickflow with $\lambda$ values ranging from 0.037 to $0.0067 \mathrm{~h}^{-1}$. This component is seen in surface water, stormflow tube, and groundwater well hydrographs. This may indicate that the rate of drainage from groundwater is strongly influenced by recharge from the soil layer for a period after precipitation has ceased. In addition, quickflow is the dominant component of stream flow after overland flow and soil interflow have ceased.

- Long-term flow and regional baseflow discharge, with $\lambda$ values ranging from 0.00576 to $0.00122 \mathrm{~h}^{-1}$. This component is seen only in groundwater well hydrographs and relates to the seasonal changes in groundwater elevations.

For hydrographs from shallow wells in clastic formations, the slopes for quickflow segments of the hydrographs are on the same order of magnitude as those determined by Shevenell (1994b) for the second and third segments of the Maynardville well regression hydrographs. These two segments were interpreted to represent drainage of (1) a well-connected fracture network in the Maynardville Limestone and (2) the matrix (including poorly connected fractures). This similarity in values between the initial regression slopes in the water table wells from the Nolichucky Shale and those in the Maynardville Limestone implies that the transmissivity of the water table interval in the Nolichucky Shale may be of a similar order of magnitude as the fracture networks in the Maynardville Limestone during high flow conditions. This interpretation supports the conceptual model of a high-conductivity zone at the water table interval that transmits most water during storm events.

\section{C.4.4.6 Conceptual Model for Transient Response}

Based on the above monitoring data, the conceptual model for water movement after impacting on the land surface is as follows (Fig. C.9):

- After precipitation begins, soil saturation increases.

- If precipitation continues, the soil eventually approaches complete saturation; water then ponds in the surface and is transmitted laterally downslope as overland flow and soil interflow to the nearest surface water channel. At the same stage, saturation of fractures in the vadose zone increases, and water is transmitted downward from the soil to the water table.

- Recharge elevates the level of the water table, and along-strike groundwater flow at the water table interval in clastic formations increases, resulting in an increase in the rate of discharge to tributary streams. At the same time, quickflow in carbonate formations occurs.

- After precipitation ceases, surface ponds drain rapidly and overland flow ceases.

- Soil saturation declines, and interflow and groundwater recharge slow and ultimately cease.

- The water table slowly declines, and baseflow returns close to pre-storm conditions.

The relative importance of components of this conceptual model varies depending on climate and therefore show seasonal variation. For example, during the high rainfall and low evapotranspiration period in late winter and early spring, soils are usually close to saturation, while overland flow, interflow, and groundwater recharge react rapidly to rainfall. During summer and late fall, when precipitation is lower and generally occurs in isolated storm events, soils are considerably drier and may not reach saturation in some rain events. Thus, overland flow occurs only during the most intense storms. 


\section{C.4.5 BEAR CREEK/MAYNARDVILLE LIMESTONE RECHARGE/DISCHARGE RELATIONSHIPS}

The solution cavity system within the Maynardville Limestone conducts flow westward under Bear Creek and plays an important role in the surface water hydrology of BCV. The numerous springs that originate on the north slope of Chestnut Ridge are locations of discharge from this cavity system and are a dominant feature of the hydrograph of upper Bear Creek. This is especially so during drought periods when most of the flow in the main-stem Bear Creek is contributed by springs (Fig. C.27; Clapp et al. 1990).

During two relatively short periods (1 to 2 weeks) in 1994, the U.S. Geological Survey completed spring and seep surveys for Bear Creek and its tributaries and for Grassy Creek and its tributaries. The surveys were carried out at high baseflow (March 14 to March 19, 1994) and low baseflow (September 9 to September 16, 1994). Table C.1 summarizes all the data taken during the spring and seep surveys in BCV and Grassy Creek, and Fig. C.28 shows the results for flow.

The spring and seep survey identified reaches of Bear Creek and its tributaries that are either net-gaining or -losing reaches. Figures C.27 and C.28 depict detailed analyses of gaining and losing reaches in streams upgradient of BCK 9.47 during high- and low-flow periods, respectively. Figure C.29 shows west-east profiles along BCV of the flow and conductivity in the main stem. These profiles reveal that a number of gaining and losing reaches of the creek alternate down the valley.

In the headwaters of Bear Creek, between Y-12 Plant coordinates 52,000E and 47,500E, the creek gains flow during both the low- and high-flow periods. This segment corresponds approximately to the reach between the Rust Spoil Area and Sanitary Landfill 1 (SL 1), where the main influxes to the creek are NT-2, NT-3, SS-2, and SS-3. Of these four influxes, only SS-2 is perennial and has flow even during low-flow periods [0.02 cubic feet per second (cfs) during September and $0.23 \mathrm{cfs}$ during March].

West of 47,500E, the creek loses flow: during the low-flow period the creek is dry in the reach adjacent to SL 1 and all the way downstream to the confluence with SS-4. Below SS-4, the creek flows for $\sim 457 \mathrm{~m}(1500 \mathrm{ft})$ and then is dry until the confluence with NT-8 (41,250E). During the high-flow period, flow decreases downstream from SL 1 until the confluence with ST-1 $(\sim 46,000 \mathrm{E})$ and steadily increases until the confluence with NT-8 at BCK 9.41. During the low-flow period, SS-4 provides the only influx of flow to Bear Creek between 47,500E and 41,250E; below the confluence with Bear Creek, this flow is lost to groundwater. During high-flow periods, flow is lost from the

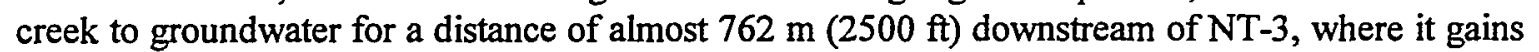
steadily with influxes from tributaries NT-5, $-6,-7,-8$, SS-4, and ST-1. For this reach of the creek, the influxes approximately balance the final outflow at BCK 9.41 (1.09 cfs in; $1.06 \mathrm{cfs}$ out), suggesting little net interaction with groundwater over this reach of the creek.

In both the high- and low-flow periods, the flow in the creek increases dramatically between $41,250 \mathrm{E}$ and $40,000 \mathrm{E}$ : from 0.0 to $0.29 \mathrm{cfs}$ in the low-flow period and from 0.44 to $2.01 \mathrm{cfs}$ during the high-flow period. This increase in flow corresponds to the influx from SS-5; however, the flow from this spring alone cannot account for the increase, suggesting additional groundwater discharge directly to the creek bed along this reach. During the low-flow period, flow in the main stem increases from 0.01 to $0.29 \mathrm{cfs}$ with an influx of $0.1 \mathrm{cfs}$ from SS-5. This implies that an additional $0.18 \mathrm{cfs}$ is derived from groundwater discharge. During the high-flow period, flow increases from 0.44 to $2.01 \mathrm{cfs}$, with $1.06 \mathrm{cfs}$ from SS-5, which implies that an additional $0.51 \mathrm{cfs}$ is derived from groundwater discharge. 
Below 40,000E, Bear Creek is a perennial stream. Both the low- and high-flow periods exhibit a similar pattern, with a losing reach from $40,000 \mathrm{E}$ to $35,000 \mathrm{E}$; a gaining reach from $35,000 \mathrm{E}$ to $32,500 \mathrm{E}$ (including the influx from SS-6); and a second losing reach over which almost half the flow is lost from Bear Creek between 32,500E and 30,000E. Below 30,000E, the creek veers to the north and steadily gains flow until the final sample point for the survey in the water gap in Pine Ridge. The losing reach between $32,500 \mathrm{E}$ and $30,000 \mathrm{E}$ is significant because, immediately below this reach, two major springs (SS-7 and SS-8) contribute a combined flow to Bear Creek that more than accounts for that lost along this reach.

In general, the flow in the creek varies in an alternating step-wise fashion down the valley. A major spring appears to be associated with each increase in flow (SS-2 and SS-3 at 48,500E; SS-4 at 43,500; SS-5 at 41,250; SS-6 at 35,250E; and SS-7 and SS-8 at 30,000E) and, in at least one case (SS-5), is probably associated with additional groundwater discharge to the creek on a similar order of magnitude as that from the spring itself. This finding indicates that the major springs in the floodplain of BCV may be associated with general groundwater discharge zones, not just the discharge from the individual spring. 


\section{C.5 REFERENCES}

Bras, R.L. 1990. Hydrology: an Introduction to Hydrologic Science, Addison-Wesley Publishing Company, Inc.

Clapp, R.B., D.K. Cox, W.C. Kyker, J.R. Jones, J.A. Watts, and B.J. Frederick. 1990. Surface Water Discharge Data for the Bear Creek Watershed, Oak Ridge, Tennessee, 1984-1988, Y/TS-407, Oak Ridge Y-12 Plant, Oak Ridge, Tennessee, October.

Dreier, R.B., D.K. Solomon, and C.M. Beaudoin. 1987. "Fracture Characterization in the Unsaturated Zone of a Shallow Land Burial Facility," in Flow and Transport Through Fractured Rock, American Geophysical Union Monograph, 42:51-59.

Dreier, R.B. and S.M. Koerber. 1990. Fault Zone Identification in the Area Surrounding the Y-12 Plant and Its Waste Management Areas, Y/TS-656, Oak Ridge Y-12 Plant, Oak Ridge, Tennessee.

Dreier, R.B., T.O. Early, and H.L. King. 1993. Results and Interpretation of Groundwater Data Obtained from Multiport-instrumented Coreholes (GW-131 through GW-135), Fiscal Years 1990 and 1991, Y/TS-803, Martin Marietta Energy Systems, Inc., Y-12 Plant, Oak Ridge, Tennessee.

Dreier, R.B. and G.L. Davidson. 1994. "Fracture Spacing and Connectivity Observed in Multiport Instrumented Wells," in GSA Abstracts with Programs, v. 25, no. 7, p. A-412.

DuBuchanne, G.D. and R.M. Richardson. 1956. Groundwater Resources of East Tennessee, Bulletin 58, Part I, Division of Geology, State of Tennessee Department of Conservation.

Eckman, R.M., R.J. Dobosy, and W.R. Pendergrass. 1992. Preliminary Analysis of Wind Data from the Oak Ridge Site Survey, Atmospheric Turbulence and Diffusion Laboratory of the National Oceanographic and Atmospheric Administration, Oak Ridge, Tennessee.

Energy Systems (Lockheed Martin Energy Systems, Inc.). 1994. Oak Ridge Reservation Annual Site Environmental Report for 1993, ES/ESH-47, prepared for the U.S. Department of Energy, November.

Ford, D.C. and P.W. Williams. 1989. Karst Geomorphology and Hydrogeology, Univin Hyman, Winchester, Massachusetts.

Foreman, J.L., K.R. Walker, L.J. Weber, S.L. Driese, and R.B. Dreier 1991. "Slope and Basinal Carbonate Deposition in the Nolichucky Shale (Upper Cambrian), East Tennessee: Effect of Carbonate Suppression by Silicilastic Deposition on Basin-Margin Morphology," in Mixed Carbonates-Silicilastic Sequences, SEPM Core Workshop, No. 15, Dallas, Texas.

Geraghty and Miller, Inc. 1986. Aquifer Test Data and Design of Recovery Wells, S-3 Ponds, Y/SUB/86-00206C/3, prepared for Martin Marietta Energy Systems, Inc., October. 
Golder and Associates, Inc. 1988a. Geohydrologic Site Assessment and Computer Model Application, Bear Creek Valley, Oak Ridge Reservation, Contract \#30X-SA706C, Tasks 1-6, prepared for Martin Marietta Energy Systems, Inc.

Golder and Associates, Inc. 1988b. Task 2, Well Logging and Geohydrologic Testing, Site Characterization and Groundwater Flow Computer Model Application, Bear Creek Valley, Oak Ridge Reservation, Contract \#30X-SA706C, Tasks 1-6, prepared for Martin Marietta Energy Systems, Inc.

Goldstrand, P.M. 1995. Stratigraphic Variations and Secondary Porosity within the Maynardville Limestone in Bear Creek Valley, Y-12 Plant, Oak Ridge, Tennessee, Y/TS-1093, Lockheed Martin Energy Systems, Inc., Oak Ridge Y-12 Plant, Oak Ridge, Tennessee.

Goldstrand, P.M. and R.B. Dreier. 1993. "Stratabound Porosity in the Maynardville Limestone, Bear Creek Valley, Oak Ridge, Tennessee," Y/TS-1008, Abs, Abstract for submission to Geological Society of America Annual Meeting, Boston, Massachusetts, October 25-28.

Goldstrand, P.M., L.S. Menefee, and R.B. Dreier. 1995. Porosity Development in the Copper Ridge Dolomite and Maynardville Limestone, Bear Creek Valley, and Chestnut Ridge, Tennessee, Y/SUB/95-SP912V/1, Lockheed Martin Energy Systems, Inc., Oak Ridge Y-12 Plant, Oak Ridge, Tennessee, December.

Haase, C.S. 1991. Geochemical Identification of Groundwater Flow Systems in Fractured Bedrock Near Oak Ridge, Tennessee, Martin Marietta Energy Systems, Inc., Oak Ridge National Laboratory, Oak Ridge, Tennessee.

Haase, C.S., E.C. Walls, and C.D. Farmer. 1985. Structural and Stratigraphic Data for the Conasauga Group and Rome Formation on the Copper Creek Thrust Sheet Near Oak Ridge, Tennessee: Preliminary Data from Test Borehole ORNL-Joy No. 2, ORNL/TM-9159, Martin Marietta Energy Systems, Inc., Oak Ridge National Laboratory, Oak Ridge, Tennessee.

Hatcher, R.D., P.J. Lemiszki, R.B. Dreier, R.H. Ketelle, R.R. Lee, D.A. Leitzke, W.M. McMaster, J.L. Foreman, and S.Y. Lee. 1992. Status Report on the Geology of the Oak Ridge Reservation, ORNL/TM-12074, Martin Marietta Energy Systems, Inc., Oak Ridge National Laboratory, Oak Ridge, Tennessee.

Hoos, A.B. and Z.C. Bailey. 1986. Reconnaissance of Surficial Geology, Regolith Thickness, and Configuration of the Bedrock Surface in Bear Creek and Union Valleys, Near Oak Ridge, Tennessee, USGS Water-Resources Investigations Report 86-4165.

HSW (HSW Environmental Consultants, Inc.). 1995. Calendar Year 1994 Groundwater Quality Report for the Bear Creek Hydrogeologic Regime at the Y-12 Plant: 1994 Groundwater Quality Data Interpretations and Proposed Program Modifications, Y/Sub/95-EAQ10C/1/P2, prepared for Martin Marietta Energy Systems, Inc., Oak Ridge Y-12 Plant, Oak Ridge, Tennessee, August.

Jacobs Engineering. 1995. In preparation. Regional Groundwater Flow Model, Construction and Calibration, Oak Ridge Reservation, Y-12/Bear Creek Valley Site, October.

Jones, S.B., B.K. Thompson, and S.M. Field. 1995. Updated Subsurface Data Base for Bear Creek Valley, Chestnut Ridge, and Parts of Bethel Valley on the U.S. Department of Energy Oak Ridge 
Reservation, Y/TS-881/R2, Lockheed Martin Energy Systems, Inc., Oak Ridge Y-12 Plant, Oak Ridge, Tennessee.

King, H.L. and C.S. Haase. 1988. Summary of Results and Preliminary Interpretations of Hydrogeologic Packer Testing in Core Holes GW-131 through GW-135 and CH-157, Oak Ridge Y-12 Plant, Y/TS-495, prepared by C-E Environmental, Inc./E.C. Jordan Company for Martin Marietta Energy Systems, Inc., Oak Ridge Y-12 Plant, Oak Ridge, Tennessee, December.

Law Engineering (Law Engineering Testing Company). 1975. Preliminary Safety Analysis Report for Nuclear Fuel Recovery and Recycling Center, prepared for the Exxon Nuclear Company.

Law Engineering. 1983. Results of Ground-Water Monitoring Studies at Y-12 Plant, Y/SUB/83-47936/1, prepared for Martin Marietta Energy Systems, Inc., Oak Ridge Y-12 Plant, Oak Ridge, Tennessee, September.

Lee, R.R. and R.H. Ketelle. 1987. Stratigraphic Influence on Deep Groundwater Flow in the Knox Group Copper Ridge Dolomite on the West Chestnut Ridge Site, ORNL/TM-10479, Martin Marietta Energy Systems, Inc., Oak Ridge National Laboratory, Oak Ridge, Tennessee.

Lee, R.R., R.H. Ketelle, J.M. Bownds, and T.A. Rizk. 1992. "Aquifer Analysis and Modeling in a Fractured, Heterogeneous Medium," Groundwater, 30(4):589-597, July-August.

Lozier W.B, C.A. Spiers, and R. Pearson. 1987. Aquifer Pump Test with Tracers, ORNL/SUB/86-32136, prepared for Martin Marietta Energy Systems, Inc. by Golder and Associates, Inc., October.

Lutz C. and R.B. Dreier. 1988. "Differences in Local Deformation History as Indicated by Fracture Orientations in Two Foreland Thrust Sheets," Abstract, Martin Marietta Energy Systems, Inc., Oak Ridge National Laboratory, Oak Ridge, Tennessee.

McKay, L.D., W.E. Sanford, J. Strong-Gunderson, and V. DeEnriquez. 1995. "Microbial tracer experiments in a fractured weathered shale near Oak Ridge, Tennessee," presented at International Association of Hydrogeologists, Solutions '95 Conference, Edmonton, Alberta, Canada, June 4-10.

Moline, G.R. and M.E. Schreiber. 1995. FY94 Site Characterization and Multi-Level Well Installation at a West Bear Creek Valley Research Site on the Oak Ridge Reservation, Draft, ORNL/TM-13029, Lockheed Martin Energy Systems, Inc., Oak Ridge National Laboratory, Oak Ridge, Tennessee, August.

Moore, G.K. 1988. Concepts of Groundwater Occurrence and Flow Near Oak Ridge National Laboratory, Tennessee, ORNL/TM-10969, Martin Marietta Energy Systems, Inc., Oak Ridge National Laboratory, Oak Ridge, Tennessee, November.

Moore, G.K. 1992. "Hydrograph analysis in fractured rock terrane," Ground Water, Vol. 30, no. 3, pp. 390-395.

Moore, G.K. and L.E. Toran. 1992. Supplement to a Hydrologic Framework for the Oak Ridge Reservation, Oak Ridge, Tennessee, ORNL/TM-12191, Martin Marietta Energy Systems, Inc., Oak Ridge National Laboratory, Oak Ridge, Tennessee. 
C5-4

Rothschild, E.R., R.R. Turner, S.H. Stow, M.A. Boyle, L.K. Hyder, O.M. Sealand, and J.H. Wyrick. 1984. Investigation of Subsurface Mercury at the Oak Ridge Y-12 Plant, ORNL/TM-9092, Martin Marietta Energy Systems, Inc., Oak Ridge National Laboratory, Oak Ridge, Tennessee. 
C6-1

\section{C.6 FIGURES}



(Source ORNL-DWG 94M-5238)

Wind rose produced from 1993 data from the eastem meteorological tower (MT5) at the Y-12 Plant.
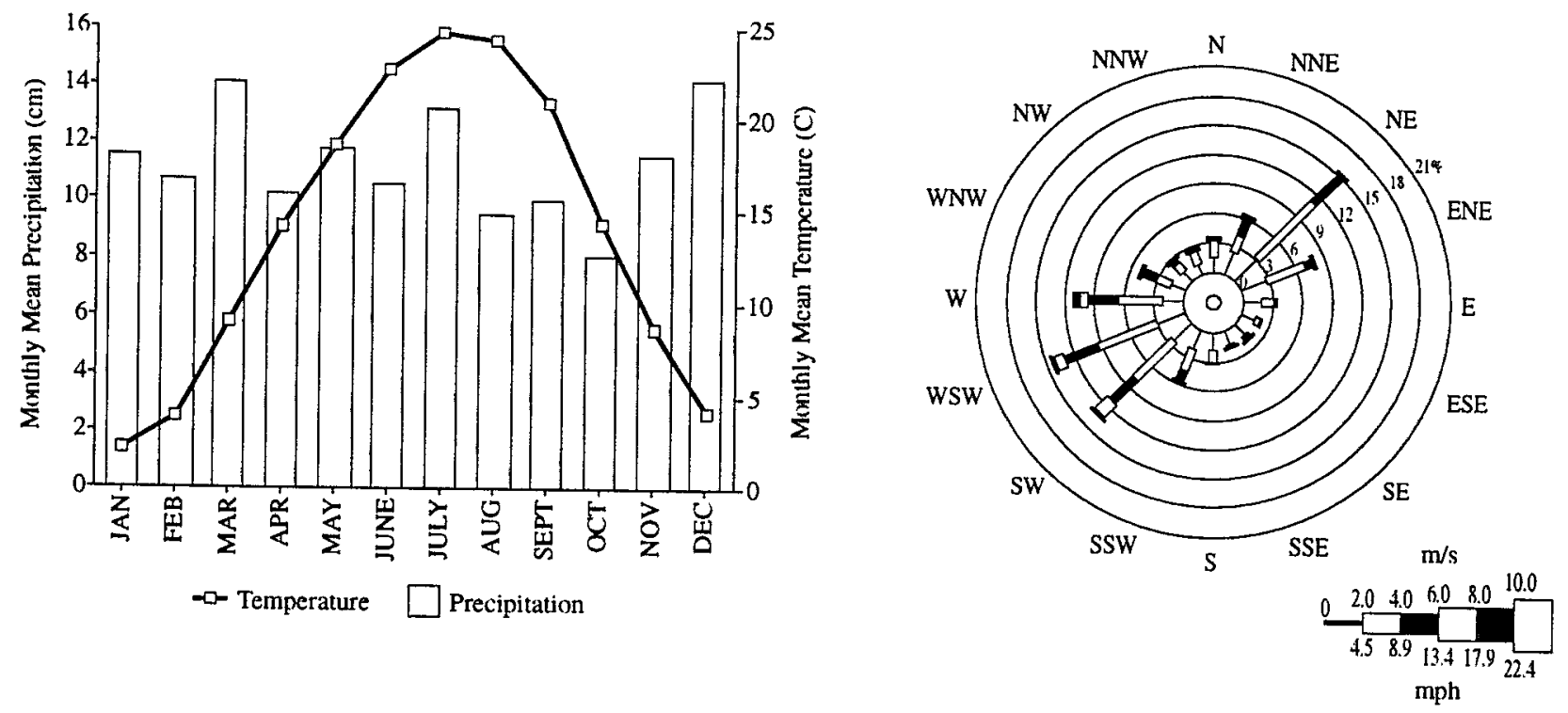

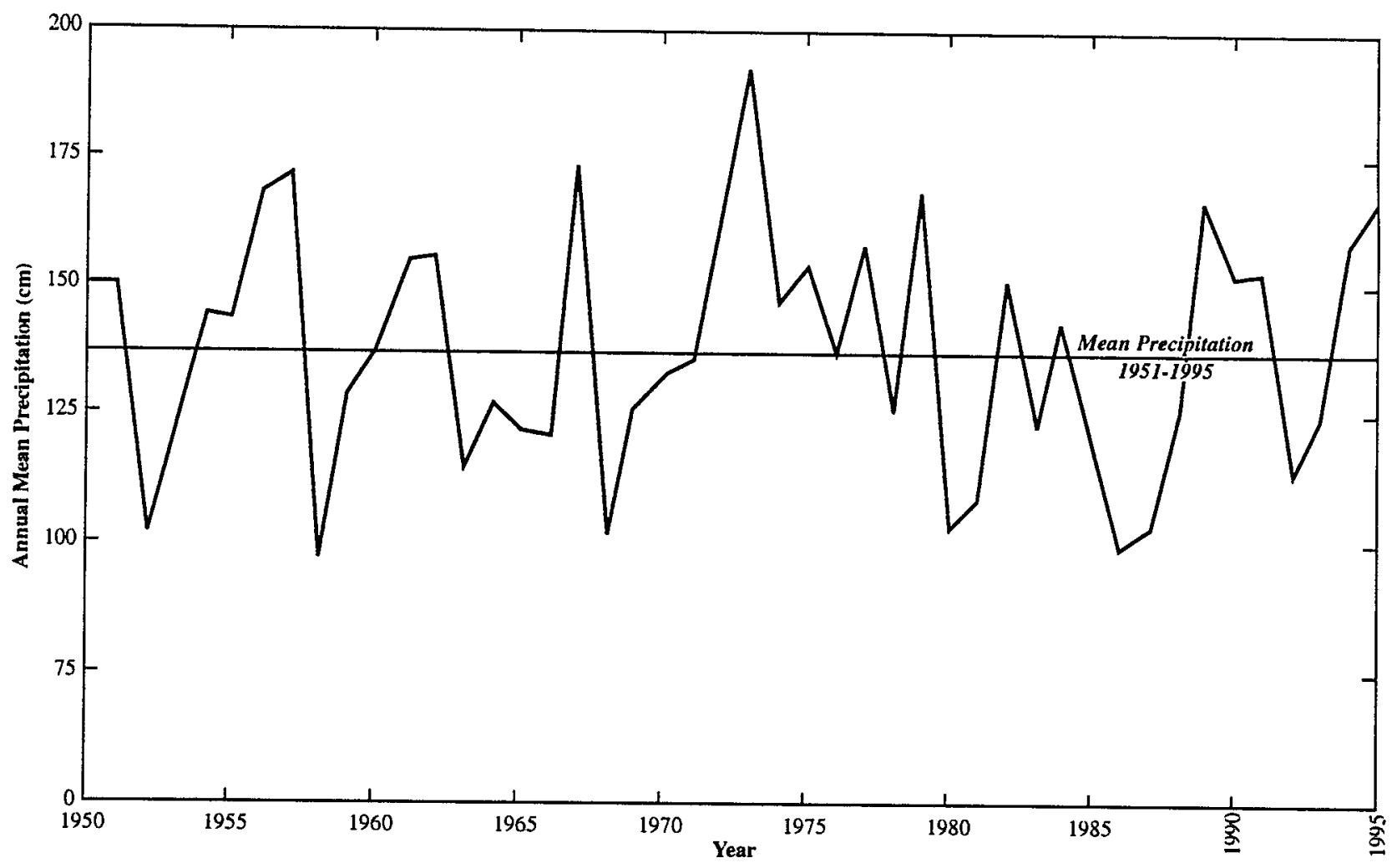

Fig. C.1 Meteorological data of ORR. (Source NOA) 

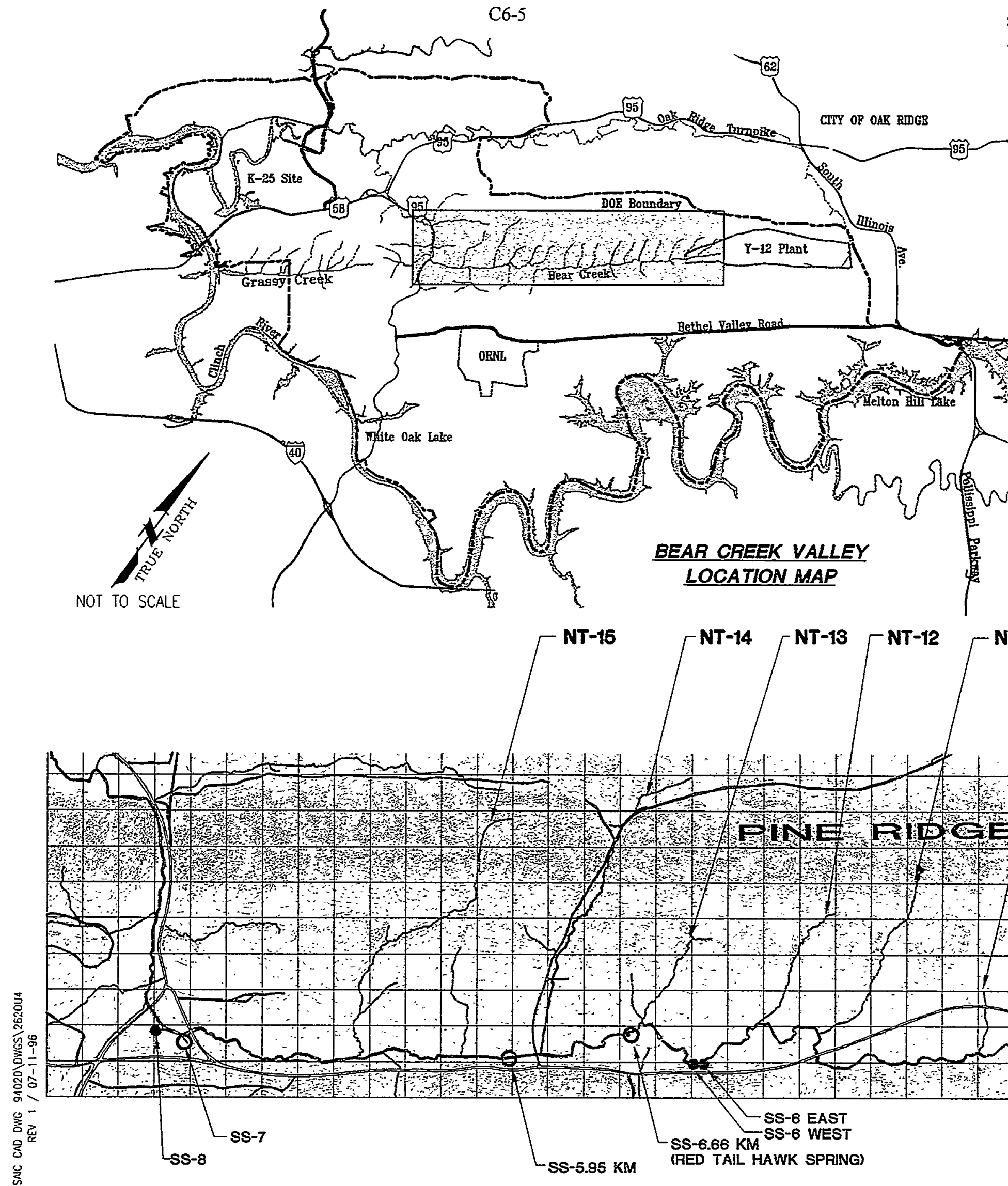

Fig. C.2. Map of BCV showing topog 


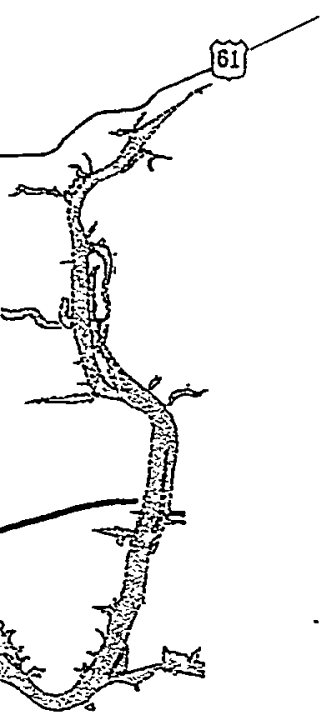

\section{BEAR CREEK \\ VALLEY}
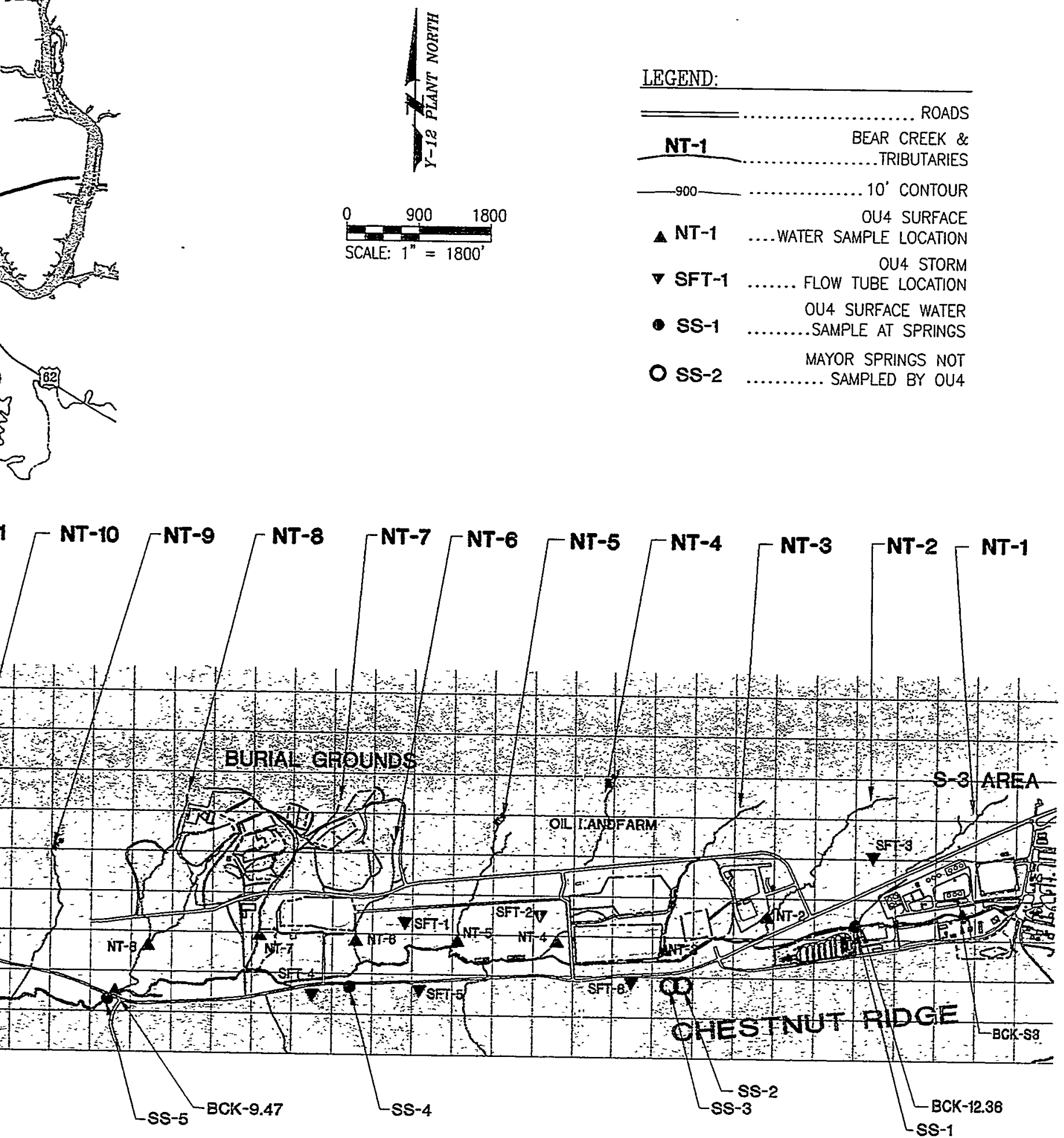

hy, named tributaries, and springs. 
C6-7
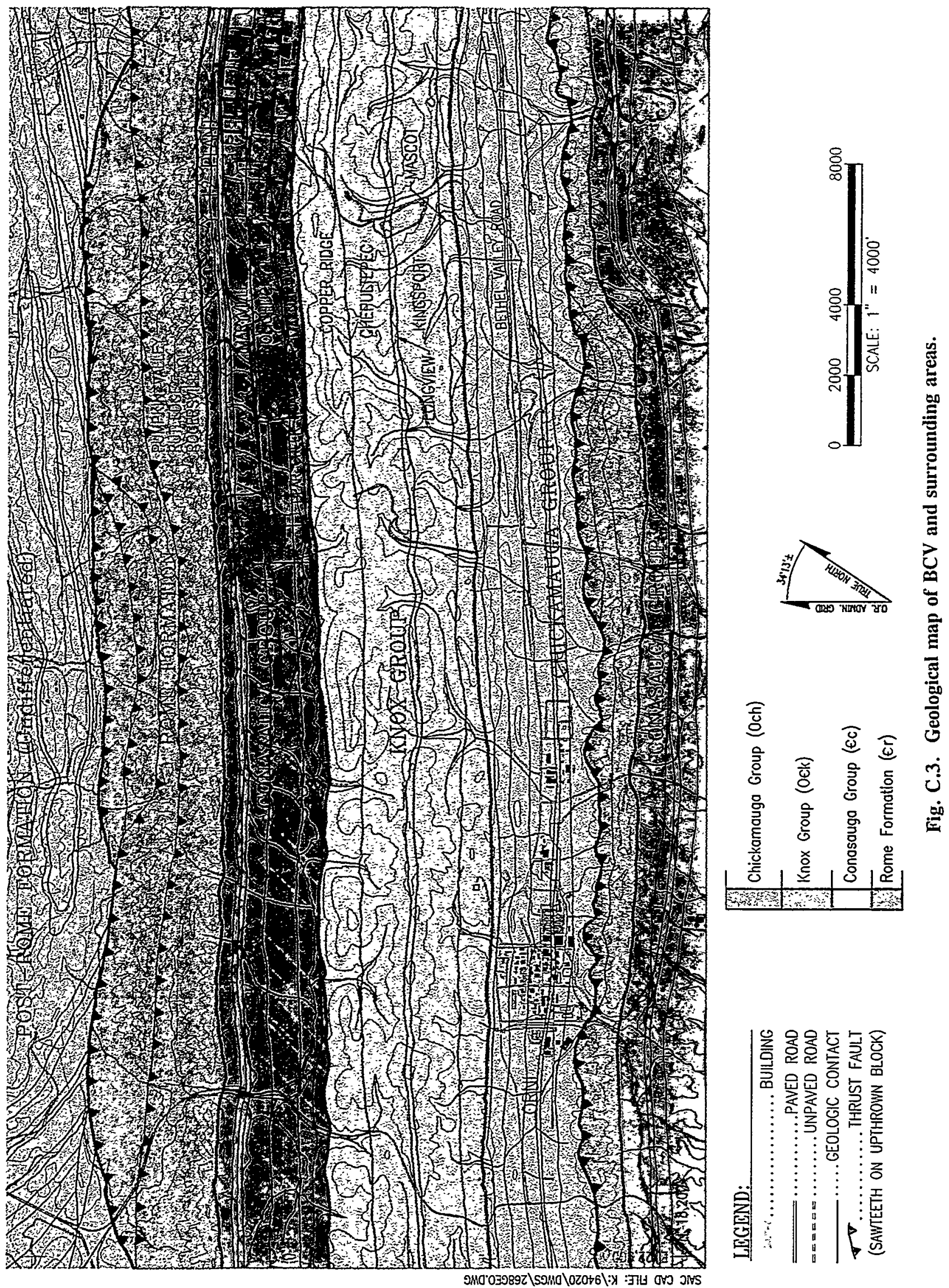
C6-9
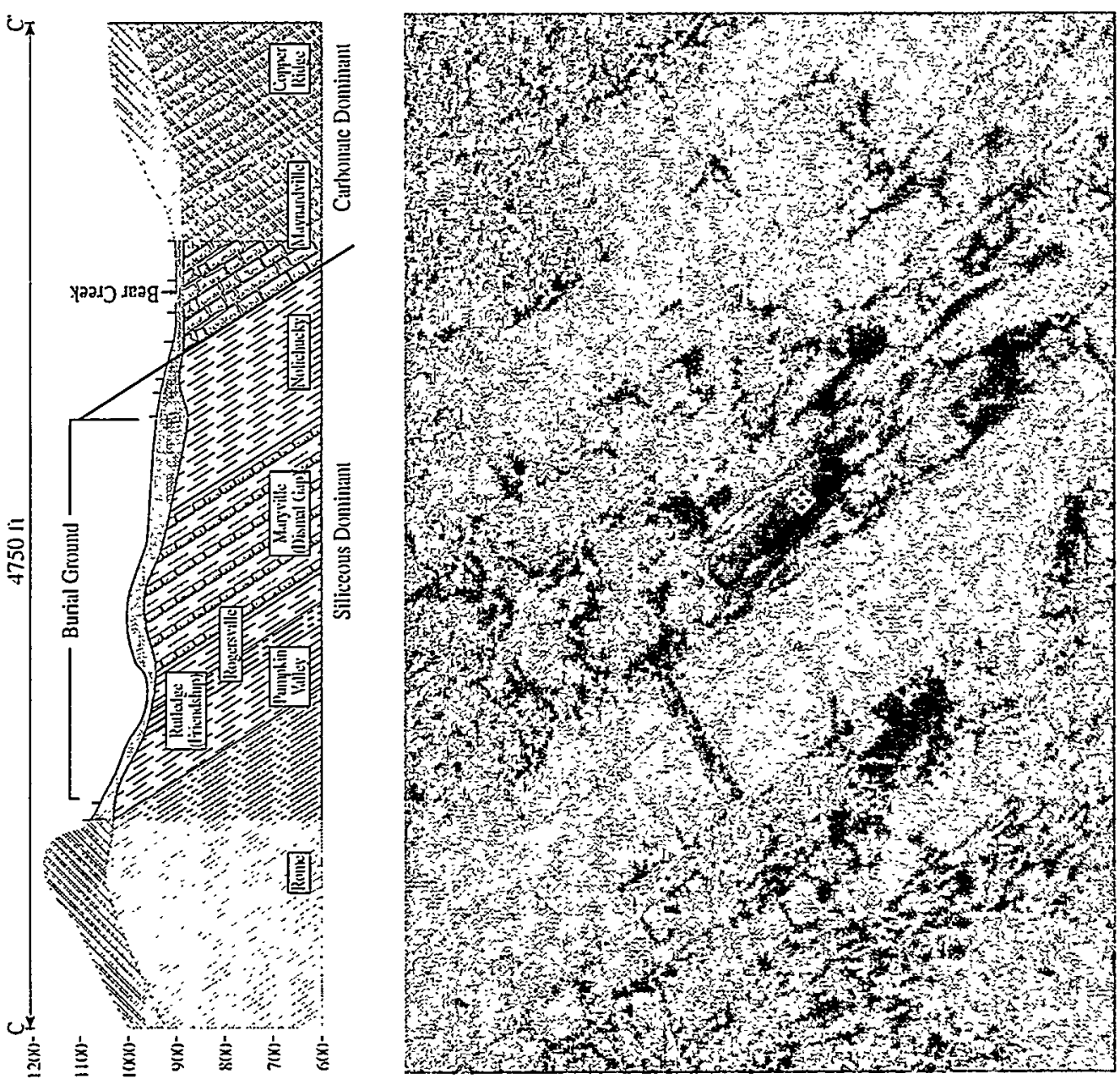

\begin{tabular}{|c|c|c|c|c|c|c|c|c|c|c|c|c|c|c|c|}
\hline \multicolumn{5}{|c|}{ 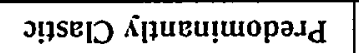 } & \multicolumn{6}{|c|}{ әุеuоq.seว } & \multicolumn{5}{|c|}{ 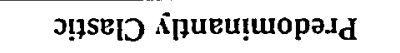 } \\
\hline \multirow[t]{2}{*}{ 咅 } & 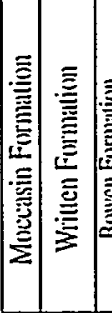 & 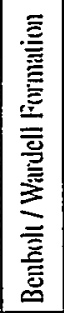 & | & 袅言 & 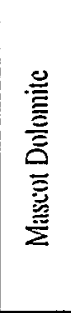 & 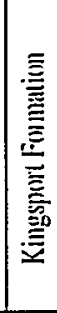 & 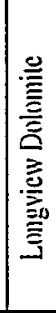 & 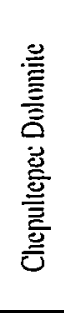 & 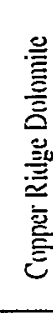 & 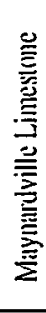 & 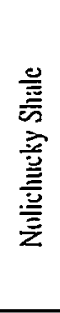 & 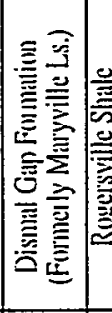 & 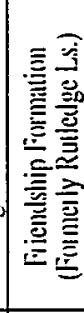 & 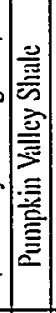 & 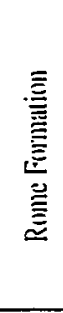 \\
\hline & 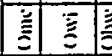 & \begin{tabular}{|l|l|}
$\underline{2}$ \\
\end{tabular} & 美交 & $= \pm$ & 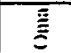 & $\Xi$ & 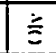 & $\Xi$ & $\bar{\Sigma}$ & $\overline{\bar{\Xi}}$ & $\Xi$ & 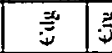 & $\bar{\nu}$ & 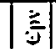 & $\overline{-}$ \\
\hline 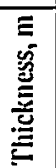 & 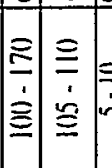 & $\begin{array}{l}\stackrel{n}{\Xi} \\
\doteq \\
\Xi\end{array}$ & 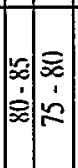 & $\mid \begin{array}{l}\equiv \\
\vdots \\
\vdots\end{array}$ & 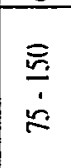 & 产 & $\begin{array}{l}\vdots \\
\vdots \\
\frac{7}{y}\end{array}$ & 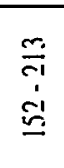 & $\stackrel{2}{\stackrel{7}{*}}$ & $\begin{array}{l}\equiv \\
\frac{\equiv}{\equiv}\end{array}$ & $\begin{array}{l}\bar{\Xi} \\
\dot{\bar{\Xi}} \\
\underline{\underline{\Xi}}\end{array}$ & 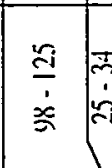 & $\frac{\equiv}{\frac{1}{m}}$ & $\begin{array}{l}\approx \\
\dot{c} \\
\bullet\end{array}$ & $\frac{\widetilde{x}}{\dot{a}}$ \\
\hline 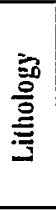 & Hith & & & & & & & & & & & 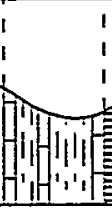 & 㑇 & & 促, \\
\hline & \multicolumn{4}{|c|}{ 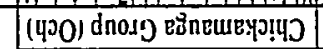 } & \multicolumn{5}{|c|}{ (મวO) dnosp xou } & \multicolumn{4}{|c|}{ (ગつ) dnoגว eôneseuoว } & & \\
\hline & Iadd & & PIPp! & & & & $\mathbf{1 0 7}$ & & & $\mathrm{d} n$ & & गाpp & & & 1107 \\
\hline & & \multicolumn{7}{|c|}{ NVIYGINYJ } \\
\hline
\end{tabular}




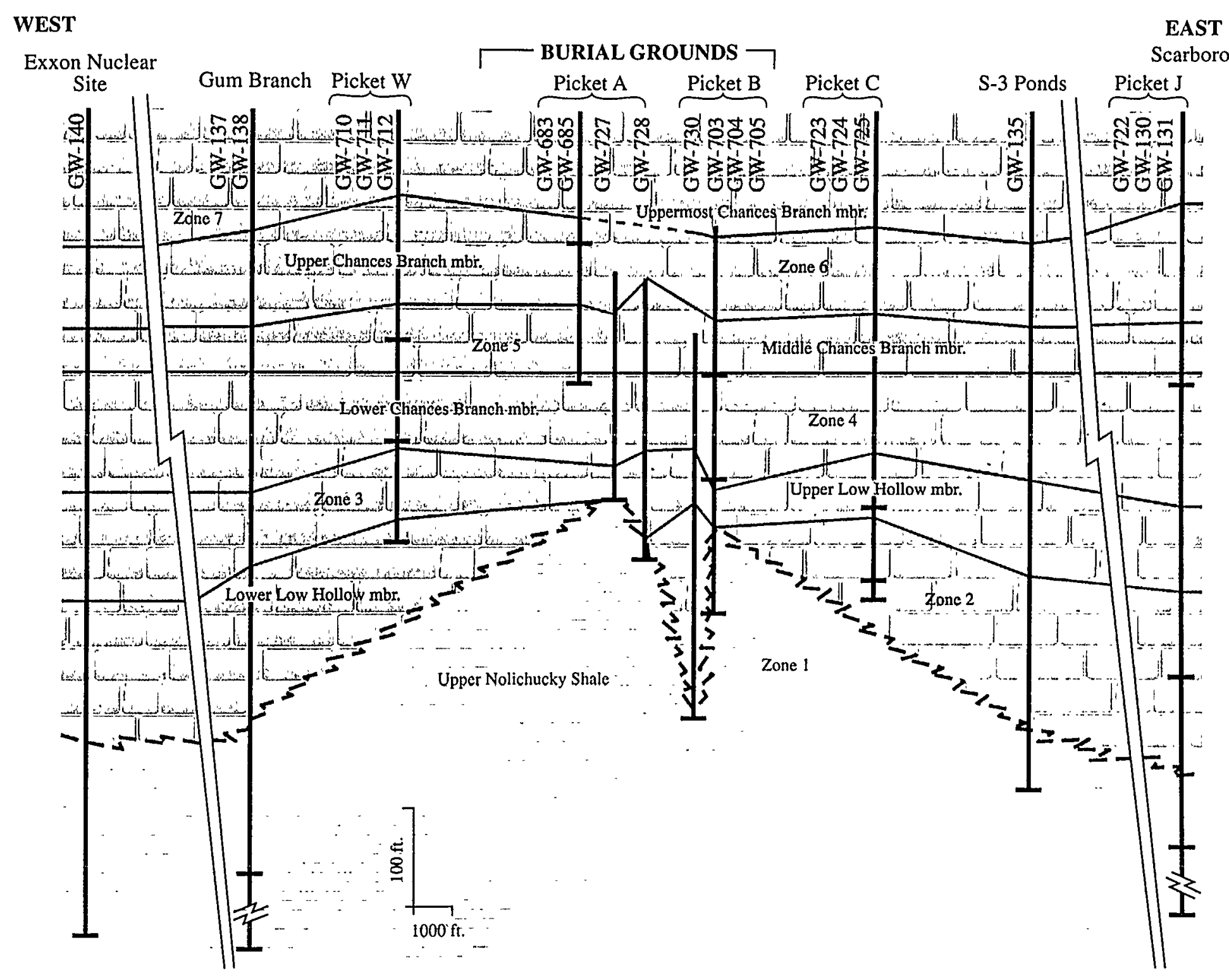

Fig. C.5. Along-strike section of Maynardville Limestone in BCV. Source: Shevenell et al. 1992. 
C6-11

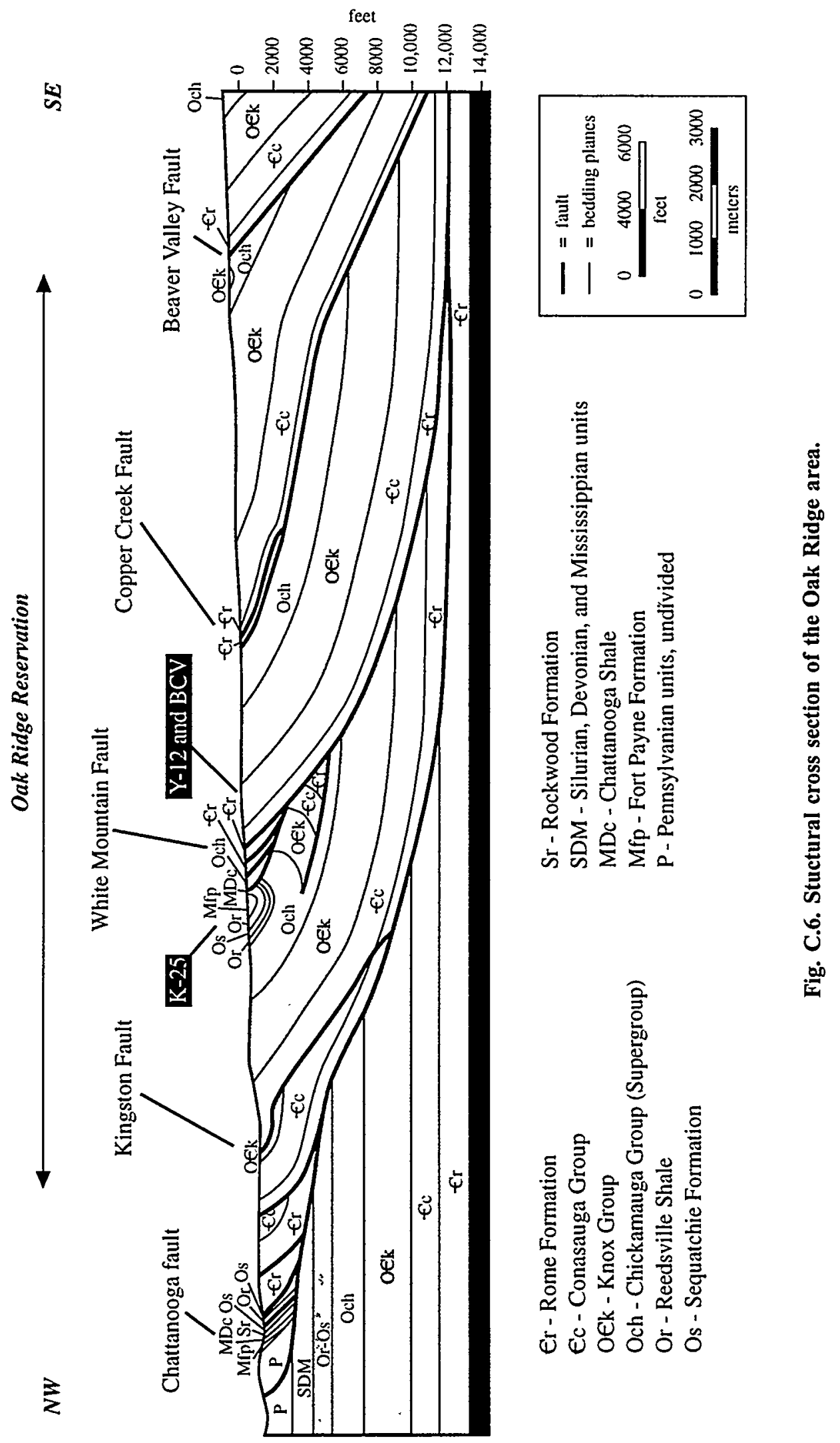


C6-12

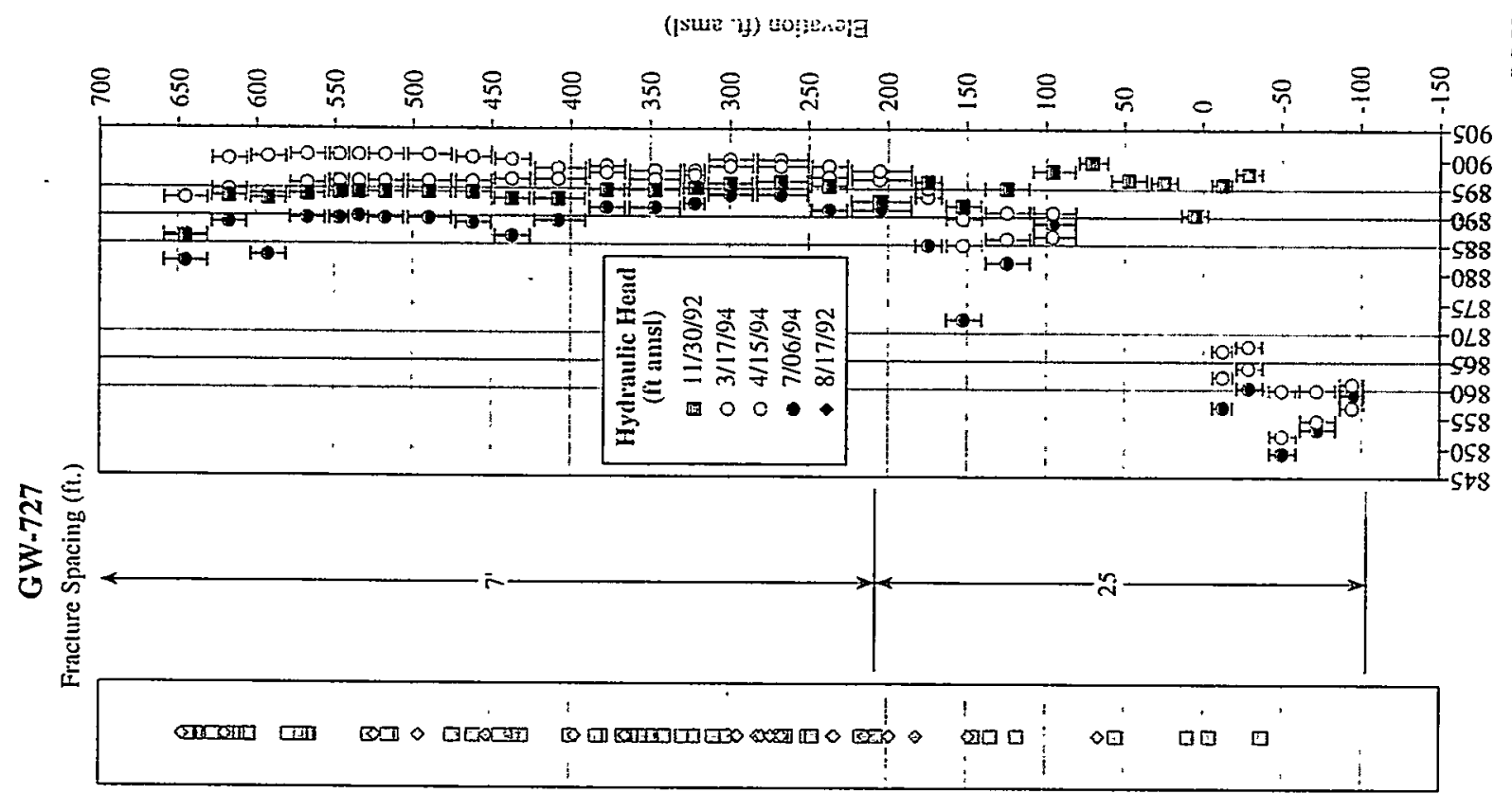

ن

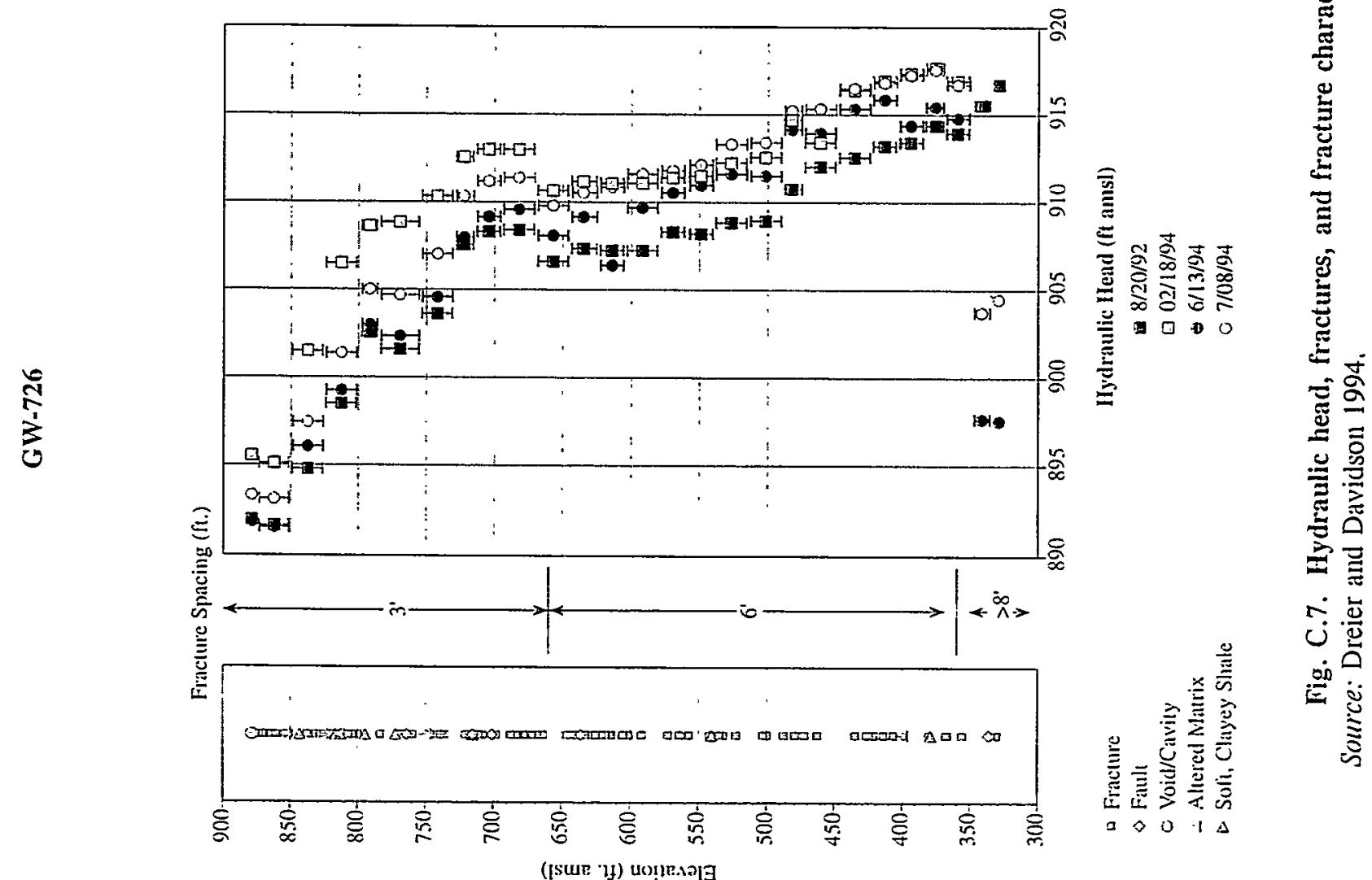


C6-13

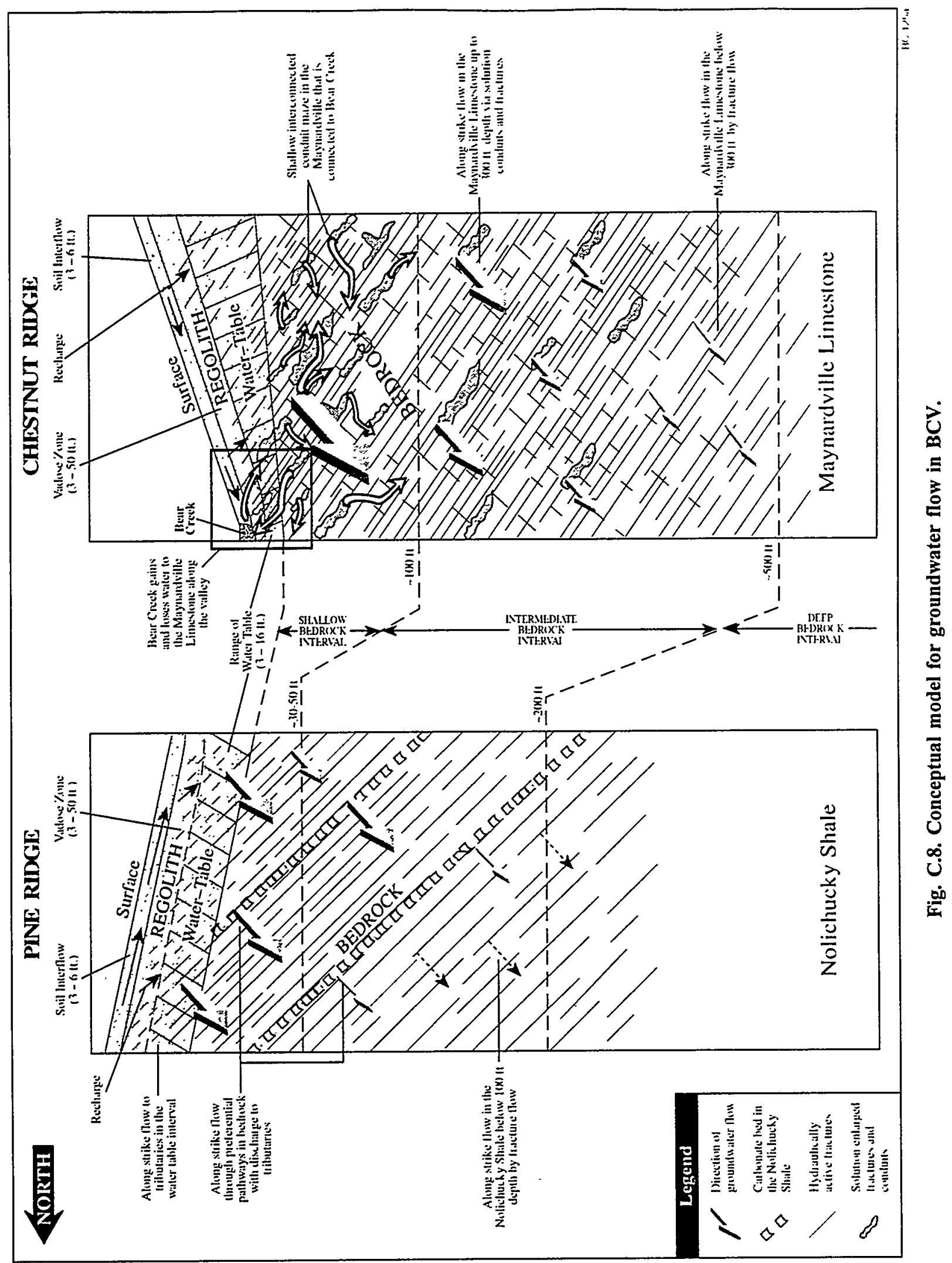


C6-14
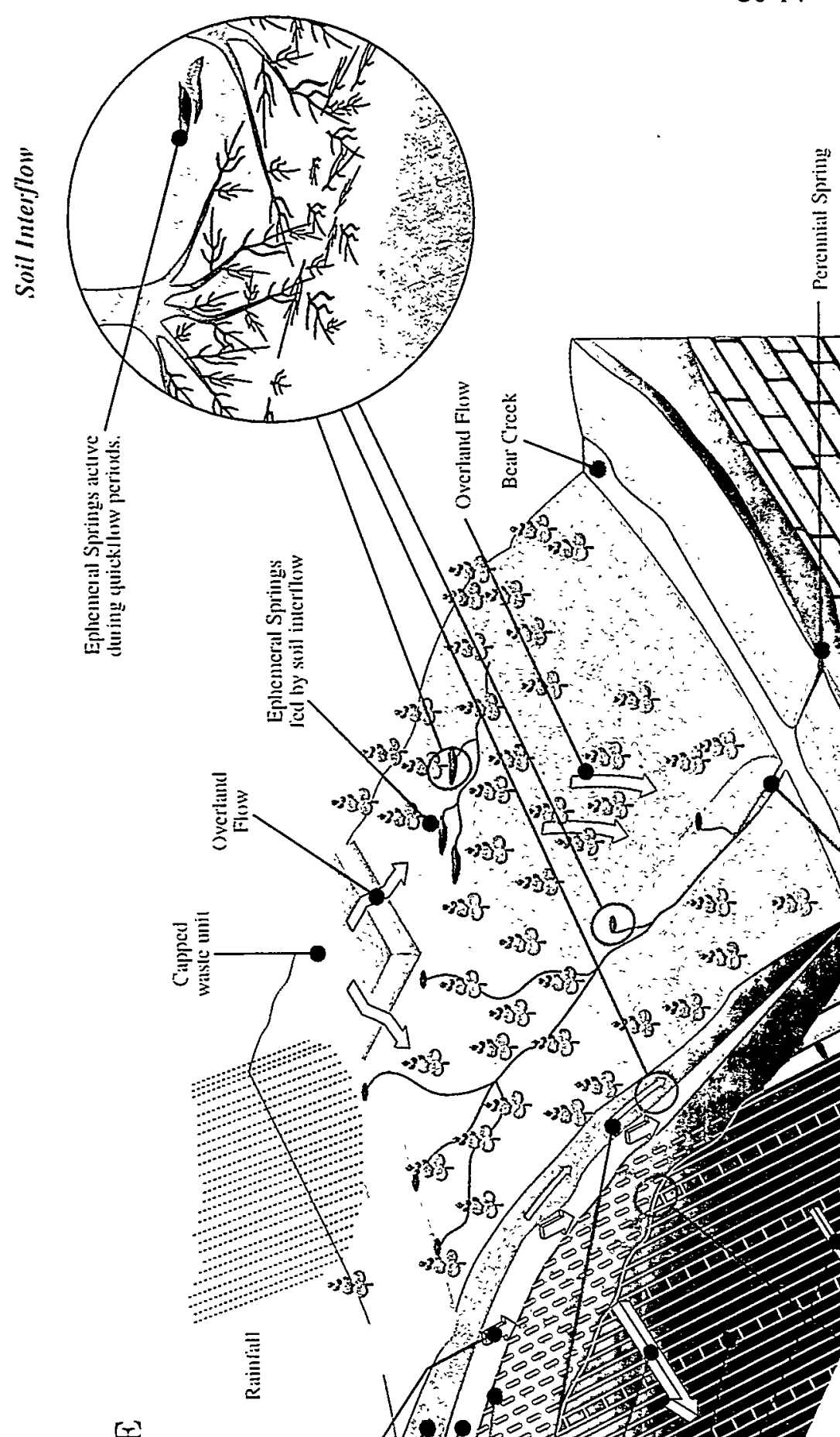

$\frac{8}{2}$
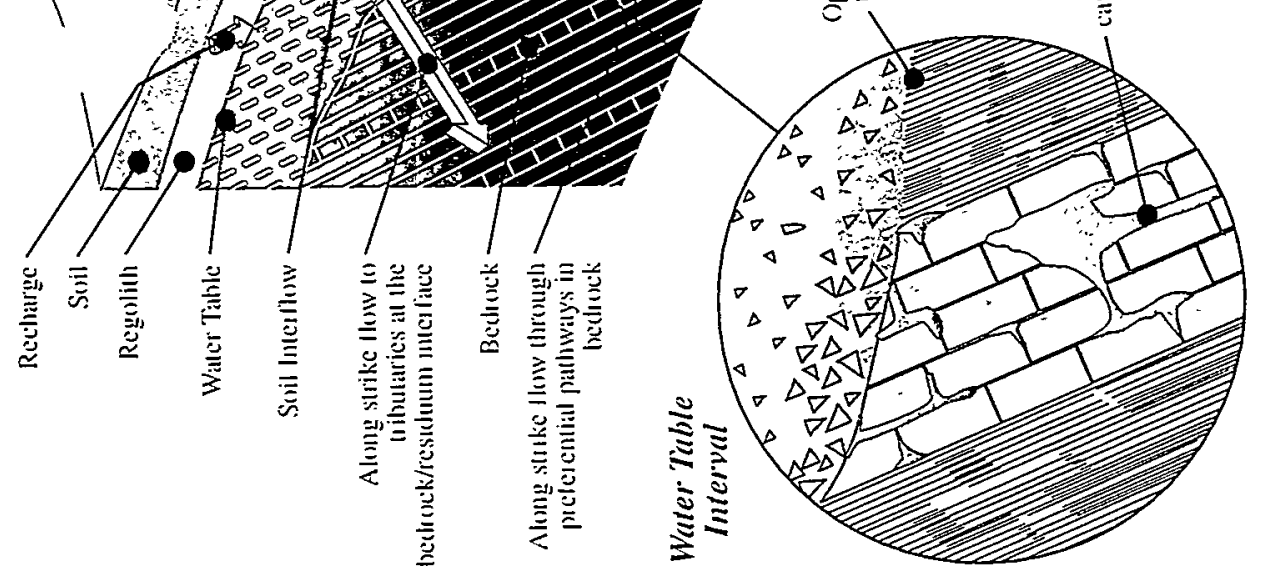

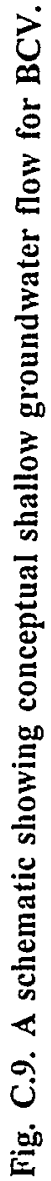




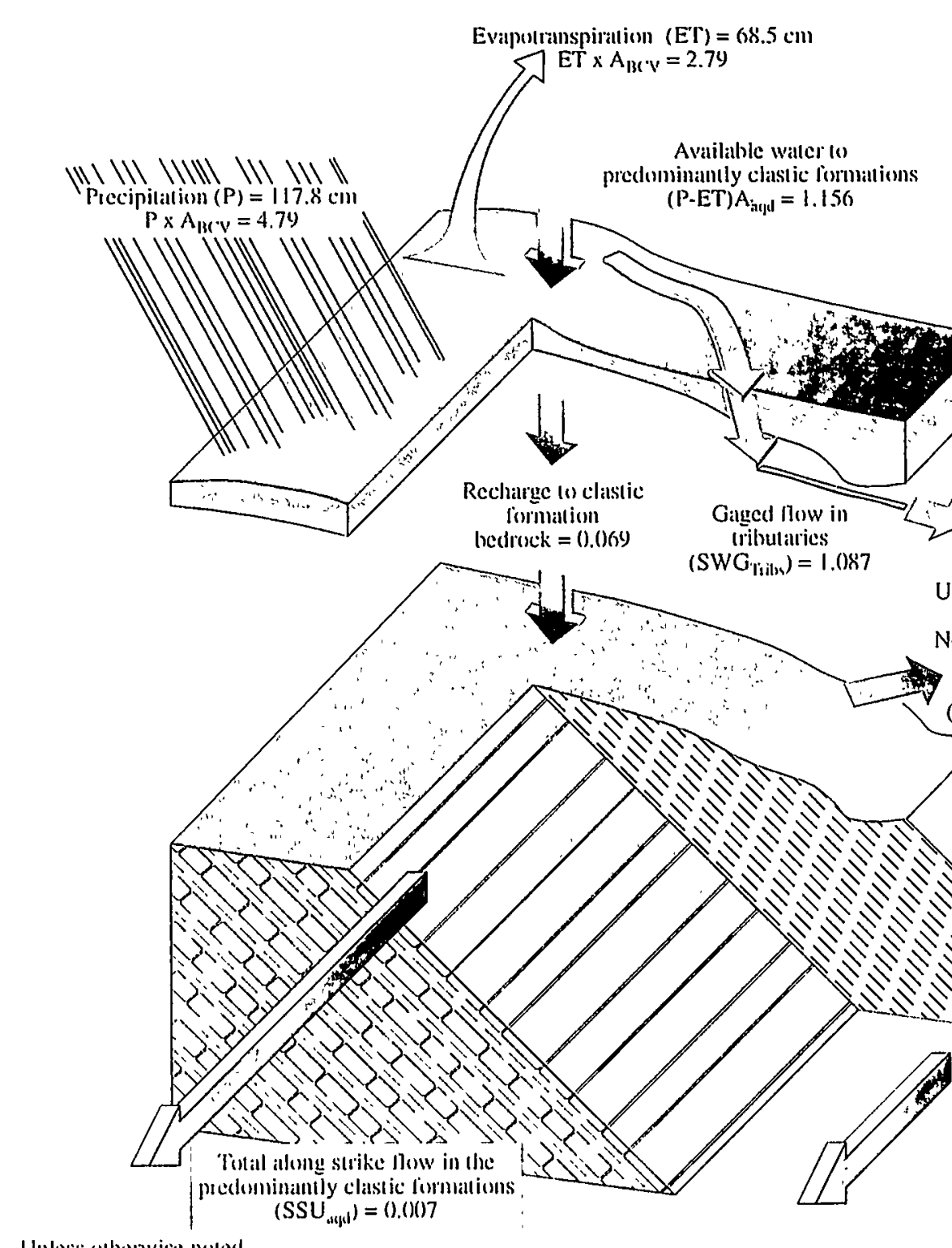

Unless oherwise nuted vilues are in $10^{6} \mathrm{mit}^{3}$
PREDOMINANTLY CLASTIC FORMATIONS

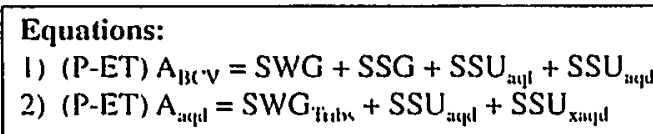

$A_{13 \cdot V}=$ Arca of $B C V$ caltelument above $B C K 9.47=4.07 \mathrm{~km}^{2}$

$A_{\text {ayf }}=$ Purtion al $A_{B C}$ v underlain by carbumalc furmations $=1.72 \mathrm{~km}^{2}$

$A_{\text {:agl }}=$ Portom of $A_{B C} \cdot v$ underlain by predominantly clastic formations $=2.35 \mathrm{~km}^{2}$

Tolal water alvilable $(\mathrm{P}-\mathrm{ET})_{13 C \mathrm{~V}}=\mathbf{2 . 0}$

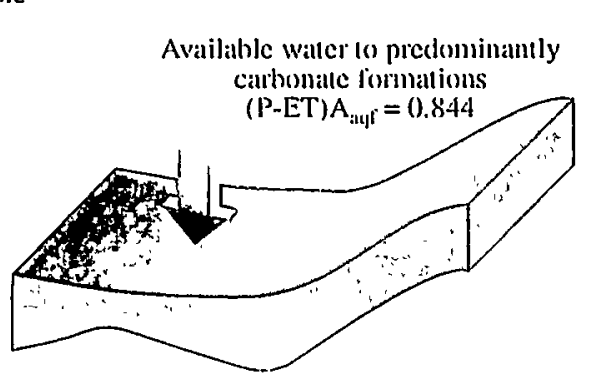

Discharge to Bear Creck $=$ 0.529 Dow tiom Nolichucky Shalc in Malynardville Limesione
$\left(S U_{x \rightarrow 1}\right)=0.062$<smiles>c1ccccc1</smiles>
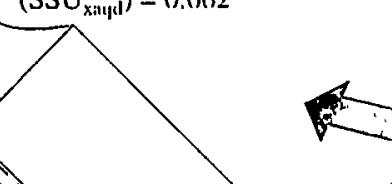

Fig. C.10. Water balance model for BCV above BCK 9.47.

Fow along valley at BCK 9.47 SS-5 (SSG)

Carthonate lormation groundwater ( $\mathrm{SSO}_{\text {aut }}$ ) cable waller on predominamtly carbonalle formiations Discharge al SS-
$(\mathrm{SSG})=0.323$

CARBONATE FORMATIONS 
, 


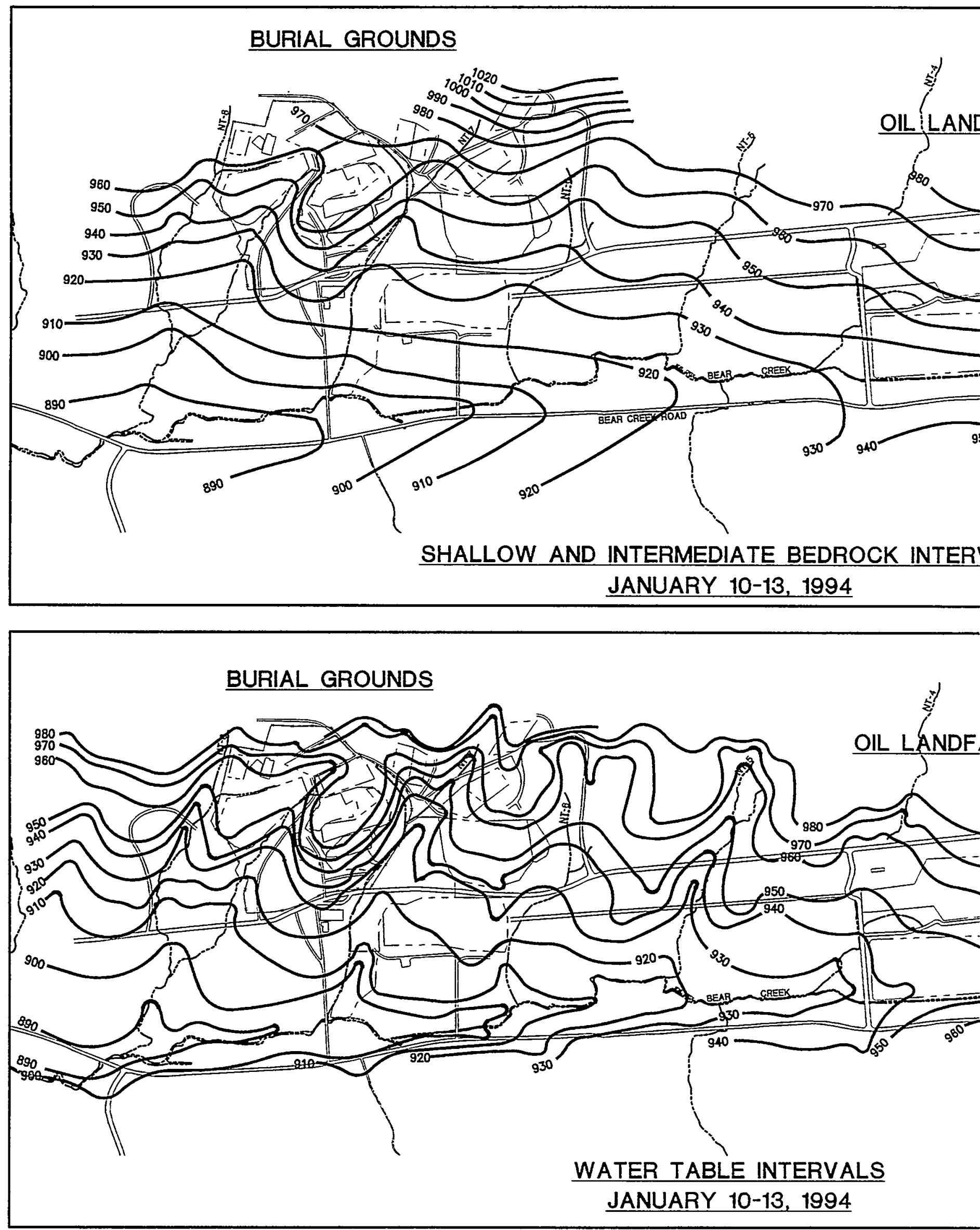

Fig. C.11. BCV groundwater elevations for January 10-13, 1994-groundwater piezometric head in BCV for water table a 


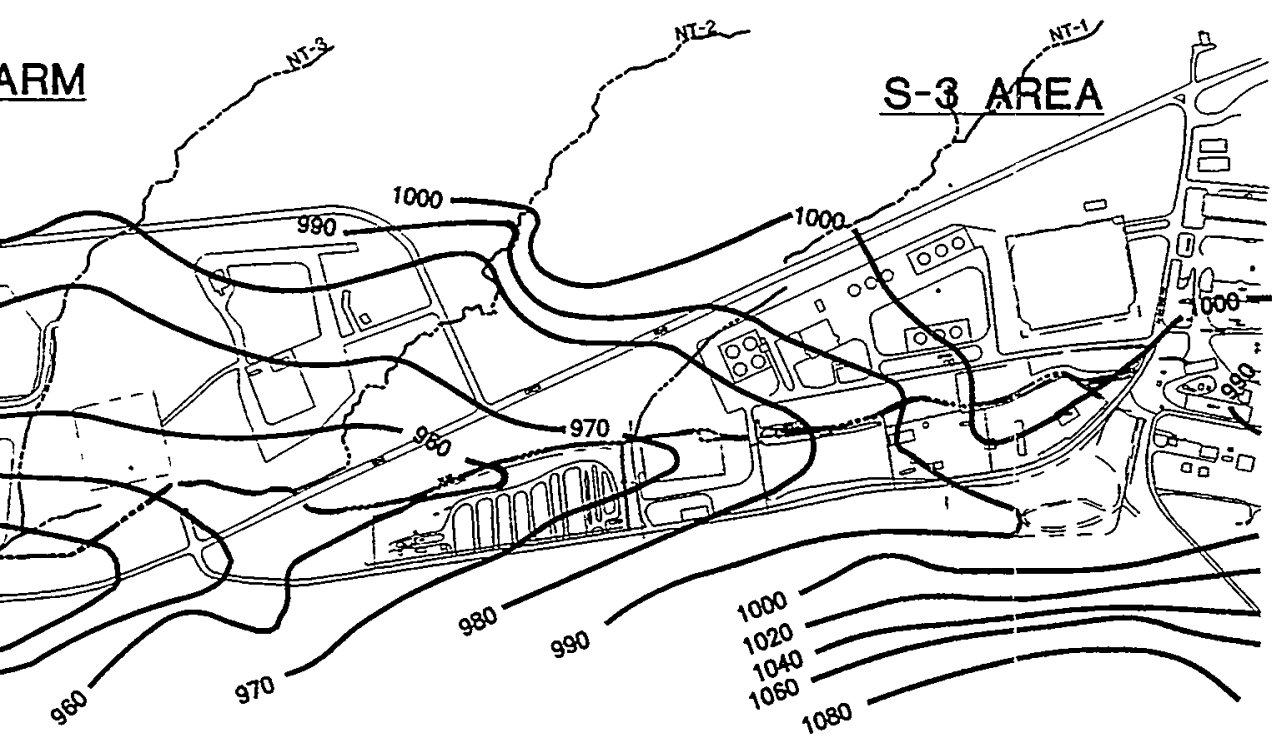

GROUNDWATER ELEVATION ..CONTOUR (ft $\mathrm{mls}$ )

DATA SOURCE:

CONTOURS FROM HSW

CONSULTANTS, INC. 1994

LS
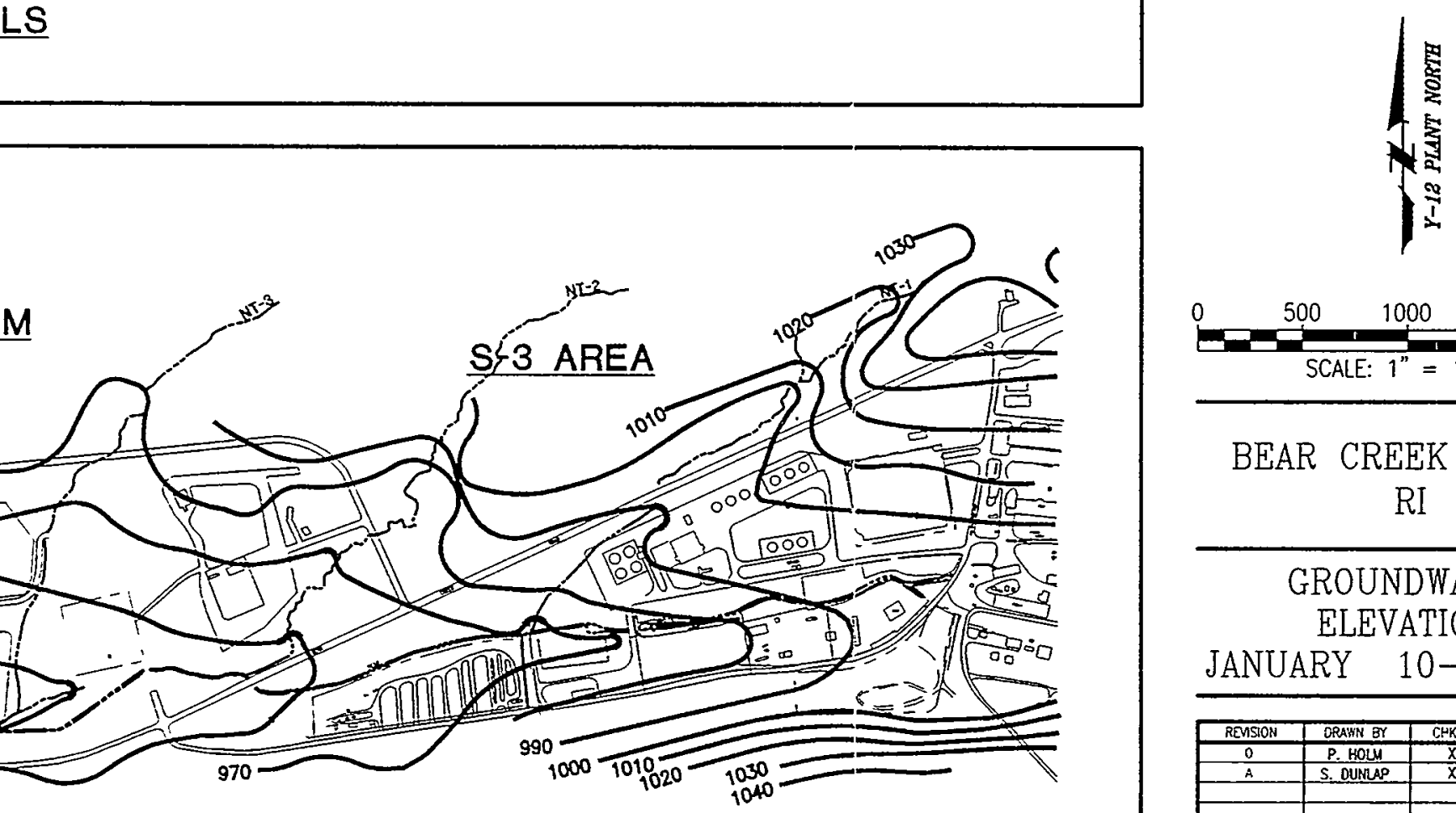

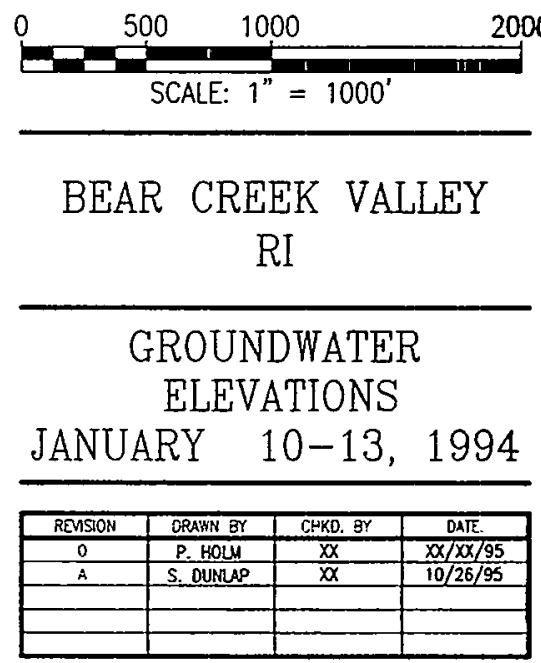

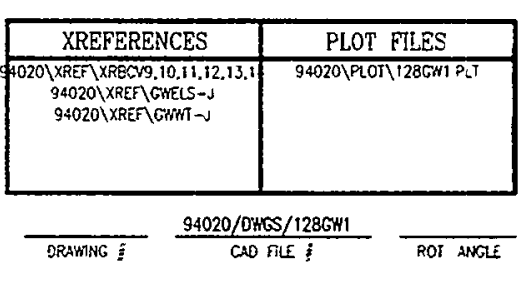



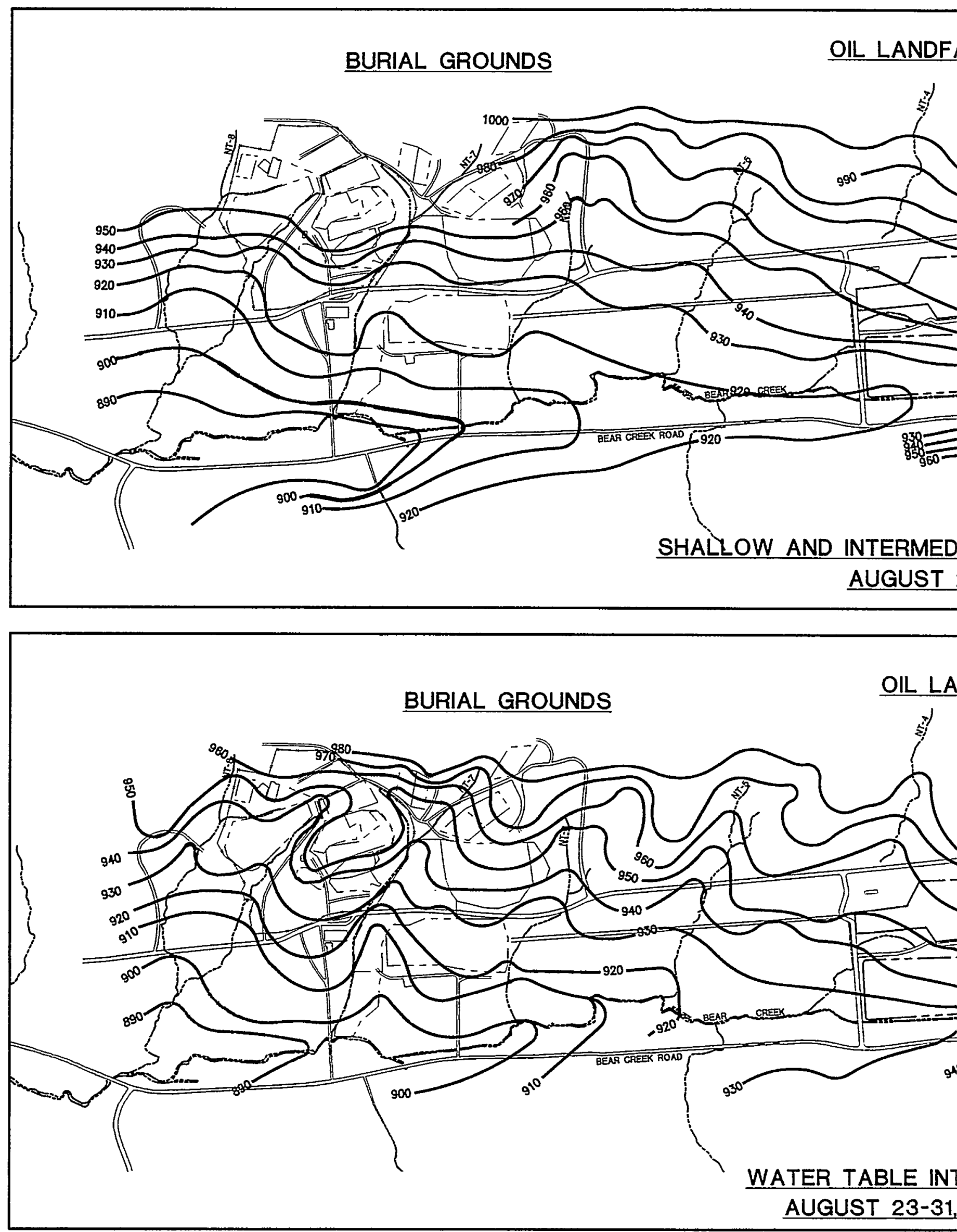

Fig. C.12. BCV groundwater elevations for August 23-31, 1994-groundwater piezometric head in BCV for water table 
M

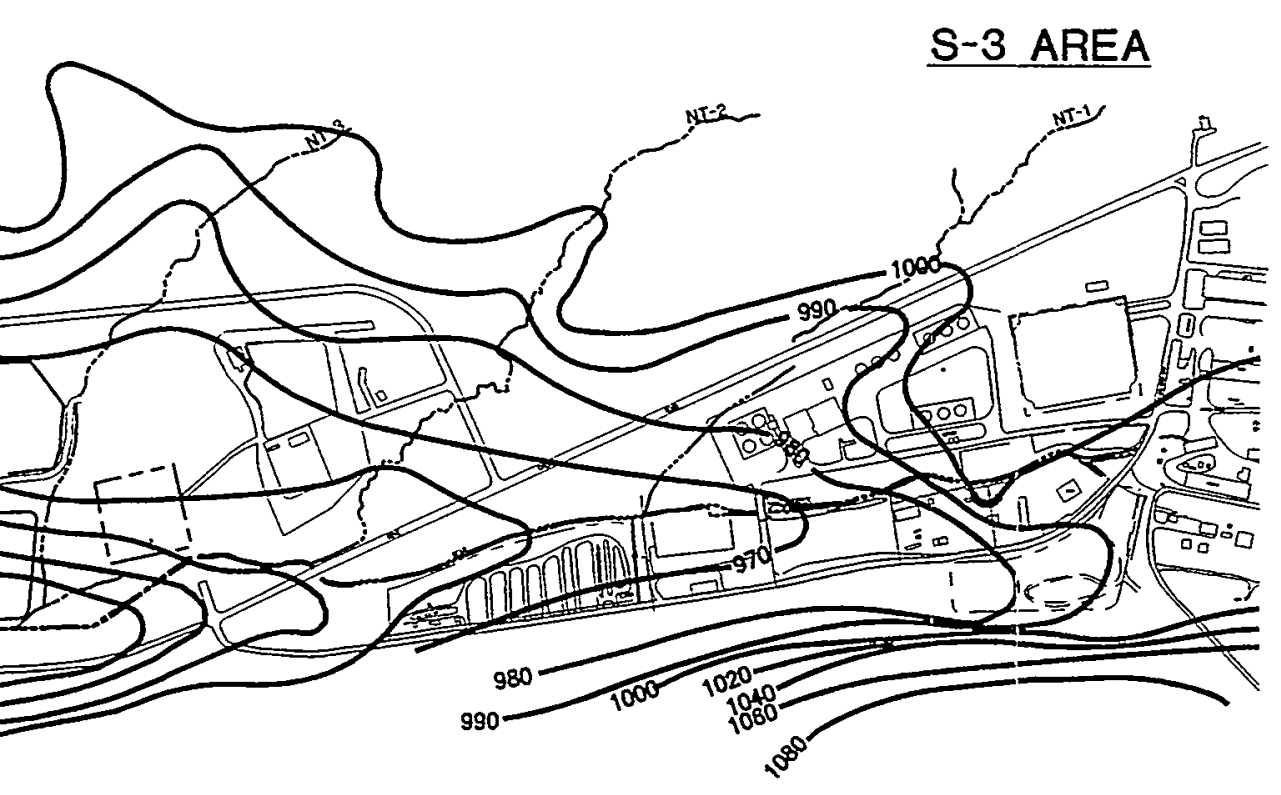

TE BEDROCK INTERVALS

\section{$-31,1994$}

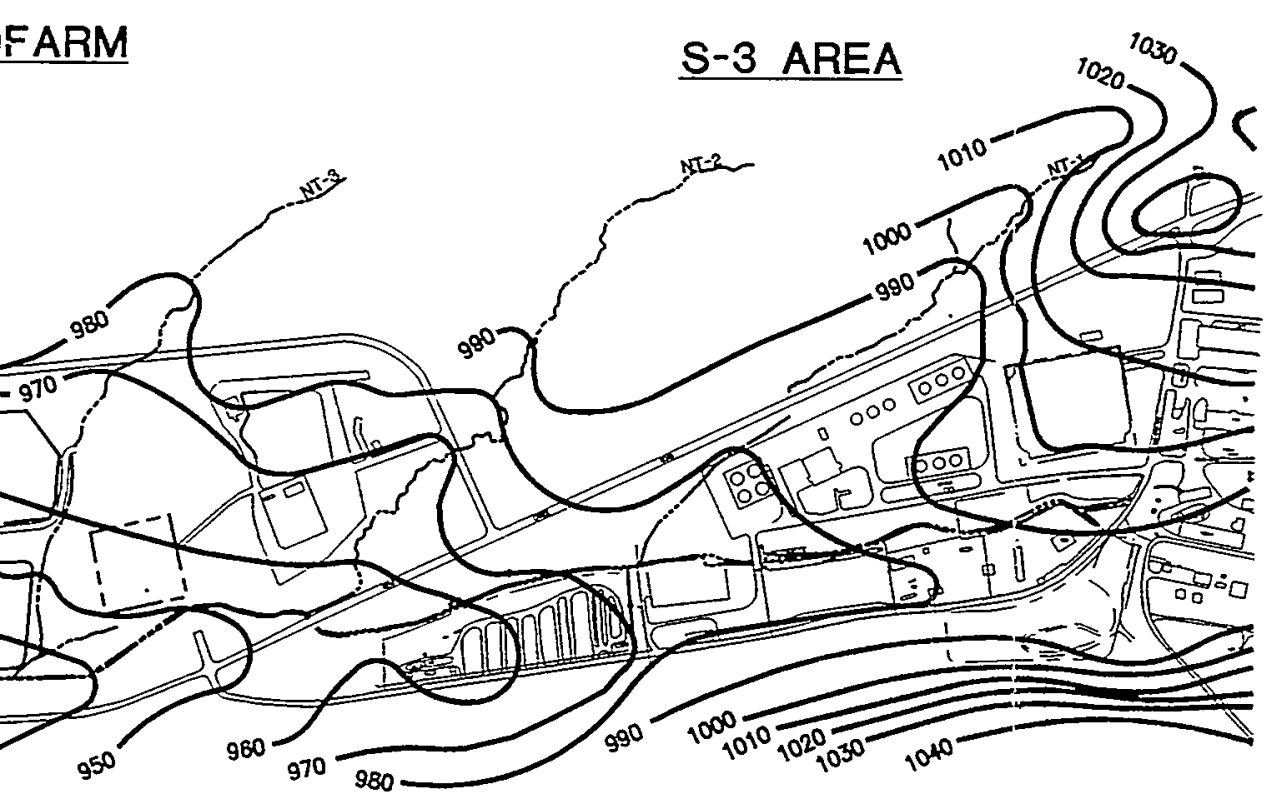

V ALS
LEGEND:

GROUNDWATER ELEVATIO! .CONTOUR (ft. $\mathrm{mls}$
DATA SOURCE:

CONTOURS FROM HSW

CONSULTANTS, INC. 1994
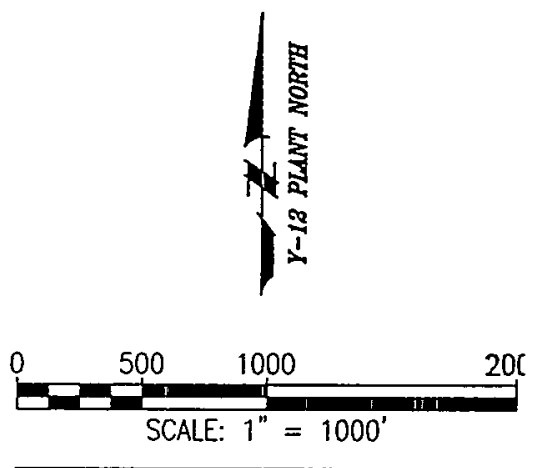

BEAR CREEK VALLEY RI

GROUNDWATER ELEVATIONS

AUGUST 23-31, 1994

\begin{tabular}{|c|c|c|c|}
\hline REMSON & DRAWN $8 Y$ & CHKD. BY & OATE \\
\hline 0 & P. HOLW & $x$ & $x \times x \times x / 5$ \\
\hline A & S. DURALP & $x$ & $10 / 26 / 95$ \\
\hline & & & \\
\hline & & & \\
\hline
\end{tabular}

\begin{tabular}{|c|c|}
\hline XREFERENCES & PLOT FILES \\
\hline 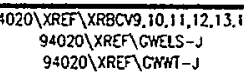 & 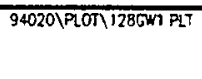 \\
\hline & \\
\hline
\end{tabular}


C6-20
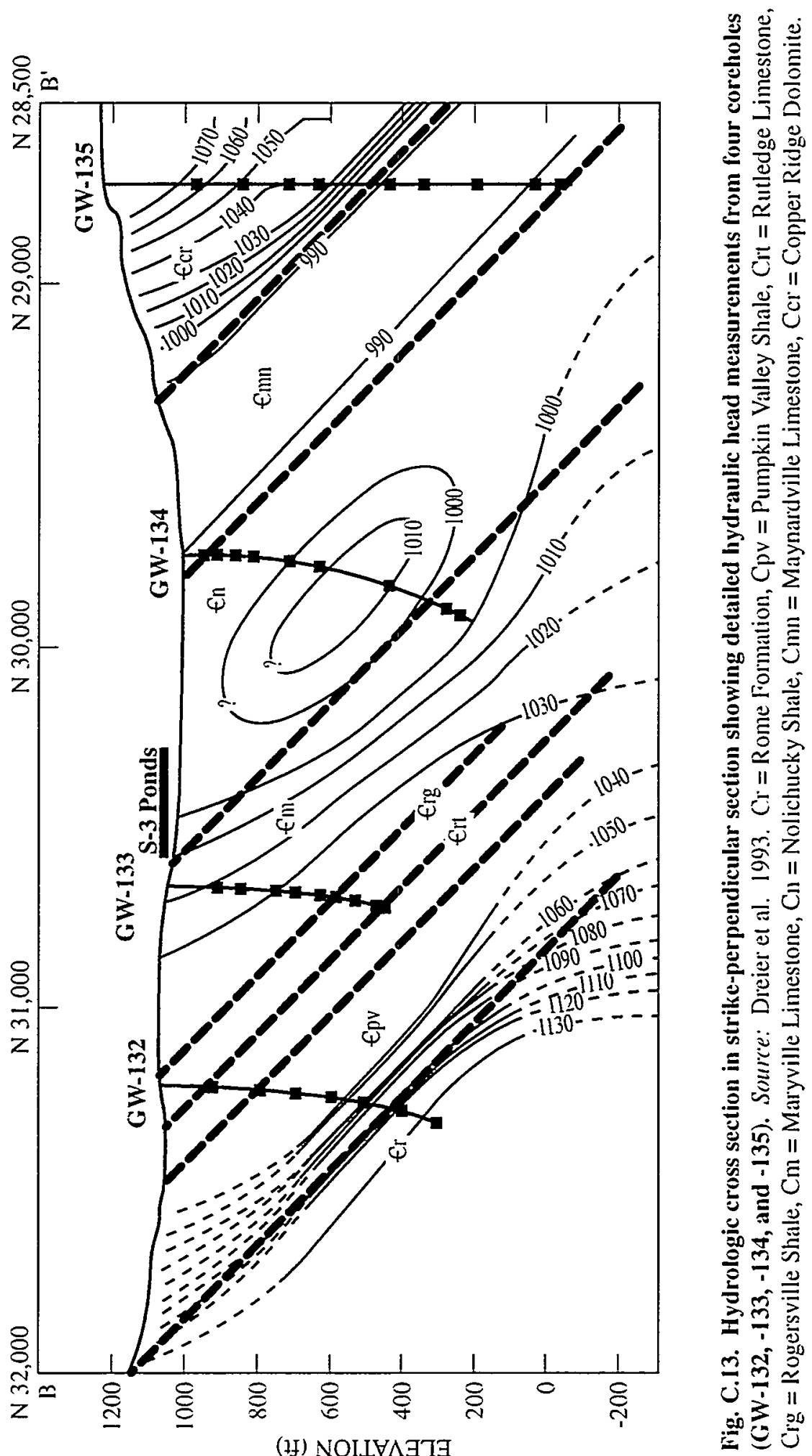

in

$z$

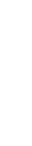


C6-21

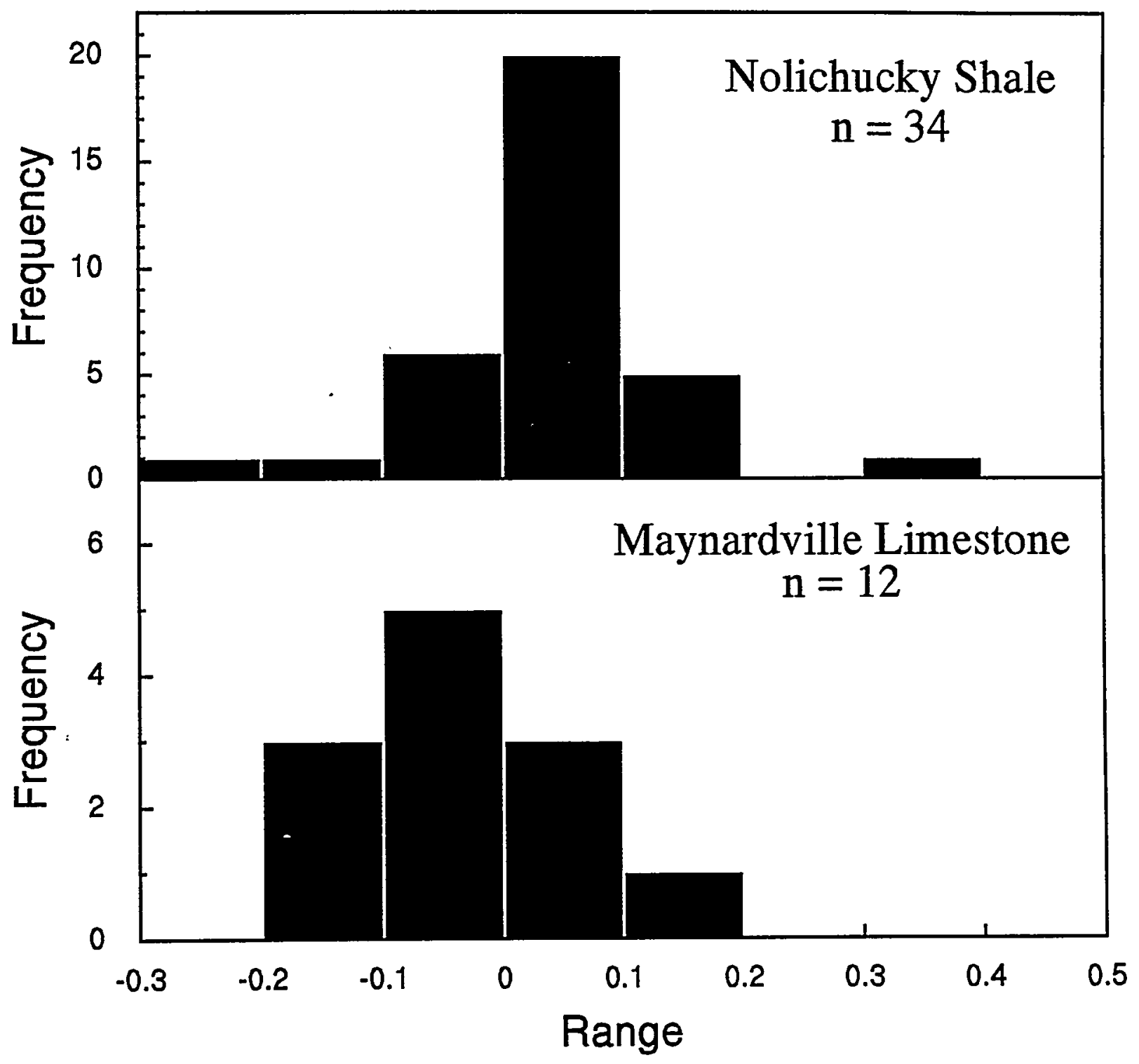

Fig. C.14. Frequency distribution of vertical hydraulic gradients in the Nolichucky Shale and Marynardville Limestone in BCV. 


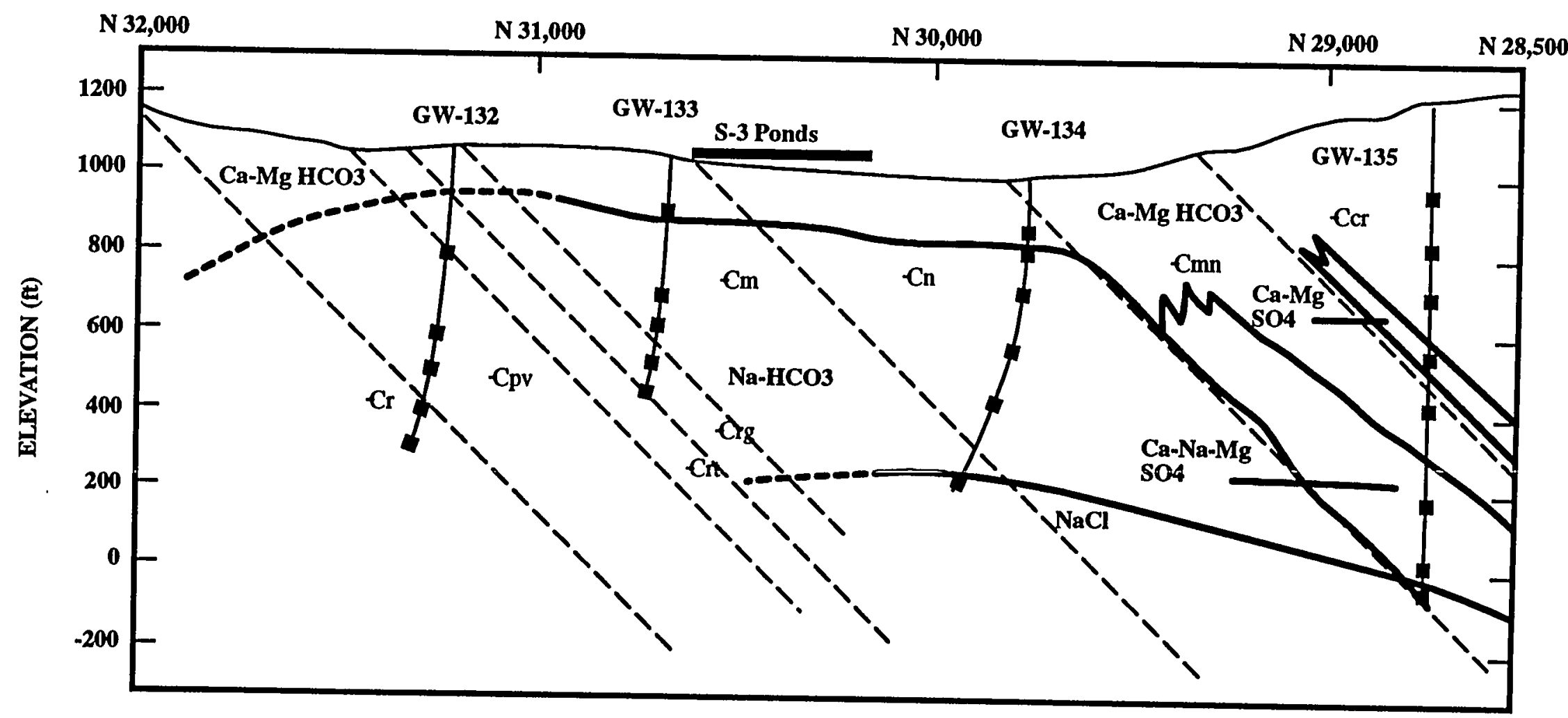

Fig. C.15. Water-type regimes in a strike-perpendicular cross section of BCV. Source: Dreier et al. 1993. Note that the effects of nitrate contamination in the vicinity of GW-134 have not been incorporated into the diagram. $\mathrm{Cr}=$ Rome Formation, $\mathrm{Cpv}=\mathrm{Pumpkin}$ Valley Shale, $\mathrm{Crt}=$ Rutledge Limestone, $\mathrm{Crg}=$ Rogersville Shale, $\mathrm{Cm}=$ Maryville Limestone, $\mathrm{Cn}=$ Nolichucky Shale, $\mathrm{Cmn}=$ Maynardville Limestone, Ccr $=\mathrm{Copper}$
Ridge Dolomite. 

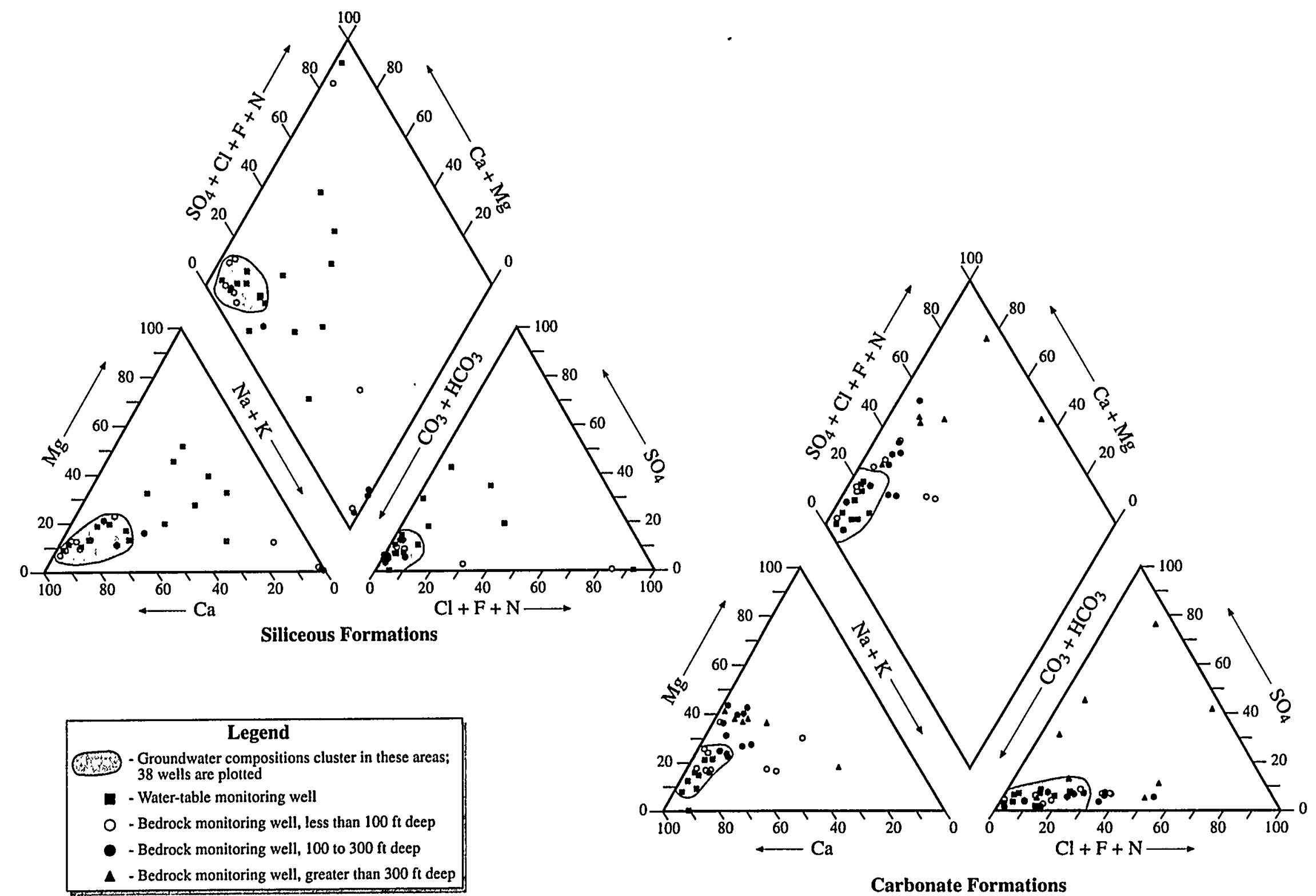

Carbonate Formations

Fig. C.16. Piper diagram illustrating groundwater geochemistry in BCV. Source: HSW 1995. 
C6-24

宅

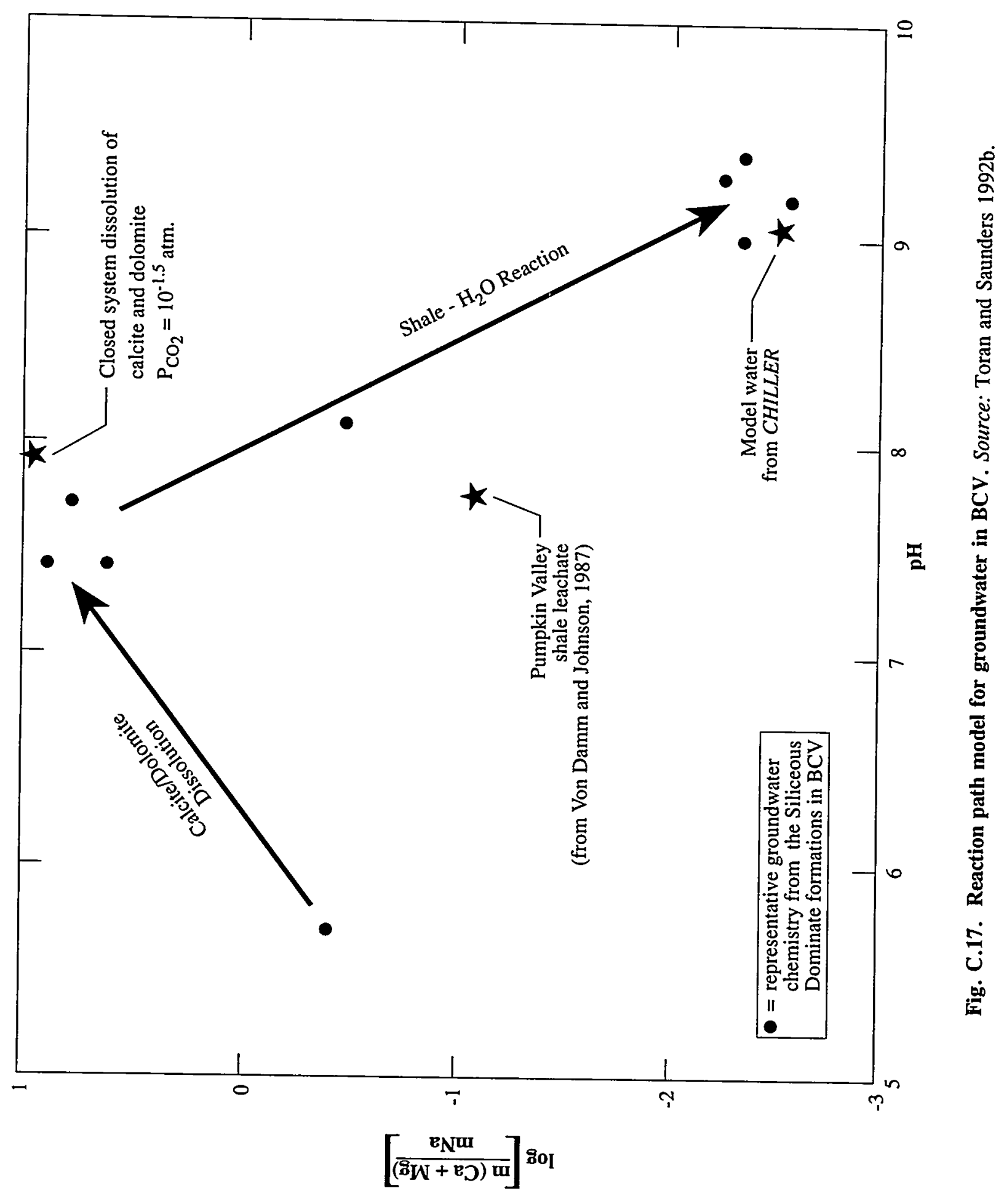




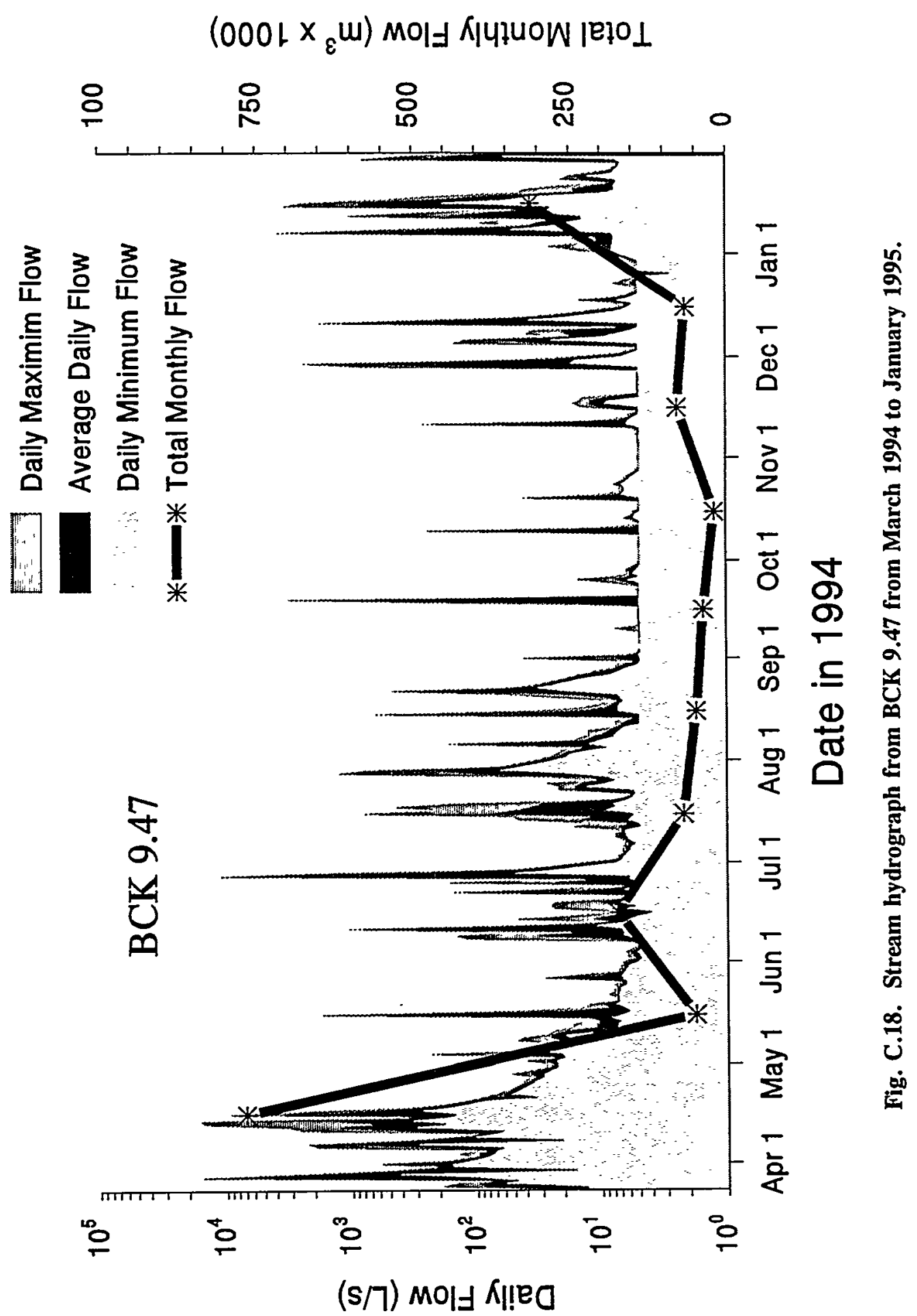


C6-26

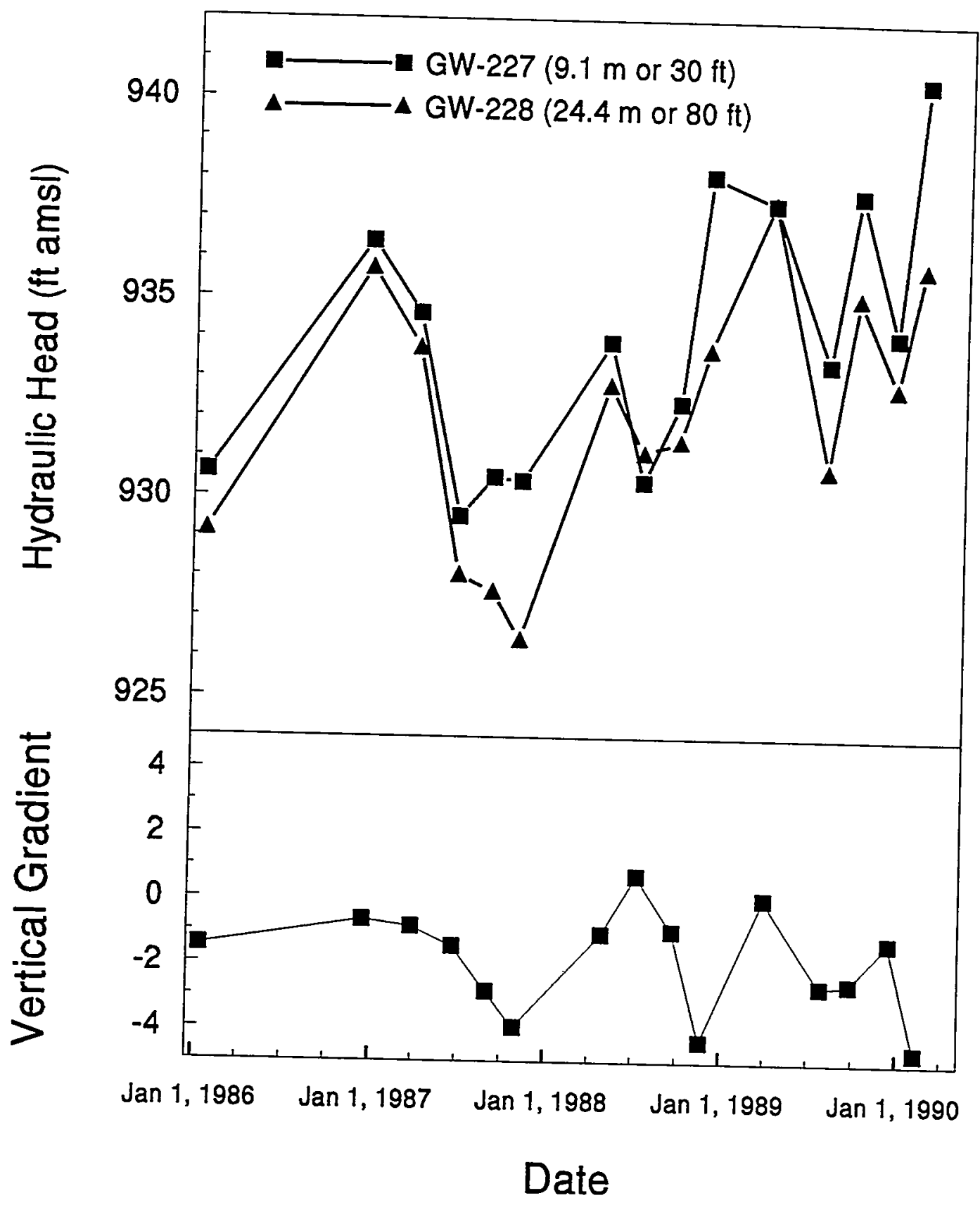

Fig. C.19. Variation of head from instantaneous measurement in GW-227 and GW-228. 


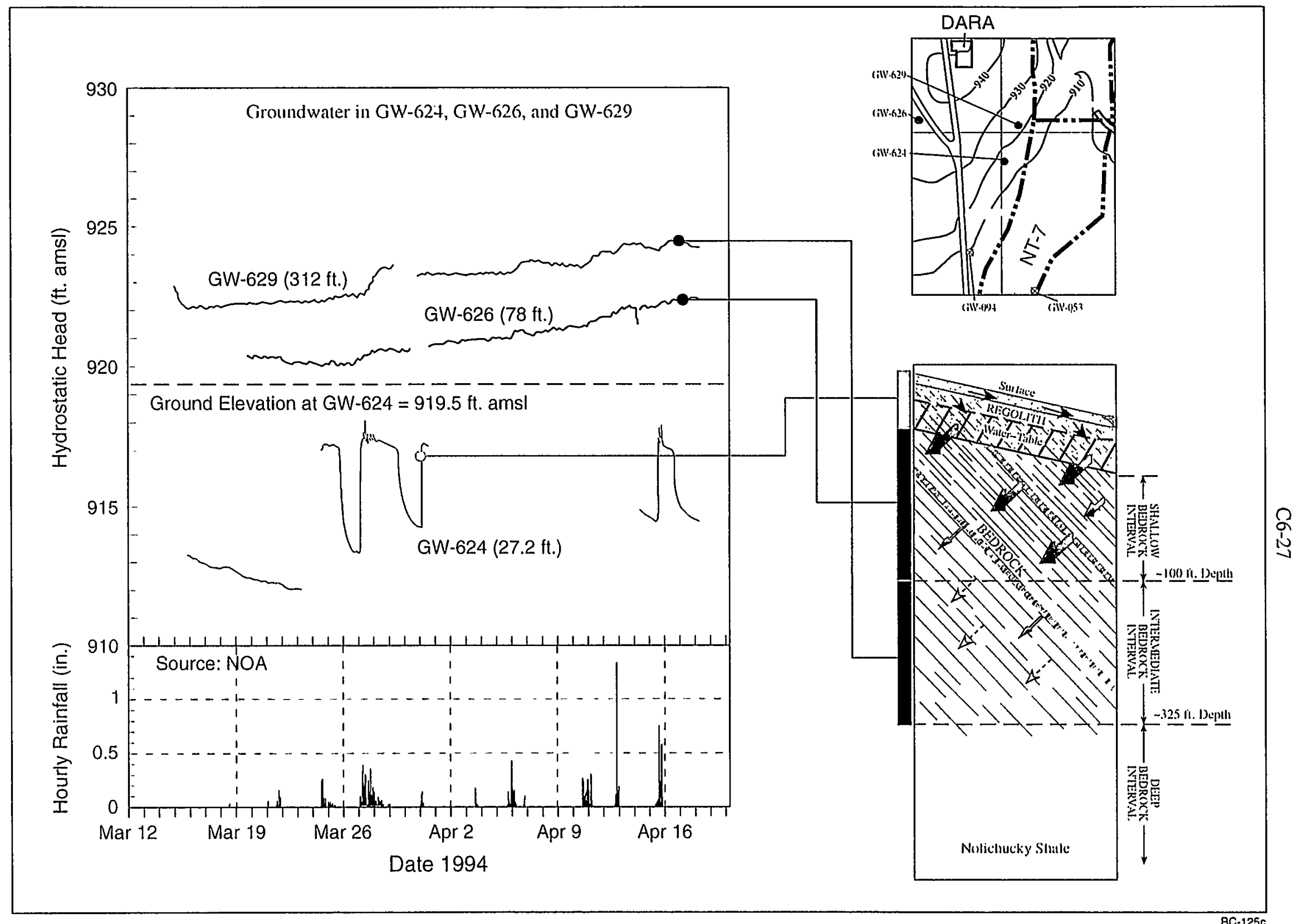

Fig. C.20. Hydraulic head monitoring in wells GW-624, -626 , and -629 in the Nolichucky Shale. 


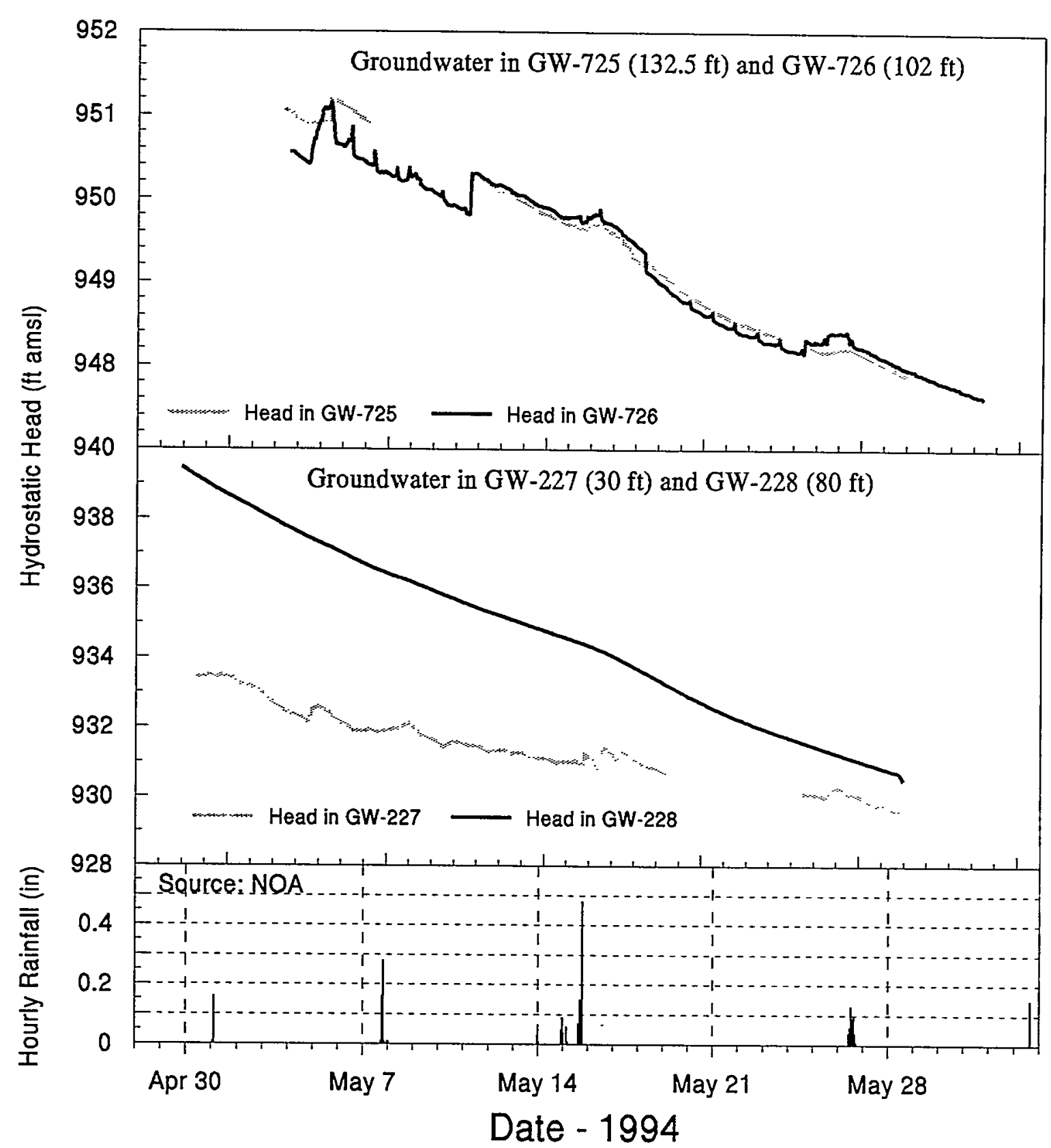

Fig. C.21. Well hydrographs for GW-725 and GW-726 at BYBY, and for GW-227 and GW-228 at SL 1. 


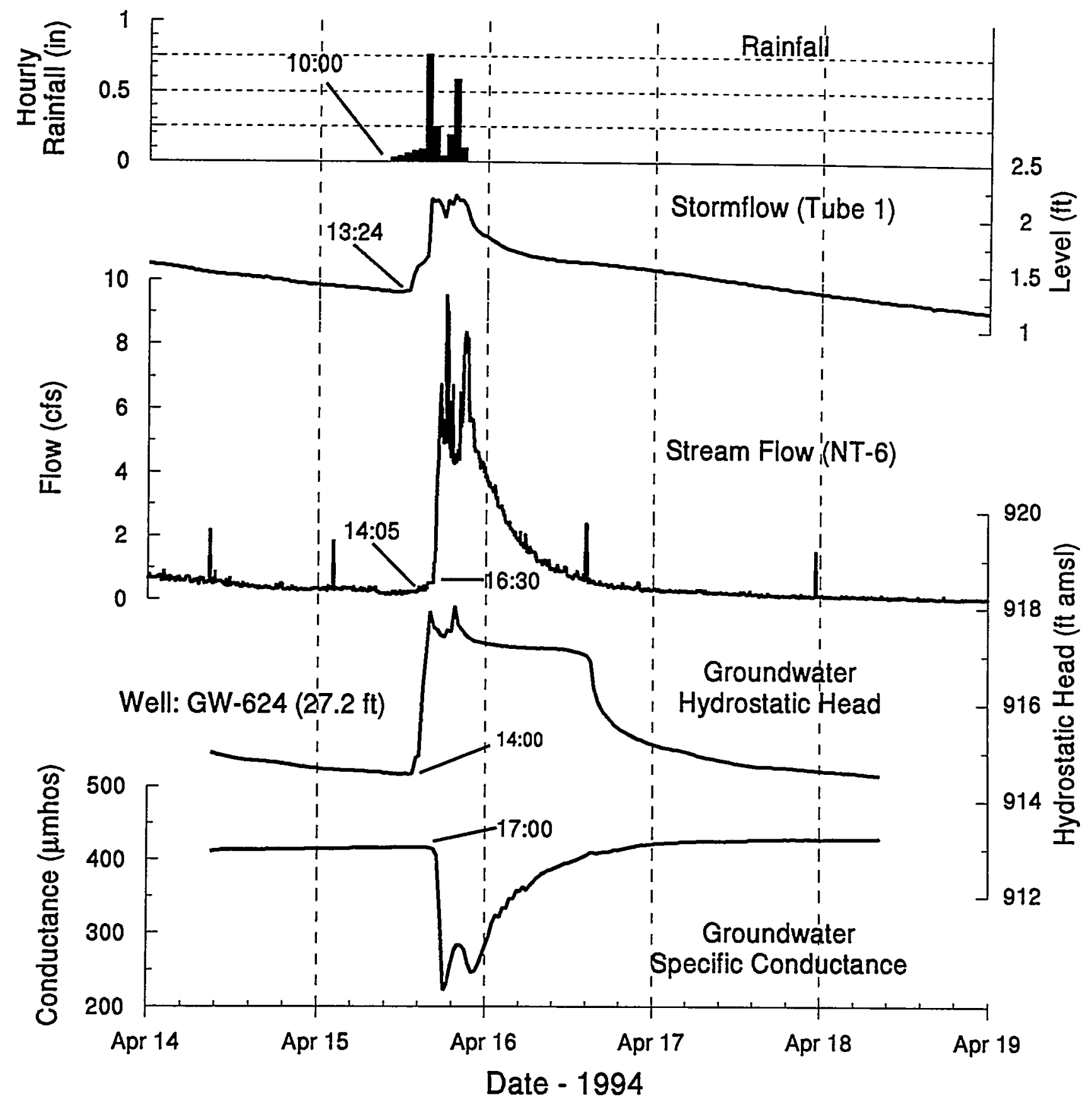

Fig. C.22. Monitoring of changes in soil saturation, stream flow, and groundwater at the BCBG for a storm on April 15, 1994. 


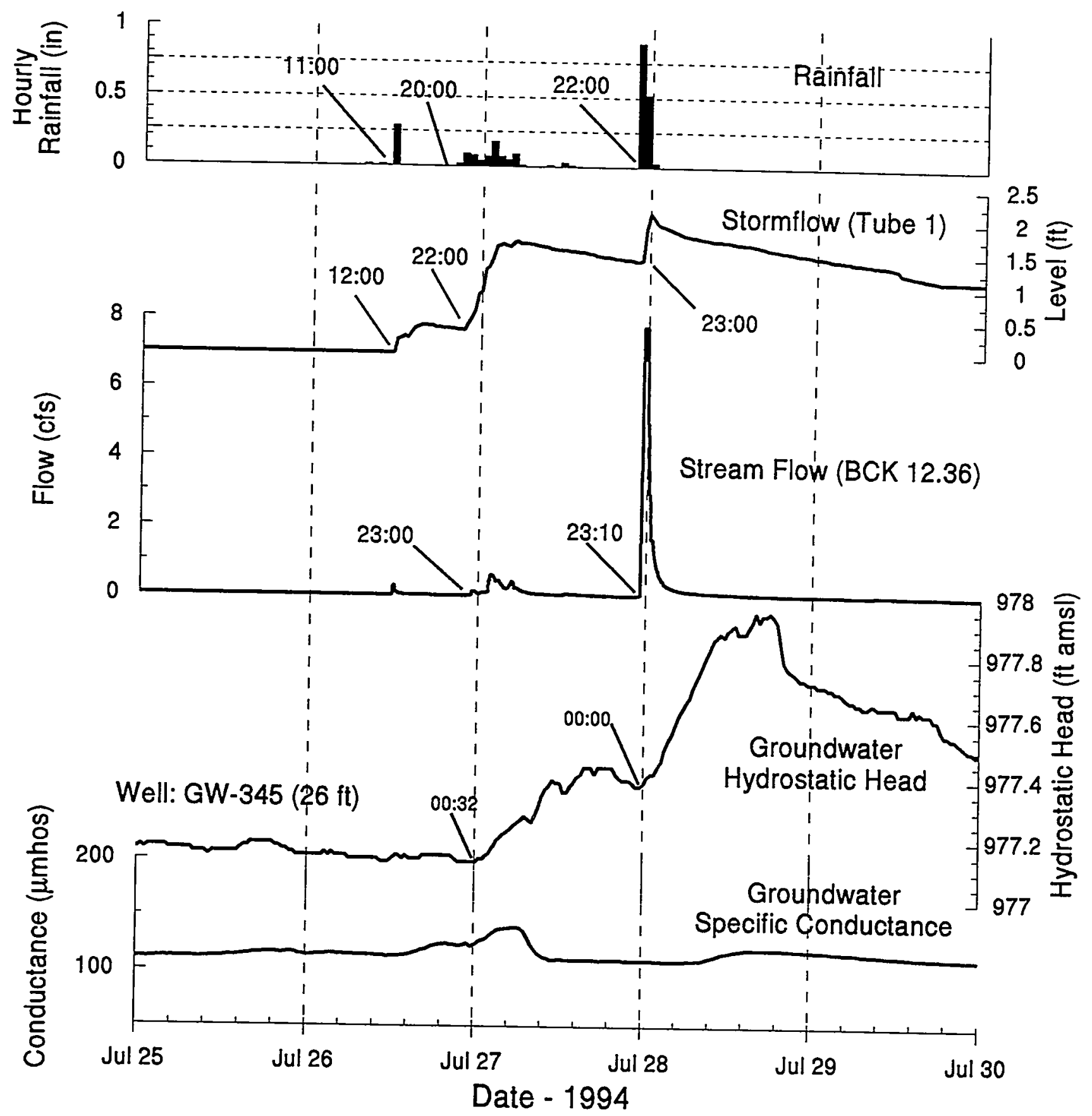

Fig. C.23. Monitoring of changes in soil saturation, stream flow, and groundwater at the S-3 Site during storms on July 26-28, 1994. 


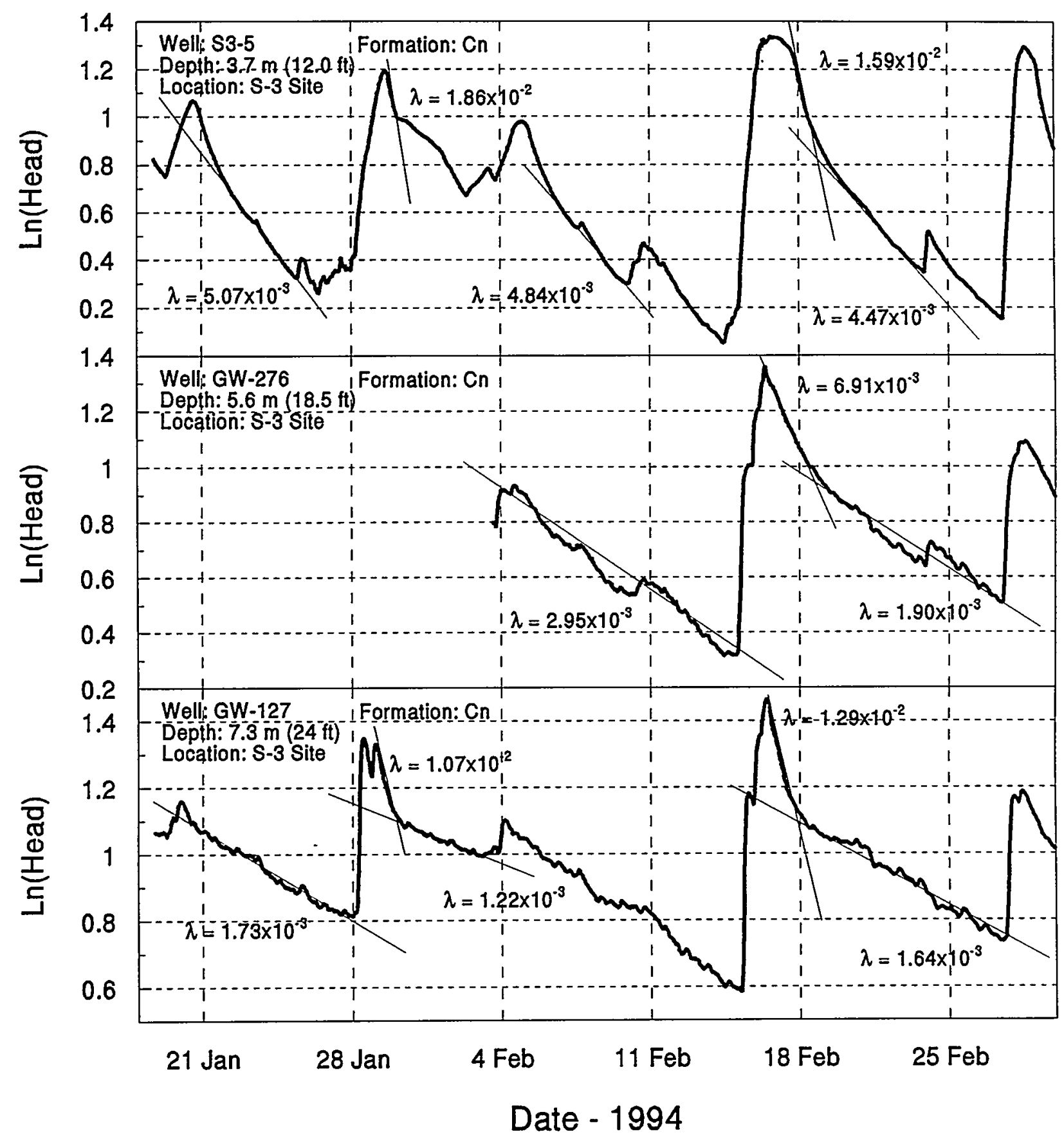

Fig. C.24. Example well hydrographs for the water table interval of the Nolichucky Shale. 

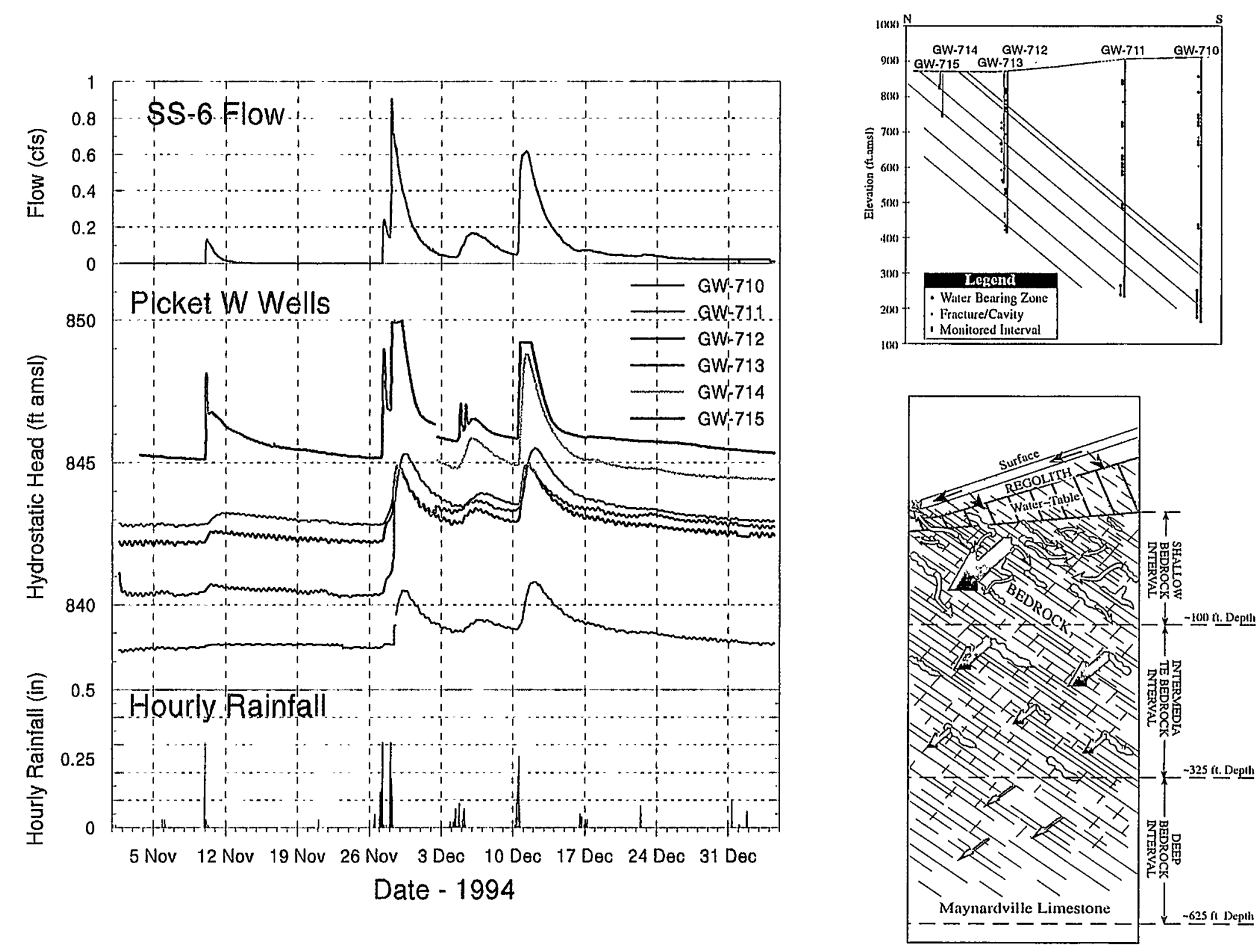

Fig. C.25. Hydraulic head monitoring in wells at the Western Picket in the Maynardville Limestone. 


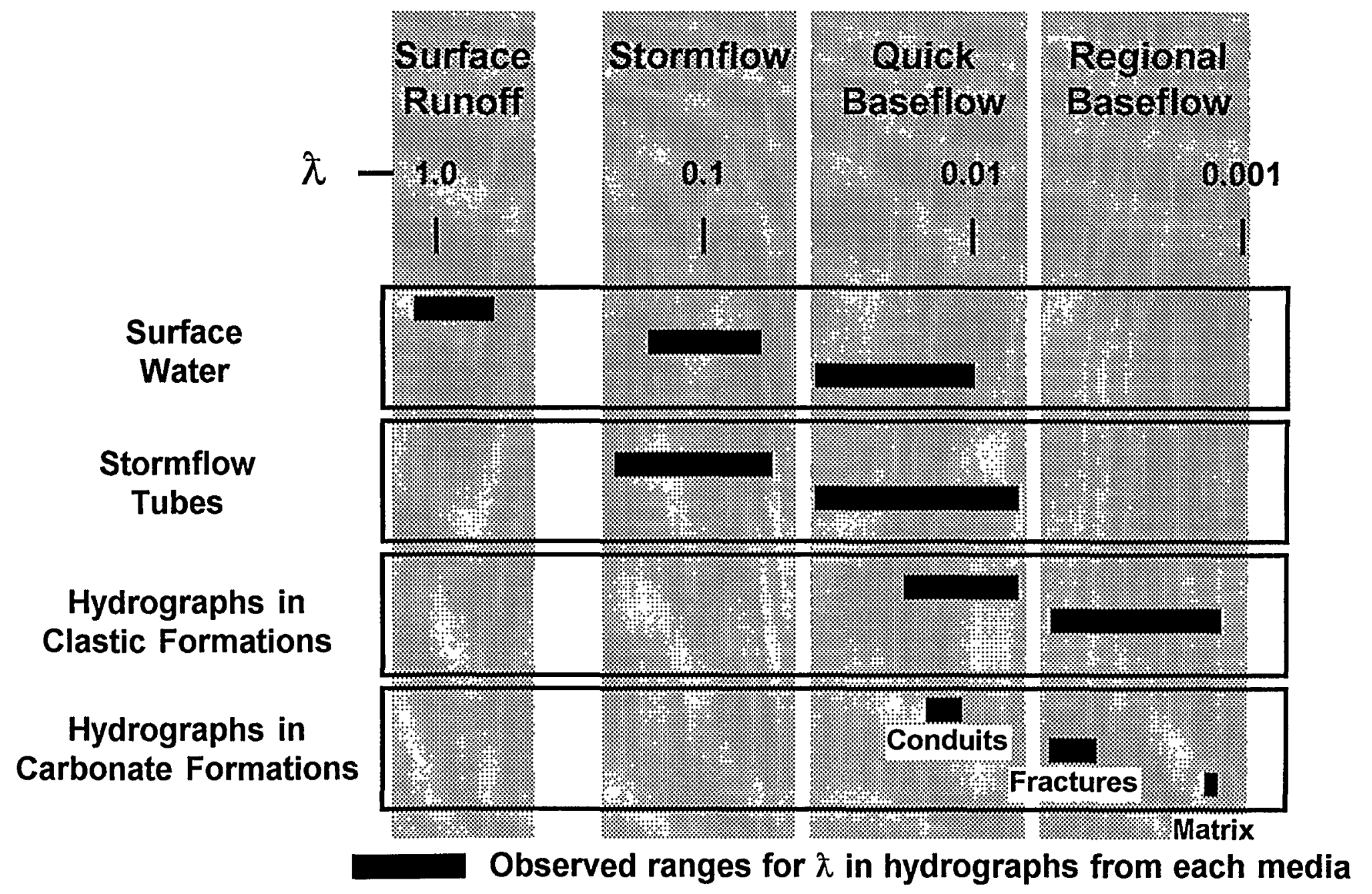

Fig. C.26. Relative magnitudes of $\lambda$ for stream flow, stormflow tubes and groundwater in BCV. 


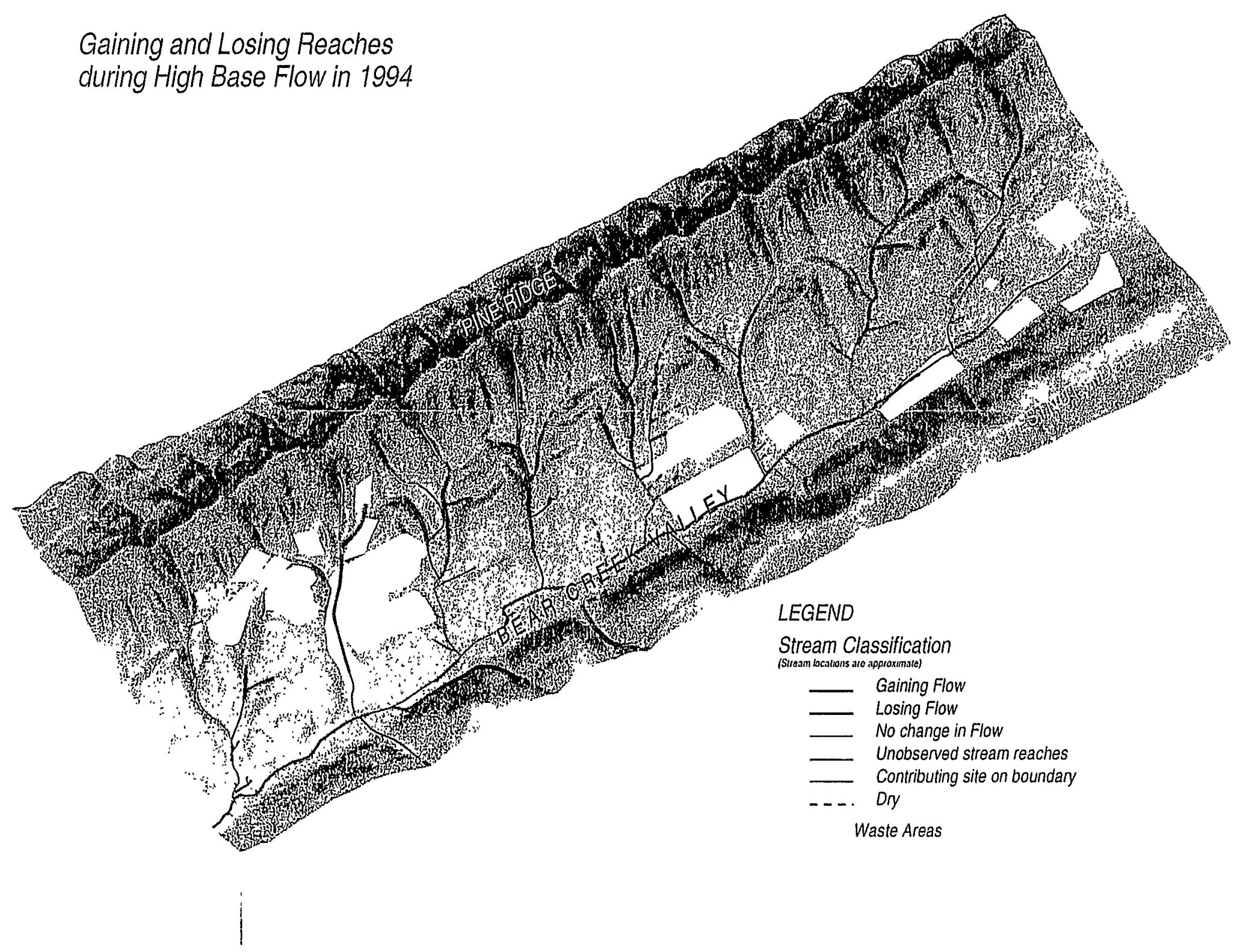

Fig. C.27. Identification of gaining and losing reaches in Bear Creek during a high-baseflow period in April 1994. 


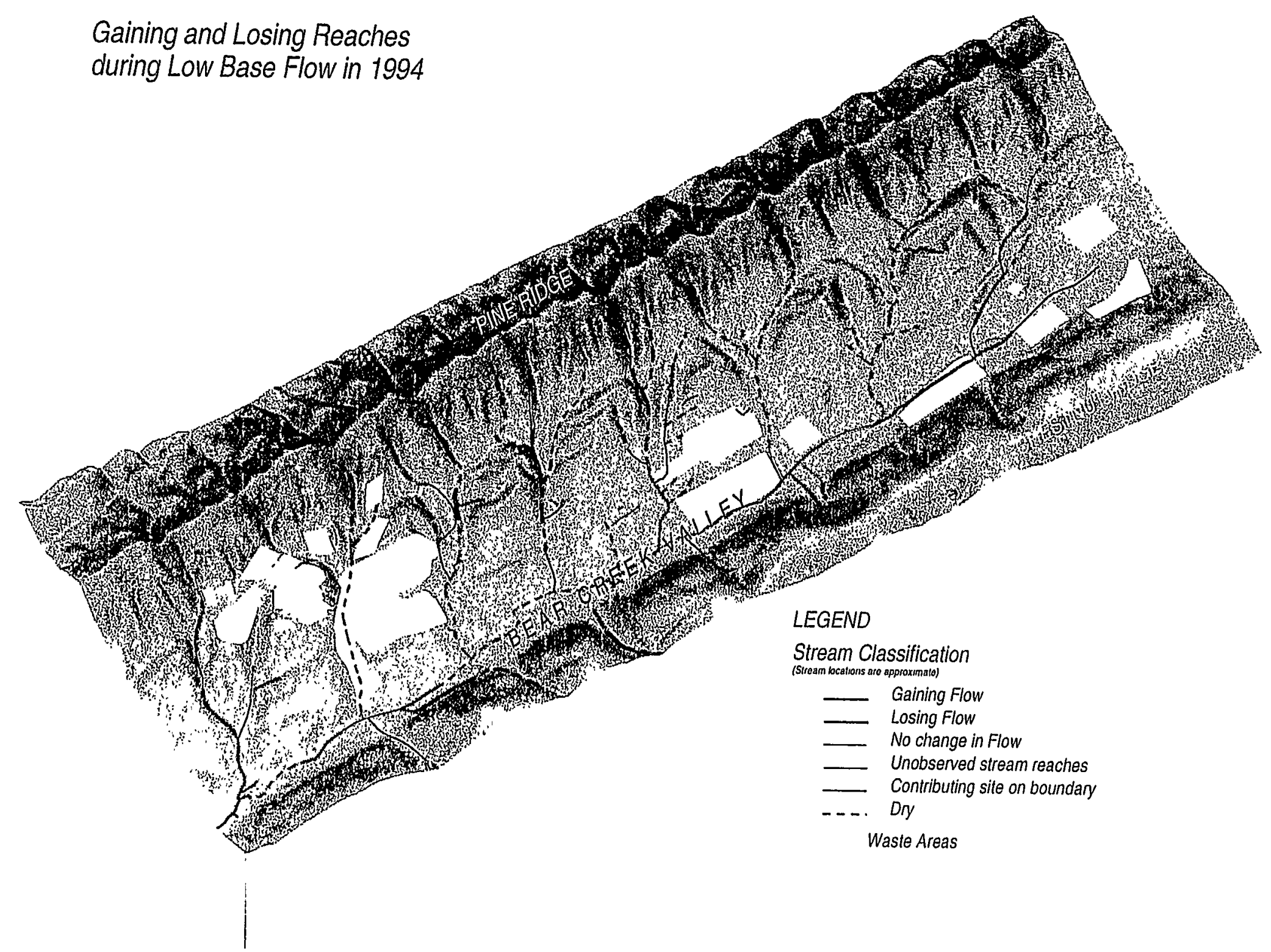

Fig. C.28. Identification of gaining and losing reaches in Bear Creek during a low-baseflow period in April 1994. 
C6-36

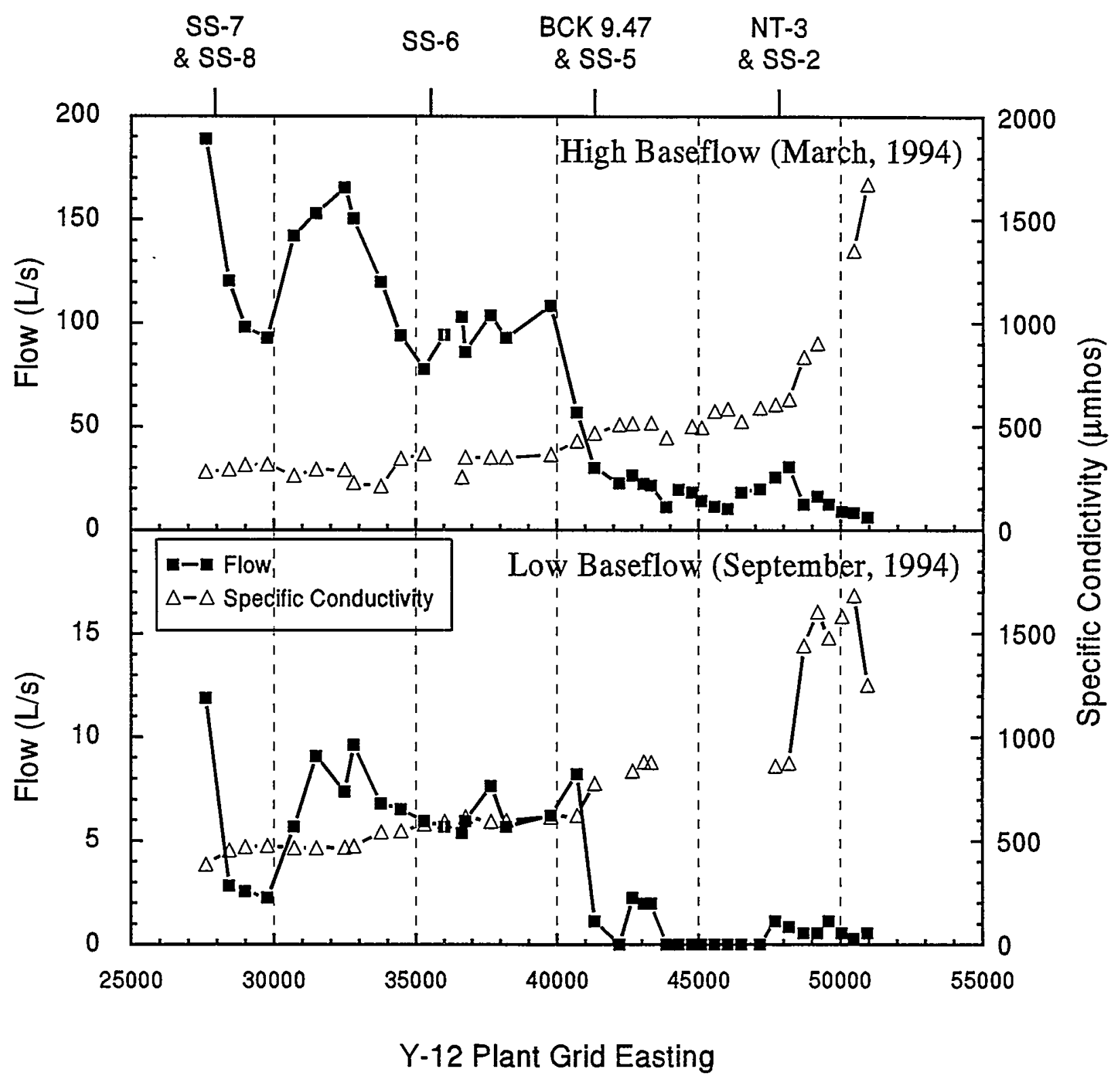

Fig. C.29. West-East profiles of Bear Creek showing flow and conductivity during the high and low baseflow spring and seep surveys (low-flow profile-September 1994 and high-flow profile-March 1995). 
C7-1

\section{C.7 TABLES}



C7-3

Table C.1 Thickness of zones identified in the Maynardville Limestone ${ }^{a}$

\begin{tabular}{|c|c|c|c|c|c|c|c|}
\hline \multicolumn{8}{|c|}{ DOWNHOLE THICKNESS OF GEOLOGICAL UNITS } \\
\hline $\begin{array}{l}\text { Well } \\
\text { Name }\end{array}$ & $\begin{array}{c}\text { zone } \\
7\end{array}$ & $\begin{array}{c}\text { zone } \\
6 \\
\end{array}$ & $\begin{array}{c}\text { zone } \\
5\end{array}$ & $\begin{array}{c}\text { zone } \\
4\end{array}$ & $\begin{array}{c}\text { zone } \\
3 \\
\end{array}$ & $\begin{array}{c}\text { zone } \\
2\end{array}$ & $\begin{array}{c}\text { Total Est } \\
\text { Cmn }\end{array}$ \\
\hline \multicolumn{8}{|l|}{ PICKET A } \\
\hline GW-685 & & & 68 & & & & $\mathrm{NA}$ \\
\hline \multicolumn{8}{|l|}{ PICKET B } \\
\hline GW-703 & & 97 & & & & & \\
\hline GW-704 & & 94 & 52 & & & & \\
\hline GW-705 & & & 48 & 125 & 30 & 0 & 301 \\
\hline \multicolumn{8}{|l|}{ PICKET C } \\
\hline GW-723 & 11 & 94 & 59 & 80 & & & \\
\hline GW-724 & & & 58 & 80 & 67 & & \\
\hline GW-739 & 19 & 95 & 56 & & & & \\
\hline GW-740 & 16 & & & & & & NA \\
\hline \multicolumn{8}{|l|}{ PICKET J } \\
\hline GW-722 & & 97 & 56 & 145 & 94 & 192 & \\
\hline GW-733 & & 142 & 63 & & & & 619 \\
\hline \multicolumn{8}{|l|}{ PICKET W } \\
\hline GW-710 & 23 & 93 & & & & & \\
\hline GW-711 & 31 & 92 & 55 & & & & \\
\hline GW-712 & & 116 & 59 & 84 & 84 & & \\
\hline GW-713 & 20 & 95 & 55 & & & & NA \\
\hline \multicolumn{8}{|c|}{ SUMMARY } \\
\hline $\begin{array}{l}\text { Well } \\
\text { Name }\end{array}$ & $\begin{array}{c}\text { zone } \\
7\end{array}$ & $\begin{array}{c}\text { zone } \\
6\end{array}$ & $\begin{array}{c}\text { zone } \\
5\end{array}$ & $\begin{array}{c}\text { zone } \\
4\end{array}$ & $\begin{array}{c}\text { zone } \\
3\end{array}$ & $\begin{array}{c}\text { zone } \\
2\end{array}$ & $\begin{array}{c}\text { Total Est } \\
\text { Cmn }\end{array}$ \\
\hline \multicolumn{8}{|c|}{ DOWNHOLE THICKNESS } \\
\hline AVERAGE & 21 & 100 & 54 & 106 & 74 & 148 & 491 \\
\hline $\begin{array}{l}\text { STANDARD } \\
\text { DEV }\end{array}$ & 5 & 16 & 7 & 23 & 24 & 68 & 106 \\
\hline MAXIMUM & 31 & 142 & 68 & 145 & 108 & 236 & 619 \\
\hline MINIMUM & 11 & 83 & 39 & 76 & 24 & 0 & 301 \\
\hline $\begin{array}{l}\text { \# OF } \\
\text { BOREHOLES }\end{array}$ & 10 & 14 & 17 & 12 & 13 & 8 & 5 \\
\hline
\end{tabular}


C7-4

Table C.1 (continued)

\begin{tabular}{|c|c|c|c|c|c|c|c|}
\hline \multicolumn{8}{|c|}{ Summary } \\
\hline $\begin{array}{l}\text { Well } \\
\text { Name }\end{array}$ & $\begin{array}{c}\text { zone } \\
7\end{array}$ & $\begin{array}{c}\text { zone } \\
6\end{array}$ & $\begin{array}{c}\text { zone } \\
5\end{array}$ & $\begin{array}{c}\text { zone } \\
4\end{array}$ & $\begin{array}{c}\text { zone } \\
3\end{array}$ & $\begin{array}{c}\text { zone } \\
2\end{array}$ & $\begin{array}{l}\text { Total Est } \\
\text { Cmn }\end{array}$ \\
\hline \multicolumn{8}{|c|}{ STRATIGRAPHIC THICKNESS (assume 43 degree dip) } \\
\hline AVERAGE & 16 & 73 & 39 & 78 & 54 & 108 & 359 \\
\hline $\begin{array}{l}\text { STANDARD } \\
\text { DEV }\end{array}$ & 4 & 12 & 5 & 17 & 18 & 50 & 77 \\
\hline MAXIMUM & 23 & 104 & 50 & 106 & 79 & 173 & 453 \\
\hline MINIMUM & 8 & 61 & 29 & 56 & 18 & 0 & 220 \\
\hline $\begin{array}{l}\text { \# OF } \\
\text { BOREHOLES }\end{array}$ & 10 & 14 & 17 & 12 & 13 & 8 & 5 \\
\hline
\end{tabular}

${ }^{a}$ Source: Shevenell et al. 1992. 
Table C.2 Valley-wide summary of results from the BCV and

Grassy Creek spring and seep survey

\begin{tabular}{|c|c|c|c|c|c|c|c|c|c|c|c|c|}
\hline \multicolumn{13}{|c|}{ SUMMARY STATISTICS Y-12 PLANT } \\
\hline \multicolumn{7}{|c|}{ High Base Flow } & \multicolumn{6}{|c|}{ Low Base Flow } \\
\hline & $\begin{array}{c}Q \\
\text { (cfs) }\end{array}$ & $\mathrm{pH}$ & & $\underset{(\mathrm{uS} / \mathrm{cm})}{\mathrm{K}}$ & $\begin{array}{c}\text { Temp } \\
\text { C }\end{array}$ & $\begin{array}{c}\mathrm{DO} \\
(\mathrm{mg} / \mathrm{l})\end{array}$ & & $\begin{array}{c}Q \\
\text { (cfs) }\end{array}$ & $\mathrm{pH}$ & $\underset{(\mathrm{uS} / \mathrm{cm})}{\mathrm{K}}$ & $\underset{\text { C }}{\text { Temp }}$ & $\begin{array}{c}\mathrm{DO} \\
(\mathrm{mg} / \mathrm{l})\end{array}$ \\
\hline Maximum & 6.89 & & 8.4 & 1710 & 21 & 16 & Maximum & 0.76 & 8.3 & 2030 & 27 & 9.2 \\
\hline Minimum & 0 & & 5.0 & 1 & 4.5 & 0.6 & Minimum & 0 & 4.8 & 5 & 13.5 & 0.99 \\
\hline Average & 0.23 & & 7.0 & 164 & 10 & 7.4 & Average & 0.02 & 7.5 & 346 & 18 & 6.9 \\
\hline Median & 0.01 & & 7.1 & 90 & 11 & 7.4 & Median & 0.00 & 7.5 & 262 & 19 & 7.7 \\
\hline Std. Dev. & 0.89 & & 0.8 & 208 & 2 & 2.6 & Std. Dev. & 0.07 & 0.5 & 329 & 2 & 2.0 \\
\hline
\end{tabular}


C8-1

C.8 SUPPORTING INFORMATION FOR APPENDIX C-DETAILED ANALYSIS OF HYDROGEOLOGIC MONITORING DATA FOR BCV OU 4 RIFA 



\section{INTRODUCTION}

This section of the RI report contains detailed analysis of hydrogeologic data from BCV. The data analyzed include hydraulic head data from Y-12 Plant monitoring over the past 10 years: constant monitoring of hydraulic head, specific conductivity, and temperature in groups of wells from the OU 4 RIFA; constant monitoring of hydraulic head from temporary piezometers from the OU 1 RIFA; and continuous monitoring of surface water flow at 13 sites from the OU 4 RIFA.

In the first two subsections of this section, two important components of the BCV hydrogeologic conceptual model are discussed in detail: the nature of vertical hydraulic gradients in BCV and the response of hydrostatic pressure in monitoring wells to precipitation. Both of these components are important to understanding the migration of contaminants in BCV. Following this, results from recent surface water flow monitoring and stormflow tube monitoring in $\mathrm{BCV}$ are presented and discussed.

\section{C.8.1 VERTICAL HYDRAULIC GRADIENTS}

\section{C.8.1.1 Historic Groundwater Potentiometric Data}

Information on location and construction details for the wells discussed in this document is available in Updated Subsurface Data Base for Bear Creek Valley, Chestnut Ridge, and Parts of Bethel Valley on the U.S. Department of Energy Oak Ridge Reservation (Jones et al. 1995). The locations of current groundwater monitoring wells in BCV that were used in this report are shown in Fig. D.1 (Appendix D).

The results of water level measurements throughout $B C V$ are summarized in the annual GWQR (e.g., HSW 1995). Figures C.11 and C.12 in Appendix C show contours of the piezometric surface for the water table interval and the intermediate and deep bedrock intervals during the high-flow period in January 1994 and the low-flow period in August 1994, respectively. The maps show that hydraulic gradients in BCV vary little in slope and direction between high-flow and low-flow time periods. In addition, the magnitude and direction of hydraulic gradients do not vary significantly between water table interval and bedrock for either the low-flow or high-flow periods.

The potentiometric maps also show that there is a general upward hydraulic gradient in the Nolichucky Shale throughout the valley. In predominantly clastic formations of the Conasauga Group, the mean hydraulic gradient is upward in $76 \%$ of well pairs (Table C.3 and Fig. C.30). Mean gradients range in magnitude from -0.22 to 0.35 (negative indicates a downward gradient); however, most of the gradients are between 0.0 and 0.1 ( $66 \%$ of all well pairs). These data are supported by hydraulic head data for the bedrock interval at the S-3 Site recorded in the transect of multi-level monitoring wells (Dreier et al. 1993) that show upward hydraulic gradients in the upper 30 to $46 \mathrm{~m}$ (100 to $150 \mathrm{ft}$ ) of the Nolichucky Shale.

Out of the eight well pairs that recorded mean downward gradients in the Nolichucky Shale, six had one well that was screened in the residuum or at the bedrock/water table interval [depth ranges from 3.7 to $9 \mathrm{~m}$ (12 to $29 \mathrm{ft}$ )]. This indicates that, where downward gradients exist in the Nolichucky Shale, they may be restricted to the shallowest interval, probably indicating a mechanism for shallow groundwater recharge. In nearly all cases, hydraulic gradients between wells screened in bedrock were upward. 
Vertical hydraulic gradients in the Maynardville Limestone vary more than those in the Nolichucky Shale and fall in a smaller range of values. Of the 11 well pairs analyzed, the range of hydraulic gradients was -0.15 to 0.1 with a mean value of 0.02 (Table C. 3 and Fig. C.30). Seven well pairs had downward gradients, and four pairs had upward gradients. At least one well in each well pair that showed mean upward gradients was screened at depths $>46 \mathrm{~m}(150 \mathrm{ft})$. These observations are supported by hydraulic head data for the bedrock interval at the S-3 Site recorded in the transect of multi-level monitoring wells (Dreier et al. 1993) that showed downward hydraulic gradients in the Copper Ridge Dolomite and Maynardville Limestone formations to depths exceeding $300 \mathrm{~m}$ (1000 ft) below Chestnut Ridge. These same borings show increases in the hydraulic head with depth close to the transition between the Nolichucky Shale and Maynardville Limestone.

The general patterns of hydraulic head suggest that, in the predominantly clastic formations in $B C V$, vertically upward hydraulic gradients predominate in the bedrock intervals. Downward gradients occur in some sections of the shallow interval and, in many instances, in the water table interval of these formations. Vertical gradients differ between the carbonate and predominantly clastic formations. Downward gradients predominate in the carbonate formations, and upward gradients may only exist at depths in excess of $300 \mathrm{~m}$ (1000 ft) or in the Maynardville Limestone close to the transition to the Nolichucky Shale.

The predominance of vertically upward hydraulic gradients in the Nolichucky Shale probably arises as a result of the strong anisotropy of the formation where conductivity oriented parallel to bedding planes may be one or two orders of magnitude greater than that across strike. Bedding in the Conasauga Group dips uniformly to the south, and recharge flow paths in bedrock are most likely downward, parallel to dip. Pressure head at depth is, therefore, partly controlled by the elevation of the recharge zone, or outcrop of that stratigraphic zone, which is topographically higher up on Pine Ridge. The overall effect is the vertical hydraulic gradients as a single point; however, due to the very low across-strike conductivities, this vertical hydraulic gradient probably does not translate into significant upward flow except at locations where structural features provide a conduit for vertical flow. In essence, it is the low across-strike conductivity that maintains the vertical gradients.

\section{C.8.1.2 Continuous Monitoring of Hydraulic Heads}

During the recent RIFA activities, hydraulic head was monitored continuously for periods up to 1 month in four groups of wells and one group of temporary piezometers in BCV. The wells and piezometers were monitored for ranges in depth and in formation. Table B.28 in Appendix B contains a list of wells for which monitoring was completed and a summary of the monitoring that was carried out. Figures C.31 to C.68 show the results of monitoring at each individual well in relation to rainfall for that time period.

The continuous monitoring data from wells in the Nolichucky Shale support the observations of vertical upward gradients in this formation. Well pairs GW-085 and -086 at the Boneyard/Burnyard (BYBY) (Fig. C.69), GW-346 and -526 at the S-3 Site (Fig. C.69), and GW-624, -626 , and -629 at the BCBG (Fig. C.20) are located close to each other and were monitored continuously for periods of $\sim 1$ month. The well groups located in the BCBG and at the S-3 Site show upward gradients throughout the monitoring period, whereas the well group at BYBY shows almost no gradient. These results are generally consistent with piezometric head data from the GWQR database.

The continuous monitoring data from wells in the carbonate dominant formations show mainly upward hydraulic gradients between the screened intervals that were monitored; this observation differs from the mostly downward gradients observed in the GWQR database. Well groups GW-045 
and -095 at BCBG (Fig. C.70), GW-725 and -726 at BYBY (Fig. C.21), and GW-227 and -228 at the SL 1 (Fig. C.21) are wells located in pairs that were monitored continuously for periods of $\sim 1$ month.

Both the well pairs GW-045/-095 at the BCBG and GW-227/-228 at SL 1 show vertically upward hydraulic gradients for the period of monitoring. The vertical upward gradient in the GW-045/-095 pair is consistent with the head data from the GWQRs, which also show a mean vertical upward gradient of 0.05 . However, GWQR data for the GW-227/-228 show a mean downward gradient between this well pair. A possible reason for this inconsistency is that the hydraulic gradient between this well pair may temporarily reverse during periods of high flow.

During the period of monitoring at this well pair, the head gradient between the wells screened decreased from 0.115 to 0.017 , which coincided with a steady decline in head in both wells. This general head decline is also seen in other Maynardville Limestone wells during the same time period (GW-725 and -736) and corresponds to monitoring during a dry period immediately following a period of intense rainfall in March and April 1994. The rate of change of head in GW-228 is almost twice that in GW-227 and indicates that head variations in GW-228 are greater than those in GW-227. A hydraulic gradient reversal resulting in downward hydraulic gradients would occur between this well pair if the relative rates of decline in head observed in each well during the monitoring period were to continue for a further week. Figure C.19 shows the variation of hydraulic gradient between these two wells observed in instantaneous data from the GWQR database. The hydraulic gradient varies from -0.093 to 0.015 , and the water levels in these wells mimic each other. Upward gradients were observed twice in this database, in July 1988 and in March 1989; vertical gradients at all other times were downward.

The anomaly between the results of these two monitoring efforts could be the result of the time period of monitoring: the GWQR data are instantaneous readings and were taken over a period of 5 years, irrespective of the current, or preceding weather, conditions. Whereas, the continuous monitoring occurred over a shorter 4-week period and was started immediately after a 2-month period in which almost $51 \mathrm{~cm}(20 \mathrm{in}$.) of precipitation was recorded in BCV. These data indicate that, although the vertical gradient between this well pair is generally downward, for short periods of time after periods of intense rainfall, upward gradients may temporarily exist.

The well pair GW-725/-736 shows almost no gradient between the well screens. This lack of difference in head between these wells is particularly notable because, during the period of monitoring, the head in both wells fell by $\sim 0.9 \mathrm{~m}(3 \mathrm{ft})$. The open intervals for these wells are vertically only $9 \mathrm{~m}(30 \mathrm{ft})$ apart; due to their proximity, a significant difference in hydraulic head between these wells might not be expected. However, these data indicate that there are good hydraulic connections between these wells. This is consistent with the drilling records for the exit pathway program where both of these wells intersected cavities and water-bearing cavities in zone 2 of the Maynardville Limestone (Shevenell et al. 1992).

\section{C.8.2 PRESSURE PULSES IN RESPONSE TO RAINFALL}

\section{C.8.2.1 Hydrograph Analysis}

Shevenell (1994b) observed rapid rises in hydrostatic pressure in wells screened in the Maynardville Limestone in BCV during rainfall events. Similar rapid rises in hydrostatic pressure in wells screened in the Nolichucky Shale were observed during the BCV RI. These changes in hydrostatic pressure during rainfall events occur in parallel with changes in the saturation state of 
soils and in the flow in creeks draining the siliceous dominant formations, providing insight into groundwater flow in each of these components (Appendix C).

Hydrograph analysis for surface water has been a standard method for estimating relative contributions to flow derived from groundwater, soil interflow, and overland flow in a stream catchment (Bras 1990). Moore (1988, 1992) and Shevenell (1994b) adapted these surface water methods to analysis of hydrographs derived from continuous monitoring of hydrostatic pressure in wells and stormflow tubes on the ORR. Shevenell (1994b) further developed these methods to allow quantitative analysis of well hydrographs in the Maynardville Limestone in BCV.

In general, the shape of the rising limb of a hydrograph (e.g., Fig. C.24) is controlled by factors such as rainfall intensity, rate of infiltration, rate of recharge, and effective porosity of the vadose zone. The slope of the regression limb of the hydrograph, however, relates to the rate of drainage of the reservoir of water upstream of the monitoring point. In the case of streams, the upstream reservoirs are ponded surface water, soil moisture, and groundwater storage; the rate of drainage is the combined rate of flow in each of these reservoirs. In the case of a well hydrograph, the upstream reservoir is groundwater storage in the aquifer, and the discharge rate is a function of the transmissivity and specific yield of the rock.

Moore (1992) identified segments of the stream hydrographs in Melton Valley that were related to drainage from soils (stormflow) and groundwater. Shevenell (1994b) identified two or three segments of the regression curve for hydrographs in the Maynardville Limestone that the study related to differential rates of drainage from conduits, fractures, and matrix porosity, respectively. These segments of the regression limb can be best identified by plotting the well hydrographs on semi-logarithmic axes.

A change in head in a well does not necessarily indicate flow to that well; rather, changes in head indicate transmittal of a pressure pulse in the aquifer. However, when the pressure pulse is accompanied by a change in specific conductivity and/or temperature of the water in the well, the change in head during a storm is the result of both transmittal of pressure and of quick flow to the well. When the pressure pulse is not accompanied by a change in specific conductivity and/or temperature of the water in the well, recharge has occurred at the water table interval and the pressure pulse has been transmitted to the monitoring well.

\section{Regression Analysis}

A hydrograph regression curve can be represented by the following equation:

$$
\mathrm{Q}=\mathrm{Q}_{0} \mathrm{e}^{\mathrm{\epsilon t}} \text {, }
$$

where $Q$ is flow in the stream at time $t$, and $\epsilon$ is the exhaustion coefficient and is the slope of the hydrograph when plotted on $\log (Q)$ vs time axes. $\epsilon$ represents the capability of the upstream reservoir to release water; where $\epsilon$ is large, the formation has a poor ability to retain water, and groundwater will drain easily. The equivalent equation can be written for the pressure head hydrographs for wells or the stage hydrographs for streams:

$$
h=h_{o} e^{-\lambda t},
$$

where $h$ is the groundwater head or stream stage and $\lambda$ is the equivalent of $\epsilon$ in Equation 1 . Shevenell (1994b) contains detailed analysis of hydrographs from wells screened in the Maynardville 
Limestone in BCV. This section of the RI contains similar analysis of hydrographs from wells in BCV.

\section{C.8.2.2 Wells Screened in Predominantly Clastic Formations}

Wells screened in the Nolichucky Shale show responses to rainfall that are dependent upon the depth of the well screen. Shallow wells showed very rapid responses to rainfall events with rising hydraulic head and, in some cases, decreases in specific conductivity. Deeper wells, especially those screened below $30 \mathrm{~m}(100 \mathrm{ft})$, showed more subdued responses to rainfall in the form of steadily rising hydraulic heads. Changes in conductivity were not observed in the deep wells.

\section{Water Table Interval and Shallow Bedrock}

Table C.4 lists the storms that occurred during the monitoring periods for each well, which are identified on the rainfall hydrographs for each well. For each well, Table C.4 lists the minimum, maximum, and mean values for the following: the time lag between the initiation of rainfall and the initiation of the hydrograph response; the time lag between peak rainfall and peak of the hydrograph; and the rise of hydrostatic pressure recorded. The following are detailed descriptions of well hydrographs that show responses to storms.

GW-624. Well GW-624 is screened between $5.2 \mathrm{~m}(16.9 \mathrm{ft})$ and $8.3 \mathrm{~m}(27.2 \mathrm{ft})$ bgs and was monitored between March 15 and April 18, 1994 during a period of intense rainfall (Fig. C.51). During this period, there were six storms with a total of $>35.5 \mathrm{~cm}$ (14 in.) of rain. The most intense rainfall during this period occurred on April 12 with an intensity of $1.35 \mathrm{in} . / \mathrm{h}$.

The responses to rainfall in this well were very rapid. The shape of the hydrographs shows a truncated peak for each storm event (Fig. C.51), with a maximum elevation for the hydrograph that does not vary between storms. Possible causes for this truncated peak are an overflow of the well casing, the level in the well exceeding the maximum pressure range for the transducer, or a natural aquifer effect that sets a maximum value on the elevation of groundwater in this region. The first two possible causes were discarded because the observed peaks were within the calibrated range of the pressure transducer, and the land elevation is $\sim 0.7 \mathrm{~m}$ ( $2.3 \mathrm{ft}$ ) above the maximum value (Fig. C.20). The truncated nature of the hydrograph suggests that, at this elevation, groundwater is able to drain rapidly from the subsurface in this region. The well is located close to NT-7; therefore, it is possible that the maximum peak height is related to the elevation of an ephemeral spring or seep at this tributary and that this spring controls the maximum elevation of groundwater in this area.

In well GW-624, the time delay from peak rainfall intensity to hydrograph peak cannot be measured due to this truncating effect. However, the time lag between the initiation of rainfall and the initial rise in the hydrograph is an indication of the speed of groundwater recharge that causes these peaks. A short lag time between rainfall initiation and rise in the hydrograph is probably indicative of quickflow (Shevenell 1994b). Unfortunately, $14 \mathrm{~d}$ of data were lost from this datalogger after it was swamped with water during a storm; however, the rising limbs of three storms were recorded (Table C.4). The mean time lag between initiation of rainfall and initiation of the rising limb of the hydrograph for the three recorded storms was $2.5 \mathrm{~h}$ and was the shortest time period of all the wells analyzed.

Specific conductivity and temperature in well GW-624 both respond rapidly to rainfall (Fig. C.51). During storm events, specific conductivity drops $\sim 200 \mu$ mhos and the temperature also drops 1 to $2^{\circ} \mathrm{C}$. The changes in conductivity and temperature are coincident with the pressure pulses, indicating that the travel time for recharge to the well screen is very short. After the storm event, specific conductivity increases and almost returns to the pre-storm values. This is consistent with the 
observations of Sanford and Solomon (1995); McKay et al. (1995); and Sanford et al. (1994) at the tracer test site in BCV where the concentration of tracers in the monitoring wells temporarily drops during transient storm events and rebounds to the previous values within a few days. In conclusion, the hydrograph record at this well demonstrates that very rapid recharge to groundwater occurs during precipitation events. In addition, these data show that the rate of drainage from the water table interval can be very rapid when the water table is elevated above the ambient levels.

GW-345. A second well screened in the shallow Nolichucky Shale (GW-345) also shows rapid response to rainfall with rising hydraulic heads (Fig. C.46). GW-345 is located close to NT-1 and is screened at 4.9 to $7.9 \mathrm{~m}$ ( 16 to $26 \mathrm{ft}$ ) bgs. The pressure responses to rainfall are not as immediate as those seen in GW-624; however, a true peak is seen for the hydrograph with no truncation. Two storms occurred during the monitoring period; the lag times between peak rainfall intensity and peak hydrograph are 13.5 and $14.5 \mathrm{~h}$. The size of the storm peaks relative to ambient groundwater elevation was also smaller than in GW-624. Peak heights were both $23 \mathrm{~m}(0.77 \mathrm{ft})$.

S-3 Site. Three existing shallow wells screened in the Nolichucky Shale and six temporary piezometers close to the S-3 Site were monitored for a period of 2 months as part of the BCV OU 1 project. Hydrographs from the three wells (GW-101, -127, and -276) all show rapid response to rainfall events (Figs. C.37, C.38, C.42, C.45, respectively). The hydrographs in GW-127 and -276 show well-defined peaks and regression curves; whereas the hydrograph from GW-101 shows peaks during rainfall events but poorly defined regression curves. The temporary piezometers (S3-1, $-3,-5$, $-6,-7,-8)$ show a mixed quality of hydrographs. Piezometer S3-5 (Fig. C.65) has well-defined peaks and regression curves in response to rainfall; S3-1 and -8 (Figs. C.63 and C.68) both show truncated peaks with poorly defined regression curves in response to rainfall; S3-6 and -7 (Figs. C.66 and C.67) show hydrographs that vary very rapidly but have seemingly little correlation to rainfall; and S3-3 (Fig. C.64) shows no response to rainfall and a general decline in head during the monitoring period.

The temporary piezometers were constructed without a screen or grout seals; and it is likely that the confused hydrographs of S3-6 and -7 are due to this incomplete construction. S3-1, -5 , and -8 react to rainfall in a similar way to the shallow wells monitored during the same time period; S3-5 responds similarly to GW-127 and -276 ; and S3-1 and -8 respond in similar ways to GW-101. It is therefore probable that the construction of these piezometers did not compromise the quality of monitoring and that these hydrographs reflect the changes in the water table.

The hydrographs for S3-5, GW-127, and -276 have very similar responses to rainfall and are probably representative of the active groundwater flow systems in the water table interval at S-3 Site. The initiation lag times in each of these piezometers ranged from 1.5 to $6 \mathrm{~h}$, and the peak lag times from 4.5 to $30 \mathrm{~h}$.

\section{Specific Conductivity Trends}

With the exception of GW-624 (discussed above, Fig. C.51), the wells in the Nolichucky Shale do not show systematic changes in specific conductivity during the monitoring periods that can be attributed to real changes in groundwater chemistry. Only GW-101 (Fig. C.37) shows a distinct drop in specific conductivity immediately following rainfall between July 26 and July 27 that can probably be attributed to the precipitation event. Approximately $3 \mathrm{~d}$ after the cessation of rainfall, the specific conductivity in this well starts to rebound; $5 \mathrm{~d}$ after cessation of rainfall, the conductivity in the well is almost returned to its former values. Similar to GW-624, change in conductivity in GW-101 implies that the precipitation event resulted in flow of recent recharge to the well. The return of specific conductivity to its original value is consistent with the observations of Sanford and Solomon (1995); McKay et al. (1995); and Sanford et al. (1994) at the tracer test site in BCV, where 
the concentrations of tracers in the monitoring wells temporarily drop during transient storm events and rebounds to the previous values within a few days.

Wells GW-345 (Fig. C.46), -616 (Fig. C.50), -526 (Fig. C.48), and -629 (Fig. C.53) each show anomalously high values of specific conductivity after the initial installation of the measuring probe, but have a rapid decrease to a stable value during the period of monitoring. This effect may be an artifact of installation of the hydrolab. None of the wells were purged before installing the hydrolabs, and this change in time could relate to the hydrolab equilibrating to the conditions at the well screen.

\section{Regression Analysis}

The hydrographs from wells GW-127, $-276,-345,-537$, and piezometer S3-5 have reasonably complete regression curves (Figs. C.42, C.45, C.46, C.49, and C.65), although the regression curve observed for GW-537 is derived from an artificially induced pressure pulse (see below). The hydrographs from these wells were analyzed following the methods outlined by Shevenell (1994b). Figure C.24 shows the hydrographs for GW-127, -276 , and piezometer S3-5 plotted on semi-log axes. The plots are normalized to the lowest water level value for each well such that the plots are able to define the slope of the hydrograph more easily.

The hydrographs for GW-127, $-276,-537$, and S3-5 each show two distinct slopes during the regression from the peak water level after a storm. These two slopes (or values for $\lambda$ ) imply two pathways for drainage in the water table interval of the Nolichucky Shale with different transmissivities. The steeper slopes (corresponding to rapid drainage) for these wells have values for $\lambda$ that range from $5.92 \times 10^{-3} \mathrm{~h}^{-1}$ to $1.86 \times 10^{-2} \mathrm{~h}^{-1}$ with a mean value of $8.06 \times 10^{-3} \mathrm{~h}^{-1}$. The shallower slopes (corresponding to slow drainage) have values for $\lambda$ that range from $7.74 \times 10^{-4} \mathrm{~h}^{-1}$ to $4.84 \times 10^{-3} \mathrm{~h}^{-1}$ with a mean of $2.05 \times 10^{-3} \mathrm{~h}^{-1}$. The peaks for GW-345 only have one slope, and the $\lambda$ values for these slopes were $2.79 \times 10^{-3} \mathrm{~h}^{-1}$ and $7.55 \times 10^{-3} \mathrm{~h}^{-1}$, respectively. These values are between the ranges of values for the steeper and shallower slopes observed for regression curves from GW-127, -276, -537, and S3-5.

\section{Intermediate and Deep Bedrock Intervals}

The well hydrographs from wells screened in the shallow, intermediate, and deep bedrock intervals of the Nolichucky Shale show more subdued responses to rainfall events than the water table wells. Well GW-076 (Fig. C.32) showed no immediate response to rainfall. Wells GW-126 (Fig. C.41), -346 (Fig. C.47), -526 (Fig. C.48), -616 (Fig. C.50), -626 (Fig. C.52), and -629 (Fig. C.53) show immediate but subdued responses to rainfall. In addition, the wells GW-626 and -629 show a longer-term increase in head over the period of monitoring in response to the high precipitation rate during the monitoring period. Head in both wells increases by $\sim 0.67 \mathrm{~m}(2.2 \mathrm{ft})$ over the period of monitoring; this value is the same as the increase in the base groundwater level in well GW-624 (a water table well at the same location) over the same time period (Fig. C.20). This suggests that this period of high precipitation [over $36 \mathrm{~cm}$ (14 in.) during 1 month] caused a relatively uniform rise in the hydraulic head throughout the Nolichucky Shale and implies that, although fracture networks in the predominantly clastic formations may not be connected enough to transmit pressure pulses rapidly, the fractures are connected sufficiently to transmit longer-term pressure changes.

\section{Cross Borehole Pressure Pulse Test in the Nolichucky Shale}

A cross borehole pressure pulse test was carried out at the scrap metal salvage yard adjacent to BYBY. Water was injected into well GW-085 [19 m (62 ft)], and hydraulic head was monitored 
continuously in the Oil Landfarm group of wells (Table B.27 in Appendix B). Two wells showed a response to the pressure injections, GW-086 and -537 (Figs. C.34 and C.49). The screen for well $\mathrm{GW}-086$ is located $8.6 \mathrm{~m}(28.5 \mathrm{ft})$ vertically above the injection well screen, while well $\mathrm{GW}-537$ is located $152 \mathrm{~m}(500 \mathrm{ft})$ east of the injection well and is screened at approximately the same depth as GW-086 [7.5 m (24.5 ft)]. Both groundwater pressure and specific conductivity responded to the injection of water in these two wells. This implies that a pressure pulse was transmitted to each well that also caused groundwater inflow to the wells from a different flow path than that usually monitored (the conductivity response does not necessarily mean a flow of injected water from the injection well to the monitoring wells, therefore, it is unlikely that injected water moved from GW-085 to -537 in the observed time frame).

During the injection test, after $\sim 10 \mathrm{~min}$ of injection, the pressure in the injection well stabilized at $80 \mathrm{psi}$ and the injection rate of $6 \mathrm{gal} / \mathrm{min}$. After $61 \mathrm{~min}$ of injection, there was a sharp rise in the injection rate that was accompanied by a fall in the injection pressure that could be maintained. From the 67th minute of the test to the end of the test (85th minute), the injection rate was $110 \mathrm{gal} / \mathrm{min}$ with the pressure in the injection well at 60 psi. Although GW-085 responded to the initial injection of water almost immediately after the observed increase in flow rate in the injection well, the response in GW-085 increased rapidly and the response in GW-537 was observed almost immediately after that sharp increase in flow. These phenomena are consistent with the opening of a flow path from the injection well to the monitoring wells. It is possible that these phenomena were the result of a break in the grout seal above the screened interval of the injection well, thus opening a flow path up the well bore and into the water table interval. Another possibility is that the breakthrough occurred along the natural fracture network in the shallow bedrock. Although these data cannot be analyzed quantitatively, the response to injection in a well located $152 \mathrm{~m}(500 \mathrm{ft})$ along strike from the injection well implies that there exists good hydraulic connectivity along strike in the Nolichucky Shale. None of the other monitoring wells used in this test responded to the injection pulse.

\section{C.8.2.3 Wells Screened in Carbonate Formations}

Well hydrographs from wells screened in the shallow, intermediate, and deep intervals of the Maynardville Limestone showed responses to precipitation. Wells GW-045 (Fig. C.30), -053 (Fig. C.31), -094 (Fig. C.35), -095 (Fig. C.36), -122 (Fig. C.39), -124 (Fig. C.40), -651 (Fig. C.54), -710 (Fig. C.55), -711 (Fig. C.56), -712 (Fig. C.57), -713 (Fig. C.58), -714 (Fig. C.59), and -715 (Fig. C.60) have hydrographs that responded to rainfall during their respective monitoring periods. Table C. 4 contains a summary of the peak responses from some of these wells. Each of these wells shows a similar response to precipitation, and the extent and rapidity of response appear to be irrespective of the depth of the well. In contrast to wells in the Nolichucky Shale, intermediate and deep wells show rapid responses to storm events. This is a consistent, well documented occurrence of a well-connected network of solution cavities and fractures in the Maynardville Limestone that extend to depths up to $106 \mathrm{~m}$ (350 ft) (Shevenell et al. 1992; Shevenell 1994b; Shevenell and Beauchamp 1994). The following is a description of key features of the monitoring data obtained for this RI.

Picket W. Hydrographs were recorded in each of the six wells at Picket W during a 2-month period between November 1994 and January 1995. During this time period, four major precipitation events were recorded, and all the wells in Picket $W$ recorded responses to each event (except where technical difficulties were encountered). Table C. 4 contains an analysis of the timing of the well hydrographs compared to the precipitation event. The responses of these wells to the same storms appear to fall into two broad groupings: one for deep wells and one for relatively shallow wells. Each of the wells has relatively sharp asymmetric peaks with a steeper rise than fall; however, the deep wells have peaks that are generally more rounded and slower to develop than those in the shallow 
wells. This is reflected in the lag time between the initial rise of the hydrograph and the initial rainfall, and in the lag time between the peak hydrograph and peak rainfall. Wells GW-710 to -714 have mean peak lag times that range from 21 to $45 \mathrm{~h}$ and are two to three times the mean initiation lag time. The hydrograph peaks in these wells decrease with depth of the well; the mean values are 1.3 in GW-710 to $-712,1.6$ in -713 , and 2.4 in -714 . GW-715 shows a very sharp initial peak response to rainfall followed by a more subdued response. The initial peaks in GW-715 reflect the precipitation rate very closely and, in events 10 and 11 where precipitation shows two peak intensities, this is matched by two separate peaks in the hydrograph. Shevenell (1994b) interpreted this as the result of this well being connected to a conduit system that transmits quick flow from two upstream conduits that converge into the single conduit tapped by this well.

\section{Picket C and Vicinity}

The hydrographs from wells GW-227, $-228,-725$, and -736 show a continuous declining trend over this period of monitoring; the greatest fall in head was recorded in GW-228 at $2.6 \mathrm{~m}(8.5 \mathrm{ft})$ and the smallest change in GW-725 of $0.98 \mathrm{~m}(3.2 \mathrm{ft})$. This time period contains three precipitation events [a total of $5.6 \mathrm{~cm}(2.2 \mathrm{in}$.)], and these wells show little or no response to these events. The period of monitoring for these wells coincided with the time period of increasing water demand from plants during the leafing-out period. The downward trend observed during this time period probably reflects a much lower rate of recharge over the valley as a whole and, with the increased water demand during this time period, it is not surprising that rapid recharge from precipitation was dramatically reduced.

\section{Regression Analysis}

The hydrographs from wells GW-094, -122 , and -124 have reasonably complete regression curves (Figs. C.35, C.39, and C.40). The hydrographs from GW-124 and GW-094 show only one slope during the regression from the peak water level after storms (Fig. C.71). The slope (or value for $\lambda$ ) for these wells range from $3.45 \times 10^{-3} \mathrm{~h}^{-1}$ to $4.14 \times 10^{-3} \mathrm{~h}^{-1}$ for GW-094, and $5.3 \times 10^{-3} \mathrm{~h}^{-1}$ to $5.96 \times 10^{-3} \mathrm{~h}^{-1}$ for GW-124. Only one storm hydrograph was available for GW-122, and this peak showed two slopes on semi-log space (two values for $\lambda$ ); however, for this peak, the slope of the initial drainage regression curve was less than the later drainage. This is anomalous since it is expected that the more rapid drainage conduits will dominate the regression hydrograph at the early stages after the storm recharge subsides (Shevenell 1994b).

The slopes observed from these three wells are in the same order of magnitude as those determined by Shevenell (1994b) for the second and third segments of the Maynardville Limestone well regression hydrographs at Picket $\mathrm{W}$. These segments were interpreted to represent drainage of the well-connected fracture network in the Maynardville Limestone and the matrix (including poorly connected fractures), respectively. Neither of these wells shows any characteristics of being connected to conduits, and these data are consistent with the absence of quickflow from these wells.

\section{Specific Conductivity Trends}

Some of the wells in the Maynardville Limestone also show immediate changes in conductivity that accompany the changes in pressure head. Wells GW-045 and -124 show responses, and Shevenell (1994b) reported that well GW-715 showed specific conductivity responses to precipitation. These three wells are screened at or above $30 \mathrm{~m}(100 \mathrm{ft})$ depth in the carbonate dominant formations; change in water conductivity implies that during precipitation events these wells are affected by quickflow in the carbonate dominant formations. Shevenell (1994b) reported that GW-715 intercepts known cavities, and drilling logs indicate that GW-124 intercepts a fracture 


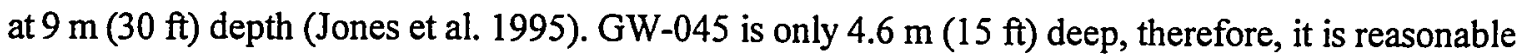
to assume that this well and GW-124 are connected to a fracture or conduit network that transmits quickflow, similar to the interpretation by Shevenell (1994b) for GW-715. The remaining Maynardville Limestone wells, for which conductivity was recorded and which show immediate response to precipitation in the hydrograph (GW-053, -94, -95, and -651), do not show immediate responses to precipitation in the specific conductivity record. This implies that these wells are not connected to quickflow conduits. Each of these wells is screened at $>30 \mathrm{~m}$ (100 ft) depth, which may indicate an approximate maximum depth for quickflow to occur.

\section{C.8.3 SURFACE WATER FLOW MONITORING DATA}

Surface water stage was recorded continuously for the period of sampling in OU 4 RIFA at each of the surface water sampling sites, with the exception of SS-8. Details of the monitoring periods at each site and the calculation of flow from stage data are contained in Appendix B.

The tributary hydrographs, and those from the two locations on Bear Creek, show similar general patterns of flow in relation to rainfall. The shape of the rising limb of a hydrograph is usually dependent on the geometry of the basin and of the storm; however, for the tributary basins in BCV, the storm geometry probably is less influential due to the small sizes of the basins. For tributaries in $\mathrm{BCV}$, the rising limbs of hydrographs are very steep, and there is little delay between peak rainfall intensity and peak discharge in the streams. In one extreme case, the level in NT-5 rose by nearly $0.3 \mathrm{~m}(1 \mathrm{ft})$ over a 20 -min time period. This implies that there is relatively little recharge prior to developing runoff in these catchments. As a result of the "flashy" nature of runoff in BCV, the flow hydrographs show a wide range in flow over short-time periods and, during a high proportion of the time, flow is at baseflow level (e.g., the annual hydrograph for BCK 9.47, Fig. C.18).

The regression section of the hydrograph is dependent on the rate of change of storage in the basin after a storm has stopped. Similar to the regression analysis for the groundwater hydrographs, the shape of the regression curve may indicate different types of storage that drain at differing rates. On the ORR, three types of water storage are anticipated: overland flow, soil interflow, and groundwater baseflow.

Fifteen storms were identified for analysis in each tributary catchment and the two locations on Bear Creek (storms were labeled 01 - 15). The results of analysis are shown in Table C.5. In some cases, hydrographs for storms were missing or were uninterpretable due to gaps in the data record; where this has happened, the section on Table C.5 for that storm at that location is left blank. At least seven storms were analyzed at each location.

Three segments of the regression hydrograph with different linear slopes were identified in many of the storms (these segments were labelled a, b, and c). In some cases, only one or two segments could be identified because of insufficient rainfall intensity to generate overland flow, or truncation of the regression curve by a second rainfall event. In these cases, the section of the regression curve was allocated to one of the hydrograph segments based on the magnitude of the value for $\lambda$.

The steepest slope on the regression curve (a) occurs immediately after precipitation ceases and is interpreted as being derived from predominance of drainage from water in surface water bodies, i.e., streams channels and ponded water. The mean values for $\lambda$ for this initial segment of the regression curve range from 0.596 to $1.26 \mathrm{~h}^{-1}$. In general, the highest values for $\lambda$ for this segment of the hydrographs tend to coincide with the most intense precipitation events; this is probably the 


\section{C8-13}

result of greater ponding and surface runoff during the most intense rainfall. Due to the rate of decline of flow during this segment of the regression curve, this time period is short-lived and, for $\mathrm{BCV}$ tributaries and main stem, ranges from 1 to $6 \mathrm{~h}$ after cessation of precipitation. In some instances, where rainfall intensity is insufficient to saturate soils, this section of the regression curve is missing.

The intermediate slopes in the regression curves (b) are interpreted as resulting from the decline in runoff and from the flow in the streams being dominated by runoff derived from soil drainage. The mean values for $\lambda$ for this segment of the regression curve range from 0.061 to $0.167 \mathrm{~h}^{-1}$. The section of the regression curve where soil drainage dominates the flow in the streams in BCV lasts from 8 to $24 \mathrm{~h}$, depending on the intensity of the storm.

The lowest slopes in the regression curves (c) are interpreted as resulting from the decline in runoff derived from groundwater discharge alone. The mean values for $\lambda$ for this segment of the regression curve range from 0.010 to $0.038 \mathrm{~h}^{-1}$. This segment of the regression curve may continue for a number of days and is usually truncated by the next precipitation event or by the stream drying up.

\section{C.8.4 STORMFLOW TUBE MONITORING}

Stormflow tubes were installed at six locations in upper BCV following construction details in Moore (1988). Water level in these tubes was recorded continuously during OU 4 RIFA. Figure C.2 shows the location of the stormflow tubes in BCV, and the time periods for each tube are listed in Table C.6. Figures C.72 and C.73 show the hydrographs from April to October 1994 for SFT1 to SFT6.

Each of the stormflow tubes showed response to precipitation buildup of water in the tube, however, responses differ between tubes. The hydrographs are somewhat like the hydrographs derived from stream monitoring in that, during a storm event, there is a very rapid increase in the level of water in the tube ( 30 to $90 \mathrm{~min}$ to peak) and, after precipitation ends, the level of water falls in an exponential manner. The regression curve from these stormflow tube hydrographs can also be interpreted in a similar manner to regression curves from surface water and groundwater. The slope of the regression curve in this instance is indicative of the rate of drainage of the soils.

Tubes in this study exhibited up to three different slopes in the regression curve. Although the slopes of the regression curve relate to soil drainage characteristics, it is possible that the rate of regression in these tubes is also strongly influenced by the tube construction, small-scale heterogeneities in the soils, and local topography. Care was taken to select similar sites for location of the tubes; however, tubes located on Chestnut Ridge (SFT4 to SFT6) were located on steeper slopes than those on Pine Ridge (SFT1 to SFT3). In general, the tubes on Pine Ridge show slower drainage rates than those on Chestnut Ridge, which suggests that local effects strongly influence the hydrograph regression.

SFT1, SFT2, SFT3, and SFT5 responded to storms throughout the monitoring period, including precipitation during the summer months with the highest evapotranspiration rates. Peak heights varied depending on the intensity of the precipitation; however, each tube attained peaks $<0.61 \mathrm{~m}$ $(2 \mathrm{ft}$ ) [the length of the tube, therefore, the maximum peak height was $0.78 \mathrm{~m}(2.56 \mathrm{ft})$ ], meaning that, in the highest intensity storms, the soils were saturated to within $15 \mathrm{~cm}(6 \mathrm{in}$.) of the surface. Two distinct segments of the regression curve were identified in most hydrographs from these sites. The initial steepest sections of the regression curves plotted on semi-log axes had mean values for $\lambda$ 
ranging from $0.058 \mathrm{~h}^{-1}$ to $0.209 \mathrm{~h}^{-1}$. The second, less steep, slopes had values for $\lambda$ ranging from $0.0067 \mathrm{~h}^{-1}$ to $0.037 \mathrm{~h}^{-1}$. The initial segments, which occurred above $0.23 \mathrm{~m}(0.75 \mathrm{ft})$ to $0.66 \mathrm{~m}(1.5 \mathrm{ft})$ in the tube, lasted for 2 to $10 \mathrm{~h}$ and are interpreted as relating to dominance of the drainage by the upper sections of the soil profile. The lower slopes are interpreted as drainage from the lower soils in the soil profile.

SFT5 and SFT6 responded very rapidly to rainfall and drained equally rapidly after the precipitation event. The rate of drainage in each of these tubes indicates that the soils at these localities were more permeable than those at the other stormflow tube locations. It was not possible to analyze the regression curve of these hydrographs due to lack of sufficient data points.

\section{C.8.5 WATER BALANCE CALCULATION METHODOLOGY}

The water balance attempts to balance the total volume of water entering the section of $\mathrm{BCV}$ above BCK 9.47 (inflow) with the total volume of water flowing along strike in BCV at BCK 9.47 (outflow). Inflow is by way of a single component: rainfall (gaged). The conceptual model for BCV has five outflow fluxes: evapotranspiration, flow in BCV at BCK 9.47 (gaged), flow in SS-5 (gaged), along-strike flow in the carbonate dominant formations over a plane at BCK 9.47 (ungaged), and along-strike flow in the siliceus dominant formations over a plane at BCK 9.47 (ungaged).

The water balance can be summarized using the following equation:

$$
\Delta \mathrm{S}=(\mathrm{P}-\mathrm{ET}) \times \mathrm{A}-\mathrm{Sr}-\mathrm{Gr},
$$

where:

$$
\begin{aligned}
& \Delta \mathrm{S}=\text { the net change in water stored in } \mathrm{BCV}\left(\mathrm{m}^{3}\right), \\
& \mathrm{P} \quad=\text { precipitation }(\mathrm{m}) \\
& \mathrm{ET}=\text { evapotranspiration }(\mathrm{m}) \\
& \mathrm{Sr}=\text { surface water outflow }\left(\mathrm{m}^{3}\right) \\
& \mathrm{Gr}=\text { groundwater outflow }\left(\mathrm{m}^{3}\right) .
\end{aligned}
$$

If no net change in the volume of water stored in BCV over the period of the water balance $(\Delta S=0)$ is assumed, then the equation for this upper section of BCV can be written as follows:

$$
(P-E T) \times A_{B C V}=S W G+S S G+S S U_{a q f}+S S U_{a q d}
$$

where:

$$
\begin{array}{ll}
A_{\mathrm{BCV}} & =\text { area of BCV up-gradient from BCK } 9.47\left(\mathrm{~m}^{2}\right) \\
\mathrm{SWG} & =\text { flow at BCK } 9.47\left(\mathrm{~m}^{3}\right), \\
\mathrm{SSG} & =\text { flow at } \mathrm{SS}-5\left(\mathrm{~m}^{3}\right) \\
\mathrm{SSU}_{\mathrm{aqf}} & =\text { subsurface along strike flow in the carbonate formations }\left(\mathrm{m}^{3}\right), \\
\mathrm{SSU}_{\mathrm{aqd}} & =\text { subsurface along strike flow in the predominantly clastic formations }\left(\mathrm{m}^{3}\right) .
\end{array}
$$

For the water balance model to be more applicable to estimating fluxes from the source areas, the valley-wide water balance can be further refined into a balance for the predominantly clastic formations and a balance for the carbonate formations. This refinement is possible because (1) the total surface water flux from the siliceous formations to the carbonate formations was measured during this time period by gauging of the tributaries draining Pine Ridge and (2) the conceptual 


\section{C8-15}

model treats the predominantly clastic and carbonate formations as almost separate hydraulic regimes. The equations for each set of formations are as follows. For the siliceous dominant formations:

$$
(\mathrm{P}-\mathrm{ET}) \mathrm{A}_{\mathrm{aqd}}=\mathrm{SWG}_{\mathrm{Tribs}}+\mathrm{SSU}_{\mathrm{xaqd}}+\mathrm{SSU}_{\mathrm{aqd}}
$$

where:

$$
\begin{aligned}
& \mathrm{A}_{\mathrm{aqd}}=\text { area of } \mathrm{BCV} \text { upgradient from BCK } 9.47 \text { that is underlain by predominantly } \\
& \text { clastic formations }\left(\mathrm{m}^{2}\right) \text {, } \\
& \mathrm{SWG}_{\text {Tribs }}=\text { combined flow in the tributaries }\left(\mathrm{m}^{3}\right) \text {, } \\
& \mathrm{SSU}_{\mathrm{xaqd}}=\text { subsurface across-strike flow from the predominantly clastic formations to the } \\
& \text { carbonate dominant formations }\left(\mathrm{m}^{3}\right) \text {. }
\end{aligned}
$$

For the carbonate formations, this equation is:

$$
(P-E T) \times A_{\text {aqf }}+S S U_{\text {xaqd }}+S W G_{\text {Tribs }}=S W G+S S G+S S U_{\text {aqf }}
$$

where:

$$
\begin{aligned}
& A_{\text {aqf }}=\quad \text { area of BCV upgradient from BCK } 9.47 \text { that is underlain by carbonate formations } \\
& \left(\mathrm{m}^{2}\right) .
\end{aligned}
$$

These main components of the water balance model (P, ET, $A_{B C V}, S W G, S S G, S_{\text {aqf }}, S_{\text {aqd }}$, $\mathrm{SSU}_{\mathrm{xaqd}}$, and $\mathrm{SWG}_{\text {Tribs }}$ ) are shown on Fig. C.10, along with their calculated values for the 10-month period monitored between March 1994 and February 1995.

Of the parameters of the water balance model shown in Fig. C.10, the values were derived in the following ways:

- $\quad P, A_{B C V}, S W G, S S G$, and $S W G_{\text {Tribs }}$ were all measured.

- $\quad \mathrm{SSU}_{\mathrm{aqd}}$ and $\mathrm{SSU}_{\mathrm{aqg}}$ were estimated from the site-wide groundwater flow model for BCV.

- ET was calculated by a process of elimination because it is the only unquantified value in Equation (2) assuming that $\Delta S=0$.

- $\quad \mathrm{SSU}_{\mathrm{xagd}}$ was derived by a process of elimination because it is the only unquantified value in Equation (3) assuming that $\Delta S=0$. 
C9-1

\section{C.9 SUPPORTING INFORMATION} FOR APPENDIX C-FIGURES 


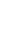




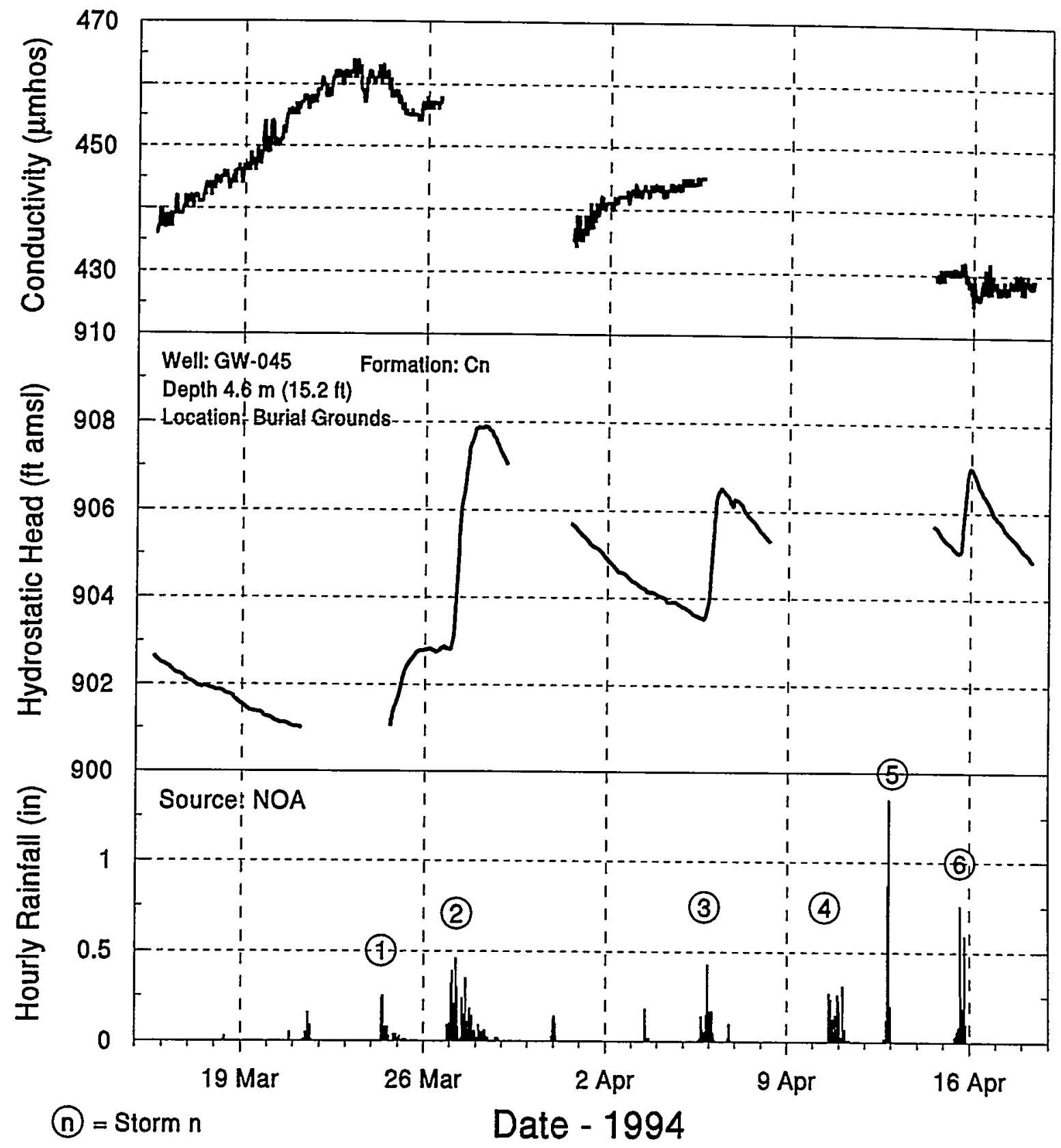

Fig. C.30. Well hydrograph and specific conductivity for GW-045 at depth of $15.2 \mathrm{ft}$ at BCBG for March 15 to April 18. 


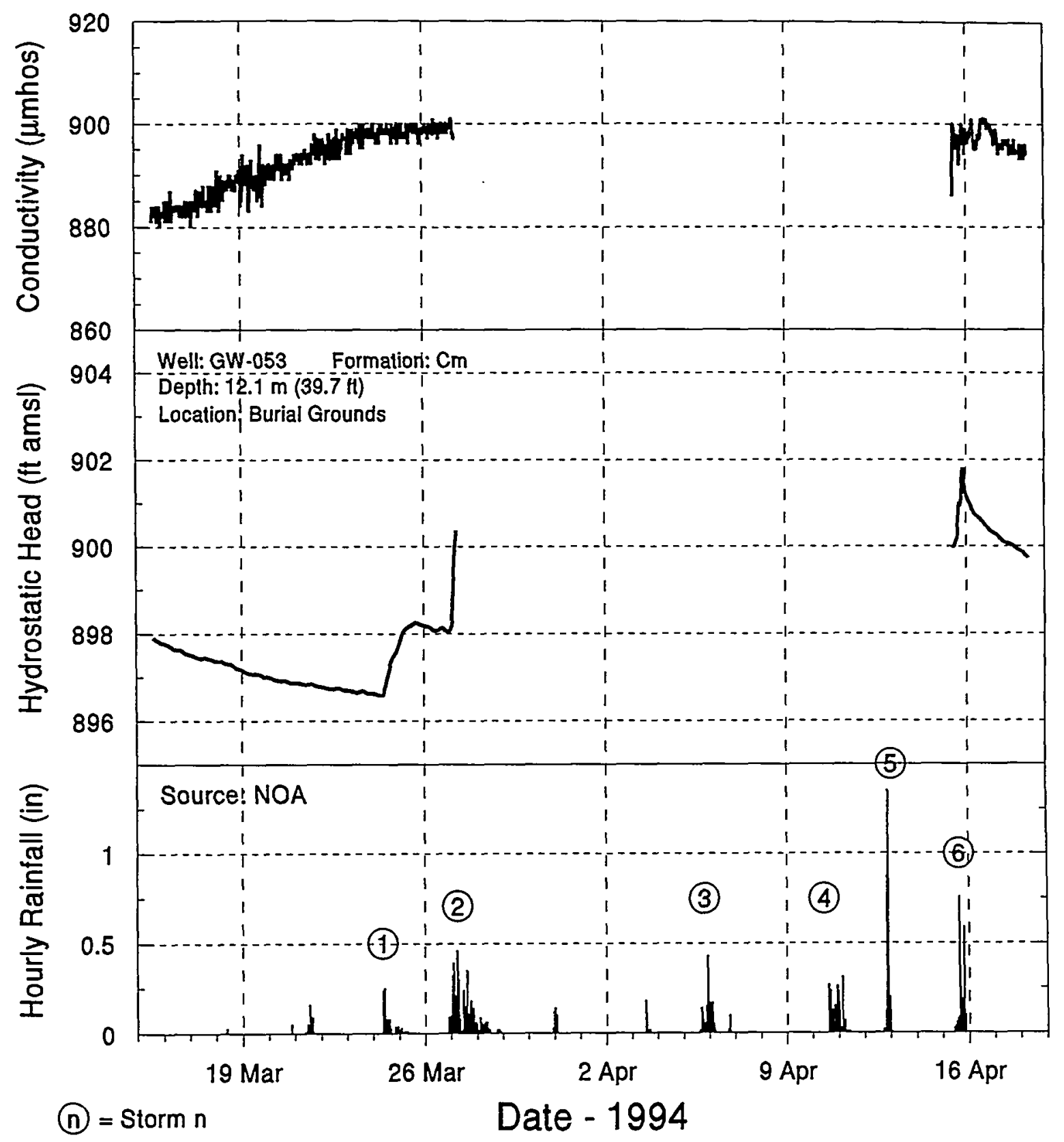

Fig. C.31. Well hydrograph and specific conductivity for GW-053 at depth of $39.7 \mathrm{ft}$. 


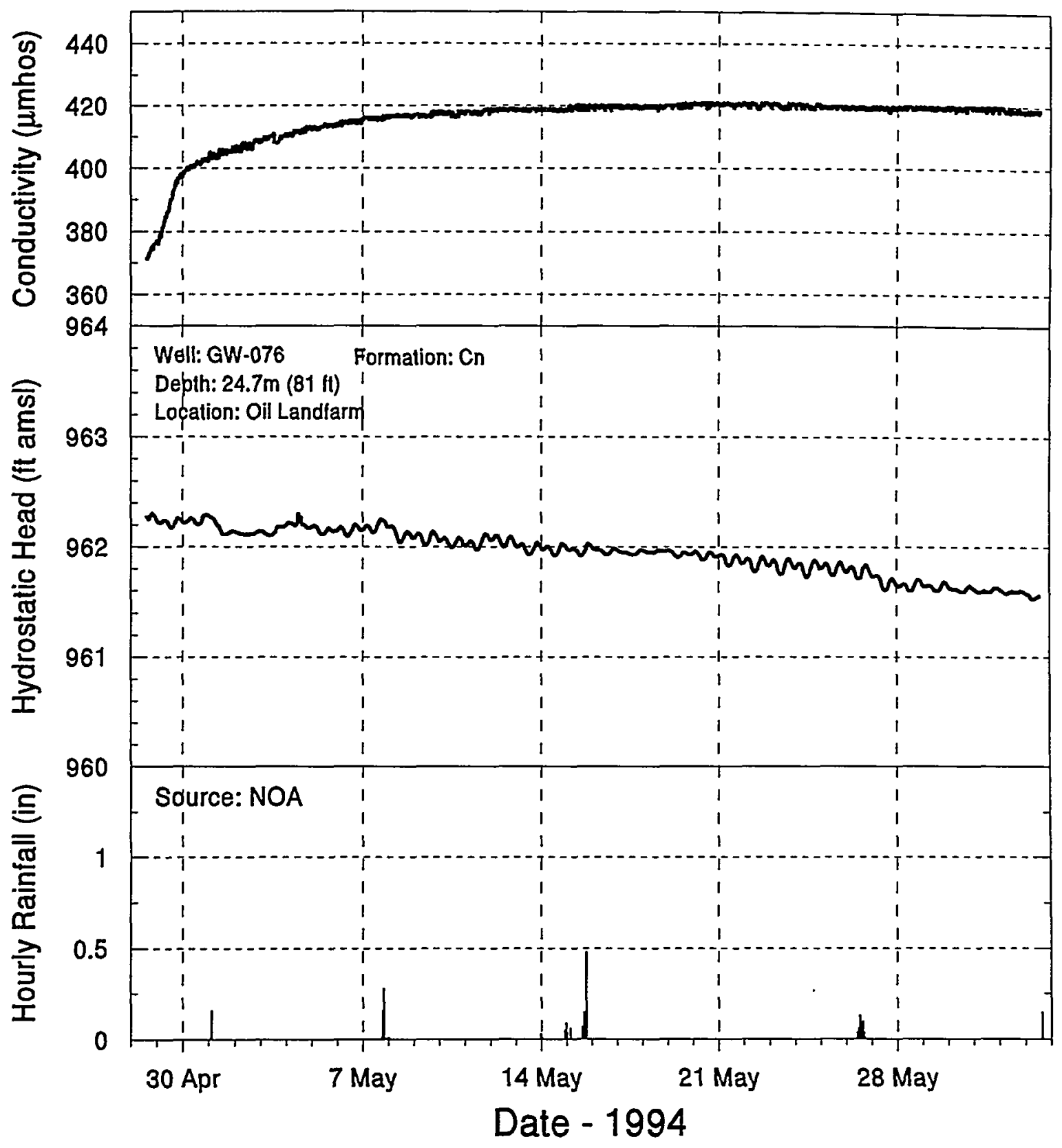

Fig. C.32. Well hydrograph and specific conductivity for GW-076 at depth of $81 \mathrm{ft}$ at OLF for April 28 to June 2. 
C9-6

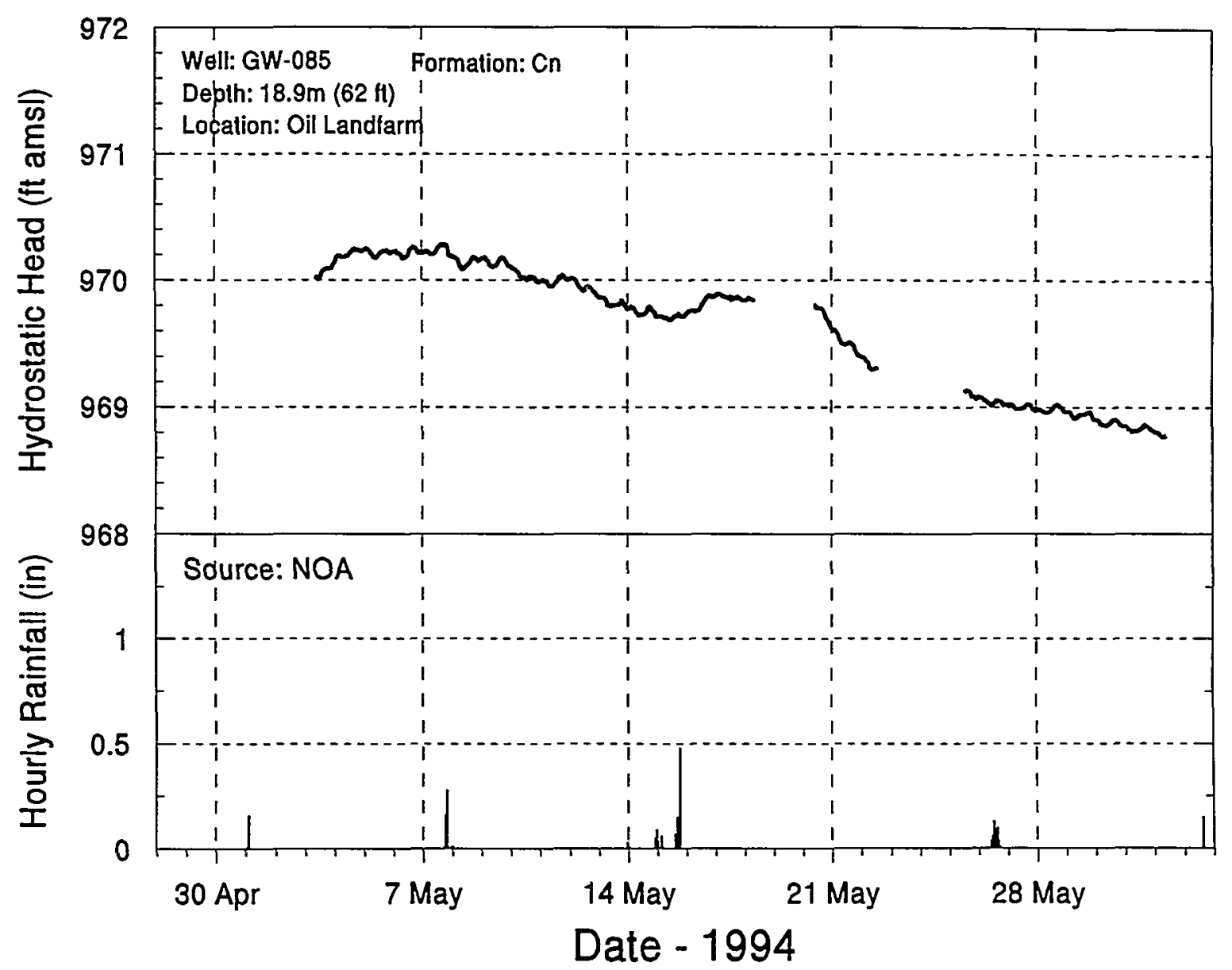

Fig. C.33. Well hydrograph for GW-085 at depth of $62 \mathrm{ft}$ at OLF for May 3 to June 1. 


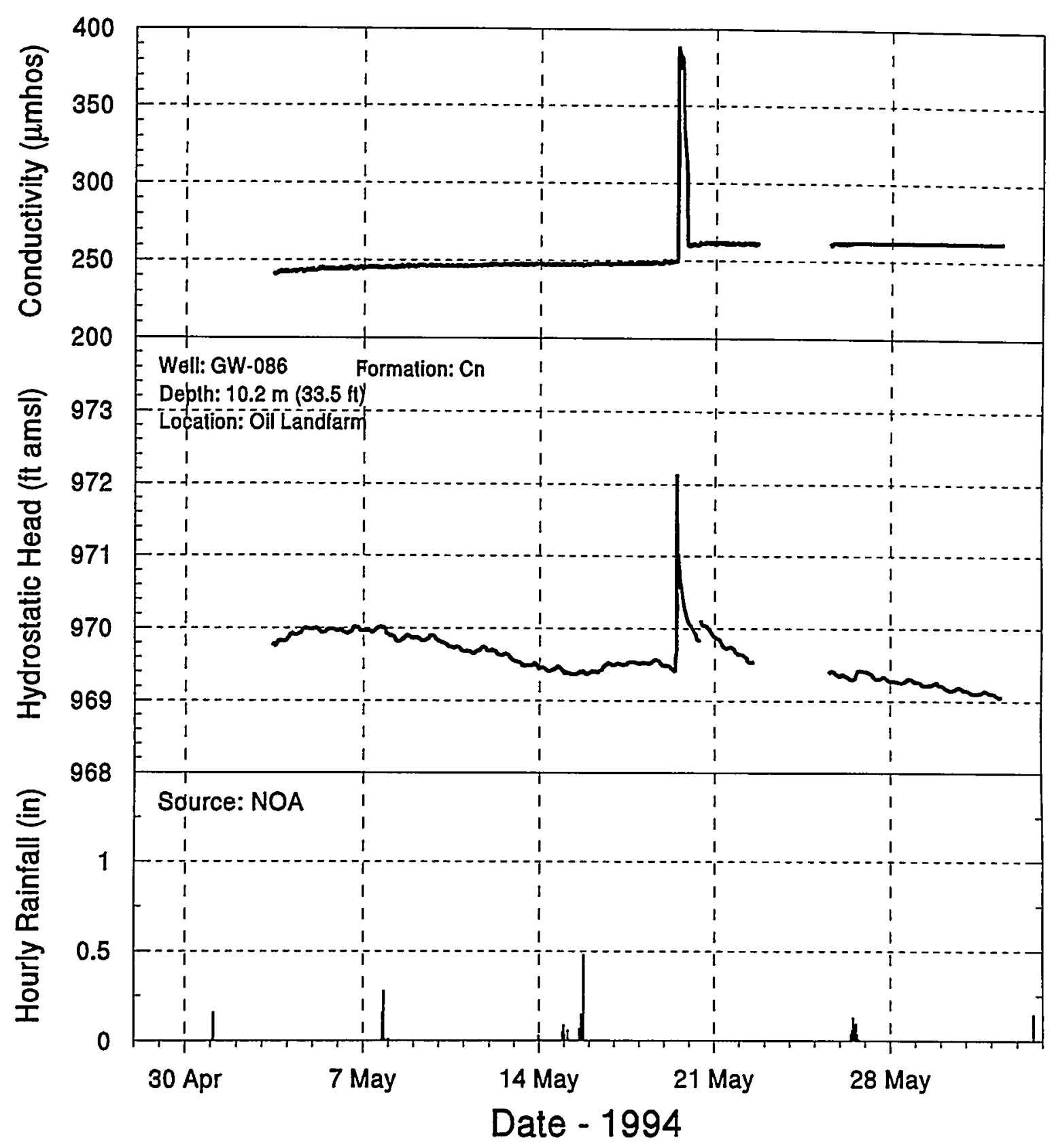

Fig. C.34. Well hydrograph and specific conductivity for GW-086 at depth of $33.5 \mathrm{ft}$ at OLF for May 3 to June 1. 
C9-8

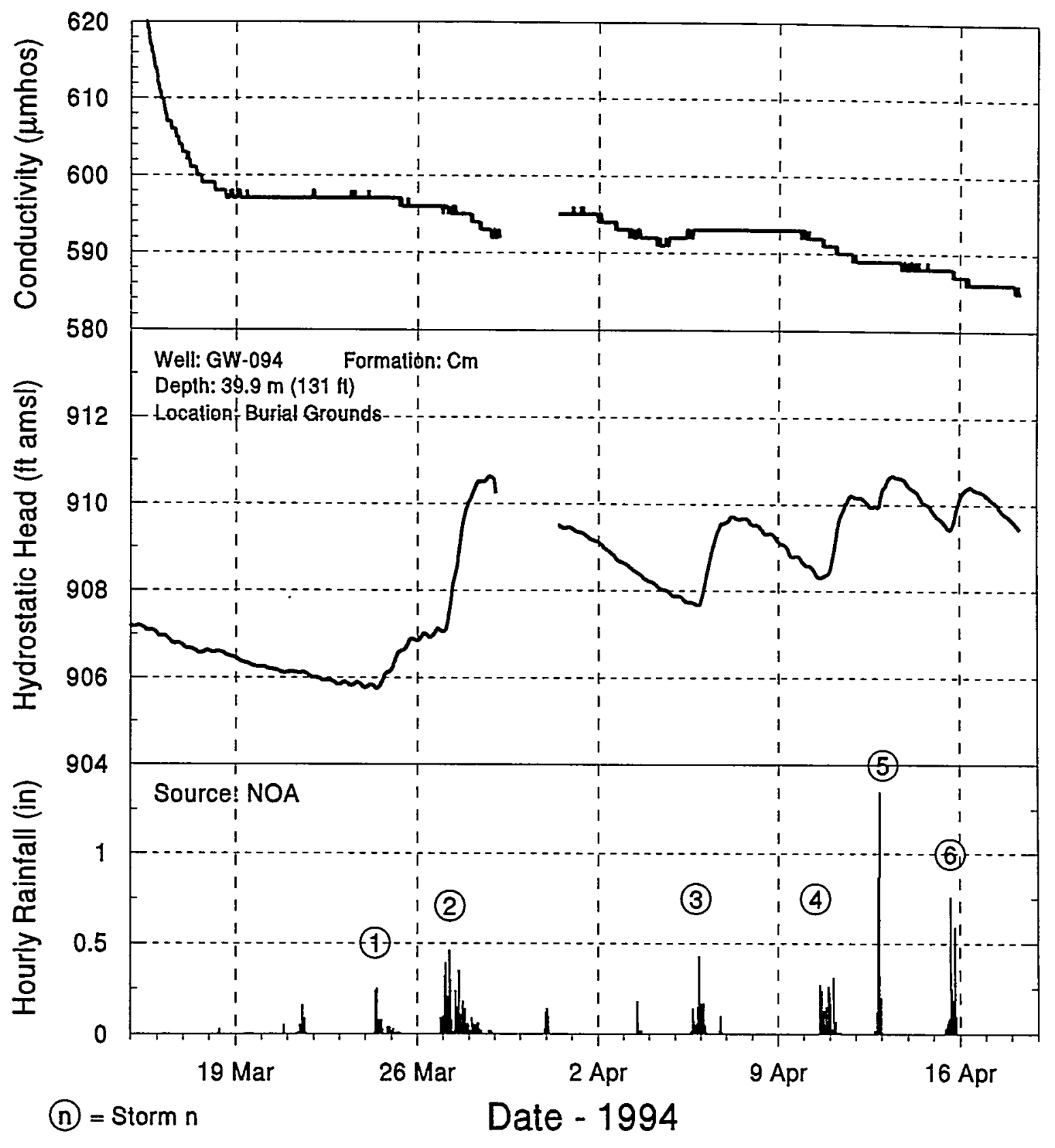

Fig. C.35. Well hydrograph and specific conductivity for GW-094 at depth of $131 \mathrm{ft}$ at BCBG for March 14 to April 18. 


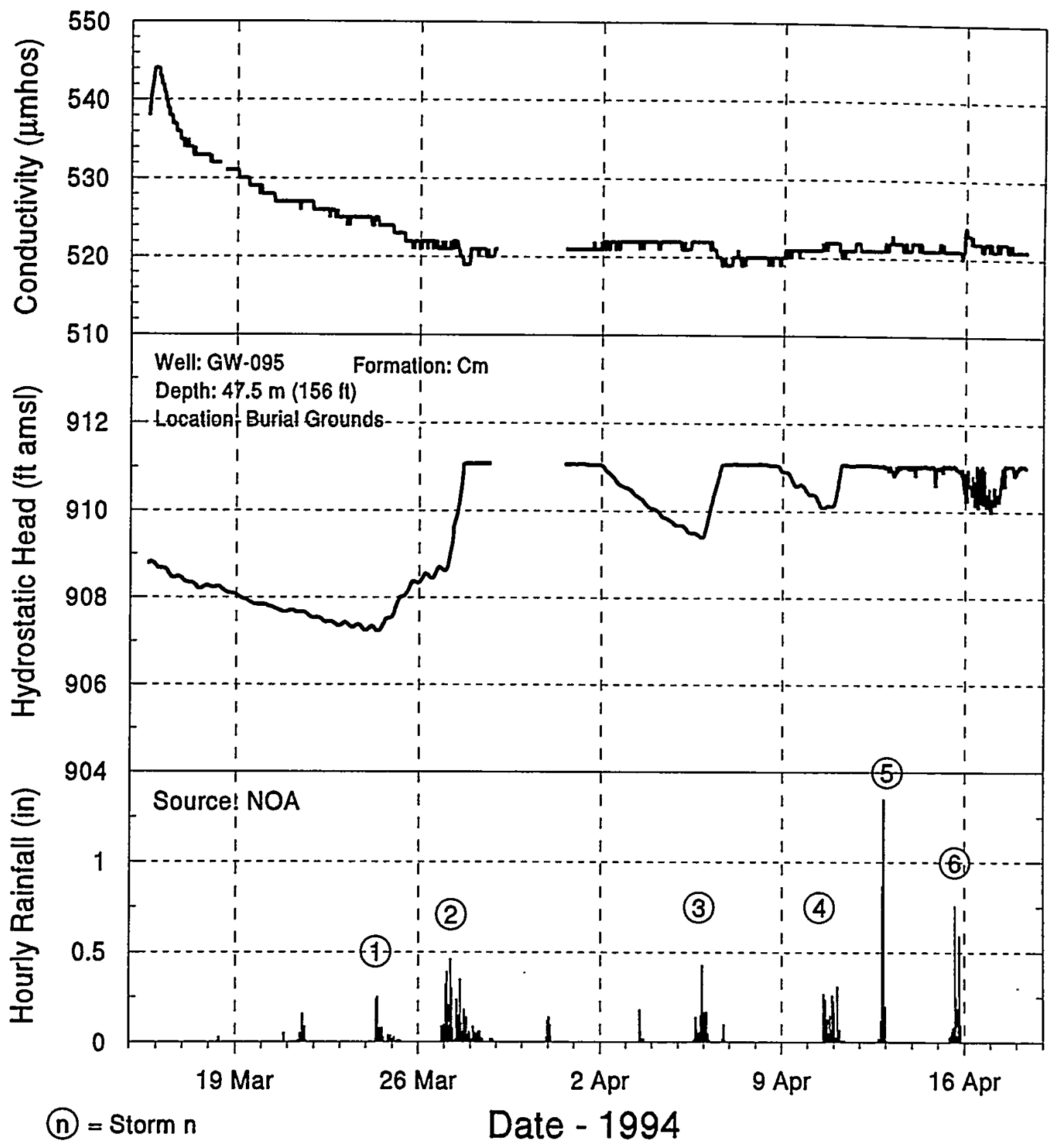

Fig. C.36. Well hydrograph and specific conductivity for GW-095 at depth of $156 \mathrm{ft}$ at BCBG for March 15 to April 18. 
C9-10

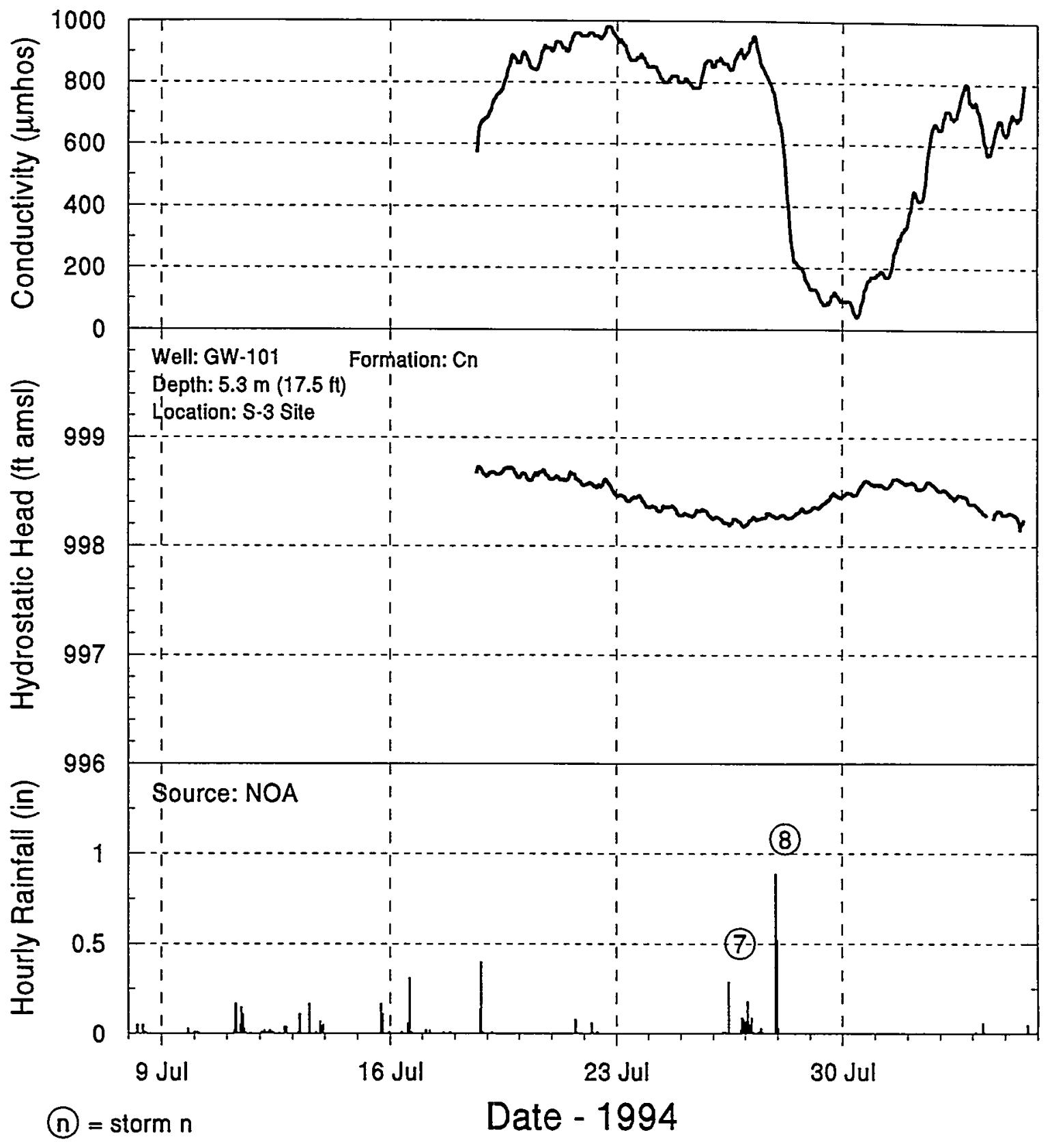

Fig. C.37. Well hydrograph and specific conductivity for GW-101 at depth of $17.5 \mathrm{ft}$ at S-3 Site for July 18 to August 4. 


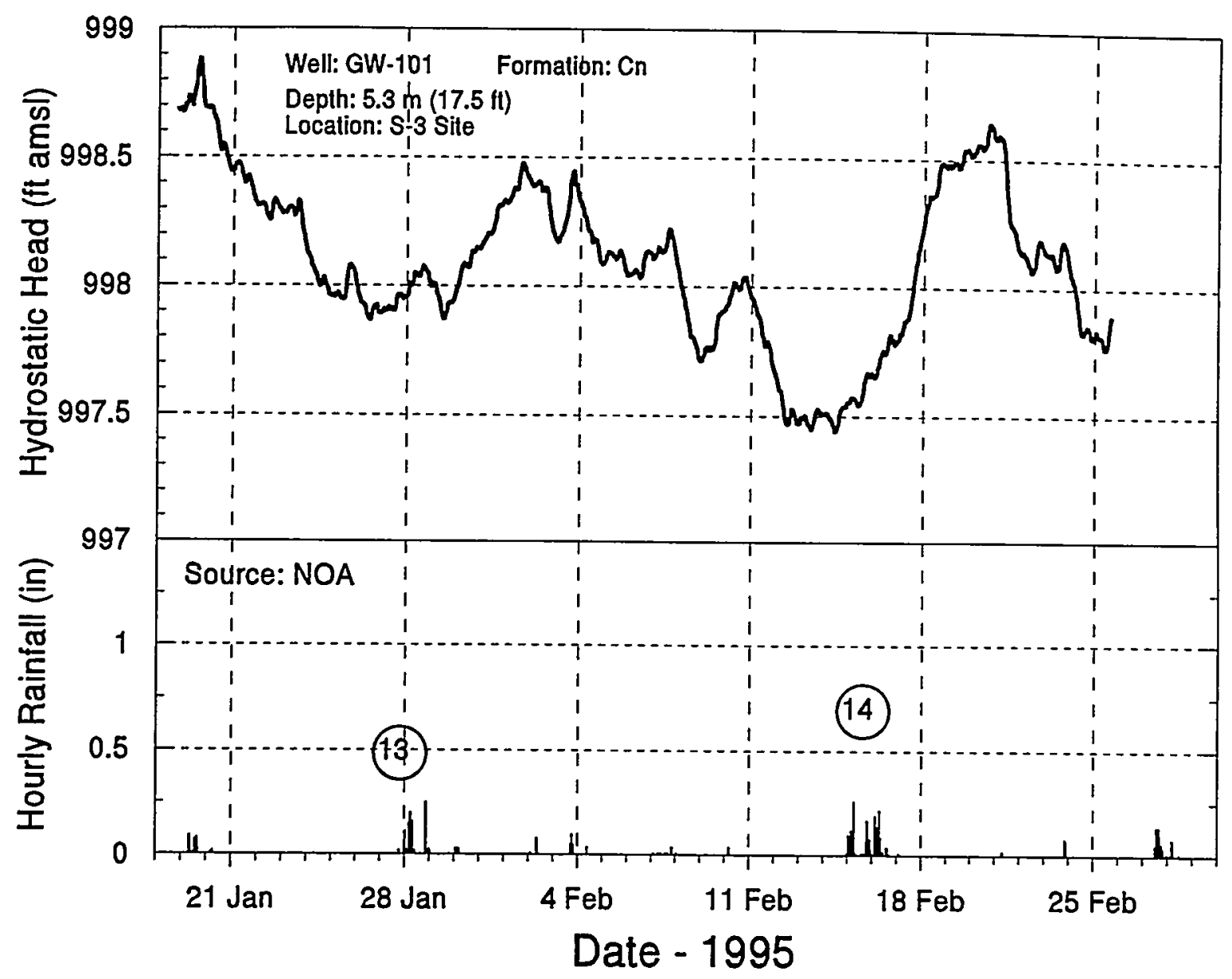

Fig. C.38. Well hydrograph for GW-101 at depth of $17.5 \mathrm{ft}$ at S-3 Site for January 18 to March 2. 


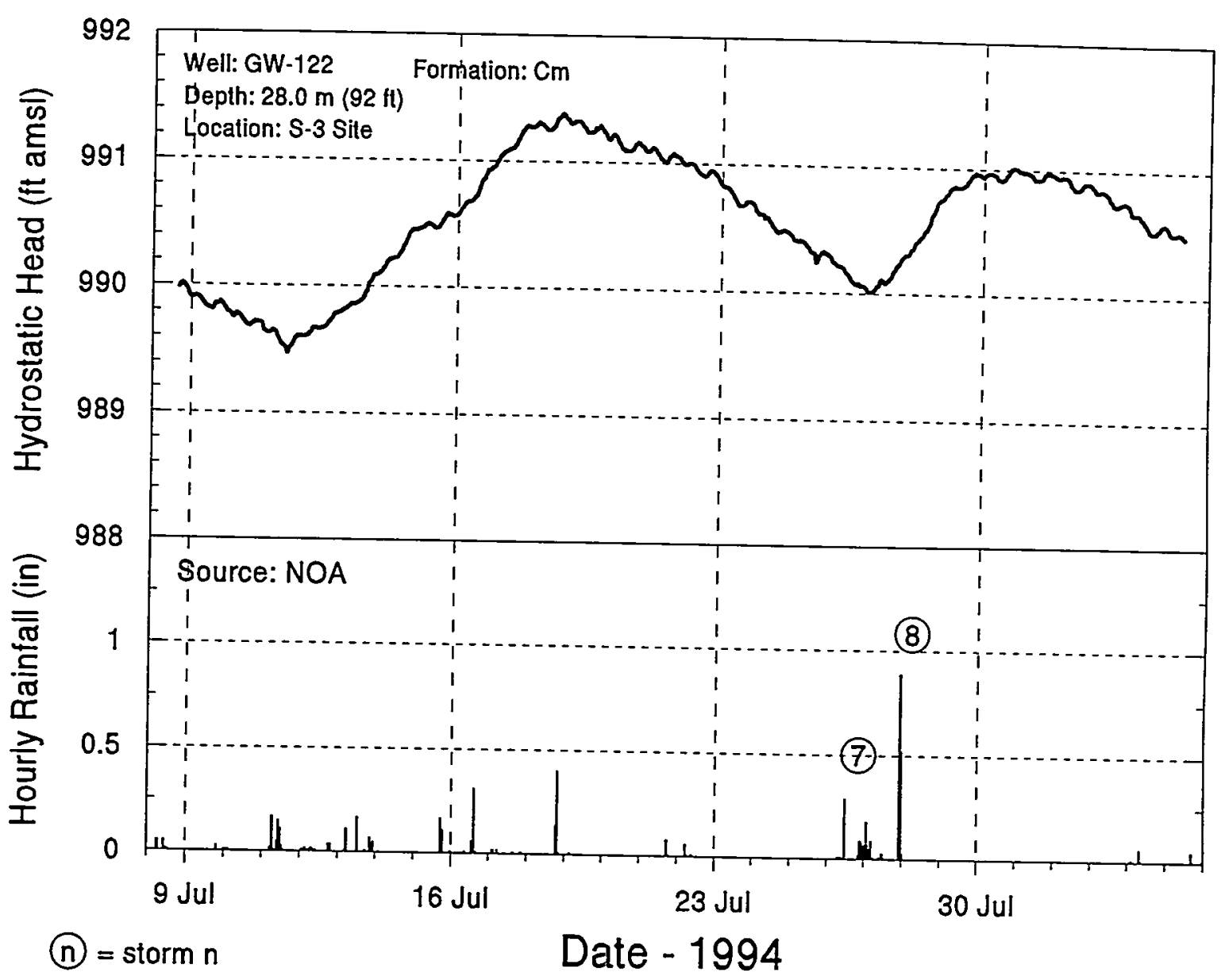

Fig. C.39. Well hydrograph for GW-122 at depth of $92 \mathrm{ft}$ at S-3 Site for July 18 to August 4. 


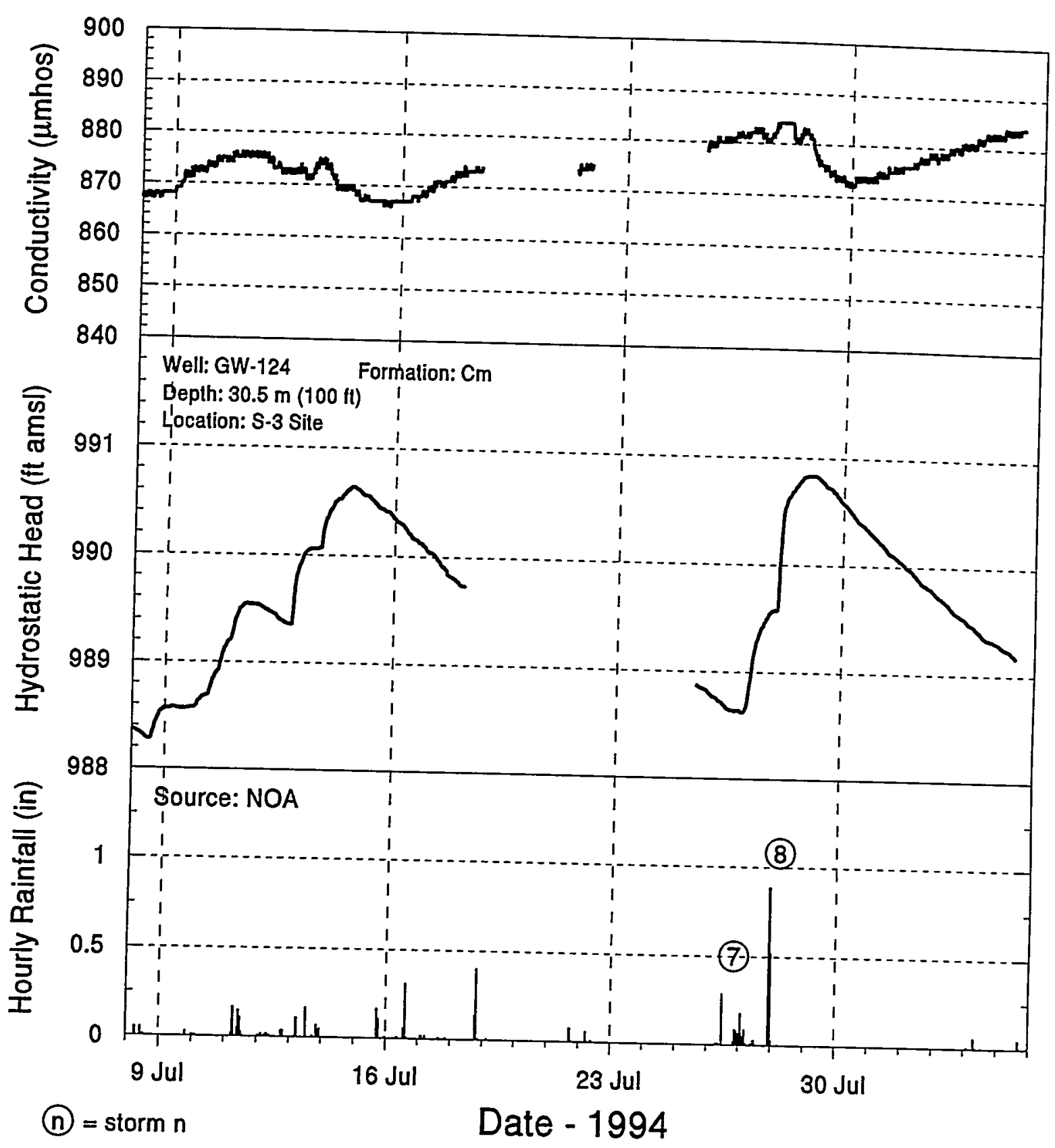

Fig. C.40. Well hydrograph for GW-124 at depth of $100 \mathrm{ft}$ at S-3 Site for July 8 to August 4 . 


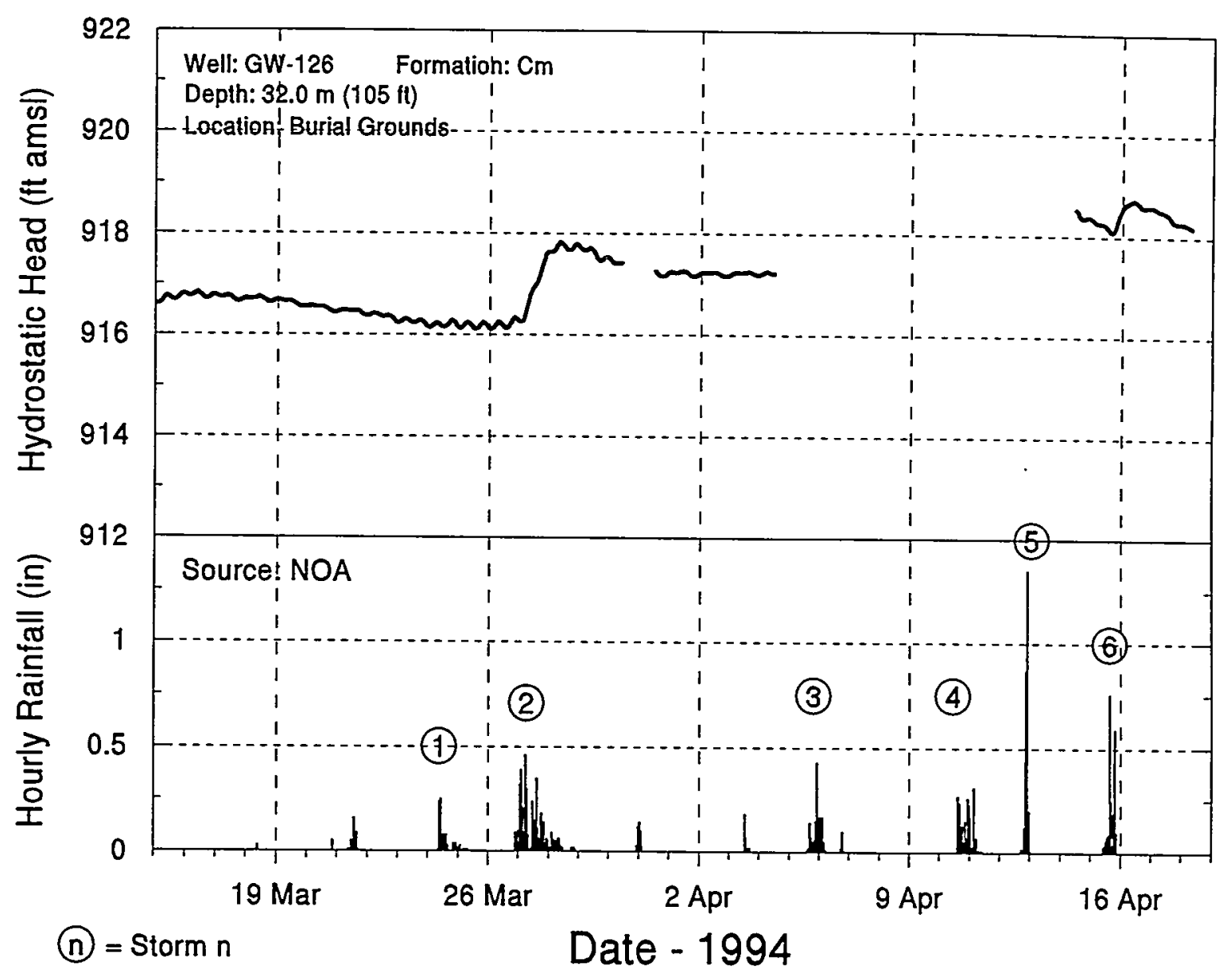

Fig. C.41. Well hydrograph for GW-126 at depth of $105 \mathrm{ft}$ at BCBG for March 14 to April 18. 


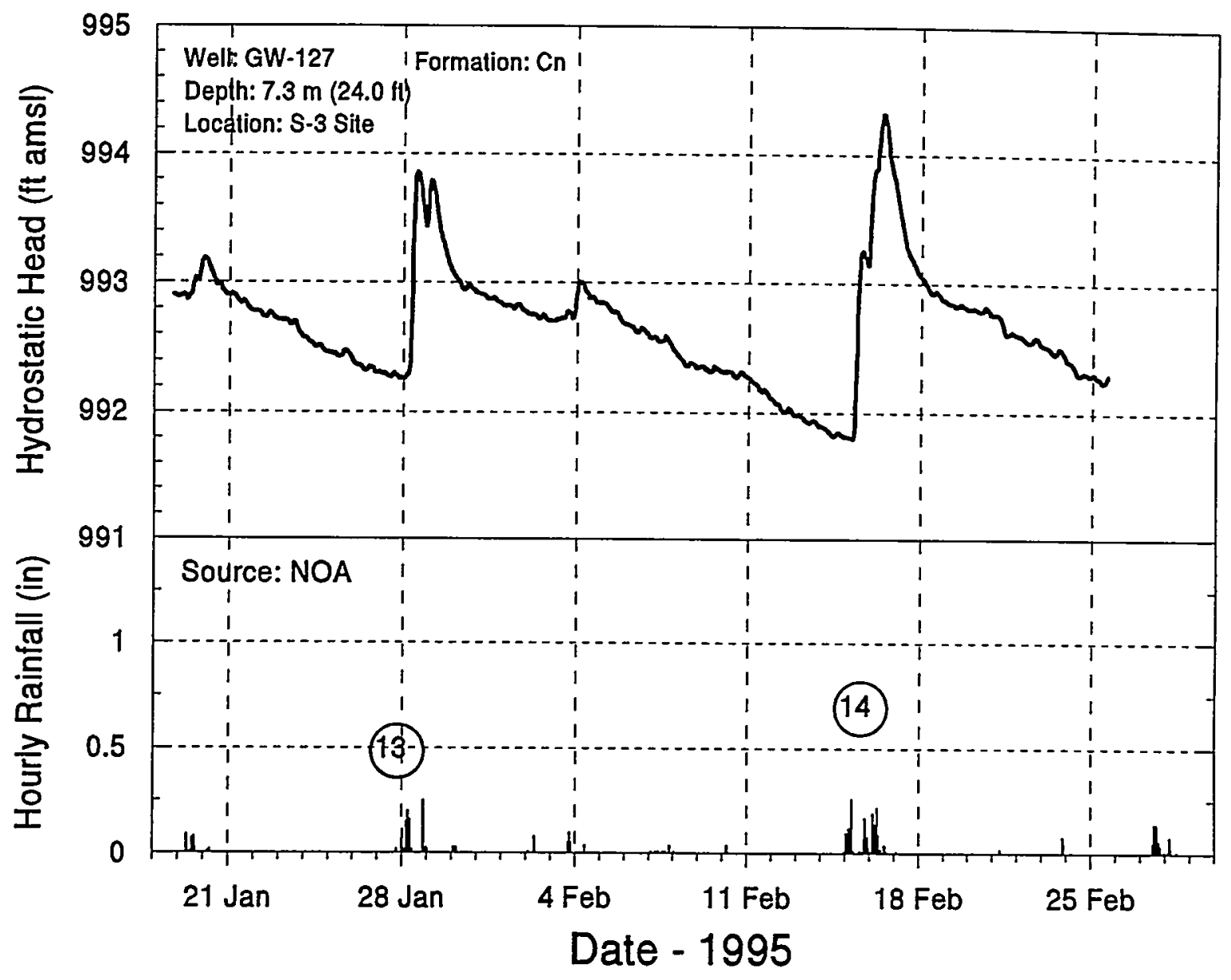

Fig. C.42. Well hydrograph for GW-127 at depth of $24.0 \mathrm{ft}$ at S-3 Site for January 18 to March 2. 


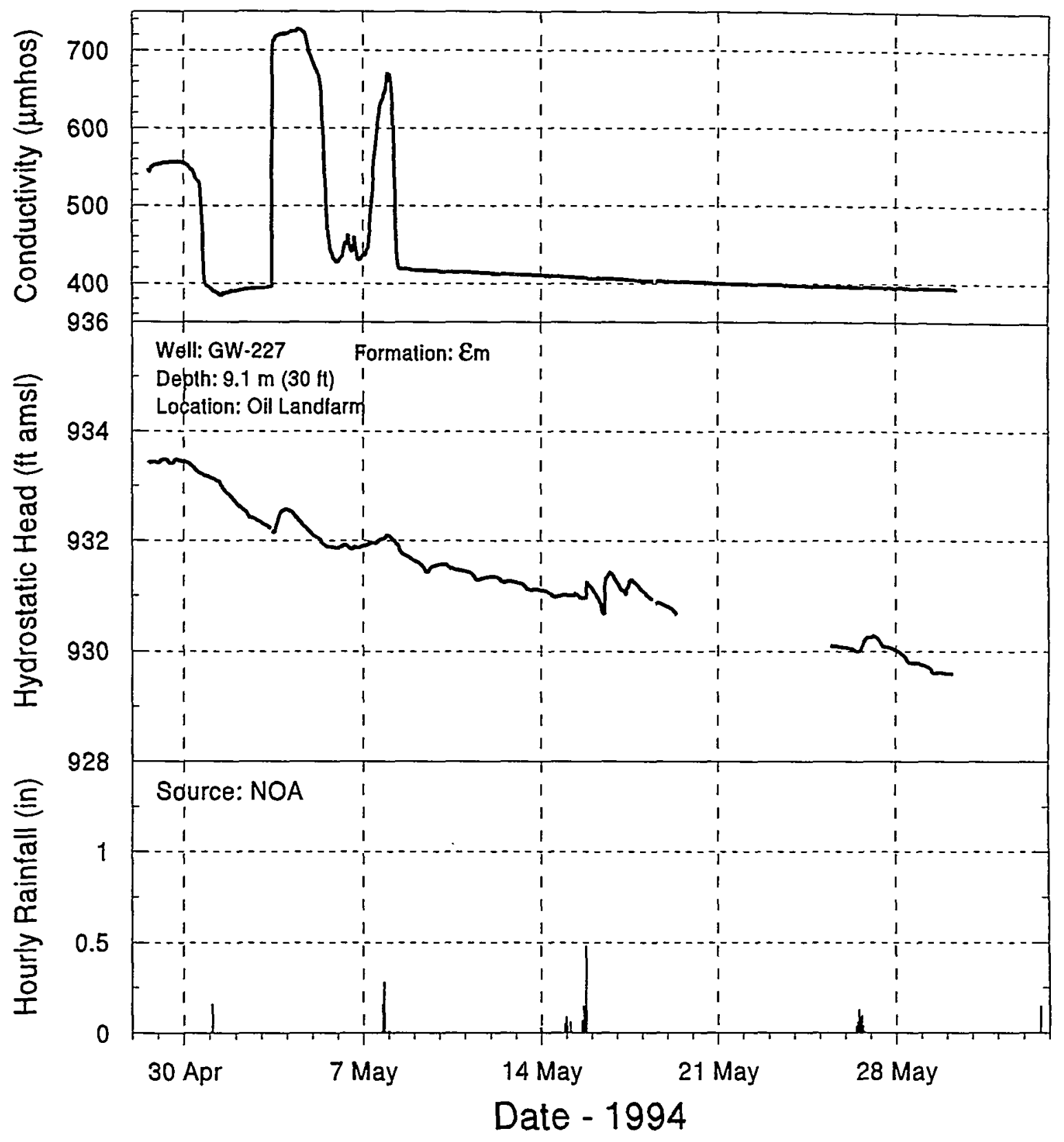

Fig. C.43. Well hydrograph and specific conductivity for GW-227 at depth of $30 \mathrm{ft}$ at OLF for April 28 to May 30. 


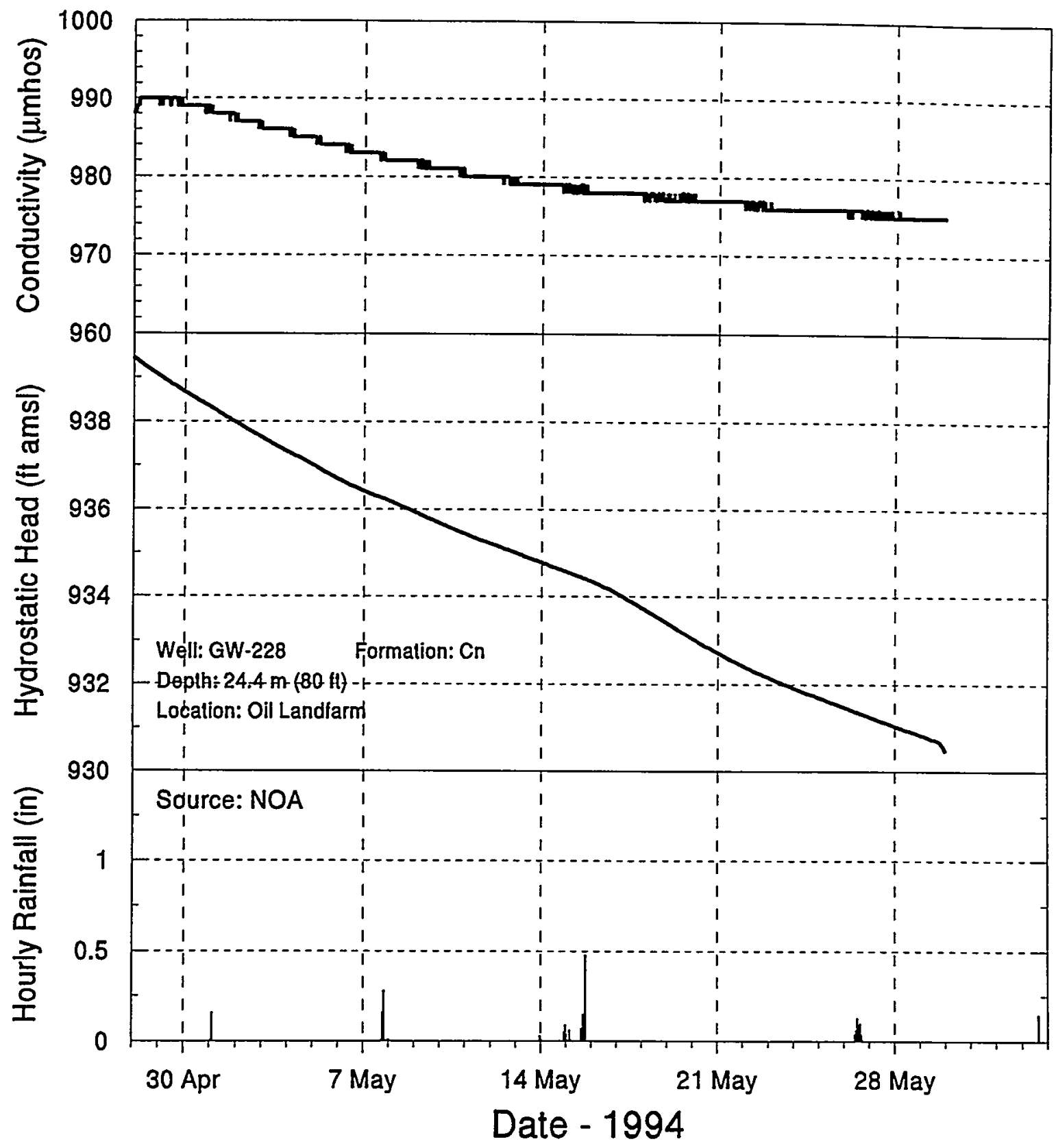

Fig. C.44. Well hydrograph and specific conductivity for GW-228 at depth of $80 \mathrm{ft}$ at OLF for April 27 to May 29. 


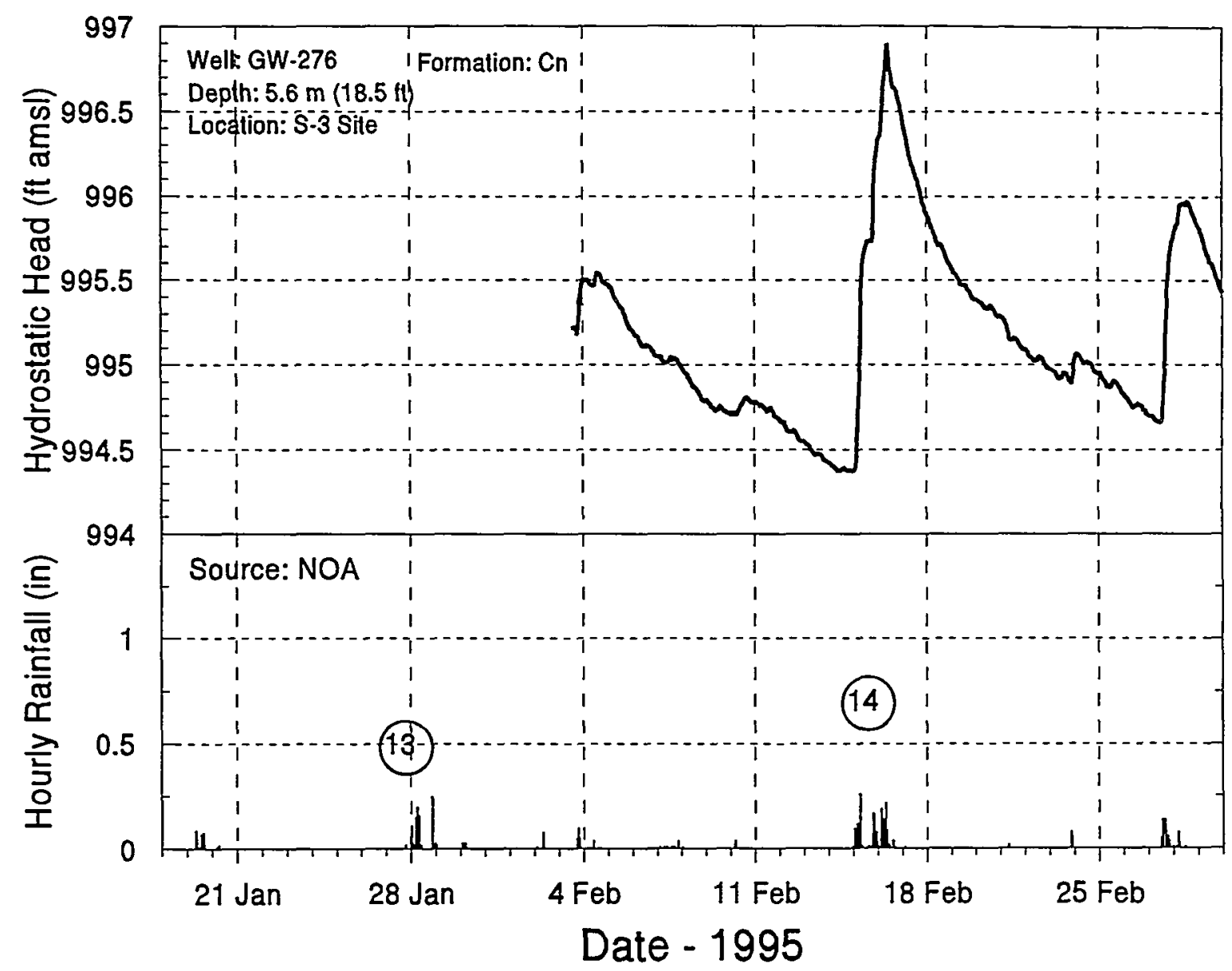

Fig. C.45. Well hydrograph for GW-276 at depth of $18.5 \mathrm{ft}$ at S-3 Site for February 3 to March 2. 


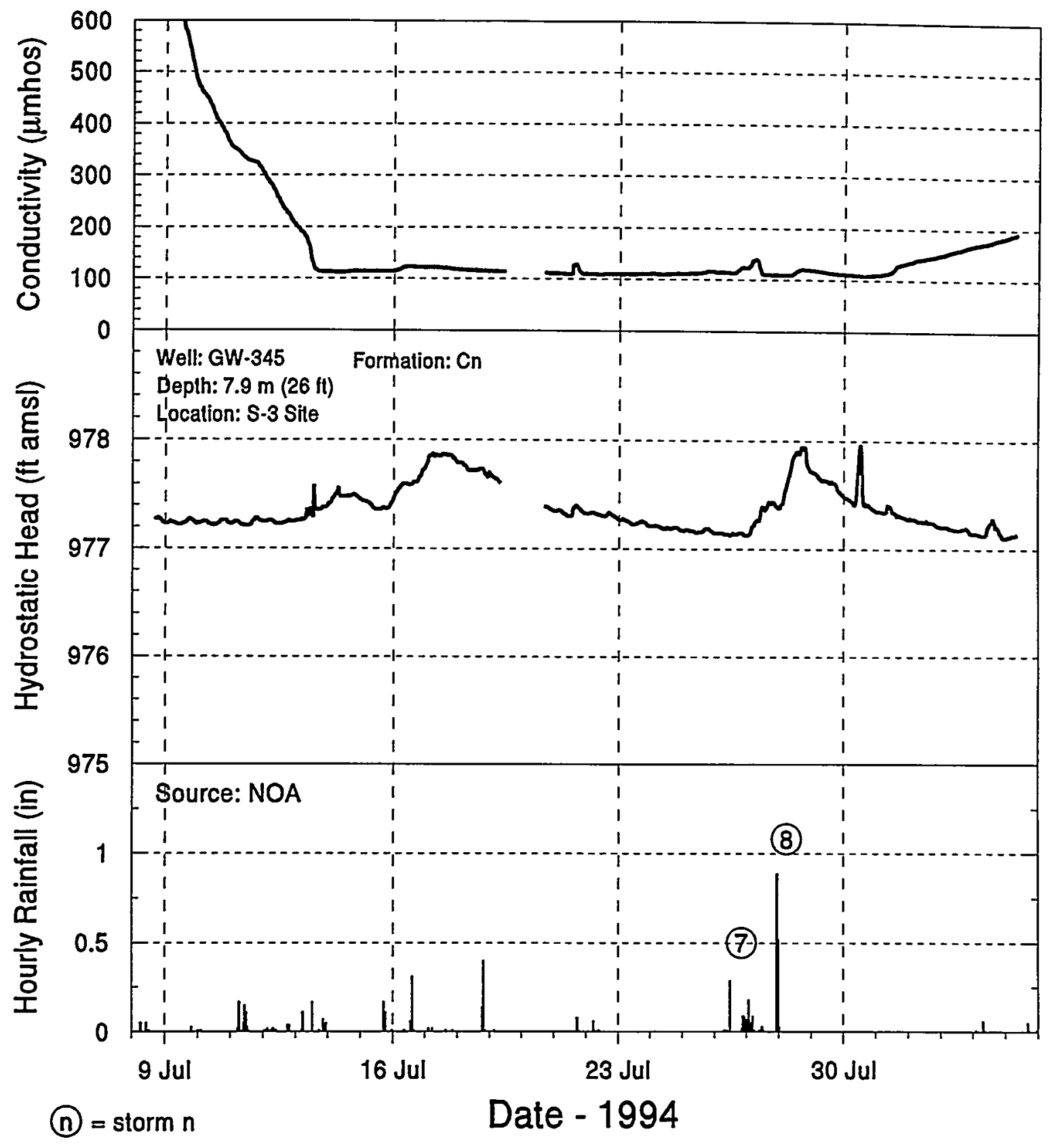

Fig. C.46. Well hydrograph and specific conductivity for GW-345 at depth of $26 \mathrm{ft}$ at S-3 Site for July 8 to August 4. 


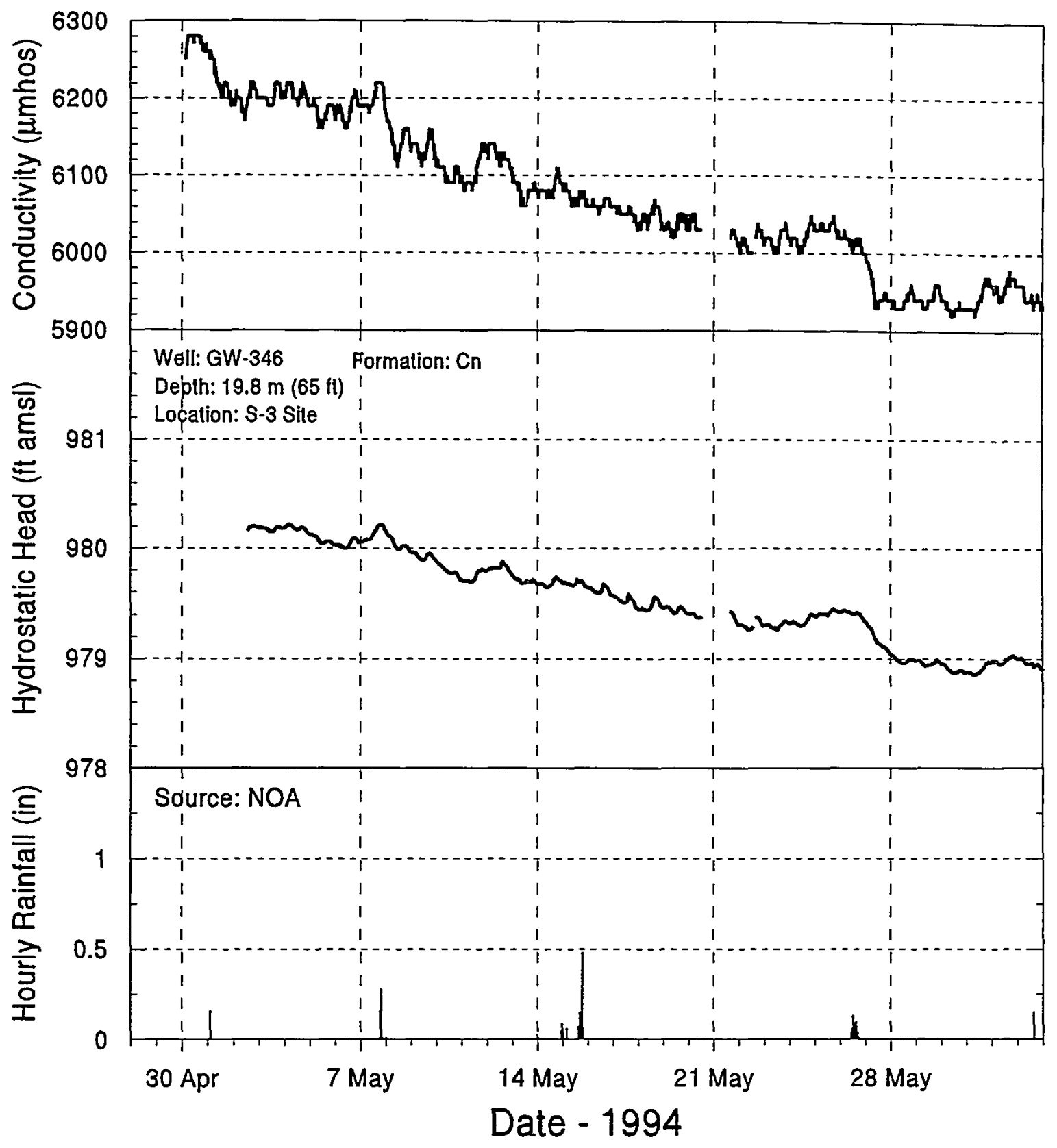

Fig. C.47. Well hydrograph and specific conductivity for GW-346 at depth of $65 \mathrm{ft}$ at S-3 Site for April 29 to June 3. 


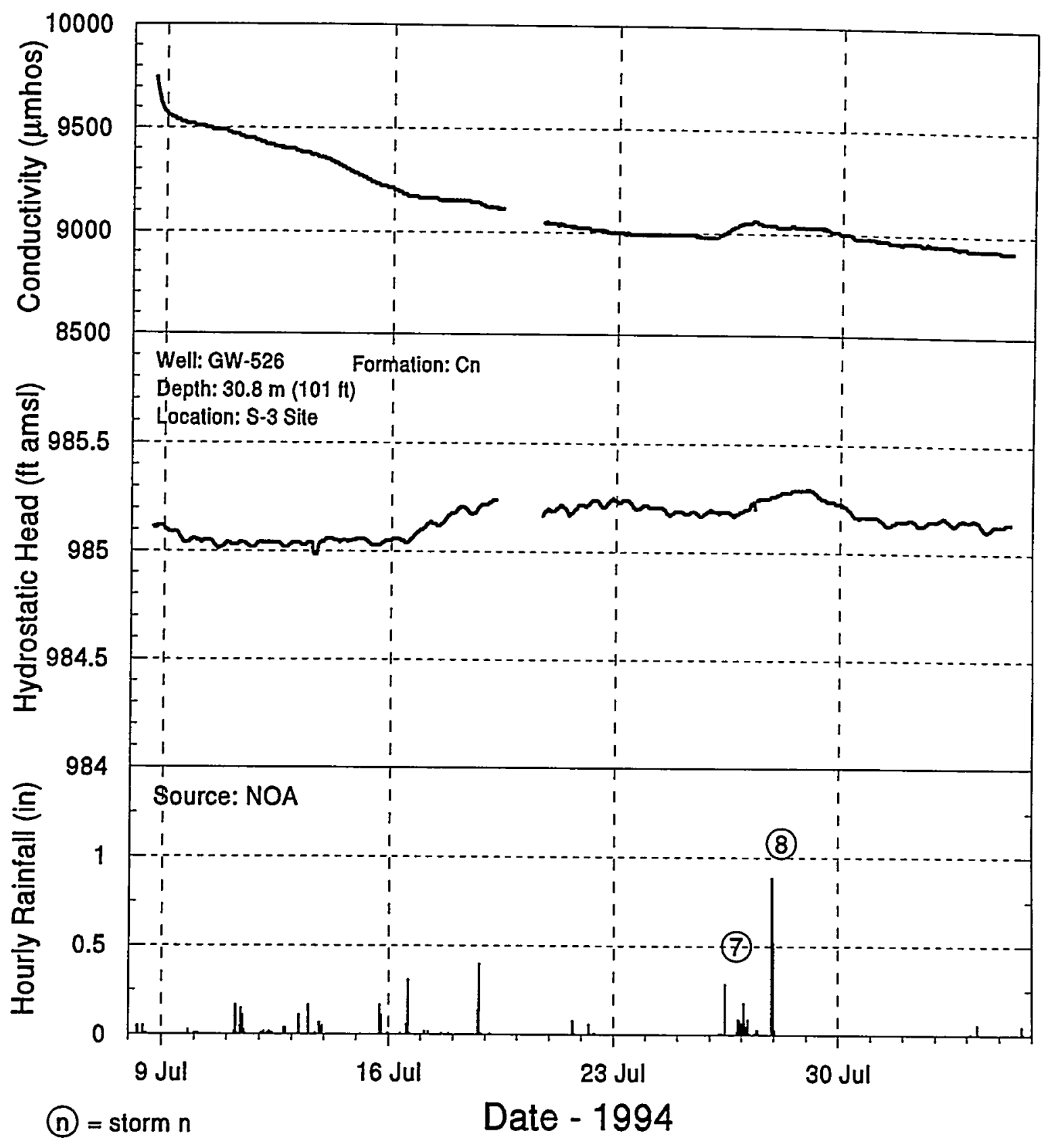

Fig. C.48. Well hydrograph and specific conductivity for GW-526 at depth of $101 \mathrm{ft}$ at S-3 Site for April 28 to June 2. 


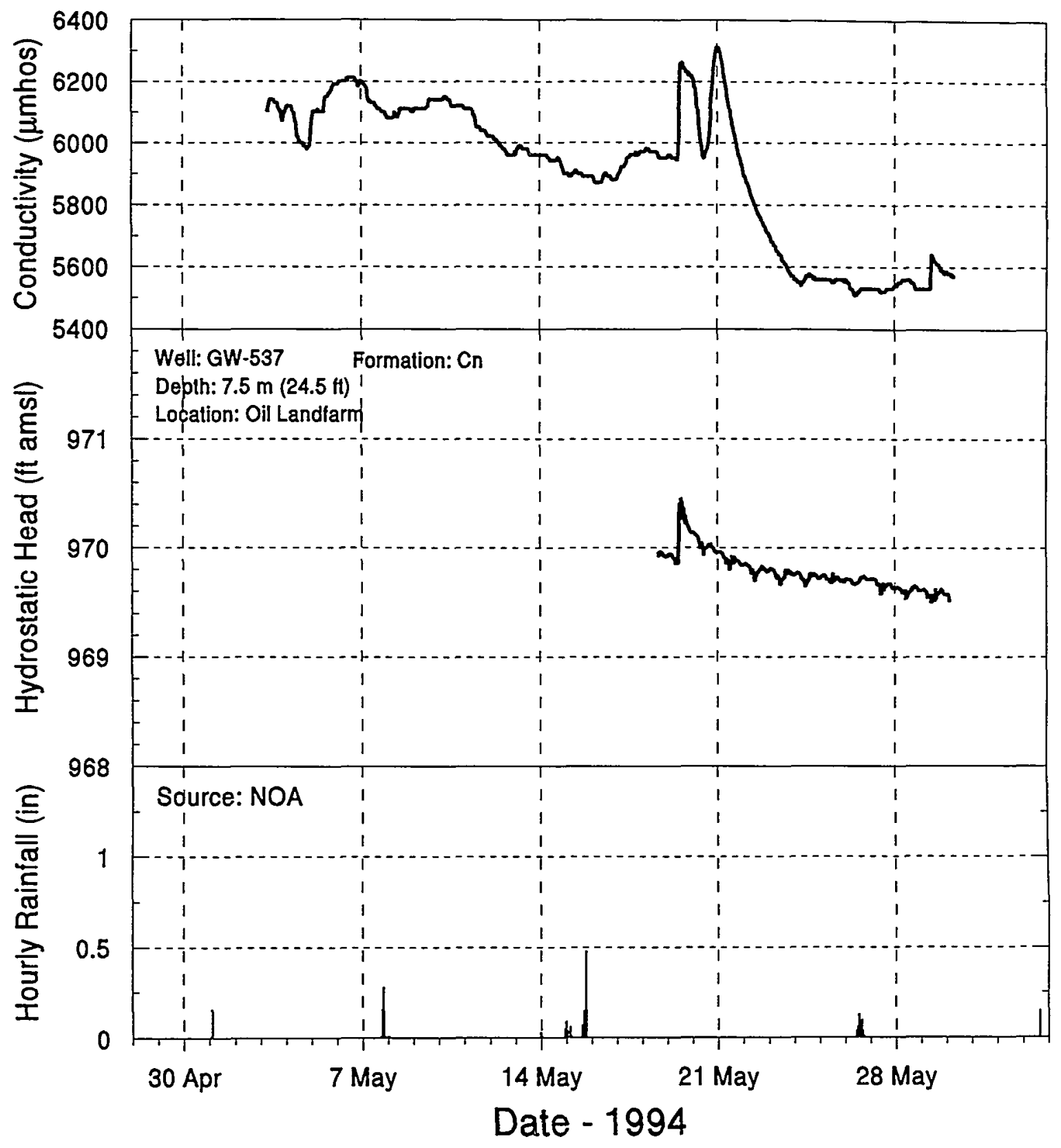

Fig. C.49. Well hydrograph and specific conductivity for GW-537 at depth of $24.5 \mathrm{ft}$ at OLF for May 3 to May 30. 


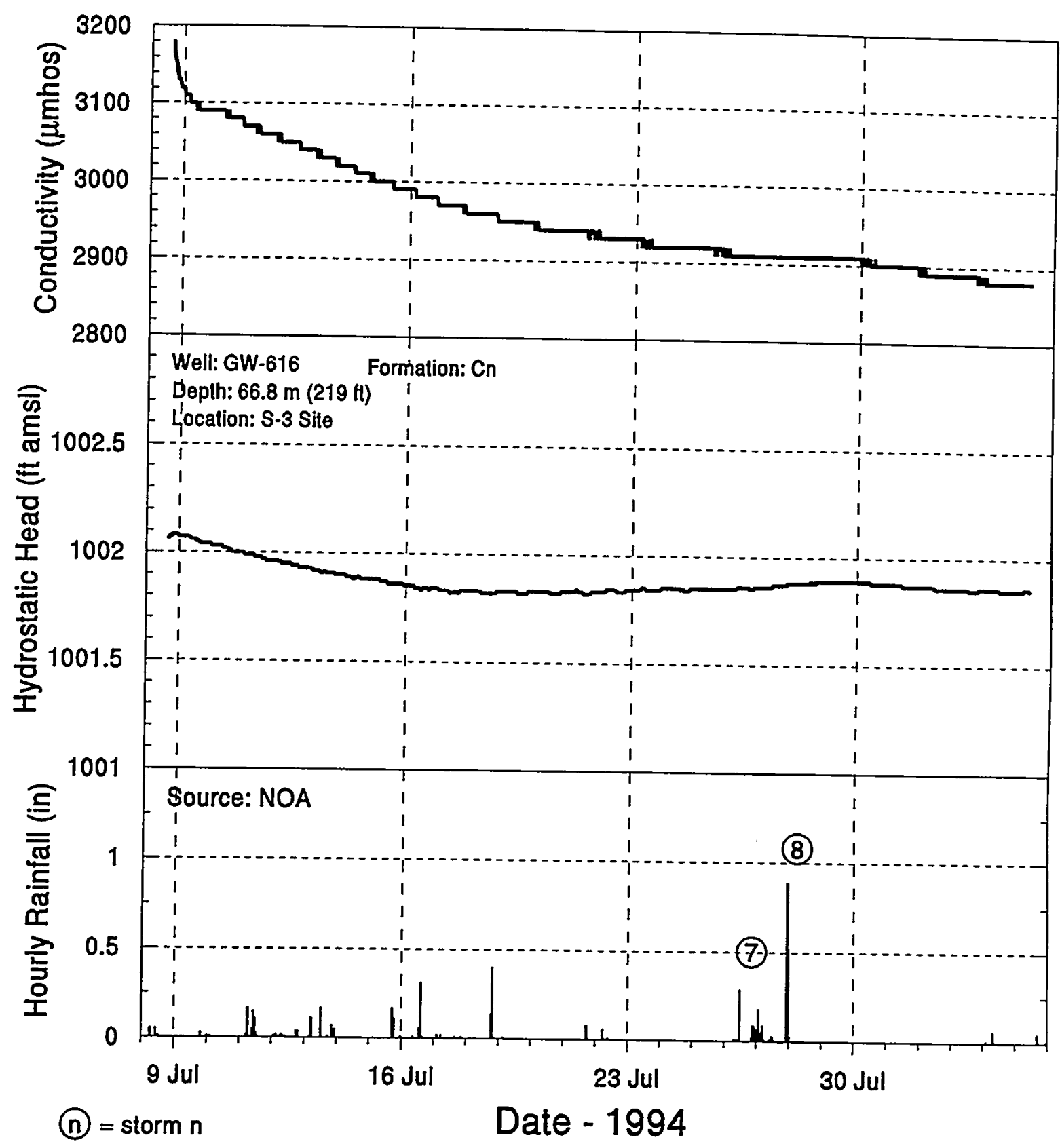

Fig. C.50. Well hydrograph and specific conductivity for GW-616 at depth of $219 \mathrm{ft}$ at S-3 Site for July 8 to August 4. 


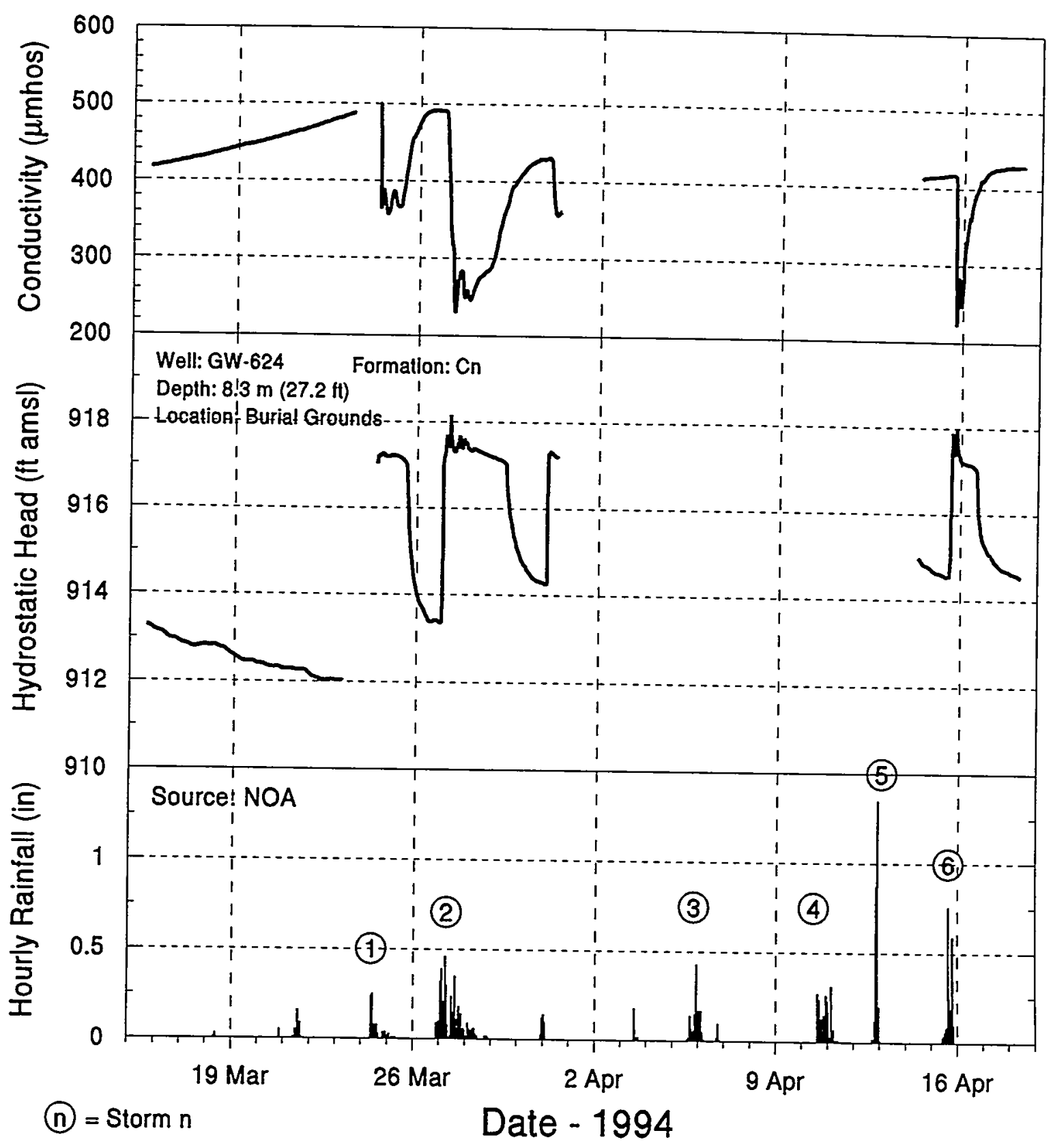

Fig. C.51. Well hydrograph, specific conductivity, and temperature for GW-624 for March 15 to April 18. 


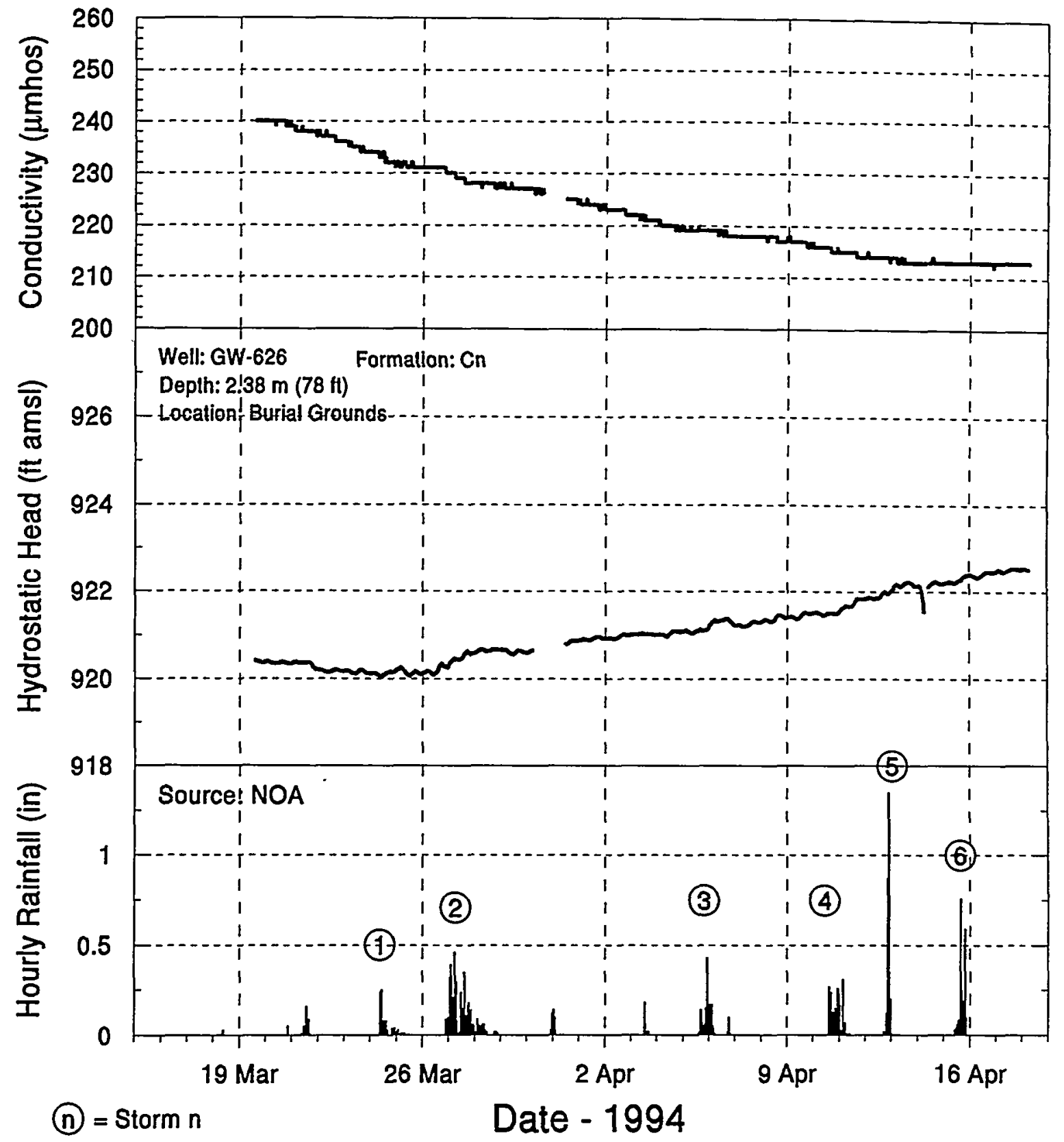

Fig. C.52. Well hydrograph and specific conductivity for GW-626 at depth of $78 \mathrm{ft}$ at BCBG for March 19 to April 18. 


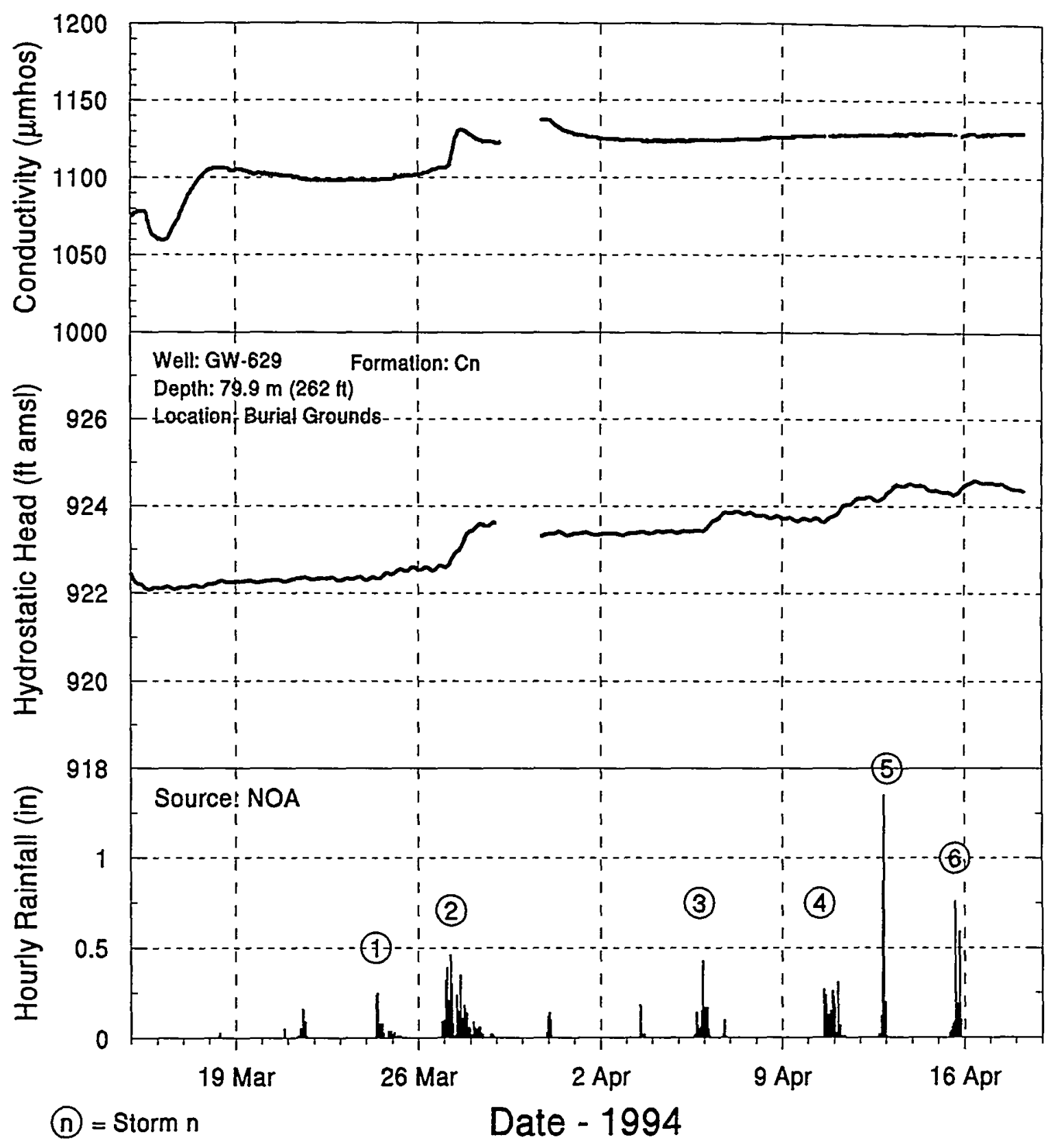

Fig. C.53. Well hydrograph and specific conductivity for GW-629 at depth of $262 \mathrm{ft}$ at BCBG for March 14 to April 18. 


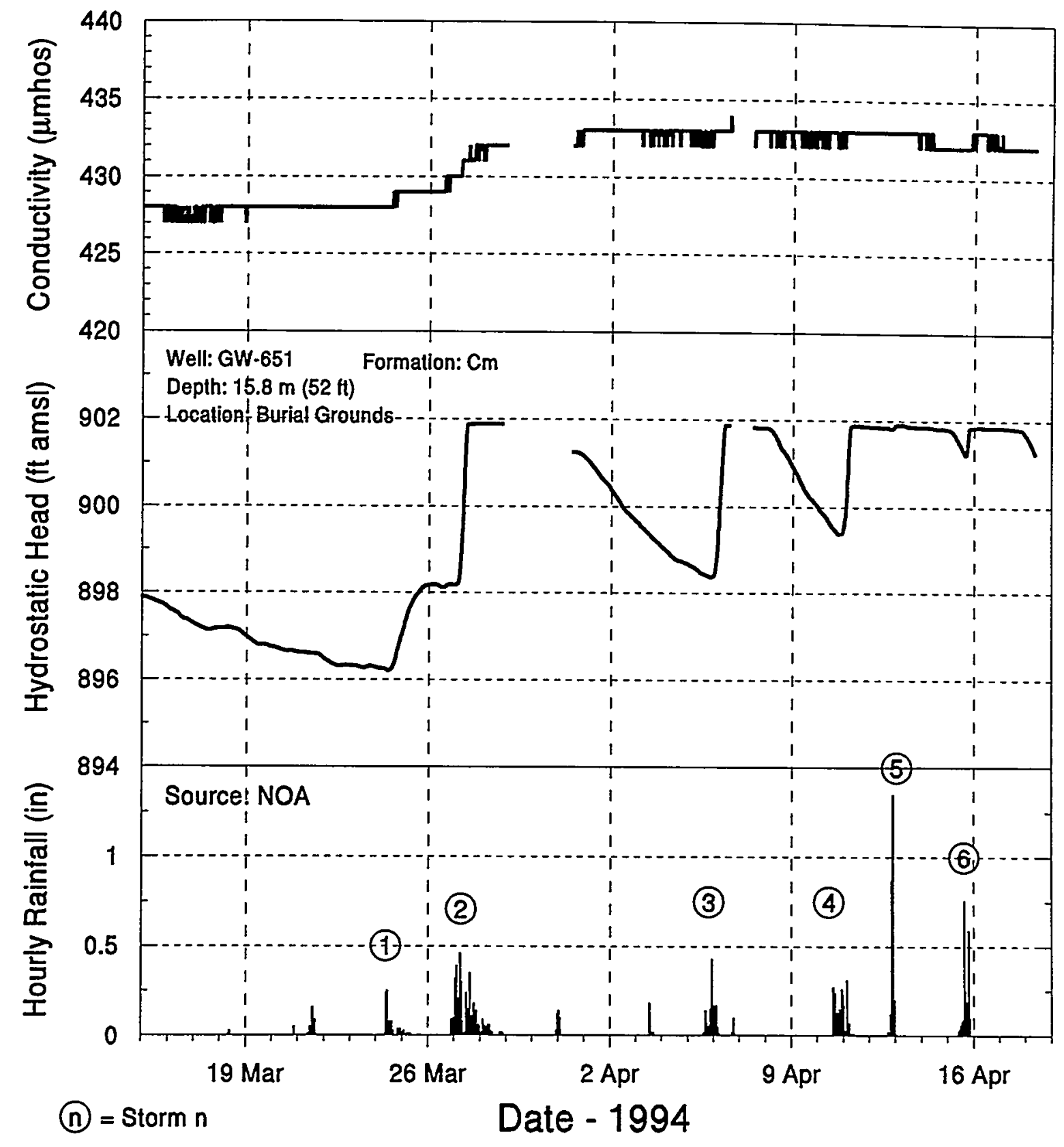

Fig. C.54. Well hydrograph and specific conductivity for GW-651 at depth of $52 \mathrm{ft}$ at BCBG for March 14 to April 18. 


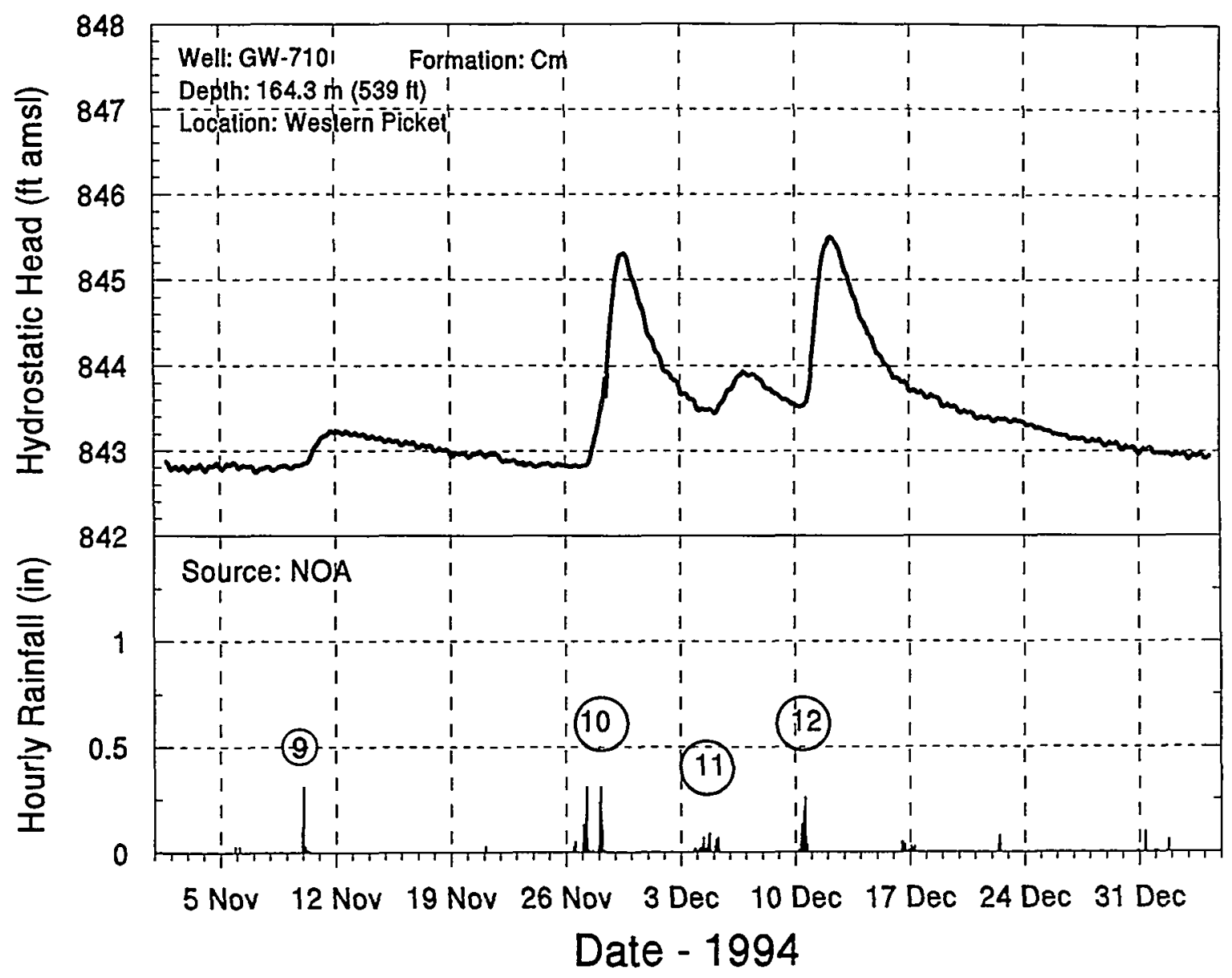

Fig. C.55. Well hydrograph for GW-710 at depth of $539 \mathrm{ft}$ at Western Picket for November 1 to January 4. 


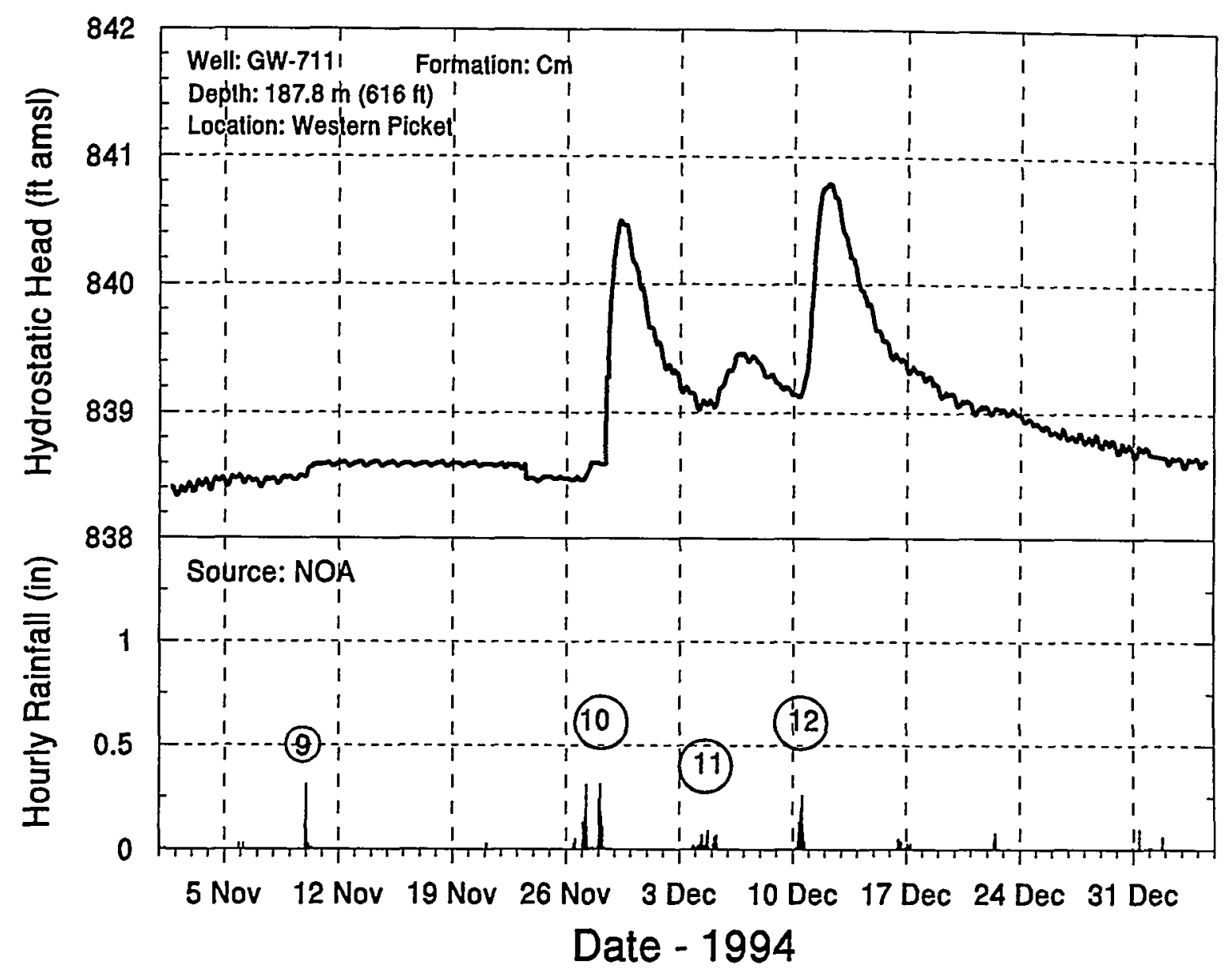

Fig. C.56. Well hydrograph for GW-711 at depth of $616 \mathrm{ft}$ at Western Picket for November 1 to January 4. 


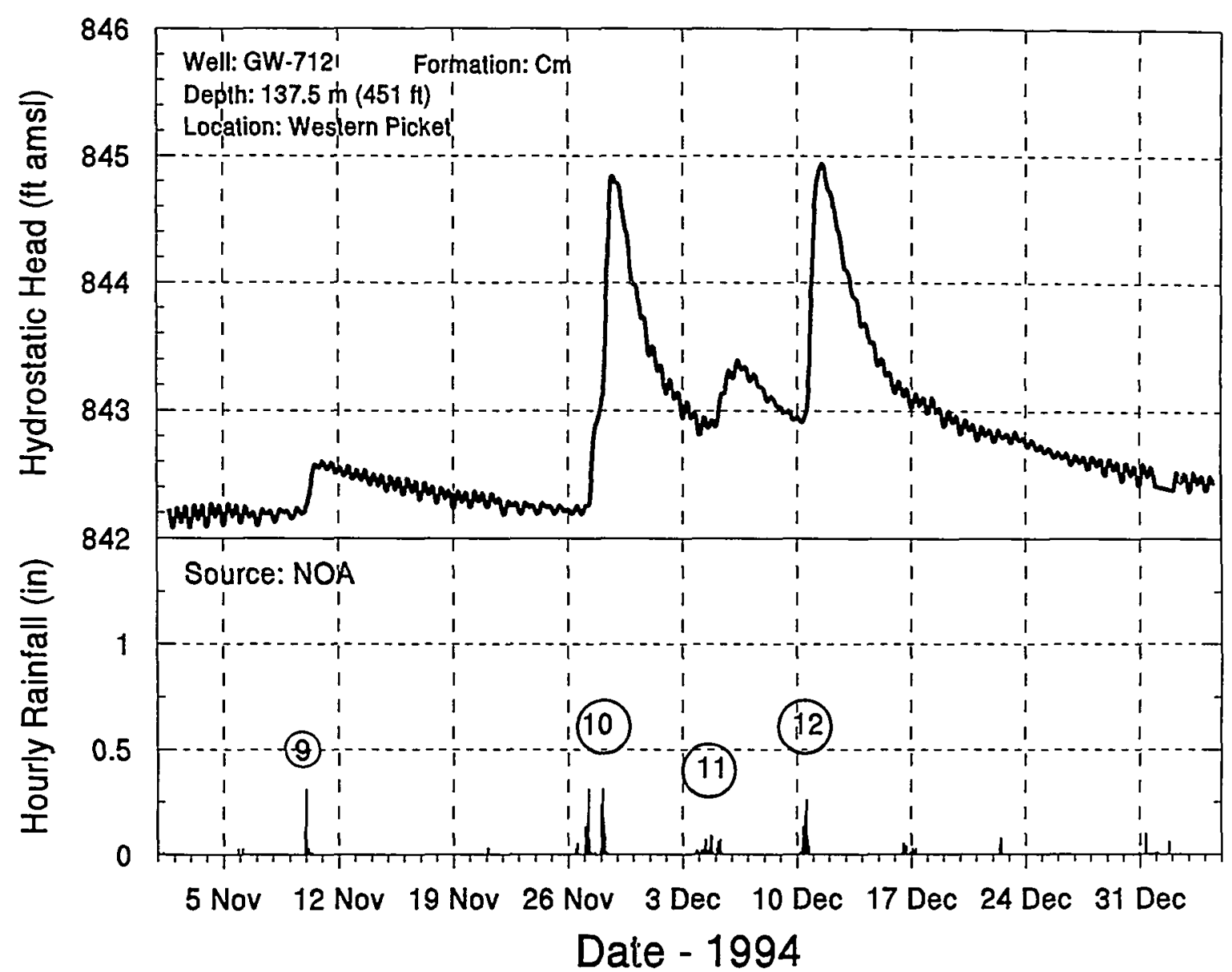

Fig. C.57. Well hydrograph for GW-712 at depth of $451 \mathrm{ft}$ at Western Picket for November 1 to January 4. 


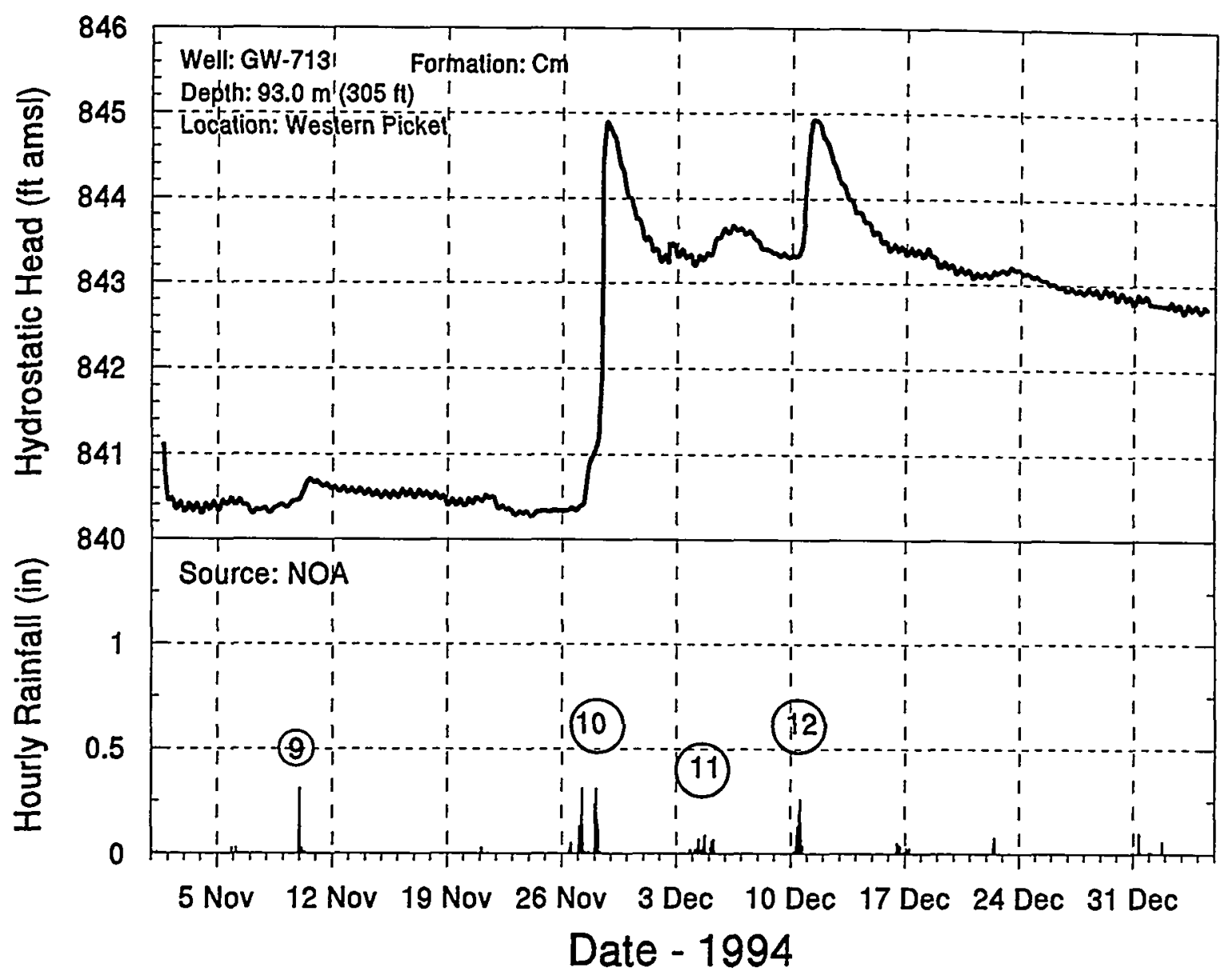

Fig. C.58. Well hydrograph for GW-713 at depth of $305 \mathrm{ft}$ at Western Picket for November 1 to January 4. 


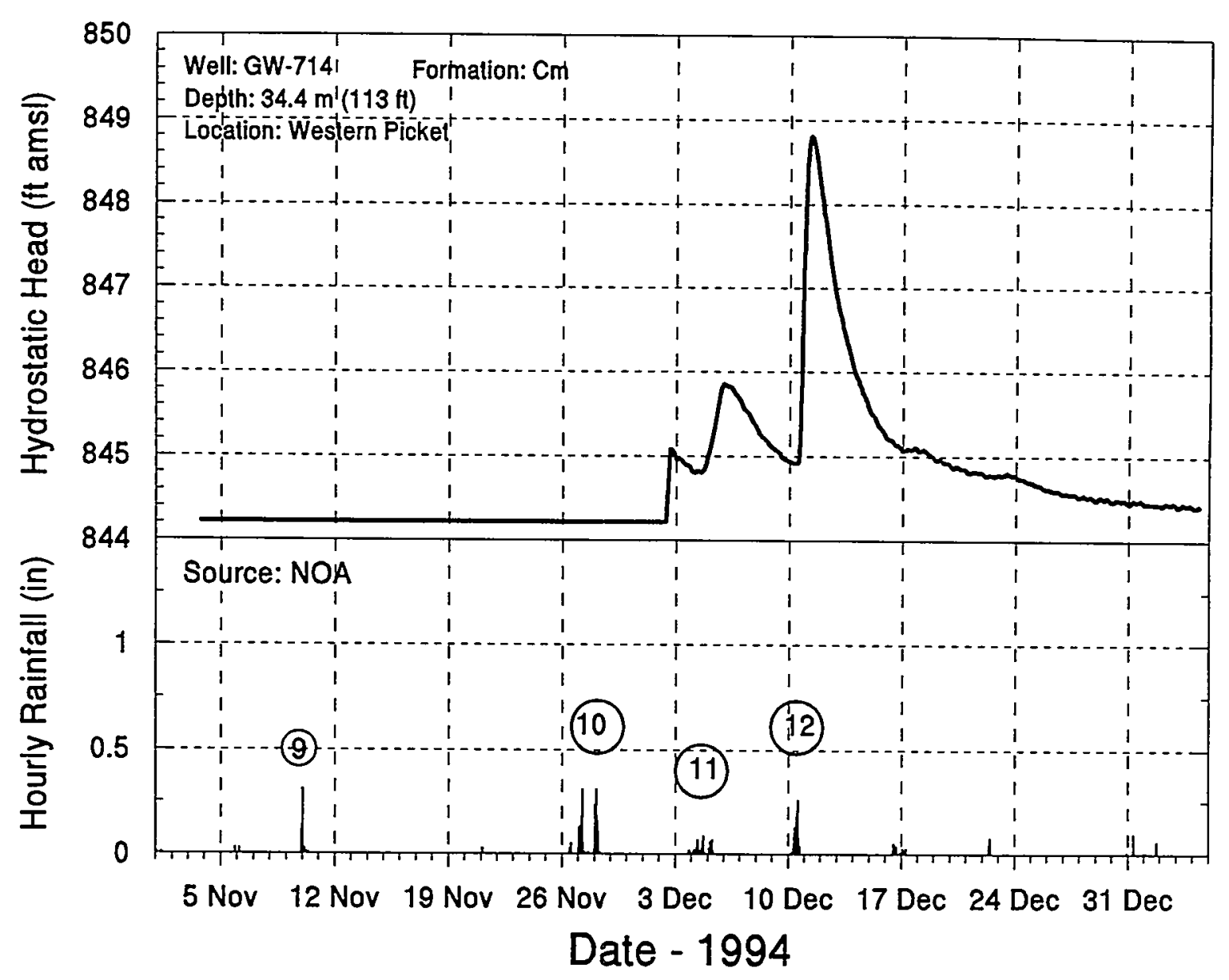

Fig. C.59. Well hydrograph for GW-714 at depth of $113 \mathrm{ft}$ at Western Picket for November 3 to January 4. 


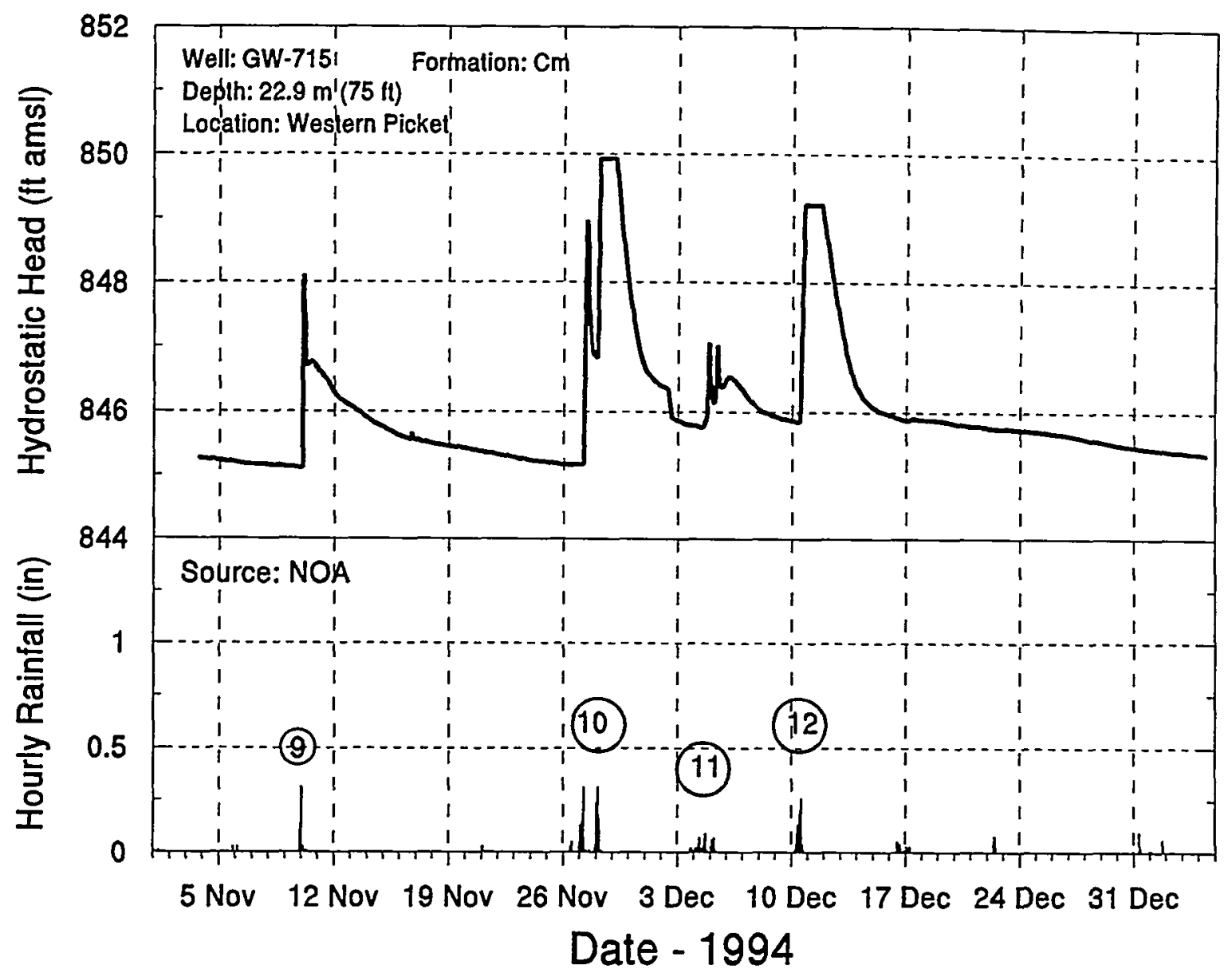

Fig. C.60. Well hydrograph for GW-715 at depth of $75 \mathrm{ft}$ at Western Picket for November 3 to January 4. 


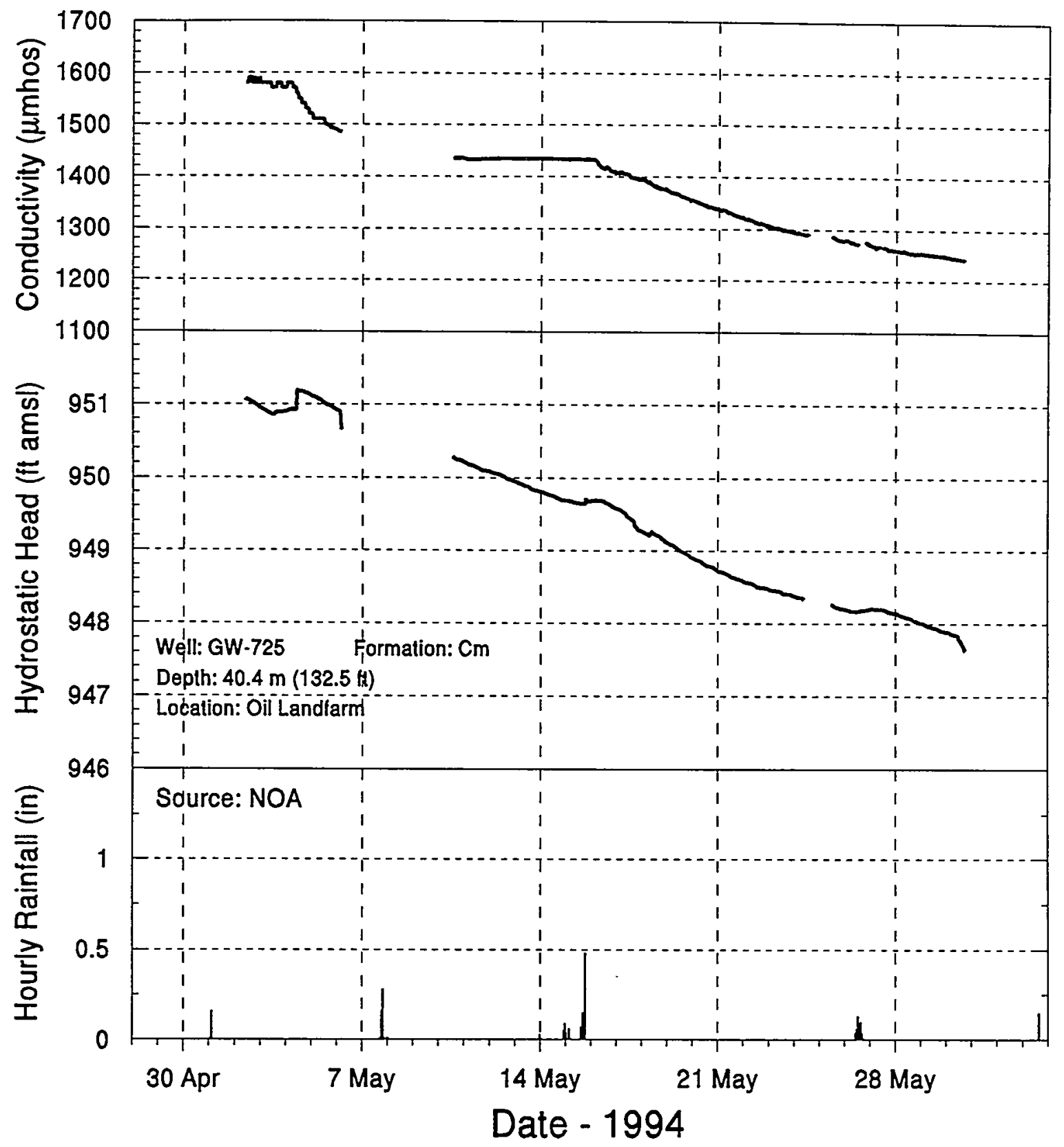

Fig. C.61. Well hydrograph and specific conductivity for GW-725 at depth of $132.5 \mathrm{ft}$ at OLF for May 2 to June 3. 


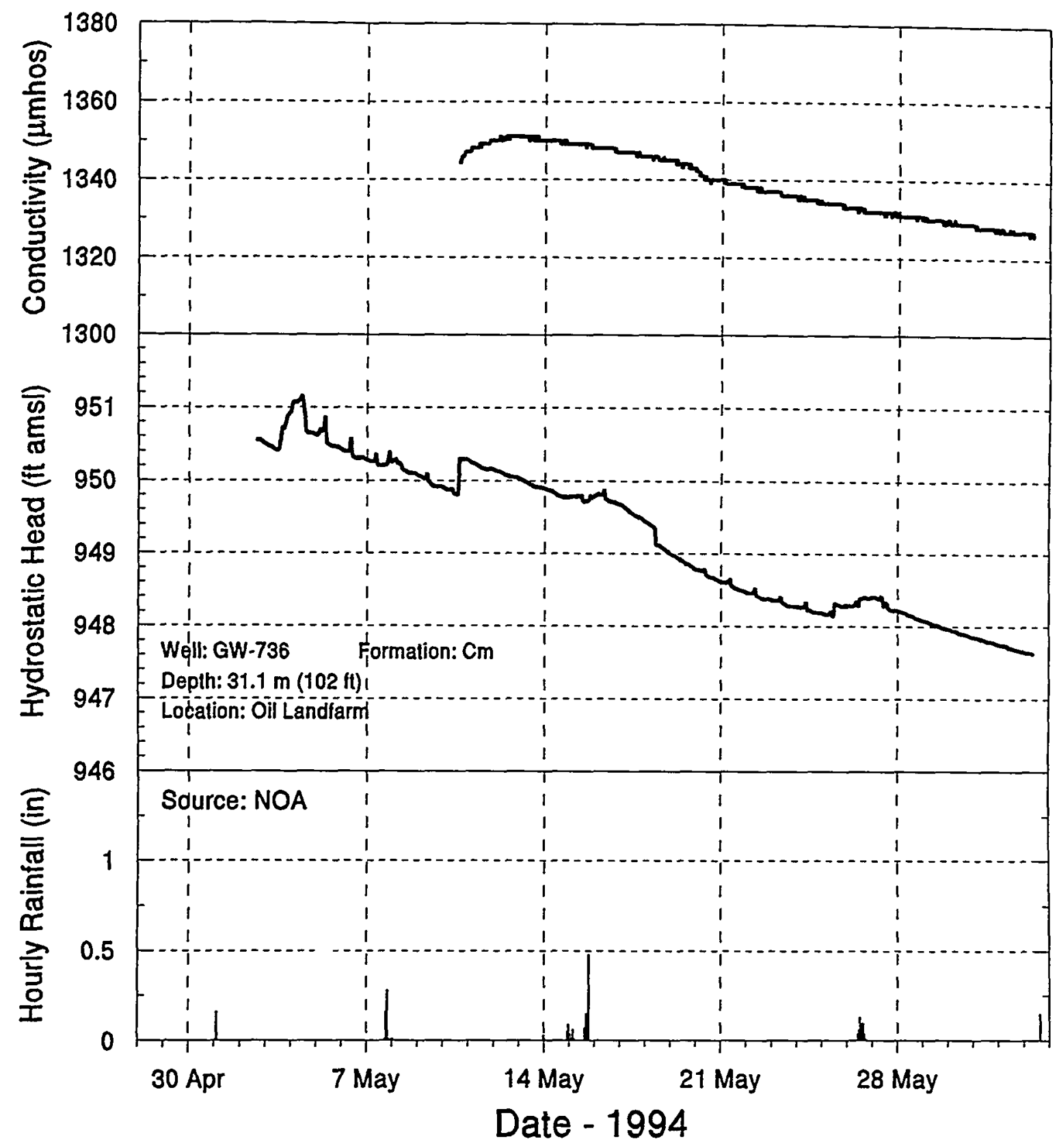

Fig. C.62. Well hydrograph and specific conductivity for GW-736 at depth $102 \mathrm{ft}$ at OLF for May 2 to June 2. 
C9-36

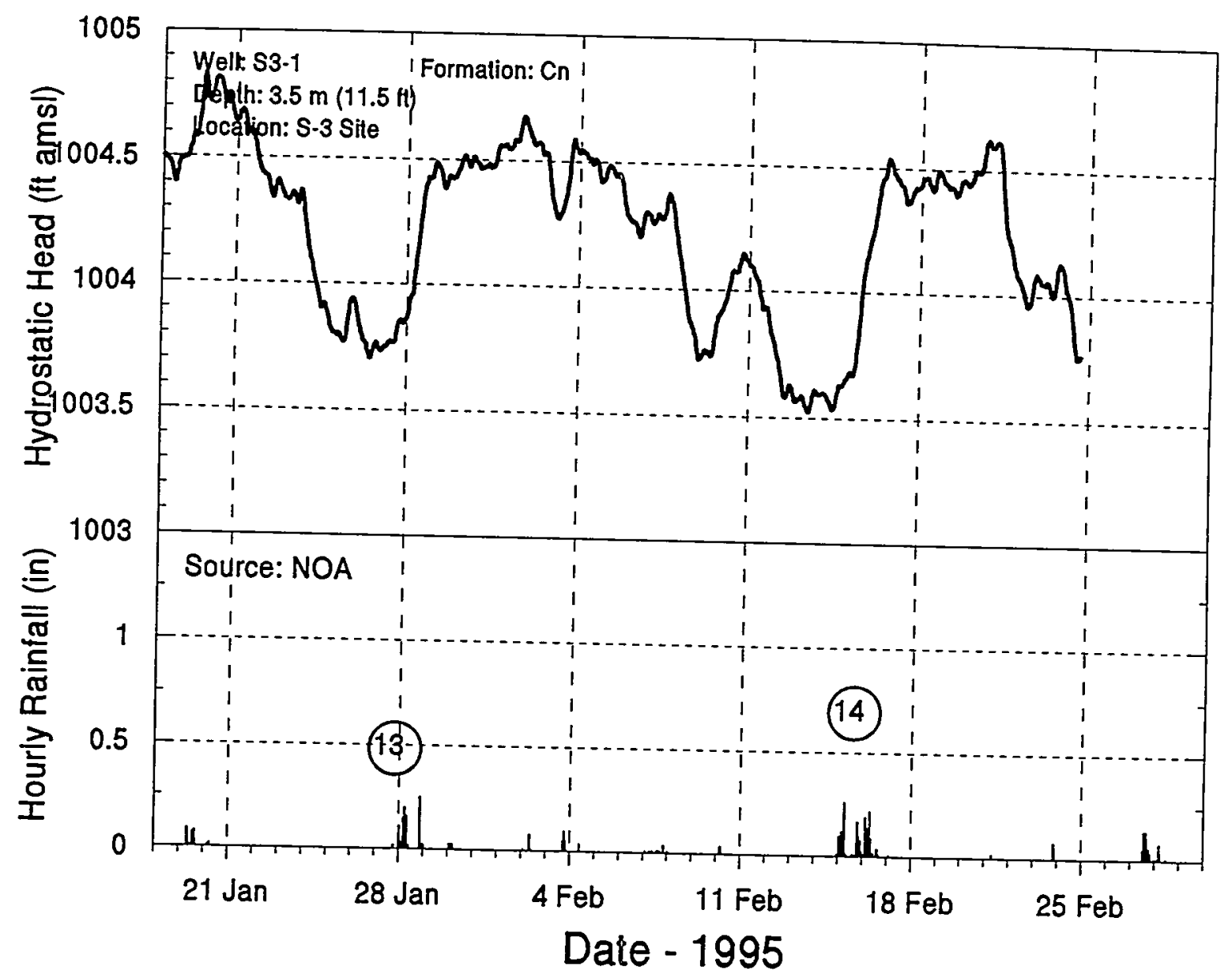

Fig. C.63. Well hydrograph for S3-1 at depth of $11.5 \mathrm{ft}$ at S-3 Site for January 17 to March 2 . 


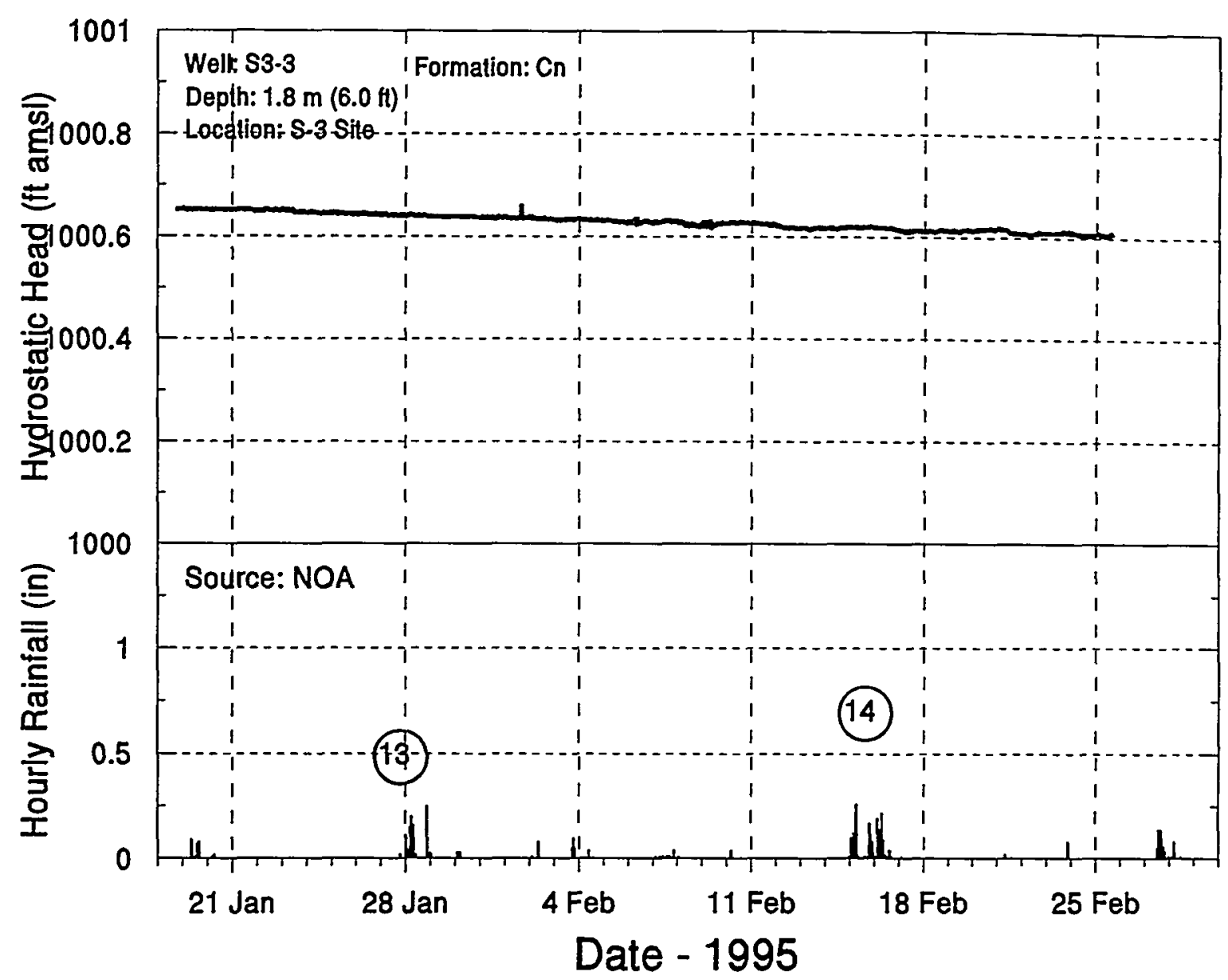

Fig. C.64. Well hydrograph for S3-3 at depth of $6.0 \mathrm{ft}$ at S-3 Site for January 18 to March 2. 


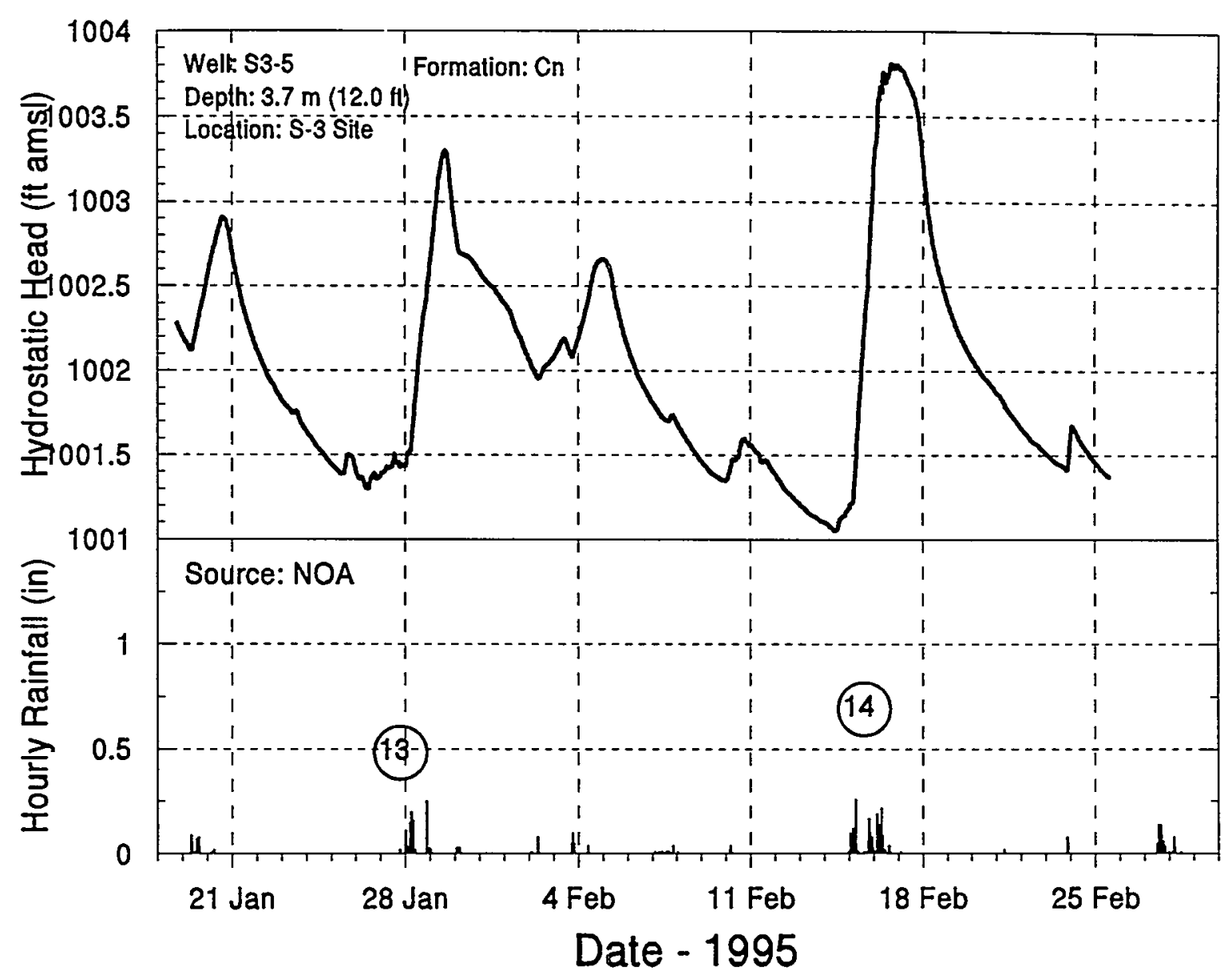

Fig. C.65. Well hydrograph for S3-5 at depth of $12.0 \mathrm{ft}$ at S-3 Site for January 18 to March 2 . 


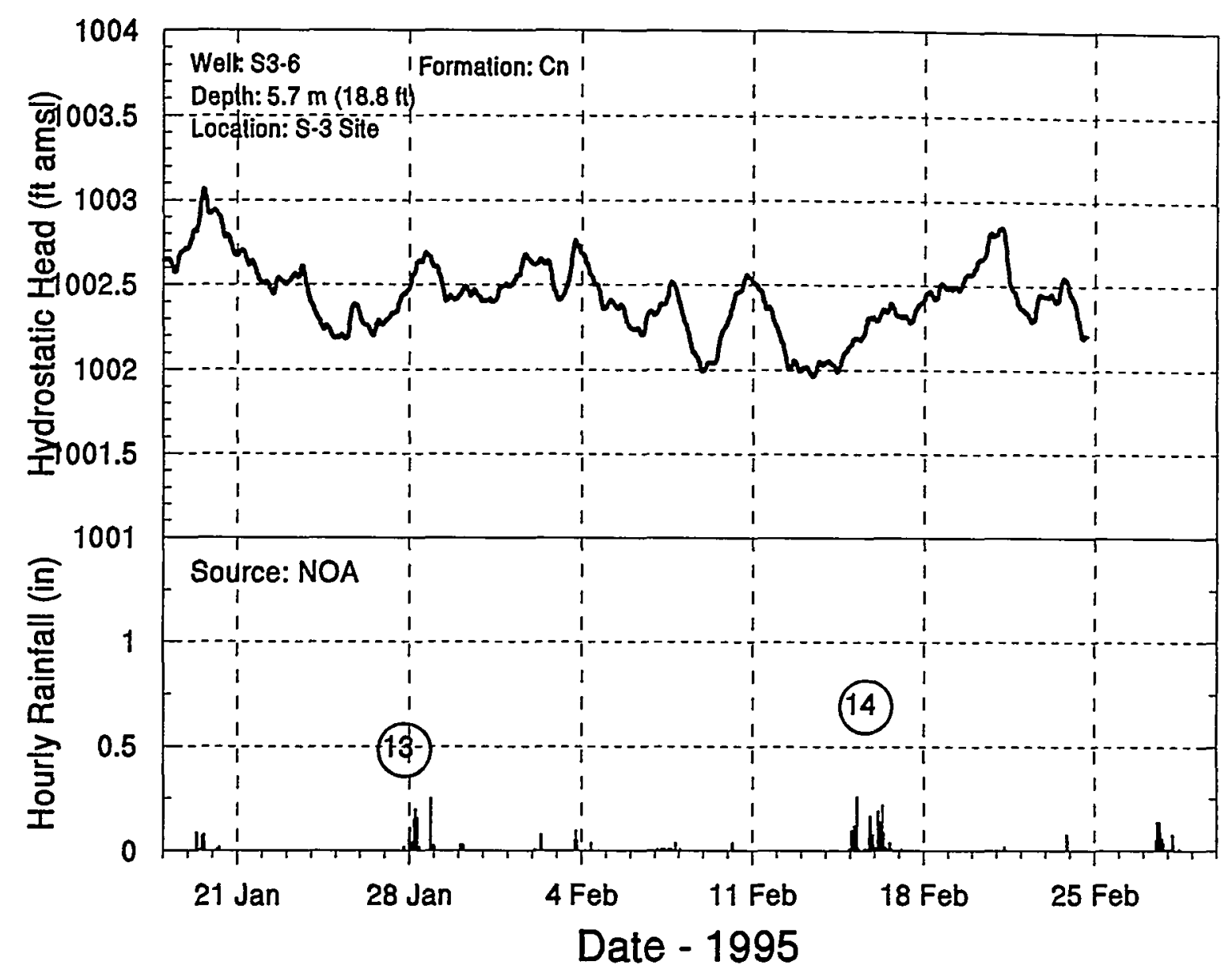

Fig. C.66. Well hydrograph for S3-6 at depth of $18.8 \mathrm{ft}$ at S-3 Site for January 17 to March 2. 


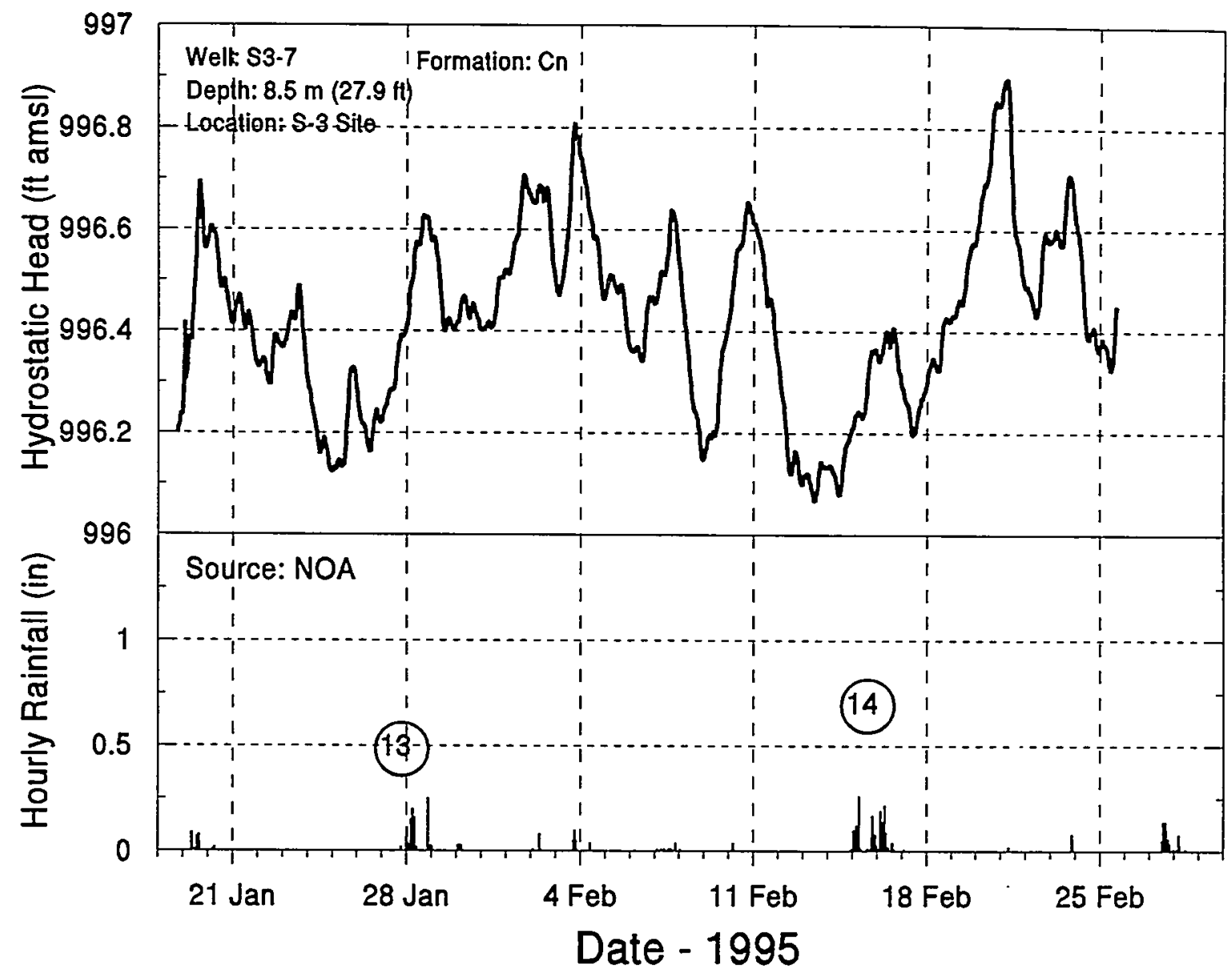

Fig. C.67. Well hydrograph for S3-7 at depth of $27.9 \mathrm{ft}$ at S-3 Site for January 18 to March 2 . 


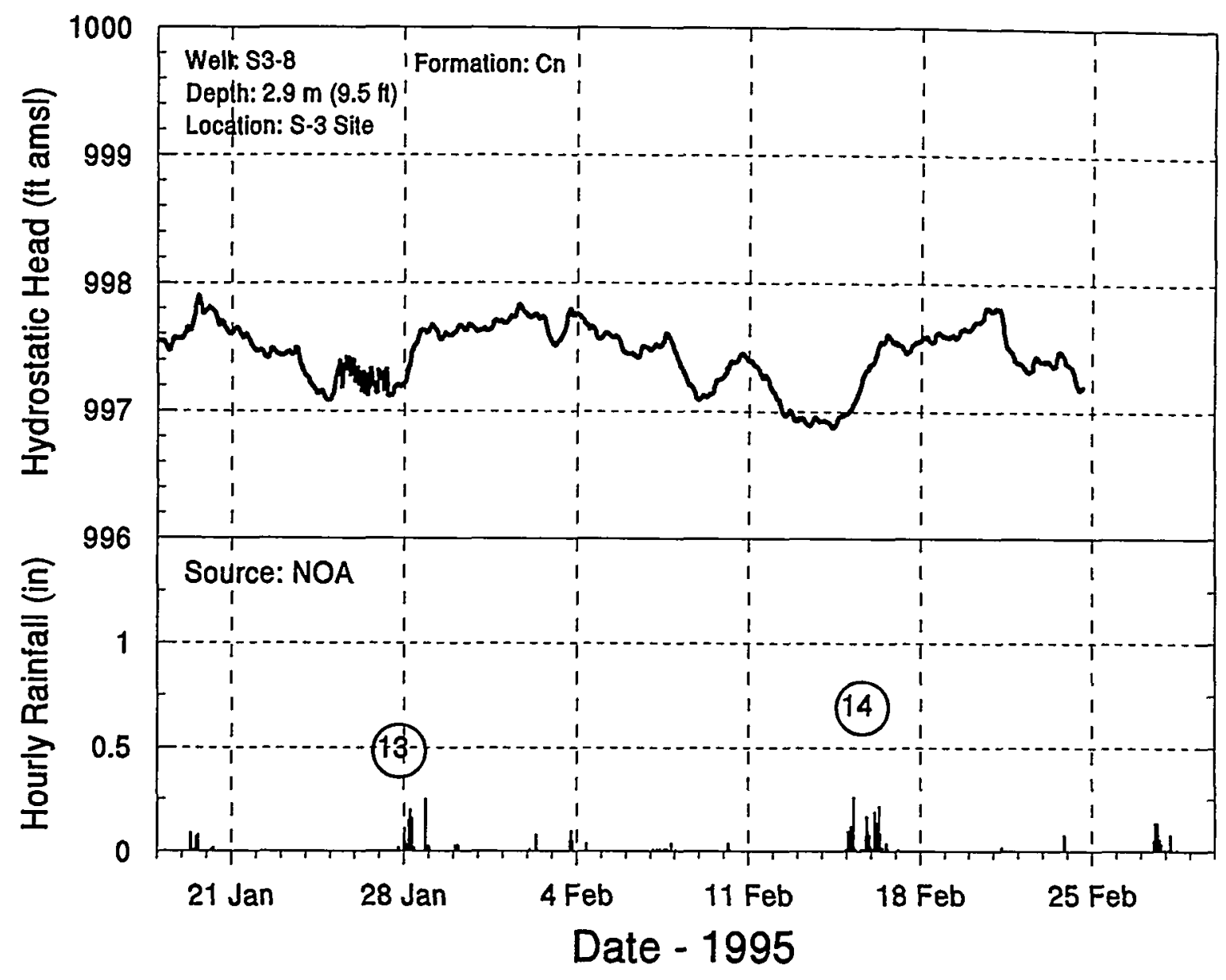

Fig. C.68. Well hydrograph for S3-8 at depth of $95 \mathrm{ft}$ at S-3 Site for January 18 to March 2. 
C9-42

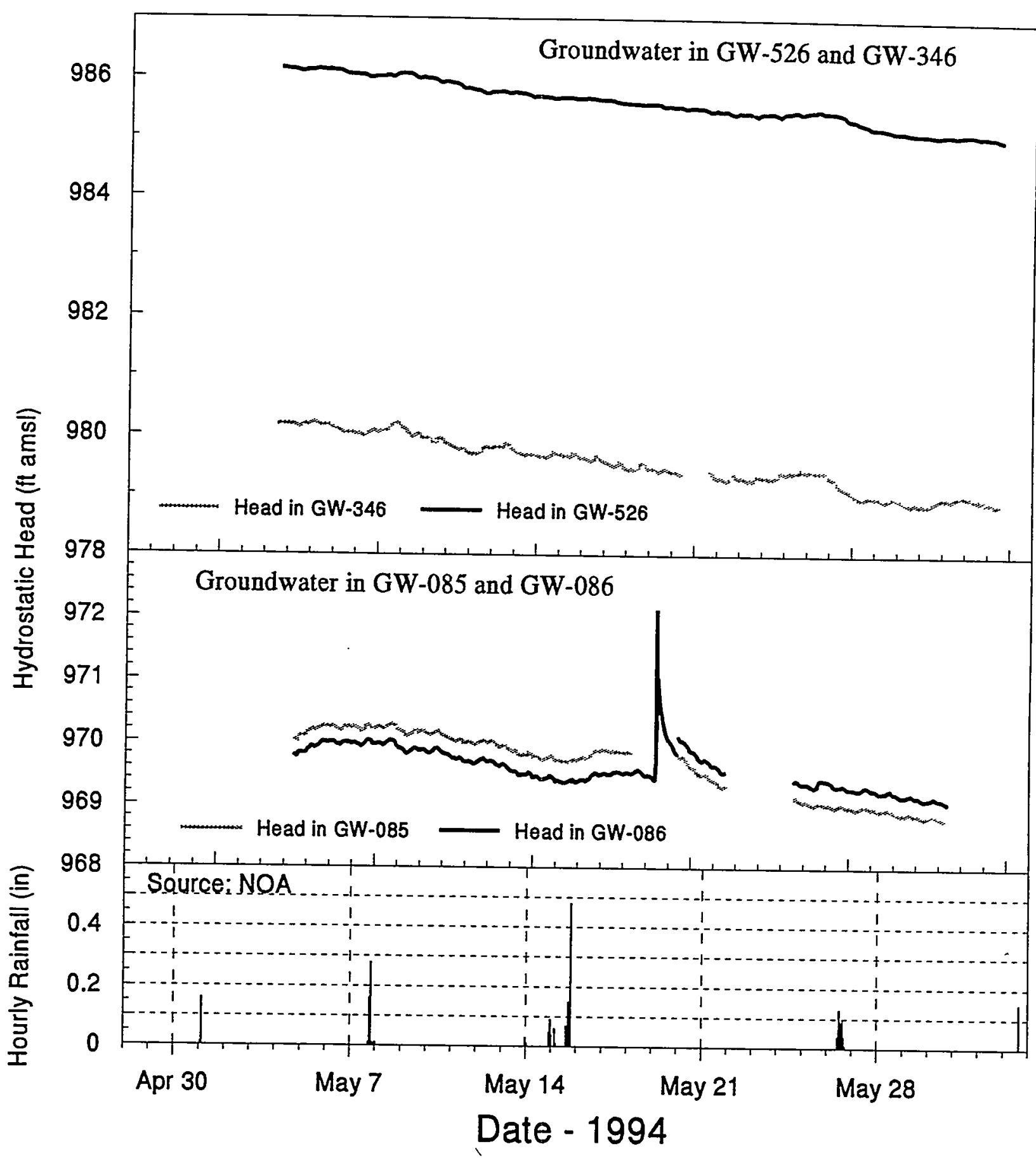

Fig. C.69. Well hydrographs for GW-526 and GW-346 at S-3 Site and for GW-085 and GW-086 at BYBY. 


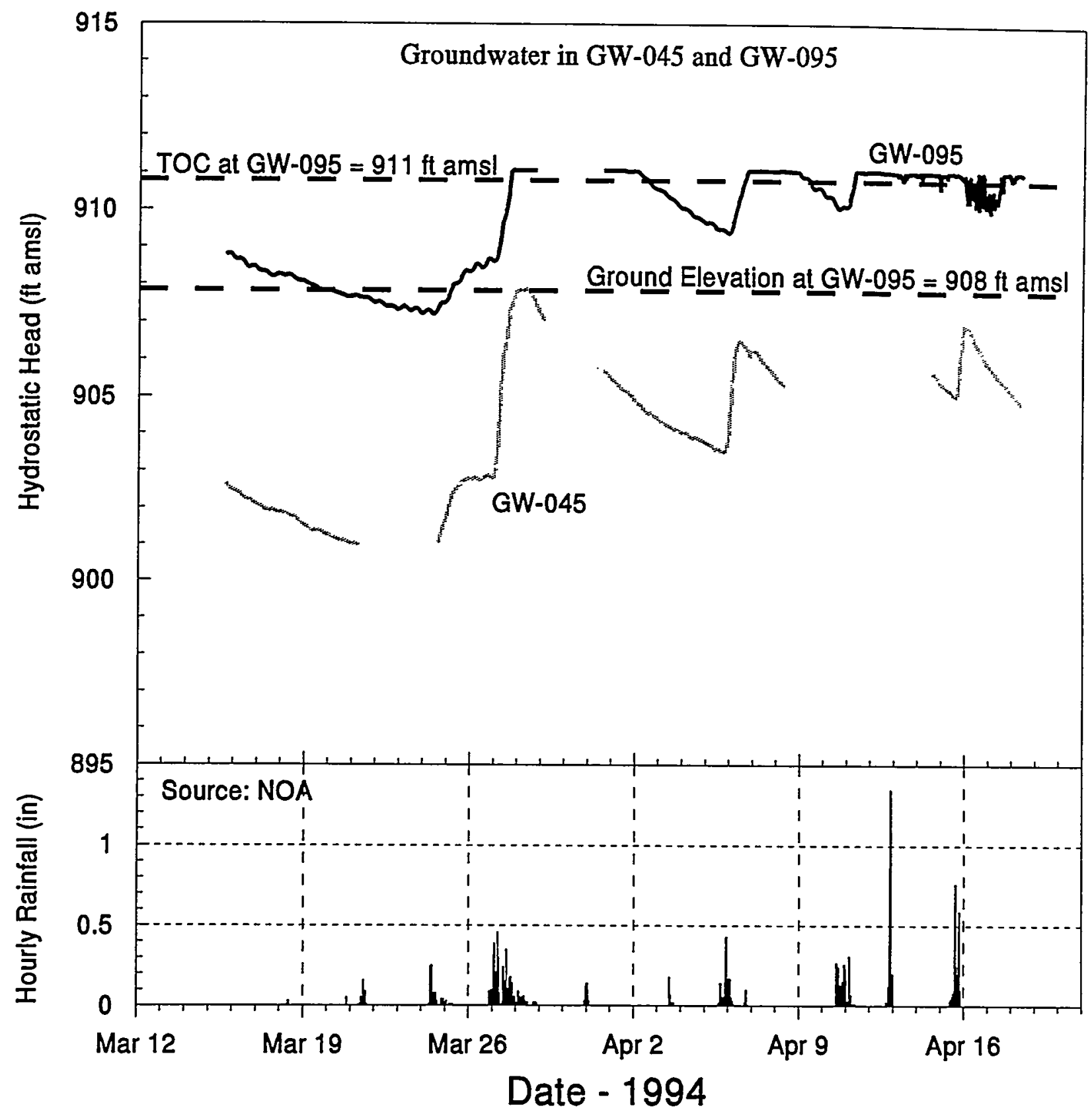

Fig. C.70. Well hydrographs for GW-045 and GW-095 at BCBG. 

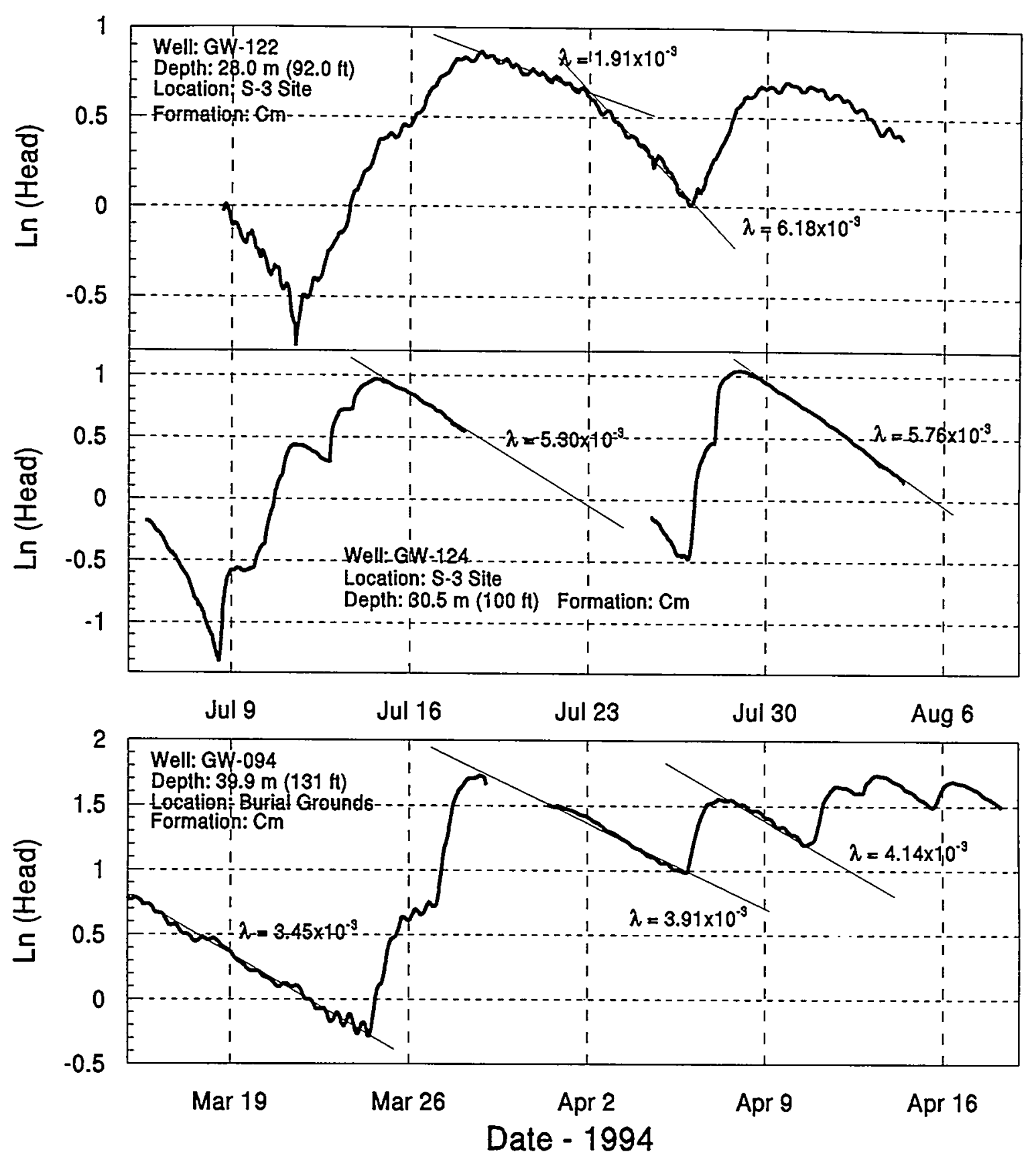

Fig. C.71. Well hydrographs for GW-094, GW-122, and GW-124 plotted in semi-log space. 


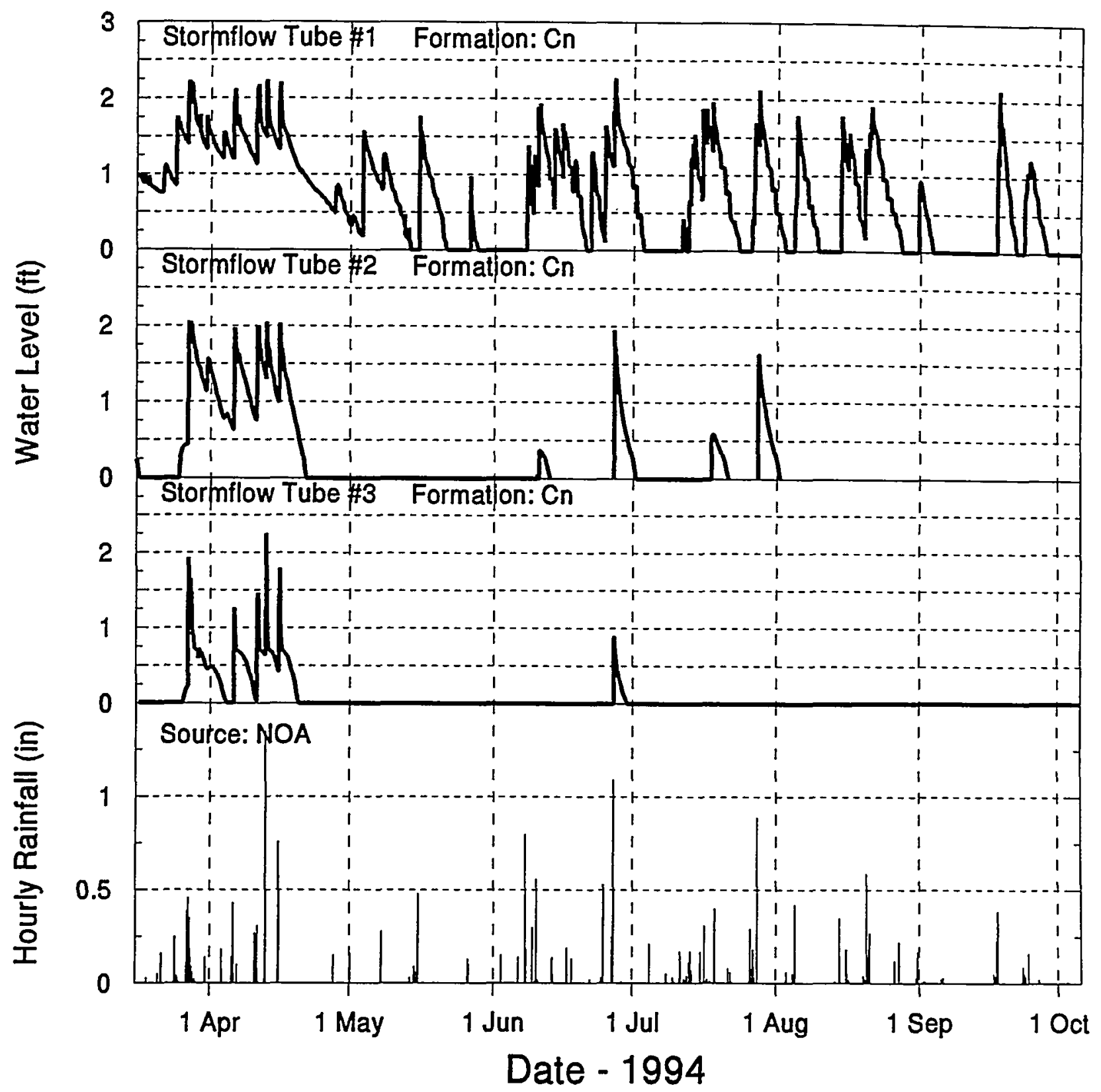

Fig. C.72. Hydrographs for stormflow tubes SFT 1, SFT 2, and SFT 3 from April to October 1994. 
C9-46

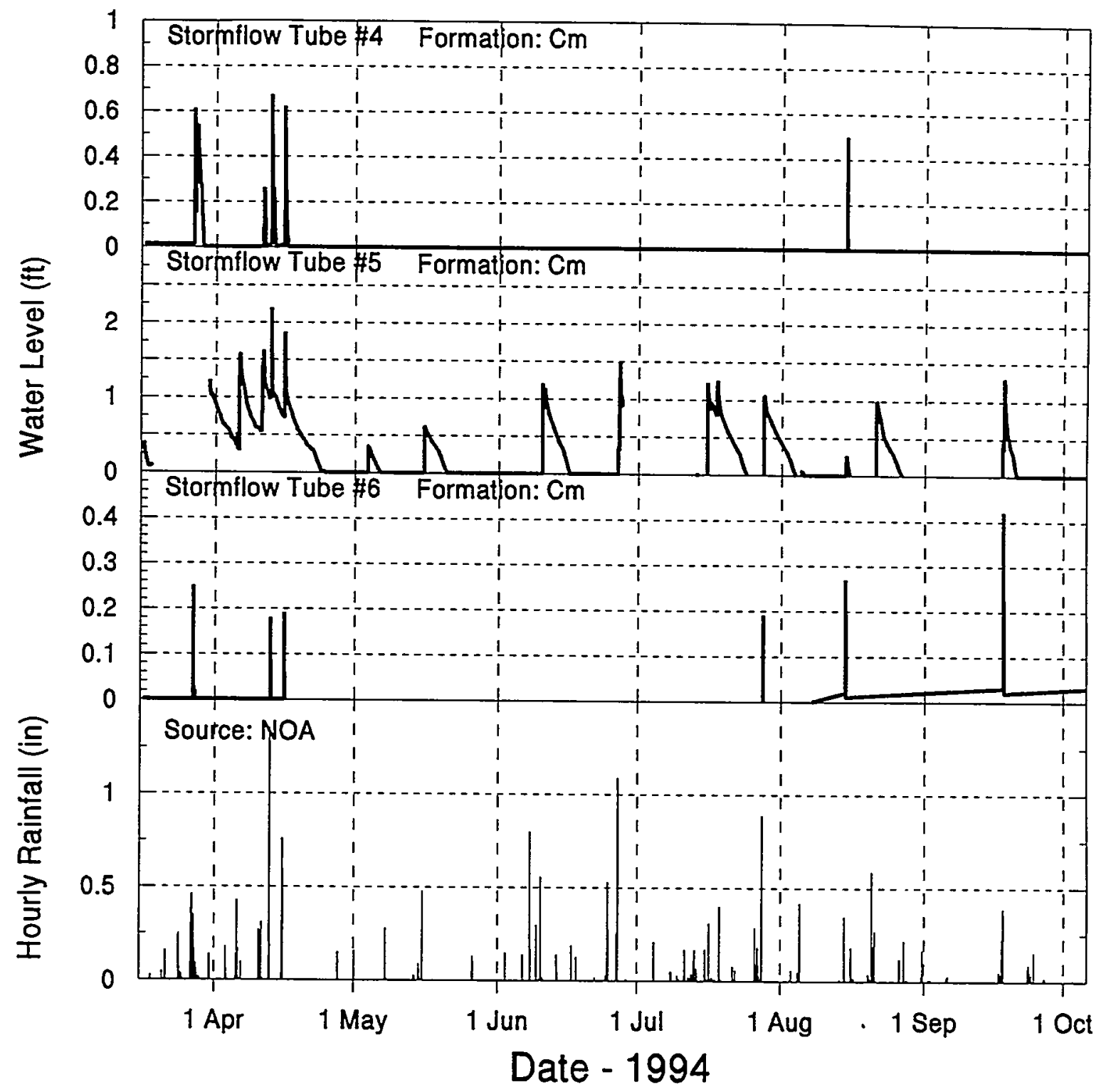

Fig. C.73. Hydrographs from stormflow tubes SFT 4, SFT 5, and SFT 6 from April to October 1994. 
C10-1

C.10 SUPPORTING INFORMATION FOR APPENDIX C-TABLES 

Table C.3 Vertical hydraulic gradients in the Nolichucky Shale in BCV.

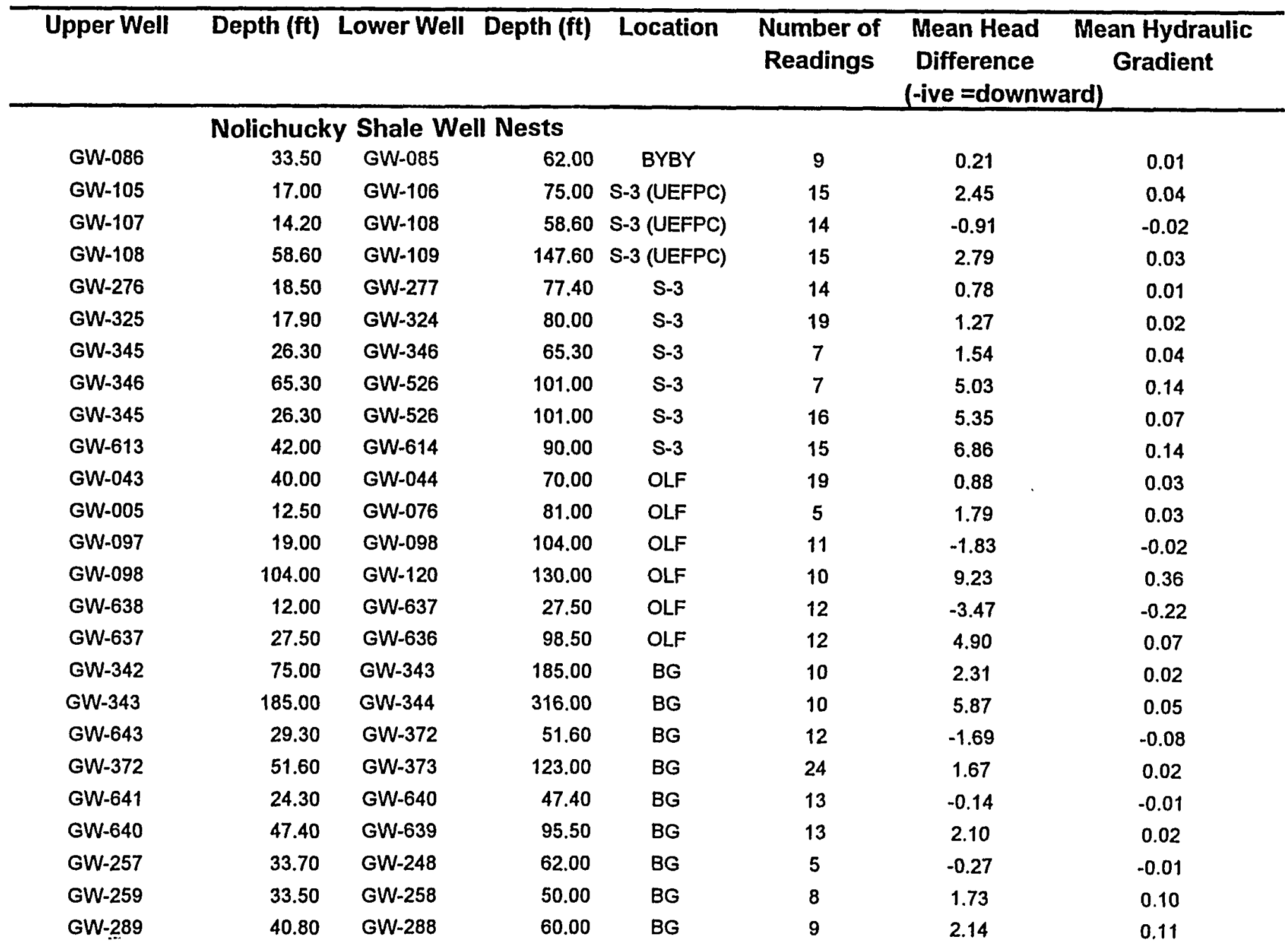


Table C.3 (continued)

\begin{tabular}{|c|c|c|c|c|c|c|c|}
\hline Upper Well & Depth (ft) & Lower Well & Depth (ft) & Location & $\begin{array}{l}\text { Number of } \\
\text { Readings }\end{array}$ & $\begin{array}{l}\text { Mean Head Me } \\
\text { Difference } \\
\text { (-ive =downward) }\end{array}$ & $\begin{array}{l}\text { Gean Hydraulic } \\
\text { Gradient }\end{array}$ \\
\hline \multicolumn{8}{|c|}{ Nolichucky Shale Well Nests } \\
\hline GW-249 & 35.10 & $G W-250$ & 61.70 & BG & 5 & -2.72 & -0.10 \\
\hline GW-287 & 12.50 & GW-286 & 32.30 & BG & 20 & -0.50 & -0.03 \\
\hline GW-291 & 19.68 & GW-290 & 35.50 & BG & 10 & 2.14 & 0.13 \\
\hline GW-047 & 25.50 & GW-374 & 124.60 & BG & 5 & 5.36 & 0.05 \\
\hline GW-078 & 21.10 & GW-077 & 100.50 & BG & 5 & 0.51 & 0.01 \\
\hline GW-080 & 30.00 & GW-079 & 65.00 & BG & 10 & 1.77 & 0.05 \\
\hline GW-072 & 101.40 & GW-071 & 220.60 & BG & 11 & 1.53 & 0.01 \\
\hline GW-622 & 20.50 & GW-623 & 274.50 & BG & 8 & 7.85 & 0.03 \\
\hline GW-626 & 78.00 & GW-627 & 254.00 & BG & 16 & 2.20 & 0.01 \\
\hline \multicolumn{8}{|c|}{ Maynardville Limestone Well Nests } \\
\hline GW-045 & 15.20 & GW-095 & 156.00 & BG & 5 & 7.08 & 0.05 \\
\hline GW-057 & 25.00 & GW-056 & 55.20 & BG & 12 & -0.00 & -0.00 \\
\hline GW-227 & 30.00 & GW-228 & 80.00 & OLF & 15 & -1.87 & -0.04 \\
\hline GW-226 & 45.00 & GW-225 & 150.00 & OLF & 21 & -3.77 & -0.04 \\
\hline GW-347 & 27.00 & GW-348 & 81.00 & $S-3$ & 21 & -6.09 & -0.11 \\
\hline GW-520 & 80.00 & GW-366 & 102.00 & OLF & 13 & -3.41 & -0.15 \\
\hline GW-366 & 102.00 & GW-367 & 125.00 & OLF & 12 & -2.79 & -0.12 \\
\hline GW-369 & 115.00 & GW-368 & 225.00 & OLF & 7 & 11.28 & 0.10 \\
\hline GW-368 & 225.00 & GW-601 & 319.00 & OLF & 6 & 15.46 & 0.08 \\
\hline GW-619 & 40.00 & GW-620 & 75.00 & S-3 (UEFPC) & 19 & -1.80 & -0.05 \\
\hline GW-740 & 165.00 & GW-739 & 289.00 & PICKET C & 9 & -0.30 & -0.00 \\
\hline GW-739 & 289.00 & GW-723 & 340.00 & PICKET C & 9 & 1.27 & 0.02 \\
\hline
\end{tabular}


Table C.4 Analysis of selected well hydrographs in BCV.

\begin{tabular}{|c|c|c|c|c|c|c|c|c|c|c|c|c|}
\hline \multirow[t]{2}{*}{ Well } & \multirow[t]{2}{*}{ Group } & \multirow[t]{2}{*}{ Depth (ft) } & \multirow[t]{2}{*}{ \# Peaks } & \multicolumn{3}{|c|}{ Delay to Start } & \multicolumn{3}{|c|}{ Delay to Peak } & \multicolumn{3}{|l|}{ Rise } \\
\hline & & & & Min & $\operatorname{Max}$ & Mean & Min & $\operatorname{Max}$ & Mean & Min & $\operatorname{Max}$ & Mean \\
\hline GW-045 & $\overline{B G}$ & & $1,2,3,6$ & 2.40 & 6.00 & 3.60 & 6.50 & 37.40 & 19.70 & 20.90 & 61.40 & 35.30 \\
\hline GW-094 & BG & & $2,3,4,5,6$ & 3.30 & 8.20 & 6.00 & 13.00 & 30.20 & 23.50 & 21.50 & 41.40 & 29.00 \\
\hline GW-095 & BG & & $1,2,3$ & 3.00 & 8.00 & 5.50 & NA & NA & $\mathrm{NA}$ & $\mathrm{NA}$ & $\mathrm{NA}$ & NA \\
\hline GW-126 & BG & & 2 & 5.60 & 5.60 & 5.60 & 25.60 & 25.60 & 25.60 & 1.50 & 1.50 & 1.50 \\
\hline GW-624 & BG & & $1,2,6$ & 1.70 & 4.00 & 2.50 & $\mathrm{NA}$ & NA & NA & NA & NA & NA \\
\hline GW-629 & BG & & $2,3,4,5,6$ & 3.00 & 12.70 & 7.80 & $\mathrm{NA}$ & NA & NA & NA & $\mathrm{NA}$ & NA \\
\hline GW-251 & BG & & $1 *, 2,3,4,6$ & 3.00 & 7.40 & 5.90 & 41.50 & 41.50 & 41.50 & 1.97 & 1.97 & 1.97 \\
\hline GW-124 & OLF & & 7,8 & 4.00 & 1.50 & 2.30 & $\mathrm{NA}$ & NA & NA & NA & NA & NA \\
\hline GW-345 & OLF & & $7,8 *$ & 3.50 & 6.53 & 5.00 & 13.50 & 14.50 & 14.00 & 0.77 & 0.77 & 0.77 \\
\hline $\mathrm{GW}-710$ & Picket W & & $9,10,11,12$ & 8.50 & 33.50 & 15.00 & 37.50 & 53.50 & 45.00 & 0.37 & 2.45 & 1.32 \\
\hline GW-711 & Picket W & & $10,11,12$ & 4.50 & 33.50 & 23.50 & 37.00 & 56.50 & 45.00 & 0.41 & 1.88 & 1.32 \\
\hline GW-712 & Picket W & & $9,10,11,12$ & 1.00 & 30.50 & 10.60 & 12.00 & 37.00 & 26.00 & 0.36 & 2.58 & 1.36 \\
\hline GW-713 & Picket W & & $9,10,11,12$ & 2.00 & 30.50 & 10.90 & 12.00 & 37.00 & 24.80 & 0.24 & 4.49 & 1.66 \\
\hline GW-714 & Picket W & & 11,12 & 8.00 & 22.50 & 15.25 & 16.50 & 26.50 & 21.50 & 1.00 & 3.88 & 2.44 \\
\hline GW-715 & Picket W & & $9,10,11$ & 2.50 & 19.00 & 8.70 & 2.00 & 3.00 & 2.50 & 1.27 & 3.75 & 2.67 \\
\hline$G W-127$ & OU $1 \mathrm{~s}-3$ & & 13,14 & 2.00 & 6.00 & 4.00 & 4.50 & 27.50 & 16.00 & 1.59 & 2.53 & 2.06 \\
\hline GW-276 & OU $1 \mathrm{~S}-3$ & & 14 & 1.50 & 1.50 & NA & 26.50 & 26.50 & NA & 2.51 & 2.51 & NA \\
\hline S3-5 & OU $1 \mathrm{~S}-3$ & & 13,14 & 2.00 & 5.00 & 3.50 & 26.00 & 30.00 & 28.00 & 1.81 & 2.53 & 2.17 \\
\hline
\end{tabular}


Table C.5 Analysis of selected stream hydrographs in BCV.

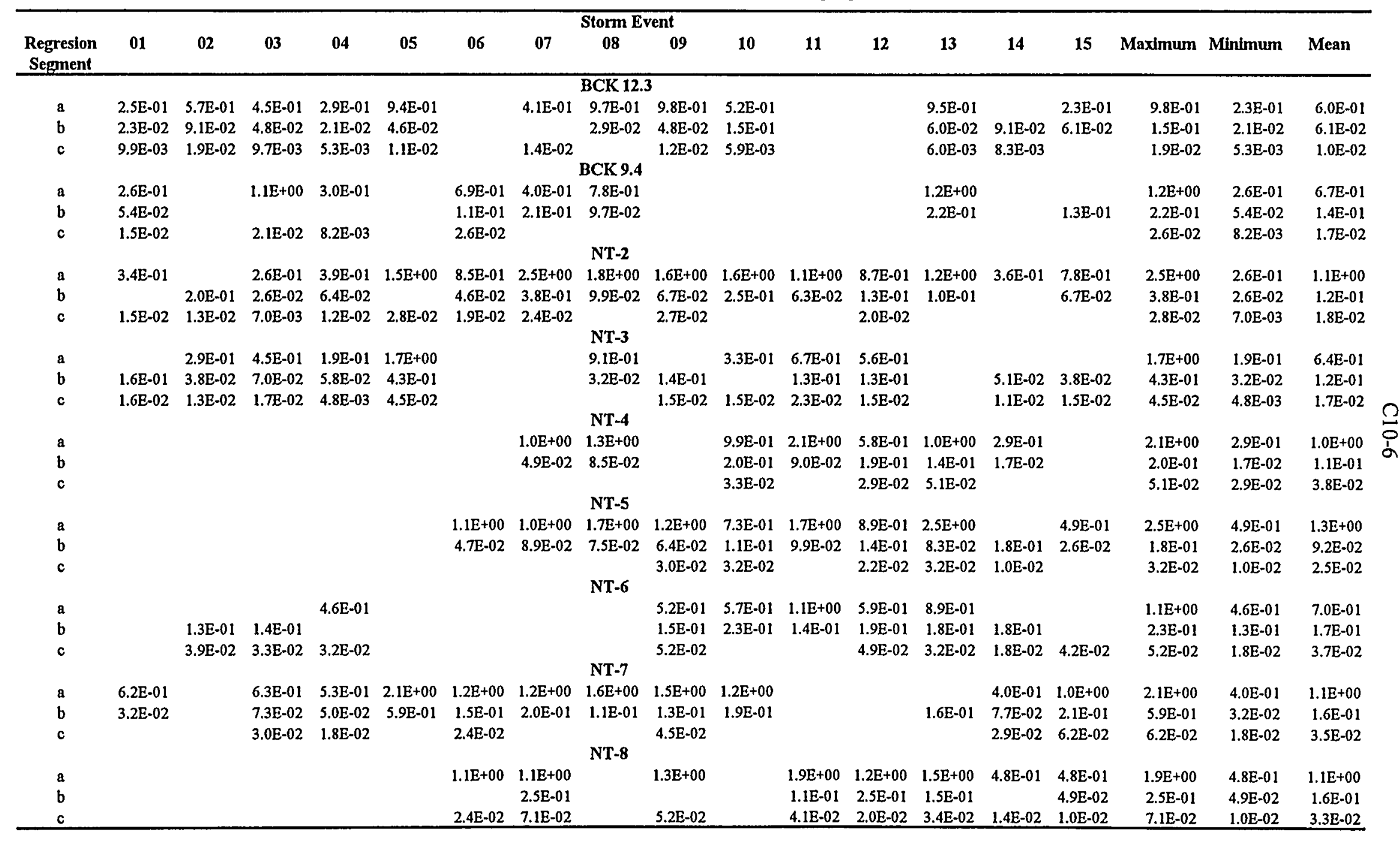


Table C.6 Analysis of selected stormflow tube hydrographs in BCV.

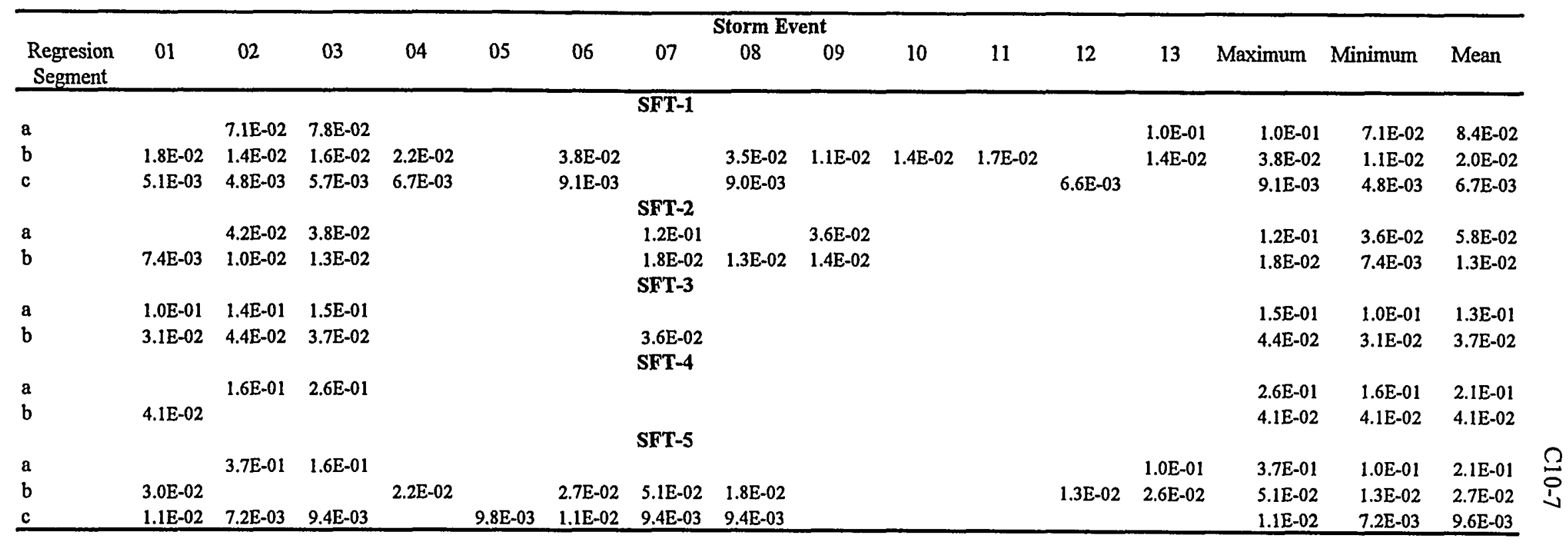




\section{DISTRIBUTION}

1. L. V. Asplund

2-3. C. S. Haase (2)

4-5. A. K. Lee/OSTI (2)

6-8. D. M. Matteo (3)

9. H. C. Newsom

10. B. D. Nourse

11. C. M. Smith

12. D. B. Watson

13. ER Central Doc. Mgmt. Center-RC

14. R. C. Sleeman, Director, Environmental Restoration Division, DOE Oak Ridge Operations Office, P.O. Box 2001, Oak Ridge, TN 37831-8541

15-17. D. Moss, Science Applications International Corporation, P.O. Box 2502, Oak Ridge, TN 37831 (3)

18. R. Stewart, Jacobs Engineering Group, 125 Broadway Avenue, Oak Ridge, TN 37830 